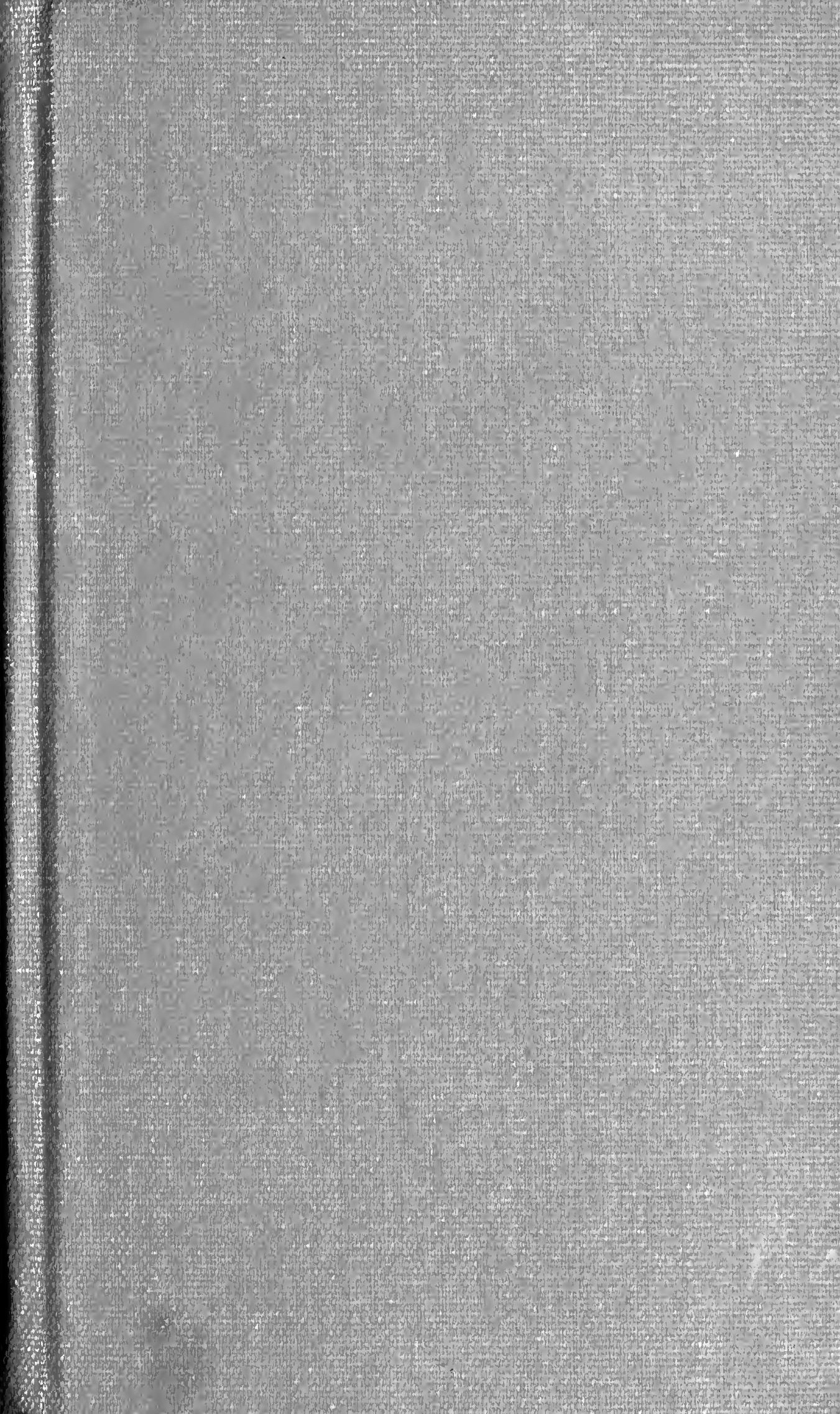




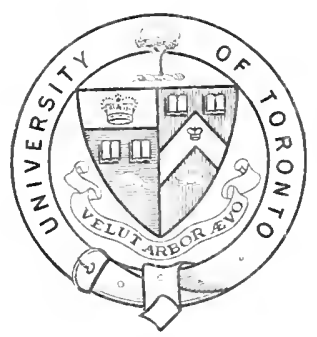

秥escutrid to

$$
\text { The Tlithary }
$$

falniuersity of Taranto

$$
\text { Iny }
$$

Eric N. Armour, Esq. 
Digitized by the Internet Archive in 2007 with funding from Microsoft Corporation 

EBg

A TREATISE

ON THE

LAW

OF

JUDGMENTS.

INCLUDING ALL FINAL DETERIINATIONS OF THE RIGHTS

OF PARTIES IN ACTIONS OR PROCEEDINGS

AT LAIV OR IN EQUITY.

By A. C. FREEMAN,

Counselor at Law.

THIRD EDITION, REVISED AND GREATLY ENLARGED.

SAN FRANCISCO:

A. L. BANCROFT AND COMPANY,

Law Book Pudlishers, Booksellers, axd Stationers.

1881 . 
Entered according to Act of Congress, in the year 1873, BY A. L. BANCROFT \& COMPANY,

In the office of the Librarian of Congress, at Washington.

Entered according to Act of Congress, in the jear 1874, BY A. L. BANCROFT \& COMPANY,

In the office of the Librarian of Congress, at Washington.

Entered according to Act of Congress, in the year 1881, Bx A. L. BANCROFT \& COMPANY, In the office of the Librarian of Congress, at Washington. 


\section{PREFACE.}

THe author of this book believes that its publication is amply justified by the importance of the subject of which it treats, by the frequency with which a correct understanding of that subject is essential to a proper and consistent administration of the law, and by the absence of any other work which even professes to treat of the matters considered in this.

A judgment is not invariably " the end of the law." Perhaps nothing so fairly demonstrates the persistence of litigants as their constant efforts to escape the consequences of prior defeats. Scarcely a term passes in any of the courts of last resort, in this country or in England, in which it does not become necessary to determine the effect of some prior adjudication. An examination of the reports will convince any one that there are but few branches of the law which had been more.frequently before the courts than the Law of Judgments.

Whoever, for the first time, gives his special attention to this branch of the law, will be less surprised at the number of the decisions, than at the assurance with which the most irreconcilable conclusions have been announced. Cases have frequently been disposed of in accordance with principles which the Court evidently regarded as indisputable, but which, in fact, were in direct conflict with the law as understood in most of the other States. Nor can this be deemed remarkable, when we remember that no attempt had been made to collate the various decisions constituting the Law of Judgments.

This work, though not formally subdivided in that manner, consists of seven parts: Part first, including chapters one to seven, shows of what the Pecord or Judgment Roll is composed, and states the various classifications and definitions of Judgments and Decrees, and the rules applicable to Entries and Amendments, and to the Vacation of Judgments at Common Law, and under the Code. Part second, consisting of the eighth clapter, is devoted to the law in regard to Jurisdictional Inquiries in collateral proceedings. The ninth and tenth chapters 
constitute the third part, and are designed to show what persons are bound by the judgment, by reason of their privity with the parties or their interest in the subject of lifigation, or through the operation of the law of lis pendens. Part fourth treats of the important incidents attending judgmonts, viz.: Merger, Estoppel and Lien; of the assignable qualities of judgments, and of their admissibility as eviclence. Part fifth considers proceedings to revive judgments scire facias, and to enforce them as causes of action or defense, with the rules of pleading applicable to those proceedings. Tho sixth part contains the chapters or Relief, Reversal and Satisfaction; showing for what causes a judgment may be avoided in equity - what are the effects of its reversal by some appellate tribunal-and what are the means and circumstances which produces its satisfaction. The seventh and last part treats of the difierent kinds of judgments, and the rules peculiar to each.

In the hope that, at least by its arrangement and citation of authorities, it may aid in the proper determination of cases yet to arise, and may, by producing a more thorough knowledge of the law, assist in the prevention of needless litigation, this work is respectfully submitted to the members of that profession for whose benefit it was prepared.

Sacramento, Cal, January, 1873. 


\section{PREFACE TO SECOND EDITION.}

Tine author has endearored to merit the kindness with which the first edition of this work was received, by making the second as complete as possible. To accomplish this result, he has consulted a large number of authorities, and has made considerable additions to the text. Particular pains has been taken to embody in this edition, the substance of the decisions published since the completion of the work as it was first given to the wolld. The prior decisions have also received attention, and have repaid it by contributing materially to the increase both of the text and of the table of cases. The Canadian reports, which, until recently, were not within the author's reach, have also been examined, and have been cited as freely as those of the other American courts. From these various sources the number of the citations has been augmented nearly twenty-five per cent, and it is hoped and believed that the value of the work has been increased in a like ratio.

Sacramento, CaL., August 1, 1874. 



\section{PREFACE TO THIRD EDITION.}

Tre lapse of nearly seven years since the publication of the second edition of this work renders necessary another edition, in order that it may not be left too far behind the most advanced stage of the law. The author has felt a desire to amplify and reconstruct his former work; but the press of other engagements has made this impossible except to a very limited extent. He has, however, added some twelve hundred cases to the authorities cited, and has increased the text about one sixth; and, in so doing, has treated some topics not considered in the former editions. Among these topics are, what are final judgments in criminal prosecutions and in intervention cases; the form of judgments with respect to designating the parties and the relief granted; fraud and perjury as grounds for vacating judgments on motion; merger arising from prosecutions and convictions in criminal cases; set-off of one judgment against another; and an entire chapter on the conclusiveness of judrments when questioned on habeas corpus. He has also given due prominence to the recent decisions of the Supreme Court of the United States by which judgments, whether foreign or domestic, seem to remain ever open to collateral attack on jurisdictional grounds.

Sacramiento, Cal., June 1, 1881. 



\section{TABLE OF CONTENTS.}

N. B. -For more complete statement of contents, see the Synopsis at the head of each Chapter.

\section{CHAPTER I.}

Definitions and Classifications of Judgments and Decrees-Final Judgments within the meaning of statutes allowing appeals..................

CHAPTER II.

THE EXTRY OF JUDGMENTS.

Is a Ministerial Act-Distinction between Judgments and Decrees - Judgment Book-Joint PartiesForm-Designating pariies, amount, proper'ty-Judgments of conviction-Juscices' Courts. ..........

\section{CH.APTER III.}

NUNC PRo TUNO ENTRIES.

Part I. Where no Judgment has been ordered or entered. Part II. Tihere Judgment has been ordered but not entered.....................

\section{CHAPTER IV.}

AMIENDING JUDGMILNTS, 57-65.

\section{CHAPTER V.}

THE RECORD, OR JUDGIENT ROLL.

Origin-Verity-Of what composed-Absence of Replacing.

\section{CHAPTER VI.}

VACATIYG JUDGMENTS.

At Common Law-By Writs of Error, Coram Nobis and Coram Vobis-Audita Querela-Causes for-Notice.. 


\section{CHAPTER VII.}

Vacation of Judrments under statutes on account of IIistake, Inadvertence, Surprise, or Excusable Neglect-Fraud and Perjury...................

\section{CHAPTER VIII.}

Inquiries in Collateral Proceedings in relation to the Jurisdiction of Courts of Record-Jurisdiction, definition and source of-Jurisdictional Findiugs.......

\section{CHAPTER IX.}

OF the persons aFfecten BX JUdGMents.

Part I. Parties. Part II. Privies. Part III. Persons bound though neither Parties nor Privies ....... 159-207

\section{CHAPTER X.}

LIS PENDLXS.

Reasons for-Commencement of - Property bound byPersons bound by-Diligence in Prosecution..... 208.230

\section{CHAPTER XI.}

MERGER.

General Principles of - Exceptions - Joint Obligations-Indivisible Causes of Action-In Criminal Prosecutions........................

\section{CHAPTER XII.}

JUDGMENT ESTOPPELS.

Part I. Nature and Extent. Part II. Requisites. Part III. Evidence to establish or rebut. Part IV. Matters Defendant need not litigate. Part V. Pleading. Part VI. Actions in conflict with Prior Adjudications. Part VII. Judgments in various Actions, Real and Personal, and Criminal. Part VIII. Motions and Special Proceedings. Part IX. Miscellaneous Matters..............................

\section{CHAPTER XIII.} IMPEACUING JUDGMENTS, 376-379. 


\section{CHAPTER XIV.}

OF THE JUDGMENT LIEN.

Part I. Nature and Creation of. Part II. Estates and Interests affected by. Part III. Priority of. Part IV. Suspension and discharge of. Part V. Extending and Reviving. Part VI. For Future Advances. Part VII. Of Foreclosure Suits. Part VIII. Of Judgments of the Federal Courts............. 380-438

\section{CHAPTER XV. \\ JUDGMENTS AS EVIDENCE.}

Part I. Mode of Proof. Part II. Admissibility and Effect.......................... 439-450

\section{CHAPTER XVI.}

ASSIGNIENT OF JUDGIIENT.

Means of-Notice of-Rights of Assignee-Prior Assignments. . . . . . . . . . . . . . . . . . . . 451-459

\section{CHAPTER XVII.}

ACTIONS ON JUDGuLNTS, 460-467.

\section{CHAPTER XVIII.}

PROCEEDINGS BY SCIRE FACIAS, 468-472.

\section{CHAPTER XIX.}

PLEADING.

Part I. General Form. Part II. Averments of Jurisdiction. Part III. Description. Part IV. Pleas in Defense. Part V. Pleas of Judgments of other States. 473-483

\section{CHAPTER XX.}

\section{SATISFACTION.}

Part I. By Payment-By Set-off. Part II. Payer's Right to Subrogation. Part III. Satisfaction by Proceedings under Execution. Part IV. Proceedings after Satisfaction...................... 
CHAPTER XXI.

REVERSED JUDGMENTS, 509-516.

\section{CHAPTER XXII.}

RELIEF IN EQUITY.

Grounds for-Parties who may Apply-Rights of Third

Persons........................ 517-559

\section{CHAPTER XXIII.}

JUDGIIENTS OF COURTS NOT OF RECORD.

Distinction between, and Courts of Record-Jurisdiction must be shown-No Presumptions in favor of-

Officers acting under Authority from .......... 560-568

\section{CHAPTER XXIV.}

JUDGMENTS DY DEFAULT.

Effect-Clerk's Authority-Appeal from-Opening... 569-575

\section{CHAPTER X̀XV.}

JIDGMENTS BY CONFESSION WITHOUT ACTION.

Statutes-Parties who may make-For what may be made-Statements-Then void-Remedy to correct. 576-585

\section{CHAPTER XXVI.}

JUDGMENTS OF OTHER STATES.

Constitutional and Legislative Provisions-Jurisdictional Inquiries-Effect of-Defenses to-Decrees of Divorce........................ 586-624

\section{CHAPTER XXVII.}

FOREIGN JUDGMENTS.

Jurisdiction-Effect-A ppeal-Are not Records..... 625-653

\section{CHAPTER XXVIII.}

JUDGMENTS IN REM.

Definition-Different Kinds-Jurisdiction-Divorce-

Decrees in Admiralty ................. 654-670

\section{CHAPTER XXIX.}

Conclusiveness of Judgments when assailed on Habeas Corpus...........................671-601 


\title{
TABLE OF CASES.
}

\author{
[N. B. -THE FIGURES REFER TO THE SECTIONS.]
}

A.

Aadie $v$ Lebrero.........212, 213

Abbie $v$ Higgins.............. 79

Abbe $v$. Rood................ 463

v. Marr............ 538

Abbot's r. Bradstreet............319a

v. Donglas........... 83

v. Dutton............ 95

v. Hackman........... 78

Aberdeen v. Blackmer........... 181

Abington v. Lipscomb......... 57

Abraham v. Plestoro.........605 $b$

Acker v. Acker.............. 553

Ackerly v. Parkinson.........., 531

Ackerman r. Crop...........60 605

Ackler'v. Ackler............. 66

Ackley v. Chamberlain......... 355

Acorn, The............... 334

Adarn v. Amold.............. 557

Adams v. Adams......... 330, 489

v. Barnes.....165, 283, 281

v. Bronghton.........237

v. Butts........... 1 12

. Cameron........... 270

v. De Cook ............6 603

v. Dyer............ 374

v. Haifard........... 243

v. Hickman............ 541

v. Jeffries........... 123

v. Oaks.............. 539

v. Pearson............ 310

v. Smith........... 47s

Adkins v. Brewer............ 530

Adliuson v. Keel............ 89

Adney v. Vernon.............. 218

Agnew v. MicElroy ..........260, 276

A gry v. Betts.............. 5:3

A icardi v. Robbins $. . \ldots \ldots \ldots \ldots, 463$

Aikins v. Bailey ............ 180

Akerly v. Vilas............... 325

Albin v. People..........432, 446

Albro v. Dayton............. 503

A'den v. Alameda Co............432a

Aldrich v. Kinney .......... 563
Alexander 8. Stewart......... 72

Alford $v$. Moore.............. 485

Allen v. Bradford............. 64

v. Carter............. 159

v. Case.............. 195

v. Dundas............. 608

v. Hall........... $319 a 467 a$

v. Holden ............ 469

v. Huntington......104b, 116

v. Irwin............ 103

v. Lyman............ 217

v. Maclellan........... 99

v. Mandaville............. 195

v. Morris............. 201

v. Norton............. 557

v. Richardson.......... 330

v. Rountree.......... 187

v. Stephanes............. 501

v. Stone.............. 498

r. The Mayor.......... 328

v. Wheatley .......... 236

Allgood v. Whitley ........... 435

Allie v. Schmitz.............. 308

Allinet v. His Creditors....... 261

Allis v. Davidson .............. 219

Altman v. Klingensmith......... $\Delta G 6$

Alves v. Bunbury ............ 414

Am. Ins. Co. v. Oakley. ....12S, 498

Ames v. Bates.............. 407a

v. Hoy ...........407, 432

Amsden v. D. S. \& C. I. R. Co. 273

Anacosta Tribe v. Murbach.... 031

Anderson v. Anderson......... 319

v. Beelue.......... los

v. Benford.......... 518

v. Fish............ \&3

จ. Kimbrough....... 55

จ. Little............ 464

v. Nagle............ 360

v. Parker.......... 70

v. Reed............ $50 b$

v. Ryder........... 155

v. Tuck........... 369

Andover Sav. Bank v. Adams .. 238

Andrews v. Bernardi .......... 130 
Andrews v. Matthews......... 360

v. Montgomery....461, 559

v. Smith...........210

v. State............ 117

v. Vartrell.......216, 224

Angell v. Draper............. 512

v. Robbins........... 523

Anschinks v. State............. $21 a$

Apperson v. Burgett............ 366

Applegate v. Edwards.......... 393

Appleton v. Braybrook.......... 414

Archer v. Masse............. 608

Argenti v. San Francisco...... 481

Arget v. Blackshear........... 589

Argyle v. Durnel........... 357a

Armory v. Armory............ 575

Armroyd v. Williams.........6 613

Armstrong v. Barton...........135a

v. St. Louis........ 275

v. Prewett......... 235

Arndt v. Arndt............. 573

Arnett v. Cloud .............. 469

Arnold v. Allinor............. 281

v. Arnold..........293, 311

v. Frazier...........4 413

v. Fuller............ 47s

v. Grimes............. 281

v. Kelly.............. 90

v. Nye............124, 128

Arnott v. Webb............ 563

Arrington v. Comey.......... 72

v. Sherry.......... 558

v. Washington.......50 501

Arthur v. Mosby............ 139

Ashby v. Glascow.............. 96

Ashley v. Hyde............. 90

v. Laird.............. 453

Aspden v. Nixon............. 252

Aspinwall v. Pimie ........... 354

Assignees v. Dorsey........... 101

Astley v. Reynolds............ 57

Atkins v. Horde............. 295

v. Hudson...........4 458

v. Sawyer........... 71

Atkinson v. Allen........... 336 v. Davies........... 7

v. Manks.......... 330

Att'y Gen. v. Lord Hotham .... 525 v. White........ 71

Audubon v. Excelsior Ins. Co... 265

Ault v. Gassaway.............. 212

v. Zehering..........217, 221

Aultman v. McLean.........12s, 139

Aurora City v. West . ..247, 267, 460

Austin v. Bell............... 350

v. Nelson............ 112

Auwerter v. Mathiot.........34s, 363

Averill v. Loucks..........229, 232

Avery v. Fitch ............... 239

Ayer v. Ashmead............ 236

Ayers v. Carver.............. 34

v. Duprey..........366, 366a

v. Waul.............. 393
B.

B. \& W. R. R. Co. v. Sparhawk. 128

Babcock v. Brown........... 112 v. Campbell.......... 253

v. McNamant......... 49

Baber v. Cook................ 43

Backus v. Clark.............. so

Bacon v. Kimmell. ............. 237

Badger v. Balger...........270a

v. Titcomb........240, 274

Bagley v. Ward............... 346,394

Bagot v. Williams............ 276

Baily v. Brownfield........... 470

Bailey v. Clayton........... 512

v. Ins. Co............6 618

v. Taaffe....106, 108, 115, 541

Bain v. Hunt.............. 451

Laker v. Cleveland ............ 272

v. Morgan............. 487

v. Morton............ 357

v. Pierson............. 213

v. Preston........... 150

v. Rand......269, 272,515

v. Rilgway.......... 95

v. Stinchfield.......... 279

v. State.............. 49

v. Stonebrader's Adin'r. 128, 40.5

- v. Wheaton..............605b

Baldwin v. Calkins.............. 145

v. Kimmel.......... 133

v. Kramer........... 93

Ballinger v. Tarbell......... $60,40, a$

Ballou v. Hudson............. C08

Balt. \& O. R. R. v. Fitzpatrick. . 462

Baltzell v. Noster............ 563

v. Randolph ... ....... 505

Bancroft $v$. Winspear ............ 240

Band v. Rice.............. 220

Bank v. Wells.............. 304

Bank's Appeal............... 545

Bank The v. Beale........... 477

v. Flagg ........... 303

v. Harrison ........ 109

v. Moss...........71, 101

v. Rogers......... 475

v. Seymour......... 70

v. Thompson ........ 343

v. Wheeler.........575

v. Wills........... 392

v. Wistar..........

Bank of Augusta v. Earle ....... 5cs

Bank of Australasia v. Harding. $\left\{\begin{array}{l}220 \\ 590 \\ 594\end{array}\right.$

Bank of Australasia v. Nias $\begin{cases}177, & 500 \\ 594\end{cases}$

Bank of Chenango v. IIyde. .... 220

Bank of Commonwealth v. Hop-

kins $\ldots \ldots \ldots \ldots \ldots \ldots \ldots 202$

Bank of Kinderhook v. Gifford.. 512 v. Jemison.. 553

Bank of Mobile v. Hall. .... . 24
Banis of N. A. v. Wheeler.22, 224, 328 
Bank of Oswego v. Babcock.... 18s | Bates v. Hinsdale........... 370

B.ml of Fenn. v. Winger...... 47s v. N. O. \& J. R. R. Co...503

Bank of Statesville v. Foot.... 108 v. Quattlebone ........ 21

Bank of U. S. v. Beverly...... 2ts $\quad$ v. Spooner............ 219

v. Patton...216, 380 v. Stanton............. 166

v. Winston ..... 339 Batts v. Winstead........... 250

Bank of Va. v. Bk. of Chillicothe 79 Bandne's Syndics v. Nicholson.. 611

Banks v. Evans............ 490

v. Shaim...........484,

Banta r. McClennan........... 475

v. Wood.............4 436

Bamnon v. The People......... 130

Baragee v. Cronkite.......... 516

Barber v. Kemuedy.......... 5:0

v. Winslow.......... 517

v. Root............ 579

Barefiell v. Bryan........... 139

Bird v. Fort.............. $5 t^{2}$

Barelli v. Delassus........... 193

Baring $r$ Clagett............. 618

Barker v. Brahan..............104h

v. Cleveland......254, 312

v. Elkins........... 504

v. Simpson........... 507

Barkhurst v. Yelverton ........ 163

Barkman v. Hopkins. ......576, 567

Burnaby's Case ............ 379

Eamard v. Gibson..........34, 35

Barnes v. Gibbs............ 202

v. Harris........... 45t

Barnett v. Judlay ............227a

v. Wolf.......... 130

Barney v. Chittenden.......... 308

ร. Dewey........... 1\&6

v. Patterson.......... $57 \mathrm{~s}$

v. White.......... 5,j

Barr v. Gratz............. 416

v. Hatch............. 350

Barrett v. Floyd...............48t

v, Garragan.......... 55

v. Oppenheimer....... $56^{2}$

v. Thompson.........475

Barringer v. Boyd........... 456

v. Boyden.........4 470

Barron v. Pagkes............ 442

v. Thompson......... 367

Darry v. Carothers............ 154

v. Patterson.......... 123

Barth v. Makeever.......... 363

Barthell v. Roderick..........500a

Bartholomew v. Candee........284

Bartlett v. B. G. L. Co. ....169, 172

v. Knight.559, 562, 567, 596

v. Spieer.......... 567

v. Yates.............. 4.22

Bartley v. Hodges............ 599

Barton v. Albright........... 167

Barwell v. Knight............ 249

Bascom v. Feazler............ $3: 0$

Batehclder v. Currier.......... 529

v. Noore.......... 137

Bateman v. Willoe........... 455

Bates v. Delevan...........39, 573

v. Gage $\ldots \ldots \ldots \ldots \ldots . . \ldots 121$
Baadin v. Kioliff............. 281

Baugh v. Batgh........91, 201, 575

Bavington v. Clarke......... $355_{i c}$

Baxley v. Linah........... 559

Baxter v. Aubrey ........... 27

v. Dear...... 150, 303, 485

v. Ins. Co........615, 615

v. Sinah ............. 57

Bayley v. Buckland........... 4.99

v. Cockerill.......... 193

Baylor v. Degarnette......... 172

Beach v. Vandenburgh ........ 469

Beal v. Smith............... 461

Beall v. Beck............... 130

v. Pearce .........272, 284

Beard, Ex parte............ 50

v. Ketehum.......... 95

Beatz v. Warren............. 6

Beausoliel v. Brown.......... 319

Bearen v. Countess Oxford...347, 306

Beazley v. Prentiss.......... 47t

Beckman v. Selover.......... 163

Beelue v. Bank of N. X ........ 423

r. Elliott............ . 299

Beech r. Abbott............. 120

Becler v. Bullett............. 151

v. Cardwell ............... $302 a$

Beekman v. Peck............. 100

Beere v. Fleming........... 270

Beers v. Hanghton.......... 40

v. Henderson.......... 463

v. Shamnon........... 7

Bceson v. Conley.............. 257

Beirne v. Mower ............... 391

Belcher v. Chamber........127, 501

Bell v. Evans................ 366

v. Gilmore.............. 393

v. Hoagland............. $\supseteq 60$

v. Mossey............ 45

v. Paymond........... $52 t$

v. State............... 384

v. Thompson .......... 93

r. Williams .........495, 498

Bellamy v. Sabine.....191, 192, 200

Bellinger v. Craigue.......250, 372

Bellows v. Shamon.......... 7

Belmont $v$. Coleman........ 177

v. Erie R. R. Co.. . . 325

v. Ponvert.......... 11

Beloit v. Morgan............. $2{ }^{2}$

Belt v. Davis............16, 18

Beltzhoover v. Commonwealth .. 235

Bender v. Fromberger......... Is

Bemdernagle $v$ Cocks......... 210

Benedict v. Smith........... 483

Benjamin v. Elmira R. R. Co... . 155

v. Wilson.......... 320 
Bennett, Ex parte.......... 118

Bennet v. Couchman.......... 169 v. Hamill.....151, 4\$4a, 513 v. Hethington......171

v. Holmes .......... 276 v. Hood............ 240 v. Musgrave.........512 v. Rankings......... 100

Bennett's Lessee v. Williams. . . . 195

Bensley v. Mountain Lake Co... 213

Benson v. Paine..........229, 231

v. Vernon.......... 100

Bent v. Pierce............. 427

Bentley v. Jones........... 15, 20

Benton v, Duffy............. 269

Benwell v. Black.... . . . . . . . 433

Benz v. Hincs......... . . 156, 252

Berger v. Williams........180, 459

Bernal v. Lynch............. 524

Bernard v. Douglas........556, $55 \mathrm{~s}$

v. Hoboken ........2.256

Bernardi v. Matteaux......... G1s

Ternert, Ex parte...........625

Berry v. Anaerson........... 50b

v. Clements ........... 370

v. Shuler........... 376

v. Whittaker........... 193

Bertline v. Bauer............. 113

Dert v. Sternberg .......... 310

Bertrand v. Gugy ........... 70

Berwick v. Duncan.......... 7

Best v. Lawson. . . . . . . . . . .467a

Bethell's Case.............. 6:1

Betts v. Bagley.........245, 523

v. New Hartford ........ 319

v. Starr..........234, 253

Betty's Lease............... 32'

Betz's Appeal . . . . . . . . . . . . . . 393

Bibb v. Avery.... . . . . . . . . . . . . 604

Bibend v. Kreutz...........497

Lickett v. Gamer............. 4s1

Eiddle's Appeal..............337a

Eididle v. Dowse............. 432

v. Wilkins

217,435

Biddleson v. Whitel........ 450,452$\}$

Lidweli v. Coleman........... 347

Bigelow v. Finch........... 356

v. Forrest . . . . . . . 625

v. Prevost. .......... 469

v. IVinsor. . . 299, 252, 254

Riggins v. Brockman.........484

Billing v. Hitchings......... 456

Billings v. Russell. . . . . . . 122, 520

Bimelor v. Dawson........560, 565

Binsser v. Barker............. 488

v. TVood.............. 180

Pirch v. Funk..........260, 267

Birckhead v. Brown... . . . . . . . 259

Bird, Ex parte............. 620

Bird v. Smith............... 435

Birlwell v. Cain............. 394

Bischoff v. Wethered .......... 5ss

Bishop of Winchester v. Beaver. 205
Bishop of Winchester v. v. Paine $\left\{\begin{array}{l}191 \\ 204\end{array}\right.$

Bishop's Heirs v. Hampton..... \&9ı

Bisland v. Hewett. ...........36la

Bissell v. Briggs. . . . . 458, 562, 596

v. Edwards...........4 413

v. Jandon........... 464

v. Wheelock..........453

Bixby v. Whitney ........... 320

Black v. Epperson............ 355

v. Nettle........... 216

v. Smith. . . . . . . . 575,576

Black \& Whitesmith's Society v.

Van Dyke............... 531

Blackburne v. Squib .......... 46\%

v. Statc........, $1 \pm 3$

v. Stupart. ...... 476

Blackleacl v. Stewart.......... 618

Black Riv. Sav. Bank v. Edwards 253

Blaikel v. Griswcld......... 5

Blair, Ex parte............. 324

Blair, In re................6\% 620

Blair v. Bartlett........... 2s2, 330

v. Caldwell....412, 439, 45

v. Chamblin .......... 349

Blaisdell v. Harris........... 58

v. Pray ........... 130

Blake v. Burley.............. 450

v. Douglas........... 151

v. Williams................ $605 b$

Blakely v. Calıler . . . . . . 135, 305

Dlakemore v. Canal Co........ 160

Blakesly v. Johnson........427, 492

Blakey v. Newby............ 156

Blp.uchard v. Russell.........605b

Blanck v. Speckman........... 487

Blanford v. Foote .......... 245

Blann v. Crocheron.......... 236

Bín v. Campluell. . . . . . . . . . 264

Bliss v. Clark............. 355

Blodgett $v$. Jordan..... $234,433,575$

Blood v. Bates............. 1:39

v. Craudall.......... 155

v. Sayre............... 530

Bloodgood v. Garsey.......162, 253

Jjloom v. Burdick............ 133

Bloss v. Plymale............ 296

Blumenthal v. Tannenholz......605c

Blumfield's Case............. 474

Bluzzard v. Phœbus......... 79

Blystone v. Blystone........1, 4S9

Blythe v. Richards............. 132

Board of S. v. M. P. R. R. 157,257 Co....... 303, 316

v. De Forrest. ...... 467

Boardman v. Acer.......... 464

Boduntra v. Goodrich... . .... 133

Bogart, In re...........531, 620

Bourss v. Clark.............. 327

Boilean v. Butler....................... 331

Boker v. Bronson............. 37

Bolan v. Bolan.............. 407

Bolen v. Crosby ............ 431

Bolgiano v. Cook........... 135 
t. lling v. Anderson.

Bolton v. McKimley.......... 90

Bombay v. Goyer............. 393

Bonafour v. Walker......... 217

Bund, Ex parte.............6.5

Bond v. Epley............... 105

v. NicNicler.......... 261

v. Pacheco........129, 534

Bonnell v. Bonnell.......... 55s

v. Henry ........... 553

Bonnesteel v. Todh....219, 220, 233

Bomifield v. Price........... 267

Bonta v. Clay.............. 557

Bouvillian r. Bourg............. 271

Borden v. Fitch...133, 559, 562, 563

Buoker's Adm'r v. Dell's........ 417

Boon v. Boun............... 72

v. Miller............500a

Booth, Ex purte............. 6.4

Booth v. F. \& II. Bank....426a, 472 v. Stamper...........484a

Boren v. Mclieliee...........4 469

Borst $v$. Buldwin. . . . . . . . . 43:

v. Nalee.............. 339

Borrowscile v. Tuttle........ 270

Boston v. Haynes........486, 50s

v. Worthington....... 181

Boston I. R. r. Dima........ 225

Buswell v. Diclserson ......... 14:

Bottorf v. Wise ............ 274

Bouchard v. Dias....... \{ 253,256

Boulden v. Lanahau........... 193

Boulette v. Owens........... 546

Bounker v. Atkyns........... 170

Eoutel v. Owens............. 546

Bowen v. Bonmer........... 445 v. Nay............. 44

Bowler v. Bluston .....563, 568, 574

Bowman v. Hovious.... . . . . . . 355

Eowyer v. Schofield............. 310

Box v. Bemnett.............. 16

Boyd's Appeal.............. 4\$9

Boyd, In re................ 347

Boyd v. Blaisdeli........... 72

v. Boylam........... 155

v. Caidwell........... 1s0

v. Chesapealse.......... 487

v. Whittield........... 181

Boylkin v. Cook.............. 163

Boyland v. Boyland........... 127

Boynton v. Willard........... 173

Brackett v. Hoitt........... 260

v. Norton............. 462

v. Winslow......... 95

Bradford v. Bradford...159, $27 \mathrm{l}, 330$ v. Bradley .......... 24

v. Coit............ 105

v. Rice.............. 105

Bradish v. Gee..........230, 500

Bradley v. Andrews............235

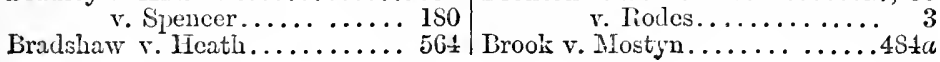

Bradshaw's Case............ 89

iradstreet $r$. Ins. Co......... 615

Lrady v. Murphy.......... 458

v. Reynolds......... 231

v. Spruck........... . 20

Bragg v. Lorio.... .......... 132

Brainard v. Cooper............ 162

Braithwaite v. Watts ......... 343

Braley v. Tieese ............ 1 122

Braley v. Seaman............ 83

branch r. Lowery ............ 405

Brand v. Staffurd............ 502

Brandling v. Ilumner.......... 343

Brandon v. Digss............ 94

branger v. Chevalier........... 72

Brazier v. Bamning............. 237

Brazill v. Isham ............ 320

Breading v. Siegworth ......... 167

Bredon v. Gillilaud........... 96

Breedlove v. Turner........... 1 1 89

Brennan's Case.............. 625

Brentuall v. Foster........... $\mathbf{2} 6 \mathbf{1}$

Bresnehan v. Price ........... 488

Brevard $v$. Hoffmann ......... 531

Brewer v. Bowman .............484a

v. Jones.............500a

v. Thomes.. ........444

Brewster v. Countryman ....... 187 v. M. U. R. I. Co .... 508

Bridendolph r. Zeller's Adm'l'... 94

Bridge $\mathrm{v}$. Sumner............ 261 v. Ward........... 356

Bridgeport Insurance Co. v. Wilsoz.................181, 336

Bridgeport Savings Bank $\checkmark$ EI-

Bridges, Ex parte............. 6.

Bridges v. Smyth.......... 53

v. Thomas........... 87

Lriggs v. Brewster. ... . . . . . $3 \geq 2$

v. Briggs.......... C05c

v. Doir............. 422

v. Milburn........... 460

v. Richmond.......... 280

$v$ Weils............. 275

Brightman v. Brightman ....... 190

Brinkley v. Brinliley ............ 5.5

Brinkman v. Shaffer.......... 128

Brinsmead v. Harrison..... 236, 237

Brintnall v. Foster........... 235

Briscoe v. Stephens .........218, 524

Brestor v. Galvin............ 114

Lrittain v. Kinuaird.......... 5 23

Brittan v. Fisher............. 7

v. Turner.............. 277

v. Wilder........... 515

Broaddus v. Broaddus........ 492

Brockenbrough v. Brockenbrough 369

Brock's Adm'r..............605

Brockway v. Kinmey.......... 272

Brodie v. Beckley............ 163

Bronson v. R. R. Co........27, 36

$$
\text { v. Tiodes.............. } 3
$$

Brook v. Mostyn............48ta dredge.................... 455 
Brooking v. Dearmond....... 156| Buffington v. Cook......... 158

Erooklyn Bank v. Republic.... 159 buffum v. Tamscleil.......... 136

Brooks v. Gibbons........... 157 Buford r. Kirkpatrick......... 570

v. IIunt............ 95 Bull v. Hopklns ........... 268

Broome v. Wootton.... ...236, 237 Bump v. Piercy ............. 545

Brown v. Ayres........... 426 Bunnell v. Pinto .........259, 320

v. Birdsall.......... 23t Bunting's Case ............ 610

v. Clarke.........216, 281 Burch v. Newberry............. 90

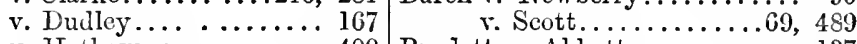

v. Hathaway......... 409 Burdett v. Abbott.............. 137

v. Hendrickson........467a Burdick v. Post ............ 271

v. King............ 273 Burford v. Kersey ........... 249

v. Kirkbride........ 261 Burgess v. Cane ............ 421

v. Joy $\ldots \ldots \ldots \ldots \ldots \ldots$. $95 \quad$ v. Lane ........... 159

v. Kendall........... 476 Burgh v. Francis ............. 357

v. Lawson............ 151 Burk v. Table MIountain Co.... 2

v. Mayer............ $330 \quad$ v. Johuson........... 121

v. Neale........... 445 Burke v. Stokely ............ 112

v. Nichols.......... 1 1 $\quad$ v. Wheat.......... 487

v. Pierce............ 357 Burkham v. Van Saun......... 546

v. Richardson......... 43 Burlen v. Shannon....159, 257, 276

v. Saratoga R. R. Co.... \&o Burling v. Goodman .......... 3

v. Scott........... 432 Burn v. Butcher ............ 58 , 611

v. Simpson.......... 44S Burnett, Ex parte ........... 624

v. Swan............ 507 Burnett v. Carlweil............. 218

v. Thornton..........489 v. Crandall........... 422

v. Toell's Adm'r.......502 v. The State.........63, 67

v. Union Ins. Co......6 $613 \quad$ v. Smith ........... 272

v. U. S............ 623 Durney v. Blodgett........... 374

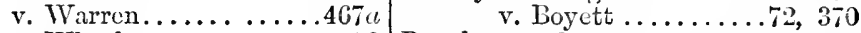

v. Wheeler........... 5s Durnham v. Stevens ...586, 58s, 590

v. White........... 472 Eurns, In re............337a

v. Willians.........36la Durns v. Belknap..........559

v. Wyncoop..........501 v. Simpson........4,432, 452

Brownfield v. Dyer.......... 127

v. Nackey.......... 318

Bruce v. Conyers............... $21 b$

Bruce v. Vogel ............370, 374

Bruen v. Hone .............. 272

Brumley v. State........... 121

Brundell v. Vaux............ 575

Birush v. Fowler............... 162

v. Robbins........... 70

Bryan v. Miiller.........555, 557

v. Moore ..............605

Bryant v. Fairfield........... 484

v. Johnson .......... 95

v. Owen .............. 180

v. Williams.......... 509

Bryans v. State.............. 318

Buchan v. Sumner............ 343

Buchanan v. Nolin.......... 502

v. Port........461, 559

v. Rucker.......414, 588

v. Smith ..........337a

Bnchegger v. Schmultz......... 3

Buck v. Buck .............. 320

v. Havens .............. 109

Buckingham v. Davis ......... 146

Lackling v. Hannah .......... 416

Butkland v. Johnson.......237, 211

Duckner v. Calcote ............ $25 \mathrm{~s}$

Bucid \& Co.'s Appeal........... 347

v. Thornbur ${ }^{\prime}$ h..........467a

Burson v. Blair................ 70

Burt v. Casey............... 46t

v. Scranton ............ 540

v. Sternburgh......... 284

Burton v. Burton ............ 323

v. Hynson.......501, 508

v. Smith............. 339

v. Wiley ...........503, 508

Burwell v. Knight.......... 279

Bush v. Lindsay.............. 124

Bushell's Case .............530, 624

Butcher v. Bank.........124, 452

Butcher v. Bank of Brownsville. 5-1

Butler v. Horwitz........... 3

v. Knight............ 463

v. Lee.............. 39

v. Miller............. 229

v. Mitchell........110, 113

v. Potter............. 580

v. Tomlinson............ 195

Buttrick v. Allen......414, 592, 605

Byers v. Engles............. 360

v. Fomler............ $4 \mathrm{CJ}$

v. Neal............ 329

v. Van Deusen.......... 321

Byrne v. Frore...............

v. Prather.......... 329 
C.

C. MI. Ins. Co. v. Clover........ 136

Cabot v. Washington.......... 356

Cadmus v. Jackson............ 135

Cagger $v$. Gardiner............ 102

Cahioon v. Speed............. 530

Cailieteau v. Ingouf.......... 125

Cake's Appeal............... 373

Calderwood v. Tevis.......... 193

Caldwell v. Richards......... 452

v. Walters.......... 150

Calhoun v. Dunning.......... 173 v. Ins. Co... ...... 615

v. Jester............ 345

v. Snyder........... 367

Calkins v. Parker............. 124

Callahian v. Griswold........... 304

Callan v. May .............. 36

Callen v. Ellison............. 131

Callicot, Inre............. 621

Camp v. Baker............. 445

v. Bennett........... 94

v. Gainer............ 443

v. Moseley............ 5:9

Campbell's Case............. 195

Camplell, In re...............s3ir

Camplbell v. Briggs........... 507

v. Bristol.......... 499

v. Brown.......... 133

v. Dutts........... 275

v. Consalus.....257, 275

v. Cross.......... 310

v. Hall ............ 299

v. Hays............ 120

v. Home Insurance Co. 575

v. Howard........4 4:33

v. Maylugh.......... 330

v. MeCahan........117

v. Mesier.......... 5i

v. Phelps.........237, 263

v. Steele.......... 2 is

v. Watson........... 17:2

v. Webb............ 529

Canal Co. v. Walker........... 545

Candee v. Clark............. 232

Canfield $v$. Miller............. 47s

Cannan v. Reynolds........... 99

Cannon v. Brame..........259, 575

v. Hemphill........24, 50e

Cape Sable Co. v. Case......... 506

Caperton v. Schmidt....249, 257, 299

Capin v. Inlabitants.......... 96

Capling v. Herman ............ 414

Carew v. Johnson............484a

Carkbuff v. Anderson.......... 348

Carleton v. Beckford.......... 563

Carlton v. Young............ 442

Carneal v. Wilson...........435, 459

Carothers v. Hartsfield......... 497

Carpenter v. Canal Co......... 157

v. Dexter............ $5: 1$

v. King........... 226

v. Pier............ Is
Carpenter v. Pike........... 5:7

v. Sheldon........ 241

v. Sherfey.......... 43

v. Stilwell.....4469, 4S0

v. Thornton........ 487

Carpentier v. Oakland......12s, $1: 32$

Carr r. Anderson............. is

v. Townseud........... 153

v. Weld............... 475

v. Woodliff........... 273

Carrington v. Holabird....... $4 \$ 4 a, 489$ v. Holly ........270

Carroll v. Hamilton............. 830

v. Watkins............ 403

Carson v. Moore............ 414

Carter r. Carriger..........140, 153

v. Coleman......... 433

v. Clark............ 327

v. James............... 381

v. Miller............. 195

v. Torrance............ 100

Case v. Beauregard .......... $2 \star 9$

v. Ribelin ............ 153

v. State................... 148

Casebeer v. Mowry............ 219

Casement v. Ringgold......... 40

Casey v. Gregory ............. 502

Casler v. Shipman .............311

Casse!l v. Scott............. $4 S 7$

Cassidy v. Leiteh............. 568

Castellan v. Guilmartin......... 163

Castelo v. Bishop............. 109

Castle v. Noyes ......179, 258, 239

Castrique v. Imrie.........594, 595

Castro v. Mllies ................ 312

v. Richardson.... ....319

Catheart v. CommonweaIth.... T9

v. Peck............. 50e

Cathron v. Eade.............. 366

Catlin v. Latson............. 43

v. Robinson .......... 363

v. Underhill .......... 413

Cattlin v. Kernot............... 470

Carrjolle v. Ferie...............319a

Cavan v. Stewart............ 414

Cavanaugh v. Peterson......... 360

Cave r. Daris .............. 501

Cavender v. Smith............. 31s

Cawley v. Leonard............. 89

Cayee v. Stovall............. 363

Ceasar Griffin's Case ......... . 623

Central Bank v. Veasey....... 456

Center v. P. \& M. Bank......... 199

Chace v. Vasquez.............. 34

Chaffe v. Morgan............. 249

Challenor $v$. Niles..........442, 414

Chamberlain v. Carlisle ........ 2st

v. Faris........ 567

v. Gaillard.......273

v. Preble........ 187

Chambers v. Clearwater........ 146

v. Dallars......... 211

v. Handley.........4Stit

v. Hodges.......71, $1 \pm 6$ 
Chambers v. Neal.......... 95|Church v. Crossman ......... 47

v. Robbirs....... $492 \quad$ v. Inbbart. . . . . . . . . 4.14

Chandler v. Drew .........407a $\quad$ v. Witherell......... 531

Chandon v. Maghee.......... 195 Churchill v. Churchill......... 529

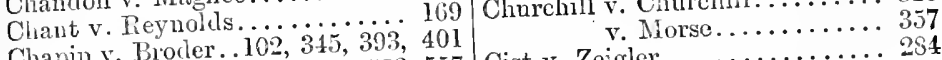

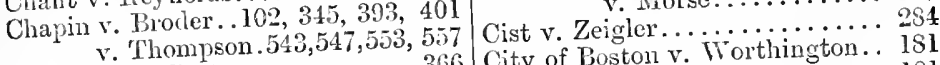

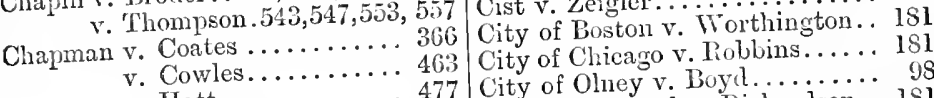

v. Hatt.......... 477 City of Portland v. Richardson... 181

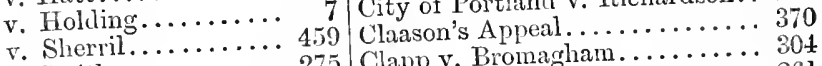

v. Smith ......... 275 Clapp v. Thomas........... 261

v. State.......... 137 Clark v. Bowling. . . . . . . . . 244

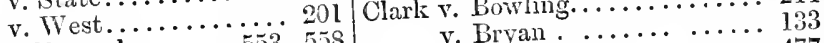

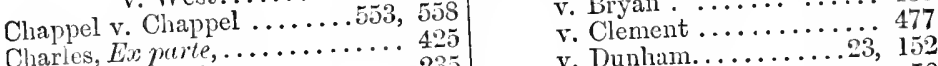

v. Gibson ............ 78

v. Hall ..........46, 70

Charles v. Haskins.................. 101

Chase's Case.............. 270

Chase v. Cheney............ 531

v. Holmes........... 517

v. Iselin . . .....................

v. Kingsland .......... 430

v. Christianson ....... 133

v.Gilman.......... 44

v. Irvin.................... 302

v. Manhardt ..........500i

v. Searles............ $19 \pm$

v. Swain ......................

Cheang-Kee v. U. S......... 309

Cheescinan v. Thorue ........ 400

Cheever v. Mirrick .......... 458 .

v. Wilson ............. Judson

Chemung Bank v. Judson ...... 614

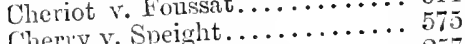

Cherry v. Speight.................. 257

Chesapeake v. Getting ............... 3

v. Swain ........ 3

Chester v. Apperson .......... 400

v. Miller .............4 409

v. Plaistow ........... 459

Chew v. Brumagin............. Gillett 114

Chicago \& N. IV. R. M. v. Gillett 114

Child v. Powder Works....... 221

Childress 8. Maun \& Co........ 59

Childs v. Bisk.............. 50

v. McChesney ............ 210

Chinn v. Hamilton ............

Chipman v. Bowman ......514, 523

v. Martin .................. 169

Chirac v. Reinecker...........

Chittenden v. M. E. Church.... 210

Chitty v. Glenn ............ 210

Choteau v. Nickolls.......... 403

v. Rice........... 28

Choynski v. Cohen...........

Chrisman v. Melne............... 279

v. Harman ............. 126

Christian v. O'Neal .......... 120

Christie v. Hale ............ 374

$\begin{array}{ll}\text { Christmas v. Russell.......50. } & 79 \\ \text { Christy's Adm'r v. Myers...... } & 745\end{array}$

Christy v. Sherman.......... 160

v. Tancred................ 180

Church v. Barker.

v. Lamb. . . . . . . 63, 72

v. Little ... . . . . . . . 435

v. MeComman......... 94

v. Moss . . . . . . . . 4. 422

v. Rowling ........... 215

v Sammons ....................

v. Thompson .......... 125

v. Wolf ............ 178

Clark, Matter of ............ 126

Clark's Case ............ 623

Clarlze v. Hogeman ........... 429

Clarkson v. Morgan. . $\left\{\begin{array}{r}199,200,201 \\ 202,201\end{array}\right.$

Clary v. Marshall............ 203

Clay v. Caperton ............ 5 59

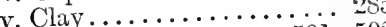

v. Fry ...........501, 502

Clearwater v. Meredith........ 267

Cleaton v. Chambliss .......... $₫ \$ 4$

Clegg v. Dearden ......241, 212, 259

Clemens v. Clemens . . 249, 273, 306

Clement, Ex parte........... 318

Clement v. English ......... 476

Clements v. Berry ........... 403

v. Gerow.....553, 554 , 555

Clemmer v. Cooker........... 575

Cleveland v. Boerum . . ........ 208

Clevinger v. Hill ............ 195

Citch ........... 342

Close v. Close. . . . . . . . . . . . 343

v. Stuart................... 481

Clond $v$ El Dorado Co......... 135

v. Wiley ........... 218

Clubine v. McMiuilen........ 151, 294

Coates v. Coates............ 17

Cobb v. Curtiss............. 293

Coburn v. Talmer.............

v. Smart .......... 210

Cochran v. Cooper .......... 270

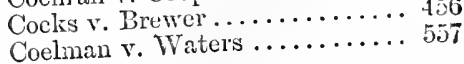

v. Clapin 
Coen v. Frink

Coliee v. Neely

Coffin v. Cottle................. 472 v. McCullough's Adm'r. . 487

Coglan v. Elden ............. 71

Cohen, Ex parte ........... 137

Coit v. Haven . . . . . . . 131, 132

v. Traey ............ 271

Colden v. Kniekerboeker...... 538

Cole v. Butler.............. 120

v. Cole.............. 118

v. Driskcll........... 79

v. Favorite.............. 174

v. Leak .............319a

v. Pemmell

43

Collman's Appeal . . . . . . . . 274

Coleman v. McAnnulty. 103, 140, 153

v. Tennessee......... 601

Coles v. Carter .............. 458

Coliege Street, 1 in re......... os

Collins v. Bennett........256, 279

v. Brook ........... 462

v. Hyslop .......... 50a

v. Lemasters .......... 231

v. Loftus........... 173

v. Mitehell ....140, 153, 176

v. Rose . . . . . . . . . 330

Collinson v. Owens.......... 163

Colquitt v. Donner.........467a

Colt v. Dubois.............. 367

Colton v. Ross. . . . . . . . . . . 608

Colvin v. Baker.............. 356

Colwell v. Bleadley.......... 330

Colyer v. Langfort's Adm'r . . . . . $484 a$

Combs v. Tarlton's Adm'r...... 163

Comeggs v. Vasse........... 425

Commercial Bank v. Martin .... 117 v. Wilson .... 136

Commissioners v. Inspeetion . . . . 253

Commonwealth v. Aluerman.... 313

v. Bakeman .... 318

v. Blood ....565, 587

v. Cook ........ 3IS

v. Dieffienbach .. 193

v. German Soe'y. 531

v. Haas ...... 220

v. Havkins.... 2:25

v. Jaekson...... $31 \mathrm{~S}$

v. Merrigan ....2 216

v. Miller...... 225

v. Miller's $A$ dimr. 220

v. Mortimer .... 269

v. Peters...... 264

v. Pike Ben. Soe. 531

v. Purehase..... 318

Comstock v. Adams.......... 333

v. Crawford........... 524

v. Drohan ............ 184

Condon v. Besse............ $55 \mathrm{~s}$

Cone v. Cotton . . . . . . . . . 123

Conger v. Chilcote.......... 174

Couk v. Lowther ............ 45

Conklin v. Furman ......... 177
Comn v. Fenn .............. $970 x$

v. Scruggs ............ 71

Connable v. Euekland........467a

Comnell v. Stelson .......... 495

Connolly v. Connolly......319 $九, 4 S 4 a$

Comrad v. Ins. Co.......33s, 378, 405

Converse v. MeArthur......... 146

Connay v. Beazley...........605c

Conway v. Ellison .......... 576

Cook v. Allen ............ 307

v. Armstrong ......... 216

v. Brown ............. 565

v. Cook............... 241

v. Darling . . . . . . . . 132

v. Diekerson .......... 87

v. Dillon..........319, 374

v. Mesely.............. 27

v. Pearce ............ 6

v. Thornhill........... 575

v. Whipple .......... 550

v. Trood............. 98

Cooley v. Brayton. . . . . . 193, 332

Coolidge v. Inglee ............ 79

Coombs v. Jordan .399, 318, 357, 383

Cooper v. Bigelow ........... 379

v. Reynolds .......... 119

Cope v. Hnmphries . . . . . . . 464

Copenheaver v. Huffaker...... 193

Copin v. Adamson........... 590

Copp r. McDugall .......... 417

Corbet v. Evans .............. 296

Corbley v. Wilson .......... 319

Corcoran v. Chesapeakie C. Co... 153

Cord v. Southwell .......... 89

Cordier v. Schloss ....549, 553, 557

Corey v. White.........227, 471

Corl v. Rigrs............. 268

Corly v. Wright............ 583

Cornell v. Barnes............ $5 \pm 3$

v. Davis........... So

Corryell, Matter of. .......... 62?

Curwin v. Benham........... 403

v. Freeland ......... 80

v. Merritt.......... 33,517

Corwithe v. Griffing. . . . . . . . 489

Coster's Ex. v. Bank of Geo. . . . 357

Coster v. Peters ............ 481

Cottle's Appeal ..........117, 470

Cotton v. MicGehee............ 93

Countryman v. Boyer......... 420

County of Buena Vista v. I. F. \&

S. Ch................. .500r

Contts v. Walker........... 339

Covell v. Covell.............. 314

Covington \& C. B. Co. v. Sargent 219

Cowan v. Braldwood.......455, 589

Cowart v. TVilliams.......... 168

Cowen v. Toole............. 489

Cowles v. Haynes. . . . . . . . . . 10.5

v. Mereer Co.......... 563

Cowper v. Andrews.......... 298

Cox v. Balger.............. 270

v. Marlatt.............. 441

v. Mobile..............4Sta 
Cox v. Thomas....124, 132, 180, 417 |Cunninglam v. Bucklin....... 530

Cox's Adm'r v. Hill........... 15s v. Calchell....... 485

Coxe v. State Bank ............467a

Cracraft v. Cochran.......... 24I

Crafts v. Clark............. 571

v. Dexter............ 132

v. Merrill.....446,447,480

v. Willinson.........4466

Cragin v. Carleton...........417a

Craig v. Aleorn.............. 87

v. Brown........... 412

v. Steamer Hartford...... 27

v. Wroth............. 97

Craighead v. Wilson.......... $3 \frac{1}{4}$

Crake v. Crake.............453

Crandall, Petition of ......... 622

Ex parte..........6.625

Crandall v. Bacon........497, 526

v. Deach............ 43

Crane v. Brigham........... 177

v. Megimnis.......... 5s6

Crank v. Flowers............ 489

Crary v. Ashley........... 78

Crawford v. Points........... 31

v. Satehwell.... .... 154

v. Simonton.... \{ $\begin{aligned} & 277,435 \\ & 459,576\end{aligned}$

v. White..........4 493

Crawford v. Whittall.......... 450

Crenshaw v. Creek........... 156

v. State.........225

Creppen v. Dexter..............319a

Crisp, Ex parte.............. 391

Critehfield v. Porter.......499, 511

Crocker v. Clements............ 482

Crockett v. Lashbrook.... . .... 297

v. Routon..........259

Croft v. Arthur................ 350

Crome v. Van Nortwick....... 79

Cromwell v. Bank of Pittsburgh. SG

v. County of Sac. $\left\{\begin{array}{r}249,253 \\ 275\end{array}\right.$

v. Craft............ 363

Crooker v. Croolver............. 193

Croppen v. Commonwealth. . . . 623

Cropsey v. Randall........... 403

Crosby v. Jeroloman... . ...232, 238

v. Leng.... ........ . 3336

v. Calhoon...........319a

Cross v. Zane.............. 478

Cronch v. Gridley............. 425

Croudson v. Leonard...249, 613, 615

Crouse v. Derbyshire......... 544

v. Miller............. 263

Crum v. Poss............... 257

Culpepper v. Austin......... 191

Culverv. Rogers............ 402

Cumming's Appeal............ 395

Cummings v. Banks........... 597

v. Bennett.......270a

v. Calgrove......276

v. Cummings.......319a

Cummins v. Kemnedy.........444a

Cunningham v. Ashley........163a

v. Harris........2 2t1

v. Mitchell....... 279

Curry v. Poundtree.......... 583

Curtis v. Ballagh............. 100

v. Bardstown . . . . . . . 270

v. Beardsley .... . . . . 528

v. Cisna's Adm'r. . . . 173, 501

v. Hitchcock. . ......199, 201

v. Lloyd.............270a

v. Root... 361, 373, 382, 475

Cushing v. Arnold ........... 440

v. Shepard............ 139

Custer v. Detterer............ 413

Cutter v. Evans.............. 180

Cuyler v. Ferrill............... 604

\section{D.}

Da Costa v. Villa.............610

Dakin v. Hudson ................ 524

Dale v. Dodurilge........... 302

v. Roosevelt ............ 103

Dalgleish v. Hodson.......... 61s

Dalton v. Bentley ............ 2:10

Daly v. Matthews ..........558, 555

Dame r. Wingate............. 283

Damon v. Bryant........... 529

Damp v. Town of Dame........ 120

Damport v. Sympson........... 289

Dana v. Gill ............104, 201

Danforth v. Thompson ........ 577

Daniels v. Clifton............ 554

จ. Winslow ........... 315

D'Arey v. Ketehum.... 219, 563, 574

Davenport v. Barnett ......... 160 v. Hubbard .......... 282

v. Stafiord .........484a

v. Wright ........ 5 5 5

David v. Smith............ 576

Davidson v. Carroil ............. 2

v. Frew ............301a

v. Heffrom......... 112

v. Myers .......339, 310

v. Murphy ......... 37

v. Root............ 385

Davie v. McDaniel ................310a

Davies v. Cottle ............. 326

v. Davies ........... 57

v. Lowndes............ 416

v. Pettit ............. 407

Davis v. Anable ............... 229

v. Barr ............. 427

v. Benton..........367, 368

v. Brown ..........253, 275

v. Connelly's Ex'r....... 5.59

v. Ehrman ............ 394

v. Headley............56t, 576

v. Lane ............. 461

v. Millburn ............ 4.27

v. Mírris............. 5is

v. Ownsby ........... 360

v. Shaver ......38, $63,67,97$ 
Davis v. Talcott. ......272, 276, 282 De Witt's Appeal............ 395

v. Willourne ......... 17 Dey v. Dox............... 287

v. Woorl .............. 162 Diamond v. Lawrence County... 194

Dawes v. Boylston.......605a, 605b Dibble v. Trulock........... 508

Dawson v. Coles............ 156 Diblee v. Davison............ 455

Day v. Cammeron .......... 57 Dick v. McLaurin.......... 97

v. Hamburgh ......... 140 v. Powell........... 24.5

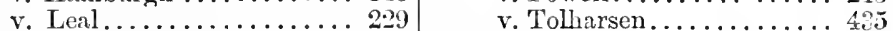

v. Valette........... 276 Dickens v. Bush......... 62

r. Zinmerman .......... 194 Dickenson v. Corlwise......... 24

Dayton $v$ Mintzer............ $122 \quad$ v. Gilliland .......... $3 \cong 5$

Deacon v. G. W. R. R. Co..... 272 Dickenson's Lessee v. Collins... . 394

Deadrich $r$. Harrington . . . . . . 5 I Dickerson v. Tillinghast. . . . . . .366

Dean r. Abel............... 538 Dickinson r. Hayes. . . . . . . . . 2 2.2

v. Nelson ............. 127

v. Thatcher............... 124

De Armond v. Allen .......... 336

Debell v. Foxworthy's Heirs. 199, 205

De Brimont $x$. Penniman ....... 5ss

De Castro v. Richardson ......69, 72

Deckard v. State ............ 623

De Cosse Drissac r. Math tone.5ss, 594

Decouche r. Saretier.........605a

Deek r. Deek................605

De Grieff v. Wilson.. ........ 180

Delacy v. Neuse Nav. Co...... 581

Deland v. Hiett ............. 463

Delah r. Hunter............ 28

Delaney v. Gault .............. 131

Delano v. Wilde.............. $4 S t$

De La Vergne v. Erertson. $\left\{\begin{array}{r}3 S 9,42 \mathrm{~S} \\ 466\end{array}\right.$

Delaware v. Ensign ........550, 554

Deloach v. Myrick........... 474

De Louis r. Jisek .............. 493

Demerritt v. Lyford ........249, 435

Demming v. Weston ........... so so

Dempey v. Bush............. 470

Denegre v. ITaun ..3SS, 393, 442, 4 1.t

Den r. Richman .............. 360

Denn v. Clarke...............4S4

Dennett v. Chick ................. 234

Demning v. Corwin ..........123, 125

Dennis r. Snell............. 458

Dennison v. Hyde ............. 257

v. Williams ......... 482

Denny v. Eddy.............. 464

v. Reynolds ............. 316

Deputy v. Tolias........4S4a, 507

Dequindre $v$. Williams ......... 131

Derly v. Jacques .......5, 261, 330

De Riemer v. De Cantillon ..... 487

Derland v. Harrington's Heirs ... 608

De Saussure v. Zeigler ......... 340

Desebats v. Berquier..........605

Deshong v. Cain............. 89

De Solry v. De Laister.........605a

De St. Lomes v. C. C. \& N. Co.. 2.77

De Tar v. Boone Co.......... 126

De Vendell r. Hamilton........ 360

Devol v. Halstead ............. 234

Dewey r. Latson............. 393

v. Peck............ 249

Dewing v. Sears............ 3

Dieks v. Hatch............ 1:20

Dickson r. Hoff........... 72

Dilly v. Bernard.............. 503

Dimes r. G. J. Canal Co. . . 145, 234

Dimiek v. Camplbell.......... \$3

District Township r. White..... 105

Ditson $v$. Ditson...........5s 2, 5st

Dixon v. Dixon............ 318

v. Judge.......... 121

Doak $r$. Wiswell . . . . . . . . . . . . 299

Doan v. Holly ............97, 102

Doano r. Glem...........70, 72

Dohson v. Pearce..133, 435, 492, 575

Dodd v. Astor.............. 326

r. Brott............ $4: 6$

Dodge $\mathrm{v}$. Coffin ...........511, 56.5

v. $\operatorname{Cog} \operatorname{lin} \ldots \ldots \ldots \ldots \ldots 121$

Dodgson v. Scott.. .......... 326

Dodswell v. Impsey........... 530

v. Stewart......... 89

Doe v. Bonlton................ 5

v. Dennison............ 154

v. Eyton.............. 499

s. Huddart. . . . . . ...... 2St

v. Ingersoll........... $4 \$ 0$

v. Jones................. 405

v. Langs............... 297

v. Leatherby ........... 63

v. NIcDenough........... 117

v. McKnight............ 339

v. Oliver............... 595

ธ. Perlins.............. 71

v. Scolen............... 295

v. Wright............... 295

Doglioni v. Crispin............605

Dollfus v. Frosh........... 325,320

Dominick v. Ecker............ 529

Donaldson v. Thompson.......6 6tt

Donnelly v. Stewart.......... 432

Domner v. Palmer.............. $3 q^{6}$

Donovan $r$. Finn ............ 487

Dooly $r$. Higgins............. 157

Doolittle v. Jon Nans......... 307

Dorente v. Sullivan.......... 126

Dorr v. Brice................ 583

v. Stockdale.......... 163

Dorrance v. Scott........... 150

Dorset v. Manchester......... 410

Dorsey v. Dorsey ..........70, 605a

v. Thompson........18, 484 
Doss v. Tyack.......... $90,484 a \mid$ Dunn v. Dunn............ 569

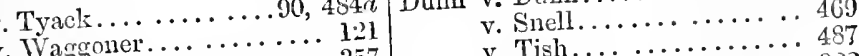

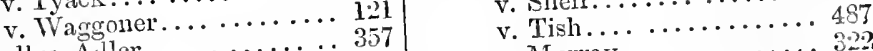

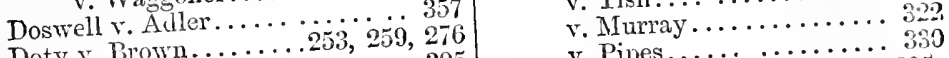

Doty v. Brown.............. 395 v. Pipes............. 3390

Doub r. Mason............. $45 \mathrm{i}, 559$ Duntze v. Levet.............

Doughty v. Fawn ............. 542 Durant v. Essex Co....... 270, 328

Douglas v. Douglas............ 58s, 5s9 Durrett v. Burghardt......... 70

v. Fulda.......... $185 \quad \begin{array}{r}\text { v. Hulse } \ldots \ldots \ldots \ldots \ldots \ldots \\ \text { Dutton v. Shaw } \ldots \ldots \ldots \ldots\end{array}$

v. Woodman................ 315

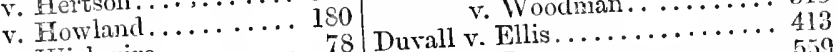

v. Wickwire....... 78 Durall v. Fearson............ 559

v. Tallop.......... 89 v. Waters.......... 350

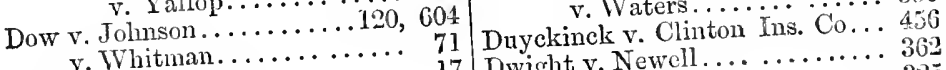

Dowling v. Polack........... 17 Dwight v. St. John......... 325

Down v. Fuller.............. 337 Dwyer v. Goran ............ 329

v. Lent................ 551 5y Dyekman v. Mlayor of N. Y

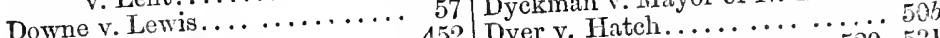

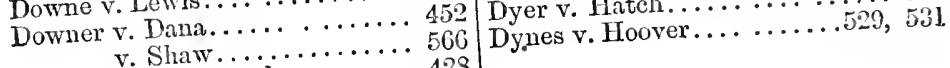

v. S. R. Bank......... 428

Downin v. Sprecker.......... 172

Downing v. Herrick..........

r. Still...........9l, 97

Dows v. Mc.Michael..........290, 330

Doyle v. Hallahan..........299, 280

r. Reilly ............. 286

Draggoo v. Graham............ 126

Drake v. Duvenick............. 487

v. Hanshaw........... 229

v. Mitchell............. 239

Draper v. Stouvenel............ 604

Draper's Ex'r v. Normanl........ 60

Draughan v. Tombeckbee Bank • ${ }_{245}$

Dresser v. Brooks..............500a

Drew v. Clark................

Drexel's Appeal............. 273

Driscoll v. Damp............. 448

Drum v. Kelly ............... 426

Drumm v. Sherman............ 420

Drummond v. Anderson .......... 539

Dryden v. Dryden............ 4934

Dubois v. Dubois.............

Duchess of Kingston's Case $\left\{\begin{array}{l}249,254 \\ 284\end{array}\right.$

Dncommon v. Hysinger.....412, 547

Dufield v. Scott............ 184

Duffy v. Gray ................. 488

Dugan v. MIcGann............... 286

Drke de Cadaval v. Collins .......467a

Duncan v. Bloomstock.......
v. Holcomb. . . . 27, 558

v. Lyon ...............319a

r. Stewart............

v. Stokes............ 273

Dunckell v. Wiles.......2 $20.281,487$

Dunham v. Downer.........553, 588

\begin{tabular}{lr} 
v. Waterman ........ & \\
v. Wilfong........... & 130 \\
\hline
\end{tabular}

Dunlap v. Clements...........

v. Cody ..............

v. Gridden............ 625

\section{E.}

Tames v. Germania T. V. ..... 340

arl of Bandon v. Becker...... 250

v. Crouch............... 20.3

arly v. Garland ............ 163

v. Moore.............. 500

Farnfit v. Winans............. 393

Earthman v. Jones........... 123

Easley v. Mcclinton...........

Easterly v. Goodmall....253, 256, 273

Eastman v. Cooper........

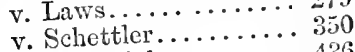

v. Wadlcigh.......... 436

v. Waterman.......... 131

Easton v. Bratton............ 27

. Pickerscill .......... 325

Eaton v. Badger.............. 120

v. Hasty $\ldots \ldots \ldots \ldots . . .575,570$

v. Mary, Matter of ...... 622

v. Ryan.............. 355

Edde v. Cowan.............. 478

.

Edgell v. Sigerson............ 253

Edmiston v. Lyde........... 201

Edmonds v. Montgomery ....... 4.1

Edmondson v. Moseby's Heir $\left\{\begin{array}{r}434 t \\ 492\end{array}\right.$

Edson v. Edson...........99, 489

Edwards v. Banksmith........ 105

v. Edwards.......... 545

v. Handley......... 503

v. MeCuriy .......... 159

v. Osgood ............ 95

v. Stevens........... 320

v. Stewart............ 250

v. Toomer..........133, 155

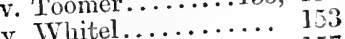

Eqberts v. Wood............ 157

Ehle v. Bingham........160, 279

v. Brown............... 30 
Ehrman v. Kendrik

202

Eidson v. Huff............. 366

Eitel v. Foote............. 135

Ela v. Smith ............530, 531

Elkred v. Hiazlitt's Adm'r....... 414

Elliott v. Hayden.....174, 236, 237

v. Holbrook......... 5 515

v. Morgan ........... 55

v. Page............. 303

v. Peirsol........... 5633

v. Porter.........225, 238

v. Shaw ............ 115

v. Waring. ........ 52l

Ellis v. Clark. . . . . . . . . . 435

v. Dunn ............ $50 b$

v. $\operatorname{Ham} \ldots \ldots \ldots \ldots \ldots \ldots . \ldots 245$

v. Jameson ............417

v. Kelly . . . . . . . . . . . 289

v. MeHenry............ 599

v. Nills.............. 330

v. Smith........... 403

v. Tousley............ 357

Elston v. Robin ............ 355

v. Schilling ......... 112

Elsworth v. Campbell......... 498 v. Noore.......... 145

Elwell v. McQueen.......... 261

Ely v. Fallman........... 124

Emanuel v. The State........ 622

Embry v. Millar. . . . . . . . . . 605

Emerson v. Sansome ......... 302

v. Udall .......... 485

Emery v. Fowler........179, 273

v. Nelson.......... 237

v. Whitwell ......... $72 a$

Emmerson v. Herriford........ 277

England v. Lowis .........398, 401

English v. Savage............ 151

Eno v. Crooke............ 471

Enos v. Smith............. 193

Enswortle r. Lambert ......... 201

Enwald r. Waterhout........ 310

Episcopal Acalemy v. Frieze... . 393

Eroin v. Bualy . . . . . . . . . . . .303ı

Erwin v. Rutherford ........4462

v. Tint............. 100

Eshelman v. Shuman........ 153

Estes, In re............ 350

Fstill v. Taul. . . . . . . . . 219, 278

Etna Ins. Co. v. Aldrich....... 92 v. Swift

Etna Life Ins. Co. v. MicCormack 102

Evans v. Ashby ............. 124

v. Bacon ..............481a

v. Commonnealth. ...... 189

v. Justine .........559," 561

v. Rees ............. 56

v. Sprigr............ 214

v. Tatem..... $\left\{\begin{array}{r}248,434,451 \\ 461,559\end{array}\right.$

Evansville R. R. Co. v. Evans-

ville................ 529

Eversule v. Plank. . . . . . . . . 460

Ewen v. Terry ............4467a
Ewer v. Coffin.............. 561

Ewing.r. Me Tairy .......2S4a, 502

v. Peck ........... 5!1

Exchange Bank v. Allen....... 71

Eyres v. Sedgricki......... 289

F.

Faber v. Hogey ............... 432

Fagg v. Clements........... 5:1

Fanchild v. Holley. . . . . . . . . 229

Fallkner v. Guild............. 129

Falvey v. Massing........... 623

Fanuin v. Thomyson .....277, 281

Farham, Lx parte........... G21

Farmers' Loan Co. v. Walwortl. . 508

Farmer $v$. Romers............ 481

Farx v. Ladd............131, 520

Farrar v. Carmichael......... 456

Farrington v. Payne......... 241

Fash v. Ravesies..........193, 2C6

Fasset v. Tallmadge.......... 477

Fanlk v. Kellum........... 55

Faulkner v. Campbe!l. ....... $5: 2$

v. Davis.......... 172

v. Harwood......... 507

Faxon v. Baxter.............

Fay v. Ames............... 180

Feaster v. Fleming........... 45:

v. Pomeroy......... 133

Fechy v. Shirley...........

Feely v. Shirley............ 83

Fellows v. Fellows........... . 5,9

Felt v. Ternure............ $\Sigma 67$

Felter v. Beale............... 241

Feltner v. Muliner........53a, 251

Fenn v. Dngdale............ 159

Fennell v. Jones...........71, 72

Fenton v. Garlick.......... 97

Fera v. Fern............... 813

Fergus v. Woodworth.... . .4S1, 005

Ferguson v. Crawiord......... 1,3

v. Howard .......... 411

v. Mahon ......455, 501

Terrer's Case...........255, 293

Ferrier v. Buzick. . . . . . . . . . . 204

Ferris v. Medlure........... \&s

Feversham v. Emerson... . . . . . 28:

Few v. Blackhouse. . . . . . . . 456

Fiegler v. Fiegler. . . . . ....... 199

Field v. Btand............. 27

v. Flanders.......... 173

ง. Giblos. ........... 123

v. Samterson .................

Filley v. Cotly........... 121

v. Duncan . . . . . 357, 344, 897

Finch v. Earl of Winchelsea. . . . 357

v. Newham ........... 191

Finnagan v. Manchester....... $5 \bullet$

Finneran v. Lconard.......182,

Finnigan v. Wauchester...... 4 . .

Firebaugh v. Ward.......... 36

First Nat. Bank v. Balcom. . ... 517

First Nat. Bank v. Indianapolis.. $46 \%$ 
First Nat. Bank of Davenport v. Bemrett................. 253

First Nat. Bank v. Rogers.. . ... 473

First Presbyterian Chureh v. New

Orleans.................. 2s7

Fischli v. Fischli........... 314

Fish v. Emerson.........38, 53, 55

v. Lane................. 491

v. Parker............ 201

Fisher v. Fisher............. 229

v. Foote............ 342

v. Ogle.............618

v. Sievres.............. $89 c$

Fishmongers r. Tiobertson......57, 60

Fisk v. Miller.......272, 275, 311

Fitch v. Boyer............. 132

v. Cormell............ 299

v. Scot.............. 7

Fithian v. Monks.............. 135

Fitzhugh v. Blake........... 444

v. Custer........... 133

Fitzsimmons v. Ins. Co........ 618

Flack v. Harrington.......... 530

Flanigan v. Bruner ........... 544

Fleischman $v$. Walker......... 120

Fleming v. Beaver ........... 470

v. Jencks ........... 109

v. Jolnnson.......... 135

v. McDonald .......... $23 \dot{b}$

Fletcher v. Campbell........... 259

v. Combes.......... 61

v. Fletcher.......... 210

v. Holmes ........... 330

v. Weils........... 102

Flichinger v. Hull ........... 516

Florence v. Jennings........... 238

Ilower $\mathrm{r}$. Loyd...............11la

Floyd v. Browne............. 236

v. Harding.......... 357

v. Jane..............484a

Foley v. Jitter ............. 350

Folger v. Colmmbia Ins. Co..... 564

Follet $v$. Hoppe............. $2 s 8$

Folsom v. Carli .............. 355

Foltz v. Pronse............... 260

Foot v. Glover ............... 45

v. Spragne ............ 281

v. Stephens ............. 124

Foote v. Gibbs .............. 270

Footman v. Stetson............. 286

Forbes v. Eden.............. 531 v. Ifyde..........83, 527

Ford v. Babcock.............. 51s

v. Doyle............. 141

v. Ford.............500a

v. Stuart $\ldots \ldots \ldots \ldots \ldots \ldots 422$

v. Surget ...........60 604

v. Tilden ............ 50a

Forder v. Davis.............. 304

Fore v. Manlove............ 429

Foreman v. Carter ........98, 127

Forgay v. Conrad..............

Formen v. Scott................. 9s

Eorquer v. Forquer........70,

Foster r. Chapman .......... 343

v. Evans. . . . . . . . . . 299

v. Glazener......123, 458, 589

v. Jackson........... 379

v. Jones.............. 1:,2

v. Martin........... 108

v. Milliner .......... 252

v. Tucker .......... $22 \mathrm{~s}$

v. The Richard Busteed.. 276

v. Wells .....2 261, 265, 273

v. Wood............ 504

Foulk v. Colbourn ...........432b

Fowle v. New Ilaven........... 241

Fowler v. Doyle ............. 45

v. Kennedy ......... 43

v. Lee............. 493

v. Rickerby .......... 485

v. Savage ........416, 419

v. Shearer........... 285

v. Trebein........... 350

v. Whiteman.......... 131

Fox v. Hoyt.............. 122

v. Hudson .............. 275

v. Woodbury............ 245

Foxcroft v. Barnes.......... 307

Francis v. Cox.............. 100

v. Wells........... 121

Frankin v. Merida .......... 61

Frayes v, Worms .............. 450

Frazer v. Thateher........... 37

Frazier v. Bishop ............. כ.tl

v. MeQueen........... 216

v. Moore............ 220

v. Williams ............. 136

Freeman v. Bass............. 255

v. Caldwell.........478

v. Clnte........... 312

v. Freeman........ 172

v. Tranah.........57, 60

Freer v. Stolenbur........... 172

Frees v. Ford.............. 518

Freet v. State ............ 71

Freligh v. Brink ............. 553

French v. Edwards........... 481

v. Loyal Ins. Co........ 209

v. Neal ............ 161

v. Pease.............. 575

v. Shotwell.......830, 512

v. Tomlin ...........6 604

Friend v. Hamill. ................ 58

Frierson v. Moody ............. 502

Frink v. Frink...........63, 72

Frost v. Dodge .............. 168

v. Koon.......156, 303, 555

v. McLeod.............. 431

Fry v. Malcolm................ 432

v. Taylor............... 608

Fulbright v. Cannefox.......... 513

Fulcher $v$. The State.......... $21 a$

Fuller, Ex parte............3ริa, 55̃

Fuller v. Stebbins ........... 56

Fullerton v. Forton.......... 559

v. Kielliher......... $43 a$

Fulton v. Hanlow........... 271 
Furniss v. Ferguson..........426a $\mid$ Genella v. Rel yea........... 40

Furnold v. Bank of Missouri .... 391 General S. N. Co. v. Guillou.... 5S3

Gerald v. Burthen ............ 5.4

Gere v. Gundlach........... 9l

G.

Gable v. Miller

5.1

Garge v. Brewster ............. 398

v. Rogers ............. 540

Gaines v. Betts.............. $53 a$

v. Kennedy.......... 219

Gainsborough v. Gifford........ 485

Gainty v. Russell ............484

Galbraith v. Neville.......... 592

ऽ. Liclener.......... 50

Galpin v. Fishburne......... 66

v. Page ............ 131

Galusha v. Butler........... 121

Gambette v. Broch........... 150

Gammon v. Inudson......... 89

Ganaway v. The State........ 89

Gandall v. Finn............. 554

Gapen v. Stephenson............ 3ร̃

Garber v. Commonwealth....... 180

Gardiner v. Bowling ..........484a

v. Houghton.......... 599

Gardner v. Buckbee..... $\left\{\begin{array}{l}249,253 \\ 256,273\end{array}\right.$

v. Dering ........... 70

v. Henry .......... 432

v. Jenkins. ..........4487

v. Spivey ......... 339

Gargan v. School District........ 136

Garibaldi v. Carroll ............ 89

Garland v. Tucker ........... 461

Garner v. Prewitt............. 24

Garnett v. Macon........... 1G3

Garrard v. Lantz ............ 363

Garrison v. Savignac ............ 162

Garth r. Campbell ............ 469

v. Ward .............. 191

Garthwaite v. Wentz.......... 46.

Garrey v. Jarris............ 463

Garrin v. Garvin ..............357a

Garwood v. Garwood.....151, 249, 257

Gaskell v. Gaskell .........172, 366

Gates v. Bemnett .............. 273

v. Preston ........256, 330

v. Salmon.............. 28

v. Treat ................319a

Gaullagher v. Caldwell......... 426

Gault v. Wallis ...............484 $a$

Gavin v. Graydin............ 458

Gay $v$. Cheney .............. ti

Gay v. Gay ............. 54 ?

v. Minot............., 140

v. Wells................

Gayle v. Singleton........... 50c

Gear v. Supervisors........... 545

Gebhard v. Garnier.........453, 565

Gees v. Shamnon............ 524

Geisriter v. Śsevler ............... 253

Gell v. Read . . . . . . . . . 313

Gelston v. Hoyt..........613, 616

Gemtaeil v. Rice............. 127
German Church v. Seiber....... 531

George v. Alexander ............ 506

v. Gillespie............ 294

v. Middongh ........ 89

v. Strangs' Ex'r........ 507

Georges v. Ifufselnmidt........ 163 Gerrish v. Brewer............. 207

v. Juhnson........... 105

v. Pratt............ $26 \mathrm{I}$

Geyger v. Story ................. 6.3

Gherke v. Jod.............. 112

Giblin v. Dougherty.......... 199

Gibbs r. Hooper................. $48 \pm$

Gibler v. Trimble...........201

Gibson v. Chotem ............ 69

v. Nicholson......... 419

v. Wilson ............ 71

Giddens v. Lea ................ 509

Giffard v. Hort ............. 172

Gifford v. Thorn............... 500

Gilbert v. Graham .............. 251

Gildwell r. Spaugh ......... 124

Giles v. Nathan ............. 05

Gillespie v. Conn. Ins. Co....... 570

v. Van Ėmont ....... 303

Gillilan v. Spratt ............ 201

Gilliland v. Seller's Adm'r...... 120

Gilman v. Contra Costa Co..... 15

v. Foote ............. 233

v. Gilman........... 503

v. Lewis............. 580

v. Rives ........... 267

Gilpin v. Page............. \&7

Gingell v. Home.................. 603

Girardin r. Dean .......... 160, $2 \pm 9$

Gist v. Daris ........186, 249,270

Glass v. Glass .................. G

v. Wheeler............. 257

Glading v. Frick............ 7

Gleason v. Peck ............. 05

Glemn v. Brush............. 3

Glidden v. Packard............

Globe, The.............. 011

Glover v. Iralman............... 126

v. Moore........... 150

Glukauf $r$ Reed........... 329

G. R. R. J. Co. v. Mossop..... 247

Goar v. Maranda ............ 121

Goddard v. Benson............ 4 (i)

v. Gray ............ 595

Godefroy v. Joy ........... 400

Godîrey v. Godfrey ............. 394

Goix v. Low ............. 618

Goldhawk v. Duane........... 405

Goldsberry r. Carter.......... 108

Golightly v. Jcllicoe ......... 27.

Gondy v. Hall................ 193

Gooch v. Atkins............. 47s

Gooch's Case .............. 250

Goodall v. Iarris............ 45 
Goodell v. Dlumer .......... 357 Green v. Branton........... 150

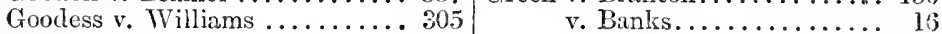

Gooding v. Hingston.......... 605 v. Burle............... 475

Goodnow v. Smith..........418 v. Clarke........... 169

Goodrich v. Bodurtha......... 218

v. City ........... 267

v. Jenkins .......... 576

v. Gale $\ldots \ldots \ldots 240,242$ 1

Goodwin, Ex parte............ 620

Goodwin v. MeGhee............ 195

v. Williams.......... 366

Groodyere v. Ince ........... 484

Gordan v. Farrar ............. 531

Gore v. Stackpole........... 205

Gorman, In re.............. 620

Gormerly v. Chapman.......... 350

Gormly v. AIcIntosh.......... 121

Gorrill v. Whittier.............. 145

Gossett v. Howard............ 124

Gossom v. Donaldson .......... 202

Gott v. Carr................... 503 v. Powell $\ldots \ldots \ldots \ldots, 482,454$

Goncher v. Clayton ........253, 330

Gould v. Evansville.......... 267 v. Hayden .......... 216 v. Lockett ...............3G $a$

Gourand v. Gourand............ 154

Gourlay v. Hutton........... 542

Gouverneur v. Titus............ 359

Gove v. Cather ..............361a

Gover v. Doheny ...............360

Governor v. Read.......... 462

Grace v. Wade .............. 366

Graceland C. Co. v. People ..... 135

Gracier v. Weil.............. 109

Graff v. Kipp............. 394 v. M. \&. M. Trans. Co... 97

Gragg v. Richardson .........447

Graham v. Gordon ............ 407

v. Grigg $\ldots \ldots \ldots \ldots \ldots$. 57

v. Long............. 150

v. Lymn ..........66, 67

v. Maingay........... 249

v. R. R. Co.......... 158

Grand T. R. W. Co. v. Amey... 16

Granger v. Clark ........... 133

Granice, Ex parte................. 620

Grant v. Bledsoe.............. 401

v. Button ............ 272

v. Schmidt.............. 69

Graves v. Flowers ........... 163

v. White........... 275

v. Woodbury............. 4227

Gray v. Brignardello..........

v. Dougherty............ 249

v. Gillilan............. 284

v. Larrimore........... 127

v. MeNeal........... 517

v. Palmer............ 40

v. Pingry ..........247, 460

v. Swan.............6 618

Greathearl v. Bromley.......... 326

Greathouse v. Bromley......... 249

Greely v. Smith.............. 260

v. White.............. 460 v. Hamilton... ...... 101, 330

v. Marks............ 355

v. Massie........... 507

v. New River Co....... 417

v. Pittsluurg R. R. Co... 69

v. Sarmiento.. .245, 570, 575

v. Slayter........... 197

v. Van Buskirk........ 573

v. White............ 191

v. IVinter............... 24

Greenabaum v. Elliott............ 286

Greene v. Daily.............. 428

v. Greene............. 334

v. Haskell............. 4s9

Greenlaw v. Greenlaw ........... 580

Greenleaf v. Maher............ 4 S9

Greer v. Mayor of N.Y........... 111

Gregg v. Cooke............. 121

Gregory v. C. G. \& C. R.R. Co... 144

v. Ford............ 498

v. Haynes.......... 140

v. Nelson............ 2

Grill v. Vernon.............. 112

Grier v. Jones................. 325

Griflie v. MoClung........... 236

Griffin, In re............... 623

Griffin v. Cunningham.......90, 117

v. Eaton............. 575

v. Reynolds........... 157

v. State...........6. 620

Griffith v. Clarke.............. 149

v. Frazier..........819a

v. Ogle............ 58

Grignon's Lessee v. Astor........ 124

Grimes $\mathrm{s}$. Morris.............. 122

Grimke v. Mayrant.......... 442

Griswold v. Hill.......57, 216, 377

v. Jackson......... 159

v. Rutland......... 95

v. Stewart........337, 415

Groning v. Ins. Co............ 615

Grout v. Chamberlain........... 163

Grover v. Grover............ 412

Groves v. Brown............ 167

Grumon v. Raymond.......... 530

Guerin v. Danforth............ 154

Guernsey v. Carver.......... 238

Guest v. Warner............ 271

Guilford v. Love.............. 124

Guirard v. Heysinger.......... 154

Guiteau v.Wisely........ 366, 48.1

Gulick v. Loder............456, 575

Gumn v. Howell............ 505

Gunther v. Blight.............. 589

Guthrie v. Baskline......... 462

v. Howard .......... 150

v. Lowry........... 575

Gwinn v. Carroll........... 124,182 v. MeCarroll........... 183

v. Williams......... 513 
H.

Inackett v. Connett.......... 2\%9

v. Manlove............. 336

Hackworth v. Zollars.... . . . . 282

Hagler v. Mercer............. 61

Hahn v. Hart. . . . . . . . . . . 489 v. Kelly.... $\left\{\begin{array}{r}7 \mathrm{~S}, \mathrm{~S} 3,123,121 \\ 125,130,132\end{array}\right.$

Haight v. Green........... 106

Hair v. Jowe. . . . . . . . . . . . . . 486

Halcombe v. Loudermilk ...... 4. 4 .

Hale v. Angel . . . . . . . . . . . 432

v. First N. B.......... 428

v. Huse ........... 322

Haleys v. Williams.... . . . . . 348

Hall v. Hamlin............. 336

v. Harrison. . . . . . . . 217

v. Holmes............. 100

v. Hudson............. 35

v. Jack............ 183

v. Lanning. . . . . . . . . 574

v. Nelson.............201

v. Odlber............ 2:0

v. Sands............ 350

v. Thayer............ 146

v. Tuttle............ 53

v. Williams. . ..562, 564, 573

Hallett v. Righters........98, 127

Mralock v. Jaudin ............ 538

Ialloway v. Platner.... .....366a

Hallowell v. MeDonnell . . . . . .227a

Hamburger v. Easter . . . . . . . . 340

IIamilton $v$. Boardmore... . . . . 358 v. Cutts.... ..186, 187

v. Quimby .......... 27:

v. Wright......... 12s

Hamlin v. Beavan........... 196

v. MeCahill .......... 510

Ilammer v. Pounds.... . . . . . . 25s

Hammet v. Blount...........17la

Hammock v. NeBride......... 324

Hampton v. McConnell . . . .559, 563

v. McDonnell........ 133

Hammatt v. Wyman. . . . . 472, 480

Finmon v. Smith........... 559

Hammond v. Howell. . . . . . . . 530

Jimpson v. Edelen........363, 364

Iarpton v. Levy........... 366

Itance's Appeal.............. 313

Hancock v. Lopez. . . . . . . . . . . 304

v. Welsh.......... 256

IIandly v. Sydenstricker ..... 367

IIanford v. MIcNair. . . . . . . . . . 109

Hanly v. Adams............ 443

v. Real Estatc Bank.... . Ts

IIanna v. Guy ............. 216

Hannaford v. Hunn. . . . . . . . . . . 294

Tanover v. Turner ........5s0, 605c

Fauschild v. Stafford....... . . 454

Haisson v. Armstrong.... . . . . . 171

v. Wolcott.......... 102

Harbeck v. Vanderbilt ....472, 473

Harbin v. Chiles............ 560
Harbor v. P. R. R. Co........ 101

Hard v. Shipman. ......... 133

Hardin v. Lee................ 91

Harding v. Alden.....550, 582, 584

v. Allen.......... 579

v. Cowing. . . . . . . . 549

v. Hale........... 269

v. Larkin........... 181

Hardy v. Broaddus... . . . . $1+\mathrm{H}_{\mathrm{S}} \iota, 4 \mathrm{4} 9$

Hargrave v. Hargrave......... 100

Hargis v. Morse...........117, 124

llargus v. Goodman.......... 311

Harkness v. Austin. . . . . . . . 97

Harlan v. Berry.............. 235

Liarmon v. Dynnm........... 24

v. Gonld........... 529

Harper v. Harvey. . . . . . . . . 462

v. Hooper........... 284

Harrington v. Glenn.......... 441

v. Higham ....... 43

v. Mc Naughton .... 245

v. Sharp.......... 367

v. Wofiard....... 126

Harris, Matter of . ..........6. 621

Harris v. Billingsley............ $7 \mathrm{~L}$

v. Clark ........... 29

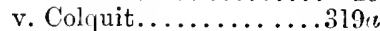

v. Dunn. . . . . . . . . $2 \% 1$

v. Hammond.......... 323

v. Hardeman .......... 563

v. Harleman .... . . . . 5 564

v. Harris.........219, 273

v. Lester............ 130

v. Miner............ 317

v. Plant \& Co.......... 159

v. Saunders............ 165

v. Vaughn..........2:3

v. Yomman ............ 513

Harrison v. Farnsworth........ 26

v. G. N. R. Co..... 6

v. Harrison. . 416, 506, 584

v. Meathorn........ 60

v. Morehouse ........319๕

v. Nettleship ........4487

v. Southern M. Co. .... 409

v. Stewartson....... 173

v. Wood..........20 231

Harshey v. Blackmarr. . 128, 499, 509

Hart v. Lazaron. . . . . . . . . . . . 497

v. Marshall........ 193, 209

Harteau v. IIartean... . . . . 580, 5s

Hartman, Ex prevte......... 620

Hartman v. Olvera............ 104

v. Osgood........... 150

Harvey v. Large.........261, 265

Harvey v. Montarue... . . . . . 206

v. Seashol..........484a

v. Tyler......... 123

v. Waklen.......... . . 403

Harvie v. Tumer............ $302 a$

Hasketh v. Ward............4 414

Hassell v. Hamilton........... 565

Flatch v. Amonlt........... 50e

Hathaway v. Heminingway..... 135 
IIanghey v. Wilson.......... 123 Jerrington v. People........ 517 Haughtwont v. Murphy... 191, 195 Iieriter v. Porter........... .11 Ilaner's Appeal............ 91 Ifelsey v. Turbut........... 193

Hausen v. State of WVisconsin...6.2 Hershey v. Dennis.......... 655

Iavelock v. Rockwoul.......693 IIervey v. Elmonds.... .91, 93, 121

Hawbridge v. Du La Crouce... 499 Jiess v. Beekman... . . . . .53a, 231

Hawes v. C. C. W. Co........276,

v. Hathaway ........... 435

v. Walthan .......... 101

Hawkins v. Bowie........... \$4. v. Lambert. . . . . . . . 165 v. State.........225

Hawks v. Truesdell......... 271

Haycle v. Green.... . . . . . . . 272

Hayden v. Bucklin....... 195, 202 v. Hayden .......... 489

Hayes v. Shaw............ 153

v. Ward............ 470

Haynes v. Meeks............ 122 v. Ordway ........... 328

Hays v. McKee............. . 78

v. Miller........66, 401

v. Yarborongh......... 50u

Hayward v. libblins. . . . . . . . 435

Head v. Gervais..........430, 408

Healy v. Root.............. 217

Heany v. Parker............407

Heard v. Lodrce............. 1so

IFeath v. Frackleton... ...... 238

Heathcote v. Ving.......... 57

Heatherly v. Hadley ..........4 460

Hefferman v. Porter.......... 531

Hiegeler v. Iicuckcll.......61, 72

Heil and Laner's Appeal. ... . . . 347

Helirinck's Aypeal........... 448

Heiiig v. Lemly . . . . . . . . . . . 409

Helm v. Sbort............. 16

Ilcimminway v. Irickes........ 539

Hempinill v. Carpenter........ 393

Henderson v. Gibson......... 93

v. Henderson. $434,591,594$

v. MicVay........ 427

v. Mitchell. .......503

v. Ping.......... 398

v. Reeves..........2 231

v. Stamford . . . . 221, 5,0

Ilendrick v. White.......... 520

Hendrichs v. Whittemore....... 120 v. Decker........ 458

Hendrickson's Appeal ...... . 370, 423

Hendrickson v. Hinckley ....... 501

IIenly v. Soper. . . . . . . .434, 593

Fienry v. Ady.............411

v. Cline.............604

v. Davis..........249, 253

v. Keys.............4784

Hensley v. Force. . . . . . . 559, 500

Hepburn v. Dundas.......... 270

v. Sewall.......... 237

Herbert v. Rowles............ 100

IIermandez v. James.......121, 497

IIerrick v. Smith...........624

Herring v. Polley........... 45

Herrington $v$. Herington... 195, 203

v. Cole..........57, 123

Iesse $r$. Mann .............. $3: 7$

Ifettrick v. Wilison.......... 103

Ileurstat $v$. Minir............. 137

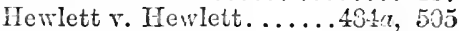

Hibbard v. Eastman. . . . .493, 492 Hilberd v. Smith........ 359, 517

Hibshman v. Dulleban....... 249

Hickey v. Stemart. . . . . . . . 193

Hickman v. Jones............ 604

Hidken, Estate of............ 163

Hidklen v. Saunders.......... 476

Hirbee v. Bowers............ 13

Higlon v. Comway . . . . . . . . . 5

Higgins, Ex parte.......... 232

Higgins' Trustees........... 353

Higfius v. Peltzer........... 150

Hillrcth's Heirs v. McIintyre's

Devisees............... 113

Hilly v. Hartrid e........... 502

Hill v. Armistead............. det

v. Bouman........... 253

v. Bowyer.............. 503

v. City of St. Louis....... . 83

v. Cimp.......166, 109, 11 .1

v. Freeman............ 2,3

v. Harris........... 515

v. Hill ............. 511

v. Hoover...............

v. Huckabee...........6 60t

v. Stevenson........... 151

v. Town of Sunuerland .... 93

Hills v. Sherwood. .......21, 231

Hillsborough v. Nicholls....... 299

Hine v. Hussey............ 143

Hines v. Jacols............. 413

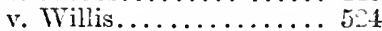

Hinesly v. Hunn's Adm'r...... 4.1

Hinsen v. Wall..........52, 571

Einton v. Brown............ 73

v. MeNiell......295, 237

v. Odenheimer........ 4.2

v. Towers........... 570

Hirchew v. Hamilton. . . . . . . . 2 23

Hiriat v. Ballon............ . 1

Hirschfield v. Franklin....... 43

Hitchcock v. Aickens.... . . . . . 559

Iitchen v. Campbell.......... 255

Hitehings v. Hollingsworth.... 16

Ilitson v. Daveuport......... 3

Hix v. Davis.............. 285

Hoard v. IVilcox............. 45

Iobbs v. Duff......27 $7,278,427$

Hobs v. Helming........... 618

Hobson v. Yancy............. 160

Ilodges v. Ashurst........... 79

v. MicCabe.......................

v. Templar......... 56 
IIodgman v. W. P. R. R. Co... 495 Howard v. Consins. . ......... 450

Tiodsail v. Stallebrasa........ 211

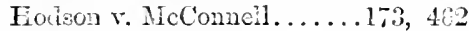

Forkman's Alpeal........... 850

Hoinman $r$. Hofman ........ 503,583 v. Porter..........2 202

Hoffmire v. Hoirmaa .......... 493

Foifming v. Grove........... s 8

Hogg $\mathrm{v}$. Charlton............ 215

Hogh $v$. Waters............. 231

Wonet v. Wallace...........

Holbrook v. Champlin ....... 4t5 v. Nurray. ....... 136

Follen v. Garrett............ 35i

Holderstaffe r. Saunders........45tu

Ioliand v. Trotter...........449

Irollard r. Hateh............. s01

Hollingaworth v. Bageley....... 117 v. Barbour...... 127

Hollister v. Dillon........... 478 v. Moliister........ 582 v. The Jutges.....63, 72

IIolman's Ileirs v. Bank....... 584

Fiolmes v. Campbell........124, 452 v. Carendolet ........ 295

v. Guion........... 217

v. Iolmes....564, 580,583

v. Honie.......... 97

v. Remsen...457, 605a, 605h

Holroyd v. Breare........... 531

Holt $v$. Alloway............. 570

Holzinger v. Elwwards . . . . . . 473

Homer $v$. Brown............. 261

v. Fish............287

Hood v. State..............562, 580

Hook v. Hood.............. 218

Hoover y. Mitchell.............. 262

Hopf $\mathrm{r}$. Myers................. 240

Hoplins r. Dana........... 262

v. Hopkins ......... 172

v. Howarl.......444, 5.58

v. Lee .....218, 257, 2.8

v. McLaren...........201

v. Woodward........ 435

Hopkinson v. Shelton............ 460

Horis v. Lockhart.............. 604

v. Jones.............. 193

Horner $v$. Doe.................. 133

v. Zimmelman........ 481

Fonsley v. Gasth............ 369

Foskins v. Hallenbaek...........484a

v. Johnson.........357a

Hotehliss v. Cutting ........40, 131

v. Nichols........2 271

Houglaton v. Lee............. $35 \overline{5}$ v. Mariner........... 214

Honllen v. Sinith............. 530

Houlditeh v. Doneral. ........595, 598

Iinouse v. Mullen.............27Gr

Houston v. Mosgrove......260, 264

v. Woleott.........5503

How $v$. Dorscheimer ......... 5 5077

Howard v. Albro............. 310

v. Clark.........129, 5ะ9 v. Kenneiy ......... 1:1

v. Kimiali $\ldots \ldots \ldots \ldots 2.3$

v. Mitenell.........

v. Norh.......... 1i;

v. Smith .......... 319

v. Thonton......... 10t

Howe . Biadley...............

v. Inderenuenee Co..... Buj

v. Martell............4t:

Howell v. Goolrieh............. 282

v. Harrell.......... 110

v. Miorean........... Gi

v. Shands........... 5

Howerton v. Spragne.......... 4t5

Ilowes $v$. Austin............. 251

Howlett v. Tarte........... 853

Hoyt v. Howe.............. 5

v. Hiulson .............. 475

v. Martense.......... 20

Hoxie v. Wirht........... 559

Hoy v. Allen................ 835

Hubbard $v$. Jubois........... 155

v. Hobson .......... 506

v. Martin..........

v. Plitlips......... 499

Inbbell v. Troadwell's Heirs . . 435

v. Hubbell.......... 55 t

Hudson $v$ Carman........... 17

v. Hudson...........

Huffer $v$. Allen............. 70

Hugh v. Higgs.............. 484

Hughes v. Cornelins ........... 013

v. Trahen ......... 4:3

v. U. S............ 80

v. Whittaker........ 193

צ. Wood.............. 102

Hughson v. Daris............ 890

Hulett v. Whipple........... 560

Huil v. Deatley's Acim?.......... 203

ช. Hull.............. 5

Hyls v. Buntim ............. 117

Humbolt M. \& NI. Co. v. Teri'y . 5,5

Humiston $v$. Stainthorp ....... 80

Humplreys v. Browne ......... 250

Hund r. Fogr. ............

Hungerford's Appeal.......... 272

Hunt v. Bates.............. 29,

v. Boyier............

$\checkmark$ Brearling..............45

v. Dutcher........... $4 \tilde{y t}$

Hunt v. Grant. . . . . . . . . . 3 it

v. Haven...........

v. Hunt.......602, $502: 33$

v. Lyle .............. 5.0

v. MeClanahain's Hei's... 211

v. San Francisco . . . . . . 589

Innter v. Davis ............... 2.?

Hunter v. Lester ............ $1 \geq 9$

y Stewart........... $=5$

Iuntington v. Plakeney........

v. Einch........90, 97

v. Grantland ........ 39

v. Jervett. . . . . . . 159 
l'untington v. Zeigler........ $70 \mid$ Jackson v. Andrews ......... 193

Huntt v. Townsend ........358, 545 v. Bartlett........463,477

Huot v. Page................ 70

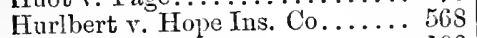

Hurlburt v. Reed............ 100

Hurlbutt v. Butenop......... 157, 193

Hurst v. Lithgrow . . . . . . . . . 352

v. Means............ 26s

v. Sheets .............467a

Hurt v. Moore.............. 50e

Huslis v. Maples ........... 465

Hustin v. Ditto ........... 95

Hutchins v. Gerrish.......... 413

v. Ridlle ........4467a

Hutchinson v. Bank of Wheeling. 319

$$
\text { v. Bours ........ } 42
$$

v. Fulghum ....... 55

Hutton v: Williams ......................

Hyde v. Curling ...........61, 68 v. Noble . . . . . . . 236, 237

Hydenfelt v. Towis ........ 145, 146

I.

Iles v. Elledge........... 573

Jilinois \& St. V. R. R. Co. v.

Coub

Ilsey v. Wilson . . . . . . . . . . . 564

Imlay v. Carpenter .......... 245

Ind. Ins. Co. v. Thomas........

Independent School District v.

Schreiner...........105, 111a

Independent School Jistrict v.

Verner.....................

Intianapolis B. \& iV. Ry. v.

lisley ............. 451

India Hubber Co. v. Hoit. . . . . . 461

Ingle v. McCurry ........... 495

Iuglehirt v. Lee ............ 506

Inglehart v. Mayer .......... 506

Insmalram v. Gildermester ...... 43

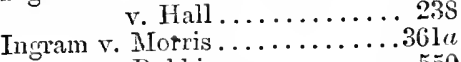

v. Robbins ......... 550

Inbahitants v. Holbrook........ 181 v. Limerick. . . . . .63, 6S

Inloe's Lessee v. Harvey . . . . . . 193

Invau v. Niead . . . . . . . . . 418

Imes v. Wylie............ 531

Innis v. Roane . . . . . . . . . 249

Inos v. iVinsper............ 530

Inslee v. Hampton. . . . . . . . 240

Ins. Co. v. French . . . . . . . . 154

v. Morse ........... 568

Irwin v. Jeffers............ 484

Isaac v. Swift . . . . . . . . . . 394

Istacs v. Clark . . . . . . . . . . 283 v. Price.......... 126

Ives v. Finch . . . . . . . . . . 4.89 v. Phelps........... 463

\section{$J$.}

Jackion v. Allen........... 355

v. Anderson........4 466 v. Benedict........... 379

v. Cadwell .......... 480

v. Chamberlain . . . . . . 366

v. Chapin .......... 348

v. Crawford......... 407

v. Cullum.......... 407

v. Dickenson ......... 195

v. Diffendorif. ... . . . 295

v. Griswold......174, 180

v. Jackson .......... 586

v. Law ........... 384

v. Lodre........... 256

v. Tarkier .......... 354

v. State........... 225

v. Smith .......... $\$ 9$

v. Tuttle.......... 171

v. Warren ........193, 206

v. Williams .......... 348

v. Wood ............. 258

Jacob's Appeal............... 373

Jacobs v. Burgwyn.......... 91

v. Hill........... 180

v. Pieree............. 186

Jacobson v. Miller.........249, 253

Jacoby's Appeal . . . . . . . . . . . . 350

Jacqnes v. Withy.........379, 476

Jacquette v. Hergunon........ .9, 560

James v. Cavit. ............ 286

v. Kirby ............ 408

v. Wortham ........... 594

Janney v. Smitl. . . . . . . . . 279

Jarboe v. Smith............... 262

Jarmin v. Saunders.......... 472

Jarvis v. Driggs. . . . . . . . . . . 330

v. Rathbone......... 4t2

Jeffery v. Fitch........... 495

Jefiries v. Morgan........... 557

v, Sherburn.......... 348

Jenkins v. Eluredge......... 71

v. Fahey........... 301

v. Frink.......... 538

v. Robertson......... 330

Jenks v. Stebbins.......... 517

Jenness v. Jenness............ 582

Jennings v. Ashley........57, 59

Jennison v. Hapgood.......... . 487

Jenny v. Glynn............ 95

Jessup v. City Bank.......... dst

Jevne v. Osgood............ 502

Jewett v. Wardleigh.........4463

Jilsun v. Stebbins ........... 487

Jolmson v. Baker............ 521

v. Beazley .....122, $319 \alpha$

v. Butler........... 217

v. Coleman . . . 489, 495,497

v. Ildred........... 111

v. Everett........... 28

v. Titzlugh ........ 245

v. Gillett.......... 51

v. Jacob............ 172

v. Jones............ 495

v. Loop............ . 459 
Johnson v. NIc Ausland....... 555

v. Mitchell. . . . . . 309

v. Nurphy . . . . . . 272

v. Pomeroy ......... 152

v. Provincial Ins. Co... 223

v. Rolvertson ........ 173

v. Snith . . . 259, 274, 317

v. Taylor........... 104

v. Unversaw........ 492

v. White.....259, 260,460

v. Wright.......63, 133

Jolley v. Foltz............ 515

Jones' Case. . . . . . . . . . . . . . 317

Jones, Ex prive...........56, 71

Jomes v. Eelt.............. $50 c$

v. Slate........... 150

v. Chase............319a

v. Chiles........... 171

v. Davis............ 57

v. Fales............ . 259

v. Frost............608

v. Gellis............ 135

v. Henry ...........478 $a$

v. IIurges . . . . . . . . . 530

v. Jamison. . . . . . . 220

v. Jones............ 524

v. Kip............ 538

v. Leech............ 112

v. Lusk. . . . . . . . . . . 109

v. MicNarran ....... 197, 195

ヶ. HeNcal.......236, 237

v. Mlinowne........... $50 c$

v. Myriek's Ex'r....... 380

v. Petaluma. . . . . . . . . 329

v. Ranson ........463,407

v. Ritter's $\Lambda$ dmir. . . . . . . 180

v. Robiuson...........608

v. Russell. .............. 108

v. Walker........37, 261

v. Weathersiee........ 310

v. Webl........... 380

v. Willianson......498, 500

v. Wilson ..........24, 469

v. Wright.........338, 377

Jordan v. Dennis.............. 121

v. Petty........... 66

v. Rolinson .... . . ... 596

v. Siefert........... 200

v. Wilson .......... 427

Jorrensen v. Griflin .........40, 41

Joseph's Adm'1 v. His Legatees. . 50

Joslin v. Coffin. . . . . . . . . . .484t

Jonct v. Mortimer........... 105

Joyce v. Joyee............. 537

v. NicAvoy .......... 513

v. O'Toole........... 45

Judd v. Gibbs............417a

Juclge v. Fillmore........... 452

Judlkins v. U. M. I. Ins. Co..... 575

Judson v. Lake. . . . . . . . . .8319a

Julian v. Teal. . . . . . . . . . 319

v. Ward........... 89

Junkin v. Daris.............. 414
K.

Kaine, $E x$ parte.......... 324

Irane v. Cook. . .....436, 562, 563

v. Fisher.........253, 263

v. Pock Riv. Co. . . . . . 307

Karns v. Kunkle........... 453

Kasson v. People............ 477

Katz v. August. . . . . . . . . . 325

Kauff v. Messner............. 280

Liean v. Riee............. 577

Kieaton v. Bank........... 98

v. Mulligan.......... 320

Keel v. Jordan.............. 89 a

Keane v. Fisher........... 180

Keanney's Case.............622

Kíeen v. Jordan............ S9

Keenan v. Miller........... 200

Keene v. Clark. . . . . . . . . . . 200

Kichoe v. Blethen.......... 40

Fieith v. Estill.............. 4

Kellogg, Ex parte........... 621

Kellogg v. Cowing . . . . . . . . 553

v. Fancher.......104, 195

v. Gilbert ......... 477

v. Schuyler ......245, 425

v. Sweeney .......... 3

Kelly v. Crapo .............. $605 b$

v. Donlin............. 249

v. Matthews.......... 79

v. Mckibben .......... 82

v. liembert. . . . . . . . . 530

v. Van Austin .......129, 533

Kelsey v. Bradbury . . . . . . . 227

v. Murphy.......218, 270

v. Ward .......... $\Sigma 53$

v. Wiley ........... 121

Kelton $v$ Jaeobs................... 201

Kemp v. Cook.......70, 90, 94, 102

v. Squires............ 100

Kendall v. Hodgkins. . . . . . . . 553

Kennedy, In re........... 4

Kennedy v. Lowe.........553, 557

v. Young.......... 71

Kenner v. Caldwell . . . . . . . . . .505 $a$

Kennersly v. Orpe ......... 179

Kenn's Case................. 610

Fent . Gerrish .................... 310

v. Ricards........482, 492

Keokuk Co. v. Alexander...... 272

IIepp v. Fullerton .......... 126

Iierby v. Chadwell. .......... 112

r. Elliott........... 410

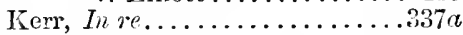

Iierr v. Blodgett. . . . . . . . 157

v. Bowie............ 102

v. Kerr....133, $562,563,583$

r. Nioore.............6 608

v. Strat................. 7

Ferrick v. Bransby .........6608

Kerrigan v. Ray........... S9

Kester v. Stark............ 307

Key v. Goodwin ........... 57 
Iiers r. Granniss . . 454 / Kronshage v. C. II. \& St. P. Ry.

Fiblile v. Buttler........78, 79

Tieffer v. Ehler............. 191

Fichmer v. Dengler .. ....... 448

v. Watts......... 4 - 8

Iiersted 5 Avery ........... $5 \mathrm{C} 3$

Kilburu v. Wootworth....... 573

File v. Lumrkin............ 113

Eilheffer v. Kerr . . . ..217, 249, 310

Kimball y. Munger......... . 467

King v. Bill . . . . . . . . . . . 192

v. Cliase ...256, 257, 273, 284

v. French ........... 557

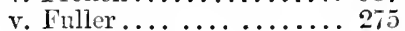

v. Goodwin ........... 476

v. Grimes............. 170

v. Harris............ 381

v. IToare......216, 231, 235

v. Merchants' Exchange... $5+2$

v. Norman ........... 180

v. Poole ............. 121

v. Randall ........... 528

v. Savory ............... 3ミ0

v. Staffort...........15, 20

v. State Bank .......... 72

Kingham v. Cowles.........4 411

Kingsbury v. Iniestra ....... 593

Fingsland v. Forest. . . . . . . 492

Kingsley v. Davis........... 231

Iinnier v. Kinnier.......... 576

Iinney v. Ogtlen's Adm'r. . . . . 485

Kinsey v. Ford............ 459

Iinsley v. Hotmes . . . . . . . . 405

Kirby v. Fitzgerald . . . . . .553, 557 v. Woot

Co................... 259

Kuchenbeiser v. Beckert. ....... 513

I.

Ladd v. Blnnt. ........474, 475

Laulley v. Creighton.......... 3:0

Lafen v. Dessesart............ 485

La Farge v. Herter. . . . . . . . . . ¿20

Lafayette Ins. Co. v. French.... 568

Laidley v. Kline.......... $357 a$

Laithe v. MeDonald..........11 ia

Lamar v. Browne............... cota

Lamb v. Shays............. 355

Lambert v. Parnell. . . . . . . . . . . 450

Lamblin v. Nance........... 550

Lamen v. Kedgewin......... . $气 07$

L'Amorenx v. Crosby.......... 513

Lamping \& Co. v. Hyatt. . . . . . . 540

Lamprey v. Nucld........... 152

Lamson v. Bradley........... 95

Land v. Elliott.............484a

v. Keirn.............. 258

Lander v. Arno........... 156, 253

Landerson v. McKinson....... 50 '

Lamels v. Branclt. . . . . . . 318, 503

Landon v. Ferguson.......... 313

Landrum v. Farmer......... $₫ 37$

Lane v. Bommelman........... 48

v. Ellinger.......... 69

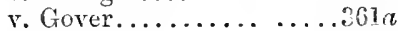

v. Lucllow........... 353

v. Nelson............ 117

v. Wheless............ 103

Kirklan v. Brown........... 286

Firkland v. Smith.........412

Kirkmatick v. Stingley ....... 259

Kirlisey v. Bates............ 79

Kiser v. Winans............. 501

Kissam v. Jough .......... 57

Fitchen v. Carmpiell ...... 179, 259

Titchins v. Hutulins.......78, 136

Kitsmiller v. Kitehen ........ 120

Flink v. Stomer Cusetta...... 16

Enam v. Nariboro .......... 187

Knickerbocker v. Smith....... 515

Iniglit v. Atkinson......... 249

v. Incomber......... 494

v. Tielcon.......... 236

Finowles $\gamma$. Lawton .......... 15t

Iinott $r$. Cunninglam ....... 236

v. Jarboe ............ 126

İnowell, Ex parte ........... 379

Lnowies $v$. Davis .......... 530

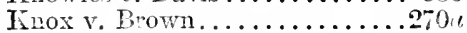

v. Maldeborongh ....... 241

Snox Co. Bank v. Doty ........ 97

Fohn v. Lovett. . . . . . . . . . . .500*

Innder v. Hufiman.........416

Konitzl.y v. Meyer........181, 597

Iirmer v. Holster.......... 117

v. Iebman ............

Kriess $v$. Seligman.......... so

Langdon v. Bnllock.......... 113

v. Raiford .......... 327

Lance, $b x$ prrte............. 6.5

Langley v. Gull. . . . . . . . . . . . 155

Laming v. Carpenter... $\left\{\begin{array}{l}3.38,517 \\ 552,553\end{array}\right.$

Lansing v. Eddy ........... 502

v. Quackenbush. . 478, 478

Iapham v. Briggs........... 501

Larrabee v. Baldwin......... 4

Larriner's Appeal . . . . . . . . . . 360

Lartigue v. Jaldwin. .......... 180

Latham v. Wiswall. . . . . . . . . . 609

Lathrop v. Brown.........356, 377

v. Stuart .........452

Lathrop \& Dale's Apreal . . . . . . 391

Latimer v. U. P. I. R. Co. . . . . 5es

Latterett v. Cook.........461, 565

Lattimer v. Ryan. . . . . . . . . 5 540

Laval v. Jiowley ............. 480

Law v. Jacksona. . . . . . . . . . $38_{4}$

Lawer v. Bandow............ 230

Lawler's Teirs v. White. . . 127, 132

Lawless v. Hackett. ........ . 5jt

v. Reese........... $84 a$

Tawrence, E.c parte......... 475

Lawrence v. Belger....... . . 405

v. Fast.......... 89

v. Ilodgson $\ldots \ldots \ldots \ldots .57$ 
Lawrence r. Hunt. . . . $169,258,2 \pi 3 \mid$ Lindell v. Leggett . . . . . . . . 253

v. Jarris. 559, 500, 563, 504 Linder v. Mouroe............. 506

จ. Lippincoti ....... 350 Linden v. Burke.............. 10.5

v. Martin......... 425 Lindsey v. James.............. 503

v. Milivankee....... 253 Linehan v. Hathaway ......2939, 304

v. Richnoind........ 57 Ling $r$. ling \& Co.......... 557

v. Vernon......255, 259 Lining v. Bentham ............ 8.39

v. Ware......... 164 Linn v. Patton..........200, $3 \pm 0$

Lawrence S. B. v. Stevens..... 212 Linion v. Hurley........... 432

Lazell v. Miller............. 285 Lintz v. Thompson............. 4.99

Lazier v. Westcott....414, 591, 597 Lippincott v. Wilson......... 37.

Lea v. Lea............... 257 Lipscomb v. Grace............ 216

LeChevalier v. Lynch........ 159 Lirette v. Carrane............... 810

Leclair v. Globenski.......... 1:1 Lister v. Mundell............ 95

Ledyard v. Brown............ 432 Little v. Alexanler ..............337a

Lee v. Baird.............. $492 \quad$ v. Birdwell ........... 50

v. Clark .............1st, 417

v. Figg.............. 557

v. Gardner............ 153

v. Giles............... 432

r. Kingsbury .........257, 303

v. Salinas.............. 193

v. Stone .................. $3: 5$

Leese v. Sherwood............ 17

Lect v. Grant ............... 109

Lefferson v. Dallas........... 36t

Leggett v. Doremus........... 250

Lesrante v. Francisco......... 286

Lewtuen v. Gouveneur .....277, 501

$\mathrm{L}=\mathrm{i}$ h $\mathrm{v}$. Linie.............. 7

Leiper v. Erden.............. 495

Leitch v. Wells..........194, 212

Lehind v. Marsh.............. 2 21

Lendall v. Pinfold............. 236

Lentz v. Lamppugh.......... 382

Leonard v. Bryant........... 337

Leslie v. State............. 319

Lesslie v. Richardson.......... 484

Lester v. Hoskins............. 455

Leviston v. Swan ........47, 70

Levy v. Joyce................ is

v. Thompson.......... 318

Lewis \& Nelson's Appeal ....... 258

Lewis v. Albred................319a

v. Armstrong ..........284a

v. Darling............ $57: 2$

v. Dutton .............. 5 23

v. Gamarge............. 463

v. New............... 197

v. Oithan's Adm'r. ..... $\approx 5$

v. Owen............. 599

v. Polmer .............. 480

v. Smith.........150, 303

v. Watrus .............. 47

v. Webb............ 90

v. Woodruff ............. 493

Lick v. Stockdale............. 87

Ligon v. McNeil.............. 4982

Ligon's Adu'l' v. Rogers........ 74

Lightsey v. Harris ........517, 520

Limericl, Inhabitants of ..63, 63, 72

Lincoln $\mathrm{v}$. Flint ............

v. 'Tower. $459,560,565,573$

Lind v. Adlims ...............

v. Cook .............. 95

v. Currie........... 527

v. Harrey........... 391

v. Moore.............. 590

v. Price............... 435

₹. The Bank .......... 379

Littledale v. Roljinson......... 390

Littlefield v. Nichols.......... 377

Littleton v. Rieharlson ........ 187

Liverpool M. C. Co. v. Hunter.. 600

Liviugston v. Bishop ......... 236

v. Jortan ...........6 604

Livingston's Petition ............ $3 ? 5$

Livermore v. Hershell. ........ 205

Lloyd $r$. Burr............... 153

v. Maddox ........... 583

v. Malone........... 513

Lock r. Nash ..............270a

v. Norbone............ 168

Lockwood v. Bates.........193, 427

v. Wildman.......4 469

Logan v. Herbert............ 356

v. Hillecrrass......... 497

Loibcl v. Stampier............ 411

Lombard v. Bayard............ 401

London v. Clerke............. 419

Long v. Burnett............ 524

v. Long...........2S1, 461

v. Morton............ 171

v. Tieville.............. 213

v. WVebb.............. 275

Longmeal v. Maple............ 270

Longwell v. Bentley...........357a

Longwworth v. Screven.......... 95

Loomis $r$. Brown............ 17

v. Riley............... 193

Lord Bagot v. Williams ......... 276

Lord Montagne v. Dudman..... .43ta

Lore v. Trunan............. 260

Loree v. Reeres............. 100

Loring v. Fol rer.............. 140

v. Ilsey........... 15

v. Monsficld............. $2 \S \tilde{5}$

Lorraine v. Long ............. $\approx s 1$

Lorton v. State............ 225

Lotliam v. Henderson........... 618

Lough s. Thornton............. 7

LonisvileC.\&C.R.R.Co.v. Letson 568 
Lounsbury v. Purdy

Lonthrop v. South worth . . . . . . . 80

Love v. Fairfield............. 424

v. Gibson ................ 150

v. Harper............. 353

v. Truman............ 249

v. Tivaltz............. 253

Lovergood v. White.......... 463

Lovejoy v. Murray ..... $\left\{\begin{array}{l}1 \mathrm{S4}, 236 \\ 237,477\end{array}\right.$

v. IVebber .......... 95

Lovell v. Felley........... 79

Lovett v. German Church ..... . 4S4

Low v. Adams. ................ 3S2

v. Dore.............. 5.3

v. Duncan..........4467a

v. Mussey.........24s, 597

v. Pratt.............. 197

Lowler v. Mayor of N. Y..... 92

Lowe v. Alexander.....518, 519, 521

v. Lowe . . . . . . . . . 5033

Lowry v. Orr................ 350

Loyd v. Mansel .............4S $4 a$

Lucas v. Curry ............ 1s0

v. Governor ........... 180

v. Nichols .......... 502

v. Spencer .......... 503

Ludlow v. Dale............615

v. Johnson ......6.65, 123

v. Fiild... 16, 191, 202, 205

v. Fiamsny ......127,487

Inmbard v. Abbey .......... 357

Lntz v. Fisher.............. 503

v. Kelly ............ 564

Lyle v. Braclford............ 195

Lyles v. Bolles .............. 119

v. Robinson ......... 131

Lyman s. Brown ............ 220

Lynch v. Kelly............ 53r

v. Iione Gas Co....... 39

v. Swantion ........... 253

Lyon r. Ingham Circnit . . . . . . 32S

v. Lyon ............ 580

v. Northrop............ 563

v. Roblins ......... 515

v. Sandford.......... 162

\section{$\mathrm{Mr}$.}

MI. \& M. Bank v. Boyd ....... 129 v. St. John. . 129, 5-19

Macarthey v. Decaix........6610

Miacrionald v. Bovington. ........227a

MIacilougal v. Young.......... 407

Mtackay v. Gordon..........563

Macky v. Coates.... ......... 154

Matiall v. Thelluson.......... 7

Niglee v. Collins.........218, 231

Mlagher v. Howe............. 79

Iilagnun v. Ins. Co...........6 61う

Marratl v. Hardy . . . . . . . . . . 2St

\$Iaguire v. Magnire... . . . . . .5S2, $5 \mathrm{~S} 1$ v. Tyler............ 218

Mahoney $v$. Van Winkle......... 302
Mailhouse v. Inloes........... 97

Mlaiuwaring v. Tompleman.... . 366

Miajors v. Cowell ........174, $19 \overline{5}$

MIakepeace v. Lukens......... 7.3

Maley v. Shattuck.......... $61 \mathrm{~s}$

Mallett v. Buteher... . . . . . . . 502

v. Foxeraft......... 30 t

v. Uncle Sam Co...... 521

Malloney v. Horan.... . . . 2.19, 3030

Mallory v. Clark............ 515

Mandeville v. Perry.......... 78

v. Reynolds.......4435

Manhattan Co. v. Evertson.... 350

Mamgait v. Deas.... . . 159, 163, 303

MIankin v. Chandler..... ..... 603

Manley v. Manley........... 5st

Manly v. Hunt............. 363

Mamn's Appeal ............ 3:3

Mann v. Atna Ins. Co....... 92

v. Iiussell........... 79

Manning v. E. C. R. iv. Co..... 596

v. MIcClnrg......... 80

v. Thompson. ....... 596

Manny v. Harris ........... 273

Mansfield v. McIntyre. . . . . . . . . 584

Manwaring v. Iouns... . . . . 459

Marine Ins. Co. v. Joung. . . . . . 243

Marks v. Cowles.........432, 484

v. Marriott.......... 321

v. Reynolds.......... 545

Marlatt v. Clary............417

Mtarr v. Wetzell........... 562

Marriner v. Smith.......... 355,512

Marriott v. Hampton. .....272, 286

Marsh v. Burroughs. . . . . . . . . 2:3

v. Pier. . . 233, 247, 294, 458

Marshal v. Shafter .......... 299

Marshall v. Aiken............ 220

v. Croom ........... 161

v. Fisher.......... 151

v. Pough .......... 156

Marshalsea, The Case of . . . 120, 529

Martens v. Gilson............ 355

Martin v. Barnhardt........... 52

v. Crow ..........2, 35

v. Dryden........... 363

v. Hewett. . . . . . . . . . 601

v. Ives........... 217

v. Kanouse.......... 87

v. Kemnely.......... 259

v. Mott........... 523

v. Nicholls ........... 593

v. Parsous.......495, $496 a$

v. Stikes............ 191

v. WVeyman ........... 513

Marvel v. Manonvier......... 499

Marx v. Fore............. 561

Miason v. Bull...........407, 408

v. Eldred. . $231,232,233,459$

v. MeNamara......... 106

v. MLessenger........ 3.4

v. Richerds.......... 532

Mass v. Shannon............ 450

Mrasser v. Strickland.......... 180 
Massey v. IVatts...

v. Westcott......... 366

Massingill ๙. Downs. . . . . . .338, 339

Masson v. Salvy........... 193

Masterson v. Gibson. . . . . . . . . .

v. Masterson. . ..... 450

v. Matthews....... 1:48

Mastick v. Thorp..481, 486, 502, 505

Mastin v. Duncan.... . . . . . 183 v. Gray............. 133

Matheson's Adm'r v. Grant's Adm'r............63, 72

Matthews v. Duryee.......... 400

- v. Houghton... . . .38, 53

v. Menedger........ 236

Matthis v. Town of Cameron.... 112

Max, Ex parte............620

Maxwell v. Goctschins........ 117

v. Owen........... 430

v. Stewart......475,576

May v. Jameson. ...........5 500

Naybee $v$. Avery............. 319

Mayberry v. McClurg......... 489

Mayer. Blease............ 430

v. Foulkrod........... 159

Mayes v. Woodall...........512

MIaytield v. Beunett......... . 130

v. State.......21 $a, 50 a$

Mayo v. Ah Loy............. 185

v. Foley.......... 135

Mayor $v$. Lamb............ 27

Mayor of Macclesfield v. Gee.. . 16

Mayor of Norwich v. Berry ..... 56

Mays v. Ifassell............ 56

Medrthur v. Dane........... 121

v. Starrett....... 79

Mtc.Ansland v. Pundt..........484

McBain v. MicBain............. 304

McCaffery $v$. Carter.......... 241

MeC'ahill v. Equitable L. I. Co. . 123

McCall v. Hitcheock.. ........ Is

r. Lenox . . . . . . . . . . . . 398

McCartney v. Kittrell. ......... . 50a

McCarver v. Nealey.......... 463

McCauley v. Fulton.......... 130

v. Hargroves....133, 562

McClanahan's Heirs v. Henderson 121

MeClellan v. Corntwell.... . . . . 54

MeCloskey v. Wingfield........ 153

McClung v. Beirne........... 470

McClure v. Gulf R. R. Co..... 530

v. McClure......... 30t

McCollum v. Eager.......... 34

McConologue's Case . . . . . . . . . . 324

McCormack v. McClure... . . . . 205

v. Wheeler.....66, 74

McCormick v. McClure. . . . . . . 484

McConnell v. Wilcox......... 531

McCoy v. Hazlett. . . . . . . . . . 463

v. Nichols........... 163

McCreary v. Casey........... 281

McCreery v. Everding. . . . . 153, 185

v. Forston........ 131

MIcCulloch v. Doak. . . . . . . . 105
McCullough, Ea parte....... 620

McCullough v. Clark. . . . . . . . 327 v. Doak......... 103

McCurdy v. Robinson......... 231

McCutchen v. MIilier... . . . . . . 194

AcDaniel v. Fox............

v. Goodall........ 464

McDermott v. Clay.......... 501

McDonald v. Butler........... 432

v. Crandall. ...... 355

v. Falvey......... 95

v. Ingraham. . . . . 245

v. Wilkie.........5\%9

MIcDonald's Succession. ... . . . 436

MicDonall v. MIcDonall. . . . . . . . 457

MeDonough's Succession. . . .252, 253

McDowell v. MIcDaniels........ 549

McElfatrick v. Taft. . . . . . . . 5.9

McElmoyle v. Cohen. . .559, 563, 575

Mckwers v. Markley.... . . . . 16:2

McFadien v. Worthington.... . 300

MIcFarland v. Derbis!ire...... . 695

McFarlane v. Harrington. . . . . 412

McGee v. Overly............ 237

McGehee v. Shafer.......... 23:

McGill, Ex parte........... 621

MeGilvrey v. Avery........221, 2.21

McGregor v. McGregor........ 5i2

McGuinty v. Herrick.......272, 279

McGuire v. Gallagher......... 4

McFarland v. Hall .......... 21

MeHany v. Schenck.......... 283

McInloe v. Hazleton.......... 497

MeIntosh v. Chew ......... . 45

ร. Jarvin .......... J

v. Lawn ..... . . . . 239

MeIntyre v. Miller.......... 4,2

McJilton v. Love... . . . . . .482, 5.59

McKice v. Gilchrist...... . . . . 350

McKeller v. Bowell............ 180

McKelway $v$. Jones............98, 499

Mclíenzie v. L'Amoreux. ... . . 157

v. Ramsay......... 524

McKim v. Odom........... 461

McKimley v. Tuttle.. . 105, 109, 113

McKinzie v. Harding..........38ira

McKissick v. McKissick..... . 3:9

McKnight v. Dunlop...311, 316, 403

McLaren $v$. Kehler........5 50 , 575

MIcLean v. Cook ............ 5.

v. Hungarin .......... 2 .5

v. Meek............ 163

v. State........... . 57

v. Stewart.......... 70

McLendon, Ex rarte......... 104

McLendon v. Dodge............ 505

v. Jones.......... 89

McLennan v. McMonies. . . . . . . 227a

Mc.Ianus v. Stevens.........50

McMillan v. Baker........... 95

v. Richardson........ 121

v. Wenner.................... 363

McNair v. O'Fallon ............ 283

v. Tolei............ 509 
McNeary v. Castlebury........ 7 $72 a$

McNeil v. Bean.............. 338

v. 10 th N. B........ 194

McPherson v. Cunlifí.........319a

v. Forrester....... 432

v. Housel......... 103

McQueen r. Fletcher......... 407

Mchise v. Mattoon........... 570

MIcRearly v. Iiogers.....25, 237, 25l

McVicar v. Beedy........... 219

Meacham v. Dudley.......... 112

Mead v. Deputy Marshal of Va.. 623

v. Mead............. 481

v. Mitchell.......305, 306

Meadow v. Rhyme...........467a

Means v. Means............ 72

Nearns v. G. T. R. W. Co..... 90

Mechanics' Bank v. Gorman..... 370

IIedkloweraft v. Huguenin...... 610

Meech v. Allen.............. 395

Meek v. Mathis............. 27

Meeker v. Ransselaer.......... 57

Meeks v. Vassault...............163a

Mleem v. Pucker.............500

Melia v. Suffolk S. B.........319a

Meily v. Wood...............357a

Mellop v. Duane.........573, 574

Micllon's Appeal.............. 363

Memphis v. Brown ........... 69

Menterbach v. Hopkins........ 469

IIenifee v. Myers............. 502

Micrcein v. People............. 324

Mercier v. Chace.............. 264

Merehants' Bank v. Mariposa... 261

Merchants' Ins. Co. v. De WVolf . 570

Merle v. Andrews......26, 35, 96

Merriam v. Whittemore....... 253

v. Woodcock......... $\Sigma 5$

Merrick v. Baltimore.......... 97

v. Mayhue......... 71

Merrill v. Sheiburne.......... 90

v. Souther.......... 427

Mërrin v. Lewis............. 302a

Merritt v. Campbell.......... 262 v. Putnam.......106, 112

Merry v. Bostwick............ 349 v. Hallett............. $3 \tilde{5}^{2}$

Mersereau v. Yearsell ........... 258

Mervine v. Parker............. 290

Metcalfe is Case............... 16

Mietcalf v. Pulversoft.......... 191 v. Metcalf.........61, 62

Metz v. State Bank........... 347

NIetzler v. Kilgore............ 370

Mevix v. Antlony............. 193

Neyer v. Butt..............505re

Nichael v. Boyd .............. 368

Michaux's Adm'r v. Brown. .... 349

Mickel v. Hidis..........130, $319 \imath$

Mickels $v$. Haskin............... 475

Míco v. Morris.............. 218

Middlesex Banl v. Butman..219, 5SS

Midd'eton v. Sinclair.......... 350
Milam County v. Robertson..... 70

Milburno, Ex parte.......... 8st

Mills v. Bough.............. 5

Miles v. Caldwell............. 299

v. Jones............. 492

v. Viliiams.........57, $5 \mathrm{~s}$

Miller v. Bank of B. C.....544, 545

v. Dungan............. 435

v. Earle.........556, 557

v. Ewing..........131, 155

v. Grice.............. 529

v. Ker'shaw.......... 195

v. Manice.........284, 458

v. MIcMIanus. ........... 252

v. Morse.......... $4 S 5$

v. Rhoads........... 184

v. Rice.............. 505

v. Royee............ 71

v. Seare............. 580

v. Sherry........195, 197

v. Smith's Ex'r......... 461

v. Snycler..........6.623

v. White........177, 450

Miller's Estate..............605a

Mlilligan, Ex parte........... 6 93

Milliken v. Whitehouse...... 177

Mill \& Co. v. Dickson.......... 93

Mílls v. Duryee.451, 461, 559, 563, 575

v. Hoag............. 24

v. Martin..........133, 529

Millspaugh v. McBride........ 100

Milne v. Noreton..........60.6

Milnor \& Co. v. G. R. R. \& B. Co.4Sta

Mims v. West................ 104

Miner v. Wallace.............. 392

v. Warner........... 350

Mincr's Bank v. Roseberry .... 336

Minier v. Saltmarsh........... 413

Jinle v. NicNamee........... 295

Minkhart v. Fankler...........

Minor v. Mech. Bank ......... 43

v. Waiter.............2s0

Nitchell v. Allen ............... 826

v. Hnckett..... $\left\{\begin{array}{l}422,489 \\ 463,478\end{array}\right.$

v. Hamilton......... 448

v. Hawley.......... 524

v. Libbey .............. 236

v. MIayo.......... 202

v. Neiriilan..........605

v. Meniey........... 132

v. Robertson........ 295

v. Finnkle............ 123

Moale v. Hollins............ 292

Molyneux v. Seymour........... 573

Monroe v. Douglas............. 597

v. May ............. 355

Montgomery v. Anderson....... 31

v. Andirews...... 475

v. Barnett ........ $55 \mathrm{~s}$

v. Byers ......... $1 ? 3$

v. Carpenter ..... 78

v. Ellis ......107, 114

v. Samory........ 309 
Montromery Co. v. American E.

Co................. 114

Moody v. Grant........... T2

v. Harper.........21s, 368

v. Townsend ......... 519

Moomey $v$. Maas.........126, 156

Mioor v. Ames.............. 530

v. M. C. Co.......... 19J

Hoore v. Byers........... 363

v. Dial. ........... 487

v. De Valle.......... 79

v. Donglas...........612

v. Ellis............ 120

v. Gamble........... 459

v. Granger.......... 355

v. Houston.......... 1:0

v. Ireland.......... 421

v. Janner's Adm'r. . . . . . 608

v. Letchford. . . . . . . . 3:9

v. Rioberts......... 58

v. Spackman.......1S2, 573

v. Towle........439, 440

Mora v. Zuzac............. 120

Moran v. Jessup. . . . . . . . . . . 294

Mordecai v. Lindsay......... 34

Norgan v. Bliss............ 2j1

v. Burnett.......... 131

v. Chester .......236, 237

v. Doulge............319a

v. Nanee.......... 309

v. Flumb...........260

v. $\operatorname{Sims} \ldots \ldots \ldots \ldots \ldots . \ldots 30$

v. Thorne......4402,409

Morrisv. Denton............ 502

v. Hollis..........4.46

v. Lneas. . . . ......... 180

v. Mowatt.........350, 357

v. Ward...........

Morrison v. Citizens' Bank . . . . 121

v. Daphman........ 72

v. Freneh......... 350

v. Unclerwood ........ 570

จ. Zeigler......... 7

Morrow v. Bremniger.......... 348 v. Weed......... $66,5: 2 \cdot 3$

Morse v. Marshall...........311, 5.9

v. Presby........... 120

v. Tappan.......4, 149, 149

Norsell v. First N. B. ........ 348

.Iorton v. Grenada......... . 450

v. Root............ 17

Miosbey v. Wall............. $2 s 1$

Moseley v. Cocke............. 141

Miosely v. Mosely............ 334

v. Tuthill ................ $60 t$

Moses v. Bradley ............ 319

v. Julian........145, 116

v. Mayor of Miobile......45t

Mosher v. Heydriek.......550, 5jl

Mosly v. Wall............. 281

Moss v. MeCulloumh .......... 177

v. Oakley ........... 177

Mosseaux v. Hrigham.... . . . . 109

Moulin v. Ins. Co. . . . . .563,5,5

Mower v. Hill... . . . . . . . . . 108

v. Kip ......34I, 392, 464

Iowry v. Chase........566, 571

Moye v. Petway..............

Ioyer v. Hinman............. 364

Indd v. Rogers.... . . . . . . . . 50

Muir v. Craig................478c

v. Leitch. . . . . . . . . . 383

Mulford v. Cohn...........48ta

v. Estudillo ......... 475

v. Patterson......... 350

Mulhollan v. Scoggin ......... 108

Mulholland v. Heynemian. . . . . . 106

lílvey $ヶ$. Gibbons........... 180

IIumford v. Overseers......... 180

v. Stocker......... 216

Munn v. Sturgess............. 565

v. Worrail. ............ 459

MIunro v. Allaire............ 821

Murloch v. De Vries........... 497

Murly v. Newman............ 499

Murfee v. Carmack .......... 370

Murphy .. Longworth......... 482

v. Winton .......... 566

MIurray v. Baker . . . . . . . . . 44 v. Ballou.........194, 491

v. Blatchford ........ 19j

v. Judson . . . . . . . . . 553

v. Liiburn . . . . . . . . . 4.

v. Lovejoy . ....... 1St, 256

v. Miuray ........... 460

In rell v. Snith . . . . . . . . . . 249

Inscatine v. Miss. R. R. Co... 459

MIussell v. Morgan............48ta

Myers v. Davis ............. 1:6

v. Fegaly .......... 37

v. Overton .......... 1:6

v. Tyson........... 403

Myrick $v$. suelden ............ 201

N.

Nardin v. Battie.......... 479

Nash v. Church..........127, 207

National Bank v. Bryant ...... 2. 23

v. Jaģers...... 151

Nations v. Johnson.......4.84, 569

Neafie v. Neafie.........207, 529

Nieall v. llill ............. 23

Neals v. Jeter .............. 216

Neil v. Meßillan ........... 57

Neilson v. Neilson. . . . . . . . . . 450

Needham v. Brenner .......... 159

Nelson v. Bagby .......... 217

v. Cromeh .......... 228

Neusbaum v. Keim............... 557

Nev. \& Sac. Canal Co. v. Kidd.. 79

New England Bank v. Lewis.... §59

New Jersey Franklinite Co. v. Ames............157, 173

New O. \& C. R. R. Co. v. Bos. worth ............... 153

Newcemb v. Dewey .......4.45, 498

ง. Drummond ...... 107 
Newcomb v. Peck

$560 \mid$ O'Brien v. Heeney............ 159

Newlon v. Hieaton ............. 574

Newman's Lessee v. Dincinnati.. 87 v. Chapman 194, 263 v. Meek ...... 492 v. Wood ...... 320

Newton, Matter of............ 623 Neyland r. White .......... 16 Niigara Ins. Co. v. Rodecker.105, 112 Nimtic Bank v. Wemnis ........ 356

Nibblett r. Scott............ 578

Nichols v. Brilgeport .......7S, 79 v. Burton .......... 232 v. Chapman ......... 369 v. Hewitt ........... 546 v. Kribs............. 554 v. Nichols ........... 102 v. Stewart............. $50 b$

Nicholson r. Patterson .........4 487 Nickleson r. Ingram .......... 267

Niles v. Battershall ............ 43

Nill v. Comparet ............ 329

Nims v. Vaughn ............. 281

Nispel v. Laparle............ 267

Neff v. Pemoyer ........... 127

Newburg r. Mumshower......... 136

Newcomb r. Newcomb....... 580

Newcomb's Ex. v. Newcomb.... 124

Newell v. Carpenter .......... 272

Newton v. Hook............. 330

Noble v. Cope................ 327 v. Holmes ............ 529

Nodine v. Greenfield ........... 306

Foel v. Wells ............... 608

North v. Mulge.........232, 557 v. Pepper............ 59

Norris v. Denton...........507, 553

v. Ifume........... 507

Northam $v$ Gordon........... 427

Norton v. Beaver ........... 392

v. Birge ...... 193, 201, 209

v. Cook.............605b

v. Doherty............ 312

v. Jamison ........... 153

v. Williams ........... 366

v. Whitney .......... 397

Norwell v. MicHenry.......... 86

Norwood v. Cobb.....412, 563, 576 v. Kenfield.......... 121

Novelli v. Rossi ............... 595

Nowlan v. Geddes ........... 267

Noyes v. Butler .......... 133, 563

v. Loeb .............. 491

Nuckolls v. Irvin. ......103, 104a

Null v. Moore.............. $40 \mathrm{~s}$

O.

Oadles v. Oarles ............ 6

O. \& M. R. R. Co. v. Shultz.... 517

Oaknley v. Aspinwall .......146, 233

v. Giles............ 154

Obenchain v. Comegys ...........

O'Bierne v. Lloyd..............

Ocean Ins. Co. v. Ficlds........ 491

Ochsenbein v. Papelier......... 59l

Ochus v. Shellon ........... 146

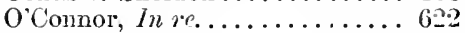

O'Connor v. Millen.......... 71

v. Varney .......... 240

Oddy v. Boril .............. 614

Odell v. Odell ............... 499

Oetgen v. Ross ................ 299

Offutt v. Offutt.............. 204

Ogden v. Larrabec........... 489

Ogilvie v. Knox Ins. Co........ 36

Ogsbury v. La Farge......... 270

O'Hara v. Stone .............. 355

Ohio \& M. T. R. Co. v. Whecler. Ees

Olanyer v. Elanchard ......... 3

Old Dominion Granite Co. v.

Clarke................ 347

Olds v. Glaze............... 576

Oliver v. Pray................484a

v. Tormes..........c05 $a$

O'Malia v. Wentworth........6.620

O'Neal v. Kittridge.......... 432

Orentt v. Ramney.......... 570

Ordinary v. Meclure............ 51

v. Wallace.......... 330

O'Riordan v. Walsh.......... 59

Orman v. Rilley.............. 121

Orme v. Roberts............ $360 a$

O'Rourke v. O'Connor........ 337

Osborn, Ex parte ............ 121

Osborn v. Toomer............. 40

Osborne v. MIoss.............. 384

Osgood v. Maguire...........605

v. Thurston ......442, 444

Osterhaut v. Roberts........ 236,237

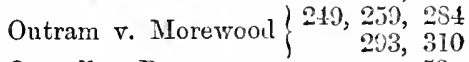

Overall v. Pero............. $53 i$

Overton v. Stevens ........... 516

Owen v. Bocrum.............. 320

v. Glover............. 476

Owens v. Alexander............ 154

v. Ranstead ........... 495

\section{P.}

P. F. W. \& C. R. R. v. Chicago. 48

P. M. L. Co. r. Chicago........ 77

Packard v. Bird ............. 84 v. Hill ............414, 456

v. Smith ............ 91

Packet v. Sickles ............ 273

Paddock v. Comm. Ins. Co...... 3

v. Palmer ......... 487

Paddon v. Bartlett........... 70

Page v. Benson ............383, 426

v. Freeman ........... 236

v. McKee........... 572

v. Wallace ............. 558

Pahlman v. Shuway .......... 319

Paine v. Gowden ............. 433

v. Mooreland ........126, 366 
Paine v. Schenectady Ins. Co. . . 57l Palmer v. Davis ............ 545

v. Hutchins .........5 5t1

v. Preston...........337a

Palsgrave v. Ross............ 69

Pan ese v. Boswell ........... 113

Pardon v. Dwire............517

Park v. Casey .............. 489

Parke v. Williams..........411

Parker v. Anderson...........443

v. Bacon ........... 422

v. Horne .......... 153

v. Hotchkiss.......... 311

v. Jackson ......... 43

v. Jones............ 502

v. Legget............ 311

v. Pool........... 545

v. Standish .......310,329

v. State. . . . . . . . 622

v. The Bank.........550

v. Thompson ......... 274

v. Walrod........... 529

Parks, Expurte......619, 620, 622

Parks v. Cuffey.............604 v. Jackson.........201, 364

Parkhnist v. Sumner........ 180, 435

Parrisli v. Farrish.........2;9, 309

Parrott v. Den............. 108

Parsons v. Copeland.........417

v. Hoyt............. 360

Partridge v. Harrow ... . . . . . .500a

Pasour v. Rhyme............ 394

Patcl v. Gray..............4\$4 $4 a$

Patterson v. Swan........... 474

Pattison v. Jones ........... 259

Patton v. Caldwell .........184, 189 v. Hammer.......... 216

Paul v. Whitman............ 1sl

v. Virginia........... 568

Pawling v. Bird's Ex'r. . . . . 559, 579

Peabody v. Phelps........... 181

v. Thatcher......... 120

Pcagram v. King.............484

Pearce v. Atwood........... 139 v. Gray............. 248

v. Olney........492, 576

v. Thackeray......... $\$ 9$

Peake v. Redd.............. 101

Pearl v. Wells................ 287

Pearse v. Coaker. ............. 299

Pease v. Clayton............. 590

Peay v. Duncan ............. 249

Peck v. Strauss.............. 126

v. Vandenberg. ......... 28

v. Woolbridge.......... 334

Peeble's Appeal.............3i9a

Pelham v. NIorcland. . . . . . . . . 492

Pelliter v. Freer............ 432

Pelton v. Platner........... 571

Pemberton v. Pemberton ....... 608

Penderleath v. McGillivray......319a

Pend ${ }^{1}$ stc 1 v. Weed........... 133

Penn -. r.ansen........... 477

$\therefore$ ".
Pennington v. Gibson...434, 450, 452

Peunock v. Hart. . . . . . . . . 393

v. Monroe.......... 80

Pennoyer v. Neff......561, 564, 567

Pennywit v. Foote.........133, 604

Penobscot R. R. Co. v. Wceks .. 131

Pentz v. Enester. . . . . . . . . . . 304

Pcople ex rel. Tweed v. Liscomb. 625

People v. Ah Gow........... 2la

v. Baker............ 580

v. Barrett ............ 318

v. Beebe............. 398

v. Bradwell ........... 121

v. Brislin.......... 253

v. Cassels........517, 620

v. Cavanaugh.......621, 625

v. Central City Bank.... 121

v. Chisholm..........475

v. Comnelly........... 201

v. Dawell........563,5s0

v. De Carilla.......... 535

v. De la Guerra........ 146

v. Downing ......... 132

v. Goodwin ........... 318

v. Hagar........... 523

v. Hall. . . . . . . . . . . 604

v. Harrison .......... 235

v. Hopson.......... 475

v. Johnson.......... 271

v. McLeod..........6.620

v. Mercein .......... 3 29

v. N. Y. Jur. Asylum ... 621

v. O'Connell .......... 109

v. Olcott ............ 318

v. O'Neil..........121, 197

v. Rains .........108, 112

จ. Roff ............6. 624

v. Sanchez .......... 121

v. Smith........225, 260

v. Sturtevant.......... 435

v. Supervisors ........551

v. Vau Kuren. ......... 2.25

v. Vilas........261, 265

v. Warren...........5 5:9

v. Wright . . . . . . . 137

Pepin v. Lachenmeyer......145, 604

Pepper v. Carter............ 350

v. Dunlap........... 34

Percy v. Clary............. 227

v. Foote ............. 259

Perdue v, Bradshaw ......... it

Perine v. Dumn. ............. 270

Perkins, Ex parte.........................

Perkins v. Fourquinet........ 27

v. Mloore ............. 267

v. Parker .........274, 329

v. Perkius ......62, 255

v. Sierra N. is. il. Co... \&4

v. WValker......... 463

Perrine v. Serrell ........... 312

Perry, In re................

v. Meddowcraft .......610

v. Wilson........... 57

Peters v. Diossy ................ 261 
Peters v. Laague.......... $496 \mid$ Pollack v. Gilbert .......... 281 v. Sunford............ 229 Pollard v. Ballwin............ 563 v. Spitzfaden .......... 154 v. Baylors .............. 295

Petersine v. Thomas ......... 249

Petrie v. Nuttall ...........159, 310 v, Woodworth ........ 347

Tettes v. Bank of Whitehall.... 4S5

Pettingall v. Rideout ........ 225

Pettigrew v. Mayor of N. Y.... 111

Pottit v. Shepherd........... 394

Pettus v. Mećlannahan ......... 98

Puttywit v. Kellogg..........604

Peyroux v. Peyroux........... 131

Tîleltz v. Pfeltz .............. 307

Thelan v. Gardner ............ 257

v. San Francisco....... 481

I'helps v. Brewer ............. 574

v. Duffy ............. 309

v. Harris........... 565

v. Sill............. 530

v. Tilton .............4 413

v. Phœbe, The........ 248

Phillips v. Allan............... 599

v. Berick............ 274

v. Eyre ............ 599

v. Hunter ... $\left\{\begin{array}{r}159,220,286 \\ 258,592\end{array}\right.$

Phillipson v. Earl of Egremont. $\left\{\begin{array}{r}99 \\ 436\end{array}\right.$

Phillpotts v. Blaisdell......... 262

Philpott v. Adams............ 459

Philson v. Bamfield........... 231

Phinney v. Barnes ............ 239

Illinney, Petitioner........... 620

Piekens v. Marlow...........475

v. Varborough......163, 502

Pickett v. Stewart........... 505

Pico v. IVebster .............. 164

Pieree v. Adams................ 79

v. Bent ...............467a

Piercy v. Sabin............. 458

Pifer v. Ward...............361 $a$

Piggott v, Addicks ........... 498

Pike v. Hill................ $9 \overline{5}$

Iillow v. Elliott.............. $26 \mathrm{I}$

Pillsbury v. Dugan........... 124

Tim v. Grazebrook........... 7

Pinson v. Ivey..............667 607

Piper v. Pearson............. 530

Piquet r. McKay ............. 284

ritheld v. Gazzam ........... 484

Pittman v. Lowe ............. 72

Pitts v. Fugate............180, 216

Pitzer v. Iiussel............ 432

Tlace v. Butternuts Manf. Co... 144

Ilatt v. Harrison ............ 624

J'leasants v. Clements.......... 312

Picque v. Perret ............. 25s

Ylummer v. Donglas ........... 557

v. Woodburne....... 460

Toindexter v. Waddy .......... 48s

Polhemus v. Empson..........357a

. Pertins ............. 55

Polk $\nabla$. Pendleton ............ 449 v. Coeks..........366, 403

v. R. R. Co..........235a

v. Wegener .......... 133

Ponce v. Underwood........... 119

Pond v. Davenport ........5 533, 557

v. Doneghy ............ 151

v. Makepeace ............ 163

Ponder v. Cox................. 485

v. Mosely........... 116

Pool v. Loomis............. 57

Pope v. Diusmore............. 533

v. Hooper............. 126

Poorman v. ('rane............ 570

v. Mitchell........249

Porter v. Bronson............. 133

v. Earthman......... 369

v. Eunis ............4463

v. Hermann........537, 540

v. Hill.............. 312

v. Ingram.......... 476

v. Liscom............ 427

v. Robinson ....151,484, 513

Porters v. Talbot ............ 64

Portfield v. Butter...............135a

Portington's Case.............. 293

Post v. Coleman............. 551

v. Neafie.............. 431

Potter v. Baker ............... 310

v. Mech. Bank .......... 124

Poultney v. Treasurers.......... 95

Powell v. Boring............. 502

v. Cyfers.............. 494

v. Knox............ 348

v. Washington........... 153

v. Weith.............. 106

v. Wright ........... 195

Powers' Ex'r v. Butler's Adm'r. . 486

Powers v. Heath's Adm'r....... 162

Pratt v. Dow .............132, 439

v. Jones..........432, 474

v. Northam.......... 491

v. Wheeler............... 350

Prentes v. Commonwealth...... 496

Prentiss v. Hinton........... 476

v. Holbrook............ 186

Preslar v. Stallworth......417, 472

Preston v. Clark............. 135

v. Tubbin........191, 202

Prevost v. Gonell............ 405

Price v. Boyd................478a

v. Dewharst .......591, 601

v. Griffin.............. 125

v. Hickok.........564, 570

v. Higgins........... $2: 8$

v. State................ 318

v. Ward ...........499, 563

Priest v. Wheelock ........... 398

Priestly v. Fernie............225a

Prior v. Richards............467 $九$

Pritchell v. Clark..............659

Proper v. IVarner........5so, $605 c$ 
Providence Tool Co. $\nabla$. Prader.. 553 | Reames v. Kearns ............ 146

Pruitt v. Pruitt............. 89 Read v. French............... 55

Pryor r. Downey $\ldots \ldots \ldots \ldots \ldots$ 117 Reading v. Reading........... 55

Public Works v. Columbia Col- Reber v. Wriglt t............

lege $\ldots \ldots \ldots \ldots \ldots \ldots \ldots \ldots 574$ Redmond v. Coffin............. 254

Puckett r. Pope........... 155 Tied wood v. Colfin............ 159

Pulaski Co. v. Stuart.......... 123 Reed, Ex parte................

Pullvian v. Christian........... 27 Reed v. Calderwood ............ 329

Purdy v. Doyle.............. $3 s s \quad$ v. Elder............... 553

v. Upton............ 551

Purviance v. Lemmon.......... 363

Pyke v. Crough............ 172

\section{Q.}

Quackenbush v. Leonard

Queen's Appeal................. 545

Gueen Aune's Co. v. Pratt......361 $a$

Quinn v. Wetherbee.......... 50s

Quivey v. Baker............. 130

\section{R.}

Raban v. Shortbridge ......... 503

Radenhurst v. Reynolds....... $72 a$

Rae v. Hinlburt............4, 571

v. Lawser............... 55s

Ragan v. Cayler............. 4S1

Rail R. Co. v. Gates ............ 108

v. Harris.......... $50 \mathrm{cs}$

v. James......... 351

v. Swasey.......... 32I

v. Wilson ........... 363

v. Whitton........ $56 \mathrm{~s}$

v. Wynne .......... 575

Ralston v. Bell.

v. Field................ 367

v. Lahee............. 151

Pamsey v. Fierndon.......259, 272

Piand v. Nutter................ 234

Tandall v. Randall............. 319

Liandolpl v. Keiler ............ 559

Raingely v. Webster...219.565, 570

Iianlin v. Barnes........... 575

v. Goddard....5S\$, 591, 597

v. Scott.........339, 377

Ransley v. Stott............. 294

Ramsom v. City New York..... 104

v. Keyes............ 379

Ranston v. Lahee............... 513

liape v. Heaton ..........133, 563,571

Riapelye v. Prince........176, 154

Ratcliff v. Baldwin............... 113

Raun v. Reynolds.........4S2, 540

Ravee v. Farmer............. 322

Rawson v. McJunkin ........... 427

Liay v. Connor...........70, 325

v. Law................. 27

v. Roe............... 196

v. Thompson...........604 604

Raymond v. Holburn........... 399

v. Merchiant........245

v. Smith........... 50e

Rea v. Forrest............. 427 v. Eldridge........... 3

v. Harvey............ 491

v. Jackson............ 419

v. Pratt.............. 128

v. Pruyn...............4469

v. Wright........... 120

Reeder v. Duncan's Adm'r...... 505

v. Bergert............ 222

Reese v. Ilolmes.............. 307

Reeve v. Kennedy............ 509

Reeves v. Cooper............... 510

Regina v. Barton............ 325

v. Brettel........... 225

v. Brightside Bierlow ... 419

v. Hartington........ 250

v. Yorkshire........ 260

Reid v. Boyd................ 453

v. Case.............. so

v. Hibbard........... 463

v. Holmes............. 153

v. Hood............. 530

v. Rioss.............. 421

v. Spoonable............. $5: 24$

Reily v. Lancaster.........139, 135

Reimers v. Druce........... 591

Rielfe $v$. NoComb............... $36 \mathrm{~s}$

Relyea v. Ramsey............. 5:4

Renick v. Ludington ........ s39, 853

Renouil v. Harris............ S7

Respublica v. Davis........... 1 so

lievill v. Pettit.............. 530

Rew v. Barker.............. 71

Liex v. Britton ............. 225

v. Carlisle ............ 621

v. Chancellor ..........6.63

v. Clayton ............. 520

v. Collyer............. 625

v. Clegg .............. 5:0

v. Grundon .............. 531

v. Jemnings ........... 225

v. Lolley ...........605c, 610

v. Pecklam ........... 520

v. Sheriff ...........238, 239

จ. Venables .............. 520

v. Wade.............. 476

v. Woolfe.............. 476

Reynolds, Ex parte .....162, 324, 625

Reynolds v. Fenton .......... 455

v. Horine ......... 487

v. Harris....427, 482, 434

v. Hosmer .........448

จ. Orvis .........521, 623

v. Reynolds ....... 279

v. Roger's Ex'r ..... 479

v. Stansbury.....124, 458 
Rhoads v. Commonwealth ..... $62 \mid$ Robinson v. Prescott ..... .... 577

Rhoades $r$ Sherrod ............ 72 v. Warl.........567, 573

Rhodes' Lessce v. Selin........ 249

Rice v. Coolidge ............. 154

v. King............311, 317

v. Morton ............ 226

v. R. R. Bank.........500a

Riehards v. Kilf ............. 132

v. MeMillan ......... 557

v. Watson.......... 18:

Richardson v. Ainsworth....... 426

v. Fuller ........ 545

v. Hickman ....... 454

v. Howk .........6 69

v. Hunter ........ 120

v. Jones........... 94

v. Mellish ........ 71

v. Stewart ........ 295

v. White.......... 212

Richmond v. Shippen ..........500a

v. Tayleur......484a, 513

Richter v. Selin ............ 356

Ricketson v. Richardson....... 527

Rildle v. Baker...........180, 493

Ridge v. Alter............. 499

v. Prather ........... 367

Riılgely's Ex'r v. Gartell....... 367

Rillgeley v. Spencer........... 251

Riclyeway's Appeal $\ldots \ldots \ldots \ldots \ldots 343$

Ridgeway v. Bank of Tenn..... 495

Rigge v. Burbridge ......... 277

Riggs v. Collins $\ldots \ldots \ldots \ldots \ldots \ldots$ 131

Riley's Adm. v. McCord's Adm. 398

Riley v. Waugh ............ 131

Ring, Ex parte ................. 324

Risher v. Roush .............500a

Ritter v. Henshaw............ 478

Ritch v. Eichelberger ..........430a

Roals v. Symmes............ 367

Robb v. Robb .............. 93

Robbins v. Chicago .......... 181

v. Harrison …..238, 277

v. Robbins...........361 $a$

v. Wells ............2 266

Roberts v. Calkwell........... 560

v. Carly............. 108

v. Robeson .......... 256

v. State ............50d, 2.5

Robertson v. Barbour ......... 60s v. Bergen ......... 113 v. Smith......2231, 453 v. Stowers ........ 117 v. Struth $\ldots \ldots \ldots \ldots, 220$ v. Wright......... 163

Robeson v. Roberts ........... 427

Robins v. Dolphin ........... 610

Robinson's Case ............156, 293

Tobinson, In re...............337x

Robilison v. Commissioners ..... 60 v. Crowder.........603 v. Howard ......... 267 v. Jones ...........6. $61 \mathrm{~s}$ v. Kruse .......... 254 v. Morse .......... 3 22

v. Weeks........42 $4,4: 6$

v. White $\ldots \ldots \ldots \ldots 426 a$

v. Wiley .......... 277

Robson v. Cranwell .............. 100

v. Eaton............ 499

Robuck v. Harkins .......... 502

Roby v. Rainsberger ......... 249

Rockhill v. Hamna ....279, 370, 37t

Rockland Water Co. v. Pillsbury.72a

Roekwell v. Brown ........... 211

v. Langley ......... 276

Rodgers v. Bonner ............. 338

Roe v. Swart .............. 394

Rogers v. Bradford ........... 70

v. Brent ........... 318

v. Burns ........... 554

v. Goswell ............ 16

v. Grannis ............ 163

v. Gwinn .........492, 576

v. Haines ............ 173

v. Higgins ........257, 260

v. Ins. Co........... $2 \frac{1}{55}$

v. Mulliner .......... 530

v. Odell .......221, 452, 575

v. Rogers........... 70,73

v. Tucker........... 307

Rohr v. Davis ................ 43

Roland v. Kreyenhagen ......... 106

Roden v. Jaco ............... $\mathbf{2 4 5}$

Roderigas v. East R. I. S. Y. .139, 319a

Roller v. Woodbridge........ 457

Rollins v. Forbes............ 401

v. Henry.............. 50e

Roosevelt v. Kellogg.......... 524

Root v. Curtis................. 873

v. Dill.............. 231

v. McFerrin........... 518

Roraback v. Stebbin ............ 515

Rose v. Himely............563, 614

v. Lewis..............319a

Ross v. Duval ................. 401

v. Grange............. 90

Rosse v. Rust.............270"

Rosser v. Bingham........... 206

Rountree v. Walker........... 249

Roussett v. Boyle............... 51

Roussillon v. Roussillon........ 5SS

Rowe, Ex parte............. 157

Rowe v. Chandler............. 43

v. Smith............... 285

Rowland $v$. Lerby .............. 401

Rowley v. Howard..........517, 521

Roy v. Horsley............. 12l

Ruby v. Grace. . ............ 45

Rndy v. Ulrich...............319a

Ringg v. Parker........6.63, 67, 72

Rumfelt v. O'Brien.......... 130

Rupert v. Dantzler............ 394

Rush v. Halsyon.............. 553

v. Rush............ 489

Russell's Appeal.............. 3í 3

Russell v. Conway...........46\%ic 
Russell v. Drummond......... is

v. Dyer............... 3.30

v. Lathrop........... 31

v. IIcCampbell. ........ 393

v. McDougall......... 72

v. Place.........253, 275

v. Shule..............216

v. Slaton............ 487

Rust $r$. Ware............484a, 506

Rutherford $v$. Crawford ....... 407

v. Fisher......... 34

Ruttan v. Levisconte........... 360

Ryan г. Boyd............. 495

v. Doyle............. li2s

v. Vallandingham ........ 567

Ryghtmire v. Durham......... 5s

$\mathrm{S}$.

S. P. Co. v. Sickles.......... 86

Sabins v. MeGhee............ 311

Sac. Sar. Bank v. Spencer...126, 152

Sackett v. Giles............. 381

Sadler v. Robins............ 434

Sage v. Harpending. .......... 3:8

v. Matheney........... 44

v. $\mathrm{McAl}_{1}$ in ........... 257

Sager v. Blain............. 265

v. Nichols........... 43

Saint Albans v. Bush.......... 132

S.int Joseph's M. Co. v. Daggett. 196

Siant Louis M. L. Ins. Co. v.

C'ravens...................4lita

Salladlay v. Bainhill........... 517

Salmon v. Price............ 478

Sirloueci $y$. Woodmas............ 618

Saloy v. Collins............31, 50e

Sam, Ex parte.............. 6:0

Same's Appeal................... 359

Sampson v. Ohleyer.162, 171, 18I, 213

Samuel v. Agnew............. 154

v. Dinkins.......... 169

v. Judin........... 16

San Antonio v. Lane............ 253

Sanbora v. Fellows .......... 517

Sumclez v. Carriaga........... 497

Sanders v. State............ 31s

Sanderson v. Caldwell......236, 2:3

v. MeGowran........ 358

Sanford v. McLean....361 $a, 468,470$ San Francisco v. S. V. R. R ... 218

Sargent v. Bigelow.......... 502

Sarton v. Smith........... 72

Satterlee v. Bliss..........171, 301

Savilcool v. Broughton........ 529

Savage v. Hussey............. 135

v. Walshe.......... 45

Sawyer v. Woodbury.......... 276

Scenck, In re................ 620

Schermerhorn v. Schermerhorn. $\left\{\begin{array}{r}7 \\ 467 a\end{array}\right.$

Scherr v. Himmelnan......... 478

Schibsby v. Westenholz ........ 5Ss
Schindel v. Suman.......... 264

Schluss v. White............. 5:37

Schmilt v. Zahensilorf.......... 247

Schnepf, In re.............337re

School District v. Prookl......... 95

S.hoonmaker v. Clearwater..... 146

Schrouder's Estate........... 70

Schroeder v. Fromme......... 544

v. Guernsey....... 360

Schurmeyer v. Johnson........ 251

Schultz, Ex parte........... 623

Schwartz, Ex paite........... 621

Scott $v$. Bennett............. 16

v. Coleman ............ 565

v. Colmesnil.......... 232

v. Harkins ............. 4:27

v. McNillan........... 195

v. Pilkington........595, $60 \mathrm{~L}$

v. Pleasants............ 135

Scriba v. Deans.............. 339

Scribner v. Hickok............. 472

Scroggins' Adm'r v. Scroggins. 70, 71

Sendider v. Van Amburgh....... 194

Scully v. Chicago etc. R. I. Co. $2-0$

Sears v. Terry ............. 517

Sebbins v. East Society........ 5.5

Secombe v. R. R. Co........ 1:23 v. Steele........... 198

Second National Bank's Appeal . 336

Second Ward Bank v. Upman. 235, 326

Secor v. Sturges..............?

Sedlon v. 'J'utop..........2.2, 974

Sedtrwick r. Cleveland ........ 20ys

Seevers v. Delashmutt........... 360

Segee v. Thomas............. 131

Selin v. Snyder.............. 131

Seller's $\mathrm{x}$. Corwin ............ 405

v. Union L. Co......... 14

Sellick v. Adams............ 32l

Semehka v. Lowe.............. 130

Semler, Petition of ........... 622

Semple r. Ware............ 332

v. Wright........330, 332

Sergent's Heirs v. Ewing...... 163

Sevies v. Rorlile............. 504

Sewall v. Sewall..........580, 605c

Seynour v. Greenwood......... 58

Shaefer v. Gates............. 133

Sliaelfer v. Weed..............

Shafer v. Scudly........... 272

v. Stonebraker......... 254

Shaffenbury, $E ;$ parie........ 620

Shaleruss v. Dixon........... 198

Shank's Case............... 625

Shannon v. Frost............ 531

Sharmon $v$ Morton............ 5.59

Sharp v. Brunnings ........... 132

v. Dangney .......... 83

v. Gray..........236,, 237

v. Lumley........... 193

v. Mayor of New York... 505

v. Spreckenyle........ 859

snaw v. Attorney-general . .60\%, 610 v. Beers.............. 
Shaw v. Davis............ 529|Sibbald, Ex parte.......... 24S

v. Gonk .........605c, 610 Sibbald v. United States...... 121

v. Hurcl............ 413 Sidensparker v. Sidensparker. . . 396

v. McGregor.......... 93 Siebold, Ex parte.....619, 620, 624

v. R. I. Co........... 157 Sigourney v. Libley ......... $1: 6$

Shawhan v. Loffer............ 132 Silver Lake Bk. v. Harding.577. 597

Shear v. Flint.......................... 240

bearman v. N. Y. Cent. Mills.. 17 Simmons v. Clark........... 575

gears v. Dusenberg......... 303 v. McKay.......... $15 \mathrm{I}$

v. Rogers .......... $350 \quad$ v. Price..........481

Sheehan's Case............ 623 Simonds v. Catlin.......... 481

Sheehy v. Mandeville.......... 230 Simons v. De Bare............ 513

v. Sheeby P. L. A. Co. . 432 Simonton v. Barrell .......... 477

Sheetz v. Kirtley............319a Simpsonv. Brewster..........270،

Sheldin v. Wright..........524 v. Cochran........442

Sheldon v. Aleox............ $283 \quad$ v. Fogo............ 589

v. Buskirk......... 529

v. Edwards........276 2628

v. Fortescue.........484a

v. Hopkins.........4 $46 \mathrm{l}$

v. Kibbe..........2 236

v. Newton........... 118

v. Shelly's Appeal. .... 338

shelton v. Gill............. 516

v. Johnson ............. 210

v. Trinin .....129, 499, 509

Shepard v. Riowe........... 474

Shepherd v. Bailleau........... 394

v. Brenton......... 56

v. Mayor of N. Y.... 222

v. Afintyre.........484a

v. Sharp.......... 16

Shepardson v. Cary............ 257

Shericlan v. Andrews. .....213, 299

Sheriff of Miidllesex's Case . .... 137

Sherman $r$. Brett............. 467

v. Boyce.......... 469

v. Dilley.........302, 328

Sherrill v. Goodrum......... 117

Sherry v. Priest............. 71

Shew v. Jones................ 339

Shields v. Miller............. 127

v. Shields.............605c

Sbinkle v. Leteher.... ....... 493

Shirley v. Fearne.........165, 175

v. Watts........... 512

Shiveley $r$. Jones............... 203

Shiver v. Shiver............. $89 a$

Shivers v. Wilson .............. 123

Shoemaker v. Brown.......... 524

Short v. Kellorg............. 62

Shooter v. MeDnffie......... 432

Shottenkirk v. Wheeler........ 487

Shotwell v. Lawson............. 193

$$
\text { v. Murray.......... } 377
$$

Shricker v. Field .............. 500

Shriver v. Lymn............

Shropshire v. Probate Judge....319a v. State.......... 145

Shufelt v. Buckley.............. 517

v. Shufelt............ 512

Shuford v. Cain............. 135

Shumway $x$. Stillman.......... 562 v. Stillwell........ 461

v. Hart.......467a,511

v. Hornbeck. .....10ib, 402

v. Jones............. 159

v. Norton...........

v. Pearson......... 159

Simson v. Hart............. 325

Sims v. Campbell............... 311

v. Gray ............. 129

Singer v. Heller............. It

Skepworth v. Cunningham.... . 369

Skillman v. Greeuwood ........ 124

Skrine v. Simmons ..........467a

Slack v. Moody............. 502

Slee v. Bloom.............. 177

Sloan v. Creason............ 233

Sloo v. Lee............... 232

Smalley v. Edey............... 270

Small's Appeal ..............370, 372

Smart v. Mason .............. 393

Smith, Ex parte...............4816

Sinith, Petition of.......... 621

Smith v. Alexander........237, 4(j)

v. Alton............ 99

v. Belmont............ 483

v. Black..........231, 282

v. Bohon........... 48 ?

v. Bowker............ 154

v. Brackett.......... 35j

v. Bradley........... 126

v. Campton............. 181

v. Chenault.......... 50a

v. Claimants......... 162

v. Coe............... 326

v. Elliott........... 284

v. Ferguson........... 151

v. Harrison.......... 4

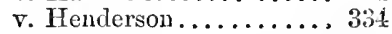

v. Holmes. ........... 80

v. Hunghes........... 475

v. Ingles............. 348

v. Jolmson . ........... $3: 0$

v. Jonles .............. 233

v. Kelly............... $\Sigma 89$

v. Kennedy........... 70

v. Kernocher.......... 213

v. MeCluskey.......... 236

v. MeDonald.......... 151

v. Meredith........... 395 
Smith v. Miller...........550 / Stafford v. Clark......260, 272, 458

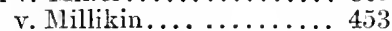

v. Moore.........1S6, 187

v. Mumford.......... 432

v. New Berne.......... 105

v. Newland........... 83

v. Nicholls....215, 220,455

v. Patten............. 154

v. Pomeroy ........124, 133

v. Powell............ 503

v. Redis........... TI

v. Reed............. 47s

v. Rines............ 236

v. Sherwood ...257, 273, 295

v. Smith.....237,456, 605b

v. Spalling ......... 325

v. State . .......56, 121

v. Talbot ..............

v. Trabue's Heirs . . . . . 36, 171

v. Trimble ............504

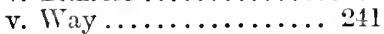

v. Whiting ........ 272

Smock v. Darle...........95, 463

Snead v. MicCoul..........339, 379

Sneed v. Ewing ............605 $\iota$

v. Town ............4\$4

v. Wiester ............ 231

Snell v. Dwight ............ 31

Snelling v. Parker ........... 352

Snowman v. Harford......... 193

Snycler v. Pobinson.......... 7

v. White................ 325

Socicty v. Hartland............ 15

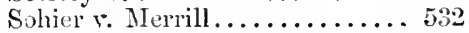

Soper v. Fry ............... 515

Solomon v. Fuller .......... 72

South \& N. R. R. Co. v. Henlein. 283

South Fork Canal Co. v. Gorclon. 483

Southside R. Ti. C. v. Daniel.272, 27t

Sorrel v. Carpenter ........191, 202

Spafford v. Beach.......... 474

v. Jamesville ........ 105

Spalding v. The People........ . 324

v. Wathen ......150, 152

Spanagel v. Dellinger ......... S5

Sparhawk r. Wills........... 238

Spaulding v. Baldwin . . . . . 124, 452

₹. Congdon........ $5 \mathrm{~s}$

v. Swift......... 95

ร. Thompson $\ldots \ldots \ldots \ldots, 112$

Speed s Ex'r r. Hamm ......... 71

Spence v. Simmons .......... 50

Spencer v. Brockway...217, 570, 57j v. Dearth....253,416,419 v. Vigneaux ........ 250

Spier v. Corll ............ 133 Spicer ฯ. U.S............ 267

Sponner v. Davis ............ 257

Sprading $v$. Conway.......... 274

Spragne v. Jones........... 70

Sprague v. Oakes ............ 159

Springfielil v. Worcester .....57, 6J

Spring Garden Comm'rs Appeal. 386

Stacy v. Thisher........... 163 v. McMillan ......... 111

Stahl v. Roost............. 393

v. Webster ...........69 69

Stalling v. Gully............ 133

Stamford v. Barry ..........

Stanard v. Rogers ............ 50.3

Standish v. Parker .........275, 310

Stanhope v. Firman......... 493

Stannis v. Nicholson .......... 863

Stanton v. Styles .......... 517

Staples v. Bralley ........... 3\%0

Staples v. Goodrich .......... 233

Starbird v. Eaton........... 79

v. Hoore .......... 95

Starbuck v. Murray ..... 133, 46i, 503

Starr v. IIechart. . . . . . . . . 489

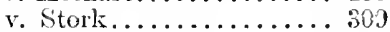

Starke . Woodward......... 218

Start v. Hoskins............. 4.28

State v. Alling ............ 14s

v. Anone............ 148

v. Armington ........... 579

v. Augusta .......... 531

v. Borden........... 131

v. Burket.................. 315

v. Castleberry.......... 1:6

v. Chafin............ $2: 5$

v. Cinn. Gas Co........ 170

v. Clark .............. 72

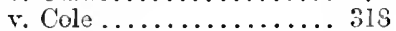

v. Colerick ........... 180

v. Commissioners......... 205

v. Comm. Bank ......... 7

v. Cooper............ 225

v. Crow ............. 529

v. Eggrlesht .......... 225

v. Elgin . . . . . . . . . 130

v. Fenderson ......620, 6:1

v. Flinn ............ 530

v. Fosdiek............ 120

ร. Gregory........... 21

v. G. IV. R. WV. Co . .240, 211

r. Harrison.......... 89

v. Helmer.......... 217

v. Hinchman . . . . . . . . 571

v. Horneman. . . . . . . . 21

v. Jumel.........50c, 252

v. King............ 72

v. Knight. . . . . . . 1:1

v. Lewis. . . . . . . . . . 225

ง. Little............. 318

r. Nayor of Mobile ..... 62

v. McAlpin .......... c3

v. MeArthur......... 14

v. MeCarty .......... 2.5

v. MeGlynn.......319a, 633

v. Moore............. 313

v. Morphine......... . 25

v. Morton........... 273

v. Mullix............21

v. Nelson. . . . . . . . . .

v. Norvell............

v. Odell............ 201 
State v. O'Neil.

v. Parish Judge

v. Primum.................. $2 \mathrm{l} c$

....71, 12

v. Ramsburg..........249

v. Richardson.........476

v. Rugan...........4407

v. Salyers........... 480

v. Sly............. 225

v. Spikes............249

v. Standifer........... 225

v. Swepson........... 318

v. Thurston..........225

v. Towle............6 620

v. Treasurers.......... 90

v. Virgin ........... 464

v. Wheeling Bridge Co.... 90

v. Williams........... 225

v. Wister...............225

v. Woodlief.............. 537

v. Woodruff........... 318

State Bank v. Arnold.......... 459

v. Carson .......... 355

State Sav. Inst. v. Nelson ...... 96

Steamboat v. McCraw......... 160

Steamer Moliie Hamilton v. Pas-

chal................... 50

Stearns v. Aguirre .........481, 533

v. Cazeux ............ 319

Steel v. Smith ................ 574

Steele v. Lineberger........... 163

v. Palmer............13ða

v. Smith ...........564, 574

v. Taylor .....193, 367, 208

v. Thompson .......... 421

Steen v. Steen ............124, 133

Steere v. Tenney ............. 60t

Stephen's Appeal ............. 367

Stephens v. Gaylord........... 453

v. Howe .......... . 286

v. Jack ........... 186

v. Roby ..........453, 459

v. Wilson ............, 72

Stephenson v. Newcomb........ 132

Steptoe v. Riead ............ 43

Stevens, Ex parte............. 390

Stevens v. Howe ............ 286

v. Hughes ......257, 310

v. Mangum ......... 122

v. $\operatorname{Ross} \ldots \ldots \ldots \ldots . . .6540$

v. Sellars ........... 363

Stewart v. Coder ........... 363

v. Goode ............ 7

v. Gray ............4 413

v. Montgomery ........ 163

v. Peterson.......... 432

v. Statc .........21c, 318

v. Stebbins ...........253

v. Thomas........... 184

Stewart's Case............. 621

Stich v. Dickinson ............. 2lc

Stickney v. Davis.............. 96

Stiger v. Brent ............. 152

Stiles v. Burch ...............319a

v. Knapp............. 487
Stiles v. Murphy .......... 367

Stilwell v. Carpenter...........467a

v. Shannon ..........6. 64

Stitphen v. Houdette ......... 313

Stinson v. Ross............ 484

Stockbridge v. West Stockbridge 407

Stockdale v. Hansard ......... 137

v. Johnson ......... 72

Stockton v. Briggs.......... 457

Stoddard v. Myers............ ] 99

v. Thompson ....... 174

Stoetzell v. Fullerton .......... 153

Stokes v. Innarr ............. 498

v. Sanborn .......... 432

Stone v. Connelly ............. 199

v. Elliott............ 194

v. Lewman ............... 492

v. Sherry.............. 495

v. Towne........... 512

v. IVood............163, 358

Stoner v. Neff.............. 305

Stoops v. Walter ............ 1S0

Story v. Kimball ............. 55

v. Patten ..............457a

Stoutenberg v. Vandenburgh.... 545

Stover v. Dunn.............. 476

Stowell v. Chamberlain ........ 267

v. Eldred .........506, 507

Stoyel v. Cadly ............. 478

Stradler v. Bird's Heirs .......... 323

Stratton v. Perry............ 245

street v. Brackley ........... 575

v. Ins. Co.............6 615

Streeter v. Narshall .............. 136

Striker v. Kelly ............. 123

Strode v. Broadwell........... 476

Strong v. Phœnix Ins. Co....... 174

Strother v. Butler........... 276

Strond v. Casey .............. 484

Struble v. Míalone ........... 461

Stuart v. Lander...........4, 432

v. Supervisors ..........4S $4 a$

Stubbs v. Leavitt........... 495

Sturly v. Jackaway........... 299

Sturdevant v. Pike ........... 572

Sturges v. Vanderbilt ......... 153

Sturtevant v. Randall ........159, 284

Stryvesant $v$. Hall .. .......... 201

v. Hone..........201

v. Mayor of N. Y... 240

Styles v. McNeil's Heirs . ...... 426

Stymets v. Brooks ............. 369

Sullenberger v. Gist ............ 7

Summers, Lx parte.......... 137

Summersett v. Summersett's Ad. 72

Sutherlin v. Underwriters ...... $21 b$

Suydam v. Barber .....221, 231, 575

v. Cannon.......... 232

Swain v. Naglee...........61, 72

Swan v. Saddlemire .......... 480

Swann v. Broome .............. 139

Swartz v. Stees............... 359

Swayne v. Lyon ................ 150

Swearengen v. Gulick .......... 132 
Sweep v. Maupin . . . . . . . . . . . 272
Sweet v. Jacocks . . . . . . . . . . . 349

v. McGlynn .......... 113

Swift v. Starke............ 574

Symonds v. Blake........... 95

\section{T.}

Tabb v. Williams........... 194

Tabler .. Wiseman.. ......... 204

Taggart r. IVood.........485, 498

Tallmadge v. Chappel. . ...217, 450

Tallman v. Farley.. ......... 357

Tamer v. Hague.............476

Tams v. Bullitt............ 167

Tapley v. Martin ............. 58

Tapp v. Rankin........... 502

Tarbell v. Greggs . . . . . . . . . 403

Tarbox v. Hayes.............540a

Tarleton v. Althusen........ 227

v. $\operatorname{Cox} \ldots \ldots \ldots \ldots \ldots 153$

v. Johnson. ......182, 183

Tarver v. McKay.......... 506 v. Tarver............ 487

Tate v. Anderson........... 478

Tate's Ex'r v. Hunter . . . . 174, 272

Tatlock v. Harris........... 319

Tayloe v. Thompson......... 339

Taylor's Adm'r v. Spindle ..... . 339

Taylor v. Alexander......... 529

v. Barnes .......... 184

v. Barron.......... 577

v. Beck........... 5, 7

v. Boyd.........205, 484

v. Boydlen........... 597

v. Bradshaw......... 503

v. Brushcup.......... 517

v. Bryden........... 559

v. Castle .......257, 259

v. Cornelius........... 349

v. Dryden.......... 575

v. Dustin .....184, 256, 273

v. Larkin . . . . . . 260, 261

v. Later. . . . . . . . . . . . 48t

v. Lewis. . . . . . . . . . . . . 496

v. Lusk............. 90

v. Root............217

v. Rumney .......... 474

v. Runyan.......512, 575

v. Shew........... 433

v. Smith........... 333

v. Snow............ 153

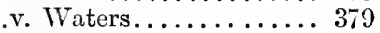

v. Yarborough ........ 270

Teal v. Terrell.............. 273

Teetor v. Abulen........... 4:3

Temple v. Scott ...........467a

Tenny v. Townsend......... 565

Terrill v. Higgs. . . . . . . . . . . 2S1

Terry v. Connecticnt Bank . . . . .484a

v. Huntington . . . . . . 529

Tessier v. WVyse............. 449

Thatcher v. Gammon.....95, 217 , 286 v. Haun........... 10s
Thatcher v. Powell.......... 123

v. Rockwell . . . . . . . 462

Thayer v. Niowry... . . . . . . . . . . 291

v. MIcGee.......... 86

The Flad Oyen ............... Glt

The 420 Nining Co. v. Bullion

M. Co..............276a

The Mary ................ 617

The Palmyra............. 34

The Phobe............... 248

The York Bank's Appeal ....... 557

Thomas v. Cleveland........ 475

v. Hubbell .......... 180

v. Kennedy.......... 353

v. Mohler............ 221

v. Perryman. ......... 463

v. Platts........... 174

v. Porter............ 553

v. Rumsey......... 231

v. Simpson ......... 3is

v. Sterns.......... 162

v. Southard .........6 611

v. Tanner ........80, 413

Thomason v. Dean........... 24

Thomasson v. Odum.........7, 45

Thompkins v. Hyatt........ 39

Thompson v. Bristow ......... 476

v. Brown ......... 157

v. Emmert. : . $\left\{\begin{array}{l}459,559 \\ 560,573\end{array}\right.$

v. Hall . . . . . 295, 297

v. Lee County . . . . . . 578

v. Mankin ......154, 441

v. Mamrow.....154, 441

v. MeKay . . . . . 272, 299

v. Multnomah County ......517, 524

v. Myrick........ 219

v. Percival........ 467

v. Renoe......... 155

v. Roberts ......... 160

v. Rogers .......... 241

v. The State....264, 584

v. Thompson...... 465

v. Van Vechten ...... 554

v. Whitman.......5563

Thorne v. Cooper ........... 272

Thornton $v$. Lane............ $1 \div 6$

Thrasher v. Haines.......... 189

Thulemeyer v. Jones. . . . . . . . . . 3S2

Thurmond v. Durham......... 507

Thurston v. Slatford........ 407

v. Spratt. ............. 186

v. Thurston .....217, 313

Tilfourd v. Oakley.......... 434

Tillotson v. Millard......... 355

Tilton v. Cofield........... 193

v. Gordan. .......... 286

Timms v. Grace ............ . 604

Tioga R. R. v. B. \& C. R. T. . . 253

Tindall v. Carson........... 412

Timmey v. Woolston........357, 354

Tobin v. Eldison ............ 530

Toby v. Brown ............... 223 
Todd v. Cumb

Tolbert v. Harrison. . . . . . . . . $467 a$

Tolen v. Tolen.............. 579

Tolson v. Kaye............ 16

Toney, Ex parte............ 620

Tooker v, Duke of Beaufort.... 58

Torrey v. Pond.............. 158

Tovey v. Lindsay...........605e

Towe v. Felton............. 472

Tower v. White.............. 303

Towle v. N. H. N. Co......... 241

v. Towle............... 180

Town v. Lamphere........... 271 v. Smith............ 272

Towndsend v. Smith........ 566

Town of Lyons v. Cooledge..... 126

Town of Omro v. Ward........ 108

Towns v. Nims............. 256

Townsend v. Chew ........... 90

- v. Cox ........435, 513

v. Griffin........5586

v. Kerns........... 334

v. Smith........ 478

Tracy v. Goodwin............ 180

v. Tracy............. 392

Trammell v. Trammell......... 70

Trapnall v. Richardson. 394, 405, 474

Trask v. R. R. Co........... 241

Travis v. Waters............ 24

v. Willis............. 545

Treadwell v. Herndong......... 358

Treasurers v. Bates........... 231

Trebilcock v. Wilson............ 3

Trescott v. Baker........... 322

v. Lewis........... 255

Tribble v. Davis............ 50c

Trimble v. Boothby ........202, 203

Triplett v. Scott.........437, 462

Troop v. Picardo............ 95

Troup v. Wood........389, 465, 475

Troy v. Smith..............4 418

True $v$. True.............. 489

Truett v. Legg.............. 2

v. Wainwright......499, 511

Truitt v. Truitt............ 193

Trumbull v. Nicholson.......... 463

Truscott v. King.........397, 466

Trustees v. Watson............ 367

Tucker v. Rohrbock.......... 252

Tudor v. Taylor............ 478

Tufts v. Tufts.............392, 394

Tunstall v. Robinson.......... 459

Turner v. Christy............. 70

v. Felgate..........104a

v. Dupree's Adm'r..... . 50a

v. Hitchcock.......... 256

v. Ireland ............ 122

v. Jenkins.......... 130

v. L. \& S. W. Ry. Co... 57

v. Plowden........24, 238

v. Roby............... 454

Turpin v. Thomas..........181, 487

Turrell v. Warren............ 132

Tuska v. O'Brien............... 249
Tuttle v. Jackson............ 407

Tutt v. Cousins............... 87

Twogood v. Franklin.......... 482

Twohig, Lx parte.............. 6.

Tyler v. Hammersly..............45ta

v. Hyde.......... 194, 270

v. Thomas............ 200

v. Walker........... 405

\section{U.}

Uhl v. May............... 357

Ullman v. Kline............... 420

Underwood v. French........ 273

Underwood v. Sledge.............. 99

Union Bank v. Hodges......231, 2.2? v. Menard......... 338

Union R. R. Co. v. Traube..... 2:1

United States v. Arredondo $\{118,2: 3$

v. Butler........ 352

v. Cushman. $\left\{\begin{array}{r}235, \\ 259 \\ 429\end{array}\right.$

v. Dashiel........ 475

v. Dewey........ $2 \geq 1$

v. Duncan.... 378, 405

v. Gamble...... 79

v. Halstead.... ... 403

v. Harrison . . . . . 69

v. Hoyt......... 229

v. Humphries. . . . 403

v. Ins. Co...... 601

v. Klein ........ 90

v. Knight ....... . 93

v, Mcclay ....... $6 \Omega 8$

v. Morrison ...339, 403

v. Shoemaker .... 313

v. Trofton......... 292

Uran v. Houdlette........... 215

\section{V.}

Vail v. Conant ............. 493

Valentine v. Havener.......... 363 v. Mahoney......169, 17t

v. Norton .......... 79

Vallance v. Sawyer ........... 412 Vallandingham v. Ryan .. \{267, 273

Vallejo v. Green............ 103

Vallie v. Dumerque............... 590

Vance v. Olinger ............ 460

Van Cleve v. Groves........... 313

Vanderhayden v. Young........ 5 53

Vanderpoel v. Van Valkenbergh. 608

Vandiver v. Hammel. . . . . . . . 4.. 432

Van Dolsen v. Abendorth....... 2:33

Van Duzen v. Livett.......... 513

Van Duzer v. Van Duzer ........ $26 \mathrm{I}$

Van Hagan, Ex prrte ......62I, $6=5$

Van Metre v. Wolf ........... 150

Van Ness v. Corkins.......... 4.3

Tan Rensselaer v. Kearney..... $2: 7$

v. Sheriff....... 
Yan Storch v, Griffin......... 413 | Wallin v. Huff.... . ...... 171

Vanuxen v. Aagelhursts.......605b Wallis v. Thomas............ $72 a$

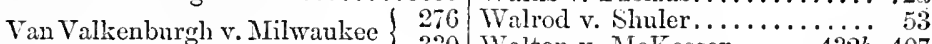

Van 330 Walton v. Mickesson......432 b, 407

Van Vechten v. Terry......... 157

Van Vliet v. Olin............ 260

Vaquelin r. Bonard .......217, 594

Vass v. Ball................6 618

Vather v. Zane...........4\$4a, 504 v. Lytle's Ex'r........4 478

Vaughn $v$. Johnson........... 487 v. Phebe........... 419

Veghte v. Hoagland........... 241

Verhein v. Strickheim........ 260

Vermont Ii. R. v. Vermont R. R. 330

Temeuil v. Harper .........32; $a$

Ternon v. Valk............ 163

Vierheller's Appeal........365, 375

Vishers v. Aldrich........379, 476

Vils v. Westo.............. 431

Vilas v. Jones ..........4S5, 502

Virginia, Ex parte ...........619

Vische: v. Vischer ........579, 5s3

Voght v. Ticknor...........418

Vogler r. Montgomery........ . 484

Tooglt v. Winch............ 2st

Vorhees v. Bank of U. S. . . . . . 563

Voorhees v. Gros.......... 475

Vose v. MIorton............. 337

Vredenberg v. Morris . . . . . . . 353

v. Snyder ........ 443

\section{TV.}

IV. A. \& G. S. P. Co. v. Sickles. 273

Waddell v. IVood........... 115

TTade $r$. Deray.............. 304

v. Judge. . . . . . . . . 324

Wadhams v. Gay..........330, 4S4

Waggoner v. Speak. . . . . . . . . 350

Wash. Ben. So. r. Bacher ...... 531

Wakeman v. Jones.......... 463

Walden v. Bodley's Heirs. .193, 270

Wales v. Bank of Michigan..... 506

v. Lyon . . . . . . . . . . . 249

v. IVillard..............319a

Walker v. Chase.........253, 273

v. Clay ............ 152

v. Davis............ 265

v. Douglas.......... 193

v. Ensign .......... 55s

v. Hill's Ex'r......... 214

v. Lathrop........... 565

v. Meseley ........... 5IS

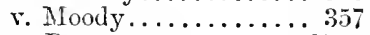

v. Perryman.........17la

v. Robbins............ 495

v. Rogan............ 147

v. Smilwwood............. 191

v. Wells............ 442

v. Wills........... 59

v. Witter ............. 592

Wallace v. Eldridge......... 5 540

Wallace's Appeal............ 393

v. Sugg. . . . . ..... 566

v. Vanderhoof ......... 443

v. Walton.......... 9l

Wamburgh v. Gates.......... 4St

Walmsley v. Robinson......... 119

Wann v. MeNuIty.......... 231

Wanzer v. Howland.......... 523

v, Self ..........261

IVard v. Barber.............. 132

v. Chamberlain . 403, 404, 406

v. Hollister........... 4St

v. Jolinson................ 231

v. MaKenzie ......... 574

v. Prather's Adm'r....... 447

TVardell v. Eilen..........95, 428

v. Mason ........... 3il

IVarden v. Bailey............ $\$ 36$

v. Tainter.......... 153

Ware v. Pennington......... 46

Warfield's Will............ 407

WVarfield $v$. Holbrook ......... 320

Waring's Heirs v. Reynolds .... 151

Waling v. Waring........... 195

Warner v. Blakeman.......... 489

v. Helm . . . . . . . . .478, 475a

WVarren v. Comings ....235, 210, 4-s v. Flagg.......... 577 v. Kingsmill......... 5. S v. Lusk............ 500 จ. McCarthy ......431, 565 v. Shuman........ 16

Warrender $v$. TTarrender .......605e Warwick v. Underwood.217, 284, 810 Wash. Ins. Co. v: Price.... I44, 145 Washburn v. Gouge.......... 150 Waterbury v. Graham...... . . 2.t WVaterhouse v. Cousins........ 523 Waterman v. Haskin ......... $37^{1}$ Water's Appeal ............. 367 Watkins, Ex parte........135, 620 Watkyns v. Abraham........ 54J

Vatson v. Hahn............ 40s v. Owens. . . . . . . 229, 23I

v. Beissig. . . . . . . . 319 v. S. F. \& S. B. R. R. Co. 109 v. Wilson......191, 202, 203

Watts v. Everett ........... 432

v. Gale ............. 180

v. Gayle........... 485

Wattson v. Dowling .......... 171

Waugh v. Chauncey ......... 219

Way v. Lewis............ 180

Wayman v. Cochrane .......... 215

Webher $v$. Gray .............. 509

Webbs v. State ........... 150, 1s0

Webster v. Adams......... 167

v. Hunter......... 503,

v. Lee $\ldots \ldots \ldots \ldots \ldots 27$

v. MeDaniel ........4tit

v. Reid ........133, 563 
$63,72 \mid$ White v. Snow . ...............

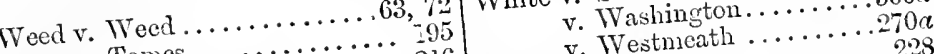

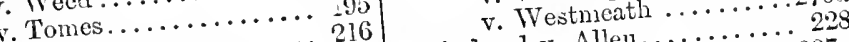

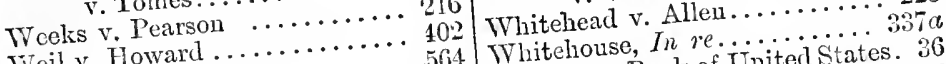

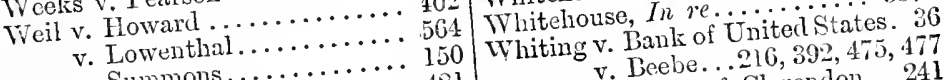

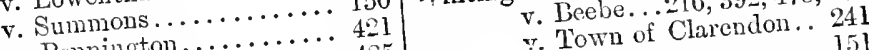

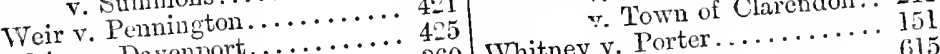

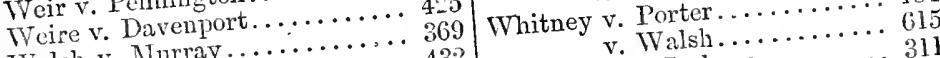

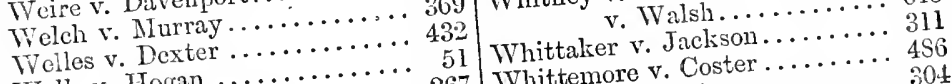

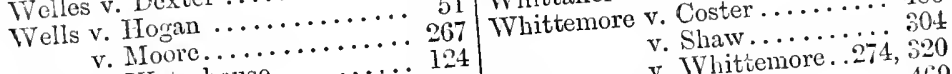

v. Waterhouse ........... 135

Wellshear v. Kelly ......... $5 . \ldots .570$ Whittier v. Hemingway ......

WVelsh v. Sykes................. 159 , 169 Whittlesey v. Delaney ....... 4SS

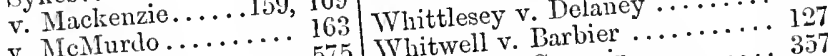

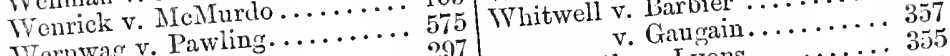

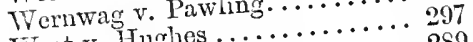

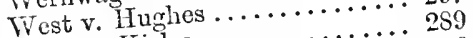

v. Kirby $\ldots \ldots \ldots \ldots \ldots \ldots \ldots \ldots$

v. WVilliamson $\ldots \ldots \ldots \ldots .256$

IVestcott v. Brock.................. 560

v. Brown ..... $\ddot{\mathrm{v}} \ddot{\mathrm{C}} \ddot{\mathrm{C}}$.

Western M. \& M. Co. v. . ..... 248

Company .................... Johnson. 34S

Western Penn. R. R. v. Johson. 150

Westervelt v. Smith ..........

Westerwelt v. Lewis .......... 16

Weston v. Charlestown..........4463

v. Clark...........560,561

Wetherill v. Stillman........... 95

Wetmore v. Law .............

VVeyer v. Thomburgh........ 235

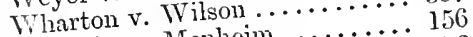

Whately $v$. Menheim .............472

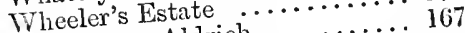

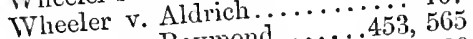

v. Raymond......261,260

v. Rnckman........201, 52

v. Scott ............. Van Houten 320

Wheelock v. Warshauer ... .... 465

Wherry v. McCannon.......... 465

Whetstone v. Colley ..........

Vhetstone ....... 435

Whicker v. Hume ........... 508

hitworth v. Lyons......... 355

Viukliffe v. Breckemridge... 195, 203

Vicks v. Ludwig............ 492

VVierich v. De Zoya ............ 512

Viggins v. Armstrong .......... 355

v. Chance............. 121

Vight v. Wallbaum............. 123

v. Warner.................... 260

Vilbur v. Gilmore..............

Wilcox v. Jackson............. 560

v. Kassock............. 274

v. Lee ................. 548

IVilcoxson v. Burton............. 366

v. Niller............ 157

Vilder v. Keeler ............. 503

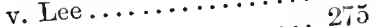

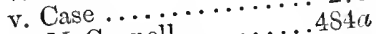

IVildey v. NIcConnell ............ 356

IVildy v. Bonney ............... 495

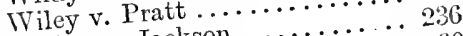

Wilkes v. Jackson ........... 60

v. Perks.............. 572

Vilkinson v. Leland............ 464

Villaume v. Gorges............ 325

Willet v. Fayerweather........... 150

Willey v. Paulk......................616

Williams v. Armroyd............ 493

Whicker v. Hent . . . . . . . . . 5 529

v. Benedict............ ] 99

v. Bowen ................. 604

v. Bruffy ..........417a

v. Cheney.........467a

v. Evans............. 253

v. Titzhugh .......... 189

Whitcomb v. Whiteomb....... 489

v. Givbs........... 595

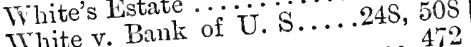

v. Brown ..............6. 605

v. Jones............ 455

v. Lee............ 334

v. Nartin........... 235

v. Cannon ............. 254

v. Coatsworth ........... 251

v. Crew .............. 261

v. McFall .......... 409,416

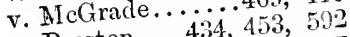

v. Gaines................ 462

v. Hall ............... 357

v. Preston...434, 453,417

v. Shaw ............. 499

v. Jones....................... 325

v. Munroe............. 196

v. Smith........... 120

v. Stewart............ 171

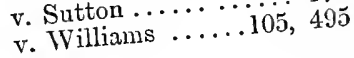

v. Perry $\ldots \ldots \ldots \ldots \ldots . \ldots \ldots .236,237$

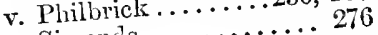




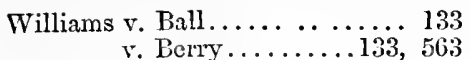

Williamson's Case........120, 620 v. Field........ 29 v. Fitzsimmons.... $61 \mathrm{~s}$ v. Holloway .. 462, 463

TVilliard v. TVilliarl. ........357a Wiilingham v. Long.... . . . . . 464 Wilıink v. Canal Co.......... 157 Willitts v. Waite............605 b Willis v. Bank of Mlobile...... . 104 v. Slarle.............. 306 v, Spraggin........... 15l v. State............ $2 S$ Willoughby v. WVilloughby.... . 6 Wilson v. Bank............ 576 v. Bank of St. Panl.....337a v. Broughton.. . ..248,500a v. Cameron.......... 286 v. City Bank...........337a v. Cleveland...........5:533 v. Collins........... 154 v. Graham ............ 564 v. Hatfield........... 432 v. Jackson.......565, 575 v. Montgomery ....489, 495 v. McClenning........ 310 v. Mlower............ 158 v. Myers.......... 57 v. Nance........... 50a v. Ray............267 v. Tiernan.........4442 v. TVadleigh......... 430 v. IVilson...........271

Wilton v. Middlesex R. R.....235a Windsor v. McVeigh........11s Wimberly v. Hurst.......... 135

Winans v. Bacon. .......... 2Sl v. Durham......... 39

Winchester v. Grosvenor . . . . . . 500

Windwart v. Allen.........4455

Wingate v. Haywood......... 486

Wiun v. Jackson . ........... 31

Winnebrenner v. Edgerton.... . 553

Winslow v. Ancrum......... 341

v. Anderson ........ 9S

v. Clark...........4 466

v. Grindal . . . . . . 162, 312

v. Lambard. . ....... 537

Winstantly v. Savage........ . 405

Winson v. Starke............ 159

Winston, Ex parte........620, 624

Winston v. Browning.......... 398

v. Taylor.......... 567

v. TVesterfeldt. . . . . . . 194

Winthrop v. Lane..........504, 507 Wintringham v. Wintringham .. 512 IViss v. IVithers..........529, 530 Wistar v. McManes........... 511 Wiswall v. Sampson......... 207 Witherly v. Mann.......... 462 VVithers v. Patterson.........119, 124

vituer v. Schatter................... 315

Vitter v. Fisher............ 316
Vittick v. Traum.......... 23S

VVixon v. Stephens.......... 21s

Wolfe v. Davis............. 96

v. Van Medre.......... 150

v. Washburn .......... 271

Wolfey v. Lebanon M. Co..... 71

Womack v. Womack..........319a

Wong Yung Quy, In re........ 6.6

Wood v. Bayard............. 152

v. Colvin............. 480

v. Davis............ 159

v. Ensel.............. 174

v. Gamble.........220, 592

v. Jackson. . 273, 2S4, 330,484

v. Keyes............ 57

v. Lake.............. 360

v. Messerly............ 394

v. Raymond...........26la

v. Stansberry......... 143

v. Toddy............ 475

v. WVard ............ 149

Woodburne v. Plummer....... 592

YVoodbury v. Bowman..... . . . . 328

Woollcock v. Bennett........48t

Woodgate v. Fleet.......... 271

Wooden v. Clemens. . . . . . . . . . 299

Woodhouse v. Williams....... 283

Woodruff v. Cook............ . 524 v. Taylor.......606, 608 v. VValling.........4 414

Voodson v. Barrett............ 502

Woodward v. Backus....... 10s, 541

v. Carson.........4432

v. Dean......... 363

v. Newhall........ 43

v. Paine.......... 5:9

v. Spaffords . . .... 232

TVoodyard v. Polsley....... $357 a$

IVoods v. Reynolds... . . . . . . 343

v. Macrae..........444

Woolson v. Gale.............443

Wooster v. Glover.......... $72 a$

v. TVoodhull......... 541

IVooster Coal Co. v. Nelson...108, 109

Worsely v. Scarborough.191, 19S, 305

Worthington v. Curd........281

Vorthington, In ve........... 317

Wright v. Butler.........240, 234

v. Cobleigh ..........46 4 it

v. De Klyne......... 270

v. Douglass..........366a

v. Dumning.............. 304

v. Fletcher......... 55

v. Hazen....... 122, 159

v. King............ 502

v. Lathrop.......... 236

v. Leclaire........... 142

v. Levy........... 428

v. Marsh ............ 308

v. Mitchell........... 4

v. Miller ......4 486, 513

จ. Parks........... 42:2

v. Salisbury ......... 278

v. Tatham ........... 205 
Wright $\mathrm{v}$. Weisenger........ 131 |Yocum $v$. Foreman.........483

v. Yell.............. 216 Yonge v. Broxsam.......... 62

Wyman v. Buekstaff......... 72 v. Shepperd......... 516

v. Campbell.........6 609 York v. Clopton........... 485

v. Dorr............ $265 \quad$ v. Steele........... 189

v. Mitchell........... 244 York Bank's Appeal.......... 347

Wynn v. Wilson........... 500 Young v. Black........... 273

Y. $\quad$ v. Bucher...............

v. Davis.............. 366

v. Grundy............. 34

v. Hubbeil........... 201

v. Pickens............. 153

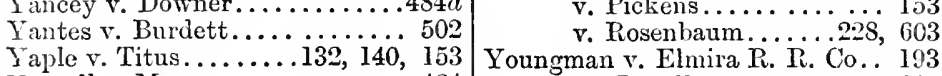

Yarnell v. Moore........... 464 Yount v. Howell........... 301

Yates v. Horansen.... . . . . . . 98

v. Lausing..........502, 530

Yerger, Ex parte............ 619

Yoakum v. Tilden........... 462 Zimmerman v. Hester........ 575 


\section{LAW OF JUDGMENTS.}





\section{LAW OF JUDGMENTS.}

\section{CHAPTER I.}

\section{PART I.-DEFINITIONS AND CLASSIFICATIONS.}

1. Lord Coke's Definition.

2. Common Law Defiuition.

$\S$ 3. Means of Enforcing.

\$ 4. Is a Judgment a Contract?

$\S \S 5,6,7,8$. Classifications and Definitions.

$\$$ 9. Definition of a Decree.

$\S 10$. Definition of a Decree, nisi.

\$11. Decree taken pro confesso.

$\S 12$. Classifications common to Judgments-and Decrees,

813. Judgments in rem and in personam.

$\$ 14$. Judgments under tho Coae.

\&15. Orders.

\section{PART II.-OF FINAL JUDGMIENTS.}

8 16. Puts an End to the Suit.

8 17. Dismissal is a Final Judgment.

$\S 18$. Vacating another Judgment.

$\$ 10$. Judgment of Condemnation.

$\$ \S 20$ and 34 . Settles all issues.

$\S 21$. Is not always a Final Adjudication.

$\$ 21 a$. In Criminal Prosecutions.

$\$ 21 b$. Dismissing Attachment Proceedings.

$\S 21$ c. Denying Right to Interven $\theta$.

82. In Equitable Proceedings.

823. May contain Directions to be Executed.

$\$ 24$. May require future Orders of the Cotart.

$\$ 25$. Requiring Transfer of Property.

$\$ 26$. Requiring Delivery of Iropeats.

8 27. Not Final.

$\$ 28$. Must be Final as to all the Defendants.

$\$ \S 20$ and 31. Interlocutory Decree.

$\S 30$. Test of Fiuality.

§32. Decree Foreclosing Llens.

§ 33. Appeals Unnecessary, not Permitted.

$\$ 34$. When Judgments Appealable.

\$35. Exceptions to Rule of Appeal.

$\S 36$. General Test.

PART I.-DEFINITIONS AND CLASSIFICATIONS.

8 1. Lord Coke's Definition.-One who sought to dignify overything connected with the common law, characterized judgments as "The very voyce of law and right." This

1 Co. Lit. 3̊a. 
language, however distant from the truth in individual cuses, is, when applied to the aggregate, but a slight exaggeration. A judgment is the end of the law. ${ }^{1}$ It finally terminates the disputes and adjusts the adverse interests of mankind. That it may in truth be the "voyce of right," legislators strive to make the law more in unison with the dictates of justice; judges, distinguished for learning, probity and wisdom, are called to the bench; and the principles educed from successive ages of legal altercation are carefully treasured for the benefit of the present and of the coming generations. Every judgment directly enforces some right or suppresses some wrong, thereby producing the end sought by every humanely conceived law. Its incidental results, extending far beyond the time at which it is pronounced, and the parties whose rights it determines, attach themselves to property or to privies in blood or in estate, and continue in binding force and obligation for indefinite periods of time.

8 2. Common Law Definition.-A judgment, except where the signification of the word has been changed by statnte, is defined as being "The decision or sentence of the law, pronounced by a court or other competent tribunal upon the matter contained in the record;" conclusion of the law upon facts found" by the court or. the jury, "or admitted by the parties." 3 The language of a judgment is not that it is decreed or resolved, but that it is considered that the plaintiff recover; or that the defendant go without day. The reasons announced by the court to sustain its decision ${ }^{4}$ and the award of execution to produce satisfaction, constitute no part of the judgment. "At law, the judgment is yea or nay, for one party and against the other; and recognizes no liens, awards no execution against specific property, unless when the proceeding is in rem; but simply contains the conclusion of " the law upon

\footnotetext{
${ }^{1}$ Blystone $v$. Blystone, 51 Penn. S. $\quad$ 'Tidd's Pr. 930; Truett $v$. I Legg, 32 p. 373 . Ma. 147.

${ }^{2}$ Jac. Law Dic.; 3 Bla. Comm. 395; Ettna Insurance Co. $v$. Swift, 12 Minn., p. 437.

4 Burk $v$. Table Monntain Co., 12 Cal. 408; Davidson v. Carroll, 23 La. Au. 108.
} 
the facts proved, and leaves the party to his legal and appropriate writ to enforce it." 1

8 3. Means of Enforcing.-The law provides the means of enforcing judgments. No court has authority to assume legislative powers by providing other means. Decisions made in some of the States proceed upon the theory that, if any court acting solely under authority conferred by the common law, should add to its jud 3 ment an order requiring satisfaction to be made in any other way or by any other means than those provided by law, as by requiring payment to be made in a particular kind of money, the appellate court would strike such order out. ${ }^{2}$ A different conclusion has, however, been sustained, by the highest tribunals of several other States; and there is now a decided preponderance of the authorities affirming the existence of the powcr to enter judgment for coined clollars, and to enforce it by an execution payable in the same kind of money. ${ }^{3}$

\section{4. Is a Judgment a Con'ract?-That a judgment is a} contract, or in the nature of a contract, has been afirmed 4 and denied ${ }^{5}$ vith equal confidence. On one hand it is urged as conclusive, that cach judgment creates an obligation capable of being cnforced by an action of debt or assump-

${ }^{1}$ Kramer $v$. Rebman, 9 Iowa, 114. Stuart $v$. Landers, 16 Cal. 372; McA judgment should be a simple sen- Guire $v$. Gallagher, 2 Sandf. S. C. 402. tence of the law, upon the ultimate ${ }^{5}$ Tiae $v$. IIulbert, 17 Ill. 572; Todd facts admitted by the pleadings or $v$. Crumb, 5 MIcLean, 172; Wyman $v$. found by the court. Gregory v. Nelson, 41 Cal. 278.

${ }^{2}$ Reed $v$. Eldredge, 27 Cal. 34s; Whitstone $v$. Colley, 36 Ill. 328; Burling $v$. Goodman, 1 Nev. 314; Olanyer v. Blanchard, 18 La. An. 615; Buchegger $v$. Schultz, 13 Mich. 420.

${ }^{3}$ Bronson $v$. Rodes, 7 Wall. 229; Chesa peake $v$. Swain, 29 Md. 483, 506; Paddock $v$. Comm. Ins. Co., 104 Mass. 521; Cheang Kee $v$. United States, 3 Wall. 320; Butler $v$. Horwitz, 7 Wall. 258; Ind. Ins. Co. v. Thomas, 104 Mass. 192; Kellogg $v$. Sweeney, 46 N. Y. 291; Hittson $v$. Davenport, 4 Col. 169; Trebilcock $v$. Wilson, 12 Wall. 6S7; Dewing v. Sears, 11 Wall. 379.

Nitchell, 1 Cow. 321; Snith v. Harrison, 33 Ala. 706; Keith v. Estill, 9

Port. 669; Masterson v. Gibson, 56 Ala. 50; Larrabee $v$. Baldwin, 35 Cal. 156-this last case applies to "contracts" as term is used in act fixing liability of stockho!ders of corporations. "A judgment is not in itself a contract." (In re Kenncdy, 2 S. C. (N. S.) 226.) "Strictly spealing, a julgment is a contract, and of that class of contracts ealled specialties; but the word con tract is not ordinari'y used in a sense that includes judgments; nor is it generally so used by law writers, nor is it so used in Scc. 20, Codle of Civil Procedure." (Burnes $v$. Simpson,

"Morse $v$. Toppan, 3 Gray, 411; 9 Kans. 65s; 12 Am. Law Res. 50.) 
sit, according to the nature of the judgment. That this obligation is based upon an implied promise, entered into by every member of society that he will pay all judgments which may be rendered against him, in consideration that the courts will assist him in preserving and regaining his righats. On the other hand, it is saic, with equal truth, that every man who commits a tort impliedly agrees, in consideration of the harm done by him, and the injury occasioned by his misconduct, to pay all damages which his wrong produces; and that the same implied premises necessary to prove tlat a judgment is a contract may be used with equal justness and efficiency, to establish the same thing of every conceivable cause of action. All anthorities assert, that the existence of parties legally capable of contracting, is essential to every contract. But a decided preponderance of authority recognizes judgments entered against lunatics and others incapable in law of contracting, as conclusively binding until vacated or reversed. It seems, then, that in order to prove that a judgment is in the nature of a contract, we must supply two of the three essentials of each contract by implication, and the third by some means not yet discovered.

\section{Class fication with Reference to Stage of the Pro-} caedings.-Judgments, considered in reference to the stage of the proceedings at which they are entered, are of four sorts :

1st. Where the facts are admitted and the law disputed, as on demurrer ;

2d. Where the law is admitted and the facts disputed, as in case of verdict;

3d. Where both the law and the facts are admitted, as in cases of confession or upon default;

4th. Where the plaintiff is convinced that the facts or the law, or both, are insufficient to support his action, and therefore abandons or withdrawshis prosecution, as in judgment upon nousuit or retraxit. ${ }^{1}$

This classification, though acquiesced in for a long time,

13 Black. Comm. 396 ; Jac. Law Dic.; Derby v. Jacques, 1 Clifford, 432; Blaikie $v$. Griswold, 10 Wis. 293. 
is neitheraccurately expressed nor correctly illustrated. There are individual cases where the law is admitted and the facts disputed, but such cases do not form themselves into a distinct class. The law arising upon a verdict is not brought to the attention of the court by any pleading, yet, far from being admitted, it is frequently the subject of animated and lengthy contests, both in subordinate and in appellate courts. Nor is it certain, as implied by the thirel subdivision, that there is any class of cases where both t'io law and the facts are admitted. A default, in no instance, authorizes any judgment to be rendered against the defendant unless a suficient cause of action is stated in the complaint. If there be any case where tho law is adnitted so as to subject the defendant to a judgment which would otherwise be regarded as erroneous, it must be where a clefault, or other confession of facts, is accompanied by such circumstances as create a presumption that he agreed to waive all errors. This would amount to an agreement to relinquish his right to reverse a judgment unsupported by law, bat not to an admission that the law, applied to the undisputed facts, would properly result in a judgment agrainst him.

86. Classification with Reference to State of the Pleadings.-Perhaps a better classification of judgments, would be one made with reference to the state of the pleadings at the time the court makes its final decision. Such a classification would not differ materially from the one heretofore given; but it could be more simply and clearly expressed. According to it, the classes would be as follows :

1. The judgment rendered where the pleadings presented no other issue than an issue of law.

2. The judgment rendered upon the decision of a court or a jary upon the issue or issues of fact made by the pleadings.

3. 'The judgment given where no issue has been made by the party required to plead.

4. Where before or after the joining of an issue of law or of fact the plaintiff abandons or withdraws his prosecution. 


\section{7. Various kinds of Judgments, and how Classified.}

- In the first class of either classification are included:

1st. The judgment given for the plaintiff, when an issue of law, formed by a demurrer to any of the pleadings in chief, is determined in his favor. It is final, and is called a judgment quod recuperet.

2l. The judgment given for defendant when a like issue is found in his favor.

3l. Judgment of respondeat ouster, a species of interloentory judgment for the plaintiff, on demurrer to a plea in abatement, when it appears that the defendant has mistaken the law on a point not affecting the merits of the case. By this judgment he is allowed to plead such further defense as he may have.

4th. The judgment given for the defendant on a demurrer to a plea in abatement, which is, that the writ be quashed.

In the second class are included :

1st. The judgment for plaintiff upon an issue of fact found in his favor.

2d. The judgment of nil capiat per breve, or per billum, when such issue is determined in his favor.

3d. Judgment quod partes replacitent. This is given if an issue be formed, and a verdict returned, on so immaterial a point that the court cannot know for whom to give judgment. The parties must then reconstruct their pleadings, beginning at the first fault which occasioned the immaterial issue.

The third class includes:

1st. Judgment nilil dicit, rendered whenever the defendant fails to plead to the plaintiff's declaration in the time allowed for him to do so. This judgment is proper, although the defendant who fails to plead in time, may lavo appeared by attorney. ${ }^{1}$

2d. Judgment non sum informatus, is the one rendered when the defendant enters, upon the record, that he is not informed of any defense to the action.

3d. Judgment by confession, relicta verificatione, entered when the defendant either confesses the action in the first instance, or when, after pleading, he, before trial, abandons his plea.

1 Stewart v. Goode, 29 Ala., 476, citing Comyn's Digest, Vol. 6, p. 147. 
4ill. The judgment non obstante veredicto. This is rendered when the plea confesses a cause of action, and the matter relied upon in avoidance is insufficient, although found true, to constitute either a defense or a bar to the action. ${ }^{1}$ This judgment can be entered only on the application of the plaintiff, ${ }^{2}$ made after the verdict and before the entry of judgment thereon. ${ }^{3}$

The fourth class comprises:

1st. Judgment of non pros, entered against the plaintiff, before any issue is joined, for not declaring, replying, or surrejoining, or for not entering the issue agreeably to the rules of the court.

2i. Judgment on nolle prosequi, which is entered when plaintiff declares that he will not further prosecute his suit, as to the whole or a part of his cause of action, or as to some or all of the defenclants. Of a similar nature is the entry of a stel processus, by which plaintiff agrees that all further proceedngs shall be stayed. This entry is usually made when the defendant becomes insolvent pending the action, and the object is to prevent his obtaining a judgment, as in case of nonsuit. ${ }^{4}$

31. Judgment of retraxit. This is given when the plaintiff, in person, ${ }^{5}$ voluntarily goes into court and enters on the record that he is in nonsuit, or that he withdraws his suit. "A retraxil differs from a nonsuit in this: one is negrative, and the other positive. The nonsuit is a mere default or neglect of the plaintiff, and therefore he is allowed to begin his suit again upon payment of costs; but a retraxit

\footnotetext{
1 Fiteh $v$. Scot, 1 Root, 35l; Bellows $\mid$ ren, 4 M. \& G. 15S; 4 Scott, N. R. 725; $v$. Shannon, 2 hill, 86; State v. Com- State $v$. Bank, 6 S. \& M. 21S, on aumercial Bank, 6 S. \& M. 218; Sullen- thority of 2 Tidd's Pr. 840. As to berger $v$. Gest, 14 Ohio, 204; Pim $v$. eases where this judgment may be Grazebrook, 2 C.B. 429;3D.\& L. 454; given, see Shepherd $v$. Halls, 2 Dowl. Moye $v$. Petway, 76 N. C. 327; Oades 453; Britton $v$. Fisher, 26 Q. B. (Up$v$. Oades, 6 Neb. 304; Atkinson $v$. per Canada) 33S; Kerr $v$. Strant, 8 Q. Davies, Il M. \& IV. 236; 2 D., N. S., B.(UpperCanada) S2; Madrall v. Thel778 ; 12 L. J. Exch. 169; Berwick $v$. lusen, 21 L. J. Rep. (N. S.) Q. B. 410; Duncan, 3 Exch. 644; Cook $v$. Pearce, Leigh $v$. Lillie, 6 H. \& N. 165; Snyder 8 Q. B. 1044.

2 Schermerhorn $v$. Schermerhorn, 5 Wend. 513; Smith $v$. Smith, 4 Wend. 46s. The proper course for a defendant against whom julgmeut has been rendered, upon pleadings which will not sustain a recovery, is by motion in arrest. Bellows $v$. Shannou, 2 Hill, 86.

${ }^{3}$ Ilarrison $2:$ G. N. R. Co., 11 C. B.

$v$. Lobinson, 35 Ind. 311 ; Lough $v$.

Thornton, 17 Minn. 253; Morris v. Zeigler, 71 Pa. S. 450; Glading $v$. Frick, 88 Pa. S. 460; Chapman $x$. Holding, 60 Ala. 522; Pim v. Grazebrook, 2 C. B. $429 ; 3$ D. \& L. 45 t; Willoughby $v$. Willoughby, 6 Q. B. $722 ; 9$ Jur. 498. ${ }^{4}$ Tild's Pr. 68l-2.

5 Thomason $v$. Odum, 31 Ala. 108.
} 542; 21 L. J.C. P. li; Beaty $v$. War- 
is an open roluntary renunciation of his claim in court, and by this he forever loses his action." 1

4 th. Judgment of nonsuit; which is of two kinds, voluntary and involuntary. When plaintiff abandons his case and consents that judgment go against him for costs, it is voluntary. But when he, being called, neglects to appear; or when he has given no evidence on which a jury could find a verdict, it is involuntary. "Where a plaintiff is demanded and doth not appear, he is said to be in nonsuit. And this usually happens where, on the trial, and when the jury aro ready to give their verdict, the plaintiff discovers some-error or defect in the proceedings, or is unable to prove some material point for want of witnesses."

\section{8. Judgment Capiatur, Misericordia, and in Actions} of Partition and Account.-The defendant, who, in a civil action, was convicted of a wrong committed vi et armis, was obliged to pay a fine to the king for the breach of the peace implied in the act. A judgment capiatur was entered against him, under which he was liable to be arrested and imprisoned until the fine was paid. A judgment, sometimes given at common law, against a party for the unjust vexation occasioned by his action, was called judgment misericordia. The interlocutory judgment in an action for partition, directing a partition to be made, was called judgment quod partilio fiat; while a final judgment in such action, quod partilio faclo firma et stctbilis in perpetuum, was entered after the return of the writ. ${ }^{3}$ The interlocutory judgment in an action of account, compelling defendant to account, was named judgment quod computet.

8. 9. Definition of Decree.-Daniell, in his "Practice in the High Court of Chancery," says that a "Decree is a sentence or order of the court, pronounced on hearing and understanding all the points in issue, and letermining the rights of all the parties in the suit according to equity and good conscience." $l($ It is to be hoped that decrees generally conform to the description here given of them. They are none the less decrees, however, if pronounced without hearing or understanding the points in issue. Neither is it

$13 \mathrm{Bla}$. Comm. 296; 31 Ala. 108.

27 Bac. Ab. 214.

35 Bac. Ab. 292.

4 Danl. Ch. Pr. 1192. 
necessary to their existence or validity, that the rights of the parties be determined according to equity and good conscience. The chief differences between decrees in equity and judgments at common law are as follows: The former are pronounced by courts of equity; the latter by conrts of law. The former result from an investigation and determination of the rights of the parties, by the means prorided and according to the pricciples recognized in equity jurisprudence; the latter result from an investigation and determination made by the more limited means, and more inflexible rules, of the common law. The former may bo adjusted to all the varieties of interest and of circumstance, and may contain such directions as are needed to carry them into effect, both in letter and in spirit; the latter are in an invariable form, general in terms, and absolute for plaintiff or clefendant. And the former often enforce rights not recognized by the common law; and which, without the aid of courts of equity, could be enforced only by the consciences of men.

8 10. Decree INisi.-A decree nisi is the decree given under the English practice, when the cause is called for hoaring and the defendant does not appear to ojen liis anstrer. Upon proof of the service of the subpœna to hear judgment, the court will enter such decree for the plaintiff as his counsel may desire, accompanying it with a clituse to the ofiect that it is to be binding, unless, being serred with process, the defendant shall, within a given time, show cause to the contrary.

8. 11. Decree taken Pro Confesso.-A decree talien pro confesso, is one entered when the defendant has made default by not appearing in the time prescribed by the rules of the court. A decree nisi is drawn by the plaintiff's counsel, and is entered by the court as it is drawn. A decree where the bill is taken pro confesso, is pronounced by the court after hearing the pleadings and considering the plaintirr's equity.

8 12. Classifications common to both Judgmen's and Decrees.-Both judgments and decrees, considered in rela- 
tion to the jurisdiction in which they were rendered, are either foreign or domestic. Considered with resgard to their effect in putting an end to an action, they are either final or interlocutory. Any judgrment or decree, leaving some further act to be done by the court, before the rights of the parties are determined, and not putting an end to the action in which it is entered, is interlocutory. But if it so completely fixes the rights of the parties, that the court has nothing farther to do in the action, then it is final. A final judgmeat or decree may only dispose of the action, leaving the plaintiff at liberty to commence another suit on the same cause, as in case of a dismissal or voluntary nonsuit by the plaintiff ; or it may, besides disposing of the action, determine all the rights involved in the suit, and become a bar to all other suits between the same parties in reference to the same subject matter.

\section{13. Judgments In Rem and In Personam.-Judgments} and decrees are either in personum or in rem. They are in personam when the proceedings are against the person; provided the adjudication be of such a nature as to be bincling only upon the parties to the suit and their privies in blood or estate. Judgments and decrees in rem are not, as the term implies, confined to proceedings where property is proceeded against as a party to the action; but include, in addition to adjudications against the thing, all those decisions or sentences, which, by the policy of the law, are binding upon all other persons as well as upon the parties to the suit. The proceedings prior to the judgment or decree may be in personam, no notice need be given except to the defendant, yet if the judgment affect the status of any person, or of any subject matter, as in a suit for divorce, it is conclusive apon the whole world, and is therefore classed as being in rem. The general nature of this class of judgments, and the various definitions given by different authors, will be considered in a subsequent chapter.

8 14. Judgments under the Code.-The Code of Procedure, adopted by several States, providing that thero shall be but one form of civil actions, defines a judgment to be "the final determination of the rights of the parties 
in an action or proceeding." 1 This definition is, in one respect, more comprehensive than the one first given in this chapter, as it includes the final decrees of conrts of equity. In another respect it is less comprehensive, because it excludes all interlocutory judgments. It is just broad enough to comprise all final judgments and all final decrees, ${ }^{2}$ and narrow enough not to comprise any which is less than final. There can now be no such thing as an interlocutory judgment in any case. ${ }^{3}$

8 15. Orders.--The class of judgments and of decrees, formerly called interlocutory, is inclucled in the definition given in the Code of the word order. "Every direction of the court or judge made or entered in writing, and not included in a judgment, is an order." 4 The Supremo Conrt of California, in one of its earliest decisions, asked tho question, "What then is the distinction between an order and a final judgment?" and answered it by saying: "Tho former is a decision made during the progress of the cause either prior or subsequent to final juilgment, settling some point of practice or some question collateral to the main issue, presented by the pleadings and necessary to be lisposed of before such issue can be passed upon by the court, or necessary to be determined in carrying the execution into effect." "The same tribunal, in a subsequent opinion, said: "An order is the judgment or conclusion of the court upon any motion or proceeding. It means cases where a court or julge grants afirmative relief, and cases where affirmative relief is denied." In New York, it has been decided that the decision of a court, overruling a demurrer and allowing the defendant time to answer, is not an order but a judgment. The grounds upon which this conclusion was based were: 1st. That an order is the decision of a motion, whilo a judgment is the decision of a trial. 2d. That a trial is

${ }^{1}$ N. Y. Code, § 245; Kansas Code, $\S 395$; Nev. Pr. Act, §144; Oregon Code, §240; Cal. Code of C. P., §577. 280.

${ }^{2}$ State $v$. McArthur, 5 Kansas, p.

${ }^{3}$ Belmont $v$. Ponvert, 3 Rob. 696; Sellers v. Union L. Co., 36 Wis. 398 ; Singer v. Heller, 40 Wis. 544.
${ }^{4} \S 400$, N. Y. Code; N. Y. Code of 1877 , sec. 767; §458, Nevada Code; $\S 521$, Kansas Code; \$513, Oregon Code; §515, Cal. Pr. Act; §1003, Cal. Code, C. P.

${ }^{5}$ Loring v. Ilsey, 1 Cal. 27.

${ }^{6}$ Gilman $v$. Contra Costa Co., 8 Cal. 57. 
an examination of an issue of law or of fact; and 3d, that as a decision upon demurrer necessarily involves an examination of an issue of law, it is a decision upon a trial and is therefore a judgment. ${ }^{1}$ If this reasoning be correct, and the premises assumed be true, it follows that there can, under the Code, be two judgments, or, in other words, two final determinations of the rights of the parties in the same action. The Code defines a judgment, but does not define it to be nothing more than "the decision of a trial." Only those decisions of trials, amounting to final determinations of the rights of the parties, answer to the definition given of a judgment. Hence, it is obvious that an order overruling a demurrer, but giving the defendant an opportunity to answer, is not a judgment within the meaning of the Code.

\section{PART II.-OF FINAL JUDGMENTS.}

8 16. Puts an End to the Suit. The 25th section of the Judiciary Act of the United States, provides that a final judgment or decree in any suit in the highest court of law or of equity of a State, in which a decision of the suit can bo had, may, in certain cases therein specified, be re-examined and reversed or affirmed in the Supreme Court of the United States. The statutes of the several States also generally provide for appeals to their highest courts from final judgments and decrees in the subordinate courts. Hence it has frequently been necessary to determine, both in the State and in the Federal Courts, whether a given judgment or decree was final within the meaning of the statute authorizing appeals. A like necessity existed at common law. Thus in Metcalfe's case, " "it was resolved that no writ of error lies till the last juagment." Lord Ellenborough declared "error can only be brought on final judgment;"3 and there are many other determinations to be found among the Common Law Reports, to the same general effect. ${ }^{4}$ There is no doubt, that in order to come within these stat-

\footnotetext{
${ }^{1}$ King $v$. Stafford, 5 How. Pr. 30; ${ }^{4}$ Mayor of Macclesfield $v$. Gee, 14 Bentley $v$. Jones, 4 How. Pr. 335.

${ }^{2} 11$ Coke Rep. 68. 3 Samuel $v$. Judin, 6 East, 333; I
N. R. 43 ; Scott $v$. Bennett, 5 L. R., Amey, 20 C. P. (Upper Can-
ada), 6 ; Tolson v. Kaje, 7 Scott, N. 11. L. Cas. 231; 5 Ir. R., C. L. $375 ;$ R. $222 ; 6$ M. \& G. 536.

20 W. R. 685. M. \&. WV. 470; Shepherd v. Sharp, I H. \& N. 114; Grand Trunk Rialway Co. v. Amey, 20 C. P. (Upper Can-
} 
utes, or to satisfy the tests applied by the common law, the judgment or decree need not finally determine the rights of the parties litigant; it is suflicient if it end the particular suit in which it is entered. ${ }^{1}$

Every definite sentence or decision by which the merits of a cause are determined, although it be not technically a judgment, or although the proceedings are not capable of being technically enrolled so as to constitute what is technically called a record, is a judgment within the meaning of the law. According to the common law rule, by a final julgment is to be understood, not a final determination of the rights of the parties, but merely of the particular suit." A judgment " that the defendant go hence, and that he recover his costs, etc.," thongh not very formal, is a good final judgment, because no further action can be talien while it remains in force. ${ }^{3}$ But a judgment for costs alone, though entered for defendant, after the jury have found a verdict in his favor, it seems, is not final, and cannot therefore be made the subject of revision after appeal. The reasons urged against regarding such a judgment as final, are that it does not dismiss the defendant without day, nor state that plaintiff shall take nothing by his suit, nor in any way, nor by any terms, profess to dispose of the subject matter of the litigation. 4

8 17. Dismissal.-The dismissal of a suit by the plaintiff is a judgment within the meaning of the Code. Where, in a suit, a temporary injunction has been issued, and the plaintiff, after giving bonds to secure the payment of all damages which may be occasioned by reason of the injunction being improperly issued, dismisses his suit, or permits it to be dismissed for want of prosecution, such dismissal is a final judgment, and an adjudication that the injunction ought not to have issued, on which an action may be maintained on the bond for all damages resulting from

'Weston $v$. City of Charleston, 2 Pet. 449; Ludlow's Heirs $v$. Kidd's Exrs., 3 Hamm. 541; Helm v. Short, 7 Bush, 623. Thus a judgment of nonsuit may be reviewed by a writ of error: Box $v$. Bennett, H. Bla. 432; Hitchins v. Hollingsworth, 7 Moore, P. C. C. 228.
${ }^{2}$ Belt $v$. Davis, 1 Cal. 13S; Klink $v$. Steamer Cusseta, 30 Geo. 504.

${ }^{3}$ Rogers v. Gosnell, 51 Mo. 468.

"Warren $v$. Shuman, 5 Tex. 450;

Higbee $v$. Bowers, 9 Mo. 354; Neyland $v$. White, 25 Tex. 319; Green $v$. Banks, 24 Id. 522. 
the injunction. Although in case of a judgment by dismissal, the issues are neither examined nor passed upon by the court, yet, by the failure of the plaintiff to prosecute lis action, they are virtually confessed. A dismissal under such circumstances, while it does not estop the plaintiff from maintaining a new suit on the same cause of action, does dispose of the rights of the parties in the action in the same manner as if there had been an adjudication on the merits. ${ }^{1}$

8 18. Judgment Vacating another Judgment.-When, in an action to set aside a judgment, the court grants the prayer of the complaint and awards a new trial, the order setting aside the judgment is a final judgment, and as such may be appealed from. The whole scope and object of the suit being to vacate the former judgment, and to procure a new trial, and the issues all being made up for that purpose, their determination necessarily puts an end to the suit. ${ }^{2}$

8 19. Judgment of Condemnation.-In a proceeding by a railroad company to condemn lands, or a right of way across lands, where the parties in interest are summoned to appear and contest with the petitioners, and where commissioners are appointed to assess the value of the property sought to be condemned, and a report is made by them and confirmed by the court, and the court adjudges that the petitioners have brought themselves within the provisions of the act providing for the condemnation, the action of the court is a final judgment within the meaning of the $347 \mathrm{th}$ section of the Practice Act, allowing an appeal from a final judgment entered in an action or special proceeding. ${ }^{3}$

\& 20. Settles all the Issues.-Sometimes several issues of law and of fact are presented for the consideration of the court in the same suit or proceeding. In such case, there

\footnotetext{
${ }^{1}$ Dowling $v$. Polack, 18 Cal. 625; ${ }^{2}$ Belt $v$. Davis, 1 Cal. 134; McCall Loomis $v$. Brown, 16 Barb. 325; Shear- v. Hitchcock, 7 Bush, 615; see, howman $v$. N. Y. Central Mills, 11 How. ever, Dorsey $v$. Thompson, $37 \mathrm{Md} .25$. Pr. 269; Coates $v$. Coates, 1 Duer, 664; ${ }^{3}$ S. P. \& N. R. R. Co. v. Harlan, 24 Leese $v$. Sherwood, 21 Cal. 1 C3. $\quad$ Cal. 337.
} 
can be no judgment from which an appeal may be taken until all the issues are determined. For although the determination of an issue of law is a trial, and the decision rendered thereon, is not an order within the definition of the Code of New York, but a judgment, still it is not until the final judgment is entered that an appeal will lie. ${ }^{1}$

\section{21. INot alvoays a Final Adjudication.-A judgment} may be final so as to authorize an appeal from the court in which it was rendered, without being final as to the subject matter in litigation. An appeal may be taken, in which case, the judgment of the inferior tribunal is not final as to the subject matter, because it may be changed by the appellate court. Thus a covenant in a deed that if the title to certain lands were not confirmed to the covenantor by the courts of the United States before which it was pending, upon the final adjudication of the same, the covenantor would pay a sum of money, does not become a cause of action when the District Court refuses to confirm the title and declares it invalid. Until the time for appeal has elapsed, or until the judgment of the highest court in which the suit could be determined, has pronounced against the validity of the title, there has been no such final adjudication as was intended by the parties to the covenant. ${ }^{2}$

\& 21a. In Criminal Prosecutions, the same policy with respect to appeals prevails as in other cases. The judgments which may be reviewed by appeal or otherwise must be final; and, generally, no judgment will be regarded as final, unless it condemns the prisoner to be punished, and sets forth particularly the amount, duration, and place of punisisment. ${ }^{3}$ The defendant can not appeal from an order sustaining a demurrer to his plea of autrefois acquit. ${ }^{4}$ Evideutly an order overruling a demurrer to an indictment can not be appealed from as a final judgment, for it leaves the issues of fact yet to be tried, and judgment thereon yet to be pronounced. ${ }^{5}$ It has also been determined that no appeal

${ }^{1}$ King $v$. Stafford, 5 How. Pr. 30; 587; Mayfield $v$. The State, 40 Id.

Bentley $v$. Jones, 4 Id. 335.

2 Hills $v$. Sherwood, 33 Cal. 474.

${ }^{3}$ Anschincks $v$. The State, 43 Tex. 289; Fulcher $v$. The State, 38 Id. 505.

4 State $v$. Horneman, 16 Kans. 452.

5 People v. Hall, 45 Cal. 253. 
can be taken where the court sustains a demurrer to an indictment, but enters no formal final judgment in favor of the defendant. ${ }^{1}$ In California, a different rule prevails, and the reasons for its adoption were very clearly and forcibly stated by Mr. Justice Crockett, in People v. Ah Oun, 39 Cal. 606, in the following langnago: "This is an appenl from an order sustaining a demurrer to an indictment for kidnaping. The order sustaining the demurrer is in tho usual form; but no other or further order judgment was entered, and the appeal is taken from this order, treating it as a final julgment or disposition of the case. The objection is urged that no appeal will lie from an order sustaining a demurrer to an indictment; that to entitle the State to an appeal, there must be a formal and final judgment; and it is claimed that the order sustaining the demurrer, standing alone, can not be deemed a final judgment, from which an appeal will lie. But we think the point is not well taken. A defective indictment is not subject to amendment, and when decided, on demurrer, to be insufficient, the cause is finally ended. The Code (sec. 144) defines a judgment to be "the final determination of the rights of the parties to the action or proceeding;' and it is evident that the final order which decides the matters at issue, adjudicates the rights of the parties, and ends the litigation, must be deemed a final judgment for the purposes of an appeal. In civil actions, an order sustaining a demurrer to the complaint is not an appealable order, for the reason that the complaint is amendable, and the sustaining a demurrer to it does not end the litigation. It is not a final determination of the rights of the parties. But in a criminal prosecution it is otherwise, and when a demurrer is sustained, the action is finally ended in that conrt. Nothing more remains to be done. It is true, in proper cases, if the defendant is in custody, the court may detain him to answer another indictment to be found by another Grand Jury. But the first iudictment is, nevertheless, finally disposed of by the demurrer, and the order sustaining which may for that reason be properly deemed to be a final judgment."

${ }^{1}$ State $v$. Gregory, 38 Mo. 501; State $v$. Mullix, 53 Id. 355.

16 
8 21b. A judgment dismissing an attachment under the Cocle of Georgia has been held by the Supreme Court of that State to be so firr final as to be subject to review on writ of error "for the reason that the whole attichment element was disposed of by dismissing the attachment. The decision was final as to it, and any judgment which the plaintiff might recover on his declaration thereafter, would have no aid from the levy of the attachment. It would take lien ouly from the date of the judgment, and the security of the replevy bond wonk be lost. To maintain his attachment it was the right of the plaintiff to have the judgment dismissing it reviewed by a separate writ of error."

\section{1c. An Order Dismissing a Peticion for Intervention} is, in Texas, not subject to review as a final judgment. The petitioner or intervenor must wait until the issues between the plaintiff and defendant are determined and their rights fixed by a final julgment, before he can appeal. ${ }^{2}$ The rule is otherwise in California ${ }^{3}$ and Louisiana, ${ }^{4}$ whether the order be one denying leave to file a complaint of intervention or-sustaining a demurrer thereto when filed and entering judgment thereupon against the intervenor.

322. In Equitable Proceeding 3.-The courts have experienced considerable difficulty in determining what, under the code, is a final judgment, in proceedings in the nature of suits in equity. Some of the decisions do not seem exactly in harmony with the others. We shall now notice the cases in which the judgments hefore the courts have been declared to be final, and shall then note several cases in which they have been considered interlocutory.

\section{23. May Contain Directions to be Executed in} Future.-A stockholder having commenced an action against a corporation and its officers, for an accounting and settlement of its affairs, a decree was, after a full hearing on the merits, entered in accordance with the prayer of the

${ }^{1}$ Bruce v. Conyers, 54 Geo. 680; ${ }^{3}$ Stich v. Dickinson, 38 Cal. 608; Sutherlin $v$. Underwriters' Aggency, Coburn v. Smart, 53 Cal. 742. 53 Id. 442.

${ }^{2}$ Stewart $v$. The State, 42 Tex. 242. An. 184. 
complaint. By this decree a receiver was appointed to take charge of the corporate assets until the further order of the court, to collect moneys due or to become due, sell stock, and pay the proceeds in accordance with directions given in the decree. The Supreme Court declared that this decree was a final judgment and subject to appeal. ${ }^{3}$ A decree entered in an action brought for an accounting and for a dissolution of a copartnership, granting the relief prayed for, ordering a sale of all the partnership assets, and specifying the manner in which the proceeds of such sale shall be distributed, is a final decree. ${ }^{2}$

\section{IMay Require Future Orders or Proceedings.-} These decisions are fully sustained by several of the decisions of the courts of the State of New York. Although further proceedings, before the master, are necessary to carry the decree into effect, yet, if all the consequential directions depending on the result of the proceedings are given in the decree, it is fiual. A decree is none the less final because some future orders of the court may become necessary to carry it into effect: ${ }^{3}$ nor because some indepeudent branch of the case is reserved for further consideration, ${ }^{4}$ or the disposition of the costs is not determined; ${ }^{5}$ nor because, when the merits of the controversy are adjudicated upon, and the equities of the parties definitely settled, an account is directed to be taken to ascertain what sum is due from the one to the other, as the result of the decision already made by the court. ${ }^{6}$ But in all cases where further proceedings are to be taken, or further orders of the court are necessary, the judgment can not be treated as final, even for the purposes of appeal, unless it determines the issues involved in the action. ${ }^{7}$ A judgment against an administrator, for a specific sum and costs, in the usual

${ }^{1}$ Neall $v$. Hill, 16 Cal. 145.

${ }^{2}$ Clark $v$. Dunham, 46 Cal. 204.

${ }^{3}$ Mills v. Hoag, 7 Paige, 18; Johnson $v$. Everett, 9 Paige, 636; Quacken. bush $v$. Leonard, 10 Paige, 131; Dickinson $v$. Codwise, 11 Paige, 189; Stovall v. Banks, 10 Wall. 583 .

${ }^{4}$ Cannon v. Hemphill, 7 Tex. 184.

${ }^{5}$ McFarland $v$. Hall, 17 Tex. 691. 
form, except that there was a clause added to the effect that the defendant should have during the term of the court to make adcitional showing, if he could, that he had previously paid the moneys or any part thereof, for which judgment was rendered against lim, was held to be final, on the ground that this clanse did not confer any new right nor detract from the effect of the judgment; ior, as the court said, a judgment may always be opened or set aside during the term at which it was rendered. ${ }^{1}$ A judgment against an administrator in the usual form, "to be released on the payment of such sum as Enoch J. Millard shall say is due and costs," was also adjulged to be final, because, "to make it absolute as far as regarded the amount due on the account, no further act of the court was necessary."

8 25. Requiring Conveyance of Property. - In the case of Tiavis v. Waters, 12 Johns. 500, a decree was sain to be final when all the facts and circumstances material to a complete explanation of the matters in litigation were brought before the court, and so fully and clearly ascertained on both sides, that the conrt has been enabled to collect the respective merits of the parties litigant, and, upon full consideration, has determined between them according to equity and good conscience. This case was for a specific performance of a contract to convey certicin lands. The chancellor latving made an order that the defendant, under direction of one of the masters of the court, on payment or tender to him of a certain sum cf money, execute and deliver to the plaintiff a good and sufficient conveyance of the real estate in controversy; this order, thongh silent as to costs, was considered as within the above definition of a final decree, and the plaintiff was not permitted to set the case down for further hearing, so as to have his bill of costs put in the decree. ${ }^{3}$

¿. 26. Final, if Requires Delivery of Property. - Where the assignee of a bankrupt filed his bill in equity to have

\footnotetext{
${ }^{1}$ Harmon v. Bynum, 40 Tex. 324. the rights of property, and directs a

${ }^{2}$ Turner $v$. Plowden, 5 G. \& J. 52; conveyance to be marle at a future 23 An. Dec. 596.

${ }^{3}$ A decree is final which determines Monr. 453.
} 
the deeds of certain lands and slaves, made by the bankrupt to the defendants, set aside, and to have the lavds and slives delivered to the assignee, and that an account of the profits of the lauds aud slaves be taken, and that such profits, when ascertained, shonld be paid over to the assignee, the court decreed that the liuds aud slives be delivered to the assignee and by him sold, and that the accomst of profits be talsen. From this lecree an appeal was talien to the Supreme Court of the United States, where it motion was mitle to dismiss the appeal, because the decree was interlocutory. The motion was denied. The court snil, that when a decree determined tho right to property, and cirected it to be given to the complainint, or to be sold for lis benefit, and he was entitled to have the decree carried into immediate effect, it was final within the meaning of the statute authorizingappeals; and that if no appeal were allowed from such a decree, the property in controversy conld be sold, or otherwise disposed of, and thereby placed so completely beyond the reach of the defendants that an appeal at in subsequent stage of the proceedings could do them no good. ${ }^{1}$

3 2i. Iot Final. - It seems certain, however, that if the decree under consideration in the above case lad simply determined the right to the property in dispute, withont giving directions for its sale, or delivery to the complainauts, no appeal would have been recognized until all the issues had been determined, aud such a decree entered as would hive completely disposed of the suit. ${ }^{2}$ A decree final in other respects is not interlocutory because it directs a taxation of costs; ${ }^{3}$ nor because, as in the case of a decree for the sale of mortgaged premises, subsequent proceedings under direction of the court, are necessary to execute the decree. ${ }^{4}$

1 Forgay $v$. Conrad, 6 How. 201. Ing the exact amount due to be cal-

${ }^{2}$ Perkins $v$. Fourniquet, 6 How. 206; culated by the master, and to be by Pulliam v. Christain, 6 Id. 209.

${ }^{3}$ Craig $v$. Steamer Hartford, 1 McAll. 91.

" Bronson v. R. R. Co., 2 Black, 531; Ray v. Law, 3 Cranch, 179. A decrec disposing of a canse, but leavhim reported at next term, is final. Meek $v$. Mathis, 1 Heisk. 534. A decree dismissing certain parts of a bill is not final. Mayor $v$. Lamb, 60 Geo. 342. 
8 28. Must be Final as to all Defondants.-The order of the court in an action for the partition of real estate, which determines the several interests of the parties to the action, and appoints a referee to make a partition between them, and report the same to the court, is not a final judgment, even against a party whom the court by such order determives to be wilhoul any title. ${ }^{1}$ A decreo declaring a legacy void as to one defendaut, but reserving all other questions, is not such a final decree as may be appealed from. ${ }^{2}$ And, as a general rule, a judgment determining the rights of some of the parties, is not final so as to anthorize an appeal until it has settled the rights of all the defendants. $^{\text {s }}$

8 29. An Interlosutory Decree is one made "pending the cause, and before a final bearing on the merits. A final decree is one which disposes of the cause, either by sending it out of the court before a hearing is hatd on the merits, or after a hearing on the merits, decreeing either in firvor of or against the prayer of the bill." But no order or decree which does not preclude further proceedings in the case in the court below, should be considered final."

8 30. Test of Finality.-A decree can never be final until the party in whose favor it is, can obtain some benefit therefrom withont again setting the cause down for further learing before the court, upon the equity reserved upon the coming in and confirmation of the report of the master, to whom a reference has been made, to ascertain certain facts which are absolutely necessary to be letermined before the case can be finally disposed of by the court, or which the chancellor thinks proper to have ascertained before lie grants any relief. But if the questions which can arise on the exceptions to the master's report are such as are merely incidental to the carrying of the decree into effect, it is final. ${ }^{5}$

${ }^{1}$ Peck $v$. Vandenberg, 30 Cal. 11; ${ }^{3}$ Harrison $v$. Farnsworth, 1 Heisk. Gates $v$. Salmon, 28 Cal. 320. The 751; Delap $v$. Hunter, 1 Sneed, 101; law has been changed by act of March $23,1564$.

${ }^{2}$ Chittenden $v$. M. E. Church, 8 How. Pr. 327.

Martin v. Crow, 2S Tex. 614; Wilis v. State, 4 Tex. App. 613.

* Chouteau $v$. Rice, 1 Minn. 24.

5 Johnson v. Everett, 9 Paige, 638. 
8 31. Interlocutory Decrees.-A decree is interlocutory which makes no provision for costs, and in which the right is reserved to the parties to set the cause down for further directions not iuconsistent with the decree already made; and so is a decree which contains a provision for a reference of certain matters, and that all further questions and directions be reserved until the coming in of the report of the referee; an order or decree pro confesso for an injunction restraining the use of an invention is interlocutory merely; but a decree dismissing a bill, ${ }^{3}$ or dissolving an injunction aud passing definitively on all the essential points in issue, is final. 4

Z32. Decree Froreclosing Iiens.-An action was commenced to enforce certain liens against real estate, aud a judgment therein was entered directing that a sale of tho premises be made, and that from the proceeds a sum specified should be paid to discharge one of the liens, and that the plaintiff should be paid an additional sum, less the amount due from lim to the defendant for rent of the premises, and that a reference be had to ascertain the amount of such rent. An appeal was taken from this judgment. 'The appellate court, on motion to dismiss the appeal, considered that as the object of the action was to ascertain to whom the whole proceeds to be derived from a sale of the premises should belong, and that as this could not be ascertained until it was known what amount ought to be deducted from the plaintiff's claims for rents, the judgment entered by the court below was not a final judgment. ${ }^{5}$ Obviously a decreo of foreclosure can not be final, if it neither determines the amount to be paid, nor ascertains or describes the property to be sold. ${ }^{6}$

833. Appeals Unnecessary not Permitted.-The policy of the laws of the several States and of the United States, is to prevent unnecessary appeals. The appellate courts will not review cases by piecemeal. The interests of liti-

1 Williamson $v$. Field, 2 Barb. Ch. $\mid{ }^{4}$ Saloy $v$. Collins, 30 La. An. 63.

281; Harris $v$. Clark et al., 4 How. 5 Thompkins $v$. Hyatt, $19 \mathrm{~N}$. Y. Pr. 78 .

${ }^{2}$ Russell $v$. Lathrop, 122 Mass. $3 c 0 .{ }^{6}$ Railroad Co. $v$. Swasey, 23 Tall

${ }^{3}$ Snell $v$. Dwight, 121 Mass. 34S. 405. 
gants require that causes should not be prematurely brought to the higher courts. The errors complained of might be corrected in the court in which they originated; or the party injured by them might, notwithstanding the injury, have final julgment in his favor. If a judgment, interlocutory in its nature, were the subject of appeal, each of such judgments rendered in the case could be brought beforo the appellate court, and litigants harassed by useless delay and cxponse, and the courts burdened with unnecessary labor.

8 34. Judgment, when Appealabie.-The general rule recognized by the courts of the United States, and by the courts of most, if not of all the States, is that no judgment or decree will be regarded as final within the meaning of the statutes in reference to appeals, unless all the issues of law and of fact necessary to be determined were determined, and the case completely disposed of, so far as tho court had power to dispose of it. ${ }^{1}$

§ 35. Excep'ions.-But owing to particular circumstances and hardships, the courts have refused to dismiss appeals from some judgments which did not completely dispose of the cases in which they were entered. Theso judgments determined particulir matters in controversy, and were of such a nature that they could be immediately enforced, and by their enforcement could deprive the party against whom they were rendered, of all benefits which ho might obtain from an appeal at any subsequent stage of tho proceedings. ${ }^{2}$ To avoid the necessity of being called upon to review such judgments, the superior courts have cautioned the inferior ones, and endeavored to impress upon them the evils resulting from the practice of entering interlocutory judgments capable of being at once enforced against a party,

1 IcCollum $v$. Eager, 2 How. U. S. 13ॅ; The Palmyra, 10 Id. 502; Chace 61; Craighcad v. Wilson, $18 \mathrm{Id} .199$; $v$. Vasquez, 11 Id. 429; Hiriart $v$. BalAyres $v$. Carver, 17 Il. 594; Crawford lon, 9 Pet. 156; Rutherford $v$. Fisher, v. Points, $13 \mathrm{Id}$. 11; Mordecai $v$. 4 Dall. 22; Young v. Grundy, 6 Liudsay, $19 \mathrm{Id}$. 200; Montgomery $v$. Cranch, 51.

Anderson, 21 Id. 396; Barnard $v$. 2Merle v. Andrews, 4 Tex. 200; Gibson, 7 Id.650; Pepper v. Dunlap, Stovall $v$. Danks, 10 Wall, 583.

5 Id. 51 ; Winn $v$. Jackson, 12 Wheat. 
and doing him irretrievable damage before a final judgment can bo entered. ${ }^{1}$

836. General Test.-Orving to the number of orders or decrees necessarily entered in a suit in equity to furnish all the relief to which the complainant may be entitled, the courts have been frequently obliged to determine which is the fincl decree. So far as any general distinguishing test can be gathered from the numerous decisions, it is this: That, if after a decree has been entered, no fu:ther questions can come befure the court, except such as are necessary to be determined in carrying the decree into effect, the derreo is final; otherwise it is interlocutory. ${ }^{2}$ But an order or decree made for the purpose of carrying a judgment or decree already entered into effect, is not a final judgment or decree, and cannot be appealed from as such. ${ }^{3}$

1 Barnard $v$. Gilson, 7 How. 650; judgment, and not before; from which Forgay v. Conrad, 6 Id. 201. The an appeal or writ of error ciu te case of Martin $v$. Crow, 23 Tex. 614, taken." But as there are intimations so far as we are able to understand it, in the opinion that the court seemed seems to deny the right of appeal to be considering the rights of A. M., even where the judgment is capable who was not a party to the judgment, of enforcement against the parties to it may be that he was the appell. $n$ t. it. The suit was by C. against A. M., If so, the general language of the M. MI., and L. M. Judgment by de- court does not raise any conflict wild fauit was entered against M. M. and the rule of the cases cited above.

L. M., and the canse continued for service against A. JI. From this judgment an appeal was taken, but by whom does not appear. In considering the appeal, the court said: "When the whole of the matter in controversy is finally disposed of as Smith $v$. Trabue's Heirs, 9 Pet. 4. so all tie parties, then there is a furus 524 ; Ogilvie $v$. Knox Ins. Co., 2 Black. 539 ; Humiston $v$. Stainthorp, 2 Wall. 106.

3 Callan v. May, 2 Black. 541; 


\section{CHAPTER II.}

\section{THE ENTRY OF JUDGIENTS.}

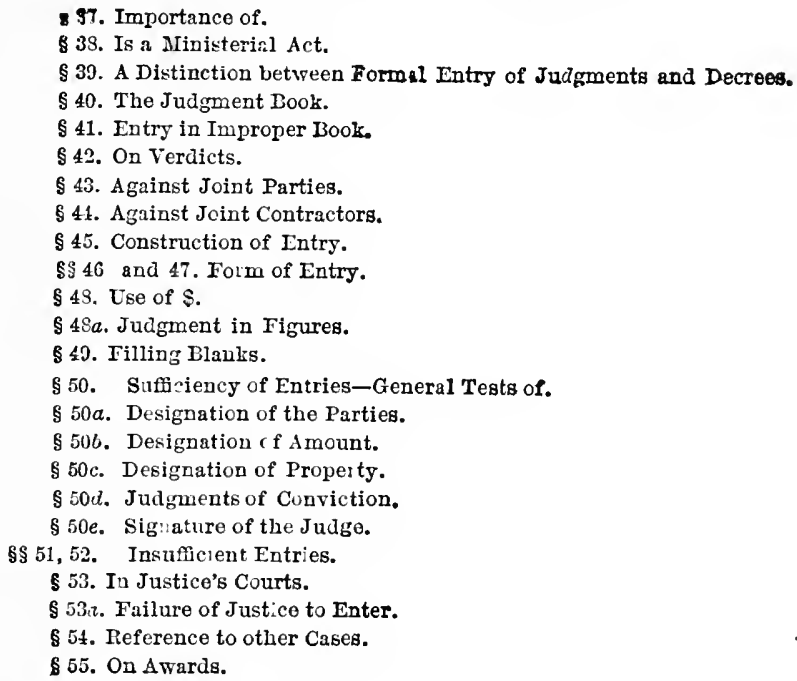

\section{OF THE ENTRY OF JUDGMENTS.}

8 37. Importance of. - The promptings of the most ordinary prudence suggest that whatever, in the afiairs ef men, has been so involved in doubt and controversy as to require judicial investigation, ought, when made certain by a final determination, to be preserved so by some permanent and easily understood memorial. Hence, all courts, and all tribunals possessing judicial functions, are required by the written or unwritten law, and often by both, to reduce their decisions to writing in some book or record required to be kept for that purpose. The requirement is believed to be of universal application. ${ }^{1}$ So that if any judgment or decree of any court, whether of record or not of record, whether subordinate or appellate, fails to be entered upon its records, the failure is attributable to the negligence or inadvertence of its officers, and not to the countenance and support of the law.

1 Meeker $v$. Van Rensselaer, $15 \mid 427$; Daridson $v$. Murphy, 13 Conn. Wend. 397 ; Jones v. Waller, 5 Yerg. 213 ; Bolker v. Bronson, 5 Bl. C. C. 5. 
8. 38. Ministerial Act.-Expressions occasionally find their way into reports and text-books, indicating that the entry is essential to the existence and force of the judgment. These expressions have escaped from their authors when writing of matters of evidence, and applying the general rule that in each case the best testimony which is capable of being produced must be receired, to the exclusion of every means of proof less satisfactory and less authentic. The rendition of a judgment is a judicial act ; its entry upon the record is merely ministerial.' A judgment is not what is entered, but what is ordered and considered. 2 The entry may express more or less than was directed by the court, or it may be neglected altogether : yet, in neither of these cases is the judgment of the court any less its juclgment than though it was accurately entered. In the very nature of things, the act must be perfect before its history can be so; and the imperfection or neglect of its history fails to modify or obliterate the act. That which the court performs judicially, or orders to be performed, is not to be avoided by the action or want of action of the judges or other ofincers of the court in their ministerial capacity. In the case of judgments, they must first be entered upon the record before they are admissible as evidence in other courts. ${ }^{3}$ For this purpose they are not otherwise perfect. The record, if not made up, or if lost or destroyed, should be perfected or replaced by appropriate proceedings in the court where the judyment was pronounced.

\section{\& 39. Distinction between Judgments and Decrees.-} In respect to the entry of judgments and of decrees upon the record, and the consequent effect of their want of entry, as affecting their admissibility as evidence in other cases, there seems to be this radical difference. A judgment can speak but by the record. A decree in the absence of any statute or provision to the contrary, takes effect immediatcly after being pronounced by the court. Its enrollment adds nothing to its force, nor to its competency as evi-

1Matthews $v$. Houghton, 11 Maine,
377; Fish v. Emerson, 44 N. Y.
376.
2 Davis $v$. Shaver, 1 Phill. N. C. 18. 3 Hall v. Hudson, 20 Ala. 284. 
dence. ${ }^{1}$ This distinction arose from the difierences in tho proceedings at law and in equity. It is inherent in the nature of the two systems. Though the code declares in general terms that there shall be but one form of action, and thereby, in a general manner, attempts to abolish tho distinctions before existing in the pursuit of legal and of equitable remedies, it has doue little by the attempt. The necossity for the recognition of equitable rights, and for granting equitalle relief, continues as before the adoption of the code. The proceedings occasioned by this necessity are substantially as they were under the old system. Among the rules of the old system, not abrogated by the new one, is the one that a decree pronounced by the court and reduced to writing, is admissible in evidence, independent of the fact of its emrollment or entry in the judgment book. ${ }^{2}$

\& 40. In Judgment Boox.-The code requires the keeping of a judgment book by the clerk, in which every judgment must be entered. ${ }^{3}$ In no case ought this requirement to be dispensed with. It applies as well where the decision of the judge is made in writing and filed as in any other case. ${ }^{4}$ The authority of the clerk to make this formal entry is founded on a judgment already valid, and whoso validity is not destroyed by his failure to enter it. A judgment drawn up in the form in which it was intended to bo entered, signed by the judge, and filed in the cause, is the judgment of the court at that time and of that term, although execution should not be issued upon it then. ${ }^{5}$ The action of the clerk, being non-juclicial, may take place at any time afterward. The usual custom, perhaps, is for him to wait for leisure moments to perform this duty. In

1 Bates v. Delavan, 5 Paige, Ch. 3 N. Y. Code, $\$ 9279$, 280; Cal. Pr. 303; Winans v.Dunham, 5 Wend. 47 ; Act, $\$ 201$; Cal. C. C. P. $\$ 633$.

Butler $v$. Lee, 3 Keyes, 73. But in Canada, the decree must be entered in the register's book, and all proceedings based thereon, and taken before such entry, are irregular and voidable. Drummond $v$. Anderson, 3 Grant's Ch. 151.

${ }^{2}$ Lynch $v$. Rome Gas Light Co., 42 Barb. 591.

4S. \& S. Plank Road Co. v. Thatcher, 6 How. Pr. 226.

5 Casement $v$. Finggold, $23 \mathrm{Cal} .33 \tilde{3}$; Mclrillan $v$. Richards, 12 Cal. 467. The omission of the elerk to sign a decree, is at most a mere irregularity which cloes not vitiate the judgment.

Hotchliss $v$. Cutting, 14 Minn. 5i2; Jorgensen v. Griflin, 14 Minn. 466. 
many cases the record is not completed until after the adjournment of the term. And this practice seems to have prevailed at common law. ${ }^{1}$ As the judgment is final before its formal entry in this book, a statute providing that an appeal may be perfected within a specified time from the "rendition" of the judgment, certainly commences to run from the time of the drawing up and signing of the judgmont, and filing it anong the papers in the case. ${ }^{2}$ The language used, in the opinion of the court, in the case of Genella v. Relyea, cited above, though not necessary to the decision of that case, is worthy of citation as founded upon reason. It indicates that the time for appeal begins to run, though no judgment be filed. "The court announced its judgment, and the order for judgment was entered in the minutes of the court on the fifteenth of August, 1865. The julgment was therefore rendered and the timo for taking an appeal commenced to run on that day."

841. Use of Improper Book.-If, as in California, 3 the clerk is required, in addition to the judgment book, to keep a "Register of Actions," and he, neglecting to keep the first named, copies the judgments into the latter, they are not therefore invalid. The substantial purpose of the statute is accomplished, although the two books are united. No harm results to any one from this union. ${ }^{4}$ But, independent of the considerations named, the judgments should be sustained. If, as the authorities state, judgments are valid when not entered in any book, they surely ought to be equally valid if entered in some record of the court, though not in the one designed for that purpose.

$\S 42$. On Verdicts.-The Code of Civil Procedure in California, ${ }^{5}$ requires the clerk to enter judgment in conformity to the verdict, within twenty-four hours after the rendition of the verdict, unless the court order the case reserved for further consideration, or grant a stay of proceed-

\footnotetext{
1 Osborne $v$. Toomer, 6 Jones Law R. 440 . 3 Cal. C. C. P. $\$ 1,65^{\prime}$; Pr. Act, g 528 .

2 Gray v. Palmer, 28 Cal. 416; Ge- 4Jorgensen $v$. Griffin, 14 Minn.464. nel'a v. Relyea, 32 Cal. 159; Kehoe v. 5 Cal. Pr. Act, $\$ 197$; Cal. C. C. P. Blethen, 10 Nev. 445. \$ 664 .
} 
ings. Unless there is doubt as to what judgment is proper, the better practice is to enter it at once. The judgment may as well be set aside as the verdict. Therefore such proceedings as may be appropriate to securing a new trial, or any other right of the losing party, can be prosecuted as adrantageously upon granting a stay of proceedings upon the judgment as upon the verdict. The immediate entering of judsment authorizes the making up of the judgment roll, and thus secures a lien on the judgment debtor's real estate. To this security he is at once justly entitled. If the conrt delays in granting it to him, he may, during the stay of proceedings, be deprived of the fruits of his litigation. ${ }^{1}$

8. 43. Joint Parties.-At common law, in a joint action, whether upon a joint or a joint and several contract, or upon several distinct contracts, the general rule was, that there could be no judgment except for or against all of the defendants. To this rule the exceptions were, first, in the case where one or more of the defendants, admitting the contract, established a discharge therefrom, as by bankruptcy; second, where sume one of the defendants plead and proved that he was incapable of contracting, when the alleged contract was made, from some disability, as infancy. So unyielding was the rule, that when one of the defendants suffered a default or confessed the action, no judgment conld be given against him, if his co-defendant succeeded in maintaining some defense affecting the entire contract. ${ }^{2}$ Codes of Procedure, adopted in several of the States, ${ }^{3}$ have abolished this rule by enacting that judgment may be given for or against "one or more of several plaintiffs, and for or against one or more of several defendants;" and "that in an action against several defendants, the court may, in its discretion, render judgment against one or more of them, leaving the action to proceed against the others whenever a several judgment is proper." Under these sections, of two

${ }^{1}$ Hutchinson $v$. Bours, 13 Cal. 50. Leigh, 606; Rohr v. Davis, 9 Leigh, 2 Taylor $v$. Beck, 3 Rand, 316; Cole 30.

v. Pennel, 2 Rand, 174; Steptoe v. 3Cal. Pr. Act, $\$ 145,146$; Cal. C. Read, 19 Gratt. 1; Woodward v. New- C. P. 578, 579; N. Y. Code, $\S 274$; hall, 1 Pick. 500; Minor $v$. Mech. Code of Wis. $\S 184$.

Bank, 1 Pet. 46; Baber v. Cook, 11 
persons sued jointly, one may obtain a judgment against the plaintiff, and tho other be subjected to a judgment in tho plaintiff's favor. ${ }^{1}$ And, in general, a several judgment may be properly rendered whenever a several action can be sustained.2 In California, in an action against two or more, a judgment may be entered against the defendants in court, excluding those not appearing and upon whom summons had not been served, though the contract appears to be jointly binding on all of the defendants. ${ }^{3}$ The practice is otherwise in New York; and that sanctioned by the California cases is spoken of in terms of strong, and, as it seems to us, merited condemnation. The plaintiff cannot, under the code, deprive the defendant of the advantage of having his joint co-contractors united with him in the action, and their property, as well as his, made liable for the judgment. Still less ought the plaintiff to be tolerated, in making all the co-contractors parties, for the purpose of avoiding a plea in abatement; and afterwards, without leare of the court, or notice to the defendant served, dropping the unserved defendants from the judgment. ${ }^{4}$ Every judgment against any joint defendant, is irregular until the other is out of the action and the issues against him disposed of. Until then, he has the right to appear at every trial of the issues. ${ }^{5}$ One of the joint defendants sued on a joint liability having answered, no judyment can be taken against those in default, until the issues formed by the answer are disposed of. 6

8 44. Joint Contractors.-Upon serving summons in a joint action, upou one or more defendan's jointly indebted upon a contract, the plaintiff may, under the code, proceed against the defendants served, unless the court direct otherwise; and if he recover, the judgment may be entered against all the defendants shown to be thus jointly indebted,

${ }^{1}$ Rowe v. Chandler, 1 Cal. 167; Parker v. Jackson, 10 Barb. 33.

sIIarrington $v$. Higham, 15 Barb. 524; Van Ness $v$. Corkins, 12 TVis. 186; Cr ndall $v$. Beach, 7 How. P. 271.

3 Ingraham v. Gildemeester, 2 Cal. 88; Uirschfield v. Franizlin, 6 Cal. 607.
4 Niles $v$. Battershall, 27 How. $\mathbf{P}$. 381; Sager $v$, Nichols, 1 Daly, 1; Fowler $v$. Kennedy, 2 Abb. P. 317. - Brown v. Richardson, 4 Tobt. 603. 6 Catlin $v$. Latson, 4 Abb. P. 248. 
so far only that it may be enforced against the joint property of all, and the separate property of those served. ${ }^{1}$ This provision is not applicable to a proceeding to foreclose a mortgage, and obtain a decree for the sale of the premises mortgaged. The fact that two persons have joined in the mortgage, does not create a presumption that the property therein described is owned by them jointly. ${ }^{2}$

8 45. Construction.-If no date appeared upon a judgment, it was presumed, at common law, to be entered on the first day of the term at which it was rendered. The rule is different in some of the United States, as in Maine, Massachusetts and New Hampshire, where the rendition is supposed to have occurred at the last day of the term, nuless the contrary appears. ${ }^{3}$ Including in a judgment one who, though named as a party to the suit, never appeared therein, and as to whom the process was returned not found, has been regarded as a mere clerical error, neither affecting the party thus included, nor furnishing any ground for a reversal in the appellate court. ${ }^{4}$ On the other hand, an appeal has been esteemed the appropriate remedy for the correction of a similar error. ${ }^{5}$ This is doubtless the better opinion. And in those States where the presumptions in favor of the jurisdiction of courts of record, are liberally indulged and applied, a party to a suit who considerer the unauthorized addition of his name in the entry of the judgment as a clerical error not requiring attention, and who failed to correct it in some manner, would be in imminent peril of such proceedings as should leave him to regret his misapprehension and neglect. The entry: "This day came the parties by their attorneys, and the plaintiff enters a retraxit," will not be construed as importing that the plaintiff did not come in person as well as by his attorney. On the other hand, it will be presumed, in support of the judgment, that as the attorney was incompetent to enter a retraxit, that

1 Cal. Pr. Act, \$ 32; Cal. C. C. P. Herring v. Polley, 8 Mass. 113; Good413 ; N. Y. Code, $\$ 136$.

2 Bowen $v$. May, 12 Cal. 348. all $v$. Harris, 20 N. H. 363.

schase v. Gilman, 15 Maine, 64; 5Joyce v. O'Toole, 6 Bush. Ky. 31; Ruby v. Grace. 2 Dur. 510. 
the plaintiff personally made the entry. ${ }^{1}$ If the entry of a judgment be so obscure as to not express the final determination with suficient accuracy, reference may be had to the pleadings and to the entire record. If, with the light thrown upon it by them, its obscurity is dispelled, and its intended signification made apparent, it will be upheld and carried into effect. ${ }^{2}$

8 46. Form. - At common law, the judgment or sentence of law commenced with "it is considered by the court that plaintiff or defendant recover," etc. Those words were considered peculiarly appropriate, as involving and expressing the idea that what was about to be ordered was not the sentence of the judges but of the law. They came to be inseparably associated in the minds of lawyers with the entry of a judgment. The chief stress was laid upon the word "considered." In Arkansas, the insertion of "ordered and resolved" in the place ordinarily occupied by "consiclered," was held to make the entry a nullity. ${ }^{3}$ No judgment, according to the view then taken, had been entered. No objection was made to the words as ambiguous, or as in any way failing to designate the "sentence" or final determination of the court. But the words used, it was thought, did not import that the law had acted or spoken in the matter, and the case was sent back to the subordinate court, to await the time when the law should speak in stereotyped language. This view was hypercritical in the extreme. No authority in support of it was cited, except the general statement in Blackstone's Commentaries, that the langrage of a judgment is not that "it is resulved or decreed," but that "it is considered." Some years later, tho same court came to consider a judgment commencing with "it is therefore ordered, adjudged and decreed." 4 Tho former decision was left unchanged, with an intimation that it was probably correct. But the three words, "ordered,

1Thomason v. Odum, 31 Ala. 108; Foot v. Glover, 4 Blackf. 313; Bell v. Conk $v$. Lowther, 1 L'd Raym. 597. Massey, 14 La. An. 831.

2 Forvler $v$. Doyle, 16 Iowa, 534; Fin- $\quad{ }^{3}$ Baler $v$. The State, 3 Pike, Ark. nagan $v$. Manchester, 12 Iowa, $521 ; 491$.

4Ware $v$. Pennington, 15 Ark. 226. 
adjudged and decreed," were said to be, when united, equivalent to "considored," and the judgment was sustained.

8 47. Form. - Whaterer may have been requisite formerly, it is evident that the sufficiency of the writing claimed to be a judgment must, at least under the code, be tested by its substance rather than by its form. If it corresponds with the definition of a judgment, as established by the code; if it "ppears to have been intended by some competent tribunal as the determination of the rights of the parties to an action, and shows in intelligible language the relief granted, its claim to confidence will not be lessened, by a want of technical form, nor by the absence of language commonly deemed especially appropriate to formal judicial records.' The entry of a judgment, like every other composition, should be comprised of those words which will express the idea intended to be conveyed, with the ntmost accuracy. It should also be a mockel of brevity, and should contain no unnecessary directions. The forms in use at common law, answer these requirements so well, that little or nothing can be gained by departing from them. Wherever tho codo renders the insertion of matters formerly required in a judgment or decree unnecessary, the practice should conform to the law now in force rather than to that which is abolished. For instance, judgments foreclosing mortgages should follow the directions of the Code of Procedure in the State wherein the judgment is entered, ${ }^{2}$ in preference to the old forms of chancery practice. They should contain only a statement of the amount due to the plaintiff, a designation of the defendants liable personally, and a direction that the premises, or so much thereof as shall be necessary, be sold according to law, and the proceeds applied to the paymeat of the judgment and costs. The copying into the decree of the directions of the statute, adds nothing to the clearness or force of these directions. All that part providing for the report of the sheriff, the,confirmation of the sale, who may becomo purchasers, and their rights pending the time for redemption, the execution of a conveyance if no redemption be made, the delivery of pos-

${ }^{1}$ Church v. Crossman, 41 Iowa, 373; $\quad{ }^{2}$ Cal. Pr. Act, $\$ 246$; Cal. C. C. P., Lewis $v$. Watrus, 7 Neb. 477 . 
session, the docketing of the judgment for any deficiency remaining after sale, accomplishes no better parpose than to incumber the record. ${ }^{1}$

8 48. Use of \$.-In actions to enforce the payment of taxes, the insertion of mumerals without any mark to designate what they were intended to represent, has, in at least one State, ${ }^{2}$ been held to leave the judgment fatally defective. A similar decision appears in the reports of the Supreme Court of the United States; but it was mado in a case where that court, as stated in its opinion, considered itself bound by the decisions of the Illinois courts. Nor do the courts of Illinois confine this principle of decision to judgments for taxes. In the case of Carpenter v. Sherfy, 71 Ill. 427, the plaintifs in attempting to deraign title to certain lands under an execution sale against their former owner, offered in evidence a judgment "for four hundred and sixty-one and ${ }_{100}^{53}$ damages." The court said: "Whether this amount is cents, mills, or what, we are left entirely to conjecture. We havo no right to indulge in presumptions as to what was found by the court; we must take the record as it reads. A judgment should be for a certain and definito sum of money. This judgment is not for any sum of money, and can only be regarded as a nullity." On the other hand, the lighest court in another Stato has determined that a verdiet and judgment are presumed to be for the things or the denomination of currency sued for, rather than for something else, and that a judgment for " 525 " upon a complaint claiming " $\$ 525$," must bo construed as being for the same denomination of money named in the complaint, and therefore not void for uncertainty, ${ }^{3}$ and this view seems to be supported by the rule that a judgment must be construed, in case of obscurity, with the aid of the pleadings and of the entire record.

8 48a. A Judgment Expressed in Figures.-As to its amount, these figures being in connection with a dollar

${ }^{1}$ Leviston $v$. Swan, 33 Cal. 480 . $\quad$ should be for dollars and cents, and

${ }^{2}$ Lane $v$. Bommelman, 21 Ill. 143; not for francs, or any other foreign Lawrence $v$. Fast, 20 Ill. 33S; P. F. currency. Erlanger $v$. Avegno, $24 \mathrm{La}$. W. \& C. R. R. v. Chicago, 53 Ill. S0. An. 77.

A judgment in the United States ${ }^{3}$ Carr v. Anderson, 24 Miss. 188. 
mark, was objected to, on tho ground that the statute required judicial records to be written in the English language; but the court was not disposed to hold that the defect was of a character to render the judgment absolutely void and of no avail in a collateral procecding. ${ }^{1}$

8 49. Filling Blanks. - A court ordered judgment to bo entered upon a promissory note, directiug the clerk to compute the amount due. Ho made the entry, leaving blanls for the amonnts. Fourteen months after he filled the blanks by inserting the proper sums. This, it was decided, might be such an irregularity as could be reached by a writ of error, but it was not available against the judgment in a collateral action. ${ }^{2}$

850. Sufficiency of Entries-General Tests of.-It now remains in this chapter to note some of the decisions in which tho sufficiency of various entries of judgments have been mooted and determined; and the general principles which may be erolved therefrom. The cases aro not altogether consistent. This arises, perhaps, from the fact that some minds are deeply impressed with the importance of matters of form, and actuated by the dread of encouraging a loose and unlawyerlike practice; while others, paying little regard to technical cousiderations, aro inclined to recognize and enforce that which, thongh confessedly informal, is capable of being readily understood and carried into effect. I think, however, that from the cases, this general statement may be safely made: That whatever appears upon its face to be intended as tho entry of a judgment, will bo regarded as sufficiently formal, if it show: 1st. The relief granted, and $2 d$, that the grant was made by the court in whose records the entry is written. In specifying the relief granted, the parties of and for whom it is given, must, of course, be sufficiently identified. According to the Supreme Court of Alabama, " a judgment should slow, the plaintiff who recovers, the defendant against whom the recovery is had, and the special thing or amount of money recovered."

\footnotetext{
${ }^{1}$ Fullerton $v$. Fielliher, 48 Mo. 542;

${ }^{2}$ Lind $v$. Adams, 10 Iowa, 398. see $\S 506$.

${ }^{3}$ Spence $v$. Simmon;, 16 Ala. S28.
} 
3. 50a. The Designation of the Parties for and against Whom the judgment is given, must in all cases be suficient to enable the clerk to know at whose instance to issue execution, and agajnst whose property it may be properly enforced. Hence a judgment for or against the captain and master of the steamer Mollie Hamilton, ${ }^{2}$ or the legatees of Philip Joseph, ${ }^{2}$ or against a defaulting witness by his proper name, but not stating in whose favor, ${ }^{3}$ is insufficient, if the whole record or judgment roll does not clearly disclose tho parties between and against whom the judgment is given. On the other hand, it is equally well settled that the names of the parties need not be stated in the body of the judgment. The name of the firm may be given, instead of the names of its individual members, or the parties may be designated generally as the plaintiffs or the defendants, provided a reference to the caption or to the pleadings, process, and proceedings in the action, makes certain the names of the parties thus designated ${ }^{*}$ and although a judgment purport to be against the defendants generally, its effect will be limited to one only if, from the whole record, it is manifest that he, and he only, was intended. ${ }^{5}$ But, in Louisiana, a judgment against certain named persons, and others, as defendants, does not create a judicial mortgage or lien against the lands of any defendant whose name is not stated in the judgment entry, although it can be ascertained by examining the pleadings. ${ }^{6}$

8. 50b. The Amount in Case the judgment be for money must be designated. It has sometimes been adjudged that the amount can not be expressed in figures, even when preceded by a dollar mark to show what the figures were intended to express.7 The Supreme Court of Illinois has also said "that amounts should not, in the judgment of a

\footnotetext{
' Steamer Mollie Hamilton $v$. Paschal, 9 Heisk. 203.

2 Joseph's Adm'r $v$. His Legatees, 5 Ala. 280; Turner v. Dupree's Adm'r, 19 Ala. 198.

s Spence $v$. Simmons, 16 Ala. 828.

- Wilson $v$. Nance, 11 Humph. 189; Little $v$. Birdwell, 27 Tex. 688; Collins $v$. Hyslop, 11 Ala. 508; Hays $v$.

Yarborough, 21 Tex. 487; McCartney $v$. Kittrell, 55 Miss. 253; Smith $v$. Chenault, 48 Tex. 455.

${ }^{5}$ Finnagan $v$. Manchester, 12 Iowa, 521.

${ }^{6}$ Ford $v$. Tilden, 7 La. An. 533.

${ }^{7}$ Smith $v$. Miller, 3 Hal. 175; 14 Am. Dec. 418.
} 
court, be entered in figures, but in all cases by letters. There is no safety in using figures for such purpose. It is not to be tolerated." We concede that the entry in figures of the amount of a judgment is unsafe, aud ought not to be encouraged. We nevertheless believe that judgments so entered would not be adjudged roid in the majority of the States. ${ }^{2}$ The amount must, in all cases, be certain. Thus judgment for a specified sum, subject to a credit "for one logshead of tobacco delivered in tho year 1799," without ascertaining the value of the tobacco, is fatally indefinite and uncertain. ${ }^{3}$ The final judgment ought to designate the precise amount recovered, and not leave it to be determined by a subsequent computation. ${ }^{4}$ But if there be a verdict for a definite sum, judgment thereon for the "said sum of dollars, assessed as aforesaid," is sufficiently explicit. ${ }^{5}$

\& 50c. The Property which is the subject of a judgment or decree, must also bo described with sufficient certainty to leave its identity free from doubt; ${ }^{6}$ but the bill or complaint may be referred to in the judgment for the purposes of description. ${ }^{7}$

\& 50cl. A Judgment of Conviction rendered may be said to consist of two parts, to wit: 1 . The facts judicially ascertained, together with the manner of ascertaining them, entered of record. 2. The recorded declaration of the court pronouncing the legal consequences of the facts thus judicially ascertained. Both of these parts are equally necessary in the rendition of a judgment of conviction. "In the first part it is usual and proper to set forth in the minntes of the court the title and number of the case, the calling of the case for trial, the appearance of the parties, the plea of the defendant, and if 'not guilty' the selection, impaneling and swearing of the jury, the submission of the evi-

${ }^{1}$ Linder $v$. Monroe, 33 Ill. 390.

${ }^{2}$ See sec. 4 Sa.

${ }^{3}$ Early $v$. Moore, 4 Munf. 262; see also Berry $v$. Anderson, 2 How. Miss. 652.

${ }^{4}$ Nichols $v$. Stewart, 21 Ill. 106; Smith $v$. Trimble, 27 Ill. 152; Anderson $v$. Reed, 11 Iowa, 177; Landerman $v$. McKinson, 5 J. J. Marsh. 234; Mudd $v$. Rogers, 10 La. An. 648.
${ }^{5}$ Ellis $v$. Dunn, 3 Ala. 632; Dyer $v$. Hatch, 1 Ark. 339.

${ }^{6}$ Gayle v. Singleton, 1 Stew. 566;

Hurt $v$. Moore, 19 Tex. 269; Jones v. Minogue, 29 Ark. 637; Tribble v. Davis, 3 J. J. Marsh. 633; Mc. Nanus v. Stevens, 10 La. An. 177.

'Jones $v$. Belt, 2 Gill, 106. 
dence, the charge of the court, the return of the verdict, and the finding of the jury. In the second part it should be declared upon the record in connection with the verdict, in the event of a conviction, that it is considered by the court that the defenclant is adjudged to bo guilty of the offense as found by the jury; and that the defendant be punished as it has been determined by the jury-in cases where they have the right to determine the amount, or the duration and place of punishment-setting forth particularly the amount, or the cluration and place of punishment, in accordance with the nature and terms of the punishment prescribed in the verdict."

8 50e. The Signature of the Judge to the judgment or the record in which the judgments are entered is sometimes required by statute; and, in some States, its omission has been held fatal, ${ }^{2}$ either as making the judgment roid, or as presumptive evidence that the alleged judgment had never received judicial sanction. More frequently, however, statutory requirements of this character have been adjudged to be directory merely."

251. "I give judgment." These words, if the parties are made certain and the arnount ascertained by other parts of the judgment, are as effective as: "It is considered that plaintiff recover," etc." "Whereupon the court orders that plaintiff pay the costs of suit, and that execution issue therefor" in a record showing the trial by a jury and a verdict for the defendants, thongh not in technical language, is sufficient to constitute a valid judgment. " "We should not hesitate to enforce a judgment because 'decreed' or 'resolved' was used instead of 'considered." " "No judgment will be reversed for the use of inappropriate or untechnical words." "No particular form is required in the proceedings of the court, to render their order a judgment. It is

\footnotetext{
1 Mayfield $v$. State, 40 Tex. 290; Roberts $v$. State, 3 Tex. App. 47; see ante, sec. $21 a$.

${ }^{2}$ Saloy $v$. Collins, 30 La. An. 63; State $v$. Jumel, $30 \mathrm{Id} .421$; Raymond v. Smith, 1 Met. Ky. 65; Hatch $v$. Arnault, 3 La. An. 482; Galbraith v. Siclener, 23 Ind. 142.

${ }^{3}$ Rollins $v$. Henry, is N. C. $3 \pm 2$; Cannon $v$. Hemphill, 7 Tex. 1S4; Cati. cart $v$. Peck, 11 Minn. 45; Childs $v$. McChesney, 20 Iowa, 431.

${ }^{4}$ Deadrick $v$. Harrington, Hemp. 50.

${ }^{5}$ Huntington $v$. Blakeney, 1 Wash. Ter. 129.

6 Taylor v. Runyan, 3 Clarkc, 474.

7 Mlinkhart $v$. Hankler, 19 Iil. 47.
} 
sufficient if it is final, and the party may be injured." 1 "A judgment, in addition to the ordinary circumstances of time and place, should exhibit the parties, the matters in dispute, and the result, but the form is immaterial." 2

\& 52. The entry must not only indicate what adjudication took place, but should also appear to have been intended as the entry of judgment, and not as a mere memorandum by the aid of which the formal record was to be constructed. "June 14, 1838, judgment sec. reg. for want of plea. January 9,1839 , sum ascertained at $\$ 155.07$. Interest from June 14, 1838." This writing, being offered as evidence of a judgment, was rejected, on the grounds that there was nothing to show by whom judgment was rendered, or against whom, nor for what amount, if in fact any judgment had ever been given by any court against any person. ${ }^{3}$ It is obvious, that in some of the cases, the entry offered in evidence has been disregarded, not from or on account of the absence of the essential elements of a judgment record, but becauss the court thought that such entry had been originally clesigned as nothing but a brief direction to tho clerk, or as a certificate made by the clerk of some judgment already formally put upon the record. Thus "Judgment renclered for plaintiff in the above entitled suit at the above named term by the court for the sum of seventy-eight and $\frac{; 7}{10}$ dollars, damages, and his costs of suit against said defendant, on motion," was determined not to be the entry of a judgment. These words certainly show the action of the court, the naturo and extent of the relief granted, and the parties of whom and for whom it was awarded. So far they are appropriate to the record of a judgment; but they do not appear to be the direction of the court itself. On the contrary, they seem rather to be the certificate of the clerk of certain events transpiring in court, as he recollects them, or as he understands them from such information as he may possess, than the original record of the court in relation to those events." The words "judgment on verclict for $\$ 3,000$

1 Wells $v$.Hogan, Breese, 337 ; Johnson $v$. Gille:t, 52 Ill. 360 .

2 Ordinar: v. MIcClure, 1 Dailey, 7.
3 Taylor $v$. Runyan, 3 Clarlie, $47 \dot{ }$ 4 Wheeler $v$. Scott, 3 Wis. 362 . 
and costs," though found among the records and showing, as they certainly do, that a final determination had been made, are not the record of a judgment. They neither show what authority directs nor how the direction is to be carried into effect. They are apparently intended as a mere memorandum for the information of the clerk. " The following entry was also rejected, on a plea of nul tiel record, as implying at most only a minute of proceedings, and not the solemn act of the conrt determining the rights of the parties: "The following jury was sworn and impanelled" (here follow twelve names), "who find all the issues in faror of the plaintiff, and assess his damages at five hundred and eighty-five dollars. Judgment at September term, 1844, \$585; the costs arising in this suit due to the county, to wituesses and officers of court, is $\$ 134.92$."2

8 53. Justices' Courts.-Though the nature of a final adjudication in a justice's court is in no respect different from that of a court of record, several causes uniting have produced rules of construction by which the records of the former court are scrutinized with less severity than those of the latter. In the first place, the higher courts being presided over by men of learning, and supplied with officers whose sole duties consist in keeping the various papers filed in court in proper place and condition, and in reducing the various orders and directions of the judges to writing upon records required by law for that purpose, a loose memorandum would naturally be viewed with distrust when ofered as the final result of all this learning and formality. Its form at once distinguishes it as an intruder, and shors its humble origin and design. But as justices of the peace, except in cities, rarely know anything of the technicai learning of the common or even of the statute law, to insist upon their keeping their records with that accuracy and formality required in courts of record, would end in the complete overthrow of most of their proceedings. Besides, as justices of the peaco have no clerks assigned them by law, there is little ground for the presumption that eren loose and disjointed memoranda, found upon their minutes or

1دIartin v. Barnhardt, 39 Ill. 9. | I 'Hinson v. Wall, 20 Alı. 298. 
dockets, were designed as rough outlines for another hand to round into more perfect form.

\section{\& 53a. Failure of Justice to enter Judgment.-In New} York, justices of the peace are required to enter their judgments in their dockets within four days after the rendition thereof. But, under the general rule that the entry of a judgment is a ministerial act, the failure of a justice to comply with this part of the law within the time required, has, by repeated decisions, been held to leave the judgment in full force. ${ }^{1}$ The judge who delivered the opinion of the court of appeals in a recent case, said the failure of the justice to obey the law, is deserving of censure, but added: "I am unable to find any principle of law requiring us to hold that the omission to docket must inflict a penalty upon the plaintiff, more justly due to the magistrate."2 In Maine, a justice of the peace, after being out of office for three or four years, completed the record of a case tried during his oficial term, by writing up a judgment in his judgment book. Of this transaction, Mellen, C. J., said : "A magistrato does not act judicially in making up and completing his record. In doing this, he performs himself what this court does through the agency of its clerk. It is a mero ministerial act. The judgment is regular."3 In a case before a justice of the peace in California, the jury rendered a verdict in favor of the plaintiff "for one hundred and seventy-five dollars in gold coin." This verdict was entercd in the justice's docket, but no judgment was, in fact, entered in pursuance thereof. Subsequently, on application of the plaintiff, the justice issued an execution, reciting that a judgment had been rendered by him for that much money, and for costs of suit. Under this execution, a sale was made by the Sheriff, at which the plaintiff became the purchaser. Relying upon title derived from this sale, the plaintiff brought an action of ejectment to recover the realty purchased by him; but the defendant insisted that the sale was void, on account of the failure to enter judgment

\footnotetext{
I Hall $v$. Tuttle, 6 Hill, 38. Wal-| 3 IIatthews v. Houghton, $11 \mathrm{MIe}$ rod $v$. Shuler, 2 N. Y. 134.

2 Fish v. Emerson, 44 N. Y. 377. 377.
} 
upon the verdict. In considering this portion of the defense, the Court said: "The justice, upon receiving the verdict, was required by statute to 'immediately render judgment accordingly.' The formal entry of the judgment was, therefore, a mere clerical duty imposed upon him by the statute, and the performance of which he had no discretion to decline. He might have been compelled to make the proper entry in his docket by judicial proceedings instituted against him for that purpose by the plaintiff; and it may be conceded that to issue an execution before judgment entered in form upon the verdict would be a bad practice, and that a timely motion by the defendant to set it aside for that reason should be supported. That would be so, however, not because such an execution would be void, but because it would be irregular merely. And a failure to make the objection would, of course, amount to a waiver of the irregularity. As was said by the Supreme Court of New York :" "We are to overlook matters of form, and to regard proceedings beforo justices of the peace according to the merits. Accordingly, in that case, a plea of former judgment in favor of the defendant was held to be supported by proof of a verdict in his favor, upon which the justice of the peace ought to have rendered judgment, but had omitted to do so." "2

\$ 54. Reference to Another Case.-The entry of a judgment, even in a justice's court, must either be perfect in itself, or be capable of being made perfect by reference to other parts of the docket, or to the papers on file in the action. An entry in which the identity of the parties can not be ascertained without referring to the entry of some other case, is fatally unccrtain. The rule of construction permitting all the records and papers in a case to throw light upon an obscure entry, is sufficiently liberal, and ought not to be extended so as to includo the records or pleadings in another suit. ${ }^{3}$

\footnotetext{
${ }^{1}$ Felter $v$. Mulliner, 2 Johns. 1S1. 11 Johns. 457; Overall v. Pcro, 7

${ }^{2}$ Lynch v. Kelly, 41 Cal. 232; sec Mich. 315.

to same effect, Gaines $v$. Betts, $2{ }^{3}$ McClellan $v$. Cornwell, 2 Cold. Douglass, Mich. 98; IIess v. Beckman, 298.
} 
8 55. On an Award.-An action being tried by referees, they reported "that the defendant is indebted to the plaintiff on the above complaint in the sum of four dollars, and nine dollars and six cents costs of suit." The justice of the peace thereupon wrote: "Judgment rendered December 26, 1840. M. Tindal." A marginal note stated the amount of judgment and costs to be the same as named in the report. This was held to constitute a sufficient entry, because the inference was unavoidable that the judgment was intended to be in conformity with the award, this inference being strengthened by the marginal note, to which resort could be properly had to explain and uphold the judgment. ${ }^{2}$

\section{Elliott $v$. Morgan, 3 Harr, 316.}

Nore. - The following entries of judgments have been considered sufficient in the higher courts: "Peacham, — 16, 18ะS. Jndgment rendered by the court for plaintiff, at $\$ 5.25$. R. Blanchard, Justice of the Peace," accompanied by marginal entry of "Costs allowed, \$5.25." See Story $v$. Kimball, 6 Verm. 541. "II. C. Anderson v. M. L. Elcan. Judgment granted $v$, defendant M. L. Elcan, for $\$ 433.90$. May 17, 1857. C. J. Spencer, J. P." Auderson v. Kimbrongh, 5 Cold. 260. In Baratt v. Garragan, 16 Iowa, 44, the transcript showed the proceedings up to and including trial, after which was written: "Judgment for plaintiff against the defendant for - October 24, 1856:

"Damages......................

"Justice's fee.................. \$0 80

"Const...................... 25

"Two witnesses............... 25

$\$ 8400$

\$55 30."

This was pronounced a perfect judgment. It exhibited the time, the parties, and the result so clearly as to be unmistakable. This case was subsequently approved in Church v. Crossman, 41 Iowa, 373. In New York, the words "Fish v. Emerson. Testimony submitted June 30, 1863.

"Judgment for plaintiff; damages................\$124 80

$12972 . "$

were held to be sufficient as the entry of a judgment. (44 N. Y. p. 376.)

On the other hand a judgment in this form: "The plaintiff filed his demand for thirty dollars; the defendant not appearing, the plaintiff proves his demand, and I gave judgment for the same," was reversed for not being such a judgment as the law requires. (Polhenus v. Perlins, 3 Green, N. J. 435.) "Ee it remembered that at Barnard, April 23d, 1836, Asaph Wilder, of Woodstock, was attached to answer James Wright, of Barnard, on former judgment of Lyman Stewart, Esq., in a case James Wright r. Loren Gay. Now the plaintiff says that the judgment of Lyman Stewart was collected by 
E. Parker, deputy sheriff, and converted same to his own use, and never accounted for same, nor any part thereof. The said Wright recovered judgment by default, for the sum of $\$ 15.15$ damages, and $\$ 1.99$ costs of suit. Winslow W. Ralph, justice of the peace." Upon a plea of nul tiel record was considered as containing no legal evidence of a juclgment, on the ground that it showed no court holden, no appearance by either party, no adjudication by the justice, no allusion to any writ or process or declaration, and no award of execution. (Wright v. Fletcher, 12 Verm. 431.) A jury returned a verdict: "We, the jury, fiud in favor of the plaintiff, and assess his damages at in the sum of $\$ 4,493$;" and the record showed the entry "whereupon the court enters judgment on the verdict." It was held that this entry had no element of a judgment other than the mere recognition of the verdict. "The ideo consideratum est is wanting." (Faulk $\mathrm{v}$. Kellums, $5 \pm$ Ill. 189.) "Gave judgment in favor of plaintiff for $\$ 171$ and costs, " is a sufficient entry of a justice's judgment. (Hutchinson $\nabla$. Fulghum, 4 Heisk. 550.)

44 . 


\section{CHAPTER III.}

OF THE ENTRY OF JUDGMENTS AND DECREES, NUNC PRO TUNC.

\section{PART I.-WHERE NO JUDGMENT WAS RENDERED.}

85. Policy and Antiquity of the Practice.

5 57. Cases where delay is occasioned by non-action of the Court.

$\S 58$. Where party is tied up by some motion.

$\$ 59$. Entry to be made only when case was ready for final judgment.

860 . Not to be made, where the delay is not by the Court.

\section{PART II.-JUDGMENT RENDERED, BUT NOT ENTERED.}

$\S 61$. Cases where judgment was rendered, but not entered.

$\$ \mathrm{c2}$. Whether parol evidence is admissible.

$\$ 63$. Cases showing that it is.

$\$ 64$. When application may be ex parte.

$\$ 65$. Withdrawal of jurisdiction.

$\$ 66$. Saving of rights of third persons.

$\$ 67$. Gives judgment same effect as if entered, when rendered.

$\$ 68$. Must be confined to clerical omissions.

\section{PART I.-JUDGMENTS NOT RENDERED.}

8 56. The policy of entering judgments and decrees, nunc pro tunc, is agreeable to the maxim "Actus curie neminem gravabit"- "An act of the court shall prejudice no one." This maxim, says Mr. Broom, "is founded in justice and good sense; and affords a safe and certain guide to the administration of the law." As an expression of the principle upon which judgments are given effect, as of some time prior to their actual entry, the maxim, in the interests of accuracy, requires to be changed to "a delay of the court shall prejudice no one," and to be limited in its application so as to affect none but the parties litigant. The power of making an entry, nunc pro tunc, seems to have been possessed and exercised by courts of law and of equity from the earliest times. ${ }^{2}$ The period in which this power could be successfully inrolzed was never limited; ${ }^{3}$ a decree in one

1 Broom's Legal Maxims, p. 115.

${ }^{3}$ Fuller $v$. Stebbins, 49 Ia. 376.

${ }^{2}$ Mayor of Norwick $v$. Berry, 4 Burr. The power may be exercised in crimi2277; Hodges $v$. Templer, 6 Mod. 191; nal prosecutions as well as in civil Evans $v$. Rees, 12 Ad. \& E. 167; Mays cases. Ex parte Beard, 41 Tex. 234; v. Hassell, 4 Stew. \& Port. 222; Shep- Smith v. State, 1 Tex. App. 403, 516; hard $v$. Brenton, 20 Iowa, 41.

Ex parte Jones, 61 Ala. 399. 
instance boing entered after the lapse of trenty-three years." The practice was confined to those cases in which some liardship would be visited upon one of the parties without any fault of his, unless ho was relieved from it by allowing his judgment to be entered at some period when he was legally entitled thereto, and of such a date as was necessary to avoid the embarrassment in which he would otherwise be involved.

8 57. Delay of the Court.-The cases naturally resolved themselves into two classes. The first comprised a large number of actions, in which no judgments had ever been rendered; but which were, so far as the suitors could make them, in condition for the rendition of final judgments. The second was composed of cases comparatively few in number, in which judgments, though formally pronounced, had, from accident or from negligence of the clerks, never been put upon the records. The first class contained not only the greater number of cases, but each of the cases within it was, in all probability, more deserving of relief than any of the cases of the second class. No case could be ranked among the first class, in which the delay to render or enter judgment was imputable to any negligence or even misapprehension of the parties. The rule that no judgment would be ordered entered nunc pro tunc, except for delay of the court, admitted of no exceptions in theory; and was so constantly observed in practice, that one of the judges remarked that he had never known of its violation during his experience, extending, at bar and bench, over a period of forty years. ${ }^{2}$ The necessity for entering judgments as of some day prior to their rendition, arose chiefly, if not exclusively, in those cases where, after the trial and submission of a cause, one of the parties died, as no judgment could properly be entered bearing date subsequent to his cleath. As the suitor who brought his action on to trial, and caused it to be tried and submitted, had manifestly

1Dan'l Ch. Pr. 1219; Lawrence v. Freeman v. Trannah, 12 C. B. 406; Richmond, J. \& TV. 241; see also Downe v. Lewis, 11 Ves. 601; Drummond $v$. Anderson, 3 Grant's Ch. 152.

2 Heathcote $v$. Wing, 11 Exc. 355 ;

Fishmongers Co. $v$. Robertson, $3 \mathrm{C}$. B. 970; Lawrence v. Hodgson, 1 Y. \& J. 368. 
been guilty of no laches, the court protected him from any prejudice he might suffer by the death of his adversary after such submission; and instead of permitting the action to abate, directed the judgment to bo given effect, if necessary, as far back as the day of the submission. Thus the time taken by the court for cleliberation was, as far as possible, prevented from working injustice to tho party who should, in the end, prevail in his suit. ${ }^{t}$

8 58. Delay Occasioned by Motions.-Besides the delay occasioned by the deliberations of the judges after the argument of a cause, the prevailing party was likely to be tied up by various motions whose pendency deprived him, for a time, of the fruits of his litigation. The consideration of these subjected him to the same peril, and entitled him to the same relief, as though he were endangered by being compelled to await the decision of the judges after the argument on the trial. Hence, if during the pendency of a motion in arrest of judgment, ${ }^{2}$ or for a new trial, "whether after verdict or nonsuit-on demurrer or writ of error; ${ }^{3}$ or to reduce the amount of an award; ${ }^{4}$ or if pending the decisions of questions of law which could not be heard on account of press of business in court, ${ }^{5}$ one of the parties die, the other may have judgment entered as of some term during the lifetime of his opponent.

8 59. Made only when Cause was ready for Final Judgment.-But in every case to entitlo the applicant to have his judgment entered nunc pro tunc, on account of tho death of one of the parties, the action must, at the time of

\footnotetext{
1 Jennings $v$. Ashley, 5 Pike, 128; Pool v. Loomis, 5 Pike, 110; Jones $v$. Le Davids, 2 Fowler's Lx. Pr. 169; Campbell $v$. AJesier, 4 Johns. Ch. 344; 8 Am. Dec. 570; Davies v. Davies, 9 Ves. Jr. 461; Wood v. Keyes, 6 Pai. 47s; Hess $\%$ Cole, 3 Zabr. 116; Griswold $v$. IIill, 1 Paine C. C. 483 ; Perry $v$. Wilson, 7 Mass. 393; Springfield $v$. Worcester, 2 Cusl. 52; Astley $v$. Rey. nolels, 2 strange, 917; Neil $v$. Me-

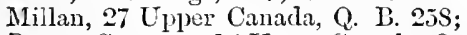
Day $v$. Cameron, 15 Upper Canada, Q. B. 175; Abington $v$. Lipseomb, $11 \mathrm{~L}$. J. Rep. (N. S.) Q. B. 15; Miles $v$. Willians, $16 \mathrm{Id}$. 47; Miles $v$. Bough, 15 Id. 30; Turner v. L. \& S. W. R. Co. 43 L. J. Ch. 430; Wilson v. Myers,

4 Hawks. 73; 15 Am. Dec. 510; McLean $v$. State, 8 Heisk. 22; Key $v$. Goodwin, 4 MI. \& Scott, 620 .

${ }_{2}^{2}$ Tidd's Pr. Sth Ed. p. 960; Griflth $v$. Ogle, 1 Binney, 172; Jrown $v$. Whiceler. 18 Conn. 199.

3 Spalding $v$. Congdion, 15 Wend. 543 ; Ryghtnyye $v$. Durham, 12 Wend. 245; Cumier v. Lowell, 16 Pick. 170; Tooker $v$. Duke of Beaufort, 1 Burr; 147.

${ }^{4}$ Bridges $v$. Smyth, 8 Bing. 29.

5 Miles $v$. Williams, 9 Q. B. 47; Tapley $v$. Martin, 116 Mass. 275; Blaisdell $v$. Ifarris, 52 N. 1I. 191; Seymour $v$. Greenwood, 30 L. J. Exch. 189; Noor $v$. Roberts, 3 C. D., N. S. 844: 4 Jur. N.S. $241 ; 27$ L.J.C. P. iol.
} 
such death, have been ready for the rendition of the final judgment. ' It is not sufficient that an interlocutory judgment had been pronounced, and proceedings were pending in pursuance of a writ of inquiry; ${ }^{2}$ nor that judgment had been given against the defendant on demurrer, with leave to amend. In each of these cases no judgment could properly have been entered when the death occurred, and that event ought not to give the survivor any greater advantage than ho previously possessed. "It" (entering judgments nunc pro tunc) "should be confined to cases where the judgment is final, as where a verdict has been rendered or a nonsuit ordered, which is confirmed by the court on motion for a new trial; or where a judgment is rendered on a special verdict, demurrer to evidence, or a writ of error. But according to the present practice, judgment on demurrer is seldom final.",

8 60. Delay, Not of Court.-If, however, the clelay is in no wise attributable to the court, nor to the tying up of the case during the time required to clispose of such motions as we have mentioned, no doubts nor difficulties, nor mistakes of law, in which one of the parties has been involved, will entitle him to this relief. If, for instance, the counsel in a case are unable to decide, at once, what form of judgment or decree is best, and while discussing this matter among themselves, the plaintiff or defendant dies; ${ }^{4}$ or if a party, upon applying to have judgment signed, does not press the matter, because one of the officers suggests a doubt as to whether it is not a legal holiday, and the defendant dies the same day, ${ }^{3}$ neither of these cases warrants the interposition of the court. The court is in no way blamable for the doubts or misapprehensions of the parties nor of their advisers, and it will not change its course of proceeding to relieve them from the consequence of any mistake of law or of fact. That there is a surviving defendant, is not a sufficient objection to the entry of judgment nunc pro tunc, if

\footnotetext{
${ }^{1}$ O'Riordan v. Walsh, 8 Ir. R., C. $\quad{ }^{4}$ Fishmongers' Co. v. Robertson, 3 L. 158.

${ }^{2}$ Jennings $v$. Ashley, 5 Pike, 128.

${ }^{3}$ North $v$. Pepper, 20 Wend. 677; Kissam v. Hamiiton, 20 How. P. 375. 376. C. B. 970 ; S. C., 16 L. J. Rep. (N. S.) C. P. 118; 4 Dowl. 656. 5 Wilkes $v$. Perkes, 5 Man. \& Gr.
} 
the other facts authorize it. ${ }^{1}$ The rule that judgment will not bo entered munc pro tunc, will be enforced even where the delay is occasioned by the party against whom the entry is sought to be made. Thus, where judgment would have been entered within two terms after the entry of tho verdict, but for the fact that the plaintiff's executor was delayed in proving a will on account of a caveat entered by the defendant against tho probate being granted, the court, though conceding the case to be ono of extreme hardship, denied the application to enter judgment nunc pro tunc, ono of the judges saying: "I think we ought not to bo induced, by our desire to do substantial justice in the individual case, to depart from those general principles which are the only safe guides for the administration of the law."

\section{PART II.-CASES OF JUDGMENTS RENDERED IUT NOT ENTERED.}

8 61. In Relation to the Second Class of Cases, some degree of negligence is always chargeable against the parties, for not attending to having the proper entries madc. Frequently, however, both parties suppose the judgment to be entered as well as rendered. Upon that supposition, process is issued and enforced, or other proceedings taken to carry out the judgment; and new rights and interests are based upon it. To protect these, it is occasionally necessary to have the judgment entered as of some time prior to their inception. The entry of judgment nunc pro tunc is always proper when a judgment has been ordered by the court; but the clerk has failed or neglocted to copy it into the record. ${ }^{3}$ The chief questions of importance in this class of cases are, how shall it be shown: 1st, that a judgnent was rendered, as alleged; and $2 d$, if so rendered, what were the nature and extent of the relief given by it. During the term the proceedings are under control of the court, and no embarrassing questions can ariso in relation to the exercise of the correctory powers of the court. But after the term, upon what evidence can a motion for the entry of

\footnotetext{
${ }^{1}$ Harrison $v$. Heathorn, 6 Scott's ${ }^{3}$ Hagler $v$. Mercer, 6 Florida, 721; N. R. 797; 1 Dowl. \& L. 529. Howell v. Morlan, 78 Ill. 162; Frank.

${ }^{2}$ Freeman $v$. Trannah, 12 C. B. 406; lin $v$. Merida, 50 Cal. 289. 21 L. J. Rep. (N. S.) C. P. 214.
} 
judgment, as of same prior term, be based? Upon this subject the decisions are not numerous. In most cases where the propriety of the entries came in question, the facts are stated in the reports, without any intimation as to how those facts were made apparent to the court. Probably the weight of authority sustains the rule, that only by some entry or memorandum on or among the records of the court, can the rendition of a judgment be proved. ${ }^{1}$ An entry must somewhere be found and produced in court, apparently made by the authority of the court. It must be in some book or record required to bo kept by law in that court. Under this rule, a decree filed among the papers in a cause, signed by the judge, when the law did not require decrees to be reduced to writing and filed, and when no part of the records showed the rendition of any decree, was considered insuficient to warrant its entry nunc pro tunc, as the former decree of the court. ${ }^{2}$ The motion docket being a book required by law to be kept, the memoranda there made are competent evidence to show the rendition of a judgment. ${ }^{3}$ So is the opinion of a judge in writing, filed among the records in a case, if the law required it to be written and filed. ${ }^{4}$

8 62. Evidence to base Entry on.-But assuming the evidence to be competent for the purpose for which it is offered, and to show the rendition of some judgment, the question then to be determined is, does it show with sufficient clearness what that judgment was ; and, if not, may its obscurity be removed by the use of other means of proof. The entry by a judge in his docket, "Jury and verdict for plaintiff, and fifteen per cent. damages," taken in connection with the papers on file, was adjudged to afford no suficient data for judgment nunc pro tunc, because the verdict may have been for less than the amount claimed by the plaintiff. ${ }^{5}$ The memoranda on the trial docket of the Orphan's Court, as follows: "Joshua Metcalf, heir of A.

'Metcalf $v$. Metcalf, 19 Ala. 319; He-
geler $v$. Henckell, 27 Cal.491; Fletcher
$v$. Coombs, 58 Mo. 430; Draughan $v$.
Tombeckbee Bank, 1 Stew. 66; 18 Am.
Dec. 35; Swain $v$. Naglee, 19 Cal. 127;
Hyde $v$. Curling, 10 Mo. 359.

50 
Metcalf, use of J. W. Williamson $v$. Adams. Judgment on demurrer. Leave to amend granted on payment of costs of term. Costs paid by S. T. Roach, attorney. Ordered to appoint auditors Benj. Walding, Natthew Johnson, and Daniel Johnson. Ordered that they report instanter. Auditors report in the hands of administrator, \$469.82," were Jield not to sustain a nunc pro tunc decree on account of their not showing the presentation of any accounts, the amounts received or paid out, the name of the administrator, nor whether the settlement was partial or final." The words on motion docket, "Oct. Term, 1841-Nonsuit," with lines drawn across the names of the plaintiff and defendant, according to the custom when a case was stricken from the docket, all done, confessedly, by the presiding judge at the time, authorize the entry of a judgment nunc pro tunc. ${ }^{2}$ The courts of Alabama, whose reports are wonderfully prolific in cases involving the power to enter judgments munc pro tunc, have viewed such entries with unfounded alarm, and have seen the dangers arising from their encouragement, througl some exaggerating medium. These courts are severe in their condemnation of the practice of assisting the record memoranda, by parol evidence. An entry on the docket, "Estate of Solomon Perkins, deceased," "Final Settlement," "Settlement made," accompanied by proof of the terms of the decree from memoranda made by the attorney on the back of the account, and by the testimony of the judge that he pronounced an oral decree in conformity with the memoranda, having been used with success upon tho hearing of a motion to have a decree ordered entered in conformity with the proof of its rendition, the action of the court was reversed upon appeal, the appellate court saying: "If we can hold this sufficient, there is no telling where we ought to stop. If a judge can refresh his memory by writings made by a third person, and prove the terms of his decree in that way, it is the same in principle as allowing the terms of any judgment, verdict or decree to be established altogether by oral testimony; and this would be a very dangerous precedent, and going much farther than any of our

Metcalf $v$. Metcalf, 19 Ala. 319. I 'Short v. Kellogg, 10 Geo. 180. 
decisions warrant." The extreme position here taken is the logical result of the general rule frequently announced, and moro frequently violated, that a record can only be amended by some matter of record. Chief Justice Gibson, more than twenty years ago, said: "The old notion that the record remains in the breast of the court only till the end of the term, has yielded to necessity, convenience and common sense." 2

8 63. Parol Evidence, as basis of.- Whether the "old notion" has yielded so far as to authorize the entry of a judgment; as of some prior date, when there is no record eridence of its rendition at such date, is doubtful; but the fact of the rendition of a judgment being made evident by the record, a decided preponderance of authority authorizes the court to proceed in its subsequent investigations with the aid of oral, as well as of written evidence. Were the rule otherwise, the power of courts to furnish relief, mado necessary by the negligence or inadvertence of their clerks, would be so restricted in its operation as to be of little or no utility. Tho instances whore, in the absence of the formal entry of judgment, the records show the fimal determination with accuracy and completeness, are few in number. Our attention should not be so riveted upon the possible evil, which might occasionally arise from establishing by parol, the terms of some unrecorded adjudication, as to make us oblivious to the more probable evil of refusing to protect the interests growing up under actual adjudications, which, though confessedly existing, have not been reduced into the most authentic form. Courts have a continuing power over their records not affected by the lapse of time. Should the record in any case be lost or destroyed, the court whose record it was, possesses the undoubted power, at any time afterward, to make a new record. In doing this, it must seek information by the aid of such evidence as may be within its reach, tending to show the nature and existence of that which it is asked to re-establish. There is no reason why the same rule should not apply, when, instead of being lost, the record was never made up, or was

1 Perkins $v$. Perkins, 27 Ala. 479. 2Rhoads v. Commonwealth, 15 
so made up as to express a difierent judgment than the one pronounced by the court. Hence the general rule that a record may be amended, not ouly by the judge's notes, but also by any other satisfactory evidence.'

"But we think it clear, upon the authorities, that the court may make such amendments upon any competent legal evidence, and that they are the proper judges as to the amount and kind of evidence requisite in each case to satisfy them what was the real order of the court."2 "Each court must necessarily be the proper judge of what it has decided and adjudged, and when it orders an amendment of the record, the presumption of other courte must necessarily be that it does not undertake to order its clerk to record what it never had decided."3 "Whether there was a mistake in the record, was a question of fact to bo established as any other fact in a court of justice by proper evidence. For this purpose the letter of the Chief Justice, the entries on the docket books, and the testimony of the witaresses who heard the decision announced in open court, were all admissible." 4 Such evidence as is competent to amend a record, ought to be competent to supply one. For a court, in interfering with an existing record, whose inaccuracy is not evident from other matters of record, moves upon more doubtful ground than in condncting investigations when no matter of record needs to be modified or overthrown. In Massachusetts, the record of a judgment was completed after the lapse of twenty years, and the proposition affirmed, that the amount of evidence for that purpose is within the discretion of the court. ${ }^{5}$ The evidence in this case was oral. In another instance, the entry seems to have been ordered, upon motion, supported by an affidavit. ${ }^{6}$ In several other cases, the reception of parol evidence has been sanctioned, for the purpose of showing the nature of the judgment alleged to have been rendered. ${ }^{7}$

1 Matheson's Admr. $\%$ Grant's 5 Rugg v. Parker, 7 Grny, 172. and Admr., 2 How. U. S. 263; Clark $v$. 9 Gray, 209.

Lamb, 8 Pick. $415 ; 19$ Am. Dec. 332. 2 Frink $v$. Frink, 43 N. H. 508.

3 Petition of Inbabitants of Limerick, 18 Maine, 183.

4 Weed $v$. Weed, 25 Conn. 337; Hol- Shaver, 1 Phill. Law. 18. lister $v$. The Judges, 8 Ohio S. 201. 
8 64. Application Tx Parte.-In Alabama, the application to enter judgment nunc pro tunc may bo made without notice. ${ }^{1}$ This rule is proper enough in that State, and in all others where the motion must be determined from an inspection of the records. ${ }^{2}$ But whenever the application calls for an investigation by the court, outside of its records, to determine either the existence or the terms of the alleged judgment, notice to the adverse party is proper and necessary.

8 65. Termination of Jurisdiction.-In Ohio it has been decided that if, after the rendition of a judgment, and before the entry thereof, the jurisdiction of the court over that class of cases is withdrawn, the court as to them ceases to exist, and can not enter its juajgment nunc pro tunc. $^{3}$ The correctness of this decision may well be doubted. The case seems to us to be one where the correctory powers of the court could have been employed in the furtherance of justice, without any infringenuent of the law. The jurisdiction of the court over the case had been completed by hearing and determining the issues involved, and by granting appropriate relief. What remained to bo done after the withdrawal of juriscliction, either in giving effect to the judgment or in correcting or completing the records, the court had power to do by virtue of its general jurisdiction, and its continuing power over its records. In considering whether there was an omission of something from its records which ought not to be omitted, the court was not in the exercise of the same kind of jurisdiction exercised by it in trying the cause; nor was the jurisdiction over the records necessarily dependent upon the continuance of jurisdiction over the subject matter of the suit. Where an action was brought under a statute, and judgment rendered, which was delayed by the pendency of a motion for a new trial, during which the statute was repealed, judgment was entered as of a time when the statute was in force. ${ }^{4}$

${ }^{1}$ Fuqua $v$. Carriel, 1 Minor, 170; ${ }^{2}$ Stokes $v$. Shannon, 55 Miss. 583; 12 Am. Dec. 46; Allen v. Bradiord, Portis $v$. Talbot, 33 Ark. $21 \mathrm{~S}$.

3 Ala. 281; Glass v. Glass, 24 Ala. ${ }^{3}$ Ludlow $v$. Johnson, 3 Hamm. 553. 468 .

${ }^{4}$ Springfield $v$. Worcester, 2 Cush. 52. 
8 66. Rights of Third Persons.-The entry of judgments or decrees nunc pro tunc, is intended to be in furtherance of justice. ${ }^{1}$ It will not be ordered, so as to affect third persons, who have acquired rights, withont notice of the rendition of any judgment. ${ }^{2}$ Crenerally such conditions will be imposed as may seem necessary to save the interests of third parties, who have acted bona fide, and without notice; but if such conditions are not expressed in the order of the court, they are, nevertheless, to be considered as made a part of it by force of the law. The public are not expected nor required to search in unusual places for evidences of judgments. They aro bound to take notice of the regular records, but not of the existence and signification of memoranda made by the judge, and upon which the record may happen to bo afterwards perfected. ${ }^{3}$

8 67. Effect of.-With the exception pointed out in the above section, a judgment entered nunc pro tunc must be everywhere received and enforced, in the same manner and to the same extent as though entered at the proper time. Though an execution may have issued, and proceedings under it culminated by the sale of property, when there was nothing on the record to support it, yet tho omission was one of evidence and not of fact, and the evidence being supplied in a proper manner, full force and effect will bo given to the fact as if the evidence had existed from the beginning. ${ }^{4}$

\section{68. Must be based on Previous Act of the Court.-}

It must be observed that the entire purpose of entering judgments and decrees, as of some prior date, is to supply matters of evidence, and not to supply or modify matters of fact. The failure of a court to act, or its incorrect action can nevor authorize a nunc pro tunc entry. If no judgments

${ }^{1}$ Hemming $v$. Batchelor, 23 W. R. McCormick v. Wheeler, 36 Ill. 114; 395; 33 L. T. N. S. 16; 44 L. J. Exch. Graham v. Lynn, 4 B. Mon. 1s; 54.

${ }^{2}$ Galpin $v$. Fishburne, $3 \mathrm{McCord}, 22$; 15 Am. Dec. 614. Acklen $v$. Acklen, 45 Ala. 609. * Graham v. Lynn, 4 B. Mon. 18; Davis $v$. Shaver, 1 Phill. N. C. 18;

${ }^{3}$ Hays $v$. Niller, 1 Wash. Ter. Rugg $v$. Parker, 9 Gray, 209; Burnett 163; Jordan $v$. Petty, 5 Florida, 326; $v$. State, 14 Tex. 455. 
be rendered, or if an imperfect or improper one be rendered, the court has no power to remedy any of these errors or omissions by treating them as clerical misprisions. ${ }^{1}$

${ }^{1}$ Gray v. Brignardello, 1 Wall. 627 ; Mo. 359 ; Gibson v. Choutean, 45 Petition of Inhabitants of Limerick, Mo. 171.

18 Maine, 183 ; Hyde v. Curling, 10 


\section{CHAPTER IV.}

\section{AMENDING JUDGMENTS.}

\$69. During Term.

§ 70. Correcting Judgment after Term.

\$ 71. Amending Judgment Entry.

\$72. Data for, in the United States.

8 73. Tardy Application.

$\$ 74$. Rights of Third Persons.

869. During Term. - "During the termo wherein any judiciall act is done, the record remaineth in the brest of the judges of the court, and in their remembrance, and therefore the roll is alterable during that terme, as the judges shall direct; but when the terme is past, then the record is in the roll, and admitteth no alteration, averment, or proof to the contrarie." Of the law thus laid down, the only part remaining unshaken to the present time is, that during the term, the proceedings remain in the breast of the judges. Not only the records during that time are subject to the revision of the court, but the judgment itself may be altered, revised, or revoked, as well as amended in respect to elerical errors and matters of form. ${ }^{2}$

8 70. Correcting Judgments. As a general rule, no final judgment can be amended after the term at which it was rendered. The law does not authorizo the eorrection of judicial errors, under the pretense of correcting clerical errors. To entitle a party to an order amending a judgment or decree, he must establish that the entry as made does not conform to what the court intended it should be when it was ordered. Thus, if a solicitor inadvertently omit from a decree some clause which he intended to insert, and pre-

${ }^{1}$ Co. Litt. $260 a ; 3$ Bl. Comm. 407 . the common law rule authorizing t'1e

${ }^{2}$ Bureh $v$. Scott, I Bland. Ch. 112; judge to set aside, eorrect, or modify Dane's Ab. clap. 146, Art. 5, \$11; his judgment at any time cluring ti: Stahl $v$. Webster, 11 Ill. 511; DeCastro term, was inapplieable to the system $v$. Richardson, 25 Cal. 49 ; Obenchain of practice in that state; that "the $v$. Comegys, 15 Ind. 496 ; Tobinson $v$. control of the conrt over causes comThe Commissioners, 12 IId. 132; Lane ing before it (except where retained $v$. Ellinger, 32 Tex. 369; Palsgrave $v$. by the statute, and except the necesRoss, 2 Jur. 95 (Lower Canada); Rich- sary control over its recorls wlich ardson $v$. Howk, 45 Ind. $45 \mathrm{I}$; United every court lias) terminates with the Strates $v$. Harmison, 3 Saw. 556; entry of julgment;" and therefore Memphis 2 . Brown, 91 U. S. 715 ; that the only mode in which a julgGreen $v$. Pittsburgh ete. R. I. Co., ment eonld be modified or vacateal 11 W. Va. 655. But in Grant 2 . was by appeal, or by motion for a Schmidt, 22 Alinn. i, it was held that new trial. 
sent the decree to the judge, who adopts it as the judgment of the court, this is no ground for an amendment; for the facts do not show that the court intended to pronounce any different decree from the one prepared by the solicitor; and to change the record would be equivalent to exercising a revisory power over the judgment itself by the same authority that pronounced it. ${ }^{1}$ But the rule, that the judgment as rendered caunot be amended after the lapse of the term, is not universally respected in the United States. On the contrary, some exceptions have secured a permanent footing. In some of the States, the courts may, at any time, add to their judgments such clauses as may be necessary to carry them into effect, when there is anything in the judgment by which to amencl. ${ }^{2}$ In New York, the omission from a decree of any matter which, if applied for on the hearing, would have been granted as a matter of course, " as necessary or proper to carry into effect the decision of the court," will be supplied on motion. ${ }^{3}$ In such case, the omission will be corrected by a distinct order, without making any change upon the decree. 4 These exceptions, tolerated at first, on the ground that they did not affect the merits of the case, so as to require a rehearing, came to be regarded as authority for interference in a matter of substance and importance. An action was instituted on the joint and several bond of two, secured by a mortgage made

1 Forquer v. Forquer, 19 Ill. 68 ; court, interest was allowed at a certain Bac. Ab. Title "Amendments," etc., F.; Scroggins' Admr. v. Scroggin, 1 J. J. M. 262 ; Powell's Appellate Proceedings, p. 387 ; Dorsey v. Dorsey, 37 Md. 74; Kemp v. Cook, 18 Md. 131 ; Bertrand v. Gugy, 9 L. C. Rep. 260 ; Huot $v$. Page, 9 Ib. 226.

2 Trammell $v$. Trammell, 25 Tex. Supp. 261. Thus, where it appears from the record that a name ought to have been inserted in the judgment, the record was amended by inserting such name. (Bank $v$. Seymour, 14 Johns. 219.) An amendment has also been anthorized after the lapse of the term so as to make the judgment bear interest, because, by the rule of the rate, and the omission to include it in the judgment must be deemed a clerical error. (Bank $v$. Wistar, 3 Pet. 431.) In England, the broad rule is laid down, that "it is always open to the court, on motion, to correct its judgment to relieve any party who may be unduly prejudiced by any act done under its order, and to prerent any injurious consequences which may flow from its error." Kelly C. B. in Huffer v. Allen, 2 Law R. Exq. Cas. 15.

3 Gardner v. Dering, $2 \mathrm{Edw}$. Ch. 131; Ray v. Connor, 3 Edw. Cl. 478; Rogers $v$. Rogers, 1 Pai, Ch. 188. 4 Clark v. Hall, 7 Pai. Ch. 382. 
by only one. A decree was taken for the sale of the mortgaged premises and against the mortgagor for the deficiency which should exist after the sale. Upon application, without suggestion of any misprision of the clerk, the decree was amended so as to be against both defendants for the deficiency. Upon appeal, the chancellor said : "I have hesitated, therefore, whether it could be proper, without a reliearing, to smend the decree in a matter of substance so material to the rights of the appellant; and, upon examination of the cases, I am satisfied such an amendment would not have been permitted in the Courts of Chancery in England and in Ireland, without discharging the emrollment and granting a formal rehearing of the canse." He considered, however, that a different rule had been established by the cases allowing amendments, by inserting what would have been granted as a "matter of course;" that in the present case, both defendants were properly parties to a decree for the deficiency; that a decreo so drawn would have been signed as "a matter of course" in the first instance; and, therefore, that the amendment, as a matter of course, had been properly made." Similar in effect was the following, from an opinion in a late case in California : "The judgment in this case, as first entered, was defective, in not designating the defendants who were personally liable for the debt; but, inasmuch as the record shows who they were, the court had power to amend the judgment at any time, by adding a clause designating the defendants who were personally liable. - But the failure of the court to render judgment according to law, must not be treated as a clerical misprision. There there is nothing to show that the judgment entered is not the judgment ordered by the court, it can not be amended. ${ }^{3}$ On the one liand it is certain that proceedings for the amendment of judgments onght never to be permitted to become revisory or appellate in their nature; ought never to be the means of modifying or enlarging the judgment, or the jndgment record, so that it shall express something which the court dicl not prononnce, even althongh the proposed amendment embraces matter which onght clearly to huve been so pro-

1Sprague $v$. Jones, 9 Pai. Ch. 395. ${ }^{3}$ Rogers $v$. Lradford, 8 Bush, 164.

${ }^{2}$ Leviston $v$. Swan, 33 Cal. 480. 
mounced. ${ }^{1}$ On the other hand there are many cases in which it so clearly appears that the judgment as entered is not the sentence which the law ought to have prononnced upon the facts as established by the record, that the court acts upon the presumption that the error is a clerical misprision rather than a judicial blunder, and sets the judgment, or rather the judgment entry, right by an amendment nunc pro tunc. ${ }^{2}$

871. Amending the Entry.-The rule that the record admits of no alteration after tho term is obsolete. Even in England the judgment may be set right and amended by another part of the record, so as to correct any misprision or neglect of the clerk in entering the names of tho parties; or in the form of the judgment. In all cases the entry of judgment may be made to conform to the record and the instructions of the clerk. ${ }^{3}$ All courts have inherent power to correct clerical errors at any time; $;^{4}$ and to malio the judgment entry correspond with the judgment rendered. ${ }^{5}$ This power exists in criminal prosecutions as well as in civil cases. ${ }^{6}$ Where tho record contains sufficient matter to show that tho judgment entered is not the one rendered, it may bo corrected in respect to the amount recovered of defendant, ${ }^{7}$ or the number of days imprisonment which ho must suffer. ${ }^{8}$ The names of the party for or against whom tho recovery has been had may be corrected in like manner;"9

1 McLean $v$. Stewart, 21 N. Y., 5 Scroggins' Adm'r. v. Scroggins, 1 S. C. 472; Milam County v. Robert- J. J. M. 362; Gibson v. Wilson, 18 son, 47 Tex. 222; Turner v. Christy, Ala. 63; Chambers $v$. Hodges, 3 Tex. 50 MIo. 145; Durning v. Burkhardt, 517; Jenkins $v$. Eldridge, 1 V. \& M. 34 TVis. 585 .

${ }^{2}$ Anderson v. Parker, 6 Cal. 201; Schroeder's Estate, 46 Cal. 316; Doane $v$. Glenn, l Col. 456; Spraguev. Jones, OPai. 305; Huntington $v$. Zeigler, 201 . S. 10; Smith $v$. Kennedy, 63 Ala. 334.

${ }^{3}$ Bac. Ab. title Amendments, $\mathrm{F}$.

${ }^{4}$ Burson $v$. Blair, 12 Ind. 371; Bank of U.S. $v$. Moss, 6 How. U. S. 31; Finnell $v$. Jones, 7 Bush, 359; Paddon $v$. Bartlett, 5 N. \& M. 384; Duvall $v$. Wells, 4 H. \& McI. 164; Brush

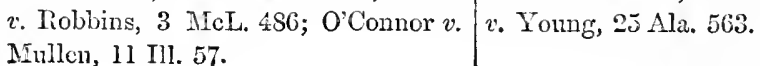

61; Harris $v$. Billingsley, 1s Ala. 43S;

Durning $v$. Burkhardt, $34 \mathrm{~W}$ is. 5s5;

Robertson $v$. Neal, 60 Mo. 579; State v. Primm, 61 Mo. 166; Wolfley $v$.

Lebanon M. Co., 3 Cal. 296.

' Ex parte Jones, 61 Ala. 399.

${ }^{7}$ Miller $v$. Foyee, 60 Ind. 189; Modawell $v$. Hudson, 57 Ala. 75; Sherry v. Priest, 57 Ala. 410.

${ }^{8}$ L.: parte Jones, 61 Ala. 399.

${ }^{9}$ Merrick $r$. Mayhue, 40 Mich. 196; 
and the entry may also be amended to show that the reeovery was for or against him in some representatiro eapreity; and if against him in such capacity, to relieve him from personal liability and subject him to the liability attaching to his representative character only. ${ }^{1}$ In Eugland the amendment must be authorized by some matter of record. Even there a verdiet was amended by the judge's notes and the affidavits of the jurors who renclered it, ${ }^{2}$ and the postea after a lapse of two years, by the judge's notes." An amendment may be made by the court which rendered the judgment and retains possession of the record, though an appeal is pending, and even after the judgment has been affirmed on appeal. ${ }^{5}$

3. 72. Data For.-In the United States, the authorities showing the data from which a judgment may be amended are contradictory. Some of the States have adopted the English practice; but a majority have adopted one more liberal. In Mississippi the rule of the English eases was understood as excluding everything not a part of the record. On that ground the notes of the judge were cleemed to bo as incompetent to amend the record by as any other parol evidence. ${ }^{6}$ In Indiana the court doubted whether any judge could, after the term, amend the entry of the judgment on the ground that it did not express his intention, when there was nothing in the record to amend by. ${ }^{7}$ The law is now well settled in Alabama, ${ }^{8}$ (Teorgia, ${ }^{9}$ Kentucky, ${ }^{10}$ Indiana, ${ }^{11}$ Missouri, ${ }^{12}$ Mississippi, ${ }^{13}$ California, ${ }^{14}$ and Nevada, ${ }^{15}$ in eou-

\footnotetext{
${ }^{1}$ Beers $v$. Shannon, 73 N. Y. 292; Conn v. Seruggs, 5 Bax. 567; Gay v. Cheney, 58 Gra. 304; Boykin v. Cook, 61 Ala. 472; Atkins $v$. Sawyer, 11 Am. Dee. 1SS; 1 Pick. 351; Speed's Ex. $v$. Hann, 15 Am. Dee. 78; 1 Monr. 16. "Coglan $v$. Elden, 1 Burr. 583.

${ }^{3}$ Doe $v$. Perkins, 3 Durf. \& E. 749.

${ }^{4}$ Exchange Bank $v$. Allen, 63 Mo. 474; Freel $v$. State, 2l Ark. 226; Dow $v$. Whitman, 36 Ala. 604; Attorneygeneral $v$. White, Bunb. 2S3; Rew $v$. Parker, $14 \mathrm{Am}$. Dee. 515, and note; Richardson $v$. Mellish, 3 Bing. $3 \pm 6$; 11 Noore, 119; 7 B. \& C. 819.

${ }^{5}$ Roussett $v$. Boyle, 45 Cal. 64.

${ }^{6}$ Dickson $v$. Hoff, 3 How. Miss. 165; Boon $v$. Boon, S S. \& M. 315; Rhodes v. Sherrod, 8 S. \& MI. 97; Burney $v$. Royett, 1 How. Miss. 39.
}

${ }^{7}$ Boyd $v$. Blaisdell, 15 Ind. 72.

8 Summersett $v$. Summersett's Adm'r, 40 Ala., p. 596.

${ }^{9}$ Pitman $v$. Lowe, 24 Geo. 429.

${ }^{10}$ Finneil $v$. Jones, 7 Bush, 359; Stephens $v$. Wilson, 14 B. Monr. Ss.

11 Makepeace $v$. Lnkens, 27 Ind. 435.

12 Saxton $v$. Smith, 50 NIo. 490; State v. Clark, 13 Mo. 432; State $v$. Primm, 61 Mo. 166.

${ }^{13}$ Moody $v$. Grant, 41 Miss. 565; Russell $v$. MeDougall, 3 S. \& M. 234.

11 MIorrison v. Dapman, 3 Cal. 255; Branger $v$. Chevalier, 9 Cal. 172; Swain $v$. Naglee, 19 Cal. 127; Hegeler v. Henckell, 27 Cal. 491; De Castro $v$. Richardson, 2ృ Cal. 49.

${ }^{15}$ Solowon $v$. Fuiler, 14 Nev. 63.

61 
formity to the rulo that no record can be amended but by matter of record. Undoubtedly, as in cases of application to enter judgment nunc pro tunc, the memoranda of the presiding judge upon the motion docket, and his written opinions, when required to be filed in the case, would generally be regarded as parts of the record. In Wisconsin, an amendatory order based upon the personal recollection of the judge, and conforming the judgment to that recollection, was sustained upon appeal. ${ }^{1}$ In many of the States, the practice has grown up of making a proposed amendment the subject of a petition and motion. The party applying is required to set forth the respect in which the record is defective, and to suggest the amendment with which he proposes to cure the defect. Notice of the motion must be given to the adverse party, and an opportunity allowed him to appear and make a contest. ${ }^{2}$ At the hearing, such evidence is received as would be competent in any other investigation. This practice is adopted either by express decisions or by tacit acquiescence in Massachusetts, ${ }^{3} \mathrm{New}$ Hampshire, ${ }^{4}$ Maine, ${ }^{5}$ Connecticut, ${ }^{6}$ Ohio, ${ }^{7}$ Illinois, ${ }^{8}$ Arkansas, ${ }^{9}$ Iowa ${ }^{10}$ and North Carolina,. ${ }^{11}$ and is sanctioned by the Supreme Court of the United States. ${ }^{12}$ It is further recommended by its justness and its liberality. "The doctrine in this country, in reference to amendments of records, may be said to have crystallized into the following legal propositions, namely: That any error or defect in a record which occurs through the ant or omission of tho clerk of the court in entering, or failing to enter of record, its judgments or proceedings, and is not an error in the express judgment pronounced by the court in the exercise of

1 Wyman v. Buckstaff, 24 Wis. 477.

2 Weed $v$. Weed, 25 Conn. 337; Means $v$. Means, 42 Ill. 50; Alexander v. Stewart, 23 Ark. 18; Hill v. Hoover, 5 Wis. 386 .

${ }^{3}$ Clark v. Lamb, 8 Pick. 415; 19 Am. Dec. 332; Rugg $v$. Parker, 7 Gray, 172.

${ }^{4}$ Frink $v$. Frink, 43 N. H. 18. 183.

${ }^{5}$ Inhabitants of Limerick, 18 Maine,
6 Weed $v$. Weed, 25 Conn. 337.

${ }^{7}$ Hollister $v$. Judges, 8 Ohio S. 201.

${ }^{8}$ Forquer $v$. Forquer, 19 Iil. 68.

${ }^{9}$ Arrington $v$. Conrey, 4 Barber, 100; King $v$. State Bank, 4 Eng. 188.

${ }^{10}$ Stockdale $v$. Johnson, 14 Iowa, 178.

${ }^{11}$ Galloway $v$. McKeithen, 5 Ired. 12; State $v$. Ting, 5 Id. 203.

${ }^{12}$ Matheson's Adm'r v. Grant's Adm'r, 2 How. U. S. 263. 
its judicial discretion, is a mere clerical error, and amendable, no matter in how important a part of the record it may be; and when the error or defect is in respect to tho entry of some judgment, order, decree or proceeding, to which one of the parties in the cause was of right entitled, and, as a matter of course, according to law and established practice of the court, it will sometimes be presumed to have occurred through the misprision of the clerk, and will always be amendable if from other parts of the record, or from other convincing and satisfactory proofs, it can be clearly ascertained what judgment, order or decreo the party was entitled to."1

The law in relation to amendments, as stated by Lord Coke, and as it undoubtedly existed until long after his time, was too harsh to successfully resist the march of legal reform, even in conservative England. As modified in that country, it is still too inconsistent with a liberal administration of the law to escape total overthrow in this country. The proposition that "the power to amend a record" is confined to cases where the record discloses that the entry "does not correctly.give what was the judgment of the court," implies that ministerial authority is more sacred than judicial authority. This proposition is sustained by the averment that a record is of "uncontrollable verity." This verity is sufficiently respected when it is allowed to protect records from collateral assault; it is unduly indulged if it operate to the exclusion of truth, in every form and on every occasion. The object in every litigation is to obtain from some court a final determination of the rights of the parties. That determination is invariably what the judges direct, and not invariably what the eleris record. Tha power of the court to make the record express the judgment of the court with tho utmost accuracy, ought not to be restricted. Upon any suggestion of error, the court ought to be at liberty to ascertain the existence or non-existence of the alleged error, by any satisfactory evidence. The record is made up in some cases after the term, and thus the opportunity of asking for corrections while it is still in the breast of the judge, is never presented. In most cases, the clerk acts

1 Doane v. Glenn, 1 Colorado, 456. 
from his recollection of what was done and said, as well as from loose, imperfect memoranda. Why then should the accuracy of his memory not be tested by the memory of other persons then present, and more especially by that of the judges, whom he may have imperfectly understood? Why may not the trial of an issue as to the correctness of a written memorial, be brought to a more just and satisfactory conclusion by hearing all the proofs offered by both parties, tending to throw any light upon the controversy, than by confining the investigation to a mere inspection of such evidence as happens to be on or among the records in the case-these records all confessedly liable to the same errors and omissions as the one sought to be reformed. Some of the courts profess to acquire their correctory power over their records solely by virtue of tho English Statutes of Amendments and Jeofails, ${ }^{1}$ while others insist that it has a higher source and a wider application, and exists by virtue of high equity powers residing in the court and enabling it to compel its records to speak the truth. ${ }^{2}$

\& $72^{\mathrm{a}}$. TJo:ice of Application. - Whenever an amendment of a judgment or decree is sought, notice should be given to the adverse party of the motion to ameid. That impartiality, which ought to distinguish the proceedings of all judicial tribunals, requires that no matter be considered by any court without giving both parties a full and fair opportunity to be heard. In regard to the amendment of judgments, the authorities fully sustain the view that the courts will not act upon an ex parte application. ${ }^{3}$ An exception to this rule may be allowed where the amendment is made from the record alone, and the judgment, as proposed to be amended, is not different from what it would have been construed to be, independent of the amendment. "No one's rights are afiected by it, as the effect of the record is not changed. All who may have consulted the record, or acted upon the faith of it, must be presumed to

\footnotetext{
1 Makepeace $v$. Lukens, 27 Ind. U. C. 521; Wooster v. Glover, 37 435. Conn. 315; McNairy v. Castleberry, 6 Tex. 286; Rockland Water Co. v. 2 King $v$. State, 4 Eng. 188.

3 Wallis $v$. Thomas, 7 Ves. 292; Pillsbury, $66 \mathrm{Me} 427$. Radenhurst $v$. Reynolds, 11 Grant's
} 
have notice of all which the proper construction of tho whole record discloses; in other words, of the effect of tho record." I

7 73. Tardy Applications.-Applications for the correction of clerical errors must be made promptly after their discovery. An application was denied in the Court of Chancery in New York, on the sole ground that the applicant had not proceeded at once, after his attention had been called to the alleged error, but had laid idle over a year. ${ }^{2}$

74. Rights of Third Persons.-Amendments of the entries of judgments and of decrees, like orders for their cntry nunc pro tunc, wiil only be permitted in furtherance of justice, and on such terms as shall protect the interests of third parties aequired for a valuable consideration without notico. ${ }^{3}$

${ }^{1}$ Emery $v$. Whitwell, 6 Mich. 491. 114; Adm'r of Ligon v. Togers, 12 2 Rogers $v$. Rogers, 1 Pai. Ch. 188. Geo. 281; Perdue v. Bradshaw, 18 3McCormick $v$. Wheeler, 36 Ill. Geo. 287. 


\title{
CHAPTER V.
}

\section{THE IUCORD, OR JUDGMENT ROLL.}

\author{
85. Origin. \\ $\$ 76$. Verity. \\ § 77. The Iostea. \\ $\S 73$. That constitutes the Foll. \\ $\S 79$. What does not. \\ $\$ 80$. Provisions of the Codes. \\ $\S 81$. Construction of the Code Provisions. \\ $\S 82$. In California and Nevada. \\ $\$ 83$. Construction in California. \\ \& 84. Interlocutory Judgnents. \\ \& 85. New Trial has record of its own. \\ $\$ 86$. States where no record is made up. \\ \$ 87. Want of, does not afiect Judgments. \\ 8 88. In Chancery. \\ § 8'. Feplacing Lost Rolls. \\ $89 \mathrm{a}$. Chancery cannot replace.
}

¿ 75. Origin.-The judgment roll or record is so inseparably connected with the judgment itself as $\mathbf{w}$ requirs some notice in this work. In the primitive stages of our common law, the pleadings were oral. The litigants appeared in court, and there carried on their leyal altercations, the plaintiff stating the grounds which, in his opinion, entitled him to the interposition of the court; and the defendant resisting those statements, by denying either their suficiency in law or their truthfulness, or by showing some fact depriving them of their ordinary force and effect. The process of statement and counter-statement continued until the court understood the point of difference, or, in other words, until an issue was formed. During all this time an oficer of the court was in attendance, charged with the duty of making brief memoranda of the respective allegations of the parties, and of the acts of the court, upon a roll of parchment. Parchment was so early and so constantly used for this purpose that it came to be regarded as an essential and indispensable part of the record. The manner and time in which the record was made up, occasioned the 
use of words of the present tense, as the "plaintiff complains" and "brings suit," the defendant "comes and defends" and "prays judgment," " the jury come and say," and " the judgment of the court is that it is considered." These words continued in use, when, by more modern practice, the record became a subsequent instead of a contemporaneous memorial.

8 76. Verity.-The record was kept in formal languane, with great care and precision. Its formality and precision, together with its contemporaneous character, gave it great authenticity. It became exclusively admissible evidence of the matter properly included in it, and of such "nneontrollable credit and verity as to admit of no averment, plea, or proof to the contrary." It became a mark of distinction to the class of courts in which it could be kept, and furnished the basis for a line of decisions which enhanced the dignity and importance of courts of record, and gave to their judgments and proceedings a prima facie credit and respect never accorded to those of courts not of record.

8 77. The Postea.-After the pleadings were written instead of oral, the record was continued. If an issue of fact was made by the pleadings, it was referred to some appropriate method of trial. The record was then made up, consisting of the placita, brief statement of the nature of the action, a transcript of the allegations of facts, time of appearance, the various acts of the court, and the award of trial. Fifty-three cases were brought to the Supreme Court of Illinois at one term, all of which were consiclered as liable to reversal, for containing no placita. This deficiency, it was held, could not be supplied by reference to bills of exceptions appearing in the record; because, without the placita, there was nothing to show any authority in the court to render judgment nor to make a bill of exceptions. ${ }^{1}$ The history of the case after this is called the postea. It shows the day of trial, before whom the trial took place, the appearance or default, the summoning and the choice of the jury, and their verdict.

IP. MI. L. Co. v. Chicago, 56 Ill. 304. 
The record was made compact and continuous by "Continnances," or ontries of the adjournment of the cause from time to time, by which the parties were temporarily dismissed, and a day fixed for their subsequent appearance. After the return of the record with its postea, the case being ready for judgment, the allowance of the proper officer may be obtained, expressing generally that judgment is given, and in whose favor. This is called "Signing Judgment." The next step is to put the judgment on record. If no trial has been had, a record is now made up for the first time. But if trial has been had, the whole proceedings, though already made up, are again entered on a roll of parchment. This proceeding is " Entering the Judgment." Though nominally the act of the court, the duty of seeing it done in proper form derolves upon the prevailing party. This last roll is deposited in the treasury of the court, and is known as the "Judgment Roll," and is also frequently styled "The Record."

87 78. Cf vohat Composed. - The rerity conceded to the judgment roll applies to nothing which it is not the duty of the clerk to record.2 Nothing can be made a matter of record by calling it by that name, nor by inserting it among the proper matters of record. ${ }^{3} I_{t}$ is, therefore, exceedingly important to understand what is or is not a part of the judgment roll; what imports absolute verity; what will be considered in proceedings in the nature of writs of error; and precisely what has authority to speak for or against the judgment in a collateral proceeding. While the record is, in general terms, a listory of the proceedings, many things clone in the progress of a case are not necessarily nor ordimarily matters of record. It is to be regretted that the courts have been contented with peremptorily excluding many papers claimed to be parts of the record, but hare rarely attempted to specify or describe those matters which

1 In relation to the matters con- 489 ; Hahn v. Kelly, 34 Cal. 391, by tained in the three preceling sections, Sawyer, J.

consult: Steph, Pl. 25, 111; Burrill Pr. 12, 16; 3 Bl. Comm. 3s6-7; Co. Litt. 60 a.; Burrills \& Bouvier's Law Dictionaries, Title "Pecord."

eDouglas $v$. Wickwire, 19 Conn.

3 Nichols $v$. Bridgeport, 27 Conn. 459; Kitehens $v$. Hutchins, 44 Geo. 620 ; Abbot v. Hachman, 2 S. \& $\mathrm{II}$. 510. 
possess an indefeasible claim to a place in tho judgment roll. In Virginia, the question, What is a common law record, was answered thus: "It is the writ for the purpose of amending by, if necessary," all the pleadings, "papers of which profert is made, or oyer demanded," papers submitted to the court by bills of exceptions, demurrers to evidence, or special rerdict, and such papers as are inseparably connected with those so submitted, and the severn proceedings at the rules or in court until the rendition of the judgment. These, and no other, are to be noticed by the court. ${ }^{1}$ In the case of paper's of which oyer is demanded, the rule laid down above, must be limited to those instances where the record shows oyer to have been granted by the court or conceded by the party. ${ }^{2}$ And the instrument will become part of the record if oyer be granted or conceded, though it be unsealed, and therefore not a paper of which oyer can be properly demanded. ${ }^{3}$ Oyer of an instrument does not include oyer of an alleged assignment, nor will it make such assignment matter of recorcl. ${ }^{4}$ The writ, or summons, is probably a part of the judgment roll, ${ }^{5}$ but on this subject tho authorities disagree. ${ }^{\circ}$

8 79. Iratters INot of Record. - No general definition has been attempted by which to determine what are not matters of record. In one case the rule is stated, as without exception, that, "No act in pais of any party to a suit can be made any part of the record except by bill of exceptions." In another case, "all intermediate proceedings of an informal, collateral, and so to speak, accidental and uncertain character, not involving directly the merits of the case, but rather appertaining to modes of proceeding," are specified as forming no part of the juchment roll. ${ }^{8}$ Among the matters which are not (unless made so by bill of exceptions or by consent, or by order of court) matters of record,

1 Manderille $v$. Perry, 6 Call. 78. |261; Kibble $v$. Butler, 14 S. \& 1 . 2 Cummins $v$. Wooduff, 5 Pike, 207.

116; Clark v. Gibson, 2 Pike, 109: 6 Childs v. Risk, 1 Morris, 439 ; Hauly v. Real Estate Bank, 4 Pile, Hays v. Nichee, 2 Blkf. 11.

c98.

3 Iussell $v$. Drummond, 6 Ind. 210.

4 Crary $v$. Asliley, 4 Pilse, 203.

- sIontgomers $v$. Carpenter, 5 Pike, i Kibble v. Butler, 14 S. \& M. 267.

8 Nichols $v$. City of Bridgeport, 27 Conn. 453 . 
are all matters of evidence, written or oral, ${ }^{3}$ including note, ${ }^{2}$ bond, ${ }^{2 a}$ or mortgage ${ }^{3}$ fled in the case, and upon which suit is brought, and agreed statement of facts ${ }^{4}$ not in nature of special verdict; all motions, ${ }^{5}$ including motions to quasil the writ, ${ }^{6}$ to amend the pleadings, for extensions of time, for continuances, for bonds, for prosecution, for bills of particulars, ${ }^{7}$ pleas stricken from the files, ${ }^{8}$ notices of notions, ${ }^{0}$ afidavits of claimants, ${ }^{10}$ bonds for trial of rights of property, ${ }^{11}$ affidavits in relation to conduct of jurors, ${ }^{12}$ all affidavits taken during the progress of the cause, ${ }^{13}$ memor:nclum of costs, ${ }^{14}$ power of attorney to confess the judgment and affidavit in relation to the death of the maker thereof, ${ }^{15}$ report of judge of proceedings at the trial, reasons for his opinion in rendering judgment or in deciding application for a new trial, ${ }^{16}$ rulings of the court upon the admission of evidence, the instructions to the jury, statement of facts made by the judge for the purpose of taking the advice of the appellate comrt, ${ }^{17}$ and a ruling of the court upon an application to strike out a portion of the pleadings. ${ }^{18}$

\& 80. Statutes.-In several of the States the matters constituting the judgment roll are specified by statute. In

1 Lovell $v$. Kelley, 49 Maine, 263 ; Cumningham $v$. Mituhell, 4 Rand, 189; Clark $v$. Gibson, 2 Pike, 109 ; Cole $v$. Driskell, 1 Blkf. 17.

2 Starbird v. Eaton, 42 Mai. 569 ; Storer $v$. White, 7 MIiss. 148 ; Pierce $v$. Adams, 8 MIass. 393.

2a Cromie v. Van Nortwick, 56 Ill. 8.33.

3 Kirby $v$. Wood, 16 Maine, 81.

4 lank of $\mathrm{Va} v$. Bank of Chillicothe, 16 Ohio, 170.

5 United States $v$. Gamble, 10 MIo. 457 : Lbbee $v$. Higgins, 2 Iowa, 535 ; Christy's Adm'r v. Myers, 21 MIo. 112.

6 Hinton $v$. Brown, 1 Bllif. 423.

$?$ Nichols $v$. Bridgeport, 27 Conn. 459.

8 Wallier $v$. Wills, 5 Pike, 166 ; and Eelly v. Matthews, 5 Pike, 223 ; Chris. man v. Melne, 6 Ind. 487.
9 Rich $v$. Hathaway, 18 Ill. 543. ${ }^{10}$ Kiibble $v$. Dutier, 14 S. \& MI. 207.

11 Kirlssey $v$. Bates, 1 Ala. 303.

12 MIann v. Russell, 11 Ill. 586.

13 Bluzzard $v$. Phebus, 35 Ind. 284. "Valentine $v$. Norton, 30 Maine, 134; MIcArthur v. Starrett, 43 Maine, 345 .

${ }^{15}$ Hodges v. Ashurst, 2 Ala. 301; Magher $v$. Howe, 12 Ill. 379.

${ }^{16}$ Coolilge $v$. Inglee, 13 Mass. 50; Catheart $v$. Commonwealth, 37 Penn. S. 108.

${ }^{17}$ Nichols $v$. City of Bridgeport, 27 Conn. 459 .

${ }^{18}$ Feely v. Shirley, 43 Cal. 369; Moore v. De Valle, 28 Cal. 171; A. Nev \& S. Canal Co. v. Kidd, 43 Cal. 181. 
most cases, however, the specification is sufficiently general and indistinct as to create a necessity for judicial construction. In New York and Wisconsin the following papers are attached together and filed, and constitute tho judgment roll:

"1. In case the complaint be not answered by any defendant, the summons and complaint, or copies thereof, proof of service, and that no answer has been received, the report, if any, and a copy of the judgment.

" 2 . In all other cases, the summons, pleadings or copies thereof, and a copy of the judgment, with any verdict or report, the offer of the defendant, exceptions, case, and all orders and papers in any way involving the merits and necessarily affecting the judgment." The statute of Oregon $^{2}$ corresponds substantially with that of New York, in this respect, except that in cases where answer is filed, tho roll, in addition to the matters enumerated, in the New York Code, must contain the proof of service, all orders relating to a change of parties, and instead of " all orders and papers," all journal entries, or orders involving the merits or necessarily affecting the judgment. In Ohio, Nebraska, Dakota and Kansas, the clerk is required to make a complete record of every cause from the petition, process, return, pleadings, reports, verdicts, orders, judgment, and all material acts and proceedings of the court; but if items of account or copies of papers attached to the pleadings bo voluminous, the court may order an abbreviation, or a pertinent description thereof. Except in Kansas, he is forbidden from recording the evidence. ${ }^{3}$ In Georgia, the clerk must record in a well bound book, within six months after the final determination of each canse, all proceedings relating thereto; 4 in Alabama a statute, otherwise similar in this respect, excepts from the record subpœnas, affidavits for continuance, commissions to take testimony, evidence, and the execution. ${ }^{5}$

I Code of N. Y. $\oint 281$; R. S. of braska, $\S 446$; Code of Dakota, $\$ 402$; Wis. Ed. of 1853, Ch. 132, $\S 35$.

2 Code of Oregon, $\$ 249$. Code of Kansas, $\$ ₫ 415,416,417,418$. 4 Code of Georgia, $\$ 256$.

3 Code of Ohio, $\$ 300$; Code of Ne- 5 Code of Alabama, $\$ 767$. 
8 81. Construction of Codes.-These statutes have not done much toward answering the question, What is the record? After enumerating the matters obviously indispensable to every judgment roll; after being precise where precision had already been attained, they employ terms whose signification is as unlimited as are the confines of space; whose application to the practical affairs of men must be as diverse as are the temperaments and the intellects of the judges by whom the application happens to be made. Who shall be able to determine with unerring accuracy what "proceedings and acts of the court are material;" what "papers, orders or journal entries necessarily affect the judgment and involve the merits of the action." Some of the matters excluded from the judgment roll under these statutes, and which, though included by the clerk as parts of the record, will be disregarded by the courts, aro motions and the papers on which they are founded, together with the ruling of the court thereon; ${ }^{1}$ matters of evidence, oral or written, ${ }^{2}$ including notes ${ }^{3}$ and mortgages ${ }^{4}$ filed in the case and constituting the cause of action, and proof of the filing of lis pendens; memoranda of costs and notice of adjustment, ${ }^{6}$ the affirlavit requisite to authorize the taking of property in replevin, ${ }^{7}$ affidavit and order of arrest, ${ }^{8}$ proof of service when the defendant has answered or demurred, ${ }^{9}$ bill of particulars, ${ }^{10}$ pleadings amended or demurrer abandoned, ${ }^{11}$ opinion of the judge, ${ }^{12}$ affidavit used in support of a motion, ${ }^{13}$ minutes made by the judge upon the trial docket. $^{14}$

8. 82. In California and Nevada. - In California and Nevada, the law providing for the judgment roll is distinct and specific. The matters which may properly be inserted in it are so clearly enumerated as leave no necessity for

${ }^{1}$ Cornell $v$. Davis, 16 Wis. 686; Demming $v$. Weston, 15 Wis. 236. 2 Cord $v$. Southwell, 15 Wis. 211. 3 Theid $v$. Case, $1 \pm$ Wis. 429.

4 Cord $v$. Southwell, 15 Wis. 211. 850.

6S. \& S. Plank Road Co. v. Thatcher, 6 How. P. 226.
7Kerrigan $v$. Ray, 10 How. P. 213. 8 Corwin $v$, Freeland, 2 Seld. 560. 9 Smith $v$. Holmes, 19 N. Y. 271. ${ }^{10}$ Kreiss $v$. Seligman, 8 Barb. 439. ${ }^{1}$ Brown v. Saratoga R. R. Co., 18 N. Y. 495.

12Thomas $v$. Tanner, 11 How.P. 426. I3Backus $v$. Clark, 1 Kansas, 303.

${ }^{1}$ Pennock $v$. MIomroe, 5 Iransas, 578. 
doubt. Section 670 of the Code of Civil Procedure, recently adopted in the first named State, re-enacts section two hundred and three of the Practice Act, with one addition, that of the proof of service of summons when the answer has been filed. It enacts that the judgment roll shall consist:

1. If no answer is filed by any defendant, of the complaint, summons, affidavit, or proof of service, memorandum of default, and copy of the judgment.

2. In other cases, of summons, proof of service, pleadings, verdict of jury or finding of the court, commissioner, or referee, bills of exception taken and filed, copies of orders sustaining or overruling demurrers, copy of the judsment and of orders relating to change of the parties.

In Nevala, the roll, in the event of no answer being filed, is made up of the same materials as in California; in all other cases, it consists of nothing but the summons, pleadings, copy of judgment, and of any orders relating to a change of the parties. ${ }^{1}$

8. 83. Construction. - In California it has been determined, by a majority of the judges of the Supreme Court, Justices Sanderson and Sawyer dissenting, that an answer stricken out is nevertheless entitled to a place in the judgment roll. "The phrase 'struck out,' as applied to a pleading, is figurative only. An order sustaining a demurrer to a pleading, defeats or suspends for a time its legal efiect in the action, and a successful motion to strike out an answer does no more. In either event, the pleading; as a document, remains in official custody." Such was the reasoning of the majority of the court. The minority said, with at least equal reason, "After the answer was stricken out, the document remained on the files as a part of the history of the case; but it was no longer, in legal contemplation, a pleading in the case." ${ }^{2}$ In two cases, Braly v. Seaman, 30 Cal. 610, and Forbes v. Hyde, 31 Cal. 342, tho decisions were founded upon the assumption that in cases where no answer was filed, and the defendant was served by means of publication, the affalavit on which the order of

\footnotetext{
$1 \S 205$, p. 228 , Stat. of Nev. of 1869. Cost bill is not part of the judgment- 208-9. roll: Kielly $v$. MeKibiben, 54 Cal. 192.

$$
{ }^{2} \text { Abbott v. Douglass, } 28 \mathrm{Cal} \text {. }
$$
}


prblication was based, and also the order itself, were parts of the judgment roll. These decisions, so far as they affected this matter, were made upon the concession of counsel in the case, and without the consideration of the court. Neither the order nor the affidavit belongs in the judgment roll, and both will be disregarded if put there. The affidavit showing the fact of publication of summons in a newspaper, and the deposit of summons and complaint in the post office, being "proof of service," must bo attached to the roll. "The affidavit and notice upon which a motion was made, ${ }^{2}$ and an order submitting a demurrer taken under advisement, ${ }^{3}$ and the ruling of the court in struking out an answer, ${ }^{4}$ are not parts of the record.

8 84. Interlocutory Judgments.- "The statute does not expressly provide that an interlocutory judgment shall constitute a portion of the judgment roll; but as such judgments often determine the rights of the respective parties, there is a manifest propriety in inserting them in the judgment roll. We are of the opinion that an interlocutory judgment comes within the meaning of the statutory requirement, that the judgment shall constitute a portion of the judgment roll."

8 85. New Trial.-The position which proceedings to obtain a new trial occupy in relation to the judgment roll, is very different under our practice from that which they occupied toward the judgment roll at common law. There, the motion for a new trial was made and disposed of before the judgment was entered. It, therefore, found its appropriate history in the same place with all the other proceedings taken prior to making up the record. But when the motion is made after the entry of the judgment, or, though made before, is disposed of after, then it must possess i record of its own, independent of the judgment roll. The result of this is, that while the judgment roll passes out of the "breast of the judge and beyond his control by lapse

\footnotetext{
1 Ifahn v. Kelly, 34 Cal. 391; Sharp v. Daugney, 33 Cal. 505; Galpin v. 238.

Page, 1 Saw. C. C. 321 ; but this de- ${ }^{3}$ Anderson v. Fisk, 36 Cal. 625. cision was reversed by the Supreme ${ }^{4}$ Feely $v$. Shirley, 43 Cal. 369. Court in Galpin v. Page, 18 Wall. ${ }^{5}$ Packard v. Bird, 40 Cal. 378. 350; 1 Cent. L. J. 491.
} 
of the term," the record of the new trial still remains in fieri, and will so remain, unaffected by the adjournment of the term, and sasceptible of alteration and amendment, until the motion is finally granted or denied.'

8 83. States Where No Reoord is Made Up.-In some of the States no record is made up, none being required by law. ${ }^{2}$ In these States the files and journal entries probably stand in place of the record and are entitled to similar verity. ${ }^{3}$ In other of the States, as in Pennsylvania and Maryland, the keeping of records fell into great confusion and neglect. For a long period of time littlo more was done by the prothonotaries, in most of the courts of these States, than to make such memoranda as would guide them in issuing executions, and as would have enabled them to draw up a formal judgment roll. Judgments, supported only by these informal memoranda, were, however, admitted in the lighest courts. The loose practice, it was thought, had prevailed so long and so universally; had bcen so thoroughly acquiesced in by bench and by bar; and had been made the foundation on which so many private interests of great extent and variety were based, that the adjudications, suficiently though informally, attested by it ought not to bo ignored; that while the entries and memoranda gave data from which a record as technical and prolix as any ever drawn in the conrt of King's Bench, could be readily constructed, they onght to be regarded as competent and satisfactory evidence of the judgment, and of snch other judicial proceedings as wore necessary to support it."

8 87. Want of Judgment Roll.-_"The judgment does not depend upon the performance of the elerical duty of

1 Spanagel $v$. Dellinger, $31 \mathrm{Cal} .470$. last named case is exceedingly inter-

2) Iorrow $v$. Weed, 4 Clarke, 77 , esting. It presents in a graphic and 127; and Norwell v. McIienry, 1 somewhat humorous style, the history Mich. 227; Lothrop $v$. Southworth, 5 of judicial records in Penn.ylvauia, Nich. 436 .

3 Thryer $v$. McGee, 20 Mich. 195.

4 S. P. Co. $v$. Siekles, 24 How. U.

S. 383; Cromwell $v$. Bank of Pittisburg, 2 Wall. Jr. 569.

the brevity with which they were entered, the little importance attached to their preservation, and, funlly, the worthy character and eccentric orthography of the prothouotarics.

The opinion of Justice Grier in the 
making up the judgment roll, or preserving the papers." The paper's constituting the roll, are therefore proper evidence and well support an execution, though they have never been attached together.2 In New York, the rule that omissions in the roll do not invalidate the judgment, has been applied where the omission consisted of the original summons, ${ }^{3}$ of an order of reference, ${ }^{4}$ of the copy of verdict, ${ }^{5}$ of the answer of defendant. ${ }^{6}$

8 S8. In Chancery, all the proceedings, including the evidence, are either written or required to bo reduced to writing. It is said, therefore, that everything so redueed to writing, becomes a part of the record, and as such, will be investigated by the appellate court. ?

\section{89. Replacing Lost Records.-The rule that the record} imports absolute verity, and is exclusively admissible evidence of the marters properly incorporated in it, might occasion much mischief, if the courts did not possess and exercise a power, unaffected by lapse of time, to replace whatever may have been defaced, lost or destroyed by accident, negligence or wantonness. The malsing up of a new roll was ordered as a matter of course in England, thirty years subsequent to the filing of the old one. ${ }^{3}$ In New York, a new nisi prius record was allowed to be filed, and a postea indorsed thereon, the applicant showing by affidavit that, six years before, a verdict had been taken and judgment thereon given, and that the nisi prius record and issue roll could not be found. ${ }^{9}$ In other States, the power of courts of record to supply, on proper proof, their own lost or destroyed records is affirmed to exist, independent of any statute, by virtue of their inherent powers "to minister ample justice to all persons according to law." The practice in proceedings involing this power, should be by mo-

${ }^{1}$ Lick $v$. Stockdale, 18 Cal. 219; Tutt $x$. Conzins, 50 Mo. 152; Galpin r. Page, 1 Saw. C. C. 309; Bridges $v$. Thomas, $50 \mathrm{Ga}$. 378; Craig $v$. Alcorn, 4 is Ia. 560.

"Sharp $v$. Lumley, 34 Cal. 611; Newman's Lessee $v$. Cincimmati, 18 Ohio, 323 .

${ }^{3}$ Hofinung $v$. Grove, 18 Abb. Pr. $14,142$.

"Martin $v$. Kanouse, $2 \mathrm{Abb}$. Pr. 390. Ward, $69 \mathrm{MI}$. 153.
${ }^{5}$ Cook $v$. Dickerson, 1 Duer, 679.

6 lienonil $r$. Harris, 2 Sanf. 641 .

'Ferris 2 . McClure, 40 11l. 99; Smith v. Siewland, 40 Ill. 100.

- Douglas $v$. Yallop, 2 Burr. 722.

9 Jackson v. Thammond, 1 Cai. 490.

${ }^{10}$ Keen $r$. Jordan, 13 Fla. 327; Gammon $v$. Kundson, 46 Ia. $45 \tilde{5}$; Gari. baldi v. Carroll, 33 Ark. 56s; George v. Miditough, 62 Mo. 540; Julian v. 
tion in tho court whose record it is proposed to restore. The plaintiff in the motion should give reasonable notice to the adverse party of the time and place, when and where, the application will be made, accompanied by a copy of the matter he proposes to have enrolled as and for the lost record, and also aceompanied by a copy of the afidavits intended to be used at the hearing. The defendant in tho motion should have an opportunity of appearing and using counter afidavits. If it appear to the court, at the hearing, that the record is lost or defaced, and what its contents were, it may then order a new roll to be made corresponding to the old one. The matter thus substituted will heneeforth be received in all courts, and given, in all respects, the same effect as though it were the original record. ${ }^{1}$

\section{89a. Chancery has no Jurisdiction to Enter.-It needs} only a substantial copy of the record intended to bo enrolled, to justify the court in allowing its substitution. It must also bo consistent with the record remaining undestroyed.2 The supplying of a lost record is a matter of which the court whero the record was made, seems to have exclusive jurisdiction. A party, instead of making a motion in the court where the record had been made, filed a bill in chancery, praying that a record lost by fire, might bo re-established. The court asserted that the power of supplying a new reeord when the original was lost, pertained

1 Adkinson $v$. Keel, 25 Ala. 551; called upon to supply the defects. Doswell $v$. Stewart, 11 Ala. 629; Mc- Probably, if after conviction and senLendon v. Jones, 8 Ala. 298; Pruit tence the record were destroyed, the $v$. Pruit, 43 Ala. 73; Deshong $v$. conrt might supply it for purposes of Cain, 1 Duv. Ky. 309; Pearce $v$. evidence, as in ciril cases. But the Thackeray, $13 \mathrm{Fla} .574$.

Note.--The power which enables conrts to supply the entire record, if lost or destroyed after judgment, extends to supplying any of the pleadings or papers in civil cases prior to the judgment. But the court has no sach power over an indictment. An indictment proceeds from the grand jury. The court has no creative or amendatory power orer it. If it is defective, another grand jury must be 792 .

defendant can be tried only on an original indictment; the court has no authority to establish a copy in the place of the original. If the original be lost, the only remedy for the prosecution is to have the defendant re-indicted. Bradshaw's Case, 16 Gratt. 507; State v. Harrison, 10 Yerg. 406; Ganaway $v$. State, 22 Ala. 773.

a Shiver $v$. Shiver, 45 Ala. 353; Bishop's Heirs $v$. Hampton, $19 \mathrm{Ala}$. 
to courts of general jurisdiction, independent of legislation, but sustained a demurrer to this bill, on the following grounds: "The jurisdiction involed by the complainant in the present case, has not been exercised by any court of chancery in England (so far as we have been able to discover with our limited means of examination), and the principles upon which the court takes jurisdiction in the case of Iost instruments, comes far short of embracing this case. The inherent power of courts to control their own records, and to supply losses therein, it seems is antagonistic to the porver of any other court to interfere and make records for them. By this proceeding, one court of special jurisdiction is invoked to take cognizance of, and to supply to another court of general jurisdiction a record, in lieu of one which has been destroyed. This power, once admitted, will place the records of the courts of common law at the mercy of the court of chancery, and might lead to absurd conflict between the law and equity side of the court over the records of the common law, one party imploring the conscience of the one to seize the power of the other, and control the history of its past action, and perhaps to compel the court of law to adopt and acknowledge as a fact, a thing of which it may deny any knowledge, and against which action the other party may justly ask it to revolt and treat as an usurpation, because its own power is ample and adequate. There is nothing here requiring the exercise of the conscience of the court which may not be attained by a simple proceeding, accorling to the course of the common liw, and, therefore, chancery has no office to perform."1

${ }^{1}$ Keen $v$. Jordan, 13 Fla. 327; Fisher $v$. Sievres, 65 Ill, 99.

78 


\title{
CHAPTER VI.
}

\section{VACATING JUDGMENTS.}

\author{
$\S$ 90. Is a Common Law Power. \\ persons. \\ $\$ 92$. Cases where third persons may apply. \\ § 93. Power to vacate, restricted in California. \\ \$ 94. Writs of Error Coram Nobis and Coram Vobie. \\ $\$ 95$. Writs of Audita Querela. \\ $\$ 96$. Vacation after lapse of the Term. \\ $\$ 97$. Irregularities. \\ $\$ 98$. Nullities. \\ $\S 99$. Fraud. \\ $\S 100$. Decrees. \\ \$ 101. Error no ground for vacation. \\ $\S 102$. Merits and Laches. \\ $\S 103$. Notice. \\ $\$ 10 t$. Conditional Vacation. \\ $\S 104 a$. Entry of Second Judgment. \\ $\S 10 \pm b$. Effect of Vacating Judgment.
}

§ 91. Application may be made by either party, but generally not by third

890. Is a Common Iaw Power.-The power to vacato judgments was conceded by the common law to all its courts. ${ }^{1}$ This power was exercised in a great variety of circumstances, and subject to various restraints. The practice in the different States is, in many respects, so conflicting that few rules can be laid down as universally applicable. One rule is, however, undoubted. It is, that the power of a court over its judgments, during the entire term at which they are rendered, is unlimited.2 Every term continaes until the call of the next succeeding term, unless previously adjourned sine die. ${ }^{3}$ Until that time, the judgment may be modified, or stricken out. ${ }^{4}$ While the right to have a judgment set aside upon sufficient showing, is secured to the applicant by the granting of an appeal in case of a denial of the right, the party whose judgment is vacated before

\footnotetext{
${ }^{1}$ Kemp v. Cook, 18 IId. 130.

3Townsend $v$. Chew, 31 IId. 247.

2 Underwood $v$. Sledge, 27 Ark. 295; $\quad{ }^{4}$ Doss $v$. Tyack, 14 How. U. S. 297; Ashley $v$. Hyde, 5 Ark. 100; State v. Taylor v. Lusk, 9 Iowa, 414.

Treasurer, 43 Mro. 228.
} 
the lapse of the term, has no remedy. The action of the court in granting a motion to set asido a judgment is discretionary, and not to be reviewed in any appellate court. ${ }^{1}$ The power of vacating a judgment must be exercised by the court, and not by a judge at chambers. ${ }^{2}$ This power must be exercised solely by the judiciary. The legislature can not set aside a judgment, nor can it empower any court to set aside a judgment which had been rendered and had passed beyond the control of the court prior to the passage of the act; because in cloing so the legislature is exercising judicial functions not accorded to it by the constitution. ${ }^{3}$

8 91. Who may Apply For. - The application to set aside a judgment may be made by either of the parties. rhe one who has been injured by the judgment may have it vacated, though it is in his faror, unless it was given at his instance, with knowledge on his part of its irregularity. ${ }^{4}$ In fact, the propriety and necessity of striking out a judgment on application of him in whose favor it is, are apparent. The judgment might be so irregular as to furnish no justification for any proceedings to execute it. If so, the party recovering it would be entitled to have it set aside, to enable him to proceed against the defendant regularly. $\mathrm{O}_{1}$. through fraud, mistake or irregularity, the defendant might procure a judgment for much less than the amount due. In this case, the plaintiff's right to have the judgment vacated is as obvious as though it was entirely in favor of the defendant. As a general rule, none but the parties to a judg-

1 Bolton $v$. McKinley, 22 Ill. 203 . the person applying must show that

${ }^{2}$ Ross $v$. Grange, 27 Q. B. (Upper he was prejudiced by the judgment, Canada) 306; Mearns $v$. Grand Trunk at its rendition. Hervey v. Edmunds, R. W. C., 6 Upper Canada L. J. 62.

${ }^{3}$ Armold $v$. Kelley, 5 West Va. 416; Merrill $v$. Sherburne, 1 N. H. 199; Burch $v$. Newbury, 10 N. Y. 374; Lewis $v$. Webb, 3 Greenl. 326; IIill $v$. Town of Sunderland, 3 Vt. 507; The State $v$. Wheeling \& Belmont Bridge Co., 18 How. U. S. 421 ; Cooley's Const. Lim. 94; Griflin v. Cunningham, 20 Gratt. 31; United States $v$. Klein, 13 Wallace, 128.

"Dorning v. Still, 43 دIo. 309. But 15.

68 N. C. 243 ; Hardin v. Lee, 51 Mo. 241; "Nothing can be clearer than that for defects, or irregularities not affecting the jurisdiction of the court, and where no fraud or collusion is imputed, the rewedy for such defects is given to the party alone, and that another judgment creditor is not entitled to have such proceedings or judgment set aside." Gere v. Gundlach, 57 Barb. 
ment can have it set aside.' Every litigant, if an adult, is presumed to understand his own interests, and to be fully competent to protect them in the courts. Ho has the right to waive all irregularities in proceedings by which he is affected, and is entitled to exclusively decide upon the propriety of such waiver. To allow disinterested third persons to interpose in his behalf, and to undertake the management of his business, according to their judgment, would creats intolerable confusion and annoyance, and produce no desirable result. To permit third persons to become interested after judgment, and to overturn adjudications to which the original parties made no objection, would encourago litigation, and disturb the repose beneficial to society. Therefore, if the defendant be the real as well as the nominal party afiected, as long as he is satisfied with the judgment, all other persons must be. ${ }^{2} \quad$ None of his subsequent assignees can complain for him. He who purchases lands liable to a judgment lien, cannot have the judgment vacated for irregularity, to avoid the lien. The best position he can occupy is that of a purchaser cum onere, ${ }^{s}$ even though he offers to prove that he made a vain search for such liens before completing his purchase." Third persons may sometimes hare a judgment vacated on the ground that it is collusive, or that the cause of action on which it is based was fictitious; but they are not allowed to take advantage of errors or irregularities of proceeding. ${ }^{5}$

- 8 92. When Third Persons may Apply.-The rule, that none but pariies to the judgment aro permitted to interfere, admits of exceptions. If a party confess judgment for too much, or not in conformity to the statute, it may be set aside by a judgment creditor; or if the defendant be a trustee about compromising the rights of his cestui que use, by confession, by default, by carelessness, or by a palpably mistaken view of his duty, the court, at the instance of the real party in interest, would interpose. The comptroller of a city, having charge of its finances, has a right to have in judgment against the city set aside, upon showing that it

${ }^{2}$ Walton $v$. Walton, 80 N. C. 26; Baugh $v$. Baugh, 26 Am. Rep. 495.

${ }^{2}$ Drexel's Appeal, 6 Barr. 272.
${ }^{3}$ Jacobs $v$. Burgwyn, 63 N. C. 196.

${ }^{4}$ Packard $v$. Smith, 9 TVis. 181.

${ }^{5}$ Hauer's Appeal, 5 W. \& S. 473. 
was obtained by the collusion or consent of other city offcials. ${ }^{1}$ Doubtless, as intimated in the preceding section, where one of the parties is a nominal and not the real litigant, the rights of the latter may be protected by permitting him, in a proper case, to move for and obtain the vacation of a judgment prejudicial to his interests. ${ }^{2}$

8 93. Law in California.-In California, the jurisdiction of a court over its judgments, except where otherwise expressly provided by statute, is, unless continued by some appropriate proceeding, exhausted at the close of the term. The process continues to be subject to the control of the court, but the judgment cannot be vacated on any account." This denial of the power of the courts to set aside their judgment, has probably been made in no other State. On the contrary, this power has been fully recognized and liberally employed in England and in the United States, both at law and in equity. The remedy by application to the court in which judgment was pronounced, seems in many States as complete as could be obtained by proceedings in chancery; and in nearly all the States has entirely superseded the remedy of audila querela, and by writ of coram nobis. As most of the authorities concede that a judgment may now be vacated on motion, for any of the matters for which a writ of coram nobis or an audita querela would formerly lie, the consideration of the matters to which those remedies were successfully applied, is material.

894. Writs of Error coram nobis and coram vobis have frequently been treated as identical. The object souglit by each writ is the same; but the method of secking it is different. The former writ issued out of the court where the error was alleged to have occurred, and was returnable before the same court. It recited that "because in the record and proceedings, and also in the rendition of the judgment of a plea in our court before $u s$, it is said a manifest error hath happened," and it then directs the judges to inspect the "record and proceedings which before us now remain," and to do what of right ought to be done to correct that error. The latter writ was made returnable before some superior tribunal, and required the record and proceedings

${ }^{1}$ Lowber $v$. Mayor of New York, 26 ${ }^{3}$ Baldwin $v$. Kramer, 2 Cal. 582; Barb. 262. Robb v. Robb, 6 Cal. 21; Bell v.

${ }^{2}$ Etna Ins. Co. $v$. Aldrich, $38 \mathrm{Wis}$. Thompson, 19 Cal. 706; Shaw v. Mc107; Mann v. Etna Ins. Co., 38 Id. 114. Gregor, 8 Cal. 521. 
to be certified to such tribunal for its revisory action.: A judgment is not to bə set aside because improperly entered, unless the showing is sufficient to authorize a writ of error coram nobis. If there be error in the process, or through the default or misprision of the clerk, it shall be corrected in the same court. But this writ camnot reach error in matter's of law. A plea in abatement setting up the death of one of parties, or that he is a slave, or a lunatic, if overruled, estops the party who presented it, from again urging those matters in the same court; for in this case, it is evident that the court misapprehended the law, but understood the facts. $^{2}$ If, however, the proceedings are based upon facts presumed by the court to exist, as when one of the parties is insane, or is an infant, or a femme covert, or has died before verdict, and the court supposing such party to be alive and competent to appear as a litigant, renders judgment, it may be set aside by a writ of coram nobis. ${ }^{3}$ But this writ does not lie to correct any error in the judgment of the court, nor to contradict or put in issue any fact directly passed upon and affirmed by the judgment itself. If this could be, there would be no end to litigation. Accordingly, where the judgment stated that defendant appeared and confessed, he was not allowed to controvert that'statement, after the lapse of the term, for the purpose of vacating the judgment. 4 The writ of error coram nobis is not intencled to authorize any court to review and revise its opinions; but only to enable it to recall some adjudication, made while some fact existed which, if before the court, would have prevented the rendition of the judgment, and which, without any fault or negligence of the party, was not presented to the court. That defendant was summoned by a wrong name, and was unable to find the declaration, and therefore did not appear, does not entitle him to this writ. It is his own fault that he did not plead the misnomer, or take judgment of nol pros. ${ }^{5}$

${ }^{1}$ Camp v. Bennett, 16 Wend. 48. | 4 Richardson's Exr. v. Jones, 12 2 Hawkins \%. Bowie, 9 G. \& J. 428; Gratt, 53.

Bridendolph $v$. Zellers' Ex'rs, $3 \mathrm{MId}$. 5 Brandon v. Diggs, 1 Heiskell, 32.5.

3Kemp v. Cook, 18 Ma. 130. 472. 
8 95. Audita Querela.-The proceeding by writ of audita querela is said to have commenced about the tenth yoar of the reign of Edward the Third. It gradually gave way in England, in most cases, to the more simple and equally efficient remedy by motion. It is nevertheless still used in some of the United States, and is sometimes sanctioned in cases where the writ of coram nobis seems peculiarly appropriate. The original purpose of the writ, and the one to which it is generally confined, is that of relieving a party from the wrongful acts of his adversary, and of permitting him to show any matter of discharge which may have occurred since the rendition of the judgment. ${ }^{2}$ It is in the nature of a bill in equity; and was invented, says Dlackstone, "lest in any case there should be an oppressive defect of justice, where a party who hath a good defense is too late to make it in the ordinary forms of law." It is a judicial writ founded upon the record and directed to the court where the record remains. ${ }^{3}$ It has the usual incidents of a regular suit, with its issues of law and of fact, its trial and judgment; ${ }^{4}$ and the persons whose judgment is sought to be vacated must be made parties and given notice. ${ }^{5}$ Besides being an appropriate remedy where some matter of discharge has arisen, the audita querelu may be employed when a good defense to the action has accrued since tho entry of the judgment, or where such defense, though existing prior to the judgment, was not brought to the attention of the court, on account of fraud or collusion of the prevailing party. ${ }^{6}$ Where the defendant, during the pendency of the suit, paid the debt, and the plaintiff afterward took judgment, it was heid that this writ would lie. ${ }^{7}$ It has also been applied for the purpose of vacating a judgment against an infant who defended without appointment of a guardian;: and a judgment against a lunatic whose guardian was not notified. ${ }^{9} \quad$ In Vermont it seems to be employed with more frequency than elsewhere, and to answer as a specific for

${ }^{1}$ Lovejoy $v$. Webber, 10 Mass. 102; Troop v. Ricardo, 9 Jur. N. S. 887; 11 Little v. Cook, 15 Am. Dec. 698; W. R. 1014; 8 L. T. N. S. 757; 33 Brackett $v$. Winslow, 17 Mass. 159.

2 Powell's Appellate Proceedings, $p$. 377. 168 .

${ }^{3}$ Poultney $v$. Treasurer, 25 Verm.

${ }^{4}$ Brooks i. Hunt, 17 Johns. 484. Beav. 122.

${ }^{6}$ Bryant $v$. Johnson, 24 Maine, 304; Wetmore $v$. Law, 3+ Barb. 5] ó; Staniford $v$. Barry, $15 \mathrm{Am}$. Dec. 692.

${ }^{7}$ Lovejoy $v$. Webber, 10 Mass. 101. ${ }^{8}$ Starbird v. Moore, 21 Verm. 520.

5rileason v. Peck, 12 Verm. 56;

${ }^{9}$ Lincoln $v$. Flint, is Verm. 247. 
all sorts of mischiefs not otherwise provided against. It there has power to vacate a judgment rendered after a suit is discontinued by agreement, or by failure of the parties to appear for trial or for irregularity, ${ }^{1}$ or in cases where a justice of the peace should have allowed an appeal, but refused to do so. ${ }^{2}$ It is the proper remedy when two judgments have been rendered on the same cause of action, and one of them is paid. ${ }^{3}$ It is not sustained by error of the court in a matter of law or of fact $;^{4}$ and is never permissible in a case where a writ of error is proper by the common law, though the right to such writ has been taken away by siatute. ${ }^{5}$ But a party having an opportunity of making his defense, or who is injured through his own neglect, can not bo relieved by audita querela. ${ }^{\circ}$ Nor can a party, by audita querela, obtain relief from a judgment rendered against him on the unauthorized appearance of an attorvey. An audita querela, like a motion to set aside a judgment, is only available in behalf of one who was prejucliced by the judgment at its rendition. If the party does not seek to avoid the judgment, his subsequent alienee will not be allowed to interfere with it. ${ }^{8}$ A party who has been discharged in insolvency, if he suffer default to be taken against him, is not entitled to have the judgment set aside for the purpose of pleading his discharge. ${ }^{9}$ As a general rule, wherever auclita querela would lie at common law, relief may now be obtained on motion. But, perhaps, in some of the States and in England, if the right to relief is questionable, or if the facts of the case are clisputed, the party moving may be compelled to have recourse to this writ. ${ }^{10}$ In a majority of the States, it is undoubtedly superseded by the more sum-

${ }^{1}$ Jenney $v$. Glynn, 12 Verm. 480; Pike $v$. Hill, 15 Id. 183.

${ }^{2}$ Edwards v. Osgood, 33 Verm. 224.

3 Bowne $v$. Joy, 9 Johns. 221.

${ }^{4}$ Lamson $v$. Bradley, 42 Verm. 165; School Dist. $v$. Rood, $27 \mathrm{Id} .214$.

${ }^{5}$ Spear v. Flint, 17 Verm. 497.

6 Thatcher $v$. Gammon, 12 Mass. 270; Griswold $v$. Iutland, 23 Verm. 324.
${ }^{7}$ Abbott v. Dutton, 44 Verm. 551; Spaulding $v$. Swift, 18 Id. 214.

${ }^{8}$ Beard v. Ketchum, 8 Upper Can. ada, Q. B. 523.

${ }^{9}$ Faxon $v$. Baxter, 11 Cush. 35.

${ }^{10}$ Giles v. Nathan, 5 Taunt. 55s;

Lister v. Mundell, 1 B. \& P. 4:27; Symonds $v$. Blake, 4 D. P. C. 263 ; 2 C. M. \& R. 416; 1 Gale, 18ะ; Bakcr $v$. Ridgway, 2 Bing. 41; 9 Hoore, 114; Wardell v. Elen, 2 Johns. Cas. 253, 
mary method of application by motion upon notice to the adverse party. ${ }^{1}$

3 96. After Term-Every judgment, regularly entered, must become final at the end of the term. In those cases in which the court afterward interferes to racate or annul a judgment, the interference can only be justified on the ground that the judgment was procured in such a manner as to indicate that it was not intended to be authorized by the court, or, if authorized by the court, that it is nugatory for want of jurisdiction over the parties. ${ }^{2}$ The interests of society demand that there should be a termination to each controversy. Courts have no power, after fully deliberating upon causes, and ascertaining and settling the rights of parties, to add clauses to their judgments authorizing the losing party to apply, at a subsequent term, to have the judgment against him set aside. If a vacillating, irresolute judge were allowed to thus keep causes ever within his power, to determine and redetermine them term after term, to bandy his judgments about from one party to the other, and to change his conclusions as freely and as capriciously as a chameleon may change its hues, then litigation might become more intolerable than the wrongs it is intended to redress. Leave granted in one term to movo to set aside a judgment at the next term, is void. ${ }^{3}$

The power of courts to set aside judgments after the lapse of the term, is subject to settled principles, and tho action of courts, if not authorized by those principles, is susceptible of review and reversal in the appellate courts. ${ }^{4}$ It must be confessed, however, that while those principles may be, and probably are, suficiently defined in each State, they vary in material respects in the different States. Ono State withholds this power altogether, others confine it to

\footnotetext{
${ }^{1}$ McMillan $v$. Baker, 20 Kans. 50; v. Glasgow, 7 Mo. 320; State Sav. Longworth $v$. Screven, 2 Hill (S. C.), Inst. $v$. Nelson, 49 Ill. 171; Merle $v$. 298; McDonald v. Falvey, 18 Wis. Andrews, 4 Tex. 200.

571 ; Smock v. Dade, 5 Rand. $639 ; 16$ Am. Dec. 7S0; Dunlap v. Clements, $5 S 4$.

$13 \mathrm{Ala}$. 775; Chambers $v$. Neal, $13 \mathrm{~B}$. Monr. 256; II uston v. Ditto, 20 Mid. 305.

${ }^{3}$ Hill v. City of Saint Louis, 20 Mio.

"Ifuntington $v$. Finch, 3 Ohio S.

${ }^{2}$ Cook $v$. Wood, 24 Ill. 295; Ashby 234.
}

86 
judgments rendered eontrary to the praetiee, or without the authority of the court, while in some it is applied within very broad limits, and seems to be kept, like reserved troops at a battle, for desperate emergencies not otherwise to be overcome. ${ }^{1}$

\section{97. For Irregularity.- "Irregular and improper eon-} duct in procuring judgment to be entered, is a well settled ground for vacating it. This has become one of the settled remedies where the impropriety or irregularity has not been induced by the fault or negligence of the judgment debtor." A judrment is said to be irregular whenever it is not entered in aceordance with the practiee and eourse of proceeding where it was rendered. ${ }^{3}$ When the writ was not returned until two months after the return day, and the judgment was entered as of the same day, it was set asido as irregular, on the ground that, if entered before the return, it was unanthorized; and, if entered subsequent to its date, it was a false record. ${ }^{4}$ Judgments prematurely entered by defaul', ${ }^{5}$ and those entered after the death of a party ${ }^{6}$ are irregular, and will be stricken out on motion. Taking judgment upon a warrant of attorney without filing a copy is, in Ohio, such irregularity as authorizes the vacation of the judgment after the term. 7 Where the duty of plaintiff required him to give notice of the taxing of costs, and he failed to do so,

${ }^{1}$ Breden $v$. Gilliland, 67 Pa. S. 36, |require." Capen $v$. Inlabitants of where the court says: "In the nature Stoughton, 16 Gray, 365; see also of the case, there is not, and ought Stickney $v$. Daris, 17 Pick. 169; Wolfe not to be, any limitation of time to the $v$. Davis, 74 N. C. 597 .

power of a court to open a judgment by default, for want of alpearance." So in Massachusetts, where a wrong verdict had been reported to the court through mistake, and a judgment was entered thercon, the court said: "We think it elear that the court had power at a subsequent term, in the exercise of a judicial discretion, on satisfactory proof that an erroneous entry had been made on the docket through mistake, to order the case to be brought forward for the purpose of vacating the previous erroneous order, and making such disposition of the case as the rights of the parties might 505.

${ }^{2}$ Huntington $v$. Finch \& Co., 3 Ohio S. 445; Downing v. Still, 43 Mo. 309; Doan $v$. Holly, 27 Mo. 256; Harkness v. Austin, 36 Mo. 47; Craig v. Wroth, $47 \mathrm{Md} .281$.

${ }^{3}$ Dick v. McLarrin, 63 N. C. 1S5; Davis v. Shaver, 1 Phill. N. C. 1S. A judgment inadvertently entcred by theclerk will be stricken out: Merrick $v$. Baltimore, 43 Md. 219.

${ }^{4}$ Graff $v$. M. \& MI. Trans. Co., 18 MId. 364.

${ }^{5}$ Mailhouse $v$. Inloes, $18 \mathrm{M}$ M. 329.

${ }^{6}$ Hohnes $v$. Honie, 8 How. P. 384.

${ }^{7}$ Knox Co. Bank v. Doty, 9 Ohio S. 
the judgment was set aside, and he was compelled to give a notice at his own expense. ${ }^{1}$

895. Nullities.-A judgment which is a nullity on account of being rendered against a corporation that does not cxist, will be vacated by the court which entered it." And, as a general rule, all void judgments will be so treated." In a case in South Carolina, the court asked itself this pertinent question: "Should the court whose process is abused by an attempt to enforce a void judgment, interfere for its own dignity and for the protection of its oflicer's to arrest further action?" and answered itself by saying: "Certainly, on proper application." In New York, julgment was vacated on motion, on ground that the summons was served by publication, and the record did not, on its own face, show sufficient facts to confer jurisdiction upon the court. ${ }^{5}$ In most of the states, a judgment will be set aside, though procured according to the ordinary forms of practice, npon showing a want of jurisdiction over the person of the judgment debtor. ${ }^{6}$ This has been done in cases of appearance made by unauthorized attorneys, upon showing by affidavits the want of authority in those persons, and that the defendant did not know of their action in his name when it occurred. The courts have acted in these cases without inquiring whether the attorneys were solvent or iusolvent; ${ }^{7}$ but, in this respect, they probably disregarded the current of the authorities. A judgment, entered while an order of reference is nnexecuted, is an irregularity, and will, therefore, be vacated at any time. ${ }^{8}$ And a judgment against an infant who did not appear by guardian, stands on the samo footing. ${ }^{9}$ Where the court ordered a case to stand over and to be continued for argument, and the clerk by mistake entered judgment ou the verdict, and issued execution, the

${ }^{1}$ Fenton $v$. Garlick, 6 Johns. 2 ss.

2 City of Olney $v$. Boyd, 50 IIl. 453.

${ }^{3}$ Forman $v$. Carter, 9 Kans. 67-1; 12 Am. L. R. 60; Hervey $v$. Elmunds, G3 N. C. 213; Winslow v. Anderson, ¿ B.v. \& Bat. 9.

"Mills \& Co. $v$. Dickson, 6 Rich. $48 \%$.

5 IIal'ett v. Righters, 13 How. P. 43.

G. hutord $v$. Cain, 1 Abb. U. S. 302; In re Colege Street, 11 R. I. 472; Cotton 2 . MeGílhee, 54 Miss. 621; Pettus v. McClannahan, 52 Ala. 55. In this last case it was held that except where fraud is charged, or it appears that one of the parties liad died, the want of jurisdiction can not be shown by evidence dehors the record.

' Yates $v$. Horanson, 7 Robt. 12; Mclielway $v$. Jones, 2 Harrison, N. J. 345.

${ }^{8}$ Stacker $v$. Cooper Circnit Court, 25 Mo. 401.

${ }^{9}$ ITeaton $v$. Banks, 10 Ired. 381. 
judgment was set aside and the execution quashed at the next term, on motion. ${ }^{1}$

8 99. For Fraud.-The maxim "that fraud vitiates everything" is applicable to judgments. Upon proof of fraud or collusion in their procurement they may be vacated at any time. ${ }^{2}$ It was held in Pennsylvania, that the Court of Common Pleas had the power to vacate a decree of divorce, when it was obtained at a previous term by fraud on the court, although a marriage had been subsequently contracted on the faith of the parties in the decree, and issue had been born. ${ }^{3}$

2 100. Vacating Decrees.-In relation to decrees there seems to be no doubt that the power of the court to discharge the enrollment and open the decree, never terminated unless there had been a regular trial on the merits. The General rule "that a decree once enrolled cannot be opened except by bill of review, or by an original bill for fraud, is subject to well founded exceptions, arising in cases not lieard upon the merits, and in which it is alleged that tho decree was entered by mistake or surprise, or under such circumstauces as shall satisfy the court, in the exercise of a sound discretion, that the decree ought to be set aside." The decree in such cases being by default, the cause of the default can never be the subject of inquiry until the decree has been pronounced, and generally not until after the term has passed. Without the exercise of this power in the court to vacate the enrollment, a party against whom a decree had been enrolled by mistake or surprise, and without any laches on his part, would be without redress. A bill of review would be of no avail, because his claim to relief is not based on error apparent on the face of the decree,

\footnotetext{
${ }^{1}$ U. S. v. McKnight, 1 Cranch, C. the court, showing that a decree had C. 84 .

${ }^{2}$ Cannan v. Reynolds, 5 El. \& Bl. 301; Phillipson $v$. Earl of Egremont, 6 Ad. \& El. N. S. 587.

${ }^{3}$ Allen $v$. McClellan, 12 Penn. S. $3 \approx 8$. The courts in Massachusetts also exercise the power of vacating judgments after the lapse of the term. In a recent case a decree of divorce was vacated upon petition addressed beenobtained at a former term against petitioner on false testimony, on a libel of which she had no notice, and of which actual knowledge was kept from her by the other party, and that the jurisdiction of the court was founded on a false allegation of dom. icile. Edson v. Edson, 108 MIass. 500. ${ }^{4}$ Cawley v. Leonard, 28 N. J. Eq. 467 ; Smith $v$. Alton, 7C. E. Green, 572.
} 
nor on account of newly-discovered evidence; and, unable to charge fraud in obtaining the decree, he would be unable to reverse it on that ground. Accordingly, it is laid down by the most eminent elementary writers, and fully sustained by the adjudged cases, thit when a case has not been heard on the merits, the court will, good cause being shown, exercise a discretionary power of vacating an enrollment, and giving the party an opportunity of having his case discussed." The fact that the merits of the case were never before the court, seems to be the controlling one in all applications for the exercise of this difcretionary power. Therefore, where the decree is perfectly regular so far as regards the appearance of the parties, and is in conformity with the general practice, it may be vacated at the discretion of the court, upon a showing of mistake, accident or surprise, or of negligence of the solicitor, by which the decision on the merits was prevented; ${ }^{1}$ or that the merits of the case were not presented to the court, on account of the guardian ad litem appointed for an infant, not sufficiently understanding the matters constituting his defense. ${ }^{2}$ Principles about as ample and liberal as those recognized at equity upon application to vacate decrees, seem to be applied to judgments in the courts of Maryland and Michigan. The courts of the former State vacate a judgment upon clear proof of fraud, surprise or irregularity, ${ }^{3}$ while those of the latter State relieve, upon motion, irrespective of the question whether the term has passed, all who have suffered from inability to make their defense. ${ }^{4}$ And, in England, little if any more stringency is applied to applications male after, than to those made during the term. In Caman v. Reynolds, 5 the court set aside a judgment by default on application of plaintiff, on the ground of mistake on his part in including demands in the judgment which wero due

12 Dane Ch. 1230; 2 Madd. Ch. Cranwell, 1 Dick. 61; Beeliman v. 466; Herbert $v$. Rowles, 30 MId. 271; Peck, 3 Johns. Ch. 415; Bennett $v$. Kemp $v$. Squires, 1 Ves. Sr. 205; Winter, 2 Id. Ch. 205.

Millspaugh $v$. MIcBride, 7 Paige, 509; 2 Curtis $v$. Ballagh, 4 Edw. Ch. 635.

Lrwin $v$. Vint, 6 Munf. 267; Carter $v . \quad{ }^{3}$ IIall $v$. Holmes, $30 \mathrm{Md}$. 558.

Torrance, 11 Geo. 654; Hargrave v. 4Loree v. Reeves, 2 Mich. 133;

Hargrave, 9 E. L. \& E. 14; Benson v. Huriburt v. Reed, 5 Mich, 30.

Vernon, 3 Bro. C. P. 626; Robson v. $\quad 55$ El. \& Bl. 301. 
from others than the defendants, and in excluding equal amounts due from defendants, whereby, if the judgment was not set aside, the plaintiffs would be prejudiced. The court thought it had power to set aside a judgment, at any time, in its discretion; and stated that it was in the habit of doing so every day, even after execution executerl, and without inquiring whether it was in term or not. In Illinois, a judgment confessed by attorney, was vacated on the ground that usury entered into the consideration upon which the confession was made. This action was said to be warranted by the practice in England, though not by that of some of the United States. ${ }^{1}$

\& 101. Error as a Ground for.-But neither a final judgment nor a final decree, pronounced upon a hearing on the merits, can be set aside after the term, upon motion, for any errors into which the court may have fallen. The law does not permit any judicial tribunal to exercise a revisory power over its own adjudications, after they have, in conternplation of the law, passed out of the "breasts of tho judges." 2 That a judgment was rendered upon default, upon considering evidence offered by plaintiff, for a sum much larger than that evidence warranted, is not a ground for vacating the judgment. The matter complained of is attributable to an error of the court, which might have happened if the defendant had been present at the trial. ${ }^{3}$ Neither is an error or misapprehension of the parties, nor of their counsel, any justification for vacating the judgment, although the counsel consented to it because deceived by fraudulent misrepresentations of third parties, ${ }^{4}$ or failed to attend the trial on account of a misapprehension as to the time of holding court. ${ }^{5}$

8 102. Merits and Want of Laches. - The most worthy object attained by the granting of motions to vacate judr-

1 Fleming $v$. Jencks, 22 Ill. 475.

2 Charman $v$. Charman, 16 Ves. Jr. 11j; Assignees $v$. Dorsey, 2 Wash. C. C. 433 ; Bank of U. S. v. Moss, 6 How. U. S. 31; Peake v. Redd. 14 Mo. 79.
${ }^{3}$ Green $v$. Hamilton, 16 MI. 517.

4 Murphy v. Merritt, 63 N. C. 502 .

5 Harbor v. Pacific R. R. Co., 32 Mo. 423. 
ments, is that of ailowing a full investigation of the matters in controversy, in crder that a disposition of the case, according to the merits may be made. Whenever that object does not appear to be the one sought, an application based on mere irregularity of proceeding will be treated with no favor. ${ }^{1}$ The rules will be strictly applied, and any laches shown against the moving party will prove fatal to his desires. ${ }^{3} \quad$ But what delay necessarily amounts to liaches is uncertain. In an early case in New York, eight days' notice of trial being given, when the defendant was entitled to fourteen days' notice, he treated it as void, and judgment was given against him. A subsequent motion, basel on the irregularity, made after the intervention of a full term, was considered too late. ${ }^{3}$ In the same State, a third of a century later, an application based on an irregularity, in giving too short a notice of an inquisition on a writ of inquiry, made after lapse of two special terms, was refused, because, "as this was an attempt to deprive the plaintiff of his judgment, on the ground of a mere irregularity, the defendant would be held to the strictest rules of proceeding, and having been guilty of laches in making his motion, he was not entitled to bo heard." This decision has been indorsed in Wisconsin, by holding that a short notice, being sufficient to put a party upon inquiry, he must ascertain whether his adversary proceeds to judgment npon it; that a motion to set aside such judgment, there being no pretense of merits, must be made at the same term, unless he can show some good cause for his delay; and that where defenclant waited more than two months, and until the expense of advertising real estate for sale had been incurred, he waived the irregularity. The defendant must not, according to some of the authorities, take any step in the case after the irregularity occurs, or it will be deemed a waiver. Thus,

${ }^{1}$ Dut in Missouri, if a judgment/showing of merits. Hanson $v$. Wol. be " irregularly obtained against the cott, 19 Kans. 207.

provisions of a statute, or the rules of ${ }^{2}$ Kerr $v$. Bowie, 3 Upper Canada, a court, a party is entitled to have it L. J. 150; Cagger $v$. Gardiner, 1 How. set aside without showing any merits." Doan $v$. Holly, 27 Mo. 256; see aiso IIughes $v$. Wood, 5 Duer, 603, note. If the julgment be void for want of juriscliction, the court will set it aside without requiring any Cormick, 20 Wis. 265. 
where an appeal was taken, because no notice of the motion for judgment was served, and the appellate court declined to interfere, on the ground that the appropriate remedy was by motion to vacate the judgment; and the defendant then applied in the court where judgment was rendered, to have it set aside, the taking of the appeal was deemed to be such a proceeding as precluded him from taking advantage of the irregularity. ${ }^{1}$ It is said in England that the true rule is, that if there be an irregularity, the party suffering by it is not bound to have it set aside in any specific time; that he may reasonably presume that his adversary, discovering the error, will abandon the defective proceeding. Dut, if the adversary take one step more, showing that he has not abandoned his process, then the movement to have tho irregularity set aside must be commenced. ${ }^{2}$ An infant having confessed judgment by attorney, and permitted it to siand until six years after coming of age, the court held that his application to vacate it came too late. ${ }^{3}$

8 103. Notice of Application.-At the close of the term the parties are dismissed sine die, and can no longer be regarded as being in court. Proceedings taken after that time to set aside a judgment, must therefore be upon notice to all the parties affected, ${ }^{4}$ and the order of a court acting in the absence of such notice, will be reversed upon appeal. 5

\& 104. Conditional Vacation.-Where the Circuit Court made an order setting aside a judgment upon payment of the costs which had accrued, the neglect of plaintiff's connsel to insist upon their payment, impliedly waived the condition upon which the judgment was to be vacated, and he could not, therefore, proceed upon the judgment as still in force. ${ }^{6}$ In Alabama, an order that a cause stand dismissed, unless plaintiff, within one hundred and twenty days, answer certain interrogatories, is not considered a final order. It

1 Jenlins $v$. Esterly, 24 Wis. 340. 2Fletcher $v$. Wells, 6 Taunt. 191. $3 \mathrm{Kemp} v$. Cook, $18 \mathrm{MI} .130$.

4 Lave $v$. Wheless, 46 Miss. 666; Coleman v. MicAnulty, 16 Mo. 173;
Hettrick v. Wilson, 12 Ohio S. 126; Nuckolls $v$. Irwin, 2 Neb. 60. 5 Vallejo $v$. Green, 16 Cal. 100. 6 Ransom $v$. City of New York, 20 How. U. S. 581. 
was said that the matter still remained in the control of the court; that it was competent for the court at a subsequent term to modify or vacate the order; that the order could not become effective until the happening of the contingency was judicially ascertained at the next term. ${ }^{1}$ The courts of the same State hold that an order setting aside a judgment upon payment of costs, is a conditional order, dependent upon the payment being made, and that it may be set aside at any subsequent term prior to the compliance with its con-. dition. ${ }^{2}$ In this opinion they are probably in error. ${ }^{3}$

\& 104 ${ }^{a}$. The Entry of a Second Judgment is not a vacation of the first. In a case arising in Nebraska, the record showed the entry of two judgments in the same action at different dates. Speaking of this state of facts, the court said: "But as there can be but one final judgment in a cause, we have the question, which is the judgment in the case? That seems to be not a very dificult question. When a judgment is once entered of record, it must stand as the judgment until it is vacated, modified or disposed of by some means provided by law: entering additional judgment entries is not one of them. A case brought regularly into court is presumed to be attended at regular terms of court by the attorneys having it in charge; and all proceedings of the court in reference to them, in the absence of fraud, will be binding on the parties, whether present or not. But, when judgment is entered, they may cease their attention. The further proceedings in the case, by petition to vacate or modify the judgment, or on error to this court, must be, on proper notice, provided by statute."

\section{\& 104 ${ }^{\mathrm{b}}$. The Effect of an Order Vacating a Judgment} may be considered: 1 st, with reference to the persons against whom the order is sought to be asserted; and $2 \mathrm{~d}$, with reference to the causes on account of which the order was entered. So far as third persons are concerned, it seems clear that their acts done by authority of a judgment which was not void, but voidable only, may be justified under the

${ }^{1}$ Ex parte McLendon, 33 Ala. 276. or the grant of relief is inoperative: 2 Willis $v$. Bank of Mobile, 19 Ala. Hartman $v$. Olvera, 49 Cal. 101.

14]. And generally if relief be ${ }^{3}$ Dana $v$. Gill, 5 J. J. MI. 242; John. granted upon certain conditions, the son $v$. Taylor, $3 \mathrm{~S}$. \& M. 92.

party must conply with the condition, ${ }^{4}$ Nuckolls $v$. Irwin, 2 Neb. 60. 
judgment, notwithstanding its subsequent vacation. With the parties to the suit this rule is not always applicable; and whether it is applicable or not, depends on the causes producing the vacation. The judgment may have been regularly and properly entered, and its subsequent vacation may have been in the exercise of mercy toward the defendant. In such case, as the plaintiff has been guilty of no neglect or misconduct, he may, no doubt, justify all his acts done under the judgment, before it was set aside. But where the order of vacation is made because of some fault or misconduct of the plaintiff in procuring the original judgment, a different rule may be involed. "If the judgment or execution has been set aside for irregularity, the party can not justify under it, for that is a matter in the privity of himself and his attorney; and if the sheriff or officer, in such case, join in the same plea with the party, ho forfeits the benefit of his defense. The sheriff or officer, however, may justify under an irregular judgment, as well as an erroneous one, for they are not privy to the irregularity; and so as the writ be not void, it is a good justification, however irregular, and the purchaser will gain a title under the sheriff." The case of a judgment set aside for irregularity differs materially from that of one reversed upon appeal. In the latter case, the error for which the judgment is ultimately avoided is imputed to the court, and the parties are not left without protection for the acts which they have done, based upon the judgment and upon their confidence in the correctness of the decision of the court. But a judgment obtained irregularly, and against law, or the practice of the court, is tainted with vices liable to result in its destruction, and for which the party practicing the irregularity is alone responsible. When, on account of these vices, the judgment is vacated, the party guilty of the irregularity seems to be as completely without any means of justification as though no judgment had ever been entered. ${ }^{2}$

1 Tidd's Practice, 1,032.
${ }^{2}$ Toung $v$. Bircher, 31 Mo. 139;
$v$. Felgate, 1 Levinz, 95; Allen $v$. Simpson v. Hornbeek, 3 Lans. 54; Huntington, 16 Am. Dec. 702. Barker $v$. Braham, 3 Wils. 368; Cole- 


\section{CHAPTER VII.}

OF VACATING JUDGMENTS UNDER STATUTES, ON ACCOUNT OF MISTAKE, INADVERTENCE, SURPRISE OR EXCUSABLE NEGLECT.

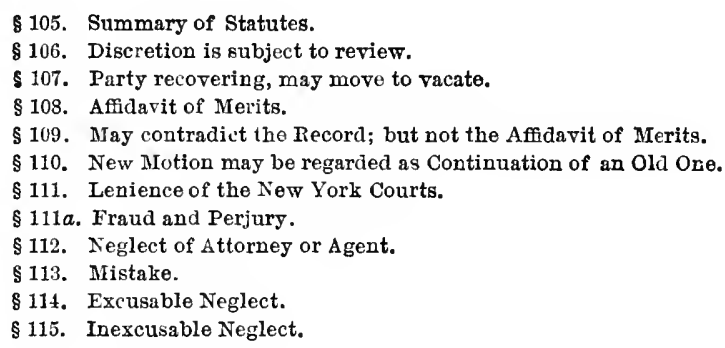

\& 105. The authority of the courts over regular judgments, has, in several of the States, been extended beyond the term in certain cases specified by statutes. The most liberal of these statutes authorize "the court at its discretion, and on such terms as may be just, at any time within one year after notice thereof, to relieve a party from a judgment taken against him through his mistake, inadvertence, surprise or excusable neglect." In other States, this provision has been substantially copied, except that the period in which an aggrieved party is authorized to apply for relief, is computed from the rendition of the judgment, instead of "from notice thereof." "In Ohio and Iowa, the

${ }^{1}$ Rev. St. of Wis., Chapt. 125, §38; Act, 68; C. C. P. of Ind. § 99; of N. Code of New York, $\S 724$. C. $\S 133$.

${ }^{2}$ C. C. P. of Cal. $\$ 473$; Cal. Pr. 
judgment may, in a specified time, though the term has passed, be relieved from "for unavoidable casualty or misfortune preventing the party from defending or prosecuting," or for "fraud practiced by the successful party in obtaining the judgment." 1 The statutes of these States further provide that the proceeding shall be by petition and summons, and that the judgment shall not be vacated unless it be first adjudged that there is a valid defense or a valid cause of action. In Vermont, the county court may set aside a judgment of a justice of the peace, recovered against a party who was prevented from appearing, by reason of "fraud, accident or mistake." 2 The statutes referred to in this section, do not supersede the necessity for moving for a new trial in cases where a trial has been had, at which the parties seeking to have the judgment vacated, were properly represented. ${ }^{3}$ If they were represented at the trial, they can only obtain relief by an application made in conformity with the rules of procedure, provided by law in reference to new trials. But if they were not at the trial, or were not represented there, on account of some mistake or excusable neglect, then their remedy is not by application for a new trial, but by an application addressed to the discretion of the court, and made under the statute authorizing relief to be granted from judgments rendered against a party through " his mistake, inadvertence or excusable neglect." "Theso statutes must be regarded as limiting the cases in which relief can be granted to applications made within the time, and for some of the causes specified in the statute, ${ }^{5}$ provided the relief is sought upon some of the grounds mentioned in such statutes. If, however, the motion is to vacate a judgment because irregularly entered, it may be granted although not made within one year after receiving notice of the judgment. ${ }^{6}$ Neither do these statutes preclude a party, in a proper case, from obtaining relief in equity, after the

${ }^{1} \S 3499$ Iowa, Revision of 1860 ; $\S \S 534$ to 541 Civil Code, Ohio.

${ }^{2}$ Rev. Stat. of Verm., ed. of 1863 p. 334 .
${ }^{3}$ McCullock $v$. Doak, 68 N. C. 267.

${ }^{4}$ McKinley $v$. Tuttle, 34 Cal. 239.

${ }^{5}$ Gerrish v. Johnson, 5 Minn. 23.

${ }^{6}$ Cowles $v$. Haynes, 69 N. C. 406. 
time for applying for relief under thesestatutes " has elapsed, provided proper reasons are shown for not making such application." Nor do these statutes apply to motions made during the term at which the judgment was entered. ${ }^{2} \mathrm{~A}$ judgment will not be vacated, on motion of a stranger to the cause, to enable him to be made a party to the action. ${ }^{3}$ Error of law is no ground for relief under these statutes." Laches in proceeding is usually fatai to the applicant for relief. ${ }^{5}$ But in Iowa the maxim is proclaimed that "Laches will not be imputed in the exercise of a legal right within the time prescribed by statute;" and hence it was determined that whosoever brings his action or motion within the year can not be barred of lis rights on the ground of laches in not sooner seeking relief. ${ }^{6}$

8106. Discretion is Subject to Review.- Under the uniform construction given to these statutes, the signification of the words " at its discretion" has been materially limited. The "discretion" here referred to is not " the power of acting without other control than one's own judgment." "It is not a mental discretion to be exercised ex gratia, but is a legal discretion to be exercised in conformity to law." If the power of the court were discretionary, in the ordinary sense of that term, the practice would necessarily be as varied as are the different temperaments of judges; and, even in proceedings before the same judge, would as probably be shaped by the personal pleasures or annoyauces of the several occasions in which he happened to act, as by those unvarying rules which, whenever applied to identical circumstances, produce identical results. But the power

${ }^{1}$ District Township $v$. White, $42 \mid 206$; Williams $v$. Williams, $70 \mathrm{~N}$. C. Ia. 608; Bond v. Epley, 48 Ia. 600.

${ }^{2}$ McCullock $v$. Doak, 68 N. C. 267. 665; Bradford थ. Coit, 77 N. C. 72.

${ }^{6}$ Independent School District $v$. Schreiner, 46 Ia. 172.

${ }^{3}$ Smith $v$. Newbern, 73 N. C. $303 . \quad{ }^{7}$ Bailey $v$. Taaffe, 29 Cal. 422;

${ }^{4}$ Spafford $v$. Janesville, 15 Wis. Johnson $v$. Eldred, 13 Wis. 4S2; 474; Landon v. Burke, 33 Wis. 453. Powell $v$. Weith, 68 N. C. 342.

5 Jouet $v$. Mortimer, 29 La. An. 
of the court is nevertheless to be liberally exercised. ${ }^{1}$ These statutes are remedial in their character, intended to furnish a simple, speedy, and efficient means of relief in a most worthy class of eases. An order of the court vacating a judgment entered by default, will not be disturbed by the appellate court, except in case "of gross abuse of the discretion of the court." 2 Both orders granting and orders denying applications under these statutes, are subject to review upon appeal. ${ }^{3}$

\section{Party Recovering may Move to Vacate.-The} literal meaning of the words employed in these statutes has been further modified by judicial construction. The statute says the court may relieve a party from a judgment " taken against him." But a party in whose favor a judgment has been rendered has been decided to be within the meaning, but not within the words, of the statute; on the ground that the law, being of a remedial character, must be liberally construed. ${ }^{4}$ Such a party, however, though nominally prevailing, may lose part of his demand. To that extent he would be entitled to an appeal; and it is no farfetched construction to say that he is, therefore, within the words as well as within the meaning of the statute.

8 108. Affidavit of Merits. - These statutes are to be employed only in furtherance of justice; and never for the purpose of enabling a party to raise some technical objection. Even where the statute does not so expressly direct, no judgment will be opened unless it is shown to be unjust. "Every consideration of expediency and justice is opposed to the opening up cases in which judgment by default has been entered, unless it be made to appear prima facie that the judgment, as it stands, is unjust." 5 In all cases an affidavit of merits must be made and filed; and in Indiana,

${ }^{1}$ Roland $v$. Kreyenhagen, 18 Cal. ${ }^{5}$ Parrott $v$. Den, 34 Cal. 79; 455; Mason $v$. MeNamara, 57 Ill. 274. Thatcher $v$. Haun, 12 Iowa, 303;

${ }^{2}$ Howe $v$. Independence Co., 29 Cal. Wooster Coal Co. $v$. Nelson, 4 Uper 72; Nerritt $v$. Putnam, 7 Minn. 493. Canada, Pr. Rep. 343; Mulhollan $v$.

${ }^{3}$ Haight $v$. Green, 19 Cal. 113; Mul- Scoggin, S Neb. 202; Anderson $v$. holland $v$. Heyneman, 19 Cal. 605; 29 Beebe, 22 Kans. 765 ; Niagara Ins. Co. Cal. 422; Hill $v$. Crump, 24 Ind. 291. v. Rodecker, 47 Ia. 162; Bank of 326.

4 Montgomery $v$. Ellis, 6 How. P. Statesville $v$. Foot, 77 N. C. 131. 
Texas, Illinois, and Missouri, must set forth matters constituting a good and meritorious defense. Where the affdavit to open a defanlt stated that, after a careful examination, the attorneys are of the opinion that they have a gool legal defense to the complaint, the judgment was not set aside; because the matter shown appeared to be of a technical character; ${ }^{2}$ and for aught that appeared to the contrary, the judgment might be perfectly consistent with fair dealing. A verified answer has been held not to obviate the necessity for an afficlavit of merits. The reasoning upon which this view is based is, that while an answer might be true, and the matters set forth in it might, upon their face, seem to form a sufficient defense to the complaint, yet they might be affected by other matters in avoidance, well known to the defendant, but which he was under no obligation to state in his answer; that in order to authorize the interposition of the court, something more onght to be required than an exhibition of facts which, if neither explained nor avoided, would present an obstacle to plaintiff's recovery; that to bring a case completely within the statute it must appear prima facie that the defendant, in addition to having an answer to the complaint, has a defense which is sufficient and meritorious when viewed in all the light which can bo thrown upon it by all the facts involved in the action. ${ }^{3}$ The affidavit should be made by the defendant personally; and if not so made, it should show some satisfactory reason why it is made by some other person. If made by the defendant, it is not indispensable that the facts relied on as a defenso be detailed, though that practice is the better one. If the facts are not set forth in the affidavit, it must show that the defendant " has fully and fairly stated the case to his counsel," and that, after such statement, he is advised by his counsel, and believes that "he has a good, full and perfect

1 Lamb v. Nelson, 34 Mo. 501; Fos- |California. Woodward v. Backus, 20 ter $v$. Martin, 20 Tex. 118; Roberts $v$. Corby, 86 Ill. 182; Castlio v. Bislop, 51 Mo. 162; Railway Co. v. Gates, 23 Ind. 23s; Goldsberry v. Carter, 28 Ind. 59; Frost $v$. Dodge, 15 Ind. 139. A different rule prevails in 100 Cal. 137.

2 People $v$. Rains, 23 Cal. 127.

${ }^{3}$ Jones $v$. Russell, 3 Howard $P$. 324; Mowry v. Hill, 11 Wis. 146. But the rule has in Wisconsin been changed by statute. See Town of Omro $v$. Ward, 19 Wis. 232. 
defense to the action upon the merits." An affidavit showing that defendant had stated "his defense" is insufficient, because it does not show that he has disclosed all the material facts affecting the action, nor what matters in avoiclance of his defense exist. It should show that he had stated "the case." ${ }^{2}$ Where the afidavit is made by some person other than the defendant, it should appear that such person is acquainted with the facts he attempts to make known to the court. An affidavit by the attorney that from an examination of the defendant's case, so far as he has been able to examine it, he verily believes it is better than plaintiff's, is therefore insufficient. It does not show that the attorney knows what the defense is; nor whether the examination was meager or thorough. Neither does he state that the defendant had fully and fairly stated the case, and "what in view of such statement is his professional opinion touching the defense." But this omission in an afflarit made by an attorney, is immaterial ; for the statements of the defendant, incorporated into an affidarit made by another person, is nothing "but hearsay, and therefore entitled to no weight."2

8109. May Contradict the Record, but not the Affidavit of Merits. In applications under these statutes the parties are at liberty to contradict the record, and to establish, by any competent evidence, the truth of the facts rpon which their claim to relief is based. ${ }^{3}$ But the hearing of evidence is confined to the question, whether the judgment has been taken through the inadvertence, mistake, surprise or excusable neglect of the defendant. The applicant is not required to make more than such a prima facie showing of merits as arises from his own affidavits. The code did not intend that there should be two trials of the merits. Therefore the defendant is not required to prove his defense, as he would at the trial, nor can his afflavits of merits be 
controverted. ${ }^{1}$ In California, in addition to an affidavit of merits, the payment of costs is an indispensable condition, to precede the setting aside of a judgment; and if relief be granted in the absence of such afflavit, and without requiring the payment of costs, the order granting it will be reversed upon appeal $;^{2}$ but if the only error is in not directing payment of the costs accruing to the plaintiff up to the time of serving notice of the motion, then the appellate court will modify the order, at the cost of respondent, by requiring the insertion of the statutory prerequisite. ${ }^{3}$

8 110. IJew Motion treated as Amendment of an Old one.-In Wisconsin, an application, granted in the lower court, was dismissed in the Supreme Court for want of an aflidavit of merits, without prejudice to a new motion. But during the time involved in determining the first motion, the period in which the statute authorized an application for relief expired. A new motion was, however, at once made; and was opposed, on the ground that it came too late. Whereupon it was adjudged to be substantially a continuation of the old motion, in the nature of an amendment of the papers on which that motion was founded; and being otherwise meritorious and in conformity to tho practice, it was granted.4

\$ 111. Lenience of New York Courts.-Theso statutes surely were not designed to confer upon the same court both an original and an appellate jurisdiction over the same cause ${ }^{5}$ nor yet to allow a party once having an ample opportunity to present his defense or cause of action, to re-present it at some future time, with such other features as a more mature reflection happened to suggest. Yet there are cases scarcely reconcilable with any obher theory. They have chiefly, if not exclusively, been determined in a State, where judgments seem to be regarded not as inviolate and

\footnotetext{
1 Pratt $v$. Keils, 28 Ala. 390; Francis $v$. Cox, 23 Cal. 323 ; Hill v. Crump, 24 Ind. 271; Gracier $v$. Weir, 45 Cal. 53; 4 P. S. R. 179; Bank v. Harrison, 4 Upper Canada Pr. Rep. 331; Wooster Coal Co. v. Nelson, Id. 343; Buck v. Havens, 40 Ind. 221.

2 People v. O'Connell, 23 Cal. 251.

${ }^{3}$ Leet $v$. Grants, 36 Cal. 288.

${ }^{4}$ Butler v. Mitchell, 17 Wis. 52; see also Howell $v$. Harrell, $71 \mathrm{~N}$. C. 161.

${ }^{5}$ Greer $v$. Mayor of New York, 4 Robt. 675.
}

102 
enduring testimonials, but as temporary structures to bo tom down, remodeled or rebuilt, whenever the builders feel competent to improve the original workmanship or design. Thus, in one case, a judyment in all respects regular, and resulting from a trial in whieh there was no pretense of any want of opportunity to defend, and at which both parties were represented by counsel, was set aside becauso of an elror of the court in estimating the value of a life-cstate. The defendant was a municipal corporation, whose counsel was an elective officer not under its control. This counsel was obliged to attend to a vast amount of business, and could not, therefore, devote much attention to any particular case. These were the reasons upon which the court justified its interposition. In another case, the action was for an amount due under a contract for work upon the strects. Judgment was obtained, the defendant being properly in court, and contesting plaintiff's right to recover part of his demand. The defendant was afterward relieved from a portion of the judgment, on the ground that a misapprehension existed between plaintiff and defendant, in making the original contract, by reason of which neither had assented to the contract as understood by the other. ${ }^{1}$ The mistake of counsel in conducting the case, arising out of his ignorance of the law, was the only ground upon which relief from another judgment was granted. The principles which, in the opinion of the court, should be applied to the case, were indistinctly defined as follows: "There may be a case so novel and peculiar in its nature, in which it is so palpable that actual injustice may and probably has been done, and where there are no other means of relief, that biso court will feel bound to relieve the party from the consequence of the inadvertence and mistake of his counsel, although it arose from a misapprehension of the law or rules of practice, if that can be done without prejudice to the rights of the parties: by which is meant, without any loss to them, other than such as may necessarily result from establishing what may be shown to be the rights of the party applying."'2

\footnotetext{
1 Pettigrew v. MIayor of N. Y., 17| ${ }^{2}$ Levy v. Joyce, 1 Bosw. 622. How, P. 492.
} 
8. 111a. Fraud Practiced in Obtaining a Judgment is generally specified as one of the grounds which entitle an innocent and injured litigant to have it vacated. ${ }^{1}$ Even if this ground were not specifically enumerated in the statute, it would generally be available to the injured party on the ground that it had occasioned the rendition of a judgment against him by surprise, or mistake, or under circumstances which, as to him, might well be deemed excusable neglect. A very serious question arises, whether the fraud for which a julgment may be vacated under these statutes, includes, in any case, the willful perjury of the successful litigant at the trial. In a comparatively recent case which was heard in the supreme court of Kansas on two or three separate appeals, that tribunal concluded, that a judgment wholly unjust, and procured by the willful perjury of the plaintiff, ought to be vacated, although the defendants did not show " unavoidable casualty or misfortune, preventing them from defending the original action." "A party," said the court, " is never required to exercise more than reasonable and ordinary diligence in preventing a fraud from being perpetrated upon him, and fraud vitiates everything it touches. Of course, a defendant failing to defend can not have the judgment vacated on account of any innocent mistake, or want of recollection on the part of the plaintiff, or other witness, nor even on account of the perjury of the other wituesses, provided the plaintiff himself is wholly guiltless. Nor can he have the judgment vacated on account of any mistake or error on the part of the court or jury, unless the record affirmatively shows such mistake or error. All such mistakes or errors each party is bound to anticipate, and to prepare for by extraordiuary diligence. But no party is bound to anticipate or to suppose that the other party will commit willful and corrupt perjury; and no party is bound to exercise extraordinary diligence in preparing to meet such perjury. In this case we think the defendants exercised reasonable diligence." The diligence which was in this calse adjudged to be reasonable and sufficient, consisted of filing an answer so that judgment could not be obtained

\footnotetext{
${ }^{1}$ Independent School District v. ${ }^{2}$ Laithe v. MeDonald, 12 Kans. 340; Schreiner, 46 Ia. 172.
}

104 
by default, nor otherwise than through false testimony; of taking ineffectual steps to procure witnesses in time for the trial; and, on ascertaining that the witnesses could not be obtained in time, of writing a letter to counsel to obtain a continuance, the letter being written in time, but not reaching its destination owing to delay in the United States mails. We are not sure that these decisions are not sustainable under the peculiar facts of the case; but, manifestly, great caution must always be exercised before vacating or grantiug relief from a judgment when the parties are regularly in court, the cause regularly brought on for trial, and the alleged grounds for relief involve a re-examination of the issues already tried. ${ }^{1}$

8 112. Neglect of Attorney.-The neglect of an attorney or agent is uniformly treated as the neglect of the client or principal, ${ }^{2}$ except in New York. A default will not be opened because the attorney had prepared a demurrer, but had failed to file it by reason of his miscalculating the time when it was dne; neither will relief be granted because the at torney forgot the day and time for trial. ${ }^{4}$ And in general no mistake, inadvertence, orneglect, attributable to the attorney, cin be successfully used as a ground for relief, unless it would have been excusable if attributable to the client. ${ }^{5}$ In Vermont, the neglect of a person who undertook to act for the attorney, is treated in the same manner as if committed by the attorney. Thus where the petitioner's attorney being suddenly called away, requested another person to attend the suit, and to get an attorney to appear, and the party agreed to comply with the request, but forgot the matter entirely, it was held that the neglect of this party could ouly be

${ }^{1}$ Flower $v$. Lloyd, $s$ Cent. Law J. $\mid$ was held to entitle his client to relief 415 ; post. secs. 289,435 , 503. on the ground of surprise. Griel $v$.

2 Austin v. Nelson, 11 Mo. 19:; Vernon, 65 N. C. 76; but when the Kcrby $v$. Chadwell, 10 Id. 392; Mer- only showing was that the defendant ritt $v$. Putnam, 7 Minn. 493; Jones had written to an attorney to appear $v$. Leech, 46 Ia. 186; Gherke $v$. Jod, for him, who did not do so, relief was 59 No. 522; Matthis $v$. Town of Cam- denied. Burke $v$. Stokely, Id. 569. eron, 62 Mo. 504; Niagara Ins. Co. $v$. Rodecker, 47 Ia. 162. In North Carolina, the failure of an attorney to enter a plea, when employed to do so, 1477.

${ }^{3}$ People $\%$ Rains, 23 Cal. 127.

${ }^{4}$ Babcock v. Brown, 25 Verm. 550.

5 Spaulding $v$. Thompson, 12 Ind. 
regarded as the neglect of the attorney, and that considered in that light, it was not excusable. ${ }^{1}$ In New York, a default and judgment thereon was set aside on showing that proceedings were utterly neglected by the attorney, who was rendered incompetent by his habits, because an attorney ought not to be permitted to intlict unbounded damage on his client, there being no redress except the doubtful one of an action for negligence. ${ }^{2}$

8 113. Mistake.-A mutual and honest mistake between the defendant and an attorney, in relation to the retainer of the latter, by reason of which the defendant was not represented at the trial, authorizes the granting of relief from the judgment. ${ }^{3}$ Where the defendants attended court until the judge announced that the cause would not be tried at that term, when they left, and the causo was afterward called and judgment entered, it was opened upon application, accompanied with affidavit of merits. ${ }^{4}$ The mistake of defendants in concluding that the judgment would not be entered against them personally, but only against them as trustees, that being the only capacity in which they were liable, justifies the court in vacating a judgment taken against them individually. ${ }^{5}$ Judgment should not be set aside on the ground that the defendant mistook the court in which the action was pending; nor becauso he did not appear on account of his having no recollection of the service of summons. ${ }^{7}$ A German was prosecuted in a criminal and in a civil action at the same time, for obstructing a highway. He understood the English language very imperfectly, and seemed to confound the two actions. He attended to the criminal action diligently, but was defaulted in the civil. He applied on the next day after the entry of the default, to have the judgment set aside, and the application was granted on payment of the attorney's fees. ${ }^{8}$ So where a very

\footnotetext{
${ }^{1}$ Davison $v$. Heffron, 31 Verm. 687.

${ }^{2}$ Elston $v$. Schilling, 7 Robt. 74; Meacham v. Dudley, 6 Wend. 514.

${ }^{3}$ McKinley $v$. Tuttle, 34 Cal. 235; 402

Panesi $v$. Boswell, 12 Heisk. 323. For contra opinion, see Kite $v$. Lump-

4 Ratliff $v$. Baldwin, 20 Ind. 16.

${ }^{5}$ Butler $v$. Mitchell, 17 Wis. 52.

'Robertson v. Bergen, 10 Ind.

${ }^{7}$ Langdon v. Bullock, 8 Ind. 341.

${ }^{8}$ Bertline $v$. Bauer, 25 Wis. 456 .
} kin, 40 Geo. p. 506. 
illiterate man applied to an attorney, and stated that his goods had been attached, that he did not owe the debt, and that he wished to have the goods released, and the attorney took proceedings to have the goods released, but did not make any defense to the action, because be did not know that any summons had been served, the judgment was set aside, because tho defendant being an illiterate man, did not know that he need give his attorney any other information than that his property was attached, and the attorney, by not laving further information, was misled as to the immediate necessity of making a defense. ${ }^{1}$

8 114. Excusable Neglect.-The defendant, as soon as served with summons, set about making such inquiries as were necessary to his defense. He was soon compelled to go beyoud the State on important business, and to remain away several weeks. On returning home, he was obliged, by importaut business, to go into another State, and to remain there several weeks. He constantly intended to prepare his answer, but owing to his absence from home, and the pressure of his other engagements, he mistook the time when his default was due. The action of the lower court in refusing to grant relief upon a showing of these facts was reversed, because "the mistake arising from the urgency and multitude of defendant's business, was such a mistalie as any prudent and vigilant man migrit, under like circumstances, fall into." An affidavit, showing that defendant had employed counsel, and had caused a subpena to issuo for his witness, but had been prevented from attending court by the dangerous illness of his wife; that his counsel was provost marshal, and on account of being engaged in enforcing the draft, had been unable to attend the trial, discloses such a state of facts that it would be an abuse of the discretion of the court to refuse to vacate the judgment. ${ }^{3}$ A defendant who was constructively served, and was absent from the State, suffering from such a bodily disability as prevented his return, is entitled to have his default sot aside. ${ }^{4}$ That defendant was attacked by a severo illuess,

${ }^{1}$ Sweet $v$. McGlynn, 5 Pac. L. R. 155. $\quad{ }^{3}$ Hill v. Crump, 24 Ind. 291.

2 Johnson $v$. Eldred, 13 Wis. $482 . \quad$ ' Sage $v$. Matheny, 14 Ind. 369. 
during which his life was despaired of, and his mind so impaired, that he was incapable of making his defense, is a good ground for vacating a judgment. ${ }^{1}$ Failure of counsel to attend the trial, owing to his illness, ${ }^{2}$ is a sufficient ground for relief, particularly if the illness was of such a character that his "forgetfulness" is excusable neglect." Although a stipulation is not binding on the parties to it, unless made in writing, yet the neglect of a party, occasioned by a verbal agreement between himself and his adversary, is "excusable." And where the plaintiff promised to call at the defendant's office " and fix the matter up," and the defendant, relying upon the promise, neglected the suit, the judgment was opened by the court. An appeal being taken, the appellate court thought that there was negligence on the part of the defendant; but that it was of the excusable nature which the statute was provided to relieve; that while it was imprudent to rely on the promise, yet it was in ill grace for the plaintiff to urge that the negligence occasioned by himself was inexcusable. ${ }^{5}$

¿ 115. Inexcusable Neglect.-Every suitor should personally attend to his case, or be represented by an attorney in fact. Therefore, an affidavit showing that the defendant expected the witnesses, whom he had subpenaed, to appear at the trial, and on that account, and because his counsel knew of the defense, did not attend personally, and the witnesses did not attend, and judgment was obtained on account of their absence, there being no one present to make an affidavit for a continuance-does not show an excusable neglect. The duty of the counsel did not extend to procuring witnesses, nor to making affidavits for continuances. The defendant, neither being present to perform that duty, nor having any one to represent him for that purpose, was culpably negligent. ${ }^{6}$ A judgment by default should not be vacated on the ground of excusable neglect, because the answer required more than ordinary time for

${ }^{2}$ Luscomb v. Maloy, 26 Iowa, 444. 326; Chicago \& N. W. R. R. v. Gil-

2 Bristor $v$. Galvin, 62 Ind. 352. lett, 38 Ia. 434.

${ }^{3}$ Montgomery Co. v. American E. ${ }^{-5}$ Stafford v. McMillan, 25 Wis. 566. Co., 47 Ia. 91.

6 Waddell v. Wood, 64 N. C. 624.

${ }^{4}$ Montgomery $v$. Ellis, 6 How. P. 
its preparation, aud the attorney was, during a part of tho time, out of town. ${ }^{1}$ Any difficulty arising from this source could, undoubtedly, be obviated by an application to the court or the plaintiff's counsel for an extension of time. An affidavit showing that defendant, when he retained counsel in the case, was under the impression that the time to auswer had not expired; that he did not recollect the precise day when the summons was served; that he was quite ill at the time, and did not as carefully note the time as he would otherwise have done-is entirely insufficient. It does not appear that the illness of defendant extended beyond one day; nor that, during that day, it rendered him unfit for ordinary business. ${ }^{2}$ The fact that the defendant did not appear and answer because he supposed the summons served on him to be a subpena, ${ }^{3}$ or some paper in another case, ${ }^{4}$ does not entitle him to relief. His failure to examine the paper is inexcusable.

${ }^{1}$ Bailey $v$. Taafe, 29 Cal. 422.

${ }^{2}$ Elliott $v$. Shaw, 16 Cal. 377.

3 State v. O'Neil, 4 Mo. App. 221.

${ }^{4}$ White $v$. Snow, 71 N. C. 232 . 


\section{CHAPTER VIII.}

$\S 116$. Description of Vold Judgments.

$\S 117$. Effect of.

\$ 118, Jurisdiction.

$\$ 119$. Sources of Jurisdiction.

$\$ 120$. Want of Jurisdiction over Subject Matter.

$\$ 121$. Loss of Jurisdiction.

\$ 122. Courts of Record, and Courts not of Record.

$\$$ 123. Courts of Record in exerclse of Special Authordty.

\& 124. Presumptions of Jurisdiction.

8 125. No Presumption against the Record.

\$ 126. Defects in Obtaining Jurisdiction.

$\S 127$. Constructive Service.

$\$$ 128. Appearance by Attorney.

8 129. Defaults.

130. Jurisdictional Findings.

8) 131. Jurisdictional Inquiries Confined to the Record.

\$ 132. Silence of Record.

8 133. Cases Permitting Inquiry beyond the Record.

8 134. Reasons for Holding Record Conclusive.

6 135. Judgment never Void for Error.

135a.Judgments without any Issue.

8 136. Judgments Void as to some of the Parties.

8 137. Judgment for Contempt.

s 138. Rendered on Surrday.

5 139. Rendered without Authority of the Court.

140. Judgment after Death of Defendant.

8 141. Against Party not Named in the Record.

8 142. When Jurisdiction over Party Ceases.

f 143. Jurisdiction Limited to Certain Purposes,

5 144. Disqualification of Judges.

S 145. Disqualification of Judges at Common Lew.

5 116. Statutory Prohibition.

\$31\%. Judges Sitting proforma.

\$ 148. Judges de facto.

s 148a.Judgment Wrongfully Altered.

8 116. Void Judgments.-The judgment being formally entered upon the record, and remaining unaffected by any proceeding to vacate it, in the case wherein it was pronounced, is likely to be offered as evidence in some other action or proceeding. The material inquiry then arising, is whether this professed determination of the rights of the parties, is what it assumes to be ; or whether, from some 
latent or patent infirmity, it is to be regarded as waste paper-a mere brutum fulmen. The manner in which this inquiry should bo conducted, and the sources from which information should be received, are subjects over which there has been, and there still is, much discussion and dissension, in which adverse conclusions have been announced on either side with an assurance approaching to dogmatism. No specific description of void judgments can be framed which does not conflict with the decisions of many of the courts. It has often been saicl that a judgment is void whenever the court which pronounced it had not jurisdiction of the parties to the judgment, or of the subject matter in controversy. This is undoubtedly true everywhere, provided the want of jurisdiction is not controverted, or is manifest from au inspection of the record. It is also true in somo of the States, even though the jurisdictional facts are asserted in the record. The weight of tho adjudged cases, as will hereafter be shown, sustains the proposition that the judgment of a domestic court of general jurisdiction is not void, except when the court has no jurisdiction over the subject matter of the suit, or when, having such jurisdiction over the subject matter, it is shown by the record to have had no jurisdiction over the judgment defendant. A judgment was said to be void if "it emanated from a court of limited jurisdiction not acting within its legitimato prerogative, or in a court of general jurisdiction, where the parties are not actually or by legal construction before the court and subject to its jurisdiction. Judgments of courts of general or competent jurisdiction are not considered under any circumstances as mere nullities, but as records importing absolute verity and of binding efficacy, until reversed by a competent appellate tribunal. They are voidable: not void." 1 This languago goes beyond what would anywhere be regarded as sound principle, if it is to be understood as asserting that all judgments of courts of general jurisdiction, having jurisdiction over the subject matter, are valid. To hold a judgment binding when the record disclosed a want of authority over the defendant, would be to impeach, rather than to sustain the absolute verity of the

1 Ponder v. Mostly, 2 Florida, 267. 
record. Some judges, while refusing to permit, any inquiry beyond the record, to show that a court, when pronouncing judgment, did not have jurisdiction over the defendants, have nevertheless said that a judgment without such jurisdiction is void, but that rules of evidence dictated by public policy, exclude such testimony, not in the record, as is necessary to make its void nature apparent. But the word void can with no propriety be applied to a thing which appears to be sound, and which, while in existence, can command and enforce respect, and whose infirmity cannot be made manifest. A judgment rendered without in fact bringing the defendants into court, unless the want of anthority over them appears in the record, is no more void than if it were founded upon a mere misconception of some matter of law, or of fact, occurring in the exercise of an unquestionable jurisdiction. ${ }^{1}$ In either case, the judgment can be avoided and made functus officio by some appropriate proceeding instituted for that purpose; but if not so avoided, must be respected and enforced.

8 117. Effect of Void Judgments.-A void judgment is in legal effect no judgment. By it no rights are divested. From it no rights can be obtained. Being worthless in itself, all proceedings founded upon it are equally worthless. It neither binds nor bars any one. All acts performed under it, and all claims flowing out of it are void. The parties attempting to enforce it may be responsible as trespassers. The purchaser at a sale by virtue of its authority, finds himself without title and without redress. ${ }^{2}$ The first and most material inquiry in relation to a judgment or decree, then, is in reference to its validity. For if it be null, no action upon the part of the plaintiff, no inaction upon the part of the defendant, ${ }^{3}$ no resulting equity in the hands of third persons, no power residing in any legislative or other department of the government, ${ }^{4}$ can invest it

\footnotetext{
1 Allen $v$. Huntington, 16 Am. Dec. 702.

${ }^{2}$ Campbell v. MTCahan, 41 Ill. 45; Roberts $v$. Stowers, 7 Bush, 295; Huls $v$. Buntin, 47 Ill. 397; Dane's Ab. Ch. 146, art. 5, $\S$ I, S; Sherrell $v$. Goodrum, 3 Humph. 430; Andrews v. State, 2 Sneed, 550 ; Hollingsworth $v$. Bagley, 35 Tex. 345 ; Morton $v$. Root, 2 Dillon, \& M. 613; Doe $v$. McDonald, 27 Miss. 610; Hargis $v$. Morse, 7 Kan. 417. 3 Kramer $v$. Holster, 55 Miss. 243. ${ }^{4}$ Pryor $v$. Downey, 50 Cal. 358; 19 Am. Fep. 656; Maxwell $v$. Goctschins, $29 \mathrm{Am}$. Rep. 242; Freeman on Void Judicial Sales, $\$ 56$; Criffin v. Cunnin ${ }^{-}$ham, 20 Gratt. 109; Lane v. Nelson, 79 Pa. S. 407; 3 C. L. J. 44.

C. C. 312; Com. Bank. v. Martin, 9 S.
} 
with any of the elements of power or of vitality. This inquiry is to be prosecuted only by an investigation of jurisdictional facts, upon whose real or assumed existence every valid judgment must stand.

8. 118. Jurisdiction.- "The power to hear and determine a cause, is jurisdiction; it is coram judice whenever in case is presented which brings this power into action; if tho petitioner states such a case in his petition, that on a demurrer the court would render judgment in his favor, it is an undoubted case of jurisdiction." "Before this power can be affirmed to exist, it must be made to appear that the law has given the tribunal capacity to entertain the complaint against the person or thing sought to be charged or affected; that such complaint has been preferred, and that such person or thing las been properly brought before the tribunal to answer the charge thereiu contained."' There can be no doubt that the filing of a petition or complaint such as onght not to be deemed sufficient upon demurrer, may confer jurisdiction. The power to decide upon the sufficiency of a cause of action as presented by the complainant's pleading, like the power to decide any other legal proposition, though erroneously applied, is binding until corrected by some superior authority. ${ }^{3}$ The definition of the word jurisdiction has undergone various judicial modifications within the past few years. It was formerly, as wo have stated, defined to be the power to hear and determine. The supreme court of California, not entirely satisfied with this cefinition, said that "it is, in truth, the power to do both, or either; to hear without determining, or to determine withont hearing." 4 The later clecisions of the supreme court of the United States introduce a new element in the description of jurisdiction, and in effect declare that it is the power and the willingness to hear and determine. "Wherever one is assailed in his person or his property, there he may defend, for the liability and the right are inseparable. This is a principle of natural justice, recognized as such by the common intelligence and conscience of all nations. A sentence of a court pronounced against a party without

\footnotetext{
${ }^{1}$ United States $v$. Arredonda, $6 \mathrm{Pe}$ - but where the fact of residence is juters, 709 .

2 Sheldon $v$. Newton, 3 Ohio S. 494.

${ }^{3}$ IIcNamara on Nullities, p. 137; risdictional, the complaint noust ave

it. Cole $v$. Cole, 4 Cent. L. J. 64.

${ }^{4}$ Ex parte Bennett, 44 Cal. S4.
}

(8) 
hearing him, or giving lim an opportunity to be heard, is not a judicial determination of his rights, and is not entitled to respect in any other tribunal. ${ }^{1}$ Where a court having jurisdiction over the subject-matter, causes its process to be regularly issued and served upon the defendant, we should, but for the decision from which we have just quoted, consider that any irregular, erroneous, or even arbitrary act on its part-such, for instance, as striking ont his answer, or otherwise refusing to consider his defense-would be no more than the erroneous exercise of its jurisdiction, and would therefore not endanger the validity of its judgment otherwise than by subjecting it to reversal on writ of error or appeal. But, according to the reasoning of the supreme court, the issue and service of process is equivalent to a direction to the defendant to appear and present his defense for the consideration of the court, and its refusal, after he does so appear, to hear him, or to permit him to assert his rights, is, in legal effect, a revocation of its process, and thereafter it has no other jurisdiction over him than it had prior to the issue of such process. ${ }^{2}$

\& 119. Sources of Jurisdiction.-Jurisdiction is conferred upon courts by the constitution and laws of the country in which they are situate, "authorizing them to hear and determine causes between parties, and to carry their judgments into effect." 3 Jurisdiction over the subject-matter is a condition precedent to the acquisition of authority over the parties, and is conferred by the "authority which organizes the court, and is to be sought for in the general nature of its powers, or in authority specially conferred." Jurisdiction over the person is obtained by service of process, or in some other manner authorized by law, as by the voluntary appearance of a party during the prog-

\footnotetext{
1 Windsor $v$. McVeigh, 93 U. S. 277; 4 Cent. L. J. 61.

"Windsor $v$. MIcVeigh, 93 U. S. 278 : "It was not," said Mr. Justice Field in this case, "within the power of the jurisdiction of the district court to proceed with the case, so as to effect the rights of the owner after his appearance had been stricken out, and the benefit of the citation thus denied. For jurisdiction is the right to hear and determine; not to determine without hearing. And where, as in that

case, no appearance was allowed, there could be no hearing or opportunity of being beard, and, therefore, could be no exercise of jurisdiction. By the act of the court, the respondent was excluded from its jurisdiction." Justices Miller, Bradley, and Hunt dissented. Judge Field, at page 283 , refers to various instances which, in his judgment, involve such a departure from the established modes of procedure as will render a judgment void.
} 114 
ress of a cause. Jurisdiction over the res "is obtained by its seizure under process of the court." 1

\section{120. Want of Jurisdiction Over Subject Matter.-A} judgment pronounced by a tribunal having no authority to cletermine the matter in issue, is necessarily and incurably void, and may be shown to be so in any collateral or other proceeding in which it is drawn in question. ${ }^{2}$ A criminal information in the Court of Common Pleas, or a common recovery or writ of right in the King's Bench, would be simply void and could not even bo pleaded in justification by the officer of the court who executed it. ${ }^{3}$ When the tribunal has not jurisdiction over the subject matter, no arerment can supply the defect, no amount of proof can alter the case. As power over the subject matter is given by law, nothing but an additional grant from legislative authority can extend that power over a class of cases formerly excepted; and neither the acquiescence of the parties, nor their solicitations, can authorize any court to determine any matter over which the law has not authorized it to act. 4 The grant of jurisdiction must proceed from competent authority. Where a court acts under and by virtue of a certain Act, and such Act is unconstitutional, its judgments are void. The jurisdiction resting on the Act, and the Act resting on no sufficient support, both must fall.5

8 121. Loss of Jurisdiction.-A tribunal, having undoubted jurisdiction of a cause at a certain stage, may lose such jurisdiction at some subsequent stage of the proceedings. This frequently happens when a judgment has been pronounced in the appellate court npon appeal. The

${ }^{1}$ Cooper $v$. Reynolds, 10 Wall. 30s. Thatcher, 3 Col. 275; Fleischman $v$.

${ }^{2}$ Gilliland $v$. Seller's Admr., 2 Ohio Walker, 91 Ill. 318.

S. 223; Morse $v$. Presby, 5 Foster, "5lieed $v$. Wright, 2 G. Greene, 15. 299; Eaton $v$. Badger, 33 N. H. 228; In the recent ease of Dow $v$. JohnWamsley v.Robinson, 2S La. An. 793; son, 9 Tieporter, 329, the Supreme Ponee $v$. Underwood, 55 Geo. 601; Court of the United States declared Lyles $v$. Bolles, $8 \mathrm{~S}$. C. 258 .

void a judgment of one of the courts

${ }^{3}$ Moore $v$. Houston, $3 \mathrm{~S}$. \& R. 169; of Louisiana, rendered against an Williamson's case, 2 Casey, 9, 18; officer in the military serviee of the The case of the Marshalsea, 10 Coke, United States, for injuries resulting 68,76 .

from the exeeution of orders issued

${ }^{4}$ Dicks $v$. Hatch, 10 Iowa, 380; by him as sueh officer, on the ground State $v$. Fosdiek, 21 La. An. 25s; that the courts of an invaded nation Mora $v$. Kuzac, 21 Id. 754; Moore $v$. have no jurisdiction to compel the Ellis, 18 Mieh. 77; Damp $v$. Town of offieers and soldiers of the invading Dane, 29 Wis. 419; Richardson $v$. army to aecount to them civilly $\%$ Hunter, 23 La. An. 255; Peabody $v$. criminally. 
judgment of the superior court in this case can not be varied in the original tribunal; nor examined for any other purposo than to carry it into effect; nor reviewed for error apparent; nor intermeddled with, further than to settle so much as has been remanded. ${ }^{1}$ Neither can the lower cont do anything to prevent the immediate execution of the judgment of tho appellate court. ${ }^{2}$ If the statute requires regular terms to bo held for the trial of causes, the court in the intervals between those terms is, for the purpose of conducting trials, in the same condition as though its authority over tho caso were entirely withdrawn. It is no longer a court. Judicial powers can not be conferred upon it by consent of the parties; and any judgment rendered upon a trial had in pursuance of such consent, is void, ${ }^{3}$ and is so wanting in even the color of jizdicial authority that it will not be reversed upon appeal.* If the same district is composed of different counties, a trial in one of the counties on the commencement day of a term in another connty, thongh sanctioned by the written stipulation of both parties, is coram non judice. ${ }^{5}$ A julge in one district may preside in another district in place of the judgo of the latter district. But this does not anthorize two judges to hold separate courts in the same district at the same time. Therefore, an order made by a judge presiding out of his district, at a time when the judge of the district where tho order is made, is also holding court therein, is void; and no one can be punished for contempt of court in disobeying such order. ${ }^{6}$ In California, a judgment by virtue of statute authority may be entered in vacation. If in a cause the

${ }^{1}$ Ex parte Sibbald $v$. U. S., 12 Pet. 4ss; McClanahan's Heirs v. Henderson's, 1 Monr. 261; McArthur v. Dane, 61 Ala. 5.99.

2 Marysville $v$. Buchanan, 3 Cal. 212; McMifan $v$. Richards, $12 \mathrm{Id}, 46 \mathrm{~s}$.

${ }^{3}$ Garlick $v$. Dumn, 42 Ala. 404; Brumley $\because$. State, 20 Ark. 77; Galusha $v$. Butterficld, 2 Scam. 227; $L x$ parte Osborn, 24 Ark. 479; Hernandez v. James, 23 La. An. 4S3; Dodge $v$. Coffin, 15 Kans. 277; Dixon $v$. Julge 5th District, 26 La. An. 119; Filley $v$. Cody, 4 Col. 109; Francis $v$. Wells, 4 Col. 274.

4 Wiclis $v$. Lndwig, 9 Cal. 175; Norwood $v$. I Teufeld, 34Cal. 333; Doss $v$. Waggoner, 3 Tex. 515; Leclair $v$. Globerski, 4 L. C. Rep. 139.

\section{6}

${ }^{5}$ Bates $v$. Gage, 40 Cal. 183; Gregg v. Cooke, Peck, S2. But in Iowa, by statute, a trial commenced with a bona fide expectation of being finished before the close of the term may be prosecuted until its close, though it reaches into the succeeding term: State $v$. Knight, 19 Iowa, 9\%. In some of the States judgment may, by consent, be signed in vacation and ordered entered as of ensuing term: Hervey $v$. Elmunds, 68 N. C. 243 ; or tried in racation and entered in term time: Roy $v$. Horsley, $25 \mathrm{Am}$. Rep. 537. See also Morrison $v$. Citizens' Bank, 27 La. An. 401.

${ }^{6}$ People v. O'Neil, 47 Cal. 109. 
court order that "upon filing of proofs, and testimony as taken by the court commissioner, and the case be submitted to the court and decided at chambers, and the decision and judgment be entered as of this term of the court;" and the court thereafter considers such testimony after the adjournment of the term, and enters its judgment in vacation, such judgment is not void. The order amounted to a submission in presenti. Such submission having been made in term time, the court was authorized to enter judgment thereon in vacation. ${ }^{1}$ The rule that a judgment is absolutely void if pronounced by a court not having jurisdiction of the subject-matter, is equally applicable, whether the julgment proceeded from a court of general or of special, of foreign or of domestic jurisdiction; and whether the judgment bo questioned directly or collaterally. But courts not having jurisdiction over a subject-matter, may, when an improper case is attempted to bo litigated before them, determine their own want of jurisdiction, and as incident to that determination, may reuder judgment for costs. ${ }^{2}$

\section{122. Courts of Record and Courts not of Record.-If,} in the examination of a judgment, it be satisfactorily ascer-

\footnotetext{
${ }^{1}$ Lix parte Bennett, 44 Cal. 85; Pa- $v$. Cummings, 39 Cal. 667; People ex cific Law Reporter, vol. 4, p. $87 . \quad$ rel., Leet $*$. County Court of Placer

"Ting $v$. Poole, 36 Barb. 242; County, Oct. Term, 1869; Burke $v$. Gornly $v$. NeIntosh, 22 Barb. 271; Jackson, 22 Ohio S. 268.

Jordan $v$. Dennis, 7 Met. 590; Blair
}

Note to $\$ 121$. Terms of Codrt.--In the absence of any statute providing to the contrary, the term is lost unless the judge appear at the appointed time and open court, and all subsequent proceedings are void. (People v. Sanchez, 24 Cal. 17; People v. Bradwell, 2 Cow. 445.) The presence of the judge is also inclispensable to the continuation of a term properly opened. Thus, in a case in Illinois, the judge having held the term until a certain day, adjourned it till the next day. He then left, authorizing (so far as he could), the clerk and sheriff to open and adjourn court from day to day, until another judge arrived. But when this action was called in quesion, the Supreme Court of the State held that " the judge had no power to authorize the ministerial officers of the court to exercise judicial powers, even in opening and adjourning the court," and that, as a consequence, the term expired on the first day of the judge's absence. (Wight $\mathrm{v}$. Wallbaum, $39 \mathrm{Ill}$. 554.) If special terms are authorized to be held after the giving of certain notice, a trial had and judgment entered at such a term; but, in the absence of the required notice, is certainly so irregular as to be set aside on appeal, and is probably void. (Oram v. Riley, 16 Cal. 186.) In the cases cited, declaring proceedings void because transacted at a time or place where the court was not authorized to transact business, the facts rendering the action coram non judice seem to have appeared on the record, or to have been 
tained that the court whose sentence it is, had jurisdiction over the subject matter of the action, and was, at the rendition of its judgment, authorized to act as a court, the next

admitted by the parties. But a question of some difficulty may arise where the record does not show whether the judgment was entered in term or not. The general presumptions indulged in favor of the proceedings of courts of general jurisdiction ought, so far as they are concerned, to make a prinia facie case in favor of those proceedings in all cases, and to shield then from all collateral attacks in those States where, as in California, jurisdictional presumptions seem to be sacred. In Tennessee, the objection was made on appeal, that while the court appenred to have been opened at the proper place at the first day of the term, it was nowhere shown where its subsequent sessions were held. But the objection was overruled, because it was presumed by law that the court was held where it first met, until the contrary was shown. (Smith v. State, 9 Humph. 10.) In regard to a case where the records of the court failed to disclose what adjournments were mitde after opening the term, the Supreme Court of North Carolina said:

"The term of a court is in legal contemplation as one day; and although it may be open many days, all its acts refer to its commencement, with the particu'ar exceptions in which the law may direct certain acts to be done on certain other days. It is seldom necessiry that the day of any proceeding should appear in making up the record, distinct from that of the beginning of each term, although a minute may be kept of each day's doings. Nor is it necessary that there should be adjournments from day to day, after the term is once opened by the judge; nor, if there should be, that they should be recorded, in order to preserve the authority of the court to perform its functions. The court may, in fact, not adjourn during the whole term, but be always open; though, for the convenience of suitors, an hour of a particular day, or of the next day, may be given them for their attendance. If the record state the time of doing an act, as the statement is unnecessary, so it is harmless surplusage, unless the day be beyond the period to which the term legally exteuds." (State $\nabla$. Martin, 2 Iredell Law, 122.) In New York it is said that a court will be presumed to have continued open until its adjournment is shown. (People v. Central City Bank, 53 Barb. 412.) Language employed by Chief Justice Wallace, of California, in the matter of the application of Bennett, on habeas corpus, at July Term, 1872, goes far toward asserting that a judgment entered in vacation, without either trial, argument, or submission, is valid. He said: "The principal objection macle for the petitioner, as we understand it, is, that the cause here was tried in chambers, and not in open court-and it is said that there is no authority to try a cause except in open court.

"But even if this be so, we do not see that it would follow that a judgment rendered in a cause which had been tried at chambers would, for that reason, necessarily be void, in the absolute sense.

"The district court unquestionably had jurisdiction of the subject mitter and of the parties litigant. Had the court itself rendered the judgment in question in open session at a regular term, without trial, without proof, and eren without submission of the cause for decision, such judgment, however 
inquiry will be whether the court was empowered to determine the rights of the parties over whom it has assumed to act. The next matter to be ascertained is, whether the judgment was rendered by a court of general or of special jurisdiction. There is no well defined test by which to determine in all cases whether a court belongs to the one class or to the other. But all courts invested with a general common law jurisdiction, in law or in equity, are, when exercising such jurisdiction, properly included in the first class; while all such courts as are erected upon such principles that their judgments must be disregarded until proceedings conferring jurisdiction are shown, belong to the second class. ${ }^{1}$ These classes are frequently designated as courts of record, and courts not of record. Courts of record, having authority over the subject matter, are competent to decide upon their own jurisdiction, and to exercise it to final judgment, without setting forth upon their records the facts and evidence upon which their decision is based. Their records are absolute verities not to be impugned by averment or proof to the contrary. ${ }^{2}$ A court may possess powers of a limited and subordinate character, and yet not be a court of special or limited jurisdiction, in the sense that it ought to certify everything precisely. ${ }^{3}$

"The use of the words 'superior' and 'inferior,' or 'limited' and 'general,' however apt they may have once been, are less so at this time and place, and their duties, in view

${ }^{1}$ Harvey $v$. Tyler, 2 Wall. 328; 367; Molins $v$. Werly, 1 Lev. 76; Colo Kempe's Lessee $v$. Kennedy, 5 Crch. $v$. Green, 1 Lev. 309; Bowsse v. Can. 185 .

${ }^{2}$ Grignon's Lessee $v$. Astor, 2 How. nington, Cro. Jac. 244.

U. S. 319; Rex $v$. Carlile, 2 B. \& Ad.

${ }^{3}$ Peacock $v$. Bill, 1 Saund. 74.

erroneous, would not be held void upon a mere collateral attack. To maintain that it would, would be to ignore the obvious distinction between a total wart of authority upon the one hand, and the erroneous exercise of the conceded authority upon the other."

And, spealsing of the power to enter judgment in vacation, the judge, in the same opinion, says: "It is a power, too, which is no more dependent upon or affected by the fact of trial had, or trial not had, than if the juig. ment had been entered in term time by the court. The hearing of proofs, the argument of counsel, in other words, the trial had-or the absence of any or all these, neither confer jurisdiction in the first instance, nor take it away after it has once fully attached." 
of our system and mode of procedure, would be better performed by the terms 'courts of record,' and 'courts and tribunals not of record." "' A court of record is that where the acts and judicial proceedings are enrolled on parchment for a perpetual memorial and testimony, which rolls are called the records of the court, and are of such high aud supereminent authority, that their truth is not to be called in question." The Circuit, District, and Territorial Courts of the United States are courts of record, and so are the Orphans' Courts in Penusylvania and Alabama, and the Probate Courts in Arkansas, Minnesota, ${ }^{3}$ Missouri, ${ }^{4}$ and California. ${ }^{5}$ Prior to 1858 the Probate Court in the last named State was a court of limited jurisdiction, and its proceedings were required to show the facts conferring upon the court its authority to act. ${ }^{6}$ The judgments of justices of the peace are favored with the same presumptions as though they were pronounced in courts of record, in the States of Penusylvania, ${ }^{7}$ Connecticut, ${ }^{8}$ Vermont, ${ }^{9}$ Tennessee, ${ }^{10}$ and Mississippi. ${ }^{11}$

8 123. Special Powers.-The jurisdiction exercised by courts of record, is, in many cases, dependent upon special statutes conferring an anthority in derogation of the common law, and specifying the manner in which such authority shall be employed. The decided preponderance of adjudged cases upon the subject establishes the rule that

\footnotetext{
${ }^{1}$ Hahn $v$. Kelly, 34 Cal. 391.

${ }^{2} 3$ Steph. Comm. 583; 3 Bl. Comm. 24.

${ }^{3}$ Dayton $v$. Mintzer, 22 Minn. 393.

${ }^{4} J$ ohnson v. Beazley, 65 Mo. 250; 27 Am. Rep. 276.

${ }^{5}$ McCauley $v$. Harvey, 49 Cal. 497. In this State the jurisdiction formerly excreised by the Probate Court is, by the recently adopted Constitution, rested in the Superior Court. The Alcalde's Court, which existed in this
}

120
State while it belonged to Mexico, was one of general jurisdiction: Braly v. Reese, 51 Cal. 447.

${ }^{6}$ Grimes $v$. Norris, 6 Cal. 621; Haynes v. Meeks, 10 Cal. 110.

${ }^{7}$ Billings v. Russell, 23 Penn. S. 189; Clark $v$. McComman, 7 WV. \& S. 469.

${ }^{8}$ Fox $v$. Hoyt, 12 Conn. 497.

9 Wright $v$. Hazen, 24 Verm. 143. ${ }^{10}$ Turner $v$. Ireland, $11 \mathrm{Humph} .447$. 1 Stevens $v$. Mangum, 27 Miss. 481. 
judgments arising from the exercise of this jurisdiction are to be regarded in no other light, and supported by no other presumptions, than though they originated in courts not of record. The particular state of facts necessary to confer juriscliction, will not be presumed; and if such facts do not appear, the judgment will be treated as void. ${ }^{1}$ The Supreme Court of the United States has laid down the rule, that when a statute prescribes the manner in which the rights conferred by it are to be pursued, and the powers delegated by it are to be exercised in a special and summary manner, the proceedings of tha court will be cousidered as of the same characteras the proceedings of courts not of record; but, when the statute confers new powers and rights, to be brought into action by the usual form of common law or of chancery practice, the proceedings and judgments of the court will have all the characteristics of the proceedings and judgments of courts of record. ${ }^{2}$ The doctrine that

${ }^{1}$ Shivers $v$. Wilson, 5 Harr. and J. | courts of general jurisdiction may be 130; Foster v. Glazener, 27 Ala. 391 and 663; Thatcher $v$. Powell, 6 Wheat. 119; Striker v. Kelly, 7 Hill, 24; Denning $v$. Corwin, 11 Wend. 647; Ludlow $v$. Jolnnson, 3 Ohio, 553; 17 Am. Dec. 609; Mitchell $v$. Runkle, 25 Tex. Supp. 132; Adams v. Jeffries, 12 Ohio, 253; Cone v. Cotton, 2 Blackf. 82; Earthman v. Jones, 2 Yerg. 493; Barry $v$. Patterson, 3 Humph. 313; Wight v. Warner, 1 Doug. Mich. 3S4.

2 Harvey $v$. Tyler, 2 Wall. 342. If the facts necessary to confer jurisdiction are shown to exist, the judgment can not be collaterally attacked, though rendered by a court in the excrcise of a special statutory authority: Secombe v. R. R. Co., 23 Wall. 108; McCahill $v$. Equitable Life Ins. Co., 26 N. J. Eq. 531. The question whether and when the judgments of such special powers are exercised juditreated as of no greater dignity than those of courts of special and limited jurisdiction, was very elaborately con. sidered by the Supreme Court of the United States in Galpin $v$. Page, 18 Wall. 350. From a full review of the recent decisions, the Court of Appeals of Virginia determined that there might be extracted therefrom "the following general legal propositions of universal application:

“ 1 . When a court of general jurisdiction acts within the scope of its general powers, its judgments will be presumed to be in accordance with its jurisdiction, and can not be collaterally impeached.

" 2 . So also when a court of general jurisdiction has conferred upon it special powers by special statute, and 121 
the judgments of courts of record are of any less force, or are to be subjected to any closer scrutiny, or that they are attended with any less liberal presumptions, when created by virtue of a special or statutory authority, than when rendered in the exercise of ordinary jurisdiction, has been repudiated in some of the States; ${ }^{1}$ and the reasons sustaining this repudiation have been stated with such clearness and force, as to prodnce the conviction that the doctrine repudiated has no foundation in principle, however strongly it may be sustained by precelent. In the first place it is shown that the discrimination between courts of record and courts not of record, "is founded upon considerations of the wisest policy, which are obvious to all. Courts of record are presided over by men of experience and learned in the law, assisted by counsel also of experience and learning, who, in the discharge of their duties to their clients, necessarily act as advisers of the court. Their proceedings are conducted with solemnity and deliberation, and in strict conformity with established modes, with which long experience has made the court aud bar familiar, and, above all, they are taken down and made a matter of record at or about the time they transpire. Of inferior courts, as a general rule, none of these things can be affirmed." In the second place it is shown, that none of those reasons upon which the discrimination between different courts rests, tends to justify any discrimination between different pro-

cially, that is, according to the course / cial, in such case its decision must be of the common law and proceedings in chancery, such judgment can not be impeached collaterally.

" 3 . But where a court of general jurisdiction has conferred upon it special and summary powers, wholly derived from statutes, and which do not belong to it as a court of general jurisdiction, and when such powers are not exercised according to the course of the common law, its action being ministcrial only and not judiregarded and treated like those of courts of limited and special jurisdiction, and no such presumption of jurisdiction will attend the judgment of the court. But in snch cases the facts essential to the exercise of the special jurisdiction must appear on the face of the record:" Pulaski Co. $v$. Stuart, 28 Gratt. 879.

1 Falkner v. Guild, 10 Wis. 572; Hahn $v$. Kelly, 34 Cal. 391. 
ceedings conducted by the same court. That whether a court proceeds according to the "course of the common law," or according to some authority conferred and some course prescribed by a statute, it is, in either case, presided over by the same judge, assisted by the same counsel and oficers; and conducted with the samo wisdom, caution and solemnity. In either case its proceedings are equally matters of record, and equally subject to fixed and wellunderstood laws. And finally, it is suggested that, as no reason has been given for regarding the same tribunal with different degrees of consideration, according to circumstances which seem not to affect its claims to our confidence, therefore all its adjudications, though arising out of the exercise of lawful jurisdiction conferred at different times, or from different but equally competent sources, should be subjected to similar rules and indulged with equal presumptions. ${ }^{1}$

8 124. Presumption in favor of Jurisdiction. - If it be ascertained that the judgment or decree under examination was rendered by a court of record in the exercise of its ordinary jurisdiction over the subject-matter in litigation, the next fact to be determined is, whether the court latad jurisdiction over the person against whom the judgment has been obtained. The preponderance of authorities shows that, in a collateral proceeding, this fact must be determined by an inspection of the matters contained in what at the time of entering the judgment, constituted the record or judgment roll. Any other paper which happens to be on file in the case aud improperly attached to the record, must be disregarded. The record, however, may be silent upon the subject of jurisdiction. It may fail to show whether the proceedings taken to bring the defendant within the authority of the court were sufficient or insuficient; or, for aught that appears by the judgment roll, no attempt may have been made to perform some act essential to jurisdiction. "Nothing shall be intended to be out of the jurisdiction of a superior court, but that which expressly

${ }^{1}$ See opinion of Sanderson, J., in Hahn v. Kelly, $3 \pm$ Cal. 391. 
appears to be so." Hence, though the existence of any jurisdictional fact may not be affirmed upon the record, it will be presumed upon a collateral attack, that the court, if of general jurisdiction, has acted correctly, and with due authority, and its judgment will be as valid as though every fact necessary to jurisdiction aflirmatively appeared. The decisions to this effect are very numerous. ${ }^{2}$ If a statute required a certain affidavit to be filed prior to the rendition of judgment, it will be presumed, in the absence of any statement or showing upon the subject, that such affidavit was filed. ${ }^{3}$ One acting in a court of record as attorney in fact for a party, will be presumed to have satisfied the court of his authority to act, and the proceedings can not be collaterally attacked, because the proof of such authority does not appear in the record. ${ }^{4}$ A case decided at an early day in New York, seemed to be in opposition to the current of authorities on the subject of the presumptions which attend the proceedings of courts of record when called in question collaterally. ${ }^{5}$ The opinion in this case, so far as it placed proceedings of "superior" courts upon the same footing with those of " inferior" courts, was soon after overruled. ${ }^{6}$ A few other cases are reported, which do not seem to be entirely consistent with the rule upon this subject. ${ }^{7}$ But it was reserved to the court deciding the case of

\footnotetext{
${ }^{1}$ Gosset v. Howard, 10 Q. B. 453; Guilford $v$. Love, 49 Tex. 715; Goar v. Maranda, 57 Ind. 339.

${ }^{2}$ Withers $v$. Patterson, 27 Tex. 491; Holmes $v$. Campbell, 12 Minn. 221; Spaulding $v$. Baldwin, 31 Ind. 376; Erans v. Ashby, 22 Ind. 15; Butcher v. Bank of Brownsville, 2 Kansas, 70; Reynolds $v$. Stansbury, 20 Ohio, 344; Bush $v$. Lindsey, 24 Geo. 245; Hahn v. Kelly, 34 Cal. 391; Calkins $v$. Packer, 21 Barb. 275; Princev. Griffin, 16 Iowa, 552; Grignon's Lessce $v$. Astor, 2 How. U. S. 319; Cox $v$. Thomas, 9 Gratt. 323; Wells $v$. Waterhouse, Wis. 28; Potter v. Mechanics' Bank, 28 N. Y. 656; Kelsey $v$. Wyley, 10 Geo. 371; Skillman v. Greenwood, 15 Minn. 102; Arnold v. Nye, 23 Mich. 286; Smith $v$. Pomeroy, 2 Dillon, C. C. 414 .

${ }^{3}$ Dean $v$. Thatcher, 3 Vroom. 470; Newcomb's Ex. v. Newcomb, 13 Bush. 544.

${ }^{4}$ Pillsbury $v$. Dugan, 9 Ohio, 117.

${ }^{5}$ Denning $v$. Corwin, 11 Wend. 648.

${ }^{6}$ Foot $v$. Stevens, 17 Wend. 483.

${ }^{7}$ Cline $v$. Gibson, 23 Ind. 11; Glidewell $v$. Spaugh, 26 Ind. 319; Gwin $v$. McCarroll, 1 S. \& M. 351.

22 Naine, 131; Ely v. Tallman, 14
} 
Steen v. Steen, 25 Miss. 513, to exhibit an extraordinary misconception of the law, by the use of the following language: "It is also a fixed rule on this subject, that the record of the judgment must show upon its face that the court did have jurisdiction of the person. Unless it so appears, the judgment is a nullity, for it will not be presumed that the court had jurisdiction unless the record shows that fact." The courts of the States of Kansas and Missomi seem to be following close in the wake of those of the State of Misisissippi. In a case in the first named State, the plaintiff's titlo depended upon a certain judgment, sale, and sheriff's deed. In attempting to prove his title he showed first that the files of the case were all burned, and next produced a journal entry of the judgment. This entry contained the statement that the defendant had been duly served by publication in a newspaper which it specified. Upon these facts the court cletermined that "until it appears not merely that the papers are gone, but also that there is no secondary proof of their contents; there is no presumption, even in favor of a court of general jurisdiction, from the existence of one part of a record, that the remainder would, if produced, contain the facts necessary to give the court jurisdiction." In a very recent decision in the state of Missouri, we find the general rule announced that "if the whole record taken together does not show that the court had jurisdiction over the defendant, then the judgment would be a nullity." 2

8 125. No Presumption Against the Record. - The presumption in favor of proceedings of courts of record are indulged only in relation to those jurisdictional matters concerning which the judgment roll is silent. But no presumptions in support of the judgment are to be allowed in opposition to any statement contained in the record. If an act be stated in the roll as having been done in a specifed manner, no presumption arises that, at some future time, the act was done in a better or more efficient manner. If it appear that the process was served in a particular mode, no other and different service can be presumed. To indulge such a presumption, would be to contradict the rec-

${ }^{2}$ Hargis $v$. Morse, 7 Kan. 417. | ${ }^{2}$ Howard $v$. Thornton, 50 MIo. 291. 
ord, which imports absolute verity. When, therefore, the record shows that certain steps were taken to procure jurisdiction, and the law does not consider those steps sufficient, the judgment will be regarded as voia, for want of jurisdiction over the defendant. ${ }^{1}$

\section{126. Defects in Obtaining Jurisdiction.-There is a} difference between a want of jurisdiction and a defect in obtaining jurisdiction. At common law the defendant was brought within the power of the court by service of the brevia, or original writ. In this country the same object is accomplished by service of summons, either actual or constructive, or of some other process issued in the suit; or by the voluntary appearance of the defendant in person, or by his attorney. From the moment of the service of process, the court has such control over the litigants that all its subsequent proceedings, however erroneous, are not void. If there is any irregularity in the process, or in the manner of its service, the defendant must take advantage of such irregularity by some motion or proceeding in the court where the action is pending. The fact that defendant is not given all the time allowed him by law to plead, or that he was served by some person incompetent to make a valid service, or any other fact connected with the service of process, on account of which a judgment by default would be reversed upon appeal, will not ordinarily make the judgment vulnerable to a collateral attack. ${ }^{2}$ In case of an attempted service of process, the presumption exists that the court considered and determined the question, whether the acts done were sufficient or insufficient. If so, the conclusion reached by the court, being derived from hearing and deliberating upon a matter which, by law, it was

${ }^{1}$ Clark v. Thompson, 47 Ill. 25; Davis, 47 Ia. 325; Sims $v$. Gray, 5 Hahn $v$. Kelly, 34 Cal. 391.

${ }^{2}$ Whitwell v. Barbier, 7 Cal. 54; Cooledge, 89 Ill. 529; De Tar $v$. Boone Dorente $v$. Snllivan, 7 Cal. 279; Smith Co., 34 Ia. 48S; Pope $v$. Hooper, 5 $v$. Bradley, 6 S. \& M. 4S5; Moomey Reporter, 72; Sac. Savings Bank $v$. $v$. Maas, 22 Iowa, 3S0; Peck v. Spencer, 53 Cal. 737.

Strauss, 33 Cal. 678; Myers v. Overton, 2 Abb. P. 344; Hunter $v$. Lester, 1s How. P. 347; Hanghey $v$. Wilson, 1 Hilton, 259; Kipp v. Fullerton, 4 Minn. 473; Cole v. Butler, 43 Maine, 401; Hendrick $v$. Whittemore, 105 Mass. 23; Drake $v$. Duvenick, 5 Pac. Law Rep. 2S; 45 Cal. 455; Myers $v$. "A distinction is to be made between a case where there is no servico whatever, and one which is simply defective or irregular. In the first case, the court acquires no jurisdiction, and its judgment is void; in the other case, if the court to wlich the process 
authorized to hear and decide, though erroneous, can not be void. When, in a proceeding by attachment, the ground required by the statute for the issuing and execution of the process has been laid, and the process has been issued and executed, the jurisdiction of the court is complete. If the subsequent proceedings do not conform to law, the judgment may be reversed. When there has been an insufficient publication, or an entire failure to publish, the proceedings are not so invalidated as to be made void. ${ }^{1}$ A service of process defective in giving four days notice, when the law required five days notice, is nevertheless sufficient to support the judgment of a justice of the peace. ${ }^{2}$ But the process may be so defective as to be in substance no process, as when it does not state the place or time where and when the defendant is required to appear and make his defense. In such case it has been held that no jurisdiction had been obtained over the person of the defendant, and that the judgment had no validity against him. ${ }^{3}$ The same conclusion was announced where the oficer serving the process was the plaintiff in the suit. 4

\& 127. Constructive Service.-In most of the decisions upon the subject, statutes authorizing the service of process by publication, have been construed as in opposition to the course of proceedings at common law; and a strict compli-

\footnotetext{
1 Paine's Lessee $v$. Moreland, 15 Ohio, 435; Beech v. Abbott, 6 Verm. 536; Matter of Clark, 3 Denio, 167; 163.
}

Williams $v$. Stewart, 3 Wis. 773 ; 4 Knott $v$. Jarboe, 1 MIet. Ky. 505. Drake on Atta. $\$ \$ 447-148$.

is returnable, adjudges the service to Swan, 277. The rule that defective be sufficient, and renders judgment service of process does not render the thereon, such judgment is not void, judgment liable to successful collateral but only subject to be set aside by the attack, has been frequently enforced court which gave it, upon seasonable in Mississippi, a State in which the and proper application, or reversed courts have, in other respects, been upon appeal." Isaacs $v$. Price, 2 Dil- loth to accord any favors to records lon C. C. 351. A judgment is not void suffering from symptoms of jurisdicbecause rendered before or after the tional infirmity. Christian v. O'Neal, return day named in the summons. 46 Miss. 669; Harrington $v$. Wofford, It is only liable to be vacated for 46 Miss. 31; Campbell v. Hays, 41 irregularity. Glover v. Holman, 3 Miss. 561.

Heisk, 519; West v. Williamson, 1 
ance with all the material directions of the statutes, has been required to appear upon the face of the record in order to impart validity to the judgment. ${ }^{1}$ A publication mado in the absence of any law anthorizing it, is the same in effect as no publication. A judgment based upon it is void." "Tho general presumption indulged in support of the judgments and decrees of the superior courts is, however, limited to jurisdiction over persons within their territorial limitspersons who can be reached by their process-and also over proceedings which are in accordance with the course of tho common law. Whenever it appears, either from inspection of the record or by evidence outside of the record, that the defendants were, at the time of the alleged service upon them, beyond the reach of the process of the court, the presumption ceases, and the burden of establishing the jurisdiction over them is thrown upon the party who involies the benefit or protection of its judgments and decrees. So too, the presumption ceases when the proceedings are not in accordance with the course of common law." Constructive service by publication in a case where the defendants are beyond the territorial limits of the court by virtue of an order made and enforced by the military authorities in time of war, and are not allowed to return, is a mere idle ceremony. It can, by no possibility, afford to defendants an opportunity of making a complete defense, or of appearing in court and attending to their interests. A judgment based upon it is void. ${ }^{4}$ But a party who voluntarily entered tho Confederate lines to engage in hostilities against the United States; and who, on that account, is not able to return, can not urge a condition of facts resulting from his own wrong, as a valid objection to proceedings against him as an $a b-$ sentee. ${ }^{5}$ But, in quite a number of cases, the same presumptions have been applied to judgments based upon constructive service as to those based upon actual service. The position is taken that presumptions of regularity are applica-

${ }^{1}$ Hallett $v$. Righters, 13 How. P. Page, 18 Wall. 350; and 3 Saw. C. C. 43; Boyland v. Boyland, 18 Ill. 552; 93; Neff $v$. Pennoyer, 3 Saw. C. C. Brownfield $v$. Dyer, 7 Bush. 505.

${ }^{2}$ Hollingsworth v. Barbour, 4 Pet. 635; 9 Reporter, 40.

466; Shiehls $v$. Miller, 9 Kan. $390 . \quad$ 'Dean $v$. Nelson, 10 Tall. 158.

${ }^{3}$ Judge Field, in Gray $v$. Larrimore, ${ }^{5}$ Ludlow $v$. Ramsey, 11 Wall. 581 ; $2 \mathrm{Abb}$. U. S. 512; and in Galpin $v$. Foreman $v$. Carter, 9 Kan. 681. 
ble to the proceedings of courts of record, not becanse of the particular means which those tribunals happen to employ, under the authority of the law, for the propose of acquiring jurisdiction over the defendant; but because of the ligh character of the courts themselves; and that this character is essentially the same in all cases, irrespective of tho methods employed in the execution of process. Therefore, the fact that the affidavit required by law to precede and authorize the order for publication, does not appear from the record, will not make the judgment vulnerable to collateral attack. ${ }^{1}$ Constructive service, though not employed in the manner now generally anthorized by statute, was nevertheless well known to tho common law, and to the chancery practice at an early period. ${ }^{2}$ It is, therefore, "a proceeding according to the course of common law."

8 123. Appearance by Attorney.-By the ancient practice, the litigants appeared in person, and were not anthorized to appear by attorney withont special authority from the crown. At a later day, the right to appear by attorney was recognized by varions statutes. Under these, the attorney was at first appointed orally in court. Subsequently, he was required to have his authority to act reduced to writing and filed in the court. The rules have been gradually relaxed until now, when it is presumed, in all collateral proceedings, that an attorney who has appeared for a litigant, withont service of process, had authority to act for the person whom he assumed to represent. ${ }^{4}$ This presumption is, in a collateral proceeding, not merely prima facie, it is conclusive; and the party whose appearance appears to have been made by an attorney, will not be permitted to prove that he never authorized the attorney to represent him. ${ }^{5} \quad$ Other decisions, however, indicate that the anthority

1 Nash v. Church, 10 Wis. 312; ${ }^{5}$ Field v. Gibbs, 1 Pet. C. C. 155 ; Lnwler's Heirs $v$. White, 27 Tex. Baker $v$. Stonebraker's Adm., 34 Mo. 250; Gemmell $v$. Rice, 13 Minn. 400; 175; Reed $v$. Pratt, 2 Hill, 64; Io:Newcomb's Ex. $v$. Newcomb, 13 Bush, mire $v$. Hoffmire, 3 Ed. Ch. 174; An. $5+4$.

2 3 Blı. Comm. pp. 2s3, 444.

${ }^{3}$ Hain $v$. Kelly, 34 Cal. 417. Ins. Co. v. Oakley, 9 Pai. 496; Carpentier v. Oakland, 30 Cal. 439; Hari-

${ }^{4}$ Harsincy $v$. Blackmarr, 20 Iown, v. Nichols, 42 N. Y. 26. 161; Amold $v$. Nye, 23 Mich. 286. 
of the attorney can always be disputed. ${ }^{1}$ But, even where the authority of the attorney to appear is, after judgment, an open question, and the judgment is liable to be treated as a nullity, upon showing that the attorney acted without authority, the judgment may be validated by a subsequent recognition of the attorney's acts, such, for instance, as paying him for his services in the action in which the judgment was entered. ${ }^{2}$ Where a warrant of attorney has been given to confess judgment, and thé plaintiff engages an attorney to act under such warrant, the case is very different from that of an ordinary appearance. If the warrant be insuficient, the defendant is not bound by the judgment. ${ }^{3}$

8 129. Default,-The record may show that the judgment was entered by the clerk, upon the default of the defendant. The clerk has no judicial functions. The statute directs the judgment. The clerk acts as the agent of tho statute, in writing out and filing its judgment among the records of the court. If the law did not authorize its agent to act, the judgment is without any authority and is therefore void. Thus, where several defendants were sued upon a joint liability, and a portion summoned to answer the complaint, the clerk, not being so authorized by law, entered judgment by default against those who were summoned and in default, the judgment was declared to be void. ${ }^{4}$ Judgment for costs entered by the clerk in the absence of a cost bill is also void. ${ }^{5}$ A judgment by dofault entered within the time prescribed for the defendant to appear in a justice's court, is void in Missouri. ${ }^{6}$ The service of notice of a motion to dissolre an attachment on account of irregularity, made by the defendant's attorney, is not such an appearance as will support a judgment by default. ? If, however, in a case where the authority of a clerk to

1 Hess v. Cole, 3 Zabr. 125; Shumway $v$. Stillman, 6 Wend. 453 ; Shelton $v$. Tífin, 6 How. U. S. 163. A judgment based on the appearance of an unauthorized agent, not shown to be an attorney, is void in the extreme sense, nor can it obtain any validity from proof of the fact that during the progress of the cause the deposition of the defendant was taken to be used in the case: Brinkman $v$. Shaffer, 23 Kans. 528.
${ }^{2}$ Ryan $v$. Doyle, 31 Iowa, 53. 3 II. \& M. Bank $v$. Boyd, 3 Denio, 257; M. \& M. Bank v. St. John, 5 Hill. 497.

${ }^{4}$ Kelly $v$. Van Austin, 17 Cal. 564.

${ }^{5}$ Chapin $v$. Broder, 16 Cal. 403.

${ }^{6}$ Howard $v$. Clark, 43 ilo. 344;

Williams $v$. Bower, 26 Mo. 601.

7 Gildden v. Packard, 28 Cal. 649. 
enter judgment is undoubted, he err in the performance of his duty, as by making the entry for too large a sum, his action is not roid, but only erroneous.'

8 130. Findings of Jurisdiction.-It may happen, when that part of the record containing the evidence of service shows an insufficient service, that other parts of the record, and especially the judgment, disclose the fact that the matter of jurisdiction has been considered and determined by the court. The conclusion or finding upon this subject may appear by recitals stating that defendint has been cited to appear, or that he has entered his appearance, or that his default for not appearing has been duly entered. These findings are as conclusive upon the parties, in all collateral proceedings, as any adjudication of the court can be. It must be presumed that they were supported by sufficient testimony, not set forth in the record. Thus, though the return upon a summons against $A$. B. certifies a service of such summons upon C. D., and the judgment states that $A$. B. has been summoned, the record is not necessarily contradictory. The error in the service of process may liave been corrected by service of the summons on the proper person. And, since the statement to this effect is made by the court, it will be conclusively presumed that it acted upon ample evidence and with due deliberation before making such statement; and the judgment will be impregnable to any collateral assault. ${ }^{2}$ The same rules and presumptions attach to proceedings in a court of general jurisdiction in California to enforce the payment of taxes, as to proceedings in any other class of actions. A recital in the decree, "that all owners and claimants of the property above described have been duly summoned to answer the complaint herein, and have made default in that behale," is sufficient to bind all claimants of the property in suit. The fact that the summons, as serred by publication, omitted the name of one of the defcndants, to whom the property was assessed, is not fatal to the decree; because, from thie

\footnotetext{
1 Bond $v$. Pacheco, 30 Cal. 530.

v. Fulton, 4 Pac. I. Rep. 170; 44

${ }^{2}$ Hahn v. Kelly, 34 Cal. 391; Qui- Cal. 355; Dunham v. Wilfong, 69 Mo. vey $v$. Baker, 37 Cal. 465; McCauley 35̃; Blaisdell v. Pray, 68 Nie. 269.
} 
abore recital, it must be presumed that the court had suffcient proof of the service of such defendant, though it does not appear in the judgment roll. ${ }^{1}$ In some of the cases al. ready cited in this section, the effect of jurisdictional fincings was carried to its utmost limit; and further, perhaps, than is justified by the more recent adjudications. The recital in the judgment of the due service of process onglit nuquestionably to prevail over any inference to be dram from the fact that the other parts of the record fail to show when or in what manner the process was served. ${ }^{2}$ Generally the recital of jurisdiction or of service of process contained in the judgment will be construed in connection with the whole record, and will be deemed to refer to the lind of service shown by the other parts of the record. Hence, if one part of the record shows that process was serred constructively, as by the publication thereof, a personal service will not be presumed, because in the judgment, the court adjudges "that service of notice has been made upon said defenctant,"3 especially where an aflidavit is found among the papers on file showing that the residence of the defendant was nuknown, and conld not bo ascertained. In Kansas, "a finding of notice is at best but prima facie evidence of notice. If an attempt at notice appears in the record, the finding, if a general one, refers to and is Iimited by such attempted notice. If that be fatally defective, there is no presumption of notice in any other or better way." "In Illinois, the general recital or finding of notice or of service of process is, as we understand the decisions in that state, conclusive as against any evidence not contained in the record $;^{5}$ but is disregarded when from the whole record it appears to be untrue, or when the record discloses the evidence upon which the re-

${ }^{1}$ Reily v. Lancaster, 39 Cal. 354; Branson $v$. Caruthers, 49 Cal. 375.

${ }^{2}$ Rumfelt $v$. O'Drien, 57 Mo. 569; Banion $v$. The People, 1 Ill. App. 496.

${ }^{3}$ Mayfield $v$. Bennett, 48 Ia. 194. 132
${ }^{4}$ Mickel $v$. Hicks, 19 Kans. 578; 27 Am. Rep. 161.

${ }^{5}$ Andrews $v$. Bernhardi, 87 Ill. 365; Mulvey $v$. Gibbons, 87 Ill. 367; Barnett $v$. Wolf, 70 Ill. 76 ; Harris $v$. Lester, S0 Ill. 307. 
cital was based, and further that such evidence overthrows rather than supports the recital. ${ }^{1}$

\section{131. Jurisdictional Inquiries, Confined "to the Rec-} ord."-We have hitherto assumed that the question of the juriscliction of a court of record over the parties to any domestic judgment must, in all collateral proceedings, be determined by the record; and that the answer to this question is not, except in some direct proceeding instituted against the judgment, to be sought from any extraneous proof. This doctrine seems to be the natural and unavoidable result of that stamp of authenticity which, from the earliest times, was placed upon the "record," and which gave it such " uncontrollable credit and verity that no plea, proof or averment could be heard to the contrary." Proceeding undoubtedly from the reliance which, in the primitire stages of practice, was placed on the official memorials of the proceedings of courts, and supported by the rule, that the best eridence ought always to be heard, to the exclusion of all inferior evidence, this doctrine has received the endorsement of the courts of last resort in more than a majority of the States of this Union. The principles on which it rests, are clearly and ably stated by Gholson, J., in Callen v. Ellizon (13 Ohio S. p. 446), in the following language: "When process is instituted-when, on a demand for it in the prescribed mode, the process of the court is issued-the steps taken under that process must be matter proper for the consideration of the court. The court must determine whether the suit is prosecuted-whether the clemand for the thing to which a right is asserted is continued. So, if it be claimed that process has been waived, the fact of waiver, or the authority to waive, as shown by the evidence, must be decided by the court. This determination or decision may be express on the rery point, as by an assertion on the record, that the process has been served, or that the party has appeared by an attorney, or it may be necessarily implied in the action of the court upon the demand of the party. The determination or decision, that a

${ }^{1}$ Barnett $v$. Wolf, 70 Ill. 76 ; Sen- Jenkins, 79 Ill. 228; Bannon $v$. The iehla v. Lowe, $7 \pm$ Iil. 274; Turner $v$. People, 1 Inl. App. 496. 
party has been served with process, or that ho has given authority to waive process, if in truth he has not been served, or given such authority, is a determination or decision, when lie has no opportunity to be heard. Hence, the right to show in opposition to the record of such determination or decision, the truth by evidence has been claimed, as required by the principles of natural justice.

"It the court acts at all upon the question whether a party has been served with process, or has authorizod an appearance in the absence of such party, then the decision must be made at the risk of an incorrect conclusion. And it would be absurd to require notice of such inquiry, as that would involve a similar inquiry, whether there were notico of that notice. The court must act upon the demand for which process has been instituted, either with or without inquiry into the fact whether such process had been served. That there should be no inquiry, that a judgment by default should be rendered without inquiry into the fact whether the process has been served on the defendant, cannot with any propriety be claimed. If then, the inquiry should be made, what effect is to be given to the determination or decision? Is it obligatory, unless impeached or set aside in the mode prescribed as to other decisions of the court, or may it be disregarded as null and void, whenever brought in question, upon allegation and proof that the party in truth had no notice or opportunity to be heard? Here arises a conflict between principles of policy, which require the former conclusion, and principles of natural justice, which lead to the latter; and, as might be expected in cases of such conflict, the decisions of courts have difiered.

"As to the judgments of courts of general jurisdiction, the decisions in this State, though perhaps not entirely uniform or consistent, do undoubtedly show a strong inclination to sustain such judgments against indirect or collateral attacks on their validity and effect. It appears to have been thought that natural justice is satisfied, when notice is required, and an impartial tribunal established to ascertain and determine whether it has been given. Nor can it be properly said that such a tribunal has jurisdiction, 131 
because it has so decided. Its decision is binding, becanse it was anthorized to make it, and because public policy and the respect due to the sovereignty it represents, at least in tribunals acting under the same sovereignty, requires that the decision should be regarded, while it remains on tho record unimpeached and unreversed.

"In the case of Lessee of Fowler v. Ihiteman (2 Obio State, 270 ), it is said to have "become established by a series of decisions in Oliio, that the finding of a court of general jurisdiction upon a subject matter properly before it cannot be impeached.' The finding in that and the previous cases there referred to, was upon the question of notice." In this case from which this quotation is made, the records stated that "defendants by George Collins, Esq., their attorney, come into court, and by virtue of his power of attorney filed in this court, confessed judgment for the clefendant," etc. It was claimed that the power of attorney found among the records, did not appear to be executed by some of the defendants, and that other of the defendants were married women, incapable of executing such power. Dut the court held that this power, though found among the papers in the case, was no part of the record. That the object of filing the power was not to furnish means to render the judgment void, "but to furriish the parties affected by the judgment ready means to apply to the court itself to correct any irregularity or error," and that no such application having been made, the judgment must be regarded as valid.

The rule that evidence will not be heard in a collateral proceeding, for the purpose of avoiding a judgment, is thus defended in the case of Coit v. Haven (30 Conn. p. 199): "Put the counsel for the defendants urge the extreme hardship to which a party may be subjected, if he may not deny and disprove the service of the writ, when he can clearly show that in fact no service was ever made on him, and that he never had notice of the suit in any form, and never heard of the judgment against him until it was mado the ground of an action. They say, with great emphasis, and the argument is certainly a forcible one, can it be that a clerk of a court may fabricate a record, or an officer make 
a false return of service, and yet there be no escape for one who is thus by a judgment in the suit made hearily indebted, or found guilty of a wrong, when in fact he is perfectly innocent, or never owed the debt, and could show it clearly if he had a chance? Will a court, they ask, because it has a general jurisdiction, protect and give efiect to such a frand?

"It will not be claimed, and has not been on the arguinent, that when a court has jurisdiction, its record speaks absolute verity, because it is the record of the court's doings; and being a court of tinal jurisdiction, there must ve an end to the matter in dispute, if it be possible to reach that end at all. And it is so necessary that confidence should be reposed in courts of a high character, as well as in the records of such courts, that on the whole, and in riew of all the considerations affecting the subject, it is the only safe rule to give the decisions of courts of general jurisdiction full effect so long as they remain in force, rather than to leave them open to be attacked in every way and on all occasions. Being domestic judgments, they can, if erroneous, be reviewed by proceedings instiunted directly for that purpose and reverser on error, or by a new trial; and, if the danger is imminent and special, relief can bo temporarily, if not finally obtained by application to a court of equity. Any other rule with regard to judgments of such courts would be attended in its application with very great embarrassment, and would be very dangerous in its general operation. The general good clearly requires, and has therefore established the rule that domestic judgments of courts of general jurisdiction can not be attacked collaterally."

If the record of a domestic court of general jurisdiction declare notice to have been given, such declaration can not bo contradicted by plea or proof, because, for reasons of public policy, the records of such courts are presumed to speak the truth, and can bo tried only by inspection." "It

1 Selin v. Snyder, 7 S. \& R. $166 ;$ R. Co. v. Weeks, 52 Maine, 45f; F:2r v. Ladu, 37 Verm. 156 ; Eastman Hotchliss v. Cutting, 14 Minn. 537 ; $v$. Witterman, 26 Verm. 491 ; Lyles $v$. Norgan $v$. Burnett, 18 Ohio, 535 ; Iubinson, 1 Bail. 25 ; Aultman v. Segee $v$. Thomas, 3 Bltchf. C. C. 11. BicLean, 27 Iorva, 129 ; Penobscot R. 
is not to be denied that a court of superior jurisdiction may so make a record in a case where, in fact, it has no jurisdiction, that the validity. of the judgment cannot be questioned collaterally." The fact of jurisdiction appearing on the record, it can not be controverted. Any other matter dotermined by the court might as well be disputed as this.?

\section{\& 132. Silence of the Record.-A large proportion of the} decisions denying the right to collaterally impeach a judgment or decree, for want of jurisdiction over the party against whom the determination has been made, have been pronounced where the service of process appears distinctly or by necessary implication upon the record. But "it is a matter of no consequence whether the jurisdiction of the court aflirmatively appears upon the judgment roll or not, for if it does not it will be conclusively presumed." ${ }^{3}$ In a recent case it is said: "We concur fully in the doctrine of the numerous cases cited for plaintiff, where it is held that a domestic judgment of a court of record of general jurisdiction, proceeding according to the course of the common law, cannot be impeached by the parties to it, where a want of juriscliction is not apparent upon the record, while it remains neither annulled nor reversed." ${ }^{t}$ It is a familiar principlo that the judgment or decree of a court of general jurisdiction can not be collaterally questioned, except for want of authority over the matter adjudicated upon. ${ }^{5}$ Fraud in procuring a judgment can not be shown by the parties to such judgment, in any collateral proceeding. ${ }^{6}$ An offer beins made to prove that the defendant, at the time of entering judgment, was but two years old, and that no service

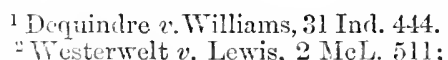
Riloy $x^{2}$. Wangh, 8 Cush. 220 ; Borden $v$. State, 6 Eng. 519; Delaney $v$. Gault, 6 Casey, 63; Galpin 2 . Page, 1 Saw. C. C. 31S; Miller v. Ewing, S S. \& MI. $4-1$; Wright $v$. Weisinger, 5 S. \& M. 210; Rigigs $i$. Collins, 2 Bissell, C. C. 265; Peyroux $v$. Peyronx, 24 La. An. 175; NeCreery $v$. Fortson, 35 Tex. 611. Probally this rule does not prevail in New York: Ferguson $v$. Crawford, 70 N. Y. 253; S. C., 26 Am. Tiep. 589.

3 Sharp $v$. Irunnings, 55 Cal. 528; Mitchell $v$. Meuley, 32 Tex. 460; Hahn $v$. Kelly, 34 Cal. 391 ; Lawler's Fieirs $v$. White, 27 Tex. 250; Coit $v$.

Haven, 30 Conn. 190.
${ }^{4}$ Pratt v. Dow, 56 Maine, 81; Granger $v$. Clark, 22 Maine, 128; Fiteh $v$. Boyer, 8 lieporter, 185; Turrell $v$. Warren, 25 Mimm. 9.

5 Yaple $v$. Titus, 41 Penn. S. 292; Shawhan v. Loffer, 24 Iowa, 217; Cook v. Darling, Is Pick. 393; Stephenson $v$. Newcomb, 5 Harring. 150; Crafts $v$. Dexter, 8 Ala. 767 ; C'ox $v$. Thomas' Admr., 9 Gratt. 323; Finneran $v$. Leonard, 7 Allen, õ 1 ; Blythe v. Richards, $13 \mathrm{Am}$. Dec. 672; $10 \mathrm{~S}$. \& R. 260; Bragg v. Lorio, 1 Woods, 209.

${ }^{6}$ Carpentier v. Oakland, 20 Cal. 439; Smith v. Smith, 22 Iowa, 516; People v. Downing, 4 Sanf. 189. 
of process had been made upon him, the court said: "The record in this case is not silent. It recites that due notice had been given. This is a finding of the court; and being shown by a record importing absolute verity, can not be contradicted." An action was commenced against a person upon judgment rendered for costs of suit, in a case whereiu he was plaintiff. Ho offered to prove that ho did not authorize the act of the attorney who instituted the former suit. It was held that while the judgment remained of record he was bound by it, and could only be relieved by some direct application. ${ }^{2}$ If the judgment or decree is silent upon the subject of the service of summons, and the service shown by the return upon the summons is not such as will give the court jurisdiction, no doubt the judgment is void. ${ }^{3}$ This, loowever, does not present a case wherein the record is silent; but rather illustrates the proposition that while one part of the record is silent another part may bear witness of a jurisdictional infirmity, destructive of the life and validity of the jurlgment.

8 133. Cases Admiting Parol Evidence.-Many courts, however, have been deeply impressed by the apparent violatiou of natural justice, involved in condemning a party who has had no opportunity of presenting his defense-no notice that any of his rights or interests were in jeopardy. Yielding, through a tenderness for the special and muavoidable injustice occasionally done to litigants, they have, in a measure, overlooked the interest of the community as a whole; and rather than sacrifice the individual for the safety of the community, they have jeopardized the best interests of the community to secure the safety of the individual. To the end that each citizen may feel assured that no injury can be done him in the courts withont his notice, actual or constructive, they have impaired public confidence in judicial authority; they have made the title to a large class of property precarious and unstable, by taking away the uncontrollable verity of the record, and substituting for it the interminable uncertainties of parol evidence; and instead of allowing parties who have acquired title at judicial sales

\footnotetext{
'Tichards $v$. Skiff, 8 Ohio S. 23 Am. Dec. 246; Finneran v. Lcon586.

${ }^{2}$ Ward $v$. Barber, 1 E. D. Smith, ${ }^{3}$ Swearengen $v$. Gulick, 67 Ill. 203; 423; St. Albans $v$. Bush, 4 Verm. 58; Bannon $v$. People, 1 Ill. App. 496.
} 138 
to rest secure in the presumption that courts of record always "act by right," those parties have been required, often without notice of the intended attack, to defend proceedings, occurring many years previous, and apparently free from vice or infirmity.

The principles which it is thought are sufficient to support the practice of leaving the question of jurisdiction orer the parties always open to dispute on collateral proceedings, are that the high and uncontrollable verity of the record never attaches until the court has obtained jurisdiction of the person of the defendant, as well as of the subject matter of the action; that in the absence of the fact of jurisdiction over the parties, there is no power competent to make a recordi that the thing offered as a record may bo nothing but an unauthorized paper, that the law contemplates, upon reasoss of natural justice, that no man shall be deprived of any of his rights of person or property without an opportunity of being heard; that whenever the judgment of any trihusal is about to be used in any proceeding, whether direct $\mathrm{nr}$ collateral, it is incumbent on the court wherein it is offered to inquire into the jurisdiction of the court rendering the judgment; and that no court can bring a party within its power by virtue of false findings and recitals. ${ }^{1}$ It is worthy of consideration that in the greater number of cases usually cited as authority for collateral attacks, the language used by the court, though sufficiently general to apply to domestic judgments of courts of general jurisdiction, valid on their face, was employed in determining the effect of judgments either of a sister State, or of a court of limited jurisdiction, or of a court whose want of jurisdiction appeared upon the record; and that in those cases where the question of collateral attack was necessarily involved, and was affirmatively determined, such determination was generally based upon mere dicla. The npinion of Judge Marcy in Sturbuck v. Blurray (5 Wend. 148; :1 $\mathrm{Am}$. Dec. 172), is frequently cited to show that want of jurisdiction over the defendaut may always be proven. He, in deciding whether such proof should be received against a record made in another State, said: "But it is strennously contended that if other matter may be pleaded by the de-

${ }^{1}$ Goudly $v$. Hall, 30 Ill. 109; Web- Kimmel, 16 Abb. Pr. 353; 1 Robt. ster $v$. Reid, 11 How. 437; Gwin $v$. 109; Johnson $v$. Wright, 27 Geo. 555. McCarroll, 1 S. \& M. 3 3 I; Baldwin $v .1$ 
fendant, he is estopped from asserting anything against the allegation contained in the record. It imports perfect verity, it is said, and the parties to it cannot be heard to impeach it. It appears to me that this proposition assumes the very fact to be established, which is the only question in issue. For what purpose does the defendant question the jurisdiction of the court? Solely to show that its proceedings and judgments are void, and therefore the supposed record is not in truth a record. If the defendant had not proper notice of, and did not appear to the original action, all the State courts, with one exception, agree in opinion that the paper introduced as to him is no record; but if he cannot show, even against the pretended record that fact, on the alleged ground of the uncontrollable verity of the record, ho is deprived of his defense by a process of reasoning that is to my mind little less than sophistry. The plaintiffs in effect declare to the defendant: The paper declared on is a record, because it says you appeared, and you appeared because the paper is a record. This is reasoning in a circle. The appearance makes the record uncontrollable rerity, and the record makes the appearance an unimpeachable fact. The fact which the defendant puts in issue is the validity of the record, and yet it is contended that he is estopped by the unimpeachable credit of that very record from disproving any one allegation contained in it. Unless a court has jarisdiction, it can never: make a record, which imports uncontrollable verity to the party over whom it has usurped jurisdiction, and he ought not therefore to be estopped, by any allegation in that record, from proving any fact that goes to establish the truth of a plea alleging want of jurisdiction. So long as the question of jurisdiction is in issue, the judgment of a court of another State, is in its effect like a foreign judgment; it is prima facie eviclence; but for all the purposes of sustaining that issue, it is examinable into to the same extent as a judgment rendered by a foreign court. If the jurisdiction of the court is not impeached, it has the character of a record, and for all purposes should receive full faith and credit." The language of this opinion, though general in terms, was used in relation to the judgmont of a court of another State, and, therefore, so far as it 
reflects upon other judgments, is a mere dictum. A number of other cases in the same State, and elsewhere, are, like the one just cited, sound and undoubted as to the points necessarily involved; but as to reflections upon domestic judgments of courts of record are mere dicta. ${ }^{1}$

\section{131. Reasons for Holding the Record Conclusive.- All the arguments adduced to show that the inquiry into}

${ }^{1}$ Borden $v$. Fitcli, 15 Jolns. 140; SAm. Dec. 225; Tollard $v$. Wegener, 13 Wis. 569 ; Bloom $v$. Burdick, 1 Hill, 150; Rape v. Featon, 9 Wis. 328 ; Pendleton $v$. Weed, 17 N. Y. 72; Steen 2 . Steen, 25 Miss. 513; Chemung Canal Bank v. Judson, 4 Seld. 254; Elwards $v$. Toomer, 14 S. \& MI. 80; Noyes v. Butler, 6 Barlb. 613; Fitzhugh v. Custer, 4 Tex. 399; Hard $v$. Shipman, 6 Barb. 621 ; Stallings $v$. Gulley, 3 Jones' Law, 34วँ; Corwin $v$. Nierritt, 3 Larb. 341; Elliott $v$. Peirsol, 1 Pet. 340; Dobson $v$. Pearec, 2 Kiem. 156; Smith $v$. Pomeroy, 2 Dillon C. C. 414 ; McCauley $v$. Hargroves, 48 Geo. 50; 15 Am. Rep. 660; Pennywit $v$. Foote, $27 \mathrm{Oh}$. St. 600; Spier v. Corll, 33 Oh. St. 236; Mastin v. Gray, 19 Kans. 45s; $27 \mathrm{Am}$. Rep. 149, reported as Mastin $v$. Duncan, 6 Cent. L. J. 32S. In this last case the court permitted the return of service of summons made by a constable, to bo controverted in an action of ejectment where the judgment founcled on such return was collaterally clrawn in question. The most candid and comprehensive review of this question which has come within our observation is that contained in the opinion of Rapallo, J., in Ferguson v. Crawford, 70 N. Y. 253; 26 An. Riep. 589. That case was an action bronght to foreclose a mortgage. The defense interposed was tllat the plaintiff's rights had been barred by a judgment foreclosing a prior mortgage. On the trial the judgment roll in the former case was put in evidence. It contained a notice of appeurance for the present plaintiff, purporting to be signed by one Nills as his attorney, and also a consent to jurgment signed on behalf of plaintiff by the same attorney. The judgment also recited that summons lad becn served on the defendants, and that none of them had appearcal except the present plaintiff by John W. Mills, his attomey. The plaintiff then called Mills as a witness and offered to prove by him, lst, that Mills' signature to the consent to judgment and notice of appearance was forged; 2l, that Mills was never authorized to appear for plaintifi; and, $3 d$, that he never did appear.

The learned jutige first alisposed of the objection that the erilence conle not be receired without oremuing Brown y. Nichols, 42N. I. 26. That case, he said, was authority for the position that when an attorncy hacl appeared, his want of authority to do so eould not be shown on a collateral attack; but here the offer was to show not only that the attorney had no anthority, but further, that lie did not in fact appear, and that lis supposed signature was a forgery. Iis honor then proceeded: "The only dificulty in the case arises upon the objection that the evidence offered tends to contradict the record, and from the athjudications which attach to the julgment of a court of general juriscijction, a conchusive presumption of jurisdiction over the parties, which can not be contradicted except ly matter appearing on the face of the record itself."

"After considerable research I lave 
the jurisdiction over the parties in the tribunal pronouncing judgment, should on all occasions be considered as open, seem to admit of ready answers. That the matters intended by a court of record for its memorials, may bo

been unable a find a single authorita- ion, that a judgment of a domestic tive adjudication, in this or any other court of general jurisdiction could not state, deciding that in the ease of a be attackerl collaterally, unless the clomestic julgment of a court of gen- want of jurisdiction appeared on the eral jurisdiction, want of jurisdiction face of the record, and that jurisdicorer the person may be shown by ex- tional facts, such as the service of the trinsic evidence, while there are a writ and the like, were conclusively great number of adjudications in presumed in favor of such a judgment, neighboring States, holding that, in unless the record showed the con. the case of such judgments, parties trary, although this rule dicl not ap. and privies are estopped in collateral actions," to deny the jurisdiction of the court orer the person as well as the subject-matter, unless it appear on the face of the record that the court had not accuired jurisdiction, and that in such cases there is a conclusive presumption of law that jurisdiction was acquired by service of process or the appearance of theparty. The cases are very numerous, but the citation of a few of them will suffice.

"In Cooke v. Darling, 18 Pick. 393, in an action of debt on a domestic judgment, the defenclant pleaded that at the time of the supposed service upon him of the writ in the original nction, he was not an inhabitant of the State of Massachusetts; that he hard no notice of the action, and did not appear therein.

"This plea was held bad on cle. murrer, on the ground that the judgment could not be impeached collaterally. In Granger v. Clark, 22 Me. 128, also an action on a judgment, the plea was the same, with the addi. tion that the judgment had been obtained by fraud; but it was held to coustitu te no defense. Coit $v$. Haven, 30 Conn. 190, was a scire facias, on a judgment, and the defendant pleaded that the writ in the original action vas never served upon him, etc.; and the court held, in an elaborate opin- Smith, 7 Id. 85; Campbell $v$. Brown, 
proved not to be a record by parol evidence, is in conflict with the principles recognized from the earliest times of our common law, that the plea of mul tiel record was to be decided only by inspection of the alleged matter of record.

6 IIow. (Miss.) 106; Shaefer $v$. Gates, which the record actually avers, and 2 B. Mon. 453; Wilcox $v$. Jackson, 13 that a recital of notice or appearance, Pet. 498; Niller $v$. Ewing, $8 \mathrm{Sm}$. \& M. Or a return of service by the sherif in 421, and numerous other cases not the record of a domestic court of gencitcl. But an examination of these eral jurisdiction, is absolutely conclucases cliscloses that they all relate either to julgments of inferior courts, or courts of limited jurisdiction or courts of general jurisdiction acting in the exercise of special statutory powers, which proceedings stand on the same footing with those of courts of limited and inferior jurisdiction ( $3 \mathrm{~N}$. Y. 511), or courts of sister States, or to cases where the want of jurisdiction appeared on the face of the record, orto cases of direct proceedings to reverse or set aside the juigment, I have not found one which adjudicated the point now under consideration, otherwise than those to which I liave referred. There are some cases which hold that the want of authority of an attorney to appear may be shown by extrinsic evidence, although the record states that an attorney appeared for the party, but those are placed expressly on the ground that such evidencs does not contradict the record. Bodurtha $v$. Goodrich, 3 Gray, 50S; Shelton $v$. Titin, 6 How. (U. S.) 1S6; 14 How. 310. Those cases are, however, in conflict with the decision of this court in Biown $v$. Nichols, 42 N. X. 26, and in many other cases.

"The learned annotators of Smith's Leading Cases, Hare \& Wallace, $1 \mathrm{Sm}$. L. Cases, rol. 1, p. $8 \pm 2$ (marg.), sum the matter up by saying: "Whatever the rule may le where the record is silent, it would seem clearly and conclusirely established by a weight of authority too great for opposition, unless on the ground of local and peculiar law, that no one can contradict that sive and can not be disproved by ex. trinsic evidence.'

"It is quite remarkable, however, that notwithstanding the formidable array of authority in its favor, the courts of this State have never sustained this doctrine by any adjudication, but, on the contrary, the great weight of judicial opinion, and the views of some of our most distinguished jurists, are directly opposed to it.

"As has been alrealy stated, our courts have settled by adjudication in regard to judgments of sister States, that the question of jurisdiction may be inquired into, and a want of juris. diction over the person shown by evidence, and have further deciled (in opprosition to the holding of courts of some of the other States) that this may be done eren if it involves the contradiction of a recital in the judgment record. In stating the reasons for this conclusion, our courts have founded it on general principles, ciuite as applicable to domestic judgments as to others, and, save in one case, Kerr $v$. Kerr, 41 N. Y. 272, have in their opinions made no discrimination between them. Borden v. Fitch, 15 Johns. 121; 8 Am. Dec. 225; Starbuck v. Murray, 5 Wend. 14S; 21 Am. Dec. 172; Noyes v. Butler, 6 Barb. 613, and cases cited.

"When we come to consider the effect of these authorities, it is dificult to find any solid ground upon whish to rest a distinction between domestic judgments and judgments of sister States in regard to this question, for 


\section{The court has ample anthority to make a record; and it is} not true that this anthority is dependent upon jurisdiction over the party against whom the record speaks. Neither is it true that maintaining the verity of the record, in col-

under the provisions of the Constitution of the United States, which require that full faith and credit shall be given in each State to the public acts, records, and judicial proceedings of every other State, it is now well settled, that when a judgment of a court of a sister State is duly proved in a court of this State, it is entitled here to all the effect to which it is entitled in the courts of the State where rendered. If conclusive there, it is equally conclusive in all the States of the Union; and whatever pleas would be good to a suit therein in the State where rendered, and noneothers, can be pleaded in any court in the United tates. Ilampton $v$. McConnel, 3 Wheat. 234; Story Com. on Const. sec. 1S3; Mills v. Duryee, 7 Cranch, 481.

"In holding, therefore, that a defense that the party was not served and did not appear, although the record stated that he did, was good, our courts must have hold that such is the law of this State and the common law, and consequently that in the absence of proof of my special law to the contrary in the State where the judgment was rendered, it nust be presumel to be also the law of that State. The judgments of our courts can stand on no other logical basis. The distinetion which is made in almost all the other States of the Union between the effect of lomestic judgments and judgments of sister States, in regard to the conclusiveness of the presumption of juriscliction over the person, is sought to be explained by saying that in regard to domestic judgments the party aggrieved can oltain relief by application to the court in which the judgment was rentered, or by writ of error, whereas, in the case of a judgment rendercd against him in another State, he would be obliged to go into a foreign jurisdiction for redress, which would be a manifestly inade. quate protection, and, therefore, the Constitution may be construed so as to apply only where the persons affectel by the judgment were within the opcration of the proceeding. This explanation, however, does not remove the diffeulty in making the distinction, for if there is a conclusive presumption that there was jurisuliction, that presumption must exist in one case as well as in the other. Tho question whether or not the party is estopped can not be male to depend upon the greater inconvenience of getting rid of the estoppel in one case than in another.

"But asicle from this observation as to the ofiect of the authorities, an $\mathrm{cx}$ amination of them shows that our courts did in fact proceed upon a groumd common to both classes of judgments. The reasons are fully stated in the case of Starbuck $v$. Murray, 5 IVend. 14S; $21 \mathrm{Am}$. Dec. 172. In that case, which was an action upon a Massachusetts julgment, the defendant pleaded that ro process was served on him in the suit in whic! the judgment sued on was rentererl, and that he never appoared therein in person or by attorncy, and this p'ea was held good, notwithstanding that the record of the judgment stated that the defendant appeared to the suit. Marcy, J., in delivering the opinion of the court, and referring to the orgument that the defendant was estopped from asserting anything against the allegation of his appearance contained in the record, says:" The julge 
lateral proceedings, is more repugnant to natural justico than the opposite course would be. A party who has been wronged, by being judged withont any opportunity to mako his defense, may avoid the adjudication in various ways.

here quoted that part of the opinion of Julge Niarcy, quoted ante, sec. 133, and then proceeded as follows:

"This is but an amplification of what is sometimes more brielly expressed in the books, that where the defense gocs to defeat the record, there is no cstoppel. That the reasoning of Marcy, J., is applicable to domestic judgments is also the opinion of the learned annotators to Phillips' Exidence: Corien and IIill's Notes (1st cd.), p. S01, note 551. Referring to the opinion of Miarcy, J., before cited, they say: 'The same may be said respecting any judgment, sentence, or decree. A want of jurisdiction in the court pronouncing it may always be set up when it is sought to be enforced, or when any benefit is claimed under it; and the principle which ordinarily forbicis the impeachment or contradiction of a record has no sort of application to the case.' The dicta of our judges are all to the same effect, al. though the precise case does not seem to lave ariscu. In Bigelow $v$. Stearns, 10 Jolns. 41, 10 Am. Dec. 189, Spencer, C. J., laid lown the broad mle tliat if a conrt, whether of limited jurisdiction or not, undertakes to hold cornizance of a cause without having gained jurisdiction of the person by having him before them in the manner required by law, the proceedings are void. In Latham $v$. Elgerton, 9 Cowen, 227 , Sutherland, J., in regard to a judgment of a court of common pleas, says: 'The prineiple that a record can not be impeacher by pleading is not applicable to a case like this. The want of jurisdiction is a matter that may always be set up against a judgment when sought to be enforced or where any beneft is claimed unter it.' Citing Mills $v$.
Martin, 19 Johus. 33, he also says, (parge 229): "The plaintiff bolow mights have applied to the court to set asice their proceedings, but he was not bound to do so. He had a right to lie by until the judgment was set up against him, and then to show that the proceedings were void for want of juriscliction.' In Davis $v$. Packard, $c$ Wend. $32 \bar{i}, 332$, in the court of errors, the chancellor, spealing of domestic judgments, says: 'II the juriscliction of the court is general or unlimited both as to parties and subject-matter, it will be presumed to have had juris. diction of the cause unless it appears afhrmatively from the record, or by the showing of the party denying the jurisdiction of the court, that some special circumstances existed toonst the court of its juriscliction in that particular case.' In Bloom v. Burdick, 1 Hill, 130, Bronson, J., says: 'The distinction between superior and inferior ccurts is not of much importance in this particular case, for whenever it appears that there was a want of juriscliction, the judgment will be voil in whatever court it was rendered;' and in People v. Cassels, 5 Hill, 164, 185, the same learned judge makes the remark, that no court or officer can acquire juris. cliction by the mere assertion of it, or by falsely alleging the existence of facts upon which jurisdictiondepends. In Harrington $v$. The People, 6 Barb. 607,610 , Paige, J., expresses thie opinion that the juriscliction of a court, whether of general or limitc:! jurisdiction, may be inquircel into, aithough the record of the judgments states facts giving it juriscliction. Iic repeats the sane view in Noyes $v$. Putler, 6 Barb. 613, 61 7 ; and in Iard v. Shipman, Id. 621, 623, 624, where 
He may appeal to some higher tribunal and have the judgment reversed; he may move in the tribunal where it was pronounced and have it set aside; or he may seek and obtain equitable aid to prevent its execution. It is true

he says of superior as well as inferior courts, that the record is never conclusive as to the recital of a jurisdictional fact, and the defendant is always at liberty to show a want of jurisdiction, although the record avers the contrary. If the court had no jurisdiction, it had no power to make a record, and the supposed record is not in truth a record. Citing Starbuck $v$. Murray, 5 Wend. 15S; 21 Am. Dec. 172. The language of Gridley, J., in Wright $v$. Donglass, 10 Barb. 97,111 , is still more in point. $\mathrm{He}$ observes: 'It is denied by counsel for the plaintiff, that want of jurisdiction can be shown collaterally to defeat a judgment of a court of general jurisdiction. The true rule, however, is that laid down in the opinion just cited (op. of Bronson, J., in Bloom $v$. Burdick, 1 Hill, 13S, 143), that in a court of general jurisdiction it is to be presumed that the court has jurisliction till the contrary appears, but the want of jurisdiction may always be shown by evidence, except in one solitary case,' viz. ' When jurisdiction depends on a fact that is litigated in a suit, and is adjudged in favor of the party who avers jurisdiction, then the question of jurisdiction is judicially decided, and the judgment record is conclusive evidence of jurisdiction until set aside or reversed by a direct proceeding.'

" The general term in that case, held that a judgnent of the supreme court was void for want of service of an attachment, notwithstanding that the record averred that the attachment had been duly served and returned, according to law. The judgment in the case cited was reversed $(7 \mathrm{~N}$. $\mathrm{Y}$. 564), but not upon the point referred to here. It can not, however, be held to be an adjudication upon that point, because the judgment was not rendered in the exercise of the general powers of the court, but in pursuance of a special statutory authority.

"In the Chemung Canal Bank $v$. Judson, 8 N. Y. 254, the general principle is recognized that the jursidiction of any court exercising anthority over a subject may be inquircd into, and in Adams $v$. The Saratoga and Washington R. R. Co., 10 N. Y. 323, 333, Gridley, J., maintains, as to the julgments of all courts, that juriscliction may be inquired into, and disproved by evidence, notwithstanding recitals in the record, and says that such is the doctrine of the courts of this State, althongh it may be different in some of the other States, and perhaps also in England; and he says the idea is not to be tolerated that the attorney conld make up a record or decree reciting that due notice was given to the de. fendaut of a proceeding, when lie never heard of it, and the decree held conclusive against an offer to show this vital allegation false. That was a case of a special proceeding, and, therefore, not an authority on the point. In Pendleton $v$. TVecd, $17 \mathrm{~N}$. Y. 75, where a judgment of the supreme court was sought to be attacked collaterally, it is said by Strong, J.: ' It is undoubtedly true that the want of jurisdiction of the person is a good defense in answer to a judgment when set up for any purpose, and that such jurisdiction is open for inquiry;' and by Comstock, J., p. 77: 'I assent to the doctrine that where there is no suit or process, appearance or confession, no valid judginent can be rendered in any court; that in such a case 
he can not generally affect the rights of innocent third parties, growiug out of a judgment regular on its face. But as to those parties, it would be as great a violation of

the recital in the record of jurisdictional facts is not conclusive; citing Starbuck $v$. Murray. 'I think it is always the right of a party against whom a record is set up to show that no juriscliction of his person was acquired, and, consequently, that there was no right or authority to make up the record against him.' Selden and Pratt, JJ., concurred in these views, but the case was disposed of on a different point.

“In Porter $v$. Dronson, 29 How. Pr. 292; and S. C., 19 Abb. Pr. 236, the court of common pleas of the city of Few Fork held, at general term, that assuming the marine court to be a court of record, a defendant in an action on a judgment of that court might set up that he was not server with process and did not appear, notwithstanding recitals in the record showing juriscliction; and in Bolton $v$. Jacks, 6 Rob. 19S, Jones, J., says that it is now conceded, at least in this State, that want of jurisdiction will render void the judgment of any conrt, whether it lic of superior or inferior, of general, limited, or local jurisdiction, or of record or not, and that the bare recital of juriselictional facts in the recorl of a judgment of any court, whether superior or inferior, of general or limited jurisdiction, is not conclusive, but only prima facie cvidence of the truth of the fact recited, and the party against whom a judgment is offered is not, by the bare fact of such recitals, estopped from showing, by affirmative proof, that they were untrue, and thus reudering the judgment roid for vant of jurisdiction. IIe cites in support of this opinion several of the cases which $I$ have referred to, and Dobson $v$. Pearce, 12 N. Y. 164, and Hatcher $v$. Rocheleau, $18 \mathrm{Iil} .92$.
"It thus appears that the currcis of judicial opinion in this State is very strong and uniform in favor of the proposition stated by Jones, J., in $\mathbf{6}$ Rob. 19S, and if adopten here is alecisive of the present case. It has not as yct, however, been directly adjudicated, and if sustained it must rest upon the local law of this State, as it finds no support in adjudications elsewhere. There are reasons, however, founded upon our system of practice, which would warrant us in so holding. The powers of a court of equity being rested in our courts of law, and cquitable defenses loeing allowable, there is no reason why, to an action upon a judgment, the defendant should not be permitted to set up, by way of defense, any matter which rould be ground of relief in equity against the judgment; and it is conceded in those States where the record is held conclusive, that when the judgment has been obtained l,y frand or without bringing the defendant into court, and the want of jurisuliction does not appear upon the face of the record, relief may be obtained in equity.

"The technical difficulty arising from the conclusiveness of the record is thus obviated. In the present case the judgunent is set up by the defendants as a bar to the plaiatiffis action. Dut it must be borne in nind that this is an equitable action, being for the foreclosure of a mortgare. The defendants set up the forcelosure in the MeFarquahar case as a bar, but being in a court of cquity, the plaintiff had a right to set $u_{1}$ any natter showing that the defendants ourht not in equity to avail themselves of that judgment. They offered to show that it was entered ex parte on forged 


\section{the principles of "natural justice" to deprive them of} property acquired for a valuable consideration, by establishing some hidden infirmity preceding the judgment, as it

papers. It does not appear that the / ble relief, and therefore, that cvidenco plaintiff ever had any knowledge of of want of notice was admissible.

it, and it is not pretended that he was legally summoned. Such a judgment would never be npheld in equity, even in favor of one ignorant of the frand and claiming bona fide under it. He stands in 110 better position than any other party claiming bona fide under a forged instrument.

"The case is analogous in principle to that of the Bridgeport Savings Bank v. Eldredge, $2 S$ Conn. 557. That was a bill filed by a second mortsagee to redeem mortgaged premises from a first mortgagee. The first mortgagee had obtained a decree of th foreclosure against the second, and the time limited for redemption had expired. The record of the decree found the fact that legal service of the bill in the first suit had been made on the second mortgagee, but in fact none had been made, and he had no actual knowlerlge of the pendency of the suit until after the time limited for redemption had expired; and he would have redeemed if he had known of the decree.

"It was held: 1 . That the decree was not in any proper sense a bar to the present suit, as a judgment at law would be a bar to a suit at law; but that, without impugning the decree, the court could, for equitable reasons shown, allow a further time for redemprion.

" 2 . That, therefore, the question whether the plaintiff conld contradict the record by showing that no service of the bill was, in fact, made upon him, did not present itself as a technical one, to be determined by the rules with regard to the verity of judicial records, but only in its rela- ju tion to the plaintiff's rights to equita-

"The bill to redeem was not framel to open the former decree, and con. tained no allegations adapted to or praying for such relief, lut was in the ordinary form of a bill for redemption, talking no notice of the previons decrec. The decree was ses up in the answer, and it was averred that it was rendered on legal notice to the plaintiff. The court, however held that this defense might bo rebuited by evidence of facts which should preclude defendants from taling advantage of a decree of which they could not conscientiously avail themselres.

"Under the system of practice in this State, no reply to an answer setting up new matter is required, but the plaintiff is allowed to rcbut it $\mathrm{k} y$ evilence. Neither is it necessary to anticipate a defense arising upon a deed or record by inserting matter in the complaint in avoidance of it. The defense may never be set up, and the plaintiff is not bound to suppose that it will be. The state of the pleadings, therefore, presents no difficulty. The only question which might be raised is, that MeFarquahar, in whose name the decree was obtained, should be before the court, but no such objection was made at the trial, and if it had been, I do not see that he has any interest in the question. All the parties claiming under the decree and sale are parties to this action, and I see no reason why the validity of the McFarquahar foreclosure call not be tried herein as well as upon a motion or in a separate suit to set aside the decree. The judgment should be reversed and a new trial ordered." 
is to deprive the defendant of his rights, by maintaining the integrity of the record. And as the law can not minister abstrict justice to all the parties, it is at liberty to pursue such a course as will best subserve public policy. This course requires that there should be confidence in judicial tribunals, and that titlos resting upon the proceedings in those tribunals should be respected and protected. The hardship arising from an erroneous or inadvertent decision upon jurisclictional questions, is no greater than that issuing from an erroneous or inadvertent decision upon other matters. That the reversal of a judgment in an appellatio conrt shall not affect rights acquired under it, by third parties, is a rule universally and uncomplainingly acknowledged.

\section{\%135. Judgment IJever Void for Error.-Jurisdiction} being obtained over the person and over the subject-matter, no error in its exercise can make the judgment void. ${ }^{1}$ The authority to decide being shown, it can not be divested by being improperly or incorrectly employed. Error of decision may be corrected, but not so as to reach those who have in good faith relied upon its correctness. ${ }^{2}$ The same rules apply to actions to recover delinquent taxes as in other cases, in respect to collateral attacks. ${ }^{3}$ It can not be shown, to avoid the effect of such judgments, that the taxes were previously paid. ${ }^{4}$ Neither will such judgment he any the less effective because it appears from the judgment roll that the assessment was illegal and void. ${ }^{5}$ A statute of the State of Missouri authorized a statutory foreclosure of mortgages and a judgment for the sale of the premises, and a personal judgment against the mortgagor. A court of general jurisdiction at law and in equity, proceeding under this

\begin{abstract}
1 Wimberly $v$. Hurst, 33 Ill. 166; C'lond $v$. El Dorado Co., 12 Cal. 12s; Lx parte Watkins, 3 T'ct. 193; Preston $v$. Clark, 9 Geo. 246; Blakely $v$. Calder, 1 Smith, 621; B. \& IV. I. R. Co. v. Sparhawk, 1 Allen, 448; Cailletean v. Ingouf, 14 La. An. 623; Bol. giano $v$. Cooke, $19 \mathrm{Ml}$. 375; Savage $v$. Finssey, 3 Jones, N. C. 149; Hathaway $v$. Hemnningway, 20 Conn. 191; Feaster $\imath$. Fleming, 56 ill. 457; Fleming $v$. Johnson, 20 Ark. 421. A judginent in excess of the amount prayed for in the complaint, or giving relief not asked for in the complaint, is not void. Chase $v$. Christianson, 41 Cal. 253.
\end{abstract}

${ }^{2}$ Pursly $v$. Hayes, 22 Iowa, 11.
3 Scott $v$ : Pleasants, 21 Ark. 301; Eitel $v$. Foote, 39 Cal. 439; Wellshar v. Kelly, 69 Mo. 313; Graceland C. Co. v. People, 92 Ill. 619.

${ }^{4}$ Cadmus $v$. Jaelison, 52 Penn. S. 295.

${ }^{5}$ Mayo $x$. Al Loy, 32 Cal. p. 47:; Mayo v. Foley, 40 Cal. 281; Jones ". Gililis, 5 P. L. R. 132, and Anderso: v. Iyyder, 46 Cal. 134.

These cases seem to me irreconcilable with a portion of the opinion in the case of Ricilly $v$. Lancaster, 50 Cal. 354. In Nayo $v$. Ah Loy, the court said, that while a tax inzosed on property on I street, to $12 y$ for inproving $J$ street, would be unathihor- 
statute, rendered against the vendee of the mortgagor a foreclosure, and also a personal judgment. This personal judgment, in an elaborate opinion, was held to be void, on the ground that, in addition to having juriscliction over the subject-matter and of the person, the court must be authorized to give the kind of relief which its judgment assumes to grant. ${ }^{1}$

\& 135a. Judgments without Issue Joined.-In the precelling section, we have shown by numerous citations, that when jurisdiction over both the parties and the subjectmatter is once obtained, no error committed in the exercise of that jurisdiction can make the proceedings or judgment of the court void. We do not remember over meeting any direct denial of this rule. But there are cases, or perhaps, more accurately speaking, expressions of the conrts, which we are unable to reconcile with the rule. Among these cxpressions are some made upon different occasious in the State of Mississippi, in regard to the effect of judgments rendered in the absence of any issne of law or of fact. The Higin Court of Errors and Appeals in that State, but a few years ago, twice declared that "a judgment without an issue to be determined by it is a nullity;"' and this lan-

${ }^{1}$ Fithian $v$. \Ionks, 43 Mo. 502. |Armstrong v. Barton, 42 Miss.

2 Steele $v$. Palmer, 41 Mliss. 89; 506.

iz d and invalid, yet if such a tar werc assessed, and a suit begun for its collection, a judgment in favor of the plaintiff, if the court had jurisdiction, would be valid. In the case of Mayo $v$. Foley, it appeared from the record that several lots had been assessed in gross, and that a judgment by default hacl been rendered in a suit upon such assessment. The assessment was conceded to bo invalia. But its want of validity was held not to affect the judgment rendered to enforce it. But in Reilly $v$. Lancaster, it appeared from the complaint in the record that the tax was levied and assessed by virtue of a certain Act of the Legislature. This Act was unconstitutional. The court decided that the judgment and the sale thereunder were void. Why Eoley. 
guage was subsequently cited and approved by the Supreme Court of the same State. In neither of the cases was any jurisdictional question presented. The parties seem to havo been properly in court. The rendition of the judgments was, therefore, but an erroneous exercise of the powers possessed by the court. The error, in each instance, was corrected upon appeal. The parties did undertake to treat tho judgments as void; and, no doubt, the language of the court is attributable to the use of the words "void" and "erroneous" as convertible terms, rather than to any intent of decluring that the judgments before them on appeal were "nullities," in the absolute sense of that term.

\& 136. Judgment as an Entirety.-A judgment rendered against persons jointly liable, is an entirety, and if void as to one defendant, is void as to all $;^{2}$ and if erroneous itis to one joint defendant should bo reversed or vacated as to all. ${ }^{3}$ If, in an action on a judgment rendered against several joint defendants, it appears that one of them was never served with process, the judgment is considered as a nullity, even against the others. ${ }^{4}$ But it is different whero the parties aro severally liable. ${ }^{5}$

\section{137. Judgment for Contempt of Court.-In Tennes-} see, it was decided that it is essential to the validity of a judgment for contempt, that it should state as ground fo: its jurisdiction, the matters constituting the alleged contempt. ${ }^{6}$ But this decision professes to be a departare from the common law, and such it undoubtedly is. ${ }^{7}$ In California, the statute "regulating contempts and their punishment, provides, that when the alleged contempt is not committed in the presence of the court, an affidavit of the facts constituting the contempt must be presented. If there be no afidavit presented, thero is nothing to set the

${ }^{1}$ Porterfield $v$. Butler, 47 Miss. 170. $\mid$ Williams, 24 Ohio S. 6.5; Gargan v. ${ }^{2}$ Shufordv. Cain, 1 Abb. U. S. 302; School Dist., 4 Col. 53; Streeter v. Kitchens $v$. Hutchins, 44 Geo. 620; Marshall, 4 Col. 535.

Commereial Bank v. Wilson, $14{ }^{4}$ Holbrook $v$. Murray, 5 Vend. 161. Grant's Ch. 473; C. M. L. Ins. Co. $v . \quad{ }^{5}$ Bufium v. Tiamsdeil, 55 Maine, 252. Clover: 36 Mo. 392. This rte is G State $v$. Galloway, 5 Cold. 326 . said to be applicable to judgments at ${ }^{7}$ Ex purte Summers, 5 Ired. 119; law only. Voorhis v. Gamble, 6 Mo. Burdett $v$. Abbot, 14. East, 1; StockApp. 1.

dale $v$. Hansard, 9 Ad. \& EI. I; Sher-

"Newburg v. Munshower, 29 Ohio iff of Middlesex's Case, 11 Ad. \& EI, S. 769; 23 Am. Rep. 769; Frazicr v. 273. 
power of the court in motion, and if the affidavit, as presented, be one, which, upon its face, fails to state the substantive facts, which, in point of law, do, or might, constitute a contempt on the part of the accused, the same result must follow-for there is no distinction in such a case between the ntter absence of an affidavit and the presentation of one which is defective in substance, in stating the facts constituting the alleged contempt." Therefore, an order of ir court punishing a man for contempt not committed in the presence of the court, unless it is based upon an afhdavit sufficient in substance, is void.' Judgments entered punishing persons for contempt of comrt, are subject to review in superior courts upon jurisdictional grounds. They are sometimes brought up on appeal, ${ }^{2}$ sometimes on certiorari, and are frequently, in effect, reviewed on writs of habeas corpus; and the action of the court is sometimes arrested by a writ of prohibition. ${ }^{5}$

8138. "Sunday is Dies non Juridicus; and by the common law, all judicial proceedings which take place on that day, are void."

8 139. Judgment without Authority of Court.-Where Pluintiff, in open court, offered to let defendant take judgment for costs, and tendered his confession to that effect, which the defendant refused to accept, and the court declined to enter, the clerk, at request of plaintiff's attorney, entered the confession in the minutes of the court. Feld, that this entry being without consent, and in face of the decision of the court, was a nullity. ${ }^{7}$ In a very recent case tho force of an apparent appointment of an administrator waspermitted to be destroyed by proof that the surrogate in fact never acted upon the application and knew nothing of it, the appointment having been written by the clerk upon a blank previously signed by the surrogate. ${ }^{8}$ But in another case, is decree entered without being legally settled, and in viola-

'Batchelder $v$. Moore, 42 Cal. 415.

2 People a' O'Neil, 47 Cal. 109; Ifeurstal $v$. Minir, 6 Pae. C. L. J.

3 Batchelder $\%$. Moore, 42 Cal. 415.

* Le parte Rowe, 7 Cal. 1S1; Lic part: Colsen, 6 Cal. 31s.

5 Teople $\%$. Wright, 27 Cal. 151; Heurstal $\%$ Niuir, 6 Pac. C. L. J.
${ }^{6}$ Chapman $v$. State, 5 Bikf. 11l; Blood $\%$. Bates, 31 Verm. 147; Swann v. Broome, 3 Burr. 1595; Pearce v. Atwood, 13 Mass. 32\%; Arthur $v$. Mosiby, 2 Bibb, 589.

7 Barefield $\%$. Bryan, 8 Geo. 463.

${ }^{8}$ Roderigas v. East, T. I. S. I. 76 N. Y. 316; 32 Am. Rep. 209. 
tion of the express directions which the clert's minutes showed were given by the court, in relation to the prorisions to be inserted, no motion being made to correct or set it aside, was regarded as the valid decree of the court. 1

\& 140. If jurisdiction be obtained over the defendant in his lifetime, a judgment rendered against him subsequently to his death, is not void. ${ }^{2}$

8 141. A Judgment against a Party not named in the complaint, nor in any other part of the record, is void. We cannot presume that one who does not appear to have been a party, had his day in court. 3

8 142. Juxisdiction continues till Judgment.-Jurisłiction over a party being obtained, continues until judgment; and he must, therefore, take notice of all the proceedings until that time. After judgment he is not regarded as always present and under control of the court. An order made after judgment setting aside a sale, no notice being given to the adverse party, will not avail the party who procared it. 4

8 143. Jurisdiction for Certain Purposes Cnly.-Sometimes a court may have jurisdiction over the defendant for certain purposes only. Thus, by a statute of the State of Onio, jurisliction was given the court of common pleas over absent defendants on publication of notice "in all cases properly cognizable by courts of equity, where either the title to, or boundaries of land may come in question, or where a suit in chancery becomes necessary to obtain the recission of a contract for the conreyance of land, or to compel the specific execution of such contract." Acting under this statute, an absent defendant was proceeded

1 Cushman $v$. Shepard, 4 Barb. 113. 411 , where it is said that judgment 2 Collins v. Mitchell, 5 Flor. 364; "must be against one capable of conLoring $v$. Folger, 7 Gray, 50j; Cole- tracting for it, is a debt." For further man v. McAnulty, 16 Mo. 173; Yaple consideration of this subject, see sec$v$ Titus, 41 Penn. S. 203; Day v. Ham- tion 153.

burg, 1 Browne, 75; Gregory v. 3Ford $v$. Doyle, 37 Cal. 346; MoseHaynes, 21 Cal. 443. For contra opin- ley $v$. Cocke, 7 Leigh, 225.

ion, sec Carter $v$. Carriger, 3 Yerg. st 1; also IIorse $v$. Toppan, 3 Gray,

4 Wright $v$. Leclaire, 3 Clarke, 221. 
against by publication of notice, to compel the specific performance of a contract, and to obtain judgment for a sum of money claimed by the plaintiff under such contract. The court gave a decree for the performance, and also for the sum of money, and authorized a levy to be made to satisfy the decree. The action of the court, in awarding the sum of money, was attempted to be justified on the ground that a court having jurisdiction for one purpose, might exercise it for the complete settlement of the matters in controrersy, but such action was declared void for want of jurisdiction over the defendant for the purpose of rendering a personal judgment against him for a sum of money. ${ }^{1}$ In the same State, proceedings were instituted to forcclose a mortgage. Service of summons was made by publication. A personal judgment was taken against the defendant. This judgment was declared to be absolutely void, because the statute did not authorize any other judgment than one for the sale of the premises to satisfy the debt secured by the mortgage. ${ }^{2}$

\section{\& 144. Disqualineation of the Judge.-It occasionally} happens that, while a court has jurisdiction over the subject matter in controversy, and the parties to the action, the judge of the court is disqualified from acting by reason of his having an interest in the suit, or his being related to some of the parties, or his being within some of the disqualifications recognized by the common or by the statuto law. "It is a maxim of every country that no man should be judge in his own cause. The learned wisdom of enlightened nations, and the unlettered ideas of ruder societies are in full accordance upon this point, and wherever tribunals of justice have existed, all men have agreed that a judge shall nover have the power to decide where he is himself a party. In England, it has always been held, that, howerer comprehensive may be the terms by which jurisdiction is conferred upon a judge, the power to decide his own cause is always a tacit exception to the authority of his ofice. Such I conceive to be the law of this State." 3 These prin-

1Boswell $v$. Dickerson, 4 MIcL. 262. 3 Wash. Ins. Co. v. Price, 1 Hopl. 2 Wood $v$. Stanberry, 21 Ohio. S. Ch. 1.

142. 
ciples extend not only to cases in which the judge is a party upon the record, but also to other cases in which he has an interest, however minute, as where one of the parties is a corporation, of which the judge is one of the stockholders. ${ }^{1}$

8145. At Common Law. - While it is well settled by the common law, that no judge ought to act where, from interest or from any other cause, he is supposed to be partial to one of the suitors, yethis action in such a case is regarded as an error or irregularity, not affecting his jurisdiction, and to be corrected by a vacation or reversal of his jurlgment, except in the case of those inferior tribunals from which no appeal or writ of error lies." "If the facts are known to the party recusing, he is bound to make his objection before issue joined, and before the trial is commenced, otherwise he will be deemed to have waived the objections in cases where a statute does not make the proceedings void. Except in cases where a statute forbids it, the parties by a joint application to the judge, suggesting the ground of recusation, expressly waiving all objections on that account, and requesting him to proceed with the trial or hearing signed by them or their attorneys, may give the judge full power to proceed as if no objection existed. This is denominated in civil and Scotch law prorogated jurisdiction; and a tacit prorogation is inferred against a plaintiff who brings his cause before a judge who is known to him to be disqualified to try it: and against a defendant, who, knowing the existence of just grounds of recusation, appears, and without objecting, offers defenses in the cause, eithor dilatory or peremptory."3

8 146. Statutory Prohibitions.-In most of the States, statutes have been passed, which, in direct terms, prohibit

1 Place v. Butternuts Manf. Co. 2s 4223 ; Gorrill v. Whittier, 3 N. H. Barb. 503 ; Gregory v. C. C. \& C. R. 268.

R. Co., 4 Ohio, S. 675; Wash. In. Co. v. Price, 1 Hopk. 1.

3 Hoses v. Julian, 45 N. H. 52 ; Shropshire $v$. State, 7 Eng. 160; Ells-

2 Dimes $v$. Grand Junction Canal worth $v$. Moore, 5 Clarke, 4SG; DiliaCo., 47 Jur. 73 and 16 E. L. and Eq. win v. Calkins, 10 Wend. 167.

63 ; Heydenfeldt $v$. Towns, 27 Ala. 
judges from acting in certain specified cases. Thus, in Massachusetts, it was provided that when a judge of probate was interested in an estate, the same should be settled in another county; and in Alabama, the statute enacted that " no judge of probato shall act in any proceeding or take jurisdiction of any matter wherein he is interested." In both of these States it has been decided that the action of any judge in any matter where he is interested, is coram non judice and void." A statute in New York directed that " no judge of any court shall act as such in any cause to which he is a party, or in which he is interested, or in which he would be disqualified from being a juror by reason of consanguinity or affinity to either of the parties." This was held to divest the judge of jurisdiction in the extreme sense, so that the consent of the parties could not give him any anthority in the case. "The party who desired it might bo permitted to take the hazard of a biased decision if he alone were to suffer for his folly-but the State cannot endure the scandal and reproach which would be visited upon its judiciary in consequence. Although the party consent, ho will invariably murmur if he do not gain his caruse; and the very man who induced the judge to act when he should have foreborne, will be the first to arraign his decision as biased and unjust. If we needed an illustration of this, the attempt which the counsel for the moving party in this case assumed toward the court, the strain of argument he addressed to it and the impression it was calculated to make upon an audience, are enough to show that whatever a party may consent to do, the State cannot afford to yield up its judiciary to such attack and criticism as will inevitably follow upon their decisions made in disregard of the prohibitions of the statute under consideration." This language shows in a clear and forcible manner, the evils resulting from the practice of permitting any judge to act under any circumstances in a matter wherein his judgment is likely to be attributed to improper motives. Nevertheless, it is stipulated in many of the statutes upon this subject,

1 Cottle appellant, 5 Pick. 493; Minot, 3 Cush. 352; State v. CastleCoffiu v. Cottle, 9 Pick. 287; Sigour- berry, 23 Ala. 85.

ney v. Sibley, 21 Pick. 101; Gay v. 2 Oalley v. Aspinwall, 3 Comst. 547. 156 
that he may act by consent of the parties interested. But the general effect of the statutory prohibitions in the several States, is undoubtedly to change the rule of the common law so far as to render those acts of a judge, involving the exerciso of judicial discretion, in a case wherein he is disqualified from acting, not voidable merely, but void. ${ }^{1}$ But a judge disqualified from trying a cause, may make such orders as "are merely formal, or as are necessary for the continnance of the cause to a future term at which a qualified judge may be present." " On this ground it has been deciled that a judge who is assignee, may, as such assignee, confess judgment against himself in the capacity of assignee, in his own court, and that if any judge is sued in his own court, there is no objection to his entering judgment against himself upon his own confession, as such entry does not require any judicial investigation or determination. 3

$\S 147$. Where two out of three Judges were disqualified from acting, by reason of having been attorneys in the case, and the parties stipulated for trial before a single judge, the judgment pronounced by such judge, the others sitting pro forma, in order to constitute a court, was held to be valid.4

1Reams $v$. Kearns, 5 Cold. 217; annul the judgments of the courts, Conrerse v. MIcArthur, $17 \mathrm{Barb} .410$; ana it ought not to be done whero Schoonmalser $v$. Clearwater, $41 \mathrm{Barb}$. the consent of the parties alone is 200; Chambers 1 . Clearwater, 1 Keyes, requisite to their validity, and its 310; Estate of White, 37 Cal. 190; entry on the record is the only adChambers v. Hodges, 23 Tex. 101; missible evidence that it was given."

People v. De la Guerra, 24 Cal. 73; Oeluus $v$. Sheldon, 11 Fla. 138.

Where the statute prohibits the judge from acting in certain cases, unless by consent of the parties entered of record, the Supreme Court of Alabrma in a recent case said: "We think that justice will be best sub- 2 sorved by ruling that the disabilities mentioned, render the proceedings of the court voidable only and not roil. These disqualifications may be unknown, or so obscure as to require a iuclicial decision to determine their existence. It is a serious thing to
Hine v. Hussey, 45 Ala. 513.

Act of Probate Judge in IIassachusetts in appointing wife's brother administrator of estate of which her father was creditor, being a case in which the judge was disqualified, wins held void. Hall $v$. Thayer, 105 iIass. 219.

2 Buckingham v. Davis, 9 MId. 321; Heydenfelat $v$. Towns, 27 Ala. 422; Moses $v$. Julian, 45 N. If. 52; Listato of White, 37 Cizl. 190.

3 Thornton $v$. Lane, 11 Geo. 520 .

4 Walker $v$. Rogan, 1 Wis. 597. 
8 148. Judge de facto.-One who supposes himself to be invested with an office, and who, not being a mere usurper, acts in good faith as a judge, may constitute a court de facto. An objection to his authority or commission must be made before the trial, or it will be disregarded.1 Where the constitution of a State required a judge to be thinty years of age, it was decided that if the appointing power selected some person as a judge, who was less than thirty years old, his acts were valid until he was removed from office.2 The authority of a judge de facto can not be called in question collaterally. His title to the office can be considered and determined only in some proceeding instituted for that purpose. ${ }^{3}$

\& 14Sa.-Judgment Fraudulently Altered - The clerk of the court, at the instance of the judgment creditor, altered a judgment by default from $\$ 1,400$ to $\$ 1,500$. This judgment, having subsequently been collaterally drawn in question, was held to be roid, in an opinion from which we present the following extract: "We admit that we have been unable to find any reported authority precisely applicable to this case; but we are clearly of the opinion that the doctrine uniformly held which renders void a note, bond or bill which has been altered in a material part, $b \dot{y}$ 'the party in whose interest the alteration has been made, must apply with equal, if not greater, force to judgments in courts of record. In most of the States the act of altering a public record, wo think, would not only be held to render void any interest the party making the fraudulent alteration might have in the record, but it would be an indictable offense. We do not hesitate, then, to say that the judgment was void from and after the alteration." 4

${ }^{1}$ Case $v$. State, 5 Ind. 1; State $v . \mid$ Dec. 61 , and note at page 66 on offAnone, 2 Nott \& Mc. 27; State $v$. cers de facto.

Alling, 12 Ohio, 16; Masterson $v$. Natthews, 60 Ala. 260; see Hildreth's heirs v. McIntyre's devisee, 19 Am.

2 Blackburn $v$. State, 3 IIead. 690.

3 Pepin $v$. Lachenmeyer, 45 N. Y. 27.

4 Hardy $v$. Broaddus, 35 Tex. 668. 


\section{CHAPTER IX.}

\section{OF THE PERSONS AFFECTED BY JODGMENT.}

\section{PART I.-OF THE PARTIES.}

\$ 119. All Persons Competent to be Parties to Judgment.

$\$$ 150. Married Women.

$\S 151$. Infants.

$\S 152$. Lunaties.

$\S 153$. Deceased Persons.

\$ 154. Judgment Dinding only on the Parties to it.

8 155. General Expressions Confined to Parties before the Court.

$\$ 156$. Parties must be in same Capacity.

$\$ 157$. Parties Bound, though not Named in the Record, if Numerous.

8 158. Must be Adversary Parties.

$\S 159$. Must be Mrutually Bound.

$\$ 1$ Co. When Second Suit does not Include all the Parties to the First Suit.

$\$ 161$. When Second Suit Includes Other Parties.

\section{PART II.-OF PRIVIES.}

162. Privity.

$\S$ 163. Administrators or Executors, and Heirs or Devisees.

$\S$ 164. Principals and Agents.

\$ 165. Assignees and Assignors.

$\S 166$. Dailors and bailees.

\& 167. Garnishees.

$\$ 168$. Heirs and Ancestors.

$\S 169$. Lessors and Lessees.

$\$ 170$. Successors and Predecessors in Oflice.

$\S 171$. Tenants in Ejectment.

8 172. Remainder Men.

§ 173. Trustees anã Cestuis que Trust.

\section{PART III.-OF PERSONS BOUND, THOUGH NEITHER PARTIES NOR PRIVIES.}

\& 174. Persons Bound, who are neither Parties nor Privies.

\$175. Evidence to Show who aro the Real Parties in Interest.

\$ 176. Parties who are Bound by Judgment against another without Notice.

\$ 177. Corporations and Stockholders.

f 178. Counties and their Taxpayers.

$\$ 179$. MIasters and Servants.

180. Principals and Sureties.

$\$ 181$. Of the Notice required to be given a Party to whom a Iftigant mas

Resort for Indemnity.

\$ 182. Attachment Proceedings.

\$ 183. Bailees and Bailors.

184. Officers and their Indemnitors.

8 185. Tenant and Landlord.

8 186. Vendee and Vendor.

$\$ 187$. Warrautee and Warrantor.

\$ 188. Parties who cannot be called on to Conduct suit.

189. Persons not Parties to Suit not Bound by reason of particlpating therein.

190. Distributee of Common Fund. 


\section{PART I.-OF THE PARTIES.}

8 149. Who may be Parties.-The power and authority of our courts extend over every class of persons and every species of property, situate within the territorial limits in which those courts are authorized to act, and subject to thie same sovcreignty which organized the courts and invested them with judicial functions. Every subject is thereforo liable to be made a party litigant, and to be bound by the result of the litigation. Those disabilities arising from infancy, from coverture, or from mental infirmities which render parties incapable of being bound by their contracts, do not have the efiect of exempting any person from tho control of the courts. Reasoning from the hypothesis that a judgment is a contract, a few of the courts have held that parties exempt from the force of their agreements, could not be bound by a judgment. Thus it was said in one case: "The fact that defendant was a married woman when the judgment was rendered against her, would alone be a good plea to this action. A judgment is in the nature of a contract; it is a specialty, and creates a debt, and to have that effect, it must be taken against one capable of contracting a debt."1

\& 150. Married Women.-The case just cited sustains the doctrine, that a married woman may disregard the process of the court, and assert against any judgment rendered thereon, the defense of coverture which was available to her as before the judgment. A judgment against a feme covert upon a note, made during her coverture, was also deemed a nullity in Maryland. The principle that a party can not impeach a judgment on any ground which might have been pleaded as a defense, it was thought had no application to such a case, because the defendant was not competent to employ an attorney to present her plea. ${ }^{2}$ The decision thus made in Maryland has been approved in Missouri, and tho reasons for such approval were expressed in the following form: "It is very clear to my mind, that the responden' was not competent to employ an attorney or make a defense

1 MIorse $\%$. Toppan, 3 Gray, 411. therefore, in the State where such In Wook $\%$. Ward, 8 Cent. L. J. 1S8, judgment was entered, had no capsin the Circuit Court of the United city to sue or defend, conld not cenStates for the Sonthern District of clude such person in any subsequeut Ohio, it was arlindged that a judgment judicial proceeding.

ogainst one who was a slave, and who, ${ }^{2}$ Grifth $v$. Clarke, 18 Mid. 457. 
in her own name. She was sued in a legal proceeding upon a personal contract altogether void at law; and shall the entry of an unauthorized judgment against her by default for non-appearance, be allowed to prejudice her? The principle that a party cannot impeach a judgment in a collateral proceeding, does not apply to a case where the defendant is a femme covert, and not sui juris. As the respondent labored under a total disability, and could neither control nor be sued at law, I think the judgment of the Law Commissioner's Court was void." 1 The spirit of the decisions in Pennsylvania is, no doubt, in accord with that manifested in Missouri and Maryland. In the first named State, a wife is liable upon certain contracts, made in reference to the improvement of her separate estate. Upon these contracts she may be sued, and a valid judgment may be rendered against her. But "every judgment against her which does not show upon its face her liability, is a roid judgment." Such is the general declaration made in a recent decision" by Judge Sharswood. In case the cause of action is stated in different counts, some counts stating fucts sufficient to constitute a cause of action against the wife, and others stating facts not sufficient for such a cause of action, he seems to concede that in a collateral attack upon the juaggment, the onus of showing that it was based upon some claim or contract by which she was not bound, rests upon the wife. Notwithstanding the decisions to which we have referred, the preponderance of authority is in faror of the rule that a judgment against a married woman is not roid; and that when erroneous, because based upon a contract which she was not competent to make, or from any other reason, it is still binding upon her until set aside upon appeal or by some other appropriate method. "The acts of femmes covert, in pais, may be, and frequently are, roid; yet this does not impair the conchusive force of judgments to which they are parties, and if they be not reversed on error or appeal, their effects cannot be gainsaid, when they are enforced by ultimate process, or when they are brought to bear on their rights, in any

โ Tiggins v. Peltzer, 49 Mo. 152; ${ }^{2}$ Swayne v Lyon, 67 Pa. S. 439. TPril ข. Simmons, 66 Mo. 617. 
finture controversy. And a judgment against husband and wife may be satisfied out of the property of either, or out of the common property."1 "There would be no safety in purchasing at judicial sales, under judgments rendered after due service of process on female defendants, if the title of the purchaser could be defeated by proof in a collateral action, that the defendant in the judgment was a married woman at the time of the institution of the suit, or that she was incapable in law of contracting the debt for which the judgment was rendered." 2 Where a mortgage was made by a woman, in her maiden name, five days after her marriage, and scire facias was thereafter regularly prosecuted against her, on the mortgage, to judgment, and a sale was had in pursuance thereof, it was held that the judgment could not, in nn action of ejectment, be impeached by proof of her coverture. ${ }^{3}$ Judgments against femmes cuvert cannot be set aside or enjoined in equity, without establishing such facts as would entitle the applicant to relief independent of the fact of coverture, with the exceptrous of judgments shown to have been obtained through the fraud of the husband, in combination with another person. It is not enough that a married woman prove facts suficient to have avoided the judgment in the first instance. She must allege and establish that she was deprived of a full defense by the contrivance of her adversary. The inaction of her husband will not sustain the charge of connivance. ${ }^{4}$ Ignorance of her legal rights, on account of which a femme covert failed to make her defense at law, will not entitle her to relief in equity. ${ }^{5}$ In Pennsylvania, the bond of a married woman, though her husband join in it, is void. A judgment entered on such bond by warrant of attorney, is void; and so is the judgment in scire facias to revive such judgment, and a sale thereunder passes no title. ${ }^{6}$

\footnotetext{
${ }^{1}$ Howard v. North, 5 Tex. 200; Baxter v. Dear, 24 Tex. 17; Spalding $v$. Wathen, 7 Bush, 659; Guthrie $v$. IToward, 32 Iowa, 54; Wolf $v$. Van Netre, 23 Iowa, 397; Glover $v$. Moore, 60 Geo. 159; Washburn v. Gouge, 61 Gco. 512.

${ }^{3}$ Hartman v. Ogborn, 54 Penn. S. 120.

${ }^{4}$ Green $v$. Branton, 1 Dev. Eq. 500.

${ }^{5}$ Van Metre $v$. Wolf, 27 Iowa, 341.

${ }^{6}$ Dorrance v. Scott, 3 Whart. 309; Caldwell v. Walters, $18 \mathrm{~Pa}$. S. 79; Graham v. Long, $65 \mathrm{~Pa}$. S. 383.

${ }^{2}$ Gambette $v$. Brock, 41 Cal. 83.
} 
8 151. Infants.-In Illinois, a decree of a court of general jurisdiction, where the record shows that notice was served on an infant defendant, in person, instead of on his guardian as required by statute, and no guardian ad litem was appointed, is voil. ${ }^{1}$ This is, however, an almost isolated exception to the current of authorities. In Kentucky, by the provisions of the Civil Code, no judgment is to be rendered against an infant until after defense by a guardian. Yet a judgment pronounced after constructive service on an infant, without the appointment of any guardian, was held to be erroneous, but binding until reversed. ${ }^{2}$ The general tendency is to regard the plea of infancy as a personal plea which may be waired." And whether such plea is interposed or not, a judgment or decree against an infant, properly before the court, is as obligatory upon him as though he were an adult, except in cases where he is allowed time, after coming of age, to show cause against the judgment or decree. ${ }^{4}$ If an absolute decree be made against an infant, he is as mucl bound as a person of full age, and will not be permitted to dispute the decree, except upon the same grounds which would be available if he were an adult. ${ }^{5}$

\section{152. Lunatios. - While an occasional difference of} opinion manifests itself in regard to the propriety and possibility of binding femmes covert and infants by judicial proceedings, in which they were not represented by some competent authority, no such difeerence has been made apparent in relation to a more unfortunate and more defenseless class of persons; but by a concurrence of judicial authority, lunatics are held to be within the jurisdiction of the courts. ${ }^{6}$ Jidgments against them, it is said, are neither void nor voidable. They can not be reversed for error on account of defendant's lunacy; the proper remedy in favor of a lunatic being to apply to chancery to restrain proceed-

1 Whitney $v$. Porter, 23 Ill. 445.

2 Simmons $v$. MeKay, 5 Bush, 25.

3 Blake $v$. Douglass, 27 Ind. 416.

4 Waring's Heirs $v$. Reynolds, 3 B. Mon. 59; Marshall $\%$. Fisher, 1 . Tones Law, 111; Pond $v$. Doneghy, $19 \mathrm{~T}$. Mon. 55s; Smith $v$. Ferguson, 3 Met. Ky. 424; Ralston v. Lahee, 8 Iowa, 23; Beeler $v$. Bullitt, 3 A. K. Marsh. $250 ; 13$ An. Dee. 161; Demnett $v$. Hemill, 2 Scho. \& Lef. 575; Porter $v$. Robinson, 3 A. K. Marsh. 254; 13 Am. Dec. 153; Wills $v$. Spraggin, 3 Gratt. 507; Smith 2. McDonald, 42 Cal. 484. 31 Ohio S. 247.
${ }^{5}$ Joyee v. McAvoy, 31 Cal. 273; English v. Savage, 5 Oreg. 518; Brown v. Lawson, 51 Cal. 615. The court has no power to appoint a guardian cel litem until proeess has been served on the infant: Galpin v. Pagre, 1 Cent. L. J. 491; 1s Wall. 350.

${ }^{6}$ Lamprey $v$. Nudd, 9 Foster, 299; Wood v. Bayard, 63 Penn. S. 320 ; Foster $v$. Jones, 23 Geo. I6s; Sacramento Savings Bank v. Spencer, 53 Cal. 737; Stigers v. Brent, 50 Md. 214; 10 Cent. L. J.473; Jolunson v. Pomeroy, 163 
ings, and to conrpel plaintiff to go there for justice. ${ }^{1}$ In a suit against a lunatic, the judgment is properly entered against lim, and not against his guardian. A lunatic has capacity to appear in court by attorney. The legal title to his estate remains in him, and does not pass to his guardian. The judgment, to be effective, can not, therefore, be against any other person than the lunatic. ${ }^{2}$

8 153. Deceased Parties. - Judgments for or against deceased persons are not generally regarded as void, on that account. ${ }^{3}$ Such judgments have sometimes been upheld in collateral proceedings, on the ground that their rendition necessarily implied that the parties were then living; and that this implied finding in support of judgments ought not to be allowed to be impeached by evidence not contained in the record. ${ }^{4}$ A suit was prosecuted for the benefit of A., in the name of a nominal plaintiff, who was dead, without any objection being made by the defendant; judgment was rendered by nil dicit. Defendant petitioned for a supersedeas. It was denied, on the ground that the defendant was estopped from urging the death of plaintiff, by his failure to plead it when he had an opportunity to do so. ${ }^{5}$ While, in a case like this, it might be proper to uphold the judgment on the grounds here taken; and while, in other cases, where the parties have not estopped themselves by neglecting to make proper pleas, the judgment may be shielded by refusing to permit any collateral attack for the purpose of showing the decease of one of the parties, still, cases arise where the death of a party appears upon the record. Even in such cases the judgment is simply erroneous, but not void. This is because the court, having obtained jurisdiction over the party in his lifetime, is thereby empowered to proceed with the action to final judgment; and, while the court ought to cease to exercise

1 Sternberg $v$. Schooleraft, 2 Barb. Case $v$. Ribelin, 1 J. J. M. 30; Hayes 153; Robertson $v$. Lain, 19 Wend. $v$. Shaw, 20 Minn. 405; Reid v. 6.50; Clark $v$. Dunham, 4 Den. 262.

2 Waller $v$. Clay, 21 Ala. 797.

3 Spalding $v$. Wathen, 7 Bush, 659; Taylor $v$. Snow, 26 Am. Rep. 311; Coleman $v$. McAnulty, 16 Mo. 173; 47 Tex. 462.

Camden $v$. Robertson, 2 Scam. 508; ${ }^{5}$ Powell $v$. Washington, $15 \mathrm{Ala}$. Stoetzell $v$. Fullerton, 44 Ill. 108; 803. 
its jurisdiction over a party when he dies, its failure to do so, is an error to be corrected on appeal if the fact of the death appears upon the record, or by writ of error coram nobis if the fact must be shown aliunde. That a judgment against a person dead at its rendition, is valid until reversed or set aside by some competent judicial authority, and that it cannot be collaterally attacked, is established by a larger preponderance of the authorities than can be brought forward to shield a judgment against a married woman from collateral assault and overthrow. But there are, nevertheless, quite a number of cases in which judgments rendered for or against a person then deceased, but over whom in his lifetime the court had jurisdiction, have been declared roid. 1 In the opinion of the court in Euald v. Corbett (32 Cal. 493), language is employed which seems inconsistent with the theory that the court retains jurisdiction to pronounce judgment against a party after his death. But no such question was before the court. The decree under consideration in that case, though rendered subsequent to the death of one of the litigants, was not pronounced until lis executor has been made a party to the suit, and was against the executor and not against the deceaserl. The decree, being against the executor, was properly held not to be binding on the heirs. Dut a later decision, in the same State, though made without any apparent consideration of the authorities upon the subject, makes it clear that the Supreme Court deem a judgment rendered in favor of a dead man, to be a mero nullity. ${ }^{2}$

\& 151. "Res inter alios acta alteri nocere non debet." "A transaction between two parties ought not to operate to the cisadvantage of a third." 3 The application of this maxim to the law of judgments, requires that no person shall be affected by any judicial investigation to which he was not a party, unless his relation to some of the parties was such as to make him responsible for the final restilt of the litiga-

1 Lee $v$. Gardner, 26 Miss. 521; Par- | Edwards v. Whited, 29 La. An. 647; ker $v$. Horne, $3 \mathrm{~S}$ Miss. 215; Tarleton Carter $v$. Carriger's Ad., 3 Yerg. 411; v. Cox, 45 Id. 430; Young v. Pickens, 24 Am. Dec. 5S5. Judgment against $45 \mathrm{Id}$. 553; New Orleans \& C. R. R. an extinct corporation is void: SturCo. $v$. Bosworth, S La. An. S0; Nor- ges v. Vanderbilt, 73 N. I. 384. ton $v$. Jamison, 23 La. An. 102; McCloskey $v$. Wingfield, 29 La. An. 141;

$2 \mathrm{McCreery} v$. Everding, $44 \mathrm{CaL} 286$.

3 Broom's Maxims, p. $\delta 5 \bar{S}$. 
tion. It is a general rule that an adjudication takes effect only between the parties to the judgment, and that it gives no rights to or against third parties. ${ }^{1}$ Though the above maxim is more generally quoted than the maxim: "Res inicr alios acta, aliis nec prodest, nec nocet." "A transaction between other parties neither benefits nor injures those not interested," yet this latter maxim is far more applicable to judgments, and to every kind of estoppel than the former, because it expresses the truth that no person can bind another by any adjudication, who was not himself exposed to the peril of being bound in a like manner, had the judgment resulted the other way. The persons who are directly parties to a judgment, can generally be ascertained by an inspection of the record; but this is not always the case. It may happen that the name of some of the parties is incorrectly stated. "The weight of authority is that, if the writ is served on the party by a wrong name, intended to be sued, and he fails to appear and plead the misnomer in abatement, and suffers judgment to be obtained, he is concluded, and in all future litigation may be connected with the suit or judgmeut by proper arerments;" 2 and when such averments are made and proved, the party intencled to be named in the judgment is aftected as though he rere properly named therein. ${ }^{3}$ In an action to which there were four defendants, the names of but three appeared in tho margin of the entry upon the record, which recited the rerdiet of the jury and the judgment of the court. This was held to be a valid judgment against all who were properly and technically parties defendant in the suit, on the ground, that this entry was to be construed by referring to the process, pleadings and proceedings in the action.* The identity

${ }^{1}$ Pothier, part 4, ch. 3, § 3, art. 5; venson, 63 Me. 364; IS Am. Rep. Society etc. $v$. Hartland, 2 Paine, C. 231.

C. 536; Chase v. Swain, 9 Cal. 130;

Peters $v$. Spitzfaden, 24 La. An. 111; MicIntosh $v$. Jarris, $\&$ Upper Canada Q. B. 535; Doe v. Dennison, S Upper Canada Q. B. 610; Chubine v. MIcMullen, 11 Upper Canada Q. B. 250; Nacky $v$. Coates, 70 Pa. S. 350; Samuel v. Agnew, S0 Ill. 55̄a; Rice $v$. Coolidge, 121 Mass. 393; Hill $v$. Ste-

2 National Bank v. Jaggers, $31 \mathrm{MI}$. 3S; Ins. Co、v. French, is How. U. S. 409; Smith $v$. Bowker, 1 Mass. 76 ; Oakley $v$. Giles, 3 East, 16S; Smith v. Patten, 6 Taunt. 115; Crawford v. Satchwell, 2 Stra. 121S; Guinard v. Heysinger, 15 Ill. „SS.

${ }^{3}$ Sarry $v$. Carothers, 6 Rich. 331.

"Wilson $v$. Collins, 11 Humph. 189. 
of names in the record of a former suit with those in a present suit, prima facie establishes identity of parties; but if the record fails to demonstrate the identity, it may be shown by evidence aliunde. ${ }^{1}$ In Georgia, a mortgage may be foreclosed without making the grantee of the mortgagor a party to the suit; but the judges seem to be divided in opinion, as to whether such foreclosure is, under all circamstances, conclusive against such grantee of all the matters established by the decree. ${ }^{3}$ A decree does not bind one who, though originally a party to the suit, was permitted to withdraw therefrom before the decree was entered. ${ }^{4}$ As against strangers to the suit, a decree of divorce is not evidence of the marriage of the parties to it. ${ }^{\circ}$

8 155. General Expressions. - In all censes where the expression in the judgment is general, it will be confined to the parties servel with process. ${ }^{6}$ Thus, where there are two defendants, one of whom is served with process and pleads, and the judgment entry recites that the parties came by their attorneys, it will be intended that no one came but he who has been summoned and has pleaded. ${ }^{7}$ In Vermont, a record similar to this was differently construed. ${ }^{8}$ In a later caso in that State, the record showed service of process on two ont of four defendants. The judgment recital was "that defendants came by their attorney." This entry, it was held, did not show an appearance as to more than the two defendanis served. As to the former case, it was said to be supportable only upon the assumption that in an action where there were but two defendants, the use of the plural term "parties," wis inconsistent with the theory that any less than two persons appeared. ${ }^{9}$ In Colorado, a judgment against the defendants, one ouly being served with process, was treated as being arainst both, and was therefore reversed. ${ }^{\circ}$ If, during the pendency of an action, a nol. pros. be entered as to somo of the defendants, a general judgment subsequently taken against the "defendants," will be construed to include ouly those as to whom no nol. pros. was entered."

\footnotetext{
${ }^{1}$ Garwood v. Garwood, 29 Cal. 514; Thompson $v$. Nanrow, 1 Cal. 42S.

2 Kuowles $v$. Lawton, 18 Geo. 476.

3 Guerin v. Danforth, 45 Geo. 493.

4 Orens $v$. Alexander, is N. C. 1.

5 Gourand v. Gomrand, 3 Kedf. 262.

c Chester v. Miller, 13 Cal. 561;

Edwards $v$. Toomer, 14 S. \& MI. 76; Miller $v$. Ewing, 8 S. \& MI. $42 \mathrm{I}$.

7 Iuckett $v$. Pope, 3 Ala. 552

8 Blood $v$. Crandall, $28 \mathrm{Vt} .396$.

9 Iivbbard v. Dubois, $37 \mathrm{Vt} .94$.

${ }^{10}$ Langley 2 . Gull, I Col. 7 I.

${ }^{11}$ Doyd $v$. Bayham, 5 Humph. 386.
} 
\& 156. In Same Capacity.-Every person may, at different limes, or at the same time, occupy different relations, act in different capacities, and represent separate, and perhaps, antagonistic interests. It is a rule of both the civil 1 and the common law, ${ }^{2}$ that a party acting in one right can neither be benefited nor injured by a judgment for or against him, when acting in some other right. As familiar illustrations of this rule, it is said that a judgment against one as tutor, ${ }^{3}$ will not prevent his recovering the same demand in his own right; that "a woman is not estopped after coverture by an admission on record of herself and her husband during coverture; and an heir claiming as heir of his mother, is not estopped by an estoppel upon him as the heir of his father."4 A plaintiff, suing as administrator of his wife, is not affected by a judgment against himself in her lifetime, in an action to which she was not a party. ${ }^{5} \mathrm{~A}$ decree against on $\theta$ as administrator, on a bill to compel the delivery of slaves claimed as a gift from the intestate, will not conclude his rights as a creditor, on a bill by him against the former plaintiffs, to set aside the gift conveyance for fraud. 6 Nor is a decree against the validity of an entry, in a suit between M. and A., any bar to a subsequent action of R., by A., his guardian and next friend, against M., involving the validity of the same entry. ${ }^{7}$ The foreclosure of a mortgage, by an action to which a widow is made a party, in her character of executrix and devisee, does not affect her claim for dower in the mortgaged premises; ${ }^{8}$ neither does a foreclosure against herself and other heirs of the mortgagee (she not having joined in the mortgage), no reference being made in the petition to her right to dower. ${ }^{9}$ In Missouri, a widow is not estopped from claiming lands in her own right, by the fact that dower had been allotted to her in the same land, ${ }^{10}$ nor by the fact that she was made a party to a suit for partition of the lands. and for the assignment of her dower therein, which suit was prosecuted to judgment and a decree entered therein, assign-

1 Pothier, p. 4, c. $3, \S 3$, art. 4 .

2.2Snith's LeadingCases, 589; Brooking $x$. Dearmond, 27 Geo. 58; Robinsin is Casc, 5 liep. 32 b. ; Benz $v$. Hines, 3 Konsas, 397; Com. Dig. "Estoppel," "C."; Linder v. Arno, 65 Me. 26.

3 'othier, p. 4, c. 3 , $\$ 3$, art. 4.

4 Ph. Ev. vol. 2. pp. 11, 12.

5 Blakey $v$. Newby, 6 MIunf. 64. 168
${ }^{6}$ Jones $v$. Blake, 2 Hill Ch. 629.

7 Marshall $v$. Rongh, 2 Bibb, 628.

${ }^{8}$ Lewis $v$. Smith, 11 Barb. 152; Frost $v$. Koon, 30 N. Y. 428 .

${ }^{9}$ Moomey $v$. MIaas, 22 Iowa, 380. See Benjamin v. Elmira I. R. Co., 49 Barb. 441 , which contains expressions contra.

10 Thompson v. Renoe, 12 Mo. 157. 
ing her dower and ordering the land to be sold. ${ }^{1}$ These decisions, however, seem to be based upon the idea that the widow can always be relieved from a judgment made against her when she was ignorant of her true rights, rather than upon the theory that her claims in the different proceedings were by different rights and in different capacities. A suit by the president of the Orphans' Court, for the use of the assignee of the liusband, for the amount of the share of the wife, is no bar to a recovery in the name of the same officer for the use of the wife and her husband, as her trustee. ${ }^{2}$ A judgment against plaintiff, suing as the assignor of a nonnegotiable promissory note, without the privity of the assignee, after the assignment was made, and notice thereof given the debtor, is no bar to an action by the same assignor, for the use of his assignee, especially if there is reason to believe that the former action was prosecuted in frand of the rights of the assignee. Sometimes one of the parties is before the court in two or more capacities, and the judgment binds him in both. 'Thus, one who is brought before the conrt as the trustee of certain bondholders, and, as such, a decree is entered against him, can not relitigate the same matter on the ground that he was himself a bondholder of some of the bonds. If he was such holder, he is bound by the former decree, becanse as trustee in the former suit "he was representing himself."

8 157. Numerous Parties.-The general rule, that no person can be treated as a party to a judgment who was not also a party to the action, is subject to some exceptions. If a suit be brought by $A$. for himself and others not named, alleging that they are a large number of persous interested mder a deed with himself as purchasers for a valuable consideration, and that they are so numerous that it is impracticable to bring them all before the court, the decree subsequently rendered in the suit can be used for the benefit of any of the unnamed parties. ${ }^{5}$ An insolvent partnership made an assignment of its effects for the benefit of creditors. One of these creditors brought an action in his own behalf and that of others who should come in and claim the

\footnotetext{
${ }^{1}$ Crenshaw $v$. Creek, 52 Mo. 101. 561 .

2 Lishelman v. Shuman, 13 Pa. S.

${ }^{4}$ Corcoran v. Chesapeake Canal Co., ${ }^{5}$ Huributt v. Butenop, 27 Cal. 50;

Dawson v. Coles, 16 Johns. 51. Carpenter v. Canal Co., 33 Ohio S. 307.
} 
benefit thereof, against the assignees for an accounting and distribution of the funds in their hands. In this action a referee was appointed with power to take and state the acconnt of the assignees, and to report the amount due such creditors as should come in under the order and seek the benefit of the action. Notice to the creditors was given by a publication made by authority of the court, and requesting them to come in and exhibit their demands. In pursuance of such notice creditors came in and exhibited their demands, an account was taken with the assignees, the referee's report was confirmed by the court, and the funds in the hands of the assignees were distributed accordingly. 'These proceedings were said to "have been sanctioned as indispensable to the distribution of trust funds and the settlement of trust estates in courts of equity;" and the decree of distribution was held to be binding upon all the creditors of the assignors, whether they knew of the proceedings or not, "just as if they had been parties to it, and their claim had been denied and defeated, nnless they can assail or attack it for fraud, and claim its absolute nullity as to them on that account." 1 While it is a general rule that cestuis que trust must be made parties to bar their equitable interests, it is well settled that they need not be, if very numerous. ${ }^{2}$ Where real estate was vested in trustees, for the use of two hundred and fifty subscribers, it was held to be unnecessary to make others than the trustees parties to the foreclosure of a mortgage. ${ }^{3}$ A similar decision was made, where the trustee for the holder of three hundred and twenty railroad bonds was sued for the purpose of foreclosing a prior mortgage. ${ }^{4}$ But it seems to be certain that the courts dislike to proceed in the absence of any of the parties in interest, and that they will only fail to order all parties to be brought before them in extreme cases where the dificulty of proceeding would otherwise be very great. ${ }^{5}$

\% 158. Adversary Parties.-Parties to a judgment are not bound by it, in a subsequent controversy, between each

${ }^{1}$ Kerr v. Blodgett, 48 N. Y. 66; see $\mid$ Willink v. Canal Co., 3 Green. Ch. also Thompson $v$. Brown, 4 Johns. Ch. $377 ;$ N. J. Franklinite Co. $v$. Ames, 1 610; Wilder $v$. Keeler, 23 Am. Dec. Beas. 507.

781; 3 Pai. 164; Egberts v. Wood, $3{ }^{3}$ Van Vechten $v$. Terry, 2 Johns. Id. 518; $24 \mathrm{Am}$. Dec. 236; Brools v. Ch. 197.

Giblons, 4 Pai. 374; McKenzie v. "Board of S. v. M. P. R. R. Co., 24

L'Amoureux, 11 Barb. 516.

${ }^{2}$ Shaw $v$. R. R. Co., 5 Gray, 170; ${ }^{5}$ Doody v. Higgins, 9 Hare App. 32. 170 
other, unless they were adversary partios in the original action. If $A$. recovers judgment against $B$. and $C$. upon a contract, which judgment is paid by $\mathrm{B}$., the liability of $\mathrm{C}$. to $\mathrm{B}$., in a subsequent action for contribution, is still an open question, because, as to it, no issue was made or tried in the former suit. ${ }^{1}$ As between the sereral defendants therein, a joint judgment establishes nothing but their joint liability to the plaintiff. Which of the defendants should pay the entire debt, or what proportion each should pay, in case each is partly liable, is still unadjudicated; ${ }^{2}$ but a judgment against two joint debtors prevents either, in a suit with the other, from denying the existence and obligation of the debt, though he may still prove, by any competent evidence in his power, that the whole burden of the obligation should bo borne by the other. ${ }^{3}$ One of several plaintiffs is not prevented by a judgment from showing, when called upon by his co-plaintifis to contribute his proportion of the expenses incurred, that he had no knowledge of the institution of the suit. ${ }^{4}$ It is the constant practice of courts of equity to decree between co-defendants upon proper proofs, and under pleadings between plaintifs and defendants, which bring the respective claims and rights of such co-defendants between themselves under juclicisol cognizance. But the language of a decree in chancery must be construed in reference to the issue which is put forward by the prayer for relief and other pleadings, and which these show it was meant to decide. Hence, though the language of the decree be very broad and emphatic,-enough, so perhaps, when taken in the abstract merely, to include the decision of questions between co-defendants, yet where the pleadings, including the prayer for relief, are not framed in such a way as to bring their rights before the court; or are framed with a view to litigate the rights of defendant and plaintiff between each other only, such general language will be held to apply between plaintiff and defendant only, and not between co-defendants. ${ }^{5}$ A decree on a bill in equity, filed

\footnotetext{
1 Buffington $v$. Cook, 35 Ala. 312 ; IIcCrory $v$. Parks, 18 Ohio S. 1.

2 Admr. of Cox $v$. Hill, 3 Hamm. 412; Duncan $v$. Holcomb, 26 Ind. 378. ?
}

3 Lloyd v. Barr, 11 Pa. s. 41.

4 Wilson $v$. MLower, 5 Miass. 407.

5 Graham v. R. R. Co. 3 Wall. 701. 
by the executor of a will against the residuary legatees to determine their distributive shares, fixing the amount of the advancement to a legatee and the amount of his distributive share, is conclusive evidence of such amount in a suit for partition of real estate devised to the legatees by the same will. 1 In cases like this, it is evident that the several persons joined as defendants are adversary parties. The only issues framed in the case, are, in respect to their relative claims under the same instrument. The plaintiff, though nominally a party, is indifferent to the result. As the entire contest must be made by defendants against each other, their position is such as to make the decree conclusive upon them whenever the same questions shall again be involved.

8 159. Parties must be Mutually Bound.-No party is, as a general rule, bound in a subsequent proceeding by a judgment, unless the adverse party now seeking to secure the benefit of the former adjudication, would have been prejudiced by it if it had been determined the other way.? "The operation of estoppels must be mutual. Both the litigants must be alike concluded, or the proceedings cannot be set up as conclusive upon either." 3 "It is essential to an estoppel that it be mutual, so that the same parties or privies may both be bound and take advantage of it."4 "Nobody can take benefit by a verdict that had not been prejudiced by it had it gone contrary." 5 A verdict and judgment in favor of a trespasser, would not be conclusive evidence in favor of a co-trespasser, in an action by the same plaintiff. ${ }^{6}$ A judgment against the indorser, is not evidence for him in an action against the maker. ${ }^{7}$ A judgment against the tenant, in a writ of entry brought by an heir, at the ex-

\footnotetext{
1 Torrey $v$. Pond, 102 Mass. $355 . \quad$ McCurdy, 13 Ill. 496; Harris v. Plant

${ }^{2}$ Redmond $v$. Coffin, 2 Dev. Eq. \& Co., 21 Ala. 639; Wright v. Hazen, 443; Wood v. Davis, 7 Cranch, 271; 24 Verm. 143.

Simpson $v$. Jones, 2 Sueed, 36.

${ }^{3}$ Vol. 1 Greenl. Ev., § 524; Manigault v. Deas, 1 Bai. Eq. 283; Burcess in Inom $v$. Lane, 3 Greenl. 165; Griswold v. \& Bl. 447.

Jackson, 2 Ed. Ch. 461; Simpson v. ${ }^{6}$ Sprague v. Oakes, 19 Pick. 455.

Pearson, 31 Ind. 1; Huntington $v$. ${ }^{7}$ Fenn v. Dugdale, 31 Mo. 580; Jewett, 25 Iowa, 249; Bradford $v$. Brooklyn $v$. Bank of Republic, 11 C. Bradiord, 5 Conn. 127; Edwards v. L. J. 330.
} 
pense of the co-heirs, to try title, cannot be taken advantage of by another of the heirs, in a suit against the tenants for mesne profits. ${ }^{1}$ A party to a divorce suit, in which the bill was dismissed, cannot use the decree of dismissal, or any of the findings of the court or jury, in a controversy between himself and a third party, for the purpose of establishing any of the facts asserted by such decree or finding. Thus, if, in an application by a husband for divorce, on the ground of adultery, the jury find the allegations of plaintiff to be true, and also find that he has been guilty of a similar offense, avd his bill is, on that account, dismissed, he cannot, on being sued for necessaries furnished his wife, defend himself by the finding of the jury in respect to her adultery. ${ }^{2}$ Neitber is the dismissal of a bill of a wife for divorce, on the ground of extreme cruelty, conclusive evidence, in an actirn by a third person against the husband for necessaries, that the wife left him without suflicient justification. ${ }^{3}$ A juj 3 ment in favor of one creditor, declaring a conveyance voil as against creditors, is not evidence in a suit by another creditor, for he would not have been concluded if the first suit had terminated differently. ${ }^{4}$ A conviction upon an indictment, is not usually admissible as evidence in any ciril action, because the parties in the civil suit are not generally parties to, nor mutually bound by the criminal prosecntion. But if a bond be given to the State that a party will abstain from committing some unlawful act, a subsequent indictment of the principal and his conviction thereunder, are, in a civil suit by the State on the bond, conclusive evidence against the principal and prima facie evidence against the surety. ${ }^{5}$ Notwithstanding the self-evident justice and propriety of the rule that estoppels must be mutual, and that no man shall bind another by an adjudication which he is himself at liberty to disregard, instances are not rare where the rule has been denied or overlooked by courts and judges, whose decisions are entitled to great respect. Lord Kenyon admitted the record of a former action, in which the defenclants in the suit before him were

\footnotetext{
${ }^{1}$ Allen v. Carter, 8 Pick. 175.

${ }^{2}$ Needham v. Brenner, 12 Jur. N. p. $434 \& 14$ W. R. 694.

3 Burlen $v$. Shannon, 3 Gray, 397. 4 Winston $v$. Starke, 12 Gratt. 317. 5 Webbs v. State, 4 Cold. 199.
} 
adversary parties, but with which the plaintiff was in no way connected, for the purpose of proving that the defendants were partners. His Lordship justified his ruling on the ground that one of the defendants who had denied the partnership in both actions, had a full opportunity to sustain his denial in the former action, by every means of proof which he could now employ.' In a case in New York, one of two heirs or devisees, having brought an action against an executor, and obtained a decree establishing the interests of both, the court held that, though the other heir or devisee might, if he thought proper, set up claims at variance with the decree, yet if he elected to claim the benefit of it, all its adjudications of rights and all its settlement of principles were conclusive in his faror against the executor." Recently it has been held in Maine that a written verdict of a jury finding a person to be the original promisor of a note instead of the endorser, as he claimed to be, is conclusive against him in a litigation with any other party to the note." In the circuit court of the United States, a decision was made to the efiect that a defendant who, after making his defense, is compelled by the court to pay a sum of money to plaintiff belonging to another, will be protected from a suit by the rightful owner;" because 1st. The equities are equal, it being no greater a hardship for one man to lose his property, than for another to pay a debt twice; $2 \mathrm{~d}$. That the lis pendens of the former suit, being notice to the whole world, the rightful owner was necrligent in not making his title known; 3d. The right of the true owner to recover his property remains unchanged, bat the person of whom he should recover it, is he into whose possession it has passed by direction of a competent judicial tribunal, and from whom a recovery could be had, as in the cases of Le Chevalier v. Lynch, Dougl. 170, and Plillips v. Hunter, 2 H. Dla. 402.

\& 160. Suit not Including all Former Parties.-A diversity of opinion exists in reference to the effect of a judg-

\footnotetext{
${ }^{1}$ Whately $v$. Menheim, 2 Esp. 608. ${ }^{3}$ Sturtevant $v$. Randall, 53 Maine,

${ }^{2} \mathrm{O}^{\prime}$ Brien $v$. Heeney, $2 \mathrm{Ed}$. Ch. 149. 2 th:

Mayer v. Foulkrod, 4 Wash. C. C. 503.
} 
ment or decree, in a subsequent action, in which some, but not all, of the adversary parties to such judgment or decree are litigants. Parke B., in the course of the argument before lim in Christy v. Tancrea (9 MI. \& TV. p. 438), said: "There is no authority that a judgment against $A$. and $B$. jointly, is evidence in an action against $\mathrm{A}$. alone, because it may have proceeded on an admission of B., which might or might not be evidence against A., according to circumstances." On the other hand, it is stated, with the utmost confidence, that a judgment in the case of $A$. v. $B$. ard $C$., will be allowed to be set up as an estoppel in a suit between A. and B.; and that this furnishes an exception to the general rule that the judgment must have been between the same parties. ${ }^{1}$ This exception seems to be consistent with the general rule. It viclates none of the principles usually applied to estoppels; but, on the contrary, is supported by those principles and the considerations of public policy on which they are based. The former adjudication ought not to be any less conclusive on the adverse parties A. and B., because other persons shared with them the advantages and disadvantages of the former suit. The matter could have been as efficiently litigated as though $\mathrm{A}$. and $\mathrm{B}$. were the sole parties in interest; and the opportunity for the settlement of their controversy having been so given, there is no reason why their controversy should be re-opened.

8 161. Between Additional Parties. - A difference of opinion is also manifest in relation to the effect of a judgment in a subsequent action, in which other persons as well as the parties to the judgment are litigants. According to the opinion given in 2 Smith's Leading Cases, p. 683 : “A judgment against a co-contractor, co-obligor, or copartner, will not be evidence where another is joined." This seems, in unost cases, to be perfectly reasonable. Otherwise, the jarty now joined will either be benefited by a decision which could not have prejudiced him, if it had gone the other way, or bound by an adjudication which he had no opportunity to resist. But it has been leeld that a judgment

${ }^{1}$ Lawrence $v$. Hunt, 10 Wend. 80;| U. S. 233; Davenport $v$. Barnett. 51 25 Am. Dec.; Ehle v. Bingham, 7 Ind. 329; Girardin v. Dean, 49 ' $\mathrm{Hes}$. Barb. 494; Dows v. McMichael, 6 Pai. 243.

139; Thornpson $v$. Iioberts, $2 \pm$ How. 
in favor of $\mathrm{A}$. is admissible evidence in a subsequent controversy involving the same questions, and in which $\mathrm{A}$. and B. are pluintiffs, though B., then being disinterested, was a witness at the former trial. ${ }^{1}$ If an action be broughtagainst a portion of several joint promisors, and they, waiving the non-joinder of the others, proceed to trial and recover on the merits, the judgment is admissible in favor of the defenclants in a future action against all the promisors on the same promise. ${ }^{2}$ In this instance it happens that persons not bound by a former suit are entitled to avail thomselves of its benefits, because their liability cannot, against their objection, continue after that of their co-rontractors has ceased; and because the defendants in the former suit must either be deprived of the fruits of their litigation, or those fruits must also be given to persons who were not parties to the suit. Besides, if the plaintiff established his cause of action against the joint promisors sued, he could not, under the operation of the law of merger, recover against any other of the promisors. To deny the effect of the judgment as an estoppel in a future action against all the promisors, would place him in a better position than if the judgment had been in his favor. For the reason that a joint debt can not be severed, it may happen that a party is not prejudiced by a judgment by which he would otherwise bo bound. Thus where, in an action against A., a town being summoned as trustee, answered that it owed A. and B.; and judgment was thereupon entered up against it for the amount, it was held this judgment cannot defeat a subsequent action by $\mathrm{A}$. and $\mathrm{B}$. for the same amount. ${ }^{3}$

\section{PART II.--OF PRIVIES.}

8 162. Privies.- "The term privity denotes mutual or successive relationship to the same rights of property." 4 This relationship is produced either by operation of law, by descent, or by voluntary or involuntary transfers from

1 Blakemore $v$. Canal Co., 2 C. M. |holding under a party litigant and \& R. 133.

${ }^{2}$ French $v$. Neal, 24 Pick. 55.

3 Hawes $v$. Waltham, 18 Pick. 451.

4 Greenl. Ev. \$ 189. A privy is one deriving title subsequent to the con:mencement of the suit. Hunt $v$. Haven, 52 N. H. 162.

176 
one person to another. Hence privies have from an early period in the history of the common law been classified as:

Privies in law, as lords by escheat, tenant by courtesy, tenant in dower, executor or administrator, the incumbent of a benefice, and all others that come in by act of the law;

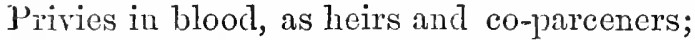

Privies in estate, as where there is a mitual or successive relationship to rights of property not occasioned by descent nor by act of law. 1

Neither this, nor any other classification of privies, is of any considerable importance in considering the operation of judgments. All privies are in effect, if not in name, privics in estate. They are bound because they have succeeded to some estate or interest which was bound in the hands of its former owner; and the extent of the estoppel, so far as the privy is concerned, is limited to controversies afiecting this estate or interest. The manner in which the estate was lawfully acquired neither limits nor extends the operation of the estoppel created by a former adjudication, and is therefore immaterial. It is well understood, though not usually stated in express terms, in works upon the subject, that no one is privy to a judgment whose succession to the rights of property thereby affected, occurred previously to the institution of the suit. A tenant in possession prior to the commencement of an action of ejectment cannot therefore be lawfully dispossessed by the judgment unless made a party to the suit. ${ }^{2}$ The assignee of a note is not affected by any litigation in reference to it, beginning after the assignment. ${ }^{3}$ No grantee can be bound by any judgment in an action commenced against his grantor subsequent to the grant, otherwise a man having no interest in property, could defeat the estate of the true owner. 4 The foreclosure of a mortgage, or of any other lien, is wholly inoperative upon the rights of any person not a party to the

12 Coke Litt. $352 \mathrm{~b}$.

Ph. Ev. vol. 2, pp. 13, 14, Mr. Garrison $v$. Savignac, 25 Mo. 47.

Greenleaf adds the class, Privies by $\quad{ }^{3}$ Powers $v$. Heath's Admr., 20 Mo. representation, in which he includes 319.

executors and administrators.

* Winslow $v$. Grindal, 2 Greenl. 64;

${ }^{2}$ Sampson v. Ohleyer, 22 Cal. 200; Marshall v. Croom, 60 Ala. 121; Cook Ex parte Reynolds, 1 Caines, 500; v. Parham, 63 Ala. 456. 
suit, whether such person is a grantee, ${ }^{2}$ judgment creditor, ${ }^{2}$ attachment creditor, ${ }^{3}$ or other lien holder. ${ }^{*}$ A judgment of freedom in favor of a woman does not establish the status of her children previously born. The right of property in the children, if rested in some person at their birth, could not be divested by any proceeding to which he was not a party. ${ }^{5}$

8163. Administrators and Executors.-A judgment against an administrator is binding on the creditors and legatees of the estate. ${ }^{6}$ If, in an action by an administrator against the widow for property claimed as assets of the estate, she recover, the judgment in her favor is, in the absence of fraud, conclusive on the creditors. ${ }^{7}$ A decree against an executor is biuding on an administrator de bonis mon ${ }^{8}$ according to some of the authorities, but the preponderance of the decisions on the subject is to the effect that there is no privity between an executor or administrator and an administrator de bonis non, and that a judgment against one is not evidence against the other $;{ }^{9}$ and that the recovery of judgment by an administrator is, after his death, no bar to an action by lis successor. ${ }^{10}$ If letters of administration are granted in different States to different persons, there is no privity between such administrators. A judgment obtained against one will furnish no cause of action against the other to affect assets in the lands of the latter. ${ }^{\text {" }}$. And the converse of this proposition is true, for a judgment obtained by one of the administrators can not be asserted as a cause of action by the other. ${ }^{12}$

Between the real and personal representatives of a deceased person there is no privity. Hence a judgment

${ }^{1}$ Brush $v$. Fowler, 36 Ill. 58.

2 Brainard $v$. Cooper, 10 N. Y. 356.

3 Lyon $v$. Sanford, 5 Conn. 544.

${ }^{4}$ Smith $v$. Claimants, 4 Nev. 254.

5 Bloodgood v. Grasey, 31 Ala. 575; Davis $v$. Wood, 7 Cranch, 271 .

${ }^{6}$ Stone $v$. Wood, 16 Ill. 177; Castellaw v. Guilmartin, 54 Geo. 299; but a judgment in an action between the administrator and heirs does not bind the legatees. Valsain $v$. Cloutier, 22 Am. Dec. 179; 3 La. 170.

7 Pickens $v$. Yarborongh, 30 Ala. 408.

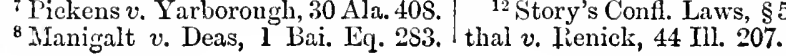

9 Thomas $v$. Stearns, 33 Ala. 137; Rogers 2 . Grannis, 20 Ala. 247; Wenrick v. McMurdo, 5 Rand. 51 ; Graves v. Flowers, 51 Ala. 402; 23 Am. Rep. 555.

${ }^{10}$ Note 259 to Ph. on Ev. by C. H. \& E.; Grout $v$. Chamberlain, 4 Mass. 611; Allen v. Irwin, 1 S. \& R. 549; Barnehurst v. Yelverton, Yelv. 83.

1I McLean $v$. Meek, 18 How. U. S. p. 16; Stary $v$. Thrasher, 6 How. U. S. 44; Brodie v. Bickley, 2 Raw. 431 . 12 Story's Confl. Laws, \$522; Rosen- 
against an administrator or executor is never conclusive against the heirs or devisees, ${ }^{1}$ and a judgment for or against an heir or devisee has no effect upon an administrator or executor. ${ }^{2}$ A decree against an executor is not binding on tho heir, "because he is not a party to the suit, can not offer testimony, adduce evidence in opposition to the claim, nor appeal from the judgment." 3 The allowance of a claim against an estate by tho administrator and the probato judge has the same effect as a judgment. But as the heirs are not bound by a judgrent against the administrator, they are at liberty to dispute any claim so allowed, because the allowance has no higher effect than a judgment. If the allowed claims are made the basis on which to obtain an order to sell the real estate, the heirs are not precluded from contesting them as freely as though they had acquired none of the properties of a judgment; for, as to the heirs, they are not yet res judicata. ${ }^{4}$ But a judgment against the personal representative is prima facie evidence against the realty. ${ }^{5}$ In proceedings against heirs by scire facias, to revive a judgment recovered against the executors, and to make it a charge against real estate, the onus of proof in respect to the justness of the claim is thrown upon the heirs. ${ }^{6}$ It is clear, however, that such proceedings do not preclude a defense upon original grounds, except where the administrator or executor is also the heir or devisee. ${ }^{7}$ For, though in this case a party claims in two capacities, a judgment against him in one capacity is also conclusive against him in the other. He represents the interests of one and the same person; and has full opportunity, in a suit against himself as the personal representative, to protect his rights as successor to the realty. It is not intended that one so situated, should have the right to be twice heard upon the

$1 \mathrm{McCly} v$. Nichols, 4 How. Miss. 4 Beckett $v$. Selover, 7 Cal. 215; 31 ; Cowen \& Hill \& Edwards, note Estate of Hidden, 23 Cal. 362; Stone 259 to $\mathrm{Ph}$. Ev.; Vernon v. Valk, 2 v. Wood, 16 Ill. 177.

Hill Ch. 257 ; Collinson v. Owens, 6 5Steele $v$. Liniberger, 59 Pa. S. 303. G. \& J. 4; Robertson v. Wright, 17 6 Sergeant's Heirs v. Ewing, $36 \mathrm{~Pa}$. Gratt. 534; Early v. Garland, 13 S. 156.

Gratt. 1.

2 Dorr $v$. Stockdale, 19 Iowa, 269.

3 Garnett $v$. JIacon, 6 Call. 308. 
sane controversy. One who suffers an administrator who has no authority, to sue and to recover judgment for a debt due the estate, and then pays the judgment, can not thereby defeat an action brought by an administrator having the right to sue. ${ }^{1}$ A written agreement to convey lands is a covenant real. If broken in the lifetime of the covenantee it passes to his personal representatives after his death, though he had commenced an action for its specific execution. The revival of the suit by the heirs, and their obtaining a decree in it for the performance of the agreement, in nowise affects the administrator. He may afterward recover clamages for the breach of the contract to convey. In such a case, there might be a decree in favor of the heirs for specific execution, saving the rights of the creditors; but the personal representative is an indispensable party, whose rights cannot be affected if he be omitted. ${ }^{2}$ As there is no privity between the personal representative and the heir, the latter can not have the advantage of an adjudication in favor of the former. Hence a perpetual injunction obtained by an executor to prevent $\mathrm{R}$. from prosecuting any action for the recovery of the arrears of an annuity against such executor or other representative of the testator, does not prohibit R. from prosecuting such action against the heirs. ${ }^{3}$

\%, 163a. The Relation between the Heirs and the Administrator of a deceased person is different in California from that recognized elsewhere. Section 1581 of the Code of Civil Procedure declares that the executor or administrator must take into his possession all the estate of the decedent, real and personal. Section 1582 of the sume Code states that "actions for the recovery of any property, real or personal, or for the possession therenf, and all actions founded upon contracts, may be maintained by or against execntors and administrators, in all cases in which the same might have been maintained by or against their respective testators or intestates." An action of ejectment having been brought by an administrator, and judgment having been rendered therein, the question arose as to the effect, under these statutory provisions, of this judgment upon the heirs of the deceased. The court held the judgment to be binding for the following reasons: "The prin\begin{tabular}{ll|l} 
' Pond $v$. Makepeace, 2 Met. Mass. & $\begin{array}{c}{ }^{2} \text { Combs } v \text {. Tarlton's Admr., } 2 \text { Dana, } \\
454 . \\
{ }^{3} \text { Dale } v \text {. Rosevelt, } 1 \text { Pai. Ch. 35. }\end{array}$
\end{tabular} 
ciple of law upon which the estoppel rests has reference to the fact that, in the former action, the hostile titles were directly opposed before the court rendering the former judgment, and that the superiority of the one over the other was ascertained and fixed by that judgment. That an administrator appearing in an action involving the interests of the estate, represents as well the heirs as the creditors of the deceased is well settled. But, he represents not only the interest of heirs and creditors, but also the title which the deceased had at the time of his death. When, therefore, in an action of ejectment, an administrator, seeking to recover the real estate of his intestate, alleges upon the record the seizin of that intestate, he thereby tenders an issue directly upon the title to the premises; if issue be joined by the defendant upon this point, and judgment be rendered, it is necessarily an adjudication that the title of the intestate was or was not superior to the title set up by the defendant in the action." After proceeding further to show that the issues in the action by the administrator, are the same as the issues in any action subsequently brought. by the heir relying upon title derived from his ancestor, the court concludes, that "if upon an action brought by the administrator agaiust a defendant in possession of real property, upon the allegation of seizin in the deceased at the time of his death, it be adjudged that the intestate was not seized, or that the defendant had the better title, the legal consequence follows that the administrator, the heirs and creditors, and all persons subsequently asserting title as having vested in themselves by reason of the death of the intestate, are alike estopped to deny the superiority of the title of the defendant adjudicated in the former action." 1 The decision of this case, like that of all other controversies in reference to estoppel by judgment, required the determination of two questions: 1st. Have the issues here sought to be litigated been before litigated and settled? and $2 d$, if so, was the litigation between the present litigants or persons with whom they are in privity? The first question was carefully considered by the court, and was, no doubt, correctly determined. The second question was disposed of by assuming "That an administrator appearing in an action involving the interests of the estate, nepresents as well the

${ }^{1}$ Cunningham v. Ashley, 45 Cal.485; I.Ieeks v. Vassault, 3 Saw. C. C. 206. 
heirs'as the creditors of the deceased, is well settled." In view of the unanimity of the numerous decisions cited in the preceding section, all holding that no privity exists between an administrator and an heir of the deceased, we are at a loss to understand when and where the contrary rule assumed by the court became, as the court states, well settled. This decision, while not in harmony with any wellsettled principle of the common law, and at variance with the language employed by all courts and judges, in considering the same or kindred questions, is nevertheless probably justified under the provisions of the code already quoted. These provisions are so ample in their scope as to indicate the intent of the legislature that the executor or administrator might sue or be sued to the same extent as his testator or intestate; and that any suit brought or defended by the administrator or executor should result in a final determination of the questions at issue.

8 164. Principal and Agent.-Agents and principals do not, as such, have any mutual or successive relationship to rights of property. They are not in privity with each other. If the principal is ever bound by a judgment against lis agent, it is in those cases in which he authorized the institution of the suit, of which we shall treat in the latter part of this chapter. An action by, and in the name of an agent for trespass for taking coin from his possession and convertiug it, in which the jury, finding that the property belonged to the principal, and therefore gave the plaintiff nominal damages, is no bar to an action by, and in the name of the principal, unless it can be shown that the former suit was bronght under his direction and for his benefit. ${ }^{\prime}$ A note transferred by delivery, was by the transferee placed in the hands of an agent with orders to demand payment, and, if necessary, to place it in the hands of an attorney for collection by suit. Payment not being made upou demand, the note was given to an attorney. He, on account of his ignorance of its ownership, sued in the name of the agent; and the suit wis successfully defended on a plea of set-off against the plaintiff. The true owner, having no notice of this action, was permitted to afterward recover in his own name. ${ }^{2}$

8165. Assignees and Alienees.-The person who pur-

${ }^{1}$ Pico $v$. Welster, 12 Cal. $140 . \quad$ | ${ }^{2}$ Lawrence $v$. Ware, 37 Ala. 553 182 
chases property, real or personal, is entitled to the benefits and subjected to the disadvantages which, by the operation of final adjudications, had attached to the property in the hands of its former owner. A mortgagee having commenced an action for the possession of the mortgaged premises, was opposed by the mortgagor's setting up the defense of usury. Failing in this defense, the mortgagor conveyed to a third person, who brought a writ of entry against the mortgagee, and songht to support his action by proof of the same usury which had been presented as a defense in a former suit. Whereupon it was held that the former judgment was an estoppel running with the land, and preventing the decree of the mortgagor from prevailing in auy action brought on the title acquired by his conveyance. ${ }^{1}$ A verdict and judgment against a feme sole will be binding on her future husband, so fur as he represents her person or succeeds to her estate. ${ }^{2}$ On the other hand, the grantee of real estate, though a witness on the trial of the former cause, may assert the judgment in favor of his grantor in reference to the real estate, as an estoppel. ${ }^{3}$ And a judgment against a claimant, upon the trial of the rights of personal property levied under execution, is conclusive evilence agaiust such claimant, in a subsequent controversy between him and the purchaser at the execution sale."

\& 166. Bailors and Bailees.-The bailor and bailee both have such an interest in the property as authorizes either to maintain an action for its injury or couversion. A judgment against a bailor in an action in reference to the property, is a bar to any subsequent suit by the bailee. ${ }^{5}$ A recovery and satisfaction by either, is a bar to any subsequent suit by the other; but a recovery and satisfaction in an action commenced by the bailee is said to be no defense to an antecedent action in the name of the bailor. ${ }^{6}$ A bailee delivering goods to a third person, believing him to be the owner, may avail himself, in any action by the bailor, as an estoppel of a judgment against the bailor, in an action wherein he sought to recover the same goods from the person to whom the bailee had delivered them. ${ }^{7}$

8167. Garnishees.- "Where one is by garnishment involuntarily made a party to a suit in which he has no per-

${ }^{\prime}$ Adams v. Barnes, 17 Mass. 365. 99.

i Ph. Ev., vol. 2, pp. 15, 16.

4 Shirley v. Fearne, 23 I.Iiss. 653.
5 Green v. Clarke, 12 N. Y. 348 .

${ }^{6}$ Steamboat v. MeCraw, 31 Ala. 659.

${ }^{7}$ Burton $v$. Wilkinson, $18 \mathrm{Vt}$. 1S6; Bates v. Stanton, 1 Duer, 79. 
sonal interest, he is fully protected by the proceedings in law, provided he acts in obedience to the orders of the court, in the surrender and payment of the property attached." ${ }^{\prime}$ But a judgment against a garnishee is never conclusive against the principal that the amount, for which the garnishee has been made liable, is the full amount due from him. Otherwise a garnishee, by confessing part of the lobt, could avoid payment of the residue. He will, in no case, be protected by the judgment beyond the amount it required Lim to pay; ${ }^{2}$ and this is the rule applied to judgments against a trustee. ${ }^{3}$ But a judgment for or against a garnishee, in an attachment issued in favor of one creditor, is not binding on any other attaching creditor. Between the two creditors there is no privity. ${ }^{4}$ After a suit is begun, and a person is summoned as the trustee of the defendant, the plaintiff has the right to litigate the question of the trustee's indebtedness, unless some litigation has been previously pending in reference thereto. Therefore, a judgment in favor of the trustee in an action between him and the defendant, is not evidence against plaintiff to prove that the party summoned as trustee was not indebted to the defendant when summoned, except the judgment be the result of a suit pending before the service of the trustee process. ${ }^{5}$

\& 168. Ancestors and Feirs.-An heir is in privity with his ancestor. Therefore a verdict for or against the ancestor is evidence for or against the heir, in controversies in relation to property descended from the ancestor to the heir. ${ }^{\circ} \quad$ No such privity exists between heirs and devisees. A decree against the former establishing that a conveyance of certain lands was made by the ancestor, has no effect upon the rights of the latter.?

\& 169. Lessor and Lessee.-The lessee and his assignees are in privity with the lessor and his successors in interest.

1 Herman on Estoppel, $\$ 119$.

2 Barton $v$. Allbright, 29 Ind. 489; Tams $v$. Bullitt, 35 Pa. S. 308.

Tims $v$. Bullitt, 35 Pa. S. 308.

3 Groves $v$. Hrown, 11 Mass. 334 ;

Evowi v. Dudley, 33 N. H. 511.

4 Wheeler $v$. Aldrich, 13 Gray, 51;

Breading $v$. Siegworth, 29 Pa. S. 396; 5 TVebster $v$. Adams, 58 Maine, 317. 6 Lock $v$. Norborne, 3 Mod. 142. 7Cowart $v$. Williams, $3 \pm$ Geo. 167.

184 
Where an action of ejectment was maintained by the assignee of the lessor, against the assignee of the lessee, for non-payment of rent, under a lease containing a covenant for re-entry, the judgment was held to be a bar to any recovery in any action by a party claiming under the purchaser at a foreclosure sale, under a mortgage executed by the assignee of the lessee, subsequent to the execution of the lease, but prior to the commencement of the ejectment suit; the decree of foreclosure being entered after the suit in ejectment was brought, but before it terminated. ${ }^{1}$ If a lessee bring an action, in respect to the lands leased, without the direction or authority of the lessor, the latter is not bound by the result of the suit, and therefore can not bind another by it. ${ }^{2}$ The landlord is not, in general, affected by any litigation against or in favor of his tenant in respect to the demised premises; ${ }^{3}$ but if the issue is such as involves the lessor's title, and he assumes the defense or the prosecution of the suit, the judgment operates upon his title as though he were a nominal party to the action." In some cases the law has been held otherwise. In South Carolina, the landlord is not bound by a judgment against his tenant, though the tenant set up the landlord's title, and the landlord was present in court at the trial assisting the tenant, and though it is made to appear that his efforts were in no way impeded by the tenant, and full opportunity was given the landlord to examine and cross-examine the witnesses, because if he had been a defendant it might have caused some change in the jury, or in the admissibility of evidence, or have in some manner affected the result. ${ }^{5}$ In another case, a judgment against a tenant after a defense conducted by the landlord was held admissible, but not conclusive, against the latter.. "Upon the ground that the lessor of plaintiff and the tenant are substantially real parties to an ejectment; a judgment in ejectment is admissible evidence in an action for mesne profits, and this, whether the action be brought by the nominal plaintiff or by the lessor of this

\footnotetext{
1 Bennett $v$. Couchman, 48 Barb. 73 .

${ }^{2}$ Wenman $v$. Mackenzie, 5 El. \& Bl. 447.

${ }^{4}$ Valentine $v$. Mahoney, 37 Cal. 389.

${ }^{5}$ Samuel $v$. Dinkins, 12 Rich. S. C. 172.

${ }^{3}$ Chant v. Reynolds, 49 Cal. 213; ${ }^{6}$ Chirac v. Reinecker, 2 Pet. 617. Bartlett v. B. G. L. Co., 122 Mass. 209.
} 
plaintiff, and whether the judgment be upon verdict or by default."'

8 170. Offices.-Successor and predecessor, in relation to offices, are considered to be in privity with each other like heir and ancestor. A judgment for or against the incumbent, concerning the rights and privileges of his office, is therefore admissible as evidence for or against his successors. ${ }^{2}$ A judgment in any controversy afiecting the rights of any person to hold an office, is conclusive upon the rights of any other person cliniming through or under him whose rights have been adjudicated. ${ }^{3}$ But whenever the title to an office may be drawn in question by different persons acting in different rights, a judgment against one is not almissible against the other. Judgment in favor of a defendant, upon an information in the nature of a quo varranto, filed by the prosecuting attorney of a county upon the relation of an individual, is no bar to a subsequent information of a similar nature, filed by the Attorney-General in the exercise of a discretion given him by statute. ${ }^{4}$

\& 171. Tenants in Ejectment.-The action of ejectment being purely a possessory action, a number of persons are considered as in privity with the defendant therein, to the extent that they must yield up the possession to a prevailing plaintiff, though their title to the property in question remains unadjudicated; and is susceptible of being successfully asserted against the now successful party in some subsequent controversy. When considering the force of a judgment in ejectment, privies "are those who entered under, or acquired an interest in the premises from or through, or entered without title by collusion with defendants subsequent to the commencing of the action." The landlord who receives possession from his tenants pending the suit, and all persons entering under defendants, or as trespassers pendente lite, are subject to be dispossessed

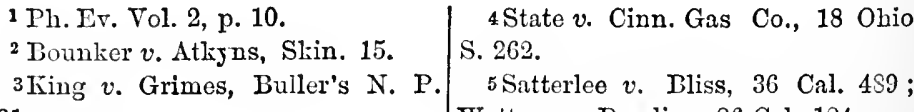

\begin{tabular}{l|l} 
& Ph. Ev. Vol. 2, p. 10. \\
& 4 State v. Cinn. Gas Co., 18 Obio \\
3 Kounker v. Atliyns, Slin. 15. & S. 262. \\
5 Satterlee v. Bliss, 36 Cal. 489 ;
\end{tabular} 231.
} 
under the judgment. ${ }^{1}$ If the writ of restitution in such cases did not authorize the removal of all persons, not in possession at the institution of the suit, a series of transfers of occupancy from one person to another would forever preclude the plaintiff from obtaining the use of his property. In the execution of this writ, it is to be presumed that all the parties found in possession are there as trespassers, or as lessees or purchasers from the defendant pendente lite. ${ }^{2}$ The statute of California provides that "An action' for the recovery of real property against a person in possession cannot be prejudiced by any alienation made by such person, either before or after the commencement of the action." 3

\& 171a. Co-owners.-A co-owner, by whatever species of co-tenancy he may hold, is not bound by a judgment rendered against his companion in interest. Discussing whether one of several co-heirs could be prejudiced by proceedings against the others, the Supreme Court of the State of Goorgia said: "Each of these grandchildren was entitled in his own right, to his share of his ancestor's estate, and to contest any conflicting claim. They do not claim through one another. The interest of each was separate and independent. Therefore, a judgment against a part, did not prevent the rest from being heard." A part owner is so free from having any interest in the result of a litigation against his co-tenant, that he is not disqualified from being a witness at the trial. ${ }^{5}$ A judgment in favor of the defendant, and against one or more of the several tenants in common, in an action of ejectment, can not prejudice any of the co-tenants not parties to that suit. A. B. and C. being owners of the undivided three fourths of the title to a tract of land, were sued in an action of trespass, for excavating a part of the land; the title was put in issue, and, from some

1 Sampson $v$. Ohleyer, 22 Cal. 200; Hanson v. Armstrong, 22 Ill. 442; Jones $v$. Chiles, 2 Dana, 25; Howard $v$. Kennedy, 4 Ala. 592 ; Smith $v$. Traube's Heirs, 1 MIcL. 8i; Wallen $v$. Huff, 3 Sneed, 82; Jackson v. Tuttle, 385 .

9 Cow, 233.
2 Long $v$. Morton, 2 A. K. M. 39.

$3 \$ 747$, Code, C. $P$.

4 Walker $v$. Perryman, 23 Geo. 311.

5 Dennett $v$. Hethington, $16 \mathrm{~S}$. d

R. 195; Hammett v. Blount, 1 Swan, 
cause, judgment was entered against them. Thereafter D., the owner of the remaining fourth, sued the plaintiff in the former action for the possession of the same premises, and established his title. Whereupon, the defendant in the second suit, insisted that as " A. B. and C. were estopped from maintaining any further action, by operation of the judgment against them, D. eould not recover to any greater extent than if the defendant possessed the title of A. B. and C. But the court held that as D," by virtue of his ownership of an undivided interest, was as against a trespasser entitled to recover the whole tract, his rights in that respect could not be changed by a proceeding to which he was not a party. That, notwithstanding the former judgment, the title of the defendant continued to be as it was prior thereto-that of a trespasser; and finally, that there was no legal impediment to D.'s recovering the entire tract, as he could have done before the judgment against his co-tenants. ${ }^{2}$

\section{172. Remainder-men and Persons not in Esse. - If} several remainders are limited by the same deed, this creates a privity between the person in remainder, and all those who may come after him; and a verdict and judgment for or against the former may be given in evidence for or against any of the latter. ${ }^{2}$ But there seems to be a eonflict of opinion as to whether the same privity exists between a tenant for life and a reversioner, unless the latter has identified himself with the litigation out of which the juclgment resulted, as by being made a party to the proceedings by aid prayer." "If there are ever so many contingent limitations of a trust, it is an established rule, that it is sufficient to bring the trustees before the eourt, together with him in whom the first remainder of inheritance is rested; and all that may come after will be bound by the cleeree though not in esse, unless there be fraud and collusion between the trustees and the first person in whom the remainder of inheritance is vested." 4 S. P. C. conveyed lands to three trustees to hold in trust: 1st.-To himself for life; 2nd.-

1 Williams $v$. Sutton, 43 Cal. 71. $\quad$ Ev. 14-5; Freer $v$. Stolenbur, 2 Abb.

${ }^{2}$ Pyke $v$. Crouch, 1 Li. Raym. 730; App. 189; Bartlett v. B. G. L. Co., Johnson v. Jacob, 11 Bush, $646 . \quad 122$ Mass. 209.

${ }^{3}$ Adams $v$. Butts, 9 Conn. 79; Ph. ${ }^{4}$ Hopkins $v$. Hopkins, 1 Atk. 590. 188 
Remainder to the heirs of his body; 3d.-Remainder to P. C. for life; 4th.-Remainder to the heirs of R. C.'s body; 5th.- Remainder in fee to the children of S. C. In an action against the trustees, this deed was set aside. S. P. C. and R. C. afterward dying, the children of S. C. commenced suit to obtain their remainder in fee. But it was held that the decree setting aside the deed, was binding on them; that the contingent remainders depended on the legal fee and the equitable estate in S. P. C. intermediate, and was liable to be destroyed by any thing which defeated those estates. ${ }^{1}$ According to the views entertained and expressed by Lord Redesdale, "it is sufficient to bring before the court, the first tenant-in-tail in being, and if there bo no tenant-in-tail in being, the first person entitled to the inheritance, and if no such person, than the tenant for life. It has been repeatedly determined, that if there be tenant for life, remainder to his first son in-tail, remainder over, and he is brought before the court before he has issue, the contingent remainder-men are barred." ${ }^{2}$ But in MIrryland where one sixth of certain property was devised to the testator's daughter " cluring her life, and after her decease to her male children on her body lawfully begotten or to be begotten, a bill in equity was filed against this daughter and her two sons, by other part owners of the land alleging that a partition could not be advantageously made, and praying for a sale of the land and the distribution of the proceeds. A decree was subsequently entered in accordance with this prayer, and was succeeded by the sale of the property thereunder. After the death of the daughter, her five sons commenced an action of ejectment to recover possession of one sixth of the land. Three of the sons had been born since the rendition of the decree under which the sale had been made; and it was contended that as they were not in esse they could not be bound by the decree. The court held that their interest could not be destroyed by their mother, as life-tenant, nor by their living brothers; "that their rights under the will were indestructible by any act of the parties having interests prior to or in common with them,"

\footnotetext{
${ }^{1}$ Campbell v. Watson, 8 Ohio,
498.
} 
and, therefore, that they were not prejudiced by the decree of sale and tho proceedings had in pursuance thereof. 1 The difference between the conclusions reached by the court in Maryland and those announced by Lord Redesdale is this: that in Maryland some person must be brought before the court having an estate of inheritance and who is, on that account, entitled to represent both his own interests and tho interests of all who may claim after his death; while, according to Lord Redesdale, if there be no person in existence possessing an estate of inheritance, then the tenant for life may bo brought before the court and treated as the representative of persons who may, by their subsequent birth, acquire interests in the estate. The views of Lord Tiedesdale are sustained by a majority of the reported adjudications on this subject.2

\section{173. Trustees and Cestuis que Trust.-As a general} rule, the trustees and their cestuis que trust are regarded as being so independent that proceedings against one has no effect upon the other, and both are essential to a complete determination of any action in reference to the trust estate. ${ }^{3}$ This rule, however, yields to convenience and necessity. Where it is impossible or extremely inconvenient to bring all the cestuis que trust before the court, either as plaintiffs or as defendants, on account of their number, the court will allow in the case of plaintiffs a few of the cestuis que trust to bring an action, and in the case of defendants, if the trustees are parties defendant, the presence of the cestuis que trust may be altogether dispensed with. What number of cestuis que trust will be regarded so great as to obviate the necessity of bringing all of them into court, is undetermined. In Harrison v. Stewardson (2 Hare. 533), twenty-one cestuis que trust were required to be joined; but in other cases, involving circumstances of unusual difficulty, when the number was but littlo greater, a part were authorized to repre-

1 Downin v. Sprecher, $35 \mathrm{Md}$. 478. Freeman v. Freeman, 9 Heisk. 301;

${ }^{2}$ Faulkner $v$. Davis, 18 Gratt. 684; 2 South. L. R. 168. Baylor's lesseev. Dejarnette, 13 Gratt. 152; Gaskell v. Gaslisll, 6 Sim. 643;

${ }^{3}$ Coilins v. Lofftus, 10 Leigh. 5. 
sent all. ${ }^{1}$ No cloubt there are many instances in which the trustee is authorized to represent lis cestuis que trust; and, in which the judgment is conclusive on the latter in the absence of fraud or collusion. Thus, where A. conreyed certain mortgaged premises to B., in trust for A.'s wife, and the mortgagee instituted suit against $\mathrm{B}$. to foreclose, whu answering, admitted the facts to be as stated in the complaint, and consented to such decree as might be right, it was held that $\mathrm{B}$. was empowered by the nature of his trust to represent the interests of his cestuis que trust to this extent, and that in the absence of any evidence of injury to her or her estate, she ought not to be allowed to reverse nor to impeach the decree. ${ }^{2}$ When a creditor makes an assignment for the benefit of his creditors, the assignee acquires the legal, and the creditors the equitable, estate. A judgment against the assignee, in relation to property embraced in the assignment, is conclusive, unless it can be avoided for fraud or collusion. ${ }^{3}$ It has been said that the cestuis que trust of a mortgagee are not necessary parties to a foreclosure suit, whether such suit is to enforce the mortgage or to make it subordinate to some other lien; and that "a final decree settling the rights of all parties may be made without bringing such cestuis que trust before the court." If a judgment be recovered in" the name of $A$., the law will protect any equitable interest of another person for whose benefit tho judgment was intended, and who was the equitable owner of the chose in action on which it was recorered, though the record does not disclose that fact. A garnishee of the nominal plaintiff can not enforce payment of the judgment to limself. ${ }^{5}$ It is not intended that the fact of the legal and equitable titlo being in different persons shall authorize the same issues to be twice bona ficle litigated. A suit by A. for the use of B., or as A.'s trustee, is binding on B. No man can be permitted, after adjudicating a matter by his trustee, to disregard that adjudication. ${ }^{6}$ The equitable owner of a chose in action is bound to the same extent as if he were a party to the record.?

${ }^{1}$ Perry on Trusts, $\$ \$ 873$ and $885, \mid{ }^{5}$ Hodson $v$. McConnel, 12 Ill. 170. and cases cited in $\$ 157$ in this work. $\quad{ }^{6}$ Peterson $v$. Lathrop, 34 Pa. S. 223;

${ }^{2} J$ Jhisson $v$. Robertson, 31 Md. 476. Calhoun $v$. Dunning, 4 Dall. 120.

${ }^{3}$ Fiell $v$. Flanders, 40 Ill. 470. 507 .

${ }^{4}$ N. J. F. Co. $v$. Ames, 1 Beas. Ch.

${ }^{7}$ Rogers $v$. Haines, 3 Greenl. 362; Curtis v. Cisna's Admr., 1 Hamm. 432; Boynton v. Willard, 10 Pick. 166. 
PART III.-OF PERSONS BOUND, THOUGH NEITHER PARTIES NOR PRIVIES.

" 174 . "Neither the benefit of judgments on the one side, nor the obligations on the other, are limited exchsively to parties and their privies." 1 Or, in other words, there is a numerous and important class of persons who, being neither parties upon the record, nor acquirers of interests from those parties after the commencement of the suit, are nevertheless bound by the judgment. Prominent among those are persons on whose behalf and under whose direction the suit is prosecuted or defended, in the name of some other person. ${ }^{2}$ As is illustrated by the case of trustee and cestui gue trust, the real party in interest can not escape the result of a suit conducted by him in the name of another. ${ }^{3}$ The fact that an action is conducted in the "names of nominal parties, can not divest the case of its real character, but the issues made by the real parties, and the actual interests involved, must determine what persons are precluded from again agitating the question; and who are estopped by the previous decision." "If an original insurer carries on in good faith, and for the protection of and with the consent or acquiescence of a re-insurer, a contest respecting a loss, the latter is bound by the judgment. "The reassured and re-insurer stand in the precise relation of all other parties where there is a liability over, and the result of one litigation binds or concludes both. There is but one matter in issue which is alike common to both, and that is, whether a loss has occurred, and a debt has accrued to the original insured. ${ }^{5}$ One who would not otherwise have been bound by a judgment, does not make himself a party thereto so as to be bound by it, merely by prosecuting a fruitless appeal therefrom. ${ }^{6}$

\& 175. Evidence to Show who were the Real Parties. For the purpose of showing that parties not named in the record, were the real parties in interest, and conducted the suit in the name of others, who were only nominal parties,

\footnotetext{
${ }^{1}$ Valentine $v$. Mahoney, 37 Cal. ${ }^{4}$ Tate's Ex. $v$. Hunter, 3 Strob. Eq. 389 .

S Storliard $v$. Thompson, 31 Iowa, 80 ; Conger $v$. Chilcote, 42 Ia. 18.

${ }^{3}$ Elliott $v$. Hayden, 104 Míass. 150; Jackson v. Griswold, 4 Hill. 522; $\mathrm{Pl}$. Ev., vol. 2, p. 10; Train v. Gold, 5 Pick. 350. 136; Conger v. Chilcote, 42 Ia. 13 ; Wood v. Ensel, 63 Mo. 193; Cole v. Favorite, 69 IIl. 457.

${ }^{5}$ Strong $v$. Phœuix Ins. Co., 62 Mío. 289; 21 Am. Tiep. 417.

${ }^{6}$ Majors v. Cowell, 5l Cal. 478.
} 
parol evidence may always be offered, and when the showing is made, the real parties are conclnded by the judgment. ${ }^{1}$

8 176. Parties Eound without Notice.-In many instances, the relation of the nominal parties to the suit to other persons, is such that the latter are conclusively bound by a judgment against the former in the absence of fraud or collusion, although they are not notified of the pendency of the suit, and are not called upon to conduct its prosecution or defense. In respect to the question who are those parties, whose interests are thus inseparably associated the decisions are often inconsistent; but undoubtedly, the general principle sanctioned by a rast preponderance of authority is that every person who has made an unqualified agreement to become responsible for the result of a litigation, or upon whom such a responsibility is cast by operation of law in the absence of any agreement, is conclusively bound by the judgment. This rule will become manifest from an examination of the adjudged cases. "Wherever this identity of interest is found to exist, all alike are concluded. Thus, if one covenant for the results or consequences of a suit between others, as if he covenants that a certain mortgage assigned by him shall produce a specific sum, he thereby connects himself in privity with the proceedings, and the record of the judgment in that suit will be conclusive against him. In the case at bar, the appellant laring bound himself, that defendants in the attuchment suit would cause the slaves levied upon and replevied to be forthcoming to abide the order of the court, has connected himself in privity with tho proceedings, and mado the judgment conclusive against him." 2

8 177. Corporation and Stockholder.-Under statutes imposing personal liabilities upon the stockholders for the debts of a corporation, great contrariety of opinion lias been exhibited in relation to the effect of a judgment against tho latter, as evidence of debt against the former. In the first case decided upon this subject in New York, the Cour's of Errors, reversing the judgment of Chancellor Kent, held that the stockholders were chargeable, on the ground thos the trustees, as agents of the stockholders, had contracted

1 Tarleton v. Johnson, 25 Ala. 300; pelye v. Prince, 3 Hill, 119; Greenl.

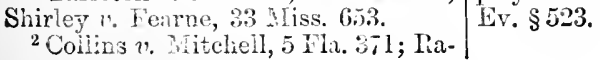

(13) 
the detat evidenced by the judgment, and that the latter could impeach the indebtedness upon no ground, except frand or error in liquidation. That the judgment must be regarded "as a solemn admission of indebtedness; but it is not binding as res judicata upon the stockholders, if it was procured by fraud, or is founded in error. ${ }^{1}$ Subsequently, in the same State, it was said, in reference to a judgment recovered upon a note, that "as against the company the judgment is conclusive evidence that the note was valid, and although the defendant was not directly a party yet, as a stockholder, he was not altogether a stranger to the judgment," and that the judgment constituted a prima facie eviclence against the stockholder. ${ }^{2}$ But the doctrine of these cases was considered as shaken by the opinion of Cowen, J., in Mloss v. McCullough (5 Hill, 131), and as late as 1860, a majority of the Court of Appeals in the same State, "refused to commit themselves to the doctrine that a judgment against the corporation is even prima facic evidence against a stockholder," while, in the opinion of the minority, "A judgment against a corporate body, is one of the highest evidences of indebtedness lnown to the law; it is a solemn admission by record, that the corporation owes the sum claimed in the suit," and that "a judgment by confession, in the absence of any pretense of fraud or collusion, is just as conclusive upon a corporation, as one rendered after litigation, and a judgment by default, is only another: mode of declaring by a record estoppel that the corporate body has no just defense, and can say nothing in bar of the claim preferred against it."3 In a suit against a stockholder, it seems to be necessary to establish the organization and existence of the corporation, and a judgment against the corporation is not conclusive evidence of those facts, in an action against the stockholder. ${ }^{4}$ But the existence and organization being proved, there seems, at the present time, to be no doubt that a judgment against a corporation is conclusive evidence of debt against its stock-

1 Slee $v$. Bloom, 20 Johns, 669.

2 IIoss v. Oakley, 2 Hill, 265, and ALoss v. MIcCullough, 7 Barb. 279.
3 Belmont $v$. Coleman, 21 N. Y. 96. 4 Hudson v. Carman, $41 \mathrm{Me} .81$. 
holders, to be avoided only on proof of fraul, collusion or mistake, and not upon original grounds. ${ }^{1}$

8 178. County and Tax Payer.-A judgment against a county or its legal representatives, in a matter of general interest to all its citizens, is binding upon the latter, though they are not parties to the suit. A judgment for a sum of money rendered against a county, imposes an obligation upon the citizens, which they are compelled to discharge. Every tax payer is a real, though not a nominal, party to such judgment. If, for the purpose of providing for its payment, the officers of the county levy and endeavor to collect a tax, none of the citizens can, by instituting proceedings to prevent the levy or enforcement of the tax, dispute the validity of the judgment, nor re-litigate any of the questions which were or which could have been litigated in the original action against the county. ${ }^{2}$

8 179. Iraster and Servant.-A suit was commenced against a master for a trespass committed by his servant, under his order and direction. After a trial upon the merits, ending in a judgment for the defendant, it was held that the plaintiff was thereby precluded from maintaining an action against the servant for the same trespass. ${ }^{3}$ Where a serrant was sued for trespass in taling property, and the master defended the suit, and justified lis servant in the taking, it was decided that the judgment was conclusive on the master, because it was his duty to indemnify the servant in acting as his agent; and that he was bound to appear and defend, and that a judgment in his servant's faror was conclusive as a defense to an action by the same plaintiff against the master for the same trespass. ${ }^{4}$

2. 1S0. Principal and Surety.-The law in relation to the effect of a judgment against a principal, for the purpose of

1 Conklin v. Furman, 8 Abb. Pr., N. S. 161; also 57 Barb. 484, 50.1; Mi1ler $v$. White, $8 \mathrm{Abb}$. Yr., N. S. 46 ; Milliken $v$. Whitehouse, 49 Me. 527. Bank of Australiasia v. Nias, 4 Eng. L. \& Eq. 252; Came v. Brigham, 39 IIe. $\mathbf{5}$.
${ }^{2}$ Clark $v$. Wolf, 29 Iora, 197.

3 Emery $v$. Fowler, 39 Me. 326; Kitchen v. Campbell, 3 Wel. 3u4; Tinnersley 2 . Orpe, Doug. 517. 4 Castle $v$. Noyes, 14 N. I. 3_9. 
charging the surety, is differently understood and applied in the different States. And in the same State, distinctions are made between different classes of sureties. It seems to be generally conceded, however, that wherever the surety has contracted in reference to the conduct of one of tho parties in some suit or proceeding in the courts, he is corcluded by the judgment. Thus, a judgment against a defendant is conclusive upon his bail, if free from fraud or collusion; and they cannot show that it is for too great a sum, nor that it was obtained on account of the defanlt or negligence of the principal. ${ }^{1}$ The sureties upon an injunction bond "assume such a connection with that suit thet thoy are concluded by a judgment in it, in a suit at law upon the bond, so far as the same issues are involved. ${ }^{2}$ Sureties upon the bond of an executor or an administrator seem also to occupy a position in which their responsibility may be fixed in suits to which they are not parties, and in which they are not tendered an opportunity to defend. "If a judgment has been recovered against an administrator, and an action thereon be commenced against the surety on his bond to the ordinary, such judgment is conclusive, unless the surety can show that it was ubtained through fraud or collusion between the creditor and the administrator." The only questions open to the sureties in a suit on such a bond, after judgment against their principal, are in reference to the making of the bond and its legal suficiency. ${ }^{4}$ "When judgment has been recovered in a court of competent jurisdiction against an administrator, showing that he has received funds belonging to an estate, and has failed to payorer the same, a breach of his administration bond is established. By this judgment the administrator is bound and the suretios are concluded to the same extent which their. principal is concluded."s The rule applicable to the sureties of an administrator is, in general, applicable to sureties on the official bonds of sheriffs, constables, guardians and

1 Parkhurst $v$. Sumner, 23 Vt. 538; ${ }^{3}$ Boyd v. Caldwell, 4 Rich. 117; Riclle v. Baker, 13 Cal. 295; Way v. State v. Coste, $36 \mathrm{Mo} 437$.

Lewis, 115 Mass. 26; Keane $?$. Fislier, ${ }^{4}$ Watts $v$. Gayle, 20 Ala. 817; 10 La. An. 261; Cutter $v$. Evans, 115 Willey $v$. Paulk, f Conn. 74.

Mass. 27; Rinsse v. Wool, $37 \mathrm{~N}$. Y. 5 Stovall $v$. Banks. 10 Wall. 583; 526; see also Stoops $v$. Wittler, 1 Mo. Jones $v$. Ritter's Adm., 56 Ala. A 1 P. 4:0. 270.

Towle $v$. Towle, 46 N. II. 432;

Chureh v. Barker, 13 N. Y. 463. 
trustees. 1 The rule is sometimes made to depend on the question whether the bond is joint or several in its nature. Whus it is said, that a judgment obtamed against a consiable for wrongful attachment is, in the absence of a frand $O r$ collasion, conclusive evidence in an action against lim and his sureties, both as to damages and to cost, if his bond is joint, because the principal is liable and his bondsmen must be jointly liable with him. 2 In some instinces, however, the sureties upon the bonds of sheriffs, constables, executors and administrators, have been deemed entitled to notice of the suits before they conld be conclusively bound.3 A bond was given by a deputy sheriff to his principal, conditioned that the deputy shonk "well and faithfully, in all things, perform and execute the duties of depnty sheriff without fraud, deceit or oppression." The sherifir being sued for an act of the deputy, gave notice to the latter, but not to his sureties. Judgment being rendered against the sheriff, he offered it as evidence in an action by him against the sureties, whereupon it was decided that "the terms of the condition of this bond do not bring it within the class of eases in which an indemnitor is concluded by the result of a suit against the person whom he has undertaken to indemnify, upon the ground that such is the fair interpretation of the terms of the contract. This condition is only that he will do liis duty as depaty sheriff. In the class of cases alluded to, the contract of indemnity is held to stipulate for the result of a litigation which the indemnitor is not a party, and to mako his liability to depend merely upon that result. There is, therefore, no reason why this case, in which the language of the condition admits of no similar construction, should be taken ont of the general rule which declares the effect of judgments as to sirangers, that they conclusively prove rem ipsam, and nothing else." In a subsequent case, in the same State,

${ }^{1}$ Garber $v$. Commonwealth, 7 Barr. 265; Heard $v$. Lodge, 20 Piek. 53.

${ }^{2}$ Evans $v$. Commonwealth, 8 Watts, 3อS; Traey $v$. Goodwin, 5 Allen, 409 ; Niasser $v$. Strickland, 17 S. \& R. 354; 17 Am. Dee. 668.

${ }^{3}$ Lneas v. Governor, 6 Ala. 826 ; State $v$. Colerick, 3 Hamm. 487; Aikins v. Baily, 9 Yerg. 111; Holson $r$. 9 Gratt. 323.
${ }^{4}$ Thomas $v$. Hubbell, 15 N. Y. 405 , reversing and overruling the opinion in the same case reportel in 18 Jirb. page 9. The same case was again decided on appeal in 35 N. T. 190. "Althongh there is a conflict of anthority on the subject, it seems to he the better opinion that, except in cases where, mpon the fair consumetion of the contract, the surety nay 197 
a deputy had given a joint bond with sureties to the effect that the obligors "should well and sufficiently indemnify and keep harmless 'the principal' from and of all manner of costs, charges, damages and expenses which he might incur or be put to by reason of any act or acts, omission or omissions of the deputy in or about the execution of his office of deputy sheriff." In an action against the sheriff he notified the deputy who appeared and managed the defense. No notice was given the sureties. The sureties sought to avoid the effect of the judgment as evidence against them. But the condition of this bond was considered as materially different from that in the case of Thomas v. Hubbell, and great stress was laid upon the fact that the bond was joint. "The defendants being jointly bound to indemnify the plaintiff, they were in privity of contract with each other, and are to be regarded and treated, qroad the contract, and the rights and liabilities connected with and growing out of it, as one person. In such a case, notice to one is notice. to all, on the same principle as where two or more persons are shown to be jointly bound by a contract, the acts and admissions of either are binding upon all the others to the same extent as upon the one doing the acts or making the admissions.

"It was no part of plaintiff"s agreement with the sureties on the boud, that they shonld have notice of suits brought against lim for the misconduct of his deputy, and their liability as indemnitors was not made to depend on such notice. The law, indeed, required notice to the deputy, in order that he might defend and discharge himself from the misconduct imputed to him, and for the purpose of rendering the judgment against the sheriff conclusive, if one shonld be obtained. The notice was properly given to the deputy, whose conduct only was called in question, and who is presumed to know the facts and circumstances far better than the sureties or the sheriff. If, in addition to giving notice to the deputy, notice had been given to the

be held to lave undertaken to be re- surety of the fact of its recovery ouly, sponsible for the result of a suit, or and not of any fact which it was when he is made privy to the suit by necessary to find in order to recover notice, and the opjortunity being such judgment:" Brandt on Suretygiven him to defent it, a julgment ship, sec. 524; De Grieff $v$. Wilson, 30 against the principal alone is, as a M. Jr. Eq. 435.

general rule, evidence against the

198 
sureties also, it would have been little more than an idlo and useless ceremony, as it is to be presumed that all they would or could have done, would have been to refer the matter to their principal, the deputy, and cast the burden of the defense, as the sheriff has done.

"By a fair and reasunable interpretation of the conditions of the bond, the parties contemplated that actions might be brought against the sheriff for the acts or omission of his deputy, and the covenant of indemnity in the condition was inserted to provicle for such contingencies." 1

In respect to sureties upon bouds and contracts, other than those already noticed, the contrariety of opinion concerning the effect upon them of a judgment against their principal, is very marked and irreconcilable. The most extreme ground taken against such a judgment was that assumed in a couple of cases in New Tork, where it was held that a surety, though notified of a suit against his principal, and though assisting in conducting it, was not bound by the jadgment, unless admitted to defend in the name of the principal, because he could not have appeared nor have managed the suit, except by the consent of his principal, nor could he take an appeal. ${ }^{2}$ In a number of cases a judgment or decree against the principal was considered as constituting not eren prima facie evidence against tho surety. ${ }^{3}$ These cases are, however, opposed by moro numerous cases, which unite in declaring the prima facie effect of such a judgment as evidence against a surety, ${ }^{4}$ but difier somewhat as to the means by which this prima facie evidence may be rebutted. In Georgia, the surety "may rebut this evidence; and he may not only look into tho judgment or decree against his principal, but he may inquire into its justness, ab origine. He may set up and prove any defense he could have proved in the original suit,

1 Fay v.Ames, 44 Barb. 327; see also Westervelt $v$. Smith, 2 Duer, 449.

2 Jackson v. Griswold, 4 Hill, 522; Douglis $v$. Howland, 24 Wend. 35.

${ }^{3}$ Lartigue $v$. Baldwin, 5 Mart. Lou. 193; Beall v. Beck, 3 Harr. and MicH. 242; McKellar v. Bowell, 4 Hawlis, 34; Morris $v$. Lucas, S Blkf. 9; King v. Norman, 4 C. B. 834.

4 Munford $v$. Overseers, 2 Rand. 313; Jacobs $v$. Hill, 2 Leigh, 393; Baker $v$. Preston, 1 Gilmer, 235; Respublica $v$. Davis, 3 Ieates, 12s; 2 Am. Dec. 360; Lucas v. Curry, 2 Bai. 403; Brandt on Suretyship, sec. 525. 
if he had been a party to it." 1 In Ohio, the surety may impeach the judgment for collusion or for mistake. But until so impeacled, it is sufficient to entitle plaintifi to recover the amount for which it was rendered. ${ }^{2}$ In one of the Circuit Courts of the United States, the rule is laid down that the surety may show fraud or collusion, or that tire debt has been paid, or that there was a clerical mistake in entering judgment. 3 A bond was given to the State to the effect that the principal would not keep a disorderly house. In an action against the surety upon the bond, it was held that the conviction of the principal in a criminal prosecution for keeping a disorderly house, was prima facie evidence against the surety.

A judgment against a surety, obtained withont fraud or collusion, in an action of which the principal or any cosurety had notice, is conclusive in favor of the surety in an action against the principal or the co-surety for contribution. ${ }^{5}$ If a judgment rendered against a principal and a surety upon their bond be paid by the latter, the former cannot, in a suit to recover from him the amount thus paid, show want of consideration in the boud. ${ }^{6}$

8 181. Notice to Indemnitors.-In many cases it happens, that if, by reason of the finding of certain facts, one of the parties to the suit is in any respect damaged, lie, in turn, has the right to recover back the amount of damages from some other person, not a party to the present litigation. The person thus exposed to a loss which some one has, in efiect, covenanted against, may make his covenantor a party to the present suit, and may thus avoid the peril and inconvenience of being required to establish against his covenantor, in a subsequent controversy, the facts which may be established by the plaintiff in the present suit. ${ }^{7}$ In order to become thus bound the covenantor must be tendered "a full, fair and previous opportunity to meet the controversy," and it is not sufficient that ho heppened to be present in court, and may have cross-

${ }^{1}$ Bryant $v$. Owen, 1 Ga. 355; Bradwell $v$. Spencer, 16 Geo. 578.

${ }^{2}$ Sturate $v$. Colerick, 3 Hamm. 487.

"Lerger $v$. Williams, 4 HeL. 577. 200
4 TVebbs v. State, 4 Cold. 199.

${ }^{5}$ J ove v. Gibson, 2 Flor. 598.

${ }^{6}$ Pitts $v$. Fugate, 41 Mo. 405.

7 Konitzky v. Meyer, 49 N. Y. 471. 
examined the witnesses. ${ }^{1}$ In general, the fact that the covenantor appeared and conducted the defense is of itself suficient proof that he had due notice of the action, and a full and fair opportunity to contest it on the merits. ${ }^{2}$ But in the absence of such appearance the question arises, whether he was given such notice of the suit as made him responsible for its termination. In respect to such notices it is said that they must be clear and precise; must inform the person to whom they are addressed, that he must appear and defend or be estopped from a defense upon his covenant; and must be given so as to afford a reasonable time for him to prepare for the trial. ${ }^{3}$ The necessity of proof of such a notice can not be aroided by showing that the warrantor sought to be bound, knew and talked of the action, said he had an agreement which would defeat it, and was informed of the time and place of the trial." "If a party to a suit has the right to resort to another upon his failure in the action, whether upon covenants of warranty or on the ground that he is indemnified by such third party, then it is clearly his duty to give full notice to his covenantor or indemnitor of the pendency of the suit, what it is he requires him to do in the suit, and the consequences which may follow if ho neglects to defend; mere lnowledge of the existence of such action is entirely insuficient to bind the party by the judgment, unless he is notified to furnish testimony, or to defend the action or to aid in it, he may well suppose the party to be in need of no assistance, and he may well rely rpon that supposition, for if the party desires his aid, it is his duty to give him a full notice, a reasonable time before the trial of the action, to enable him to prepare for it. ${ }^{5}$ In an action against a city for a defect in one of its highways, caused by $\mathrm{A}$., the judgment against the city, if $\mathrm{A}$. be notified of the suit, is conclusive in a subsequent suit against him by the city, in relation to the existence of the

1 Turpin $v$. Thomas, 2 Hen. and M. 139; 3 Am. Dec. 615.

${ }^{2}$ Harding $v$. Larkin, 41 Ill. 413.

${ }^{3}$ Boyd v. Whitfield, 19 Ark. 447;

Davis $v$. Wilbourne, 1 Hill, S. C. 27 .
${ }^{4}$ Paul v. Witman, 3 W. and S. 409.

${ }^{5}$ Sampson $v$. Ohleyer, 22 Cal. 200; Peabody $v$. Phelps, 9 Cal.213. 
defect, the amount of injury to the individual, and the fact of the exercise of due caution by the party injured. ${ }^{1}$ Some recent decisions in courts of very high authority, enforcing the rights of a city to recover back from a property holder a sum which she has been compelled to pay, on account of his act or negligence, for personal injuries occasioned by a defect in her highways, either establish an exception to the usual rule in regard to notices to defend, or else clispense with several essentials of such notices, as the law was formerly understood. In Massachusetts, it is sufficient to bind the property holder by the judgment against the city, if he had notice of the pendency of the suit, and of the fact that the city intended to hold him responsible, and had an opportunity to furnish evidence, though he did not take upon himself the defense of the suit, and was not requested to do so. ${ }^{2}$ Cases in the Supreme Court of the United States go much farther in the same direction. In the first of these cases it is maintained that a property owner who knows of the suit pending against the city for dimages in front of his lot, is, in an action against him by the city, bound by the judgment against the eity; and upon such judgment being produced, can only show in his defense, that the damages were caused, or contributed to, by the city herself. It is not necessary that any notice be served informing him that the city will hold him responsible." In a later case involving similar issues, the court said: "Express notice is not required; nor was it necessary for the ofticers of the corporation to have notified lim that they would look to him for indemnity. The conclusive effect of a judgment respecting the same cause of action, and between the samo parties, rests upon the just and expedient axiom that it is for the interest of the community that a limit should be opposed to the continuance of litigation; that the same cause of action should not be brought twice to a final determination. Parties inclucke all who are directly interested in the subject matter, and who have the right to make de-

1 City of Portland $v$. Richardson; 496; Inhabitants $v$. Holbrook, 9 Al$54 \mathrm{MIe} .46$.

len, 17.

2 Boston $v$. Worthington, 10 Gray, 3 City of Chicago $v$. Robbins, 2 Black, U. S. 418 . 
fense, control the proceedings, examine and cross-examine witnesses, and to appeal from the judgment. Persons not having those rights, substantially, are regarded as strangers to the cause; but all who are directly interested in the suit and have knowledge of its pendency, and who refuse or neglect to appear and avail themselves of these rights, are equally concluded by tho proceedings."

8 182. Attachment Proceedings. - If property is attached, and the defendants in the attachment or the general assignees put in their claim to the property, and are heard in full in reference to such claim, they become parties to the proceeding, and bound by the judgment. ${ }^{2}$ Any creclitor, who defends an attachment, on the ground that the debt attached is due to him is precluded, if he fail in his defense, from contesting the validity of the attachment as against the plaintiff, or as against the garnishee. ${ }^{3}$

8 183. Bailee or Bailor.-If, in an action against the bailee for the property, the bailor employed counsel, and managed the case, and put his title in issue, as a defense for the bailee, the judgment is conclusive on all the title of the bailor at the time of its rendition. ${ }^{4}$

8 184. Officers and their Indemnitcrs. - A party who indemnifies an attaching officer, and who, when suit is brought, appears and has complete control of its lefense, is bound by the judgment as an estoppel, in a subsequent litigation, to the same extent as if he were a party to the record $;^{5}$ he is equally bound where, though not participating in the conduct of the suit, he was given due notice of the action, and was tendered an opportunity to assist in its defense. ${ }^{6}$ If no notice of the suit be given, and no opportunity is allowed him to make a defense, the judgment is but prima facie evidence against the indemnitor." "Cove-

\footnotetext{
${ }^{1}$ Robbins $v$. City of Chicago, 4 Wall. $65 \mathrm{~s}$.

${ }^{4}$ Tarleton v. Johnson, 25 Ala. 300.

${ }^{5}$ Murray $v$. Lovejoy, 2 Clifford, 191;

${ }^{2}$ Moore $v$. Spackman, 12 S. \& R. Lovejoy $\because$ Murray, 3 Wall. 1. 257.

${ }^{6}$ Miller $v$. Rhoades, 20 Ohio $\mathrm{S}$.

${ }^{3}$ Coates v. Roberts, 4 Rawl. 104; 494.

Richardson v. Watson, 23 Mo. 34; ${ }^{7}$ Stewart v. Thomas, 45 Mo. 44.
}

Tarleton v. Johnson, 25 Ala. 300. 
nants to indemnify against the consequences of a suit, are of two classes. 1. Where the covenantor expressly makes his liability depend on the event of a litigation to which he is not a party, and stipulates to abide the result; and 2, where the covenant is one of general indemnity merely, against claims or suits. In cases of the first class, the jadgment is conclusive evidence against the indemnitor, although he was not a party, and had no notice; for its recovery is the event against which he covenanted. ${ }^{1}$ In those of the second class, the judgment is prima facie evidence only against the indemnitor, and he may be let in to show that the principal had a good defense to the claim. ${ }^{2}$ In each of the classes of cases above mentioned, the indemnitor is, of course, understood as saving the right, which the law gives in every case where the suit is between third persons, of contesting the proceeding on the ground of collusion, for the purpose of charging him."3

8 185. Tenant and Landlord. - A landlord, having notice, and defending an action of ejectment in the name of his tenant, camnot afterward, in a controversy with the latter, show that his eviction, under the judgment, was not by title paramount. ${ }^{4}$ But a tenant cannot justify his attornment to a third person by merely showing that such party has recovered a judgment against him for the possession of the premises. He must go further, and show that his landlord was notified of the pendency of the action, and had an opportunity to defend, otherwise the landlord is neither bound nor estopped by the judgment.

\& 186. Vendee and Vendor.-A purchaser, or any subscquent vendee, upon being sued for the property, in trover or replevin, or in any action involving the title, may give notice of the pendency and nature of the suit, to the original vendor, and require him to defend, or to assist in defending

\footnotetext{
${ }^{1}$ Patton $v$. Caldwell, 1 Dall. $419 . \quad{ }^{3}$ Bridgeport Insurance Co. v. Wil-

${ }^{2}$ Dufincld $v$. Scott, 3 T. R. 374 ; son, 34 N. Y. 280.

Smith $v$. Compton, 3 B. \& A. $40^{-} ;$; "Wheclock $v$. Warschaver, $34 \mathrm{Cal}$. Lee v. Clark, l Hill, 56; Rapelye v. 265; MeCreery v. Everding, 54 Cal. Prince, 4 Hill, 119; Aberdecn $v$. Black- 168.

mar, 6 Hill, 324; Taylor $v$. Barnes, $69 \quad{ }^{5}$ Douglas $v$. Fulda, 45 Cal. 592; 5 N. I. 430; Comstock v. Drohan, 15 Pac. Law R. 162.

N. Y. S. C. 373 .
} 
the same, and after such notice, the vendor, whether he defends or not, cannot question the finding of title involved in the judgment. ${ }^{1}$ Dut the judgment is conclusive against the rendor, though not notified of the suit, if he appear as a witness and testify that he had no title at the date of his sale. $^{2}$ In all other cases, no judgment, whereby a third party has recovered property from a vendee, can be given in evidence, to show want of title in the vendor, unless ho was uotified of the suit. ${ }^{3}$ If a sheriff levy upon property and is sued by a claimant thereof, and in such suit the claimant is defeated, such judgment is conclusive against the claimant in a controversy between him and a person who derives title to the property through a sale made under such lery." In South Carolina, after a very elaborato consideration of the question, it was determined that the right of a vendee to give notice to his vendor, and thus couclude him by the julgment, was limited to questions of title, and could wot be extended to a case in which the quality of goods sold, and not the title thereto, was the question at issue. ${ }^{5}$

8. 187. Warrantee and Warrantor.-As the sale of personal property always involves a warranty of title, the rules and proceedings there applicable in fixing the liability of the vendor to his vendee upon recovery of the property by some claimant, are also applicable to a vendor of real estate with a corenant of warranty of title, when he is sought to be made liable to his vendee, claiming to have been evicted under title paramount. Any judgment by which the warrantee is dispossessed, if after proper notice to his warrantor, " is plenary evidence against the warrantor, in a suit on the warranty." A warrantor souglat to escape from the result of a judgment, on the ground that the warrantee had been called as a witness by plaintiff at the trial. The court said: "There are authorities to the point that the record of a verdict and judgment can not be used in favor of one, who, by his evidence, has contributed to their recovery.

${ }^{1}$ Thurston $v$. Spratt, 52 Maine, 202; Gist v. Daris, 2 Hill Ch. 335; Bender $v$. Fromberger, 4 Dallas, 436; Hamilton v. Cutts, 4 Tyng. 349.

${ }^{2}$ Bamey $v$. Dewey, 13 Johns. 224.

${ }^{3}$ Stephens $v$. Jack, 3 Yerg. 403; Jacob $v$. Pierce, 2 Rawle, 204.

${ }^{4}$ Prentiss v. Holbrook, 2 Nich. 372.

${ }^{5}$ Smith v. Moore, 7 S. C. 209 ; 24 Am. Rep. 47.
${ }^{6}$ Hamilton v. Cntts, 4 Mass. 349; Knapp v. Narlboro, 34 Vt. 235; Chamberlain v. Prehle, 11 Allen, 370; Littleton ". Richarelson, 34 N. H. 167; Allen $v$. Pountree, 1 Spear, 80: Brewster v. Countryman, 12 Went. 440; Smith $v$. Moore, 24 Am. liep. 479.

\section{5}


But this court is of 'opinion that this exception to the general rule defining the parties by whom evidence may bo nsed, would introdnce an incouvenient collateral inquiry, and that no practical evil will result from maintaining tho general rule unimpaired, and that it is important that the rules of evidence should be broad and well defined. ${ }^{1}$ If a person gnarantee anything, whether real or personal, to be of a speeified quality or character, he may be brought in privity with an action, to which his guarantee is a party, involving the character or quality of the thing guaranteed. Thus, a party selling a note, giaranteeing it to be valid, may be required to prosecute an action, in which a defense has been tendered, involving the validity of the note. If he neglects to do so, and the defense is successfully made, he may not in a suit between himself and his vendee show that the note was valid. ${ }^{2}$

8 18S. Parties not Obliged to Conduct Suit.-It seems that there are cases where, although a party to a suit may have the right to recover over against another, yet he is not permitted to make sueh other person a party to the litigation. A., having left a note with a bank, afterward sued it for neglecting to give notice to the endorsers. This bank, claiming that the negligence was attributable to its cashier, notified him of the suit, and that he would be held responsible. He was offered the defense, but declined to undertalis it. A. recovered judgment. After this the bank sued its cashier for negligence. The judgment against the bank was treated as admissible evidence to show the fact and the amount of the recovery which had been had against plaintifis; but not for any other purpose, becanse, "This is not a case where recovery over had been given by law or provided by contract between the parties," and because the question whether the neg!igence was chargeable to the cashier, neither was nor could be litigated in tho former suit. ${ }^{3}$

"189. Not Bound by Assisting in the Suit.-Unless a person is one of the real or nominal parties to the suit, or is so identified in interest with some of such parties that he is obliged to participate in the conduct

${ }^{1}$ Grifinn $v$. Reynolds, 17 How. U. ${ }^{3}$ Bank of Owego $v$. Babcock, 5 Hill, S. 600 .

Carpenter $v$. Pier, 30 Vt. 81 . 152. 
of the proceedings, if requested, he camnot be bound by the judgment. The fact that he managed the cause as agent $t^{1}$ or attorney ${ }^{2}$ will not preclude him from impeaching the judgment. Neither will his being present at the trial as a witness, though interested in the subject matter of the controversy, bind him by the result. Thus, where A. sued a sheriff for a horse levied upon as the property of $B$., and recorered judgment, $\mathrm{B}$. being present and testifying at the trial, it was held in a subsequent suit by $B$. against $A$. for the same horse, that "It is of no consequence, prima facie, that the plaintiff was a witness for the defendant in the action brought by this defondant. He had no right as a witness to examine or cross-cxamine other witnesses, or to call other witnesses who might have better knowledge of the facts than himself. A mere witness has no control over a case whatever, and has no right to appeal. The plaintiff here was under no obligation, legal or moral, to defend for the shoriff, and he had no right to defend or to interfere."3 Even an agreement between several persons, by which each was to be bound by a verdict, and to have the right to cross-examine the witnesses, was regarded as insufficient to make the judgment binding on any of the parties who would not have been bound by it in the absence of such agreement. $^{4}$

\& 190. Distributees of Common Fund.-_"The principle is well settled in respect, to proceedings in chnneery for the distribution of a common fund among the several parties in interest therein, either on application of the trusteo of the fund, or of the administrator, legatee, or next of kin, or on the application of any party in interest, that an absent party who had no notice of the proceedings, and not guilty of willful laches or unreasonable neglect, will not be concluded by the decree of distribution, from the assertion of his right by bill or petition against the trustee, executor or administrator; or, in case they have distributed the fund in pursuance of an order of the court, against the distributees." 5

1 Thrasher $v$. Haines, 2 N. H. 443.

2 Breedlove $v$. Turner, 9 Mart. Lou. $353,375$.

${ }^{3}$ Yorks v. Steele, 50 Barb. 397.
4 Patton v. Caldwell, 1 Dallas, 419. ${ }^{5}$ IVilliams $v$. Gibbes, 17 How. U. S. 239 , 


\section{CHAPTER $\mathrm{X}$. \\ PERSONS BOUND BY LIS PENDENS.}

\$191. Reasons for Law of.

$\$ 102$. Law of, applies to suits at Liw and in Equity.

$\S 193$. Transfers pendente lite cannot prejudice suit.

$\S 194$. Property, bound by.

$\S 195$. Commencement of.

196. Suit must affect specific property.

$\S 197$. Property must be pointed out by the pleadings.

$\$ 198$. Is notice of all material facts in the pleadings.

$\$ 199$. Amendments of pleadings.

$\S 200$. No lis pendens between co-plaintiffs or co-defendants.

$\S 201$. Affects none but pendente lite alienees and incumbrancera

$\$ 202$. Diligence in Prosecution.

$\S 203$. Revivor.

$\S 204$. Dismissal, without prejudice.

$\S 205$. Writs of Error and Bills of Review.

$\$ 200$. Termination of lis pendens.

\$2 20\%. Lis Pendens, with the property in court.

$\S 208$. Involuntary Transfers.

$\S 209$. Vendee of a Vendee.

$\S 210$. Confined to State where Property is situate.

$\S 211$. Attorney's Lien.

$\$ 212$. Statutes.

$\S 213$. Ejectment in California.

§ 214. Notice may be filed before the complaint.

8 191. Reasons for Law of Lis Pendens.-Besides tho nominal parties to a judgment or decree, many others are brought within its influence, and made to respect its commands and to abide by its settlements. Prominent among these parties, are all those persons who have brought themselves within the principles involved in the law of lis pendens. The rules applied to third persons, becoming interested in the subject matter in litigation, by acquiring the title of one of the parties to the controversy, pendente lite, have been explained and justified upon the assumption that those rules were based upon notice, actual or constructive. It has been said "that all people are supposed to be attentive to what passes in courts of justice," and that, from being attentive, they must be informed of the varions matters in process of litigation in those courts. But the more reasonable view is that the law of lis pendens is not based upon

1 Worsley $v$. Earl of Scarborough, 3 Atk. 392; Green $v$. White, 7 Blkf. 242. 208 
presumptions of notice; but upon a public policy, imperatively demanded by a necessity which can be met and overcome in no other manner." "It is a careless use of languago which has led judges to speak of it" (lis pendens) "as notico because it happens to have, in some instances, a similar effect with notice." "The justice of the court would be wholly evaded, by aliening the lands after subpena served, and the suitor subject to great delay, expense and inconvenience, without any certainty of at last securing his interest. ${ }^{3}$ In fact, the doctrine of lis pendens, as understood and enforced at common law, does not seem to have required even such constructive notice as would in all cases put a man of ordinary sagacity on his gizard, or as would have enabled him to ascertain whether the property in which he desired to acquire an interest, was involved in litigation. The commencoment of lis pendens dated from the service of the subpena, though it was not returnable until the next term. No lis pendens existed until the bill was filed, yet the filing being made, tho lis pendens, by relation, was considered as in foree from tho service of the subpena. Under such a system, it might frequently happen that a man would be bound by a suit whoso object he could only conjecture, no means of information being accessible. That evory man should be presumed to be present in the courts and attentive to their proceedings, is a most unnatural presumption-a fiction not merely improbable, but impossible, since by no human power can one man be at all times in attendance upon the sereral tri-. bunals of his country, in which claims to specific property are determined. But the necessity of the rules of lis pendens is so apparent and so unavoidable, that the early existence and continued application of these rules wero indispensable to a wise public policy. If, during the pendency of any action, at law or in equity, the claim to the property in controversy could be transferred from the parties to tho suit so as to pass to a third party, maffected either by the prior proceedings or the subsequent result of the litigation,

${ }^{1}$ Newman $v$. Chapman, 2 Rand. 98; $14 \mathrm{Am}$. Dec. 766; Bellamy v. Sabine, 1 De G. \&.J. 566. (14)
${ }^{2}$ Watson v. Wilson, 2 Dana, 406.

"Ludlow's Heirs v. Kidd's Ex., 3 Ohio, $5+1$. 
then all transactions in our courts of justice would, as against men of ordinary forethought, prove mere idle ceremonies. A series of alienations protracted into the boundless future, would forever preclude the prevailing party from obtaining that to which he had vindicated his claim. The necessity of lis pendens and the perils which it was designed to avert, were thus forcibly stated by Chancellor Kent, in a case which is regarded as a pioneer in the United Strates on the subject on which it treats, and which enjoys the distinction of being quoted and approved in every part of our country: "The counsel for the defendants have made loud complaints of the injustice of the rule, but the complaint was not properly addressed to me; for if it is a well settled rule, I am bound to apply it, and it is not in my power to dispense' with it. I have no doubt the rule will sometimes operate with hardship upon a purchaser without actual notice; but this seems to be one of the cases in which private mischief must yield to general convenience; and, most probably, the necessity of such a hard application of the rule will not arise in one out of a thousand instances. On the other hand, we may be assured the rule would not have existed, and have been supported for centuries, if it had not been founded in great public utility. Without it, as has been observed in some of the cases, a man upon the service of a subpena, might alienate his lands, and prevent the justice of the court. Its decrees might be wholly evaded. In this very case, the trustee had been charged with a gross breach of his trust, and had been enjoined by the process of the court, six months before the sale in question, from any further sales. If his subsequent sales are to be held valid, what temptation is held out to waste the trust property, and destroy all the hopes and interests of the cestui que trust? A suit in chancery is, in such cases, necessarily tedious and expensive, and years may elapse, as in this case, before the suit can be brought to a final conclusion. If the property is to remain all this time subject to his disposition, in spite of the efforts of the court to prevent it, the rights of that helpless portion of the community, whose property is most frequently held in trust, will be put in extreme jeopardy. To bring home to every purchaser the charge of 210 
actual notice of the suit, must, from the very nature of the case, be, in a great degree, impracticable."

8 192. Is a Rule both at Law and in Equity.-In the case of King v. Bill (2S Comn. p. 593), the statement is made that lis pendens is a purely equitable rule, recognizable only in equity. This case is, however, chiefly, if not exclusively, remarkable for the clearness and precision with which it misstates the law of lis pendens. It has no force as an authority, being overruled by the case of Neuton v. Dirge, (35 Conn. p. 250.) According to the opinion of Lord Justice Turner, "That this doctrine belongs to a court of law, no less than to courts of equity, appears from a passage in 21 Inst. 375, where Lord Coke, referring to an alienation by a mesne lord pending a writ, says, that the alienee could not talie advantage of a particular statute of Westminster, because he came to the mesnalty pendente brevi, and in judgment of law the mesne as to the plaintiff, remains seized of the mesnalty, for pendentelitenitil imnovetur." In many of the States, statutes have been passed in which the doctrine of 7 is pendens is regulated and limited. These statutes are believed not to apply to actions in the fecleral comrts of the State, unless alopted by the rules of those courts, and particularly not to apply to suits in equity in those conrts, mnless so adopted."

8193. It is now a miversally recognized rule of law, that no alienation or transfer of the subject-matter of the controversy, made while the suit is being prosecuted with due diligence, need be noticed by the parties to the action. Such alienation, though valid between the parties thereto, is roid as agaiust the judgment or decree finally rendered in the suit."

${ }^{1}$ Murray v. Ballou, 1 John. Ch. p. | Preston $v$. Tubbin, 1 Vern. 286; Sorrell 569, decidel in 1815. To show that $"$. Cuppenter, 21 . IVms. 432; Anon. lis pendens was tiren old an.l well 1 Vern. 31s; Finch $x$. Newnham, 2 established in our law, the Ciancellor Vern. 216; Walker v. Sinalwool, Amb. quoter the ordinance of Lord Bacon, 676; Bishop of Winchester v. Pains, that "no deeree bindeth any that 11 Ves. 191. For" a very similar view cometh in bonc file, by conveyance of lispendens, ses Ballamy va'sine, from the defendant, before the bill 1 Do (4. \& J. 535, deciled in 13.57; cxhibited, and is made no party, also Haughwout $v$. Nurplly, $22 \mathrm{~N}$. J. neither by bill nor order; but where $E_{7} .511$; I Ietcalfe $v$. Pulvertoft, $2 \mathrm{~V}$. he comes in perrlente lite, and while \& B. 205.

the suit is in full prosecution, and ${ }^{2}$ Bellamy $v$. Sabine, 1 Do G. \& J. without any color of aliowance o: 534; Secombe v. Steele, 2J IIow. U. privity of the court, there recrularly S. 94.

the decree bindeth;" an:l cited the " Miajors v. Cowell, 51 Cal. 481.

coses of Martin v. Scikes, 1 Cas. in ${ }^{4}$ Norton v. Birge, 35 Com. 250; Ch. 150; Culpepper $v$. Austin, 2 Ch. Bayer v. Cockerill, 3 Iansas, 2S2; Cas. 115; Garth v. Ward, 2 Atk. 174; 


\section{194. Property kound by.-Courts have occasionally} exhibited a reluctance in applying the doctrines of lis pendens to any property other than real estate. And it lias been said that at least no movable personal property to which possession constitutes the chief evidence of title, is bound by the suit, in the hands of a bona fide purchaser, without notice. But " it may be conceded that, at this clay, lis pendens applies with equal force to controversies in regard to personal property." ${ }_{1}$ The only exception to this

1 McCutchen $v$. Miller, 31 Miss. 65; 511 , where the application of lis prn. Tabb $v$. Williams, 4 Jones Eq. 352; densto personalty, seems to be donbted Murray $v$. Ballou, 1 Johns. Ch. 566; in general, and to be al together denied For application to negotiable notes as to personal property, sought to bo past due, see Kellogs $v$. Fancher, 23 made available to the satisfaction of a Wis. 21; to purchase of a patont pend- judgment, by means of a creditor's ing litigation, to have it declared void, bill. The case of Leitch $v$. Wells, Tyler $v$. Hyde, 2 l3latchf. 30s; to suit referred to in this note has been reto subject bank stock to a certain versed upon appeal. Three of the trust, Leitch v. Wells, 48 Barb. C37; commissioners of appeals by whom to 'creditor's bill to reach furniture, the case was decided, wrote separate Scudder $v$. Van Amburgh, $4 \mathrm{Ed}$. Ch. opinions each, assigning somewhat 20 ; to ralload bonds in Pennsylvania, different grounds from those urged by where such bonds, contrary to the decisions in other States, are held nonnegotiable. Diamond $v$. Lawrence County, 37 Penn. S. 353. See, however, Chase v. Searles, 45 N. H.,

Lee $v$. Salinas, 15 Tex. 495; Moux $v$. Anthony, 6 Eng. 411; Shotwell $v$. Lawson, 30 Miss. 27; Walden $v$. Bodley's Heirs, 9 How. U. S. 34; Copenheaver v. Huffaker, 6 B. Monr. 1S; Jackson v. Warren, 32 Ill. 331; Loomis v. Riley, 24 Ill. 307; Inloe's Lessee v. Harrey, 11 MId. 519; Sharp ๘. Lumley, 3t Cal. 611; Barelli v. Delassus, 16 La. An. 250; Calderwood テ. Tevis, 23 Cal. 335; Horn $\approx$. Jones, ¿s' Cal. 194; Montgomery $v$. Byers, 21 Cal. 107; Boulden $\approx$. Lanahan, 29 MI. 200; Hurlbutt $v$. Bultenop, 27 Cal. 50; Truitt $v$. Truitt, 39 Ind. 16; Commonwealth $\approx$. Dieffenbach, $3 \mathrm{Gr}$. Cas. 368; Hughes $v$. Whitaker, 4 Heisk. 599; Walker $v$. Douglas, 89 Ill. 425; Sirowman $v$. Harford, 62 Ne. 434; Tilton $\%$ Cofiel, 93 U. S. 163; Jackson v. Andrews, 22 Am. Dec. 574. The rule is as applicalle to incumbrancers his brethren for the reversal. Upon the question whether the property in controversy was of such a nature that it could be bound by lis pendens, Commissioner Earl wrote as follows: mira $\mathrm{C}$ Co son $v$. Saloy, 12 La. An. 776; and affects purchasers at sheriff"s sale to the same extent as if the alienation was voluntary. Fasl a. Ravesies, 32 Ala. 451; Steele $v$. Taylor, 1 Minn. 274; Hall v. Jack, 32 Mll. 253; Hersey v. Turbett, 27 Penn. S. 418; Cooley $v$. Brayton, 16 Iowa, 10; Hart $\%$. Nar shall, 4 Miun. 294; Crooker v. Crooker, 57 Mai. 395; Berry v. Whitaker, 5S Mai. 422. In MePlierson $\approx$. Housel, 2 Teas. Ch. 299, it was decided that the vendee of the defendant in a foreclosure suit takes the property, subject to all costs which may be made in the ease, including those occasioned by an appeal, prosecuted by the defendant subsequently to liis conveyance. 
concession is negotiable paper, not past due. ${ }^{1}$ When such paper is the subject of the suit, the court ought to require it to be brought into court, or so placed that the defendant camnot commit a fraud upon the law by making the judgment unavailable. ${ }^{2}$ Every consideration of necessity and of public policy which demands and justifies the law of lis penders as applied to real estate, also demands and justifies the application of the same law to personal property. In fact, the ease with which personalty could be trinsferred to parties having ro notice of the litigation, is much greater than in the case of real estate. The probability of the defendant's entirely defeating the object of the suit, by a transfer of the property pendenle lite, is rather greater in the case of personal than of real estate, and the necessity of some law, prohibiting such transfer, to the prejudice of the prevailing party, is therefore greater in the former case than in the latter. But the necessity of preserving the negotiable character of negotiable paper, not due, so as to require no inquiry beyond inspection of the paper itself, in relation to its ownership, has properly been considered paramount to the necessity of avoiding transfers pendente lite, and that c!sss of paper, therefore, is the only property not liable to bo affected by the doctrine of lis penclens.

8 195. Commencement.-Lis pendens, except when some statute provides otherwise, begins from the service of the

1 Winston v. Westfeldt, 22 Ala.| 2 Stone $v$. Elliott, 11 Ohio, S. 252; 730 ; Mims. v. West, 38 Geo. 18; Day Keiffer v. Ehler, 18 Penn. S. 388. v. Zimmerman, $68 \mathrm{~Pa}$. S. 72.

"Since the decision of MINeil $v$. corporate bonds, payable to bearer. Tenth National Bank ( 46 N. Y. 32J), Incleed, I do not find that it has ever certificates of stock, with blank as- been applied, and I do not think it siguments and powers of attorney at- onght to be applied, to any of the tuched, must be nearly as negotiable ordinary articles of commerce. Pubas commercial paper. The doctrine lic policy does not require that it of constructive lis pendens has never should be thus applied. On the conyet been applied to such property. trary, its application to such property This doctrine must have its limita- would work great mischief, and lead tions. It conld not be applied to to great embarrassments." Leitch $v$. ordinary commercial paper, nor to Wells, 48 N. Y. 613. bills of lading, nor to government or 
process or subpena, and not before. ${ }^{1}$ It is also necessary, at common law, that a bill be filed, but upon such filing the lis pendens begins, from the service of the subpena. ${ }^{2}$ In Wisconsin, under the Code, a summons and complaint in a proceeding to obtain an injunction, may be served before either is filed in court. Property intended to be afiected by such a proceeding, having been transferred bona ficle without notice, after service on the defendant, but before filing of the papers in court, it was held that the doctrine of lis pendens ought not to be applied where there was no record of the suit, although the process had been served. That while there is no hardship in requiring purchasers to examine the records of the county, there is a manifest hardship in requiring them to take notice of that which no examination, however patient and industrious, could reveal, and that no case exists, under the Code, enforcing lis pendens before papers are filed, and none ought to exist. ${ }^{3}$ The doctrine that upon the filing of the bill or complaint, the lis pendens takes effect at an interior date corresponding with the late of the service of the subpena, has been most emphatically repudiated. This doctrine is based upon an anonymous case decided in 1685, and reported in 1 Vern. 318. This case, it is claimed, has never been affirmed or approved in any manner, in the almost two centuries of time intervening since its decision. But on the other hand it may also be claimed to have stood during that long period of time without being, until very recently, made the subject of judicial dissent. The following are the views of $\mathrm{Mr}_{\mathrm{r}}$. Commissioner Earl, expressed in the case of Leitch $v$. Wells, and sanctioned by the judgment entered in that case by the Commission of Appeals of the State of New York: "Suits in equity may now be commenced by the service of the summons alone; but it would be quite monstrous to hold

1 Allen $v$. Mandaville, 26 Miss. 397; $302 ; 13$ Am. Dec. 239; Majors v. Butler v. Tomlinson, 3S Barb. 641; Cowell, 51 Cal. $47 \mathrm{~s}$.

Elwards $v$. Bankswith, 35 Geo. 213; "Anon, I Vern. 31S; Sugden VenHerrington $v$. Herrington, 27 Mo. dors, 1045.

560; Lyle v. Bradford, 7 Mionr. 115; ${ }^{3}$ Kellogg $v$. Fancher, 23 Wis. 21. Hanghwout $v$. Miurphy, $22 \mathrm{~N}$. $\vec{J}$. Eq. And an order to file a complaint nunc 545; I'owell $v$. Wright, 7 Beav. 44t; mo tunc as of the clay when the notice Jackson $v$. Dickenson, 15 Johns. 309; of action was filed, will not make the S Am. Dec. 236; Camplell's Case, 2 lis pendens operative against a purBland. 209; 20 Am. Dec. 360; Minrray chaser after the filing of the notiee and $v$. Blatehford, 1 Wend. 583; 19 Am. before the filing of the complaint. Dec. 537; Scott $v$. NicMillan, 1 Litt. W Weeks $v$. Tomes, 16 IIm, 349. 
that the suit shall be deemed pending from the time of such service, so as to be 'constructive notice' to all the people of the State of its pendency. No record is kept of the issuing of the summons, and it is not required to be filed. It may be issued by any one of several thousand lawyers in the State, or by any one of several hundred thousand persons in the State competent to be plaintifis in a suit, and it might not be possible for a stranger to the suit, by any degree of diligence, to learn that it hin been issued or served; and if he did perchance learn of $i t$, it would give him no notice whatever of the subject matter of the litigation. If, therefore, the mere service of a summons should be lis pendens, so as to bind strangers, it would introduce great uncertainty and embarrassment into transactions in reference to personal property, prorided the rule of lis pendens were extended as broadly as claimed for the plaintiffs in this case. I therefore hold that there is no lis pendens, so as to give constructive notice to strangers, until a summons had been served, and a complaint, distinctly stating the subject of the litigation, and specifying the claim made, has been filed in the proper clerk's office. The rule, as thus stated, is sufficiently hard and nureasonable." While lis pendens can in no case commence at common law until process is issued and served, ${ }^{2}$ a constructive service produces the same effect as a personal service. Whenever the service may be malo by publication, the lis pendens is complete, upon the actual publication of the notice for defendant to appear; ${ }^{3}$ but it seems that there is no lis pendens until the order for publication is fully executed." The acceptance of service of subpena as of a prior date, in pursuance of a previous agreement, will not bind any lands conveyed prior to the time when the acceptance of service was in fact made. ${ }^{5}$ Where a defective subpena was served, and afterward the service was set aside and the subpena amended so as to bear date

${ }^{1}$ Leitch $v$. Wells, 48 N. Y. 611. In Goodwin v. McGehee, 15 Ala. 232. this case it seems to be assumed that In Newman $v$. Chapman, 2 Rand. 13 ; the eanlier çase of Hayden $v$. Encklin, 14 Am. Dec. 766, it is sail that, at 9 Pai. 513, was inconsistent with the common law, lis pendens dated from decision reported in 1 Vernon. But the teste of the writ.

Chancellor Walworthinsteal of doubt- "Chandron v. Magee, \& Ala. 5io; ing the case in 1 Vein., cited it, and Bennet's Lessee $v$. Williams, 5 Onio, also similar ease of Moor v. Welsh te1; Hayden ". Bucklin, 9 Pai. 511. Copner Co., 1 Eq. Ca. Alr. 39, with "Clevinger v. Jill, 4 Libb, 49s; apparent approhation.

wichlifie $v$. Jreelsinriclee, 1 Bush, 443; Miler $v$. Sheriy, 2 Wall. $207 ; \therefore 3 \mathrm{Am}$. Dec. 183. Wharing ?. Inring: $\%$ Alb. P. $422 ; 1$ Carter $v$. Mills, 39 Mo. 432 .

5 Miiler v. Kershaw, 1 Eai. Eq. 479; 
the day the service was set aside, it was held that lis pendens did not begin until service of the amended subpena. ${ }^{1}$

8 196. Irust be Specific. - In order to bring the doctrine of lis pendens into effect, it is indispensable that the litigation should be about some specific thing, which must necessarily be affected by the termination of the suit. It coes not apply to an action for divorce and for alimony to bo paid out of the husband's estate, because such a suit does not apply to any specified part of the husband's estate, real or personal. ${ }^{2}$ The judgment which may be obtained may, from the docketing thereof, constitute a lien on certain property; but in this, as well as in all other respects, it no more constitutes a lis pendens, or a claim to particular estate, than a suit upon a promissory note or any other sufficient cause of action. It is not sufficient that the judgment, unless otherwise paid, will be satisfied out of the sale of certain real estate. A mere suit to recover a money judgment does not prevent alienations by the defendant pendente lite, unless it is in the enforcement of a lien on, or otherwise is directed against the title to specific property. ${ }^{3}$

8 197. Property must be Pointed Out.-It is further essential to the existence of lis pendens, that the particular property involved in the suit " must be so pointed out by the proceedings as to warn the whole world that they intermeddle at their peril." Where a suit was, among other things, to restrain a trustee from "selling any more of the trust negroes," it was held not to affect the purchaser of a negress, because there was nothing calling attention to her in the bill as the identical property in litigation." Hence a general bill for an account of real or of real and personal estate does not create such a 7 is pendens as will affect a purchaser, but the rule is otherwise when it is sought to charge a particular estate with a particular trust. ${ }^{5}$ In a recent case it was said that a bill "must be so definite in the description, that any one reading it can learn thereby what propcrty is intended to be made the subject of litigation." But

1 Allen $v$. Case, 13 Wis. 621 .

2 Lrightman $v$. Brightman, i R. I. 112; Hamlin v. Bevans, 7 Ohio, 161; Fiviey v. Feigley, 7 Mld. 537.

ist. Joserh Mf. Co. v. Dagrett, S4 Ill.

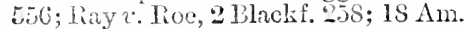
Dec. 150; Whitev. Perry, 14 W. Va. 66.

${ }^{4}$ Lewis $v$. New, 1 Strob. Eq. 1S0; Jones $v$. McNarrin, $6 \mathrm{~S}$ Me. $33 \pm$.

5 Sugden on Vendors, 1045.

${ }^{6}$ Niiller $v$. Sherry, 2 Wall. 237; Low $v$. Pratt, 53 Ill. 438. 
as it is also stated in the same opinion, that it was evident that the pleader in the original case did not lave in his mind the property now sought to be affected by lis pendens, the language of the court is probably to be construed as applicable only to those cases in which there is nothing to put a purchaser upon inquiry, and not to the cases where the pleadings, though sufficient to put a purchaser on his guard, do not, in themselves, contain a particular designation of the property in controversy. In a case where, by the decision of Chancellor Kent, a purchaser was held to bo bound, the property described in the bill was "divers lands in Crosby's manor," held in trust for the plaintiff by the defendant Winter. "The Chancellor said: "It is true there might have been 'divers' lands in 'Crosby's manor,' held in trust by Winter, and yet the lots sold to defendant have been heid by him in his own absolute right. But, thongh this was a possible, it was an improbable fact; and if ever a bill contained sufficient matter to put a party upon inquiry, the bill in 1809 answered that purpose. The doctrine of lis pendens is indispensable to right and justice, in the cases and under the limitations in which it has been applied; and according to the observations of Lord Chan. cellor Manners, we must not suffer the rule to be frittered away by exceptions. Was it too much to have required of a purchaser charged with notice of all the facts in the bill, to have called upon Winter to discover the source of his title? The general rule is, that what is sufficient to put the party upon inquiry, is good notice in equity. The least inquiry even of Winter himself, would have satisfied tho purchaser that the lots he purchased were parcel of the trust lands mentioned in the bill."1 From this decision, which seems to be sustained by reason, it would follow that the description in the bill need not, in itself, be so specific as to necessarily and beyond all possibility include a given tract of land. But that it is ample for the purpose of inroling the rule of lis pendens, if the land in all probability comes within the description, and if prospective purchasers, upon reading the bill, are advised by it that the land with which they propose to meddle, may be, and probably is, a parcel of the lands in litigation.

8 198. Lis Pendens is Notice of Every Fact contained in the Pleadings, which is pertinent to the trial of the mat1 Creen v. Stayter, 4 Tohns. Ch. 39. 
ter put in issue by them; and, in a chancery case, of the contents of exhibits to the bill which are produced and proved." But lis pendens does not affect any property not necessarily bound by the suit. Thus, if money be secured upon an estate, wo litigation about that money, but not about the estate, can affect a purchaser of the estate. ${ }^{2}$ Lis pendrns is notice of all facts apparent on the face of the pleatings and of those other facts of which the ficts so stated necessarily put the purchaser on inquiry; ${ }^{3}$ but it is not notice of every "equity which by possibility can arise out of the matters in question in the suit."

8 199. Amendments.-It is further necessary, in order to conclude a purchaser by virtue of the judgment, that by the record in the case at the time of the purchase, the parties to the suit and the nature of the claim made to the property, should be so stated that no subsequent amendment will bo necessary. If any amendment is made, lis pendens as to the matters and parties involved in the amendment, dates from the time it is made. The amending of a bill to show a new equity creates a new lis pendens. 'Thus, where property was sought to be subjected to the payment of plaintiff's demands upon one ground, and that ground becoming untenable, the bill was amended to show another equity, upon which plaintiff prevailed in the suit; a purchaser preceding the amendment was held not to be bound by the decree. ${ }^{5}$ The decisions in Ohio have established an exception to this rule. A bill was filed to snbject lands to the payment of a judgment which was subsequently reversed and a new trial ordered. Upon the new trial tho plaintiff again recovered. He then filed his supplemental bill, showing the new judgment, and asking that the same lands be subjected to its payment. A question afterward arising whether the lands were bound by lis pendens prior to the filing of the supplemental bill, the court said: "It is assumed, that when the right to recover, in the bill in equity, was taken away by the reversal of the judgment, the suit ceased to be pending, so far as to bind the property. We are not satisfied that this position is a sound one. No

${ }^{1}$ Center v. P.\&M. Bank, 22 Ala. 743. ${ }^{4}$ Shalcross $v$. Dixon, 7 L. J. Ch. N.

2 Worsley $v$. Earl of Scarborough, 3 Atl. 392.

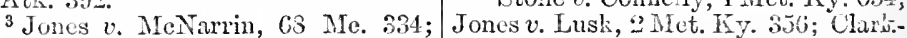
Lockwond v. Bates, 1 Del. Ch. 435; son v. Morgan, 6 B. Monr. 441.

12 A 1а. I.e. 1:1.

213 
such distinction is to be found in the books. But the dloctrine seems plain, that by the institution of a suit, the subject of litigation is placed beyond the powers of the parties to it-that whilst the suit continues in court, it holds the property to respond to the final judgment or decree. Tho supplemental bill was engrafted into the original bill and becomes identified with it. The whole was a lis pendens, effectually preventing an intermediate alienation." Tho introduction of new parties is, as to those parties and their grantees, a new lis pendens to which under a statute requiring the filing of a notice, a new notice is indispensable. ${ }^{2}$ If a bill of review set up matter not in issue in the original suit, then, all parties coming in after the original suit, aro not bound by the bill of review unless made parties to it. ${ }^{3}$ There can be no doubt that the alienee of the plaintiff is as much bound by the judgment as the alienee of the defendant." But it does not seem to be essential to the binding of the plaintiff's vendee, that at the time of the transfer, the defendant should hare disclosed his defense, or lis claim to affirmative relief. Thus, a mortgagor having a power authorizing him to sell the premises to pay his debt, commencel a suit to foreclose, to which he made $A$. and $B$. junior mortgagees parties, and subsequently sold the lands under his power of sale to $C$. After such sale, A. and B. filed their cross-bill. Upon these facts it was decided that the institution of the suit created a lis pendens against the plaintiff, and gave the junior mortgagees the right to litigate their claims against him, connected with the mortgage; that this richt could not be divested by means of any subsequent sale or transfer, made to a third party; and that plaintiff could not lull $\mathrm{A}$. and $\mathrm{B}$. into security by tendering them an opportunity of controverting his claims, and then, by having recourse to his power of sale, avoid their equities.

8 200. Co-Plaintifis and Co-Defendants. - The doctrine of lis pendens, not being founded upon any of the peculinr tenets of a court of equity as to implied or constructive notice; but being a doctrine common to the courts, both of

\footnotetext{
1 Stodklard v. Myers, S Ohio, 203, | was neither an extinguishment nor a affirmed in Giblon $v$. Dongherty, 10 release of plaintiff's rights.

Ohio S. 365, on the ground that the ${ }^{2}$ Curtis $v$. Hitchcock, 10 Pai. 30 .

sulustantial object of the suit was at ${ }^{3}$ Debell $v$. Foxworthy's Heirs, 91 . all times the same; and that reversal Monr. 228 .

of the judgment for an irregularity "Dellamyv. Sabine, 1 De C. \&.J. 580.
} 
law and of equity, and resting "upon this foundation-that it would plainly be impossible that any action or suit could be brought to a successful termination, if alienation pendente live were permitted to prevail"- -should not be carried any farther than is necessary to answer the purposes which called it into being. The doctrine of lis pendens must, therefore, be restrained within its proper sphere, and not so enlarged as to produce results, not at all essential to the carrying the judgment or decree into complete effect. Thus, if in an action by one plaintiff against two or more defendants, it appear from the pleadings that one of the defendants has certain equities against the others, but those equities do not in any way affect the present litigation between plaintiff and the defendants, and the rights of the defendants between each other are not sought to be determined, no lis pendens can be created, beyond the purposes of the suit, and an alienco of one of the defendants is not charged with implied notice of the equities between the co-defendants. ${ }^{1}$ It would seem to be perfectly clear, in the absence of all authority upon the subject, that there could be no lis pendens between coplaintiffs or co-defendants in any action not designed to settle the rights of such plaintiffs or defendants, between each other, no matter how many facts, not material to the present controversy, happened to find their way into the record. If, however, upon proper pleadings one of the defendants is shown to have certain rights as against the others affecting specific property and entitling him to relief with respect to such property, in the present action, a purchaser after such pleadings have been filed, and notice of the defendant's claim for relief registered as lis pendens, is bound as a purchaser penderte lite. ${ }^{2}$

8 201. Affects only Pendente Iite Intermedalers.-The lis pendens " is ouly constructive notice of the pendency of the suit as against persons who have aequired some title to, or interest in, the property involved in the litigation," under the parties to the suit, "or some of them pendentelite." It can, in no circumstances, operate upon parties whose rights were acquired anterior to the commencement of the suit. ${ }^{4}$ An exception to this rule is sustained by a recent

${ }^{1}$ Rellamy $v$. Sabine, 1 De G. and 522 ; S. C. 52 N. H. 162; IInnghwout J. 503 .

-Tyler $v$. Thomas, 25 Besv. 47. worth v. Lambert, 4 Johns. Ch. 605; v. AImphy, 22 N. J. Lq. 5t5; Ens-

S. Suilyvesantr. IIall, 2Barb. Ch. 151. People v. Conncily, 8 Abl. Pr. 128;

${ }^{4}$ Ilunt $v$. IIaven, 12 Am. L. Rieg. Chapman $v$. IVest, 17 N. Y. 125. 220 
case in Connecticnt, wherein it is decided that a person holding title to real estate, by virtue of an unrecorded conveyquee, is bound by a judgment against his grantor. ${ }^{1} \mathrm{Un}-$ less this single exception may be maintained, it is universaliy true that lis pendens applies only to rights and interests involved in the controversy, and acquired of a party thereto after the institution of the suit. ${ }^{2}$ One in possession, prior to a suit, can not be divested of such possession under a judgment against his grantor. This rule applies where the possession is held under an executory contract as well as under a completed purchase and payment. ${ }^{3}$ Parties having an interest in lands by contract of purchise with the legal holders of military land warrants, having paid the purchase money, and being in possession, are necessary parties to a suit, instituted by the legal holders of the same, to compel an assignment of such warrants, and all interest acquired under them by entry, location and survey. If not made parties, they are not prevented by the doctrine of lis pendens from proceeding, during the pendency of such suit, to elothe their junior equity with the legal title by procuring patents from the United States. ${ }^{4}$ In a case decided in New York in 1833, the defendlants had made contracts to purchase, under which they had entered into possession of the lands, and held and improved the same for sereral years. Suit was then commenced against their vendor, during the pendency of which, they, without any actual notice, completed their payments and procured conveyances. They were sought to bo bound by the decree rendered against their grantor; but it was decided that tho reasons on which the doctrine of lis pendens were founded, were inapplicable to the case; that it was unreasonable to compel the humble tenant, in possession of the land, to examine the files of the courts every time he wished to pay an installment of the purchase money; while no hardship could be occasioned by requiring plaintiff to make parties

1 Norton $v$. Birge, 35 Conn. 250 . | veyance was not recorded, conld not

2 Hopkins $v$. McLaren, 4 Cow. 677 ; be affected by the suit, the entire purCurtis $v$. Hitchcock, 10 Pai. 399. In pose of such filing being to bind subseHall $v$. Nelson, 23 Barb. 88, it was quent purchasers and incumbrances. lid that the effect of filing lis pen- ${ }^{3}$ Clarkson $v$. Morgan, 6 D. Monr. dens under the statute was ontirely $4+1$.

prospective. That a purchaser, prior ${ }^{4}$ Gibler $v$. Trimble, 14 Ohio, 323. to filing of lis penders, though his con- 
to his suit all persons in the open possession of the lands to be affected thereby. ${ }^{1}$ As the operation of the law of lis pendens cannot extend to persons acquiring title under either of the parties anterior to the commencement of the suit. it is, if possible, still less applicable to persons whose title wis never at any time derived from either of the parties. Therefore, whoever claims adversely to the parties in litigation, and by title paramount to theirs, cannot be prejudiced by their suit. ${ }^{2}$

2 202. Diligence.-The doctrine of lis pendens, though upheld as a necessity, is, as against a bona fide purchaser without notice, considered as a hard rule, and not to be farored." On the one hand it is said that "courts gladly ariail themselves of any defect in the pleadings or proofs of the plaintiff to prevent its operation upon such a purchaser"" while, on the other hand, it is held that the benefit of lis pendens can only be lost by unusual and unreasonable delay, and not by ordinary negligence. ${ }^{5}$ There can be no doubt, however, that to affect purchasers, there must be a close and continuous prosecution of the suit; the exercise of a reasonable diligence unaccompanied with " any gross slips or irregularities by which injury could accrue to the rights of third parties."6 What constitutes unreasonable want of diligence, or undue delay, must be decided under the particular circumstances of each case. No general rules upon the subject have come under my observation; and perhaps none can be framed which would be of any particular service. In Kentucky, suit was commenced to foreclose a mechanic's lien; and became ready for judgment by reason of the defendant's filing an admission of the allegations of the complaint. Three years later, no decree being entered, the defendant mortgaged the same premises to a party having no knowledge of the lien or suit.

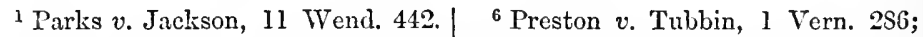

${ }^{2}$ Allen v. Morris, 34 N. J. Law I59; Clarkson $v$. Morgan, 6 B. Monr. 44l; Stuyvesant $v$. Hone, 1 Sand. Ch. 419. Watson v. Wilson, 2 Dana, 406; My-

${ }^{3}$ IIayden $v$. Bucklin, 9 Pai. 511; rick v. Selden, 36 Barb. 22; LdmesSorrell $v$. Carpenter, 2 P. Whns. 4S3. ton $v$. Lyde, 1 Pai. 687; 19 Am. Dec.

${ }^{4}$ Ludlow $v$. Kidd, 3 Ohio, 541.

${ }^{5}$ Gossom $v$. Donaldson, 18 B. Monr. 454; Trimble $v$. Boothby, $14 \mathrm{Oh}$.
} 230. 
The delay was deemed sufficient to relievo the purchaser from the operation of lis pendens. ${ }^{1}$

\%203. New Suit, and Revivor.-If a suit were not prosecuted with effect as if, at law, it were discontinned or the plaintiff suffered nonsuit; or if, in chancery, the suit werc dismissed for want of prosecution, or for any other canse, not on the merits; or if, at law, or in chancery, any suit abated; although in all such cases a new action could be brought, it could not affect a purchaser during the pendency of the first suit. ${ }^{2}$ In case of abatement, however, the suit might be continued in chancery by reviror, or, at law, in real actions abated by death of a party, by joumies accounts, and the purchaser still bound by the judgment or decree. ${ }^{3}$ But in all cases there must be no lachcs in reviving the suit; for a failure to revive in a reasonable time results in a suspension of the lis pendens. ${ }^{4}$ In Kentucky, "a reasonable time" is one year. ${ }^{5}$ A reasonable excuse for the delay complained of, is always available to keep up tho is pendens." 6

\& 201. Dismissal.-During the pendency of an action in equity, for a specific performance, A. purchased the subject matter in controversy. The bill was subsequently dismissed, without prejudice, with leavo to proceed de novo. To the subsequent proceeding $A$. was made a party, but contended that his purchase was without notice of the plaintiff's rights. It was decided that the effect of the former suit, as a lis pendens, was not impaired by the dismissal of the bill, with leave to proceed de novo; that by the immediate filing of his bill de novo, the plaintiff had been constant and continuous in his prosecution; and that it might well be doubted whether $A$. would not have been affected by lis pendens, if his purchase had taken place after

${ }^{1}$ Ehrman $v$. Kendrick, 1 Met. Ky. ${ }^{4}$ Trimble $v$. Boothby, 14 Ohio, 109; 146. Shiveley $v$. Joncs, 6 B. Monr. 274;

${ }^{2}$ Newman $v$. Chapman, 2 Rand. 9S; Watson $v$. Wilson, 2 Dana, 406. 14 Am. Wec. 766; Watson v. Wilson, ${ }^{5}$ Hull v. Deatly's Admr., 7 Bush, 2 Dana, 40s; Herrington $v$. Herring- 687.

ton, 27 Mo. 560.

32 Rand, 9S; 14 Am. Dec. 760; $2,443$.

Dana, 408. 
the dismissal of the first bill, and before the filing of the second. ${ }^{2}$ But in another case, the doctrine that a purchaser rending a bill dismissed without prejudice, is bound by the subsequent bill, is expressly denied. ${ }^{2}$

\section{205. Writ of Error and Bill of Review.-According} to some of the authorities, a purchaser after final decree, and before writ of error or bill of review is prosecuted, is a pendente lite purchaser. Hence, a party purchasing land, from a person who had obtained a conveyance of the land, from a commissioner appointed by the court for that purpose, is liable to have his title divested, if the decree should be set asicle by bill of review, filed after the purchase $;^{3}$ and this, although the defendants were infants, and allowed a number of years to file their bill of review. ${ }^{4}$ But in relation to writs of error, the position has been taken that " until service of citation, a writ of error is not to be considered as pending, so as to affect strangers as 7 is pendens. It is contended that a writ of error is but the continuance of the original suit, and like a bill of revivor, or an appeal, reinstates the suit, and refers all things and partios to its first commencement. We do not concede that such, in all cases, would be the consequence of a bill of review or of an appeal. But in this case, we think, the analogy does not hold good. In the obvious nature and character of the proceeding, a writ of error is a new and originai suit. Original process issues in it, and must be served, to bring the adverse party into court. The relative character of the parties is changed; new pleadings are made up, and a final judgment upon it, though it may operate on another canse, is, nevertheless, a termination of the new suit or process in error." As the result of these views, it was determined that when lands hat been awarded to $A$. by the decree in a chancery suit, and he had been placed in possession thereof, his subsequent conveyance of the lands passed a title not liable to be di-

1 Ferrier v. Buzick, 6 Iowa, 258; 228; Clarey v. Marshall, 4 Dana, 95; Bishop of Winchester $v$. Paine, 11 Earle $v$. Crouch, 3 Met. Ky. 450; Gore Vesey, Jr. 200.

2 Clarkson $v$. Morgan, 6 B. Monr. 441.

$v$. Stakpoole, 1 Dow, 31 .

' 4 Ludlow's Heirs $v$. Kidd's Ex'r., 3 Ohio, 541; Dishop of Winchester $v$.

${ }^{3}$ Debell $v$. Foxworthy, 9 B. MIomr. Deavor, 3 Ves. Jr, 314. 
vested by a writ of error, muless the proceedings upon such wit wero commenced, and citation served on the defendint in error prior to his conveyance. ${ }^{1}$

\section{206. Termination of I.is Pendens.- "There is no such} doctrine in this court, that a decree made here shall be an implied notice to a purchaser, after the eause is ended; but it is the pendency of the suit that ereates the notice, for as it is a transaction in a sorereign court of justice, it is supposed that all people are attentive to what passes there, and it is to prevent a greater mischief that would arise by people's purchasing a right under litigation, and then in contest; but where it is only a decree to account, and not such a one as puts a eonclusion to the matiers in question, that is still such a suit as does affect people with notice of what. is doing. ${ }^{2}$ By virtue of a statute of Indiana, when a decree for the conveyance of land is not complied with, it shail, notwithstanding, bo deemed and taken to have the same force in all courts of law and equity, as if the conveyance had been made. Pending a suit for specific performance, the defendant conveyed the property in controversy to $W$. Afterivards, a decreo was entered and a conveyance was made. This conveyance was recorded among the records of the court, bat not among the records of the county. Subsequently W. conveyed to J. It was decided that $J$. obtained the title, because the decree was not notice, and the records of the county did not discloso any defect in W.'s title; that the case conld not be distinguished from that of judgment and sale at law, where a purchaser under execution, who does not put his deed on record stands, in respect to the registration laws, as if he had purchased from the defendant. ${ }^{3}$ Bat a purchaser from a mortgagor, after a deeree of foreclosure, is liable to be removed from possession under a writ of assistance. "It cannot be objected that the case is no longer lis pendens, after decree and sale, and a conveyance executed, because the Court of Chancery

1 Taylor $v$. Boyd, 3 Ohio, 393; Lud- 3 Atk. 392 ; Harvey v. Montague, 1 low $v$. Kidd, 3 Ohio, 541; McCormick Vern. 122; Sug. Vend. 1047 ; Ludlow v. McClure, 6 Blackf. 466 .

v. Kidd, 3 Ohio, 541 .

2 Worsley $v$. Earl of Scarborough, 3 Rosser v. Bingham. 17 Ind. 542. 
is not functus officio, until the decree is executed by delivery of possession."

\section{207. Where Realty is in Possession of the Court.} In case real estate is taken into possession by a court, through the appointment of a receiver, or by sequestration, it is not to be intermeddled with, without leave of the court. Any person having a paramount claim, by judgment or mortgage, should appear in court and obtain leave to proceed. The court will direct a master to inquire into the circumstances, or as to the priority of the lien; and will take care that the fund realized from the land is applied accordıngly. The party having a prior legal encumbrance, and having no notice of the proceeding in equity, may, no donbt, still hold such oncumbrünce after the land is sold at equity, and might, after the land had been removed from the possession of the Court of Chancery, pursue his legal remedy; but if, while the land is in custody of equity, ho take out execution and sell, the purchaser will take no title as against the chancery sale. ${ }^{2}$

8 208. Involuntary Transfers.-A distinction no doubt exists as to the effect of voluntary transfers pendente lite, and those compulsory transfers made by operation of law, in which, as in involuntary proceedings in bankruptcy, the property of a party is transferred to an assignee for the benefit of creditors. Such assignee is not bound to know what suits are pending to afiect the property of the assignor; and he will not, in any event, be bound by any proceeding pending against his assignor at the tirne of the transfer, unless he is made a party thereto. ${ }^{3}$ But where the proceeding is voluntary, it is instituted ratier for the benefit of the applicant, than for the protection of his creditors. A transfer in such a case forms no exception to the rule of ordinary transfers pendente lite. The assignee is bound by the judgment whether he bo made a party or not. ${ }^{4}$ But a purchaser at an execution sale is considered as a voluntary purchaser. He acquires no title superior to that possessed

\footnotetext{
1 Jackson $v$. Warren, 32 Ill. 331. | ${ }^{3}$ Sedgwick $v$. Cleveland, 7 Pai. 290.

2 Wiswall v. Sampson, 14 How. J. ${ }^{4}$ Cleveland $v$. Boerum, 24 N. X. S. p. 52. 
by the judgment defendant at the moment of the creation of the judgment lien. If, when such lien attached, the title for the defendant had already been tied up by tho pendency of some other suit, the purchaser at the execution sale can acquire nothing which is not also subject to the hazard of such other suit. Such purchaser is bound by the result of pending litigation; and there is, therefore, no necessity of making him a party thereto. 1

8 209. Vendee of Vendee. --An early case in Virginia is understood as restricting the doctrine of lis pendens to purchases and conreyances from the parties to the suit, and as laving no foree against a person who obtains a transfer pendente lite, from some person, who, though not himself a party to the suit, obtained his title pendente lite from one who was such a party. ${ }^{2}$ This ease, so far as our observation extends, has never been affirmed; but the cases necessarily in clirect conflict with it do not seem to be numerous. ${ }^{3}$ The general expression that lis pendens only afiects purchasers from parties to the suit pendente lite, is of frequent occurrence in the reports. Upon examination of the cases in which such expressions are employed, they will generally, if not invariably, be found to be intended as statements of the rule applieable to transfers made prior to the institution of any suit, or to transfers pendente lite of titles existing independent of that in litigation. It would be very strange that if, after the gencral application of the doctrine of lis pendens had been upheld for ages as absolutely indispensable to the administration of justice, a limitation should be imposed which is necessarily subversive of the whole doctrine. If two or more pendente lite transfers are to be allowed to thwart the purposes of a suit, then the principles of necessity and of public policy, of which so much has been said, are to be regarded as decidedly more important than the interests of a pendente lile parchaser, but decidedly less important than the interests of his rendee. If the final judgment in any action in reference to specific property may be nullified by two transfers, instead of by one, the

1Steele v. Taylor, 1 Minn. 278; Hart v. Marshall, 4 Minn. 296.
2 French $v$. Loyal Co., 5 Leigh. 627. 3 Norton $v$. Birge, 35 Conn. 250. 
difficulty of the extra transfer is not likely to furnish any considerable protection to the judgment.

\& 210. Confined to the State. - The general rule, that $l i s$ pendens is notice to the whole world, has been restricted by a decision of the highest court in Tennessee. It was there decided that lis pendens applies to movable property only while it remains within the State where the suit is prosecuted; that if property situated in some other State be removed into Tennessee pendente lite, and there sold, a purchaser, without notice, is not bound by the juctgment. The reasoning upon which this decision was supported, was that the doctrine of lis pendens rests upon the necessity of preventing any obstruction to the execution of judgments; that the judgment of another State can not have process issued upon it here, and, therefore, the reason of the doctrine is not applicable to proceedings in other States. ${ }^{\text {I }}$

8 211. Iien of Attorneys.- Where by law the attorneys in a cause have a lien upon property involved in litigation, for their fees, the lis pendens is a general notice of such lien, and the client can not, by a pendente lite transfer, defeat the claim. ${ }^{2}$

8 212. Statute Requirements. - The hardship to bona fide purchasers of resl estate, without notice, arising from the law of lis penclens, has been greatly ameliorated in England, and in many, if not in all, of the United States, by statntes requiring the filing of notices of the pendency of actions affecting real property. Thus, in England, by statute 2 Vict. C. 1157, it was enacted that no lis pendens shall bind a purchaser or mortigagee, without express notice, until a memorandum or minute thereof, containing the name and the usual or last known place of abode, and the title, trade or profession of the person whose estate is intended to be affected thereby, and the court of equity, and the title of the cause or information, and the day when the bill or information was filed, shall be left with the Senior Master of the Court of Common Pleas, who shall forthwith enter the

' Shelton $v$. Johnson, 4 Sneed, 6\$3. ${ }^{2}$ Hunt v. McClanahan, 1 Heiskell, Compare with Fletcher $v$. Fletcher, 9 p. 503.

Dana, 372. 
same particulars in a book, in alphabetical order, by the n.ume of the person whose estate is to be affected. In the United States the notice is not generally required to state all of the particulars specified in the English statutes, our law-makers being satisfled with a notice showing the naturo of the suit, the parties thereto, the court where pending, and the property to be afiected thereby ; and the filing of such notice in the oflice where the records affecting real estate are kept, and the indexing of the notice, alphabetically, according to the names of the parties to the suit. If no notice is filed, pendente lite purchasers are wholly unaffected by the judgment, ${ }^{1}$ unless they have actual knowledge of the suit, in which event they are not protected by the statute. ${ }^{2}$

8 213. In Fijectment.-Section twonty-seven of the California Practice Act required the filing of notice of the pendency of actions afiecting the title to real estate. This section, it was held, did not apply to actions of ejectment, nor to any actions affecting the possession only. In such actions the title is not affected, but remains after judgment as it was before. Therefore, the pendente lite rendee of either of the parties was held to be bound by the judgment rendered against his grantor. ${ }^{3}$ In New York, where a judgment in ejectment has no further or higher efiect than in California, a difierent, and, it seems to us, more rational conclusion was reached. The Supreme Court in that State, in disposing of the question, said: "The eflect given by this statute to the judgment recovered in an action of ejectment clearly rendered that action one which affected the title of the property in controversy in it. For it bound that title, not only as to the parties to the action, but also as to all who derived title uncler them from the time of the commencement of the action. To that extent the judgment, while it remained in force, conclusively settled the rights

${ }^{1}$ Richardson $v$. White, 18 Cal. 102; v. Pierson, 5 Mich. 456; Sugden on Ault v. Gassaway, 18 Cal. 205; Abadie Vcndors, 1013.

v. Lobero, 36 Cal. 390; Leitch v. ${ }^{3}$ Long v. Neville, 29 Cal. 131.

Wells, 48 Barb. 637.

The statute has since been changed,

${ }^{2}$ Sampson $v$. Ohleyer, 22 Cal. 200; and lis pendens may now be filed in Abadie v. Lobero, 36 Cal. 390; Balier ejcctment suits. 
of the parties, and those claiming under them, to the property in controversy. No judgment cosceming the rights of parties to real property could have any greater effect than that upon the title of those afiected by it. The action was one for that reason in which a notice of its pendency should have been filed in order to secure this statutory result against subsequent purchasers and encumbrancers, not otherwise having notice of the pendency of the surt or the recovery of the judgment." But this decision was reversed by the Court of Appeals, on the ground that it is dificult to see how in an action of ejectment a notice of lis peridens can be necessary to bind even purchasers pendente lite by tho judgment." Proceedings to condemn land are of the class requiring notice of lis pendens to be filed, to affect pendente lite purchasers without notice. ${ }^{3}$

\section{214. Filing Iis Pendens before Complaint.--It is no} objection to the lis pendens that is was filed several days before the suit was commenced. The object is to give notice, and a lis pendens so filed, gives as much notice as ono filed simultaneously with the complaint. ${ }^{4}$

\footnotetext{
129.

${ }^{1}$ Sheridan $v$. Andrews, 3 Lansing,

${ }^{2}$ Sheridan $v$. Andrews, 49 N. Y. 482.

${ }^{3}$ Bensley, $v$. Mountain Lake Water Co., 13 Cal. 306.

${ }^{4}$ Houghton $v$. Mariner, 7 Wis. 244; but in New Jersey a lis pendens filed ing the notice, but before the actual before the bill has been characterized filing of the complaint. as a fraud and a nullity. Walker $v$.

\section{Wceks $v$. Tomes, 16 Hum, 349, it was held that an order to file a complaint munc pro tunc as of the day on which the notice of action was filed, could not operate to cut off the rights of a purchaser acquired subscquent to fil-}




\section{CHAPTER XI.}

\section{MERGER; OR FORJIER RECOVERY.}

\$215. General Principles.

$\S 216$. Includes all Causes of Action.

$\S 217$. Judgment as a New Debt.

$\S 218$. Depends on Valid Judgment.

$\S 219$. Judgments of no Extra-Territorial Effect.

$\$ 220$. Foreign Judgments.

$\$ 221$. In Sister States.

§ 222. Examples of Nerger.

$\$ 223$. Lxceptions.

$\$ 224$. NLerger pendente lite.

$\S 225$. Criminal Prosecutions and Convictions.

\&225a. Principal and Agent.

$\S 226$. Principal and Surety.

$\$ 227$. Co-Plaintiffs and Co-Defendants.

$\S 227 a$. Suits on Bills and Notes.

$\S 228$. Warrantor and Grantee; Garnisbee and Principal; Corporation and Stockholder.

$\S 229$. Collateral Securities.

$\S 230$. Foreclosure of Security.

$\S 231$. Joint Obligors.

$\S 232$. Partners.

$\S 233$. Joint Debtor Acts.

$\S 234$. Exceptions to Law of Co Obligors.

$\$ 235$. Joint and Several Obligors.

$\S 235$. Recovery in a Different Right or Capacity.

$\S 236$. Tort-Feasors.

$\S 237$. Whether Recovery Vests Title.

$\$ 288$. Indivisible Demands, Ex Contractu.

$\$ 239$. Actions on Account.

$\$ 240$. Only One Action on One Contract.

$\$ 241$. Only One Action on One Tort.

$\S 242$. In Cases for Injury by Nuisances.

$\S 243$. Several Torts.

$\$ 244$. Exception to General Law of Merger.

$\S 245$. Proceediugs in Insolvency.

\section{215. General Principles.-The rendition and entry of} a judgment or decree establishes, in the most conclusive manner, and reduces to the most authentic form, that which had hitherto been unsettled; and which had, in all probability, depended for its settlement upon destructible and uncertain evidence. The cause of action thus established and permanently attested, is said to merge into the judgment establishing it, upon the same principle that a simple contract merges into a specialty. Courts, in order to give a proper and just effect to a judgment, sometimes look behind, to see upon what it was founded, just as they would, 
in construing a statute, seek to ascertain the occasion and purpose of its enactment. The cause of action, though it may be examined, to aid in interpreting the judgment, can never again become the basis of a suit between the samo parties. It has lost its vitality; it has expended its force and efiect. Ail its power to sustain rights and enforce liabilities has terminated in the judgment or decree. ${ }^{1}$ It " is drowned in the judgment," and must henceforth bo regarded as functus officio.

The well established principle of law, that no further action can be prosecuted, between the same parties, upon a matter already ripened into judgment, is supported by a variety of reasons. Its operation is, in many respects, beneficial. Its existence has been variously acconnted for, according to the purposes subserved, and the reasons involved in the vast number of cases in which it has been recognized. The early cases place the rule upon the sole ground that an inferior remedy has been changed to one superior. Thus, it was said, if a man brought debt upon a bond and had judgment in a court of record, the contract by specialty, being of a more base nature, was changed into a thing of record, and no further suit could be brought to vex the defendant; but if plaintiff had his judgment in a court not of record, he might bring another action, because his bond had not been changed into a matter of higher nature. ${ }^{3}$ In later cases, in addition to the mere assertion that the judgment is of a higher nature than the cause of action, the allowance of a new suit is shown to be a superfluous and vexatious encouragement to litigation, injurious to the defendant, and of no benefit to the plaintiff. 4 The doctrine of merger is also frequently supported, on the ground that the cause of action has become a thing adjudicated and precisely determined and ascertained, and, therefore, upon principles of public policy, not to be again made the subject of judicial inquiry. But, in our judgment, the bar occasioned by a former recovery

\footnotetext{
${ }^{1}$ Wayman $v$. Cochrane, 35 Ill. 152; $\quad{ }^{3}$ Viner's Abr., citing 6 Rep. $44 \mathrm{~b}$. IIogg $v$. Charlton, 25 Penn. S. 200. and 45 a. b.

${ }^{2}$ Bidulleson $v$. Whitel, I W. Bla. ${ }^{4}$ Smith $v$. Nicolls, 5 Bing. N. C. 507.
} 
has been gradually strengthened and extended, until it has become independent of the reasons generally assigned in its support. We donbt whether, in a majority of the United States, two suits could bə prosecuted to judgment on the same cause of action, against the objection of the defendant, irrespective of the question whether the first judgment was of a higher or lower nature than the cause of action. If, for instance, an action were brought in a justice's court, upon a judgment of the district court, for a sum less than three hundred dollars, and prosecuted with effect, the judgment recovered would be of a lower nature than the one sued upon; it would be no more a thing adjudicated than the cause of action was; and yet the plaintiff would probably not be at liberty to bring similar actions ad libilum. The new judgment, though inferior as an instrument of eridence to the old one, and not attended by the same liberal, jurisdictional presumptions, ought, nevertheless, to entirely supplant the old one, because it is the most recent judicial determination of the rights of the parties, and because the plaintiff has roluntarily elected to abandon his former judgment to secure one which, though in an inferior court, is conclusive in favor of the continuance and amount of his claim.

8 216. Includes all Causes of Action. - The weight of authority in the United States shows that whatever may be a cause of action will, if recovered upon, merge into the judgment or decree. A contract by specialty merges into a judgment in the same manner as a simple contract. ${ }^{1}$ A judgment is extinguished when being used as a cause of action; it grows into another judgment. ${ }^{2}$ It may even be merged by a statutory judgment. Thus, if the law provides for the execution of a forthcoming or delivery bond, which, when forfeited, shall have the force and efiect of a judgment on which execution may be issued, a forfeiture of such bond

${ }^{1}$ Pitts $v$. Fugate, 41 Mio. 405; Fing | Whiting $v$. Seebe, 7 Eng. 549; Gould $v$. Hoare, 13 M. and W. 494; Andrews v. Hayden, 63 Ind. 413; Frazier $v$. v. Varrell, 46 N. 11.17.

${ }^{2}$ Chitty v. Glenn, 3 Monr. 425; McQueen, 20 Ark. $6 \mathrm{~s}$. 
discharges the judgment upon which it was given. ${ }^{1}$ On the other hand, some American cases, proceeding upon tho theory that no merger can take place until some higher remedy or evidence is created, deny that one judgment can merge into another of equal degree. ${ }^{2}$ On this ground a motion to enter satisfaction of a judgment because it had been recovered upon in another action, was denied. ${ }^{3}$ The effect of this ruling would be that the estate of the debtor could be involved by a multiplicity of record liens, and his chattels seized under a great number of executions, and himself financially ruined by the expenses of divers proceedings, all based upon a single and indivisible demand.

8 217. Judgment is a New Debt.-Every judgment is, for most purposes, to be regarded as a new debt. The chief and perhaps the only exception, being in cases whero the techuical operation of the doctrine of merger would produce manifest hardship, and even those cases are by no means universally excepted. This new debt is not, in general, afiected by the character of the old one. Though the canse of action may have arisen from a tort, the judgment is not, therefore, any the less a contract or in the nature of a contract. Hence, it may be the foundation of an action of debt, ${ }^{4}$ or of a set-off, under a statuto permitting matters ex contractu to bo set-off. ${ }^{5}$ Neither is it infected by the usurious nature of the cause of action. ${ }^{6}$ The

1 Brown v. Clark, 4 How. U. S. 4; surety. At the maturity of the reBank of U.S. v. Patton, 5 How. Miss. plevin bond execution issued thereon, 200; Wright $v$. Yell, 13 Ark. 503 ; and was returned unsatisficd. After Ilamma $v$. Guy, 3 Bush, 91; Cook v. this, a second capias pro fine was isArmstrong, 25 Miss. 63; Neale v. sued, but it was, on motion, quashed Jeter, 20 Ark. 9S; Black $v$. Nettle, 25 on the ground that the oriorinal judgArk. 606 ; liussel $v$. Shute, 25 Ark. ment levying the fine had been merged 469; Lipscomb v. Grace, 26 Ark. 234 . in the replevin bond. Commonwealth But a difierent rule prevails in Alabama; see Patton $v$. Hamner, 33 Ala. 307. In Kientucky, a person having pleaded guilty to an indictment charging him with being a common gambler, was arjudged " to make his fine to the commonwealth by the payment. of fifty dollars." For this fine a $c a$ pias pro fine was awarded against him which he replevied with one W.as his

v. Merrigan, 8 Bush. 132.

2 Weeks v. Pearson, 5 N. H. 324.

3 Mumford $v$. Stocker, 1 Cow. 178:

Criswoll $v$. Hill, 2 Paine, C. C. 492;

Andrews $v$. Smith, 9 Wend. 53.

${ }^{4}$ Johnson v. Butler, 2 Iowa, 535.

5 Tiylor $v$. Troot, 4 Kieyes, 335.

6Thatcher $v$. Gammon, 12 IIass. 203.

234 
assignee of a note sued the maker, who had an offset to the note consisting of a judgment against the assignor. This set-off the maker did not present when sued upon the note, and judgment was therefore rendered against him without taking the set-off into account. Suit was subsequently brought in another State upon this last judgment; and in this last action the defendant sought the benefit of the set-off, which he had before neglected to assert. The court refused to entertain the set-off because "the note and all the equities existing between the parties were merged in the judgment." A judgment rendered in one State, upon a forfeited recognizance taken for alleged violation of its penal laws, can be made the basis of an action in another State, though objected to on the ground that one State wiil not aid in enforcing the penail laws of another. ${ }^{2}$ The samo rule is applicable to actious upon judgments given for violations of local police regulations, or for any other local causes of action. ${ }^{3}$ In all such cases, no inquiry will bo made in relation to the facts preceding the judgment, to ascertain whether the original action would have been enforced by the court now called upon to enforce the judgment. A debt due to the estate of a deceased person, if sued upon and recovered by an administrator, is, in law, the debt of him who recovers it, and in whose name the judgment is rendered. He holds the legal title, subject only to his trust as administrator. He may sue upon the judgment in his own name, without describing himself as administrator; and may, therefore, pursue the judgment defendant, by action on the judgment, in a different state from that in which the letters of administration were issued, ${ }^{4}$ and there can scarcely be a doubt that a judgment rendered in favor of an administrator so merges the debt that it may be treated as his personal efiects so far as to authorizo

1 Ault $v$. Zehering, 38 Ind. 433 . judgment." Holmes v. Guion, 44 2Spencer $v$. Brockway, 1 Hamm. Mo. 168.

$259 ; 13$ Am. Dec. 615

4 Bonafous $v$. Walker, 2 Term $\mathrm{R}$.

3 State of Ind. v. Helmer, 21 Iowa, 126 ; Biddle v. Willins, 1 Pet. 6SC; 370; Healy $v$. Root, 11 Pick. 390. A Tallmadge $\%$. Chappel, 16 Mass. 71; judgment by consent has been said to Fall $v$. Fiarrison, $21 \mathrm{Mo} .227$; Allen have the same effect as any other, be- $v$. Lyman, 27 Verm. 20 ; Nelson $v$. cause "the consent was merged in the Bagby, 25 Tex. Supp. 205. 
him to maintain suit thereon in a foreign country, without there taking out letters of administration. ${ }^{1}$

\& 218. Depends on Vaiid Judgment.-Merger depends for its existence and continuance upon a valid judgment. Thereforc, if such a mistake is made in the name of tho parties as to render the judgment ineffective, the cause of uction does not merge, and a subsequent suit may be brought thereon. ${ }^{2}$ If, in support of a plea of judgment recovered, the defendant introduce the proceedings or record of a court, from which it appears that the plaintiff had taken a judgment which is coram non judice, such judgment will bo as unavailing, as a defense for the defendant, as it would be as a cause of action for the plaintilf. ${ }^{3}$ In all such cases it is obvious that the judgment produced is, in fact, no final determination of the rights of the parties, and that no obstacle has intervened to prevent them from seeking such determination. Though the judgment was valid at its entry, it may be reversed or set aside. In such cases tho merger ceases. ${ }^{4}$ If plaintiff recover judgment against ono of several joint obligors, and it is reversed, he may proceed against all of them in a new action. ${ }^{5}$ The mere taking or granting of an appeal does not so impair the julgment as to destroy its effect as a merger of the original cause of action. ${ }^{6}$

₹ 219. Judgment of IJo Extraterritorial Efrect.-A judgment, valid in the jurisdiction where it was rendered, may have no extraterritorial effect. If so, the operation of the merger extends no farther than the other incidents growing out of the arjudication. ${ }^{7}$ In the case of Swift v. Stark, 2 Oregon, p. 97, the court thought that a judgment rendered under a statute of one of the States, providing for the entry of judgment against two or more joint debtors, upon service of summons on but one, merged the canse of action against the one not served, though, as to him, it was admitted to constitute only a prima facie evidence of in-

1 Vanquelin $v$. Bouard, $15 \mathrm{C}$. B. (N. S.), 341 ; S. C., 33 L. J. (N. S.) C. P. 78; S. C., 12 W. R. 128.

2 Wixom $v$. Stephens, 17 Mich. 51s.

3 Briscoe $v$. Stephens, 9 Muore, 413 ; Mico 2 . Morris, 3 Lev. 234; Adney $v$. Vermon, 3 Lev. 243.

"Goodrich v. Bodurtha, 6 Gray, 32s. 
debtedness. But this portion of the opinion of the conts was not necessary to the determination of the case. It does not seem to be the result of any careful examination of principles or adjudged cases ; and it is opposed by very high authority. ${ }^{1}$ In Michigan, such a judgment creates no personal liability against the unsummoned defendant. Neither is it a merger of the cause of action. The conclusion of the court was sustained by the propositions: First, that neither the analogies of the common law, nor the reasons on which the rule is based, apply to proceedings under such a statute. Second, that, by commencing an action against all the obligors, the plaintiff evinced an intention to pursue them jointly. Third, that the judgment, thongh joint in form, was effectual against but one. Fourth, that by the statute the unsummoned defendants could bo brought in, and made personally liable, after the judgment, while at common law their liability would have been extinguished."

8 220. Foreign Judgments.-A foreign judgment is received with different degrees of regard in different States, and among different nations. Wherever it is enforced as a final adjudication between the parties, it ought also to be a bar to another suit. In Louisiana, a statute giving to foreign judgments the same force with those of the sister States, was decided to inhibit any further proceedings in the original cause of action. ${ }^{3}$ In England, a foreign judgment is, in most respects, carried into effect to the same extent, which, under the provisions of our Constitution and the laws of Congress, a judgment rendered in one of these United States would be enforced in another. But it is, nevertheless, not regarded as a matter of record, nor as being of a higher nature that the original cause of action. Hence, it does not debar plaintiff of the remedy which every subject has of bringing his action, and ho has his option, either to resort to his original ground of action or to bring assumpsit on the judgment. ${ }^{4}$

${ }^{1}$ D'Arcy $v$. Kctchum, 11 How. U. « Bank of Australasia v. Harding, 9 S. 165 .

${ }^{2}$ Bonesteel $v$. Todd, 9 Mich. 371 .

C. B. 661 ; Robertson $v$. Struth, 5 Q.

B. 941 ; Smith $v$. Nicholls, 5 Bing. N.

${ }^{3}$ Jones $v$. Jamison, 15 La. An. 35. C. 20S; 7 Dowl. 2S2; Hall $v$. Odber, 
7 221. In Sis:er Btates.-A judgment in any of the State or Federal courts, upon valid personal service, being regarded as a debt of record, and as entitled to full faith and credit, is a merger in every part of the United States, in the same manner as in the State where it was rendered. ${ }^{1}$ If actions are simultaneously pending, upon the same cause of nction, in different States, a judgment in either will bar the further prosecution of the other. ${ }^{2}$ This rule is inflexible, and yields to no circumstance of hardship or inconvenience. Its application is not arerted by the pendency of an appeal, ${ }^{3}$ nor by the fact that the defendant has property in the State where the action is still pending, but none in the State where judgment has been given. ${ }^{4}$ We have already stated that a judgment having in other respects no effect beyond the State where it was rendered, is also beyond that State, no merger of the original cause of action. ${ }^{\circ}$ But if the judgment be against ono having his domicil in the State where it was rendered, it will, according to the weight of the authorities, be given the same effect elserwhere, as would be accorded to it in the juriscliction where it was created. Ilence, though it be based upon constructive service of process, and infected with irregularities in the proceedings by which it was procured, and be, on that account, voidable in the State where it was entered; still, as it is binding on the parties until avoided by some appropriate proceeding, it will, in the absence of such proceeding, be regarded even in other States as a merger of the original cause of action. ${ }^{6}$ But no judgment is to be given any greater effect elsewhere than it had in the jurisdiction in which it originated. The consequence of a judgment, in respect to its effect as a merger of the original demand, being dependent upon the

\footnotetext{
${ }^{1}$ Barnes v. Gilubs, 2.Vroom, 317; ${ }^{4}$ Child v. Powder Works, 45 N. H. Ault v. Zehering, is Ind. 429; United 547 . States $v$. Dewey, 6 Biss. 501.

${ }^{2}$ MeGilvray \& Co.v. Arery, 30 Verm. 538; Rogers v. Odell, 39 N. H. 452.

${ }^{3}$ Bank of N. A. $v$. Wheeler, 28 Conn. 433.

5 See sec. 219.

${ }^{6}$ Henderson $v$. Staniford, 105 Mass. 504; 7 Am. Riep. 551.
}

11 East, 118; Phillips v. Hunter, 2 H. | Frazier v. Moore, 11 Tex. 755; Wcod Bla. 402; Lyman v. Brown, 2 Curtis, v. Gamble, 11 Cush. 8. 550; Bonesteel v. Todd, 9 Mich. 375; 
law of the land, a modification or repeal of the law of the land will modify or avert the incident of merger. Thus, if a statute, as in Missouri and Maryland, provide that a joint contract shall be construed as joint and several, the merger of such a contract by a recovery thereon, must be treated as though it had arisen out of a joint and several, and not out of a joint contract. 1

8 222. Instances of Merger.-Where a statute provicled for the presentation and establishing of claims against estates, before the County Court, it was held that a claim so established merged into the judgment establishing it, and would no longer draw interest as a claim. ${ }^{2}$ If, in proceedings to condemn land, a mortgagee is awarded the amount secured by his mortgage, the indebtedness is merged into the judgment of condemnation, and he can maintain no further proceeding to obtain his debt, except upon the award. ${ }^{3}$ A statute, in Ohio, provided that a mortigagee might prosecute a scire facias and obtain a judgment for his debt, with execution against the mortgaged premises only. After the mortgagee proceeded under this statute his debt was merged, so that he could have no further action upon it. 4

8 223. Exceptions.-In order, however, to create a merger, the plaintiff must have had an opportunity to recover his entire demand. A plea of judgment recorered will not be supported, unless it appears that the precise thing in controversy in the second suit could have been recovered in the first. Thus, if plaintiff, proceeding in a Court of Admiralty, obtain a judgment of condemnation against a vessel for a collision, and have her sold, he is not precluded from proceeding to recover such further clamages as he may have suffered from the collision, in excess of the value of the vessel condemned; because he could not have recovered this excess in the proceeding against the ressel. ${ }^{5}$

1 Suydam v. Barber, 18 N. Y. 468 ; Thomas $v$. دIohler, $25 \mathrm{MId} .36$.

2 Mitchell v. Mayo, 16 Ill. 83.

${ }^{3}$ Shepherd $v$. Mrayor of .N. Y., 13 How. P. 286. 
It has also been decided that a judgment obtained against a steamboat is not a bar, until satisfied, to an action against the owners upon the same liability, on the ground that the remedy against the boat is cumulative. ${ }^{1}$ The courts in Michigan refused to apply the law of merger to a case where, though no legal impediment existed to a full and alequate recovery in the first suit, such recovery was prerented by the fact that the defendant, being the agent of the plaintiff, had, until subsequent to the reudition of the first judgment against him, fraudulently concealed from plaintiff the existence of certain items of indebtedness, which, had they not been so concealed, would have been included in the former suit. ${ }^{2}$ A judgment for a debt does not prevent the plaintiff from subsequently maintaining an action to bar the defendaut's equity of redemption in tho lands on which a mortgage had been given to secure the same debt; ${ }^{3}$ and if two distinct judgments have been entered on the same cause of action, the merger of one of those judgments in a statutory judgment does not affect the other. ${ }^{4}$

2 224. Pendente Lite.-No demand included in the. plaintiff's complaint, or in the defendant's set-off, or counter-claim, can be allowed, if at any time before its allowance it has been taken into account in forming a judgment in another action between the same parties. ${ }^{5}$

7225. Criminal Prosecutions and Convictions.-The doctrine of the earlier authorities was that all civil remedies in favor of a party injured by a felony were merged in the higher offense against society and public justice; or, at least that such remedies were suspended, and could not be pursued until after the trial and conviction of the offender. ${ }^{6}$

${ }^{1}$ Toby $v$. Brown, 6 Eng. 308.

${ }^{2}$ Jolinson $v$. Provincial Ins. Co., 12 Mich. 216.

${ }^{3}$ Harris $v$. Vaughn, 2 Tenn. Ch. 483.

${ }^{4}$ National Bank of Monticello $v$. Bryant, 13 Bush, 419.
${ }^{5}$ Andrews $v$. Varrell, 46 N. H. 17; McGilvray $v$. Avery, 30 Verm. 533; Bank of North America $v$. Wheeler, 28 Conn. 433.

${ }^{6}$ Foster $v$. Tucker, 3 Greenleaf, 45s; $14 \mathrm{Am}$. Dec. 243, and note; Boston R. R. Co. v. Dana, 1 Gray, 83, 97. 
This doctrine is obsolete; and the civil remedy may be pursued either before or after the prosecution and conviction of the criminal. ${ }^{1}$ The doctrine also formerly prevailed that the conviction of certain felonies was a bar to any prosecution for any other felony, whether committed subsequently or antecedently to the conviction. The result of conviction for most felonies was that the offender became by operation of law "in a state of attainder." It was early held that persons being thus attainted might plead the same in bar to a subsequent prosecution for any other felony, for by his first attaint his possessions were forfeited, his blood corrupted, and he became dead in law; therefore any further conviction wonld be fruitless. This plea was styled the plea of autrefois attaint, or former attainder. ${ }^{2}$ The early common law rule has been recoguized to a very limited extent in this country; but is donbtless now obsolete $^{4}$ in America, and abolished by statute in England. ${ }^{5}$ The conviction of an offense, like the recovery of judgment in a civil action, is a bar to any further prosecution based ou the same canse of complaint. The question often arises whether the offense of which one is accused is not a part of an offense of which he has been alrealy convicted, and if so, whether the whole crime is not merged in the former conviction. Thus one who by the same act passed four forged checks to the teller of a bank, was adjudged to be guilty of but one offense; and his conviction of uttering one of the checks was held to preclude his subsequent prosecution for uttering the others. ${ }^{6}$ The lareeny of several articles at one time, and by one act, thongh belonging to different persons, is but one offense. The State can not split this offense

${ }^{1}$ Hilliard on Torts, vol. 1, p. 59, 60; $\quad{ }^{4}$ Hawkins v. State, 1 Porter, 475; note to Foster $v$. Tucker, $14 \mathrm{Am}$. Dee. State $v$. McCarty, 1 Bay, 334; State 213, and the anthorities there cited; v. Commissioners, 2 Murphey, 371.

Pettingall v. Ricleont, 6 N. H. $454 ; \quad{ }^{5}$ St. $7 \& 8$ Geo. IV.c. 28 , s. $4 . \quad$ The 25 Am. Dec. 473.

${ }^{2}$ See note to Crenshaw $v$. State, 17 Am. Dec. 791, and the authorities there cited.

${ }^{3}$ Crenshaw v. State, 1 Mart. \& Y. ${ }^{6}$ State $v$. Egglesht, 41 Iowa, 574. 122; 17 Am. Dec. $7 \mathrm{SS}$. 
into parts, and prosecuto it by fractions. A conviction of - any part may be pleaded in bar to a prosecution for any other part. ${ }^{1}$ And generally where a criminal act is indivisible, the conviction of any part of the act bars a prosecution for any other part. ${ }^{2}$ It has been beld that a conviction for arson bars a subsequent prosecution for murder occasioned by the arson. ${ }^{3}$

\& 225a. Prinoipal and Agent may both be severally liable on the same obligation or as the result of the same transaction. Where this is the case, a judgment against the agent seems to preclude the obligee from proceeding against the principal. Hence the recovery on a bill of lading against the master of a ship is a good defense to an action against the owner, on the same bill of lading, though satisfaction has not been obtained. ${ }^{4}$ This is because the suing of the master to judgment is an election to pursue him rather than the owner, and makes the latter subject to a recovery against him by the master, and he ought not at the same time to be liable to separate actions in favor of different persous resting upon the same cause.

8 226. Principal and Surety.-In Vermont, a judginent against the principal and the surety merges not only the cause of action, but, as between the plaintiff and the defendant, the relation of principal and surety; so that, at liww, the surety can not avoid the judgment by proving that since its entry some favor or preference has been given the

${ }^{1}$ Lorton $v$. State, 7 Mo. 55; State I Hawkins, 11 Bush, 603; State $v$. Chif$v$. Nelson, $29 \mathrm{Me} .329$; People $v$. Van fin, 2 Swan, 492; Commonwealth $v$. Kuren, 5 Parker C. R. 66; State $v$. Miller, 5 Dama, 320; State $v$. Lewis, Williams, 10 Humpl. 101; State v. 2 Ilawks, 9S; 11 Am. Dec. 711; RobMorphine, 37 Mo. 373; Jaekson v. erts v. State, 14 Geo. 8; People v. State, 14 Ind. 327; Contra, Regina v. Smith, 57Barb. 46. See 1 Whart. Cr. Prettel, 1 Car. \& M. 609; State v. I. $\$ \$ 464,465$.

Thurston, 2 MeMillan, 382.

${ }^{3}$ State $v$. Cooper, 1 Green N. J. ${ }^{2}$ State v. Standifer, 5 Port. 5ะ3; 361; 25 Am. Dee. 490.

State v. Wister, 62 Mo. 592; State $v$. $\quad$ "Priestley v. Fernie, 3 H. \& C. 977; Sly, 4 Oreg. 277; Commonwealth v. 11 Jur. N. S. 813; 13 W. R. 1089. 
priacipal, suficient, if given before the judgment, to relieve the surety from further responsibility. ${ }^{1}$ But the preponderance of the authorities is decidedly against the Vermont cases, and in faror of the rule that the judgment creditor is still bound to give no preference to the principal debtor, and to do no act by which the liability of the surety can be increased. And that those acts which are sufficient to discharge the surety before judgment, will entitle him to a release afterward, and will constitute a complete defense to an action at law on the judgment."

8 227. Co-Plaintiffs or Defendants.-The merger of the canse of action has no effect upon the liabilities of the coplaintiffs or the co-defendants, between each other. Those liabilities are not in issue in the case, and therefore are not affected by the final determination of the action. In extinguishing a demand, a judgment has no greater effect than mere payment. It leaves the liability of other parties to the defendant unaffected. A recovery upon a noto against the maker and indorsers, does not so merge the note as to prevent the indorsers from paying the judgment, receiving the note, and maintaining action on it against the maker. ${ }^{3}$ So a judgment against co-defendants creates no liability between them, if none before existed. Thus, tort feasors, where the injury committed is malum in se, have no right of contribution between each other. Ifence, a judgment recovered against them for such tort, and satisfied by one of their number, is wholly incompetent to establish a claim against the others. ${ }^{4}$

\& $227^{\text {a }}$. Suits on INotes and Bills.-The recovery upon a promissory note, though a merger of the cause of action as between the parties to the suit, is not necessarily a complete merger of all other causes of action which may arise out of the note. Thus, the fact that an indorsee has recovered

1 Marshall v. Aiken, 25 Verm. 332 ; 252; Baird v. Tice, 1 Call. 18; CarpenDunbam v. Downer, 31 Verm. 249. ter $v$. King, 9 Met. 511.

${ }^{2}$ Rice v. Morton, 19 MIo. 263; Com- ${ }^{3}$ Lielsey v. Bradbury, 21 Darb. 531; monwealth $v$. Miller's Adm. $8 \mathrm{~S}$. \& R. Corey v. White, 3 Bar'b. 12.

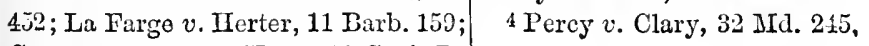

Commonwealth $v$. Haas, $16 \mathrm{~S}, \& \mathrm{I}$. 
judgment against an acceptor, does not prevent a drawer who has taken up the note from recorering another judgment against the same acceptor. ${ }^{1}$ So it is no defense to an action by an indorsee against the maker of a note, that a prior indorsee, while the holder, and before the plaintifi took it, recorered judgment against defendant and the payee. ${ }^{2}$ Dut if judgment be recovered against one of the joint makers, this is a discharge of all the other makers from all suits by the same plaintiff and all persons in privity with him. ${ }^{3}$

\section{229. Judgments against Warrantors, Gamishees, and} Stock Companies.-Judgment against the original warrantor in faror of the last grantec, with satisfaction, will bar any action by the intermediate grantees. ${ }^{4}$ In this case it is erident that the demand, which consists of the contract of warranty and the breach thereof, has passed to the last grantee, and is drowned in the judgment. Taking judgment against a garnishee does not merge the clemand against the principal. Judgments may be recorered against both, and proceeded upon until one is satisfied. ${ }^{5}$ Judgment against a joint stock company merges the original liability. Rechress against the stockholders must, in New York, be procured by an action against them on the judgment. ${ }^{6}$ A different opinion is stated by the court in Young r. Rosenbaum, 39 Cal. 645. C. J. Rhodes there says that the liability of the stockholders is not merged, extinguished nor suspended by a judgment against the corporation. The remarks of the court, both in the New York and the California case, so far as applicable to this subject, are mere dicta, arising from the consideration of hypothetical facts, and not of the issues before the court. It is a little remarkable that the premises assumed by each court were identical, while the results attained were diametrical. Both judges assumed that the liability of the stockholder was that of a prineipal debtor,

\footnotetext{
${ }^{1}$ Macdonald $v$. Eorington, 4. T. R. lowell $v$. NacDonell, S Upper Canada 825 .

${ }^{2}$ McLennan $v$. McMonies, $23 \mathrm{Up}$ per Canada Q. B. 115; Tarleton $v$. Allhusen, 2 Ad. \& El. 32.

${ }^{3}$ Barnett $v$. Juday, 3S Ind, S6; Hal- 661. C. P. 21.

${ }^{4}$ Brady $v$. Spurck, 27 Ill. 481.

${ }^{5}$ Price $v$. Higgins, 1 Litt. 273.

${ }^{6}$ Witherhead $v$, Allen, 28 Barb.
} 
and not that of a surety. But one court treated the case as one in which plaintiff had two distinct causes of action (one against the corporation and one against its stockholders), either of which could be prosecuted to judgment without afiecting the other; while in the other court the liability was considered like that of a partnership, in which a recorery against the firm makes each partner responsible under the judgment, and releases him from the original debt.

8. 2:0. Collateral Securities.-The prosecution to judgment of any chose in action, given as collateral security, in no wise merges or discharges the original debt. As the debt continued in full force, independent of the security, so it remains unaffected by the judgment which is the same security in another and higher form. ${ }^{1}$ No other cause of action than the one sued upon can merge in the judgment. Hence the successful prosecution of an action on the original debt will not impair the right to proceed upon the security. ${ }^{2}$ The cases of Denson r. Paine, 9 Abb. Pr., 23 and 17 How., Pr. 407 ; Peters r. Sanford, 1 Den., 224, and Averhill v. Loucks, 6 Barb. 19, present singular examples of violations of the unquestioned principle of law, that the merger of a security does not merge the original debt. In the two cases first named, the plaintiff had taken the note of one partner to secure a debt due from the firm. In the last named case the plaintiff took a bond and warrant of attorney from one of the partners, for a similar purpose. Judgments haring been entered in the sereral cases, on the notes and also on the bond, the question arose, whether an action could be maintained against the respective co-partnerships on the original indebtedness. In each case it was held that the recovery against one partner on the collateral security given by him, had merged the demand against the co-partnership. But from the opinion of the court in each case, the conclusion is irresistible that no question was

${ }^{1}$ Drake v. Mitchell, 3 East. 251 ; Bltchf. 326 ; Day v. Leal, 14 Johns. Watson $v$. Orens, 1 Tich. 111; Daris 104 ; Chipman v. Jartin, 13 Johns. $v$. Anable, 2 Hill, 339 ; Bank of Che- 240.

nango $v$. HJde, 4 Cow. 567 ; Fairchild ' Tisher $v$. Fisher, 99 Mass. 303 ; v. Holly, 10 Conn. 475; Butler v. Butler v. Mriller, 1 N. Y. 496.

IIiller, 5 Den. 159 ; U. S. v. Hojt, 1 
supposed to be involved, except the effect of the entry of a judgment against a partner, for a partnership debt. In each of the three cases, however, a judgment upon a collateral security did, in fact, bar an action for the original debt; but neither case is authority to overturn the proposition, that the merging of a mere security never involves the real indebtedness. TWe cannot but wonder that three cases involving the same question should be determined in the same State, without the attention of either court being directed to a rule of law so familiar to the profession and so decisive of the matters under consideration.

8 230. Foreclosure of Security:--The foreclosing of a mortgage, held as security, in a suit in the name of the assignor and the assignee, does not change the relation of the plaintiffs to each other. If the assignee purchase the mortgaged premises at a sale under the decree, ho will hold them subject to redemption on the same terms, as the mortgage could havo been redeemed upon prior to tho suit. ${ }^{1}$

\section{231. Joint Obligons.-- Whenever two or more persons} are jointly liable, so that if an astion be commenced against any less than the whole number, the non-joinder of the others will sustain a plea in abatement, a judgment against any of those so jointly bound, merges the entire cause of action. The cause of action being joint, the plaintiff can not be allowed to sever it against the objection of any of the defendants. By taking judgment against one, he merges the cause of action as to that one, and puts it out of his power to maintain any further suit either against tho others severally, or against all combined. ${ }^{2}$ A different conclusion was announced by Chief Justico Marshall, in the case of Sheehy v. IIandevinle, 6 Granch. 253. He there held that a judgment against one of the maliers of a joint note, did not merge it as to the other maker. Notwithstanding the respect everywhere entertained for the opinions of this great jurist, this particular one was rarely assented to in the State courts, was doubted and eriticised in England,

\footnotetext{
${ }^{1}$ Hoyt $v$. Martense, 16 N. Y. 231. Lawer $v$. Bandlow, Wis. Leg. N.,

${ }^{2}$ People v. Harrison, S2 Ill. S4; March 25, 'S0, p. 200.
} 
and, after many years, was directly overruled in the same court in which it was pronounced. ${ }^{1}$ The cases sustaining it are few, ${ }^{2}$ while those which oppose it are very numerous. ${ }^{3}$

\section{232. Partners.--It is well settled that the liability of} partners for a debt clue from the firm is such that a several action can not he maintained against ench partner, if a plea in abatement be interposed. In case no such plea is made, and a judgment is obtained against one or more of the partners, no further suit can be maintained. ${ }^{4}$ This rule in relation to partnerships yields to no hardship. Thus, where plaintiff procured one member to confess judgment for the firm, the confessing member was held to be bound by the judgment, whilst his co-partners were neither bound by the judgment, nor liable to any other action upon the same liability. ${ }^{5}$ And a judgment against the known members of a partnership, discharges the secret or dormant members. The fact that plaintiff was not informed as to all the persons bound, does not prevent the liability from merging in the recovery. ${ }^{6}$ This rule has been violated in South Carolina. Where plaintiff sold goods to A. and took his note for the purchase money, a judgment recovered upon the note, was held not to prevent a further action from being sustained against B., who had, since the judgment, been discovered to be A.'s co-partner. ${ }^{7}$ This caso

1 Mason $v$. Eldred, 6 Wall. 231.

${ }^{2}$ Treasurers $v$. Bates, 2 Bailey, 362; Collins $v$. Lemasters, 21 Am. Dec. 469 , and note; Sneed $v$. Wiester, $2 \mathrm{~A}$. K. Marsl. 27i; Union Bank $v$. Hodges, 11 Rich. 480.

${ }^{3}$ Ward $v$. Johnson, 13 Mass. 148; Thomas $v$. Rumsey, 6 John. 26; Suydam $v$. Barber, 18 N. Y. 468; Brady $v$. Reynolds, 13 Cal. 31; Wann $v$. MeNulty, 2 Gilm. 359; Smith $v$. Black, 9 S. and R. 142; 11 Am. Dec. 686; Philson $v$. Bamfield, 1 Brev. 202; Benson $v$. Paine, 17 How. P. 407; Henderson $v$. Reeves, 6 Blackf. 101; King $v$. Hoare, 2 D. and L. 3s2; Maghee v. Collins, 27 Ind. S3; Kingsley $v$. Davis, 104 Mlass. 17s; Root $v$. Dill, 38 Ind. 169; Harris $v$. Dunn, 18 Upper Union Bank $v$. Hodges, 11 Rich. 480. 
is, however, entirely unsupported by authority, not likely to be anywhere sustained.

8 233. Joint Debtor Acts.-In some of the States provisions have been incorporated into the Codes of Civil Procedure, authorizing a judgment to be rendered in any action against several persons jointly liable, without service on all of the defendants, such judgment to be satisfied out of the individual property of the defendant served and the joint property of all the defendants. It is further provided in the States of Michigan and New York, that "such judgment shall be conclusive evidence of the liabilities of the defendant who was served with process in the suit, or who appeared therein; but against every other defendant it shall be evidence only of the extent of the plaintiff's demand after the liability of such defendant shall have been established by other evidence." This clause recognizes the continuance of the liability of a defendant, not served with process, after judgment has been rendered against him as provided in the statute. Its effect, therefore, is to prevent the incident of merger from attaching to the judgment and operating as a release of any defendant who, though a party to, was not personally 'served in the suit. Such defendant may be subsequently sued, and subjected to a personal judgment. ${ }^{1}$

8 234. Exceptions.-If, in Indiana, one of the joint promissors die, and judgment is afterwards obtained against the survivor, who is insolvent, the original debt will furnish a claim liable to be enforced by proceedings against the estate of the deceased. ${ }^{2}$ Where a joint promise is made by parties residing in different States, a recovery against ono in the State where he resides does not bar an action against the other party in the other State. ${ }^{3}$ In both of these cases it is evident that some modification of the doctrine of merger is indispensable to secure to plaintiffs the full bene-

${ }^{1}$ Oakley v. Aspinwall, 4 Coms. 515; Bonesteel $v$. Tod,l, 9 Mich. 379; Mason $v$. Eldred, 6 Wall. 239.

${ }^{2}$ Weyer $v$. Thornburgh, 15 Ind. 124; 549.

Devol v. Halstead, 16 Ind. 287. 
fit of their contracts. In the first case the parties liablo could not be joined in one action. The plaintiff, therefore, showed no intention of releasing one party by pursuing tho other. In the second case no judgment could be secured in any State court, binding on both promissors. To give to a judgment against either the effect of a merger of the cause of action against both, would, therefore, be to require plaintiff, without any fault of his, to abandon his remedy against a part of the co-obligors.

8 235. Joint and Several Contractors.-A judgment against any less than the entire number of persons bound by a several or a joint and several obligation, does not release the residue until satisfied. ${ }^{1}$ Joint and several contracts have been considered as furnishing two distinet remedies : one by a joint action against all the obligors, the other by a several action against each. The result of this is that an action against all on the joint liability, in nowise affects an action against each on the several liability ; and a several judgment against each leaves untouched the right to proceed jointly against all. ${ }^{2}$ On the other hand, in ex parte Rowlandson, 3 P. Wms. 405, Lord Ch.: J. Talbot said: "At law, when $A$. and $B$. are bound jointly and severally to $J$. S., if J. S. sues A. and B. severally, he can not sue them jointly; and, on the contrary, if he sues them jointly he can not sue them severally, but the one action may be pleaded in abatement of the other." In Pennsylvania, the plaintiff, by instituting a joint action, is presumed to elect to proceed jointly, and is bound by such election. If, therefore, he accept judgment against less than the entire number sued, he is not permitted to proceed against the others. ${ }^{3}$

\section{235a. Recovery in a Different Right or Capacity.-A} recovery by partners for an injury done to their business

${ }^{1}$ Harlan $v$. Berry, 4 G. Greene, 2I2; $\quad{ }^{2}$ United States $v$. Cushman, 2 Sum. McReady $v$. Rogers, 1 Nebr. 124; ner, 426; Charles $v$. Liaskins, 11 Iowa, Elliott $v$. Porter, 5 Dana, 299; Arm- 329.

strong $v$. Prewett, 5 Miss. 476; King ${ }^{3}$ Beltzhoover $v$. Commonwealth, 1 $v$. Hoare, 13 M. \& W. 504; Hix v. Watts, 126; Williams v. HeFall, $2 \mathrm{~S}$. Davis, 68 N. C. 233. 
by certain slanderous words, does not merge a cause of action existing in favor of any member of the firm for the injury done him personally by the same words. In this case the injury to either partner as an individual could not have been the subject of a recovery in the former action; and hence it could not be merged in the result of such action. So, if under a statute a child is entitled to recover for bodily injuries suffered by it, and its father is also entitled to maintain an action to recover for the loss of the services of the child resulting to him from the same injury, it is clear that a recovery by the child can not preclude a subsequent recovery by the father; nor can the recovery by the parent, as administrator of the child, preclude his subsequent recovery in an action brought in his own right." "A judgment in an action of assumpsit bronght by a husband and wife, on a contract by a carrier of passengers to carry the wife safely, for injuries to the wife while being carried, is a bar to another action of assumpsit on the same contract, by the husband alone, to recover for the same injuries. A different rule prevails when the action is in tort against the carrier for a breach of public duty, except, perhaps, in States like New Jersey, where by statute the husband may, in such an action, add claims in his own right to those of his wife."

\& 236. Trespassers.-Theliability of persons joining with one amother in the commission of a trespass, is joint and several, and the effect of a judgment recovered against them, in merging the cause of action, is, in America, governed by the rules applicable to judgments upon joint and several contracts. ${ }^{5}$ The early English and American anthor-

${ }^{3}$ Duffy v. Gray, 52 Mo. 528.

2 Wilton $v$. Middlesex Railroad, 125 Mass. 130.

${ }^{3}$ Bradley $v$. Andrews, 51 Verm. 525 .

${ }^{4}$ Pollard v. R. R. Co., 101 U. S. 223.

5 Elliott $v$ Porter, 5 Dana, 209 ; Tishop, 1 Jobn 000; 3 Am.

Riann $v$. Crocheron, 19 Ala. 617; United Society $v$. Underwood, 21 250 
ities sustained an opposite conclusion. ${ }^{1}$ In England, after some considerable doubt had been manifested upon this question, the courts decided to follow the early decisions, instead of concurring in the departure taken by the American courts. "We entertain," said Willis, J., in the Common Pleas, "the highest respect for the American jurists, and are always ready to receive instruction from their decisions upon questions of general law. But tho question whether a plaintiff is to be allowed to maintain a second action against one whom lie ought to have sued jointly with another in a former action, is purely one of procedure, and on such a question we are bound by the authorities in our own courts. ${ }^{2}$ This decision of the Common Pleas subsequently coming on to be reviewed in the Exchequer Chamber, was affirmed on the ground that it was sustained by principle as well as by precedent. Kelly, C. B., in the beginning of his opinion, in considering the question upon principle, reasoned as follows: "The defendint, by way of plea, alleges that an action was brought for the same cause against the other wrong-doer, and a judgment obtained against her, which remains in full force; and the question is, whether that affords any defense to this action. That a judgment and execution, with satisfaction, would be a defense, is not disputed. A long series of authorities has so laid down; but it was doubted whether judgment and execution, without satisfaction, was a bar also. It will be right, therefore, to consider whether this latter is not, upon principle, a good and valid defense. If it were held not to be

${ }^{1}$ Lendall v. Pinfold, l Leon. 19; several American decisions: Hunt v. Chitty Pl. 89, citing Cro. Jac. 74, 2 B. Bates, 7 R. I. 217; Wilkes $v$. Jack\& P. 70-71; 1 Saund. 207a; Broome $v$. son, 2 H. \& M. 355.

Wooton, Cro. Jac. 73; Yelv. 67; War- ${ }^{2}$ Brinsmead v. Harrison, L. R. 7 den $v$. Bailey, 4 Taunt. SS; King $v$. C. P. 551 . See also Sloan $v$. Creasor, Hoare, 13 Nees. \& W. 494. 22 Upper Canada Q. B. 130.

These cases are also sustained by

Am. Rep. 214; 11 Bush, 265; Knight 529; Sheldon v. Kihbe, 3 Conn. 214; $v$. Nelson, 117 Mass. 45S; Ayer $v .8$ Am. Dec. 176; Turner $v$. Hiteheock, Ashmeal, 31 Conn. 447; Wright v. 20 Ia. 310; McGehee $v$. Shafer, 15 Tex. Lathrop, 2 Ohio, 33; $15 \mathrm{Am}$. Dec. 198. 
a defense, the effect rould, in the first place, be to encourage any number of rexatious actions whenever there happened to bo several joint wrong-doers. An unprincipled attorney might be found willing enough to bring an action against each and every of them, and so accumnlate a vast amount of useless costs, if judgment against one of them did not operate as a bar to proceedings against the others. The mischief would not eren rest there. Judgment having been recovered against one or more of the wrong-doers, and damages assessed, if that judgment afforded no defense, the plaintiff might procecd to trial against another of them, and the second jury might assess a different amount of damages. Which amount is the plaintiff to lery? There are other grounds upon which it would be extremely inconvenient and unjust if a second action could be maintained. But, independently of tho mischief which would result from holding the law to be as contended for, let us see low the anthorities stand. In the first place, there is no anthority whatever-since the reigns of the Hemrss and the Edwards, nothing approaching to an authority has been cited-to show that such a plea as this mould not be a good defense. In the absence, therefore, of authority to the contrary, upon principle, and upon what I conceire to be binding authority in its favor, I come to the conclusion that such a plea as this affords a good defense." But, with all due deference to so high an authority, it strikes us that, while professing to discuss this question upon principle, the Chief Baron cliscussed it only with reference to considerations of hardship and inconvenience. The only way in which it can be discussed upon principle is to demonstrate that the cause of action is joint and not joint and several. This the Chief Baron did not attempt. If considerations of convonience are to govern in cletermining tho application of the law of merger, it might be clenied in many instances where the liability is clearly joint and several. By way of illustration, suppose that one of the makers of a joint and several note, on being sued thereon interposes a defense; and, upon tho trial of the cause, the jury

: Brinsmead v. Harrison, L. R. 7, C. P. 557. See also Sloan v. Creasor, 22 Upper Canada, Q. B. 130. 
allows the defonse, in whole or in part. Another action may then be bronght against the other promissor, he may interpose the same defense, and support it by the same evidence, and yet the jury before whom the second action is tried, may find a verdict entirely difierent from that found in the first action. In such case, the plaintiff would, no doubt, take out execution on the judgment which happened to be most favorable to his interests. Or, sippose the note to be made by twenty joint and several promissors. In that event, it is possible that the payee might find an attorney willing, or eren anxions, to prosecute twenty separate suits, and in each suit to incur and tax the largest amount of costs allowable by law. In fact, the inconvenience and injustice of allowing sereral judgments to be recorered, upon any joint and several liability, are as likely to arise in suits upon promissory notes, as in actions to recover for trespasses and torts committed by two or more persons. If hardship and inconvenience control the judgment of the court in the latter class of actions, they ought equally to control in the former. A few of the American cases, while admitting that the successful prosecution of an action against one trespasser, does not affect the cause of action against his co-trespassers, decide that the mere issuing of an execution is a conclusive election to consider the defendant as exclusively responsible. ${ }^{1}$ But a majority of them $^{2}$ discountenances this manifest absurdity. If the mere election to pursue one trespasser were binding on the plaintiff, as a release of all the co-trespassers, it seems difficult to understand why that election is not as obvious when the suit has been prosecuted to final judgment, as when the plaintiff takes the first step towards its enforcement. If, on the other hand, such election in no way involves the several causes of action against the other trespassers prior to the issuing of an execution, it is difficult to perceive why or how that event necessarily involves them.

J Allen v. Wheatley, 3 Blackf. 332; Aik. 195; Sharp v. Gray, 5 B. Monr. Fleming v. McDonald, 50 Ind. 278; 4; Jones $v$. MeNeal, 2 Bai. 466; LoveBlann v. Crocheron, 20 Ala. 320; joy $v$. Murray, 3 Wall. 1; Page $v$. White $v$. Philbrick, 5 Greenl. 147; 17 Freeman, 19 Mo. 421; Floyd $v$. Browne, Am. Dec. 214.

${ }^{2}$ Nurray $v$. Lovejoy, 2 Clif. 191; v. Cunningham, 2 Sneed, 204; Griffie Sheldon v. Kibbe, 3 Conn. 214; 8 Am. $v$. McClung, 5 West Va. 13s; Osterhout Dec. 176; Sanderson $v$. Caldwell, $2 \mid v$. Roberts, 8 Cow. 43. 
How vain and delusive that law must be, which declares the right of an injured party to proceed severally against every person concerned in committing an injury; which sustains him until the liability of every wrong-cloer is severally determined and evidenced by a final judgment; and which, after thus "holding the word of promise to his ear breaks it to his hope," by forbidding him to attempt the execution of either judgment, upon penalty of releasing all the others. Plaintiff can have but one satisfaction for each trespass, whether he has recovered several judgments or none. Such satisfaction abates all actions pending, and discharges all judgments obtained, against co-trespassers. ${ }^{1}$ Pursuing trespassers, or any of them severally, is a conclusive election to consider the trespass as several, and is a bar to a joint action subsequently instituted. ${ }^{2}$

8 237. Vesting Title.-There, instead of suing for the mere damages occasioned by an act of trespass or conversion, the plaintiff recovers judgment for the value of the property injured or converted, it has frequently been held that the recovery vests the title to the property in the defendant; and that, as it would be unjust for the defendant to acquire title to the property taken or injured, while others might be made liable to pay the entire value thereof in a subsequent action, the plaintiff could not be allowed to proceed against any person concerned in the trespass or conversion and not included in the first action. ${ }^{3}$ If, indeed, the more rendition of a judgment transferred the title of the property in such cases to defendant, the plaintiff's cause of action would of course cease to be held by him, and his claim to further proceedings based upon it, could not be supported. But the American courts have not generally attributed this effect to judgments. The transfer of title, in their opinion, does not take place until the judgment is completely satisfied, and the value of the property as ascer-

${ }^{1}$ Mitchell v. Libbey, 33 Maine, 74. $\mid 147 ; 17$ Am. Dec. 214; Emery v.

2 Murray $v$. Lovejoy, 2 Cliff. 191; Nelson, 9 S. and R. 12; Buckland $v$. Smith $v$. Rines, 2 Sumner, 348 .

${ }^{3}$ Campbell v. Phelps, 1 Pick. 61; 11 Am. Dec. 139; Broome $v$. Wooton, Yelv. 67; Adams $v$. Broughton, 2 Stra. 107S; White $v$. Philbrick, 5 Grcenl.

Johnson, 15 C. B. 145 ; S. C., 23 L. J.

C. P. 204. This last ease has been overruled by Brinsmead $v$. Harrison, L. R. 6 C. P. 5 Ss. 
trined by the court, has been paid to the plaintiff. Until such payment, therefore, there is no obstacle to prevent him from seeking redress in the courts against any one originally liable.' But when the judgment has been paid, the title to the property is for most purposes vested in the defendant by relation, at the date of the conversion. The plaintiff elects by his proceeding against the defendant to compel the latter to become a purchaser of the property and to pay its value at the date of the conversion. When the plaintirif has succeeded in compelling this involuntary purchase and payment, the title thereby acquired by the defendant relates back to the date of the conversion, because that is the period at which the plaintiff has chosen to treat the property as purchased from him by the defendant. ${ }^{2}$ Therefore, if after recovering judgment for the conversion of certain chattels, the plaintiff retake the same chattels into his possession, and subsequently to such retaking he enforce the collection of the judgment, such collection vests the property in the defendant as of the date of the original conversion and entitles him to an action against the plaintiff for the retaking: ${ }^{3}$ But the relation of title back to the period of the conversion will not be permitted to take effect to the prejudice of innocent third persons so as to make them liable as trespassers. ${ }^{4}$

8. 238. Indivisible Demands Dr-Coneractu.--That a single or entire demand can not be split so as to constitute the basis of more than one suit; and that the recovery upon any part of such demand merges the whole, is not disputed, ${ }^{5}$ although the plaintiff may have assigned some por-

${ }^{1}$ Osterhout $v$. Roberts, 8 Cow. 43; Spivey $v$. Morris, $1 \mathrm{~S}$ Ala. 254; Smith $v$. Alexander, 4 Sneed, 4S2; Sanderson $v$. Caldwell, 2 Ail. 203; Jones $v$. MicNeil, 2 Bai. 466; Morgan $v$. Chester, 4 Coun. 3s̃; Matthews $x$. Menedger, 2 McL. 145; Hyde $v$. Noble, 13 N. H. 501; McGee $v$. Overby, 7 Eng. 164; Sharp $v$. Gray, 5 B. Monr. 4; Hepburn r. Sewell, 5 H. \& J. 212; Lovejoy $v$. Nurray, 3 Wall. 1; Elliott $v$. Hayden, 104 Mass. 180; Smith $v$. Smith, 50 N. H. 219; McReady $v$. Rogers, 1 Neb. 127.
${ }^{2}$ Hepburn v. Sewell, 5 Har. \& J. 211.

${ }^{3}$ Smith $v$. Smith, 51 N. H. $5 \% 1$.

${ }^{4}$ Bacon $v$. Kimmel, 11 Mich. 201.

${ }^{5}$ Staples $v$. Goodrich, 21 Barb. 317; Waterbury $v$. Graham, 4 Sanf. 215; Warren $v$. Comings, 6 Cush. 103; Smith $v$. Jones, 15 Johns. 2:2; Marsh $v$. Pier, 4 Rawle, 273; Crosby $v$. Jeroloman, 37Ind. 277; Dutton $v$. Shaw, 35 Mieh. 431; Guernsey $v$. Carver, 24 Am. Dec. 60; Turner $v$. Plowden, 23 Id. 596. 
tion thereof to a third person. ${ }^{1}$ It is equally certain that one person may, at the same time, hold several distinct causes of action against another; and may maintain an action on any of such causes, without prejudicing his right to proceed upon any of the others. ${ }^{2}$ Great difficulty has been experienced in determining what constitutes an entire or single demand; and many irreconcilable adjudications have been made upon the subject. It may be laid down as a general rule, that each separate agreement or transaction will give rise to one entire and independent cause of action, and to but one. Thus, if several parcels of merchandise bo sold at one time, tho transaction will constitute but one demand. ${ }^{3}$ A note payable in one year, with interest payable semi-annually, comprises two distinct contracts : one to pay the principal sum and the other to pay the interest. A judgment, after the principal is due, in an action for interest, does not merge both contracts. ${ }^{4}$ F. discounted a bill drawn by J. upon A., and J. and A. agreed at the same time that in case the bill was not paid at maturity, they would pay thereon $£ 20$ for each month, and F. sued J. on the bill, claiming no interest, and recovered. It was afterwards held that the arreement to pay $£ 20$ per month interest was a distinet agreement upon which $F$. could recover in another action, for every month until the bill had merged into the judgment obtained upon it. ${ }^{5}$ A note signed by A. B. \& Co., and by A. B., furnishes two causes of action: one against A. B. and the other against the firm. Each cause of action may be recorered upon sererally. ${ }^{\circ}$ Where the law provided that the plaintiff should have judgment in certain cases, unless an aflidavit of defense was filed, the defendant having filed such affidavit as to part of the claim, the plaintiff took judgment for the balance. The court, thereupon, held that there could be but one final

${ }^{I}$ Ingraham $v$. Hall, $11 \mathrm{~S}$. and R. 78 . the effect of a recovcry for interest.

2 Robbins $\%$. Irarrison, 31 Ala. 160; It merely determined that such a reRex $v$. Sheriff, 1 B. and Ad. 672; covery wasimproper after the principal

Vittiek $v$. Traum, 27 Ala. 563.

3 Smith $v$. Jones, 15 Johns. 229.

${ }^{4}$ Andover Sav. Bank $v$ Arlams, 1 Allen, 28; Sparhawk $v$. Wills, 6 Gray, 163. The case of Howe $\because$. Bradey, $19 \mathrm{Me} .31$, is sometimes cited as sustainiugadifferent view; and perhaps it inferentia'sy does. But that case did not involve any question concerning became due. The dissenting opiniol of Jurlge Emery appears to us to bo more in eonsonance with reason and anthority than the opinion of the majority as delivered by Judge Shepley. ${ }^{5}$ Florence $v$. Jenings, 2 C. B. (N. S.) $4 \tilde{j} 4$.

${ }_{6}^{6}$ Gilman \& Co. $v$. Foote \& Co., 22 Iowa, 560 . 
julgrnent in an action, and that plaintiff was precluded from proceeding for the disputed portion of the claim. ${ }^{1}$

8 239. Actions on Account.-In actions for goods sold, for money loaned and received, or for labor performed, at various times, the whole sum due at the commencement of the suit, probably constitutes but one demand. It is said to bo reasonable for the courts to presume, in such cases, that an agreement existed in pursuance of which the plaintiff, for a definite period of time, or at the will of both parties, was to furnish goods, to loan money, or to perform labor; and that the amount due under the agreement should constitute but one cause of action. ${ }^{2}$ The amounts due upon a book account aro generally regarded as constituting an indivisiblo demand. ${ }^{3}$ Some courts, however, consider each separate charge as a distinct causo of action, not to be affected by proceedings for the recovery of other charges, antecedent or subsequent. ${ }^{4}$ A contract to pay the hire of a horse and buggy, is so distinct from the implied obligation to pay for damages thereto during the period of the hiring, that judgment for the hire does not affect the claim for damages. ${ }^{5}$

\& 240. Indivisible Demands. - Where the action is upon a contract, it merges all amounts due under or arising out of the contract, prior to the suit. They constitute a single, indivisiblo demand. The plaintiff cannot be allowed to split up tho various covenants or promises contained in one contract, and to recover upon each separately. He can have but one recovery upon one contract. ${ }^{6}$ If a railroad company agree to build a crossing, this can not be distinguished from a covenant to do any other act. Upon a breach of the covenant, by a failure to erect the crossing,

${ }^{1}$ Brazier $v$. Banning, 20Penn. S. 345.

${ }^{2}$ Secor $v$. Sturgis, 16 N. Y. 548; Bunnell $v$. Pinto, 2 Conn. 431; Pinney v. Barnes, 17 Conn. 420 .

${ }^{3}$ Avery v. Fitch, 4 Conn. 362; Lucas $v$. Le Compte, 42 Ill. 303; 2 Smith's Learling Cases, 671.

${ }^{4}$ Rex $v$. Sheriff, 1 B. and Ad. 672; McIntosh $v$. Lown, 49 Barb. 550.

(17)
${ }^{5}$ Shaw v. Beers, 25 Ala. 449.

${ }^{6}$ Goodrich v. Yale, 97 Mass. 15; O'Beirne $v$. Lloyd, 43 N. Y. 248; Hopf v. Myers, 42 Barb. 270; Warren $v$. Comings, 6 Cush. 103; Dalton $v$. Bentley, 15 Ill. 420; Chinn v. Hamil. ton, Hemps. 438; Draper v. Stouvenel, 38 N. Y. 210. 
the covenantor may bring an action. The judgment obtained in such action will be consiclered as a full compensation for all damages which have arisen or which may arise from the breach of the covenant; and the plaintiff can not therefore recover for any damages sustained by him subsequently to the former recovery. ${ }^{1}$ If a bond be giren to a constable to indemnify him from all damages, charges, trouble and expense that he might be put to by reason of a lery upon and sale of specified property, all these items constitute a single demand. ${ }^{2}$ Judgment for a breach of a covenant in a lease, is a bar to an action for any other breach, previously committed. ${ }^{3}$ This doctrine though well sustained is pronounced heretical in $M$ c Intosh v. Lown, 49 Barb. 550, where the extreme ground is attempterl to be maintained, that each successive breach of any contract constitutes an independent cause of action, so that a plaintiff, after recorering for one breach of a covenant in his lease, is at liberty to recover damages for any preceding breach. To the same effect is the opinion in the case of Badger v. Titcomb, 15 Pick. p. 409. There, the defendant, being the keeper of an office for procuring crews for vessels, agreed to pay plaintiff a specified sum for each man shipped. The court decided that the plaintiff could maintain an action for the breach of this contract, occurring antecedent to another breach upon which judgment has been obtained. Of course, the recovery mpon a contract does not affect any distinct cause of action subsequently accruing. Thus an endorser, who, upon being compelled to pay part of a note, recovers the amount paid, from a second endorser, will, when obliged to pay the balance, be in condition to successfully prosecute another action against the second endorser." Presenting an entire demand as a defense to an action, or as a set-off, and its partial allowance merges the whole demand. When the set-off, being fully established, exceeds

${ }^{2}$ Smith $v$. Great Western R. W. Co. 6 Upper Cavada, C. P. 156, citing Manning $v$. The Eastern Counties $\mathrm{R}$. W. Co., 12 Mees. \& W. 237.

2 Bancroft $v$. Winspear, 44 Barb. 209.
${ }^{3}$ Bendernagle $v$. Cocks, 19 Wend. 207; Fish $v$. Folley, 6 Hill, 54; Stuyvesant $v$. Mayor of N. Y., 11 Paige, 414.

${ }^{4}$ Wright $v$. Butler, 6 Wend. 2s4; $21 \mathrm{Am}$. Dec. 323. 
tho plaintiff's demand, the defendant can not in a subsequent action recover the excess. ${ }^{1}$

8 241. Indivisibie Demands, Ex Delicto.-The rule that one cause of action cannot be split into several, is as applicable to actions ex delicto as to those ex contractic. A single act of trespass or conversion can be the foundation for but one claim for damages. A judgment for plaintiff in replevin for a portion of the things taken, is a bar to a subsequent action for damages for the same taking, it not being shown that any of the things not recovered in the former action were concealed or so disposed of, that as to them the replevin would not lie. ${ }^{2}$ The rule is without exception, that if several chattels be taken at the same time, a recovery of any of them, whether in trespass or in trover, merges the entire demand arising ont of the taking, and no further recovery can be had in any form of action. ${ }^{3}$ The propriety of this rule is manifest. To allow as many suits to be prosecuted as there are articles taken or detained by the defendant, would be to inflict upon him a penalty more serious than any anthorized by the penal laws, and to obstruct the tribunals of justice with a clond of petty cases, supported by the same facts and involving the same legal principles. "It would be outrageous to allow a thousand actions for taking a thousand barrels of flour." When a honse and a shop were burned by the same fire, through the negligence of defendant's servants, a judgment for the damages occasioned by the burning of the shop, was adjudged to be a bar to a recovery, in a subsequent action, for the destruction of the house. ${ }^{5}$

All the damages which can, by any possibility, result from a single tort, form an indivisible cause of action. Every cause of action, in tort, consists of two parts, to wit : the unlawful act, and all the damages which can arise ont of it. For damages alone, no action can be permitted. Hence, if

1 Simes v. Zane, 24 Penn. S. 242; Cal. 81; Veghte $v$. Hoagland, 5 Dutch. Inslee $v$. Hampton, 11 Hun, 156; 125; Buckland v. Johnson, 15 C. B. O'Connor $v$. Varney, 11 Gray, 231.

${ }^{2}$ Bemett $v$. Hood, 1 Allen, 47 ; Herriter $v$. Porter, 23 Cal. 385. 355 .

3 Union R. R. Co. v. Traube, 59 Mo.

4 Farrington v. Payne, 15 Johns. 432; Bates $v$. Quattlebone, 2 Nott \& McC. 205; Cracraft $v$. Cochran, 16 145. A recovery for the conversion of certain chattels bars any subsequent recovery for other chattels converted by the same act, although the plaintiff was prevented from including them in the former suit, by the frand of tile defendant. MicCaffrey $v$. Carter, 125 Mlass. 330 .

Iowa, 301; Cunningham v. Harris, $5{ }^{5}$ Trask v. The Railroad, 2 Allen, 331. 
a recovery has once been had for the unlawful act, no subsequent suit can be sustained. There must be a fresh act as well as a fresh damage. ${ }^{1}$ A recovery in trover for the conversion of slaves, is a bar to any claim either for trespass in forcibly taking them, or in assumpsit for the value of their services during the period of their conversion." Judgment upon contract, for breach of agreement in not discharging an execution, merges the claim for damages occasioned by an arrest under the same execution. ${ }^{3}$ The fact that the damages now sought to be compensated had not arisen when the former judgment was obtained, does not form any exception to the rule." Thus, where the defendant had made an excavation into plaintiff's coal mine, through which water flowed, and plaintiff recovered damages for making the aperture, and afterward brought another action to obtain compensation for damages occasioned by the flowing of water through the opening into his mine, it was held that as defendant was under no legal obligation to close the excavation, no fresh act had been done, and no further suit could be maintained. ${ }^{4}$ In this case the damages upon which the second suit was based, though accruing subsequent to the commencing of the first suit, were the natural and inevitable result of the excaration. The absence of that fact, however, would not have changed the result. The rule yields to no hardship. Unforeseen and improbable injuries resulting from any act, are, equally with existing and probable injuries, parts of an inseverable demand. After judgment recovered for an assault and battery, parts of the plaintiff's skull came out, and he sought to recover for the damage thus occasioned, and it was decided that he could not, becanse the defendants had not committed any fresh wrong. ${ }^{5}$ The principles of this case were afirmed by a majority of the judges of the Supreme Court of Ver-

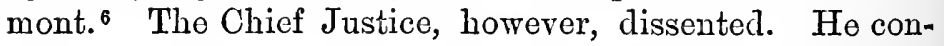

${ }^{1}$ Hodsoll $v$. Stallebrass, 11 Ad. \& El. 301 .

${ }^{2}$ Cook $v$. Cook, 2 Brev. 349; Thompson $v$. Rogers, 2 Brev, 410; Yowle $v$. N. H. \& N. Co., 107 Mass. 352; Smith v. G. W. R. W. Co., 6 Upper Canada C. P. 156.
${ }^{3}$ Smith $v$. Way, 9 Allen, 472.

4 Watson $v$. Van Meter, 43 Iowa, 76; Fowle $v$. New Haven, 107 Mass. 352; Clegg $v$. Dearden, 12 Q. B. 576.

${ }^{5}$ Fetter $v$. Beale, Salk. 11.

${ }^{6}$ Whitney $v$. Town of Clarendon, 18 Verm. 252. 
tended that there could not have been any recovery for this damage in the first action, because it had not then arisen; and that the law ought not to be so construed as to require juries upon the trial of actions to estimate prospective damages. The injustice of such a requirement is selfevident. No case can arise involving claims for serious injuries to the person, in which the assessment of damage, as the law now stands, can be otherwise than imperfect and unfair. In the majority of cases, defendants must pay for damages which never develop; while in the minority, the most serious injuries must be borne without compensation. A recovery in an action for false imprisonment brought during the imprisonment, does not merge any claim for damages for the continuance of the same imprisonment. ${ }^{1}$ In an action for malicious prosecution the plaintiff may, in addition to the damages occasioned by the unlawful arrest and detention, recover for injury to his reputation by reason of the false accusation. Therefore, a judgment for false imprisonment is a bar to an action of slander for the same accusation on which the imprisonment was procured.2 But such a judgment is no bar if the utterances complained of, though of the same character and purport, were made at a different time from the accusation by means of which the false imprisonment was occasioned. ${ }^{3}$

8 242. Cases of Nuisance.-In cases of muisance, the injury may be of two kinds: first, the injury produced by the act; and second, that occasioned by the continuing of the nuisance produced by the act. For, while a trespasser is under no obligation to rebuild or replace what he has torn down or destroyed, he who creates a nuisance is under a continuing obligation to abate it. 4 Therefore, only the damage done at the date of the writ can be compensated in that suit. If that damage exposes the plaintiff to the expenditure of money, he may recover the full amount which he is liable to expend, whether it has been already paid out or not. The material inquiry in the second action is

1 Leland $v$. Marsh, 16 Mass. 389. 579.
3 Rockwell v. Brown, 36 N. Y. 207.

4 Clegg v. Dearden, 12 Q. B. 576. 
whether the damages on which it is based are attributable to the original act, or to the continuing of the state of facts produced by that act. In the latter case a new cause has arisen, and a new action will lie. "There may, of course, be cases where it may be difficult to draw the line, but it is apprehended they will not be numerous. Wherever the nuisance is of such a character that its continuance is necessarily an injury, and when it is of a permanent character, that will continue without change from any cause except human labor, there the damage is an original damage and may be at once fully compensated, since the injured person has no means in his power to compel the individual doing the wrong to apply the labor necessary to remore the cause of injury, and can only cause it to be done, if at all, by the expenditure of his own means. But where the continuance of such act is not necessarily injurious, and where it is necessarily of a permanent character, but may, or may not be, injurious, or may, or may not be, continued, there the injury, to be compensated in a suit, is only the damage that has happened. Thus the individual who manages the water he uses for mills, so as to wash away the soil of his neighbor, is liable at once for all the injury occasioned by its removal, because it is, in its nature, a permanent injury; but if his works are so constructed, that upon the recurrence of a similar freshet, the water will probably wash away more of the land, for this there can be no recovery until the damage has actually arisen; because it is yet contingent whether any such damage will ever arise. If a person erects a dam upon his own land, which throws back the water upon his neighbor's land, he will be answerable for all damage which he has caused before the date of the writ, and ordinarily for no more, because it is, as yet, contingent and uncertain, whether any further damage will be occasioned or not, because such a dam is not of its own nature, and necessarily, injurious to the lands above, since that depends more upon the manner in which the dam is used, than upon its form. But if such a dam is, in its nature, of a permanent character, and from its nature must continue permanently to affect the value of the land flowed, then the entire injury is at once 
occasioned by the wrongful act, and may be at once recovered in damages." ${ }^{1}$ Thus, where in building a canal a river is dammed as a feeder to the canal, and the lands of an adjacent owner are permanently flooded, he cannot recover eaci year the damage occasioned by the non-use of the land for that year, but must at one time recover the damages, to wit, the full value of the land. A railroad must be regarded as permanent in its nature, and not as intended to affect somo temporary purpose, after which it is to be discontinued. The damage occasioned, therefore, to a roadway and bridge, by the construction of a railroad track over them must be estimated for a permanent appropriation. Parties affected by such appropriation are entitled to recover at once their full damages, and if they recover any part they cannot further recover in a subsequent action. ${ }^{2}$

8 243. Several Torts.-But separate torts give rise to separate causes of action, and each cause remains unaffected by a judgment for any other tort subsequent or antecedent. Thus, a sailor who has maintained an action in a Court of Admiralty, for an assault and battery committed on the high seas is not thereby precluded from obtaining in a common law court a judgment for an assault and imprisonment on shore during the same voyage. ${ }^{3}$ But where $A$. took a bond, conditioned that B. should abstain from injuring certain property, a recovery under the bond was held to estop A. from obtaining compensation for any injury committed after taking the bond, and before the commencement of the first suit: that while A. could have separately recovered for each distinct injury, independent of the bond, yet, having elected to proceed under the bond, he was bound by that election; and could neither sustain another action upon the bond, nor disregard it by proceeding upon the tort alone.4 A person having the choice of two remedies, can prosecute but one of them to judgment. A recovery in assumpsit on a policy of insurance bars a subsequent action of covenant on the same policy. ${ }^{5}$

\footnotetext{
1 Troy $v$. Cheshire R. R. 3 Fos. 3 Adams $v$.Haffards, 20 Pick. 127. 83.

4 Goodrich $v$. Yale, 97 Mass. 15.

2 Town of Troy $v$. Cheshire R. R. 5 Marine Ins. Co. v. Young, 1 Co., 3 Foster, 83 Cranch, 340.
} 
\& 244. Exceptions to General Law of IMerger.-The law of meger as applied to judgments does not forbid all inquiry into the nature of the cause of action. Such inquiry may be prosecuted for any purpose consistent with the judgment; and is frequently necessary to its interpretation. The place where a contract was made may be ascertained in order that the lex loci, which was a part of the contract, may have its effect upon the judgment. If the prevailing party was entitled to certain privileges or exempted from certain burdens under his contract, he may be entitled to the same privileges and exemptions, in many cases, under his judgment. And, whenever justice requires it, judgments will generally be construed not as a new debt, but as an old debt in a new form.

\section{245. Doctrine of Merger Modified in Proceedings in} Bankruptcy.-In no class of cases has the technical operation of the doctrine of merger been so frequently limited as in those where the effect of a discharge of a debtor under laws for the relief of insolvents, had to be determined. In many cases judgments entered subsequently to the filing of the debtor's petition have been deemed to be beyond the scope of his discharge, ${ }^{2}$ while in perhaps a still greater number of cases it has been held that whenever a cause of action, existing at the time of the filing of the debtor's petition, was of such a nature that the discharge would have affected it, any judgment recovered thereon prior to the decree of discharge will be affected to an equal extent; and that within the meaning of those laws such judgments are never to be regarded as new debts, arising subsequently to the filing of the petition. ${ }^{3}$ A contract made in a foreign country,

\footnotetext{
${ }^{1}$ Evans $v$. Sprigg, 2 Md. 457; Wy- |360; Clark v. Rowling, 3 N. Y. 216; man $v$. Mitchell, 1 Cow. 316; Clark Rogers v. Ins. Co., 1 La. An. 161; v. Bowling, 3 Comst. 216.

${ }^{2}$ Bradford $v$. Rice, 102 Mass. 472; Ellis $v$. Ham, 2S Me. 3S5; Kellogg $v$. Schuyler, 2 Den. 73; Uran $v$. Houdlette, $36 \mathrm{Me} .15$; Roden $v$. Jaco, 17 Ala. 344.

Dick $v$. Powell, 2 Swan. 632; Stratton v. Perry, 2 Tenn. Ch. 633; Harrington v. McNaughton, $20 \mathrm{Vt}$. 293; McDouald $v$. Ingraliam, 30 Miss. 3\$9; Betts $v$. Bagley, 12 Pick. 572; Raymond $v$. Merchant, 3 Cow. 147; Fox $v$. Wood-

${ }^{3}$ Blanford v. Foote, 1 Cowp. 13s; bury, 9 Barb. 49S; Dresser v. Brooks, Imlay $v$. Carpenter, 14 Cal. 173; 3 Barb. 429; 2 MI. 457. Jolinson $v$. Fitzhugh, 3 Barb. Ch.;
} 264 
Chap. XI.] DOCTRINE OF MERGER.

and merged into a judgment here, is for the purpose of proceedings under these laws to be regarded like a new obligation created under and exclusively subject to our laws. Hence the discharge of the defendant, in the foreign country, from all his liabilities, will not affect the judgment. ${ }^{1}$ But a judgment rendered in Massachusetts, upon a contract made in New York, between citizens of the latter State, comes within the operation of a discharge in insolvency granted by the courts of New York, while both plaintiff and defendant were residents of that State. ${ }^{2}$

${ }^{1}$ Green v. Sarmiento, 3 Wash. 17. ${ }^{2}$ Betts v. Bagley, 12 Pick. 580. 


\section{CHAPTER XII.}

THE JUDGMENT AS AN ESTOPPEL.

\section{PART I.-NATURE AND EXTENT OF JUDGMENT ESTOPPEIS.}

5 246. Definition of Estoppcl.

\$ 247. Judgment Estoppel not odious.

8 248. Decrees.

243. General extent of Judgment Estoppel.

PART II.-REQUISITES TO JUDGMENT ESTOPPEL.

250. Must be free from fraud and collusion.

8 251 . Must be a final adjudication.

8 252. Identities demanded.

253. Ideutity of subject matter.

254. Identity of Purpose.

B 255. Identity of Form.

5 256. Identity of Issues.

257. Facts must have been directly in issue.

5 258. Can not extend to collateral questions, nor to matters inferred only by argument.

259. Identity of Evidence.

8 260. Must arise from Judgment on the merits.

8261 , Motion for nonsuit, is waiver of trial on the merits.

5 261a.Estoppel not created by nonsuit.

$\S 262$. Dismissal by agreement.

263. Classification of Judgments not on the merits.

s 264. Judgments of dismissill for want of jurisdiction and roid jragments.

8 265. Judgments where remedy was misconceived.

266 . Judgment for want of proper parties.

f 267. Judgments on Demurrer.

$\$ 268$. Judgment in suits prematurely brought.

$\$ 269$. Claims not admissible under the pleadings.

$\$ 270$. Decree of bill dismissed.

5270 a.Bill dismissed before the hearing.

5271 . Does not extend toimmaterial findings.

PART III. - OF EVIDENCE TO ESTABLISH OR REBUT THE JRESUIPTION OF RES JUDICATA.

8 272. Whether matter in issue may be shown to bave not been put in evidence. $\$ 273$. Tstoppel may be shown by parol.

$\$ 274$. Parol evidence to rebut presumption of Estoppel.

8 275. Record not to be impugned.

$\$ 276$. Onus of Proof.

$\$ 276 a$. Where there are two or more defenscs disposed of.

PART IV.-MATTERS WHICH DEFENDANT MAY OR MAY NOT LITIGATE.

\$277. Set-off not presented.

$\$ 278$. Set-orf not decided.

$\S 279$. Set-off rejected.

266 
Chap. XII.] the JUdGMENT as AN ESTOPPEL.

s 2so. Set-off voluntarily allowed.

$\$ 281$. Equitable defenses.

$\S 282$. Cross-claims.

PART V.-OF PLEADING FORIIER JUDGMENT AS AN ESTOPPEL.

$\S 283$. Necessity.

$\S 284$. Consequenco of Neglect to Plead.

PART VI. - OF ACTIONS TENDING TO CONTRADICT FORMER ADJUDICATIONS.

284a.Defenses and Causes of Action already Adjudicated.

\$ 285. Action for Payments unt Credited.

$\$ 280$. Action for Credits lot Allowed.

\$ 287. Action for Money Paid to satisfy Judgments.

$\$$ 288. Action for Money Paid under Legal Process.

$\S 289$. Action for Obtaining Judgments by Fraud or Perjury.

$\$ 290$. Motions for Satisfaction.

\$ 291. Taking Judgnent for Sum Paid, as Consideration for a Promise.

\& 292. Exceptional Cases.

\section{PART VII.-JUDGJIENTS IN VARIOUS ACTIONS.}

\section{FIRST.-IN ACTIONS AFFECTING THE TITLE OR POSSESSION} OF REAL ESTATE.

§ 293. Distinctions appllcable to Real Actions.

294. Common Recovery.

$\$ 295$. Ejectment at Common Law.

$\$ 296$. Ejectment at Common Law on Confession.

$\$ 297$. Ejectment at Common Law-Evidence for Mesne Profits.

$\$ 298$. Ejectment at Common Law-Costs in.

8 299. Ejectment under Recent Statutes.

$\$ 300$. Ejectment under Recent Statutes-Pleadings in.

$\$ 301$. Ejectment under Fecent Statutes-Issues in.

\$302. Ejectment under Recent Statutes-How Estoppel Rebutted.

$\S 302 a$. Forcible Entry and Unlawful Detainer.

$\S 303$. Foreclosure Suits.

\& 303a.Judgments affecting Right to Dower.

$\$$ 304. Partition.

8 305. Partition, plaintiff not in possession.

$\$ 306$. Partition against persons not in esse.

8 307. Partition against persons unknown.

$\S$ 308. Partition, fual without deed.

6 309. Quieting Title.

6 310. Trespass on Real Estate in other suits for trespass.

311. In actions of Ejectment.

SECOND.-JUDGIENTS IN PERSONAL ACTIONS.

8 312. Suits for Breaches of Tarranties.

\& 313. Divorce.

314. Alimony.

6 315. Against Partnership.

6 316. Replevin.

317. Trespass.

THIRD.-CRIIINAL CASES.

6 318. Judgments in, effect in Criminal Cases.

\& 319. Judgments in, effect in Clvil Cases. 
FOURTI.-PROBATE PROCEEDINGS.

\$ 319.aDecrees and Orders of Probate Courts.

\section{PART VIII.-ESTOPPELS ARISING FROM MOTIONS AND SPECIAL PROCEEDINGS.}

$\$ 320$. Awards of Arbitrators.

$\$ 321$. General Submi sion of demands.

$\S 322$. Demands not Disputed.

\& 323. Bills of Review.

\$324. Habeas Corpus.

$\S 325$. Motions and Special Proceedings.

$\$ 326$. Rules applied to Motions.

\$ 327. Proceedings supplementary to Judgment.

PART IX.-MIISCELLANEOUS MATTERS.

$\$ 327 a$. Establishing Identity of Defendant.

§ 328. Appeal, effect of.

\$ 329. After acquired rights.

$\S 330$. Defaults and Admissions.

$\$ 331$. Defauits and Admissions, English cases on.

8 332. Latest Adjudication prevails over Prior Ones.

§ 333 . Reversal.

PART I.-NATURE AND EXTENT OF JUDGMENT-ESTOPPEL.

8 246. Definition of Estoppel.-Having treated of the parties whose relation to an adjuclication is such as to bind them by the facts which it necessarily affirms, to the same extent that the immediate parties to the record are bound, we come now to the consideration of the question: What facts does a judgment or decree so establish, that neither the parties nor their privies can ever afterward gainsay them? But, before undertaking to consider, or to answer the question, we may, without wandering far from our subject, show that the word estoppel, in the sense in which it is defined by Lord Coke, is a term not proper for the designation of that conclusiveness which confessedly attends every final determination of the rights of the parties to any action or proceeding. According to that definition, an estoppel is "where a man is not permitted to speak the truth." Whatever is settled by a judgment, is the result of an investigation, conducted under the most favorable rules that mankind has been able to devise, for the exposure of falsehood and the ascertainment of truth. Unless the law is much less "than the perfection of human wisdom," this result can rarely be inconsistent with truth. In the common, as in the civil law, "The authority of res judicata induces a presumption that every thing contained 268 
in the judgment is true, and this presumption being juris et cle jure, excludes every proof to the contrary." The term estoppel, as applied to judgments, should therefore be defined as that which prohibits a party from disputing the truth.

§ 247. Not Odious.-The word estoppel, as associated with judgments, has ceased to be odious. It is more than freed from opprobrious appellations; the vocabulary of the judges has been well nigh exlausted to supply it with honorable and endearing titles. This will be made evident by quotations from a few American and a few English cases: "The doctrine of estoppel by a former judgment between the same parties, is one of the most beneficial prineiples of our jurisprudence, and has been less affected by legislation than almost any other." "The maxim, that there must bo an end to litigation, was dictated by wisdom and is sanctified by age." That an estoppel is odious, is not to be applied to former adjudications. The prevention of relitigation, after year's have elapsed, does not necessarily shut out the truth. The doctrine of estoppels in judgments, instead of being odious, is one of the most conservative and salutary doctrines of the law." "It has been affirmed that there is no such thing as an equitable estoppel. But the doctrine of election, which prevents a party from claiming in repugnant rights, and which has been advantageously introduced into courts of equity, is manifesily an extension of this principle. In courts of law they aro for the most part reconcilable to the purest morality; and when they produce neither hardship nor injustice, they merit indulgence, if not favor. The conclusiveness of judgments which conduces so essentially to peace and repose, has no other foundation." "The very object of instituting courts of justice, is, that litigation should be decided, and decided finally. That has been felt by all jurists. It

1Pothier, Part 4, C. 3, Sec. 3, Art.| ${ }^{4}$ Gray v. Pingry, 17 Verm. 419. 3, Vol. 1.

5 Gibson, J. in Martin v. Ives, $17 \mathrm{~S}$.

2 Justice Miller, in Aurora City v. and R.p. 364-6. See also Nelson, J. West, 7 Wall. 82. in Van Renssalaer $v$. Kearney, 11 ${ }^{3}$ Carothers, J. in Warwick v. Un- $\mid$ How. U.S. 326.
derwood, 3 Head, Tenn. 238. 
is longr since a reason has been assigned why judgments should be considered final, and should not be ripped up again-Ne lites sent immortales, dum litantcs sunt mortales. Human life is not long enough to allow of matters, once disposed of, being brought under discussion again ; and for this reason it has always been considered a fundamental rule, that, when a matter has once become res judicata, there shall be an end to the question." 1 The doctrine of estoppel is not strictly applicable to a judgment. A judgment is not the act of a party; an estoppel is. A judgment is a bar, not because a party has done some act which precludes him from asserting a right or title; it is properly a bar, on principles of public policy, because the peace and order of society, the structure of our judicial system, and the principles of our government require that a matter once litigated, should not again be drawn in question between the same parties or their privies. ${ }^{2}$ A party whose interests are placed in jeopardy by a trial, has a right to judicial immumity from the consequences of further trials involving the same issues. If a claim is in issue and is not withdrawn at the trial, it should be disposed of by the judgment; and if the court, under such circumstances, reserves such claim by reciting in the judgment that " no judgment is hereby rendered touching the same," this action, it is said, will be reversed on appeal, by making the judgment a final bar to the further prosecution of the claim. ${ }^{3}$

8 24:S. Res Judicata, enforced in Equity.-A final decree in chancery is as conclusive as a judgment at law. ${ }^{4}$ Such decrees are available as estoppels, whether the second action involving the same question be at law or in equity. ${ }^{5}$ Hence, a decree dismissing a bill for foreclosure, on the ground that the mortgage was void, is a complete defenso to

1 Willes, J., in G. N. R. R. Co. v. S. 78; White $v$. Bank of U. S., 6 Mossop, 17 C. B. 140.

${ }^{2}$ Huston, J., in Kilheffer $v$. Kerr, 17 S. and R. $319 ; 17$ Am. Dee. 658 ; Kennedy, J., in Marsh $v$. Pier, 4 Rawle, 273. 498.

${ }^{3}$ Sehmiat $v$. Zahensdorf, 30 Iowa,

${ }^{4}$ Sibbald's Case, 12 Pet. 492; Evans v. Tatem, 9 S. and R. 261; 11 Am. Dec. 717; Kelsey v. Murphy, 26 Penn. Hamm. 529; Bank of U. S. v. Beverley, 1 How. 148; Low $v$. Mussey, 41 Verm. 393; Maguire $v$. Tyler, 40 Mo. 406.

${ }^{5}$ Stark $v$. TVoodward, $1 \mathrm{~N}$. and MeC. p. 32S; Hook v. Hood, 2 How. Miss. S67; Moody v. Harper, 9 George Miss. 599; Western M. \& M. Co. v. V. C. C. Co., 10 W. Va. 250 , 270 
an action of ejectment subsequently brought by the mortgagor. "A verdict and judgment of a court of record or a decree in chancery puts an end to all points thus decided between the parties to the suit. In this there is, and onght to be, no difference between a verdict and judgment in a court of law and a decree in a court of equity. They both stand on the same footing, and may be offered in evidence under the same limitations; and it would be difficult to assign a reason why it should be otherwise."1 A judgment at law is conclusive on the same question in equity. ${ }^{2}$ "Nor is there anything anomalons or unusual in setting up a former adjudication as an estoppel to an action for equitable relief. There is nothing unjust or inequitable in insisting upon an estoppel by a judgment upon the same point ; on the contrary, the rule is a beneficial one, and it is a matter in which the public is said to have an interest as well as the parties, that there should be an end to litigation." 3 It will be seen from tho authorities just cited and quoted, that the law of estoppel arising from a former adjudication, is equally applicable, whether the second action or proceeding or the former litigation be of a legal or of an equitable nature. And this adoption of the law of estoppel as a part of the principles of equity jurisprudence, shows that it is, by common consent, deemed consistent with and necessary to a disposition of the rights of the parties, according to equity and good conscience.

8 249. Extent of the Estoppel.-There is no doubt that a judgment or decree necessarily affirming the existence of any fact is conclusive upon the parties or their privies, whenever the existence of that fact is again in issue between them, ${ }^{4}$ not only when the subject matter is the same, but

1 Smith $v$. Kernochen, 7 How. U. Trials, 261; Gahan v. Maingay, 1 S. 195; Hopkins $v$. Lee, 6 Wheat. Irish T. R. 54; Crondson v. Leonard, 109; Marsh $v$. Buroughs, 19 Am. L. 4 Cranch, 436; Outram v. Morewood, R. 718; Wilson v. Boughton, 50 MIo. 3 East, 315; Gardner $v$. Buckbee, 3 17; The Phœbe Stuart's Ad. R. Cow. 120; 15 Am. Dec. 256; Peay v. (Lower Canada), 63.

2 Pearce $v$. Gray, 2 I. and C. Ch. Cas. 322.

${ }^{3}$ San Francisco $v$. S. V. W. TV., 39 Cal. 473.

${ }^{4}$ Duchess Kingston's Case, 11 State

Duncan, 20 Ark. S5; Hibshman $v$.

Dulleban, 4 Watts, 183; Gist v.

Davis, 2 Hill Ch. 335; Lare $v$. Truman, 10 Ohio S. 45 ; Wales v. Lyon, 2 Mich. 276. 
when the point comes incidently in question in relation to a different matter, ${ }^{1}$ in the same or any other court, except on appeal, writ of error, or other proceeding provided for its revision." " "It is a universal principle, that where power or jurisdiction is delegated to any public officer or tribunal orer a subject matter, and its exercise is confided to his or their discretion, the acts so done are binding and valid as to the subject matter; and individual rights will not be disturbed collaterally, for any thing done in the exercise of that discretion within the authority and power conferred. The only questions which can arise between an individual claiming a right under acts done, and the public or any person denying its validity, are, power in the officer, and fraud in the party. All other questions are settled by the decision made or act done by the tribunal or officer, whether executive, legislative, judicial, or special, unless an appeal is taken." 3 After judgment on the merits, the parties "cannot canvass the same question again in another action, although, perhaps, some objection or argument might have been urged upon the first trial which would have lod to a different judgment." "An adjudication is final and conclusive, not only as to the matter actually determined, but as to every other matter which the parties might have litigated and have had decided, as incident to or essentially connected with the subject matter of the litigation, and every matter coming within the legitimate purview of the original action, both in respect to matters of claim and of defense." "Where the matter adjudicated is by a court of peculiar and exclusive jurisdiction, and the same matter comes incidentally in question before another court,

${ }^{1}$ Gray v. Dougherty, 25 Cal. 272; 4; Jacobson v. Miller, 41 Mich. 90; Caperton v. Sclimidt, 26 Cal. 493; Garwood v. Garwood, 29 Cal. 521.

2 Demeritt $v$. Lyford, 7 Foster, 541.

${ }^{3}$ United States v. Arredondo, 6 Pet. 729; Waugh $v$. Chauncey, 13 Cal. 12 .

${ }^{4}$ Greathead $v$. Bromley, 7 T. R. 456.

${ }^{5}$ Harris v. Harris, 36 Barb. 88; Clemens v. Clemens, 37 N. Y. 59; Burford v. Kersey, 48 Miss. 643; Bates v. Spooner, 45 Ind. 4S9; Estill $v$. Taul, 2 Yerg. $466 ; 24$ Am. Dec. 49S; Petersine $v$. Thomas, 28 Oh. S. 596; Tuska v. O'Brien, $6 \mathrm{~S}$ N. Y. 446 ; Cromwell $v$. County of Sac., 94 U. S. 351; Case $v$. Bcauregard, 101 U. S. loney $v$. Horan, $49 \mathrm{~N}$. Y. I
685; Thompson $v$. Myrick, 24 Minn.
well $v$. Knight, 51 Barb. 267. Roby $v$. Rainsberger, 27 Oh. S. 674 ; Knight $v$. Atkinsson, 2 Tenn. Ch. 334 . Failure to plead matters of defense which might have been pleaded is a waiver of them forever. Dewey $v$. Peck, 33 Iowa, 242; Lawrenee S. B. $v$. Stevens, 46 Ia. 429; Murrell $v$. Smith, 51 Ala. 301; Kelly $v$. Donlin, 70 Ill. 378; Gaines $v$. Kennedy, 53 Miss. 103; Covington \& C. B. Co. v. Sargent, 27 Oh. S. 233 . But to come within this rule, the matter claimed to be barred inust be sueh that the party was bound to present it. Malloney $v$. Horan, $49 \mathrm{~N}$. Y. 115 ; Bar272 
the sentence in the former is conclusive upon the latter, as to the matter directly decided, not only between the same parties but against strangers, unless it can be impeached on the ground of fraud or collusion."' The discovery of new evidence, not in the power of the party at the former trial, forms no exception to the rule in relation to estoppels, whether the second action is at law or in equity. ${ }^{2}$ If a judgment of reversal provide that it is not to prejudice any future claim which the appellee may make on further proof, this judgment is nevertheless conclusive in a second action, unless the proof is different from that in the first action. $^{3}$ To render a matter res judicata, it is not essential that it should have been distinctly and specifically put in issue by the pleadings. It is sufficient that it bo shown to have been tried and settled in the former suit." When a matter is once adjudicated, it is conclusively determined as between the samo parties and their privies; and this determination is binding as an estoppel, in all other actions, whether commenced before or after the action in which the adjudication was made. ${ }^{5}$ The effect of a judgment as res judicala is not limited nor enlarged by the reasons given by the court for its rendition, ${ }^{6}$ nor by the failure of the court to give its reasons in writing on every point when required to do so by the constitution of tho State. ${ }^{7}$ Neither can the force of a judgment as res judicata be destroyed or impaired by showing that it was clearly erroneous, and ought not to have been rendered. ${ }^{8}$ Precisely what conditions are indispensable to a judgment in one action, in order that it may be received as conclusive in another, has never been specified in any very distinct or satisfactory manuer. Wo shall, however, proceed to show those requisites which have been enumerated by various judges.

PART II.-REQUISITES TO JUDGMENT ESTOPPERS.

8 250. Judgment must be Free from Collusion.--According to the statement made by Wedderburn in his argu-

${ }^{1}$ Lessee of Rhodes $v$. Selin, 4 beer $v$. Mowry, 55 Pa. S. 419 ; Contre, C. C. 716 .

${ }^{2}$ Kilheffer $v$. Kerr, 17 S. and R. ${ }^{6}$ Chaffe v. MIorgan, 1307; Girardin $310 ; 17 \mathrm{Am}$. Dec. 658 .

${ }^{3}$ Innis $v$. Roane, 4 Call, 379. 299.

${ }^{4}$ Bigelow v. Winsor, 1 Gray,

5 Poorman $\%$. Mitchell, 48 Mo. 45; Allis $v$. Davidson, 23 Minn. 442; Case-

(18) v. Dean, 49 Tex. 243.

'Henry v. Davis, 13 W. Va. 230.

${ }^{8}$ Case $v$. Beauregard, 101 U. S. C3S; State v. Ramsburg, 43 MI. 32ร; Rountree v. Walker, 46 Tex. 300; Linehan v. Hathaway, 5t Cal. 251. 
ment in the celebrated case against the Duchess of Kingston, and adopted by Lord Brougham in a subsequent case, to receive credit as an estoppel, a judgment or decree must be " a judicial determination of a cause agitated between real parties, upon which a real interest has been settled. In order to make a sentence there must be a real interest, a real prosecution, a real defense, and a real decision. Of all these requisites not one takes place in a fraudulent or collusive suit. There is no judge, but a person invested with the insignia of a judicial oflice is misemployed in listening to a fictitious cause proposed to him. There is no party litigating; there is no party defendant, no real interest brought in question." It is also said that the principle of res judicata can not be involied to sustain fraud. Therefore, in an action agaiust several judgment defendants upon a judgment, one of them may show that it was obtained by a conspiracy between the plaintiff and one of the defendants.

?.251. Judgment must be Final-No question becomes res adjudicata until it is settled by a final judgment. For this reason, the verdict of a jury is not admissible as evidence to create an estoppel, before it has received the sanction of the court, by passing into a judgment. Until then, it is liable to be made nugatory by an order arresting judgment or granting a new trial. ${ }^{4}$ But where no power exists to destroy the effect of a verdict, it is conclusive in the absence of any judgment. Thus, where a justice of the peace was, by law, bound to ester a judgment according to the findings of the jury, and had no authority to arrest it nor to award a new trial, it was held that his omission to comply with the law did not prevent the rerdict from barring a new suit. "The entry of judgment was a thing, of course, and in justice and sound policy, the verdict ought to be equally conclusive against any further litigation between the same parties, on the same matter, as if the formal entry of judgment had been made." The same reasons which require that a verdict should not, by itself, be regarded as con-

1 Earl of Bandon $v$. Becher, 3 Cla. and F. 479.

Whitaker $v$. Bramson, a Paine, 209; IcReady $v$. Rogers, 1 Nebr. 124;

2 Duchess Kingston's Case, 11 State Humphreys $v$. Browne, 19 La. An. 158; Trials; Batts v. Winstead, 77 N. C. Schurmeier $v$. Jolnnson, 10 Minn. 319; 238.

${ }^{3}$ Spencer $v$. Vigneaux, 20 Cal. 442. Now Brunswick.

${ }^{4}$ Ridgely $v$. Spenser, 2 Binney, 70; ${ }^{5}$ Felter $v$. Mulliner, 2 Johns. 181. 274 
clusive, are equally applicable to such interlocutory judgments or decrees, as may, at any time, be modified or racated by the court which rendered them. ${ }^{1}$ The rule upon this subject, and the grounds upon which it is based, are well stated by Pothier. He says: "A judgment, to have the authority, or even the name, of res juclicata, must bo a definitive judgment of condemnation or dismissal. A provisional condemnation, then, can not have either the name or the anthority of res judicata, for althongh it gives the party obtaining it a right to compel the opposite party to pay, or deliver provisionally, the money or things demanded, it does not put an end to the canse, or form a presumption juris de jure, that what is ordered to be paid or delivered is due, since the party condemned may bo admitted in the principal case to prove that what he was ordered to pay was not due, and consequently to obtain a reversion of the judgment." 2

8 252. Identities Demanded.-_"To make a matter res adjudicata, there must be a concurrence: 1st, of identity of the subject-matter; $2 \mathrm{l}$, of the cause of action; $3 \mathrm{~d}$, of person and parties; and 4th, in the quality of the persons for or against whom the claim is made." 3 According to another case, the requisites are: 1st, that the judgment preceed from a court having jurisdiction; $2 d$, that it bo between the same parties; and $3 d$, that it be for the same purpose. ${ }^{4}$ In Massachusetts, to ascertain whether a judgment is a bar, the courts will inquire:

1st. Whether the subject-matter in controversy has been brought in question, and within the issue in the former proceeding, and has terminated in a regular judgment on the merits;

2d. Whether the former suit was between the same parties, in the same right or capacity, or their privies claiming under them;

31. Whether the former judgment was before a conrt of competent jurisdiction. ${ }^{5}$

That a judgment, to constitute an estoppel, must pro-

${ }^{1}$ Baugh $v$. Baugh, 4 Bibb, 5J6. $\quad{ }^{*}$ Aspden v. Nixon, 4 How. U. S. 2 Pothier Ob., part 4, ch. 3, sec. $3,467,497$. art. 1.

5 Bigelow v. Windsor, 1 Gray, 209.

${ }^{3}$ Benz $v$. Hines, 3 Kansas, 397; See, also, M[cDono h's Succession, 24 State v. Jumel, 30 La. An. 861; 2 La. An. 33; Miller v. Me.Nanis, 57 Iil. Bouvier Dic., Title "Ries Judicata." 126; Tucker $c$. Rohrback, 13 Mich. 75. 
ceed from a court of sompetent jurisdiction, is a proposition which requires neither arguments nor authorities to prove its existence, or to illustrate its application: Tho necessity of a judgment being between the same parties, or their privies, and the limitation and extensions of the rule in this respect, have already been fully considered in the chapter on parties. But the cases cited seem to demand the existence of the following identities between two suits, to constitute the first decided a bar to the further prosecution of the second, to wit: 1st, identity of subject matter; $2 d$, identity of causo of action; and $3 d$, identity of purpose or object. While a concurrence of these identities usually attends, when ono case is determined by the decision in another, yet the second named, only, is indispensablo to impart a conclusive efiect to a former judgment, as will be manifest by reference to a few of the reported cases.

8 253. Ilentity of Subject Matter.-The principle is recognized and supported in most of the American cases, that a decision upon any material point, is conclusive thongh the subject matter of the two suits be different. ${ }^{1}$ N. sued R., a servant of C., for property. C. defended for his servaut, claiming title uncler a chattel mortgage from $H$. ; N. claimed under judgment against $H$., and sought to impeach the mortgage, on the ground that it was fraudulent as to creditors. At the trial, N. failing to prove his judgment, tho decision was in favor of $R$. C. afterward sued $N$. for the same property, and contended that the judgment in favor of R., under the circumstances, was conclusive that the property belonged to C. N., to avoid the operation of the estoppel, contended, 1st, that in the former suit, the chattel mortgage matter had not been determined; $2 \mathrm{~d}$, that the parties were different. Bet it was held that the issues in the first suit were such that the findings of either in favor of C., constituted an estoppel. One issue was the bona fides of the mortgage,

${ }^{1}$ Spencer $v$. Dearth, 43 Verm. 9S; Barb. 321; Waller v. Chase, 53 Me. Betts $v$. Starr, 5 Conn. 550; 13 Am. 25s; Cromwell v. County of Sac., 04 Dec. 94, and note; Doty v. Brown, 4 U. S. 351; 4 Cent. L. J. 416.

N. Y. 71; Williams $v$. Fitzhugh, 44

276 
the other was the title of $\mathrm{N}$. to the property in dispute, $N$. having failed to show that lie was a judgment creditor, could not on that account, raise the question of bona, fides, and he is now estopped. ${ }^{1}$ A verdict in a summary proceeding, to remove a tenant for non-payment of rent, finding that no rent is due, is conclusive in favor of the tenant, in a replevin suit brought by him to recover cattle distrained by the landlord, to satisfy the same claim of rent. ${ }^{2}$ The only matter essential to making a former judgment on the morits, conclusive between the samo parties, is that the question to bo determined in the second action, is the same question judicially settled in the first. A judgment is conclusive, not only as to the subject matter in suit, but as to all other suits, which, though concerning other subject matters, involve the same questions of controversy. ${ }^{3} \mathrm{~A}$ judgment in favor of a bond holder, upon certain municipal bonds against the town issuing them, is conclusive on the question of the validity of other bonds being part of the same issue, in an action between the same parties, all the objections and matters of defense in the second action having been equally available to the town in the first. ${ }^{4}$ If A., as a defense to an action against him, plead that he has been released from the liability, by virtue of his discharge in a proceeding for the relief of insolvent debtors, and the plaintiff seek to avoid the discharge, on the ground that it was procured by frand, a judgment for the defendant is conclusive in his faror upon the question of fraud, in any other action between the same parties, though upon a different contract. $^{5}$ If an issue be tried in any proceeding, as to whether the defendant is a member of a firm, the result of the trial will be conclusive between the parties whenever the same issue again arises between them. ${ }^{6}$ After a judgment has been recovered for a quarter's rent upon a lease, no defense can be made in a subsequent action for rent alleged to be due upon the same lease, substantially involv-

${ }^{1}$ Castle v. Noyes, 14 N. Y. 329.

${ }^{2}$ White $v$. Coatsworth, 6 N. Y. 138 .

${ }^{3}$ Gardner v. Buckbee, 3 Cow. 120; 15 Am. Dec. 256; Bouchaud v. Dias, 3 Denio, 238; Babcock v. Camp, 12 Ohio S. 11.
${ }^{1}$ Beloit v. Morgan, 7 Wall. 619; San Antonio v. Lane, 32 Tex. 411.

${ }^{5}$ Merriam $v$. Whittemore, 5 Gray, 316; Van Dolsen v. Abendroth, $43 \mathrm{~N}$. Y. S. C. 470 .

${ }^{6}$ Lynch $v$. Swanton, 53 Maine, 100. 
ing the same points deciled agrinst the defendant in the first suit. If an instrument has been judicialls construed, this construction must be adopted in erery other controress between the parties, in which the eflect of the same instrument is brought in question." A. sold land to $B$., and agreed to cease keeping tarem, on adjacent lnd, as soon as B. built certain buildings. B. aftermari recorerea in an action for a breach of this agreement. In a second action, claining damages for a subsequent breach, it was held that the on!? matters upon which defendant was not concluded, were the subsequent breach and the amount of damages resulting from it. ${ }^{3}$ If a suit to recorer an installment of purchase mones, be dafended on account of an alleged failure of title occasioned by incumbrances, the decision of the court is conclusire upon that subject, in an: future action, to recorer a sabsequent installment falling dae on the same purchase." Atier a decree in faror of plaintift, upon a contract for the parment of moner in installments, the only question open to litigation, in respect to ant subsequent installment, is whether as to it the defendant is in default. [pon this question, the defendint is entitled to a hearing, and if a sale be made without such hearing, for the purpose of paring a sum which has fallen due since the entrr of the original decree, and which is alleged to remain unpaid, the sale is roid." The recorery by judgment of a sum claimed to be due as interest on a promissort note, precludes the defendant from contesting the parment of the principal, on the ground that the note was procured by fraud; ${ }^{\circ}$ or upon ans other defense inrolred in the former suit. ${ }^{\overline{7}}$ A note and a mortgage for its securits alleged to be made at the same time, are not necessaril in separable. The note mas hare been delirered, aud the wortgage not; or the former mar hare been obtained br fraud and duress, and the latter not. Hence, a judgment against the ralidity of the mortgage does not per se establish the invalialits of the note." If an assessment be imposed on

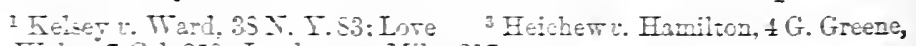

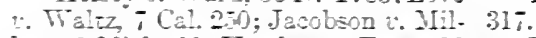

Ier. 11 litich 90 ; Howlez $\tau$. Tazte, 10

C. B. (N. S.) SI3.

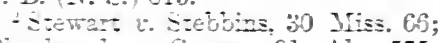

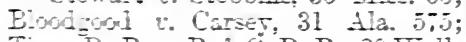
Tiog $=$ P. P. ז. B. \& C. P. P., 20 T all $13 \%$

¿ Kang *. Fisher. 2 Wazs. 246.

5 Perlins 2 . Perkins, 10 Jich. 16 .

${ }^{6}$ Eigell 2. Sigerson, 20 Mo. 533.

- Back Rirer Saving Bank $v$. Ed. Ta=ds, 10 Gray, $35 \%$.

¿Lander t. Irno, 65 Je. 26. 
certain lots, parable in installments, the recorery on any installment maroidably afims the ralidit of the assessment, and preciudes it from being controrerted in a subsequent action betreen the same parties for subsequent? accruing installments; ${ }^{1}$ and, on the other hand, where the issue of the certificate of a special assesment is restrained, on the ground that the contract with the city mas unutidorized, the judgment is conclusive against the citr or its assignee in an action to collect the amount of the assessment.? Some of the English courts, if we mar judge from the oninions expressed br Lorl Chelmsford, lent the application of the principle of res julicala to cases where the subject-matter of the two suits is not identical. Hence he determined that a jugdment against one poor late was not binding in a controrersy in reference to a subsequent rate, though the isstles in the tro controrersies rere the same. ${ }^{3}$ The effect of a judgment upon a subsequent action inrolring the same issues, but a difierent though similar subject-matter, las recently been rert fally considered in the Supreme Coum $c_{2}^{\text {f }}$ the Cnited States. The conclusion there reached is, that when ant issue is, in fact, litigated and determined, saci determination is conclusive mpon the parties and their privies in any subequent action in which ihe same issue is dratru in question, though the sulject-matter of the action be disterent. In order to successfully intole this rwe, it must he shomn that in the former action the issue rous in fact litigated and leciled. It is not suficient that it was there so inrolred that it might hare been litigated. Tith respect to the subject-matter of an action, each partr must bring forward erers canse of action or defense involrea in the pleadings, and the julgment will of ten be conclusire not not only upon the matters litigated, but also apou those which the parties might hare litigated in that action. Dat in at subsequent action inrolring a dizerent subject-matier, the former adjudication can not be relied upon, meses it appears not that the issue now presented was presented, and ought to hare been litigated in the prior action: but, fur-

${ }^{1}$ People $a$ Brisin. So T1. 4.23: Iehmer 2 Paple. so I11. 601.

"Commissimers: Inspecors, I. I.

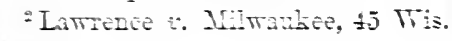
1 H. I. S… A. $\therefore$. 30.5. 
ther, that it was litigated and decided, as well as involved.' Thus, where a suit to recover upon certain coupons failed, because it was not shown that the plaintiff was a purchaser of the bonds to which they were attached, for value and before maturity, he was held not to be estopped in an action on the bonds from showing that he did purchase them before maturity, it not appearing that this issue was the subject of controversy in the former suit. ${ }^{2}$ So, also, the omission of the indorser of a series of notes, when sued upon one or more of them, to assert a defense equally available as against all of them, does not preclude him from relying upon

${ }^{1}$ Cromwell $v$. County of Sac., $94 \mathrm{U}$. tent evidence, the subsequent allegaS. $351 ; 4$ Cent. L. J. 416; Davis v. Erown, 94 U. S. 423; Russell v. Place, 94 U. S. 606.

${ }^{2}$ Cromwell $v$. County of Sac, $94 \mathrm{U}$. S. 351. In this case, Judge Field, delivering the opinion of the court, said: "In considering the operation of this judgment, it shonld be borne in mind, as stated by counsel, that there is a difference between the effect of a julgment as a bar or estoppel against the prosecution of a second action upon the same claim or demand, and its effect as an estoppel in another action between the same parties upon a difierent claim or cause of action. In the former case, the judgment, if rendered upon the merits, constitutes an absolute bar to a subsequent action. It is a finality as to the elaim or demand in controversy, including parties and those in privity with them, not only as to every matter which was offered and received to sustain or defeat the claim or demand, but as to any other almissible matter which might have been offered for that purpose. Thus; for example, a judgment rendered upon a promissory note is conclusive as to the validity of the instrument and the anount due upon it, although it be subsequently alleged that perfect defenses actually existed, of which no proof was ofierecl, such as forcery, want of consideration, or payment. If such defenses were not presented in the action, and establishca by compe-

tion of their existence is of no legal consequence. The judgment is as conclusive, so far as future proceedings at law are concerned, as though the defenses never existed. The lancuage, therefore, which is so often used, that a judgment estops not only as to every ground of recovery or defense actually presented in the action, but also as to every ground which might hase been presented, is strictly aecurate when applied to the demand or elaim in controversy. Such demand or claim, having passed into judgment, can not again be brought into litigation between the parties in proceedings at law upon any ground whatever. But where the second action between the same parties is upon a difierent elaim or demand, the judgment in the prior action operates as an estoppel only as to those matters in issue or points controverted, upon the determination of which the finding or verdict was rendered. In all cases, therefore, where it is sought to apply the estoppel of a judgment rendcred upon one cause of action to matiers arising in a suit upon a difierent eause of action, the inquiry must always be as to the point or question actually litigated and determined in the original action, not what miglst have been thus litigated and determined. Only upon such matters is the judgment conclusive in another action." 
such defense when sued upon other notes of the same series. ${ }^{1}$

\& 254. Icientity of Purpose. - It has been said that the cause and object of the action being the same, the former judgment bars the suit, but the principle runs through nearly all the American cases, that a judgment is conclusive, if upon the direct point, though the objects of the two suits be different. ${ }^{2}$ A judgment against the assignee of an insolvent debtor in an action bronght to set aside a conveyance, is conclusive against lim in an action of trover, to recover of the same defendants any of the property included in the conveyance. ${ }^{3}$ One who defends an action to recover for work, on the ground that the work was so done as to bo of no value, and fails to establish his defense, is precluded from afterward maintaining any suit against the plaintiff for damages alleged to have arisen from the unstillful doing of the same work."

2 255. Idenitity of Form of Action.-By the rules of the civil, as well as of the common law, "res judicata is not changed by a change in the form of action." It is not material that the form of action be the same, if the merits were tried in the first. A judgment for the defendant in trover, for conversion of goods, is a bar to an action against him for money had and received from tho proceeds of the sale of the same goods. No party can bring the same cause of action twice to a final determination. ${ }^{6}$ The form of procedure is immaterial. If proper parties join issue upon a question of law or of fact, before a competent court, they must abide by the decision. Hence it was held in Lonisiana, that a party who had proceeded by rule to arrest an execution, and had in that manner had a complete hearing on the

1 Davis $v$. Brown, 94 U. S. 423; Russell $v$. Piace, 94 U. S. C66. The tendency in the English courts is to confine the eficet of a jud gment estoppel to the issues actually litigated. Goncher v. Clayton, 11 Jur. N. S. 107; 34 L. J. Ch. $ธ 23 ; 13$ W. R. 336.

2 Note 261 to Ph. Ev.; Barker $v$. Cleaveland, 19 Mich. 230; but in Robinson $v$. Kruse, 29 Ark. 575, the recovery by plaintiff in replevin was decided not to prevent the defendant from sustaining an action against the former plaintilif for the conversion of the same property.

${ }^{3}$ Bigelow v. Winsor, 1 Gray, 299. Alerriam v. Woodcock, 104 Hass. 326.

${ }^{5}$ Pothier, p. 4, c. 3 , s. 3 , art. 4; Eastman v. Cooper, 15 Pick. 285.

'Lawrence $v$. Vernon, 5 Sumner, p. 20; Hitchin $v$. Camplbell, 2 W. Bla. 778 and 827; Ferrer's Case, 6 Coke, 7. 
merits, resulting in a discharge of the rule, was barred from obtaining an injunction in an action brought for that purpose, unless he could show other facts than those existing at the time of discharging the rule. ${ }^{1}$ But in this application of the law of estoppel, the court in Louisiana probably proceeded contrary to the current of decisions, as will be seen when we consider, in a subsequent section of this chapter, the estoppels arising from the decisions of motions. As a general rule, no one will be debarred by the decision of any motion or proceeding arising out of an action, but will be allowed to litigate the same matters in auy independent suit in which they are drawn in question. But "when one is barred in any action, real or personal, by a judgment on demurrer, confession, verdict, etc., he is barred as to that or the like action of the like nature for the same thing forever."

8 256. Identity of Issues. - It will be seen, from examining the authorities already cited, that to render any judgment or other final adjudication proceeding from court of competent jurisdiction, arailable as a bar in a second action between the same parties or their privies, two things only are essential, viz.: 1st, That the issue in the second action, upon which the judgment is brought to bear, was a material issue in the first action, necessarily determined by tho judgment therein; $2 d$, That the former judgment was upon the merits. The chief dificulty in applying a former juclgment to a present litigation, arises from the necessity of determining what wero the matters affirmed or denied by the former decision. In determining this question, it may be, and frequently is, impossible to obtain sufficient data to form any satisfactory conclusion, without looking beyond the record in the former suit, and ascertaining from any other competent evidence, what were the real issues brought beforo the court, and necessarily entering into the consideration of the judgment. And whether the issues in the former action sufficiently appear from the record, or are made known by extrinsic prools, the necessity still remains of deciling whether a matter controverted at the former

- 1 Trescott $v$. Lewis, 12 La. An. 197. ${ }^{2}$ Westcott v. Brock, 2 Col. 335; 
trial, was a material issue, or a mere matter of evidence brought forward to aid in establishing some material issno. Courts have, from time to time, endearored to lay ciown general rules, or more properly speaking, general leseriptions, by which to determine what questions are, and what are not settled by a former adjudication. We shall now state some of these general descriptions, leaving the reater to harmonize them if he can, and feeling that if he cannot, he is not less successful than we have been.

A judgment is conclusive upon every matter actually and necessarily decided in the former suit, though not then directly the point in issue. If the facts involved in the second suit, are so cardinal that, without them, the former decision cannot stand, they mast now be taken as conclusively settled. In an order of settlement, John G. and William G. were adjudged to be the lawful children of William G.. and Esther G., and to have their settlement in a certain township. Afterward, a contest arose in relation to the settlement of Esther G. Whereupon, it was considered that, as the settlement of the children depended on that of their father, and on his marriage with thoir mother, Esther, the father's sertlement and marriago must have been decided as the ground work of the former order, and that as those facts which upheld the order of settlement of the children, were necessarily and exclusively applicable to their mother, her settlement was fixed by the decision in relation to that of her children. 1 And in Vermont it was decided that the adjudication upon an order of removal, that a woman had a settlement in TV. was conclusive between the same parties, in a proceeding to remove her illegitimato son, who, being a minor, conld obtain no settlement for himself, and whoso settlement was therefore necessarily identical with that of his mother. ${ }^{2}$ In a number of cases, several notes were given in payment for property purchased of the payee; and in a suit on the first note due, the defense of want of consideration arising from fraud in the sale, or from the worthless character of the property sold,

1 Regina v. Hartington, $4 \mathrm{El} . \& \mathrm{Bl} . \mid 2$ Cabot v. Washington, 41 Vt. 168. p. 780 . 
was made. The opinions of the courts as to whether the decision upon the first note was conclusive upon the same questions arising in suits upon the other notes, seem to be very equally divided. In New York, ${ }^{1}$ and in Georgia, ${ }^{2}$ the former judgment is a bar; in Massachusetts ${ }^{3}$ and in Iowa, ${ }^{4}$ it is not. In the last named State it is conceded, however, that a decision upon the validity of one of the coupons attached to a bond, is conclusive upon the validity of any other coupon attached to the same bond. ${ }^{5}$ In New York, where $A$. and $B$. were sureties for the same person on two bonds, an action by A. for contribution from B., for money paid upon one bond, was held to be conclusive in a like suit upon the other bond, the same defense being offered in both suits. ${ }^{6}$ In New York it is well settled that the recovery by a physician of a judgment upon his claim for professional services, is a conclusive affrmance of the valuable character of those services, and, as such, is a bar to any action against him for malpractice, ${ }^{7}$ although the former judgment was rendered without any claim of malpractice being offered as a defense, ${ }^{8}$ and although such defense was expressly withdrawn before going to trial. ${ }^{9}$ E. a tenant, committed an act of bankruptey. An assignee was appointed, who entered on the demised land, and drove off cattle to prevent their being distrained. They were pursued and seized by the landlord's bailiff. The assignee brought an action of replevin for the cattle. This action turned upon the question whether the assignee, by his entry, became a tenant, that is, whether he had elected to receive the lease instead of relinquishing it as damnosa hereditas. The action having been determined against him, it was held, in a subsequent controversy between him and the landlord, to conclusively establish his tenancy. ${ }^{10}$ Still there

${ }^{1}$ Gardner $v$. Buckbee, 3 Cow. 120; 15 Am. Dec. 256.

${ }^{2}$ Freeman $v$. Bass, 34 Geo. 355.

3 Eastman $v$. Cooper, 15 Pick. 276.

* Clark v. Sammons, 12 Iowa, 368.

5 Whitaker $v$. Johnson Co., 12 Iowa, p. 595.

${ }^{6}$ Bouchaud v. Dias, 3 Denio, 243.

${ }^{7}$ Edwards $v$. Stewart, 15 Barb. 67.

${ }^{8}$ Gates $v$. Preston, 41 N. Y. 113. 534.

${ }^{10}$ Hancock $v$. Welsh, 1 Stark. N. P. 347. A. gave a horse to B. to board, with instructions not to use him. B. used the horse and foundered him. A. abandoned the horse and sued for his conversion. B. then sued for the horse's board. A. set up defense of the conversion. The justice, on de- 
are not wanting cases in which a question has been allowed to be relitigated, on the mere pretext that the matter necessarily involved in a former action was only collaterally or incidentally in issue. Thus, in an early case in New Hampshire, the plaintiff recovered damages for the nonfulfilment of a contract to work for a year, though he had defended an action against him by the defendant for two months labor of the same year, on the ground of a special hiring for the whole year, and had failed in his defense.' In New Jersey, a chief of police was discharged on a certain day, by the town council, if it had power to do so. $\mathrm{Ho}$ commenced a suit for his salary, after the attempted discharge, and obtained judgment. Ho then sued for salary accruing after the commencement of the former actioa. It was conceded that the question of his discharge was decided in his favor in the first suit; but it was consilered the question was not concluded in the second action because it was a matter of law. ${ }^{2}$ A good illustration of the rule that the efiect of a former adjudication extends to every question necessarily litigated between the parties, and is not confined to actions having the same purpose, or involving tho same subject matter, is found in a case decided by the Supreme Court of California. J. W. and T. made a note in favor of D. T., being the owner of a tract of land, soon after conveyed it to $D$. After the maturity of the note, $D$. sued J. T. and W. upon it. J. made no defense. T. and W. answered that they were accommodation makers without any considerations, and that the deed to D. was made and accepted as a discharge of the note. Issue was taken upon this point, and the trial of the caso was directed to the question, whether the deed was accepted as a security or as a satisfaction of the debt. The jury found in faror of the defendants, and judgment was entered accordingly. Two

1 Town $v$. Nims, 5 N. H. 259; 20 Am. Dec. 578.
2 Bernhard $v$. City of Hoboken, 3 Dutcher, 412.

murrer, overruled this defense, and not possible for A. to have been liable afterwards entered judgment against A. for the horse's board. This was held to estop A. from maintaining his nett, 46 N. Y. 490. action for conversion; because it was) 
diass after entry of this judgment, T. conrered the same lands to J., Who, thereafter, commenced suit against D. to recorer them, on the ground that the former deed to $D$. was a mortgage. It was held that the character of the deed ras in issue in the former action, and that J. could not prore its character to be different from what it was then detarmined to be. ${ }^{1}$ But in Indiana, an adjudication in an action to recorer certain properts, that the assignment under" which plaintifl claimed was roil on account of being taintel br fraud, was hell to be confined in its effect to tho subject matter of that controrerse, and not to impair the claim of the plaintiff to other property included in the same assignment. ${ }^{i}$ An entirely similar opinion is supported by the courts of Yew Hampshire, on the grounds that the assigument is, in the first action, a matter of eridence, and not a matter in issue; and that the onl issue before the court is, Thether plaintifl has title to the subject matter of the suit."

\section{5i. Extends only to Eacts in Issue.-The former} rerdict is conclusire only as to facts directly and distinctly pat in issue, and the finding of which are necessary to

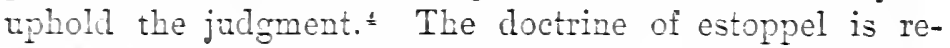
stricted to facts directl $\Gamma$ in issue, and does not extend to facts which mas be in controrersy, but which rest in eridence, and are merely collateral. "A fact or matter in issue is that upon which plaintiff proceeds br his action, and which the defendant controrerts in his pleadings, while colliateral facts are such as are offered in eridence to establish the matters or facts in issue."s "It must appear that the matter set up as a bar was in issue in the former suit. If a suit be brought to procure the entry of satisfaction of a mortgage, and the judgment is that the mortgage is not satished because a specified amount remains unpaid, this judgment is, in subsequent controrersies between the parties, conclusire that the mortgage mas not paid, but the amount

1 Jackson $r$. Lodge, 33 Cal. 25.

An. 331; Glass $x$. Wheeliss, If La.

${ }^{2}$ Proberts $t$. Robeson. 2- Ind 45t. An. 397; Henry $r$. Daris, 13 W. Ta.

${ }^{3}$ Ling r. Chase, 15 X. H. 9; Taşlor 230; Crum 2. Doss, i Rep. $10 \pi$. ข. Irstin, 43 ‥ H. 493 .

${ }^{\ddagger}$ Garmood $\tau$. Garmood, @o Cal. 5̊1;

* Hunter $x$. Daris, 19 Ga. f13; De Fing $r$. Chase, 15 X. H. 16.

St. Fomes $x$. C. C. \& $\mathrm{x}$. Co., $\because \pm \mathrm{La}$. 
due is still unsettled because it was not in issue in a fortoer suit." A decree setting aside a deed does not affect any title Leld br defendant, and not deraigned through such deed." An astoppel extends berond rhat appears on the face of the judgment to erery allegation which, having been made on the one side and denied on the other, ras at issue and determined in the course of the proceedings. It not only establishes the case of the plaintiff, bat disprores or negatires that of the defendant. ${ }^{3}$ The record of a former recover: is competent eridence in a second action "rhen the point in issue is the same in both, or then some question risisel and to be passed upon in the last has alreadr been determined in the first." "I "It is not the object of the suit, tho recorert, or fruits of the litigation alone, that constiute the estoppel, but the facts put in issue aud found, upon which the recorers is based-facts in issue as distinguished from the eridence in controrers.." "It is not necessars to the conclusireness of the former judgment that the issue should hare been taken upon the precise point which it is proposed to controrert in the collateral action. It is suscient if that point was essential to the former judgment.: "Every point which has been either expressiy or by necessarr implication in issue, which must necessarily hare been decided in order to support the judgment or decree, is concluded.": "It is allowable to reason back from a judgment to the basis on which it stands, upon the obrious principle that, where a conclusion is indisputable, and could hare been dramn onl from certain premises, the premises are equalls conclusire and indisputable with the conchusion. But such an inference must be ineritable, or it cannot bo dramn."

\section{\%25S. Confined to Iriatters in Issue and Deciled.- - To} judgment or decree is eridence in relation to ans matter which came collaterally in question, nor to ans matter inci613.

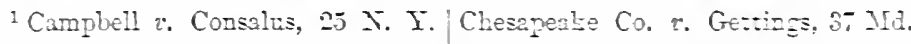

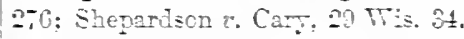

? Beeson r. Comler. 19 Mich. 103.

s Sterens $r$. Hughes, ; Caser, Ssl.

4 Sage $\tau$. McAlpin, 11 Cush. 165.

${ }^{6}$ Lee $v$. Kingsbur. 13 Tex. Qs.

i B. of S. r. M. P. R. R. Co., 94

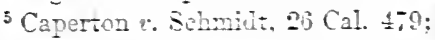
Wis. 124. see also Phelan $x$. Gardner, 43 Cal. Lea $x$. Lea, Id. \pm 93 306; Rogers $r$. Hizgins, 57 Iil. It4; 1 
dentally cognizable, or to be inferred from the judgment only by argument or construction. ${ }^{1}$ An estoppel cannot bo created by mere argument. A. owned a saw-mill, and A. and $B$. owned a grist-mill, both of which were mu by water from the same dam, and had wheels on the same level, and were equally affected by backwater from the mill of C., situate on the same stream. A. brourht an action against $C$. for damages occasioned by water being backed upon his saw-mill, in which it was settled that C.'s dam backed tho water so as to injure the saw-mill. A. and $B$. then sued for damages occasioned to their grist-mill, and, upon trial, it was found that C.'s dam did not back the water upon the grist-mill. After the judgment in favor of C., A. commenced a secoud action against $C$. for damages to the sawmill. It was agreed that, upon the facts of the case, there ought to be the same finding in respect to both the sawmill and the grist-mill. The Court held that the former adjudication between $\mathrm{A}$. and $\mathrm{C}$. was upon the precise question now in controversy; that the judgment in the case concerning the grist-mill was, at most, not upon the same point involved in the present suit, but upon a fact which, by argument only, is shown to be applicable in this case. That this is not one adjudication against another, but only an adjudication one way, and a probable argument founded on another adjudication of a distinct question the other way. It leaves the effect of the first judgment untouched. ${ }^{2}$ In determining what has been decided, and what has therefore become a binding adjudication, the actual judgment of the Court must be consulted, and, so far as it speaks, must be allowed to control. Its clear import cannot be modified or controlled by the expressed opinions of the Judges by whom the judgment was pronounced, nor by the reasons urged by them in its support. In ascertaining whether a particular matter has become res judicata, the reasoning of

${ }^{1}$ Lawrence $v$. Hunt, 10 Wend. 81 ; peal, $67 \mathrm{~Pa}$. S. 165; Howard v. Kim25 Am. Dec. 539; Jackson $v$. Wood, 3 ball, 65 Me. 308; Hammer $v$. Pounds, Wend. 27; Wood $v$. Jackson, 8 Wend. $35 ; 22 \mathrm{Am}$. Dec. 603; Hopkins $v$. Lee, 6 Wheat. 109; Lewis \& Nelson's Ap57 Ala. 348; Land $v$. Keirn, 52 Miss. 341 ; Henry $v$. Davis, 13 W. Va. 230. ${ }^{2}$ Mersereau $v$. Pearsall, 19 N. Y. 108. 288 
the Court is less to be regarded than the judgment itself, and the premises which its existence necessarily affirms. 1

8 259. Identity of Evidence.-The best and most invariable test as to whether a former judgment is a bar, is to inquire whether the same evidence will sustain both the present and the former action. 3 If this identity of evidenco be found, it will make no difference that the form of tho two actions is not the same. ${ }^{3}$ Thus, a judgment for defendant, in a suit fur wheat cut and carried away, is a bar to an action of trespass, quare clausum fregit, for cutting and carrying away the same wheat, because the estoppel depends not on the identity of the action, but on the identity of the proofs. ${ }^{4}$ Whatever be the form of action, the issue is deemed the same whenerer it is in both actions supported by substantially the same evidence. ${ }^{5}$ If it be so supported, a judgment in one action is conclusive upon the same issue in any other suit, though the cause of action be different. ${ }^{6}$ But where, as in Mississippi, an action of replevin must be brought within one year, but an action in trover may be maintained at any time within two years, a plaintiff, defeated in an action of replevin because it was brought after one year from the taking, may thereafter sustain trover for the same taking. In both cases the evidence required to support the plaintiff's cause of action, though in most respects identical, is not entirely so, because in the first action proof of taking within a year is indispensable, while in the second action such proof is entirely immaterial. ? On the other hand, if different proofs be required to sustain two actions, a judgment in one of them is no bar to the other. If the evidence in a second suit between tho

1McDonough's Succession, 24 La. 3 Ramsey v. Herndon, 1 McL. 450; An. 34; Plicque v. Perret, 19 La. 318; Martin $v$. Kennedy, 2 Bos. \& Pul, 71. Hill v. Bowman, 14 La. 445; Buckner Duncan $v$. Stokes, 47 Geo. 505.

v. Calcote, 6 Cush. Miss. 432 . 4 Johnson $v$ Smith, 8 Johns. 333.

2 Kitchen $v$. Camplell, 3 Wils. 304; 5Hitchin v. Campbell, 2 Blacks. Clegg v. Dearden, 12 Q. B. 576; Crock- 827; Outram v. Morewood, 3 East. ett $v$. Ronton, Dudley, 254; Hunter $v$. 346; Birkhead v. Brown. 5 Sanf. 134. Stewart, 31 L. J. Chonc. 346; Taylor v. Castle, 42 Cal. 371; Canuon v. Brame, 45 Ala. 262; Percy v. Foote, 584.

36 Conn. 102.

6 Doty v. Brown, 4 N. Y. 71.

7 Johnson $v$. White, $13 \mathrm{~S}$. and $\mathrm{II}$. 
same parties is sufficient to entitle plaintiff to a recovery, his right can not bo defeated by showing any judgment against him, in any action where the evidence in the present suit could not, if offered, have altered the result. Thus, a judgment against a vendor suing for purchase money, before it is due, or against the payee of a note, in an action against three, when the note was only the note of two, is no bar to a subsequent suit in the first named case, after the money is due, nor in the second case upon the note, as the note of $t w o$, for in neitler of these cases could evidence, amply suffeient to maintain the second action, have had any influence in the first. ${ }^{1}$ For the same reason judgment for defendant, in an action on a note as a contract to pay money, is no bar to a suit against him on the same note as a contract to pay money in foreign bills. ${ }^{2}$ Suit was brought on a promissory note alleged to be lost, and which was described as payable on demand, with interest from date. The defendant pleaded a former judgment in bar. In the previous suit the note was described as in this, except that it was alleged to be payable one day after date. It was held, that, as the issue joined in the former suit would not have permitted plaintiff to recover upon proof of a note payable on demand, the former judgment was not a bar. ${ }^{2}$ An account stated operates as a change of the original indebtedness, and is in the nature of a new undertaking. An action upon it is not founded on the original items, but upon a balance ascertained by the mutual understanding of the parties. $^{3}$ Therefore if, in an action on a contract, the defendant introduces in evidence a judgment roll showing that plaintiff had previously commenced an action, setting forth the same contract, and alleging that a specified sum was due as an account stated, in which action defendant prevailed, this recovery is no bar to the present suit. In deciding this point the Court said: "A judgment is a bar, if the cause of action be the same, though the form be different. The cause is the same when the same evidence will support both actions; or, rather, the judgment in the for-

1 Firkpatrick $v$. Stingley, 2 Cart.|Lawrence $v$. Vernon, 3 Sumner, 20. 273: N. E. Bank $v$. Lewis, 8 Pick. 113; 2Jones v. Fales, 4 Mass. 255.

U. S. v. Cushman, 2 Sumner, 426; 3Pattison v. Jones, 27 Ind. 457. 290 
mer action will be a bar, provided the evidence necessary to sustain the judgment for plaintiff, in the present action, would liave authorized a judgment for him in the former. Tho present action would have been sustained upon proof of a contract and the performance on the part of plaintifl, and non-payment by the defendants. This proof would not hare sustained the former action. Therefore the judgment is not a bar."1

8 260. Mexits.-The estoppel arising from a judgment or decree is not odious, becanse it is confined to those points which either were in fact litigated and determined between the parties, or which were determined in the absence of any actual contest, but not until after a full legal opportunity was given both parties to make such contest as they might deem proper. It follows from this that no judgment can be available as an estoppel, unless it is a judgment on the merits." But an occasional difficulty may arise in deciding what is a judgment on the merits, as the term is generally employed by judges and lawyers. To create such a judgment, it is by no means essential that the controversy between plaintiff and defendant be determined "on the merits," in the moral or abstract sense of those words. It is sufficient that the status of the action was such that the parties might hare had their law-suit disposed of according to their respective rights, if they had presented all their evidence, and the court had properly understood the facts and correctly applied the law. ${ }^{3}$ But if either party fail to present all his proofs, or improperly manage his case, or afterward discover additional evidence in his behalf, or if the court find contrary to the evidence, or misapply the law,

\footnotetext{
1 Taylor $v$. Castle, 42 Cal. 371. So Strickhein, 57 Mo. 326. Judgment a note offered in evidence, in an ac- by consent for defendant after a plca tion on an account stated, and reject- in abatement has bcen sustained is not ed becanse not admissible in that form on the merits. Jordan $v$. Siefert, 126 of action, may be subsequently re- Mass. 25.

coverel upon an action thereon in ${ }^{3}$ Hughes $v$. United States, 4 Wall. proper form. Lindell $v$. Leggett, 1 232; Lore $v$. Truman, 10 Ohio S. 45; Mo. 432; 14 Am. Dec. 298; and a Birch $v$. Funk, 2 Met. Ky. 544; Johnfailure to recover against one as a son v. White, 13 S. \& M. 584; Agnew common carrier, does not shicld him v. McElroy, 10 S. \& MI. 5i2; Brackett from liability as a warehouseman. $v$. Hoitt, $20 \mathrm{~N}$. H. 257; Van Vleet $v$. Kronshage $v$. C. M. \& St. P. Ry. Co., Olin, 1 Nev. 95; Wilbur v. Gilmore, 45 Wis. 500.

${ }^{2}$ Taylor $v$. Larkin, $12 \mathrm{Mo}$. 103; Bell N. Y. $3 \mathrm{~S}$; Kenan $v$. Miller, 2 Kelly, $v$. Hoagland, 15 Mo. 360; Houston $v$. Ga. 325; Rogers $v$. Higgins, 57 IIl. Nusgrove, 35 Tex. 594; Verhein v. 244.
} 
in all these cases the judgment, until corrected or vacated in some appropriate manner, is as conclusive upon the parties as though it had settled their controversy in accordance with the principles of abstract justice. Frequent instances occur tending to convince us of the unwelcome truth, that many judgments, which in law are regarded as being "on the merits," are, in fact, repugnant to any disposition of the rights of the parties "on the merits," as those words would be employed in relation to the ordinary affairs of men. If, in an action on a judgment, the plea of nul ticl record be interposed, and the plaintiff fail, owing to a defect in the certificate, he is estopped from afterward asserting the judgment, though its validity was free from doubt. ${ }^{1}$ Assignees of a bankrupt, failing in a suit because they cannot prove an act of bankiuptcy sufficiently early, cannot afterward maintain an action for the same demand, though they secure evillence, for want of which they suffered the former defeat." A former suit, in which the defendant recovered on the erroneous ground that the cause of action had not then accrued, is a bar to a further prosecution. ${ }^{3} \mathrm{~A}$ plaintiff sued on a recognizance, but failed in his suit because he did not prove that the recognizance had been filed as required by statute. It was held that the judgment procluded him from afterward alleging or proving that the filing existed prior to the former suit. 4 Certain justices, having jurisdiction to act, allowed several accounts without giving them any particular consideration, supposing that several important matters of law were involved, and that an appeal lay to the quarter sessions. But it was decided that no such appeal could be taken. The justices, after the decision, were anxious to hear the matter on the merits. A mandamus being applied for to compel them to do so, Lord Denman, C. J., said: "We think we have no power to issue this mandamus to the justices to hear and decide upon the allowance of accounts, they having already done so, though under a mistaken notion that an appeal lay to the sessions, and though they are now anxious to euter on the merits of the.case. To unravel the grounds and motives which may

\begin{tabular}{l|l} 
1 Foltz v. Prouse, 15 Ill. 434. & 3 Morgan v. Plumb, 9 Wend. 287. \\
2Stafford v. Clark, 1 Car. \& P. 403. & 4 People v. Smith, 51 Barb. 360.
\end{tabular}

292 
liave led to the determination of a question once settled by the jurisdiction to which the law has referred it, would be extremely dangerous; but many authorities prove that it is beyond our own competency, and there is none to the opposite effect." 1

8 261. Nonsuit. Judgments of nonsuit, of nol. pros, of nolle prosequi, of dismissal, and of discontinuance, are exceptions to the general rule, that when the pleadings, the court and the parties are such as to permit of a trial on the merits, the judgment will be considered as final and conclusiro of all matters which conld have been so tried. ${ }^{2}$ A nonsuit "is but like the blowing out of a candle, which a man at his own pleasure may light again." 3 Under no circumstances will such a judgment be deemed final, whether entered before or at the trial. ${ }^{4}$ That such judgment was ontered by the court, upon an agreed statement of facts, will not give it any force as an estoppel. ${ }^{5}$ A judgment of nonsuit was entered against plaintiff on a certain count of his complaint, for not replying to a special plea within the time required by the court. The effect of the judgment was held to be to turn plaintiff out of court, and to place him, as to such count, as though it had never been filed. 6 The dismissal of a claim against an insolvent estate, for want of proof, has the same effect in Louisiana as a nonsuit, and will not support the plea of res judicata. ${ }^{7}$ If, upon the trial bcfore a justice of the peace, he expresses an opinion against the plaintiff, who thereupon withdraws his suit and pays the costs, this is but a dismissal of his suit, not affecting any future action. ${ }^{8}$ Parol evidence will not be admit-

\footnotetext{
${ }^{1}$ Regina $v$. Yorkshire, I Ad. \& El. N. $\$ .625$.

2 Harvey $v$. Large, 51 Barb. 222; Audubon $\%$ Excelsior Ins. Co., $27 \mathrm{~N}$. Y. 216: The People $v$. Vilas, $36 \mathrm{~N}$. Y. 460; Baudin $v$. Roliff, 14 Am. Dec. 81; Dana v. Gill, I J. J. M. 242; 20 Am. Dec. 255; ITarrison $v$. IVood, 2 Ducr, 50; Merchants' Bank Ass'n v. Mariposa Co., 7 Rob. 225. With respect to judgments of dismissal other than those entered by agreement, see Wheeler $v$. Ruckman, 51 N. Y. 391; Kelton $v$. Jacobs, 5 Baxter, 574; Brown $v$. Kirkbride, 19 Kans. 585; Wanzer $v$. Self, 30 Oh. S. 378.

3 March on Arbitraments, 215, cited in Clapp $v$. Thomas, 5 Allen, 158.

${ }^{4}$ Foster $v$. Wells, 4 Tex. 101; Pillow $v$. Elliott, 25 Tex. Supp. 3ø2; Tay. lor $v$ Larkin, 12 Mo. 103; Greely $v$. Smith, I W. \& M. ISI.

${ }^{5}$ Homer $v$. Brown, i6 How. U. S. 354; Bridge $v$. Sumner, 1 Pick. 371; Morgan $v$. Bliss, 2 Mass. 113; Derby $v$. Jaeques, 1 Clifford, 425; Knox $v$. Waldoborough, 5 NIe. IS5.

${ }^{6}$ Howes $v$. Austin, 35 Ill. 396.

7 Allinet $v$. Creditors, 15 La. An. 130.

${ }^{8}$ Jones $v$. Walker, 5 Yerg. 428.
} 
ted to show that a cause was tried upon the merits, but that the justice entered a judgment of nonsuit because he stipposed he could not enter any other. ${ }^{1}$ In New York it is the duty of a justice of the peace, before whom a cause has been tried and submitted, to determine it. He can not evade this duty by entering a judgment of nonsuit. If he attempt to do so, his judgment may be reversed upon appeal." The prosecution of an appeal in such a case seems to be an idle ceremony; beeause the defendant is entitled to treat the judgment as a final adjudication upon the merits. "If the cause be submitted to the justice, and he take timo to make up his judgment, the plaintiff can not then voluntarily submit to a nonsuit. The case is sub judice upon the merits, and must be disposed of upon the merits; and $I$ apprehend it is not then in the power of the justice to nonsuit the plaintiff. His determination of the case is equivalent to a verdiet of a jury and a judgment thereon; and, although he may eall his judgment a judgment of nonsuit, and enter it accordingly, if the record or minutes of the trial show that it was rendered after the cause was submitted to him, and after he took time to deliberate, and not at the trial, it will be considered a judgment for the defendant, and will be a bar to any subsequent action." ${ }^{3}$ But it seems to be well established, in the same State, that the fact that the cause was submitted for judgment, must appear from the docket and minutes of the justice; and that when he has entered a judgment of nonsuit, it is not competent for the purpose of showing that the decision was not upon the merits to put him upon the stand as a witness, and have him state the circumstances preceding the entry of the judgment. "It would be dangerous to permit an inquiry into the evidenee and proceedings of a trial before the justice, to show that the kind of judgment rendered by him was not such as he ought to have rendered, and to give effect to it as it should have been, rather than as it is." 4 A judgment was reversed upon appeal to the Supreme Court, and the cause remanded for

1 Brintnall $v$. Foster, 7 Wend. 103. 3 Elwell $v$. McQueen, 10 Wend. 522;

2 Young $v$. Hubbell, 3 Johns. 430; Gillilan $v$. Spratt, 8 Abb. Pr. N. s. 15. Hess $v$. Beekman, 11 Johns. 457; Pe- 4 Brintnall v. Foster, 7 Wend. 104. ters $v$. Diossy, 3 E. D. Smith, 115. 
further proceedings. The plaintiff, afterward becoming nonsuit, was allowed to bring another action, on the ground that the rule in reference to nonsuits was not altered by the cases having been in the Appellate Court." "A dis'missal or nonsuit, not determining the rights of the parties, cannot support the plea of res adjualicata. Nor will the reasoning and opinion of the conrt upon the subject, on the evidence adduced before it, have the force and efiect of a thing adjudged, unless the subject matter be definitely disposed of by the judgment." a "At common law there is no form of an entry in the books of a judgment clismissing an action. Every judgment against a plaintiff is either upon a retraxil, non-pros, nonsuit, nolle prosequi, disconticuance, or a judgment on an issue found by jury in favor of defendant, or upon demurrer. The inducements or preliminary recitals in these several kinds of judgment are variant, but the conclusion in each is always the same; it is as follows: 'Therefore it is considered by the court that plaintiff take nothing by his writ, and that the defendint go without day, and recover of plaintiff his costs.' Of these several judgments, none but a retraxit, or one on the merits, will bar subsequent actions." 3

8 261a. The Defendant's Motion for a Nonsuit is a Waiver of his right to have judgment upon the merits, and also of his right to litigate new matter set up in his answer, and upon which he has demanded affirmative relief. In an action to quiet title, the court, on motion of defendant, ordered a nonsuit. He then offered to prove the new matter alleged by him, but the court refused to hear the evidence. This refusal having been made a ground of an appeal, was sustained by the Appellate Court on the following grounds: "A defendant, conceiving that the plaintiff has failed to prove his case, may waive a motion for a nonsuit, and proceed to prove his own case, and have judgment on the merits. But if he move for a nonsuit, and the nonsuit be granted, he cannot proceed and have judgment on the merits; because, by reason of the nonsuit, the plaintiff is vir-

1 Holland $v$. Hatch, 15 Ohio S. 464. 3 Bond v. MIcNider, 3 Iredell, 440. 2Fisk v. Parker, 14 La. An. 491. 
tually out of court. A nonsuit granted on the motion of the defendant is equivalent, in its operation on the action, to a dismissal, with the consent of the defendant." 1

8 262.-Dismissal by Agreement.-Recently the Supreme Court of California considered the effect of a judgment of dismissal, entered by agreement. Such a judgment was compared to that of a retraxit at common law, and the court were of the opinion that, like a retraxit, "such a dismissal, when had by such consent, amounts to the open and voluntary renunciation of a suit pending." The court adopted the language of Chief Justice Robinson, of Kentucky, as follows: "It has frequently been decided by this court, that the legal deduction from a judgment dismissing a suit 'agreed' is, that the parties had, by their agreement, adjusted the subject matter of the controversy in that suit; and the legal effect of such a judgment is, therefore, that it will operate as a bar to any other suit between the same parties, on the identical canse of action then adjusted by the parties, and merged in the judgment therein rendered, at their instance, and in consequence of their agreement."2 These decisions are not intended to conflict with the rules universally understood as applying to roluntary dismissal in the absence of an agreement. To avoid all misapprehension on this subject, the court in California said: "We are not to be understood as holding that a mere dismissal of an action by the plaintiff under the statute, and without any agreement upon his part to do so, is to be held to constitute a bar to its renewal, nor that a judgment of nonsuit, even entered by consent, would have that efiect, but only that a judgment of dismissal, when based upon and entered in pursuance of the agreement of the parties, must be understood in the absence of anything to the contrary expressed in the agreement, and contained in the judgment itself, to amount to such an adjustment of the merits of the controversy, by the parties themselves, through the judg-

I IVood $v$. Ramond, 42 Cal. 644.

${ }^{2}$ Bank of Commonwealth $v$. Hopkins, 2 Daua, 395. See also Jarboe $v$. Smith, 10 B. Monr. 257; Phillpotts $v$.
Blaisdel, 10 Nev. 19; Hoover $v$. Mitchell, 25 Gratt, 337; contra, Iloífman v. Porter, 2 Brock, 156. 
ment of the court, as will constitute a defense to another action afterward brought upon the same cause of action."1

\&263. Judgments not on Merits.-Mr. Smirh, in his Leading Cases, clivides those judgments which are not a bar to another action, because not on the merits, into the following classes:

1st. Where the plaintiff fails for want of jurisdiction in the court to hear his complaint, or to grant him relief.

2l. Where he has misconceived his action.

3d. Where ho has not brought the proper parties before the court.

4th. Where the decision was on demurrer, and the complaint in the second suit sets forth the cause of action in proper form.

5th. Where the first suit was prematurely brought.

6th. Where the matter in the first suit is ruled out as inadmissible under the pleadings. ${ }^{2}$

3 264. Want of Jurisdiction.-The first of the above subdivisions should include not merely all those cases dismissed for want of jurisdiction, but also all cases in which, though a court assumes to dispose of a suit on the merits, the judgment is void for want of authority in the court making it. ${ }^{3}$

In Massachusetts, a widow may present her petition to the Probate Court, to have her homestead set off from the rest of the estate of her deceased husband. If, however, the heirs clispute her claim, the court is ousted of all further jurisdiction in the matter, and the issue formed between her and the heirs must be tried in some other court. But a widow having presented her petition, and the heirs having filed their opposition, the Probate Court proceeded to hear the matter as though it had jurisdiction; and after a trial, in which all the parties in interest participated, entered a decree denying the petition, on the ground that the petitioner had no homestead right. In proceedings before a court of competent jurisdiction, she afterward sought to as-

1 Merritt $v$. Campbell, 47 Cal. 5 42 . | del $v$. Suman, 13 Md. 210; State $v$.

2 Smith's Leading Cases, p. 673. Odell, 4 Dlackf. 156; Commonwealth

${ }^{3}$ Lin $v$. Campbell, 14 Jolns. 482; $v$. Peters, 12 Met. 387 ; Thompson $v$. Offutt $v$. Ofiutt, 2 II. \&G. 17S; Schin- State, 6 Neb. 102. 
sert her claim to the homestead. It was opposed on the ground that, by the decree of the Probate Court, her rights had been terminated. But the Supreme Court, in considering the effect of the decree, said: "It is then further urged that, if this be so, yet it is not competent for the tenant, who was the petitioner to the Probate Court, to set up want of jurisdiction in reply to the plea in bar in this suit, even if it might have availed her in the Probate Court, or on an appeal. But we think this an erroneous view of the matter, and that these judgments of the Probate Court are to be treated as wholly void. They would have been so if in her favor, and they ought to have no more effect, having been against her." 1 While a court may have jurisdiction of the parties to the action, and, for certain purposes or to a certain extent, may be authorized to determine some of the issues in controversy, yet if it go beyond the bounds of its authority, its decision as to these matters not within its jurisdiction can not acquire the force of res juclicata. ${ }^{2}$

3 265. In Misconceived Actions.-The second subdivision embraces a great number of cases. The exception which takes these cases out of the general rules in relation to estoppel, is a very important one, saving the plaintiff from the loss of his claim, through any error of judgment on the part of his attorney in determining what form of action is best suited for the enforcement of the plaintiff's rights. ${ }^{3}$ Wherever the adoption of a Code of Civil Procedure has obviated the necessity of choosing between different forms of action, the number of cases in which plaintiffs will be obliged to invoke the protection of this exception will be much less than if the common law rules were still in force. If, by mistake, plaintiff bring trespass instead of trover, and judgment be given against him on that account, the defendant can not, successfully, assert it as a bar to a subsequent action of trover. 4 If a defendant, in an action against him on a promissory note, obtain judgment on a

\footnotetext{
1Mercier $v$. Chace, 9 Allen, 242. $\mid 3$ Foster $v$. Wells, 4 Texas, 101 ; Liv-

a Hiouston $v$. MIusgrove, $3 \tilde{5}$ Texas, ermore $v$. Herschell, 3 Pick. 33 ; Wyman v. Dorr, 3 Greenl. 18j. 4 Chitty Pl. 108.
} 591. 
plea of infancy, the note being given by him for a chattel which he lad obtained through fraud, and had refused to deliver to the owner on demand, an action in tort may still be maintained for the conversion of the chattel. ${ }^{1}$ A plaintiff who, bringing an action of replevin for a sum of moncy, is defeated in that action because it lies to recover only things existing in specie, is not estopped by the judgment against him from prosecuting a subsequent action as upon the contract, for the same sum of money. The former juclgment is conclusive that the defendant did not have the specific money; but it does not determine whether he is liable for money had and received. ${ }^{2}$

3. 266. Want of Proper Parties. The third subdivision is applicable to cases in which the want cf proper parties, either plaintiff or defendant, is apparent from an inspection of the record; and also to cases where, though the proper parties apparently come before the court, one or more of them have no capacity to sue. ${ }^{3}$

8 267. Judgments on Demurrer.-A judgment on demurrer to the plaintiff's complaint is conclusive of everything necessarily determined by such judgment. If the court decides that plaintiff has not stated facts sufficient to constitute a causo of action, or that his complaint is otherwise liable to any objection urged against it upon demurrer, such decision does not extend to any issue not before the court on the hearing of the clemurrer. It leaves the plaintiff at liberty to present his complaint in another action, so corrected in form or in substance as to be no longer vulnerable to the attack made on it in the former suit. ${ }^{4}$ But a judgment upon demurrer may be a judgment on the merits. If so, its effect is as conclusive as though the facts set forth in the complaint were admitted by the parties or established

1 Walker $v$. Davis, 1 Gray, 506.

${ }^{2}$ Sager $v$. Blain, 44 N. Y. 445.

${ }^{3}$ Rolubins $v$. Wells, 1 Rob. N. Y. 666; Corl $v$. Riggs, 12 Mo. 430; Wheeler $v$. Ruckman, 7 Rob. 447; S: C., 35 How. Pr. 350 ; White $v$. Gaines, 29 La. An. 769.

${ }^{1}$ Robinson $v$. Howard, 5 Cal. 428; Gerrish v. Pratt, 6 Minn. 53; Gil- man $v$. Rives, 10 Pet. 29s; Nickelson $v$. Ingram, 24 Texas, 630; Birch $v$. Funk, 2 Met. Ky. 544; Wells v. Moore, 49 Mo. 229; Spicer v. U. S., 5 Nott \& II. 34; Gould v. Evansville \& C. R. R. Co., 91 U. S. 526; Stowcll $v$. Chamberlain, 60 N. Y. 272; Bonnificld $v$. Price, 1 Wy. Ter. 223 . 
by evidence submitted to the court or jury. No subsequent action can be maintained by the plaintiff, if the judgment be against him, on the same facts stated in the former complaint. ${ }^{1} \quad$ If any court err in sustaining a demurrer and entering judgment for defendant thereon, when the complaint is sufficient, the judgment is nevertheless "on the merits." It is final and conclusive until reversed on appeal. Until then the plaintiff cannot disiegard it and maintain another action. The effect of a judgment still in force is never diminished on account of any mistake of law on which it is founded.2 A judgment in favor of defendant on demurrer to an answer, is a bar to a subsequent suit for the same cause of action. 3 If a demurrer be put in to a good plea in bar, it will estop the plaintiff, though his declaration bo defective, because his demurrer confesses the grounds of defense. ${ }^{4}$ Although an answer has been filed, yet if judgment be entered against plaintiff upon the pleadings for defects in his complaint, this, like judgment upon demurrer, is no bar to a subsequent suit, in which the cause of action is sufficiently set forth. ${ }^{5}$

\section{\& 263. Premature Suits.-That a judgment obtained} for the reason that an alleged demand is not yet due, is no bar to an action brought on the same demand, after it has fallen due, is a universally acknowledged rule, applicable to every case in which a judgment can be rendered against any one because he has undertaken to assert a claim which has yet to ripen into a cause of action. A suit upon a bond before condition broken, in which plaintiff fails, on that account, to recover, is no bar to any action brought against the same defendant after condition broken. ${ }^{6}$ When a vendee brought an action to recover money paid by him as purchase money for a tract of land, and failed because he had not yet been evicted, he was allowed to maintain a subsequent action, upon showing his evictiou since the former

\footnotetext{
${ }^{1}$ Clearwater $v$. Meredith, $1 \mathrm{TV}$ all. 25; |Turnure, $48 \mathrm{Ia} .397$; Nispel $v$. Laparle, Aurora City $v$. West, 7 Wall. 82; Now- 74 Ill. 306.

Ian $v$. Geddes, 1 East, 634; Bouchaud $v$. Dias, 3 Denio, 244; Goodrich $v$. City, 5 Wall. 573; Perkins $v$. Moore, 16 Ala. 17; Gould $v$. Evansville \& C. R. R. Co., 91 U. S. 526; Felt $v$. ${ }^{2}$ Vallandingham $v$. Ryan, 17 Ill. 25. ${ }^{3}$ Wilson $v$. Tay, 24 Ind. 156.

${ }^{4}$ Lampen $v$. Kedgewin, 1 Mod. 207.

${ }^{5}$ Gerrish $v$. Pratt, 6 Minn. 53.

${ }^{6} \mathrm{McF}$ Farlane $v$. Cushman,2l Wis. 401. 300
} 
suit. ${ }^{1}$ If a suit be brought for several demands, some of which are due, and others of which are not due, and a general verdict be given for the plaintiff, he may show in a second suit, for the demands not due at the trial of the first suit, that, though presented to the court or jury, they were disallowed because not yet due. ${ }^{2}$ If, from the record in the first suit, it appears that the demands were prematurely sued upon, it will be presumed that they were on that account rejected by the jury, and that they form no part of the judgment. But it may be shown that the demand, though not due, was not objected to by the defendants, and was allowed by the jury. ${ }^{3}$ Under the Code the same answer may present permanent defenses along with those of a temporary nature. Thus, to an action upon a draft, the clefendant may answer: "first, that the draft is usurious; seeond, that it is paid; and third, that the suit is premature, because defendant has not been allowed days of grace." If this action should proceed to trial, resulting in a finding in favor of the defendant upon each of these issues, followed by a general judgment in his favor, such judgment will be as conclusive in relation to the permanent defenses of payment and usury as upon the temporary defense in relation to the days of grace. If the plaintiff should believe that the findings are correct as to the temporary, and incorreet as to the permanent, defenses, he must, to preserve his rights, take such proceedings as will enable him to overthrow the findings upon the permanent defenses, and to obtain a judgment without prejudice to a subsequent action. ${ }^{4}$

8 269. Claims not Admissible.-Any claim of the plaintiff, which is offered by him, but is ruled out because not admissible under his pleadings, is, if it were not admissible, to be afterward treated as though it had not been offered. 5 Not being involved in the issues, it cannot becomo res judicata, unless, without objection by the defendant, or through

1 Hurst $v$. Means, 2 Sneed. 516. |Kane $v$. Fisher, 2 Watts, 246; Yaldon 2 Kane $v$. Fisher, 2 Watts, 245; Bull $v$. Hubburd, Com. Rep. 321.

ข. Hopkins, 7 Johns, 22. 4 Sheldon $v$. Edwards, 35 N. Y. 279. 3 Crouse v. Miller, 10 S. \& R. 155; 5 Baker v. Rand, 13 Barb. 152; Harding v. Hale, 2 Gray, 399. 
error of the court, it is allowed and becomes a part of the judgment. If, however, the court erroneously rejects a claim as inadmissible, when it should be admitted, this error must bo corrected upon appeal; and, until reversed, the judgment is conclusive against the rejected claim. Whero a defendant in scire facias, on nul tiel record pleaded, prevailed because the scire facias stated the judgment to bo against James $H$. Green, and the record offered was against James Green, it was held that this was no bar to a second scire facias. ${ }^{1}$ So an acquittal upon an indictment charging the burning of the barn of Josiah T., is no bar to a prosecution for burning the barn of Josias T. ${ }^{2}$

8 270. Dismissal of a Bill in Equity.-_"The dismissal of a bill in chancery stands nearly on the same footing as a judgment at law, and will be presumed to be a final and conclusive adjudication on the merits, whether they were or were not heard and determined, unless the contrary is apparent on the face of the pleadings, or in the decree of the court." 3 Only two cases lave come under our observation, in which the decree dismissing a bill has not been considered as necessarily final and conclusive, ${ }^{4}$ while the cases are numerous sustaining the view that such dismissal is a bar to any subsequent bill, unless it appears on the record to have been made without prejudice, or otherwise not on the merits. ${ }^{5}$ If, in fact, a decree be rendered dismissing a bill, because of some defect in the pleadings, or for want of jurisdiction, or because complainant has an adequate remedy at law, or on any other ground not involving the merits, it is the general practice, both in England and in the United States, to state in the decree that the dismissal is without prejudice; and the omission of these words is an error which will be corrected upon appeal. ${ }^{6}$ A dismissal

${ }^{1}$ Benton $v$. Duffy, Cam. \& Norw. 98. Perine $v$. Dunn, 4 Johns. Ch. 142;

${ }^{2}$ Commonwealth $v$. Mortimer, 2 Neafie $\because$ Neafie, 7 Johns. Ch. 1; 11 Virg. Cases, 325.

3 Smith's Leading Cases, vol. 2, p. 412; Parrish $v$. Ferris, 2 Black, U. S. 667; Wileox v. Balger, 6 Ohio, 406; 606. The English rule seems to perTaylor $v$. Yarborongh, 13 Gratt. 183; mit the complainant to show that the Seully v. C. B. \& Q. R. Co., $46 \mathrm{Ia}$. dismissal of his bill was not on the 528; Adams $v$. Cameron, $40 \mathrm{Mich}$. 506; merits, although the record does not Cochran v. Conper, 2 Del. Ch. 27; state it was "without prejndice." Thompson $v$ : Clay, 16 Am. Dec. 108. Beere $v$. Fleming, 13 Ir. C. L. R. 506,

${ }^{4}$ Wright $v$. De Kilyne, 1 Pet. C. C. Exch.; Longmead $v$. Maple, is C. B. 199; Chase's Case, 17 Am. Dec. 277; N. S. 255; 11 Jur. N. S. 177; 13 W. 1 Bland. Ch. 206. R. $469 ; 12$ L. T. N.S. 143.

${ }^{5}$ Kelsey $v$. Murphy, 26 Penn. S. 78; ${ }^{6}$ Durant v. Essex Co., 7 Wall. 107. 302 
of a libel for clivorce in Massachusetts stands on the same footing as the dismissal of a bill in equity; and, unless it appears on its face to be made "without prejudice," will be a bar to another libel for the same cause." Where the plaintiff did not in his bill show any interest or liability, requiring the aid or interference of a court of equity, and it was dismissed on that ground, he will not be estopped from bringing a new bill stating matters suficient to authorize the action of the court. ${ }^{2}$ If a bill filed does not bring before the court all the parties necessary for a proper determination of the suit, but the bill, instead of being dismissed on that account, is dismissed for want of equity, this is a bar to any future bill seeking the samo relief." A bill to redeem was filed. The defendant having answered, the plaintiff failed to reply, and, withoul the knowledge of the defendant, dismissed the suit. The defendant afterward had judgment entered in his favor for costs. It was held, the bill being dismissed without any restriction, that this was a judgment on the merits, and as such it was a bar to any future bill for the same cause. 4 If a bill by a vendor, seeking a specific performance of a contract to purchase, be dismissed on account of some defect in his title, the doors of courts of equity are, and ought to be, forever closed upon him, though he may afterward be able to make a good title. If the court intended to grant the complainant further time, it should have continued the cause, and thereby given him an opportunity to complete his title, or should have dismissed the bill without prejudice. In case it dismisses the bill generally, the right of the vendor to compel a specific performance is thereby conclusively and perpetually negatived. ${ }^{5}$ A section of the law of the United States in relation to patents provides that, where two patents interfere, any person interested may apply in equity, on notice to the adverse parties, and the court may adjudge and declare either of the patents void, in whole or in part, or inop-

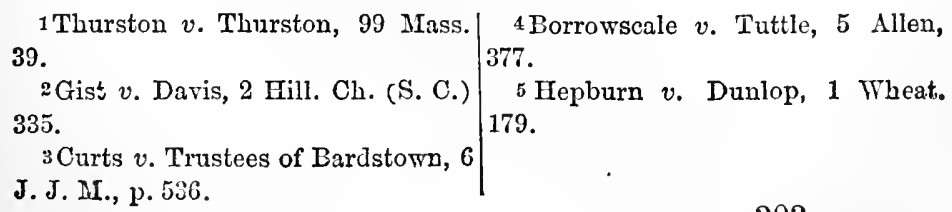


erative and invalid in any particular part of the United States. ${ }^{1} \quad$ The effect of a decres entered, generally dismissing a bill brought before the court under this act, is not equivalent to a judicial declaration that the patent of the conplainant is either inoperative or void. In announcing this conclusion, the court, after suggesting that the dismissal may have been ordered because the plaintiff did not show that defendant violated his rights, or because the defendant may have shown a license from the plaintiff, said: "A judgment or decreo under this statute can not be accepted as determining that point, unless it be direct and affirmative in terms, and in the words of the statute. The court must adjudge the patent void in whole or in part, or inoperative and invalid in some particular part of the United States. Had the decree asserted the interference of the patents, and declared either of them void, that decree would have been conclusive. ${ }^{2}$

\section{270a. A Bill may be Dismissed before the Hearing,} on the motion of the plaintiff, upon payment of costs. ${ }^{3}$ Such a dismissal has no higher effect as res judicata than the voluntary dismissal of an action at law. ${ }^{4}$ This rule was applied where the cause had been set down for hearing; but before the testimony was published the complainant dismissed his bill.5 In a case before Chancellor Kent, the decree relied upon as a bar was one dismissing a former bill, because no one appeared on the part of the complainant at the hearing. The Chancellor said: "The merits of the former cause were never discussed, and no opinion of the court has ever been expressed upon them. It is, therefore, not a case within the rule rendering a decree a bar to a new suit. The ground of this defense by plea is, that the matter has already been decided, and here has been no decision of the matter." But "this decision has since been

1 \& 16, Patent Act 1836; 5 U. S.|v. Westmeath, 1 Beatty, 17t; Knox v. Stat. at Large, p. 123. Brown, 2 Bro. C. C. 185.

2Tyler v. Hyde, 2 Blatchf. $308 . \quad 4$ Walden $v$. Bodley, 14 Pet. U. S. 3 Cummins v. Benuett, 8 Pai. 79; 160; Conn. v. Penn., 5 Wheat. 427; Simpson v. Brewster, 9 Pai. 245; Car- Badger $v$. Badger, 1 Clifi. C. C. 241. rington $v$. Holly, 1 Dick. Ch. 280; 5 Badger v. Badger, 1 Cliff. C. C. Curtis v. Lloyd, 4 Myl. \& Cr. 194; 241.

Lock v. Nash, 2 Madd. Ch. 389; White 6 Rosse v. Rust, 4 Johns. Ch. 300. 
overruled, on the ground " that, as the bill was dismissed after publication had passed, it was the same thing, in legal effect, as though the cause had been brought to a hearing on the pleadings and proofs." 1

8 271. Immaterial Findings.-The effect of every judgment or decree, as an estoppel, is restricted to such matters as might have been litigated under the pleadings. ${ }^{2}$ Thus, if plaintiff, in an action in relation to real estate, avers no title beyond his own life, the judgment rendered in his favor is not conclusive as to any greater title than he put in issue. $^{3}$ The agreement of the litigants that matters, not in issue, may be given in evidence, and may be determined by the verdict of the jury, will not enlarge the effect of the judgment as an estoppel." Nor can evidence be admitted "to show a prior or contemporaneous parol agreement bctween the parties, the efiect of which would be to materially vary the terms of the decree and change the rights of tho parties thereunder." A divorced husband cannot, in a proceeding by his former wife to obtain an allowance for tho support of their child, show that the decree of divorce was entered in pursuance of a parol agreement, by the terms of which she was to provide for the child. ${ }^{5}$ The rule that no judgment or decree is conclusive of anything which is not required to support such judgment or decree, is not a mere rule of construction to be employed in giving effect to an adjudication, where the record fails to disclose what finclings were made by the court or jury. It is an unyielding restriction of the powers of the parties, of the court, and of the jury. If the language of a decree be general, it will bo restrained to the issues made in the case, and to tho subject matter under consideration by the court. ${ }^{6}$ But if " a decree in express terms purports to affirm a particular fact or rulo of law, yet, if such fact or rule of law was immaterial to the issue, and the controversy did not turn upon it, the decree

1 Ogsbury v. LaFarge, 2 N. Y. 114,| ${ }^{4}$ Campbell v. Consalus, 25 N. Y. citing Byrne $v$. Frere, 2 IIolloy, 157. 613; Wolfe $v$. Washburn, 6 Cow. 262;

2'Town $v$. Lamphere, 34 Verm. 365 ; Guest $v$. Warner, 9 Ex. 379.

Duncan v. Holcomb, 26 Ind. 378; Dur- 5 Wilson v. Wilson, 45 Cal. 399.

dick $v$. Post, 12 Barb. 10 s.

3 Bradford $v$. Bradford, 5 Conn. 127; 363. 
will not conclude the parties in reference thereto." "The declaration in a decree of the character of the title of one of the parties, when the consideration of such character is foreign to the case and unnecessary to its disposition, has no force upon the parties or privies, nor upon any one else, as an adjuclication of title. ${ }^{2}$ The special finding of a jury not confirmed by any judgment of the court, nor involved in any general verdict, cannot be relied upon on a trial before another or the same jury, in the same or another suit, as proof of the facts so found. It is only when such special finding has become the basis of a judgment, that the matters affirmed or denied by it are res adjudicata. ${ }^{3}$ No record is conclusive as to the truth of any immaterial allegations contained in the pleadings. Thus, in an action of debt on a bond, it may be shown that the bond was made at A., though in a former suit it was described as being made at B. A conviction for felony, upon a general verdict, is never conclusive that the offense was committed on the day named in the indictment, for time was not of the essence of the offense. And this rule will hold good in relation to all facts stated in the pleadings of either party, whether denied or admitted by his adversary, if the existence or non-existence of those facts could have no effect upon the final determination of the rights of the parties.4 The Nerw York Court of Appeals has, however, recently determined that the acceptance of a judgment by confession for certain goods " as sold and delivered" by plaintiff to the defendant, is conclusive against the former, in an action against the husband of the former defendant for the conversion of the same goods. ${ }^{5}$

PART III.-OF EVIDENCE TO ESTABLISH OR REDUT THE PRESUMPTION OF RES JUDICATA.

\section{272. Whether Matter in Issue can be Shown to} have been Omitted.-We have shown that the rule excluding from the conclusive effect of a final adjudication all of those matters which were not material to the decision of the controversy made by the pleadings, is an inflexible rule. It seems that there ought to be a rule the converse of this, and equally inflexible, to the effect that there shall be in-

\footnotetext{
1 Woodgate v. Fleet, 44 N. Y. 1; People v. Johnson, 3S N. Y. 63; S. C., 5 Trans. App. 299; Hotehkiss $v$. Nichols, 3 Dily, 13s; Coit $v$. Tracy, 8 Conn. 26S; 20 Am. Dec. 110.

2 Fulton $v$. Hanlow, 20 Cal. 450.

3 Hawks v. Truesdell, 99 Mass. 557.

${ }^{4}$ Ph. Ev., vol. 2, p. 2 of 4 th Am. cd.

5 Field $v$. Bland, 21 Alb. L. J. 511.
} 306 
cluded in the conclusive effect of every final adjudication erery matter material to the disposition of the controversy, as made by the pleadings, when the cause is submitted for decision; and such, probably, is the generally recognized rule at the present day. But it is opposed by decisions which permit either the plaintiff or the defendant, in certain cases, to show that a matter asserted as a claim or as a defense by his pleading, was not attempted to be asserted by him at the trial. Thus, it has been said that "if a party attempt, on the trial of his action, to prove a demand against the defendant, and fail, he cannot set it up again on a second action; but if he can clearly show that he omitted to giro any evidence of his demand in the action, he is not conclucled from doing so afterward."1 In the case from which this quotation is made, a plaintiff, haring two demands, clearly distinct, sued upon both, and obtained a default. In executing the writ of inquiry, he gave evidence upon $b_{4} t$ one of his demands, and recorered judgment accordingly. In rendering a decision permitting a second action to be maintained for the demand not allowed in the first, Lord Kenyon said: "In truth, this is a question of great delicacy. We must take care not to tempt persons to try experiments in one action, and when they fail, to suffer them to bring other actions for the same demand. The plaintiff who brings a second action ought not to leave it to nice investigation, to see whether the two causes of action are the same. He ought to show, beyond all controversy, that the second is a difierent cause of action from the first, in which he failed. In this case it is clearly shown that this demand was not inquired into in the former action." " "But, if plaintiff, having several causes of action against the defendant, on the trial offers evidence on these causes, and fails for want of sufficient evidence to sustain some of them, he can not bring another action for those causes of action on which he failed. Where the plaintiff fails to recover all that he is entitled to for want of some proof on the first trial, he should move to set aside the verdict that he has

${ }^{1}$ Seddon $v$. Tutop, 6 T. R. 607; ${ }^{2}$ Sedion $v$. Tutop, 6 D. \& E. 607; Thorpe $v$. Cooper, 5 Bing. 116; Deacon Newell $v$. Carpenter, 118 Mass. v. G. W. R. W. Co., 6 Upper Canada, 411.

C. P. 241; Wadley $v$. Green, 2 Tyrwhit, 390 . 
obtained." But so far as the plaintiff is concerned, most of the American cases go further. They declare that he will not be allowed to bring another action, because in the first he gave no evidence of his demand; ${ }^{2}$ that he will not be permitted to reserve, or, from any cause, not to produce part of his evidence; and that the judgment will be conclusive as to every matter which he could have proved in the first.suit, and which was not proved nor withdrawn. ${ }^{3}$ The defendant, however, although his pleadings present a claim, need not give evidence in its support, unless it is such a matter that he is compelled to present and litigate it in the first suit. Thus, where a defendant, sued for the price of a horse, set up as a defense a breach of warranty of soundness of the horse, and failed to appear at the trial, and judgment was rendered against him, he was allowed afterward to recover of the plaintiff for the same breach of warranty, becanse this was an affirmative cause of action which defendant had a right to litigate as a plaintiff. In cases like this, the question whether the claim was presented and submitted as a defense, may be settled by proof at the trial on the second action. But, if the claim is specifically embraced in the pleadings, the presumption is, that it was presented at the trial, and considered in the rendition of the. judgment. ${ }^{4}$ If a court erroneously reject evidence offered to prove a claim or defense, on the ground that it is inadmissible, such claim, nevertheless, on rendition of the judgment, becomes res judicata, and so remains nntil the judgment is vacated or reversed by some appropriate proceeding. ${ }^{5}$ If such evidence was offered to establish a canse of action, stated in a particular count of the plaintiff's declaration, and the plaintiff, failing to strike out or withdraw that count, suffers a general verdict on the whole cause, the judgment will be a bar to another action on the claim so at-

${ }^{1}$ Stafford $v$. Clark, 2 Bing. 377; | cordance with the English cases alBrockway $v$. Kinney, 2 Johns. 210; ready cited; Southside R. R. Co. $v$. McGuinty $v$. Herrick, 5 Wcnd. 240. Daniel, 20 Gratt. 366.

${ }^{2}$ Ramsey $v$. Herndon, 1 McL. 450. ${ }^{4}$ Burwell v. Knight, 51 Barb. 267;

${ }^{3}$ Baker $v$. Rand, 13 Barb. 152; Fisk McDaniel $v$. Fox, 77 Ill. 343.

v. Miller, 20 Tex. 579; Exr. Tate $v .{ }^{5}$ Beall $v$. Pearre, $12 \mathrm{Md}$. 555; BurHunter, 3 Strob. Eq. 136. But in nett v. Smith, 4 Gray, 50; Grant v. Virginia the rule seems to be in ac- Button, 14 Johns. 377.

308 
tempted to be established. ${ }^{1}$ A judgment of a court possessing competent jurisdiction is final, not only in reference to the matters actually or formally litigated, but as to all other matters which the parties might have litigated, and had decided in the cause. ${ }^{2}$ A party cannot try his action in parts. The judgment is conclusive, not only of the matters contested, but as to every other thing within the knowledge of the complainant, which might have been set up as a ground for relief in the first suit. ${ }^{3}$ If the determination of a question is necessarily involved in the judgment, it is immaterial whether it was actually litigated or not. ${ }^{4}$ Where, in fact, items of an account wero specifically set forth in the statement of the causes of action in a former suit, and, though known to exist, were for some reason overlooked and not considered, they cannot in law be the ground of a second action, ${ }^{5}$ nor can they be made the ground of such action, though they were omitted, owing to an error of the justice before whom the case was tried, in rendering his judgment. ${ }^{6}$ The omission of a court to award relief prayed for, is an adjudication, in effect, that the complainant is not entitled thereto." Hence, if, in an action on a note and mortgage, judgment is rendered on the note without any order of sale, this is conclusive that the plaintiff has no lien, and he can not afterward maintain an action to foreclose his mortgage. ${ }^{8}$ From the decisions eited in this section, the conclusion is irresistible, that a judgment or decree is conclusive upon all causes of actions and all matters of defense presented by the pleadings, and not withdrawn before or during the trial, except-1st, where the plaintiff claims upon several and distinct causes of action, in which case he may, according to some of the authorities, maintain a second action upon any one of those causes, upon which he can show that he offered no evidence at tho trial of the for-

${ }^{1}$ Smith v. Whiting, 11 Mass. 445, note 204 to $\mathrm{Ph}$. Ev.

2 Bellinger $v$. Craigue, 31 Barb. 534; Davis $v$. Tallcott, 2 Kern. 184; Marriott $v$. Hampton, 7 T. R. 265; Bruen v. Hone, 2 Barb. 596.

${ }^{3}$ IIamilton $v$. Quimby, 46 Ill. 90; Shaffer $v$. Scuddy, 14 La. An. 575.
${ }^{4}$ Barker v. Cleveland, 19 Mich. 230.

${ }^{5}$ Keokuk v. Alexander, 2I Iowa, 377.

6 Town $v$. Smith, 14 Mich. 34 S.

7 Thompson $v$. McKay, 41 Cal. 221.

${ }^{8}$ Johnson $v$. Murphy, 17 Tex. 216. 
mer case; $2 d$, where the defendant pleach a matter as a defense which he might havo successifully employed as a cause of action against the plainitiff; in which case it ippears that the right to such cause of action is not lost to the defendant, unless he followed up his pleading by offering evidence upon it in the former suit. With the possible exceptions here stated, a judgment is conclusive upon all the material issues made by the pleadings, and also upon all material allegations of matters of claim or of defense which the party against whom such allegation is made does not choose to controvert.

\section{273. Evidence to Show what was Decided.-A few} early cases proceeded upon the theory that a former judnment would be received as evidence in a second action, only as to those matters which, from an inspection of the record, could be shown to have been settled in the first. ${ }^{2}$ Dut it happens frequently, and perhaps in a majority of eases, that the matters litigated between the parties to an action cannot be ascertained from the record. It is now generally, and perhaps universally, conceded, that parol evidence may be received for the purpose of showing whether a question was determined in a former suit; ${ }^{3}$ and that "the estoppel extends beyond what appears on the face of the judgment to every allegation which, having been made on one side and denied on the other, was at issue and determined in the course of the proceedings; and that while there exists a strong presumption that the judgment covers every matter in the issues and apparently settled by the judgment, yet,

\footnotetext{
${ }^{1} 2$ Smith's Leading Cases, 660. In |v. Harris, 2 Johns. 29; 3 Am. Dec. this first class may be ineluded those $3 S 6$.

cases in which several counts are in- 3 Taylor $\%$ Dustin, 43 N. II. 493; serted in a declaration, and the gen- King 2 . Chase, 15 N. 1I. 9; Foster $v$. cral issue being pleaded, a general Wells, 4 Tex. 101; Walker $v$. Chase, judgment is entered thereon. Such 53 Maine, 258; Wood v. Jackson, 8 judgment is prima facie evidenee of Wend. 9; 22 Am. Dec. C03; Tcal v. the prior adjudication of every de- Terrell, $4 \mathrm{~S} \mathrm{Tex}$. 491; Estill $v$. 'T'anl, mand which might have been litigated 24 Am. Dee. 498; Young v. BIack, 7 under the I, leadings; but this evidence Cranch, 565; Driscoll $v$. Damp, 16 may be overcome by proving that Wis. 106; Davis $v$. Brown, 91 U. S. some particular claim was ncither pre- 423; Vallandingham v. Ryan, $17 \mathrm{Ill}$. scnted nor eonsidered: Hangerford's 25; Russell v. Place, 94 U. S. 606; Appeal, 41 Comn. 322; Dickinson $v$. Hill $v$. Freeman, 7 Cieo. 211; State $v$. Hayes, 31 Conn. 423; Sweet v. Mau- Morton, 15 Mo. 53; Brown v. King, pin, 65 Mo. 65.

"Smith $x$. Sherwoorl, 4 Conn. 276; 10 Am. Dec. 143; Church v. Leavenworth, 4 Day, 281; 1 Esp. 43; Manny
} 
that this presumption may be overcome by clear proof that no evidence was given as to that fact by the plaintiff, or that defendant failed to take alvantage of some defense which he might have made available." 1 It may always bo shown by evidence aliunde, that any matter which the issue was broal enongh to cover, arose and was determined in the prior suit. $^{2}$ The record may be first put in evilence, and then it may be followed by such parol evidence as may be necessary to give it proper effect. ${ }^{3}$ If the record in an action of ejectment does not show on what grounds the plaintiff or defendant recovered, it may bo explained by showing what title was established or set up in the action. ${ }^{4}$ Judgment on the merits against the master, in an action of trespass for the act of his servant, is a bar to an action against the servant for the same act, though such judgment was not rendered until after the general issue was pleaded to the action against the servant; and parol evidence is admissible to show that the same matter is in controversy in both actions." An entry of "dismissed at costs of plaintiff, being susceptible of a double construction, i.e., that it was a julgment for defendant on the merits, or a judgment of nonsuit or discontinuance, may bo explained by evidenco of the justice to show which character of judgment he intencled to enter." "When a number of issues are presented the finding in any one of which will warrant the verdict and judgment, it is competent to show that the finding was upon one rather than on another of theso different issues. For does the subsequent application of the verdict to a single count by the court, preclude this inquiry." In order to show by evidence aliunde that a matter is res judicata, it must appear not only that it was properly in issue in the former trial, but also that the verdict and judgment necessarily involved its determination. ${ }^{7}$

\section{271. Evidence to Rebut Apparent Estoppe1.-If it} appear, prima facie, that a question has been adjudicated,

1 Clemens $r$. Clemens, 37 N. Y. 59.

2 Chamberlain $v$. Gaillard, 26 Ala. 504; Dunckel $v$. Wiles, 1 Kern, 420; Harris $x$. Harris, 36 Barb. 88; Lawrenee $v$. Hunt, 10 Wend. 80; $25 \mathrm{Am}$. Dee. 539; Gardner v. Buckbee, 3 Cow. 120; 15 Am. Dec. 250; Eastman $v$. Cooper, 15 Pick. 270 .
${ }^{3}$ Briggs $v$. Wells, 12 Barl. 507.

${ }^{4}$ Enery $x$. Fowler, 39 Naine, 3-6. ${ }^{5}$ Carr $v$. Woodlefr, 6 Jones, N. C. 400.

${ }^{6}$ WV. A. \& G. S. P. Co. $v$. Sicliles, 24 How. U. S. 333

7 Pachet Co. v. Sickles, 5 Wall. 5 So. 
it may be proved by parol testimony that such question was not in fact decided in the former suit. ${ }^{2}$ Where items could have been proved in a former action, the presumption arises that they were proved, but it may be rebutted aliunde. ${ }^{2}$ If a matter wero pleaded as a credit, it is competent to show that it was not offered as a credit on the trial, and that the court in deciding the case expressly excluded it from consideration. ${ }^{8}$ Parol evidence is also admissible, according to some decisions, to prove that a former action in a justice's court was not tried on the merits, but was a nonsuit. ${ }^{4}$ In an action for goods sold, the plaintiff, to avoid the plea of res judicata, may show that the previous judgment against him was rendered on the ground that the time of credit given on the goods had not expired. ${ }^{5}$ If the defendant in a real action plead a former recovery as a bar, the plaintiff may prove that he failed in his suit on the sole ground that his grantor was disseised at the time of conveying title; and the plaintiff may thereupon establish liis title under a subsequent conveyance from such grantor. ${ }^{6}$ Whero the subject-matter las "been in litigation before, the evidence that the merits were not passed upon ought to exclude all other hypotheses."7

8 275. Record not to be Impugned.-It is important that the evidence offered to explain a record, should not contradict it. For it can not be shown, in opposition to the record, that a question which appears by it to have been settled, was not in fact decided, ${ }^{8}$ nor that, while a special cause of action was in issue, a different matter was in truth litigated. Bat in New York it is said a different rule may apply to justices' courts, because the proceedings in

${ }^{1}$ Johnson $v$. Smith, 15 East, 213; Whittemore $v$. Whittemore, $2 \mathrm{~N}$. II. 26; Parker $v$. Thompson, 3 Pick. 429; Plillips v. Berick, 16 Johns. 136; 8 An. Dec. 2n9; Wheeler v. Van Houten, 12 Johns. 311; Coleman's Appeal, 62 Pa. S. 252; Southside R. I. Co. v. Daniel, 20 Gratt. 363; Spradling $v$. Conway, 51 Mo. 51; Bottorff $v$. Wise, 53 Ind. 52.

2 Balger v. Titcomb, 15 Pick. 416; Welster $v$. Lee, 5 Hass. 334; Golightly $v$. Jellicoe, 4 T. R. 14i; Seddon $v$. Titop, 6 T. T. 607.

3 Smith $v$. Talbot, 11 Ark. 666.
4 Easton v. Bratton, 13 Tex. 30.

5 Wilcox v. Lee, 1 Rob. N. Y. 355.

6 Perlins v. Parker, 10 Allen, 22.

'Baxter v. Aubrey, $41 \mathrm{Mich} .13$.

8 Fisk v. Miller, 20 Tex. 579; Graves v. White, 13 Tex. 123; Fox $v$. Hudson, 20 Kíans. 246; Armstrong v. St. Lonis, 69 Mo. 309; Long v. WV Minn. 380; Underwool v. French, 6 Oreg: 66.

9 Camplell v. Butts, 3 Conrst. 173; Campbell v. Consalus, 25 N. Y. 616; Standish v. Parker, 2 Pick. 20: 13 Am. Dee. 393. 
them are informal. ${ }^{3}$ Parol proof ean be given to show the grounds of a judgment only when such grounds do not appear from the record itself. In no case can any nuatter be alleged or proved to have been passed upon, except it bo such as might have been given in evidence, legitimately, under the issuo joined. ${ }^{2}$ Whero a complaint is free from ambiguity, it can not be shown that the judgment given thereon was for damages occasioned by injuries to land not within the premises described in the complaint. ${ }^{3}$ A provisjon of a statute provided that whenever a sheriff ficiled to mako xnoney on an execution, by the first day of the term beforo which it was returuable, the plaintiff might suggest that the failure was attributable to want of diligence, and that, npon such suggestion, the conrt should cause an issue to be made to try the fact. In an action upon a sheriff's bond, for not malking money on an execution, the defendants pleaded that an issue made under this statute had been fond in their favor. Plaintiffs replied that the matters, neglects, and defaults complained of, were not the same identical ones in respect to which defendants recovered their judgment. It was held that the matters sought to be put in issue in the replication were necessarily involved in the former trial, and that to uphold the replication wonld be to permit a second litigation of the same questions; that the facts in issne in the suit appear by necessary intendment to be the ficts involved in the proceeding under the statute, and that to say they were not so involved, is to contradict the record itself. ${ }^{4}$ When the subject-matter of the present and the former action is not the same, the principles stated in this section may, in somo instances, seem inapplicable. Thus, if after an action has been prosecuted to final judgment on a boud or note resulting in a recovery by the pliintiff, the defendant can never, in another action involving the same note, be permitted to show that he had a good defense thereto, which he failed to present for the consideration of the court in the first action, and thereby preserved it from the operation of the judgment; in other words, he can not show that the matter of his defense has not become

\footnotetext{
${ }^{1}$ MeLean v. Hungarin, 13 Johns.| ${ }^{3}$ Gay v. Wells, 7 Pick. 219.

18.; Ting v. Fuller, 3 Caines, 152; ${ }^{4}$ Chapman $v$. Smith, 16 How. U. S. Wilder $v$. Case, 16 Wend. 533.

2 Briggs $v$. Wulls, 12 Larb. 567. 114. 
res judicata, for to do so would clearly contradict the record. But if the defendant were to be sued upon another note or bond of the same series, and to which he in fact had no other defenses than those which existed against the former note or bond, he may show that some valid defense existing against both was not presented and litigated in tho former action, and may avail himself of such defense in the present case, thongh forever barred from using it against the recovery in the prior action. ${ }^{1}$

\& 276. Cnus of Proof.-There are two classes of cases in which evidence aliunde is admissible for the purpose of showing what matters are res judicata, viz.: 1st-all those cases in which, from the record alone, no intimation is given whether a particular matter has been determined or not; 21 -all those cases in which, from the record, it ippears that a particular question was probably determined. As a general rule, the ouns of establishing an estoppel is, by the law, cast upon him who invokes it. ${ }^{2}$ Uncler this rule there can be no doubt that, in all cases coming under the first class, it is incumbent upon a party alleging that a quesiion has been settled by a former adjudication, to support his allegation by evidence aliunde. But in relation to cases of the second class, there appears to be a radical difference of opinion. On the one side it is claimed that, "where the declaration in the second action is framed in such a manner that the causes of action may be the same as those in the first suit, it is incumbent upon the party bringing the second action to show that they are not the same." "A party who brings a second action must not leave it to nice inrestigation to see whether the two causes are the same. He ought to show, beyond doubt, that the second is a different cause of action from the first, in which he failed."4 In cases where several issues are made by the pleadings, and evidence is given upon all those issues, and a general verdict is obtained, the question arises as to which of the

${ }^{1}$ Cromwell $v$. County of Sac., 94 U. Talcott, 14 Barb. 611; Smalley $v$ S. 3J1; Davis $v$. Brovin, 94 U. S. 423; Edcy, 19 Ills. 207; Van Valkenburg Russcll 2 . Place, 94 U. S. 606.

2 Cummings $v$. Colorove, $25 \mathrm{~Pa}, \mathrm{~s}$. 150; Bennett $v$. Holmes, 1 Dev.\& Bat. 430; Strother v. Dutler, 17 Ala. 733; ${ }^{4}$ Agnew v. McLlroy, 10S. \& M. 552; Doty $v$. Lrown, 4 N. Y. 71; Davis $v$. I Baxter $v$. Aubrey, 41 Mich. 13.

314 
issues this verdict is conclusive. In Vermont, ${ }^{1}$ in Pennsylvania, and in Indiana," the presumption is, that it is conclusive that all the issues were found in favor of the prevailing party, and he is permitted to rebut that presumption, if he can, by showing that the finding and judgment were npon a particular issue. In Missachusetts, it is setthed, by a number of decisions, that a general verdict in favor of a party presenting several claims or defenses, is not of itself prima facie conclusive upon any of those claims or defenses. Thus, in an action for breaking several covenants in a lease, the plaintiff recovered general rerdict for nominal damages. In a subsequent action, the record in the former action was held not to show, of itself, that the breach now in question is rez judicata. The cause was remanded for further proceedings, in which it was shown, by evidence aliunde, that the breach involred in the second action was one of the questions litigated in the former suit, and on which evidence was offered at the trial. With this proof to support it, the former judgment was considered a bar." According to some of the most recent and anthoritative adjudications upon this subject, "if there be any nneertainty in the record, as, for example, if it appear that sereral distinct matters may have been litigated upon one or moro of which judgment was rendered, the whole subjectmatter of the action will be at large and open to a new contention, unless the uncertainty be removed by extrinsic evidence showing the precise point involved and determined." In an action where plaintiff sought to recover from defendant for board of the latter wife's, and at the trial relied on two grounds, viz: 1st-that she was absent from her husband by his consent; 2 - -that she was justifiably absent from him on account of his cruelty to her-a judgment was rendered for plaintiff. This judgment was held to establish against defendant, that his wife was justifiably absent; and to leave the jury to judge from the judgment and from such other evidence as came before them, whether the ground of the former recovery was absence by consent, or absence on

\footnotetext{
${ }^{1}$ White $v$. Simonds, 33 Vt. 178. $\mid \quad{ }^{4}$ Sawyer $v$. Woodbury, 7 Gray, 499.

${ }^{2}$ Rockwell $v$. Langley, 19 Penn. S. ${ }^{5}$ Russell $v$. Place, 9t U. S. 600 ; 502.

${ }^{3}$ Day v. Vallette, 25 Ind. 42. Chrisman's Ad. v. Harman, 29 Crati. 494.
} 
acconnt of cruelty. ${ }^{1}$ In the same State a decree dismissing a bill was relied upon as a bar. It appeared from the record that some temporary defenses were relied upon in the former suit, bnt that the bill was dismissed withont specifying any reatsons, and without any restriction upon its effect. It was decided not to be conclusive on the merits. In announcing this decision, the court said: "To be a bar to future proceedings, it must appear that the former judgment necessarily involved the determination of the same fact, to prove or disprove which it is offered in evidence. It is not enough that the question was in issue in the former suit. It must also appear to be precisely determined. Where in the answer various matters of defense are set forth, some of which relate to the maintenance of the suit, and others to the merits, and there is a general decree of bill dismissed, it is impossible to hold the decree a bar to future proceedings." 2

\& 276a. Where there are Several Defenses, any one of which is sufficient to defeat the action, and the court or jury finds specially in favor of the defendant upon all of them, each becomes res judicata, and the judgment is upon the merits, although some of the defenses are in the nature of pleas in abatement, and go only to defeat the present action. ${ }^{3}$ If a bill in equity be demurred to upon several distinct grounds, and on this demurrer a general decree be entered of bill dismissed, this is a judgment upon the merits, though some of the grounds of demurrer did not involve the merits of the suit. ${ }^{4}$

PART IV.-MIATTERS WHICH NEED NOT BE LITIGATED.

\& 277. Set-off not Presented.-It has already been stated that the defeudant is not barred, by judgment, of any matter of defense which he was not bound to present to the court.or jury, and on which he offered no evidence at the trial. The statutes of set-off are for the benefit of defendants, and plaintiffs can not compel defendants to avail them-

${ }^{1}$ Burlen $v$. Shannon, 14 Gray, 433. Min. Co., 3 Saw. C. C. 634; Hawes $v$.

${ }^{2}$ Foster $v$. The Richard Busteed, C. C. W. Co., 5 Saw. C. C. 287; 7 100 Mass. 409; Burlen v. Shannon, 99 Reporter, 100; Sheldon v. Edwards, 35 Mass. 200.

N. Y. 286 .

${ }^{3}$ The 420 Mining Co. $v$. Bullion ${ }^{4}$ House $v$. Mullen, 22 Wall. 42. 316 
selves of those benefits. It is well understood that, unless some State statute provides otherwise, the defendant may waive his set-off or counter-claim in any action against him, and thereafter litigate it in an action instituted by himself. ${ }^{1}$ By the recently adopted code of California, if the counterclaim arises "out of the trausaction set forth in the complaint as the foundation of the plaintiff"s claim," or is "connected with the subject of the action," and the suit is in any other than a justice's court, the defendant, by omitting to set up such counter-claim, waives all right to subsequently employ it as a cause of action. (Secs. 438 and 439, C. C. P.) But if the action be in a justice's court, then the defendant must present all facts, "constituting a defense or counterclaim, upon which an action might be brought by the defendant against the plaintiff in a justice's court;" and if ho fail so to do, "neither he nor his assignee can afterward maintain an action against the plaintiff therefor." (Secs. 855 and 856 , C. C. P.) In some States, while the right to waive a set-off or counter-claim, and institute a suit upon it afterward, is recognized, yet defendants are discouraged from so doing, by a provision of the statute, providing that in the subsequent action they shall not recover costs. ${ }^{2}$ While all matters of defense are barred, the distinction between a matter of defense and a cross-claim must be constantly kept in view. A cross-claim, set-off, or matter of recoupment may be interposed by defendant, but he is not bound to do so. Thus, though in an action for the price of goods sold, defendant might give in evidence a breach of warranty in those goods, or of deceit in the sale, and so defeat the action in whole or in part, yet he is under no obligation to do so, and he may maintain his cross-action for the damages, after having submitted to the judgment for the price. ${ }^{3}$ When part performance of a contract (e.g., to work for a year) forms the ground of an action, the defendant may suffer judgment and afterward may sue and recover

${ }^{1}$ Waterman on Set-off, p. 631; Hobbs | Mich. 215; Emmerson v. Herriford, 8 $v$. Duff, 23 Cal. 596; Robbins $v$. Har- Bush, 229; Fannin v. Thomasson, 45 rison, 31 Ala. 160; Le Guen v. Gouverneur, 1 John. Cas. 501; 1 Am. Dec. 121; Robinson $v$. Wiley, Hemps. 38; contra, see Crawford $v$. Simonton, 7
Porter, 110; McEwen v. Bigelow, 40 Geo. 533.

${ }^{2}$ Code of Ohio, 96, 119; Cocie of Nebraska, 102, 126; Ed. of 1852, of State of Indiana, p. 41.

${ }^{3}$ Cook $v$. Moseley, 13 Wend. 277. 
damages for the breach of the contract. ${ }^{1}$ A. sued B. to recover the price of constructing a kitchen range. The defendant paid into court a sum which plaintiff accepted as a full satisfaction. B. then sued A. for negligently performing the work, and was permitted to recover, on the ground that the recovery in the second action was not inconsistent with the work sued for in the first, being of some value. ${ }^{2}$

8 278. Set-off not Decided.-If the defendant sets up and claims a set-off, and the record shows that the court excluded all evidence in relation to the set-off, the judgment cannot be used as an estoppel in an action by the defendant for the same set-off," because, "although a court of law declines to determine a question of set-off, yet it is not res judicata, so as to preclude an inquiry in a court of equity." And the same rule prevails where, instead of the court's excluding the evidence, the defendant failed to present any proof in support of his counter-claim. ${ }^{5}$

\& 279. Set-off not Allowed.-There is no doubt that if a set-off be presented by defendant in his pleadings, and attempted to be supported by evidence to the jury, it will, whether allowed or disallowed, become res judicata. It is settled by the judgment as conclusively when it does not appear to have been allowed, as though there were an cxpress finding against it. ${ }^{6}$ When the set-off has been presented to the jury, and evidence offered to sustain it, the effect of the judgment afterward rendered cannot be changed in a subsequent action, by showing that the jury did not in fact consider the set-off in making their verdict. ${ }^{7}$ If a judgment be pleaded as a set-off, when it is a proper matter of setoff, and be disallowed by the jury, it is extinguished, and can no longer be the basis of an action. If the plaintiff afterward issue execution upon it, he is a trespasser. ${ }^{8} \mathrm{~A}$

1 Britton v. Turner, 6 N. H. 481.

${ }^{2}$ Rigge $v$. Burbidge, 15 M. \& W. 598.

${ }^{3}$ Hobbs u. Duff, 23 Cal. 596.

${ }^{4}$ Hackett $v$. Connett, 2 Ed. Ch. 73.

5 Eastmure $v$. Laws, 7 Scott, 461 ; Reynolds $v$. Reynolds. 3 Hamm. 268 ; Janney $v$. Smith, 2 Cranch C. C. 499.
6 Wright $v$. Salisbury, 46 Mo. 26.

7 Baker $v$. Stinchfield, 57 Maine, 363.

${ }^{8} \mathrm{M}$ eGuinty $"$. Herriek, 5 Wend. 240.

The same rule applies to matters of defense erroneously rejected. Collins $v$. Fennett, 46 N. Y. 400 . 
claim presented as a set-off, and not allowed, will not be barred, except it was in such a condition as to have been barred if then offered as a cause of action in a suit by the defendant against the plaintiff. Thus, if when offered, it is not legally a set-off, because not yet due, it may, if not allowed, be employed as a cause of action, or as a set-off in any subsequent suit between the same parties. If the defendant plead matter which he might have made the basis of a suit, and on the trial cross-examine the plaintiff's witnesses in reference to the matters so pleaded in defense, ho caunot avoid the efiect of the judgment on the ground that he introduced no witnesses to testify on the subject, nor because the referee decided the case before the defendant was prepared with all his proofs. ${ }^{1}$

The language generally employed in treating of this subject, is such as to indicate that to conclude a claim of set-off, it must be presented to the jury, and some evidence given upon it. But it has been decided that a set-off not withdrawn becomes res judicata, though no evidence be given to support it, and the defendant was not prepared to give such evidence at the trial of the former case. ${ }^{2}$ This seems to be a just and reasonable decision. There is as much propriety in requiring defendant either to litigate or withdraw his demands, as there is in requiring the plaintiff to support or withdraw his alleged causes of action.

\section{280. Voluntary Allowsance of an Orf-Set.-A plaintiff} cannot, in a suit against the defendant, compel the latter to present or litigate his counter-claim, by giving him credit

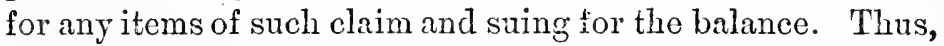
if A. sue B. upon an account in which he credits B. with certain goods, B. may suffer judgrment by default, and may then sue A. for the goods, if the credit was not their full value. The value of the goods is not fixed by the former judgment, because it was not directly in issue, and the defendant offered no evidence upon it. $\mathrm{He}$ is not bound to offer such evidence at his own expense, when he can, by commencing another action, offer it at the expenso of his

1 Eule v. Dingham, 7 Barb, 494. | | ${ }^{2}$ Eastmure v. Laws, 7 Dowl. 431. 
adversary. ${ }^{1}$ But if the credits for goods were of their full value, this is a good defense to an action brought by the defendant against the plaintiff for the same goods. ${ }^{2}$ If the plaintiff bring an action in which he credits defendant in certain sums, and claims an amount specified as a balance due, the defendant may come in and confess judgment for the amount sued for, and this will not prevent him from sustaining a subsequent action for demands due to him from the plaintiff, and not allowed by the latter in the first suit. $^{2}$

8 281. Equitable Defenses.-It follows from the rule, that a matter can not become res judicatica until it can be tried upon the merits, that a failure at law does not affect a remedy or defense, cognizable only in equity. 4 Whenever a "party has equitable rights, not cognizable in a court of law, which would in a court of equity have prevented such an adjudication as was made in the court of law, the judisment will interpose no obstacle to redress in equity since the court of law had no proper jurisdiction of the subject matter forming the basis of redress in equity." 5 Under the Code of Procedure as in force in New York and in California, matters formerly recognized only in equity may be interposed as defenses to actions at law. The question has arisen in both States, whether it is incumbent on the defendant to present his equitable defense, or whether he may suffer judgment to be taken against him, and subsequently assert his claims in equity? The answer given to the question in the former State is, that, " as a general rule, the defendant who has an equitable defense to an action, being now authorized to interpose it by answer, is bound to do so, and shall not be permitted to bring a separate action merely for the purpose of restraining the prosecution of another action pending in the same court." 6 In California, however, the

${ }^{1}$ Minor $v$. Walter, 17 Mass. 237; son, 23 Geo. 321; Worthington $v$. McEwen $v$. Bigelow; 40 Mich. 215.

2 Briggs $v$. Richmond, 10 Pick. 392; 20 Am. Dec. 526.

${ }^{3}$ Kauff $v$. Messner, 4 Brewster, 98.

${ }^{4}$ Mosby $v$. Wall, 23 Miss. S1; White $v$. Crew, 16 Geo. 416; Arnold $v$. Grimes, 2 Clarke, 1; Pollack $v$. Gilbert, 16 Geo. 398; McCurry v. RobinCurd, 22 Ark. 277; Nims $v$. Vaughn, 40 Mich, 356.

5 Story's Eq. Jur., sec. 1573; Dun-

ham v. Downer, 31 Vt. 249.

${ }^{6}$ Winfield $v$. Bacon, 24 Barb. 154;

Foot $v$. Sprague, 12 How. Pr. 355;

Fannin v. Thomasson, 45 Geo. 553. 
answer is in direct conflict with that given in New York. In an early case it was held that: "Although a party may set up an equitable defense to an action at law, his remedy is not confined to that proceeding. Ho may let the judgment go at law, and file his bill in equity for relief. Our practice, while it enlarges the field of remedy, does not take away pre-existing remedies by implication." " Ten years later it was said that: "This decision has been acquiesced in and acted on as settled law by the profession from the time it was rendered, and, so far as we are advised, its correctness has never been the subject of judicial doubt."2 Accordingly a defendant who, having an equitable defense to an action of ejectment on the ground that he was entitled to a conveyance from the plaintiff, and who first pload such defense, and afterward withdrew it, and suffered judgment to be taken against him, was allowed in a subsequent suit to compel the specific performance of the contract to convey. A like rule prevails where the defendant, pleading an equitable defense, without withdrawing it, fails to appear at the trial, and judgment is therefore given against him without any presentation or consideration of his defense. ${ }^{3}$ Where an equitable defense is presented, which might have been made the subject of an original bill, the defendant can not, after verdict in favor of the plaintiff, present the same matters in equity as grounds for aftirmative relief against plaintiff. ${ }^{4}$

8 2S2.-Cross-Claims.-Whenever a plaintiff seeks to recover for some matter which he might have presented in a former action against himself, as the foundation for a claim in the nature of a cross-action for damages, the test of his right to recover in the second action, after having waived lis cross-claim in the first, is, can all the facts necessary to support the judgment rendered against him exist at the same time with the facts necessary to support the crossclaim sought to be enforced in the seeond suit? For if, in order to recover in the first action, the plaintiff must have shown the falsity of the allegations mado by defendant in the second suit, then the former judgment is a bar. Thus,

${ }^{1}$ Lorraine $v$. Long, 6 Cal. 452.

${ }^{2}$ Hough v. Waters, 30 Cal. 309; Hills v. Sherwood, 48 Cal. 356. 
if plaintiff sue upon a contract to do certain work upon his part, alleging a full performance, and claiming the price stipulated by the contract, his recovery depends upon a full compliance with his agreement, and estops the defendant from afterward contending that he sustained any damage from the non-fulfillment of the contract. ${ }^{1}$ A judgment in furor of a physician and surgeon for professional services is a bar to an action against him by the defendant in the former action for malpractice in rendering those services. ${ }^{2}$ If, however, a matter in the nature of a defense and crossclaim is pleaded, the contrary of which need not necessarily be established by plaintiff in making out his cause of action, under the allegations in his complaint, the defendant may withdraw it at or before the trial, without losing his right to assert it in a subsequent suit. Thus, the recovery upon a complaint for work and labor done, etc., will not estop defendant from recovering damages sustained by him by the manner of performing the work and labor; because the claim of the defendant " not being necessary, or at all involved, as part of the plaintiff"s evidence, prima facie, it has not been tried or passed upon," and is not barred unless put in issuo by the answer. ${ }^{3}$ A defense set up by way of recoupment or counterclaim, and not withdrawn from the consideration of the court, and adjudged to be insuficient, thereby becomes res judicata, and can not thereafter support an independent action. ${ }^{4}$

PART V. - PLEADINGS TO MAKE FOMNER JUDGMENT AVAILABLE.

3,283. Ivecessity of Pleading.-Conceding that the pleadings and issues in a second action are such as to entitle one of the parties to place in evidence, before the court or jury, the record of a former action, for the purpose of showing that a question in issue in the second action has been decided in the first, it still remains to be considered whether the pleadings in the second action are such as to make the former judgment conclusive of the facts upon which it is grounded. In all these cases, where a party relying upon a former adjudication as an estoppel had no

${ }^{1}$ Daris $v$. Talleot, 12 N. Y. IS4. ${ }^{3}$ Foster $v$. Milliner, 50 Barb. 355; Matters of defense can not be litigated Davenport $v$. Hubbard, $46 \mathrm{Vt}$. 200; 14 in a second action because not pleaded Am. liep. 620 .

in the first. Hackworth $v$. Zollars, ${ }^{4}$ South \& N. A. R. R. $v$. Henlein, 30 Iowa, 433.

${ }^{2}$ Blair $v$. Bartlett, 75 N. Y. 150; Me. 363. Howell $v$, Goodrich, 69 Ill. 556. 
opportunity to plead it, it is equally a bar as though an opportunity had been given and it had been pleaded. ${ }^{1}$ 'Thus, if in an action of trespass quare clausum, the defendant plead title in a third person, under whom he claims without showing how such title was aequired, nor when it accrued, the plaintiff may, at the trial, gire in evidence an award against the title of such third person, without pleading it. ${ }^{2}$ Where the declaration contains no intimation of the source of plaintiff's title, the defendant is not bound to plead an estoppel, nor to show that the title claimed by plaintiff proceeds from a given source, and then intercept it by pleading a former adjudication. And if an estoppel by judgment, or otherwise, form part of the muniment of either party's title, he is no more bound to set it forth in his pleadings than he is to insert therein any of his title deeds. ${ }^{3}$

\& 2St. Neglect to Plead Former Judgment.-According to the practice at common law, a judgment, though not pleaded as an estoppel, could be given in evidence under the general issue. ${ }^{4}$ Upon this point there is no doubt; but upon the question, of what effect is to be given to it when so put in evidence, great contrariety of opinion exists. In the celebrated case agaiust the Duchess of Kingston, ${ }^{5}$ a case more frequently cited, we think, than any other ever decided in an English Court, a former adjudication is spoken of as being "as a plea, a bar; and as evidence, conclusive." Whether the judge writing the opinion in this case understood that a former adjudication was "as evidence conclusive," though not pleaded as an estoppel, or whether he intended the language employed by him should be applicable only to those cases in which the conclusive effect of a former judgment was invoked by the pleadings, is unknown; but it is probable that he designed merely to state to what extent a former adjudication might prevail, if properly insisted upon, by a party entitled to its benefits, and that he had no intention of pointing ont the means essential to securing those benefits. However this may be, it is certain that a decided preponderance of the authorities in England sus-

1 Dame $v$. Wingate, 12 N. H. 291; Dows $v$. McMichael, 6 Pai. 139; Howard $v$. Mitchell, 14 Mass. 241; McNair $v$. O'Fallon, 8 No. 185; Isaacs $v$. Clark, 12 Verm. 692; Woodhouse $v$. Williams, 3 Dev. 508 .
${ }^{2}$ Shelton $v$. Alcox, 11 Coun. 240.

${ }^{3}$ Aclams $v$. Barnes, 17 Mass. 365.

${ }^{4}$ Chitty on Pl. 198.

520 Howard's State Trials, 47S. 
tains the view that the record of a former action, if given in evidence under the general issue, when it might have been pleaded as a bar, "is not conclusive, but is a mere matter of argument or inference" in favor of the party presenting it. ${ }^{1}$ In the United States, however, the authority of the Euglish decisions on this subject has not been universally respected. Still, there are a number of cases in this country assertiug that a "judgment which if plead would have been a perfect bar, is, when given in evidence, under the general issue, not conclusive on the jury, but only evidence to be weighed by them," " because if not plead the matter is left at large, and the party may thiuk he can do better than he did before." In New York the cases are hardly consistent with one another. In Wright $\mathrm{v}$. Butler (6 Wend. 284; $21 \mathrm{Am}$. Dec. 323), it is said: "In actions where the former recovery can be set up in pleading by way of estoppel, the party must plead it, or it will not be conclusive on the jury in the second action; but in actions of assumpsit, etc., where the party has no opportunity to plead the former verdict as an estoppel, the record thereof may be given in evidence, and is conclusive and binding on the party, the Court and the jury, as to every fact decided by the former verdict." In Wood v. Jackson (8 Wend. '10, 35; 22 Am. Dec. 603), Chancellor Walworth states that "There is a certain class of cases in which the party may avail himself of an estoppel, by pleading the same is bar to a suit, or in reply to allegations set ont in a plea. In such cases, if he neglects to make the objection in that manner, and puts the facts directly in issue, without pleading the former verdict or decree as an estoppel, the jury may find according to the truth of the case, on the issue. But this principle is only applicable to cases where special pleading is required; it does not extend to actions of

${ }^{1}$ Chitty's Pl. 19S; Ontram $v$. Morewood, 3 Last, 346; Vooght $v$. Winch, 2 Barn. and Ald. 662; Hannaford $v$. Hunn, 2 Carr. \& P. 14S; Magrath $v$. Harly, 4 Bing. N. C. 782; Doe v. Huddart, 2 C. MI. \& R. 316; Fever$\operatorname{sham} v$. Lmerson, 11 Exch. 385; Dimes v. G. J. Canal Co., 9 Q. B. 469, 517; Hooper $v$. Hooper, McClel. \& Young's Exch. 509.
${ }^{2}$ Cleaton $v$. Chambliss, 6 Rand. 86 ; Town v. Nims, 20 Am. Dec. 578; Howard v. Mitchell, 14 Mass. 242; Bartholomew $v$. Candee, 14 Pick. 167; Long $v$. Long, 5 Watts, 103; Smith $v$. Elliott, 9 Barr, 345; Adams $v$. Barnes, 17 Mass. 36S; Picquet $v$. McKay, 2 Blackf. 465.

${ }^{3}$ Redmond v. Coffin, 2 Dev. Eq. 445.

\section{4}


assumpsit where an estoppel, as a former recovery or bar, is embraced within, and may be given in evidence uncier the general issue." "Neither does it apply to cases where the plaintiff's title is by estoppel; or where the party relying upon the estoppel had no opportunity to plead the same specially, as a bar. From these principles it necessarily follows that in ejectment, where special pleading is not allowed, the defendant, in support of his possession, may give in evidence any matter which would have operated as a bar, if pleaded by him by way of an estoppel to a real action." These cases and some others in the same State, ${ }^{1}$ incline to the view that in those actions where a judgment can properly be given in evidence under the general issue, its effect is conclusive, unless the case is such that some special pleading is allowed; and, taken altogether, they rather affirm than deny the English rule upon the subject. The greater number of the American cases, however, repudiate the theory that a former adjudication can, in any event, be properly admitted in evidence for the purpose of determining any issue in the second action, by proving how the same issue was determined in the first, without being absolutely conclusive so far as it is applicable to the second action. The judgment, if admitted under the pleadings, must be received as, what it purports to be-a final determination of the rights of the parties. The reasons for this departure from English precedents are thus forcibly and conrincingly stated by Kennedy, J., in the case of Marsh v. Pier (4 Rawle, 273) : "The maxim, nemo debet bis vexari, si conslat curice quod sit pro una et eadem causa, being considered, as doubtless it was, established for the benefit and protection of the party, he may therefore waive it; and unquestionably, so far as he is individually concerned, there can be no rational objection to his doing so. But then it ought to be recollected that the community has also an equal interest and concern in the matter, on account of its peace and quiet, which ought not to be disturbed at the will and pleasure of every individual, in order to gratify vindictive and litigious feelings. Hence, it would seem to follow, that whenever, on the trial of a cause, from the state of the pleadings in it, the record of a judgment rendered by

\footnotetext{
${ }^{1}$ Burt $v$. Sternburgh, 4 Cow. 559; 3 Cow. 120; 15 Am. Dec. 250; Miller $15 \mathrm{Am}$. Dec. 402; Garuner v. Buckbee, $v$. Nanice, 6 Hill, 114.
} 
a competent tribunal upon the merits in a former action between the same parties, or those claiming under them, is properly given in evidence to the jury, that it ought to be conclusively binding on both court and jury, and to preclude all further inquiry in the cause; otherwise the rule or maxim expedit republica ut sit finis liium, which is as old as the law itself, and a part of $i t$, will bo exploded and entirely disregarded. But if it be a part of our law, and it seems to be admitted by all that it is, it appears to me that the Court and jury are clearly bound by it, and not at liberty to find against such former judgment. A contrary doctrine, as it seems to me, subjects the public peace and quiet to the will or neglect of individuals, and prefers the gratification of a litigious disposition on the part of suitors, to the preservation of the public tranquillity and happiness. The result, among other things, would be, that the tribunals of the State would be bound to give their time and attention to the trial of new actions for the same causes, tried once or oftener, in former actions between the same parties or privies, without any limitation other than the will of the parties litigant, to the great delay and injury, if not exclusion occasionally, of other causes which never have passed in rem judicatem. The efiect of a judgment of a cour' having jurisdiction orer the subject matter of controversy between the parties, even as an estoppel, is very different from an estoppel arising from the act of the party himself in making a deed of indenture, etc., which may or may not be enforced, at the election of the other party; because, whaterer the parties may have done by compact, they may undo by the same means. But a judgment of a proper court, being the sentence or conclusion of law upon the facts contained within the record, puts an end to all further litigation on account of the same matter, and becomes the law of the case, which cannot be changed or altered, even by consent of the parties, ard is not only binding upon them, but upon the courts and juries ever afterward, so long as it shall remain in force and unrerersed." In a case in Naine, the Supreme Court, declining to pass upon the question, because it was not then material, stated that when it necessarily arose, they should give it a very careful consideration before they would hold

\footnotetext{
${ }^{1}$ See also Cist $v$. Zeigler, 16 S. \& R. 5 Conn. 550; 13 Am. Dec. 94. 573; 16 An. Dec. 573; Detts $v$. Starr, 
"that the conclusiveness of judgments and the consequent peace of the community, and the convenience of fresh litigants shall depend upon the option of persons litigiously disposed, or upon the accuracy of pleaders." Following this intimation, and, it is to be presumed, upon careful consideration, this court subsequently decided that a former judgment might be pleaded as an estoppel, or given in evidence under the general issue, and that whichever course was pursued, the result is the same. " In Illinois, the courts "do not sanction the technical distinction which makes a former recovery a bar only when pleaded as an estoppel;" and believe that the rule adopted by them "is cloubtless the safer rule, and the one alone upon which an end may bo made to litigation, and unsuspecting imnocence and right may repose regardless of, and undisturbed by, technical rules of pleading." ${ }_{4}$ In Tennessee, ${ }^{5}$ Vermont, ${ }^{6}$ Iowa, ${ }^{7}$ Maryland, ${ }^{8}$ and New Hampshire, ${ }^{9}$ any judgment or decree, whenever properly in evidence before the court or jury, is as conclusive as if specially pleaded as a bar.

Aside frem considerations of public policy, which seem to have influenced some of the American decisions just cited, they seem to be more sustainable than the line of decisions with which they are in conflict. If we concede that principles founded in public policy do not prohibit the parties to an adjudication from re-opening, by mutual consent, matter's already litigated, and from indulging their litigions dispositions to an unlimited extent, it does not follow that a court or jury should be at liberty to re-investigate matters which have been before judicially investigated and determined, when that determination is properly placed before such court or jury to influence the decision in the second action. If the judgment is admissible in any case under the general issue, its admission ought to produce some well defined and unavoidable result. It ought to be received as

\footnotetext{
1 Sturtevant $v$. Tandall, 53 Mai.149. 7 George v. Gillespie, 1 Iowa, 421.

${ }^{2}$ Walker $v$. Chase, 53 Mai. 258. $\quad{ }^{8}$ Beall $v$. Pearre, 12 1Id. 550; Shaf-

${ }^{3}$ Vallandingham $v$. Tiyan, 17 Ill. 25. fer $v$. Stonebraker, 4 G. \& J. 345.

4 Gray v. Gillilan, 15 Ill. $453 . \quad 9$ Chamberlain $v$. Carlisle, 6 Foster, 238.

5 Warwick $v$. Underwood, 3 Head. $5 \pm 0$; Ting v. Chase, 15 N. H. 9; Tay6 Blodgett $v$. Jordan, 6 Verm. 580 . lor v. Dustin, 43 N. II. 493.
} 
conclusive of all the questions settied by it, or rejected altogether. To admit it in evidence, with the understanding that it may be regarded or disregarded, at the pleasure of the court or of the jury, is to establish a rule which authorizes the final determination of the rights of parties, not according to settled and unvariable principles, but at the mere caprice of men. Every law and every interpretation of law must be imperfect and unjust, if, when applied to identical facts, it may result in diametrical judgments. Under the decisions, leaving the effect of a former recovery to the caprice or discretion of a court or a jury, it may happen, that of two actions, each supported by the same evidence and involving the same issues, a part of the evidence in each case being the record of a former recovery, one action may result in a judgment for plaintiff and the other in a judgment for defendant, and yet the two adverse judgments be equally consistent with law. If the failure to plead a former adjudication in bar is a waiver of the benefits accruing under it, then it should not be allowed to be placed in evidence in the second action. But why should a party be deemed to waive a matter while his pleadings are such that he may lawfully present it in evidence before the jury? Why should the court or jury be at liberty to consider a matter as waived which is included in the issues, established by the evidence, and relied upon at the argument? The English rule is inconsistent with itself. It treats a former adjudication as inconclusive, because not specially pleaded; but permits it to be given in evidence, in order that the jury may, if they choose, give it as conclusive an effect as if it were pleaded specially. In the United States this inconsistency will, in time, undoubtedly disappear. In some of the States the rules of pleading are now so altered as to require a former adjudication to be specifically alleged by the party relying upon it, before it can be given in evidence. Other States will probably adopt the same rule. But where the common law system of plealing is retained, a judgment will, no doubt, at some not far distant day of the future, whenever received in evidence, be carried into effect irrespective of the question whether it was admitted under the general issue or in support of a special plea. 


\section{PART VI.-ACTIONS TENDING TO CONTRADICT FORMER JUDG- IIENT.}

8. 2S4 $t$.-Defenses and Causes of Action once presented and considered can not be again asserted in another suit without a violation of the principles of res judicata. But the obstinacy with which litigants press their claims upon the attention of courts, is such that it is not uncommon for matters once fully determined to be again made, or at least attempted to bo made, the subjects of judicial inquiry. Sometimes the circumstances attending the former decision are such as to render the application of the law of res judicata apparently a matter of great injustice. Hard cases havo loug been characterized as the quick sands of the law. Such cases are quicksands in which the law of res judicata sometimes sinks so far that the judges are entirely unable to see it, or even to remember it. Generally, however, such is not the case; and the instances are comparatively fow in which any cause of action or any matter of defense is allowed to prevail where it is inconsistent with the facts necessary to uphold any previons adjudication between the same parties. Therefore a plaintiff taking judgment for too small a sum, without the fraud or fault of his adversary, can not maintain a subsequent action to recover the remainder; ${ }^{1}$ nor can a defendant avoid the effect of a judgment against him by showing that the debt on which it was based was void for want of consideration, or that such debt had been merged in a former judgment. ${ }^{2}$

7 2S5. Suits for Payments not Credited.-A few cases have been decided, mainly, if not exclusively, in Massachusetts, in which causes of action have been recognized and enforced, in direct opposition to a former judgment. In the first of these cases, a note was placed in the hands of an attorney for collection. After collecting a portion of the sum due, he failed to give the proper credit, and thereafter sued and recovered judgment for the full amount of the note. The debtor was permitted, while the original judgment remained in force, to maintain an action against the attomey for money had and received, on the ground, that when the

1 Ewing v. McNairy, 20 Ohio, S. 316. | 2Lewis v. Armstrong, 45 Geo. 131. 
attorney received the payment, there arose an implied trust that he would credit it on the note. ${ }^{1}$ In a later case, the same remedy was held to be available in behalf of a debtor against whom, after reception of a partial payment, tho creditor had taken judgment by default for the whole sum.2 In the same State, A., having obtained judgment against B., and extended his execution ipon certain real estate, thereby became a tenant in common with C. A. then sued C. for a share of the rents and profits of the estate, and obtained a judgment, which C. paid. After this, A.'s judgment against B. was reversed on writ of error. C., while the judgment against him was still unaffected by any proceeding directed against it, was permitted to recover from $\mathrm{A}$. the money paid to obtain its satisfaction, on the ground that, from circumstances occurring since the payment to him, A. hail no right to retain the money. ${ }^{3}$ Where an action, on a judgment rendored in Kentucky, was brought in Texas, the defendant was permitted to avoid it, in part, by proving that, during the progress of the former suit, he resided in the last named State; that he paid a part of the demand before judgment, pendente lite, and reposed confidence in the plaintiff in Kentucky to make the proper credits, who had failed to do so. ${ }^{4}$

\section{\& 2S6. Suits for Credits not Allowed.-There can be} no doubt that these decisions are in direct conflict with the true rule upon the subject; that they were induced by yielding to the hardship of the particular cases in which they were pronounced, and are good illustrations of the maxim, "that hard cases make bad precedents." 5 They are altogether inconsistent with a vast number of English and American authorities. "It is clear, that if there be a bona fide legal process under which money is recovered, although not actually due, it can not be recovered back, inasmuch as there must be some end to litigation." ${ }^{6}$ A party having

1 Fowler $v$. Shearer, 7 Mass, 14 . payments on articles sold, and who in

a Rowe $v$. Smith, 16 Mass. 306. See an action for the price of such articles Loring $v$. Mansfield, 17 Mass. 394.

3 Lazcll v. Miller, 15 Mass. 207.

4 Clay v. Clay, 13 Tex. 195.

5 Smith's Lead. Cas. vol. 2, p. 667. 2. Cameron, 1 Kerr, (Now Brunswick)

6 Duke de Cadaval $v$. Collins, 4 Ad. 542.

\& El. $867 .-\Lambda$ party who has made

330 
found a receipt for a debt which he had been compelled to pay by judgment, having sought to recover back the money paid, Lord Kenyon, before whom the case came, said: "I am afraid of such a precedent. If this action could be maintained, I know not what canse of action could ever bo at rest. After recovery by process of law, there would be no security for any person." 1 To a similar effect is the opinion in a recent English case, denying the right to recover back part of a debt paid before judgment, but which plaintiff did not credit. "It is not," said the court, " competent to either party to an action, to aver anything either expressing or importing a contradiction to the record, which, while it stands, is, as between them, of uncontrollable verity." a Substantially the same view is taken in nearly all of the United States. The only remedy of the defendant in such cases, is by appeal, new trial, proceedings in chancery, or in the nature of an andita querela. ${ }^{3}$ And no doubt equity would not interfere in his behalf, unless the failure to present his defense of payment was occasioned by accident, surprise, or mistake, or the fraud of the opposite party, unmixed with any contributory fault or negligence of the complainant. ${ }^{4}$ In the case of Binck v. Wood, 43 Barb., p. 315, it was decided that the maker of a promissory note, against whom a judgment by default had been taken, could not recover for any payment made on the note prior to the suit, and not considered as a credit in entering judgment. The authorities on tho subject were reviewed. The early cases in Massachusetts were thought to be inconsistent with the later case of Loring v. Mlansfield, 17 Mass. 394. The case of Smith v. Willes, 26 Barb. 463, was overruled; and the other cases in New Iork, as well as those in the other States, and in England, were deelared to unanimously sustain the view, that while a judgment is permitted to stand, no money paid upon it can be recovered. If, after the rendition of a judgment, any facts occur making it clear that

1 Iarriott $v$. IIampton, 7 T. R. 269; $v$. Francisco, 3 MIunf. 83; James v. ssa, also, Phillips $v$. Lunter, 2 H. Dla. Cavit, 2 Brev. 174; Stephens $v$. Howe, \$10.

${ }^{2}$ Iufter v. Allen, 12 Jur. N. S. 930, and 2 Law. R. Exe. Cases, 15.

${ }^{3}$ Kirklan $v$. Broun, 4 Humph. 17. Corbet v. Evans, 25 Pa. St. 310; Tilton v. Gordon, 1 N. II. 28; Le Grand 127 Mass. 164; Greenabaum v. Elliott, 2 Cent. L. J. 439.

"Doyle $v$. Tieilly, 13 Iowa, 103.

5 They surely are at variance with Stephens $v$. Howe, 127 Míass. 164. 
the judgment should not be enforced, relief may be given in equity, or an action for money had and received may be maintained. ${ }^{1}$ Even in Massachusetts, no action can bo sucessfully prosecuted to recover back usurious interest included in a judgment which defendant has satisfied. ${ }^{2}$

\section{8,287. Suits for Money Paid on Judgments where De-} fenses are Concealed.-A. brought an action against $B$. to recover the insurance on a lost vessel, and secured a judgment, which was paid. B. subsequently commenced suit to recover back the money thus paid, on the ground that the vessel was alrearly lost when the insurance was effected; that he did not know of such loss when the former judgment was obtained, and that such loss was fraudulently concealed by A. The former judgment was determined to be a bar, because "provision being made by the statute for a review of judgments within a time thought reasonable by the Legislature, it must be supposed that a limit was intended of the right of parties to complain of the wrong done," and because no reported case could be found "in which the merits of a decided cause have been allowed to be re-examined in any independent action." 3 If an agreement be made to extend the time for payment of a note, this constitutes a matter of defense, which, if not presented, is lost. No action can, therefore, be sustained for a violation of the agreement. But it is otherwise if the agreement be not to sue for a limited time. ${ }^{4}$ A quantity of wheat was purchased, and a nominal sum paid to bind the bargain. The vendee afterwards sued the vendor for non-delivery, and recovered judgment for full value of the wheat. The vendee then sued for the price agreed to be paid for the wheat. The action, it was decided, could not be maintained. The rendee should have insisted on a proper measure of damages. Not having done so, he could not succeed in a cross action. 5

\section{\& 28S. Actions by Third Persons. - The general rule} that the law will not allow money paid upon legal process to

\footnotetext{
${ }^{1}$ Smith v. McCluskey, 45 Barb. Dec. 218; First Presbyterian Church 610. $v$. New Orleans, 30 La. An. $2 \check{5} 9$.

${ }^{4}$ Pearl $v$. Wells, 6 Wend. 291.

5 Dey r. Dox, 9 Wend. 129; $24 \mathrm{Am}$. Footman $v$. Stetson, 32 Maine, 17.

${ }^{3}$ Homer $v$. Fish, 1 Pick. 436; 11 Am. Dec. 127.
} 
be recovered back, does not apply where the transaction is res inter alios acta. The assignee of a bankrupt not being in privity with him, may recover money taken from the bankrupt, under execution, after his act of bankruptcy. ${ }^{1}$

\section{2S9. Suits for Obtaining Judgments by Fraud, Con-} sp:racy or Perjury.-The settled policy of the law, forbidding that a matter once adjudicated shall be again drawn in issue while the former adjudication remains in force, does not permit the prosecution of an action for obtaining a judgment by false and fraudulent practices, ${ }^{2}$ or by false and forged evidence. ${ }^{3}$ Neither can a party against whom judoment has been recovered, sustain an action against his adrersary, and the witnesses for damages occasioned by their conspiring together and procuring a judgment by fraud or perjury, as long as judgment remains in force and unrerersed; becanso the charges made in the second action are conclusively negatived by the former adjudication. ${ }^{4}$ Where in process of foreign attachment, a judgment has been entered, discharging the trustee on his disclosure, the plaintiff cannot sustain an action on the case against the trustee, for obtaining his discharge by falsehood or fraud in his disclosure, and by fraudulent collusion with the principal defendant. The action against the trustee would, if it wero allowable, involve a re-examination of the questions determined by his discharge when summoned in the former suit. ${ }^{5}$ The defendant, in a judgment of foreclosure, cannot sustain an action to recover on account of usurious interest included in the judgment. The fact of usury, if it existed, was available as a defense in the former suit; and whether pleaded as a defense or not, is conclusively negatived by the decree of foreclosure. ${ }^{6}$ In Kentucky money coerced from defendant through a judgment procured by fraud, may be recovered back from him by an action in equity withont

${ }^{1}$ Follett $v$. Hoppe, 5 C. B. 243; | citing Damport v. Sympson, Cro. Eliz. Phillips $v$. Hunter, H. Bla. 402. 520 , and Eyres $v$. Sedgewicke, Cro.

${ }^{2}$ Hillsborough $v$. Nichols, $46 \mathrm{~N}$. H. 379.

${ }^{3}$ Note 265 , by C. H. \& E. to Ph. Ev.

* Dunlap v. Glidden, 31 Mai. 435, Jac. 601 .

${ }^{5}$ Lyford $v$. De Merritt, 32 N. H. 234.

${ }^{6}$ Heath $v$. Frackleton, 20 Wis. 320 . 
racating or otherwise setting asido the original judgment. $^{1}$

8 2892. A judgment for plaintiff in an action for goods sold and delivered, is a bar to a subsequent suit by defendant for nun-clelivery of the same goods.?

8 290. Motion for Satisfaction.-The recovery of judgment, being conclusive of the amount due, and that the plaintiff is the person to whom it is due, a motion for entry of satisfaction on the ground that plaintiff was not the real party, and that the cause of action belonged to another person, to whom payment has been made since the entry of judgment, is inconsistent with the judgment. Hence no evidence in support of the motion can be heard. ${ }^{3}$

\& 291. Failure to Give Credit as a Consideration for a Fromise.-While the defendant cannot, leaving the judgment in force, recover of plaintiff a sum which ought to have been credited but was not, it seems that a promise made after judgment, to allow credit for a payment mado prior to judgment, may be proved by defendant in an action against him on the judgment. This evidence was considcred as admissible, on the ground that, without directly contradicting the judgment, it disclosed a state of facts constituting sufficient consideration for the promise of the plaintiff to credit the amount, and that such amount was to be treated as money paid on the judgment. 4 In this instance a consideration for the promise to credit on the judgment was essential to the defendant's partial defense to the second action. In order to establish this consideration, the court listened to evidence whose only object was to show that the former judgment was unjust, and that not to take advantage of its unjustness, was a suffeient moral obligation to sustain the promise. In proving this consideration, it therefore, appears to me, that the former judgment was assailed, and the principle of res judicata violated.

8 292. Cases in which Recovery Back was Permitted. Where A. having sued B., who settled, paying $\$ 3$ as a

1 Ellis v. Kelly, 8 Bush, 621; West v. Kerby, 4 J. J. Marsh, 56.

${ }^{2}$ Smith $v$. Kelly, 2 Hall's Rep. 217.
${ }^{3}$ Mervine v. Parker, 18 Ala. 241.

4 Thayer $v$. Mowry, 36 Mai. 257. 
full discharge of A.'s claim, who thereupon agreed to dismiss his suit, but who, instead of doing so, took judgment for $\$ 25, \mathrm{~B}$. was permitted to maintain an action for clamages, in not dismissing according to his agreement. ${ }^{1}$ No doubt that, although the second suit is predicated upon matters which might have been used as a defense in the first, yet if it involves no inquiry into the merits of the former judgment, and is sustainable on grounds entirely independent of such judgment, the rule inlibiting re-litigation of decided issues is in no danger of violation. But great contrariety of opinion is likely to become manifest in deciding whether a second suit is sustainable on grounds not involved in the first, and actions will no doubt occasionally be prosecuted with success, and result in a seeming disregard of some formor adjudication. Thus, in Whitcomb v. Williams, 4 Pick. 223, the plaintiff, having purchased goods of the defendants, paid them partly in cash and partly by his note. He afterwards discovered that he had paid for more than he received; but, nevertheless, he suffered judgment to be taken against him on the note, without interposing his defense of want of consideration. He then sued to recover back the amount paid on this judgment, and prevailed, because, in the opinion of the court, the giving of the note was equivalent to payment for the goods, and a cause of action immediately arose, and steered clear of the note and tho judgment thereon; and though the mistake might have been corrected in the suit on the note, yet that the plaintiff had a right of election, as in cases of set-off.

PART VII.-THE EFTECT OF JUDGMENTS IN VARIOUS ACTIONS.

FIIST-IN ACTIONS INVOLVING TITLE TO, OR THE POSSESSION OF, REAL ESTATE.

7. 293. Distinction between Appication of Pes Judicata to Real and to Personal Actions.-The high regard of the people among whom the common law grew into being for real property, evinced itself in a vast variety of ways in the different branches of that law; and in none of those branches did it make itself moro evident than in that regulating the

1 Cobb v. Curtiss, 8 Johns. 470. 
effect of former adjudications. The pursuit of any of the forms of personal action to a judgment on the merits, completely barred all other actions based on the same right, in every other form. But that the law gave "consecutive remedies for injuries to real estate is recognized in all the books that treat on real actions. It is stated by Booth, in the first page of his book. He recommends beginning with the lower rather than with the higher remedy; for, he says, 'a recovery in that of the lower nature will not be a bar to an action of a higher nature, and therefore it is not prudent to set forth a writ of right, when you may have a writ of entry." ", $\mathrm{He}$ cites Ferrer's case, 6 Coke, 7 . In that case, it was decided that there was a difference between real and personal actions; that in personal actions the bar is perpetual, for the plaintiff can not have an action of a higher nature; but if demandant be barred in a real action by judgment, he may have an action of a ligher nature to try the same right again." In Viner's Abridgement it is said that "a recovery in assize is no bar to a formedon. A recovery in assize is a bar to another assize, but not in mort d'ancestor; nor is a recovery in mort d'ancestor a bar to a writ of right." $\mathrm{Un}$ der the common law system of procedure, "a judgment, therefore, in each species of action is final only for its own proper purpose and object, and no further. A judgment in trespass affirms the right of possession to be, as between plaintiff and defendant, in the plaintiff at the time the trespass was committed. In a real action it affirms a right to the freelold of the land to be in the demandant at the time of the writ brought. Each species of judgments, from one in an action of trespass to one upon a writ of right, is equally conclusive upon its own subject matter." "A bar in a real action, by judgment on demurrer, confession, verdict, etc., is a bar to any other action of the like nature for the samething, which is the case likewise in personal actions, but in personal actions the bar is perpetual, and the defendant has no remedy but by writ of error or attaint. In real actions on the contrary, if a man is barred by judgment in one action, he may bring another of a higher nature, anu

1 Arnold $v$. Arnold, 17 Pick. 4. 3 Outram v. Morewood, 3 East. 346.

2 Viner's Ab. Judgment, Q. 
try the same right again. Thus if barred in an assize of novel disseisin, yet upon showing a descent or other special matter, he may have an assize of mort d'ancestor, a writ of aiel, or besciel, or of entry sur disscisin to his ancestor. So if a man is barred in a formedon in descender, yet he may have a formedon in reverter or remainder, for that is an action of a higher nature, and in which the feo simple is to be recovered. But a recovery in assize is a bar to every other assize, and in a writ of entry in nature of an assize, for they are both brought upon the plaintiff's own possession, and are of the same nature, and a judgment in a writ of aiel is a bar in a writ of besaiel or cosinage, for they are both ancestral actions of the same nature."1

8. 294. Common Recovery.-A judgment in commor recovery is as conclusive as in any other case. It can not be collaterally assailed, except for fraud, or, as in other real actions, because the defendant was not a tenant of the freehold. If there be a proper tenant of the freehold, all the expectant interests are involved in the result. The issue in tail can not falsify any point tried by the action. The judgment is, that demandant recover his title to the land. No one, claiming under the title represented by the tenant in precipe, can avoid this judgment otherwise than by writ of error. If there was no such judgment against the voucher as would give to those in remainder the nominal recompense which belongs to the form, this does not avoid the judgment, but only affects its regularity. ${ }^{2}$

8 295. Ijectment at Common Iaw.-At common law, a judgment in ejectment is not, in any case, conclusive upon the tille of either of the parties." "It is a recovery of the possession without prejudice to the right, as it may afterward appear, even between the same parties." 4 Its only

${ }^{1}$ Roscoe on Real Actions, p. 213, Pollard v. Baylors, 6 Munf. 433; citing Com. Dig. Action (K. 1 \& 3); Holmes v. Carondolet, 38 Mo. 551; Robinson's Case, 5 Rep. 32 b. ; Cow- Smith $v$. Sherwood, 4 Conn. 276; 10 per $v$. Andrews, Hob. 40; Mary Portington's Case, 10 Rep. 3Sa.

${ }^{2}$ Ransley $v$. Stott, 26 Pa. St. 126; 1 Rolle, 447; 3 Bulst. 247.

${ }^{3}$ Mitchell $v$. Robertson, 15 Ala.412; Jackson $v$. Dieffendorff, 3 Johns. 270. Hinton v. McNiell, 24 Am. Dec. 315; 
eflect "is to put plaintiff in possession, according to his right and title in the premises." "It is always in the power of the party failing, whether claimant or defendant, to bring a new action. The structure of the record also renders it impossible to plead the former recovery in bar to tho second ejectment; for the plaintiff in the suit is only a fictitious person, and as the demise term, etc., may be laid in many different ways, it can not be made to appear that the second ejectment is brought upon the same title as the first." : Several verdicts in favor of the same party, and his adversary's accepting a lease and promising to give no more trouble, are not conclusive against the latter. ${ }^{3}$.But, notwithstanding its inconclusive efeect, a judgment in ejectment seems to have, even at common law, been admissible in evidence in a second ejectment, where the parties were substantially the same as in the first; and to have been allowed to go to the jury in the second action, to be by them treated as persuasive, though not conclusive evidence of the facts upon which it was based.4 "The inconclusiveness of a verdict and judgment in ejectment is clue to the form of the action, not to the character of the subject matter of the controversy. There is no charm about land, as land, which relieves it from the operation of the general rule, that a judgment between same parties, or their privies, directly upon the same matter, is the end of the controversy. That it is an estoppel against future litigation of the same question, is evident, from the fact that a fine, a common recovery, a simple judgment on a writ of right, and, indeed, judgments in any real action, have always been held conclusive." 5

\section{\& 296. In Ejectment upon Confession. - In Kentucky,} the fact that the judgment in ejectment was rendered upon confession, does not make it more conclusive than if it were based on the verdiet of a jury; ${ }^{\circ}$ but in Pennsylvania, the

\footnotetext{
1 Minke v. MIcNamee, 30 MIl. 294. Doe $v$. Wright, 10 A.\& E. 763; Thomp-

2 Adams on Ejectment, 351.

3 Richardson $v$. Stewart, 2 S. \& R. 375. 87. son $v$. Hall, 31 Upper Canada Q. B. ${ }^{5}$ Stevens $v$. Hughes, 31 Penn. St.

4 Doe v. Seaton, 1 Tyx. \& G. $19 ;$ S. 381. C. 2 C. MI. \& C. 728; Wright $v$. Ta- ${ }^{6}$ Botts $v$. Shields, 3 Litt. 32. tham, 1 A. \& E. 3; Bull, N.P. 232 b; 
rule is otherwise. A judgment by confession in ejectment is there "treated as a solemn judicial confession of want of litle; a.total and unconditional surrender of the field of controversy, and as such, conclusive forever on the defendant and all his privies."

8297. In Actions for IrIesne Profits.-In actions for mesne profits, a judgment in ejectment is, as against defendant, conclusive evidence of title in the lessor of the plaintiff from the time of the demise laid in the declaration, and that he was not in possession at the institution of his ejectment suit. Beyond the time laid in the demise it proves nothing, because beyond that time the plaintiff alleged nothing; nor does it prove that the plaintiff was not in possession between the date laid in the demiso and the commencement of the action. ${ }^{3}$

8. 29S. Payment of Costs. - The action of ejectment is said to be peculiarly a creation of the court. The court will so far control its creation as to stay proceedings in the second suit, if the costs resulting from failure in a former suit remain unpaid, ${ }^{4}$ if it appear that the second action turns on the same question of titlo as the first, though a different parcel of land be claimed and a different person bo made defendant. ${ }^{5}$ This seems to be the only power which the courts have reserved by which, if need be, to prevent this, their creation, from perpetually harassing the occtpants of real estate, by the repeated assertion of pretensions whose worthless character has been judicially ascertained.

2 299. Ejectment, Miodified by Statutes.-Wherever the common law form of ejectment is abolished, and the action is commenced by the parties in their own names, the judgment is an estoppel, a valid bar to any subsequent action, unless the privilege of commencing another is given

\footnotetext{
${ }^{1}$ Secrist $v$. Zimmerman, 55 Penn. S. 446 .

${ }_{2}$ Shumake $v$. Nelm's Admr., 25 Ala. 126 ; note 270 by C. H. \& E. to Ph. Er; Buntin v. Duchane, 1 Blackf. 56; Aslin v. Parkin, 2 Burr. 666; Dewey $v$. Osborn, 4 Cow. 329; Doe v. Langs, 9 Upper Canada Q. B. 676; Thompson v. Hall, $31 \mathrm{Ib}$. 376; West v. Hughes, 1 H. \& J. 574; 2 Am. Dec. 539; Crockett v. Lashbrook, 17 Am. Dec. 98; Hinton v. McNeil, 5 Oh. 509; 24 Am. Dec. 315.

A judgment by default in ejectment is, in England, grood evidence of title for plaintiff in an action for mesne profits; but is not even mima facie evidence that defendant was in possession. (Pearse v. Coaker, 4 Law. R. Exq. Ca. 92.)

${ }^{3}$ TVest $v$. Hughes, 2 Am. Dec. 539; 1 II. \& J. 574 .

${ }^{4}$ Danvers $v$. Morgan, 17 C. B. 530.

${ }^{5}$ Doe on Demise Brayne v. Bather, 12 Q. B. 941. 
by statute. Technically and substantially, under the form of procedure in which the action to recover real estate is conducted in the name of the real claimant, who need not depend for his success on anything but his tille, we no longer have an action of ejectment. "TWe can see no reason why a judgment upon a matter in regard to realty, once put in issue, litigated and determined, whether it be title, right to present possession, or something else, should not be conclusive, as well as when it relates to personalty. No principle of the common law would be violated by such a result. Nor would it be contrary to any principle of public policy. The form of the complaint in an action to recover real estate may be adapted to the estate sought to be recovered, and the facts desired to be put in issue." ${ }^{2}$ A judgment in ejectment, like every other final adjudication, bars only the causes of action and matters of defense put in issue in the former suit, or which, if not put in issue, were of such a nature that the neglect to put them in issue was an irrevocable confession of their non-existence. ${ }^{3}$ If the plaintiff sue for two parcels of land and recover but one, or for a large tract and recover but a part thereof, the judgment, though silent as to the part not recovered, is nevertheless conclusive that the plaintiff was not entitled thereto. ${ }^{4}$ No doubt the parties in their pleadings may limit their controversy to a particular title. ${ }^{5}$ But in the absence of any limitation made by the pleadings, the defendant must, at his peril, protect all his rights in the land, or connected therewith. If, after erecting buildings, he suffer judgment to be taken against him for the possession of the land, he cannot surrender possession and afterward maintain an action against the plaintiff for the value of the buildings. ${ }^{6}$

8 300. What Pleadings Involve Title.-If the complaint allege that plaintiff was, at a specified time, possessed of lands, and that he claims such lands in fee simple absolute, and that being so possessed thereof, and being so the owner thereof, the defendant entered and ejected plaintiff,

\footnotetext{
1 Sturdy $v$. Jackaway, 4 Wall. 174; ${ }^{2}$ Caperton $v$. Schmidt, 26 Cal. Miles v. Caldwell, 2 Wall. 35; Beebe 479.

v. Elliott, 4 Barb. 457; Sheridan v. Andrews, 3 Lansing, 129; Campbell $v$. Hall, 16 N.Y. 575; Castle $v$. Noyes, 14 N.Y. 329; Fitch v. Cornell, 1 Saw. C. C. 156; Oetgen v. Ross, 54 Ill. 79; Doyle v. Hallam, 21 Minn. 515.

${ }^{3}$ Foster $v$. Evans, 51 Mo. 39.

${ }^{4}$ Thompson $v$. McKay, 41 Cal. 221;

Woodin $v$. Clemons, 32 Iowa, 280.

${ }^{5}$ Marshall $v$. Shafter, 32 Cal. 176.

${ }^{6}$ Doak v. Wiswell, 33 Maine, 355.
} 
etc., it tenders an issue of tille. If to this complaint tho defendant make a general denial, a subsequent judgment for defendant is conclusive upon all the titlo held by the plaintiff at that time." "It must be admitted by every one that a recovery operates as an estoppel to this extent, to preclude the losing party from denying that, as to him, the prevailing party was, at the time of the rendition of the judgment, entitled to the possession. It would seem necessarily to follow that in order to avoid the estoppel, the losing party must show other right to possession than that which he had when the estoppel was created. He is bound to show such right, becanse his former claim of right was determined by the recovery."

\& 301. Issues Concluded by Judgment in Ejectment.Uuder the code a judgment in ejectment is conclusive of but two points: the right of possession in plaintiff at the commencement of the suit, and the occupation of the premises by the defendant at the same date. At common law the judgment was, in an action for mesne profits, conclusive of title at the time of the alleged demise. Under our practice the rule is different, becauso the plaintiff is entitled to recover upon proof of right to the possession at the commencement of his suit; and an allegation, on his part, in relation to the date of the acquisition of his title is immaterial."

\& 302. Avoiding Effect of Former Judgment.-Whenever, in an action for possession of realty, the question of title is put in issue by the pleadings, the judgment, prima facie, constitutes an estoppel to the assertion of any titlo which existed in the losing party at the time of the former suit. To avoid this estoppel he may show that, by reason of some lease or license, his title conld not be asserted in the former suit." Judgment in ejectment never affects after acquired title. Therefore a defeated party may, in any subsequent suit, show, by parol or otherwise, that the riglit to the possession has come to hini since the former suit. ${ }^{5}$

\& $302 a$. Judgments in Actions of Forcible Entry and Unlawful Detainer are, to the same extent as judgments in other actions, conclusive upon the questions within the

1 Marshall v. Shafter, 32 Cal. 176. ${ }^{4}$ Sherman v. Dilley, 3 Nev. 21; ${ }^{2} \mathrm{Ib}$.

Chase $v$. Irvin, 87 Pa. St. 286.

${ }^{3}$ Yount $v$. Howell, 14 Cal. 465; Sat- ${ }_{5}^{5}$ Miahoney $v$. Van Winkle, $33 \mathrm{Cal}$. terlee $v$. Dliss, 36 Cal. 489. 448; Emerson $v$. Sansome, 41 Cal. 552. $\check{3} 41$ 
issues, and determined by the conrt or confessed by tho parties. ${ }^{1}$ The title to the property is never in issue in these actions; and therefore the judgment, whether for plaintiff or defendant, can not affect the title. ${ }^{1}$ The failure of plaintiff to recover in such an action is a bar to his subsequent recovery upon the same cause of action; but does not preclnde him from sustaining the second suit if he can show that from failure to give the requisite notice, or from some other canse, since removed, the former judgment was rendered against him. ${ }^{2}$

\& 303. Judgments of Foreclosure.-The judgment in a writ of entry to foreclose a mortgage is conclusive on all the title held by defendant at the date of the judgment. ${ }^{3}$ If the defendant in a foreclosne suit answers, claiming the whole equity of redemption, and the complainant makes no replication, the decree will be conclusive on the latter, so that he can not afterwards set up other claims." Where a bill was opposed by the widow of the deceased mortgagor, on the ground that the property mortgaged was hers, and the conrt found that the husband had a life estate, and directed such estate to be sold, it was held that the rights of the mortgagees were thereby confined to the lifo estate, and that they could not, in any subsequent action, show that the samo property belonged absolutely to the husbaud. ${ }^{5}$ In an action for foreclosure no rights onght to be litigated except those which are claimed muder the mortgagor. If the court undertakes to determine claims hostile to the title of the mortgagor, its decree will certainly be erroneons and liable to reversal in an appellate court; but it is not coram non judice and void. On the contrary, it is valid until reversed, and is not subject to any collateral attack. ${ }^{6}$ But the priority of respective liens is a proper question to be determined in a foreclosuro suit. If a decree disposes of the question of precedence between two mortgages, it is fiual upon that point, thongh the bill neither asked for such a decision nor for general relief. The words, "that it is ordered, adjudged and decreed that the defeudants and all persons claiming under them, or either of them, since the

${ }^{1}$ Dale $v$. Doddridge, 9 Neb. 13s; ${ }^{4}$ Tower $v$. White, 10 Pai. 395.

Beeler $v$. Cardwell, 29 Mo. 72; Harvie ${ }^{5}$ Manigault $v$. Holmes, 1 Bai. Eq. $v$. Turner, 46 Mo. 444.

${ }^{2}$ Merrin $v$. Lewis, 90 Ill. 505. $2 S 3$.

${ }^{3}$ Shears v. Dusenbury, 13Gray, 292. $\mid$ R. Co., 24 Wis. 121. 
commencement of this cause be forever barred and foreclosed of their equity of redemption, and claim of, in or to the mortgaged premises, and every part and parcel thereof," are sufficient to show the decision of a question of priority and to prevent its being again contested." If specified persons be made defendants, and it be alleged that they claim some interest in the premises "as subsequent purchasers or incumbrancers, or ollerwise," a general decree will preclude them from asserting any rights acquired from the mortgagor after the execution of the mortgage. But it will not divest any rights held paramount to the title of the mortgagor, when he executed the mortgage. ${ }^{2}$ The right of the wife of the mortgagor to dower, is such a paramount right, if she be made party, after becoming a widlow, to a suit to foreclose a mortgage executed by her husband alone, and no allegation be made in the bill in reference to her claim for dower, the decree will not be considered as affecting her dower estate. $^{3}$ But if the adverse claim of a party be set up, and in fact litigated, the decree is binding on him. The homestead interest is necessarily disposed of by a decree to which both husband and wife are parties; and the latter can not, therefore, successfully resist an action for property sold under an order of sale issued in a foreclosure suit, to which she was a party, on the ground that the land sold is her homestead."

\& 303a. Judgments Affecting Right of Dower.-It seems that in order to conclude the wife's right of dower it must, in all cases, be necessarily and specifically put in issue, whether the proceeding be to foreclose a mortgage to which the wife was not a party, or to enforce any other claim to which her right of dower was paramount. II. and wifo conveyed their real property to his brother. Mr.'s creditors subsequently recovered judgment against him and obtained the appointment of a receiver. This receiver obtained $a$ judgment against $M$. and wife, and M.'s brother declaring tho conveyance fraudulent and void as to creditors, and directing a sale of the premises, and that the parties in possession should deliver possession to the purchaser. Prior to the sale M. died. His wife brought an action to recover

\footnotetext{
${ }^{3}$ Board of Supervisors v. M. P. R. $\quad{ }^{3}$ Lewis $v$. Smith, 9 N. Y. 502.

R. Co., 24 Wis. 123 .

${ }^{2}$ Frost $v$. Koon, 39 N. Y. 444, cit- Baxter $v$. Dear, 24 Tex. 17.

ing Lewis $v$. Smith, 11 Barb. 156;

Bank of Orleans $v$. Flagg, 3 Larb. Ch.

318; Elliott $v$. Pell, 1 1'ai. 263. 
dower in the premises; and the judgment against her in the action to set aside the deed was claimed to bar her from asserting any claim to dower, although she had not presented any such claim in her answer, nor did the judgment purport to dispose of any such claim. The Court of Appeals, in disposing of this branch of the case, said: "She is bound by that judgment, whatever may be its legitimate effect. The judgment is final and conclusive upon her, as to all matters put in issue and litigated in the action. But, as stated above, the matter of her inchoate right of dower was not put in issue and litigated therein. *** The plaintiff in this action might have raised in that action the question that she had a right of dower, as yet inchoate but which might become complete; and might have asked that if it should be found to exist, the judgment should make provision therefor. But was she bound to do so? This would not have been matter in direct opposition to the action in defense to the claim made by the plaintiffs therein; it would have been a quasi admission of the cause of action set up, and a seeking for relief in the judgment which must follow. And when the authorities say that a judgment is final and conclusive upon the parties to it, as to all matters which might have been litigated and decided in the action, the expression must be limited as applicable to such matters only as might have been used as a defense in that action as against an adverse claim therein; and such mattors, as, if now considered, would involve an inquiry into the merits of the former judgment. The existence of an inchoate right of dower in the plaintiff would not have been a defense to the action of the receiver for a sale of the premises and a satisfaction from the avails of the sale of the judgment debt which ho represented. It conld not, if pleaded and shown, have prevented a judgment substantially that which was rendered. The most which could have been effected would have been to have secured in the judgment an auxilliary provision, recognizing and protecting the contingent right. And again: it was a right pre-existent the claims and defenses there litigated, and paramount to any right of the plaintiff in that action there song!: to be enforced. *** TVe are of the opinion that the plaintiff is not estopped by tho record in the action brought by the receiver." ${ }_{2}$ But when an action

${ }^{1}$ Malloney v. Horan, 49 N. Y. 115, Grover, J., dissenting. $3 \pm 4$ 
is brought for an assignment of dower, or the claim to dower is otherwise brought in issue and determined, the judgment is conclusive. ${ }^{1}$

3 304. Judgments of Partition.-We find it declared in one case that "a writ of partition, or a petition for partition, which is but a substitute for the former, is a mere possessory action," and that it, at most, can bar nothing but possessory actions. ${ }^{2}$ Few, if any, authorities sustain this view. On the contrary, there can be no doubt that a judgment in a proceeding for the partition of lands, is as conclusive upon the matter put in issue and tried, as a judgment in any other proceeding, and may bo set up as a bar to a writ of entry involving the same questions of title. ${ }^{3}$ All questions of title and of possession may be finally determined in a suit for partition. ${ }^{4}$ A judgment in such a suit establishes the title to the land partitioned, and is conclusire upon any adverse claim of title, or of possession, existing at the date of its rendition. The law requires the court to ascertain and determine the rights of the parties, and makes it the duty of the parties to disclose their adverse claims. The decree necessarily afirms that the parties to it are tenants in common, joint tenants or coparceners. ${ }^{5}$ Such decree is conclusive that, at its rendition, the land set off to one of the parties, with a spring thereon, was held in common by the parties prior to the judgment. ${ }^{6}$ If a widow be made a party to proceedings in partition under an allegation that she is entitled to dower, the decree is conclusive on her homestead right. ${ }^{7}$ A decree for partition does not create any new title. ${ }^{8}$ The only object and effect of the action is "to sever the unity of possession," and to convert "that which was before a joint possession into a several one." It does not prejudice the claim of one of the parties to recorer a sum due from another for purchaso money; be-

1 Ervin $v$. Irady, 48 Mo. 560.

2 Mallett $v$. Foxcroft, 1 Story, 474.

${ }^{3}$ Whittemore $v$. Shaw, 8 N. H. 393; Doolittle $v$. Don Maus, 34 Ill. 457; Pcntz $v$. Kuester, 41 Mo. 450; Hancock $v$. Lopez, 53 Cal. 36?; Linehan $v$. Hathaway, 54 Cal. 251; Jenkins v. Fahey, 73 N. Y. 355 .

${ }^{4}$ Godfrey v. Godfrey, 17 Ind. 6.

${ }^{5}$ Forder v. Davis, 38 Ho. 107; Clapp v. Bromagham, 9 Cowen, 569.

${ }^{6}$ Edson $v$. MIunsell, 12 Allen, 600.

7 Wright $v$. Dunning, 46 Ill. 271.

${ }^{8}$ MicClure $v$. McClure, 14 Penn. S. 134; Tabler $v$. Wiseman, 2 Ohio S. 211; McBain $v$. McBain, 15 Ohio S. 337. ${ }^{9}$ Wade $v$. Derny, 4 Pac. L. R. 5. 
cause the question of indebtedness from one of the tenants in common to the other for his share of the real estate, is not made an issue in the proceeding. ${ }^{1}$

\& 305. Judgment for One not in Possession.-Though the statutes generally direct that a partition can be sought only by some one in possession, yet the fact of possession is not a jurisdictional fact, in the absence of which the action of the court is void. If all the parties in interest are brought before the court, its decree will be binding, until vacated or reversed, though the applicant was not one of the parties authorized by law to ask for a partition. ${ }^{2}$ A tenant in common of a vested remainder may, while the tenant for life is in possession, maintain an action for partition. ${ }^{3}$

8 306. Persons not in Esse.-In proceedings for partition, as well as in other actions affecting realty, it is suffcient to bring into court the person entitled to the first estate of inheritance with those claiming prior interests, omitting all claiming or who may claim in reversion or remainder after the vested inheritance. The decree will therefore pass a title free from any claims which might otherwise subsequently vest in persons not in esse at the time of its rendition. ${ }^{4}$ An English case recognizes an exception to this principle of virtual representation, by denying its applicability in cases where the person seized in fee is liable to have his seizen defeated by a conditional limitation or an executory devise, because, in that event, the estate is insufficiently represented by tho person holding the first vested estate of inheritance. ${ }^{5}$ This exception is repudiated so far as it seems to be noticed in the United States. ${ }^{6}$

8 307. Unknown Owner.-Under statutes providing that proceedings in partition may be prosecuted against unknown "owners, a decree, regularly obtained, is conclusive, in the absence of fraud or collusion, of the claims of a party in

1 IIcClure $v$. MeClure, 14 Penn. S. $v$. Gaskell, 6 Sim. 643; Nodine $v$. 134.

Groenfield, 7 Pai. 514; Cheeseman v.

2 Blakeley $v$. Calder, 15 N. X. 617. Thorne, 1 Ed. Ch. 629; see sec. 172.

3 Mead $v$. Mitchell, 17 N. Y. $210 ; 3$ Goodess v. Williams, 2 Y. \& C. Clemens $v$. Clemens, 37 N. Y. 59.

4 Vills v. Slarle, 6 Ves. 498; Gaskell 6 Mead v. Mitchell, 17 N. Y. 210. 346 
possession claiming in severalty, who was only a party to the proceeding under the general designation of unknown owners. By failing to answer, he admits that the land is held in common, and that the petitioners are entitled to have it partitioned. 1

8 308. Conclusive vrithout Deed of Partition. - A judgment in partition, under the statute, is final between the parties, and is conclusive evidence of title without the exeeution of any deeds either by the parties or by commissioners, 2 and without the making of any partition, because it ascertains all the rights involved, and leaves nothing to be done but to carry it into effect. ${ }^{3}$

8309. Action to Quiet Tisle.-If the defendant recover judgment on the merits, in a proceeding to quiet title under the statute authorizing suits to determine conflicting claims to real estate, the fact that he has a title is as conclusively established as a judgment in favor of the plaintiff wouid have established that defendant had no title. ${ }^{4}$ An action was brought to quiet title based upon two inconsistent grounds. The court ordered plaintiff to elect upon which of these grounds he would proceed. He made such election, prosecuted his action to judgment, and was defeated. He next commenced another action based upon the ground which he had abandoned nuder the order of the court in the former litigation. The former judgment was relied upon as a bar, and was so considered by the judge, because, under the statute athorizing a suit to ascertain and quiet the title of the parties, "the plaintiff cannot, at his option, split it up into many suits, with which to harass and weary the defendant. By the final decree in such a suit, the title to the premises, as between tho parties, is determined, and all questions or matters affecting such title are concluded thereby. If either party omits to set forth and prove all the

${ }^{1}$ Cook v. Allen, 2 MIass. 461; Nash| 2 Wright v. Marsh, 2 G. Greene, 94; v. Church, 10 Wis. 303; Tane v. Tock Barney v. Chittenden, 2 G. Greene, River Co., 15 Wis. 179; citing Kester 165.

$v$. Stark, 19 Ill. 328; Foxcrof $v$.Barnes, ${ }^{3}$ Allie $v$. Schmitz, 17 Wis. 169. SO Mai.128; Rogers $v$. Tucker, 7 Ohio, S. 417; Pfeltz $v$. Pfeltz, 1 II'd. Ch.

4 Parrish v. Ferris, 2 Black. 606. $4 \check{a} 5$; Reese $v$. Holmes, 5 Rich.Eq. 531. 
grounds of his right, or his adversary's want of it, he can not correct his error by bringing another suit upon the portion or fragment of the case omitted." Under an act of the legislature of Louisiana, "for the further assurance of purchasers at judicial sales," the purchaser of property may apply to the clerk of the court, in whose office the deed of sale was recorded, for a monition or advertisement and "praying that process may be granted requiring all parties alleging any informality or irregularity in the sale to show cause, if any they have, why the sale shall not be confirmed and homologated." If advertisements in conformity with this act are duly published, and no opposition being made, the court confirms and homologates the sale, "it is clear that the judgment in the monition proceeding affords conclusive proof that the judicial conveyarce of the property vested a complete titlo in the purchaser at the sheriff's sale." The dismissal of a bill to remove a cloud from the complainant's title, or to cancel some deed or evidence of title held by the defendant, by no means establishes that the latter has or that the complainaut has not a good title; for the dismissal may have proceeded either on the ground that the alleged deed or other matter was in law no cloud upon the complainant's title, or that the controversy between the parties was one which ought to be determined in a court of law. ${ }^{3}$

\section{JUDGMENTS IN ACTIONS OF TRESPASS ON REAL ESTATE.}

\& 310. First-In Like Actions. - It seems to be generally, if not universally, conceded, that where one has maintained trespass quare clausum fregit against another, and afterward sues for a subsequent trespass, the former recovery is conclusive in reference to the title set up to the premises at the time of such recovery, and the defendant can offer in evidence no title not acquired by him since the prerions suit." "A recovery in any one suit upon issue joined on

\footnotetext{
${ }^{1}$ Starr v. Stark, 1 Saw. C. C. 275 , by Judge Deady.

${ }^{3}$ Phelps $v$. Harris, 101 U. S. 370; 12 C. L. N. 326.

${ }^{2}$ Montgomery $v$. Samory, 99 U. S. ${ }^{4}$ Dert $v$. Sternburgh, 4 Cow. 5509. 482.
} 
matter of title is clearly conclusive upon the subject-matter of such title; and a fuding upon titlo in trespass not ouly operates as a bar to the future recovery of damages for the trespass founded on the samo injury, but also operates by way of estoppel to another action for an injury to the samo subject right of possession. It is not the recovery, but the matter alleged by the party, and upon which the recovery proceeds, that creates the estoppel. The estoppel in trespass precludes parties and privies from contending to the contrary of that point of fact which, having once been put in issue, has been solemnly found." A judgment in trespass, grounded upon the theory that the land described in the pleadings is within the boundaries of one of the parties, is conclusive upon that question in any other action of trespass between the same persons. ${ }^{2}$ Some cases, howerer, proceed upon the theory that, in order to make a judgment in trespass conclusive of tille even in auother action of trespass, the title must have been placed in issue by plea of soil and freehold, or by some other equivalent plea. ${ }^{3}$ In Massachusetts, an action on the caso for the interruption of lights, or other easements, tried upou the general issue, does not affect the title. But if the defendant plead title in bar, and issue be taken on it, the verdict will be conclusive in subsequent controversies. ${ }^{4}$ In the same State, a judgment in an action for the obstruction of a private way, on the general issue, is admissible but not conclusive evidence in a subsequent suit for the continuance of the same obstruction. ${ }^{5}$ In an action for overflowing lands, occasioned by a mill-clam, a former recovery between the same parties is conclusive as to the title of the land, so far as it was involved in the former suit. ${ }^{6}$ Then it has been adjudged that

${ }^{1}$ Outram $v$. Morewood, 3 East, 346; $\quad{ }^{4}$ Standish $v$. Parker, 2 Pick. 20; 13 Illinois \& St. R. R. v. Cobb, 82 Ill. Am. Dec. 393.

1S3; Campbell $v$. Cross, 39 Ind. 155;

Bowyer $v$. Schofield, 1 Abb. App. 177.

2 Warwick $v$. Underwood, 3 Head, 238.

${ }^{5}$ Parker $v$. Standish, 3 Pick. 288;

Kent $v$. Gerrish, Is Pick. 564.

3 Potter $v$ Baker, $19 \mathrm{~N}$ H 166 ;

Stevens $v$. Hughes, 31 Penn. S. 383. 
defendant has no right to flow plaintif"'s land without paying damages therefor, he can not, in a subsequent suit to increase the amnual rent, show a right by prescription, or by grant prior to the former judgment. ${ }^{1}$ Judgment for plaintiff in an action of trespass, in which the defendant denied the trespass, and set up that he had a right of way over the land, is, in Massachusetts, not conclusive that defendant liad no right of way, but only that ho had trespassed on some portion of plaintiff's land. ${ }^{2}$

\section{Second-In Actions in Ejectment.-In Pennsyl-} vania, a recovery in an action of trespass quare clausum fregit, if the only plea be liberum tenementum, is not conclusive of the title in a subsequent action of ejectment for the same land. ${ }^{3}$ But in South Carolina, an opposito view is maintained. The defendant who, making such a plea and setting forth his claim by metes and bounds, has a verdict and judgment in his favor, may use this judgment as conclusivo evidence of title in an action brought by him against the former plaintiff for the land included in the plea, for the judgment is equivalent to a finding that the titlo to the whole land included in the plea is the property of the defendant." In New York, a recovery in trespass is as conclusive as a recovery in any other form of action. The reasoning used in support of this liberal rule is, that the matter of estoppel depends on the identity of the cause of action, and not on the identity of the form; that the canses of action are the same whenever they can be supported by the same evidence, though they may be founded on different writs. ${ }^{5}$ In Massachusetts, a judgment for the plaintiff in an action of tort in the nature of trespass quare clausum fregit is, perhaps, never conclusive upon the title. " "But

${ }^{1}$ Adams v. Pearson, 7 Pick. 341; $19 \mid$ per Canada, Q. B. 606; Whittaker $v$. Am. Dec. 290, and note.

Jackson, 2 Hurls. \& C. 926.

${ }^{2}$ Howard $v$. Albro, 100 Mass. 236. ${ }^{5}$ Rice v. King, 7 Johns. 20; Mc-

${ }^{3}$ Sabins $v$. McGhee, 36 Penn. S. Knight $v$. Dunlop, 4 Barb. 36; Camp453. bell $v$. Cross, 39 Ind. 155.

${ }^{4}$ Parker $v$. Leggett, 13 Rich. 171. ${ }^{6}$ Arnold v. Arnold, 17 Pick. 4; See also Chambers v. Dollar, 29 Up- Morse $v$. Marshall, 97 Mass. 519. 350 
the trial of an action of trespass may turn upon the question of title, and if that question is put in issue, tried and passed upon by the jury, or court, or a referee, the verdict or finding, and judgment following it, are competent eridence of that fact in a subsequent writ of entry between the same parties, even if it does not operato as a conclusive estoppel." In Indiana, a recovery in an action of trespass upon title to land being put in issue, no judgment being rendered on such title further than it might be supposed to enter into the determination of the action, and no decision upon tho titlo being essential to the judgment, is no bar to an action of ejectment." "So where the declaration, in an action of trespass, or trespass on the case, for an injury to land, alleges that tho plaintiff was well seized and possessed of the land as a good indefeasible estate in fee simple, it is sufficient on the trial for the plaintiff to show a lawful possession at the time when the injury was committed. And a judgment for the plaintiff in such a case, upon a general issue, is conclusive evidence between the parties and their privies only of such title as the plaintiff was bound to prove." The fact that a judgment is entered for nominal damages, does not depreciate its effect as res judicata. ${ }^{4}$ A judgment in an action of trespass to try titles is, in Texas, conclusive upon the title held by the losing party in its rendition. ${ }^{5}$

8312. Suits for Breach of Warranty.-The successful prosecution of an action for a breach of warranty of a contract necessarily affirms, for all future actions, the making of the contract. ${ }^{6}$ A judgment for the defendant in an action of tort for a false representation of the soundiness of a horse, is a bar to a subsequent action of contract on the defendant's promise, at the time of the exchange, that the horse was sound. ${ }^{7}$ P. brought an action in chancery to set aside a sale and to enjoin the collection of the purchase

\footnotetext{
1 White $v$. Chase, 128 Mass. $15 S$.

${ }^{2}$ Hargus $v$. Goodman, 12 Ind. 629.

${ }^{3}$ Hilliard on Torts, vol. 1, p. 49s; Parker v. Hotchkiss, 25 Conn. 321 .
}

${ }^{4}$ Casler v. Shipman, 35 N. Y. 533.

${ }^{5}$ Fisk $v$. Miller, 20 Tex. 579.

${ }^{6}$ Burker $v$. Cleveland, 19 Mich. 230.

7 Norton $v$. Doherty, 3 Gray, 372. 
money, on the ground of frand practiced by the vendor in making the sale. Failing in chancery, P. commenced suit at law to recover damages for breach of warranity. It was held that the issues in the two actions were different. That while, as afirmed by the judgment in chancery, the vendor may not have been guilty of fraud, it nowise necessarily followed that he did not make a contract of warranty, nor that such contract, if made, was not broken. ${ }^{1}$ In an action for breach of warranty of the character, quality or quantity of goods sold, if it be conceded that the contract was made by the parties and has been fulfilled by the vendee but broken by the vendor, the issue presented to the court or jury is, What are the damages occasioned by the breach of the vendor's warranty? These damages must be estimated the same, whether the purchase money has been paid or not. After a recovery by the vendee, the vendor may maintain an action for the whole of the purchase money, if it has not been paid. The effect of the judgment for the vendee in his action for breach of warranty, is to establish the making of the contract, and that the vendor has suffered in a prior suit all damages sustained for its non-performance. $^{2}$ If a party proceed upon the theory that a contract has been totally rescinded by the failure of a vendor to perform his part thereof, the juclgment is conclusive on the vendee of all damages suffered by him, including an amount advanced on the contract, and equally conclusive against the vendor of the abrogation of the contract, and of his right to recover any sum stipulated for its performance. ${ }^{3}$ If a warranteo recover and have satisfaction of his warrantor on his covenant to warrant the title to real estate, he cannot afterwards regain possession of the land from the warrantor on that deed. Ho is estopped by the judgment procured in his own behalf, and which proceeds upon the theory that the deed did not convey the title. ${ }^{4}$

8 313. Divorce.-One who brings a bill for divorce, which, upon a trial on the merits, he fails to sustain, cannot

\footnotetext{
474.

${ }^{1}$ Pleasants $v$. Clements, 2 Leigh, ${ }^{3}$ Barker $v$. Cleveland, 19 Mich. 230; Freeman $v$. Clute, 3 Barb. 424.

${ }^{2}$ Barker v. Clereland, 19 Mich. 230; ${ }^{4}$ Porter $v$. Hill, 9 Mass. 34; 6 Am. Perrine v. Serrell, 30 N. J. 458. 352 Dec. 22; Wiuslow v. Grindal, 2 Greenl. 64.
} 
afterward proceed for the samo oftense, ${ }^{1}$ though the decreo simply dismisses his bill." "A libel for divorce from the bonds of matrimony, and a libel for divorce from bed and board, are proceedings having a direct and intimate relation to each other. They seek for different degrees of change in tho married relation, and concern tho same subject matter." In this case, "the libellant in the first suit asked a decision of the court upon the question whether she had been so cruelly treated as to justify a judicial sentence of separation from her lusband; and the judgment given was that she was not. This judgment was plainly a bar to any new application from bed and board, upon the same ground up to that time, whether upon the same or different evidence;" and it is also a bar to the more complete remedy of divorce from the bonds of matrimony. "A sentence of divore necessarily affirms the marriage; and no proceeding can afterward be had to declare the marriage void ab initio." A decree of divorce, so far as it affects the status of the parties, is considered as a judgment in rem, and if free from fraud and collusion, is binding on the whole world. ${ }^{5}$ But cxcept in relation to the status of the parties, it is subject to the usual rulo that estoppels must bo mutual; and does $\mathrm{n}^{-\mathrm{t}}$ conclude any third person in reference to the facts which it necessarily affrms or denies. A decree dismissing a bill for divorce, sought on the ground of alleged adultery of a wife, is not evidence against the husband that the wife did not commit adultery prior to the petition for divcree or during its pendancy, in an action against him for necessaries furnished to her during their separation. So far as the parties to this action are concerned, the matter is not res judicata. The judgment in the divorce suit not being binding on the plaintiff in this suit, he cannot avail himself of it for the purpose of binding the defendant. ${ }^{6}$

\footnotetext{
1 Bishop on Marriage and Divorce, 5 Rishop on Marriage and Divorce, Vol. 2, $\$ 766$. Vol. 2, $\$ 755,756$.

${ }^{2}$ Thurston $v$. Thurston, 99 Mass. 6 Gill $v$. Read, 5 R. I. 313 . In

${ }^{3}$ Fera $v$. Fera, 98 Mass. 155.

${ }^{4}$ Bishop on Marriage and Divorce, Vol. $2, \$ 765$. Maine a divorce procured by une of the spouses, is no bar to an action for divorce subsequently brought by the other. Each may obtain a divorce
} 39. 
8 314. Alimony.-The question of a proper allowance to the wife is one of the issues which should be litigated in the action of divorce. The decree is therefore conclusive on this subject, and the wife cannot afterwards maintain a suit to recover additional alimony. "In England the rule is otherwise; and the courts there can allow alimony on a petition filed after the decree of divorce. ${ }^{2}$

8 315. Par!nership.-If a plaintiff obtain judgment against two as copartners, this is conclusive in a second action between the same parties of the fact of the partnership of the defendants. ${ }^{3}$ And where defendants, being sued, pleaded in abatement the non-joinder of others whom they claimed to be their copartners, and succeeded in maintaining their plea, the record in this suit is conclusive in a subsequent action against those who interposed the plea in abatement, that the several persons were partners, as alleged in the plea. ${ }^{4}$

8 316. Replevin.-In consequence of the rule, that the conclusiveness of an adjudication is not affected by a change in the form of the action, one who has failed in replevin can not subsequently maintain an action of trespass for the taking of the same goods. ${ }^{5}$ A judgment in replevin clesignating the rights of the parties, is as conclusive on an intervenor as it is on the plaintiff or on the defendant. ${ }^{6}$ A recovery in replevin is equally conclusive on the defendant, whether he took issue on the plaintiff's allegation of ownership or confined himself to a denial of the taking and detention. ${ }^{7}$ A determination of the rights of property in a replevin suit is conclusive in an action on the replerin bond. ${ }^{8}$ Judgment in replevin on plea of non detinet, accompanied by a notice that the goods were the property of the defendant, rendered on a special verdict, finding that defendant unlawfully detained the goods, but silent on the

from the other; or, in other words, there may be two decrees dissolving the same marriage. Stilphen $v$. Houdlette, $60 \mathrm{Me} .447$; also, $5 \mathrm{~S} \mathrm{Me.} 513$.

${ }^{1}$ Fischli v. Fischli, 1 Blackf. 360; 12 Am. Dec. 251.

${ }^{2}$ Covell v. Covell, L. R. 2 P. \& D.
${ }^{3}$ Dutton $v$. Woodman, 9 Cush, 255.

${ }^{4}$ Witmer $v$. Schlatter, 15 S. \& R. 150.

5 Ewald $v$. Waterhout, 37 Mo. 602.

6 Witter $v$. Fisher, 27 Iowa, 9.

7 Wells $v$. McClenning, 23 Inl. 409.

${ }^{8}$ Denuy $v$. Reynolds, 24 Ind. 248. 411. 
issue of property, is not conclusive on the title where it does not appear from the record that the title was rassed upon, because no decision in relation to title was essential to the judgment, a mere right of plaintiff to a lien being sufficient to support his action. ${ }^{1}$ Whenever the defendant is, nuder the pleadings, entitled to try the title and to have the property returned to him, in case he succeeds, he is bound to present his evidence of title, and can not seek his remedy by a cross suit. ${ }^{2}$ A judgment for the defendant, when he merely traverses plaintiff's complaint without askfor a return of the property, establishes either that plaintiff lias no title or that the defendant does not unlawfully detain. In order to give proper effect to such a judgment, it must be shown aliunde on what grounds the court or jury proceeded in the former action. ${ }^{3}$

8 317. Trespass.-Judgment for the defendant in an action for taling goods, is a bar to a subsequent action of assumpsit for the ralue of the same goods. ${ }^{4}$ The plea of not guilty, in an action of trespass de bonis asportatis, puts nothing in issue but the wrongful taking. The simple rerdict of not guilty applies to the wrongful taking, and leares the question of title unsettled. ${ }^{5}$ A recorcry by the defendant in an action on the case for cutting and carrying away wheat, bars an action of trespass quare clausum fregit for the same cause. ${ }^{6}$

8 318. Criminal Cases.-The principles applicable to judgments in criminal cases are, in general, identical, so far as the question of estoppel is involved, with the principles recognized in civil cases. An acquittal or a conviction, under all indictment for any ofiense, is a bar to any subsequent indictment substantially like the former. ${ }^{7}$ But in criminal as in civil actions, it is essential that the judgment be on the merits and not tainted with fraud. ${ }^{*}$ Thus going into a farorable court, and submitting to a conviction, in order to escape a severe penalty, is no bar to a bona fide

${ }^{1}$ Board of S. v. MI. P. R. R. Co., 24 Wis. 125.

2 McKnight $v$. Dunlop, 4 Barb. 36.

3 Angel $v$. Hollister, 38 K. Y. 378.

* Rice $v$. King, 7 Johns. 20.
${ }^{5}$ Harris $v$. Miner, 28 Ill. 139.

${ }^{6}$ Johnson $v$. Smith, 8 Johns. 383.

${ }^{7}$ Lesshe $v$. State, 18 Ohio S. 390.

${ }^{8}$ State $v$. Swepson, 79 N. C. 632. 
prosecution. ${ }^{1}$ A nolle prosequi in a criminal case has no greater effect than a nonsuit in a civil case. But the former can only be entered before the trial. After the trial has commenced the relation of the defendant to the cause is materially changed. The jury having been called, he has a right to their verdict, unless some inevitable casualty interposing prevents its rendition. If, in the absence of any such casualty, a nolle prosequi be entered without the consent of the defendant, it is equivalent to an acquittal. ${ }^{2}$ The acquittal of the accused will be no bar to a subsequent prosecution, if the former indictment was such that no conviction could have been legally liad upon the evidence necessary to support the second indictment. ${ }^{3}$ Though no nolle prosequi can be entered without consent of the defendant, after the submission of ary evidence to the jury, where the trial is regularly brought on, yet if the arraignment of the defendant is omitted, and he is tried without any plea, he is not put in jeopardy, because there is no issue to which the evidence can be applied, and a nolle prosequi may therefore be entered without his consent. ${ }^{4}$ Thoever, being convicted on a valid indictment, avails himself of any remedy to relieve himself of the conviction on the ground that it is irregular or erroneous, does so on the implied condition of submitting himself to a new trial, whether he applies for it in the court below or not. ${ }^{5}$ Whenever a charge includes a minor charge, an acquittal of the former includes the latter. Thus a verdict of not guilty on an indictment for murder bars a prosecution for manslaughter. ${ }^{6}$

1 Note 202, Ph. Ev.; State $v$. Little, 1 N. H. 257; Commonwealth $v$. Jackson, 2 Va. Cas. 501; Commonwealth $v$. Alderman, 4 Mass. 477; State $v$. Cole, 48 Mo. 70.

${ }_{2}$ U. S. $v$. Shoemaker, 2 MeLean, 114. For authorities showing when the defendant is so far placed in jcopardy, to be entitled to be considered as acquitted, unless a verdict of guilty has been found against him, see $E x$ parte Clements, 50 Ala. 459; People m. Olcott, 2 Johns. Cases, 301; 1 Am. Dec. 16S, and note; State $v$. Woodruff, 2 Day, 504; 2 Am. Dec. 122; People $v$. Barrett, 2 Caines, 304; 2 Am. Dec. 239; People v. Goodwin, 18 Johns. 187; 9 Am. Dec. 203; Commonwealth $v$. Cook, 6 s. \&. R. 577; 9
Am. Dec. 465, and note; State $v$. Noor, Valker, 194; 12 Am. Dec. 541, and note; State $v$. Burket, 2 Mill, $15 \tilde{y}$; 12 Am. Dec. 662; Commonwealth $v$. Purchase, 2 Pick. 521; 13 Am. Dec. 452.

${ }^{3}$ Ph. Ev. 56; State $v$. Norvell, 2 Yerg. 24; 24 Am. Dec. 458 .

4 Bryans $v$. State, 34 Geo. $3 \cong 3$.

${ }^{5}$ Stewart $v$. State, 13 Ark. 736.

${ }^{6} \mathrm{Ph}$. Ev. 56; Sanders $v$. State, 55 Ala. 42. The true test is, "Could the prisoner, upon any evilence that night have been produced, have been convicted upon the first indictment of the offense that is charged in the second?" Common wealth v. Bakeman, 105 Mass. 53; State v. Horneman, 16 Kans. 452; Price $v$. State, 19 Oh. 423. 
8 319. Judgments in Criminal Cases as Evidence in Civil. - The record of a conviction or of an acquittal is not, according to a decided preponderance of authority, conclusive of the facts on which it is based, in any civil action. Thus, an action of trover for money alleged to be stolen, is not prejudiced by the acquittal of the defendant on a prosecution for theft in taking the same goods. ${ }^{2}$ A. was indicted and convicted of obstructing a highway. After the removal of the obstruction, he commenced an action against $B$. for using the same highway. In this action the question arose whether the conviction conid be pleaded against $A$. as an estoppel. The conrt held that it conld not, but that it might, however, be placed in evidence for the purpose of showing that the locus in quo was a highway. ${ }^{3}$ The chief reason for excluding the record of a criminal prosecution from evidence in a civil case is, that the parties to the two proceedings are different. One who has been damaged by some criminal act of another has a claim for remuneration, independent of the right of the public to proceed against the offender, and to inflict the penalty prescribed by law. This right to compensation in clamages onght not to be, and is not, dependent on the success or failure of the prosecution conducted by the people. If it were, the party most injured would be prejudiced by a proceeding to which he was not a party, and which he had no power to control. A person convicted of any offense is not estopped by the conviction from disputing the facts on which it is based, in a civil action, because his adversary in the civil action would not have been barred if the prosecution had terminated in an acquittal. Notwithstanding the weight of reason and of precedent, opposing the admission of any record of a criminal cause as an estoppel in any civil action, it must be admitted that the precedents are not, on this subject, consistent with one auother. In one case it was declared not to be an error to instruct a jury, on a trial in a civil action for

${ }^{1}$ Betts $v$. New Hartford, 25 Conn. 185; vol. 1 Greenl. Ev. \$537; Corbley $v$. Wilson, 71 11l. 209; Steel $v$. Cazeanx, 8 Mart. 31s; 13 Am. Dec. 238, and note.
${ }^{2}$ Hutchinson $v$. Bank of Wheeling, 41 Penn. S. 42; Beausoliel v. Brown, 15 La. An. 543.

${ }^{3}$ Petrie $v$. Nuttall, 11 Exc. 569. 
an assault and battery, that the conviction of the defenclant on an indictment for the same offense, showed that the plaintiff was entitled to damages; in another, the record of the conviction of the defendant upon an indictment for adultery was received in a subsequent action against him for divoree, as evidence both of the adultery and of his marriage to plaintiff; ${ }^{2}$ and the record of plaintife's conviction has been adjudged to be conclusive evidence against him in an action for malicious prosecution resulting in such conviction. ${ }^{3}$ Of course judgments in criminal, liko those in civil cases, are always competent evidence of their own rendition. Thus, in an action for malicious prosecution, the record in the criminal case may be put iu evidence to establish the facts that there was a prosecntion resulting in an acquittal. In prosecutions against accessaries, or against receivers of stolen goods, the conviction of the principal is admissible, for the purpose of establishing that a conviction of the principal has been had, but not to show that a crime was committed, or that the principal is, in fact, guilty."

\section{319a. The Decrees and Orders of a Probate or Sur-} rogate's Court, made in the exercise of jurisdiction conferred upon it by law, are as final and conclusive as the judgment decrees or orders of any other court. The character and finality of res juclicalc attach to the decisions made in probate or surrogate's courts, irrespective of the nature of the issue determined, provided always that tho court had jurisdiction to determine it. Hence, whether the adjudication be for or against the validity of a will, for or against granting letters of administration, allowing or disallowing an account, granting or refusing to grant a homestead, it is in either case a final settlement of the matter of which it assumes to dispose, and it can not be collaterally attacked, impeached, or avoided in the same nor in any other court, by any of the parties thereto nor by any person in privity

${ }^{1}$ Moses v. Bradley, 3 Whart. 272;|leaf, 100; 16 Am. Dec. 237; Randall see also Horwood $v$. Smith, 2 D. \& E. $v$. Randall, 4 Greenleaf, 326. 750; Maybee v. Avery, 18 Johns. 352. ${ }^{3}$ Herman on Estoppel, § 155.

2 Anderson $v$. Anderson, 4 Green- ${ }^{4}$ Note 273 to Ph. Ev. 358 
with them. ${ }^{1}$ It is, however, as in other cases, essential that the parties to be affected be brought within the jurisdiction of the court by the service of the notice prescribed by law, ${ }^{2}$ and that the court have jurisdiction over the subject-matter. The question occasionally arises, whether the grant of letters testamentary or of administration on the estate of a person in fact living, but supposed to be dead, is an act beyond the jurisdiction of the court, and therefore, so utterly roid that no person is protected in dealing with the executor or administrator while his letters remain unrevolsed. The weight of authority is very decidedly to the effect that the decease of the supposed decedent is a prerequisite to the jurisdiction of the court, and that he is wholly unaffected by the proceedings for the settlement of his estate $;^{3}$ the only adjudication, so far as we are aware, in conflict with the rule here stated, having been rendered by the Court of Appeals of the State of New York. ${ }^{4}$

\section{320. Awards of Arbitrators. - The effect of a valid} award upon the matters submitted to the arbitrators is equivalent, so far as the question of estoppel is concerned, to the effect of a valid judgment. " "No satisfactory reason can be assigned why a judgment, as an act by the law, should estop the parties, and an award, which is another name for a judgment, which the parties have expressly stipulated

\begin{abstract}
${ }^{1}$ Harris $v$. Colqnit, 44 Geo. 663; | ley, 62 Mo. 417; Jones v. Chase, $55 \mathrm{~N}$. Rose $v$. Lewis, 3 Lans. $3 \geq 0$; Stiles $v$. Burch, 5 Pai. 135; Womack $v$. Womack, 23 La. An. 351; Rudyv. Ulrich, 63 Pa. S. 17i; Penterleath $v$. MeGillivray, Stuart's Lower Canada R. 470; Shropshire $v$. Probate Judge, 4 How. Miss. 142; Cole v. Leak, 31 MIiss. 131; Crippen v. Dexter, 13 Gray, 330; Abbott $v$. Bradstreet, 3 Allen, 587 ; Simpson $v$. Norton, 45 Me. 281; Davie $v$. MlcDaniel, 47 Ga. 195; Caujolle $v$. Ferrie, 5 Blatchf. 22.5; S. C., 13 Wall. 465 ; Castrov. Riehardson, 18 Cal. 478; State v. MeGlynn, 20 Cal. 233; Judson $v$. Lake, 3 Day, 326; Gates $v$. Treat, 17 Conn. 392; Harrison $v$. Morehouse, 2 Kicre (New Brunswick), 584; Lewis $v$. Allred, 57 Ala. 628; Hutton v. Williams, 60 Ala. 107; Cumnings v. Cummings, 123 Mass. 270; Johnson $v$. mings, 123 Mass. 270; Johnson v. 63 N. Y. 460; 20 Am. liep. 555. II. 231; Roderigas v. East River Sav. ings Inst., 63 N. Y. 469; 20 Am. Rep. 555 ; Connolly $v$. Connolly, 9 Reporter, 830.

${ }^{2}$ Crosley v. Calhoon, $45 \mathrm{Ia} .557$; Michel v. Hieks, 27 Am. Rep. 161; 19 Kans. 578.

${ }^{3}$ Melia v. Simmons, 45 Wis. 331 ; 30 Am. Rep. 746; Jochumsen $v$. Surfolk Savings Bank, 3 Allen, S7; MiPherson $v$. Cunliff, 11 S. \& R. 422; 1.1 Am. Dee. 612; Wales v. Willard, 2 IIass. 120; Griffith v. Frazier, 8 Cranch, 9 ; Allen $v$. Dundas, 3 T. R. 125; Duncan v. Steuart, 25 Ala. 408; Peeble's Appeal, 15 S. \& R. 42; Morgan v. Dodge, 44 N. H. 259; Bolton v. Jacks, 6 Hob. 166.

${ }^{4}$ Toderigas $v$. East River Sav. Inst.,

52 Smith's Leading Cas. 671.
\end{abstract}


should be final as to the subjects submitted, should not be equally conclusive." The authorities disagree in relation to the effect of an award, upon a submission of all demands, on a matter which in fact was never presented to the arbitrators. In New York, the position is taken, that "it would be a very dangerous precedent to allow a party, on a submission so general, intended to settle everything between the parties, to lie by, and submit only part of his demands, and then institute a suit for the part not brought before the authorities. The object of the submission was to avoid litigation; and neither party is at liberty to withhold a demand from the cognizance of the arbitrators, on such submission, and then to sue for it."2 Just and reasonable as this view seems, it has not met with general approbation. On the contrary, it seems to be well settled by a decided preponderance of authorities, that, notwithstanding the general language of the submission, the award will conclusively determine nothing not in fact submitted; and that the prima facie final effect of the award may be overthrown by any evidence which sufficiently proves that a specified matter was never presented to the arbitrators. ${ }^{3}$ Dut in Massacliusetts, if a general submission of all demands be made, it is in the power of either of the parties to insist upon the presentation of any claim held by his adversary; and if any party, upon being requested to place any matter before the arbitrator's, decline to do so, he is precluded from ever afterward asserting it. ${ }^{4}$ By following the course pointed out by this decision, most of the evils arising from permitting a party to avoid the effect of an award by showing that a maiter was overlooked and not presented, may be avoided. For either party may, if he wish, escape from

\footnotetext{
1 Brazill v. Isham, 12 N. Y. 9.

2 Wheeler $v$. Van Houten, 12 Johns. 311; Owen $v$. Boerum, 23 Barb. 187, Cases sustrining the N. Y. Cases are Smith v. Johnson, 15 East. 213; Bunnell $v$. Pinto, 2 Conn. 431. An award is conclusive as to the matters submitted; but if it is doubtful from the terms of the submission whether a matter was submitted and passed ted as to the fact of the case. Keaton v. Mulligan, 43 Geo. 308.

${ }^{3}$ King $v$. Savory, 8 Cush. 309 ; Edwards $r$. Stevens, 1 Allen, 315; Bixby v. Whitney, 5 Green]. 192; Newman v. Wood, MLart. \& Yerg. 190; Buck $v$. Buck, 2 Verm 420; Whittemore $v$. Whittemore, 2 N. H. 26; Engleman $v$. Engleman, 1 Daua Ky. 437.

4 Warfield $v$. Holbrook, 20 Pick. 531. tipon, then evidence should be admit-
} 
the vexation of subsequent litigation, so far as regards any pretension of his adversary of which he has any knowledge. Still, it would seem more logical, and more consistent with the principles applied to other legal controversies, to require each party to remember his own demands, instead of requiring his adversary both to ascertain and suggest the existence of such demands, or to be subjected to the iuconrenience of another litigation.

8 321. General Submission.-A general submission of all actions, and causes of action, and of all quarrels, controversies, trespasses, damages and demands whatsoever, authorizes the arbitrators to take cognizance of questions concerning real property. The law does not require a more specific submission as to one kind of property than as to another. ${ }^{1}$

8 322. Matters not in Dispute.-It is generally conceded that the mere existence of a cause of action will not bring it within a general submission, if it is not a matter of dispute between the parties when the agreement to submit to arbitration is consummated. ${ }^{2}$ But the submission of a controversy growing out of a specified contract or transaction, or of an account relating to a particular course of dealing must be so regarded that neither party shall be allowed to rebut the conclusive effect of the award, by showing thet some item was not laid before the arbitrators. ${ }^{3}$ But a judgment on an award in favor of the builder and against tho owner of a house upon a submission of all domands, is no bar to an action against the builder by the owner, to recover a sum which he was, subsequently, though before payment of the award, compelled to pay to discharge a mechanic's lien. ${ }^{4}$

\& 323. Bill of Review.-A complaint for the review of a judgment is in the nature of a writ of error. A second

${ }^{1}$ Sellick $\%$. Addams, 15 Johns. 197; Robinson $v$. Morse, 29 Verm. 4Ci; Munro v. Alaire, 2 Cai. 327; 2 Am. Trescott v. Baker, 29 Verm. 459.

Dec. 320; Marks v. Marriott, $1 \mathrm{Ld}$. Raym. 114; Byers $v$. Van Deusen, 5 Wend. 268.

${ }^{3}$ Briggs $v$. Brewster, $23 \mathrm{Vt}$. 100;

Dumn $v$. Murray, 9 B. \& C. 780.

${ }^{2}$ Ravee v. Farmer, 4 T. R. 146;

* Hale v. Huse, 10 Gray, 99. 
complaint to review the same judgment, after a final hearing on the former complaint will not be permitted. ${ }^{1}$

8 324. Habeas Corpus.-The principle of res adjudicata is not usually applied to proceedings on habeas corpus. A party may apply successively to every court having jurisdiction to grant the writ for his discharge, until he exhausts the entire judicial authority of the State. "How far judges would go in their examination after a case had once been determined, is a question which must rest exclusively in their own sound judgment; but a previous examination cannot prevent their right to re-examine the whole case if they should think proper to do so." ${ }^{2}$ On the other hand, the principle of res adjudicata is deemed applicable in the State of New York to proceedings on habeas corpus, so far, at least, as they involve an inquiry into and a determination of the rights of husband and wife to the custody of one of their children. The decision on a former writ will there be conclusive in a subsequent application, unless some new fact has occurred which has "altered the state of the case, or the relative claims of the parents to the custody of the child in any material respect." The principles of public policy requiring the application of the doctrines of estoppel to judicial proceedings, in order to secure the repose of society, are as imperatively demanded in the cases of private individuals contesting private rights under the form of proceeding in habeas corpus, as if the litigation were conducted in any other form. Otherwise, as is well stated in the opinion of Senator Paige "such unhappy controversies as these may endure until the entire impoverishment or the death of the parties renders their farther continuance impracticable. If a final adjudication upon a habeas corpus is not to be deemed res adjudicata, the consequences will be lamentable. This farored writ will become an engine of oppression, instead of a writ of liberty." The courts of Massachusetts

${ }^{1}$ Coen $v$. Funk, 26 Ind. 289; Strn-|Bell v. State, 4 Gill. 301; Wade $v$. der $v$. Heirs of Byrd, 7 Ohio, 18t. Judge, 5 Ala. 130; Ex parte Reynold's,

${ }^{2}$ In the matter of Pertins, 2 Cal. 6 Park. 276.

429; matter of Edward Riug, 28 Cal. ${ }^{3}$ Mercien $v$. The People, 25 Wend. 247; Ex parte Kaive, 3 Blatehf. C. C. 99.

1; In re Gaylord Blair, 4 Wis. 522; 
are in full accord with those of New York upon this subject. In the first named state a person discharged upon hábects corpus was again taken into custody, and was again brought before a court upon a writ of habeas corpus, when he insisted that his former discharge was a conclusive adjudication, that he was entitled to his liberty unless some cause could bo shown authorizing his detention and not existing at the time of his previous release. The court said: "The decision upon that writ, after notice and full hearing, dischargiug him from the custody of Captain Wheaton, was an adjudication that he was not liable to be held as an enlisted soldier, and a conclusive determination of all questions of law and fact necessarily involved in that result. Any facts which the respondent deemed material upon that issue should have been proved at that hearing, and any ruling in matter of law with which he was dissatisfied should have been then reserved. The judicial discharge of a prisoner upon habeas corpus conclusively settles that he was not liable to be held in custody upon the then existing state of facts. Nor is it material that the petition for the first writ was made by the prisoner's father, and that for the present writ by himself. Neither the form of the writ, nor the effect of the discharge, is raried by the name on which the petition is presented."

8 325. Motions and Orders.-"The principle of res actjudicata, which preveits a matter being twice litigated, has no application to a mere interlocutory motion." The decision of a motion is nerer regarded in the light of res acljudicata." 3 Such are the general declarations made in divers cases. If conceded to be technically correct, they are not well calculated to convey to the reader an accurate conception of the effect of the decision of a motion, upon subsequent proceedings in the same case. The decision of a motion will be considered first, with regard to its effect

1 McConolgue's case, 107 Mass. 170, | iff, 1 Cow. 501; Simson v. Hart, 14 citing Er parte Nilburn, 9 Pet. 701; Johns. 75; Akerly $v$. Vilas, 19 Ind. R. Spalding $v$. People, 7 Hill, 301; Bet- Rec. 154; S. C., 5 Chicago Legal ty's case, 20 Law Reporter, 455 . News, 73.

${ }^{2}$ Belmont $v$. Erie R. R. Co., $52 \quad{ }^{3}$ Snyder $v$. White, 6 How. Pr. 321 ; Barb. p. 637; Van Rensselaer $v$. Sher- Laston $v$. Pickersgiil, 7.5 N. Y. 599. 
in other cases, and second, with regard to its effect upon motions involving similar questions, in the same case. As a general rule, the decision of a motion or of a summary application "will not be so far conclusive upon the parties as to prevent their drawing the same matters in question again in the more regular form of a suit either in law or equity." The reasons for holding such decisions not to be conclusive in a regular suit, were in an early case in New York stated to be, because "it is a fact, well known, that such motions do not admit of that grave discussion and consideration as questions arising on demurrer, in arrest of judgment or for a new trial. Again: decisions on summary application can never be thrown into the shape of a record, and become the subject of review in any other court." 2 A statute of Kansas provides that a court may either reject or confirm a sale made under execution. It was held that while the court might, on hearing the motion for confirmation, inquire into the fraudulent conduct of the officers conducting the sale, or of the bidders attending it, yet that the decision of the motion would not affect the ultimate rights of the parties in a regular suit involving the same issues. It will be seen that the reasoning of the court in the case of Simson v. Hart (14 Johns. 75), which seems to be a leading American case upon the subject, is inapplicable to those motions which admit of "grave discussion and deliberation," and are capable of "being thrown into the shape of a record," and being the "subject of review in another court." In New York, the decision of a motion, notwithstanding the general declarations to the contrary frequently made, may be res judicata. This is proved by the case of Dwight v. St. John (25 N. Y. 203). Upon tho trial of that case, the plaintiff gave in evidence the papers, upon a motion made by the defendant in the Supreme Court, to have the judgments cancelled and discharged of record, as satisfied. Upon the motion being made, the court ciirected a reference to inquire and report as to the facts set up by the parties, which were substantially the same as those averred by them in the second action. Upon the coming in of the referee's report, the court denied the mo-

${ }^{1}$ Dickenson $v$. Gilliland, 1 Cow.495. $1{ }^{2}$ Simson v. Ilart, 14 Johns. 75. 364 
tion to satisfy the jadgments. In the second action the decision of this motion was claimed as res judicata. In allowing this claim, the Court of Appeals said : "Upon this point it is to be observed, that some decisions (made before tho existence of the code), especially that of Simson v. Lart, in the Court of Errors (14 Johns. 63), are chiefly based upon the ground that such summary proceedings as they passed upon were then heard without full proofs, and were not reviewable - whereas, in the case before us, the lhearing was upon full proofs; and the code has entirely taken arway the other ground, by making the proceeding liable to review. Since, then, a full hearing, with the right of appeal, was open to the defendant, on that motion, how is he to avoid the binding effect of that decision, so far as it corers what was actnally and necessarily tried on that reference?" After specifying the issues which, in its judgment, were involved in the motion in the former action, and were then determined against the defendant, the court adds: "To this extent, therefore, the defendant should be held concluded by that adjudication," and "so much, then, is finally adjudicated against the defendant; and this court has now no power to interfere with that decision." From this decision we may infer that in New York, if not in other States, the decision of a motion is as final and conclusive as the decision of a trial, if the proceedings permit of a full hearing upon the merits, and the order made is liable to review in some appellate court.' In Georgia, the denial of a motion to set aside a judgment was assumed to estop the applicant from prosecuting a subsequent motion for the same purpose. ${ }^{2}$

We now come to consider the question, whether the granting or denying of a motion, during the progress of a cause, or even after the rendition of a judgment, amounts to a prohibition of a subsequent motion involving the same issues which have been considered and determined ou tho former application. "Courts, to prevent vexations and repeated applications on the same point, have rules which preclude the re-agitation of the same question on the samo state of facts. These rules are for the orderly condnct of business, and are not founded on the principle of res judicala. It is not uncommon, in courts of law, to deny a motion one day and on another to grant it on a more enlarged

\footnotetext{
${ }^{1}$ Petition of Livingston, 34 N. Y. 555. ${ }^{2}$ Grier v. Jones, 54 Geo. 154.

Sce Easton v. Pickersgill, 75 N.Y. 599. 365
} 
state of facts." The rules hero reforred to soem to require that leave of tho court must first be obtained before a motion can be renewed upon substantially the same grounds as those upon which the court has already passed. "It is entirely in the discretion of a court to hear a renewal of a motion or not. They can, as they deem adrisablo, hear it on precisely the same papers. This, of course, will bo rarely allowed; it would be productive of the most serious inconvenience; but, still, there may be occasions which would render it essential to justice." ${ }^{\prime 2}$ The reasons assigned for investing courts with a discretionary power in rehearing matters decided upon motion are applicable only to those proceedings from which no redress can be obtained by appeal. "In motions such as these, not appealable, a grievous wrong may be committed by some misapprehension or inadvertence of the judge, for which there would be no redress, if this power did not exist." A motion may bo renewed without leave upon new matter; but "the new matter' which will alone justify the renewal of a motion, without leave, must bo something which has happened, or for the first time come to the knowledge of the party moving, since the decision of the former motion." "Af davits which merely present additional or cumulative evidence on the points before presented, are not to be considered as showing new grounds for a motion."

8 326. Rules Applied to Motions. - It will be seen from an examination of the cases, both English and Amorican, that while the doctrine of res adjudicata is in general said not to be strictly applicable to motions, yet that the courts have in its place adopted rules, which, in the prevention of the re-agitation of the same matter, operate substantially like the rules of res judicata, so far, at least, that the decision of a motion heard upon the merits is conclusive of a

${ }^{1}$ Simson $v$. Hart, 14 Johns. 63; Bel- ${ }^{3}$ Same cases named in preceding mont $v$. Erie R. R. Co., 52 Barb. 637; citation.

2 White v. Junroe, 33 Barb. 650. 4 Willett v. Fayerweather, 1 Barb. Dollfus v.Frosch, 5 Hill, 493; Smith 72. v. Spalding, 3 Irob. 615; Katz v. Au- 5 Ray v. Connor, $3 \mathrm{Ed} . \mathrm{Ch} .478$. gust, cited in Belmont $v$. Erie R. R. Co., 52 Birb. 637. 
subsequent motion in the same case proceeding upon the same grounds. ${ }^{1}$ The court will rarely use its discretionary powers to allow the renewal of a motion, unless "in the circumstances of the opposition there is something to excito suspicion of unfairness, or a belief that the party moring is taken by surprise, or if the motion be denied because of some defect in the moving papers, arising from ignoranco of the practice. So a party may obtain leave to renew, on falsifying the affidavit used in opposition, or showing that the facts stated in it are explainable so as not to amount to a denial of the grounds of the motion. A motion will sometimes be opened on the question being changed by new materials discovered or arising afterwards." ${ }^{2}$ The same degree of diligence will be required of a party in sustaining his motion as would be sufficient to free him from the imputation of laches, if he were engaged in the trial of the case. If he make his application, and from his own neglect support it by insuficient materials, and the rule is on that ground discharged, he can not be afterwards allowed to supply the deficiency and renew the application. ${ }^{3}$ Upon motions as upon trials, public policy and courts of justice unite in requiring that there shall be an end to litigation. "And if a party will not be vigilant in prosecution or defonse; and will suffer tlic time to go by for the production of his proofs without a sufficient excuse, he must not afterwards complain." In England, it is a general rule, believed to be applicable to all the courts, that after an appli-

${ }^{1}$ Davies v. Cottle, 3 T. R. 405; Mitch- given, upon the ground that the morell $v$. Allen, 12 Wend. 200; Dodd $v$. ing party can produce additional eviAstor, 2 Barb. Ch. 395; Bascom $v$. dence in support of his motion, unFeazler, 2 How. Pr. 16; Greathead $v$. less it also appears that a new state of Bromley, 7 T. R. 455; Benjamin $v$. facts has arisen since the former hearWilson, 6 Lower Canada, Jurist, 246; ing, or that the then existing facts Simith $v$. Coe, 1 Sweeny, 385. Speak- were not presented, by reason of the ing of motions for anclias writ of pos- simprise or excusable neglect of the session, the S. C. of Cal. at Oct. moving party." Forde v. Doyle, 44 Term, 1872, says: "The doctrine of Cal. 635.

res adjudicata, in its strict sense, does ${ }^{2}$ Note to Dollfus v. Frosch, 5 Hill, not apply to such motions made in the 494.

course of practice, and the courtmay, ${ }^{3}$ Regina $v$. Inhabitants of Barton, upon a proper showing, allow a re- 9 Dowl. 1,021. newal of a motion of this lind once ${ }^{4}$ Ray v. Connor, 3 Ed. Ch. 478. decided. But this leave will rarely be 
cotion has been made and has friled on account of defectivo materials, they will not allow any further inquiry. An exception exists when the affidavits have been wrongly entitled, or there has been somo defect in the jurat. None of the cases, however, go to the extent of holding, that under no circumstances can an application be made on fresh materials. ${ }^{1}$ If a party fails in his motion on the ground of any formal defects in his papers, or from any cause not affecting the merits of his application, he should ask leave to renew the motion, or that it be denied without prejudice to another motion. If his request is granted, it should be so stated in the order. If his motion is denied generally, it is necessary to obtain leave to renew it, though it failed on account of some informality. ${ }^{2}$ In Wisconsin, the denial of a motion to vacate a judgment is a bar to a writ of error coram nobis. ${ }^{3}$

8 327. Proceedings Supplementary to Judgment. Proceedings taken for the purpose of obtaining possession of land by the aid of a writ of assistance, though upon due notice, and after a contest on the merits, are not, in a subsequent action, conclusive of any of the matters involved in the decision of the motion. Thus, where upon application of a purchaser under a decree of foreclosure, a writ issued, under which C. was dispossessed of certain premises, and C. afterwards, upon application to the court, procured an order restoring him to possession, on the ground that the land from which he had been removed was not included in that described in the deed, such order being obtained after a full trial upon the merits of the issue involved in the application for restoration, it was decided that the question whether the deed did include the same premises was not res judicata, because the estoppel of a former adjudication can only arise "in a cause regularly tried on its merits upon issues duly joined by proper pleadings between the same parties or their privies," and because the motions and orders in the former cause, "although the parties to the second action appeared in and were interested in the result

I Dodgson $v$. Scott, 2 Exc. 457.

${ }^{2}$ Dollfus $v$. Frosch, 5 Hill, 493.

${ }^{3}$ Second Ward Bank $v$. Upman, 14 368 
of such motions, were in no sense judgments in an action between these parties upon issues joined in a cause pending between them."

Where money resulting from a sale of property is in court, and the application of a claimant is, upon motion in his behalf, heard, considered and denied, his elaim becomes res judicata, and he cannot maintain assumpsit for the same money. ${ }^{2}$ Proceedings supplementary to execution under the Code of California, requiring the judgment debtor to appear before a court or referee, "to answer concerning his property, are but a substitute for a creditor's bill at common law. It is only a summary method of purging the debtor's conscience, and compelling tho disclosare of any property he may have which is subject to execution. The proceeding was intended to be summary and effectual, and affords the widest scope for inquiry concerning the property and business affairs of the judgment debtor. It is truo there are no formal issues framed; for in the very nature of the proceedings it would generally be impossible to framo specific issues in advance of the examination of the judisment debtor. Nevertheless, witnesses may be called and examined on either side; and after hearing the case the court or referee is to decide what property, if any, tho judgment debtor has which is subject to be applied to the satisfaction of the judgment, and to direct its application accordingly. The proceeding is purely juclicial, involving an examination into the facts upon sworn testimony, and the decision of questions of law arising on the facts proved. The judgment creditor and debtor are parties to the proceeding, and each is at likerty to call and examine witnesses in respect to any contested fact which may be brought in issue in the course of the proceeding. If the parties to such a proceeding, as between themselves and privies, are not estopped from again litigating the same matters in another form of action, the whole proceeding would be but a judicial farce, accomplishing no useful end." It is too plain for argument, that after an adjudication in such a proceeding,

${ }^{1}$ Boggs v. Clark, 37 Cal. 236; for ${ }^{2}$ Langdon v. Raiford, 20 Ala. 532; similar views see Carter v. Clarke, 7 Noble v. Cope, 50 Penn. S. 17. Robt. 43. 
in reference to the liability of property to be applied to the satisfaction of the execution, the only remedy left either of the parties is, by taking an appeal, and that while the adjudication remains in force, both parties are estopped from litigating the same question, in any other case or by any other form of proceeding. ${ }^{\text {' }}$

3. 327a. The Identity of the Defendant may be so established by the judgment against him as to become res judicata. This is the case when he unsuccessfully defends an action on the ground that he is not the person intended to be named in a writing or judgment produced and sought to be asserted against him. ${ }^{2}$

8. 328. Effect of Appeal.-In California, ${ }^{3}$ Louisiana, Colorado, and Nevada, ${ }^{4}$ an appeal is considered as suspending the operation of a judgment for all purposes, so that it is not admissible as evidence in any controversy between the parties. This position is not sustained by the decisions in other States. On the contrary, the effect of an appeal with proper bond to stay proceedings, is held to be, that it suspends the right to execution, but leaves the judgment until annulled or reversed, binding upon the parties as to every question directly decided. 5 In Connecticut, the operation of an appeal depends upon the character of the jurisdiction of the appellate court. If the latter court has authority to try the cause de novo, and to settle the controversy by a judgment of its own, and to enforce such judgment by its own process, then it is plain that by the appeal the judgment of the inferior court is not merely suspended, it is vacated and set aside, and can no longer have effect as an estoppel. But if the appeal is in the nature of a writ of error, conferring power ou the appellate court to determine such errors as may have occurred at the trial or in the decision

\footnotetext{
${ }^{1}$ Verneuil $v$. Harper, 28 La. An. ably prevails in New Hampshire. 893.

2 McCullough $v$. Clark, 41 Cal. 298.

${ }^{3}$ Woodbury $v$. Bowman, 13 Cal. 634.

${ }^{4}$ Byrne $v$. Prather, 14 La. An. 653; Glenn v. Brush, 3 Col. 26; Sherman $v$. Haynes $v$. Ordway, 52 N. H. 254. ${ }^{5}$ Sage $v$. Harpending, 49 Barb. 166; Harris $v$. Hammond, 18 How. P. 123; Burton $v$. Burton, 2S Ind. 342; Nill $v$. Comparet, 16 Ind. 107; Allen $v$. The Major, 9 Geo. 286. Dilley, 3 Nev. 21; and this rule prob-
} 
of the canse, and giving the court, upon such determination, no other anthority than that of reversing, modifying, or affirming the judgment of the inferior court, and of remitting the case back to the tribunal whence it came, that such tribunal may conform its judgments and proceedings to the views of its superior; then the judgment appealed from does not, until vacated or reversed, cease to operate as a merger and a bar. 'The effect of a judgment is not limited by the fact that, on appeal, it was affirmed on an equal division of the judges. ${ }^{2}$

2329. After Acquired Rights.-From the rule that an adjudication affects no claims which the parties had no opportunity to litigate, it results that no judgment or decre日 can prejudice rights which had not accrued to either of the parties it the time of its rendition. A decision that a right exists, or that a wrongful act has been committed, leaves the party at liberty to show, at a future time, that since the decision was pronounced the right has expired, or the wrong has been abated. ${ }^{3}$ Intervening events affecting the issue may be shown to prevent a former judgment from being conclusive, even where the title has been tried in a writ of entry. While a judgment of a court on the application of a parent for the custody of a child is, in New York, res judicretra as long as the circumstances continue the same, it ceases to be so whenever any change takes place in those circumstances. ${ }^{5}$ Under no circumstances will a judgment or decree take effect upon rights not then existing. ${ }^{6}$ If a decree be entered quieting title and enjoining the defendant from making any further contest against tlie plaintiff's title, this general language will be confined to rights in issue, and will not prevent the plaiutiff from asserting a subsequently acquired title. ${ }^{7}$ But a judgment is conclusive upon every right

\footnotetext{
${ }^{1}$ Bank of N. A. v. Wheeler, $28 \mid$ Parker $v$. Standish, 3 Pick. 2Ss; Dwyer Coun. 433; Curtis $v$. Beardsley, 15 $v$. Goran, 29 Iowa, 126; Neafie $v$. NeaConn. 518.

${ }^{2}$ Lyon $v$. Ingham Circuit, 37 Mich. 37\%; Durant v. Essex Co., 7 Wall. 107 .

${ }^{3}$ McKissick $v$. McKissick, 6 Humph. 75; Gluckauf v. Reed, 22 Cal. 468; fie, 7 Johns. Ch. 1; 11 Am. Dee. 380. ${ }^{4}$ Perkins $v$. Parker, 10 Alien, 22; Morse $v$. Marshall, 97 Mass. 519,

${ }^{5}$ People $v$. Mercein, 3 Hill, 416.

${ }^{6}$ Jones $v$. Petaluma, 36 Cal. 290.

${ }^{7}$ Reed v. Calderwood, 32 Cal. 109.
} 
and title which the parties might have asserted, and does not become less final because the losing party afterwards receives another and more formal evidence of title. If defendiant has made proof and payment under the pre-emption laws before judgment against him, and afterwards procures a patent, this is not a "new title" upon which he may make another" contest. "It is merely a formal assurance of the estate which he had already acquired by proof and payment."

8330. Defaults and Admissions.-The rule, that a judgment is conclusive of every fact necessary to uphold it, admits of no exceptions; and is equally applicable, whether the final adjudication resulted from the most tedious and stubborn litigation, or from a suit in which no obstacle was presented to defeat or delay plaintiff's recovery. ${ }^{2}$ A julgment by default is attended with the same legal consequences as if there had been a verdict for the plaintiff. There exists no solid distinction between a title confessed and one tried and determined." 3 A stipulation between the parties, that a particular kind of judgment may be entered, while it ought to regulate the entry, has no subsequent effect. It does not alter the character of the judgment actually entered, even if the entry be different from that provided for in the stipulation. In cases where no defiult is entered, the admissions made by either of the parties, whether in direct terms or by failure to traverse material allegations when called upon to do so, are as conclusive and

1 Byers $v$. Neal, 43 Cal. 210.

${ }^{2}$ Judgment by default or consent is binding as res judicata. Wllis $v$. Mills, 23 Tex. 5S4; Fletcher v. Holmes, 25 Ind. 45S; Dunn v. Pipes, 20 La. An. 276; Derby v. Jacques, 1 Clif. C C. 425; Newton v. Hook, 48 N. Y. 676; Brown $v$. Nayor, 66 N.Y. 355; Jarvis v. Driggs, 69 N.Y. 143; Doyle v. Hallam, 21 Minn. 515; Van Valkenburgh $v$. Milwaukec, 43 Wis. 574; Blair $v$. Bartlett, 75 N. Y. 150 . In the case last cited the court emphasizes the ract that while the former judgment was by default, yet the court was, notwithstanding such default, required

to take testimony and to liave proof of all the allegations essential to plaintiff's recovery. Wallhams v. Gay, 73 Ill. 415 , shows an inclination on the part of the courts of that state to follow the English decisions and to deny that res judicata can arise except when a court after argument and consideration comes to the decision of a contested matter.

${ }^{3}$ Bradford $v$. Bradford, 5 Conn. 127; Gates v. Preston, 41 N.X. 113; Green v. Hamilton, $16 \mathrm{Md}$. 317 ; Note 270 to $\mathrm{Ph}$. Ev.; Gates v. Preston, 3 L. T. Rep. 221.

${ }^{4}$ Semple v. Wright, 32 Cal. 659. 372 
as available as a bar, as if they were proved by witnesses. An admission by way of a demurrer to a pleading, is just as effective in favor of the opposite party as though made ore temus before a jury.' If the tenant, in a writ of entry, plead non-tenure, and the plea be admitted by the plaintiff, it operates as an estoppel of record in the same manner and to the same extent as if found by a jury. ${ }^{2}$ Also, if the defendant interpose a good plea in bar, to which plaintiff makes no reply, and the court on that account orders judgment to be entered that the case be dismissed, such judgment, thongh informal, is good as a plea in bar. ${ }^{3}$ What is here said with reference to the effect as res judicata of a judgment entered by consent or upon default must be considered in connection with tho limitations expressed and the authorities heretofore cited, ${ }^{4}$ showing that where the subjectmatter of the two actions are different, nothing is res judicata which was not in fact presented to the court and determined in the former action. ${ }^{5}$ Irrespective of its effect as res judicuta, a judgment by consent is regarded as in the nature of a contract or binding obligation between the parties thereto, which neither in the absence of frand or mistake has the right to set aside or disregard, and which as against each is a waiver of errors and irregularities; ${ }^{6}$ and when such consent judgment embraces matters or extends to relief not involved within nor responsive to the issues in the case, it, with respect to such matters and relief, no doubt partakes more of the character of a voluntary agreement between the parties than of a judgment of the court determining a controversy between real litigants. ${ }^{7}$

83 331. English Cases.-The decisions in England are, no doubt, somewhat at variance with those in this country

${ }^{1}$ Bouchaud v. Dias, 3 Denio, $243 . \quad v$. Rose, 59 Ind. 33; Allen $v$. Richard-

${ }^{2}$ Hotchkiss $v$. Hunt, 56 Mai. 252. son, 9 Rich. Eq. 53; French $v$. Shot-

¿Campbell v.Mayhugh, 15 B.Monr. well, 5 Johns. Ch. 564; Atkinson v. 145.

${ }^{4}$ See $\S 253$.

${ }^{5}$ Adams v. Adams, 25 Minn. 72; Colwcll $v$. Bleadley, $1 \mathrm{Abb}$. App. Dec. 400.

${ }^{6}$ Jones $v$.Webb, 8 S. C. 202; ManManks, 1 Cow. 709; Bradish v. Gee, Amb. 229.

${ }^{7}$ Vermont etc. R. R. Co. v. Vermont etc. R. R. Co., 50 Vt. 500. Consent judgments do not bind third persons: Carroll v. Hamilton, $30 \mathrm{La}$. nion v. Fahy, 11 W.Va. 4S2; Collins An. 520. 
in regard to the effect of declining to traverse a material issue tendered by the opposite party. The tendency there is to confine the estoppel to matters disputed." "A party is estopped from saying that any issue was improperly decided, but he is not estopped in a future action by an admission on the record. He is not to be estopped by any matter not in dispute and upon which the jury never gave judgment." A lessee was sued upon a lease and mude an ineffectual defense. Afterwards, being sued for subsequently accruing rent under the same lease, he answered that, prior to the former action, tho lease had been anvulled by an agreement between the parties substitnting another and different lease in its stead. This defense was not suggested in the prior suit, though as available in that as in the second. The former judgment was decided to be no bar to this dense. The grounds of this decision were, that a default, or an admission by neglect to traverse in an action upon any contract, admits nothing but the execution of tho contract, and leaves the defendant at liberty to show, in a future action, any defense arising under the contract since its execution, and that " nobody ever heard of a defendant being precluded from setting up a defense in a second action because he did not avail himself of the opportunity of setting it up in the first action." Wo submit, however, that this position is clearly untenable. The judgment in tho first action being for rent upon a lease, could only be supported by a valid lease existing in full force until and including the latest period of time for which rent was allowed. The judgment for defendant in the second action could ouly be upheld, under the issues made in that action, on the ground that the lease was inoperative during the time for which rent was recovered on it in the first action. It is impossible that the second judgment was not in utter disregard of the first, when the facts necessary to uphold the one are irreconcilable with the facts necessary to uphold the other.

83 332. Last Judgment Prevails.-Rights acquired by virtue of a judgment or decree are liable to be terminated

${ }^{1}$ Jenkins v. Roberton, 1 H. L. Scotch $\quad{ }^{2}$ Carter v. James, 2 D. \& L. 236. App. 177. See also Goucher v. Clay- See contra Boileau v. Rutlin, a Exc. ton, 11 Jur. N. S. 107. 665,681 . 
in the same manner. Thus, if two Mexican grants are so confirmed at different dates that the same land is included in both decrees, and the confirmee of the first grant, being a party to the second confirmation, fails to assert the former decree in his favor as a bar, his rights will be divested by the second decree. ${ }^{1}$ So where A. foreclosed a mortgage, making B. a party to the suit as a subsequent incumbrancer, and obtained a decree against B. as such; and B. afterwards foreclosed lis mortgnge, making $A$. a party as a subsequent incumbrancer, and also obtained a decree, it was decided that if "A." wished to avail himself of his clecree, he should have set it up in the second action, and that, not having done so, his rights under it were lost. ${ }^{2}$

8333 . Reversal. - The reversal of a judgment is a complete extinguishment of the estoppel. It may still have uffect as a muniment of titlo in favor of a purchaser under it; but this benefit does not extend to any collateral fact found by the verdict or judgment. ${ }^{3}$ A judgment vacated or set aside is no longer a bar; ${ }^{4}$ and if a decree of divorce be annulled, the marital rights, obligations and status of the parties are revived, although one of them has, in the mean time, married and borne children of the last marriage. ${ }^{5}$

\footnotetext{
${ }^{1}$ Semple v. Wright, 32 Cal. 659; $\quad{ }^{4}$ Taylor v. Smith, 4 Ga. 133.

Semple v. Ware, 42 Cal. 619.

${ }^{2}$ Cooley $v$. Brayton, 16 Iowa, 10.

${ }^{3}$ Wood v. Jackson, 8 Wend. 9; 22 Am. Dec. 603.
} 


\title{
CHAPTER XIII.
}

\section{IMPEACHING JUDGMENT.}

\author{
8334. When Impeachable and by Whom, \\ \$ 335. What Strangers may Impeach. \\ $\$ 336$. For Fraud and Collusion. \\ $\S 337$. For Error. \\ \$ 337a Impeaching in Bankruptcy.
}

8 334. When Impeachable and by Whom.-We have already shown the final and conclusive nature generally conceded to belong to judgments sought to be attacked upon jurisdictional or upon other grounds. But there are a few instances in which, it is said, judgments may be impeached. A general statement of the law upon this subject, announced with great apparent confidence in its correctness, has been made in the following language: "The distinction between cases in which judgments may and those in which they may not be impeached collaterally, as derived from the authorities and founded in common sense, may be stated thus: They may be impeached by facts involving fraud or collusion, which were not before the court or involved in the issue or matter upon which the judgment was rendered. They may not be impeached for any facts, whether involving fraud or collusion or not, or even perjury, which were necessarily before the court and passed upon." But this language, in our judgment, does not correctly state the distinction. It is true, that fraud and collusion are the chief grounds available for the purpose of impeaching a judgment. But they are not available for the purposes of impeachment, merely because they were not before the court nor involved in any of the issues in the former action. Tho parties to an action can not impeach or set at nanght the judgment, in any collateral proceeding, on the ground that it was obtained through fraud or collusion. It is their 
business to see that it is not so obtained. If, without any fault or neglect of one party, his adversary succeeds, by fraud, in obtaining an inequitable and unauthorized judgment, he must take some proceeding prescribed by law to amnul the judgment, and can not, in the absence of such annulment, treat it as an invalid. It is only third persons who have the right to collaterally impeach judgments. They are accorded this right because, not being parties to the action, nothing determined by it is, as to them, res judicata. The rule is correctly stated in Cowen, Hill \& Edwards' Note 291 to Phillips' on Evidence, as follows: "Judgments of any court can be impeached by strangers to them, for fraud or collusion; but no judgment can be impeached for fraud by a party or privy to it."1

\section{\& 335. What Strangers May Impeach.-It must not,} however, be understood that all strangers are entitled to impeach a judgment. It is only those strangers who, if the judrment were given full credit and effect, would be prejudiced in regard to some pre-existing right, that are permitted to impeach the judgment. Being neither parties to the action, nor entitled to manage the cause nor appeal from the judgment, they are, by law, allowed to impeach it, whenever it is attempted to be enforced against them.

8 336. Fraud.-Whenever a judgment or decree is procured through the fraud of either of the parties, or by the collusion of both, for the purpose of defrauding some third person, he may escape from the injury thus attempted by showing, even in a collateral proceeding, the fraud or collusion by which the judgment or decree was obtained."

\footnotetext{
${ }^{1}$ Greene v. Greene, 2 Gray, 361; Ordinary v. Wallace, 2 Rich. S. C. Fcck $v$. Woodbridge, 3 Day, 30; Field 460; DeArmond $v$. Adams, 25 Ind. 455; $v$. Sanclerson, 34 Mo. 542; Callahan $v$. Hackett $v$. Manlove, 14 Cal. 85; Hall Griswold, 9 Mo. 7S4; Mason v. Mes- v. Hamlin, 2 Watts, 354; Sidensparker senger, 17 Iowa, 261; Townsend $v$. v. Sidensparker, 52 Me. 481; Crosby Kerus, 2 Watts, 183; Osborne $v$. Moss, v. Leng, 12 East, 409; Lloyd $v$. Mad7 Johns. 161; 5 Am. Dec. 252; Mosely dox, Moore, 917; Brilgeport Ins. Co. $v$. Mosely, 15 N. Y. 334; Williams $v$. $v$. Wilson, 34 N. Y. 2S1; Miners' etc. Nartin, 7 Geo. 37S; Hammock v. Bank v. Roseberry, S1 Pa. St. 309; McBride, 6 Geo. 178; Smith $v$. Hen- Second Nat. Bank's Appeal, $85 \mathrm{~Pa}$. derson, 23 La. An. 649. St. 528.

${ }^{2}$ Atkinson $v$. Allen, 12 Verm. 619;
} 
3 337. Error.- "It is a general and established rule, that when a party's right may be collaterally affected by a judgment, which, for any cause, is erroneous and void, but which he cannot bring a writ of error to reverse, he may, without reversing it, prove it was erroneous and roid in any suit in which its validity is brought in question."1

8337a. Impeaching in Bankrupicy.-A judgment may be impeached for the purpose of showing that it was procured and suffered for the purpose of avoiding the operation of the national bankrupt act. To successfully impeach it, it must be shown-1st, that it was procured and suffered within four months prior to the filing the petition in bankruptcy, and with a view of giring plaintiff a preference over other creditors; $2 \mathrm{~d}$, that the defendant was insolvent at the time; $3 \mathrm{~d}$, that the plaintiff had reasonable cause to believe the defendant insolvent, and procured the judgment to secure a preference over other creditors. Upon being so impeached it will be held invalid, and all proceedings based thereon set aside, as being superseded by the bankruptcy proceedings. $^{2}$ But if the judgment be procured less than four months before filing the petition, it is valid if not intended to prefer one creditor over another, and thereby to thwart the objects which the act was intended to accomplish. $^{3}$ The act was not designed to discourage diligent creditors in collecting their debts, nor will it rob them of their liens procured through such diligence, and not in fraud of the act. ${ }^{4}$

But except for the purpose of showing that it was designed as a means of avoiding the equal distribution of the debtor's property among his creditors, a judgment is no more liable to collateral impeachment in proceedings under the bankrupt act, than it is to such impeachment in the courts of the

1 Vose $v$. Morton, 4 Cush. 27; Leonard $v$. Bryant, 11 Met. 370; Downs $v$. Fuller, 2 Met. 135; Griswold $v$. Stewart, 4 Cow. 458 .

${ }^{2}$ Buchanan $v$. Smith, 7 N. B. Reg. 513; Wilson $v$. City Bank, 9 Id. 70; In re Trice Fuller, 1 Saw. C. C. 245.

${ }^{3}$ Bidclle's Appeal, 68 Pa. St. 13.

4 In re Kerr, 2 B. R. 124; In re Campbell, B. R. Sup. 36; S. C., 1 L.
T. R. 30; S. C., 7 A. L. Reg. 100; In re Sclinepf, B. R. Sup. 4l; S. C., 7 A. L. Reg. 214; S. C., 2 Bt. 72; Clark $v$. Iselin, 21 Wall, 360; 7 Ch. L. N. 185; 2 Cent. L. J. 210; 11 B. R. 337; Vilson $v$. City Bank, 17 Wall, $473 ; 6 \mathrm{Ch}$. L. N. 149; 9 B. R. 97; Little $v$. Alexander, 21 IVall. 500; 7 Ch. L. N. 339; 12 B. R. 134. 
State where it was rendered. ${ }^{1}$ After quite a number of decisions in the lower courts, to the contrary, it is now settled by the judgment of the Supreme Court of the United States, "1st, That something more than passive non-resistance of an insolvent debtor to regular judicial proceedings, in which a judgment and levy on his property are obtained, when the debt is due and he is without just defence to the action, is necessary to show a preference of a creditor, or a purposo to defeat or delay the operation of the bankrupt act; $2 \mathrm{~d}$, That the fact that the debtor, under such circumstances, does not file a petition in bankruptcy, is not sufficient evidence of such preference, or of intent to defeat the operation of the act; $3 \mathrm{~d}$, That, though the judgment creditor in such case may know the insolvent condition of the debtor, his levy and seizure are not void under the circumstances, nor any violation of the bankrupt law ; 4 th, That a lien thus obtained by him will not be displaced by subsequent proceedings in bankruptcy against the debtor, though within four months of the filing of the petition."

1 In re Burns, 1 B. R. 174; S. C., B. | ton, 45 Vt. 159; In re IVhitehouse, 4 R. Sup. 38; S. C., 7 A. L. Reg. 105; S. B. R. 15; In re Robinson, 2 B. R. C., 24 Leg. Int. 357; In re Campbell, 10s; 6 Blatchf. 253.

B. R. Sup. 36; S. C., 1 L. T. B. 30; S. ${ }_{2}^{2} 1$ Wilson v. Bank of St. Paul, 1 C., 7 A. L. Reg. 100; MrKinsey v. Am. L. T. (N. S.) 1; 17 Wall, 489; 6 Harding, 4 B. R. 11; Palmer v. Pres- Ch. L. N. 149; 9 B. R. 97. 


\section{CHAPTER XIV.}

\section{OF THE JUDGMENT LIEN.}

\section{PART I.-NATURE AND CREATION OF THE LIEN.}

$\S 338$. Nature of.

$\S 339$. Creation of.

$\S 340$. Judgment must be Final and Definite.

$\S 34$. Includes Interest.

\$ 342. Coutrolled by Law.

$\S 343$. Docketing.

$\S 344$. Docketing, Correction of.

$\$ 345$. Docketing, Judrment of Appellate Court.

\$346. Docketing Justice's Judgment.

$\S 347$. Misspelling of names, and other irregularities.

\section{PART II-ESTATES AND INTERESTS AFFECTED BY TFE LIEN.}

§ 318. Equitable Estates.

$\S 349$. Equity of Redemption.

\$ 350. Lands fraudulently conveyed.

$\S 351$. Fixtures.

$\S 352$. Rents.

$\S 353$. Term of Years.

$\$ 351$. Estates in reversion or remainder.

$\$ 355$. Lands exempt from execution.

$\S 356$. Int $\in$ rests affected.

$\S 357$. Limited to Actual Interest of Debtior.

\$ 357a. Against part owner.

\& 358. Against Trustees and Administrators.

$\S 359$. Lands intended to be conveyed.

$\S 360$. Vendor's Lien.

$\S 361$. Property of Wife.

$\S 361 \mathrm{a}$. Wife's right of dower.

$\S 362$. Equitable Lien.

$\S 363$. Interests of Vendees and of Vendors.

$\S 364$. Vendee entitled to notice of Liens against Vendor after saie if in possession.

$\S 365$. Judgment for Purchase Money.

$\S 366$. Precedence over Unrecorded Deed, etc.

$\S 366 \mathrm{a}$. Purchase by Judgment Creditor.

$\S 367$. After Acquired Title.

$\S 368$. After acquired title, precedence of Llens on.

\section{PART III.-OF THE PRIORITY OF JUDGMENT LIENS.}

$\S 369$. Judgments of same term.

$\S 370$. Fractions of a day.

$\S 371$. Ofice Hours.

$\$ 372$. Judgment on day of sale.

\$ 373 Conveyance or Incumbrance of Land simultaneously with its acquisition. 380 
$\$$ 374. Priority acquired by diligence.

\$ 375 . Priority acquired by superior equity.

$\S 3 i g$. On writ of error bond.

\$ 377 . Sales under Junior Judgment.

\& 3is. Preferred debts to United States.

\section{PART IV.-OF THE SUSPENSION AND DISCHARGE OF LIENS.}

§ 379. Suspension by Ca. Sa.

$\S 380$. Suspension by Forthcoming Bond.

§ 381 . Vacation and Restoration of Judgment.

$\$ 3$ 32. Stay of Execution on Appeal.

\& 383. Dormant Execution.

\$ 334. Discharge by act of defendant.

$\S 385$. New County.

$\S 286$. By non-claim.

§ 387. Pischarge through Fraud.

$\$ 388$. Discharge by merger of Judgment.

$\S 359$. Cannot be restored by agreement.

$\S 390$. Discharge by sale.

\$ 391. Payment without discharge.

\section{PART V.-EXTENDING AND REVIVING.}

\$392. Scire Facias does not.

s. 2n3. Inability to execute process.

$\S 394$. Sale after expiration of Lien.

\$ 395 . Equity will not extend nor limit.

§ 396. Transcript from another County.

\section{PART VI.}

\$ 397 . Liens for future advances.

\section{PART VII.-FORECLOSURE SUITS.}

$\S 393$. Merger of Lien.

8 399. Sale to satisfy Senior and Junlor Liens.

$\S 400$. Surplus Proceeds.

$\S 401$. Of different kinds of decrees.

$\S 402$. Liens restricted by Statute.

\section{PART VIII.-JUDGMENTS IN THE FEDERAL COURTS.}

$\$ 403$. Adoption of State Laws.

504. How State Laws were adopted.

$\$ 405$. Co-extensive with jurisdiction of Court.

$\$ 40 c$. Decrees in Admiralty.

\section{PART I.-NATURE AND CREATICN OF THE LIEN.}

8 338. IJature of Judgment Lien.- "A judgment is not a specific lien on any particular real estate of the judgment debtor, but a general lien upon all his real estate, subject to all prior liens, either legal or equitable, irrespective of any knowledge of the judgment creditor as to the 
existence of such liens." "In short, a judgment creditor has no jus in $r$, but a mere power to make his general lien effectual, by following up the steps of the law, and consummating his julgment by an execution and lery on the land. If the lebtor should sell the estate, he has no right to follow the proceeds of the sale into the hands of the rendor or rendee, or to claim the purchase mones in the hands of the latter. "A judgment lien on land constitutes no property or right in the laud itself. It confers only a right to lery on the same to the exclusion of other adrerse interests, subsequent to the judgment; and when a lers is actually made on the same, the title of the creditor for this purpose relates back to the time of the judgment, so as to cut out intermediate incumbrances. Subject to this the defendant mas conrer the land.": As a judgment creditor has a mere general lien, he cannot, like a mortgagee or other holder of a specific lien, sue for such waste as injures his security. ${ }^{3}$ The lien of a judgment attaches to all the interest which the debtor had at the rendition of the judgment. A subsequent sale under the judgment relates back so as to transfer all the title which the debtor had when the lien attached. ${ }^{*}$ But where costs are incurred in enforcing a lien, they are to be paid out of the proceeds realized, and are preferred to the lien. This is said to be true where there are sereral julgment liens, and, through proceedings instituted by the holler of the junior lien, the lands are sold for the purpose of haring the proceeds distributed among the lien holders according to their rank and precedence, and the sale does not produce funds suficient to satisfy eren the senior lien." This, said the court, "seems to us a rery just practice. Even the senior lien could not have been enforced without the same costs, and it has no right to expect a junior one to arait its enforcement. They hare a right to insist upon a sale in order to learn whether the net proceeds of the sale will reach them, and then to seek satisfaction otherwise, if it does not. On the same principle the expense of an audit

${ }^{1}$ Rodgers $v$. Bonner, 45 N. Y. 379; ${ }^{3}$ Lanning $v$. Carpenter, 45 X. Y. Int. Schoul Dist. $v$. Werner, 43 La. 412; Ind. School Dist. $v$. Werner, 43 643.

2 Conard $v$. Insurance Co., 1 Pet. 3\%. 413: see, also, Doe \& Peabody $r$. Mchuight, Ber. (New Brunswich) $3 ; 6$.

\section{Ia. 643 .}

545 .

nion Bank $v$. Maynard, 5l Mo. ${ }_{5}^{5}$ Jones v. Wright, 60 Geo. 364. 
in distributing the fund is always paid out of the fund whether the lien on which the sale was had is reached by the proceeds or not." "The lien, if not an effect of the judgment, is inseparably connected with it. And this is the case, whether the lien was created by the judgraent and execution or by statute. And in either case, where the riglit has attached in the courts of the United States, a State has no power, by legislation or otherwise, to modify or impair it." Therefore, a State law, passed after the rendition of a judgment in a United States court, requiring judgrments to be recorded in a particular way, in order to make them a lien, does not impair or affect the lien of such cxisting judgment, though it be not recorded."2

2399. Creation of the Lien.-The statutes of the sereral states of this Union generally declare that judgments shall be liens for some specified period of time, from the date either of their docketing or of their rendition. But the lien undoubtedly existed by virtue of certain English statutes so anciently adopted as to be regarded as part of our common law, and also by virtue of other English statutes subjecting to execution lands situate in the colonies. "Wo find it laid down by compilers and by cornmentators on the law of Engrland, thiat the lien of judgments upon lands in that country was created by the statute de mercatoribus, also styled the Statute of Acton Burnell, 11th of Edward the First, and by the Statute of Westminster 2d, 13th Edward the First, chapter 18, by the latter of which statutes the writ of elegit was given, bs enacting that 'he who recovereth in debt or damagres, may have either a feri facias on the chattels of the debtor, or a writ on which the sheriff shall deliver to him all the chattels of the debtor, saving only his oxen, and beasts of the plough, and half of his land, till the debt be levied upon a reasonable price or extent." "3

In 3d Bac. Ab., Execution, D, p. 392, the law is thus stated: "When the plaintiff has judgment, he has his election to sue out what execution lie pleases, but he can not

\footnotetext{
${ }^{1}$ Shelly's Appeal, $33 \mathrm{~Pa}$. S. 210; 2 Massingill $v$. Downs, 7 How. U. see also IIcNeil $v$. Lean, 32 Verm. S. 760.

42\%.

${ }^{3}$ Bac. Ab. Tit. Ex.
} 
regularly take out two different executions on the same judgment, nor a second of the same nature, unless upon failure of satisfaction out of the first. Therefore, if the plaintiat, upon a judgment or recognizance at common law, sues ont an elegit, he can have no capias ad satisfaciendum afterwards to take the boly, because he hath determined his choice, by that writ, to the goods and chattels and a moiety of tho land, which having been entered upon record, he is thereby estopped, and though he takes but an acre of land in execution, yet it is held a satisfaction of the debt, be it never so great, because in timo it may como out. The exceptions to this restriction of the plaintiff's right to another execution, are the return of nithil on the first, and the return of the sheriff, that he hath levied only on the goods of the defendant; because, plaintiff being entitled to levy on the land also, should not bo precluded from the benefit conferred by the statute. But if the land be delivered, though of never so littlo value, that will be a bar, if the sheriff hath delivered a moiety of the land according to the statute."

In Virginia, Maryland and Mississippi, in the absence of any statute, in direct terms giving them that effect, judgments were treated as liens upon real estate, as the necessary result of the various English and colonial statutes subjecting lands to execution. "This judgment lien is a uniform consequence of the real estate being liable to be taken and extended under an execution upon such judgment. Whenever, then, such a liability exists, the lien arises as the constant incident of such a judgment; and where the property can not be taken in execution, there is no lien." The lien was inseparably associated with the right to take out an elegit. If this right was suspended, the land was free from the lien during such suspension. If the right to

${ }^{1}$ Snead $v$. MeCoull, 12 How. U. S. |Wheat. 177; Scriba v. Deanes, 1 407. Brock, 166; Bank of U. S. v. Win-

${ }^{2}$ Coombs $v$. Jordan, 3 Bland's Ch. ston's Exr., 2 Brock, 252; Burton $v$. 284; 22 Am. Dec. 236. See, also, in Smith, 13 Pet. 464; Shrew v. Jones, 2 relation to the creation of the lien by McL. 7S; Davidson $v$. Myers, $24 \mathrm{Md}$. early English and colonial statutes, 555; Renick $v$. Ludington, $14 \mathrm{~W}$. Va. and its inseparable connection with 367 ; Borst $v$. Nalle, 28 Gratt. 423; the right to issue the elegit, the casc Taylor's Ad. v. Spindle, 2 Gratt. 44. just cited, and Rankin v. Scott, 12

384 
take out an elegit continued though a fieri facius had already issued and was still out, the lien continued though a levy had been made under the fieri fucias. ${ }^{1}$ A statute enacted by the lerislature of the state of Texas, provided that whenever final judgment shall be rendered in any court of record, said judgment shall become a lien, etc. The words "shall be" were by a majority of the court construed as equivalent to shall have been; and the act was therefore given a retroactive operation so far as to mako judgments entered prior to its passage, liens upon the defendant's real estate, taking effect contemporaneously with the act itself. ${ }^{2}$ In harmony with the general rule that a lion does not exist except in consequence of the right to execution for a definite amount to be made ont of the real property of the judgment debtor, a judgment upon the foreclosure of a mortgige does not becomo a lien upon any property not embraced in the mortgage, until a sale had been mado, the deficiency ascertained, and a judgment entered or docketed therefor. ${ }^{3}$

8340. Judgment must be Final and Definite.-Because the lien of a judgment is inseparably associated with the elegit or with the right to take lands in execution, it follows that there can be no lien except upon such judgments as tho plaintiof is entitled to satisfy by levy upon the lands of tho debtor. A judgment by default which is interlocutory in its nature, and which can not become final until the amount is ascertained, is of itself no lien, nor will the lien of the final judgment when entered thereon, relate back to tho entry of interlocutory judgment. ${ }^{4}$ The julgment must be for a specified sum. If it be that "plaintiff do recover judgment as prayed for;" or that he pay out an estate, when collected, to certain general legatees, after retaining a certain sim in his hands to pay connsel fees and allowance to himself,${ }^{6}$ or that an execution issue for any deficiency which

1 Massingill $v$. Downs, 7 How. 760 ; U. S. $v$. Morrison, 4 Pet. 124; Tayloe $v$. Thomson, 5 Pet. 35s; Burton $v$. Smith, 13 Pet. 464.

2 Hoore $v$. Letchford, 35 Tex. 155; Gardner $v$. Spivey, Id. 508.
${ }^{3}$ Hibberd $v$. Smith, 50 Cal. 511; Linn $v$. Patton, 10 W. Va. 187.

${ }^{4}$ Davidson $v$. Myers, 24 Md. 533; De Saussure $v$. Zeigler, 6 S. C. 12.

${ }^{5}$ Lirette $v$. Carrane, $27 \mathrm{La}$. An. 293.

${ }^{6}$ Hamburger $v$. Easter, 57 Ga. 71 . 
may exist after selling certain designated property, ${ }^{1}$ in all these cases there is no judgment lien.

8. 341. Includes Interest. - The lien of a judgment includes all amounts for which execution may properly issue. In the absence of any statutory provision, interest conld be recovered only by an action on the judgment; and was therefore no lien until it merged into the second judgment. But in all cases where the statute has provided for the collection of interest by execution, it is as much a lien as the principal sum recovered. ${ }^{2}$

8. 342. Lien not Subject to Control of the Court.-The lien of a judgment or decree is regulated by law; and can not be restrained or extended by the court so as to take effect upon particular real estate. ${ }^{3}$ Its general nature can not be made special. "While courts of law have generally the power to revole, correct or quash their own process in the course of their ordinary jurisdiction, there is a manifest impropriety in a court of law undertaking to grant relief, on the ground of equities existing ontside of the process in favor of one not a party to the suit." The character of the cause of action does not affect the nature of the lien. Therefore a judgment for purchase money has no lien superior to that of a judgment on any other cause of action. ${ }^{5}$

2 343. Docketing. - "The dogget, or as it is commonly called the docket or docquet, is an index to the judgment invented by courts for their own ease, and the security of purchasers, to avoid the tronble and inconvenience of turning over the rolls at large. The practice of docketing judgments seems to have obtained as early as the reign of Heury the Eighth, in the Court of Common Pleas, where the dockets are entered on a separate roll called the Docket Roll or Common Docket, which is of so bigh an anthority as to even warrant an amendment of the judgment itself. But in the King's Bench the docket was originally nothing more than a note on parchment or paper, containing the christian and surname of plaintiff and defendant, the debt and dam-

\footnotetext{
1 Eamesv. Germania Turn Verein, 74 ${ }^{3}$ Castro v. Illies, 13 Tex. 229. IIl. 5t; Linn $v$. Patton, 10 WV. Va. 187. ${ }^{2}$ Mower v. Kip, 2 El. Ch. 165; Winslow $v$. Ancrum, 1 McC. Ch. 105; 311.

Sims $\%$. Campbell, 1 McCh. 53; 16 Am. Dec. 595.

${ }^{4}$ Clonts $v$. Ritch, 12 Fla. 633

5 Fisher $v$. Foote, 25 Tex. Supp.
} 
ages recovered, with the term and number of the judgment roll." 1 While judgments are for other purposes valid as soon as rendered, they do not become liens upon real estate, at least against subsequent purchasers, without notice, until docketed. ${ }^{2}$ Such purchasers are not bound to examine for judgment liens further than to look into the proper dockets. If the clerk or prothonotary fails to make the proper entries in his dockets, the only remedy of an aggrieved judgment creditor is by action against the officer. ${ }^{3}$ If a subsequent judgment be first docketed, a purchaser under it will obtain the title to the real estate sold, free from the lien of a prior uudocketed judgment. ${ }^{4}$

\& 344. Correcting Docketing.-If, by mistake, the judgment be docketed for too small a sum, the docketing may, on motion, be corrected; but not to affect the rights of purchasers and incumbrancers acquired prior to the correction. ${ }^{5}$

8.345. Judgment in Appellate Court.-If, on appeal, the judgment of the inferior court be affirmed, with costs or damages, these costs and damages do not constitnte a lien until docketed in the lower ceurt. If it were otherwise, purchasers could never ascertain what burdens were imposed upon real estate by judgments until the last moments cluring which appellate anthority can be exercised had elapsed. ${ }^{6}$

8 346 . Jusitices' Judgment. - In California, Justices of the Peace aro not authorized to keep a lien docket. They have, it is true, a book, which is called a docket. The purpose of this book is to preserve a written memorial of the acts of the justices and of the proceedings hild and the judgments entered by and before them. Justices' dockets can not be employed to create liens. Their judgments become liens when transcripts, or abstracts thereef, certified by the justice, are filed in the office of the County Recorder.

1 Tidd's Praetice, 939.

2 Foster $v$. Clapman, 4 MeCord, 291; Close $v$. Close, 28 N. J. Eq. 472 . In some of the States it seems clear that a judgment is a lien as against the defendiants and all persons having notice thercof, whether docketed or not. Renick $v$. Ludington, 14 W. Va. 367 .

${ }^{3}$ Rilgway \& Co.'s Appeal, 15 Penn. S. 177 ; Woods $v$. Reynolds, 7 W. S. 406 ; Hance's Appeal, 1 Penn. S. 40s; Buchan $r$. Sumner, 2 Barb. Ch. 195; Landon $v$. Ferguson, 3 Luss. Ch. 349;
Braithwaite $v$. Watts, 2 Cromp. \& Jerv. 31s; Brandling $v$. I'inmmer, $\because 6$ L. J. R. (N. S.) Ch. 326 .

tMann's Appeal, 1 Penn. S. 24. In Canada, judgnients are not doelieted. They may be registered, and from the registry thereof they beems liens. Bank $v$. Thompson, 9 Grant s Ch. 5l; Doe $v$. Lonlton, 9 Q. ]3. (U. C.) 532 . ${ }^{5}$ IIunt $v$. Grant, 19 Wend. 90.

${ }^{6}$ Daniels $v$. Winslow, 4 Minn. 318; Chapin $v$. Broder, 16 Cal. 403. 
This transcript must formerly have been a copy of the judgment. If it was in form similar to the docket entries required to be made in the dockets liept by the County Clerk of Judgments in the District Court, it was manthorized by law, aud ereated no lien. ${ }^{1}$ But now an abstract may be made and filed instead of a transcript. ${ }^{2}$

8 347. Mis-spelling of Names and Other Irregularities.-The proper spelling of his name is not essential to a sufficient docketing against the defendant. All that the law demands in this respect is, that the pronunciation of the name written by the clerk shall correspond with that of the name of the person whose realty is sought to be charged. "Identity of sound is a surer designation of the names of persons than identity of orthography." This rule is so liberally applied, that though the name, as spelt on the docket, would ordinarily be pronounced differently from the name of the defendant, yet if, aceording to the prevailing usage in that part of the country, the two names would be similarly spoken by its inhabitants, the docketing will ereate a lien. Thus were, in a portion of the State of Penusylvania, "Bubb" was commonly pronouneed like Bobb, the eutry and docketing of a jadgment against "John Bobb," was held to charge purchasers under "John Bubb," with notice. "In examining titles, the searehers must take notice of the different ways of spelling the same name. But if the spelling is so entirely unusual that one would not be expected to think of it, then it would not impart notice." exception to the rule making a docketing preserving the identity of sound sufficient, exists when, though the identity of sound is still respected, the name is indexed under the wrong initial. Thus, while "Yoest" and "Joest" are pronounced alike in the German, searchers for judgment incumbranees against "Yeost," are not bound to consult the indices under the letter "J." Nor is the seareher required to know how the name he is examining may be spelled according to the rules applicable to foreign languages; and to ascertain whether some entry in the docket maly, if pronounced under those rules, represent the name of the

1 Bagley $v$. Ward, 27 Cal. 369.

${ }^{2}$ C. C. P., Secs. 897 to 900 .

${ }^{3}$ Hicyer $v$. Fegaly, 39 Penn. S. 429; on anthority of 2 Str. $839 ; 2$ Taunt.
401; 2 Carnes, 362; Petrie v. Woodworth, 3 Cai. 219.

${ }^{4}$ Myer v. Fegaly, 39 Prm o $10 n$ 388 
owner of the real estate he is searching. "The docket must be kept in our own language." A docketing against "A. Jones" is sufficient to charge the lands of "Abel Jones," if he uniformly writes his christian name with the initial only, and there is no other "A. Jones" in the same county." The addition of "junior," being no part of a man's name, is not essential to a docketing against a son, though lis father has the same name and resides in the same convty. ${ }^{3}$ Under a law requiring that the docket "particularly state and set forth the names of the parties," an entry of the firm name of the defendants, withont their christian names, creates no lien." The entry under the letter " $G$ " of "Green, Wilson \& Mitchell," no christian name being shown, imparts "no notice, and affects neither subsequent purchasers nor jadgment creditors." The Supreme Court of California dissent from the decisions just cited. Under a statute of that State requiring the names of defendants to be entered in the docket in alphabeticil order, the question arose whether a judgment docketed against "Chipman and Anghinbaugh" created a lien against the lands of W. W. Chipman. The contt thus answered this question: "It was evidently intended that the surnames should precede the christian names, and the omission of the christian name of the defendant Chipman did not deprive the docket of the useful function of directing the attention of those interested. to the existence of the judgment, and to all its iucidents." If this statement on the part of the court regarding the effect of the omission of the christian name of the defendant, be understood as a statement of an actual fact, then the decision is free from objection; but, viewed as a conclusion of law drawn from the other facts, we think it very questionable. We do not doubt the wisdom of thoso decisions which declare that a substantial compliance with the provisions of the statute is all that ought to be exacted $;{ }^{7}$ but subsequent purchasers and incumbrancers ought not to be sacrificed to the indolence, inattention, or incapacity of those whose daty it is to docket the judgments of the court. The

\footnotetext{
'Heil and Lauer's Appeal, 40 Penn. S. $\quad{ }^{5}$ Ridgway \& Co.'s Appeal, 15 Penn. 453; Buchan $\approx$. Sumner, 2Barb. Ch. 197.

'Joncs' Estate, 27 Penn. S. 336.

${ }^{3}$ Bidwell $\approx$. Coleman, 11 Minn. $7 S$.

${ }^{4}$ The York Bank's Appeal, 36 Penn. S. 458 .

S. 177 .

${ }^{6}$ Iibberd $v$. Smith, 50 Cal. 511.

7 Hesse $v$. Mann, $40 \mathrm{~W}$ i. 560 . 
docket ought, at least, to be a fair index to the names of the judgment debtors; and this it can never be, if it does not contain a reference to the christian as well as to the survames; something to distingnish the particular Brown or Smilh whose realty is songht to be charged, from the meny other persons bearing the same name. So, too, the entries ought to be made in the book in common use at the time; and if entered so far out of their order that they would probably escape the attention of a reasonably diligent searcher, the docketing ought to be adjudged insuficient. It must, however, be admitted that our views in this respect are not in harmony with some of the decisions. ${ }^{1}$ In Virginia, after much consideration, it has been determined that the indexing was not essential to creation of a docket lien." The decision was placed upon the ground that, in that State, the docket and its index were separate and distinct; and that the judgment creditor, by procuring the entry or record of lis judgment in the docket, fully complied with all which tho statute required of him; and upon the further general ground that an index is not an essential part of a record. In tho majority of the States, the proper indexing of the defendant's name, or its entry under the proper letter in the docket, is indispensable to the creation of a lien against a purchaser or incumbrancer in good faith without notice. ${ }^{3}$ The docketing of a judgment is a ministerial act, and may be effectively performed on a non-judicial day. ${ }^{4}$ It has been held that the docket must be so far perfect as to contain within itself everything required by the statute; that it can not bo aided by refereuce to the judgment or prior proceedings; and, therefore, that the use of numerals withont anything to show whether they represent dollars, is fatal. ${ }^{5}$ This is very questionable. We judge the better rule to be that thus stated: "A subsequent purchaser, however, is affected with such notice as theindex eutries afford; and if they are of such a character as would induce a cautions and prudent man to make an examiuation, he must make such investigation, or the failure to do so will be at his peril." A judgment agaiust. defendant by a wrong namo being valid against him, miy

${ }^{1}$ Hesse $\tau^{\prime}$. Mann, 40 Wis. 560.

2 Old Doininion Granite Co. Clarke, 28 (iratt. 617.

3 Nletz v. State Bank, 7 Neb. 165. 390
* In re Worthington, 7 Biss. 4j5; 16 B. R. 52.

5 In re Boyd, 4 Saw. 262; I6B. R. 137.

- Metz v. State Bani, 7 Nob. 172. 
be properly docketed by entering the correct name, and showing also the title of the cause as it stood with the wrong name.' PART II.-ESTATES AND INTERESTS AFFECTED BY THE LIEN. 8. 348. Equitable Interests.-At common law a judgmont lien did not attach to a mere equity, though tho equity were accompanied by possession." This rule of the common law prevails in several of the United States, ${ }^{*}$ and is generally applied in the absenco of any statute undoubtedly creating a different rule. Thus, though a statute provided that a judgment should " be a lien on all real property of the jurdgment debtor not exempt from execution, owned by him in the county at the time of docketing," it was held not to make a judgment a lien on the equitable title of the defendant. $^{5}$ This common law rule has been abolished in Englind. Judgments in that country are liens on "all lands, tenements, rectories, advowsons, tithes, rents and bereditaments (including lands and hereditaments of copyhold or customary mature) of or to which such person shall at the time of entering such judgment or at any time afterwards be seized, possessed or entitled for any estate or interest whaterer, at law or in equity, whether in possession, reversion, remainder or expectancy, or over which such person shall at the time of entering such judgment or at any time afterwards lave any disposing power which he might withont the assent of another exercise for his own benefit." Laws having substantially the same effect as the provisions just quoted from the English statute, are in force in a majority of the States of the American Union. Equitable estates, while not subject to any judgment lien which could be recognized and enforced at law, were, in equity, as much bound by such lien as legal estates were. In Pennsylvania, on account of the want of a court of chancery, tho courts were, from necessity, obliged to treat all judgments as having an immediate operation upon equitable as well as upon legal estates. Therefore a party who, in that State, pur-

${ }^{1}$ Beavan $v$. Countess Oxford, $3 \mathrm{Sm}$. \& G. 11 .

${ }^{2}$ Jickson $v$. Chapin, 5 Cow. 485 ; Russeii $v$. Houston, 5 Ind. 180; Jeffries $v$. Sherburn, 21 Ind. 112; Norsell v. First N. B., 3 C. L. T. 433; 91 U. S. 357; Coombs v. Jordan, 3 Pland. Ch. 20t; $22 \mathrm{Am}$. Dec. 236; Dixon v. Dixon, 81 N. C. 323. 330.

* Powell v. Knox, 16 Ala. 361.

5 Smith $v$. Ingles, 2 Oregon, 43.

1 and 2 Vict. C. 110, \$13.

'Michaux's Adm. v. Brown, 10

Gratt. 61:; Haleys v. Wiliams, 1 Leish, 1.10; $19 \Lambda$ m. Dec. 743 ; Lee $v$. Śtone, 23 Am. Dec. 583. 
chased land, paying a portion of the purchase money and taking possession, but who has not received any conveyance, has an estate to which a judgment lien may attach. ${ }^{1}$ Where the vendor held the right to obtain title on certain terms from the State, the land was held to be bound by a judginent lien, though not the rendor but the vendee complied with the terms and obtained the patent. ${ }^{2}$ In the same State, several legatees agreed to take land instead of the money which would arise from the land if it were sold. It was liokl that a judgment against one of them, rendered after such agreement, bound his share as soon as it was set apart to him. 3 The general tendency of the American statutes creating and regulating judgment liens is to make such liens a charge upon whatever estate the judgment debtor may have, irrespective of the question whether his titla is legal or equitable, perfect or inchoate. A judgment lien may, therefore, attach to lands purchased of the government but for which no patent has issued. 4 The interest which is subject to the lien must be an interest in the land itself. 5 Hence a devise to children, but giving their father the right to live on the land during his life, confers no estate on the father which ean be subject to a judgment lien. ${ }^{\circ}$ An easement consisting of a right of way with such an occupancy as is necessary to give this right effect is not subject to judgment liens. ${ }^{7}$

\section{349. Equity of Redempsion.-An equity of redemp-} tion in real estate is subject to the lien of a judgment. ${ }^{8}$ If

${ }^{1}$ Auwerter $v$. Mathiot, 9 S. \& R. 397; Russell's Appeal, 15 Penn. S. 319.

${ }^{2}$ Carkhnff $v$. Anderson, 3 Binn. 4.

${ }^{3}$ Brownfield $v$. Mackey, 27 Penn. S. 320 .

${ }^{4}$ Levi $v$. Thompson, 4 How. U. S. 17; Landes $v$. Brant, 10Id.348; Huntingron v. Grantland, 33 Miss. 453; Cavender $v$. Smith, 5 Iowa, 157; Jackson $v$. Williams, 10 Ohio, 69; Rogers v. Erent, 5 Gilm. 573.

5 Horrow $v$. Brenizer, 2 Rawle, 185; Thomas $v$. Simpson, 3 Barr. 69.

${ }^{6}$ Calhoun v. Jester, 11 Pa. St. 474.

7 Testern Pa. R. R. Co. v. Jolnnston, 59 Pa. S. 294.
${ }^{8} \mathrm{Julian} v$. Beal, 26 Ind. 220; Taylor v. Cornelius, $60 \mathrm{~Pa}$. St. 187. But it is well settled in Illinois that the right of a judgment debtor to redeem lis property from a forced sale thereof, is a personal right which can not be affected, impaired or transferred to another by virtue of the !ien of any judgment against the debtom; in other words, the statutory right io redeem is an interest to which the lien does not attach. Merry $v$. Bostwick, 13 Ill.398; Watson v. Reissig, 21 Id. 231; Blair $v$. Chamblin, $39 \mathrm{Il}$. 526. 
before the sale under a decree of foreclostre a judgment be docketed against the defendant, it will be a lien on the surplus proceeds arising from the sale; but if not docketed until after the sale, it cloes not constitute any lien on such surplus." So a deed of trust made to secure the payment of money, giving the trustee power to sell in case of nonpayment, and reserving the right of the grantor to redeem, will leave the grantor with an interest to which the lien of a subsequent judgment will attach. If the trustee sell in pursuance of his authority, he can convey title clear of the lien. The surplus proceeds of the sale are subject to the lien, while in the hands of the trustee. But he is not bound to search the records; and therefore is relieved from all liability, if, without any knowledge of the existence of any judgment, he pays over the surplus without regard to the lien. ${ }^{2}$ In Illinois it is said that the surplus, after sale by trustee, must be distributed among the general creditors, regardless of liens. ${ }^{3}$

\section{\%, 350. Lands Fraudulently Conveyed.- "Whoever} goes ont with an execution to seek the fruits of his judgment is too apt to find that fraud has forestalled him. It then becomes his business to pursue those fruits wherever frud has taken them; to wrest them from the possession of his alversary, wherever they may be found; and to prepare himself to show that the refuge to which they liave been taken is still the refuge of fraud. In many instances the aid of equity is invoked. But generally this is unnecessary; for a transfer made to hinder, delay, or defraud cieditors, while, as between the parties, it conveys the title, has, as against a creditor proceeding under execution, no such effect. As against the fraudulent transferee, the creditor may seize the property, whether real or personal, as that of the fraudulent vendor, and may proceed to sell it under execution. The title transferred by such sale is not a mere equity-not the right to control the legal title, and to have the fraudulent transfer vacated by some appropriate proceeding; it is the legal title itself, against which the

${ }^{1}$ Sweet $v$. Jacocks, 6 Pai. 355 .

${ }^{2}$ Cook v. Dillon, 9 Iowa, 407.

${ }^{3}$ Pahlman v. Shumway, 24 Ill. 127. 
fraudulent transfer is no transfer at all. ${ }^{1}$ And what is true of fruduluent transfers is equally true of fraudulent mortgages, liens, julgments, execntions, and all similar devices for hindering, delaying, or defrauding creditors. Property held under and by virtue of a frandulent lien, execution or transfer, is subject to execution precisely as if such transfer had not been made and such lien had not been given; and this whether it was wholly or partly fraudulent. For if, on account of fraud, it be void in part, it is at litw void in toto." A purchaser uncler a jadgment rendered against tho grantor subsequent to the conveyance, will obtain the superior title and will be permitted to impeach the former deed for frand. ${ }^{3}$ The right to issue execntion and to sitisfy it by the sale of the defendint's real estate, ordinarily implies that the judgment is a lion upon such real property. There are manifest dificulties in extending this rule to all cases where real property has been transferred to hinder or defraul creditors. In the first place, the apparent title is in the frudululent vendee, and nothing appears of record to impugn the fairness of the transfer or to warn purchasers and incumbrancers that it remains subject to execution against the vendor. In the second place, the title in fact passes by the transfer not only as between the parties, but also as against creditors who do not assail the transfer by some proceeding at law or in equity having for its object the subjection of the property to the payment of their claims against the vendor. Perhaps on the levy of the execution its lien may, as against persons not purchasers or incumbrancers in good faith and for value, relite back to the rendition or docketing of the judgment. But we think the better rule is that one who has obtained judgment, and

\footnotetext{
${ }^{1}$ Freeman on Ex., $\$ 136$, citing Hall |Bland, 569; 18 Am. Dec. 350; Midv. Sandis, 52 Me. 355; Gormerly v. dleton v. Sinelair, 5 Cr. C. C. 509; Chapman, 51 Geo.425; Pratt $v$. Wheel- Lawrence $v$. Lippencott, 1 Halst. 473; er, 6 Gray, 520; Austin v. Bell, 20 Croft v. Arthur, 3 Desau. 223; Shears Johns. 442; 11 Am. Dec. 297; Lowry v. Rogers, 3 B. \& Ad. 363; Staples $v$. :. Orr, 1 Gilm. 70; Gooch's Case, 5 Bralley, 23 Conn. 107; Fowler v. Tre. Co. 60; Jacoby's Appeal, 67 Pa. S. bein, 16 Oh. S. 493; Foley v. Bittcr, 434; Hofman's Appeal, 44 Pa. S. 95; 34 Mrd.646.

Eastman $x$. Sehettler, 13 Wis. 321; ${ }^{2}$ Freeman on Ex., $\$ 136$, and eases Pepper $v$. Carter, 11 Mo. 540; Barr $v$. there eitel.

Hatch, 3 Ohio, 527; Russell $v$. Dyer, ${ }^{3}$ Eastman $v$. Schettler, 13 Wis. 324; 33 N. H. 186; Duvall v. Waters, 1 Miner v. Warner, 2 Grunt's Cas. 448. 394
} 
has not by levy or otherwise taken any further steps to obtain salisfaction out of property fraudulenlly trausferred, bas no lien thereon, and, in the event of the bankruptey of the defendiunt, that he could not be awarded preference as a lien holder"; and that the judgrment creditor first proceeding in equity to set aside the conveyance and to sulject the lind conveyed to the payment of his judgment, will thereby obtain the fruits of his diligence and overreach persous having prior judgments against the same grantor. ${ }^{2}$ We concede, howerer, that numerous decisions exist declaring that a judgment lien does not attach to premises transferred by the defendant to defraud his creditors. ${ }^{3}$

? 351. Fixtures.-Fixtures pass by virtue of sales under judgment. Therefore, if by the statute of a State, the rolling stock of railroads are made fixtures, they are subject to judgment liens. ${ }^{4}$

8 352. Rents.-If, upon filing a bill to have land sold under the plaintiff's judgment, a receiver of the rents and profits be appointed, all the moneys which come into his hands for rents are, in equity, subject to the lien of the judgment. If the lands bo sold, for a sum insufficient to satisfy the plaintiff's lien, these funds held by the receiver are immediately applicable towards paying the balance due. ${ }^{5}$ A deed reserving a rent charge leaves the grantor an interest in the realty which may be taken and sold under execution. ${ }^{6}$

8 353. Term of Years. - An estate in lands for a term of years being at common law a chattel, was not bound by the lien, and was liable to be affected by a judgmeut ouly through a levy aud sale under an execution like other personal property. ${ }^{7}$ It has, lowever, been made the subject of judgment liens, by statute, in some of the states. ${ }^{8}$

8 354. An Estate in Reversion or Remainder, though it does not entitle the reversioner or remainder-man to the immediate possession of lands, is nevertheless, for the pur-

${ }^{1}$ In re Estes, 12 Cent. L. J. 135.

${ }^{2}$ Lyon $v$. Robbins, 46 Hil. 277.

3 Manhatton Co. v. Evertson, 6 Pai. Ch. 465 ; MeKee $v$. Gilchirist, 3 Watts, 231 ; Jacoby's Appeal, 67 Pa. S. 455 ; Minlford $v$. Peterson, 35 N. J. Law, 133.

${ }^{4}$ R. R. Co. v. James, 6 Wall. 750. nett, 40 Ia. 537.
${ }^{5} 2$ U. S. v. Butler, 2 Blatchf. C. C. 201.

${ }^{6}$ Hurst $v$. Sithgrow, 2 Yeates, 24; $1 \mathrm{Am}$. Dee. 326.

7 Merry $x$. Hallet, 2 Cow. 497; Vredenberg $v$. Morris, 1 John. Ca. 223.

${ }^{8}$ First N. B. of Davenport v. Ben. 395 
poses of sale and conveyance, whether voluntary or involuntary, treated as an estate in possession. It was liable to bo takeu under an elegit, and is subject to judgment lieus, and, in most of the United States, may be sold under a fitri facias. ${ }^{1}$

3 355. Property Exempt from Execution.-We liave already seen that the law of judgment liens resulted from and depended upon the right to apply the real estate of the judgment debtor to the satisfaction of the debt. Wherever this right does not exist, by virtue of some law exempting specified property from execution and forced sale, no jutlgment can, as to such property, take effect as a lien. Hence homesteads exempted from execution by statute, are thereafter, as long as they retain their homestead character, clear from all judgment liens; and may, notwithstauding judgments docketed against their owners, be by them conveyed or encumbered without furnishing any opportunity for such liens to attach. ${ }^{2}$ But if the relinquishment of the lomestead claim so far precede the conveyance of the homestead, that they can not be regarded as simultaneons acts, theu, an opportunity being given for the attaching of liens, the purchaser receives the property subject to all judgments docketed against the grantor at the time of the conveyance. ${ }^{3}$ By early decisions of the Supreme Courts of Wisconsin and Minnesota, statutes providing in general terms that judgments should be liens on all the defendant's real estate, were construed as extending such liens over homesteads, which by law were exempt from. sale under execution. As a consequence of this construction, the owner of a homestead could not alienate it without at the same moment, by removing the homestead character, leaving the property liable to be sold under any judgment against the alienor at the date of the conveyance. ${ }^{4}$ This rule also

I Burton v. Smith, 13 Pet. 462; 218; Gapen v. Stephenson, 17 Kans. Watson on Sheriffs, 208; Woodgate $v$. 617; Black $v$. Epperson, 40 Tex. 162; Fleet, 44 N. Y. 1; IVilliams v. Amory, Houghton v. Lee, 50 Cial. 103.

14 Mass. 20; Bishop of Bristol's case, 2Leon. 113; Brown\%. Gale, 5 N. H.416; Hiumplreys $v$. Humphreys, 1 Yeates, 427 ; Den $v$. Hillman, 2 Halst. 180.

2 Monroe $v$. May, 9 Kians. 475; Morris v. Warl, $5 \mathrm{Il}$. 247; Lamb $v$. Shays, Millard, 7 Id. 513. See to same ef1. Lowa, 567; Wiggins $v$. Chance, 54 fect, Swith v. Braclictt, 36 Barb. 571. III. 173; Freeman on Executions, sec.

3 Marriner $v$. Smith, 27 Cal. 619; Green v. Marks, 25 Ill. 222; Ackley v. Chamberlain, 16 Cal. 181.

${ }^{4}$ Hoyt $v$. JIowe, $3 \mathrm{~W}$ is. 752; Folsom v. Carli, 5 Minn. 335; Tillotson $v$. 396 
prevails in several other states.' As a judgment is no lien on al homestead, if property, by abandonment or otherwise, loses its homestead character, prior judgments will attach as of the moment of the abandonment, and will, therefore, have no precedence orer one another; and the julgment creditor who first proceeds to enforce his judgment, will thereby gain a priority over the other judgment creditors, and will be entitled to have his judgment first satisfied out of the late homestead." But if a judgment lien has attiched to real estate, it can not be divested by the subsequent occupation of the premises as a homestead. ${ }^{3}$ If a homestead be foreclosed and sold under a decree of the conrt, aud judgment be docketed for a deficiency remaining after the sale, such docketed judgment constitutes no lien on the homesteacl. ${ }^{4}$

8 356. The Interests Affected by the Isien.-Whenever a lien attaches to any parcel of property, it hecomes a charge upon the precise interest which the judgment debtor has, and no other. The apparent interest of the debtor can neither extend nor restrict the operation of the lien, so that it shall encumber any greater or less interest than the debtor in fact possesses. "Under our system, judgments are liens upon all interests in real estate, legal or equitable. And it is wholly immaterial, as between the parties, whether the interest of the judgment debtor appears of record or not." Where judgments are liens upon equitable interests, such interests are bound, whether the instruments or conveyances attesting the defendant's rights are recorded or unrecorded. ${ }^{6}$ The charge cast upon lands by a judgment lien, can in no wise be limited or impaired by any act or omission of the debtor. The creditor has a charge on the interests of the defendant in the land just as they stood at the moment the lien attached. Neither by conveyance nor by mortgage, ${ }^{7}$ nor by making or accepting a lease, subsequent to the judgment, can the defendant prejudice the

1 Eaton v. Ryan, 5 Neb. 47; 10 West. Jur. 630; State Bank $v$. Carson, 4 Neb. 498 ; Moore $v$. Granger, 30 Ark. 574; Jackson v. Allen, 30 Ark. 110; Whitworth $v$. Lyons, 39 Miss. 467.

${ }_{2}^{2}$ Bliss v. Clark, 39 I1l. 596; Mc-

\begin{tabular}{c|c} 
Donald $v$. Crandall, 43 Ill. 231. & ${ }^{7}$ Morris $v$. Mowat \\
${ }^{3}$ Elston $v$. Robinson, 21 Iowa, 531. & 22 Am. Dec. 661.
\end{tabular}
${ }^{4}$ Martens $v$. Gilson, 13 Nev. 459; Hershey $v$. Dennis, 53 Cal. $7:$.

${ }^{5}$ Lathrop $\approx$. Brown, 23 Iowa, 40; Logan $v$. Herbert, 30 La. An. 1). 1, p. 727.

${ }^{6}$ Pichter $v$. Selin, S S \& R. 425;

Niantie Bank $v$. Dennis, 37 Iil. 331.

7 Morris v. Mowatt, 2 Pai. Ch. 5£6; 
rights of the plaintiff. If the defendant accept a lease from a third person, the purchaser at the sale under a lien existing prior to such lease, is at perfect liberty to dispute the title of the defendant's lessor. ${ }^{1}$ The title of heirs and devisees in the real property of their ancestor or testator is, after his death, generally subject to execntion; and, when so, it must necessarily be affected by the julgment lien. The interest of the devisee can, however, not be alieurated so as to impair powers or extinguish rights and interests which the devisee himself could not affect;" " copyhold estates, and all other tenancies at will, or by sufferauce, are not subject to execution. The reason of the rule is apparent. An occupant by the permission and at the will of the owner has no estate which he can transfer by a voluntary conveyance, aud no possession which can be regarded as independent of or adverse to, that of the owner. Hence, he has no interest in the title, nor in the possession, susceptible of transfer by execution." "Estates in reversion or remaiuter are also subject to execution at law, and must therefore be bound by the judgment lien. ${ }^{5}$

8 357. Lien Confined to Actual Interests.-The judgment lien is a lien only on the interests of the judgment debtor, whatever it may be. Therefore, though he seems to have an interest, yet if he lhave none in fact, no lien can attach. ${ }^{6}$ The rights of the lien owner can not exceed those which might be acquired by a purchase from the defendant with full notice of all existing legal or equitable rights belonging to third persons. ${ }^{7}$ The attaching of the lien upon the legal title forms no impediment to the assertion of all equities previously existing over the property. ${ }^{8}$ The judg-

\footnotetext{
1 Tinney $r$. Woolston, 41 Ill. 215. For illustrations of the instances in which estates in real property are subject to judgment liens, see Coombs $v$. Jorlan, 3 Bland. Cl. 284; 22 Am. Dec. 236; also Freeman on Exccutions, chapters XII and XIII.

2 Freeman on Executions, sec. 183.

3 Bridge v. Ward, 35 WVis. 6s7; O'Hara \%. Stone, 48 Ind. 417; Leggett v. Doremus, 25 N. J. Eq. 122.

${ }^{1}$ Freeman on Ex., sec. 177, citing Wildy 2 . Bonney, 26 Miss. 35; Waggoner $\approx$ Speak, 3 Ohio, 292; Colvin $v$. Laker, 2 Barb. 206; Bigelow $v$. Finch, 11 Barb. 498.

${ }^{5}$ Freeman on Ex., sec. 178, and cases there cited.

'Churchill $v$. Morse, 23 Iowa, 229; Coombs v. Jurdan, 22 Am. Dec. 236; 3 Bland's Ch. 284; Uhl $v$. Mray, 5 Neb. 157; Lumbard v. Abbey, 73 Ill. 177; Doswell v. Adler, 2S Ark. 83; Holden v. Garrett, 23 Kans. 98.

7 Baker $v$. Morton, 12 Wall. 150.

8 Coster's Ex. v. Bank of Geo., 24 Ala. 37, 64; Walke v. Mooly, 65 N. C. 599; Filley $v$. Duncan, I Neb. 134; Floyd $v$. Harding, 28 Gratt. 401; Wharton v. Wilson, 60 Ind. 591; Frazer $v$. Thatcher, 49 Tex. 26; Goodell $v$. Blumer, 41 Wis. 436.
} 
ment lien being general, is liable to be displaced in equity in favor of a lien having greater equity. Thus where A., being unable to pay for a lot, agreed with C., that the latter should advance money to so improve the property purehased, that such a sum could be borrowed upon it as security, as would enable him to make the necessary payment to D., the owner. The eonveyance from $D$. was to be heli as an escrow until the state of the improvements to be erected, warranted the loaning of the desired amount of money. The advances made by $\mathrm{C}$. were then to be secured by a second mortgage. The first mortgage having been foreclosed, a eontest arose between $\mathrm{C}$. and a judgment ereditor whose lien attached anterior to the date of C.'s mortgage, whereupon it was decided that as there was no period of time when A. could liave held the lot frce from the claims of C., it was impossible for any person to so hold it by virtue of a general lien against $A .^{1}$ The juctgment lien is, in equity, but a eharge on the title held by the defendant when the lien attaches, or which is subsequently acquired. It can only hold the legal estate subject to tho equity." "It is well settled that a judgment lien on the land of the debtor is subject to every equity which existed against the debtor at the rendition of the judgment; and courts of equity will always limit the lien to actual interest of the juclgment debtor." "3 "The lien of the juclgment ereates a preferenee over subsequently acquired rights, but in equity does not attach to the mere legal title to the land, as existing in the defendant at its renclition, to the exclusion of a prior equitable titlo in third persons. Guided by these eonsiderations, the court of chancery will protect the equitable rights of third persons against the legal lien, and will limit that lien to the actual interest whieh the judgment debtor had in the estate at the time the judgment was rendered." 4 Hence, if a deed may be set aside in equity against the grantee for duress, the same relief may be had against a judgment creditor of the grantee. ${ }^{5}$

1 Tallman v. Farley, 1 Barb. 280. $\quad{ }^{3}$ Ellis v. Tousley, 1 Pai. Ch. 2S0;

${ }^{2}$ Whitworth $v$. Gaugain, 1 Ph. 728; Morris $v$. Mowatt, 2 Pai. Ch. 586; 22 Burgh v. Francis, 3 Swanst. 536, n.; Am. Dec. 661.

Finch v. Earl of Wincielsea, 1 P. ${ }^{4}$ Drown v. Pierce, 7 Wall. 205. Wms. $27 \%$

5 Balser v. Morton, 12 Wall. 150. 
\& 357 a. - A judgment entered against a part owner binc?s his moiety of the property, but is subject, as in the case of ownership in severalty, to all existing rights and equities. Property may stand in the name of copartners as tenants in common, while it is in equity regarded as the property of the copartnership. The partners or the creditor's of the firm may insist that real estate be treated as partnership assets. In such a case, a judgment against either partner would take effectas a lien upon his legal title, and on that only. It could not confer on the judgment creditor any right to withdraw any portion of such realty from the firm assets. ${ }^{1}$ If the lands of a co-tenant be subject to a judgment lien, such lien will, after partition, whether by suit or by agreement, attach to his share of the land as set off to him, ${ }^{2}$ or in case the land is sold, then to his share of the proceeds. ${ }^{3}$

8358. Against Trustees and Administrators.-Trustees have no right or anthority to act in opposition to their trusts; nor to proceed in relation to the trust estate in a different matter from that provided in the instrument creating the trust. If they hold lands with power to sell or mortgage on specified conditions, they can not affect the titlo by proceeding by different means or upon other conditions. If they seek to bind the land by a confession of judgment, their action, being without anthority, creates a lien on nothing but their personal interests, and can not result in a transfer of the estate of the cestuis que trust. ${ }^{4}$ Administrators are not invested with the title to the real estate of their intestates. Judgments against them, even in their official capacities, are not liens on real estate. ${ }^{5}$ Such judgments can be satisfied out of the lands of the deceased, only in the same manner in which satisfaction of other demands may be procured; namely, by an application to the Probate Court for an order directing the administrator to

\footnotetext{
${ }^{1}$ Meily $v$. Wood, 71 Pa. St. 4SS; Hoskins $v$. Johnson, $24 \mathrm{Geo} .625$.

${ }^{5}$ Hamilton $v$. Beardmore, 7 Grant's Ch. 236; Laidley $v$. Kline, $8 \mathrm{WV}$. Va.

${ }^{2}$ Polhemus $v$. Empson, 27 N. T. 218; Woodyard $v$. Polsley, 14 W. Ta.

Eq. 190; Barrington $v$. Clarlse, 2 P. \& 211. Where a judgment against an

W. 124; 21 Am. Dee. 432; Longwell executor is an admission of assets, $v$. Bentley, $23 \mathrm{~Pa}$. S. 103; Williard $v$. and he is therefore personally responWilliard, 56 Pa. S. 127; Argyle $v$. sible, it is as much a lien as if ren* Dwinel, 29 Mc. 45.

${ }^{3}$ Garvin $v$. Garvin, 1 S. C. (N. S.) 55 . gin's Trusts, 2 Giff. 56?; S. C., 30 L.

${ }^{4}$ Huntt \& Ives $v$. Townshend, 31 J. R. (N. S.) Ch. 405. Md. 336 .
} 
sell real estate. On this application, the judgment is neither entitled to be treated as a lien nor as conclusire evidence of the debt. ${ }^{1}$ At common law no judgment could be entered up after the death of the defendant. But by statute (Car. 2, C. 8) it was provided that the death of eitiner party between verdict and judgment should not thereafter be alleged for error against any judgment entered within two terms after verdict. This statute was construed as giring full force to the judgment authorized by itsoprovisions; and such judgments were held to be liens on the lands of the debtor in the hands of his heir. ${ }^{2}$ In California, judgment may be entered up after a verdict, or the decision of any issue of fact, though one of the parties lias died; but such judgment is no lien, and is simply payable in the course of administration. ${ }^{3}$

8 3.9. Lands Intended to be Convcyed.-If A., intending to convey or incumber Black Acre, through mistake conveys or incumbers White Acre, and he afterward corrects his error, or his deed is reformed by proceedings in equity, his granteo will acquire title superior in equity to the lien of any judgment rendered after the intended conveyance of Black Acre. ${ }^{4}$

8 360. Vendor's Lien. - A mortgage, trust deed, or other instrument given to secure the purchase money, takes precedence over a prior judgment lien against the vendee. ${ }^{5}$ But if a mortgage bears date several days after the purchase, and does not purport to be given to secure the payment of purchase money, a purchaser is not, in the absence of actual notice, affected by the higher character of the mortgage lien arising from the nature of the debt secured by it; and will, if the judgment lien accrued prior to the date of the mortgage, obtain the title free from the claim

\footnotetext{
1 Stone v. Wood, 16 Ill. 177; Tread-1 4 Gouverneur v. Titus, 6 Pai. Ch. well $v$. Herndon, 41 Miss. 33. 347; Swarts $v$. Stees, 2 Kansas, 236.

2 Sanders $v$. MeGowran, 12 M. \& 5 Parsons v. Hoyt, 24 Iowa, 1ut; W. 221; and 1 D. \& L. 405.

${ }^{3}$ Cal. Pr. Act, \& 202 ; C. C. P., $\delta$ 669. Hughson $v$. Davis, 4 Grant's Ch. 583; Futtan $v$. Levisconte, 16 Q. B. (Upper Canada) 495 .
} 
of the mortgagee. ${ }^{1}$ While a judgment lien against a grantee is ordinarily subject to any lien in favor of the grantor for purchase money, whether recorded or not, yet an exception probably exists in favor of a judgment debtor who has advanced money, relying as security for his payment upon the apparently unincumbered title of the debtor in the real estate. Potter, J., in a recent case in New York, said: "I think, upon the whole authorities cited, it may be laid down as a sound rule of equity, that a judgment creditor who advances his money upon the faith of unincumbered title upon the record, without notice, is entitled to the lien acquired thereby, in preference to secret, unrecorded lien of the vendor for a part of the purchase money; that such judgment creditor is to be regarded as a quasi purchaser for a valuable consideration, without notice." ${ }^{\prime 2}$

8 361. On Property of Wife.-The right of a wife to her property after a violation by the husband of his marital obligations, is superior to the lien of any judgment rendered against him after such violation, and secures to her the immediate use of her lands free from such lien, upon her substantiating her right by procuring a decree of separation for the misconduct of her husband. The rights of the wife cannot be enforced against a bona ficle purchaser without notice, under a sale made before the filing of the bill for separation. ${ }^{3}$

7. 361 ${ }^{\text {a }}$ Wife's Dower.-A judgment rendered against a man at any time prior to his marriage creates a lien which after the marriage will continue to be paramount to the wife's claim for dower; ${ }^{*}$ but if the lien attaches subsequent to the marriage it can not defeat the wife's right to dower. ${ }^{5}$

1 Curtis $v$. Root, 28 IIl. 367.

2 Hullett $v$. Whipple, 58 Barb. 224.

${ }^{3}$ Van Duzer $v$. Van Duzer, 6 Pai. Ch. 366; Sackett $v$. Giles, 3 Barb. Ch. 204.

${ }^{4}$ Gueen Anne's County v. Pratt, 10 Mil. 5; Davidson v. Frew, 3 Dev. 3; 22 Am. Dec. 708; Hodges v. McCabe, 3 Hawks, 78; Lane $v$. Gover, 3 Har. \& McIl. 394; Robbins $v$. Robbins, $S$ Pai. 117; 23 Am. Dec. 773; Brown v. Williams, 31 Me. 403; Bisland $v$. Hewett, 11 S. \&. Mt. 164.

${ }^{5}$ Pifer $v$. Ward, 8 Blkf. 2ృ̃; Gould $v$. Luckett, 47 Miss. 116; Gove $v$. Cather, 23 Ill. 634; Shaeffer $v$. Weed, 3 Gilm. 511. If the judgment be entered on the day of the marriage it does not have precedence over the wife's claim for dower, but is subBlackf. 174; Sandford v. McClean, 3 ordinate thereto. Ingram $v$. Morris, 102 
8 362. Every equitable lien, to entitle it to precedence over a judgment lien, ought to be founded on some new consideration; for if the equities be equal, the holder of a jurlgment lien will be allowed his legal rights. Thus an agreement to make a mortgage to secure a pre-existing clebt, will not be enforced as an equitable lien against the lien of a judgment rendered subsequently to the agreement and prior to the execution of the mortgage. ${ }^{1}$

\section{363. Liens against Vendors and Vendees before} Conveyance Made.-We have already shown that the lien of a judgment attaches to the rcal, as contra-distinguished from the apparent interest of the judgment debtor. It follows from this rule that upon the recovery and docketing of a judgnient against a vendor or a vendee, the interest which may pass by any sale made to render such lien avaiiable, will be governed, if the lien be against the vendee, by the proportion of the purchase money paid by lim; and, if it be against the vendor, by the portion of purchase money remaining unpaid. In other words, the purchaser under a lien against a vendee, will be entitled to a conveyance from the rendor, upon precisely the same terms which would have been open to the rendee under his contract; and a purchaser under a lien against a vendor will be compelled to make a conveyance to the rendee upon precisely the same terms upon which the vendor could have been compelled to convey. In all cases a purchaser at a sale under a judgment "succeeds to the rights and responsibilities of the judgment debtor, and to no other." 2 If the entire sum due from the vendee be paid, a lien against the vendor can attach to nothing but the mere legal title, and can transfer to a purchaser, with notice of the payment made, nothing

4 Harr. Del. 11l. As a judgment lien does not affect the husband's seizin, it ean not, until by a sale it has transferred the title, destroy the wife's right to dower; and she may have her dower assigned to her, unless a sale has been made, lut she holds the as. signment subject to the contingency of losing it, by a subsequent sale lad during the life of the lien. Scribner on Dower, p. 573.

${ }^{1}$ Dwight v. Newcll, 3 N. Y. 185.
${ }^{2}$ Catlin v. Robinson, 2 TVatts, 373; Auwerter v. Mathoit, 9 S. \&. I. 402; McNullen $v$. Wenuer, 16 S. \& R. 20: 16 Am. Dec. 543; Purviance $x$. Lem. mon, 16 S. \& I. 294; Stannis $r$. Nicholson, 2 Oregon, 322; Cromwell v. Craft, 47 Miss. 44; Stewart $v$. Corler, 11 Pa. S. 94; Garrard $v$. Lantz, 12 Pa. S. 193; Mellon's Appeal, $32 \mathrm{~Pa}$. S. 12S; Railroad Co. v. Wilson, 7 Rie. porter, 243. 
but the right to hold such title until the vendee asks for it, and the obligation to transfer it to the rendee when demanded. ${ }^{1}$ If a valid contract of sale be made, but no part of the purchase money be yet paid, the purchaser has such an equitable interest as courts of equity will protect against the lien of any judgment docketed subsequently to the making of the contract. ${ }^{2}$ If, after lands are held under an agreement to sell, a judgment is docketed against the reulce, and the vendor conveys to the vendee, reserving a lien for purchase money still unpaid, the lien of the judgment is thereby enlarged so as to embrace the whole estate, subject, however, to the vendor's lien. ${ }^{3}$

\section{364. Liens accruing against Vendor after the Sale,} as notice to Vendee.-While it is everywhere conceded that a judgment lien accruing against a vendor after the making of the contract of sale, extends to all his interest remaining in the land, and entitles the purchaser at the sale to all sums still to be paid by the vendee, yet it is well settled that the latter, if in possession of the lands sold, is not bonnd to ascertain before maling each payment that no judgment has been obtained against his vendor. Whoever takes and keeps possession of land by these acts of ownership, gives such notice of his rights to the whole world, that no ono can safely assume to act in ignorance of them. He is so far exempted from the operation of the registry acts, that a deed made by his grantor can in no event prejudice his interests; and so far exempted from the operation of the litw charging all persons with notice of the lien arising from the docketing of a judgment, that such docketing, while he is in possession of the land, is not notice to lim of the chargo

1 Lnunsbury $v$. Purdy, 11 Barb. 490; of such notes, a judgment will not, Thomas $z^{\prime}$. IKennedy, 2t Iowa, 397; after lis death, constitute a lien on McMu'len $\because$. Wenner, 16S. \&. T. 18; the land nor on the notes, but tho 16 Am. Dee. 543; Manly $v$. Hunt, 1 notes when collected will be assets in Ohio, 257.

2 Lane $\%$. Lullow, 2 Paine C. C. 591 ; Irampson $v$. Edelen, 2 Harr. \& J. 61; 3 Am. Dec. 530; Keirsted v. Avery, 4 Pai. Ch. 9.

3 Episcopal Acalemy $\%$. Frieze, 2 Watis, 16.

In Forth Carolina, it has recently becn lecld that if a vendor of land takes notes for the part of the purchase money remaining unpaid, re- was a party to such decree: Stevens taining the title to secure the payment $\} v$. Sellars, 59 Geo. 540 .

$40-1$ 
thereby created on the purchase money remaining unpaid. Ne may, therefore, from time to time, pay to his vendor such sums as fall due; and he will always be entitled to the benefit of such payments, unless it can be shown that they were made with actual linouledge of a lien on the vendor's interest in the land. This construction of the law seems to have been dictated by a consideration of the hardship to be inficted on the vendee in possession by establishing a different rule. "It may be said a party holding a contract upon which payments remain to be made, may, before making such payments, examine for judgments against the rendor; but it would be an intolerable inconrenience to require this, where the payments, as is usually the case, are to be made annually or oftener; and should such examination ever be strict, the rendee would have to run the risk of an incumbrance intervening while he was going from the ofice where the search was made to the residence of the vendor, to make the payment." In delivering the opinion of the then lighest court of the State of New York, granting vendees in possession a like exemption from the operation of the doctrine of lis pendens, Senator Seward said: "Was not their possession notorious; and is it not a well settled principle of law, that possession of land is notice to all the world, requiring those who would concern themselves in it, or litigate for it, to take notice not only of the possession itself, but of the right, title and interest, whatever it may be, of the possessor? Is it not far more equitable and just to require the complainant thus to take notice of such an obvious, notorious interest, than to hold the humble tenant, located in the woods in the extreme western part of the State, to search the office of the register or assistant register at Albany or New York, every time an installment becomes due on his contract, to see, if peradventure, a bill may not have been filed by some creditor, heir or devisee, which may possibly involve the vendor's title?"2

${ }^{1}$ Moyer $\approx$ Hinman, 13 N. Y. 180, Harr. \& J. 64; 3 Am. Dec. 530; Filley reversing the judgment of the Su- $\approx$. Duncan, 1 Nebr. 154 .

preme Court in same case reported in "Parks $\%$ Jackson, 11 TFend. 442; 17 Barb. 137; Hampson v. Edelen, 2, 25 An. Dec. 656. 
In Ohio a judgment becomes a lien as of the first day of the term. A party had, in that State, made a parol contract for the purchase of lands and had paid a small part of the purchase money. He knew that an action was pending against his vendor which might result in a judgment. Notwithstanding this knowledge he paid the vendor the balance of the purchase money and received a conveyance of the premises. A judgment was subsequently rendered against the vendor, and if allowed to take effect as of the first day of the term had precedenee over the conveyance. The rendor sought to have this lien removed; but the jud joment creditor insisted that, to the extent of the purchase money remaining unpaid on the first day of the term, the judgment was a valid lien, which ought not to be discharged withont payment of the residue of the purehase price. The court thought this claim of the judgment creditor rested upon souncl principles and was well supported by aut'sority. "The defendant in error," said the court, "was under no obligation to pay to her vendor the remainder of the purchase money during the term of court at which she knew judgment might be rendered against him. She might have required indemnity against the heir of such judgment, or retained the unpaid purehase money for its extinguishment. Its voluntary payment during the term gave her, as we think, no equity against the judgment ereditor."1

\section{Lien of Judgment for Purchase IMoney.-To} the general rule that a sale under a judgment against a vendee affects nothing but his interest in the land, must be admitted an exception arising in all cases where the judgment is recovered for balance of purchase money. In all these cases, the judgment creditor must be considered as selling, in addition to the vendee's present interest, all tho interest to which he would have been entitled upon payment of the money sued for. The purchaser, therefore, succeeds to the title held by both vendee and vendor. ${ }^{2}$ "Nothing is better settled than this, that if the vendor, at the time of parting with his title, takes a mortgage or judg-

'Lefferson $v$. Dallas, 20 Ohio S.68.|2 Vierheller's Appeal, 24 Penn. S. 106; Ziegler's Appeal, 69 Id. 471. 
ment as a part of the transaction to secure his purchase money, he retains a lien upon the estate conveyed, not to be displaced by any other encumbrance." Hence, if at the date of the conveyance a mechanic's lien existed against the vendee for certain buildings on the land, such lien cannot take precedence over a judgment entered on the same day the conveyance was made, to secure to the vendor the payment of the residue of the purchase money. ${ }^{1}$

\section{366. Cf the Pricrity of Unrecorded Instruments over} Judgment Liens. - Wherever, under the law, a deed or mortgage ${ }^{3}$ is valid without being recorded, a subsequently attaching judgment lien against the grantor or mortgagor will not be of any benefit to the lien holder as against the deed or mortgage. But a purchaser at a sale under a judgment is to the same extent as if he were purchaser at it private or voluntary sale, protected from claims previonsly acquired by third persons from the judgment debtor, of which he has no actual nor constructive notice. ${ }^{4}$ But if, at the time of the sale, the purchaser have actual notice of any legal or equitable right in a third person, or if, in the absence of such notice, the instrument evidencing such right be properly of record, or if possession be held under it, then the title acquired by the purchaser cannot prejudice the interests of such third person. ${ }^{5}$ In some of the United States, however, the registry laws so modify the effect of conveyances and other instruments concerning real estate, as to give a judgment lien precedence over any unrecorded instrument of which the judgment creditor had no

1 Stoner $v$. Neff, 50 Pa. St. 260.

2 Irorton $v$. Williams, 9 Iowa, 528;

Bell $\%$. Evans, 10 Towa, 353 ; TVilcoxson v. Miller, 49 Cal. 193; Apperson 2 . Burgett, 33 Ark. 328; Schroeder $v$. Guernsey, 73 N. Y. 430.

${ }^{3}$ Cathrow $\%$. Eade, 1 Sm. \& G. 423; Seevers $\approx$. Delashmutt, 11 Iowa, 174; Larimer's Appeal, 22 Penu. S. 41; Hampton $v$. Levy, $1 \mathrm{McC}$ Cord Ch. 107. A judgment creditor is not a purchaser for value, and therefore his lien is subordinate to pre-existing rights. Beavan v. Oxford, 6 De G. \& M. \& G. 507; Goodwin $v$. Williams, 5 Grant's
Ch. 539; Gillespie v. Van Egmondt, 6 Id. 533.

${ }^{4}$ Paine $v$. Mooreland, 15 Ohio, 435; Cooper v. Blakey, 10 Geo. 263; Ehle v. Brown, 31 Wis. 414; Jackson $v$. Chamberlain, 8 Wend. 625; Den $v$. Richman, 1.Green, N. J. 43; Ayres $v$. Duprey, 27 Tex. 605; Miorrison $v$. Funk, 23 Penn. S. 421.

${ }^{5}$ Davis $v$. Ownsby, 14 Mo. 170; Hoy v. Allen, 27 Iowa, 20S; Valentine $v$. Havener, 20 Mo. 133; Chapman v. Coats, 26 Iowa, 2ss; Byers v. Engles, 16 Ark. 543. 
lnowledge at the date of the attaching of the lien of his judgment; 1 and the holder of the lien takes all the title the records show to be in the judgment debtor. ${ }^{2}$ In Alabama, by statute, when a conveyance of real estate is made, it must be recorded within sixty days, or it will be void against creditors or subsequent purchasers without notice; under this statute it has been held that if the judgment creditor is not affected with notice of an unrecorded deed, he acquires a lien not limited nor avoided by the deed, and under which a perfect title may be acquired by a purchaser having full notice of the former deed; $;^{3}$ and in general, under this or similar statutes, if the lien once attaches so as to take precedence over prior deeds in favor of a judgment creditor, it is not liable to be defeated ty the subsequent recording before amy sale of a previously executed instrument, nor by giving actual notice of the existence of such instrument. 4

3, 366 . Purchase by Judgment Creditor.-We have seen that the lien of a judgment is subordinate to all rights, whether legal or equitable, capable of enforcement against the judgment debtor when the lien attached; but that stranger's purchasing at an execution sale, become, thereby, purchasers within the meaning of the registry laws, and as such, are protected. The judgment creditor may also become a purchaser at the sale. In so doing he may make a bid and thereby produce a complete or partial satisfaction of his judgment. The question then arises whether he thereby becomes a purchaser for value, and whether as such he is protected by the registry law from infirmities in the debtor's title, of which, when purchasing, the creditor had no notice, actual or constructive. In Iowa, a judgment debtor, at the rendition of the judgment, held lands under an implied trust, in pursuance of which, subsequent to the judgment, he made a conveyance to his cestui que trust. The latter

${ }^{1}$ Guitean $v$. Wisely, 47 Ill. 433; waring $v$. Templeman, 51 Tex. 205; MeFadlen $v$. Worthington, 45 Ill. Firebaugh $v$. Ward, 51 Tex. 409; Eid302. The tendeney of the recent stat. son v. Huff, 29 Gratt. 338; Anderson rites and the decisions interpreting $v$. Nagle, 12 W. Va. 95; Andrews $v$. them, is to give a juclgment lien pre- Natlsews, 59 Geo. 466; Wood v. Lake, ccdenee over a prior unregistered con- 9 Reporter, 342; Young $v$. Devries, 31 reyance or incumbrance, espeeially if Gratt. 304.

the plaintiff hal no notice of it when his jud gment was docketed or registercil, or the levy of his writ made. Gires ${ }^{\prime}$. TVade, 45 Tex. 523; Cavanaugin $\%$ Peterson, 47 Tex. 19S; Míain- $v$. Ravesies, 32 Ala. 451.

${ }^{2}$ Martin v. Dryden, 1 Gilm. 187; Massey $v$. Westeott, 40 IIl. 160.

${ }^{3} \mathrm{De}$ Vendell $v$. Hamilton, 27 Ala. 156.

- Pollard v. Cooke, 19 Ala. 185; Fash 408 
failed to record his deed, and the lands were sold to the creditor without any notice of the deed or of the facts ont of which it arose. The Supreme Court thought this a proper case in which to apply the "wholesome rule of equity, that, where one of two innocent persons must suffer, the loss will fall upon that party who has been guilty of the first negligence;" and therefore sustained the title of the creditor based on the purchase under his own judgment. ${ }^{1}$ This case was but an affirmance of a prior decision in the same State, declaring that, "when a ereditor merges his judgment into a title, without actual or constructive notice of prior equities, he becomes a purchaser and is entitled to protection in the absence of equitable circumstances, with any other subsequent bona fide purchaser."2 But probakly the current of authorities dissents from the conclusions reached in Iowa and maintain that "to constitute a person a bona fide purchaser within the meaning of the statute, he must, upon the faith of the purchase of the property, have advanced for it a raluable consideration;" and that "if he was a creditor antecedent to his purchase, and paid for the purchase by a credit on his demand, then, inasmuch as he has parted with no consideration on the faith of the purchase, he is not a bona fide purchaser within the meaning of the statute." 3

33 367. After Acquired Title.-As long ago as the year 1813, in the case of Calhoun v. Snyder, the judges in Pennsylvania, in deference to a long course of decisions in that State, were constrained to decide that no judgment could erer attach as a lien upon lands in which the judgment dobtor had no interest, at the date of its rendition. The judge delivering this opinion at the same time said, "I am well satisfied that by the English common law, lands purchased by the defendant after judgment, but aliened before execution, were bound by the lien." ${ }^{4}$ Forty-seren years later it was said in the same State that, "Whatever may be thought of the doctrine of Culhoun v. Snycler, that a judgment lien does not bincl subsequent acquired real estate, it is too firmly established in the jurisprudence of this State, to be shaken at this day." The rule thus established in

${ }^{3}$ Gower $v$. Doheney, 33 Iowa, 36. v. Donglass, 10 Burb. 97; Dickerson

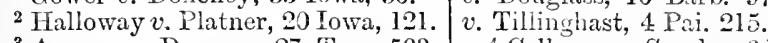

3 Ayres v. Duprey, 27 Tex. 593; Orme v. Roberts, 33 Tex. 768; Wright

${ }^{4}$ Calhoun $v$. Snyder, 6 Binney, 135.

5 Waters' Appeal, 35 Penn. S. 6.3. 
Pennsylvania, and confessedly repugnant to the common law, was adopted in a few other American cases. ${ }^{1}$ It is, nevertheless, clearly repudiated in favor of the common law rule by the vast majority of the American decisions. ${ }^{2}$ The rule of Calhoun v. Snycler is, in Pennsylrania, restricted to real estate in which the judgment debtor had no inlerest. If at the rendition of a judgment the debtor had entered into a binding contract for the purchase of lands, the lien bound not only his present interest under the contract, but all the interests which he might subscquently acquire thercby; and took precedence over a judgment entered against the defendant immediately after his acquisition of the title by a conveyance from his vendor. ${ }^{3}$

\section{363. Frecedence of Judgment Iiens on after acquirod} Iands.-A statute of the State of Mississippi provided "That in all cases the property of the defendants shall be bound and liable to any judgment that may be entered up, from the time of entering such judgment." In considering the effect of the provision just quoted it was held that as the lion could not attach to property owned by another, it could not take effect upon after acquired real estate until the moment of its acquisition," and that npon taking effect it did not relate back to the rendition of the judgment. From this view it follows that if two judgment lieus have been docketed against a defendant, they will both attach to subsequently acquired property at the same moment, and neither will have any priority over the other on account of its prior docketing or rendition. ${ }^{5}$ This construction seems to be of undisputed correctness, and to be adopted whererer the question lias arisen. ${ }^{6}$ In such cases the judgment liens being equal, the holders thereof are permitted to acquire

${ }^{3}$ Roads $v$. Symmes, 1 Hamm. 281; Davis $v$. Benton, 2 Sneed, 665; Colt $v$. $13 \mathrm{Am}$. Dec. 62l; Harrington $v$. Sharp, Dubois, 5 Reporter, 659; Barron $v$. 1 G. Greene, 131; Stives $v$. Nurphy, Thompson, 9 Reporter, 766.

4 Hamm. 92; Filley $v$. Duncan, 1 Neb. 134.

2Ridge v. Prather, 1 Blackf. 401; Ralston v. Field, 32 Geo. 453; Itandly $v$. Sydenstricker, 4 West Va. 605; Trustees $v$. Watson, 13 Ark. 74 ; Tidgely's Ex'rs v. Gartrell, 3 Har. \& McH. v. McComb, 2 Head, 558. See Scc. 449; Steele v. Taylor, 1 Minn. 274; 355 as to Homesteads Abandoned. 
priority in accordance with principles to be stated in a subsequent section of this chapter.

PART III-OF THE PRIORITY OF JUDGMENT LIENS.

83 369. Judgments of Same Term.-At common law all judgments were, by legal fiction, supposed to be entered on the first day of the term at which they were recovered. But it was a maxim of the same law that, "A legal fiction is always consistent with equity." Therefore, whenerer the purposes of justice required it, the true time of eutering judgment might be averred and proved. ${ }^{1}$ While neither the existence of the maxim nor its applicability to cases requiring a determination of the rights and equities of lien holders seems ever to have been drawn in question, undoubtedly a very decided contrariety of opinion was expressed by the judges in deciding parallel cases in which the precedence of judgment liens was considered. As between different ereditors, there would rarely bo any violation of the principles of equity occasioned by placing on an equality, judgments in fact entered on different days of the same term. Hence, we find it declared that such judgments are equal as liens, and entitled to bo paid pro rata out of the debtor's real estate. ${ }^{2}$ But this declaration was, by no means, true in all parts of the United States. In Maryland, judgments rendered on different days of the same term were never treated as relating to the first day of the term, but were given effect as liens according to the priority of their entry. ${ }^{3}$ In Pennsylvania, for moro than a century preceding the year 1805 , by an uninierrupted practice, the legal fiction was disregarded, and judgments took precedence over one another according to the date of their rendition. "As between conflicting judgment creditors, the well known rule applied to the truth of the fact as to the entry of judgments qui prior est tempore, potior est jure.": A similirr rule was laid down at an early date by the Supreme Court of the United States. ${ }^{5}$ But, howerer the fiction of law by which judgments are considered as being rendered on the first day of the term, may affect one judgment lien in a contest with other liens of the same nature, it seems to

\footnotetext{
${ }^{1}$ Broom's Maxims, 122; Morgan v. Nance, 26 Geo. 283.

" Porter $v$. Earthman, 4 Yerg. 35s; Johuson v. Mitchell, 17 Geo. 593.

${ }^{3}$ Anderson $v$. Tuck, 33 Mr. 225.

${ }^{4}$ Welch $v$. Murray, 4 Yeates, 197.

${ }^{5}$ Velch v. Murray, 4 Dall. Pem. 320. 
be generally conceded that it can not prejudice the interests of bona fice purchasers. Whenever a purchaser before the signing of judgment, without notice and without being guilty of auy fraud, acquires an interest in real estate, that interest can not be charged with the lien of any judgment subsequently entered against his grantor, though such judgment might, as between itself and other judgments, rank as though entered at the beginning of the term, and at some time prior to its actual rendition. In Virginia, the rule that judgments relate to the first day of the term has always prevailed;' unless the court in fact met for the term on a day subsequent to that appointed by law for the first day of the term, in which case a judgment lien was decided not to overreach a conveyance recorded before the day on which the court met, though after the time when it ought to have met. ${ }^{3}$ In order to rank as of the first day of the term at which it was rendered, the judgment must be the final determination of an action which was in such a condition that it might have been tried and disposed of on the first day if it had happened to have the first place on the calendar." The reason why judgments rendered at different dates were over treated as of equal rank, was because all the cases ready to be tried at the opening of a given term, were equally entitled to the precedence arising from being first decided; and in order to avoid giving any suitor an advantage dne entirely to the fortuitous circumstance that his cause was first called for trial, it was thought proper, by aid of a legal fiction, to assign his judgment a place in no wise superior to that assigned to others equally entitled to precedence.

₹370. Fractions of a Day.-The common law fiction assigning the same period of time to the entry of all judgments of a single term, is very generally abolished in the United States, either by statutory enactments, or by a long course of practice grown up in defiance of the common

\footnotetext{
${ }^{1}$ Morgan v. Sims, 26 Geo. 283. A | Brockenbrough v. Brockenbrough, 31 judgment entered against a defendant Gratt. 530.

who has died since the first day of the ${ }^{3}$ Skepwith's Ex. $v$. Cunningham, 8 term, is valid, because it has relation Leigh, 272. The case of Horsley $v$. as of the first day of the term; but such Garth, 2 Gratt. 471 , does not, so far a judgment is not a lien. Nichols $v$. as we can judge, overrule or limit the Chioman, 9 Wend. 452; Stymets $v$. case last cited. Brools, 10 Wend. 207.

2 Coutts $v$. Walker, 2 Leigh, 292;

${ }^{4}$ Wišhers $\%$. Carter, 4 Gratt. 407.
} 
law of England. Therefore it is now, in this country, more important to determine whether the lien of a judgment extends over the whole of the day on which it attaches, than it is to understand whether, under the common law practice, it extends over a whole torm. The decisions upon the question whether fractions of a day should be regarded in determining the effect properly to be accorded to a judgment lien, have extended over three classes of cases. The first cliss includes cases involving the precedence of judgment liens between one another; the second elass includes cases involving the relative priority of judgment over other liens; and the third class includes cases determining the rights of purchasers in good faith from judgment debtors, prior to the actual rendition and docketing of the julgment. It seems to be well settled in relation to cases of the first class, that unless the law provides for fractions of days, all judgments entered on the same day will be regarded as if entered at the same time, and as creating liens equal in point of priority, and entitled to be paid pro rata out of the debtor's real estate. ${ }^{1}$ Still this rule evidently does not prevail in North Carolina, for it is there decided that the law will talio notice of fractions of days in the contests between creditors seeking to have funds realized from the sale of lands applied in satisfaction of their judgment liens. ${ }^{2}$ The law applicable to cases of the second class is unsettled. In Pennsylvania, between mortgages and judgments, no fractions of days will be considered. A mortgage and a judgment entered on the same day will be regarded as taking effect simultaneously, and as entitled to be paid pro rata. ${ }^{3}$ In Tennessee, on the other hand, a mortgagee is treated with the same indulgence granted to a purchaser. ${ }^{4}$ In determining the riglats of purchasers as opposed by holders of judgment liens, fractions of days will undoubtedly be considered, because it is " necessary for the purposes of simple justice to ascertain the

${ }^{1}$ Rockhill $v$. Hanna, 4 McL. 555; ${ }^{3}$ Hendrickson's Appeal, 24 Penn. Bruce $v$.Vogel, 35 Mo. 100; Mechan- S. 363; Claason's Appeal, 22 Penu. S. ics' Bank v. Gorman, 8 W. \& S. 304; 359.

Burney $v$. Boyett, 1 How. Miss. 39; ${ }^{4}$ Mirfee v. Carmack, 4 Yorg. 270; Metzler $v$. Kilgore, $23 \mathrm{Am}$. Dec. 76.

2 Bates $v$. Hindale, 65 N. C. 423.

Berry v. Clements, 9 Hump. 312. 
hour of the entry of the lien." But, even here, judges who conceded the necessity and propriety of considering fractions of days, have, nevertheless, refused to enter into any examination, beyond the record, in order to ascertain the precise hour at which a judgment was rendered or docketed. In. their opinion the matter of precedence was to be adjudged in favor of the judgment lien, unless upon the record it appeared to be subsequent to the purchase, and the inquiry into the actual period when the lien in fact attached was, if permitted to be pursued beyond the record, liable to produce evil and inconvenience not to be compensated by the probable good to flow from such inquiry. ${ }^{2}$ Dut the more sensible view is that announced in Penusylrania, where it was held that, in a contest with a purchaser from the judgment debtor, "as an indispensable measure of justice, the precise time at which the judgment was entered must be shown by less than record proof," and further, that to affect lands in the hands of a purchaser, a judgment must not only be simultaneous, but anterior. ${ }^{3}$ It is a little remarkable that the keen sense of the "purposes of simple justice" under which the courts of the last named State have professedly been impelled to protect purchasers, has not also operated for the benefit of mortgagees and other lien holders who, like purchasers, part with some valuable consideration upon their faith in a title which seems to bo perfect, and which, in fact, is perfect at the moment the consideration is parted with. Certainly if " the law clivides the day where equity requires it," 4 it cannot but divide it to prevent loss to one who loans money or parts with anything valuable, when the inducement for his action is the security given him upon the then unincumbered real estate of the borrower. In fact the equity of a mortgagee to the extent of his claim is not necessarily nor ordinarily inferior to the equity of a purchaser; and nothing but our regard for precedents, supported neither by justice nor by reason, can induce us to extend any protection to the latter which we would withhold from the former.

\footnotetext{
1 Small's Appeal, 24 Penn. S. 395; Inlly $v$. Creighton, $70 \mathrm{~Pa}$. St. 490. ${ }^{3}$ Mechanic's Bank $v$. Gorman, $8 \mathrm{~W}$.

2 I iurfee $v$. Carmack, 4 Jerg. 270; Berry $v$. Clements, 9 Hump 312. \& S. 304.

4 Small's Appeal, 24 Penn. S. 398.
} 414 
8 371. Office Hours.-Notice will not be taken of the fraction of the day preceding office hours, in determining the relative precedence of judgments among one another. All records taken to the clerk's office before office hours, will be regarded as if filed at the time provided by law for opening that office. ${ }^{1}$

\& 372. Judgment on Day of Sale.-If lands are sold under a judgment, another judgment entered on the same day, but previously to the sale, is nevertheless, according to the construction of the law adopted in Pennsylvania, a lien on the land, and as such, entitles its holder to the residue of the proceeds of the sale to the extent of its amount, after all senior liens, if any, are satisfied.2

\section{373. Conveyance or Incumbrance of Land, simulta-} neously with its Acquisition.-Nodoubtone against whom a judgment has already been docketed, may purchase land, and at the same time he receives his conveyance, may give, to secure any portion of the purchase money, a mortgage, which will take precedence over the judgment as a lien on the lands purchased. 3 If an absolute deed be made, and intended as a mortgage, and afterwards a judgment be docketed against the grantor in such deed, and the grantee then reconvey, at the same time taking a mortgage as security for his debt in lieu of the deed, this mortgage will take precedence over the judgment lien. ${ }^{4}$ The reason assigned for this, is that the conveyance and incumbrance of the land being simultaneous, no opportunity is given for the judgment lien to attach. But it has also been decided that if, upon acquiring land, the judgment debtor immediately executes a mortgage, not for purchase money, the lien of the mortgage will be subordinate to that of the judgment. ${ }^{5}$ If this decision be correct, the simultaneous execution of the conreyance and of the mortgage has no power to prevent the attaching of the judgment lien, and we must look for some other reason upon which to justify the decisions giv-

1 Wardell $v$. MIason, 10 Wend. 575.

2 Small's Appeal, 21 Penn. S. 398.

${ }^{3}$ Curtis $v$. Root, 20 Ill. 53; Cake's

Appeal, 23 Penu. S. 186.
4 Christie $v$. Hale, 46 Ill. 117.

ธRoot v. Curtis, 38 Ill. 192. 
ing precedence to mortgages for purchase money, than that of simultaneousness. This reason is readily found when wo remember that it is a universally recognized principle of law that no judgment lien can be a eharge upon any greater interest than the defendant owns. A purchaser who has pair only a portion of the sum contracted to be paid, has no title which is not liable to be subjected to the lien of the venctor for umpaid purchase money. A judgment against such a vendlee must, therefore, be subordinate as a lien to that held by the rendor; and for this purpose, it is perfectly immaterial whether the claim is put in the shape of a vendor's lien, or of a mortgage to secure the payment of purehase money. As a confirmation of the theory that it is not the simultaneous nature of the incumbrance, but the fact that it represents an interest in the land, never in fact orned by the incumbrancer, which gives it precedence over judgment liens of anterior date, we cite a case decided in Pennsylrania. A convesance of lands was made and delivered to tho grantee sixteen miles from the county seat, where the records were kept. This transaction was completed on Saturday evening. At the same time, the grantor took judgment bonds to secure payment of the balance dne upon the purchase money. He had judgment entered upon these bonds on the following Monday. This judgment was afterward given precedence as a lien on the land purehased, orer judgments previously docketed, because it was thought to be unreasonable to require judgment to be entered on Saturday night, or on Sunday. ${ }^{1}$ Now in this case abundant timo was given for the judgment lien to attach if it were possible for it to attach, so as to outrank any vendor's lien, of which reasonable notice was given.

\section{₹ 374. Priority acquired by Diligence.-If two or moro} judgments, on account of their contemporaneous rendition or docketing, or from any other cause, are equally entitled to precedence as liens on the real estate of the judgment debtor, this equality may be destroyed, in order to give precedence to the lien holder who first attempts to subject any specitic real estate to the payment of his lien. "Tho 
law favors diligent creditors;" and the courts seem to be unanimous, whore liens are otherwise equal, in according to him who first takes property in execution, the right to be first satisfied out of its proceeds. ${ }^{2}$ Where diferent judgment creditors pursue different remedies, each is considered as having elected to follow tho romedy with which he commences, and therefore is treated as entiting himself to precedence in regard to that remedy and as forfeiting his claim to precedence in any of the other remedies pursued by his co-creditors. Jucgments were sererally on the same day entered in faror of P., S. and R. P. took the defendant on ca. sa. P. and $S$. each took out $f i$. fas. on the same day and levied on the defendant's lands. Afterwards, the defendant was released from imprisonment by operation of larss provided for the relief of insolrents. P. then took ont fi. $f a s$, and levied on the lands already levied upon $b y$ P. and S. Writs of renct. exp. being subsequently issued on all of the judgments, the land was sold by the marshal, producing a sum insufficient to pay the several liens of $I$., S. and P., whereupon it became necessary to determine the relative claims of $R$., S. and P. upon the proceeds of the sale. In pronouncing the opinion of the court, it was stated that, by the common law, he who, where the liens of several judgments were equal, first extended the land of the defendant by elegit, thereby beame entitled to be first satisfied ont of it; and that, in case one judgment creditor took out an elegit, another took the body of the defendant on a ca. sa., and the third took $f i$. fas. on goods and chattels, each would thereby elect his remedy and entitle himself to priority therein. Applying these common Jaw rules to the case under consideration, the court applied the proceeds of the marshal's sale to the satisfaction of the claims of P. and $5 .{ }^{2}$

\section{375. Priority acquired by Superior Equity.--Two} judgments were entered on the same day, and were, thorefore, equal in point of time. $B_{y}$ one, $A$. recorered against B. and C.; by the other, B. recovered against C. It was

${ }^{1}$ Cook v. Dillon, 9 Iowa, 407; Lip- $\mid$ Burney v. Boyett, 1 How. Miss. 39; pincott $v$. Wilson, 40 Iowa, 425; Wa- Frecman ou Ex., \$203.

terman $v$. Haskin, 11 Johns. 22s; ${ }^{2}$ Rockhill $v$. Hanna, 15 How. U. S. Adams v. Dyer, 8 Johns. 347; 5 Am. 189.

Dec. 344; Bruce v. Vogrel, $2 S$ IIo. 100; 
held that the equity of $A$. to be paid out of C.'s land, was superior to that of $B$. ; and he was therefore awarded the entire proceeds of a sale of C.'is real estate. ${ }^{1}$

8 376. On Writ of Frror Bond.-A statute of Texas enacted that a writ of error bond shall have the force and efrect of a judgment, upon which execution may issue in case of forfeiture. The forfeiture tales place on the afirmance of the judgment by the appellate court. The lien of the statutory judgment binds all lands owned by the sureties at or subsequent to the execution of the bond, though alienated before the judgment of aflirmance is pronounced. ${ }^{2}$

\section{Sales under Junior Judgments.-The sale of} lands under execution in mo wise affects the lien of a prior judgment, nor does it necessitate any change in the proceedings required to mako such lien effectual. ${ }^{3}$ The holder of the elder lien may, at any time, during the life of his lien, sell the land previously sold under a junior judgment. Upon the expiration of the statutory period of redemption, he may take out his deed and thereby obtain title paramount to, and free from, all sales and claims based upon junior liens. ${ }^{4}$ If the same plaintiff have two judgment liens on the same land, he may sell under the junior, without releasing or otherwise affecting the senior, unless it can be shown that he was guilty of some fraud upon the purchaser as by misleading him in relation to the existence of the senior judgment. ${ }^{5}$ The sale of lands under a junior judgment passes title subject to all prior liens. The money produced by such sale, therefore, cannot be applied to the satisfaction of such liens; but must, to the extent of his debt, be given to the creditor under whose judgment it was realized..$^{6}$

\section{Preferred Debts of United States.-The fifth sec-} tion of the Act of March 3, 1797, provided: "That when any

\footnotetext{
${ }^{1}$ Vierheller's Appeal, 24 Penn. S. under the junior: Jones v. Wright, 106.

${ }^{2}$ Berry v. Shuler, 25 Tex. Supp. p. 140.

${ }^{3}$ Lathrop v. Brown, 23 Iowa, 40. This is not universally true. In some of the States the senior judgment 60 Geo. 364.

${ }^{4}$ Rankin $v$. Scott, 12 Wheat. 177;

Littlefield $v$. Nichols, 42 Cal. 372 .

${ }^{5}$ Shotwell v. Murray, 1 Johns. Ch. 512.

${ }^{6}$ Bruce v. Vogel, 38 Mo. 100.
} takes the proceeds, though the sale is 
revenue officer, or other person, hereafter becoming indebted to the United States, shall become insolvent, or where the estate of any deceased debtor in the hands of his exceutor or administrator shall be insufficient to pay all his debts, the debt due to the United States shall be paid first." Tho priority here created does not yield to any class of creditor's; therefore, in the distribution of assets, the claim of the United States has the precedence over judgment liens held by individuals. ${ }^{1}$

\section{PAPT IV. -OF THE SUSPENSION AND DISCHIRGE OF JUDGNENT}

\section{LIENS.}

8 379. Suspension by Ca. Sa. - A judgment may, through various circumstances, seem to be no longer of any force or effect; and may afterwards, by virtue of some judicial proceeding, or by the happening of some unexpected event, be restored to its former condition. From its inseparable connection with the judgment, the lien may seem first to lose and then to regain its vitality. The restoration of the judgment and of its lien, is always subject to the rights acquired during their temporary suspension. The taking of the defendant in execution has always, at common law, been recognized as an extinguishment of the judgment, subject to the contingency of a revivor by virtue of his death in prison, or his escape therefrom withont the plaintiff's consent. But while the happening of this contingency may restore to plaintiff the right to enforce his judgment by action or by appropriate process, it does not prejudice interests acquired by third persons while the debtor was in custody. "The arrest waives and extinguishes all other remedies on the goods or lands of the debtor while the imprisonment continues, and if the debtor be discharged by the consent of the creditor, the judgment is forever extinguished, and the plaintiff remitted to such contracts or securities as he has taken as the price of the discharge. But if the plaintiff be remitted to other remedies by a discharge of his debtor by act of law, or by an escape, it will not operate to restore his lien on the debtor's

1 U. S. v. Duncan, 12 Ill. 523; Conrad v. Insurance Co., 1 Pet. 444. 
property, which he has elected to waive or abandon as against creditors who have obtained a precedence during such suspension. The case of Sneed v. Michoul (12 How. 407), in this court, fully confirms this doctrine. It is to be found in the common law as early as the Year Books, and is admitted to be the law in almost every State in the Union. (See Year Book, 33 Henry VI., p. 48; Foster v. Jachson, Hobart, 52; Barnaby's Case, 1 Strange, 653; Vigers v. Aldrich, 4 Barr, 2483; Jacques v. Withy, 1 T. R. 557; Taylor v. Wa. ters, 5 Miaule \& Selwyn; Ex parte Fnowell, 13 Vesey jun. 193. And in New York, Cooper v. Digelow, 1 Cow.; Ranson, v. Keyes, 9 Cow. 128. In Pennsylvania, Sharp v. Speckenglt, 3 Serg. \& R. In Massachusetts, Little v. The Bank, 1.1 Mass. 443.)" 1

8. 330. Suspension by Forthcoming Bond.-A forth. coming bond has, in some of the States, when followed by a statiatory judgment thereon, the efiect of operating as $x$ satisfaction of the original judgment. ${ }^{2}$ But if the securities upon such bond prove insolvent, it may, in a court of law, be quashed on motion of the creditor. In that event he is remitted to his rights under his judgment. It is said that a court of equity may, without the formality of quashing the bond, treat it as a nullity, and afford the creditor such relief as he would bo entitled to if it had not been given. ${ }^{3}$ In a case where it was claimed that the quashing of the bond and the racation of the new or statutory judgment, restored the plaintiff to the benefit of his lien as it stood when the bond was given, the claim was denied in the following language: "We do not assent to this view of the effect of the order vacating the new judgment, so far, at least, as respects the liens or rights of third parties, which have legally attached in the meantime to the goods of the defendant, discharged from the original judgment by the giving of the forthcoming bond. After the lien was suspended or discharged, the original judgment being in contemplation of law, satisfied by the new and substituted

1 Tockhill v. Hanna, 15 How. 189; Jackson $v$. Jenedict, 13 Johns. 533; Griswold $v$. Hill, 2 Paine C. C. 492.
2 Bank of U. S. v. Patton, 5 How* Miss. 200.

3 Jones v. Myrick's Ex'r, 8 Gratt.
179 . 
security, the debtor was at liberty to deal with the property as his own, and it remained in his possession, sulject to any charge or lien impressed upon it either by act of tho party, or by operation of law, the same after the forthcomingr bond as before the entry of the original judgment. Possibly, as between the parties, the judgment revived, but it wonld be against principle, and work manifest injustice, to give to it this retrospective operation, so as to extinguish the intermediately acquired rights of third persons. We deny to it this effect. It would be otherwise if the forthcoming bond had been shown to be void, as it might then be treated as a nullity, and as affording no foundation for the statutory judgment consequent upon the for"eiture."

3. 391. Vacation and Restoration of Judgment.-The Facation of judgment by order of the court, like its extinguishment by the operation of a forthcoming bond, leares the judgment debtor at liberty to dispose of and encumber his real estate as if the judgment had never been rendered. Upon a reversal of the order of vacation, the judgment creditor is restored to all his rights, except so far only that his restoration can not prejudice persous not parties to the suit, in relation to any interest they have acquired during the vacation. But liens existing in subordination to that of the judgment at the date of its vacation, will occupy a like subordinate position after its restoration. "When the order vacating a judgment is set aside, the lien is reriv' in all its pristine vigor, and is as effective as before the order was made, except as to rights acquired in the meantime. ${ }^{2}$

382. Appeal, with Stay of Executicn.-The stay of exncution consequent upon filing a sufficient boud for that parpose, pending an appeal, neither discharges nor susyends the lien; it merely suspends, during the pending of the appeal, the right of the judgment creditor to realize the benefit of his lien by a sale of the defendant's real estate. $^{3}$ In Georgia, a different rule prevails. By statute a judgment so appealed from loses its lien, except for the

\footnotetext{
${ }^{1}$ Lrown $v$. Clarke, 4 How. U. S. 13, ${ }^{3}$ Low $\pi$. Arlams, 6 Cal. 277; Curtis 14. v. Root, 23 Ill. 337 ; Thulemeyer $v$. King $v$. Harris, 31 N. Y. 330, Jones, 37 Tex. 560. afîrming 30 Earb. 471 . 
single purpose of preventing alienations. If of two juctgments, equal as liens, one is appealed from, it loses its place as a lien. If, in the higher court, judgment be entered in favor of the appellant, it does not relate back, but operates as a lien only from the time of its entry in the Appellate Court. A similar efiect seems to have heen pro. duced by an appeal in Pennsylvania from an award obtained under a compulsory arbitration act, which declures that such an award "shall have tho effect of a judgment agianst the party against whom it is made, and be a lien on his real estate until such judgment be reversed on appeal." "Tho creditor appealed, and thereby secured a judgment moro favorable to himself; but it was held that he could not claim under both judgments, and could not have a lien by virtue of either. That a purchaser, after the anard and before the judgment, took title free from the award becurso it was superseded, and free from the judgment becauso it did not exist." In California " the lien continues two years, unless the enforcement of the judgment be stayed on appeal by the execution of a sufficient undertaking, in which case the lien of the judyment ceases."

"383. Dormant Execution.-." Questions in regard to dormant executions, generally, and I believe, invariably, ariso between conflicting elaimants of personal property. The doctrine on this subject does not apply to real estite, the lien upon which depends upon the docketing of the judgment aud not upon the execution or levy." The lien of the judgment, as to real estate, never becomes dormint until it expires by the limitation imposed by statute. ${ }^{*}$ The plaintiff has a right to enforce his lien during any part of the time provided by law. Therefore he may, if he sees proper, agree with the defendant not to take out execution during any specified period, without subordinating his lien to that of junior julgments. ${ }^{5}$ But if he causes an execution to be taken out and levied upon personal property, thereby producing a conditional satisfaction of his own judgment, and depriving other judgment creditors of the benefit of a levy on the same personalty, he can not with-

1 Snelling $v$. Parker, 8 Geo. 122. $\mid{ }^{4}$ Muir $v$. Leitch, 7 Barb. 341. 344 .

"Lentz $v$. Lamplugh, 12 Penn. S.

${ }^{3}$ C. C. P., $\$ 671$.

${ }^{5}$ Love $v$. Harper, 4 Humph. 113 Muir $v$. Leiteh, 7 Barb. 341. 
draw his levy and insist on the operation of his judgment as a lien on real estate to the prejualice of third parties. ${ }^{1}$

One who enters satisfaction will not be permitted to cancel it and revive lis judgment lien to tho prejndice of strangers who have acted on their faith in the apparent satisfaction." On the other hand, it has been deternined that an entry of satisfaction procured by fraul will be vacated, even when third persons have become interested in thos property, unless they show that they knew of and were induced to act by such entry. ${ }^{3}$ So if a judgment be satisfed by the sale of property, the vacation of the sale revives the judgment lien, ${ }^{*}$ so that it has precedence over junior judgment liens which acerued prior to the vacating of the sale. ${ }^{4}$ Generally the revival of a judgment operates prospectively only, and does not impair conveyances made prior to such revival. ${ }^{5}$

\section{\& 834. Discharge by Act of Defendant.-Payment is} the only act by which the defendant can discharge or avoid the lien of a judgment. ${ }^{6}$ It is the duty of a sheriff haring an execution, to receive payment of the julgment, if a tender of the amount due be made to him. But such tender neither discharges the judgment nor removes its lien. If the tender be refused, the remedy available for the debtor is, to apply to the cont on motion to restrain the sale and to enter satisfaction of the judgment. If no attempt is mado to obtuin such redress in court, the party mulsing tho tender can not treat the judgment as satisfied. "The doctrine of tender is not applicable, for that can not be made after an action is commenced; and, in cases where a tender is made in season, and the creditor refuses, the efiect is merely to discharge the debtor from subsequent interest. The principal is never discharged, unless mider peculiar circumstances, as where there was not, after the tender and refusal, any remedy to enforce the payment of the debt, or the performance of his duty. The debt still remains due and the judgment in force."

\& 385. New County.-A lien which has once attached must remain until it is discharged by act of the parties,

${ }^{1}$ Lyon c. Hampton, 20 Penn. S. 46.

2 Page $v$. Benson, 22 IIl. 484.

${ }^{3}$ Tienick $v$. Ludington, $14 \mathrm{WV}$. Va. 367.

${ }^{4}$ McHany $i$. Sclienk, SS IIl. 337.

${ }^{5}$ Coombs v. Jordan, 3 Bland. Ch.

3s4; 22 Am. Dec. 236.
6 Tinney $v$. Wolston, 41 Ill. 219.

${ }^{7}$ Jackson $v$. Law, 5 Cow. 248 , affirmel on appeal in Law $v$. Jackson, 9 Cow. 641 . 
removed by subsequent legislation, or expired by statutory limitation. Therefore, the erection of a new county, subsequently to the docketing of the judgment, including in its limits the lands of the debtor, does not release or otherwise affect the lien. ${ }^{1}$

8 386. By Ton-Claim.-In Pennsylvania, a long series of decisions established the rule, that a sale made by an oficer under an execution divests all liens of a definite amount, and that the lien creditor, omitting to claim out of the proceeds of the sale, nevertheless loses his right to resor't to the land. ${ }^{2}$

8 397. Of Judgments Discharged by Frauds.-If the plaintiff, through fraudulent misrepresentations, is induced to release his lien or to satisfy his judgment, an intervening purchaser of the property, who participated in the fraud, will not be protected from the lien thus sought to be avoided. ${ }^{3}$

8 383. Discharge by Merger of Judgment.-The mergex occasioned by one judgment being recovered upon another, as it extinguishes the judgment sued upon, as a caruse of action, also destroys its effect as a lien.

8. 389. Can not be Restored.-The payment of a judgment in whole or in part, releases the lien to the extent of the payment; and it can not be restored as a lien by any subsequent agreement between the parties. ${ }^{4}$ In Ponnsylvania, it seems to be competent for the parties in interest to proloug the lien by agreement. Thus, A. recovered judgment against B., April 4, 1346; B. afterwards conveyed to $C$. real estate liable to the judgment lien. D. then had judgment against C., July 24, 1850. On the twenty-eighth day of March, 1851, A. and C. agreed that the first named judgment should continue to be a lien for another term of five years. It was afterwards decided that A. and C. had power thus to prolong the lien; that $B$. was not a necessary pirty to the agreement; that the terre tenant being the only person injured by the arrangement, was the only one who need join with the plaiutiff thercin; and that D., being a

${ }^{1}$ Davilison v. Root, 11 Ohio, 98; Bowman $v$. Hovions, 17 Cal. 471 .

2 Commrs. of Spring Gardens' Appeal, 8 Watts \& S. 44.

3 White $v$. Jones, 33 Inl. 159.

424
${ }^{4}$ Purdy $v$. Doyle, 1 Pai. Ch. 55s; Denegre $v$. IIaun, 13 Iowa, 210.

5 De La Vergne v. Lvertson, I Pai. Ch. 181; 19 Am. Dec. 411; Troup. v. Wool, 4 John. Ch. 247; Renick $v$. Ludington, 14 W. Va. 367. 
mere second incumbrancer, could not avoid C.'s contract with A. ${ }^{1}$

8 390. Dizcharge by Sale under.-A., B. and C. had jaugments against D., having priority as here namerl. $B$. levied upon and sold D.'s land, realizing a sum insufipcient to pay lis judgment. A deed under this sale issued to the purchaser, the time for redemption litving first expired. Difondime, A. sold the same land under his judgment. B., during the period allowed for redemption from 1 .'s sale, but subsequently to the expiration of the period allotted for reciomption from his own sale, attempted to redeem as a judgment creditor, and paid money suffeient for thut purpose, and $\mathrm{C}$. thereafter attempted in like manner to redeem from B. Upon these facts, the court decided, that by the sale under B.'s judgment, which had become absolute by the issanance of the deed therefor, the lien of B.'s judgment, and of all judgments orer which it had precedence, was exhausted; and that therefore neillier $B$. nor $C$. was qualified to make a valid redemption. ${ }^{2}$

8. 391. Payment without Discharge.-In some cases of which we shall treat more fully in the chapter upon "Satisfaction," payment of a judgment may be made to the plaintiff withont producing the discharge thereof. This happens, as we shall see, when the party making the payments, though compelled to do so for his own protection, or to fulfill some obligation on which he is not primarily liable, is entitled in equity to be invested with some portion or with all the rights previously held by the judgment creditor. Whenever, after payment, the judgment may be kept alive for any purpose, its lien will survive for a like purpose. Thus a party purchasing land of a surety, subject to a judgment against several co-sureties, and who is for his own protection compelled to pay plaintiff to avoid the lien, need not thereby discharge the lien on lands held by the other defendants. It becomes the duty of the creditor, on such payment, to instantly transfer to the payer, the judgment and all its securities for its satisfaction. If he refuses to do so, a suit in equity may be maintained to subject the other lauds to

I Sames' Appeal, 26 Penn. S. 184. I ${ }^{2}$ Ex parte Stevens, 4 Cow. 133. 
the payment of a ratable part of the amount which the purchiser has been compelled to pay. ${ }^{1}$

PART V.-EXTENDING AND REVIVING.

83 392. Scire Facias.-The lien of judgments being generally created and limited by statutes prescribing the period of its duration, is, for the most part, kept strictly within the bounds thus assigned to it. The object of a scire facias is not to extend or to continue the lien, but to enable plaintiff to make it available by execution. Therefore, if the law provide that judgment liens shall continue for in number of years, but that execution can issue only within a shorter period, it may be neeessary for the plainiff to revive his judgment'so as to obtain execution after the lapse of this shorter period and before the expiration of the lien. In case he proceeds to revive lis judgment by scire facias, this will not prolong the lien beyoud the time prescribed by statute. In Ohio, a judgment may become dormant and thereby lose its lien as against a mortgage made by the debtor during the life of tho lien. A revival of the judgment cannot affect the mortgage or any other prior lien."

¿ 393 . Inability to Exrecute Frocess. - In Tenneswee, the impossibility of executing the process of the courts luring the late civil war, has been urged as a sufficient reason for extending the lion of judgments beyond tho period prescriber by statute. This care did not end, as most hard cases are said to do, by making a bad precedent. Tho court adlered to the law, and declined to relieve the manifest hardship resulting therefrom, by judicial legislicion. ${ }^{4}$

8 394. Stay of Execution. -The remarls made in the preceding section, commending the decision in Temnessee, as an exarnple of adherence to law when the temptation to judieial legislation was almost irresistible, are by $n 0$ means applicalble to several constructions given by the courts to the effect of stays of execution, made without the consent of the plaintif. In Pennsylvauia, a statute provided that no judg-

1 Furnold $v$. Bank of Mo., 44 Mo. v. Kip, 6 Pai. Ch. S5; Whiting v. Beebe, 336; Ev parte Crisp, 1 Atk. 133; Lath- 7 Enc. 5i 7 ; Norton $v$. Beaver, 5 Oinio, rop \& Da!e's Appeal, 1 Penn. S. 512; 180; Bank $v$. Wells, 12 Mio. 364.

Lidlerdale $v$. Robinson, 12 Wheat. ${ }_{3}^{3}$ Tracy $v$. Tracy, 5 McL. 406 ; Miner 594 .

${ }^{2}$ Deneqre $v$. Haun, 13 Iowa, 240; Tufts $v$ : Tufts, 18 Wend. 621; Hower

$v$. Wallace, 10 Ohio, 403.

${ }^{4}$ Smart ?. Mason, 2 Lieiskell, 223, 
ment should continue to be a lien on the real estate of tho debtor during a longer period than five years from the first return day of the term of which such judgment might be entered, unless revived in the manner prescribed by law. Under this it was held that if judgment were rendered with a stay of execution the lien would continue five years from the expriration of the stay. ${ }^{1}$ In California, the statute regulating the lien and docketing of judgments provides: "that the lien shall continue for two years, unless the juclgment be previously satisfied." At quite an early clay the Supreme Court of the State, was called upon to decide whether a stay of execution resulting from filing a sufficient bond for that purpose, extended the time during which the lien could continue. The statute, it will be seen, made no exceptions whatever. Notwithstanding the protest of counsel against judicial legislation, and their requesting the court to "not forget that wise old saying of one of the English judges that "hard cases are the quicksands of the law," it was held that the period during which he was tied up by the stay was not to be counted against the judgment creditor. The reasoning employed in the opinion of the court, seems, to my mind, rather to show that the legislators ought to haro incorporated some exception in the statute, and that they would have done so, if their attention had been attracted to the propriety of so doing, than that the language employed by them indicated even an intention to permit of any exceptions. The court said: "The first reading of the act would seem to be conclusive in favor of the appellant, but when we come to examine the legal solicism of allowing a party by his own motion, thus to defeat the remedy which the law has given the creditor, and to destroy the security furnished, which must inevitably result if the construction contended for be sustained, we are necessarily put upon inquiry as to the intention of the legislature and the possibility of escape from any such absurd consequences.

"The obvious intention was to charge the estate of the judgment debtor, and to give the creditor two years to make his money. The statute intended that this time should run from the date of the judgment, or period at which the

1 Pennock v. Hart, 8 S. \& R. 369. 
plaintiff was in a situation to take out execution, and pursue his remedy to final satisfaction. By the defendant's own act, the force of that judgment has been suspended, and the lien, which is merely an incident, must share a like fate. It would be absurd to say that a lien attached upon a judgment, and expired by its own limitation, while the jadgment was still in fieri, and could not bo prosecuted to full fruition.

"The defendant would thus be able to abridge, if not destroy, the lien, and in all cases where a period of more than two years interrened between the date of the judgment in the court below and the final judgment in this court, to substitute personal for that security which the law gives the successful party." This decision and the ono cited from the Pennsylvania reports, are of the class which Mr. Sedgwick, in his work, says "can hardly fail to bring to the lips of the student the motto of this volume: Great is the mystery of judicial interpretation." 2 They certainly violate the rules laid down by the same author, and by him sustained by the citation of numerous cases: "That if that intention is expressed in a manner devoid of contradiction and ambiguity, there is no room for interpretation or construction, and the judiciary are not at liberty, on consideration of policy or hardship, to depart from the words of the statute; that they have no right to make exceptions or insert qualifications, however abstract justice or the justice of the particular case may require it." ${ }_{3}$ The reasoning advanced by Chief Justice Murray, in the opinion from which we have quoted above, in the case of Dexey v. Latson, is equally applicable to all cases in which the plaintiff has been prevented by the act of the court, or of the defendant from prosecuting his judgment "to full fruition." This might as well happen where a stay of execution is produced by an injunction, as by a bond on appeal. The equities of the two cases are equal. But so far as we are informed, the exception has not been expressly affirmed or denied, in any other cases than those arising from a stay of execu-

'Dewey $v$. Latson, 6 Cal. 130; Af- ${ }^{2}$ Sedgwick on Stat. and Const.Law, ffirmed in Englund $v$. Lewis, 25 Cal. p. 305. 337.

sId., p. 295. 
tion accompanying the rendition of the judgment, or occa sioned by a bond on appeal. If the undertaking on appeal be insuficient in amount to stay proceedings, the lien of the judgment will not be prolonged thereby. ${ }^{1}$ Neither can the lien be extended by an agreement between the parties to stay execution, nor by any stay not entered of record, that being the only place at which all purchasers are bound to look.2 A statute of Ohio limited the lien of judgments to one year after their rendition, and provided that in case the judgment was against a principal and surety, the plaintiff should be restrained from proceeding against the latier until the property of the former was exhausted. Under this statute, it was decided that, though the execution against the surety was delayed by order of the court, the plaintiff lost his lien at the expiration of the jear. ${ }^{3}$

8 394a. Sale after Expiration of Lien.-The time during which judgments have the force of liens on the lands of judgment debtors is usually prescribed by statute. In many instances, executions have been taken out and levies made within the time preseribed for the continuance of the lien, but so late that the sale did not take place until after the lapse of such time. In regard to such cases, so fir ats our observation has extended, it has, except in the State o. Missouri, been uniformly held that the execution and lery did not continue the lien; and that to preserve the priority acquired by the judgment, the sale must be made during the statutory period. The title acquired at such a sale is therefore precisely the same as though the judgment had never been regarded as a lien. ${ }^{5}$

${ }^{1}$ Chapin $v$. Broder, 16 Cal. 403.

2 Bombay $v$. Boyer, 14 S. \& R. 253; 16 An. Dec. 404.

${ }^{3}$ Earnfit $v$. Vinans, 3 Ohio, 135. In Indiana, an agreement by which execution is stayed has the effect of continuing the duration of the lien. Applegate $v$. Edwards, 45 Ind. 329. The rule is otherwise in Pennsylvania. Hempliill $v$. Carpenter, 6 Watts, 24; Wallace's Appeal, 5 Pa. S. 106; Betz's Appeal, 1 Pa. S. 27\%; see Ayers $v$. Waul, 44 Tex. 549; Russell v. McCanpbell, 29 Tex. 31.

${ }^{4}$ Bank $v$. Wells, 12 Mo. 361; Durrett $v$. Hulse, 67 Mo. 201; Woad $v$. Messerly, 46 Mo. 25 J.
${ }^{5}$ Bayley $v$. Ward, $37 \mathrm{Cal}$ 121; Isanc $v$. Swift, 10 Cal. 81 ; Toe v. Swart, 5 Cow. 294; Little $v$. Harvey, 9 Wend. 158; Tufts $v$. Tufts, is Vend. 62I; Graff $v$. Kipp, 1 Edw. Ch. 619; Pettit $v$. Shepherd, 5 Pai. 493; Rupert v. Dantzler, 12 S. \& M. 697; Beirne $v$. Mower, 13 S. \& M. 427; Davis v. Lhrman, 20 Penn. S. 25s; Birdwell v. Cain, 1 Cold. 302; Dickinson's Lessee $v$. Collins, 1 Swan, 516; Shaphard $v$. Bailleul, 3 Tex. 26; Trapuall $v$. Iichardson, 3 Eng. 543 ; Jamesv. Wortham, Ss Ill. 69; Pasour $v$. Rhyme, $82 \mathrm{~N}$. C. 149 . 
8 395. Equity will not Extend nor Iimit.-One who has neglected to enforce his judgment lien in proper time, will not, in equity, be relieved from the consequences of his neglect. ${ }^{1}$ In general, courts of equity will not interpose to take away any advantage which a creditor has obtained by his diligence in securing a judgment lien on the debtor's estate. Thus, when a judgment lien has become a charge on the individual real estato of a partner for a firm debt, equity will not displace it in favor of a junior judgment against the same partner for his personal debt. In this case, courts of equity in the administration of assets, were it not for the judgment lien, would have given the creditors of the individual preference over the creditors of the partnership; or, in other words, they would have distributed partnership effects to the creditors of the partnership, and the personal effects of each partner to his personal creditors. But those courts "never interfere where the law has given one class of creditors an absolute preference over the others; but recognize and enforce all antecedent liens, claims and charges existing on the property according to their priorities." " But these rules in nowise impair the authority of courts of equity to prevent judgment creditors from retaining an advantage which they secured through misrepresentation or some other unconscientious and inequitable device. Thus, if land be conveyed to trustees for the benefit of creditors, being at the time subject to judgment liens, and the trustees proceed to sell the land, the purchasers may have the creditors enjoined from proceeding to enforce their liens, if they can clearly establish that they were led by the creditors to believe that they would look to the trustees for their claims. In the absence of a clear affirmative showing that the creditors made such representations, they will be allowed the full advantage of their liens. ${ }^{3}$

8 396. Transcript from Another County.-By the two hundred and seventh section of the California Practice Act, now adopted as the six hundred and serenty-fourth section of the Code of Civil Procedure of the same State, the filing of a certified copy of a judgment from a court of another

\footnotetext{
1 Smith v. Meredith, 30 MId. 429; ${ }^{2}$ Meech v. Allen, 17 N. Y. 300; Douglas v. Huston, 6 Ohio, 162. 430 
county with the County Recorder, gives the judgment force as a lien in the county where filed, for two years from the fling, though its lien may have expired in the county in which the judgment was rendered.'

PART VI.

83 397. For Advances to be Made._A judgment may be taken as an indemnity against contingent liabilities or to secure future advances. An indorser may take judgment to indemnify himself from the consequences which may flow from lis indorsement, and may assign the same to another person, who becomes security in his stead. This judgment will, in favor of the substituted security, have precedence over a junior judgment docketed before he was compelled to pay the indorsed notes. ${ }^{2}$ A recording act, in substance declaring that every convevance not recorded shall be void against any subsequent purchaser in good faith, etc., makes the records notice to subsequent, but not to prior, purchasers or incumbrancers. Therefore, if a judgment be confessed, to secure future advances, and a mortgage be subsequently made and recorded on the judgment debtor's real estate, the judgment creditor is not affected thereby, unless charged with actual notice, but may proceed to complete his advances. If the mortgagee wish to avoid the judgments standing as security for further advances, he should gire the judgment creditor actual notice of the mortgage. ${ }^{3}$.

\section{PART VII.-JUDGIIENTS OF FORECLOSURE.}

8399. Merger of Lien. - The cases determining the effect of a judgment of foreclosure of a mortgage, as a merger or extinguishment of the mortgage lien, though few in number, are irreconcilable in spirit. In New York, a mortgage was foreclosed, but the decree not docketed. On this stato of facts, the Supreme Court held, that " this mortgage was merged in the decree entered upon it, which decree was enrolled, but not docketed. The lien of the mortgage was thus extinguished and gone. That a judgment at law extinguishes the debt upon which it is obtained, is too plain a proposition to require argument, or authority, to prove. And I am not able to see why a decree of a court of equity should not have the same effect. Indeed, it seems to me

${ }^{1}$ Donner $v$. Palmer, 23 Cal. 40.

${ }^{2}$ Norton v. Whiting, 1Pai. Ch. 578.

${ }^{3}$ Truscott $v$. King, 6 Barb. 316.

431 
that the rule applies equally in both cases. The decree was not a lien because it was not ducketed." This part of the decision, though not essential to the determination of the case, and though, so far as we know, not directly affirmed in the same or any other court, seems to have been recognized as correct by the Conrt of Appeals of the same State. $^{2}$ In Missouri a judgment lien continues for but three years, while the lien of a mortgage does not expire until twenty years. The Supreme Conrt of that State considered that a judgment on a mortgage debt secured by mortgage, though rendered more than three years, did not thereby cease to be a lien; but that it might be revived by scire fucias, and the mortgaged premises subjected to its payment at any time luring the twenty years provided as a limit to the mortgage lien. ${ }^{3}$ In Iowa, it is well settled that if a judgment or decree be entered, foreclosing a mortgage, tho lien of the mortgage continues until the judgment is satisfed or is barred by the Statuto of Limitations. ${ }^{4}$ That the lien of the judgment necessarily relates back to the lien of the mortgage lias always been the rule in Pennsylvania. ${ }^{5}$ The distinction between a decree directing the sile of the mortgage premises and a statutory judgment locketed for any deficiency which may remain after the sale must be remembered. On the former, execution may at ouce issue, and to be effective, must necessarily overreach the alienations made subsequent to the mortgage, at least as against all parties to the suit. On the latter, no execution can issue, nor can there be any lien till the amount of the deficiency is ascertained and judgment docketed therefor. ${ }^{6}$

\& 399. Decree Including Senior and Junior IrorígageIn an action of foreclosure the holder of a senior mortgago may be made a party defendant; and the decreo may be so entered as to require his lien to be first satisfied ont of the proceeds of the sale. The purchaser under such a decree probably takes title as well by the senior as by the junior mortgage. "He, at all events, acquires such an

1 The People $v$. Beebe, 1 Barb. 379.

2 Gage $v$. Brewster, 31 N.Y. p. 2:26.

"Riley's Admr. v. MeCord's Admr., 21 Mo. 285; see also Priest $v$. Wheellock, 59 Ill. 114.

${ }^{4}$ Hendershott $v$. Ping, 24 Iowa, 134; Stahl $v$ Roost, 34 Id. 476.

${ }^{5}$ De Witt's Appeal, $76 \mathrm{~Pa}$. S. 283; McCall v. Ienox, 9 S. \& R. 310.

${ }^{6}$ Beil v. Gilmore, 25 N. J. Eq. 104; Winston $v$. Browning, 61 Ala. So; Hershey $v$. Dennis, 53 Cal. 77. 
interest as a court of equity will protect from the lien of a judgment subordinate to the senior and paramount to tho junior mortgage, by requiring the judgment creaitor before asserting his lien to pay the amount of the senior mortgage."1

\& 400. Eurplus. - "The surplus money arising on a sale of land under mortgage foreclosure stands in the place of the land, in respect to those having liens or vested rights therein, and the widow of the owner of the equity of redemption is entitled to dower in the surplus, as she was in the land before the sale."

\& 401. Different Kinds of Decrees. -The two hundred and forty-sixth section of the Practice Act of California, as originally enacted, provided that in an action to foreclose a mortgage or other lien, "the court shall have power by its judgment to direct a sale of the property, or any part of it, the application of the proceeds to the payment of the amount due on the mortgage, lien or incumbrance, with costs, and execution for the balance." Under this section it was well established by a series of decisions, that a definite personal judgment might at once be rendered against the mortgagor, under which the sheriff could make a sale and apply the proceeds, without any proceedings on the part of the court being required to ascertain the deficiency; or a decree might be taken according to the course pursued under the old chancery system, "adjudging the amount due upon the personal obligation of the mortgagor, and directing a sale of the premises and the application of the proceeds to its payment, and apply, after tho sale, for the ascertainment of any deficiency, and execution for the same. ${ }^{3}$ A judgment of the first named kind constituted a lien on the real estate of the defendant from the docketing thoreof; but a decree according to the chancery form constituted no lien on the other lands of the debtor. The reasons for holding such a decree not to be a lien were thus stated by the court: "A mere contingent provision, referring to no particular amount, and in abeyance until the contingency is determined, is not within the meaning of tho statute. It may become a valid and perfect judgment; but

i Raymond $v$. Holborn, 23 Wis. 57. Rollins v. Forbes, 10 Cal. 299; Eag-

2 Mathews v. Duryee, 45 Barb. 69. lund v. Lewis, 25 Cal. 337.

${ }^{3}$ Rowland $v$. Leiby, 14 Cal. 156 ; 
until the amount to be recovered is ascertained and fixed, no effect can be given to it as a lien. In the present case the provisions in question were of this character, and no general lien was acquired by the docketing of the judgment. It is no answer to say that the judgments contained a statement of the amount due. There was no personal judgment for this amount, nor was there anything in the nature of a personal judgment, beyond the mere direction for the issuance of an execution, in the event of the insuficiency of the mortgaged property to pay the debt. The whole matter was contingent, indefinite and uncertain, and so long as this continued to be the case, no effect whatever could be given to it."'

8 402. Liens restricted by Statute.-But the two hundred and forty-sixth section of the Practice Act was amended in 1861, by the addition of a clause providing that if it be ascertained from the return of the sheriff, that a balance is still due to the plaintiff, "the judgment shall then bo docketed for such balance against the defendant or defendants, personally liable for the debt, and shall from the time of the docketing thereof be a lien upon the real estate of the judgment debtor." This section, as thus amended, has, with a slight change in form, been adopted as the seven liundred and twenty-sixth section of the Code of Civil Procedure. Tho amendment of 1861 " seems to have been designed to limit the remedy of the mortgage creditor to his security, in eases when a decree for mortgaged premises is had, until that was exhausted, and then to give him a lien on all his debtors' real property subject to execution for the balance remaining due, from the time the same should be duly ascertained and the judgment docketed for that balance." "With respect to a judgment in personam coupled with a decree foreclosing a mortgage, and directing a sale of the mortgaged premises, the judgment is to be docketed for the balance which may remain due after the mortgaged prop-

${ }^{1}$ Chapin $v$. Broder, 16 Cal. 403, af- pressed in Hays v. Jiller, 1 Wash. firmed in Englund v. Lewis, 25 Cal. Terr. 143. 337 ; see also similar conclusions ex-

434 
erty is exhausted, and from that event, that is, the docketing, the judgment shall be a lien on the debtor's real property, and may thereafter subsist as a lien for two years."1

\section{PART VIII.-JUDGJLENTS IN THE FEDERAL COORTS.}

8 403. Adoption of State Laws.-The lien of definite judgments in personam, in the federal courts, is governed by the laws of the State in which the judgment is entered. It must not be supposed from this statement that a Stato lias authority in virtue of its own sovereignty to legislate upon this subject, or in any respect to extend or limit the lien of the judgments or decrees of federal courts. Tho applicability of State laws, arises from their adoption by Congress, or by the federal courts, or perhaps by both.2 The lien of the judgments and decrees of federal courts, in the State where entered, is the same as that given by law to the judgments of the highest courts of original and general jurisdiction in that State $;^{3}$ and they cease in the same manner, and at like periods, as judgments and decrees in such States. ${ }^{4}$ Judgment liens must be ereated by the government under whose authority the judgment is rendered. The States therefore may determine the effect of judgments in their own courts, but not the effect of judgments in the United States courts. ${ }^{5}$ A State law requiring judgments to be enrolled in the county where the lands to be charged are situate, before becoming liens, therefore, cannot affect the lien of judgments in the federal courts. ${ }^{6}$ Though congress has adopted the laws of the several States, this does not adopt such laws as the State may thereafter enact. Notwithstanding the repeal or modification of the State statute, the execution of the judgments of federal courts remains subject to the control of the statute as it stood when

${ }^{1}$ Culver $v$. Rogers, 28 Cal. 520. The Williams $v$. Benedict, 8 How. U. S. same rule prevails in Nevada. WVeil v. Howard, 4 Nev. 384 .

${ }^{2}$ Clements $v$. Berry, 11 How. 411; U. S. v. MLorrison, 4 Pet. 124; Ralston ข. Bell, 2 Dall. 158; Ward v. Chamberlain, 2 Black, 438 .

${ }^{3}$ Pollard v. Cocke, 19 Ala. 188. 107; Rev. St. U. S., sec. 967; Myers v. Tyson, 13 Blatchf. 242.

${ }^{5}$ Corwin v. Benham, 2 Ohio S. 36.

${ }^{6}$ Carroll $v$. Watkins, 1 Abb. U. S. 474; U. S. $v$. Halstear, 10 Wheat. 51; U. S. $v$. Humphries, 7 Rep. 330; Cropsey $v$. Crandall, 2 Dlatchf. $3 \dot{i l}$;

${ }^{4}$ Chouteau $v$. Nuckolls, 20 Mo. 442; Ward v. Chamberlain, 2 Black. 430. 
adopted by the United States; and it has been held, in at least one of the Circuit Courts, that the Revised Statutes upon this subject are not to be treated as new acts, but rather as a continuation of the former statute. ${ }^{1}$

8 404. How State Laws were Adopted. - In respect to the manner in which the State laws were adopted, a difference of opinion is manifest from the decisions made by judges of federal courts. One view is-1. "That the lien of judgments in the courts of the United States does not result from any direct legislation of Congress on that subject. 2. That under the Judiciary Act, which ordains that the laws of the several States shall be rules of decision at common law, the courts of the United States have uniformly adopted the principles of State policy and jurisprudence on the subject of the lien of judgments, so far as the same were applicable, treating them as rules affecting real property and its transmission by descent or purchase." other view is thus stated by $\mathrm{M}$. Justice Clifford in Warl v. Chamberlain (2 Black.) 430. "Expressions are to be found in one or more of the cases referred to, which countenance the idea that the State laws in respect to the lien of judgments and decrees were adopted by the courts of the United States;" but upon a closer examination of the subject it will appear, we think, that those laws are recognized and substantially adopted by the "Acts of Congress regulating process in the courts of the United States." His Honor, after referring to the several acts passed by Congress upon the subject, and especially to the third section of the act of May 19, 1828, which provides "that writs of execution and other final process, issued on judgments and decrees rendered in any of the courts of the United States, and the proceedings thereon, shall be the same, except their style, in each State, respectively, as are now used in the courts of such State," adds: "Undoubtedly Congress intended, by that provision, to adopt the State laws in respect to the pro-

'Myers $v$. Tyson, 13 Blatchf. 242. | bell v. Griggs, 23 Am. Dec. 790, and With reference to creditors' bills in note.

State courts in aid of judgments in ${ }^{2}$ Lombard $v$. Bayard, 1 Wall. Jr. courts of the United States, see Tar- 196. 
ceedings on final process, as they existed at the date of the act, and the effect of the enactment, or one of its effects, was to render judgments and decrees for the payment of money rendered in the federal courts, a lien on the land of the debtor, in all cases and under like circumstances as when rendered in State courts. Under the earlier process acts, this court twice decided that the laws of the States furnished the rule of decision in respect to the lien of judgments and decrees rendered in the federal courts, upon the land of the debtor, and since the passage of the act under consideration it has been trice affirmed by this court as a matter of listory, that the act was passed to confirm the view expressed in those decisions."

\& 405. The liens of the judgments of the several courts of the United States are charged upon all the lands of the judgment debtors, situate within the territorial limits of the jurisdiction of the court pronouncing judgment, upon which a judgment of like character entered in one of the courts of the State in which such lands are included, would have been a lien. ${ }^{2}$

8406. Decrees in Admiralty.-It seems that until the year 1862, the decree or sentence of a Court of Admiralty was not supposed to create a lien on the debtor's lands. Mr. Justice Grier, in that year, in a very vigorous dissenting opinion, said: "It is now seventy years since the establishment of Courts of Admiralty in these States, yet it seems that the boundary of their jurisdiction is not yet settled. During all this time it has never been supposed that the definitive sentence or decree of a Court of Admiralty was a lien, or could be levied on lands. The dominion of the Acimiral was over the sea-the ships and nen who frequented it-their contracts and their torts. His court proceeded either against the ship or the owner, by arrest of the thing

\footnotetext{
${ }^{1}$ Beers $v$. Haughton, 9 Pet. 361 ; ers $v$. Fowler, 7 Eng. 276; Sellers $v$. Ross v. Duval, 13 Pet. 64.

${ }^{2}$ United States $v$. Duncan, 12 Ill. 301, and note; Prevost $v$. Gorrell, 5 523; Trapnall $v$. Richardson, 13 Ark. Reporter, 616; 12 West. Jur. 369; 543 ; Den $v$. Jones, 2 McL. 83; Con- Lawrence $v$. Belger, 5 Reporter, 532; rad $v$. Insurance Co., 1 Pet. 453; By- Branch v. Lowery, 31 Tex. 96.
} 
or the person." But a majority of the court were of the opiuion that, whatever the practice or understanding of the courts may have been, the terms of the act of 1828 were too broad not to include Courts of Admiralty. Justice Clifford, in the opinion assented to by a majority of the judres, said: "Courts of justice may construe a legislatire opinion, but they can not repeal what is expressly enacted. When Congress, in plain and unambiguous terms, declares that writs of executions on decrees rendered in amy of the courts of the United States, and the proceedings thereupon, shall be the same as are now used in the courts of such State, it is not possible for this court to hold that the decrees of one of the courts of the United States are not embraced in that provision; especially not, as the very court whose decrees it is said are excluded from the provision, is specifically mentioned in the first section of the same act as one of the courts of the United States, and its proceedings there made the subject of special and material regulation. Exclusivo original jurisdiction in admiralty and maritime cases is conferred upon the District Courts of the United States, but the Circuit Conrts hear such cases on appeal, and, as a matter of daily practice, render decrees therein for the payment of money; and it is not to be doubted, we think, that such decrees are as much within the provisions under consideration as decrees in equity; and, if so, no reason is perceived why the same rule should not be applied to decrees of a like character rendered in the District Courts."1

${ }^{1}$ Ward v. Chamberlain, 2 Black. U. S. 430. 


\title{
CHAPTEP XV.
}

\section{JUDGMENTS AS EVIDENCE.}

PART I.-OF THE MIODE OF PROOF.

\author{
$\$$ 407. Necessity of Record Proof. \\ \$ 408. Proof of Copies. \\ $\S 409$. Judgment Book as Evidence. \\ $\S 410$. Inferior Courts. \\ $\$ 411$. Anthentication of Sister States. \\ $\$$ 412. The Certificate. \\ $\S 413$. The Judge. \\ $\S 414$. Authentication of Foreign.
}

PART II.-ADMISSIBILITY AND EFFECT.

\author{
$\S$ 415. Statement. \\ \$ 416. Judgment as Proof of Itself. \\ $\$ 417$. Judgment as matter of Inducement. \\ $\S 417 a$. Judgment as an Admission. \\ $\S 413$. Judgment to show that Plaintiff is a Creditor of Defendant. \\ $\$ 419$. Questions of Public Nature, provable by evidence of Reputation. \\ $\$ 420$. Decree.
}

PART I.-OF THE MIODE OF PROOF.

\& 407. Necessity of Record Proof.-At common law, "when the existence of a judgment is put in issue, upon a plea or replication of mul tiel record, it must be proved by the production of the record itself; which is inspected by the court wherein it is, if it be a record of the same court, or if of a different court, a certiorari must be sued on for bringing it in. And if it be a record of an inferior court, the certiorari may be issued out of the superior one; but if it be of a superior court, or court of equal jurisdiction, there is no way to have it but by certioncri and mittimus out of chancery." In a recent case in North Carolina the position is maintained that, in no event, can the production of the record be dispensed with. That, if it be lost, the party who wishes to use it in his behalf, must take such proceedings in the court where it was made as are necessary to create a new record, and have it substituted in place of

1 Tidd's Pr. 913; Greenl. Ev. Secs. 501 and 502, Vol. 1. 
the old one. ${ }^{1}$ This view is in direct conflict with that expressed by Mr. Greenleaf in his work on evidence, in which he lays down the following rule: "If the record is lost, and is ancient, its existence and contents may sometimes be presumed; but whether it be ancient or recent, after proof of the loss, its contents may be proved, like any other document, by any secondary evidence, where the case does not, from its nature, disclose the existence of other and better evidence."' In Canada, a defendant in cjectment claimed under a sheriff's deed. He showed that the files, dockets and all papers of the court had been destroyed by fire, except a fee book, in which book there was a fee for a judgment entered in a case therein specified. He then proved, by parol evidence, the rendition and contents of the judgment; and that the sheriff's deed had issued in pursuance of a sale had under such judgment. The admission of this evidence was urged on appeal as an crror sufficient to warrant a reversal; but the judge who delivered the opinion of the Appelate Court, said: "Conceding that matters of record, such as the judgment and writ here, should be ordinarily proved by exemplification, yet when the records themselves are proved to be wholly destroyed, it seems simply an impossibility to exemplify them. No doubt there are cases where the court have ordered a record to be made up from the best materials available, to supply the place of one that was lost, but in the case before us there was nothing on which a record could be made up, and it could hardly be advisable to leave it wholly to the imagination of the Clerk of the Court to make up a record from an entry in a fee book." But in the absence of the loss or de-

1 Walton $v$. McKesson, 64 N. C. 77. Am. Dec. 15s; Davics v. Pettit, 11

${ }^{2}$ Vol. 1, Greenl. Ev., Secs. 84 and 509; McQueen v. Fletcher, 4 Rich. Eq. 152. Mr. Greenleaf's rule is, beyond a doubt, sustained by the weight of the authorities. Ames $v$. Hoy, 12 Cal. 11; in the matter of Warfield's Will, 22 Cal. 64 ; Stockbridge $r$. West Stockbrilge, 12 Mass. 400; Jackson $v$ Crawfords, 12 Wend. 533; New- $v$ Kerby a9 Geo 65t. Watson $v$ comb v. Drummond, 4 Leigh, 57; Hahn, 1 Colorado, 385; Mason v. Bull, Jackson v. Cullum, 2 Blkf. 228; 18 26 Ark. 164.

440 
struction of the record, it cannot be proved otherwise than by the original, or by a duly authenticated copy. ${ }^{1}$ But in case of the admitted loss of the original record, no proof of its contents will be received except the best and most authentic proof which remains susceptible of production. ${ }^{2}$

8 40S. Proof by Cories. - "As to the proof of records, this is done either by mere production of the records, without more, or by a copy. Copies of the record are, 1st, exemplifications; $2 d$, copies made by an authorized oficer; $3 d$, sworn copies. Exemplifications are either first under the great seal, or, secondly under the seal of the court where the record remains. In the United States, the great seal being usually, if not always, kept by the Secretary of State; an exemplified copy, under the seal of the court, is ustially admitted, even upon an issue of mul tiel record, as sufficient eviclence." An office copy of the record is made either by an officer having no other authority than the order of the court directing him to make the copy for the convenienco of suitors, or by an officer whose duty it is, by the law, to furnish copies. In the first case, the office copy is not proof except in the same cause and in the same court wherein it was ordered to bo made. In the second case the offee copy is equivalent to the record." "The proof of records, by an examined copy, is by producing a witness who has compared the copy with the original, or with what the offeer of the court, or any other person, read as the contents of the record." 5

8. 409. The Judgment Book, according to the common law practice, seems to have been a mere minute or memorandum book, containing, however, wo entry which could constitute any evidence of the judgment. The judgment became a permanent record only when the roll was brought into court and filed. It could not be proved by mere docket entries." "The minutes from which the record is made up, and even a judgment in paper, signed by the

1 State $v$. Rugan, 6S Mo. 214; Ruth-| ${ }^{5}$ See vol. 1, Grcenl. Ev., 50S, for erford $r$. Crawford, 53 Gco. 13s; Tut. further rules in relation to proof by tle $r$. Jackson, 21 Am. Dec. 306.

${ }^{2}$ Note to Sec. 84, Vol. 1, Greenl. Ev.

${ }^{3}$ Tol. 1, Greenl. Ev. 501.

*Tol. 1, Gircenl. Ev. \$507. copies; and Abbott's Trial Ev, chap. xxix.

${ }^{6}$ Brown $v$. Hathaway, 10 Minn. 303; Godefroy $v$. Jay, 1 Moore \& P. 236. 
master, are not proper evidence of the record." 1 But where, instead of conforming to the common law system of procedure, the law requires the extry to be made in the judgment book, and a copy thereof to be made and filed as part of the judgment roll, the entry in the book must be regarded as the formal and permanent record entry, and therefore as evidence of the judgment. ${ }^{2}$ The vacature of a judgment must be enrolled, or entered of record, before it can be given in evidence against the judgment. ${ }^{3}$

8 410. Judgments of Inferior Courts. - "The judgments of inferior courts are usually proved by prodncing from the proper custody the book containing the proceedings; and as the proceedings in these courts are not usually made up in form, the minutes, or examined copies of them will be admitted, if they are perfect. If they are not entered in books, they may be proved by the officer of the court, or by any other competent person. In either case, resort will be had to the best evidence, to establish the tenor of the proceedings; and, therefore, where the courso is to record them, which will be presumed until the contrary is shown, the record, or a copy, properly authenticated, is the only competent evidence. The caption is a necessary part of the record; and the record itself, or an examined copy, is the ouly legitimate evidence to prove it." ${ }_{4}$ In an action in Canada, on a judgment rendered by a justice of the peace in Michigan, the judgment was proved by introducing the book in which the judgment was recorded, and by proving that the handwriting was that of the justice, and ibat the witness remembered the rendition of the judgment. ${ }^{3}$

\section{411. Authentication of Judgments of other States.-} "The statute of the United States of the twenty-sixth of May, 1790, declares, that the records and judicial proceedings of the courts of any State shall be proved and admitted in any other court within the United States, by the attestation of the clerk and the seal of the court annexed, if there

1 Vol. 1, Greenl. Ev. §505. 2 Williams $v$. MeGrale, 13 Minn. $\mid \begin{aligned} & \text { rison } \\ & 278 .\end{aligned}$

46. Thus, in South Carolina, the entry in the judgment book, and not the judgment roll, is the best evirison v. Manufaeturing Co., 10 S. C.

${ }^{3}$ MeKnight $v$. Dunlop, 4 Barb. 36. ${ }^{4}$ Greenl. Lv. 513, vol. 1.

${ }^{5}$ I Ierby $v$. Elliott, 13 Upper Canada denee to jrove the judgment. Har- Q. B. 367. 
be a seal, together with a certificate of the judge, chief justice, or presiding magistrate, as the case may be, that the said attestation is in due form of law." Any State may pass a liww dispensing with any part of the authentication prescribed by the act of Congress; but no State can require that a judgment be authenticated in a different manner than that provided by Congress. ${ }^{3}$

8412. The Certificate.-The copy of the record or judicial proceeding ought to be complete, and not a mere transcript from the minutes or some part thereof." A certificate as follows: "I hereby certify that the aforegoing is truly taken from the record of proceedings of Prince George's County Court," and being otherwise in due form and properly attested, was held to be sufficiently certified and attested to entitle it to be received in evidence. ${ }^{5}$ A certificate of a clerk certifying the transcript to be a "full, true and complete transcript of all the proceedings had in the above case as now remaius of recort and on file in my office," accompanied by the certificate of the judge, that "the certificate is in due form of law," is a sufficient anthentication. ${ }^{6}$ Aud, in Pennsylvania, a certificate that " the foregoing copy of records is truly taken and correctly copied from the records of judgments of said court remaining in my office," has frequently been taken and presumed to bo a copy of the whole record. The certificate of the judge, that " the certificate is in due form," is conclusive, ${ }^{8}$ although the certificate of the clerk itself appears, on inspection, to

' Ferguson $v$. Harwood, 7 Cranch, annexed, if there be a seal, together 405. Sec. 905 of the present Revised with a certificate of the jud gc, chief Statutes is as follows: "The acts of justice, or presiding magistrate, that the legislature of any State or Terri- the said attestation is in clne form."

tory, or of any country subject to the jurisdiction of the United States, shall be anthenticated by having the seals of such State, Territory, or country affixed thereto. The records and judicial proceedings of the courts of any State or Territory, or of any such country, shall be proved or ad. mitted by any other court within the United States, by the attestation of the clerk, and the scal of the court

2 Kingman $v$. Cowles, 103 Mass. 283.

${ }^{3}$ Parke $v$. Williams, 7 Cal. 247.

${ }^{4}$ Pepin $v$. Lachenmeyer, $45 \mathrm{~N} . \mathrm{Y}$. 27.

${ }^{5}$ Ferguson $v$. Harwood, 7 Cranch, 40 s.

${ }^{6}$ Blair $v$. Caldwell, 3 Mo. 353.

'Reber $v$. Wright, 6s Penn. S. 471; and cases there cited.

${ }^{8}$ Grover v. Grover, 30 MIo. 400. 
be manifestl? ambiguous and incomplete. The julge seems to be rested with the poter to determine whether the artestation is in due form and his certificate to that etiect is tual. ${ }^{2}$ It has been determined that the certificate of the judge "must be annered to the exemplification of the recorl, and can not be on a separate piece of paper." "The attestation of the cons must be according to the furm nsed in the State from which the record comes; and it nust be certified to be so by the presiding judge of the court, the certificate of the clerk to that effect being insuficient. Tor will it sufhce for the judge simply to certify that the person who attests the copr is the clerk of the court, and that the signature is in his handmriting. The seal of the court must be annered to the record with the certificate of the clerk, and not to the certificate of the judge. In Illinois it has been held that the juige is not requirel to state that the person certifring is the clert, noi that the seal annered is the seal of the court; that the seal sperts for itself, and is presumed to be attachel by the oncer charged by lam with the custody thereof." If the court whose record is authenticated, has no seal, that fact shochl be stated either in the certificate of the clerk, or in that of the judge.

513. The Judge's Certificate is indispensable. ${ }^{6}$ It mus: appear that the judge who undertakes to attest the recort is the judge of the court which rendered the julgment. An attestation br T.A.J., "presiding jadge of the Supreme Court of the State of Ner Fork, in the serenth Cistrict, is defectire in not showing him to be judge of the county where the judgment was entered. ${ }^{\prime T}$ The authentication must be bs the judge, if there be but one. If there be more than one, it must be br the chiej justice or presiding jurge. The judge certifring must, at that time, be the judge, chief justice, or presiding judge. Hence, where the

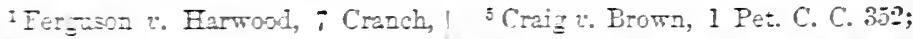
40. Kitland $\imath$ Smith, 2 Martin N. S. ZNorwool $\therefore$ Cotb, 20 Tex, 5s5; 497 .

Jifarine 2 . Harrington, 2 Bay, 5\%. ${ }^{6}$ Eutchins 2. Gerrish, 52 1. H. 205.

¿Greezl. E5., rol. 1. sec. 500\%. 'Phelps 2 . Tilton, 1\% Ind. 423.

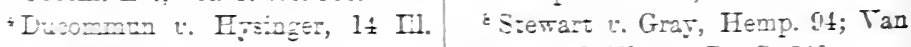
$\therefore \div 3$.
} 
judges act as chief justice br rotation, the authertication can not be made by ans one of them, but only by the one Who, for the time being, is chief.' If the jadge be also ex oficio clerk of the court, he must certify first as cleris aud second as judge in the same form and substance as when the two of cinces are not united in one person." If a court cease to esist, and its records are transferred to another court, the clerk and judge of the latter therebs become proper persons to authenticate the records of the former. ${ }^{3}$ Where sereral judges preside in the same court, neither having ans temporary or permanent rank above the others, and all being apparently on perfect equality mith ose another, an authentication in mhich all unite, has been regarded as sufficient."

\section{Authentication of Foreign Judgments. - Foreign} juigments are authenticated either-"1. Br an exempincation under the great seal. 2. Br a cops prored to be a true copr. 3. By the certificate of an of cer authorized by law, which certificate must itself be properls authenticated."

If all these means be berond the reach of the party other and inferior testimony may be receired. But a cons of a foreign decree, certified br the signing of a name tith the aduition to it of "Secretare of State of foreign a with a prirate seal, is neither suficient as an authentication nor admissible as secondary eridence. ${ }^{5}$ A foreign juigment is suffeiently authenticated $\pi$ hen a copr is prohucel, accompanied bs an affidarit stating that the aflant appied to the reputed clerk of the court, for a cops of the recori of the judgment; that he assisted the clert in comparing the copy with the record, and in fixing the seal of the court to the copr; and saw the same clerk attest the copr by puttiug his name to it. ${ }^{5}$ A record with the attesiation of the clerk, with the seal of the court and the certiciate of the chief justice, that the person attesting the record is the clerk, and that his signature is genuine; and with the cer-

1 Shat r. Hurd, 3 Bibo, 3.1.

${ }^{2}$ Catlin $r$. Enderhill, 4 MoLean, 199; Durall r. Ellis. 13 Mo. Q03; Bissell 2 . Elmarts, 5 Day, 360; 5 Am Dec. liov.
3 Thomas 2. Tamer, 6 Mcze. 30.

${ }^{4}$ Arnold $\iota$. Frazier, 5 Smò. 33.

${ }^{3}$ Charoh r. Hubbart, a Cranch. 15:.

- Butrrick t. Allen, 5 MLEs. 2-93; 5 Am. Des. 105. 
tificate of the Assistant Secretary of State of the province, accompanied by that of the Governor in charge of the province, attested by the great scal, and certifying that such court is lawfully and duly constituted, and specifying its jurisdiction; and which also verifies the signature of the clerk and of tho chief justice, is a sufficient exemplification. ${ }^{1}$ The admission of a record of a forcign court is authorized "if the proceeding has the attestation of the clerk of such court, with the certificate of the Chief Justice that the person attesting is such clerk, and that his signature is genuine; and with the further certificate of the Secretary of State, or other oficer holding the great seal, purporting that the court is duly constituted, specifying generally the nature of its jurisdiction, and verifying the seal and signature of the clerk and of the Chief Justice;" and if it be admitted that the person signing as clerk was in fact such clerk, the certificates of the Chief Justice and of the Secretary of State are superfluous. ${ }^{2}$ A copy of a judgment entered at Havana, signed by the clerk who was keeper of the records of the court; with proof that his signature validated all its proceedings; that the court had no seal; that the seal used to the certificate was that of the Royal College of Notaries, and that the document is authenticated in the way in which records were commonly authenticated, when sent to foreign countries, was held to be a sufficient exemplification. ${ }^{3}$

\section{PART II.-OF ADMISSIBILITY AND EFFECT OF JUDGMENTS.}

2415 . In treating, in different parts of this work, upon the various effects directly and indirectly resulting from judgments, and in considering the different persons who are, under the law, bound by judgments as parties or privies thereto, nearly all the questions naturally falling within the

${ }^{1}$ Lazier v.Wescott, 26 N. Y. $146 . \quad$ Braybrook, 6 M. \& S. 34; 2 Stark. 6;

${ }^{2}$ Capling $v$. Herman, 17 Mich. 524. Buchanan $v$. Rucker, I Camp. 63; 9

${ }^{3}$ Packard $v$. Hill, 7 Cow. 434. For East, 192; Loibel $v$. Stampfer, 16 L. T. further rules in regard to authenti- N. S. 720; Junkin $v$. Davis, 22 Q. B. cation of forcign judgments, sec $\$ \$ 514$, (Upper Canada) 369; Woodruff $v$. 515, Greenl. Ev. and notes; Alves Walling, 12 Id. 501; Junkin v. Davis, $v$. Bunbury, 4 Camp. 28; Cavan $v$. 6 C. P. (Upper Canada) 403; Hesketh Stewart, I Stark. 525; Henry v. Adey, v. Ward, 17 Id. 190.

3 East, 221; 4 Esp. 22s; Appleton v. 
second subdivision of this chapter have been already suffciently noticed. We shall therefore confine the remainder of this chapter to the consideration of those cases in which judgments may properly be admitted in evidence for and agrainst persons neither parties nor privies thereto, nor otherwise bound by the judgment as an estoppel.

\section{\& 416. To Prove Itself._ "A judgment may be offered} in ovilence for two purposes: 1st, To establish the mere fact of its own rendition, and those legal consequences which result from that fact; $2 d$, In addition to the first purpose, for the further purpose of proving some other fact as found by that rerdict, or upon whose supposed existence the judgment is based." For the first of these purposes every judgment is admissible in evidence against the whole world. Judgments in rem are generally considered as admissible against all persons; but their nature and efect will be made the subject of a separate chapter. A judgment may constitute part of a cliain of title to real or personal estate, or, though not amounting to title, it may show the character of the possession of one of the parties to a suit. In either case it is admissible in evidence for or against strangers as well as for or against the parties to the original suit. $^{2}$ Whenever a judgment transfers a title, or is tho founclation of a claim to possession, it is admissible upon the same principle as a voluntary conveyance. ${ }^{3}$

8 417. As Matter of Inducement.-Judgments are also available as evidence against third parties by way of inducement, or to prove the existence of any collateral fact. ${ }^{4}$ Thus if a principal should be sued for the negligence of his agent, the judgment against him in this suit would be evidence in a suit against the agent by the principal, for the purpose of showing what the consequence of the negligence had been; "as evidence of the quantum of damages, though not as to the fact of the injury." A judgment against a

${ }^{1}$ Notes 273 and 274 to Phil. Ev. by $\mid$ Davies $v$. Lowndes, 1 Bing. N. C. Cowen \& Hill; Williams $v$. MoGrade, 597.

13 Minn. 46; Spencer $v$. Dearth, $43{ }^{3}$ Fowler $v$. Savage, 3 Conn. 90; Ver. 98; Harrison v. Harrison, 39 Koogler v. Huffmann, 1 McC. 495.

Ala. 499.

${ }^{4}$ King $v$. Chase, 15 N. H. 9.

${ }^{2}$ Buckingham $v$. Hannah, 2 Ohio S. $\quad{ }^{5}$ Green $v$. New River Co., 14 T. R. 651; Barr v. Grattz, 4 Wheat. 220; 590; 2 Smith's Lead. Cases, 585. 
grantee in an action for the possession of land, is always evidence against his warrantor, for the purpose of showing an eviction.' Where one party agrees to indemnify another for some act done, a judgment rendered against the latter in consequence of such act, is evidence agaiust the former for the purpose of showing the damages sustained by the person indemnified. ${ }^{2}$ So in an action for contribution between sureties, a judgment in favor of a common creditor, and against the principal debtor and one of the sureties, to which the defendant in the second suit was not a party, is nevertheless competent evidence, not merely of its own rendition, but also by way of inducement to the evilence that the plaintiff in the present suit had discharged the debt on which the former suit was based. ${ }^{3}$ - A judgment against a sheriff, for the default of his deputy, is at least prima facie evidence against the latter and his sureties, to prove that the sheriff had been subjected to the payment of a certain amount of liability.

\& 417 a. As an Admission.-A record or judicial proceeding is admissible in evidence in favor of one not a party to it, when it contains a declaration or admission made by the person against whom it is offered. In such circumstances, it does not have the unimpeachable verity of a record. It is not conclusive against the person who made the admission or declaration; but such admission or declaration is of no higher dignity than if made in some other manner; and may be explained or rebutted. The afirmative declarations made by a litigant in his pleadings, may very properly be received as evidence against him, having at least as much effect as like statements made by him in letters or in ordinary conversation. ${ }^{5}$ His mere failure to deny a particular allegation or to interpose any defense whatsoever, certainly ought to have far less weight than his

${ }^{1}$ Booker's Adm'r v. Bell's Ex., 3 Bibb, 175; 6 Am. Dec. 641; Marlatt v. Clary, 20 Ark. 251; Gragg v. Richardson, 25 Geo. 570; Williams $v$. Shaw, 7 Am. Dec. 706; Patton v. Kennedy, 10 Am. Dec. 744; 1 A. K. Marsh. 389.
${ }^{2}$ Lee $v$. Clarke, 1 Hill, 56; Copp $v$. McDougall, 9 Mass. 1.

${ }^{3}$ Presiar $v$. Stallworth, 37 Ala. 405.

${ }^{4}$ Cox $v$. Thomas, 9 Gratt. 323.

${ }^{5}$ Parsons $v$. Copeland, 33 Me. 370 ; Williams $v$. Cheney, 3 Gray, 215; Judd v. Gibbs, 3 Gray, 539; Greenleaf on Ev., secs. 527a, and 195. 
afirmative declarations; but it seems that such failure is nevertheless competent evidence in another action, and in favor of a stranger to the former suit, and that a judgment by default is receivable in evidence as an admission of the material facts stated in the complaint. ${ }^{1}$

8 418. To Prove that Plaintiff is a Creditor.-Some conflict of authority exists in regard to the question, whether, in a suit to set aside a conveyance by one claiming to be a ereditor of the grantor, a judgment in favor of the plaintiff and against the grantor, is evidence against the grantee to show that the plaintiff is a creditor as he claims to be. In one instance, at least, such a judgment was rejected, because, as to the grantee, it was res inter alios acta. ${ }^{2}$ But the better opinion, and the one generally adopted, is, that such judgment is mima facie, though not conelusive, evidenee against the grantee, of the fact of his grantor's indebtedness. "It is not ineonsistent with the rule of res iuter alios acta, that a judgment should be taken even against third persons, to be what it purports to be, till the contrary is shown."

8 419. Questions of Public Nature.-Judgments are also admissible, for and against third persons, in regard to questions which in general are susceptible of being determined mainly by evidence of common repute; such as questions in regard to customs, tolls, pedigrees, prescription, ete. The solemn adjudication of a court, based, as it is presumed to be, upon testimony, is properly considered as better proof of a fact than evidence of mere general reputation ean be. " Judgments "are sometimes admissible to prove the existence of a public highway; but never, except where the party elaims by prescription; and then, merely to corroborate the presumption of there having been a grant." "5 A., in a suit against C. for breaking his close, ofiered in evidenee the record in a like action of $A$. against $\mathrm{B}$. wherein B. had pleaded the same defense now elaimed by C., namely,

${ }^{1}$ St. Louis MI. L. Ins. Co. v. Cravens, |Church $v$. Chapin, 35 Verm. 231; In69 Mo. 72; Cragin $v$. Carleton, 21 Me. man $v$. Mead, 97 Mass. 310.

492; Ellis $v$. Jameson, 17 Me. 235.

2 Troy $v$. Smith, 33 Ala. 469.

${ }^{4}$ Spencer v. Dearth, 43 Verm. 9S,

${ }^{3}$ Vogt $v$. Ticknor, 4S N. II. 242; Goodnow v. Smith, 97 Mass. 69;। 104.

${ }^{5}$ Towler v. Sarage, 3 Conn. 96. 
a right of public footway, in which A. had prevailed. Lord Kenyon said: "The record was admissible evidence, though between other parties, as to the finding upon the right to a public footway, which was negatived." On the trial of an iudictment against a town for not repairing an ancient highway, a similar indictment against an adjoining town through which the same highway ran, to which said town had submitted, was admitted as evidence tending to prove that the road was a lighway. ${ }^{2}$ So in a trial for tolls claimed by prescription, verdicts in other actions, against other defendants, wero admitted, because a recovery against a stranger was at least as good evidence as payment by the same stranger would be. ${ }^{3}$ Another exception to the rale, that jrdicial records are admissible only for and against the parties thereto, exists in the case of an adjudication in regard to the settlement of paupers. If, for instance, it be determined by a competent tribunal that a parper has his settlement in the town of $A$., this determination is conchusive against $A$. in a contest with any other town. Such adjudications seem to be judgments in rem, and binding on everybody. A judgment is generally admissible in an action between strangers to it, to prove any point upon which hearsay is competent evidence. Thus pedigree may be shown by hearsay or by common reputation. There plaintiff"s right to freedom is in question, the court may receive in evidence the judgment in an action between other parties establishing the right of one of plaintife's ancestor's to freedom. This right is of a public nature, capalble of proof by common repute, and such repute is as satisfactorily shown by such a judgment, as by having witnesses testify what was the common reputation of such ancestor with reference to this right. ${ }^{5}$

8 420. Decrees.- "A decree in the Court of Chancery may be given in evidence on the same footing and under the same limitations as a verdict or judgment of a court of common law."6

1 Reed $v$. Jackson, 1 East, 355 .

${ }^{4}$ Dorset $v$. Mancliester, 3 Verm. 370 ;

${ }^{2}$ Regina $v$. Brightside Bierlou, 13 Gibson $v$. Nicholsou, 2 S. \& R. 422. Q. B. 933 .

5 Vaughan $v$. Phebe, 1 Mart \& Y. 1; 181.

${ }^{3}$ City of London v. Clerke, Carth. 17 Am. Dec. 770. 


\title{
CHAPTER XVI.
}

\section{THE ASSIGNIIENT OF JUDGJIENT.}

\author{
421. At Common Law. \\ \$ 422. May be by Parol. \\ $\$$ 423. Order for Proceeds. \\ $\$$ 424. Partial Assignment. \\ $\$$ 425. Future Judgments. \\ $\S 426$. Notice of Assignment. \\ $\$ 426$ a.Right of Assignee against Assignor. \\ $\$ 427$. Rights of Assignee against Defendant. \\ 8 428. Rights of Assignee against Third Persons. \\ $\S 429$. Prior Assignment. \\ $\S 430$. Assignment by Agent. \\ $\$$ 430a.Assignee, no longer necessary party. \\ $\S 431$. Fights Passing by the Assignment.
}

8 421. At Common Law.-At common law, the assignment of a judgment did not authorize the assignee to bring an action thereon in his own name. ${ }^{1}$ The effect of an assignment was merely to transfer an equitable title. To all actions, therefore, having for their object the subjecting of property to the payment of judgments, the assignors wero necessary parties as holders of the legal title. ${ }^{2}$ But tho assignee, by virtue of his equitable interest, had the right to control the collection of the judgment, and for that purpose to use the name of the plaintiff, his assignor, and to receive the money collected. ${ }^{3}$ The common law inhibition preventing the direct assignment and transfer of the legal as well as of the equitable title to judgments, is no doubt abolished in a majority of the States of this Union; and its place has been taken by statutes under which it is not merely the privilege, but also the cluty, of the assignee to control and enforce the judgment in his own name.* If a statutory mode of assimning judgments be provided this does not operate as an inhibition against all other modes of

I Edmonds v. Montgomery, 1 Iowa, 143; Reid $v$. Ross, 15 Ind. 265; Moore v. Ireland, 1 Ind. 531.

2 Elliot v. Waring, 5 Monr. 239; $17 \mathrm{Am}$. Dec. 69.
${ }^{3}$ Weir $v$. Pennington, 6 Eng. 745.

${ }^{4}$ Charles v. Haskins, 11 Ia. 329; Steele $v$. Thompson, 62 Ala. 323; 9 Tieporter, 74. 
assignment. It is cumulative, and does not prevent a party from making an equitable assignment in any other lawful way, and such assignment as to all persons having notice thereof is as effective as the sfatutory assignment. ${ }^{1}$

8. 422. Assignment by Parol. - With respect to its assignable qualities, a judgment is governed by the rules applicable to other choses in action. The assignment need not be made under seal. ${ }^{2}$ Nor is it indispensable that there should be any written evidence of the transfer. ${ }^{3}$ The rights of the prevailing party to his judgment, may be transferred by a conveyance of the land concerning which the judgment was rendered. Thus the grantee of a plaintiff who has recovered judgment for the possession of real estate, having become the real party in interest, may maintain proceedings to revive the judgment. ${ }^{4}$

\& 423. Order for Proceeds.-But an assignment, whether unwritten or written, parol or under seal, must indicate an intention to transfer the title to the property assigned. Therefore, an order on the clerk of a court to pay over to "A," the amount of a jurlgment held by the drawer, is not, even in equity, an assignment. The order cannot, by its terms, become operative until the judgment is extinguished by payment. Therefore, it cannot be presumed that an assignment was intended.5 An order on the judgment dobtor to pay a sum less than the judgment, is not an assignment. It is a mere evidence of indebtedness, on which the payee may sue the drawer, if payment be not made. ${ }^{6}$

\& 424. Partial Assignment.--Judgments, like other choses in action, cannot be assigned in part without the assent of the debtors, for the reason that entire demands cannot, against their objection, be split, for the purpose of annoying defendants. ${ }^{7}$

1 Burgess v. Cave, 52 Mo. 43.

2 Mitchell $v$. Hockett, 25 Cal. 539; Ford $v$. Stuart, 19 Johns. 342.

3 Briggs v. Dorr, 19 Johns. 95; Clark v. MIoss, 11 Ark. 736; Bartlett $v$. Yates, 7 Jones, 615; Steele $v$. Thompson, 62 Ala. 323; 9 Reporter, 74; but in Parker v. Bacon, 26 Miss. Burnett v. Crandall, 4 C. L. J. 230.

425 , it was held that an assignment "by delivery" merely, was insufi. eient.

${ }^{*}$ Wright $v$. Parks, 10 Iowa, 342 .

5 Teetor $v$. Abrlen, 2 Cart. 183.

${ }^{6}$ Thomas $v$. Porter, 3 Bush. 17\%.

7 Love v. Fairfield, 13 Mo. 300; 452 
8 425. Future Judgments.-It is no valid objection to an assignment that at the date of its execution no judgment existed. "The assignment carries the whole title to the subject-matter of the action, and of course to the judgment, when perfected. As between the parties to the assignment, clearly the whole right passes to the assignee, and the defendint, the moment the judgment is perfected, becomes the debtor of the assignee and not of the nominal plaintiff." "Mere personal torts, which die with the party, and do not survive to his personal representative, are not capable of passing by assignment."2 The character of a chose in action is not changed by a verdict. ${ }^{3}$ If, therefore, the plaintiff in an action for malicious prosecution, after obtaining a verdict in his favor, but before the entry of judgment thereon, assign the verdict and the canse of action, such assignment is a nullity. The judgment, when entered, will not beloug to the assignee; and may be satisfied by payment to the plaintiff or to a sheriff holding execution against him. ${ }^{4}$

8 426. Of Notice of Assignment.-We find the rule lail down in some decisions in general terms, that "secret assignments can not be allowed to entrap innocent parties." This rule, though manifestly of a very equitable charecter, is, we think, hardly sustained by the reported decisions. If it is strictly true in any case, it is in regard to the effect of an assignment, withont notice, upon the rights of the judgment debtor. It is undoubtedly true that if the assignee give no notice of the change of ownership in the judgment, and permit the assignor to control the execution, the judgment debtor will be protected in all payments which he maty make to the apparent judgment creditor. ${ }^{5}$ On the other hand, the assignee will be protected from all acts of the parties after notice of the transfer. ${ }^{6}$ But the debtor is only protected from the claims of the assignee, in cases where ho has paid directly to the assignor. Thus

\footnotetext{
${ }^{1}$ Robinson $v$. Weeks, 6 How. Pr. $\quad{ }^{4}$ Lawrence $v$. Martin, 22 Cal. 173. 161; Weire $v$. City of Davenport, $11 \quad{ }^{5}$ Gaullagher v. Caldwell, 22 Penn. Iowa, 49. S. 300; Page $v$. Benson, 22 Inl. 484; 2 Comerys v. Vasse, 1 Pet. 213; Dodd v. Brott, 1 Minn. 270; Styles Hodgman v. Western R. R., 7 How. v. MeNeil's heirs, 6 Mart. N. S. 2\%; Pr. 492.

17 Am. Dee. 183.

${ }^{3}$ Crouch v. Gridley, 6 Hill, 250; ${ }^{6}$ Hughes v. Trahern, 64 Ill. 48; Kellogg v. Sehnyler, '2 Denio, 73; Ex Ullman v. Kline, 57 Ill.'268. parte Charles, 14 East, 197.
} 
cases have arisen, both in New York and in California, under statutes authorizing the garnishment of debtors and the payment by them to the plaintiff in the garnishment, of sums due from them to the defendant therein. In each of these cases, it has been decided that a payment made by the debtor, after an assignment and without any notico thereof, would not protect him from the claim of the assignee. ${ }^{1}$ The opinion of Johnson, one of the justices of the Supreme Court of New York, in the case of Robinson v. Weeks (6 How. Pr. 161), contains the most complete statement with which we have met, of the grounds upon which these cases were determined. The part disposing of this branch of the case is as follows: The Code, \& 393, provides, that "after issuing of execution agaiust property, any person indebted to the judgment debtor may pay to the sheriff the amount of his debt, or so much thereof as shall bo necessary to satisfy the execution, and the sheriff's receipt shall be sufficient discharge to the amount so paid."

"The difficulty in the way of the clefendant is that at tho time of making these payments to the sheriff, he was not in firct indebted to the judgment debtor whose debts he volunteered to pay. The nominal plaintiff here had at that time no debt or demand against the defendant, which lie could enforce at law or in equity. It will hardly answer, I think, to say that as he received no notice of the assignment, he had a right to regard himself as the debtor of the plaintiff, and is therefore to be protected. The code, it is true, anthorizes a debtor of the judgment debtor to pay the amount of his debt upon any execution against the latter in the sheriff's hands; but it does not make it his duty to do so. It imposes no obligation on him whatever, and if a party indebted, instead of paying his debt to the person to whom he supposes himself indebted, and where he might learn the true state of the matter, chooses to go and pay another debt, which the law does not require him to pay, and to a person who has no opportunity of knowing whether or not he is really the debtor of the person whose debt he

${ }^{1}$ Brown v. Ayres, 33 Cal. 525; 161; Richardson v. Ainsworth, 20 Countryman $v$. Boyer, 3 How. Pr. How. Pr. 530. 386; Robinson $v$. Weeks, 6 How. Pr. 
undertakes thus to satisfy, I think he does it at his peril. He must see to it that he pays his creditor's debt, or the law will not protect him. Ho should be regarded as a volunteer, taking the risk of paying the riglut debt. Flad the defeudant paid the nominal plinintiff the amount of the judgment and talken his discharge, withont notice of tho assignment, he would, without doubt, have been protected. Snch payment and discharge would lave been good against the assignee omitting to give notice of his rights. But the assignee in that case would have had his remedy against such nominal plaintiff by an action for a breach of the implied conditions of the assignment. Here, however, the party assigning has done nothing in violation of the assignment."

8 426a. Rights of Assignee against Assiçnor.-One who makes an assignment of his judgment, iucurs an obligation to respect his own assigument, and therefore, to do no act inconsistent with his changed relation to the judgment. "A party who, after having for a valuable consideration assigned a jadgment, satisfies it, clearly incurs a liability to his assignee. If the satisfaction price is given on payment of the judgment, the money may be recovered by the assignee in an action for money had and received, and if the satisfaction is given without payment, and the assignee is prejudiced thereby, he is entitled to recover against his assignor the damages sustained. In the absence of proof to the contrary, the presumption arising from a satisfaction price is that it was given on payment of the judgment." The assignor is not liable to pay the amount of the judgment in case the judgment debtor proves insolvent; ${ }^{3}$ lnt his assignment ordinarily implies a guaranty that he is the owner of the judgment, and that it remains wholly unpaid. ${ }^{4}$

8 427. Rights of Assignee against the Parties.-The assignee of a judgment receives tho same subject to all existing equities between the parties thereto; and it is immaterial

1 For differcnt view, see Drumm v. Sherman, 20 La. An. 96. 'Booth $v$. Farmers and Mechanics' 485.

Bank, 50 N. Y. 399.
3 Robinson $v$. White, 4 Litt. 237.

${ }^{4}$ Furniss v. Ferguson, 45 N. Y. 
whether he had notice of these equities or not. ${ }^{1}$ The assignee, by virtue of the assigument, occupies a no better position than the judgment creditor wonld have occupied, in the absence of any assigument. ${ }^{2}$ If the assignee purchase property under sale upon his own execution, he, like the plaintiff purchasing in such cases, is liable to lose his title by a reversal of his judgment. ${ }^{3}$ The power of the court to set off one judgment agaiust another is not terminated by an assignment. "A purchaser and assignee of a judgment, eren for a valuable consideration and withont notice, takes subject to a right of set-off existing at the time of the assignment, for an assigneo takes subject to all equitible as well as legal defenses which can be urged against the assignor."4 Where an insolvent judgment defendaut recorered a smaller judgment against the plaintiff, it was held that the latter had, eo instanti, an equitable right to set of his judgment agrinst it, of which right he could not bo defeated by an assigument. ${ }^{5}$ However, there are other cases directly antagonistic to those just cited, and which limit the anthority to set off one judgment against another, after assignment made, to cases where it can be shown that the assignor was insolvent at the time of the assignment of his judgment. ${ }^{6}$ But the assignee is not prejudiced by agreements inconsistent with the face of the judgment. Thus, if a party taking a bond and warrant of attorney, agreeing by a separate instrument not to enter up judgment, nor to have it entered $u_{i}$ by any other person, assign for a valuable consideration, and without notice of the agreement, to a third party who enters up judgment, this judgment will be held to be good and valid and unaffected by this secret agreement. ${ }^{7}$

${ }^{1}$ Blakesly $v$. Johnson, 13 Wis. 530; Bates, 12 Am. Dec. 121, but Ullman Seott $v$. Harkins, 32 Geo. 302; Me- $v$. Kline, 87 Ill. 268, is an authority Jilton $v$. Love, 13 Ill. 4S6; Jordan r. for the proposition that an assiguee Black, 2 Murf. N. C. 30; Robeson $v$. without notice is protected from a setRoberts, 20 Ind. 155; Rawson $v$. AIcJunkins, 27 Geo. 482; Rica v. Forrest, 83 Iil. 275 .

2 Northam $v$. Gordon, 23 Cal. 255.

${ }^{3}$ Reynolds $v$. Harris, 14 Cal. 667.

${ }^{*}$ Porter v. Liscom, 22 Cal. 430; Ifobbs v. Duff, 23 Cal. 596; Graves $v$. Woodbury, 4 Hiil, 559; Bent v. Picree, 69 Me. 381; Lockwood v. off not reducel to julgment and having no connection in its origin or nature with the judgurent assigned.

${ }^{5}$ Merrill $v$. Souther, 6 Dana, Ky. 305.

${ }^{6}$ Henderson $v$. MeVay, 32 Ala. 471; Davis $v$. Milburn, 3 Iowa, 168.

${ }^{7}$ Davis $v$. Barr, 9 S. \& R. 137. 


\section{428. Rights of Assignees against Third Persons.-} The purchaser of a judgment stands in the same position as the assiguee of a note past due. The holder of such a bill "takes it as a dishonored bill, and is affected by all the equities between the original parties, whother he has any notice thereof or not. But when we speak of equities between the parties, it is not to be understood by this expression, that all sorts of equities existing between the parties, from other independent transactions between them, are intended, but only such equities as attach to the particular bill, and, as between these parties, would be arailable to control, qualify or extinguish any rights arising thereou." "The judgment is property which may be purchased like any other property. The purehaser is bound to inquiro into the defenses of the debtor. $\mathrm{H}_{\theta}$ has the means to do this, but he could not be held to inquire into the latent equities existing in the hands of third persons. The law, when it made this sort of property subject to sale, gave it the protection which it extends to all other property. $B e$ tween the parties, the assignee of equities stands in the place of his assignor, with no better rights; but as to the clains of third persons, the purchaser of an equity stands unaffected by frauds of which he has no knowledge, express or coustructive." A judgment was entered and a mortgage recorded on the same day. The judgment creditor asreed with the mortgagee, that the lien of the latter should have precedence over the judgment lien. 'The judgment was subsequently assigned, for value and without notice of this agreement. On this state of facts, it was decided that the assignee conld not be bound by this, nor any other secret agreement in favor of one not a party to the judgment." The courts of Vermont, differing from nearly, if not quite, all other courts, enforce against the assignees of judgments all the equities which conld be enforeed against the assignors, whether in fivor of the parties to the judgment, or of third persons. Thus in the case of Downer v. South Royalton

1 Story on Bills, sec. ㄹo.

2 Wright \& Co. v. Levy, 12 Cal. 257; S. 363; Starr v. Hoskins, 26 N. J. Eq. Greene v. Daily, 5 Míason, 214; Mur- 414; Hale v. First N. B. 50 Ia. 612. ray $v$. Lilburn, 2 John. Ch. $4 \div 2$. 
Bank (39 Ver. 25) $)^{1}$ the coctrine is asserted and applied, that the vendors of closes in action can, in no case, convey a higher right than they possess; that, therefore, the vendee, without notice, of a judgment held for another, or subject to the equitable rights of another, holds such judgment subordinate to all the equities to which it was subject in the hands of the original plaintiff. If, after notice of the assjgnment, the defeudant pay the judgment to the plaintiff, who thereupon enters satisfaction on the record, the entry may be set aside on application of the assignee. ${ }^{2}$ But in the vacation of such entry, respect should be paid to the rights of third persons acquired while the judgment was discharged of record. If the assignee, after procuring a vacation of the entry of satisfaction, take out execution and attempt to enforce it, he will be enjoined from taking proceedings tending to impair the interests of third persons who, acting in good faith, without notice, and after an examination of the records, acquired rights while it appeared on the record that the judgment was discharged. ${ }^{3}$

8 429. Frior Assignment. - "Between two bona fide purchasers of a chose in action not negotiable, the purchaser. first in time is prior in right." In the purchase of a judgment the rule of caveat emptor applies. If the vendor has no title the vendee can obtain none, though the vendor, once having title, has transferred it without the knowledge of his rendee. ${ }^{4}$ This rule is equally applicable whether the second transfer is voluntarily made by the plaintiff, or results from a levy and sale under execution. ${ }^{5}$

8 430. Transfer by Agent.-Au attorney-at-law has not, by virtue of his general authority as such, the power to assigu his client's judgment. ${ }^{6}$

\& $430 \mathrm{a}$. The Assignor having by his Assignment parted with his interest in the judgment, is no longer a necessary

\footnotetext{
1 See also De La Vergne $v$. Evertson, 19 Am. Des. 411; 1 Pai. Ch. 181.

2 Wardell v. Eden, 2 Johns. Cas. 258.

"Beebe $v$. Bank of N. Y., 1 Johns. 528.

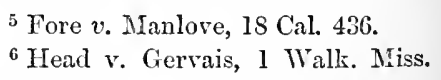




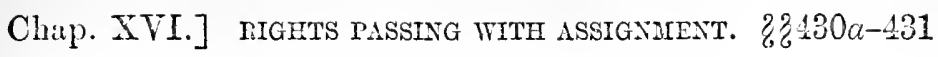

or proper party to proceedings for the purpose of setting it aside, or for the purpose of enjoining or obtaining other relief from it. ${ }^{1}$

\& 431. Rights Passing vrith Assignment. -The assignment of a judgment which was roid because in excess of the jurisdiction of the court, has been held to transfer the debt for which the judgment was entered. ${ }^{2}$ And it seems that the assigument of a judgment necessarily carries with it the caluse of action on which it was based, ${ }^{3}$ together with all the beneficial interest of the assignor in the judgment, and all its incidents. The assignee is, therefore, entitled to the benefit of an appeal boud, which, at the time of the assignment, stood as security for the payment of the judgment in the erent of its affirmance on an appeal then pending." The assignment of a judgment, procured by fraud committed on the assignor, dnes not transfer the right of such assignor to have the judgment set aside, or to proceed to recover damages for fraud or deceit. The assignment of the judgment is an aflirmance of the judgment by the assignor. ${ }^{5}$

1 Riteh $v$. Eichelberger, 13 Fla. 169.

2 Brown v. Scott, 25 Cal. IS9.

${ }^{3}$ Bolen $v$. Crosby, 49 N. Y. 183; Vila $v$. Weston, 33 Conn. 50.
* Ullman v. Kline, 87 Ill. 268.

5 Borst v. Baldwin, 30 Barb. 150. 


\section{CHAPTER XVIT.}

\section{OF ACTIONS UPON JUDGMENTS.}

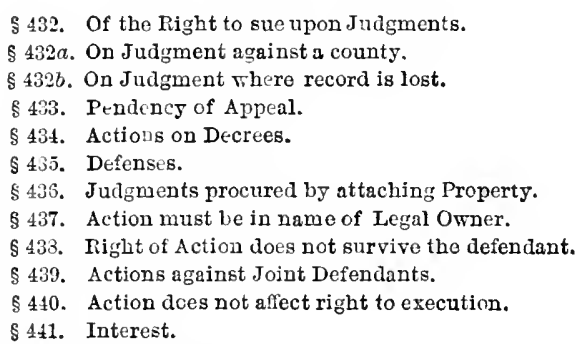

\&432. Of the Right of Action.-In Connecticut, at a very early date, an action on a judgment was not sustained, because it was deemed unnecessary and vexatious, unless plaintiff succeeded in showing that, otherwise, he could not have the full effect of his judgment. ${ }^{.}$This position has since been abandoned in the same State; and in its place the true rule has been adopted, that "no other reason" for bringing the suit "need be stated in the declaration, than that the judgment remains unpaid." Other courts have exhibited a great aversion to actions upon judgments when no special reason is shown why redress can not be obtained without such actions. ${ }^{3}$ Thus, in South Carolina, no action can be maintained upon the judgment of a magistrate's court, until after the expiration of the time in which execution may issue to enforce such judgment. In Oregon, after a

${ }^{1}$ Welles $v$. Dexter, 1 Root, 253, de- nelly $v$. Stewart, 25 Upper Canada, Q. cided in 1791. In Lower Canada it B. 39s, affirming MePherson $v$. Forhas been held that if an action can be rester, $11 \mathrm{Il}$. 362 .

bronght, under any cireumstances, on a judgment in the same conrt wherein it was rendered, it must only be when the defendant is abont to leave the Province to defrand his creditors. Pelliteer $v$. Freer, 11 L. C. 199. In Upper Canada no action lies upon the judgrnent of the Division Court. Don-

${ }^{2}$ Denison $v$. Williams, 4 Conn. 402; Ives $v$. Finch, 28 Conn. 112 .

${ }^{3}$ Biddleson v. Whitel, W. Bl. 507.

${ }^{4}$ Lee $v$. Giles, 1 Bai. L. 449; $21 \mathrm{Am}$.

Dee. 476 ; Vandiver $v$. Hammet, 4 Rich, 509; Ligon $v$. McNiel, 6 Rich, 377; Shooter v. MIcDuffie, 5 Iiich, 61 . 
full consideration of the authorities, it was at a comparatively recent late, determined " that the plaintiff can not claim a strict right to sue his judgment as often as he may choose withont showing any necessity for such a conrse;" "that neither the common law nor the practice in the various States of the Republic, nor anything inherent in the subject, based on sound reason, gives to a judgment creditor an absolute right of action on a domestic judgment unless such action is necessary in order to enable the plaintiff to have the full benefit of his judgment." We understand the courts of Kentucky to deny the existence of a right of action on a judgment, for the satisfaction of which plaintiff or his assignee can proceed by the ordinary method of execution, levy and sale. ${ }^{2}$ In some other States action can not be prosecuted on a domestic judgment until leave of the court is obtained. ${ }^{3}$ The objection urged in each case is that to allow a second action while plaintiff has, for the enforcement of the first judgment, every remedy which ho conld possibly employ to compel the satisfaction of a second judgment, is to permit the defendant to be vexed, harassed and put to costs without conferring any corresponding benefit on the plaintiff. The objection is true in fact, and is doubtless entitled to much weight. It lias, nevertheless, been generally overruled. In Kansas, the Supreme Court, in determining that an action could bo sustained in that State on a domestic judgment, said: "The proceeding seems harassing and vexations, and to serve no purpose that conld not be reached by a more simple and less costly method. But these are reasons why the law should be changed, and not that it should be disregarded. When the legishaturo makes the change this court will cheerfully enforce the law. The question has been settled under codes similar to omi own." At common law a party has a right of action upon his judgment as soon as it is recovered. This right is neither barred nor suspended by the issuing of an execution; nor

\footnotetext{
1 Pitzer v. Russel, 4 Oreg. 124.

${ }^{2}$ Smith $v$. Belmont etc. Iron Co., 11 Bush, 390.

${ }^{3}$ Watts $v$. Everett, 47 Iowa, 269.

${ }^{4}$ Burnes $v$. Simpson, 9 Kans. 663, citing Simpson v. Cochran, 23 Iowa, 81; Ames v. Hoy, 12 Cal. 11.

${ }^{5}$ Hale v. Angel, 20 Johns. 342; Smith $v$. Mumford, 9 Cow. 26; Linton $v$. Hurley, 114 Mass. 76; Wilson $v$. Hatfield, 121 Mass. 551; O'Neal $v$. Kittredge, 3 Allen, 470. 
because, from having the right to take out execution, the plaintiff's action seems to be nnnecessary. ${ }^{1}$ A judgment may be enforced by action, though the right to take out execution has terminated by lapse of time. Thus, in Califormia, where the right to execution contiuues only five years, aud the judgment is liable to be defeated as a cause of action at the end of the same period by a plea of the Statute of Limitations, it has been held that though an execution may no longer be issued, the plaintiff may still maintain an action on his judgment if the defendant neglects to plead the Statute of Limitations against it. ${ }^{2}$ The plaintiff may, at the same time, prosecute an action of debt to recover upon, and a scire facias to revive his judgment. A judgment in his favor in the latter proceeding does not affect the former. The judgment upon the scire facias, and that upon the action on the judgment, become co-existent securities for the same debt. The payment of either satisfies the other. ${ }^{3}$ But no action can be sustained upon a judgment satisfied on its face, or which, from the record, appears to be satisfied by a lery under execution. The record must be held conclusive until avoicled by some proceeding bronght for that purpose. ${ }^{4}$ Where a putative father was ordered to pay a specified sum weekly to support a child, it was held that au action of debt would lie to compel the payment of these weekly installments, and that, in such action, the plaintiff need not show that the child still lives, nor that the weekly allowance is due. These are defenses which, if they exist, the defendant should set up. ${ }^{5}$ A judgment, not final, can not be enforced by action. It must be something more than a more interlocutory judgment or order. ${ }^{6}$

${ }^{1}$ Albin $v$. People, 46 Ill. 372; Stewart v. Peterson, 63 Penn. S. 230; Kingsland \& Co. v. Forrest, 18 Ala. 519; Gardner v. Henry, 5 Cold. 458. In Michigan it was held that an action of debt conld be sustained on the judgment of a Justice of the Peace immediately after its rendition, though by statute the execution had been stayed. McDonald $v$. Butler, 3 Mrich. 55s.
${ }^{2}$ Stuart v. Lander, 16 Cal. 372.

${ }^{3}$ Carter $v$. Colman, 12 Ired. 274.

${ }^{4}$ Pratt $v$. Jones, 22 Verm. 341.

${ }^{5}$ Stokes v. Sanborn, 45 N. H. 274.

${ }^{6}$ Ledyard $v$. Brown, 39 Tex. 402; Fry $v$. Malcolm, 4 Taunt. 705; Biddle $v$. Dowse, 9 D. \& R. 404; 6 B. \& C. 255; Sheehy v. P. L. A. Co., 2 C. B. N. S. $211 ; 3$ Jur. N. S. 748; 26 L. J. C. P. 301 . 
8. 432a. Action on Iudgment against a County.-The object of a judgment against a county is to obtain an audited demand which shall no longer be open to contest. If a statute provides that no person shall, in any case, sue a county unless he has first presented lis demand to the Board of Supervisors for allowance, a judgment creditor of the county must present his judgment to such Board and have it allowed as an audited demand within the time provided by law. On being so allowed it will stand in the same position and be subject to payment in the same manner as other audited demands. No action can be sustained on such judgment; but if the Board of Supervisors refuse to allow the judgment when properly presented to them, they may be compelled to do so by a writ of mandate. ${ }^{1}$

\& 432b. Lost Record.-According to some of the anthorities no action can be sustained upon a lost record. The record must first be restored by a direct proceeding for that purpose, "for the reason that if its existence is put in issue, the court passes npon it by an inspection of the record." ${ }^{\prime 2}$ But the reason here assigned for the rule is not sound. It is true that when the existence of a record is put in issue, the courts ordinarily determine such issue by inspecting the alleged matter of record. But we think the authorities heretofore cited clearly establish the rule, that a record may be proved by parol when the original is shown to have been lost or destroyed; ${ }^{3}$ and wo therefore believo that an action ought to be and can be sustained on a lost or destroyed record.

8433. Pending Appeal.-The pendency of an appeal does not suspend the plaintifes right of action upon his judgment, unless the defendant gives a sufficient bond to stay proceedings. ${ }^{4}$ In Massachusetts, after appeal, the judgment " no longer, in legal construction, remains in force, and can not be the foundation of a now action." The

${ }^{1}$ Alden $v$. County of Alameda, 43 dam $v$. Hoyt, 1 Dutch. 230; Faber v. Cal. 270. Hogey, 117 Mass. 107; 19 Am. Rep.

${ }^{2}$ Foulk $v$. Colburn, 48 Mo. 230; 398; Woodward $v$. Carson, 86 Pa. S. Walton v. Mcliesson, 64 N. C. 77 .

${ }^{3}$ See Sec. 407.

${ }^{4}$ Taylor $v$. Shew, 39 Cal. 536; Suy- Paine v. Cowdin, 17 Pick. 142. 
pendency of an appeal can not be proved by parol evidence. ${ }^{1}$ If the defendant bring a writ of error, and the plaintiff bring an action on his judgment and recover, he can not, it is said, sue ont execution on his second judgment until the writ of error is determined. ${ }^{2}$

3.434. Upon Decrees.-In the earlier stages of the common law, its courts and judges were not willing to notice the lecrees of the courts of chancery, nor to render any assistance in carrying them into effect. They could not, therefore, be enforced by action. ${ }^{3}$ In England, the right of action upon domestic decrees, founded on equitable considerations, is still denied on the ground that they can be enforced by appropriate process." But as to foreign and to colonial decrees no such objection exists; and they may, whenever they direct the payment of any sum specified with certainty, be regarded as good considerations for an action of assumpsit. ${ }^{5}$ In the United States, "We lay it down as a general rule that in every instance in which an action of debt can be maintained upon a judgment at law for a sum of money awarded by such judgment, the like action can be maintained upon a decree in equity, which is for an ascertained and specific amount, and nothing more; and that the record of the proceedings in the one case must be ranked with and responded to as of the same dignity and binding obligation with the record of the other." The same rules are applicable to actions on the decrees of surrogates. ${ }^{7}$

\$ 435. Defenses. - It follows, as a matter of course, from the conclusive effect given to every final adjudication, that, to an action upon a judgment or decree, no defense should be entertained which might have been interposed to

${ }^{1}$ Blodgett v. Jordan, 6 Verm. 5s0. N. S. 2s8; 9 Jur. 755; 13 L. J. Q. B.

2 Benwell $v$. Black, 3 T. R. 643.

3 Williams $v$. Preston, 3 J. J. M. 600; 20 Am. Dec. 179; Hügh v. Higgs, S Wheat. 697 . 274.

${ }^{4}$ Carpenter $v$. Thornton, 3 B. \& Ald. 52; Henly $v$. Soper, 8 B. \& C. 16; 2 MI. \& R. 153.

${ }^{6}$ Pennington $v$. Gibson, 16 How. U. S. 65; Post v. Neafie, 3 Cai. 22; Tilford \& Co. v. Oakley, Hemp. 197; Nations $v$. Johnson, 24 How. U. S. 203; Evans v. Tatem, 9 S. \& R. 252; $11 \mathrm{Am}$. Dec. 717; Warren v. McCar.

${ }^{5}$ Sadler $v$. Robins, 1 Camp. 253; thy, 25 Ill. 95.

Henderson $v$. Henderson, 6 Ad. \& El. ${ }^{7}$ Dubois v. Dubois, 6 Cow. 494. 464 
defeat the original action.' Thus, no proof can properly be received for the purpose of showing that, prior to the entry of the judgment, part of the claim was paid. For in a suit upon a promissory note, given in satisfaction of a judgment, will any evidence be admitted to impeach the consideration for the note by proving that, prior to the judgment, part of the cause of action was paid. ${ }^{2}$ An action upon a recognizance against bail, was defended ou the ground that the plaintiff in the original suit was persuaded to consent to the judgment against him while in a state of intoxication, procured by the plaintiff. This defense was held to be concluded by the former adjudication, on the ground that every matter which might have been urged was finally disposed of by the judgment. But the further defense, that the judgment was entered by collusion between the parties to the former action, for the purpose of deframling the bail, being made, was held to be a good answer in favor of the bail, both at law and in equity. ${ }^{3}$ So far as this decision denied the efficacy of the defense that the judgment was obtained by intoxication of the defendant, bronght about by the plaintiff, its correctness may well be doubted. While the defendant was bound, under ordinary circumstances, to present all his defenses, he ought to have been exonerated from the consequences of any neglect procured and induced by any device of his opponent designed and executed to secure an unconscionable advantage. Where, as under the Code, law and equity are administered by the same tribunals, and the disposition of the entire controversy between parties, in one action, is intended to bo encouraged, such frand as would entitle a party to relief from a judgment upon application to chancery, constitules a good defense to an action on such judgment." Whenever,

${ }^{1}$ Hayward $v$. Ribbans, 4 East, 311; Carneal $v$. Wilson, 3 Litt. 80; WhetBiddle $v$. Willins, 1 Pet. 692; Ellis stone $v$. Whetstone, 31 Iowa, 56 ; v. Clarke, 19 Ark. 420; Crawford $v$. Clark v. Little, 41 Ia. 499; Handerille Exr's of Simonton, 7 Porter, 110; $v$. Reynolds, 6s N. Y. 528. But Allgood $v$. Whitley, 49 Ala. 215; where an equitable defense is sought Bolling v. Anderson, Tenn. Ch. 127. to be interposed, it must be fully dis-

${ }^{2}$ Bird $v$. Sinith, 34 Maine, 63.

${ }^{3}$ Parkhurst $v$. Sumner, 23 Verm. $53 \mathrm{~s}$.

elosed. It is not sufficient to state that the judgment was obtained by the fraud and eovin of the plaintiff.

${ }^{4}$ Dobson v. Pearce, 12 N. Y. 156; Hopkins $v$. Woodward, 75 Ill. 62. 
by proceedings in scire facias, or by action, a judgment is songht to be used to the detriment of a third person, he may avoid its effect by showing that the plaintiff and defendant in the former action colluded together and thereby procured the judgment for the purpose of defranding him. ${ }^{1}$ The defeudant is as conclusively bound by the decision of any question of law as he is by the finding upon any issue of fact. If the judgment bo erroneous, lis only remedy is by appeal. ${ }^{2}$ One who is proceeded against for his disobedience of an injunction, or of auy order of a court, is never permitted to justify his conduct by showing error of the court in making its order or judgment. Ho must either show that he did not disobey the order, or that the court had no jurisdiction to make it. ${ }^{3}$ Because it necessarily involves an attack upon the correctness of a former adjudication, and would tend to encourage infinite litigation, the defendant in an action upon a judgment is nevor permitted to show that it was procured by perjury. ${ }^{4}$

A judgment such as the court was competent to pronounce, "cannot, in an action therein in our courts, be imperiled by a citizen or foreigner, by averment and proof that the court had not jurisdiction of the person of the defendant." If a judgment be either so irregular that it should be set aside on motion or reversed on appeal, it is nevertheless valid until so vacated or reversed, and an action may therefore be sustained thereon. ${ }^{6}$

\section{436. Judgments Procured by Attachment.-Judg-} ments obtained by means of attaching property, do not generally create a personal liability, but are limited in their operation to the property attached. They are, therefore, at least outside of the States where pronounced, commonly considered as not constituting any cause of action against the defendant.

\footnotetext{
${ }^{1}$ Philipson v. Earl of Erremont, 6 Ad. \& EI. N. S. 587; Fowler v. Rickerby, 2 MI. \& G. 760.

${ }^{2}$ Hawes $v$. Hathaway, 14 Mass. 233; Dick $v$. Tolhaisen, 4 H. \& N. 695.

"People v. Sturtevant, 9 N. Y. 263.

${ }^{4}$ Demeritt $v$. Lyford, 7 Foster, 541.

${ }^{5}$ Miller $v$. Dungan, 35 N. J. Law, 391.

6 Townsend $v$. Cox, 45 Mo. 401.

${ }^{7}$ Easterly $v$. Goodwin, 35 Conn. 273; Kane v. Cook, 8 Cal. 449; Nelson Durand's Succession, 24 La. An. 352; Banta v. Wood, 32 Iowa, 473; Lastman $v$. Wadleigh, $65 \mathrm{Me}$ 251; $20 \mathrm{Am}$. Rep. 695.
} 


\section{437. Action must be in Name of Legal Owner.-}

Every action upon a judgment must be brought in the name of its legal owner. If the judgment be entered in favor of A. for the use of B., the latter can not maintain a suit thereon in his own name. He must use the name of $A$. in whom the legal title is rested. ${ }^{1}$

\section{? 438. At Common Law, a Judgment does not survive} the defendant against whom it is rendered. By no mode known to that law, can a judgment be enforced against the administrator of a deceased debtor. As to him its character as a judgment is functus officio. ${ }^{2}$

8 439. Actions against Joint Defendants. - Tho plaintiff in an action on a judgment must recover against all of the defendants or none. Whatever constitutes a good defense for one of the defendants operates for the benefit of the others, because the obligation is joint. ${ }^{3}$ 'That a judgment is enjoined, is a complete defense to any action upon it. ${ }^{4}$ Tho commitment of defendant to prison under execution does not discharge an action pending on the judgment. ${ }^{5}$

8. 440. The plaintiff is entitled to execution on his judgment, notwithstanding the pendency of an action upon it. ${ }^{6}$

24 441. Interest.-At common law, judgments did not draw interest. In an action on a judgment of a sister State, the common law will, in the absence of any showing to the contrary, be presumed to prevail in that State, and no interest will be allowed. ${ }^{7}$ By some State statutes judgments carry interest whether the original indebtedness did or not. ${ }^{8}$ A change in the statute fixing the rate of interest which judgments shall bear does not operate retrospectively, and can not affect pre-existing judgments. ${ }^{9}$

1 Triplett $v$. Scott, 12 Ill. 137.

${ }^{2}$ U. S. $v$. Cushman, 2 Sumner, 310.

3 Pratt v. Dow, 56 Maine, 81.

${ }^{4}$ Blair v. Caldwell, 3 MIo. 353.

5 MLor $v$. Towle, 39 Maine, 133.

${ }^{6}$ Cushing $v$. Arnold, 9 Met. 23;

Moor v. Towle, 3S Maine, 133. 


\section{CHAPTER XVIII.}

\section{PROCEEDINGS BY SCIRE FACIAS.}

$\S$ 442. Definition and Object.

$\S$ 443. Judgment on.

$\S 444$. Not a New Suit.

$\$$ 445. Defenses inconsistent with the Judgment.

$\$ 446$. Pleadings in.

$\$$ 447. Variance.

$\$$ 418. Parties Bound by.

$\$ 449$. Who are Terre-Tenants.

8 442. Definition and Object.-" A scire facias is a writ founded on some matter of record, as a recognizance or judgment, etc., on which it lies to obtain execution, or for other purposes, as to repeal letters patent, hear errors, etc. In general it is a judicial writ issuing out of a court where the record is, yet, because the defendant may plead thereto, it is considered in law an action; therefore a release of all actions is a good bar to scire facias." "A scire facias is a judicial writ issued for the purpose of substantiating and carrying into effect an antecedent judgment." "Before a judgment is either satisfied by payment or barred by lapse of time, it may become temporarily inoperative so far as the right to issue execution is concerved, and so continue until something is done by which such right is revived. In this condition it is usually called a dormant judgment. This dormancy in judgments was, at common law, usually created either by a change in the parties plaintiff or defendant, or by the lapse of time without issuing of execution. "Where any new person (that is, one not originally party to the judgment), is to be charged or benefited by the execution, or where more than a year and a day have elapsed since the signing of judgment, and that delay has not been caused by the party chargeable, and measures become necessary before execution can be proceeded in. ${ }^{33}$ There

1 Tidd's Pr. 1030.

${ }^{2}$ Jarvis $v$. Rathburn, Kirby's R. Foster on scire fucias, 6. 220; Denegre $v$. Haun, 13 Iowa, 240. 
wero also cases in which execution was to be issued in certitin contingencies only, and in which it became necessary, to establish the existence of the contingency before the writ could be regularly sued out. So, the judgment might have been satisfied, through fraud or mistake; or by an extent upon property not belonging to the defendant, and it might therefore be necessary to set aside the apparent satisfaction, and to obtain leave to issue further execution. When from any cause it becamo necessary to apply to a cont for a revivor of the right to issue execution, the remedy of the plaintiff was by scire facias. A scire facias, as the term is nsed in this chapter, is a writ issued out of the court wherein a judgment has been entered, ${ }^{1}$ or to which the record has been removed, reciting such judgment, suggesting the grounds requisite to entitle plaintiff to execution, and requiring the defendant to make known the reason, if any there be, why such execution should not issue. ${ }^{1}$

\& 443. Judgment on. -The judgment which may be rendered for the plaintiff on scire facias, is not a new judgment for the amount of the original debt, damages and costs. The entry should be "that plaintiff have execution for the judgment mentioned in the said scire facias and his costs."2 The practice in Pennsylvania is different. There scirc facias is not a mere judgment that execution issue, but a new judgment for a greater sum than the old one. The new judgment is a lien on lands not bound by, the old one. It seems also to merge the original judgment, so that if a second scire facias is desired, it can only be obtained on the first scive facias, and not on the original judgment. ${ }^{3}$

Z 444. Is not a New Suit.-A scire facias to revive a judgment is not a new suit, but the continuation of an old one. ${ }^{4}$

${ }^{1}$ Walker $v$. Wells, 17 Geo. 547;|39; Woolston $v$. Gale, 4 Halst. N. J. Grimke $v$. Mayrant, 2 Brev. 202; Os- 32; Camp v. Gainer, 8 Tex. 372; Murgood $v$. Thurston, 23 Pick. 110; Tin- ray v. Baker, 5 B. Monr. 172; Hanly dall $v$. Carson, 1 Har. N. J. 94; Bar- v. Adams, 15 Ark. 232; Walton $v$. ron v. Pagles, 6 Ald. 422; Carlton $v$. Vanderhoof, Pennington, 73.

Young, 1 Aik. 332; Wilson v. Tierman, 3 Mo. 757; Vallance $v$. Sawyer, 4 Greenl. 62; 2 Sellon's Pr. 198; Foster on scire facias, 19; Bingham on Judgt. and Ex. 123; Challenor $v$. Niles, 78 Ill. 78.

${ }^{2}$ Vredenburgh $v$. Snyder, 6 Iowa,

${ }^{3}$ Custer v. Detterer, 3 W. \& S. 28.

${ }^{4}$ Denegre $v$. Haun, 13 Iowa, 240; Fitzhugh $v$. Blake, 2 Cranch C. C. 37; Hopkins $v$. Howard, 12 Tex. 7; Challenor $v$. Niles, 78 Ill. 78; Freeman on Ex. sec. 81 . 
It is in form, but not in fact, a separate action. Therefore satisfaction of the original judgment is a satisfaction of the scire facias. The reversal of the original judgment has the same effect on the scire facias. " Being a judicial writ, a scire facius must pursue the nature of the judgment. If the judgment be joint, the scire facias must also be joint. ${ }^{2}$ It must also be issued from the court having the record on which it is founded. Hence bail cannot be proceeled against on scire facias in the court where the suit was commenced, if the judgment was pronounced in the Superior Court. ${ }^{3}$

\% 445. Defenses Inconsistent with Iudgment.-The principles of estoppel attached to final adjuclications, are as operative and as conclusive in proceedings on scire facias as in any other cases. No defense can be made which existed anterior to the judgment. " The defendant cannot show, on scire facias to revive a judgment, that the note for which it was rendered was paid before the rendition of the judgment, ${ }^{5}$ or had ceased to be the property of the plaintiff: ${ }^{6}$ The rule that nothing admissible as a defense in the original action, is admissible against proceedings on scive fucius, is confined to the parties and their privies, and does not operate to the prejudice of strangers. ${ }^{7}$ In Massachusetts, a judgment charging an alleged trustee on his default in the original action, has never been regarded as conclusive against him. He might always, on scire facias, introduce proof to show that he was not in fact chargeable. ${ }^{8}$

\& 446. Pleading.-The approved precedents show that, in scire facias, it is not essential to aver that no execution has been issued within the year and a day. The common averment is, "That, although judgment aforesaid, in form aforesaid, is given, execution nevertheless for the debt and damages aforesaid remaius to be made to him," the plaintiff. The averment that said judgment remains unsatisfied and unpaid, is good in substance. ${ }^{9}$

${ }^{1}$ Eldred v. Hazlett's Admr., 33 Penn. S. 16.

${ }^{2}$ Carson $v$. Moore, 23 Tex. 450; Austin $v$. Reynolds, 13 Tex. 544.

${ }^{3}$ Osgood $v$. Thurston, 23 Pick. 110.

${ }^{4}$ Bowen v. Bonner, 45 Miss. 10. 470
${ }^{5}$ Camp $v$. Baker, 40 Geo. 148.

${ }^{6}$ Koon $v$. Ivey, 8 Rich. Law, 37.

${ }^{7}$ Griswold $v$. Stewart, 4 Cow. 459.

${ }^{8}$ Brown $v$. Neale, 3 Allen, 74.

${ }^{9}$ Albin $v$. State, 46 Ill. 372. 
\& 447. Variance.-If the recitals in the scire fucias point to the judgment sought to be revived, with such certainty that the defendants are informed what judgment is intended, it is sufficient. If there be an exact coincilence of names of parties, of the conrt, of the debt and amount of the judgment, and of its having been entered on an award, there can be no doubt of the identity of the judgment recited, and that offered in evidence, though the judgment in respect to the costs, was not recited in the scire fucius. ${ }^{1}$

\& 448. Parties Bound by.-In Pennsylvania, the writ of scire facias, if sued out for the pmpose of continuing the lien of a judgment, must be served on the terre-tenants, or occupants, of the land, if there are any. If any of the terretencuts, or occupants, are not made parties, the proceeding, as to them, has no effect on the lien. ${ }^{2}$ Proceediugs in the same State on scire facias have been held to be inoperative against a party who was neither a terre-tenant nor a cliirnant uncler a title which was ever subject to the lien. Thus, a purchaser of land prior to any judgment against the owner, being subsequently summoned as terre-tenant, made default, and judgment thereon was entered against him. This was held not to estop him from setting up his title against that of the purchaser at a sale under the judgment on the scire facias, and showing that instead of being a terre-tenant, he held by title paramount to the judgment. The reasoning on which this decision was founded, was that the statute only anthorized the summoning of the terre-tenant, and that the summoning of another person, being unauthorized, was void. ${ }^{3}$

\& 449. Terre-Tenants.-In Maryland, upon the decense of a sole judgment defendant, execntion may be had by suing out scire facias against the heirs and terre-tenamls, withont making the personal representative a party. "Who are terre-tenants, within the meaning of the law, whom it is

1 Ward v. Prather's Adm., I J. J. |Helfrich's Appeal, 3 Harris, 5s2, and M. 4. overruling Himes $v$. Jacoks, I Penn.

${ }^{2}$ Brown $v$. Simpson, 2 Watts, 233.

3 Drum v. Kelly, 34 Penn. S. 415; affirming Kiehner $v$. Watts, 1 Harris, 3S; Mitchell $v$. Familton, 8 Barr. 4 S6;

Rep. 152; Kiehner $v$. Dengler, 1

Watts, 424; Minier $v$. Saltmarsh, 5 Watts, 293.

${ }^{4}$ Tessier $v$. Wyse, 3 Bland, 40. 
necessary to make parties to scire facias? All who are in possession, deriving title under the judgment debtor, such as heirs, devisees, alienees after the judgment. They are in, as of the estate of the judgment debtor, and before judgment can be revived and enforced by execution against the land, so as to divest their title, it is necessary to warn them by the scire facias, so that they may lave an opportunity of making their defense, and of claiming contribution from others holding laud of the judgment debtor, bound by the judgment. Where a party is in possession, holding title adverse to that of the defendant, or paramount to his, such party is not a terre-tenant, within the meaning of the law, because his rights are in no manner affected by the judgment. If he has a good title the judgment does not bind his land, nor can a sale under the execution affect his interest. One who purchased the lands at a tax sale, and went into possession, is not a terre-tenant. If the sale was valid, the purchaser held a title paramount to the judgment, and not to be affected by the proceedings under the execution. If the sale was invalid, then the purchaser was in possession without title under the judgment debtor, and not as his terre-temant."

${ }^{1}$ Polk $v$. Pendleton, $31 \mathrm{MI}$. 118. the remedy by motion to obtain the The subject of scire facias is more revival of dormant judgments is also fully treated in Chapter VIII of Free- considered.

man on Executions, in which chapter 


\section{CHAPTER XIX.}

\section{OF PLEADING JUDGIIENTS.}

\section{PART I}

$\$ 450$. General Form.

\& 451. Plea inust correspond in dignity with the Judgment.

\section{PART IL.-AVERMENTS OF JURISDICTION.}

\$ 452. Of Courts of Record.

$\S 453$. Of Courts of Record in other Countries and States.

$\S 454$. Of Courts of limited and special Jurisdiction.

$\$ 455$. Of Pleas to the Jurisdlction.

\section{PART III.-DESCRIBING JUDGMENTS.}

$\S 456$. Great particularity required.

$\$ 457$. Variance.

\section{PART IV.-PLEAS OF DEFENSE.}

§ 458. General Issue.

$\S 459$. Nul Ticl Record.

$\S 460$. Of former Adjudication.

\section{PART $\nabla$.}

$\S 461$. Pleas of Judgments in other States.

8. 450. Pleading, General Form.-As every judgment is conclusive on the parties while it remains in force, it is not necessary in asserting it as a cause of action or of defense, to aver any of the anterior proceedings or considerations on which it is based. The approved precedents of declarations upon judgments state the date or term at which the judgment was recovered, the court in which, and the place where, it was rendered, and the amount which, by the consicleration of the court, the plaintiff has recovered. Though the complaint be by an assignee, no demand for payment need be averred. ${ }^{1}$ Neither is it essential to state that the judgment is still in full force or rirtue, or that it remains unsatisfied, or that it is still the property of the plaintiff. It is sufficient to allege that the sum named is still due. ${ }^{2} \mathbf{A}$

${ }^{1}$ Moss $v$. Shannon, 1 Hilt. 175; 65; Biddle $v$. Wilkins, 1 Pet. U. S. Masterson v. Matthews, 60 Ala. 260; 686.

Pennington $v$. Gibson, 16 How. U. S. ${ }^{2}$ Blake $v$. Burley, 9 Iowa, 592. 
judgment in favor of an administrator is assets in his hands. He need not, in suing upon it, describe himself as administrator, nor to aver the issuing of letters of administration. Fis right to sue and his official capacity have passed in rem judicalum. ${ }^{1}$ So in an action against a stockholder, based upon a judgment against the corporation, it is unnecessary to aver the nature of the indebtedness out of which the judgment arose. ${ }^{2}$

\section{451. Pleas Adapted to Dignity of Judgment.-The} actions which may be brought upon judgments, and the pleas which may be made in such actions, depend upon the character and dignity of the judgment in controversy. ${ }^{3}$ If the judgment sued upon is a record, the action must be in debt, and the plea must be nul tiel recorl. 'The proceedings of Courts of Chancery are not records, ${ }^{4}$ therefore nul tiel record is a bad plea to an action upon a decree. ${ }^{5} \mathrm{Judg}$ ments of justices of the peace are generally considered as matters not of record, and are therefore declared upon in assumpsit instead of in debt. ${ }^{6}$ But in somo of the States they are treated as records, and must be sued upon as such.?

\section{PART II-AVERMENTS OF JURISDICTION.}

8. 452. Jurisdiction of Courts of Record.-From the well known rule that courts of superior or general jurisdiction are presumed to act by right and within the anthority conferred upon them by law, it follows that their judgments and decrees are in all cases of at least prima facie validity. In asserting such a judgment or decree as a cause of action, or as a ground of defense, the plaintiff need state no jurisdictional facts. Accoruing to the opinion reported in a Irentucky case, ${ }^{8}$ "it is sufficient to state briefly that the plaintiff impleaded the defendant, and by the consideration of the court recovered judgment, etc." In Vermont, it has been said

'Biddle v. Wilkins, I Pet. 692; Litt. 260; Buller's Nisi Prius, 245; 1 Crawford v. Whittal, Doug. 4, note A; Gilbert's Law of Ev., 49.

Talmage $v$. Chapel, 16 Mass. 71 .

${ }^{2}$ Milier $v$. White, 57 Barb. 504.

${ }^{3}$ Mills $v$. Duryee, 7 Cranch, 481; Indianapolis B. \& WT. Ry. Co. v. Risley, 50 Ind. 60.

${ }^{5}$ Evans $v$. Tatem, 9 S. \& R. 252; 11 Am. Dec. 717.

${ }^{6}$ Green $v$. Fry, 1 Cranelı C. C. 137.

ז Bain $v$. Hunt, 3 Hawhs, N. C. 572.

${ }^{8}$ Caldwell $v$. Riehards, 2 Bibb, 331;

${ }^{4}$ Doughty v. Fawn, Yelv. 226; Co. Burnes v. Simpsou, 9 Kans. 663. 474 
that enough of the previous proceedings should be stated to show that the parties were properly in court, and that the subject matter of the controrersy was such as the court had authority to determine; and that, for this purpose, a mero statement that the defendant being summoned or attached "with the common form, taliter processium est, is ordinarily suficient." 1 But in so far as these cases indicate that it is essential to aver anything whatever to show the jurisdiction of courts of record, they are not sustained by the authorities. It is the settled practice "to allege generally, that the plaintiff, by the consideration and judgment of the court recovered the sum mentioned." a "It was long ago settled that, in pleading a judgment, it is unnecessary to show by averment that the court had jurisdiction." 3 The averment that " the judgment was duly entered," is sufficient. "The presumption of law is conclusive that all the requisite prior proceedings were had in the case, till the contrary appears. Proceedings in the United States District Court under the baukrupt act form no exception." 4

\section{Courts of the Sister States, and of Foreign} Countries.-Tho presumptions in favor of jurisdiction ar' the same whether tho judgment relied upon is domestic, foreign, or of one of the sister states of this union. It is, therefore, only essential that the judgment, if pronounced in another state, be averred to have been duly rendered. ${ }^{5}$ The same rule is applicable to a foreign judgment. If tho court had no jurisdiction, that fact should be raised by the defendant's plea. ${ }^{6}$

\section{\& 454. Courts of Special Jurisdiction.- "It is suficient} to state the judgment concisely, even though it were recov-

1 Downer $v$. Dana, 22 Verm. 337.

${ }^{2}$ Chitty Pl. 354; Biddle $v$. Wilkins, 1 Pet. 686.

${ }^{3}$ Spaulding $v$. Baldwin, 31 Ind. 376; Rogers $v$. Odell, 39 N. II. 452; Pennington $v$. Gibson, 16 How. 65 ; Butcher $v$. Bank of Brownsville, 2 Kansas, 70 ; Holmes $v$. Campbell, 12 Minn. 221; Judge $v$. Fillmore, 1 Chip. 423.

${ }^{4}$ Lathrop $v$. Stuart, 5 M.IcLean, 167.

${ }^{5}$ Reid $v$. Boyd, 13 Tex. 241; Bissell v. Wheelock, 11 Cush. 277; Stephens $v$. Roby, 27 Miss. 744; Williams $v$. Preston, 3 J. J. M. 600; Wheeler $v$. Raymond, S Cow. 311. For contra view, see Ashley $v$. Laird, 14 ind. 222; Karns $v$. Kunkle, a Minn. 313; Snith v. Mulliken, 2 Minn. 319; Gebliard $v$. Garnier, 12 Bush, 321; 23 Am. Tiep. 721.

${ }^{6}$ Robertson $v$. Struth, 5 Q. B. 941 ; D. \& M. 773; 8 Jur. 404; 2 Chitty Pl. $243-4$. 
ered in an inferior court not of record." 1 It is necessary to show that the court had jurisdiction over the person and the sutject malicr. And the general allegation that the court had jurisdiction is not sufficient. The facts upon which the jurisdiction depends must bo stated. But it is no longer essential that the proceedings be set forth at large. It is enough to state the facts conferring jurisdiction, and then say taliter processium fuit, the judgment was rendered. The exception to this rule is where plaintiff in an action has been subjected to costs, in which case, having brought the suit, he is liable under the judgment whether the court had jurisdiction or not. ${ }^{2}$ In declaring on a justice's judgment rendered in a suit commenced by summons, alleged to bo duly issued and served, it is unnecessary to aver that the summons was returned, or that it specified a particular hour for the appearance of the defendant, or that the court was held at the time and place named in the summons, or that tho sum sued for was within the jurisdiction of the court, or that the defendant resided in the county. The service of process in the county makes a case of prima facie jurisdiction. ${ }^{3}$

Many of the States have passed statutes in which it is provided, that in pleading the judgment or determination of a court of special jurisdiction, the facts conferring jurisdiction need not be stated; but that the "averment that the judgment or determination was duly given or made shall be suficient."4 This statute is not complied with by alleging that "a judgment was entered in said action." Though it probably is not essential that the precise words of the statute be employed, they cannot be substituted by words not having the same eflect. The word "duly" seems to be indispensable. ${ }^{5}$ The answer in a suit upon a promissory noto set up the defendant's discharge by virtue of a decree in insolvency. A demurrer being interposed on the ground that the answer did not show that the note was included in

1 Chitty Pl., vol. 1, p. 370.

2 Turner v. Roby, 3 Comst. 193.

${ }^{3}$ Barnes v. Harris, 4 N.Y. 375.

¿ 59, Cal. Pr. Act; $\$ 456$, Cal. C.

C. $P$. ; Keys v. Grannis, 3 Nev. 548 ; 538 .
Crake v. Crake, 18 Ind. 156; Richardson $v$. Hiclsman, 22 Ind. $244 ; \oint 169$, Code of N.Y.

5 Hunt v. Dutcher, 13 How. Pr. 
the defendant's schedule, the court held that the allegation that a judgment had been duly made and rendered discharging defendant from the demand sued upon, was suficient, and that, whether the demand was included or not was a matter to be determined at the trial by inspecting the rccord. ${ }^{1}$ This provision of the statutes has been decided to be inapplicable to foreign judgments. ${ }^{2}$ But in Indiana, at least, it is applied to judgments rendered in any of the sister States. ${ }^{3}$

8 455. Plea to the Jurisdiction.-A plea to the jurisdiction of a court of general jurisdiction must set forth the facts showing want of authority in the court which rendered the judgment, and must be certain in every particular. If, by any reasonable intendment, the facts alleged can exist, and the court at the same time have jurisdiction, the plea is bad. ${ }^{4}$ This principle has been applied to foreign judrments in several instances by the English courts. Thus, a plea that defendant was not served with process issuing out of the said court, nor had he any notice of such process, nor did he appear in said suit, was held bad on demurrer, because it did not show that no process issued, nor that defeudant was not summoned so as to have a full opportunity for defense. ${ }^{5}$ The showing of a party that at the time the suit was commenced and down to the termination of it, he was not only absent from the place, but had no one there to represent him or on whom any process could be served, is suficient to avoid the prima facie evidence of a foreign judgment. 6 But, according to another English case, this showing would not be sufficient, because it does not directly state that defendant was not a subject of or domiciled in the county where judgment was rendered. ?

\section{PART III.-DESCRIPTION OF JUDGIIENTS.}

8 456. "In averring matters of record, great particularity should be observed. Any misstatement in the description

${ }^{1}$ Hanscom $v$. Tower, 17 Cal. $518 . \quad{ }^{5}$ Reynolds $v$. Fenton, 3 C. B. 157.

${ }^{2}$ Hollister $v$. Hollister, 10 How. P. 6 Smith $v$. Nicolls, 5 Ring. N. C. 539; MIcLaughlin $v$. Nichols, $13 \mathrm{Abb}$. 208; see also Ferguson v. Liahon, 3 Pr. 244.

3 Crake v. Crake, 18 Ind. 156.

4 Diblee v. Davison, 25 Ill. 486 , P. \& D. 113.

${ }^{7}$ Cowan $v$. Braidwood, 9 Dowl. 27. 
of a record in pleading is, as a general rule, fatal to such pleading. The averments and proof must be identical." ${ }^{\prime}$ The precise words of the record need not be followed. "Surplusage, or immaterial omissions not matters of substance, are attended with no other consequences than in other cases. As to matters of description, it is otherwise, and there the record produced must conform strictly to the plea. It has been considered that if any circumstances descriptive of the record be untruly stated, though they were not necessary to be stated at all, it will be fatal on nul tiel record. This is because the issue puts in question the identity of the record set up as evidence of the former recovery. The party to a suit, by pleading a record with a prout patet, profiers that issue, and it is incumbent on him to maintain it literally; this as well where the averment has reference to particulars which need not be specifically stated upon the record as to those which must be so."2 In describing a judgment, the court in which it was rendered, ${ }^{3}$ the place where the court was held, ${ }^{4}$ the names of the parties, the date or term at which it was entered, and the sum recovered must be shown.5 Action was brought against $\mathrm{L}$. B. and $\mathrm{E}$. his wife, upon a judgment alleged to have been recovered against her while she was unmarried, by the name of $\mathrm{E}$. R., to which the plea of nul tiel record was interposed. The judgment when offered in evidence, was objected to because against $\mathrm{E}$. R. and others, instead of $\mathrm{E}$. R. alone. The court held that, if the defendants desired to take advantage of the non-joinder of others, they could do so only by a plea in abatement. That, in this case, there was no variance because there was a judgment against $E$. $R$; ; and that an action of debt on a judgment is not different in principle from the ordinary case of an action of debt against several joint contractors, in which case, objections

1 Lawrence $v$. Willoughby, 1 Minn. 14 Ark. 672; Chitty's Pl. Vol. 2, p. 87; Chitty Pl. Vol. 2. p. 482-3, and notes.

2 Whitaker $v$. Bramson, 2 Paine C. C. 209. For instances of cases regarding fatal and non-fatal variances, see case justciter; also Barringer $v$. Boyd, 27 Miss. 473; Central Banl v. Veasey, 483, and notes; Few $v$. Backhouse, 1 W. W. and H. 658; Billing $v$. Hitchings, 18 L. J. Rep. (N. S.) Ex. 192. 3 Prckard $v$. Hill, 7 cow. 434.

${ }^{4}$ Duyckinels v. Clinton Ins. Co., 3 Zabr. 279. 
cannot be taken on the ground of variance, but only, if at all, by way of plea in abatement. ${ }^{1}$ A different construction prevails in Georgia." But where the declaration averred a judgment against $A$. and B., and the record put in eridence showed a judgment rendered in another state upon service on A. alone, under the "joint debtor act," it was held that the judgment was valid against $\mathrm{A}$. only; and that the description of it as being against $A$. and B., was, therefore, a fatal rariance. ${ }^{3}$

\& 457.- Variance.-The misclescription of a.juclgment in regard to tho term at which it was rendered is said not to be fatal where the record is set up as mere matter of inducement, as in case for a false return. ${ }^{4}$ In South Carolina, at an early day, it was decided that want of a writ and of a copy of the cause of action, blanks in the cleclaration, and a clerical error as to date of rendition, are none of them fatal objections to a judgment on plea of nul tiel record, because sufficient appears to show that a judgment was entered as alleged in the pleadings. ${ }^{\circ}$ But a less liberal rule prevails elsewhere in regard to matters of clescription. Such matters must be literally proved. Under allegation of judgment at December term, 1830, proof cannot be admitted showing judgment at December term 1831, nor will judgment of August 17 be admissible under allegation of August 16. ${ }^{6}$ There must be an identity of sound between the names of the parties as stated in the pleadings, and the names of the parties as shown in the record offered. An averment of judgment against Barnard Hysinger is not supported by a production of a record against Larent Hysenger. ${ }^{7}$

\section{PART IV.-DEFENCES.}

8 453. General Issue.-A defendant, sued upon a demand, may, under the plea of the general issue, show that such

1 Cocks $v$. Brewer, 11 M. \& W. 51. 6 Howard v. Cousins, 7 How. Miss. 66.

2 Howell $v$. Shands \& Co., 35 Geo.

3 Smith $v$. Smith, 17 Ill. 4 S2.

4 Chitty P1. 230, note c.

- Farrar v. Carmichael, 1 Brev. 392. 114; Gulick v. Loder, 2 Green, N. J. 572; 23 Am. Dec. 711.

7Duncommun $v$. Hysinger, 14 Ill. 249 , 
demand is merged in a former judgment. 1 We have already, in another chapter, considered the authorities bearing on the question whether a former adjudication, put in evidence under the general issue, is conclusive upon the court or jury ${ }^{2}$ It appears to be certain that a judgment was admissible under the general issue in actions in assumpsit, ${ }^{3}$ case, ${ }^{4}$ and trover, ${ }^{5}$ but was not in trespass and covenant. ${ }^{6}$ Under the code a judgment cannot be given in evidence as a former recovery under the general issue. It must be specially pleaded.' Under the general issue (nil debet), in an action on a judgment rendered in another State, the defendant may show that the court had no jurisdiction to render the judgment. ${ }^{8}$ Ordinarily an officer is protected by an execution fair on its face, and, therefore, on being sued for lerying upon and selling property need not aver the existence of the juclgment. But if the property was such as by law is exempt from execution, except for purchase money, and the defendant wishes to prove that he levied under execution upon a judgment for purchase money, he must aver in his answer the existence and consideration of the judgment. ${ }^{9}$

8 459. Nul Tiel Record.-This is the only proper plea to call in question the existence of the judgment as stated in the pleading of the party by whom it is brought forward. The non-existence of the judgment, or a variance in its statement in the declaration, must bo taken advantage of by this plea. ${ }^{10}$ It involves two questions; one of fact and the other of law. The first is whether such a record as is

${ }^{1}$ Warren $v$. Comings, 6 Cush. 103; |ricks $v$. Deeker, 35 Barb. 298; Brady Marsh $v$. Pier, 4 Rawle, 273; 26 Am. v. Murphy, 19 Ind. 2js; Adkins $v$. Dec. 131; Mason $v$. Eleled, 6 TVall. 231.

${ }^{2}$ See $\S 284$. A judgment, whenever properly arlmitted in evidence under the pleadings, is as conchisive as if specially pleaded. Gavan $v$. Graydon, 41 Ind. 559.

${ }^{3}$ Stafford $v$. Clark, 1 Carr \& P. 403; Reynolds $v$. Stansbury, 20 Ohio, 344; Stafford $v$. Clark, 9 Moore, 724; 2 Bing. 377 .

41 Chitty Pl. 491.

5 Mi ler v. Manice, 6 Hill, 114.

${ }^{6} 1$ C'l.tty Pl. 4S8, 491, 506; Coles $v$. Carter, 6 Cow. 691.

'Piercy $x$. Sabin, 10 Cal. 22; Hend-

Hudson, 19 Ind. 392.

${ }^{8}$ Foster v. Glazener, 27 Ala. 391; Bissell $v$. Briggs, 9 Mass. $462 ; 6 \mathrm{Am}$. Dec. 88; Stephens v. Gaylord, 11 Nass. 266.

${ }^{9}$ Dennis $v$. Sncll, 54 Parb. 411.

${ }^{10}$ Jacquette $v$. Hingmon, 2 ircL. 129; Lincoln v. Tower, 2 McL. 473; Crawford $v$. Ex's of Simonton, 7 Porter, 110. A plea of mil tiel record to an action on the judgment of a colonial court is bal in England. Plrilpot $v$. Adams, 7 H. \& N. SS8; 31 L. J. Exch. 421; Chapman v. Sherrie, 5 Ir. R. C. L. 36, Q. B. 
alleger in fact exists. The second is what judgment should be promounced if the record is proved as alleged. ${ }^{1}$ If tho record produced shows that the court did not have jurisdiction of either the person of the defendant, or the subject of the controversy, it must be disregarded." "As this plea only goes to the existence of the record, the defendant must plead payment, or any matter in discharge of the action." 3 Hence, if in an action on the judgment of a sister State, the executions are put in the record and show a levy upon personal property, this levy and the satisfaction thereby produced, cannot be taken advantago of under the plea of mul tiel record.4 "But if a recovery be pleaded in bar, and the judgment afterwards reversed beforo the day given to bring in the record, then, upon mul tiel record the issue must be found for the plaintiff; because by the reversal the record is avoided ab initic."5 Under this plea the defendant cannot prove aliunde, that the parties or the cause of action was different in the former suit. ${ }^{6}$ The plaintiff to entitle himself to a recovery, under this plea, must produce a record which does not appear, when produced, to be satisfied.?

\& 460. Former Adjudication.-A plea of former recovery should show that some question involved in the former judgment is identical with some issue in the present action; $;$ that the former action and the present were between the same parties or their privies; ${ }^{9}$ and, in case the parties are not nominally the same, facts showing their privity with the parties to the present action must be stated. $^{10}$ The plea of former judgment, as a defense to an action of ejectment, should show, in addition to the facts

1 Maule, J., in Bradley v. Gray, 3 C.; see also Kinsey v. Ford, 38 Darb. C. B. $7 \simeq 0$. 195.

2 Thompson v. Emmert, 4 MeL. 96 ; Bergen $v$. Williams, 4 JieL. 125.

3 Tidd's Pr. 651.

6 State Bank $v$. Arnold, 7 Eng. 180.

${ }^{7}$ Blair $v$. Caldwell, 3 Mo. 353.

${ }^{8}$ Hopkinson $v$. Shelton, 37 Ala. 306;

4 Stephens $v$. Ioby, 27 Miss. 744; Tunstall $v$. Tobinson, Hempstead, 229.

Lockwood $v$. Wildman, 13 Ohio, 450;

Heatherly $v$. Hadly, 2 Oregon, 269;

Johnson $v$. White, 13 S. \& MT. 584.

5 Tidd's $\mathrm{Pr} .745$, citing $7 \mathrm{Ld}$. Raym, 274; 2 Ld. Raym, 1014; 2 Sall. 329, S.

${ }^{9}$ Greely $v$. Smith, 1 IV. \& M. 181 .

${ }^{10}$ Greely $v$. Smith, 3 W. \& MI. $2 \% 6$; Goddard v. Benson, 15 Alb. Pr. 101.

481 
that the parties to the two actions and the lands in controversy are the same, that the title of the parties in issue in the first action is the same title in issue now. ${ }^{1}$ But in Olio, in actions in relation to personalty, it is sufficient to state a prior recovery to have been between the same parties, for the same property, without averring that it was for the same conversion.2 A plea of judgment recovered in the court of a foreigu country, must show that, the judgment is final and conclusive between the parties in the place where it was rendered. " "When the record of a former judgment is set up as establishing some collateral fact involved in a subsequent controversy, it must be pleaded strictly, as an estoppel, and the rule is, that such a pleading must be framed with great certainty, as it cannot be aided by an intendment. Technical estoppels, as contended by defendants, must be pleaded with great strictness, but when a former subject is set up, in bar of an action, or as having determined the entire merits of the controversy, it is not required to be pleaded with any greater strictness than any other plea in bar, or any plea in avoidance of the matters alleged in the antecedent pleading of the party." " One who desires to 'rely upon a former judgment as a bar, must plead it, if he have an opportunity to do so.

\section{PART V.}

8461. Judgments of the Sister States.-It is now well settled that the judgment of a court of record of any of the States must be treated as a record in every other State both by the plaintiff in his declaration ${ }^{6}$ and by the defendant in lis plea." "Pleas in bar of suits commenced on judgments of sister States must deny, by clear and positive averments, every fact which would go to show jurisdiction, whether with reference to the person or the subject-matter." An

1 Vance $v$. Olinger, 27 Cal. 358.

${ }^{2}$ Eversole $v$. Plank, 17 Ohio, 61.

${ }^{3}$ Plummer $v$. Woodburne, $4 \mathrm{~B}$. \& $\mathrm{C}$. 625 ; Frayes $v$. Worms, $10 \mathrm{C}$. B. N. S. 149.

${ }^{4}$ Aurora City v. West, 7 Wall. 82; Gray v. Pingry, 17 Verm. 419; Perkins $v$. Walker, 19 Verm. 144.

${ }^{5}$ Briggs $v$. Mlilburs, 40 Mich. 512; Murray v. Murray, $€$ Oreg. 26.

'Garland $v$. Tucker, 1 Bibb, 361;

McKim v. Odom, 3 Fairf. 91; India
Rubber Factory $v$. Hoit, 14 Verm. 92; Andrews $v$. Niontgomery, 19 Johns. 162; 10 Am. Dec. 213.

'Evans v. Tatem, 9 S. \& R. 2ృ̃2; $11 \mathrm{Am}$. Dec. 717; Davis v. Lane, 2 Carter, 548; Mills v. Duryee, 7 Cranch, 4S1; $2 \mathrm{Am}$. Lead. Cases, 4 th ed. 791.

' Latterett $v$. Cook, 1 Iowa, 1; Moulin $v$. Insurance Co., 4 Zabr. 222; Shumway $v$. Stillman, 4 Cowen, 292; $15 \mathrm{Am}$. Dec. 374. 
answer to an action on a judgment of a court of record of another State, is, therefore, insufficient, if it states only that the defendant was a non-resident, and had no notice of the action, without expressly showing that he clid not appear by person nor by attorney.' Where the defendant pleaded that he was never within the State, that he nerer had any notice of the suit, and never appeared therein, a replication "that said judgment was not recovered against defendant without his knowledge and without notice to him in manner and form as in said plea alleged," was held to bo good. ${ }^{2}$ But this case seems hardly consistent with Long v. Long, 1 Hill. 597. There the replication alleged that defendant was personally duly notified, according to the rules and practice of that court and the law of that State. It was held to be "bad in substance. It states that the defendant was 'personally duly notified,' but not of the process, the action, or anything else in particular. $\mathrm{He}$ had due notice; but of what? The pleader has stopped short of the conclusion at which he seems to have been aiming. If due notico of the process or action had been alleged, I should still think the replication bad in substance, as well as in form. Due notice may sometimes be appropriate words in a pleading, but when the inquiry is whether a court has obtained jurisdiction of the person of the defendant, the allegation that he was 'personally notified' does not belong to legral language. The averment should be that he was served with process to appear and answer, or that he appeared in the action either in person or by attorney." 3 In cleclaring upon the judgment of a justice of the peace of another State, it must bo alleged that the statutes of that State gave the justice jurisdiction of the subject matter of the surt." "A general averment of jurisdiction is not enough. The statute giving jurisdiction to the justice, and the existence of the jurisdictional facts required by such statute, must be pleaded." 5

${ }^{1}$ Fosterer $v$. Glazener, 27 Ala. 391; Starbuck v. Murray, 5 Wend. 148; 21 Am. Dec. 172; Struble $v$. Malone, 3 Clarke, $5 \$ 6$.

${ }^{2}$ Buchanan v. Port, 5 Ind. 264.
${ }^{3}$ Long $v$. Long, 1 Hill, 597.

${ }^{4}$ Thomas $v$. Robinson, 3 Wend. 267.

${ }^{5}$ Sheldon $v$. Hopkins, 7 Wend. 435; Grant $v$. Blesdoe, 20 Tex. 456; BeaI v. Smith, 14 Tex. 305 . 


\section{CHAPTER XX.}

\section{SATISFACTION OF JUDGMENTS.}

\section{PART I.-BY PAYMENT.}

$\S 462$. Towhom made.

$\S 463$. How made.

$\S 464$. Presumption of Payment.

$\$ 405$. Time as Evidence of Payment.

\$4C6. Paid Judgment.

\$ 46\%. Payment of another Judgment for the same Demand.

$\S 467 a$. Payment by set-off against another Judgment.

\section{PART II.-PAYER'S RIGHT TO SUBROGATION.}

5468 . Payment by a Stranger.

$\$ 409$. Payment by an Officer.

$\$ 470$. Payment by a Surety.

$\$ 471$. Payment by an Indorser.

8 4i2. Payment by a Co-Defendant.

\$ 473. Payment partly by Co-Defendant and partly by Third Person.

\section{PART III.-SATISFACTION BY PROCEEDINGS UNDER EXECU. TION.}

5 474. By Levy on Lands.

$\$ 475$. By Levy on Personal Property.

846. Dy Discharge of Defendant from Custody.

5 477. Suspension while Defendant is in Custody,

$\$$ 478. Salo under Execution, and Vacation of Satisfaction produced thereby. $\$ 478$. Vacation of Satisfaction.

\$479. Other Means of Satisfaction.

\section{PART IV.}

8 480. Proceedings after Satisfaction.

\section{PART I.-BY PAYMENT.}

8 462. To whom Payment may be IMade. - Payment will, of course, operate as a release if it be made to the plaintiff, or to any person authorized by him, or by law, to receive it. If there be more than one plaintiff, a payment to either will discharge the entire judgment. ${ }^{1}$ If, however, it be shown by the record, or be, by any means, brought to the knowledge of the debtor, that the judgment

${ }^{1}$ Erwin $v$. Rutherford, 1 Yerg. 169; Freeman on Co-tenancy and Partition, secs. $178,179$. 
was recovered for the use of another than the plaintiff, it can only be satisfied by payment to the real party in interest. ${ }^{1}$ So, if the judgment be assigned, the plaintiff is no longer a proper person to receive payment; and a payment to him thereafter does not extinguish the judgment if it can be shown to have been made with notice of the assignment. Direct notice to the defendant is not essential to secure the rights of the assignee. It is sufficient if it can be shown that the former had information given in such terms and under such circumstances as were well calculated to arrest his attention. ${ }^{2}$ If an officer having authority in his official capacity to receive payments of judgments, receive money to pay the debt, before judgment when he has no authority to receive it, and he retain the money until after judgment, and then write on the record tho word "settled," this will bo held to indicate an intention to hold the money in his official capacity and will be regarded as a satisfaction of the judgment. ${ }^{3}$ An attorney-at-law retained to prosecute a domand has, by virtue of that retainer, the authority to receive payment of the judgment, when recovered. Until the defendant has notice of a revocation of this authority, he will be entitled to the credit of all payments made to the attorney. ${ }^{4}$ The relation of a prochein ami to the action is that of an officer of the court, specially appointed to enforce and preserve the rights of the infant in whose behalf he acts. Ho may employ an attorney, carry the suit on to judgment; and may, if there be no regularly constituted guardian of the infant, receive the money recorered of the defendant, and thereupon may enter a valid satisfaction of the judgment. ${ }^{5}$ The attorney who is employed by the prochein ami to prosecute the suit, is thereby authorized to receive payment of the judgment, and to enter satisfaction thereof when such payment is made. ${ }^{6}$

${ }^{1}$ Triplet $v$. Scott, 12 IIl. 137; Hod-|S0S; Brackett v. Norton, 4 Conn. 517; son $v$. McConnel, 12 Ill. 170; Thatcher $v$. Rockwell, 4 Cal. 375.

$10 \mathrm{Am}$. Dec. 179.

${ }^{2}$ Guthrie $v$. Bashline, 25 Penn. S. 80.

${ }^{3}$ Governor v. Read, 33 Ala. 254.

${ }^{4}$ Harper $v$. Harvey, 4 West Va. 539; Yoakum v. Tilden, 3 liest Va. 167; Wilkinson \& Co. v. Holloway, 7 Lcigh, 277; Mills $v$. Chandler, 9 Reporter, patrick, $30 \mathrm{Md}$. 624.

5 Thite $v$. Hall, Moor, S52; Morgan v. Thorne, 7 Mrees. \& W. 400; Collins v. Brook, 4 H. \& N. 270; S. C., 5 H. \& N. 700; S. C., 29 L. J. Ex. 259; S. C., 6 Jur. N. S. 999.

' Baltimore \& O. R. R. Co. v. Fitz- 
8 463. How Payment may be Made.-The plaintif may accept payment in any manner, or in any kind of currency; and having once accepted currency, note, check or any other article of value as a substitute for a legal tender, cannot revoke his acceptance and enforce payment in money.' The mere taking of a note for a pre-existing debt does not of itself amount to a payment. Hence, the giving of a note will not operate as a satisfaction of a judgment unless it be shown that the plaintiff accepted it in payment, and not as additional evidence of the same debt. ${ }^{2}$ Whether the plaintiff is bound by an agreement, under which lie obtains part payment through his promise to satisfy the whole judgment, is a disputed question. On the one sille it is insisted, that the agreement to discharge any portion in excess of the payment, is a nudum pactum, and cannot therefore extinguish the entire judgment. ${ }^{3}$ On the other side, it is affirmed, with great confidence, that the plaintiff cannot retain the fruits of his compromise, and, at the same time, enforce lis judgment as to the part agreed to be releasect." But a satisfaction under seal is good though full payment were not made. ${ }^{5}$ An attorney at law has, by virtue of his general retainer, no authority to satisfy a judgment without payment of the full amount in money. If he compromise by taking less than the entire sum due, or by receiving anything else than money, the plaintiff is not bound by the compromise. ${ }^{6}$ In England, the retainer and authority of an attorney cease at the entry of the judgment; and he cannot, by virtue of an implied authority arising from his previous relation to the case, make a binding agreement to stay the execution, nor affect a valid compromise of the judgment.7 But if he be employed after judgment to conduct proceed-

${ }^{1}$ Lyon $v$. Northrop, 17 Iowa, 314; Wilkinson \& Co: v. Holloway, 7 Leigh, Weston v. Clark, 37 Mlo.572; Witherby 277; Wakeman v. Jones, I Cart. 517; $v$. Mann, 11 Johus. 51S; Ives $v$. Chapman $v$. Cowles, 41 Ala. 103; Phelps, 16 Minn. 451.

Jones $v$. Ransom, 3 Ind. 327; Abbe $v$.

2 IfCoy $v$. Hazlett, 14 Kans. 430. Rood, 6 MeL. 107; Jewett $v$. Ward-

3 Deland $v$. Hiett, 27 Cal. 611; Gar- leigh, 32 Maine, 110; Vail v. Conant, vey $v$. Jarvis, $5+$ Barb. 179 :

t Reil v. Hibbard, 6 Wis. 175. 665 .

5 Beers $v$. Hendrickson, $45 \mathrm{~N}$. $\mathrm{Y}$.

${ }^{6}$ Garthwaite $v$. Wentz, 19 La. An. 196; Lewis $v$. Woodruff, 15 IHow. P. 539; Benedict v. Smith, 10 Pai. 126; 440; Butler v. Knight, L. R. 2 Exc. Beers $v$. Hendrickson, 45 N. Y. $665 ; 109$.

Jackson v. Bartlett, \& Johns. 361;

15 Verm. 314; Lewis $v$. Gramage, 1 Pick. 347; Smock $v$. Dade, 5 Rand, 639; 16 Am. Dec. 7S0; NeCarver $v$. Nealey, 1 Iowa, 360; Trumbull $v$. Nicholson, 27 Ill. 149.

${ }^{7}$ Lovegood v. White, L. R. 6 C. P. 
ings to enforce satisfaction thereof, such employment anthorizes him to bind his client by a compromise. ${ }^{1}$ The burden of showing that an attorney was authorized to accept any thing but money, is upon the party making such payment. No such anthority will be presumed. ${ }^{2}$ Where the law authorizes the sheriff or any other officer to accept payments of judgments, his authority is as limited as that of an attorney acting under a general retainer. ${ }^{3}$ The return of a sheriff, endorsed on an execntion, that ho returns it satisfied by taking two notes, etc., does not establish, prima fucie, a satisfaction of tho julgment; for, though the plaintiff may have assented to the taking of the notes, this certificate does not prove such assent." In Lonisiaua, while that Stato was under tho control of the authorities of the Confederate States, and confederute notes wero tho circulating medium, a plaintiff had execution issued on his judgment, and caused the sheriff to enforeo the same. The debtor's property was sold by the sheriff, who received the purchase money in confederate notes. The plaintiff never called for these notes; but after tho occupation of the State by the Federal forces, he endeavored to compel the sheriff to pay in lawful money of the United States, the price realized at the sale. The Supreme Court of that State gavo the following reasons for denying the plaintiff's demand: "The plaintiff resided in New Orleans, and ho must be presumed to have known that no other currency was in general circulation; and we cannot resist the conviction that by placing the writ in the hands of the sheriff to sell the property of his debtor, he authorized him to receive confederate treasury notes for the price. We know from the history of the times, that the sheriff could not hare demanded with safety any other money in payment of the price of property sold at public auction, and that he conld not have enforced tho payment of any kind of money at that time, and still he was obliged to execute the writ. The demand of tho plaintiff is withont equity." But in Alabann, an administrator who in 1863 paicl to his successor in office, in Confederate notes, the amount of a decree entered against

\footnotetext{
${ }^{1}$ Butler $v$. Kniglit, L. I. 2 Exc. Ellis $v$. Smith, 42 Ala. 349; Aicardi 109.

2 Portis $v$. Ennis, 27 Tex. 574. v. Robbins, 41 Ala. 541 .

${ }^{4}$ Mitchell v. Hackett, 25 Cal. 539.

${ }^{3}$ Mitchell $v$. Hackett, 14 Cal. 661;

${ }^{5}$ Harvey $v$. Walden, 23 La. An. 142.
} 
him in 1860, was held to have produced "no satisfaction of the decree in whole or in part."

8 461. Presumpition of Payment. - At common law, every judgment was presumed to be paid, after the lapse of twenty years. ${ }^{2}$ In Maine and in MIassachusetts, and perhaps in other parts of the United States, statutes have been enacted on this subject, in substantial conformity to the common law. In the two States named, the statute provided that every judgment should be presumed to be paid after twenty years from the period when any duty or obligation accrued thereunder. In Tennessee the period was reduced to sixteen years, apparently by a piece of judicial legislation, made early in the listory of that State, and ever afterward recognized and enforced by its courts. ${ }^{3}$ But whether existing under the common law, or under the statutes referred to, or by virtue of rules adopted by any court, this presumption was never conclusive. It only threw upon the party seeking to enforce his judgment, after twenty years of inaction, the burden of showing that it remained umpaid." The presumption is overcome, if it "be made to appear that the plaintiff has used diligence to enforce the judgment, or that the defendant has paid interest, or otherwise acknowledged it." What is sufficient to rebut the presumption of payment arising from lapse of time, is a question, which, like all other questions of fact, is very much within the discretion of the court or jury. Lord Ellenborough, in a case decided by him, ${ }^{6}$ held that this presumption was not overthrown by proof that the defendant was, during the whole time, in indigent circumstances; that he was most of the time abroad; that, while in England, he lived under an assumed name; and that, in the opinion of his friends,

\footnotetext{
1 Thompson $v$. Perryman, 45 Ala. 620 .

2 Miller $v$. Smith's Exrs., 16 Wend. 425 ; Cope $v$. Humphries, $14 \mathrm{~S}$. \& R. $15 ; 1$ Greenl. Ev. 93 ; The State of Tunnessee $v$. Virgin, 36 Geo. 390؛ Willingham $v$. Long, 47 Geo. 545 .

3 Blackburn $v$. Squib, Peck's R. 64; MIcDaniel v. Groodall, 2 Cold. 391; Anderson $v$. Settle, 5 Sneed, 202.

4 Knight v. Macomber, 55 Maine, 132 ; Brewer $v$. Thomes, 28 Maine, 81; Denny $v$. Eddy, 22 Pick. 533; Bissell $v$. Jaudon, 16 Ohio S. 498; Anderson $v$. Settle, 5 Sneed, 202; Yarnell $v$. IIoore, 3 Colu. 173.

${ }^{5}$ Burt $v$. Casey, 10 Geo. 179.

${ }^{6}$ Willaume v. Gorges, 1 Camp. 217.
} 
he was riever possessed of means sufficient to pay the judgment. None of the American cases carry this presumption so far. Proof that three executions were issued and returned unsatisfied; that the debtor stated that he was unable to pay, and that he put his property out of his hands, and was reputed to be insolvent, suffieiently rebuts the presumption of payment. ${ }^{1}$ Proof of partial payments during the twenty years, or of any acknowledgment of the continuing obligation of the judgment, is also suficient. ${ }^{2}$ The verdict of a jury, finding that a judgment is unpaid, is sufficiently sustained by proof of the insolvency of the defendant, or of his relationship with plaintiff, or of amy other circumslance calculated to satisfy the minds of the jurors that the judgment is still clue. ${ }^{3}$

\section{465. Time as Evidence of Payment. - "Presump-} tions are founded on the ordinary course of things. It is not usual for a creditor to clelay enforcing the payment of a debt due him for such a length of time. The fact that he does so, evinces a consciousness that it was not owing, and creates a strong presumption of payment." "This is an extract from the opinion of the Supreme Court of Tonnessee, in a case in which that court held that, after the lapse of seren years, during which no effort was made to collect a judgment, the jury might properly consider this long period of inactivity as a circumstance to be weighed by them in determining whether the judgment remained unpaid. In a later case, in the same State, proof that the plaintiff resided for thirteen years in the same neighborhood with his judgment debtor, during all that time making no attempt to collect his judgment; that plaintifi then moved away without any attempt at collection, and that the defendant all the time had ample property to satisfy the judgment, was held to create a presumption of payment, though the period of sixteen years allowed by the law of that State, had not yet elapsed.5 While the presumption of payment, based upon 132.

1 Kuight $v$. IIacomber, 55 Maine, 3 Yarnell $v$. MIoore, 3 Cold. 173;

2 Denny v. Eddy, 22 Pick. 533; Rissell v. Jaudon, 16 Ohio $\$ .493$; Jower v. Kip $2 \mathrm{Ed}$. Ch. 165.
Boardman $v$. De Forest, 5 Conn. 8.

${ }^{4}$ Leiper $v$. Erden, 5 Yerg. 97.

5 Husky v. MIaples, 2 Cold. 25. 
lapse of time alone, is an arbitrary presumption not created by any less than the full term provided by law, still there is no cloubt that the lapse of a long period of time, though less than the full term of limitation, is a proper circumstance for the consideration of the jury, and that, in connection with other circumstances, it will create the presumption of payment. $^{1}$

8 466. Paid Judgment.-Payment produces a permanent and irrevocable discharge, after which the judgment cannot be restored by any subsequent agreement; ${ }^{2}$ nor kept on foot to cover new and distinct engagements. " But in England, the rule seems to be different. A defendant there confessed judgment for $£ 500$. The debt due from him to the plaintiff was subsequently increased to $£ 1,000$. It was then agreed that the last named sum might bo paid in installments, for which the judgment should stand as security. It was held that neither the defendant nor his grantee, with notice, could satisfy the judgment by paying the $£ 500$, or any sum less than the whole amount for which the defendant had agreed that it might stand as security. ${ }^{4}$ If a judgment bo confessed for the purpose of securing future advances, and such advances, afterwards made to the amount of the judgment, are paid by the debtor, the judgment, as against subsequent purchasers or incumbrancers, is functus ofjicio. It cannot stand as continuing security for further advances, nor for the final balance of current account between the parties. ${ }^{5}$ The fees of the sheriff on execution are no part of the judgment. They constitute a demand against the party for whom the services aro performed. If the judgment be paid, the sheriff's authority is extinguished; and he cannot lawfully proceed to levy upon property to enforce the collection of his costs. ${ }^{6}$ But an entry on a docket

${ }^{1}$ Baker $v$. Stonebraker's Adm'r, 36 Averill $v$. Loucks, 6 Barb. 19; De La Mo. 33s; Wherry $v$. MeCammon, 12 Fich. Eq. 337; Winstanly v. Savage, $2 \mathrm{McCorl}$ Ch. 43ð; Goldhawk $v$. Duane, 2 Wash. C. C. 323; Thompson $v$. Thompson, 2 Head, 405; Kinsler $v$. Holmes, 2 S. C. (N. S.) 483.

${ }^{2}$ Marvin $v$. Vedder, 5 Cow. 671; Winslow $v$. Clark, 2 Lans. 380; Vergne $v$. Evertson, 19 Am. Dec. 411. 3 Troup v. Wood, 4 Johns. Ch. $2 \approx$ S. "Crafts $v$. Wilkinson, 4 Ad. \& El. N. S. 74 .

${ }^{5}$ Truscott $v$. King, 6 N. Y. 147.

${ }^{6}$ Jackson $v$. Anderson, 4 Wend. 474; Craft v. Merrill, 14 N. Y. 456. 
acknowledging the payment of the debt and interest does not satisfy the whole judgment. It may be revived by scire fucias against a terre-tenant, to collect the costs recovered by plaintiff as a part of his judgment. ${ }^{1}$

\section{\& 4i7. By Payment of Another Judgment.-Sometimes,} as where a trespass is committed by several, separate ju?gments may be rendered against two or more persons upon the same cause of action. The acceptance of payment upon either of these judgments relenses the other;', so if one judgment be rendered on an original obligation, and another judgment be entered upon an obligation given as collateral security to the first, the payment of either judgment discharges the other; and a sale made under the latter after it is so satisfied, is void. ${ }^{3}$ And in the States where, though a plaintiff is allowed to maintain separate actions against each of several tort-feasors, his taking out execution agaiust either is regarded as an irrevocable election to pursue that one ouly; snch election is a satisfaction of all the judgments against the other tort-feasors. ${ }^{4}$

$\& 467 a$. Set-off--The satisfaction of a judgment may be wholly or partly produced by compelling the judgment creditor to accept in payment a judgment against him in faror of the judgment debtor; or, in other words, by setting off one judgment against another. This is nsually brought about by a motion in behalf of the party who desires to have his judgment credited upou or set off against a judgment against him. The court in a proper case will graut the motion. Its power to do this cannot be traced to any particular statute; and exists only in virtue of its general equitable authority over its officers and suitors. ${ }^{5}$ This an-

\footnotetext{
${ }^{1}$ Altman $v$. Klingensmith, 6 Watts, 43 Id. 430; Burns $v$. Thornburgh, 3 145.

${ }^{2}$ Sherman v. Brett, 7 Wis. 139; Jones $v$. Riansom, 3 Ind. 327; Thompson v. Percival, 5 B. \& Ad. 925; First N. B. $v$. Indianapolis P. Co. 45 Ind. 5.

${ }^{3}$ Craft $v$. Merrill, 14 N. Y. 456.

4 Boardman v. Acer, 13 Mich. 77.

${ }^{5}$ Chandler v. Drew, 6 N. H. 469; Hutchins $v$. Riddle, 12 Il. 464; Hund 39 N. J. L. 239; Ames v. Dates, 119 v. Fogg, 22 Id. 98; Brown v. WVarren, Mass. 397.

\begin{abstract}
Watts, 7S; Simpson v. Hart, 14 Jolns. 63; 1 Johns. Ch. 91; Stilwell v. Carpenter, 2 Abb. N. C. 23s; Slirine v. Tarbell, 16 Ir. 491; Prior $v$. Richards, 4 Bibb. 350; Williams $v$. Evans, $2 M \mathrm{C}$. Am. Dec. 7ఃs; Brown v. IIendrickson,
\end{abstract} Simmons, 36 Geo. 402; Ballinger $v$. Cord, 203; Duncan $v$. Bloomstock, 13
} 
thority was formerly restricted to courts of equity; but is now very generally exercised by courts of law. The judgments sought to be set off against each other may have been renclered in the same or in different courts. In the first case there can be no difficulty; but in the latter it has sometimes been held that a court of law was inadequate to afford relief and that resort to chancery was therefore unaroidable. ${ }^{1}$ This position is believed to be intenable. The conrt of law in which the judgment is entered can give relief, by virtue of its equitable power, and may direct that the judgment of another court be credited upon or set off aginiust $i t s$ judgment, ${ }^{2}$ except when the rights of the parties are too intricate and complicated to be adjusted elserwere than in equity." This exception is, however, but a recognition of the general principle everywhere conceded, that the setting off of one judgment against another rests in the sound discretion of the court, and will not be compelled except when, by so doing, the court can accomplish substantial justice between the parties." "It is well settled, both in England and in this country, that judgments in cross actions may be set off, the one against the other, when the parties in interest are the same, on motion addressed to the court in which one or both of the actions is pending. If the amounts are equal, both will be satisfied. If the amounts are unequal, the smaller will be satisfied in full, and the larger to the extent of the smaller, and an execution will issne for the balance." The right of set-off cannot be destroyed by a fraudulent assignment; nor even by an assignment made in good faith after both judgments hitd been rendered and the right to set off had therefore accrued prior

1 Webster $v$. MIcDaniel, 2 Del. Ch. 297.

${ }^{2}$ Duncan v. Bloomstock, 13 Am. Dec. 72s; Schermerhorn v. Schermerhorn, 3 Eai. 100; Ewen $v$. Terry, 8 Cow. 126; Kimball $v$. Munger, 2 Hill, 364; Brown v. Hendrickson, 39 N. J. L. 232; Best v. Lawson, 1 Miles, 11; Coxe v. State Bank, 14 Am. Dcc. 117; 3 Hal. 172; Pierce $v$. Bent, $69 \mathrm{Me}$. 381.

3 Story v. Patten, 3 Wend. 331.

${ }^{4}$ Simson v. Hart, 14 Jolins. 63; 492 
to the assigument. ${ }^{1}$ In some instances the right of set-off exists thou h the parties are not, in all respects, the same. Thus a judgment in favor of $A$. and against $B$. and C., may bo set off against one in favor of $B$. and against $A . ;^{2}$ and a judgment in favor of a "principal alove may be applied in satisfaction of one against him and his sureties."

PART II.OF THE RIGHT OF THE PAYOR TO SUBROGATION.

8 468. Payment by a Stranger.-Payment of a judrment by a third person, will operate as an extinguishment or not, according to the intention of the parties when tho payment is made. If the parties intend still to keep the judgment on foot, they may do so, proceeding in the name of the plaintiff." But a third person making an absolute payment, in the absence of any mnderstanding with the creditor that the judgment is to be kept alive, is not equitibly entitled to be subrogated to the rights of the latter. "It is only in cases where the person advancing money to pay the debt of a third party, stands in the situation of a surety, or is compelled to pay it to protect his own rights, that a court of equity substitutes him in the place of the creditor, as a matter of course, without any agreement to that effect. In other cases the demand of a creditor which is paid with the money of a third person, and without any agreement that the security shall be assigned or kept on foot for the benefit of such third person, is absolutely extinguished." ${ }^{\prime \prime}$

\& 469. Payment by Officer.-An officer to whom an execution had been given, neglected to levy thereunder in due time. He then paid the judgment voluntarily, without taking any assignment, and returned the execution as unsatisfied. He afterwards procured the issuing of an alias for his own benefit; but the court held that, by his payment, Le had, under the circumstances, produced an absolute and

1 Pierce v. Bent, 69 Me. 351.

${ }^{2}$ Simpson $v$. Hart, 14 Johns. 63; Wright $v$. Cobleigh, 23 N. H. 32; Allen $v$. Hall, 5 Met. 263.

${ }^{3}$ Pierce $v$. Bent, 69 Me. 386.

${ }^{4}$ Null v. Moore, 10 Tred. 324.

${ }^{5}$ Sandford $v$. McLean, 3 Pai. Ch. 117; 23 Am. Dec. 773; Head v. Gervais, Walker, 577; $12 \mathrm{Am}$. Dec. 577. 
irrevocable satisfaction of the judgment. ${ }^{1}$ If, however, instead of paying voluntarily, he had waited until compelled to pay by a judgment of the law, the legal effect of his payment would have been to invest him with the rights of the original judgment cred:tor. ${ }^{2}$ But in the State of New York, a position is taken which denies the distinction here made between a voluntary and an iuvoluntary payment made by an officer who has become liable for his neglect in executing process. "No distinction," says the court, "has been taken between payments voluntarily made by the sheriff and those made upon compulsion in consequence of a liability incurred by him, and there is no difference in principle. It cannot be material whether a sheriff voluntarily pays the amount of a claim of his own money, or by a voluntary breach of duty places himself in a position in which the payment can be enforced against him. An action is denied to him becanse such a practice would be not only against the rules of law, but would tend to multiply suits and increase litigation. ${ }^{3}$

"The right to enforce the execution for his own benefit has been denied him from principles of policy and the grand inconvenience which would ensue." It will be seen, from the decision from which this extract is made, that, in no case, will a sheriff who has paid a sum sufficient to satisfy the plaintiff's demand, be permitted, by taking an assignment, or otherwise, to keep alive a judgment which, but for his own negligence, he would have satisfied by levy and sale under execution." The grounds of this denial are based upon principles of public policy, and are thus clearly and convincingly stated in the same decision:

"It is not so much a question of individual right as of public policy. It is fit and proper that the judgment debtor shonld be made to pay his debts, and it is the province and business of the sheriff to whom process is issued to compel him to do so, by a proper, vigilant, and seasonable perform-

${ }^{1}$ Lintz $v$. Thompson, 1 Head, 456; ${ }^{3}$ Jones $v$. Wilson, 3 Johns. R. 484; Arnett $v$. Cloud, 2 Geo. 53; Garth $v$. Menderback $v$. Hopkins, 8 Johns. R. Campbell, 10 Mo. 154.

2 Smith $v$. Alexander, 4 Sneed, 482; Allen $v$. Holden, 9 Mass. 133; 6 Am. Dec. 46 and note; Chester $v$. Plaistow, 43 N. H. 545.

436; Whittier $v$. IIemminway, 22 Maine, 238; Beach v. Vandenburgh, 10 John. 361.

${ }^{4}$ Bigulow $v$. Prevost, 5 Hill, 566; Boren $v$ McGehee, 6 Port. 432. 
ance of his duty; but it is not discreet or consistent with just views of policy, by any inducements to encourage a lax or careless discharge of the responsible duties devolved upon sheriffs. If an officer, intrusted with the execution of final process, may, without peril of ultimate loss, select his own time for its execution, he may seriously interfere with the rights of the creditor by delaying the process to his prejudice, and he may at his option employ the same process to annoy and oppress the debtor, and to make gain to himself. Both the debtor and creditor will be in a measure subject to the caprice of the sheriff, and serious inconveniences will result, if rights either equitable or legal are held to result to a sheriff from his own breach of duty." While, no doubt, a sheriff who pays a judgment absolutely cannot afterwards use it to indemnify himself, we think the weight of authority and of reason in favor of the proposition, that he may at any time purchase the judgment and take an assignment thereof, and thereafter enforce the juclgment, especially if there bo nothing oppressive or fraudulent in his conduct. ${ }^{2}$

\& 470. Payment by Surety.-The law in relation to a surety who has paid a judgment against himself and his principal, has been thus stated in North Carolina: "The right of a surety to keep alive a judgment, which he has paid, by having an assignment made to a stranger, for his benefit, is unquestionable. When he advances the money, he has a clear equity (if he desired it), to be subrogated to the rights of the creditor, and to use the creditor's judgment for the purpose of coercing payment against the principal. Whether money advanced in such a way be an extinguishment or a purchase, seems to be a question of intention. If it be paid, and nothing be said or done to show a contrary intendment, an extinguishment will be presumed; but if an assignment be made to one not a party, so as to show a purpose to keep it alive, it is sufficient. That a party de-

${ }^{1}$ Carpenter $v$. Stilwcll, 11 N. Y. 61. Am. Rep. 489; Allen v. Holden, 9 Sherman $v$. Boyce, 15 Johns. 443; see Mass. 133; 6 Am. Dec. 46; Dunn $v$. also Reed $v$. Pruyn, 7 Johns. 426; 5 Snell, 15 Mass. 4S1; Cheever $v$. Mir. Am. Dec. 287. rick, $2 \mathrm{~N}, \mathrm{H} .37 \mathrm{G}$.

${ }^{2}$ Heilig $v$. Lemly, 74 N. C. 98; 21 
fendant furnishes the money, and that the assignment is made on a day subsequent to the advancement of the money, can make no difference, provided it was intended, at the timo it was advanced, as a purchase, and not as a payment."

No doubt the above language in no wise overestimates the rights of sureties. The doctrine of subrogation is recognized in its fullest extent in the civil law, under which " a surety paying the debt is subrogated to the rights of the creditor ipso facto." " "It is equally a settled principle in the English chancery, that a surety will be entitled to every remedy which the creditor has against the principal debtor, to enforce every security, and to stand in the place of the creditor, and have his securities transferred to him, and to avail himself of those securities against the debtor. This right of the surety stands not upon coutract, but upon the same principle of natural justice upon which one surety is entitled to contribution from another." " This right of a surety is operative against a grantee of the judgment debtor who has taken real estate subject to the lien of the judgment. ${ }^{4}$ The entry of satisfaction on a judgment collected from a surety by execution, such entry not being made at the instance of the surety, is not a sufficient ground for refusing subrogation. Whether the fact of payment is or is not apparent from the record, has no influence on the rights of the parties.

8 471. Payment by Indorser._- "There can be no cloubt that upon payment of a note or bill of exchange by a party thereto, who is not primarily liable for its payment, he becomes entitled to the possession of the bill or note, and may maintain an action upon it against any or all the prior parties thereto who have been properly charged; and if the

${ }^{2}$ Barringer v. Boyden, 7 Jones' See also Cottrell's Appeal, 23 Penn. S. Law, N. C. 187. See also Dempsey $v$. Bush, 18 Ohio S. 376.

${ }^{2}$ Sandford $v$. McLean, 3 Pai. 117; $23 \mathrm{Am}$. Dee. 773.

${ }^{3}$ IIayes $v$. Ward, 4 Johns. Ch. 123; $8 \mathrm{Am}$. Dec. 554. * McClung v. Beirne, 10 Leigh, 394. note. 496

${ }^{5}$ Baily $v$. Brownfield, 20 Penn. S. 41. For further consideration of the rights of a surety who has paid a judgment, see Fleming $v$. Beaver, 2 Rawle, 12S; 19 Am. Dec. 629, and 
contract of the party liable is merged in a judgment, the right of the person paying is to the judgment, as, but for the merger, it would have been to the bill or note. The payment by an indorser does not extinguish the liability of the maker or acceptor, and the endorser may take an assigument of any judgment which may bo recovered by tho holder, and enforce it for his own benefit."

\section{Payment by One of Several Jointly Bound.-}

Whether one of the several persons against whom a joint judgment has been recovered, may pay the judgment and still keep it on foot, by any means, or for any purpose, is a question upon which the authorities are very equally divided. In an early case in New York a decree was entered against several, withont designating the sum to be paid by each. One of the defendants paid the full amount of the decree, at the same time stipulating with plaintiff's solicitor for the right to reimburse himself. An execution being issued at the instance of the defendant who had paid, it was at first stayed; but, upon petition for vacation of this stay, the Chancellor said: "The defendant who had paid more than his due proportion, or who had paid the whole, when the same ought to be borne by the co-defendants, or some of them, was entitled to stand in the place of the plaintifi, and to use the decree for his protection and indemnity, so far as it clearly and certainly appeared that the other defendants ought to contribute." In this case the defendants were not jointly bound on any obligation made by them anterior to the decree. They were the administrators of the mortgagee, and assignees under him. Upon a bill filed against them by the mortgagor, they were required by tho decree to pay a sum named for rents and profits; but tho decree did not designate the sum to be paid by each. Ono of them paid the entire decree, to prevent "an impending execution." This decision, therefore, because the case of which it disposed differed in these material circumstances from ordinary cases resulting in a joint judgment, can hardly be considered as authority on either side of tho

${ }^{1}$ Eno v. Crooke, 10 X. I. 66; Corey ${ }^{2}$ Scribner v. Hickol, 4 Johns. Ch. v. White, 3 Barb. 12. 530. 
question. At all events, the recent decisions in the samo State, are in opposition to the general tenor of the Chancellor's remarks in Scribner v. Hickok. In the most recent case in New York, treating on this subject, Selden, J., in pronouncing the unanimous judgment of the Court of Appeals, said: "The general principles upon which this case depends, are simple and plain. Where one of several defendants against whom there is a joint judgment, pays to the other party the entire sum due, the judgment becomes thereby extinguished, whatever may be the intention of the parties to the transaction. It is not in their power, by any arrangement between then, to keep the judgment on foot for the benefit of the party making the payment. If, therefore, in such a case, a defendant take an assignment to himself, or, unless under special eircumstances, oven to a third person for his own benefit, the assignment is void and the judgment satisfied." The rule, as laid down in New York, seems to be recognized in Massachusetts, ${ }^{2}$ and is distinctly afirmed and applied in Alabama and North Carolina where the joint defendants are co-sureties. ${ }^{3}$ On the other hand, the right of any defendant to furnish money to pay tho whole judgment, and, by taking an assignment to a third person, to employ the judgment as a means of enforcing contribution from lis co-defendants, is distinctly and conficently affrmed. The right to subrogation in such cases, is said to depend only on the intention of the debtor in making the payment." "To eonstrue that as a payment which was meant to be an assignment is a contraction of terms."

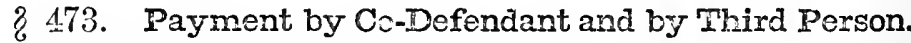

J. V., being defendant in a judgment, of which, as between him and his co-defendants, he was liable for one seventh, paid the judgment by giving the plaintiff one seventh in moncy, and a note indorsed by $\mathrm{C}$. V. for the remaining six

${ }^{1}$ Harbeek $v$. Vanderbilt, 20 N. Y. ${ }^{4}$ Coffee $v$. Tevis, 17 Cal. 239; Wheel395. Followed in Pooth v. F. \& M. N. Bank, $7 \pm$ N. Y. 228 . er's Estate, 1 Md. Ch. S0; Brown $v$. White, 5 Duteh. N. J. 516, reversing

2 Irammatt $v$. Wyman, 9 Mass. 13s. White $v$. Brown, 5 Irl. 307.

3 Preslar v. Stallworth, 27 Ala. 405; Towe $v$. Felton, 7 Jones, 216; Hinton 728.

v. Odenheimer, 4 Jones Eq. 400.

${ }^{5}$ McIntyre $v$. Miller, 13 M. \& W. 
serenths. An assignment of the judgment was, at the same time, made to J. V.'s attomey, to be held by him to indemnify C. V. for his liability as indorser of the note. C. V., having been obliged to pay the note, the question arose, whether he was entitled to enforce the judgment by execution. The court held, that if the payment of the judgment had been made by J. V. and C. V. jointly, and an assignment taken in the name of a third person, such assignment, so far as intended to protect J. V., would be roil, but as to $\mathrm{C}$. V., would be ralid; that although C. V. did not pay money, he became contingently liable to pay it, "and an assigument of the judgment to protect him against this liability, was just as legitimate and proper as it would have been to indemnify him for money paid;" and further, that as the law always presumed a lawful rather than an unlawful intent, it must be presumed, in the absence of evidence to the contrary, that the assignment was taken for the lawful purpose of protecting C. V.1

\section{PART III.-BY PROCEEDINGS UNDER EXECUTION.}

8 474. Levy on Lands.-A return of "lands delivered" on an elegit is a legal satisfaction of the judgment, ${ }^{2}$ though the debtor's interest in the land and its income is set off to the creditor at a yearly value to continue for a term of years, should the debtor so long live, and he, having only a lifo estate, die before the expiration of the term of years. ${ }^{3}$ But the nature of the proceedings, by levy and sale under execution, is entirely different from that which formerly resulted in setting off to the creditor sufficient lands of the debtor to discharge the debt. By a levy of land under execution, the creditor acquires no property in the land, absolute or conditional. Such levy, unless consummated by a sale (and then only to the extent of the proceeds realized), is no satisfaction of the judgment; ${ }^{4}$ and an action may 335.

1 Harbeck $v$. Vanderbilt, 20 N. Y. | Pratt $v$. Jones, 22 Verm. 341 ; Blum233.

${ }^{2}$ Hinesly v. Hunn's Admr., 5 Harr.

3 Thomas $v$. Platts, 43 N. H. 620; 150 field's Case, 5 Rep. $87^{a}$; Com. Dig. Execution, H.

4 Spafford v. Beach, 2 Doug. Mict. 
be prosecuted on such judgment while the levy is still subsisting. ${ }^{1}$ But it is said that the court will so control its process as to prevent the plaintiff from harassing defendant and putting him to unnecessary cost, by abandoning a levy on land and proceeding to make a new levy on other property." 2

\section{\& 475. Levy on Personal Property.-Levy upon per-} sonal property, sufficient in value to satisfy the execution, is frequently said to operate per se as an extinguishment of the judgment. ${ }^{3}$ In regard to the effect of such a levy, there is no substantial conflict of opinion, though judges have differed somewhat from one another in describing this effect and the means by which it is produced. None of the decisions assumes that a levy produces any absolute satisfaction. It is a satisfaction sub modo; the levy must be fairly exhausted before further proceedings can be taken, and while these proceedings are going on, the plaintiff camnot have another execution, nor sue on the judgment, nor redeem lands under it. ${ }^{4}$ After the levy, if the sheriff waste the property, or it is lost through his neglect, the satisfaction is absolute. ${ }^{5}$ If, without any fault of the plaintiff, or of the sheriff, the levy does not produce proceeds sufficient to satisfy the execution, then the plaintiff is entitled to proceed, for so much as remains unpaid, as if no levy had been made. ${ }^{6}$ If, after levy upon sufficient personal property, the court orders that the judgment be not enforced, the order releases the levy, but does not discharge the judg-

${ }^{1}$ Deloach v. Myrick, 6 Geo. 410; Reynolds $v$. Ex'rs of Rogers, 5 Ohio, 169; Patterson v. Swan, 9 S. \& R. 16; Beazley $v$. Prentiss, 13 S. \& M. 97; Shepard $v$. Rowe, 14 Wend. 260; Taylor $v$. Ranney, 4 Hill, 619; Ladd v. Blunt, 4 Mass. 402.

2 Trapnall $v$. Richardson, 13 Ark. 513.

${ }^{3}$ Ex parte Lawrence, 4 Cow. 417; 15 Am. Dec. 386; Wood v. Torrey, 6 Wend. 562; Carr v. Weld, 19 N. J. Eq. 319; IIoyt $v$. Hudson, 12 John. 207; Troup v. Wood, 4 Johns. Ch. 228; People v. Chisholm, 8 Cal. 29.
${ }^{4}$ First National Bank v. Rogers, 13 Minn. 407; Mountney v. Andrews, Cro. Eliz. 237; Green v. Burke, 23 Wend. 501; McIntosh $v$. Chew, 1 Blackf. 289; Bank $v$. Rogers, 15 Mínn. 381; Maxwell $v$. Stewart, 22 Wall. 77. ${ }^{5}$ Pickens $v$. Marlow, $2 \mathrm{~S}$. \& $\mathrm{M}$. 428; Ladd $v$. Blunt, 4 Mass. 402.

${ }^{6}$ Barret $v$. Thompson, 5 Ind. 457; Banta v. McClennan, 1 MeCarter, 120; Hoard $\%$ Wilcox, 47 Penn. S. 5l; Curtis v. Root, 28 Ill. 367; Mickles $v$. Haskin, 11 Wend. 125; Voorhees $v$. Gros, 3 How. P. 262; People v. IIopson, 1 Denio, 574. 
ment. ${ }^{1}$ The restoration of the property to the defendant, at lis request, or by some act for which he is responsible, prevents the levy from operating as a satisfaction, so far, at least, as his rights are concerned." When third persons, as sureties, are collaterally liable, the release of the levy cannot revive the judgment as to them $;^{3}$ and, in general, so far as the rights of third persons are concerned, the levy upon goods is a satisfaction of the judgment, to the extent of their value, unless plaintiff is deprived of the benefit of his lery without any fault of his. ${ }^{4}$ It is apparent that the satisfaction, if such it may be called, produced by a levy on personal property, is liable to be removed by a variety of circumstances. Therefore, it is probable that the tcrm "suspension" is more applicable to the efiect of such a levy than the term satisfaction. Thus, Chief Justice Bronson, in People v. Hopson (1 Denio), said: "If the broad ground has not jet been taken, it is time it should be asserted, that a mere levy on sufficient personal property without anything more, never amounts to a satisfaction of the judgment. So long as the property remains in legal custody the other remedies of the creditor will be suspended. He cannot have a new execution against the person or property of the debtor, nor maintain action on the judgment, nor use it for the purpose of becoming a redeeming creditor. The mere levy neither gives anything to the creditor nor takes anything from the debtor. It cloes not divest title. It only creates a lien on the property." the distinctions here taken show a difference in the choice of terms in which to convey the same iclea, rather than any material difference of opinion. By whaterer term we desig. nate the result of a levy on personal property, and from whatever cause that result is thought to proceed, the result remains the same, and casts upon the party who has made such a levy, before he can proceed further, the onus of establishing that, from no fault of his or of the officers, or

1 Mulford $v$. Estudillo, 32 Cal. 131.

2 U. S. v. Dashiel, 3 Wall. 6ss; Holbrook v. Champlin, IIoffm. Ch. 148; Thomas' Ex'r v. Cleveland, 33 Mo. 126; Smith v. Ilughes, 24 Ill. 270.

${ }^{3}$ Mulford $v$. Estudillo, 23 Cal. 94;

Howerton $v$. Sprague, 6t N. C. 451 .
${ }^{4}$ Lyon $v$. Hampton, 20 Penn. S. 46; Hunt $v$. Breading, 12 S. \& T. 37; 14 Am. Dee. 665 , and note.

${ }^{5}$ See also to same effect, Whiting v. Beebe, 7 Eng. 421 . 
from some act or consent of the defendant, the levy has not proved productive of a complete satisfaction.'

8 476. Discharge of a Defendant talren in Errecution. At common law, the discharge from custody of a defendant taken in execution, was a satisfaction of the judgment. If such defendant resained his liberty, no further proceedings could be taken for the same debt, unless he had escaped without the consent of the creditor, or had procured such consent through fraud. ${ }^{2}$ The debtor after lis discharge by consent could not lawfully be retaken, though he procured this consent by giving a new security, which was deferted on account of an informality ${ }^{3}$ or agreed that the judgment should be revived, or that he would pay the debt at a future day; ${ }^{4}$ or that the judgment should continue in force as security, and should be enforced by execution, if not paid. 5 The rigor of the common law was relaxed in England, in the reigns of James the First and of William the Third, by statutes anthorizing the arrest of defendant on a new exeention, if his liberty had been gained by privilege of either House of Parliament, or by eseape from prison "by any ways or means howsoever ;" and also authorizing the ereditor to sue out a new execution against the property of a debtor dying in prison. ${ }^{6}$ These statutes are supposed to be part of the common law of Massachusetts $;^{7}$ and if so; they must be equally applicable to the other English colonies in this country. Both in this country and in England, several exceptions seem to be recognized, in addition to those provided by these statutes, or existing at the earlier periods of the common law. A discharge from custoly because plaintiff refuses to pay the prison fees, is now no

${ }^{1}$ Barret $v$. Thompson, 5 Ind. 457; ${ }^{3}$ Jaques $v$. Withy, 1 D. \& E. 552; MeIntosh $v$. Chew, l Blkf. 289.

${ }^{2}$ Vigers $v$. Aldrich, 4 Burr. 24S3; King $v$. Goodwin, 16 Mass. 63; State v. Richardson, is Ala. 109; Jaques v. Witly, 1 D. \& E. 557; Porter $v$. Ingraham, 10 Mass. 88; Cattlin $v$. Kernott, 3 C. B. N. S. 796; Lambert v. Parnell, 15 L. J. Q. B. 55; S. C., 10 Jur. 31. Clarke $v$. Clement, 6 D. \& E. 525.

${ }^{4}$ Thompson v. Bristow, Barnes' notes, 205; Tanncr $v$. Hague, 7 D. \& E. 420.

${ }^{5}$ Blackburn $v$. Stupart, 2 East, 243; Coburn v. Palmer, 10 Cush. 273.

${ }^{6}$ Sts. Jac. 1, c. 13; 21 Jac. 1, c. 24; $\mathrm{S} \& 9 \mathrm{Wm}$. III, c. $2 \pi$.

` Coburn v. Palmer, 10 Cush. 273. 
satisfaction of the judgment. ${ }^{1}$ Ncither is a satisfaction produced by a discharge of the debter from custody under laws for the benefit of insolront debtors. The plaintiff may, notwithstanding such discharge, proceed to enforce 'his lien on lands of the debtor though they have been conveyed to third porsons pending the imprisonment." In Massachusetts, the discharge of a debtor, by virtue of a void recognizance, is not regurded as a discharge by consent, but as an escape, and the judgment, therefore, is not released in consequence of the arrest and liberation. ${ }^{3}$ The imprisonment of a debtor for a fine is not a discharge thereof. Therefore his release from imprisonment by the people or by the king does not discharge the fine. ${ }^{4}$

\section{477. Suspension while in Custody.-The taking of the} defendant in execution, like the lery upon sufficient goods, operates as a suspension of the judgment for the time being. ${ }^{5}$ But if there be two or more defendants the taking of one of them in execution does not suspend the plaintifi's right to take the others. He may proceed to arrest the defendants successively, and if a return of non est inventus be made as to one, the plaintiff may proceed against his bail, though the other defendants be in custody. ${ }^{6}$ All other means of enforcing the judgment are suspended. No action can be maintained on it while any of the defendants are in custody; because such action must be joint, and the judgment being, for the present at least, lischarged as to the one in prison, cannot constitute a joint canse of action. 7 But the discharge of one defendant from custody with tho consent of the plaintiff, being a satisfaction of the judgment, operates as such in favor of his co-defendants. ${ }^{8}$ If several actious be prosecuted to judgment against persons engaged

1 Prentiss $v$. Hinton, 6 Blackf. 35 ; $v$. Wade, Skin. R. 12; The King $v$. Eidden $v$. Saunders, 2 T. I. 391; Stover $v$. Dunn, 3 Strob. 413 ; Nardin $v$. Battie, 3 East. 87 ; and 5 East. 147.

${ }^{2}$ Owen $v$. Glover, 2 Cranch, C. C. 578; Strode $v$. Broadwell, 36 Ill. 419.

${ }^{3}$ Brown $v$. Kendall, 8 Allen, 209.

${ }^{4}$ State v. Richardson, 18 Ala. 109 ; Rex v. Woolf, 1 Chitty R. 401; Rex

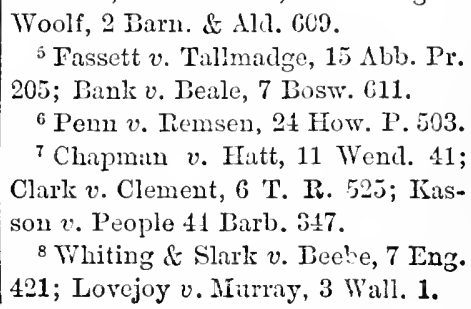

503 
in committing the same act of trespass, the discharge by plaintiff of the defendant in either judgment satisfies all the judgments. "The plaintiff in the judgment was entitled to but one satisfaction for the injury which he had sustained by the trespass committed by the defendants in the judgments, and that he has had by the imprisonment of one defendant and his discharge therefrom." An attorney at law, having no authority as such to satisfy a judgment without full payment, cannot authorize the discharge of a defendant taken in execution.2

8 478. By Sale under Execution.-In some States, a sale of property under execution, until vacated or set aside, is, to the extent of the sum realized, an absolute, irrevocable satisfaction of the judgment; and if the law provide that in case the purchaser's title, through any defect, fail, he may have an action against the defendant in execution, the rule is the same. The judgment cannot be revived. The purchaser must pursue the remedy given by the statute. $\mathrm{He}$ cannot proceed by action on the judgment. ${ }^{3}$ If the plaintifi proceed under a valid judgment but upon roid process, and thereby produce a satisfaction of his judgment, he may on account of the void character of the process, be compelled to restore to the defendiant the property taken under the execution, or to account for the proceeds thereof. In such caso it is evident that the satisfaction of the judgment has been produced without any gain to the plaintiff, or any loss to the defendant. The former may, therefore, on motion, made to the court wherein the judgment was rendered, have the satisfaction set aside, and be allowed a new and regular exceution with which to enforce his judgment. ${ }^{4}$ But the execution, judgment and sale may all be perfectly regular,

${ }^{1}$ Kasson $v$. People, 44 Barb. 347. |all eases where the defendant had

${ }^{2}$ Jackson $v$. Bartlett, 8 Johns. 361; title, and throngh some irregularity Kellogg v. Gilbert, 10 Johns. 220; $\mathbf{c}$ in the proceerlings, it was not divest. Am. Dec. 335; Simonton v. Barrell, 21 Wend. 362.

${ }^{3}$ Halcombe $v$. Loudemilk, 3 Jones, N. C. 491.

${ }^{4}$ Stoyel $v$. Cady, 4 Day, 225; Arnold $v$. Fuller, 1 Ohio, 460; Smith $v$. Reed, 52 Cal. 345. The rule mentioned in the text seems to extend to $v$. Dlunt, 4 Miass. 402. 
but the defendant may have no interest whatever in property sold. In such case if the plaintiff be the purchaser, a satisfaction is also produced without any resulting benefit to the plaintiff, or any detriment to the defendant. The question then arises, is this satisfaction irrevocable; or may the plaintiff have it vacated, and proeure a new execution? Upon this question the anthorities are quite evenly divided and are clearly irreconcilable. On the one hand, it is insisted that as "the maxim caveat emptor" applies to all purchasers at sheriff's sales," the purchaser takes all risks; and, therefore, that he cannot have the sale and the satisfaction thereby produced, vacated on account of the failure of the defenclant's title." On the contrary, it is claimed that "the doctrine of cavect emptor, has its legitimate force in precluding any idea of warranty by the defendant in exeeution, or by the sheriff;" and, therefore, that it interposes no obstacle to prevent the plaintiff from obtaining that relief to which upon principles of natural justice, he seems entitled."' The cases, as we have shown are of two classes, the first cliss comprising cases where the purehaser fails to obtain title owing to some irregularity in the exeeution or the proceodings thereunder, and the seeond elass including all those cases where the failure of title results from the fact, that the defendant had no title to be transferred. Independent of statutory provisions, it seems to be clear that the purchasing creditor is entitled to relief in cases of the first class; while of cases of the second class, nothing can be said except that the authorities are inconsistent and quite evenly balaneed, with, perhaps, a slight preponderance also in favor of granting relief. In California the Code of Procedure provides that: "If the purchaser of property at sheriff's sale, or his suecessor in interest, fail to recorer possession in consequence of irregularities in the proceedings concerning the sale, or because the property sold was not subject to execution and sale, the eourt having

${ }^{1}$ Vattier $v$. Lytle's Ex., 6 Ohio, |ner $v$. Helm, 1 Gilm. 220. But even 4S2; Freeman $v$. Caldwell, $10 \mathrm{Watts,} \mathrm{in} \mathrm{these} \mathrm{States} \mathrm{the} \mathrm{sale} \mathrm{will} \mathrm{not} \mathrm{be}$ 10; Salmond $v$. Price, 13 Ohio, 383; set aside if the defendant has some Follister $v$. Dillon, 4 Ohio St. 205; interest in the property, as when he Lansing $v$. Quachenbush, 5 Cow. 38. has the legal title subject to eertain

${ }^{2}$ Ritter $v$. Henshaw, 7 Fowa, 98; liens. Holtzinger $v$. Edwards, 51 Ia. Tudor v. Taylor, 26 Vt. 444; Adams 383. v. Snith, 5 Cow. 250; see also War- 
jurisdiction thereof must, after notice and on motion of such party in interest, revive the original judgment."1 This statute clearly provided for all cases which we have referred to as of the first elass; and it has recently been adjudged to extend over cases of the second class. In the case of Cross v. Zane, decided by the Supreme Court of that St:te, ${ }^{2}$ the plaintiff took out execution, and levied it upon lands in which defendant had no interest, and became the purchaser at the sale. On ascertaining that defendant had no interest in the property, plaintiff petitioned the court to set aside the sale and revive the judgment. The Supreme Court reversing the judgment of the District Court, which had denied the petition, said: "If the controversy here were to be determined by the application of the general principles of law, there would certainly be found to be an irreconcilible conflict between the adjudicated cases upon the point. But, as we construe the statute, the case is covered by the provision that the original judgment may be revived 'when the properity sold was not subject to execution and sale.' The statute, being remedial in its character, is to receive a liberal construction, and we think that where, as here, the property sold was not the property of the defendant in execution, but wholly that of a stranger, it amounted to a sale of property not subject to execution and sale, within the intent of the act."

8 473. Relief in Rquity afcer Sale on DreculionWhether on a purchase of lands to which defendant liad no title, the plaintiff as purchaser may obtain relief at law or not, it seems to be generally conceded that he may be relieved in equity; ${ }^{3}$ and relief has sometimes been denied at law on the sole ground that the more proper forum is a court of equity."

\& 479. Other Means of Satisfaction. --Every judgment continues in force until paid to or released by plaintiff, dis-

${ }^{1}$ See 705 Code C. P. A similar Henry v. Keys, 5 Sneed, 4S9; Price v. statute exists in Tennessee. Edde $v$. Boyd, l Dana, 436; Jones $v$. Henry, Cowan, 1 Snced, 295. ${ }^{2}$ Cross $v$. Zane, 47 Cal. 602; Seherr 293.

v. Himnelman, 53 Cal. 312.
${ }^{3}$ Warner $v$. Helm, 1 Gilm. 220;

3 Litt. 428; Muir $v$. Craig, 3 Blackf.

${ }^{4}$ Lansing v. Quackenbush, 5 Cow. 506 
Chap. XX.] proceEdings after satisfaction. ZZ179-480

charged by proceedings under execution, or under acts for the relief of insolvent debtors, or until barred by the statutes of limitation, or merged in another judgment. Plaintifi may waive his rights in one instanee without prejudicing his elaims in others. Thus, A., having two jadgments against B., sold land of the latter under the junior judgment, producing a sum more than suffieient for its satisfaction. Ho made no claim for the supplus under the lien of lis elder judgment, but permitted it to be taken by another creditor. The court held that ho did not thereby lose his judgment, but might proceed to satisfy it out of B.'s other property. ${ }^{1}$ If the defendant deliver to the plaintiff a promissory note of third parties, iin satisfaction of the judgment which note is void because frandulently obtained, it is not necessary for plaintiff to return the note before taking out execution. ${ }^{2}$ If an entry of satisfaction on the record was made in consideration of a note which, by mistalie, was for too small a sum, an action may be sustained for the unsatisfied part. ${ }^{3}$

\section{PART IV.}

\& 480. Proceedings after Satisfaction. - While the courts have generally protected all third persons, acting bona fide and withont notice, on their confidence in judicial records, from "all secret vices and infirmities" in the proceedings of the conrts or of their offeers, this protection, it seems, has not been extended so as to shield purchasers from the perils of secret satisfactions of judgments. Tho laws usually, if not universally, provide that the entry of satisfaction may be made on the docket, and that the execition with a memoranda of the proceedings under it shall be returned to court, and thus lead purchasers to expect that if, from an examination of the dockets and papers on file in the case, no release or satisfaction of the judgment is disclosed, that none, in fact, exists. Principles of public policy are said to require that bidders at judicial sales should have confidence in the titles there to be acquired; and that, in order to create such confidence, they should

\section{5.}

1 Bank of Penn. v. Winger, 1 Raw. 
not be prejudiced by any defect not known to them, nor discoverable by examining the record. Therefore, it seems that good faith toward purchasers, as well as the principles of public policy recognized and enforced for the benefit of the whole community, demands that purchasers and other third persons acting in good faith should not be injured through secret releases, in order to preserve the interests of those persons whose negligence in not making those releases apparent on the record, produced the mistake of fact under which the purchaser acted. Nevertheless, we havo the authority of many cases showing that a sale or other proceeding under a satisfied judgment is void under all circimstances. ${ }^{1}$ The reasoning on which these cases are based was thus stated by the Court of Appeals of the State of New York: "The judgment was the sole foundation of the sheriff's power to sell and convey the premises, and if the judgment was paid when he undertook to sell and convey, his power was at an end, and all his acts were without authority and void. The purchaser under a power is chargeable with rotice, if the power does not exist, and purchases at lis peril." " There are, however, a few authorities tending to establish the proposition that a sale under a judgment satisfied in fact, but not of record, is valid if made to a stranger to the execution having no notice actual or constructive of its satisfaction. ${ }^{3}$

1 Swan $v$. Sadalemire, 8 Wend. 676; N. Y. 61; Laval $v$. Rowley, 17 Ind. 36. Lewis v. Palmer, 6 Wend. 3cs; Wood ${ }^{2}$ Craft $v$. Merrill, 14 N. Y. 4.56. v. Colvin, 2 Hill, 566 ; State v. Sal- ${ }^{3}$ Morton v. Grenada, 8 S. \& II. 773; yers, 19 Ind. 432 ; Neilson $v$. Neilson, Doe v. Ingersoll, 11 Id. 249; Banks $v$. 5 Barb. 565; Hammatt v. Wyman, 9 Evans, 10 Id. 35; Jackson v. Cadwell, Blass. 138 ; Carpenter v. Stillwell, $11 \mid 1$ Cow. 622.

508 


\section{CHAPTEP XXI.}

\section{REVERSED JUDGMENTS.}

\$481. Effect of Reversal.

$\S 482$. Restitution between the Parties.

483. Cases denying Fiestitution between tho Partles.

$\$ 484$. Cases denying Restitution from third persons.

8. 481. Effrect of.-The reversal of a judgment by any competent authority, restores the parties litigant to the same condition in which they were prior to its rendition. The judgment reversed becomes mere waste paper; and the parties to it are allowed to proceed in the court below to obtain a "final determination of their rights," in the same manner, and to the same extent, as if their cause had nerer been heard or decided by any court. ${ }^{1}$ Neither, in the subsequent prosecution of the cause, can suffer detriment, nor receive assistance from the former adjuclication. If a judnment of reversal be reversed by a superior tribumal, this last reversal reinstates the original judgment. ${ }^{2}$ A reversal by agreement, or upon confession of errors, is as potent as though it were the result of the most persistent litigation. ${ }^{3}$ A judgment having been recovered in a justice's court, tho defendimt paid it; but, afterwards, he appealed and obtained a reversal, on technical grounds, by which he was awarded restitution and his costs of appeal. He did not collect the sum to which he was entitled under the juclsment of restitution. The plaintiff commenced another action for the same cause. The defendant then pleaded, as a bar, the former judgment and its payment. The court held that, by the proceedings on appeal, in the first suit, the judgment therein had been extinguished; that the payment

${ }^{1}$ Ragan $v$. Cuyler, 24 Geo. 400; Stearns $v$. Aguirre, 7 Cal. 443; Phelan French $v$. Edwards, 4 Saw. C. C. 125. v. San Trancisco, 9 Cal. 16; Mead $v$.

${ }^{2}$ Simmons $v$. Price, 18 Ala. 405; Mead, 18 Barb. 57s. Argenti $v$. San Francisco, 30 Cal. 45s; ${ }^{3}$ Marhee $v$. Collins, 27 Ind. 83. 
made in the former suit was on the judgment, and not on the antecedent debt; that such debt was still in force, unafiected by the reversed judgment and its payment; and that the defendant could plead his judgment, obtained on appeal, as an off-set, but not as a bar, in the present action. ${ }^{1}$

\section{432 . Restitution between the Parties.-Upon the re-} versal of the judgment against him, the appellant is entitled to the restitution, from the respondent, of all the advantages acquired by the latter by virtue of the erroneous judgment. The successful appellant is entitled to a restitution of everything still in possession of his adversary, in specie; not the value, but the thing. ${ }^{2}$ If money has been collected by the plaintiff in the judgment, under execution, an action lies against him to recover it back. ${ }^{3}$ The statute of limitations commences running in relation to such actions in favor of respondent from the time of the reversal.4 If the plaintiff purchases the property of the defendant at a sale under a judgment or decree, his title will be defeated by a subsequent rerersal. ${ }^{5}$ But a subsisting judgment, though afterwards reversed, is a suflicient justification for all acts done by plaintiff in enforcing it, prior to the reversal. Thus if the defendant be taken in execution, the subsequent reversal of the judgment will not render the plaintiff liable to an action for false imprisonment. For the act of imprisonment, when directed by the plaintiff, was sanctioned by a then valid judgment. ${ }^{6}$ But the plaintiff on the reversal is liable to an action to recorer the damages occasioned by a sale of the defendant's property made under the judgment prior to its reversal. Trhere the plaintiff has purchased the property and still has it in his possession, the defendant may, at his election, affirm the sale and have his action for damages. An assignee of a judgment is not a stranger thereto. If he take out execution and sell the defendant's property, and become the purchaser thereof, and the judgment be subsequently reversed, he stands in a no better posi-

${ }^{1}$ Close $v$. Stuart, 4 Wend. 95.

${ }^{2}$ Gott v. Powell, 41 Mo. 416; Bickett $v$. Garner, 31 Oh. S. $2 S$.

${ }^{3}$ Raun $v$. Reynolds, 18 Cal. 275.

${ }^{4}$ Crocker v. Clements, 23 Ala. 296. nolds $v$. Harris, 14 Cal. 667; Twogood v. Franklin, 27 Iowa, 239; Marks v. Cowles, 61 Ala. 299.

${ }^{5}$ Gott v. Powell, 41 Mo. 416; Rey53.

${ }^{6}$ Simpson $v$. Horenbeck, 3 Lansing,

510 
tion than the original plaintiff in like circumstances. As against such assignee, the defendant may recover possession of the property parchased; or, ratifying the sale may recover the value of the property affected thereby. ${ }^{1}$ If a suit be brought to foreclose a lien, and another lien holder be made a party defendant, and assert his claim by cross bill, and a decree be entered under which a sale is made to the defendant lien holder, who pays the money into court, and the money is thereupon distributed by the court among all the lien holders according to their priorities, such purchaser, though a party to the suit, is protected in his purchase, from a subsequent reversal of the decree. ${ }^{2}$

\section{483. Cases Denying Restitution between the Par-} ties.--We have stated in the preceding section, that a plaintiff purchasing at a sale under his own execution, is liable to the loss of the property thus bonght, upon the reversal of his judgment. This statement, we believe, is fully supported by the present state of the authorities. While the decisions directly in point may not be numerous, the expressions made in a large number of cases show that the opinion of the juclges has been nearly unanimons to the effect that the plaintiff cannot, after the reversal of his judgment, retain the property of the defendant acquired after such judgment. But the case of Parlier v. Anderson (5 T. B. Monr. 455), ${ }^{3}$ decided in Kentucky, nearly half a century ago, is authority to show "That the parties to a judgment or decree are, equally with all others, at liberty to bid and purchase property exposed for sale under a judgment or decree, and there is the same reason for protecting the same interests acquired by a party under a purchase as that of a stranger." The doctrine thrus laid down has recently been recognized and reasserted by Justice Field, of the Supreme Court of the United States, in a case decided by him in the Ninth Circuit. In this caso he said, "Expressions were cited from various opinions of difierent judges, to the effect that, by the reversal, the defendant or unsuccessful party in the court below is to

\footnotetext{
${ }^{1}$ Reynolds $v$. Hosmer, 45 Cal. 630; Reporter, 526. This rule can not apMeJiton $v$. Love, 13 Ill. 486. ply where the judgment is reversed 349.

${ }^{2}$ Miurnhy $v$. Longworth, 14 Ohio S.

${ }^{3}$ See also Gossom $v$. Donaldson, 18 valid judgment: Smith $v$. Bohon, 12 B. Mour. 230; Yocum v. Foreman, $7 \mid$ Bush Ky. 448 .
} 
be restored to all things which he lost by the erroneous judgment or decree, and that protection is afforded to strangers at judicial sales in order to encourage bidding. Expressions of this kind may be very just and appropriate in connection with the principal facts of the special cases in which they are used; but they do not express a rule applicable in all cases, or furnish the true reason for the protection extended to purchasers at judicial sales. The principle that the defendant or unsuccessful party in the court below is to be restored to all things which he lost by the erroneous judgment or decree, cannot apply to those tiaings the title of which may be transferred by proeeedings taken for the enforcement of the judgment or decree when its enforcement is not stayed pending the appeal. The restoration in specie in such cases being impossible without infraction of the principle by which judgments of courts are upheld and enforced, it follows that the right which the reversal gives must be that of action to recover an equivalent for the lost thing. And perhaps the rule may be stated thus: That the defendant or unsuccessful party in the court below is to be restored, by reversal, to all things which he lost by the erroneous judgment or decree, if the title to them has not passed by the previous enforcement of the judgment or decree, and in such case he is to have a right of action for a money equivalent. The rule, as thus stated, would leave the parties to take advantage of the proceedings for the enforcement equally with third persons. There is no reason why they should not have the same protection extended to them as to strangers. The judgment or decreo is equally binding upon all, and should be equally efficacious for protection. When the judgment or decree directs a sale of property of the defendant, it may be regarded as a power of attorney to the officer charged with its execution created by the law, and, like any other power, suficient to give validity to the acts of the officer until the power is revoked by the reversal. There is no prohibition in the law, or objection in the reason of the thing, against a party taking advantage of the proceedings had for the enforcement of the judgment which he has recovered. Strangers are protected, not because a contrary rule would discourage bidding, but 
because they have a right to rely upon the validity of the judgment, and invole its protection for all acts done under it whilst it is in foree, and for the rights they have acquired thereby." Judge Field then proceeded to quote at length from the opinion of the court in Parker v. Anderson, and added after such quotation, that "With the views thus forcibly expressed we fully concur." "

8 431. Restitution from Third Persons.-The law permits judgments and decrees to be enforced, during the time in which appeals may be taken, and also while appeals are pending and undetermined, unless some bond or other security given as required by law, operates to stay the proceedings. Courts have always construed the law so as to impart confidence in judicial sales, by protecting purchasers thereat, from those ill consequences which the latter might suffer if the title acquired by them depended upon the frreedom of prior proceedings from all errors of law. It was thought to be unjust to require purchasers to suffer for errors committed by the judges of the subordinate courts, and impolitic, by making such a requirement, to discourage bidders at such sales, and thereby to expose large amounts of property to the hazard of being sacrificed at. nominal prices. Thereforo, it is a rule, nowhere disputed, that third persons purchasing at a sale, made under the authority of a judgment or decree, not suspendeil by any stay of proceedingss, thereby acquire rights which no subsequent reversal of such judgment or decree can, in any respect, impair. ${ }^{2}$

1 South Fork Canal Co. v. Gordon, Md. 25; Feaster v. Fleming, 56 IIl. 2 Abb. U. S. 479, 483. Judge Field, 457; Fergus $v$. Wool worth, 44 Inl. 37 ; by whom the abore ease was decided, Ward $v$. Hollins, I4 Mil. 15s; Stroul has since in Galpin $v$. Page, deter- $v$. Casey, $55 \mathrm{Tex} .710$; Stinson $v$. Noss, mined by the Supreme Conrt of the 51 Me. 556; Jesup v. City Bank, 15 U. S., at Oct. Term, 1873, shown Wis. 604; Taylor v. Laner, 26 La. An. that he is fully conscious that the 307; Marlss v. Cowles, 61 Ala. 24; princples annonneed by him, and Wood v. Jackson, 22 Am. Dec. 608; quotul above in the text, are against Lesslie $v$. Richardson, 60 Ala. 563; the weight of the anthorities:

2 Reynolds $v$. Harris, 14 Cal. 667; Farmer v. Pogers, 10 Cal. 335; Hubbell $v$. Broadwell's Heirs, 8 Ohio, 1:0; Hanschild $v$. Stafford, 27 Iowa, 301; Frost $v$. MicLeol, 19 La. An. 69; Lov. ett $v$. German Reformed Church, 12 Barb. 67; Coster $v$. Peters, 7 Rob. 386; 4 Abb. Pr. N. S. 53; Pitfield $v$. Gazzam, 2 Ala. 325; Gott v. Powel!, 41 Mo. 416; Dorsey $v$. Thompson, 37 ] 
Nor is the fact that the purchaser was notified not to purchase, because the judgment was claimed to be erroneous, and that an attempt would be made to procure its reversal, of any consequence. ${ }^{1}$ In Illinois, while it is conceded that the purchase by the plaintiff in the judgment, is subject to be annulled by a subsequent reversal, the assignee from plaintiff, of the certificate of purchase, under an assignment made before any reversal, is held to occupy as favorable a position as if he, instead of being an assignee, were the original purchaser at the sale. ${ }^{2}$ Such also is the rule in Missouri: "The purchaser in such cases must be regarded as a purchaser without notice, since he buys from a party who derives title from a judgment and execution valid at the time, and really occupies the same position as if lie hal himself bought at the sheriff's salo. Whilst, therefore, the title of the plaintiff in the execution would be anuulled by the reversal of the judgment, the sale or conveyance by the plaintiff to a third person before the reversal of the judgment would be valid, and the purchaser, supposing the purchase to be in good faith, would be protected from the risks which his vender would be subject to." 3 On the other hand, after a very thorough consideration, this question has received an entirely different answer from the Supreme Court of Alabama." This court very justly concluded that " the right of a party aggrieved by an erroneous judgment, to a restoration to the condition in which he was when it was rendered, would bo of little avail, if through the mechanism of an alienation to a party bound to know that the right exists, it conld be defeated;" and the court shows by the common livw authorities that upon the reversal of a judgment lands extended upon elegit were revested in the defondant, though the plaintiff had in the mean time sold and conveyed to a stranger. ${ }^{5}$ The rule which protects strangers purchasing at judicial sales, from

${ }^{1}$ Irwin $v$. Jeffers, 3 Ohio S. $399 . \quad 3$ Oh. 337; 17 Am. Dec. 603; McAus-

${ }^{2}$ Guiteau $v$. Wiseley, 47 Ill. 433; land $v$. Pundt, 1 Neb. 211.

Horner $v$. Zimmermall, 45 Ill. 14; Wadliams $v$. Gay, 73 Inl. 422.

"Vogler $v$. Montgomery, 1 C. L. J. 65; 54 Mo. 577; McCormick v. McClure, 6 Blackf. 466; Taylor v. Boyd,

${ }^{4}$ Marks $v$. Cowles, 61 Ala. 299.

${ }^{5}$ Goodycre $v$. Ince, Cro. Jac. 246; Bryant v. Fairfield, 51 Me. 154; De. lano $v$. Wilde, 11 Gray, 17.

514 
the loss of title by a reversal of the judgment, was doubtless adopted from considerations of public policy, which required that such strangers should be encouraged to bid, and the danger of the sacrifice of the debtor's property by a sale for less than its value thereby dimiuished. This object is in no respect promoted by an extension of the rule to purchasers who do not bid at the forced sale. Neither the interests of the community in general, nor of the class whose property is to be sold under execution, can be in any degree shielded from sacrifice by this extension, which, after the sale has been made, and the sacrifice has been realized or avoided, merely authorizes the purchaser to transfer a better titlo than he ever acquired.

In Iowa, a statute provides that property acquired by a bona fide purchaser, shall not be affected by a future reversal of the judgment. A purcliase at an execution sale having been made by the attorney of the plaintiff, and the judgment being afterwards reversed, the question arose whether an attorney of the plaintiff could be a bona fide purchaser within the meaning of the statute. The court held that "a purchase of land at a sheriff's sale by the plaintiff in execution or his attorney, with actual knowledge of the pending appeal, is at the peril of the purchaser, and the party or his attorney thus buying is not within the meaning of the statute a bona ficle purchaser." It is further intimated by the judge delivering the opinion of the court, that he doubts whether any person having notice of a pending appeal, is protected by this statute as a bonc fide purchaser. This statute is, undoubtedly, a mero declaration of the previous common law rule; and, like that rule, was adopted from a conviction of the policy of encouraging bona ficle bidding at involuntary sales. The fact of notice of the pendency of an appeal, therefore, can not be material in determining whether a purchaser should be protected by the statute. The taking of an appeal is a matter always easily ascertained by an examination of the papers on file in the clerk's office; and, if knowledge in relation to this fact affected the rights of purchasers, no hardsh'p would result from requiring them to make snch an examination. But the greater the number of persons having information of

${ }^{1}$ Twogood v. Franklin, 27 Iowa, 239. 
the appeal, the fewer, according to the views of this judge, would be the number qualified to becomo bona fide purchasels, and the greater would be the diminution of that competition which the statute was, no donbt, desigued to enconrage. We can see no reason why an attorney may not be a bona ficle bidder. If no stay of execution is procured by the defendant, the sale may, at the option of the plaintiff, proceed, though an appeal be taken and every person in the State notified of that fact. The interests of defendants in general require that everybody may bid. If the attorney is prohibited or discouraged from bidding, the defendant is thereby injured by the decrease in competition. If an attorney complies with his bid, by payment out of his own funds, on what grounds is it less a bona ficle bid than if made by some other person? The title of plaintiff is held to be liable to be divested by a reversal, because lis purchase is paid for by a judgment which he onght not to have had, and because it is neither just to the defendant, nor conducive to a good public policy, that the advantages secured by an erroneous adjudication should be longer retained. But an attorney who has paid the amount of his bid, with or without notico of an appeal, stands in a different position from that of a party to the suit, and in a similar position to that of a third person purchasing; and he ought, therefore, to be subjected to none of the perils visited on the former, and entitled to all the privileges secured by law to the latter. It is clear that an attorney is as much affected by the irregularity of process which he takes out as his client is, and that if the irregularity be such as to avoid a sale made to the client, it will equally avoid a sale made to the attorney.' On this ground it has been assumed to be, and probably is, well settled that the plaintiff's attorney, if a purchaser at the sale, is liable to lose his title by the reversal of the judgment. ${ }^{2}$ But notwithstanding these decisious we can not avoid thinking that there is a vast difference between an irregularity, in which an attorney participates, and a perfectly regular proceeding, in which the only vice is an honest error of law made by the court; and that this difference ought to lead to a corresponding difference in the law applicable to the two cases.

${ }^{1}$ Simonds v. Catlin, 2 Cai. 63.

${ }^{2}$ Stroud v. Casey, 25 Tex. 754; Galpin v. Page, 18 Wall. 350. 516 


\section{CHAPTER XIII.}

\section{IELIEF IN EQUITY, FROM JUDGMENTS AND DECREES.}

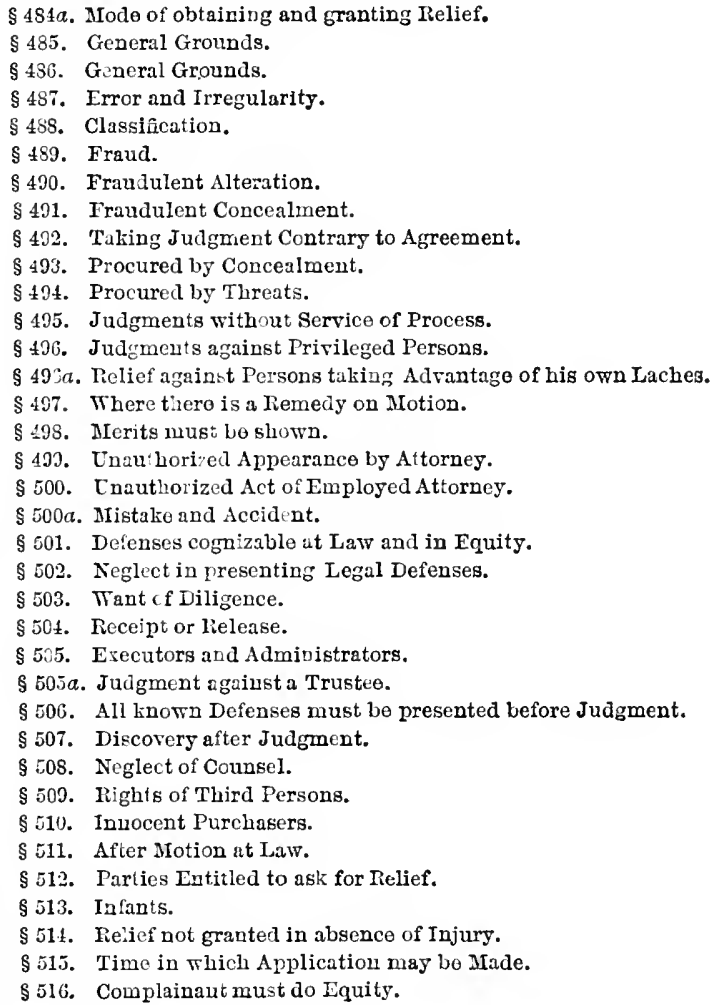

¿ 481a. Mode of Obtaining and Granting Relief.-The judgment or decree against which relief is sought may be eitber: 1. A judgment in some criminal prosecution, imposing a fine or other punishment; 2, a decree in equity, or 3 , a judgment at law. In the case of a criminal prosecution, equity will rarely, and wo think will never, interpose. ${ }^{1}$ In the case of a decree in equity the court may set it aside

${ }^{1}$ Lord Montague $v$. Dudman, 2 Ves. Ala. 198; Stuart v. Supervisors, 83 Sr. 396; Holderstaffe $v$. Saunders, 6 Ill. 341; Tyler $v$. Hammersly, 44 Mod. 16; Gault v. Wallis, 53 Geo. Conn. 419. 675; Moses $v$. Hayor of Mobile, 52 
during the term in which it was entered. ${ }^{1}$ If, howerer, the term has expired and it is sought to impeach tho decree for fraud, collusion, and the like, the remedy is by an original bill in the nature of a bill of review, which may bo filed withont leave of the eourt $;^{2}$ or if the party injured be an infant he may proceed "either by a bill of review, or supplemental bill in the nature of a bill of review, or he may so proceed by original bill." 3 If relief is based upon the ground of newly diseovered evidence, it must bo sought by bill of review. ${ }^{4}$ If it is a judgment at law against which relief is elaimed, the remedy at chancery is by original bill, ${ }^{5}$ in the nature of a bill of review, though aceording to somo of the authorities the bill is not considered an original bill unless it brings parties before chancery in addition to the parties to the judgment at law. ${ }^{6}$ The jurisdiction of equity to interfere in any way or to any extent with proceedings at law, though it excited the jealousy of the eommon law judges, and was hotly contested, has been well established for nearly three centuries. ${ }^{7}$ The interference is, however, in all eases indirect. The judgment is not eanceled nor vacated, nor is the court of law nor its judge enjoined from proceeding, nor is a new trial granterl in express terms. The court of equity acts exelusively upon the person of the adverse party by preventing him from making an inequitable use of his judgment. Sometimes he is restrained absolutely, and sometimes the injunetion enjoins him from proceeding unless he first submits to a new trial at law. ${ }^{8}$ The

${ }^{1}$ Doss $v$. Tyack, 14 How. U. S. 297. | Beav. 457; 2 De G. J. \& S. 373, 417.

2 Daniell's Ch. Pr. 4th Am. ed. pp. 974,1584 , and 1585, citing Loyd $v$. Mansel, 2 P. Wins. 73; Sheldon $v$. Fortescne, 3 P. Wms. 111; Davenport $v$. Stafford, \& Beav. 503; 9 Jur. 801; Evans v. Bacon, 99 Mass. 213; Pateh v. Gray, L. R. 3 Ch. App. 203; Ex parte Smith, 34 Ala. 455; Pearson $v$. Nevitt, 32 Miss. 180; Edmondson $v$. Moseby's Heirs, 4 J. J. M. 501; Terry v. Commercial Bank, 92 U. S. 454.

${ }^{3}$ Daniell's Ch. Pr., 4th Am. ed. pp. 164, 173, citing Riclmond $v$. Tayleur, 1 P. Wms. 737; Carew $v$. Johnson, 2 Sch. \& L. 292; Brook v. Mostyn, 10 Jur. N. S. 554; 13 W. R. 115; 13 518
* See note to Brewer v. Bowman, $20 \mathrm{Am}$. Dec. 160; Commolly v. Con nolly, 9 Reporter, 830 .

5 Story's El. Pl., sec. 426; Mussel1 v. Morgan, 3 Bro. Ch. 79; Bennett v. Hamill, 2 S. \& Lef. 576.

${ }^{6}$ Denn v. Clarke, 8 Pet. 1.

7 See Spence's Ch. Jur., vol. 1, p. 673-675; note to Oliver $v$. Pray, 19 Am. Dec. 608 .

8 Sancey $v$. Downer, 5 Litt. 8; 15 Am. Dec. 35 and note; Hunt $v$. Boyier, 1 J. J. M. 4St; 19 Am. Dec. 116; Gainty $v$. Russell, 40 Conn. 450; Floyd $v$. Jane, 6 Johns. Ch. 4S9; Banks v. Shain, 6 Litt. $4 j l$. 
mode and extent of the relief may bo varied, according to the circumstances of the case, to make the remedy both efficient and equitable. While it is true, that the authority now given by statute to courts of law, to grant new trials, has very nearly dispensed with the necessity of resorting to chancery for that purpose, still instances occasionally oceur in which no application for a new trial is made in the original action, or if made, it was not disposed of on the merits, owing to the operation of some canse which is generally regarded as sufficient to invoke with success the aid and protection of courts of equity. In theso instances chancery still has power to afford relief by requiring tiro snccessful party to submit to a new trial.' In some very peculiar cases a new trial has been decreed because tho evidence of the facts constituting the complainant's defense, was not discovered until after the entry of the judgment at law and the lapse of the time in which he could then move for a new trial. ${ }^{2}$ In some of the States, a new trial will be directed in equity, on the ground of newly discovered evidence, if the complainant was, when sued at law, acting in a representative capacity without any personal knowledge of the facts constituting his defense; ${ }^{3}$ or when the plaintin must. have known his demand to be unconscionable, as where, knowing that he had been paid in full, he obtained judgment because of the temporary inabidity of the defendant to find his receipt." Bills in equity for new trials havo been sustained where it was shown that the jury harl been tampered witli, where the party was " taken by surprise, and evidence was produced at the trial which he could have no reason to expect would be produced;"' where the cause

${ }^{3}$ Carrington $v$. Holabird, 17 Com. 530; $19 \mathrm{Id} .84$; Howe $v$. Martell, 28 Ill. 445; Shepard $v$. NeIntyre, 5 3S1.

Dana, 5i6; Mulford $v$. Cohn, is Cal. 42; Bootl $v$. Stamper, 6 Geo. 172; Deputy $v$. Tobias, 1 Blackf. $311 ; 12$ Am. Dee. 243.

${ }^{2}$ Deputy v. Tobias, 12 An. Dee. 243; Peagram v. Fing, 2 Hawls, 605; 11 Am. Dee. 793; Cox $v$. Mobile, 44 Ala. 611; Ilarvey $v$ Seashol, 4 W. Va. 115; Barrett $v$. Floyıl, 3 Call, 531;

Vathier $v$. Zane, 6 Gratt. 246.
${ }^{3}$ Hewlett $v$. Hewlett, 4 Lilw. Ch. 7; Gardiner $v$. Sowling, 12 Giil \& $J$.

1 Vildey $v$. McConnell, 63 Ill. 28s; Biggins v. Broekman, Id. 316: Gardincr $v$. Eowling, 12 Gill \& J. 381.

${ }^{5}$ Lawless 2 . Reese, 3 Bibi, 486; Cummins $v$. Kennedy, 4 J. J. MI. C.5. ${ }^{6} \mathrm{Ch}$. Pr. vol. 1, p. 457; 3 G. \& Wat. on N. T. 1531; Sneed v. Town, 4 Eng. 5335; Gibbs $v$. Hooper, 2 Miylne \& K. 353 . 
was unexpectedly set for trial at a special term of cont of which complainant had no knowledge;' when the verdict of the jury was given under a mistake on their part; ${ }^{2}$ where the successful party, through some fraudulent device or misrepresentation, prevented his adversary from attending at the trial, ${ }^{3}$ and where the judge at law was disqualified by reason of interest. ${ }^{4}$ In one instance a new trial was granted because the complainant had by some mistake of the clerk of the court failed to give a proper bond, whereby his right of appeal was lost. ${ }^{5}$ In the case of Hoskins $v$. Hattenback, 14 Ia. 314, it appeared that Hattenback sued Hoskinsin October, 1859, in trespass, and recovered judgment for two thousand four hundred dollars. In October, 1860, Hoskins filed a bill for a new trial, in which he averred that the chief issne in the former action was whether an alleged purchase by Hattenback of certain goods from Hememan \& Gambert was fraudulent as against creditors; that ho succeeded at the trial in proving a frandulent purpose on the part of the clebtors, but could not show that Hattenback had lnowledge of the frand; that he used every means in his power to obtain evidence of such knowledge; that he discovered one witness, who stated that he would swear to facts which would clearly establish such knowledge, but that the witness, at the trial, surprised complainant by swearing to a different state of facts, and thus leaving him without evidence; that complainant could not discover other evidence in time to move for a new trial; that on September 17, 1860, complainant discovered that one Godfret Hatten back would testify that the plaintiff in the former suit told him, witness, that plaintiff was to get two thousand dollars for his trouble and services; that the debtors, H. \& G., were to get the balanee; that they told said plaintiff, at the time of the sile, that they wero in debt, and wished to sell to prevent their creditors from collecting their demands. A demurrer was interposed to this bill, in the consideration of which

1 Joslin v. Coffin, 5 How. Miss. 539 .

${ }^{2}$ Cochran v. Street, Wythe, 60; Rust $v$. Ware, 6 Gratt, 50; Woods $v$. Macrae, Wythe, 78 .

${ }^{3}$ Land v. Elliott, 1 S. \& Mr. $60 \mathrm{~S}$;

Chambers $v$. Handley, 4 Bibb, 234.
${ }^{4}$ Milnor \& Co. v. G. R. R. \& B. Co. 4 Geo. 355.

${ }^{5}$ Ohiver $v$. Pray, 4 Oh. 175; 19 Am. Dec. 505 . 
the court, by Wright, Judge, said: "But does the bill show suficient to anthorize a court of equity to grant a new trial? The text-books anc cases are full of learning on this subject. Withont, however, entering into the discussion, we state such general propositions as are necessary to the determination of the case before us. In Colyer $v$. Laugfort's Aclministrator, 1 A. K. M.Iarsh. 174, it is said that: "In general, where it is proper for a court of law to grant a new trial, if the application is male while that court lias anthority to do so, it is equally proper for a court of equity to grant a new trial, if the application be made on grounds arising after the court of law had ceased to have power to do so." That case wals not unlike this, and is sustained by Depnty $v$. Tobias, 1 Blackf. 311 [12 Am. Dec. 243]. In Dalance v. Loomis, 22 11l. 82, Walker, J., uses this language: 'If it appears that the judgment complained of is unjust, and that the party in good faith has used, or attempted to use, all the meaus given him by law to assert his rights, by activo efforts on lis part made in good faith, and to the extent that a party has it in his power to use, but has, nevertholess, been prevented from presenting his defense to the claim, equity should grant a new trial at law.' And seo Story's Eq. Jur., sec. S87. In this case, the testimony of the witness referred to could not have been obtained at the trial. It consists of declarations or admissions made by Hattenback long after that time. Of its materiality there can be no room for doubt. As to its effect or weight, of conrse, it is not for us to speak, further than to remark, that, if the witness shall be credited by the jury, then, according to the averments of the bill, complainant's defense would be complete, and a different verdict would be foumd."

8 485. Grounds of Pelief in General. - In respect to the general grounds upon which the interposition of conrts of equity may be successfully invoked to obtain relief from judgments or decrees, there seems to be a perfect unanimity of opinion. The actual adjudication of any question is in fact fural, under all circumstances, unless corrected by somo appellate tribunal; and is uever subject to re-examination in any other than an appellate court, mpon any issuo of law 
or of fact, nor upon the sole ground that the former decision is contrary to equity or good conscience. It is always a condition precedent to the proper action of a court of equity, in interfering with a judgment or decree not before it upon appeal, that facts be disclosed establishing that the matter now in the form of an adjudication, is, in truth, without any fault of the party seeking to avoid its effect, a determination in which he could not present his cause of action, or his grounds of defense, as the case may be, to the consideration of the court. These principles can be best illustrated and supported by reference to some of the opinions expressed by the lighest authorities both in England and in the United States.

"I do agree the court ought to be very tender how they help any defendant after a trial at law in a matter where such defendant had an opportunity to defend himself." 1 According to the opinion of Lord Redesdale, "The inattention of parties in a court of law, can scarcely be mado the subject of interference in a court of equity. There may be cases cognizable at law, and also in equity, and of which cognizance cannot be effectually taken at law, and therefore equity sometimes interferes; as in cases of complicated accounts where the party has not made lefense because it was impossible for him to do so effectually at law. So, where a verdict has been obtained by fraud, or where a party has possessed himself of something, by means of which he has an unconscientious advantage at law, which equity will either put out of the way, or restrain him from using it." "The rule allowing parties to appeal to chancery against a judgment in any court is of great strictness and inflexibility; and it is necessary that it should be so, as otherwise the jurisdiction of that court would soon supplant all other tribunals. A court of equity, therefore, will not lend its aid unless the party claiming its assistance can impeach the judgment by facts, or on grounds of which he could not bave availed himself at law, or was prevented from doing it by fraud, or accident, or the act of the oppo-

$1 \mathrm{By}$ the Master of the Rolls in ${ }^{2}$ Bateman $v$. Willoe, 1 Scl. \& Lef. Gainsborough $v$. Gifford, 2 P. Wms. 201. 424 . 
site party, unmixed with negligence or fault on his own part." "When a party has once an opportunity of being heard and neglects to do so, he must abide the consequences of his neglect. A court of equity cannot reliere lim though the judgment is manifestly wrong." " "Tho general rule is, that where there is a defense at law chancery will not grant relief, unless complainant can show that, owing to particular circumstances, not arising from his own neglect or inattention, he has been deprived of the benefit of his defense at law." ${ }^{3}$ The general rule is, that relief will not be "granted against a judgment at law, on the ground of its being contrary to equity, unless defendant was ignorant of the fact in question pending the suit, or it conld not have been received as a defense, or unless he was prevented from availing himself of it by fraud or accident, or the act of the opposite party, unmixed with negligence or fraud on his part." ${ }_{4}$

\% 496. General Grounds of Relief- While the courts of equity in England, and in the several States of this Union, have uniformily refused their aid in all cases where their action would involve either the usurpation of appellate jurisdiction, or the granting of a second opportunity of presenting a cause upon its merits, they have, on the other hand, uniformly extended their beneficent principles and their varied and efficient means of relief over a large and well defined class of cases, to the end that no man should retain an unconscientious advantage procured by him, in a conrt of law or of equity, through his own fraud, or through some excusable mistake or unavoidable accident on the part of his adversiry. The jurisdiction of courts of equity "to set aside a decree obtained by fraud, in an original

1 Watts $v$. Gayle, 20 Ala. 817; Little $v$. Price, $1 \mathrm{H}$ 'd. Ch. 182; Emerson $v$. Udall, 13 Vt. 477; Pettes $v$. Bank of Whitehall, 17 Vt. 135; Windwart $v$. Allen, 13 I'd. 196; Lafon v. Desessart, 1 IIart., N. S. 71; Benton $v$. Roberts, 3 Rob. La. 224; Ponder $v$. Cox, 26 Geo. 485; Viller $v$. Morse, 23 v. Mich. 365; Lester $v$. Hoskins, 26 Ark. Lins, 26 Ark. 63.

63; Alford $v$. Moore, 15 W. Va. 597.

2 York $v$. Clopton, 32 Geo. 362.

3 Cunningham $v$. Caldwell, Hardin, 131.

4 Kinney $v$. Ogden's Adm'r,2 Green. Ch. 168; seo also Taggart $v$. Wood, 20 Iowa, 236; Baxter $v$. Denr, 24 Tex. 17; Williams $v$. Lee, 3 Atk. 223; Vilas 
bill filed for that purpose has long been unquestioned." 1 "Any evidence which clearly proves it to be against conscience to execute a judgment of which the injured party could not have availed himself in a court of law, or of which he might have availed himself at law, but was prevented by fraud or accident, unnised with any fault or negligence of himself or his agent, will justify an application to chancery." ${ }^{2}$ To entitle a party to relief from a judgment or decree, it must be made evident that he had a defense upon the merits; and that such defense has been lost to him, without such loss being "attributable to his own omission, neglect or default." " The loss of a defense, to justify a court of equity in removing a judgment, must, in all cases, be occasioned by the fraud or act of the prevailing party, or by mistake or accident on the part of the losing party, unmixed with any fault of himself or his agent."

\& 437. Frror and Irregularity.-It has already been intimated that neither an erroneous conclusion, upon which a judgment was based, nor any irregularity of proceeding, not involving the jurisdiction of the tribunal pronouncing it, can have any effect in determining the question whether the judgment should be set aside or restrained in equity. Such, beyond doubt, is the law. "A court of equity will never set aside or enjoin a judgment on the ground of error or mistake in the judgment of the court of law." 5 Nor will this general rule be varied because the judgment was upon default, unless there was fraud or surprise or other good reason for the failure to defend; ${ }^{6}$ nor on the ground that the Supreme Court had overlooked or mistaken material

I Wright $v$. Miller, I Sanf. Ch. 103; v. McCullough's Admr., 30 Ala. 107: Whittemore v. Coster, 3 Green's Ch. Ludlow $v$. Ramsey, 11 Wall. 581; Tar438 .

2 Narine Ins. Co. v. Hodlgson, 7 Cranch, 3:2; Ex'rs Powers $v$. Admr's, Butler, 3 Green Ch. 465.

${ }^{3}$ Hair $v$. Lowe, 19 Ala. 224.

4 Wingate $v$. Haywood, 40 N. H. 437; Hibbard v. Eastman, 47 N. H. 507 ; Mastick $v$. Thorp, 29 Cal. 444; Boston $v$. Haynes, 33 Cal. 31.

${ }^{5}$ Story's Eq., Sec. 1572; Paddock v. Palmer, 19 Vt. 581 ; Baker v. Morgan, 2 Dow's Rep. 526; Shottenkirk $v$. Wheeler, 3 Jolns. Ch. 279; Holmes $v$. Riemsen, 7 Jolns. Ch. 2S6; Cofin ver $v$. Tarver, 9 Pet. 174 ; McDonall $v$. McDonall, 1 Bai. Eq. 324; De Riemer v. De Cantillon, 4 Johns. Ch. 85; Stockton $v$. Brigrss, 5 Jones' Eq. 309; Reynolds $v$. Horine, 13 B. Monr. 234; Dunn v. Fish, 8 Blackf. 407; Donovan v. Fim, Hop. Ch. 59; $14 \mathrm{Am}$. Dec. 531; Drake v. Hanshaw, $47 \mathrm{Ia}$. 291 ; Burke $v$. Wheat, 22 Kans. 722; Roller $v$. Wooldridge, 46 Tex. 455 ; Jilsun v. Stebbins, 41 Wis. 295.

6 Turpin $v$. Thomas, 2 H. \& M. 139; 3 Am. Dec. 615. 
facts shown by the record," nor because the court "through haste and inadrertence," rendered an erroneous decision. ${ }^{2}$ If a judgment, in an action to foreclose a lien, is entered against the defendant personally as well as against the property, when no personal judgment is prayed for in the compliint, such personal jurlgment, though erroneous, is not void. But the entry of such judgment, in the absence of any special agreement or understanding between the parties, is not fraud, and is not to be set aside in equity. ${ }^{3}$ Relief cannot be granted because the court erred in admitting or in excluding eridence. There must always be some special ground of relief other than error of law. ${ }^{*}$ All errors of decision and of proceeding must be settled in the tribumals in which they originate, or by an appeal to some appellate tribunal; and in no case will the court of equity take ipon itself a revisory jurisdiction. ${ }^{5}$ Hence, where bonds were taken, under a certain act of the legislature to regulate the sale of spirituous liquors, and a judgment was rendere? upon one of such bonds, and thereafter, in another action, the act was declared unconstitutional, it was held that an injunction should not be granted to restrain the execution of the judgment. The judgment "was founded on the bondis, aud not on the act; and of the suit upon them, the Circuit Court had full jurisdiction. The act being void, the bouds are simply unsupported by any valid consideration; and this being the case, the judgment rendered upon these bonds, though it may be deemed erroneous, is not void, and must be held operative until, in accordance with the ordinary rules of procedure, it is reversed by a court of error." ${ }_{6}$ s a final judgment or decree cannot be avoided in equity on account of any errors of law entering into it and affecting the merits of the controversy, it could hardly be contended that mere errors in proceeding could have a greater effect. It is therefore conceded that equity will not interfere with

\footnotetext{
${ }^{1}$ Tussel v. Slaton, 39 Geo. 195; Harrison v. Nettleship, 2 Mylne \& Nicholson $v$. Patterson, 6 Humph. Keene, 423; Noore v. Dial, 3 Stew. 394.

${ }^{2}$ Dunham v. Downer, 31 Verm. 249. $\quad 5$ Jennison v. Hapgood, 7 Pick. 1;

${ }^{3}$ Murdock v. DeVries, 37 Cal. 527. 19 Am. Dec. 258.

${ }^{4}$ Vaughn $v$. Johnson, 1 Stock. 173; ${ }^{6}$ Cassel $v$. Scott, 17 Ind. 514.
} 
a judgment on account of alleged irregularities occurring in the exercise of lawful jurisdiction. ${ }^{1}$

8 488. Classification.-The exclusion of error and irregularity from the grounds upon which relief from a judgment or decree may be obtained, leaves but one ground available in any case, which is that the party could not successfully prosecute his claim nor make his defense in the original action, because it was not there available to him as a claim or defense, or, if so available, he was, without any fault on his part, prevented from asserting it. The causes, by reason of which the party could not successfully prosecute or defend, and by which he is entitled to the aid of courts of chancery to relieve him from the consequences which would otherwise attend a final adjudication pronounced against him, naturally divide themselves into two great classes. The class which we shall first consider includes all those cases in which a defense or prosecution could not be made on account of the frand or act of the prevailing party. In the second class, are embraced all those cases in which a party is excused from presenting his side of the controversy, although liis failure to present it did not arise from the act or fault of his adversary.

8 489. Fraud.-Chief among the cases belonging to the first named class, are those in which the judgment or decree was obtained by fraud. It is a general rule, too familiar to require any citation of authorities in its support, that "A judgment, either of a legal or of an equitable tribunal, may be in effect vacated by a court of equity, if it was obtained by fraud." A few cases will bo noticed as illus-

\footnotetext{
1 Blanck v. Speekman, 23 La. An. (Dec. 720; Poindexter $v$. Waddy, 6 146; McInloe $v$. Hazleton, 19 Wis. MIunf. 418; 8 Am. Dec. 749; Dugan 567; Stiles v. Knapp, 2 Ga. Decis. v. McGann, 60 Geo. 353; Whittlesey 36; Boyıl $v$. Chesapeake, 17 Md. 195 ; Gardner $v$. Jenkins, 14 Md. 55.

${ }_{2}$ Munn $v$. Worrall, 16 Larb. 221; Corwithe $v$. Griffin, 21 Barb. 9; Burch v. Seott, I Bland. Ch. 112; Brown v. Thornton, 47 Geo. 47t; Ogden v. Larrabee, 57 Ill. 359; Cowin $v$. Toole, 31 Iowa, 513; Hayden $v$. Inaylen, 46 Cal. 332; Carrington $v$. Holabirl, 17 Conn. 530; Greene $v$. Haskell, 5 I. I. 447; Kent $v$. Ricards, $3 \mathrm{Ml}$. Ch. 392 ; Hahn v. Hart, $12 \mathrm{~B}$. Monr. 426; Crank v. Flowers, $t$ Heisk. 629; Binsse $v$. Barker, 23 Am.

v. Delaney, 73 N. Y. 571 ; Bresnehan v. Price, 57 Mo. 422. "It is the just and proper pride of our matured system of equity jurisprudence that fraud vitiates every transaction; and, however men may surround it with forms, solemn instruments, proceedings conforming to all the details required in the laws, or even by the formal judg. ment of court, a court of equity will disregard them all if necessary, that justice and equity may prevail." Warner v. Blakeman, 4 Keyes, 507.
} 
trating the application of this rule. If a confession of judgment be made by virtue of a letter of attorney, fraudulently obtained, both the judgment and the letter of attorney will be annulled. ${ }^{1}$ Suit was commenced against several defendants. The summons being returned as to one defendant, "Executed by loaving a copy," the plaintiff's attorney erased all the return, except the word "exccuted," and thereby obtained a judgment. Writ of error was sued out, but the judgment was aflirmed by the appellate court. Afterwards the original judgment was set aside at chancery on the ground of fraud, not apparent on the face of the record, in relation to the service of process, and which could not therefore be asserted against the judgment on appeal. ${ }^{2}$ A judgment was obtained by attachment, during defendant's absence, for a sum claimed to be due for tho board of his wife. Relief was obtained by the defendant, upon showing that it was the duty of plaintiff under an agreement to furnish such board, and that he, at the time the suit was commenced, had funds of defendant in his hands, on the ground that otherwise a party having no opportunity for defense, would be subjected to a gross wrong and fraud. ${ }^{3}$ A plaintiff filed a complaint against his wife praying for a divorce on the ground of desertion. Ho obtained an order for the service of summons by publication, by alleging that he did not know the place of her residence. Judgment by default was afterwards entered, based upon such service. The wife instituted proceedings to set aside the decree, alleging that the separation was voluntary, and in pursuance of written articles; that the plaintiff well knew where she resided; that no copy of summons or complaint was ever served on her personally, nor bj depositing a copy thereof in the post-ofice directed to her, and that she had no knowledge of the suit until long after the clecree was entered. A demurrer being interposed, the court held that the allegations of the wifo showed such a fraud upon her, and upon the court in the divorce case, for the purpose of avoiding a contest upon the merits, as authorized the setting aside of the decree. ${ }^{4}$ Decrees of divorce may, when obtained by fraud, be vacated in the same manner and

${ }^{1}$ Johnston $v$. Loop, 2 Tex. $33 \mathrm{I}$.

M. 205 .
3 Moore $v$. Gamble, 1 Stock. 246.

${ }^{4}$ Jolmson $v$. Coleman, 23 Wis. 452 . 
under the same circumstances which would warrant the vacation of any other decree, ${ }^{1}$ although the party who obtained the fraudulent judgment has contracted another marriage. ${ }^{2}$ A decree against an administrator, founded upon a bond, will bo set aside for frand, if it appear that the court was deceived by plaintiff's tearing off from the bond a paper annexed thereto, showing credits which ought to have been applied to the bond, as the administrator is not presumed to be cognizant of the transactions of liis testator. ${ }^{3}$ Equity will not relieve a party from a judgment procured by his own frand." If the defendant in an action has been discharged by a decreo in bankruptcy, and is prevented from availing himself of this discharge by any trick, fraud or device of the plaintiff, equity will grant him relief. ${ }^{5}$ Collusion, being one of the forms in which fraudulent clesigns are frequently pursued, is as objectionable as any other form of frand, and vitiates all judgments into which it enters, and the person against whom it is employed may find relief in equity. ${ }^{6}$ The fraud for which a judgment may be vacated or enjoined in equity must be in the procnrement of the judgment. If the cause of action be vitiated by fraud, this is a defense which must be interposed, and unless its interposition be prevented by fraud, it camnot be asserted against the judgment. ${ }^{7}$

\& 490. Fraudulent Alteration. - If a judgment properly obtained, is afterwards fraudulently altered, so as to inclucie a person not served with process, and not originaily named in the judgment, equity has jurisdiction to vacate it. ${ }^{8}$ "Fraud is one of the heads of original and undoubted equity jurisdiction; and to alter and change the record of a judgment, by increasing the sum for which it was rendered, without authority or consent, is a gross and palpable fraud, although it may also be a crime." An injunction will, there-

1 Adams v. Adams, 51 N. H. 2Ss; 12 Am. Rep. 134; Edson v. Edson, 103 Mass. 590; 11 Am. Rep. 393; True v. True, 6 Minn. 458; Boyd's Appeal, 38 Pa. S. 241.

stwitcomb $\approx$. Whitcomb, 46 Ia. 437; Rusl $v$. Rush, 46 Ia. $648 ; 26$ Am. Rep. 179.

${ }^{3}$ Carneal v. Wilson, 3 Litt. So.

${ }^{4}$ Blystone $v$. Blystone, 51 Pa. S. 373.
${ }^{5}$ Starr v. Heckart, 32 Md. 267; Greenleaf $v$. Maher, 2 Trash. C. C. 41; Manwarring $v$. Kouns, 35 Tex. 174; Park v. Casey, 35 Tex. 535. 'Hardy $v$. Broaddus, 35 Tex. 668; Mayberry v. MicClurg, 51 Mo. 256. inuscatine $v$. Miss. R. R. Co., 1 Dill. C. C. 536.

${ }^{8}$ Chester $v$. Miller, 13 Cal. 558. 
fore, be issued to restrain the collection of a judgment so altered. ${ }^{1}$

\section{\& 491. Fraudulent Concealment. - The concealment of} facts which, if known at the trial, would have prevented the recovery, is always good ground for coming into equity to obtain relief from a judgment at law." Thus, if an administrator suppresses the receipt of a sum of money obtained by him for the benefit of the estate, and thereby causes his accounts to be closed without his being charged with that sum, they will be reppened at equity on the ground of fraud, although the statute declares the lecree of accounting final and conclusive. ${ }^{3}$-A jurlgment recovered by a vendor for an amount due as purchase money of lands, will be enjoined in equity if it can be shown that, after the recovery, the defendant discovered that the vendor had conveyed the land to his children previously to conveying to the defendant, the defendant's deed containing covenants of warranty, and the plaintiff's estate being insolvent. A bill was filed to set asido a judgment recovered upon a policy of insurance, in which it was charged that the ship insured was lost by the boring of holes in her bottom, and by fraudulently casting her away; that such fraud was unknown when the judgment was rendered, and was fraudulently concealed by tho plaintifis in tho former suit. Upon demurrer, it was decided that these charges, if sustained, would entitle complainant to the relief demanderl, because a perfect and valid defense at law has been made unavailable by the fraudulent concealment of the plaintiffs and the total and excusable ignorance of the defendants. ${ }^{*} \mathrm{H}$. sued R.; S., who was liable with $R$. ., was pit on the stand as a witness; but just before becoming a witness, he, withont knowledge of R., paid H. the amount claimed. Judgment was rendered against $P$. before he knew of the payment made by $\mathrm{S}$. H. afterward endeavoring to collect his judgment, $\mathbb{P}_{\text {. set up }}$ these facts, and prayed for an injunction. To oppose the issuing of the injunction, $H$. insisted that the fact of payment ought to have been disclosed as a defense prior to the judgment. But the court held that " $R$. was not bound to present to a court of law a fact of which he knew nothing, and of which

\footnotetext{
${ }^{1}$ Babcock $v$. McCamant, 53 Ill. 214. $\quad 3$ Pratt $v$. Northam, 5 Mason, 8..

${ }^{2}$ Fish $v$. Lane, 2 Haywood, 52:; ${ }^{2}$ Ocean Ins. Co. v. Fields, 2 Sitory Noyes $v$. Loeb, 24 La. An. 48.
}

$(3 \pm)$ 
he had no canse to suspect anything, and to which he was in no manner priry."

8 492. Talring Judgment Against Agreement.-It has frequently happened that one of the parties litigant, has failed to present his claim or defense because he has relied upon some agreement or understanding between himself and his adversary, which, if observed, rendered such presentation unnecessary. And with more than occasional frequency, if we may judge from the reports, these agreements have been designed to lull a party into security and inactivity in order that some unconscientious advantage could be talien of him. In all such cases, courts of equity, when asked to do so, have invariably restored the injured party to his rights under the agreement, and have wrested from his opponent all those fruits he had hoped to harvest and enjoy through fraud and duplicity. ${ }^{2}$ An action was commenced against $A$. and others. A., having a good defense, the plaintiff agreed to dismiss as to him, and on that accoint A. failed to defend. The judgment taken in violation of this agreement, was set aside and the execution restrained. ${ }^{3}$ Similar action was taken where the defendant was assured that he was sued pro forma because he was supposed to be a necessary party, and that no judgment would be taken against him; and a decree was nevertheless taken against defendant, ${ }^{4}$ and so, when after the commencement of a suit an accord and satisfaction had talen place between the parties, and upon that account, the defendant failed to appear and plead, and he was relieved from the judgment. ${ }^{5}$ The principle that taking judgment in opposition to an agreement or representation of a party or his attorney, is such a fraud that the parties will be restored to their former position, is equally applicable if there be but one defendant, or if the defendant on account of the agreement fails to answer,

1 Reed $v$. Harvey, 23 Ark. 44. 2 Holland $v$. Trotter, 22 Gratt. 136; Chambers v. Robbins, 28 Conu. 552;

Kent v. Ricards, $3 \mathrm{Md}$. Ch. 392; Neuman $v$. STeek, Sm. \& M. Ch. 331.
3 Johnson $v$. Unversaw, 30 Ind.435; Stone $v$. Lewman, 28 Ind. 97.

${ }^{4}$ Broaddus $v$. Broaddus, 3 Dana, 536.

5 Jarman $v$. Saunders, 64 N. C. 367. 
or after answering fails to attend the trial, ${ }^{1}$ or if the person against whom the recovery has been had was a garnishee, who, being summoned, had answered showing that he had no funds of the defendant in his hands, and had thereupon been assured that no further proceedings would be taken against him. ${ }^{2}$ Where A. was sued upon a note and mortgage and the plaintiff for a valuable consideration released him from personal liability; but took judgment in violation of his contract, and issued execution thereon, such execution was restrained on the ground that "it was against conscience for the mortgagee to retain his advantage." It makes no difference that the agreement is void because made on Sunciay, or was oral when the rules of the court required all stipulations to be in writing. If it can bo shown that it was successfully employed to prevent the defendant from making his defense, then the plaintiff will not be allowed to retain the advantage it has secured him. ${ }^{4} \mathrm{~A}$ judgment will be annulled for fraud if it was procured by prevailing on a justice of the peace to take up a case in the absence of a defendant to whom the justice had announced in the morning that he was sick and could not try the cause, and who would have been present at the hour of trial but for such announcement, the plaintiff being present when the defendant left the court, and afterwards returning and inducing the justice to proceed with the case..$^{5}$ In this instince, while the prevarling party had not personally made those statements which induced the defendant to forego presenting his defense at the appointed time, he had adopted statements made by another and employed them for an unconscionable purpose, and had thus brought himself fairly witlin the rule that no one shall retain an advantage at law secured by his own fraud and misrepresentation. But relief was granted in an early case in Virginia, which seems altogether unjustifiable, because it sanctions the

\footnotetext{
1 Dobson v. Pearce, 1 Abb. Pr. 97; 2 Pelbam v. Moreland, 6 Eng. 442. Rogers $v$. Gwinn, 21 Iowa, 58; Dob- ${ }^{3}$ Hibbard $v$. Eastman, 47 N. H. son $v$. Pearce, 12 N. Y. 165; Pearce $v$. 507.

Olney, 20 Conn. 541; Wierich $v$. De- ${ }^{4}$ Blakesley v. Johnson, 13 Wis. Zoya, 2 Gilm. 385; Edmonson v. 530.

Moseby's Heirs, 4 J. J. M. $497 . \quad 5$ Miles $v$. Jones, 28 Mo. 87.
} 
restraining of a judgment on account of a misrepresentation to which the plaintiff was neither directly nor indirectly a party. Three persons were sued as co-partners. One of them, who in fact was not a partner with the others, neglected to defend because he was assured by his co-defendants that the matter would be adjusted. An injunction was granted and the parties placed in their original position. ${ }^{2}$

\section{493. Procured by Concealment. - The concealment} of material facts is looked upon with such abhorence, if employed to obtain an unjust judgment, that relief has been granted from judgments so obtained, when any considerable degree of diligence would have revealed to the losing party and have enabled him to present to the court, the evidence for want of which he was defeated at the trial. Thus a plaintiff, knowing a judgment to be satisfied, brought an action as a judgment creditor for the purpose of setting asicle a conveyance as being made in fraud of his rights. After he had obtained his decree, the defendants discovered that, while no satisfaction was marked upon the docket, yet one was filed among the papers in the case, anterior to the commencement of the suit against them. They then instituted proceedings to set aside the decree annulling their conveyance, and obtained the relief sought, on the ground that by examining the locket where the entry of satisfaction ought to be made, they had used sufficient diligence to entitlo them to protection from one asserting a claim known to him to be fully paid. ${ }^{2}$ But as a general rule no party can be relieved on the ground of any fraudulent practice or concealment on the part of his adversary, unless he, on his part, exhausted all proper diligence to defend the original action. This is particularly the case where some fraudulent device is employed by the other side in the management of his case, or in adducing the testimony of perjured witnesses. Upon discovering any such fraud the party against whom it is employed must at once use all the means in his power to countervail it. He cannot either neglect or refuse to employ the means in his power to obtain a proper determination of the action in opposition to the fraud practiced upon him;

1Lee v. Baird, 4 Hen. \& M. $453 . \quad$ | 2 Shinkle v. Letcher, 47 Ill. 216. 
and then, if through lis supineness, the fraudulent device proves successful, resort to a court of equity and obtain relief. ${ }^{1}$

8. 494. Personal Threats.-The allegation in a complitint to obtain relief from a judgment or decree, stating that the defendant did not make his defense because prerented by threats of personal violence from attending at the trial, is wanting in the averments essential to authorize the intervention of a court of equity. It fails to show that the plaintiff was, in any manner, responsible for those threats, or that the case could not bo efficiently managed by an agent or attorney, in the absence of the defendant. ${ }^{2}$

8 495. Want of Notice. -Wo shall now consider the circumstances in which a defendant may be relieved from a judgment or decreo rendered in an action wherein his failure to defend is not chargeable to the plaintiff. Prominent among the grounds of relief belonging within this class of cases, is the one that the court has proceeded to condemn a party withont first giving him an opportunity to be heard. A julgment prononnced withont service of process, actual or constructive, and without the defendant's knowing that a conrt has been asked to adjudicate npon his rights, is regarded with such disfavor at law that a variety of motions, writs, and proceedings, are there provided to overthrow it; and, in many conrts, it is at all times and upon all occasions liable to be entirely disregarded upon having its jurisdictional infirmity exposed. But proceedings in equity are peculiarly appropriate for the expostre of this infirmity. They permit of the formation of issues upon the question of service of process; and of the trial of those issues, after full opportunity has been given to those who seek to sustain, as well as to those who seek to avoid, the judgment. If, at such trial, it satisfactorily appears that the defendant was not summoned, and had no notice of the suit, a suffcient excuse is shown for his neglect to defend, and equity will not allow the judgment, if unjust, to be used agaiust

${ }^{1}$ Ridàle $v$. Eaker, 13 Cal. 295. | | ${ }^{2}$ Powell $\imath$. Cyfers, 1 Heiskell, 526. 
him. ${ }^{1}$ Thus an order of sale of land granted upon the petition of an administrator, without service of process upon infant heirs who havo no general guardian, will be set aside upon making application in equity. ${ }^{2}$ If the record does not disclose the jurisdictional defect, an afirmance of the judgment in an appellate court does not divest equity of the authority to grant relief. "The afirmance of a void judgment, on grounds not touching but overlooking its invalidity, does not make it valid."

There seems to be but little dissent from the proposition that the want of service of process may bo shown in equity in opposition to the statement in the judgment roll. ${ }^{4}$ Still, the position has been taken by the lighest court in the United States, and by some of the State courts, that this proposition must be confined to those cases in which the false return, if the jurisdictional declaration is found in the return of an oficer, is in some way connected with the net or procurement of the plaintiff. Thus, in an action to enjoin a judgment, wherein it was proved that no process was served and that the return was false, the court said: "The respondents did no act that can connect them with the false returu. It was the sole act of the marshal, through his deputy, for which he was responsible to the complainant for any damages that were sustained by him in consequence of the false return. This is free from controversy; stiil, the marshal's responsibility does not settle the question made by the bill, which is, in general terms, whether a court of equity has jurisdiction to regulate proceedings, and to afford relief at law, where there has been an abuse in the various details arising ont of execution of process,

\footnotetext{
${ }^{1}$ Ingle v. MeCurry, 1 Heisk. 26; Stubbs $v$. Leavitt, $30 \mathrm{Ala}$. 352; Jefiery $v$. Fitch, 46 Conn. 601; Ryan $v$. Boyd, 33 Ark. 778; Martin v. Parsons, 49 Cal. 95; Williams $v$. Williams, 57 Ind. 500.

2 Tyler $v$. Walker, 1 Heiskell, 734.

${ }^{3}$ Wilson $v$. Montgomery, 14 S. \& 452.

${ }^{4}$ Dridgeport Sav. Bank $v$. Eldredge, 28 Conn. 556; Newcomb $v$. Dewey, 27 Iowa, 381 ; Bell $v$. Williams, I Iread, 229; Stone $v$. Skerry, 31 Iowa, 582; Ridgeway $v$. Bank of Tennessec, 11 Humph. 525; Owens $v$. Ranstead, 2I Ill. 161; Johnson $v$. Coleman. 23 Y is. M. 205.
}

\section{4}


original, mesue and final. If a court of chancery can be called on to correct one abuse, so it may be to correct another; and in effect, to vacate judgments, whero the tribunal rendering the sume would refuse relief, either ou motion, or on a proceeding by auditre querela, where this mode of redress is in use. In cases of false returns affecting a defendant, where the plaintiff at liww is not in fiunlt, redress can only bo had in the court of law where the record was made, and if relief can not wo had there, the party injured must seek his remedy against the marshal." Dut the obvious and conclusive answer to this line of argument is thus briefly stated in the opinion of the Supreme Court of Temnessee: "The action for a false return is an inadequate remedy for such an injury; for it might be that after a minous sacrifice suffered in the payment of a judgment so recovered, and the delay and expense of litigation with the officer who made the false return, he might be unablo to make the proper indemnity, or succeed in evading lis liability." Desides the improbability of the party who is compelled to paya judgment being ablo to secure indemnity from an officer making a false returu, not only for tho amount paid but for tho loss occasioned by liaving to sacrifice lis estates in order to mako an immediate and compulsory payment, and tho consequent inadequacy of why remedy at law, where the judgment is for a sum of money, there are a number of cases involving the possession of, or title to, real or personal property, in which, conceding the liability of the oficer making tho falso return, no adequite remedy can exist, except that of restoring the parties to their position before judgment and permitting a defense upon the merits.

\& 496. Judgments against Privileged Persons.-But, if process be served, the defeudant must appear and protect his interests. If he is privileged from service as a member of a legislative or other political body, the privilege is a

${ }^{1}$ Walker $v$. Robins, 14 How. U. S. ${ }^{2}$ Ridgeway $v$. Bank of Tenn., 11 5S4; to the same effect, Johnson $v$. Hump. 523.

Jones, 2 Neb. 133; Taylor $v$. Lewis, 2 J. J. M. 400; 19 Ain. Dec. 135. 
personal one, which must be claimed by motion in the case. Courts can not, ex officio, take notice of the persons thus privileged. And if, in the absence of any claim being interposed, judgment is pronounced against them, it will not be intermeddled with in equity. ${ }^{1}$

\& 496a. Relief to prevent party from taking advantage of his own neglect, wrong, or mistake, may be granted. Thus where A. sued to quiet title, and it appeared that he claimed under a tax judgment and sale, and that he was a court commissioner charged by law with the duty of examining whether process in the tax case had been properly served, and that such process had not in fact been served, the court enjoined him from enforcing his tax title. "It is immaterial," said the court, "that he acted, as the court finds, in good faith and without any fraudulent intent." * * * "He has through his own laches or neglect obtained an unconscionable advantage over the defendants, against which a court of equity will afford relief. It was through his fault that the decree was obtained without any service of process, and it would be against good conscience to allow him to profit by his own wrong."

8 497. While there is Remedy at Law.-The anthorities do not agree upon the question whether equity will interfere with a judgment on the ground of want of jurisdiction over the defendant, while he has it in his power to employ some efficient remedy in the original case. In Kentucky, "though an original judgment be void and be capable of being reversed on appeal, yet the Circuit Court has power, in an action for that purpose, to enjoin it, and to vacate proceedings nnder it." " In Wisconsin, the fact that the judgment might be set aside, upon motion, for want of jurisdiction, is no objection to a proceeding in equity, becanse such proceeding "is, beyond doubt, as a remedy equally appropriate both for an investigation of the issues involved, and the awarding of appropriate relief as a mo-

\footnotetext{
${ }^{1}$ Peters $v$. League, 13 Md.58; Prentis v. Commonwealth, 5 Rand. 697; and 49 Cal. 94.

16 Am. Dee. 7s:, and note.

${ }^{3}$ Landrum v. Farmer, 7 Bush, 46.
} 536 
tion." Similar rules prevail in Iowa, ${ }^{2}$ Tennessee ${ }^{3}$ and Ionisiana, ${ }^{4}$ but, in California, equity will not interpose while the statute remedy by motion exists; ${ }^{5}$ and in some of the other States, courts of equity have wisely declined to interfere where an adequate remedy existed at law. ${ }^{6}$

8 498. Merits must be shown.-It has been held that a judgment rendered without service of process, and without the knowledge of the defendant, may be relieved against withont any showing on the question of merits, for the reason that, "in such a case the injury consists in the rendition of a judgment against a party, without notice and opportunity of defense; and that it is unjust and unconscientious to attempt to enforce a judgment so obtained." But tho better estiblished rule, undoubtedly, is, that notwithstanding an alleged want of service of process, a court of equity will not interfere to set aside a judgment until it appears that the "result will be other or different from that already reached."

8 499. Cnauthorized Appearance of Attorney.-Tho early calses undoubtedly tolerated the proposition that a judgment, based upon the unanthorized appearance of an attorney, and in the absence of any service of process rpon the defenclant, formed an exception to the general rule, that a judgment which the party agiinst whom it was pronounced had no opportunity to prevent, would be treated as iuvalid in equity. It was said that " the mere appearance of an attorney for a party, even withont authority, is ilways deemed sufficient for the court, which will look no further, but proceed, and will leave the party to his remedy against

${ }^{1}$ Johnson $v$. Coleman, 23 Wis. 452.

${ }^{2}$ Connell v. Stelson, 33 Iowa, 147.

${ }^{3}$ Caruthers $v$. Hartsfield, 3 Yerg. 366; 24 An. Dee. 5 So.

${ }^{4}$ Hernandez v. James, 23 La. An. 4 S4.

${ }^{5}$ Bibench v. Kreutz, 20 Cal. 109; Sanehez $v$. Carriaga, 31 Cal. 171; Logan $v$. Hillegrass, 16 Cal. 201.

${ }^{6}$ Crandall v. Bacon, 20 WVis. 639; Hart v. Lazaron, 40 Geo. 396.
'Bell v. Williams, 1 Head, 229; Ryan v. Boyd, 33 Ark. 7\%S.

${ }^{8}$ Taggart v. Wood, 20 Iowa, 236; Gregory v. Ford, 1t Cal. 13s; Fowler v. Lee, 10 G. \& J. 303; Piggot v. Al. dicks, 3 G. Greene, 427 ; Crawford $v$. White, 17 Iowa, 560; Stolies $v$. Knarr, 11 Wis. 389. 
the attorney," unless the attorney was in irresponsible or suspicious circumstances, or his appearance was through the procurement of the plaintiff. ${ }^{2}$ In chancery, the rule was, in cases where a solicitor appeared without authority, that if the adverse party had acquired no rights, the party for whom the solicitor presumed to act might apply to the court and have the proceedings corrected, and the solicitor compelled to pay the costs. But if the adverse party hal acquired any rights, or had been subjected to the payment of any costs, the proceedings were permitted to stand, if the solicitor were responsible, and the injured party left to seek redress against the solicitor. ${ }^{3}$ Now it seems to be a rule applicable to the greater part, if not to the entire United States, that a judgment, resting upon the mauthorized appearance of an attorney, may be anuulled in equity, irrespective of the question whether the attorney is responsible or irresponsible, the judgment lien being preserved to secure the plaintiff from loss, should he afterwards recover at a trial on the merits. ${ }^{5}$ The reasons inducing this change in the rule, together with a general statement and history of the law upon this subject, aro thus set forth in an opinion written by Chief Justice Dillon, of Iowa: "The ancient common law required the parties to be present and prosecute, or defend, in person. It required a patent or special authority from the crown to enable parties to appear by attorney. Afterwards, by various statutes, the right to appear by attorney was recognized. In the earlier stages of the law the attorneys were appointed orally in court. Afterwards they were allowed to be appointed by warrant, out of court, ancl the practice of the court was to require the warrant to be filed, which, however, might be done at any time

\footnotetext{
1 Burrill's Practiee, note $a$ to p. 37, citing 6 Johns. 34, 296; 1 Binney, 214; I Pet. C. C. 155; 9 Wend. 409; 2 Hill, 64 .

${ }^{4}$ Ridgre $v$. Alter, 14 La. An. S6r; Marvel $v$. MLanouvrier, I4 La. Ail. 3; Wiley $x$. Pratt, 23 Ind. 628.

${ }^{2}$ Hoffmire $v$. Hoffmire, $3 \mathrm{Ed}$. Ch. ${ }^{5}$ Gifford v. Thorn, 1 Stoek. 702, 174; 7 Cow. 259; 6 Wend. 5l4; 9 Wend. $43 \pi$.

${ }^{3}$ Am. Ins. Co. v. Oakley, 9 Pai. Ch. 496 . 722; Allen v. Stone, 10 Barb. 547; Ellsworth $v$. Campbell, 31 Barb. 134; De Lonis $v$. Meek, $2 \mathrm{G}$. Greene, 55; Jones $v$. Williamson, 5 Coin. 371; Newcomb $v$. Dewey, 27 Iowa, 331.
} 
before judgment; and the want of it in the record was aided by statute and conld not be assigned for error. This strictness has been gradually relaxed, until it is at the present time the settled rule, that although an attorney camot without special authority admit service of jurisdictional process upou his client, yet it will be presumed in all collateral proceedings, and perhaps on appeal or in error, that a regular attorney at law who appeared for the defendant, though not served, had authority to do so. To entille a party who has been represented by an unanthorized attorney to be relieved, he must negative the presumption of authority in the attorney; and this he can not ordinarily do by appeal or writ of error. He must apply for relief either by motion or by bill in equity. No examination of this subject would be complete without reference to the leading authorities in English and American courts. It is laid down as law in an early case in Salkeld, that 'when an attorney takes on himself to appear, the court looks no further, but proceeds as if the attorney had sufficient authority, and leaves the party to his action against him.' This rule has, we submit, no foundation in reason to stand upon. It obliges a person to be bound by the unauthorized act of a mere stranger. It binds him by the judgment of a court without a day in court. It relieves the other party of the duty which in reason belongs to him, viz.: to serve his process, and to see, at his peril, that his adversary is in court. It carries ont this nsounduess by compelling the vorong party to look to the attorney. Then reason and logic would say, if an attorney appeared for me without my knowledge or authority cxpress or implied, I should not be bound by the act if never ratified or promptly disavowed, and if the adverse party, being ignorant of the want of authority, and carelessly omiting to serve process, or to require the attorney to show his anthority, has been damaged, he, and not myself, should be the one to look to the attorney.

"That such a rule as the one laid down in 1 Salkeld, S6, should permanently stand, without modification, as the liuw of enlightened tribunals, wonld be impossible. But, as I shall proceed to show, "the courts instead of overturning have

11 Salk. 86. 
gradually undermined it, till, if it now stands, it is tottering and ready to fall.' In 1 Salkeld, 88, ' an attorney appeared and judgment was entered against his client and he had no warrant of attorney, and now the question was, if the court could set aside the judgment? Et per cur.: If the attorney be able and responsible we will not set aside the judgment. The reason is, the judgment is regular and the plaintiff onglist not to suffer, for there is no fault in him: but if the attorney be not responsible or suspicious, we will set aside the judgment, for otherwise the defendant has no remedy and any one may be undone by that means.' Such a doctrine conkl not impose on the fine understanding of Lord Mausfield, and the case of Rolson v. Eaton (K. B. 1785, 1 Term. 62), without professedly overruling the cases in Salkeld, choes so in effect by proceeding upon directly opposite principles. This will be obvious from a brief statement of the case, which was an action for money had and received. The defenclant pleaded that the plaintiff, William Hodgson, by lis attorney, had before sued the defendant and recovered a judgment for the same cause of action; that the defendant, by order of the court, paid the amount of such recovery into court, and the same had been received by the plaintiff's saicl attorney. This was apparently a good defense. To it the plaintiff replied that he never retained said Hodgson to sue the defendant or authorized him to receive the money. Both parties were innocent of frand. The warrant of attorney was forged; Hodgson, ignorant of the forgery, collected the money, and in good faith paid it to the forger. And the question was, could the defendant rely upon the former recovery, or must he pay the money twice? Now, I suppose, if on grounds of public policy a defendant is bound by the act of an umauthorized attorney who appears for him, the plaintiff ought, upon the same ground, to be bound by the act of an unauthorized attorney who appears for him. The principle is the same. It was decided that the defendant must again pay the money. And the ground of the decision was that the attorney who prosecuted the former suit in the plaintiff's name had no authority for so doing." Jukge Dillon then proceeds to consider the cases in New York upon this subject, and then adds: 
"In other States it is now the constant practice to relievo parties, sometimes by motion and sometimes in chancery, from judgments rendered against them in consequence of the totally manthorized acts of a pragmatical attorney. ${ }^{1}$

"And in England, in the Court of Exchequer, the rule as laid down in Salkeld, has quite recently, and upon great cousideration, been criticised and partially, at least, overturned. See Bayley v. Buchland (1 Exch. 1 W. H. \& G. 1), where Rolfe, B., alluding to 1 Salkeld, 88, says: "The nonresponsibility, or suspiciousness, of the attorney, is but a vague sort of criterion of safety to the defendant, and by the hypothesis the defendant is wholly without blame, and may, notwithstanding, be ruined. It is true that the plaintiff is equally blameless, but then the plaintiff, if the judgment be set aside, has his remedy against the defendant as before, and suffers only the delay and the possible loss of costs.' And the court, where the appearance for the defendant is unauthorized, proceeds to make a distinction between cases where process luas been served, and cases where it has not. If, says the court, the process is served, the plaintiff innocent of any frand or collusion, and the attorney is responsible, the party for whom the attorney appeared is confined to his remedy against him. The reason given is, that here the plaintiff is without blame, and the defendant is gnilty of negligence in not appearing and making his defense by his own attorney, if he has any defense on the merits. But, on the other hand, "if the plaintiff, without serving the defendant, accept the appearanco of an unauthorized attorney for the defendant, he is not wholly free from the imputation of negligence; th : law requires him to give notice to the defendant by serving the writ, and he has not done so. The lefendant then is wholly free from blame, and plaintiff not; so we must set aside the judgment." "2

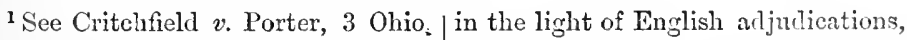
518; Shelton $v$. Tiffin, 6 How. U. S. to Doe $v$. Eyton, 3 B. \& Atlul. 7Ss; 163; Camplell v. Bristol, 19 Wen I. Hubbart $v$. Phillips, 13 M. \& W. 700; 101; Truett $v$. Wainwright, 4 Gilm. 14 L. J. (N. S.) 108; Willians $v$. 420; De Louis $v$. Meek, 2 G. Creene, Smith, 1 Dowd. P. C. 632; Mndry v. 55; McKelway $v$. Jones, 2 Harr. (N. Newman, 1 C. M. \& R. 402; Odell $v$. J.) 345; Price $v$. Ward, 1 Dutch. 225. Odell, 1 Irish Exch. (Jones) S1; Morgan

${ }^{2}$ Harshey $v$. Blackmarr, 20 Iowa, $v$. Thorne, 7 MI. \& W. 400; Hawbridge 161. Judge Dillon refers all those $v$. De La Crouce, 3 M. G. \& S. 7千2; inclined to jursue the subject further Stanhope v. Firman, 3 Bing. N.C. 303.
} 
8500. Authorized Act of Regular Attorney.-If the attorney is authorized to appear, the jurisdiction over the defendant is perfect, and the subsequent action of the attorney, not induced by the frand of the adverse party, is binding on the client at law and in equity. According to Lord Hardwicke, "When a decreo is made by consent of comnel, there lies not an appeal or rehearing though a party did not really give his consent; but his remedy is against his counsel; but if such decree was by fraud and covin it may be relieved against, not by rehearing or appeal, but by original bill;"' and such beyond doubt, is still the rule. $^{2}$ The rule that a party cannot in equity find relief from the consequence of his own negligence, or of a mistake of the law, is equally applicable where the mistake or neglect is that of his attorney employed in the management of the case. ${ }^{3}$

\& 500a. Mistalre, Surprise, and Accident.-Mistakes of fact, whether made by the court or by one of the parties, have been successfully employed as grounds for obtaining the interposition of courts of equity, and securing the relief of the party injured by the mistake." Thus a suit was brought on a note, and the defendants made no defense, and " the attorney who was attending the case made a mistake in calculating the interest on the note, and when the case was called for judgment, the judge, without calculating the amount, asked the attorney, who, being under a mistake himself, replied $\$ 405.55$, and the judgment was rendered by mistak $\theta$ for that amount, when it should have been for $\$ 507.80$." The plaintiff discovering the mistake after it was too late to correct it on motion, brought a suit in equity to correct it, by compelling the defendant to pay the amount left out by mistake; and it was lield that equity had, under the circumstances, jurisdiction to grant the relief sought. ${ }^{5}$ It seems to

1 Bradish $v$. Gee, 1 Ambl. Ch. 229. $\quad{ }^{4}$ Chase $v$. Manhardt, 1 Bland's Ch.

${ }^{2}$ Gifford $v$. Thorn, 1 Stock. 702, 722; Jones $v$. Williamson, 5 Cold. 371 . 350; Ford v. Ford, Walker, 505; 12 Am. Dec. 5S7; Drew v. Clarke, Cooke, 373; 5 Am. Dec. 69S.

3 Wynn v. Wilson, Hemp. 695; Wilson $v$. Boughton, 50 Mo. 17; Chester $v$. Apperson, 4 Heisk. 639; see, to same effect, Boon v. Miller's Shricker v. Field, 9 Iowa, 366; Win- Exrs., 10 Mo. 457.

chester $v$. Grosvenor, $4 \mathrm{~S} \mathrm{III.} 517$. 
bc well established by the authorities, that a mistake in calculating the amount cue by which the judgment was entered for a wrong sum, may bo corrected in equity. An crror in computation is not necessarily attributable to negligence, for "the most careful and expert calculators sometimes make mistakes." So where a judgment is occasioned by the mistake of the judge, the party against whom it was entered may have relief in equity. In Georgia a meritorious bill of exceptions was clismissed because of a mistake in a date made by the certifying judge. A bill was then fled to enjoin the judgment, and for a new trial. The Supreme Court of the State in passing upon this case, said: "Courts of equity are open to grant relief in cases of great injustice and wrong, arising from mistake without negligenco and fanlt upon the part of counsel or parties. The dismissal of the case was owing to the misdate of the judge in his certificate. It was the dnty of the judge to have put the correct date. The fault was not one for which the law shonld punish parties, and for which, under the rules, the case was dismissed. It was not beyond tho reach of a court of equity to intcrpose and tako jurisdiction of the parties and subjectmatter; and if it appeared there was merit in the case, and injustice would result from the act or mistake of the judge in the premises, it was the duty of a court of equity to elljoin the collection of the judgment, and stay proceedings until a fair and full hearing upon the merits had been had." Relief will be granted when judgment was occasioned by the failure of attorney to make defense, and this failure aroso not from his neglect but from incorrect information given him with respect to the terms of the court. ${ }^{3}$ But equity will never interpose to vacate or enjoin a judgment on the ground of mistake or ignorance of law; nor because

I Barthell v. Roderick, 3.t Iowa, fense of a suit, in eonsequence of 51S; Partridge $v$. Harrow, 27 Iowa, which, judgment was entered by de96. fault.

${ }^{2}$ Kohn v. Lovett, 43 Ga. 130; sec, ${ }^{3}$ County of Buena Vista v. I. F. \& also, Brewer v. Jones, 44 Id. 7I, S. C. R., 49 Ia. 657.

where the mistalie for which the "Inbbard $v$. Martin, 8 Yerg. 498; judgment was opened in equity was Richmond $v$. Shippen, 2 Pat. \& H. the mistake of the judge in failing to 327; Meem $v$. Rucker, 10 Gratt. 506; mark the name of counsel to the de. Schricker $v$. Field, 9 Iowa, 366. 
of a mistake of law caused by the opinions or suggestions of the judge before whom the cause was tried.' In addition to mistake there are other causes, which, though not chargeable to any fraud or misconduct of the prevailing party, are nevertheless sufincient to warrant the interposition of equity to prevent the enforcement of an unjust judgment or decree. These other causes include sickness, accident, surprise, and all other causes by reason of which, and without any fault on his part, the losing party is unable to present liis cause of action or defense. ${ }^{2}$

8 501. Defenses Cognizable at Law and in Dquity.If a party, sued at law, has a defense of an equitable character, but of which a court of law can take cognizance, he need not, in general, present his equitable defense, but may allow judgment by default to bo taken against him, and may afterwards assert his equitable defense. for the purpose of obtaining relief against tho judgment. ${ }^{3}$ A recovery in an action of ejectment, in which nothing but the legal title is in issue, is no bar to any proceedings in chancery founcled on the equitable title. ${ }^{4}$ But if the party sued at liw, makes his defense there, he is considered as electing to defend at law, and is bound to present every defense which ho can. ${ }^{5}$ His election to defend at law is considered as irrerocably made "by offering any defense whatever, it matters not whether by demurrer to the declaration, by plea in abatement, or in bar."' Cases have occurred in which it is silid that the rule that he who makes an ineffectual defense at law will not be allowed to call equity to his aid, will sometimes yield to a case of peculiar and extraordinary hardship. The defense of usury being presented at law before a justice, mas by him disallowed. The appeal attempted to bo taken from his judgment was dismissed through no fault of the appellant, but on account of some error of the justice or his clerk.

1 Risher $v$. Roush, 22 Am. Dec. 442; ב 110.95.

2 Rice $v$. Railroad Dank, 7 Humpl. 39; White $v$. Washington, 5 Gratt. 645 .

${ }^{3}$ Clay $v$. Fry, $3 \mathrm{Bibb}, 24 \mathrm{~S} ; 6 \mathrm{Am}$. Dec. 6r̃4.

${ }^{4}$ Allen $v$. Stephanus, 18 Tex. 65s; Brown v. Wyncoop, 2 Blkf. 230.

544 
The appellant was then granted relief in equity on the ground " that it would be highly unjust and nureasonable to turn the party away because he had tried to make his defense at law." It is not improbable that this, like many other cases of "peculiar and extraordinary hardship," has rather occasioned a violation, than established an exception to the true rule.

\section{2, 502. Legal Defenses, Neglect in Presenting.- "While} the law affords complete remedies to those who are diligent, it cannot level its rules to subserve the purposes of those who are guilty of negligence and delay." It is, therefore, a general rule that parties are to be lield to the exercise of caution and diligence in the management of their law suits, and are not to be allowed a double opportunity of presenting their defenses. ${ }^{3}$ A complainant in equity seeking to aroid the effect of a judgment against him at law, must, therefore, always disclose a sufficient excuse for not making his defense in the original action." One who purchases real estate for which an action of ejectment is pending, if he rely upon his grantor or his grantor's attorney to conduct the defense without making any agreement with them in reference to the subject, cannot have the judgment set aside in equity, on the ground that he did not know of the time of the trial. Those who purchase law suits must not neglect to defend them. ${ }^{5}$ Nor will any judgment bo opened for want of proper evidence to identify property, ${ }^{6}$ nor for any negligence in making proofs at a trial. ${ }^{7}$ Sureties can not be relieved because their principal was granted an extension of time befor $\theta$ the suit, the interposition of that defense not

${ }^{1}$ Cave $v$. Davis, 5 Monr. 392.

${ }^{2}$ Norris $v$. Denton, 2 Cal. 37s.

${ }^{3}$ Casey $v$. Gregory, 13 B. Monr. 505; Robuck v. Harkins, 38 Geo. 174; Slack $v$. Wood, 9 Gratt. 40; Lansing “ v. Eddy, 1 Johus. Ch. 49; Parker v. Jones, 5 Jones' Eq. 276; Tapp $v$. Rankin, 9 Leigh. 47s; Wright $v$. King, Har. Ch. 12; Powell v. Boring, 44 Geo. 160; Hiley v. Hartridge, 44 Geo. 623; Brand v. Stafford, 2S La. An. 51; Sargeant v. Bigelow, 34 Minn. 370.
4 Menifee v. Myers, 33 Tex. 691; Yancy v. Fenwick, 4 Hen. \& M. 423; Jevne $v$. Osfrood, 57 I1l. 340.

5 Mastick v. Thorp, 29 Cal. 414. " By refusing to relieve partics against the consequences of their own negrlect, it (the law) seeks to make them rigilant and careful." Ewing $v$. MIcNairy, 20 Ohio S. 315.

${ }^{6}$ Pickens v. Yarborough, $30 \mathrm{Ala}$. 40 S.

7 Yantis v. Burdett, 3 Mo. 457. 
being prevented by fraud, accident, or the wrongful act of the plaintiff. ${ }^{1}$ In some cases relief has been granted from judgments based upon usury, ${ }^{2}$ and also upon gambling debts, ${ }^{3}$ probably because these causes of action were regarded with great aversion; but these cases are opposed by other adjudications of at least equal weight, ${ }^{*}$ and they certainly make inroads on well-established principles, without any sufficient justification for so doing.

8 503. Want of Diligence.-In the management of a case, the parties are bound to use such a degree of diligence "as is requisite in the ordinary business of life." No litigant can come within the rule in respect to diligence, who does not give his personal attention to his case, at least, so far as to place it in the hands of his counsel, and to afford that counsel all the means and information necessary to conduct his part in the litigation. A party can not have an injunction because he wrote to an attorney to attend to the case. He will not be excused from attending to it himself, until he shows that he could not have done so, on account of circumstances not imputable to limself. ${ }^{6}$ If a party merely writes to an attorney to attend and make lis defense, but pays no fee, and institutes no inquiry in relation to the case, and it happens, that, from misapprehension or otherwise, the attorney does not make such defense, the " laches are too gross to be relieved. It is the duty of litigants to be vigilant in caring for their interests, and they

${ }^{1}$ Vilas $v$. Jones, 1 N. Y. 274. Frierson $v$. Moody, 3 Humph. 561 ; or other games. Mallett $v$. Butcher, Brown v. Toell's Ad., 5 Rand. $543 ; 1641$ Ill. 382. The statute is strictly Am. Dec. 759; but equity will only construed, and is not available in favor take jurisdiction where the defense of one, who neglecting to defend at of usury could not have been made at law, suffered judgment on a note given law without great embarrassment and for money, but on the result of an elecdifficulty, in consequence of the great tion. Lucas $v$. Nichols, 66 Ill. 41. number of usurious contracts and securities. Id., and Lindsley $v$. James, 3 Cold. 477; Buchanan v. Nolin, 3 Humph. 63, 559 .

${ }^{3}$ Woodson $v$. Barrett, 2 Hen. \& M. 86; Skipwith $v$. Strother, 3 Rand. 214; Clay v. Fry, $3 \mathrm{Bibb}, 248 ; 6 \mathrm{Am}$. Dec. 654. Such relief is given in Illinois, by statute, wheu judgment is rendered ${ }^{4}$ Giddens $v$. Lea, 3 Humph. 133.

${ }^{5}$ Burton v. IViley, 26 Verm. 430; Luttrell $v$. Fisher, 11 Heisk. 101; Tay. lor $v$. Bradshaw, 6 Mon. 145; 17 Am. Dec. 132; Henderson $v$. Mitchell, 1 Bai. Eq. 113; $21 \mathrm{Am}$. Dec. 526; Edwards $v$. Handley, Hardin, 611; $3 \mathrm{Am}$. Dec. 745 .

${ }^{6}$ Stanard $v$. Rogers, 4 H. \& M. 438. 546 
are not to presume that a lawyer, to whom they have paid nothing, from whom they liave never heard, is taking care of their interests." 1 And where the party retains an attorney, but does not attend court, nor furnish witnesses, he cannot be relieved on showing that he fears the attorney was in the interest of his adversary. ${ }^{2}$ Equity will not relieve on the ground of the absence of a witness who, with diligence, could have been procured, nor on the ground that a witness was guilty of perjury, nor because the suitor was absent from court; for it is his business to be there. ${ }^{3}$ Neither is a party to be relieved because he failed to prove his defense for want of the evidence of the nominal plaintiff, who, contrary to the expectations of the defendant, was not present at the trial. ${ }^{4}$ Sureties on whom process was served, and who did not consult their principal, and who failed to interpose any defense, cannot enjoin the judgment for usury. ${ }^{5}$ A. was summoned as a garnishee in a suit of B. against C., and having answered that he owed C. a specified sum, judgment was entered accordingly. Afterward A. was summoned in a suit by $\mathrm{D}$. against $\mathrm{C}$., when he again answered that he owed $C$. the sum for which judgment had already been given, and a second judgment was therempon entered against $A$., and by him was paid. When the first judgment was about to be enforced, A. sought to enjoin its collection on the ground that he had no notice of its rendition when he paid the second judgment, and that he was absent from the State for six weeks after being summoned in the first action. But the court thought that he might have known of the first judgment by exercising the slightest diligence, and refused to render him any aid. ${ }^{6}$ One who has permitted judgment by default to be rendered against him upon a note, will not be relieved from the judgment on the sole ground that the note was given on a condition which had failed. ${ }^{7}$

1 Hill v. Bowyer, 18 Gratt. 364.

2 Albro v. Dayton, 28 Ill. 325.

${ }^{3}$ Gott v. Carr, 6 G. \& J. 309; Dilly v. Barnard, 8 G. \& J. 1 I 1 .

- Wilder v. Lee. 61 K. C. 50.
5 Smith v. Powell, 50 I1l. 21; Lucas v. Spencer, 27 Ill. 15.

6 Houston $v$. Wolcott, 7 Iowa, 173.

i Raburn $v$, Shortridge, 2 Blackf. 480. 
8, 504. Receipt and Release.-Formerly it seems that a case could be reopened in equity upon the finding of a receipt or release, or other "evidence of a permanent and unerring nature to points before in issue." 1 This exception to the general rule, requiring prudence and diligence on the part of the defendant, is founded on the case of Countess Gainsborough v. Gifford, 2 Peere Williams, p. 424, in which it is said that relief will be granted where defendant finds plaintiff's receipt which had been lost, or if the plaintiff's book appeared to be crossed and the money paid before action brought. But if this case is to be understood as granting relief where the defense is payment or release, upon any other terms or under any other circumstances than if any other kind of defense had been made, it cannot bo regarded as the law at the present timo. Where a person against whom a judgment had been obtained, paid a portion thereof, but, in an action upon this judgment, neglecting to plead payment, suffered the second judgment to be recovered without the allowance of any of his payments, it was held that neither he nor his bail could be relieved in equity; and that this case formed no exception to the rule, that relief will not be granted "against a judgment at law on the ground of its being contrary to equity unless the defendant in the judgment was ignorant of the fact in question pending the suit or it could not have been received as a defense, or unless he was prevented from availing himself of the defense by fraud, accident or the act of the opposite party unmixed with negligence or fault on his part." But where judgment was recovered against $C$. and $K$., and afterwards revived against $\mathrm{K}$., C. having died, it was subsequently to such re-

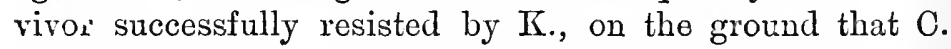
paid the judgment in his lifetime, of which fact $\mathrm{K}$. conld not procure any evidence when he suffered the judgment of revivor. ${ }^{3}$

\section{505. Representatives of Deceased Persons. - It is}

\footnotetext{
${ }^{1}$ Mitford's Ch. p. 7S; Winthrop v. Dunean v. Lyon, 3 Johns. Ch. 356; Lane, 3 Des. 324; Story's Eq. Jur. 8 Am. Dee. 513; Barker v. Elkins, 1 ร 879 ; see, also, Vathir v. Zane, 6 Johus. Ch. 465. Gratt. 246. ${ }^{3}$ Kiser $v$. Winans, 20 Ind. 428.

${ }^{2}$ Foster $v$. Wood, 6 Johns. Ch. 90;
} 
obvious that an administrator or executor is not to be held to great strictness in relation to a defense arising in the lifetime of the deceased, without allowing the adverse party to take undue advantage of his necessarily superior knowledge of the matters in controversy. The fact, that the person seeking relief from a judgment is an administrator, is a material fact in considering the question of laches, because it is not probable that he, with due diligence, could make as complete a defense as his intestate could, if living. That since the trial, the administrator has discovered witnessess by whom proof of payment can be made, is a good ground for relief, for the reason that he had no means of tracing the payment made by the deceased, and is therefore exempted from the rule that no relief can be granted where the defense could be made at law. ${ }^{2}$ An administrator or executor, who, believing that he has assets of the estate ample for the payment of all its debts, suffers judgment to be entered against him, will be relieved in equity, if those assets become insuficient through an unexpected depreciation of their value. Otherwise he would be made responsible, without any fault on his part, the defense arising subsequently to the judgment being one that he could not make available in the original cause by any proceduro provided at law. ${ }^{3}$

8505a. A Judgment against a Trustee in a suit to charge the trust estate, will be enjoined on the application of the cestui que trust, if it appear that the latter was not a party to the suit, and that the cause of action sued upon was not a valid claim against the trust estate, and that the interest of the trustee was best subserved by having judgment entered against him. ${ }^{4}$

8 506. Known Defenses Must be Made.-All matters, known at the time of the trial at law, or capable of being ascertained by reasonable inquiry, ought not to be availabie in a chancery suit. ${ }^{5}$ The subsequent discovery of facts known to the witnesses called at the trial, but not known to 368.

\footnotetext{
${ }^{1}$ Hewlett $v$. Hewlett, 4 Edw. Ch. 7.

${ }^{2}$ Tieeder $v$. Duncan's Admr., 1 Bibb,

${ }^{4}$ Meyer $v$. Butt, 44 Geo. 471.

${ }^{5}$ Kenner $v$. Caldwell, 1 Bai. Eq. 149; 21 An. Dec. 538.

Pickett $v$. Stewart, 1 Rand, 478. 
the parties calling them, is no ground of relief. ${ }^{1}$ There must be an end to litigation. No doubt the courts are extremely cautious in granting relief from a judgment on tho ground that the party injured was ignorant of the existence of his defense until after the rendition of the judgment. 2 The true rule upon this subject is thus expressed in a recent decision: "Equity will not relieve a party against a judgment at law, on the ground of a defense of which he was ignorunt until after the judgment was rendered, unless ho shows that, by the exercise of ordinary diligence, he could not discover it, or that he was prevented from employing such diligence by fraud, accident, or the act of the opposite party, unmixed with negligence on his part." ${ }_{3}$ But whenever a case arises in which a party has an unjust judgment or decree rendered against him, owing to his ignorance of his defense, and the circumstances are such that his ignorance exists without any fault, laches, or want of diligence on his part, ho is certainly entitled to relief in equity. ${ }^{4}$ Whenever a party asks a court of equity to grant him a new trial, he must show some reason for not getting it at law. ${ }^{5}$ In Virginia, a judgment was enjoined on account of a mistake made by the jury - the making of such mistake not being known in time to be made a ground for a new trial. ${ }^{\circ}$ That the application for a new trial at law was not heard, on account of a sudden and nnexpected adjournment of the court for the term without doing any business, and before either the applicant or his counsel could get to court, is a good ground for relief in chancery. ${ }^{7}$

8. 507. Discovery after Judgment.-A material difference exists between ignorance of the facts constituting a defense, aud ignorance of the evidence necessary to establish those facts. A defendant who has no intimation of the existence

1 Harrison v. Harrison, 1 Litt. 137, Ch. 308; Hubbard v. Hobson, Breese, but see Stowell $v$. Eldred, 26 Wis. 504 .

${ }^{2}$ George $v$. Alexander, 6 Cold, 641 ; but see Inglehart $v$. Mayer, 4 Johns. Ch. Md. p. 514.

${ }^{3}$ Garrett v. Lynch, 45 Ala. 211. 147; Inglehart $v$. Lee, 4 Md. Ch. 514; Cape Sable Co's. Case, 3 Bland. 606; Baltzell ч. Randolph, 9 Fla. 366. 5 Mastick $v$. Thorp, 29 Cal. 444; Harrison $v$. Harrison, 1 Litt. 137. 6 Rust $v$. Ware, 6 Gratt. 50. 7 Tarver v. MIcKay, 15 Geo. 550.

- Wales $v$. Bank of Michigan, Har. 550 
of a defense, and who therefore believes the cause of action produced against him to bo good and valid, is not put upon inquiry, and may suffer judgment to bo rendered against him withont being guilty of any want of reasonable diligence. Dut a defendant, knowing of the existence of somo defense is put upon inquiry, and is, therefore, bound to exercise the highest degree of diligence in discovering and prodncing the evidence necessary to establish all the facts material to his defense and of which ho has any knowled gुe. If the requisite evidence can be obtained only from his adversary, he should at once take such steps as are necessary to compel his adversary to disclose it. Therefore, the submission to a trial at law precludes a party from going into equity to compel plaintiff to disclose evidence in relation to any matter of which the defendant had any knowledge or intimation previous to the trial at law. ${ }^{1}$ Discovery cannot be had after jadgment, on the ground, that the defense was completely in the knowledge of the plaintiff; nor because tho defendant had a credit or set-off which he had no evideneo in his possession to prove. It must appear, in addition to the fact that the credit or defense can be established by the plaintiff, that the defendant was not aware of the fact now songht to be bronght out, prior to the trial. ${ }^{3}$ But if a party, exercising due prudence and diligence, is not, at the trial, aware of the fact constituting a good defense, he may, after judgment, if such fact is to be established only by the oath of his adversary, go into equity and procure a new trial and a discovery. "To preclude a party from redress, because he has submitted to a trial at law, without going into chan-

1 Campbell v. Briggs, 3 Rob. La. ther appears that the losing party had 110; Green v. Massie, 21 Gratt. 358; no personal lnowledge of the facts, Burker $v$. Simpson, $1 \mathrm{John}$. Ch, 465; and was therefore obliged to depend Brown v. Swan, 10 Pet. 497; Thurmond $v$. Durham, 3 Yerg. 99 ; Norris $v$. Hume, 2 Leigh, 33t; 21 Am. Dec. 631.

2 Norris $v$. Deuton, 2 Cal. 378. But, it is said, a party has a right to rely on the presumption that his adversary will not commit perjury. If his opponent, being called as a witness, against himself, testifies falsely and thereby obtains judgment; and it fur- 125. on his adversary, the judgment will be set aside in equity, upon showin: that clear proofs have been obtained since the trial establishing the falsehood of the testimony through which the judgment was secured. Stowell v. Eldred, 26 Wis. 504.

${ }^{3}$ George $v$. Strange's Ex., 10 Critt. 499; Faulkner v. Harwood, 6 Rand. 
cory for a discovery, would cut up this branch of remedial justice by the roots and oblige every defendant at law to file a bill of discovery in the first instance. The discovory of new matter after a trial at law, which was within the knowledge of the plaintiff, but of which defendant had no information, and nothing to lead him to an opinion even that matters were different from the ostensible case presented by the plaintiff, is sufficient to authorize equitable relief." 1

\section{\% 508. IJeglect or Error of Counsel.-It is undonbtedly} the true rule, that neither the ignorance, the blunders nor the misapprehension of counsel, not occasioned by the adverse party, is any ground for vacating a judgment or decree. ${ }^{2}$ A court of equity will not grant relief on the ground of rights lost by a misapprehension of the rules of practice, 3 nor because counsel was surprised at a ruling which deprived him of the right of review on appeal. "It would be an extraordinary interposition on the part of a court of equity, to set aside a judgment obtained for aught that appears to the contrary, after a full and fair investigation upon the merits before the circuit judge, merely upon the ground that counsel had, by a mistake at law, cut off his right to review." Neither will relief be granted on the ground that an attorney through design or ignorance, mismanacred the defense, ${ }^{5}$ or that the client being absent on account of sickness, the counsel, throngh a misapprehension of the facts, consented to the decree; ${ }^{6}$ nor because an error was made in preparing statement for new trial in a tax suit, by which error, the statement showed that the \$ appeared before the figures on the roll, when in fact the assessment was void for want of such $\$$. It is the duty of attorneys to prepare their statements, so as to show such errors of the subordinate court, as they intend to rely on in the appellate court; and the failure to perform this duty is an omission so necessarily chargeable to negligence and want of ordinary care and diligence, that it cannot furnish any ground for relief in

1 Winthrop v. Lane, 3 Des, 323; Deputy $v$. Tobias, $12 \mathrm{Am}$. Dec. 243 .

${ }^{2}$ Boston $v$. Haynes, 33 Cal. 31; White $v$. Bank of U.S., 6 Hamm. 529.
${ }^{3}$ Dibbe $v$. Truluck, 12 Fla. 185.

${ }^{4}$ Farmer's Loan Co. v. Walworth Co. Bank, 23 Wis. 249.

${ }^{5}$ Burton v. Hynson, 14 Ark. 32.

${ }^{6}$ Burton v. Wiley, $26 \mathrm{Vt}$. 4:30. 
equity. ${ }^{1}$ In New York, the courts vacate judgments on motion, if shown to be obtained by reason of the ignorance or negligence of an attorney, and say that they will not allow a client to be ruined, because he has retained "an imeompetent, negligent, or unworthy attorney."2

\section{509. Rights Acquired by Third Persons.-Whatever} is sail in this chapter, in relation to racating, enjoining, or otherwise interfering in equity with a judgment or decree, must, in the absence of any statement to the contrary, be understood as applying to a contest between the parties to the original judgment or decree, or to persons acquiring under them with notice of all the facts. The principles applicable after third persons have, for valuable considerations and without notice of any defects, obtained rights under one of the parties, have not been discussed as frequently as could be expected and cannot be considered as finally settled. In relation to judgments obtained by some fraudulent device, in a case where the parties are properly in court, third persons are not to bo affected in their interests based upon the judgment unless they can be shown to hare acquired with knowledge of the fraud. Int where the complainant seeks to avoid the effect of any judgment or decree, on the ground that no process was in any manner served upon him, and that he had no knowledge or notice of the proceedings, the question arises whether he is obliged to suffer all the consequences which would result from a regular judgment, because a third party has made outlays occasioned by his faith in the judgment or decree. Recently in California, proceedings were instituted for the purpose of impeaching a judgment for taxes, and annulling a sale made thereunder, on the ground that the process in the tar suit was never served on the defendant therein. The Supreme Court in deciding the case, said: "The defendant being a purchaser for value at a judicial sale, without notice of the extrinsic facts which are relied upon to impeach the judgment, cannot be affected thereby. No principle is better settled than that a purchaser, at a judicial

1 Quin v. Wetheibee, 41 Cal. 247. | $\begin{aligned} & \text { 2 Sharp v. Mayor of Trew York, } 31 \\ & \text { Barb. 578. }\end{aligned}$ 
sale, without notice under proceedings regular upon their face, and had in a court of competent jurisdiction, is not affected by any mere error of the court, for which the judgment might be reversed upon appeal, nor for any serret vice in the judgment, not appearing on the face of the record, and which can be made to appenr only by the production of extrinsic evidence. He is bound at his peril to inquire whether it sufficiently appears on the face of the record, that the court had jurisdiction to render the judgment, and whether there is a valid execution. But nothing more is required of him. Unless the plaintiff in the action be also the purchaser at the sale, the latter will not be afeeted by any mere error of the court, even though the judgment be afterwards reversed for such error; nor can his rights be impaired by any secret vice in the proceedings resulting from fraud or other similar cause, of which he had no notice. As between the parties to the action, a judgment fraudulently obtained, will be set aside and held for naught when the frand is made to appear. But there wonld be no security in titles acquired at judicial sales if the rights of a bona fide purchaser, without notice, could be orerthrown by subsequent proof, that the judgment was obtained by fraud, or that the record, which showed a due service on the defendant, was in fact false. The repose of titles, and indeed every consideration of public policy, demunds that a purchaser at a judicial sale, without notice, under proceedings regular upon their face, and by a court of competent jurisdiction, should be protected, as against mere error's of the court, and against secret vices in the proceedings, founded on fraud, accident, or mistake, and which can only be made to appear by the proof of extrinsic facts not appearing on the face of the record. No prudent person would purchase at a judicial sale if he incurred the hazard of losing his money in case it should be made to appear that the judgment was obtained by perjury or other frandulent practices, or that the record on which he relied as proving a service on the clefendant was, in fact, false. These propositions are too familiar to require the citation of authorities in their support, and wo hare been referred to none which appears to contravene them, unless it be two 
cases decided by the Supreme Court of Iowa." The court proceeds further to declare in general terms that, as against a purchase under execution sale, the same rules and presumptions apply in an action in equity, to aroid the sale, as are applicable in a collateral attack upon the judgmeat. ${ }^{1}$ The decisions referred to in Iowa, declare that a judgment procured by the appearance of an unauthorized attorney will be vacated in equity, though such vacation destroys the rights acquired by a bona fide purchaser without notice. The court in California not being called upon to decide tho precise question involved in these cases, speats of their doctrine as follows: "If an unauthorized appenance by an attorney for a non-resident defendant, who was not served with process, can afterward be shown to invalidate the title of a bona fide purchaser, without notice, at the execution sale, it stands, so far as I am aware, as a solitary exception to the general rule, and the doctrine ought not to be further extended." It is here intimated that he who buss when the defendant is ostensibly in court, attending to his interests, by the means with which those interests are commonly protected, may possibly take his title accompanied with perils, which cannot attach themselves where the defendant is not in any manner represented in the progress of the cause. If a distinction can be made in the two classes of cases, it should be in favor of the party who purchased under the judgment in the case where an attorney has appeared; for if any court has the power to take and exercise jurisdiction over a defendant in no manner served with process, and in any erent to bind him by its judgment, then it surely cannot be that the appearance of an attorney presuming to act for such defendant, can divest the court of its jurisdiction. But while the decisions made, where an unauthorized attorney has appeared, and that made in California, in the absence of service, where no attorney had appeared, may not be necessarily inconsistent that they cannot both stand. It is obrious that the reasoning on which the decisions in Iowa were based, would, if applied to the case arising in

${ }^{1}$ Reeve $v$. Kennedy, 43 Cal. 649; Cal. 17; 5 P. L. R. 133; see, also, affirmed in Stokes $v$. Geddes, 46 MIcNair $v$. Toler, 21 Minn. 175. 
California, have led to a different result from that attained in the case of Reeve v. Kennedy. The Iowa cases adopt the reasoning of the Supreme Court of the United States in Shelton r. Tiffin (6 How. U. S. 163). In that case the effect of a judgment against one L. P. Perry, was drawn in question. An attorney, inadvertently, and without any fraud or collusion, appeared for L. P. Perry. A regular trial was hart, there being other defendants who were properly in court, and a judgment was obtained for $\$ 7,560$. Execution having issued, the property of L. P. Perry was sold to Samuel Anderson. The court said: "In this case, I. P. Perry was not amenable to the jurisdiction of the court, and did no act to authorize the judgment. He cannot, therefore, be affected by it, or by any proceedings under it. The judgment being void for want of jurisdiction in the court, no right passed to Samuel Anderson under the marshal's sale." After quoting this case, the court in Iowa said: "It cannot validate a judgment void for want of jurisdiction, that there has been a sale under it."

8 510. Innocent Purchaser. - A., holder of a senior mortgage, was summoned as a defendant in an action to foreclose a junior mortgage. The summons served stated that a foreclosure would be taken, subject to A.'s lien. He was therefore advised that he need not appear. A decree was taken without saving his rights, and a sale was made under such decree. A., hearing, three years afterward, of the decree and sale, endeavored to have them set aside. The court held that the decree being regular on its face, protected the innocent purchaser, and that A.'s only remedy was against the plaintiff and his solicitor. ${ }^{2}$

\section{Relief after Denial of Motion at Law. -} Courts of law, in some instances, may determine, on motion, applications of which courts of equity would also take cognizance, if the matter were brought before them in an independent action. In such cases, the summary disposi-

1 Harshey $v$. Blackmarr, 20 Iowa, ${ }^{2}$ Hamlin v. McCahill, Clarke Ch. 161 and 183-4; Bryant $v$. Williams, 249.

21 Iowa, 329. 
tion of a question upon motion, resulting in a denial of the relief claimed, does not preclude the party from obtaining the aid of chancery. Thus, though the right to set off one judgment against another is strictly an equitable right, yet courts of law may recognize and enforce it; but a reíusal by a court of law to allow the set-off, after full consideration of all the rights and equities, is no bar to a bill in equity for an injunction and a set-off. ${ }^{1}$ Upon the same principle, the denial of a motion to open a judgment, does not preclude a court of equity from subsequently granting the relief cenied at law. The decision of such motion is not such a res adjudicatu as precludes equity from re-examining the question. The opening of a judgment in a court of law is always $e x$ gratia, while restraining the plaintiff from proceeding on the judgment is, in equity, a matter of right. The facilities for investigating the issues presented in the motion are usually better in equity than at law. ${ }^{2}$

\section{Parties who may obtain Relief. - No person} will be permitted to proceed in equity against a judgment or decree to which he was not a party, and which did not, at its rendition, affect any of his rights. If the parties to an adjudication are satisfied with it, no outside persons will be permitted to intermeddle with it, at law or in equity. ${ }^{3}$ The grantee of land charged with a judgment lien at tho date of the grant, cannot have the judgment set asile for fraud, ${ }^{4}$ nor can he, in any manner, inquire into the consideration of the judgment for the purpose of impeaching or avoiding it. ${ }^{5}$ Having taken the land subject to a lien, of which the grantor made no complaint, the grantee must abide by that lien, unless he can show that it was procured by fraud and designed and calculated to prejudice him as a subsequent purcliaser. ${ }^{6}$ If an applicant seek to open a judgment on the ground that it is in fraud of his rights as a creditor of the judgment debtor, he will not be listened to

\footnotetext{
${ }^{1}$ Simpson v. Hart, 14 Johns, 63.

${ }^{2}$ Simpson v. Hart, 14 Johns. 63, and Wistar v. McManes, 54 Penn. St. 318; Truett $v$. Wainwright, 4 Gilm. 41s; Contro, Critchfield $v$. Porter, 3 Hamm. 518.

${ }^{3}$ Mayes v. Woodall, 35 Tex. 687; Stone $v$. Towne, 91 U. S. 341 .

4 Marriner $v$. Smith, 27 Cal. 619.

${ }^{5}$ French $v$. Shotwell, 5 Johns. Ch. 554; same case, 6 Johns. 235.

${ }^{6}$ Shufelt $v$. Shufelt, 9 Pai. 137.
} 
until he has made his own debt certain and indisputable by a judgment against his alleged debtor.'

8 513. Infancy.-A judgment against an infant is not void. ${ }^{2}$ The usual practice is to insert a provision allowing an infant a day after he comes of age, to show cause against a decree pronounced against him. And, except where the practice has been changed by introducing a modification of the common law in this respect, the omission of this clause is an error which will undoubtedly be corrected on appeal. According to some of the authorities, the right to show cause against a decree is the absolute right of every infant defendant; a right which is not taken away by the omission to provide for it in the decree, and which may be enforced by bill of review or by original bill, showing that, upon the facts, the original decree is improper. ${ }^{3}$ But the better opinion is that " an infant defendant is as much bound by a decree in equity as a person of full age; therefore, if there be an absolute decree made against a defendant who is under age, he will not be permitted to dispute it, unless upon the same grounds as an adult might have disputed it, such as fraud, collusion or error." 4 An absolute decree against an infant is, at least, so far binding on him, that he can neither by bill of review, nor by an original bill, nor by any other proceeding, impeach it so as to prejudice the interests of a bona ficle purchaser without notice. This is equally true, whether the judgment or decree is sought to be set aside on the ground that there was error in the judgment of the court in not giving a day to show cause, or error in other respects in the judgment rendered; ${ }^{5}$ or whether the judgment or decree was obtained by the guardian or other representative of the infant, for the purpose of defrauding him of his estate. ${ }^{6}$ A judgment against an infant on a bond and warrant of attor-

1 Wintringam $v$. Wintringam, $20 /$ Ch. 178; Tuchenbeiser $v$. Beckert, 41 Johns. 296; Wiggins $v$. Armstrong, 2 Ill. 173; Richnond v. Tayleur, 1 P. Johns. Ch. 144; Angell v. Draper, 1 Vern. 399; Shirley $v$. WVatts, 3 Atk. 200 ; Bennet $v$. MInsgrave, 2 Ves. 51.

2 Martin $v$. Weyman, 26 Tex. 460; Fulbright $v$. Cannefox, 30 Miss. 425; Townsend v. Cox, 45 Miss. 401 ; Porter $?$. liobinson, 3 A. K. M. 254; 13 Am. Dec. 153.

Wms. 734; Lloyd v. Malone, 23 Ill. 43; IVright $v$. Niller, 1 Sanf. Ch. 103. ${ }^{4}$ Dan. Ch. Pr. 205; Ralston $v$. Lahee, 8 Iowa, 23.

5 Joyce $v$. McAvoy, 31 Cal. 273; Bennett $v$. Hamill, 2 Scho. \& Lcf., p. 575.

${ }^{6}$ Gwinn $v$. Williams, 30 Ind. 374;

${ }^{3}$ Harris $v$. Youman, 1 Hoffman, IVright $v$. Miller, 1 Sanf. Ch. l03. 558 
ney given by him for articles furnished to him in defiance of the request of his guardian will be set aside in equity. ${ }^{1}$

8 514. Where there is no Injury.-A proceeding in the courts of a sister State, confessedly illegal, out of which no injurious consequence is flowing, and which no attempt is made to enforce, cannot be made the foundation of an action in the courts of this State to have it declared void. This decision was made in New York, upon an action brought there to annul a decree of divorce rendered in Michigan, without any service of process upon the husband, who was a resident of the former State. The relief was refused " because the matter can be ascertained to be illegal by reference to the books, as well as by getting the opinion of this court upon it."' In Califormia, a judgment entered by default by a clerk in the absence of authority will not be restrained in equity, because the court can, at any time, upon motion, arrest the process based upon such judgment. ${ }^{3}$

8 515. Time to Apply.- In Illinois, it has been held that in those cases where the service of process is constructive, and the law on that account allows a defendant a specified time to appear and have the judgment opened to make a defense on the merits, the time for prosecuting a bill or review or a writ of error does not run against the defendant until the judgment has been made final in fact as well as in form, by the lapse of the time granted him by statute in which to apply to set it aside. ${ }^{4}$

8 516. The general rule that he who seeks equity must do equity, is applicable to all complainants seeking relief from judgments against them. Courts of equity never interpose to wrest from any party any legal advantage he may have gained, without requiring his adversary to do complete justice, either by paying the amount due or by submitting to any other order of the court which may be necessary to adjust the rights of the parties with each other, according to fair dealing and good conscience. ${ }^{5}$

${ }^{1}$ L'Amoreux $v$. Crosby, 2 Pai. 422; | Reeves $v$. Cooper, 1 Beas. Ch. 223; $22 \mathrm{Am}$. Dec. 655.

${ }^{2}$ Hill $v$. Hill, 28 Barb. 23. Baragee $v$. Cronkite, 33 Ind. 192;

${ }^{3}$ Chipman v. Bowman, 14 Cal. 157; ton v. Stevens, 8 Mo. 622; FlickSanchez $v$. Carriaga, 31 Cal. 170.

${ }^{4}$ lyon $v$. Robbins, 46 Ill. 277. inger $v$. Hull, 5 Gill, 60; Shelton $v$. Giil, 11 Oh. 417; Hill v. Harris, 42

${ }^{5}$ Creed v. Scruggs, 1 Heiskell, 590; Geo. 412. 


\title{
CHAPTER XXIII.
}

\section{JUDGMENTS OF COURTS NOT OF RECORD.}

\author{
8 517. Chief Distinction. \\ $\S 518$. Whether Jurisdiction can be shown aliunde. \\ $\S 519$. Docket Recitals. \\ $\$ 520$. Justice's Court. \\ $\$ 521$. Service of Process. \\ $\S 522$. Facts to authorize Process. \\ $\S 523$. Cases where Court may decide on its own Jurisdiction. \\ 8524 . As Conclusive as other Judgments. \\ $\S 525$. Want of Jurisdiction makes Void. \\ $\$ 526$. Adjournment without day. \\ $\$ 527$. No Presumptious of Jurisdiction. \\ \$ 528. Judgments against Persons under common name. \\ 529. Ministerial Officers acting under Void Judgmeuts. \\ $\S 530$. Judicial officers acting without authority. \\ $\S 531$. 'Tribunals acting Judicially.
}

8517. Chief Distinction. - The chief distinction between judgments pronounced by courts of record and those pronounced by courts not of record, arises from the presumption of law that the former courts act within their jurisdiction, while, so far as jurisdiction is concerned, no presumption is indulged in favor of the latter. Whoever relies upon the judgment of a court of special jurisdiction must establish every fact necessary to confer jurisdiction upon the court. The proceedings of all courts not of record, must be shown to be within the powers granted to them by law, or such proceedings will be entirely disregarded. The acts of these two classes of courts have been properly likened to the acts of general agents and the acts of special agents. The former are to be regarded as valid in all cases to the extent that all persons relying upon them need show nothing beyond the general grant of authority; while the latter, to be binding, must first be shown to fall within the limits of a special or restricted grant. ${ }^{1}$ There is a further

${ }^{1}$ Clark $v$. Holmes, 1 Doug. Mich. People, 6 Barb. 607; Taylor v. Brus390; Sears ?. Terry, 26 Conn. 273; cup, 27 Md. 219; O. \& M. R. R. Co. Shufeldt $v$. Buckley, 45 Ill. 223; Stan- v. Shultz, 31 Ind. 150; Thompson $v$. ton $v$. Styles, 5 Exc. 583; Gray v. Mc- Multnomah Co., 2 Oregon, 34. Neal, 12 Geo. 424; Harrington $v$. ; 
distinction in regard to the proceedings of these two classes of courts, arising from the fact that courts of special jurisdietion have no record, and therefore no unimpeachable memorial of their transactions. Any statement in relation to jurisdiction found among the papers, minutes, or other written matter kept by these conrts, seems to be but prima facie evidence; in opposition to which it may be shown, by any satisfactory means of proof, that the authority of the conrt did not extend over the matter in controversy, nor over the parties to the suit. ${ }^{1}$

3.518. Fvidence to Support.-The necessity of affirmatircly establishing the jurisdiction of courts of record, by evidence aliznde, can nerer arise while the authority of those courts is always presumed. No donbt a case of actnal jurisdiction might exist in an inferior court at the rendition of the judgment, withont the evidence necessary to make the juriscliction apparent in collateral proceedings being preserved among the records. Tet general expressions used in many cases indicate that, when the judgment of a con't not of record is offered in evidence, for any purpose, it must appear, from inspection of the records, that jurisdiction existed. ${ }^{2}$ These expressions were mainly, if not exclusively, made in reference to a state of facts out of which the question of supporting judgments of inferior courts by means of aliunde proof of jurisdictional facts, could not arise. In California, the question has been directly involved and decided, in a decision in which the rule that jurisdiction must be apparent on the face of the proceedings was limited to those jurisdictional facts which the law directs the court to set forth on its records. Any other fact essential to jurisdiction may bo established by evidence aliunde; ${ }^{3}$ and this

${ }^{1}$ Rowley v. Iloward, 23 Cal. 40I;| 20 Ala. 409; First National Bank v. Pardon r. Drire, 23 Ill. 574; San- Baleom, 35 Conn. $3 j 1$.

born $v$. Fellows, 2 Foster, 439; Cor- 2 Simons v. De Bare, 4 Bosw. 551; win $v$. Merritt, 3 Burb. 3.2 ; People v. Ford $v$. Babeock, 1 Denio, 15s; Frees Cassels, 5 Hill, 164; Salladay $v$. Bain- $v$. Forl, 2 Selıl. 176; Walker $v$. Mosehill, 29 Iowa, 555; Barber $v$. Winslow, 1y, 5 Denio, 102; Lowe $v$. Alexander, 12 Wenl. 10:; Jenks $v$. Stebibins, 1115 Ciul. 296; Root $v$. MeFerrin, 37 Johns. 224; Sears $v$. Terry, 26 Conn. Miss. 17; Anderson v. Binford, 58 , 273; Cark $v$. Holmes, 1 Dong. Mich. Temn. 310.

400; see, however, Lightsey $v$. Harris, ${ }^{3}$ Jolley v. Foltz, 34 Cal. 321. 
view is sustained by the most recent decisions in Norw York. ${ }^{1}$

85 519. Recital in Docket.-The recital in the docket of a justice of the peace, that "summons was returned duly scrved," is a mere conclusion of law, adding nothing to the $e^{r 2}$ ect of the officer's return. That return is as much a part of the record as the docket. If it fail to show service, a recital in the docket based upon it cannot give validity to the judgment. ${ }^{2}$

8 520. Justices' Courts.-It seems to have been presumed at common law, that justices of the peace procecded lawfully and had acquired jurisdiction over the defendant, until the contrary appeared. ${ }^{3}$ In some of the United States, the records of justices are considered as entitled to the same absolute verity as the records of other courts; and no evidence is aclmitted to impeach them collaterally, thongh offered for the purpose of showing want of jurisdiction over the defendant." In Massachusetts, "the rule which makes the judgment of a court of record binding upon the parties, until reversed by proper proceedings therefor, although jurisdiction of the person was not properly obtained, is applicable as well to a justice of the peace as to one of a court of general jurisdiction." s

8 521. Service of Prceess - To confer jurisdiction on a court not of record, the process must be properly serred. A judgment founded on a service of process, made by a constable having no anthority to serve it, is void. ${ }^{6}$ So is a judgment founded upon a return signed "E. C., Deputy Sheriff," as the law does not recognize the act of a deputy sheriff, except for and in the name of his principal. "Where

1 Van Denzen $v$. Sweet, 51 N.Y. 381. dered by a justice of the peace is not

${ }^{2}$ Lowe v. Alexander, 15 Cal. $\Omega 90$. roid because he failed to file the com-

3 Rex $v$. Venables, 1 Str. 630; Rex plaint. Barber $v$. Kennedy, 18 Minn. v. Cleg, 1 Str. 475; Rex v. Peckham, 216.

Carth. 406; Rex $v$. Clayton, 3 East.cs. ${ }^{5}$ Hendrich $v$. Whittemore, 105

${ }^{4}$ Billings $v$. Tiussell, 23 Ponn. S. Mass. 23.

191; Tarbox $v$. Hays, 6 Watts. 39s; ${ }^{6}$ Reynolds $v$. Orvis, 7 Cow. 269; Fare v. Ladd, 37 Vt. 158; Lightsey v. Gallatian v. Cunningham, 8 Cow. 361. Harris, 20 Ala. 411. A judgment ren- 7Rowley v. Howard, 23 Cal. 401. 
the return of the constable shows that the summons lias becn served in the township in which the suit was commenced, and the justice acting on such return enters judgmont, such judgment cannot be collaterally aroided by showing that the defendant resided in another township; but where the record fails to establish that the defendant was sued or served with summons in the proper township, a judgment by default is void." In Texas, it has been decided that the issuing and serving of the writ give a justice of the peace jurisdiction; and that, therefore, a judgment is not void, though prematurely rendered before the time mentioned in the citation. ${ }^{3}$ But, a judgment by cefault where the summons issued by a justice required less time for the defendant to appear than was provided by statute, has been adjudged to be void. ${ }^{4}$

8. 522. Facts Authorizing Process. - Sometimes, certain facts are required to be proved to a court of limited jurisdiction as a ground for the issuing of process. In such case the tribunal must necessarily julge for itself upon the sufficiency of the proof offered. If there be any evidence, though slight and inconsiderable, having a legal tendency to prove the necessary facts, the process will be held valid until the action of the conrt in issuing it be set aside by some direct proceeding. Dut if there be an entire absence of proof, the process is void. In the one case there is a mere error of judgment, in the other a want of every matter upon which the court is authorized to act. ${ }^{5}$

8 523. Whenever the juriscliction of a court not of record depends on a fact which the conrt is required to ascertain and settle by its decision, such decision, if the court has juriscliction of the parties, is conclusire and not subject to any collateral attack. ${ }^{6}$ Thus, where the Surro-

${ }^{1}$ Fagg v. Clements, 16 Cal. 239. |Vanderheyden v. Young, 11 Jolns.

${ }^{2}$ Lowe v. Alexander, 15 Cal. 296; 150; Evansville R. R. Co. v. EvansMallett $v$. Uncle Sam Co., 1 Nev. 18s. ville, 15 Ind. 421; Wanzer $x$. How-

${ }^{3}$ McNeill v. Hallmark, 28 Tex. 157. land, 10 Wis. 16; Angel $v$. Robbins,

${ }^{4}$ Johnson v. Baker, 38 Iil. 98. $\quad$ I R. I. 493; Dyckman v. Mayor of

${ }^{5}$ Morrow $v$. Weed, 4 Iowa, $77 . \quad$ N. Y., 1 Seld. 434; Agry v. Betts, 12

${ }^{6}$ Brittain v. Kinnaird, 1 Brod. \& Mai. 415; Low v. Dore, 32 Mai. 27; Bing. 432; Betts v. Bagley, 12 Pick. Waterhouse $v$. Consins, 40 Mai. 333; 572; Martin v. Mott. 12 Wheat. 19; People $v$. Hagar, 52 Cal. 1S2. 
gato in New York, was empowered to appoint guardians for minors residing in the county wherein the court was held; and a petition was presented, stating that $A$. B. was such a minor, and without any guardian, and upon the hearing of such petition evidence was given in relation to the residence of the minor, and an appointment thereupon made, it was subsequently considered that the jurisdictional fact of residenco was thereby established, so that the appointment could not bo collaterally assailed by proving that $\mathrm{A}$. B. did not resido in the county. ${ }^{1}$

8 524. As Conclusive as other Judgments. - When a court of special jurisdiction, having authority to decicle the matter in controversy, acquires jurisdiction over the parties to the suit, its judgment is final and conclusive, unless reversed by some appellate court. Such judgment cannot bo overhauled or controverted in any original suit, at law or in equity. Its merits can nowhere be collaterally investigated. No error, however palpable, will vitiate it." "An inferior" court having acquired jurisdiction, the same intendments will be made in its favor as in the case of superior courts." Courts not of record are like special agents, we "must see their authority" before regarding their decisions as lawful ; but, seeing it, we are to respect it. Their authority is not the less certain because specified and confined." "It is well settled, that when the jurisdiction of a court of limited and special anthority appears upon the face of its proceedings, its action cannot be collaterally attacked for mere error or irregularity. The jurisdiction appearing, the same presumption of law arises, that it was rightly exercised, as prevails with reference to the action of a court of superior and general authority. ${ }^{5}$

${ }^{1}$ Lewis $v$. Dutton, 8 How. P. 103. Denio, 416; Woolruff $v$. Cook, 2 Ed.

${ }^{2}$ Bell $v$. Raymond, is Conn. 100; Shoemaker $v$. Brown, 10 Kans. 3S3; Telyea v. Tiamsay, 2 Wend. 602; Roosevelt $v$. Kellogg, 20 Johns. 208; Bernal $v$. Lynch, 36 Cal. 135; Gees $v$. Shannon, 2 Vatts, 71; Dakin $v$. Hudson, 6 Cow. 221; Sheldon $v$. Wright, Ch. 262; Rieid $v$. Spoon, 66 N. C. 415. 3 Thompson v. MIultnomal County, 2 Oregon, 34.

'MeKenzie v. Ramsay, 1 Bailey, 457.

${ }^{5}$ Comstock v. Crawford, 3 Wall. 1 Seld. 497; Mitchell v. Hawley, 415 Iowa, 213. 
8. 525. Want of Juxisdiction makes Void. $-A$ limited tribunal, taking upon it the exercise of jurisdiction not belonging to it, its decision is a nullity, from which there need not be an appeal. ${ }^{1}$ Judgment of a justico in a sum exceeding his jurisdiction, is void. ${ }^{2}$

8526. Adjournment without Day.-A justice who adjourns a cause without specifying the hour of the day nor the place to which it is adjourned, thereby loses jurisdiction over the parties, and a judgment subsequently rendered by him is invalid. ${ }^{3}$

8527. No Presumptions of Jurisdiction. - As nothing can be presumed in favor of the jurisdiction of a justice of the perce, the matter's requisite to authorize service of summons by publication, must afirmatively appear. If the statute provides that before ordering summons to be published, it must appear that plaintiff has a good cause of action; and the only showing on the sabject is an afichavit stating in general terms " that a good cause of action exists," this is insufficient, and the judgment procured thereby is a liullity. ${ }^{4}$

8 52S. When two or more persons are associated in business, in California, under a common name, the statuts authorizes suit to be brought against them in such name. Under this statute complaint was filed against the "Independent Company." The summons was issued against tho Independent Tunnel Company, and was returned served on " $\boldsymbol{R}$," a member of the Independent Company. Judgment entered against the Independent Tumnel Company was held to be roid on the ground that the record failed to show any suit or service on the last named company. ${ }^{5}$

8. 529. Offoers Acting under Void Judgment.-Questions in regard to the responsibility of officers for acts done by virtue of process issued upon void judgments, arise moro

1 Att'y Gen'l $v$. Lord Hotham, $1 \mid{ }^{3}$ Crandall $v$. Bacon, 20 Wis. 639. Turn. \& R. 219; Briscoe v. Stephens, 2 Bing. 213.

2 Jones $v$. Jones, 3 Dev. 360; Hinds Iichardson, 26 Cal. 153.

v. Wilis, 13 S. \& R. 213.

5 Fing v. Randlett, 33 Cal. 218. 
frequently out of the proceedings of courts not of record than out of proceedings in the higher courts. A roid judgment entered in one of the inferior courts has, no doubt, sometimes been treated as incapable of being a justification for any act clone under it, either by the parties or by any oficer of the court. ${ }^{1}$ But the general rule seems now to be almost miversaily acknowledged and enforced, that an oificer, acting under process, regular and valid on its face, and issued by a court which might lawfully exercise jurisdiction over the subject matter of the action, is protected although the court had no jurisdiction orer the defendant, unless the officer had notice of that fact. ${ }^{2}$ It is silic that when want of juriscliction arises from a fact of public notoriety which may legally be presumed to be in the officer's knowledge, he is not protected by his process. ${ }^{3}$ Some cases in New York deny the responsibility of officers although they knew of the facts, from which it appeared that the court had no jurisdiction of the person of the defendint, 4 or of the subject matter of the controrersy. ${ }^{5}$ Lut no donbt an offeer acting under process issued in a case of which tho court could not, in any circumstances, have juriscliction, is liable as a trespasser. ${ }^{6}$

8 530. Judicial Ofcers Acting without Authority.While judicial offeers, whether of superior or of inferior courts are not responsible for any errors of judgment made

1 Yates $v$. Lansing, 9 Johns. 424; $6 \mid v$. Wilkio, 13 Ill. 29; Shaw v. Davis, Am. Dee. 290; Terry v. Huntington, 55 Barb. 389; Whipple $v$. Tient, 2 Irardr. 480; Case of the Narshalsea, Gray, 410; Churchiil v. Churehill, 12 10 Coke, 68; Wise $v$. Withers, 3 Verm. 661; Niller v. Griee, 1 Tich. Cranch, 331; Mills $v$. Martin, 19 14j; State $v$. Crow, 6 Eng. 642; MrifoJohns. 35; Woodward v. Paine, 15 Jolns. 493.

${ }^{2}$ Harmon $v$. Gonld, 1 Wright Ohio, 769 ; Taylor $v$. Alexamter, 6 Hamm. 145; Coon v. Congden, 12 Wend. 496; Shcldon v. Van Buskirk, 2 Coms. 473; Dominick $v$. Eacker, 3 Barb. 19; Noble $v$. Holmes, 5 Hill. 194; Ilarget $v$. Blackshear, Taylor N. C. 107; Damon v. Bryant, 2 Pick. 411; Clay $v$. Caperton, 1 Monr. 10; 15 Am. Dee. 7 ; Cornell v. Barnes, 7 Hiil. 3j; MeLean $v$. Cook, 23 Wis. 364; Dynes $v$. Hoover, 20 How. U. S. 65; McDonald don v. Conway, 12 Mo. 295; Cimp v. Mosely, 2 Florila, 171; Campbell $v$. Webb, il Mld. 47l. This question is considered at length, am the anthorities thereon collected in Savacool 2 . Boughton, and the note thereto; 21 Am. Dee. 181, 190.

${ }^{3}$ Batcheldor v. Currier, 45 N. IT. 460; Parker v. Wallrod, 16 iVend. 518.

${ }^{4}$ Webber v. Gay, 2.1 Wend. 485.

3 People $v$. Warren, 5 Hill. 440.

6 IIoward v. Clark, 43 Mo. 344. 
by them while acting within their jurisdiction, ${ }^{1}$ they are, when assuming to act beyond the scope of their anthority, respousible as trespassers. ${ }^{2}$ If a complaint states fiucts sufficient to give jurisdiction to a judicial officer, with whom it is filed, he is not responsible for any acts done under it, though it afterwards appears that the complaint is untrue, and that the jurisdictional averments therein are false. ${ }^{3} \mathrm{~A}$ justice of the peace who enters judgment and issues execntion against a defendant not served with summons, thero being no return showing such service, and no appearance by defeudant, is liable as a trespasser for acts done under the execution. ${ }^{4}$

8 531. We have shown in this chapter that the decisions of courts not of record are conclusive upon all questions which such courts have jurisdiction to decide $;^{5}$ and that the judges of such courts, like those of higher judicial tribunals, may decide upon all matters properly before them, withont the danger of being made responsible for any errors of judgment. ${ }^{6}$ A large number of persons and of tribunals, not ordinarily spoken of as "judges," nor as "courts," aro

1 Miller $v$. Seare, 2 Bl. Rep. 1141; |Houlden $v$. Smith, 14 Ad. \& El. N. S. Yates $v$. Lansing, 9 Johns. 424; 6 Am. Dec. 303; Phelps $v$. Sill, 1 Day, 315; Lining $v$. Bentham, 2 Bay, 1; Bushell's case, 1 Mod. 119; Hamond $v$. Howell, 1 Mod. 184; 2 Mol. 218; Downing $v$. IIerrick, 47 Me. 462; Doswell $v$. Impey, I B. \& C. 163; Ela v. Smith, 5 Gray, I35; Burnham v. Stevens, 33 N. H. 247; Moor v. Ames, 3 Cai. 170; Butler $v$. Potter, 17 Johns. 145; Friend v. Hamill, $34 \mathrm{Ml}$, 298; McClure $v$. Gulf R. R. Co., 9 Kans. 3S2; Little $v$. Moore, I South. 74; 7 Am. Dec. 574; Gregory v. Brown, 4 Bibb, 2s; 7 Am. Dec. 781; Jones $v$. Ilughes, 5 S. \& R. 29S; 9 Am. Dee. 364; Reid $v$. Food, 2 N. \& HIeC. 168; 10 Am. Dec. 582; Cunningham $v$. Bucklin, S Cow. 17s; 18 Am. Dee. 432.

${ }^{2}$ Blood v. Sayre, 17 Vcrm. 609; 841; Pease $v$. Chaytor, 1 Best \& Smith, 65s; Revill $v$. Pettit, 3 Met. Ky. 314; Cohoon v. Speed, 2 Jones, 139; Kinowles $v$. Davis, 2 Allen, 61; Pijer v. Pearson, 2 Gray, 120; Wise v. Withers, 3 Cranch, 331; Atkins $v$ Brewer, 3 Cow. 206; 15 Am. Dec. 261; Flack $v$. Harrington, Breese, 213; 12 Am. Dec. 170; Kelly v. Rembert, Harper, 65; 18 Am. Dec. 643; Grumon $v$. Raymond, 1 Conn. 40; $6 \mathrm{Am}$. Dee. 290; State $v$. Flinn, 9 Blackf. 72 ; 23 Am. Dee. 380; Rogers $v$. Minlliner, 6 Wend. 597; 22 Am. Dec. 546.

${ }^{3}$ Low ther $v$. Earl of Radnor, 8 East, 113.

${ }^{4}$ Inos v. Winspear, $18 \mathrm{Cal} .397$;

Tobin v. Addison, 2 Strob. 3.

${ }^{5}$ See $\$ 3523-4$.

c See $\$ 530$. 
nevertheless authorized to investigate and determine certain questions. Their authority in this respect is juclicial; and their determinations are conclusive, until set aside by some competent authority. They cannot be made liablo for errors in deciding. Their jurisdiction, like that of other courts not of record, must always be affirmatively shown to impart validity to their decisions. As a general rule, whenever any person or persons have authority to hear and determine any question, their determination is, in effect, a judgment having all the incidents and properties attached to a similar judgment pronounced in any regularly created court of limited jurisdiction acting within the bounds of its mthority.

Note.-The following officers and tribumals have been held to act judicially in certain cases, and their decisions treated as possessing the same effect as the julgments of courts not of recorl, and, therefore, as not being liable to any collateral attack, cxcept for want of juriscliction: Board of Pilot Commissioners (Downer $v$. Lent, 6 Cal. 94); Board of Supervisors determining nccessity for new official bond (People v. Supervisors, 10 Cal. 344); or deciling upon the jurisclictional and other $\mathrm{q}_{1}$ uestions involved in proceedings to organize reclamation or swamp land districts, the notice required by law having first been given (Peolle v. Hagar, 52 Cal. 152); Benevolent and otlicr associations cletermining questions involving the rights of their members (Black and Whitesmith's Socicty $v$. Vandyke, 2 Whart. 309; Anacosta Tribe $v$. Murbach, 13 Mil. 91 ; Conmonwealth v. Pilse Ben. So. S Watts \& S. 247); Commissioners appointed to decide whether an execution should run against the boly of the defendant (Howe v. Newbegin, 34 2ie. 15); Commissioners of County locating lmblic highway (Stone $v$. Angusta, 16 МLe. 127); College Orders (Rex v.Grundon, 1 Cowp.315); Chureh Tribunals (Church $v$. Witherell, 3 Pai.
206; Gable $v$. Miller, 10 Pai. 627; German Ref. Church v. Seibert, 3 Barr. 291; Shamnon v. Frost, 3 B. Monr. 258; Forbes $v$. Eden, 1 Scotch \& Dir. App. 61s; Chase $v$. Cheney, Jan. Term 1871 of S. C. of Illinois); Inspectors of Elections passing on qualifications of person offering to vote (Gordon $z^{\prime}$. Farrar, 2 Doug. Mich. 411; Brevard $v$. Hoffman, 18 Md. 479); Mayor of city leciding whether to call out the military to suppress a riot (Ela $v$. Smith, 5 Gray, 135); Nilitary Court: (Dynes v. Hoover, 20 How. U. S. 65; Hefferman $v$. Porter, 6 Coll. 391; In re Robt. Bogart, U. S. C. C., Vol. 5 P. L. R. 125); Register and Receiver of Land Office (McConnell $v$. Wileos, 1 Scam. 314); Stewart of Court Baron (Holroyd $v$. Breare, 2 B. \& Alu. 473); Vicar General of a Bishop in excommunicating (Ackerly v. Parkinson, 3 II. \& S. 411). But in all cases jurisdiction of the defendant must be obtained to bind him by the adjudication (Commonwealth v. German Socicty, 15 Penn. S. 2.51; Delaey v. Nense Navication Co., 1 IIawks, 27t; Wash. Ben. So. v Bacher, 20 Penu. S. 425; Innes $v$. Wylie, 1 Car. \& li. 257 ; Queen $v$. Saddler's Co., 10 II. L. Cas. 104$)$. 


\title{
CHAPTER XXIV.
}

\section{OF JUDGMENTS BY DEFAOLT.}

\author{
532. Effect. \\ 533. Entry by Clerk without Authority. \\ \$ 534. Erroneously Entered by Clerk. \\ ร55. Disqualification of Judge does not Disqualify Clerk. \\ 536. Entry by the Court. \\ $\$ 537$. On Appeal, no Presumptions of Jurisdiction. \\ $\S 538$. Whether an Appeal Lies. \\ $\S 539$. On Good and Bad Counts. \\ $\S 540$. Errors Reviewed on Appeal. \\ $\S 541$. Opening. \\ \$ 542. Terms Imposed.
}

8 532. Erect of.-The effect of a ralid judgment by default, remaining unvacated and unrerersed, is generally conceded to be the same as though it had resulted from the trial of issues formed by appropriate pleadings on the part both of the plaintiff and of the defendant. The decisions sustaining this statement, as well as the few tending to controvert or modify it, are cited under various heads in this book, and, therefore, need not be reproduced in this place. ${ }^{1}$ The vacating or enjoining of a judgment by default, is governed by the same rules and must he supported by the same cause which would be sufficient to warrant the vacating or enjoining of any other judgment. ${ }^{2}$

8 533. Entry by Clerk without Authority. - Judgments may be entered after default, either by the clerk of the court, acting ministerially, or by the court acting judicially. "The clerk derives all his powers from the statute, and as they are special, no intendments are to be made in support of his act, but in each ease it must appear that what he did was within the authority conferred on him by the statute; and whether the act done by him be considered as purely ministerial or of a mixed nature, partaling of clemonts both ministerial and judicial is of no practicel importance. The question is, had he anthority to enter tho

1 See $\$ \oint 330$ and 331.

2 Sohier v. Merril, 3 W. \& II. 179; Masou v. Tichards, 3 Gilm. 55. 
defendant's default and thereupon judgment final against him as the case stood at that time?" If this question is answered in the negative, or, in other words, if the clerk had no authority to enter the default, or if, having authority to enter the default, he had no authority to enter judgment thereon, then any judgment entered by him, without tho direction of the court, is void. ${ }^{2}$

8 534. Erroneously Enčered by Clerk.--But it may happen that, though the authority of the clerk to act is concedecl, he proceeds to exercise this authority erroneously. The question then arises: "Is the judgment void so as to be an absolute nullity incapable of enforcement, or is it simply an erroneous judgment, which may be enforced until modified on motion made in the proper manner at the proper time, or on appeal from the judgment? In such case, we do not think the judgment would be absolutely void, in consequence of an error of the clerk in determining the amount. It would be an error committed in the performance of an act within his jurisdiction to perform, which could be corrected on motion made in time, or on appeal, but which would not vitiate the judgment if not corrected. There is no want of jurisdiction over the subject matter, but only an error in its exercise. Until modified or reversed, the judgment was valid."

8 535. Disqualification of Judge.-The entry of a default by the clerk, being a ministerial act, " the disqualification of the judge or his court to try or render judgment in the case, does not disqualify the clerk from performing this ministerial act." 4

2 586. Entry by the Court. - The entry of judgment upon default, by the court, acting by its clerk, being the exercise of judicial authority, is liable to be questioned collaterally, if, from the record, want of jurisdiction over

\footnotetext{
${ }^{1}$ Providence Tool Co. v. Prader, 32 $\mid$ den $v$. Packard, 28 Cal. 649; Wilson Cal. 634. $v$. Cleaveland, 30 Cal. 192; Curry $v$.

2 Stearns $v$. Aguirre, 7 Cal. 443; Roundtree, 51 Cal. 184.

Chipman v. Bowman, 14 Cal. 157; ${ }^{3}$ Bond 2 . Paeheco, 30 Cal. 530.

Iilly v. Van Austin, 17 Cal. 564; Glid- $\quad{ }^{4}$ People $v$. De Carrillo, 35 Cal. 37.
} 
the sabject matter of the action, or over the person of the defendant, is apparent; to be reversed upon appeal for any errors in the exercise of established jurisdiction; and to be vacated in the court wherein it was entered, for irregularities in the proceedings, or in the absence of such irregularities, in order to permit of the production of meritorions defenses. The law in regard to collateral attacks founded upon jurisdictional defects, has already been considered in tho chapter upon inquiries in regard to jurisdiction. We shall, therefore, confine this chapter to a brief statement of the matters sufficient to occasion the reversal of a judgment by default, when made the subject of review in an appellato tribunal; and of the facts warranting a vacation of tho judgment in the court wherein it was entered.

8 537. Jurisdiction not Presumed on Appeal.-On appeal, presumptions in regard to the regular acquisition of juristiction orer the defendant in the court below, do not prevail. If the record fails to show that juriscliction has been obtained, the judgment will be reversed. ${ }^{1}$ Thus, if the return on the summons be signed by A. B., Under Sheriff, it is a nullity, because the court cannot recognize the act of a deputy or under-sheriff, except when done in the name and as the act of his principal. For this reason the judgment founded upon such return will be reversed. ${ }^{2}$ The same action will be taken by an appellate court, where, though service is shown, the summons is radically defective. ${ }^{3}$ A judgment by default against two defendants, only one of whom has been summoned, is erroneous, and will be reversed as to both when the cause of action is joint. ${ }^{4}$

¿ 538. Whether Appeal Iies.-When process is served, it is incumbent on the defendant to appear and to disclose his defense, but a difference of opinion exists in regard to the necessity of his appearing and objecting by demurrer to a complaint which is so radically defective as to disclose no cause of action against him. On one hand, it is insisted

1 Schloss $v$. White, 16 Cal. 65. 2Joyee $v$. Joyce, 5 Cal. 449.

s Stato $v$. Woodlief, 2 Cal. 211;
Porter $v$. Hermann, 8 Cal. 625. 4 Winslow $v$. Lambard, 57 Me. 356. 
that if the defendant neglects to adopt his remedy of demurring to the complaint because it does not state facts sufficient to constitute a cause of action, that he cannot sustain an appeal.' On the other hand, and especially in California, judgments by default are held to be proper subjects of appeal, and are rerersed when the complaints on which they are based do not state matter's suflicient to constitinte a cause of action. The defiult, it is reasonably suggested, does not admit any fact which the plaintiff has not thought proper to allege. ${ }^{2}$ The rule adopted by the Supreme Court of California, and the reason for its adoption, were thus stated by Justice Sanderson:

"Nor is there any force in the idea that a distinction is to be made between cases which were once denominated cases at law, and cases which were once called cases in equity; and that on appeal from judgments by default, this court will review errors in the latter cases, and not in the former. There is matter in some of the cases cited by respondents which gives color to such an idea; but we say of them, as we have said of the others, there is no foundation for the distinction.

"Nor is there any force in the suggestion that this court will exercise original instead of appellate jurisdiction if it entertains the points made in this appeal. It is true that, as a matter of fact, the court below lias never passed upon the suffeiency of the complaint; yet it is equally true that, as a matter of law, it has. Though entered by the clerk without the clirection of the judge, it is as much the judgment of the court as if it had been announced from the bench, and the defendants are as much entitled to the opinion of this court, upon the sufficiency of the complaint, as they would have been had they appeared and demurred. Questions of jurisdiction and of the sufficiency of the com1)ivint, upon the point whether the facts stated constituted

${ }^{1}$ Jones $v$. Kip, 1 Code R. 119; Adrms $v$. Oaks, 20 Jolns. 282; Pope v. Dinsmore, 8 Abb. Pr. 429; Dorr $v$. Birge, 8 Barb. 351; Colden $v$. Knickcrbacker, 2 Cow. 31; Dean $v$. Abel, 1 Dick. 2s7.
${ }^{2}$ Abbe v. Marr, 14 Cal. 210; Barron $v$. Frink, 30 Cal. 4S6; Choynski थ. Cohen, 39 Cal. 501; Childress $x$. Mann \& Co., 33 Ala. 206. 
a cause of action, are never waived in any case, and may bo made for the first time in this court.

"The idea which finds countenance in some of the cases cited by the respondents, that at all events this court will cleal more liberally with judgments by default than with others, and will pass over errors for which it would reverse a judgment rendered upon a trial, we here talse occasion to say, is without foundation. It is true we will not reverse a judgment by default for mere technical defects in the complaint which fall short of an entire want of something which is material to the plaintiff's right to recover. So the cases referred to declare, and in this respect they are sound. The error in those cases was in giving countenance to the implication that the court would do so in any case by not deelaring the rule to be universal. On the question of reversal, this court can make no distinction between judgments by default and judgments upon issue joined and tried, for the statute makes none. It will reverse the former where it would the latter." 1

8539. On Good and Bad Counts.-A difference of opinion exists in regard to judgments upon default based upon complaints contrining several counts, some of which are good and others defective. In California, it is held that the default "confesses all the issuable facts of the sereral causes of action counted upon," and that "the fact, that by reason of one of them having been imperfectly stated, no judgment could be rendered on that count, does not afeet the right of plaintiff to take judgment on those which are rightly stated," and therefore that the judgment by default will not be reversed. ${ }^{2}$ But in Massachusetts an opposite conclusion is sustained. The court, considering this question in that State, said: "The damages after a defaut are general, and without looking into the papers fled, to see how the damages were in fact assessed, there is nc legal ground to presume that they were not assessed on this count. The rule is well settled in case of a verdict, and general damages, when one count is bad in substance, that

1Hallock v. Jaudin, 31 Cal.167. | $\begin{gathered}2 \text { Hunt v. City of San Francisco, } 11 \\ \text { Cal. 250. }\end{gathered}$ 
the judgment must be reversed, except where it can bo amended, by the certificate of the judge, so as to show that the damages were assessed on the good counts alone. The same reasons apply with even more force in case of general clamigros on a default."

8. 510. Errozs on Appeal.- "There may bo error in a judgment by default, as well as in a judgment rendered npon issue joined in the pleadings and tried by a jury; and in the former as well as in the latter case, the error may be corrected on appeal." 2 This error may consist in rendering judgment where there is an entire want of jurisdiction over the defendant, or where there is no sufficient statement of a cause of action against him. In both of these cases, as we liare seen, the appellate court will exercise its supervisory powers. But its authority is not confined to the correction of these extreme and radical errors. It will interpose to correct errors and irregularities in the proceedings, and though the proceedings be regular, will correct errors of the court or of its clerk entering into the judgment to the prejudice of the appellant. It will reverse a judgment by default entered before the expiration of the time allowed for the defendant to answer; ${ }^{3}$ or founded upon a summons radically defective, ${ }^{4}$ and will so modify any judgment by default as to free it from error, and to make it such a judgment as, in the opinion of the appellate court, ought to liave been rendered upon the facts confessed by the default.

\&541. Opening.-The courts possess and exercise a very large discretion in vacating judgments by default, for the purpose of permitting a defense to be made on the merits. No rule can be laid down on this subject which wonld be applicable in all the different States. In Missouri, the rile is, "that a meritorious defense and a reasonable degree of diligence in making it, are all that it is necessary to establish, in order to justify the setting aside of a default." 5 In de-

1Dryden $v$. Dryden, 9 Pick. 546; $v$. Reynolds, 11 Cal. 14; Lamping \& Hemmenway $v$. Hickes, 4 Pick. 496. ¿Stevens $v$. Ross, 1 Cal. $9 t$.

3 Burt v. Scranton, 1 Cal. 416.

4 Porter $v$. Hermann, 8 Cal. 619. Co. v. Hyatt, 27 Cal. 99; Lattimer $v$. Ryan, 20 Cal. 633; Wallace v. Eldredge, 27 Cal. 49j; Hardinor v. Cowing, 28 Cal. 212.

5 Gage v. Rogers, 20 Cal. 91; Raun 6Adams v. Hickman, 43 Mo. 168. 
ciding upon the question of diligence, the action of tho court will be reviewed only in extreme cases, involving an rbuse of the discretion rested in court. ${ }^{1}$

8 542. Imposition of Terms.-It is a rulo almost universally acknowledged and applied, that a default will not be opened without imposing such terms as forbid that any advantage be taken of mere technical errors. A defendant in default has no right to a hearing except upon matters "which touch the honesty and justice of the case." : But the rule has been denied, or at least materially modified, in New York. Thus, in that State a default will be opened without imposing the condition that the defendant shall not plead the statute of limitations, unless it be shomn that such plea will be more difficult to controvert than before the default was taken. ${ }^{3}$ In a case where the court opened a default to allow the defendant to plead that the note sued upon was given for a gambling debt, the following forciblo and apparently unanswerable reasons were giren for its lecision: "There should be no selection or choice by the courts as to what law should be enforced, or what should be eraded or nullified; what should be favored; what treated with disfavor. The principle and policy of this faror and disfavor are wrong. If it is hard to allow such a defense, the law is to blame in providing the defense. The courts should not undertake to say that certain defenses provicled by law are hard and unconscionable, and therefore undertoke to legislate against them."

1 Woodward v. Backns, 20 Cal. 137; Bailey $v$. Taaffe, 29 Cal. 422; Wooster v. Woodhull, 1 Johns. Ch. 539; Frazier $v$. Bishop, 20 Mo. 417; Ewing $v$. Peck, 17 Ala. 339; Palmer v. Hutchins, 1 Cow. 42. See chapters.6 and 7 of this book.

2 Bailey v. Clayton, 20 Penn. S. 295; King v. Merchants' Exchange Co., 2 Sanf. 697; Gay v. Gay, 10 Pai. 374;
Bard v. Fort, 3 Barb. Ch. 632; see Ante, fo 103 aut 102.

3 Douglas $v$. Douglas, 3 Ed. Ch. 390; Gourlay v. Hutton, 10 Went. 595.

4 Bank of Kinderhook $v$. Gifford, 40 Barb. 659.

Note.-For various matters in relation to opening and vacating judgments by default, see chapters 6 and 7 on Vacaling Judgments. 


\title{
CHAPTER XXV.
}

\section{JCDGMENTS ON CONFESSION WITHOUT ACTION.}

\author{
$\S$ 543. Statutes in Regard to, strictly construed. \\ $\$ 544$. What Judgments aro within the Statutes. \\ $\S 545$. Who may make the Confession. \\ $\S 546$. What may be confessed for. \\ $\$ 547$. Jurisdiction of the Court. \\ $\$ 548$. Consent of the Plaintiff. \\ \$ 549. General Requisites of Statement. \\ $\S 550$. Verification of Statement. \\ \$551. Signing Statement. \\ §552. Sufficient Statements. \\ \$ 553. Statement on Iromissory Note. \\ $\S 554$. Statement for Goods Sold. \\ \$555. Statement for Money Lent. \\ \$ 5ic. Statejnent for Lalance Due. \\ \$5.7. When Void. \\ \$ 5i8. Remedy of Defendant for correction of Errors in.
}

8 513. Statute Strictly Construed.-The statutes of sereral of the States provide that "a judgment by confession may be entered without action, either for money dne, or to become due, or to secure any person against contingent liability on behalf of the defendant, or both, in the manner prescribed by this chapter;"' and then prescribe that a verified statement must be made by the party confessing, and filed with the clerk. The anthority thus given by statute must be strictly pursued. ${ }^{2}$

8 544. What Statute Applies to.-The question has frequently arisen, whether a judgment under consicleration was a judgment by confession, within the provisions of these statutes, or was authorized and sustained by law existing independent of these statutes. It is certain that the statute does not apply to any judgment confessed in an action regularly commenced and in which process is regulirly issued and served; ${ }^{3}$ and it seems to be essential that

1 Sec. 371 Cal. Pr. Act; sec. 1132 3 Hoguet $v$. Wallace, 4 Dutch. 524; Cal. C. C. P.; sec. 382, N. Y. Code. Miller $v$. Bank of British Columbia, 2 Chapin v. Thompson, 20 Cal. 686; 2 Oregon, 291; Crouse $v$. Derbyshire, MI. \& MI. Bank of Phila. v. St. John, 10 MIich. 479; Schroeder v. Fromme, 5 Hill, 497; Edgar v. Greer, 7 Iowa, 31 Tex. 602. 136. 
tho process should be server, and that, though action bo regularly instituted, the voluntary appearanco of the dofendant and his admissions of the facts stated in the complaint, will not sustain the judgment, in the absence of the statement prescribed by statute.' Dat the service here spolken of is not necessarily a service in the usual manner. The acceptance of serrice by the dofendant is equivalent to service in the oxdinary form, and tares the case ont of the uperation of the statute, requiring an aflidavit as to the justness of the debt. ${ }^{2}$

8. 545. Who may Malre the Confersicn. - Upon the general rule that whatever a person may do for himself he may also do by mother, it is affirmod that a ralid confession moy be made $b_{y}$ an ageat if within his whthority. ${ }^{3}$ If the agent excecls his authority by confessing for too great an anount, the judgment is roid only as to such excess. ${ }^{*}$ But a partner has not, by his general power to act as agent for the partnership, authority to confess a jud gment against his firm. In New York, it has been hold that a public offec: liable to be sued for services rendered for the public at his request may confess judgment for the amount due. The court said: "The statute is broad enough to include publis oficers, and I am of opinion that in every case where a person is liable to be prosecrted to judgment, he may lawfully confess a judgment for the amount justly dne. II can conceive no sound reasons of pnblic policy, which require the public to be buthened with the costs of litigation in every case where a clainant proceedss to pat his claim into judgment. ${ }^{6}$ In Oregon, ju. gment against a corporation may be confessed by any of its oflicers or agents on whom a summons argainst the corporation could be lawfilly served. ${ }^{7}$ A

${ }^{1}$ Flanigan v. Bruner, 10 Tex. 25\%. $\mid v$. Fuller, 2 Oregon, 179; Elliott $v$.

${ }^{2}$ Gerall v. Burthee, 29 Tex. 203.

${ }^{3}$ Parker $v$. Poole, 12 Tex. 86.

"Davenport $v$. Wright, 51 Penn. S. 292.

${ }^{5}$ Stontenburg $v$. Vandenlungh, 7 How. Pr. 229; Canal and Lend Mine
Co. v. Wakker, 11 L. C. 433 ; Christy v. Sherman, 10 Iowa, 535; Banl's bia, 2 Oregon, 201. Appeal, 56 Penn. S. 458; Richarison! $4 \approx 3$. How. Pr. 257.

37 Miel. 236; contra opinion, see Bump v. Pierey, 4 N. Y. Leg. Obs.

${ }^{6}$ Gere $v$. Supervisors of Cayuga, 7

Tiiller $v$. Bank of British Colum. 
judgment by confession against a husband and wife, is so invalid as against the latter, that she may have it set aside. ${ }^{1}$ But if she elect to allow it to remain and permit her property to be sold under it, the sale is effectual to transfer her title. ${ }^{2}$ A trustee cannot confess a judgment so as to bind the trust estate. ${ }^{3}$

\section{\& 546. What may be Confessed for.-The statute pro-} rides that the confession may be for money due or to become due. This, it has been held, does not authorize the entry of judgment without action upon a demand for damages arising out of a tort." Judgment by confession must be for a sum certain. Where a party confessed judgment for such sum as should be awarded, before the award was made, the action of the justice in subsequently entering judgment in accordance with the confession, was reversed. ${ }^{5}$

8547. Jurisdiction of the Court.-Judgments by confession are in no wise exempt from the rule applicable to other judgments that, to be valid, they must be entered in a court having jurisdiction over the subject matter of the action. "Though no adjudication is in fact required, in entering a judgment of confession without action, yet it has all the qualities, incidents, and attributes of other judgments; and cannot be valid unless entered in a court which might have lawfully pronounced the same judgment in a contested action." "Where the law requires judgments to be signed by the judge, its provision exterds to judgments by confession, and renders them roid if not so signed. ${ }^{7}$

2548. Consent of Plaintiff.-A judgment by confession entered without the knowledge or consent of the creditor in whose furor it is, is, prior to the ratification by him, invalid for all purposes, being neither operative as a lien, an estop-

1 Wotkyns $v$. Abrahams, 14 How. Pr. 191; 24 N. Y. 72; Brittin v. Wilder, 6 Hill, 242.

2Romaback $v$. Stebbins, 33 How. Pr. 27s; Kniekerbacker $v$. Smith, $16 \mathrm{Abh}$. Pr. 211; Palmer $v$. Davis, 28 N. Y. 212. With respect to judgments confesserl by married women, see Travis v. Willis, 55 Miss. 557; Quim's Appeal, S6 Pa. S. 447; Edwards v. Edwards, 29 La. An. 597.
${ }^{3}$ Mallory v. Clark, 20 IIow. Pr. 41s; Narks $v$. Lieynolds, 12 Abb. Pr. 403; Huntt '. Townshend, 31 MId. 336.

${ }^{4}$ Boutette $v$. Owens, 2 Sandf. 655; Boulette v. Owen, 2 Code R. 40; Burkham v. Tan Saun, 14 Abb. P. N. S. 163.

5 Nichols $v$. Hewit, 4 Johns. R. 423. ${ }^{6}$ Lamingv. Carpenter, 23 Barb. 402. ${ }^{7}$ Chajpin r. Thompson, 20 Cal. 631. 
pel, nor as a merger of the demand. Bat if the creditor afterward accepts and ratifies it, it becomes, from the moment of its acceptance, valid; and attended with all the results incident to other valid judgments. ${ }^{1}$

2 519. General Requisites of Siatement.-The statute provides for a statement in writing, signed by the defendant and rerified by his oath, showing the amount for which judgment may be entered, and authorizing its entry ; stating concisely the facts out of which the indebtedness due, or to become due, arose ; or, in case the confession is intended to secure a contingent liability, stating concisely the facts constituting the liability, and showing that the sum confessed does not exceed such liability. The object of the statement is to so inform persons with whose interest the judgment conflicts, as to enable them to ascertain the truth or falsity of the claims on which it is based. The statement "should be specific in sums, dates, and considerations, to enable other creditors, with reasonable facility, to investigate its genuineness, and protect themselves from fraud." But "it need not state enough of the transaction to enable creditors to judge without inquiv' A statement need not be more definite than a complaint on the same cause of action. ${ }^{4}$

8 550. Verification of Statement. - That the defendant "believes the above statement of confession is true," has been held to be a sufficient verification, on the ground that he could be convicted of perjury, if the statement were untrue. 5 But, subsequently, in the same State, and by the court of last resort, a similar verification was decided to be insufficient, and the rule was established that as to matters within the knowledge of the defendant, he must make a direct statement, and as to other matters, he must state his information, and add that he believes it to be

1 Wilcoxson v. Burton and McCarty, 3 McDorrell v. Daniels, 38 Barb. 27 Cal. 228. 375.

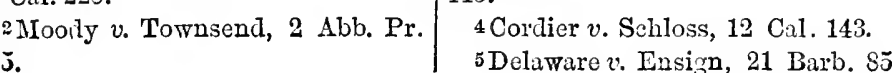


true." "That the facts stated in the above confession are true," is a good rerification. ${ }^{2}$ If the verification be defective, it may bo amended even when the judgment is offered in eridence in another case. ${ }^{3}$

8 551 . Signing Statement.-If the verification and statement are on the same page, and the signature of the defendant is to the former only, this is a substantial compliance with the requirement of the statute, that the statement "mast be made and signed by the defendant."

8 552. Sufficient Statements.-The statement need not aver in the terms of the statute that the amount "is justly due, or to become due." What the statute requires is, that the facts set forth shall make it apparent that a debt is "justly dne or to become dne." That being done, an additional averment in the langrage of the statute is surplusage. Thongh a just debt, once existing, may have been released or discharged, still the defendant is not required to negative all the conceivable possibilities of the case, and thereforo the statement need not assert that the debt has not been paid nor otherwiso discharged. ${ }^{5}$

8553. On Promissory Notes.-If the statement be upon a promissory note, it is sufficient to set forth its amount and date, with the consideration for which it was made and the time when it was made payable. ${ }^{6}$ The words "that amount being had of the plaintiff by the defendant," have been considered a sufficient statement of the consicleration of a note; $;^{7}$ and so have the words " being for money paid by plaintiff for me, on the real estate $I$ now own at Irving." A statement showing the date and amount of a note and the time when dne, and arerring that a specified sum is justly due for principal and interest to date, is in-

\footnotetext{
${ }^{1}$ Ingram $v$. Robbins, 33 N. Y. 409. $\quad{ }^{5}$ Lanning $v$. Carpenter, 20 N. Y.

${ }^{2}$ Mosher $v$. Ileydriek, 30 How. P. 447.

$161 ; 45$ Barb. 549 .

${ }^{3}$ Cook $v$. Whipple, 55 N. Y. 150; I' Am. Rep. 202.

${ }^{6}$ Clements $v$. Gerow, 1 Keyes, 297;

Kellogg $v$. Cowing, 33 N. Y. 408;

Lanning $x$. Carpenter, 20 N. Y. 447 ;

${ }^{4}$ Purdy $v$. Upton, 10 How. Pr. 494; affirming 23 Barb. 40?; Kirby $v$. FitzPost v. Coleman, 9 How. Pr. 64; gerald, 31 N. Y. 417.

Mosher $v$. Heydriek, 30 How. P. 161; 'Freligh v. Brink, 22 N. Y. 418. 45 Barb. 519.

${ }^{8}$ Acker $v$. Acker, J. Keyes, 291.
} 
sufficient." The following statements on notes have been held insufficient: "That we, A. H., E.H. and J.H., are indebted to A. B. upon a note, of which the following is a copy" (setting out copy); that the debt is justly due to plaintifss, on a note made on a specified date by defendant to plaintiffs on a setriement made at a certain time, for a given sum, and lue one day from date; 3 that the note was made (giving date, amount and time of payment), "for money had and receired by me of said plaintiff, at my request;"; that the note was giren for "liabilities incurred by the plaintiff for me by his indorsement of my notes, which tho said plaintiff is to pay or has paid;" that "said note was given in good faith for a debt justly due plaintiff and is unpaid; and this confession of judgment is given without fraud." 6 When a statement is upon a bond, its consideration is not sufficiently set forth by showing that it was given for a promissory note made by defendant to A., and endorsed by $\mathrm{A}$. to plaintiff. The mere making and endorsing of a note is no suficient consideration for a bond, unless such making or endorsing was upon some consideration. ${ }^{7}$ The consideration for the making of a note is insufficiently described, by stating that the note was "given for goods sold and delivered, and money had and received. Indeed, the failure to state the amount due severally for goods and for money itself, would be fatal."s

2 554. Goods Sold.-In New York, statements based on indebtedness for goods sold and delivered, have frequently been sustained, though exceedingly rague and indefinite, both as to the character and quantity of the goods, and as to the date of their purchase. The anthorities in that State

${ }^{1}$ Chappel v. Chappel, 12 N. Y. 215. Lank of Finderhook $v$. Jenison, 15 How. Pr. 41; Winnebrenner $v$. Edgerton, 30 Barb. 185; Pond v. Davenport, 44 Cal., 481; Edgar v. Greer, 7 Iowa, 136.

2 Bonnell v. Henry, 13 How. Pr. 112; Norris v. Denton, 30 Larb. 117; Fendall v. Hodgins, 1 Bows. 659; Mirray v. Judson, 9 N. Y. 73.
3Dunham $v$. Waterman, 17 N. Y. 9. 4 Daly $v$. Mathews, 20 How. I'r. 267.

5 Von Beck $v$. Shuman, 13 How Pr. 472.

c Tennedy v. Lowe, 9 Iowa, 580.

7 Reading $v$. Reading, 4 Zabr. 353.

8 Cordier v. Schloss, 18 Cal. 576. 
show that it is sufficient to state that the indebtedness "has arisen for goods, wares and merchandise sold and delivered," and that such sale and delivery was in a certain month, or since a certain day, or within the last two years, or in two certain Jears. ${ }^{1}$ A statement that the "indebtedness arose on the sale and conveyance, by the plaintiff to the defendant, of his right, title and interest in the boats, property and effects of William Mastin \& Co., in January, 1854," was regarded as insufficient by Chief Justice Denio. But, "on consultation, however, it appeared that all the other judges had come to the conclusion that it was valid, because it was thought to afirm, with reasonable certainty, that the amount for which the judgment was confessed was the agreed price to be pain by the defendant for the interest of the plaintiff in the property of William Mastin \& Co., npon the purchase by defendant of that interest." ${ }^{2}$ The vagneness sanctioned by these decisions is not encouraged by adjudications made in other States. In Wisconsin, a statement showed that the defendants purchased of plaintiffs " is large quantity of goods, wares and merchandise" of a speci. fied ralue, and that a sum named remained umpaid. When this statement came before the Supreme Court, it was regarded as insufficient. An early case in New York, declaring that "if the consideration was for goods sold, tho specification ought to state the kind, quantity and price of the goods, and the time of the sale, as in a bill of parcels,"3 was approved as containing a correct statement of the law on the subject." In Missouri, it is said a statement onght to show when and what lind of property was sold, the aggregate price, and the payments, if any, so as to afford a clew to the creditor, if he wished to investigate the matter; but that the statement need not be as precise as a bill of particulars. ${ }^{5}$

8 555. For Money Ient.-It is sufficient to state that

${ }^{1}$ Delnware $v$. Ensign, 21 Barb. 85; Gandall $v$. Finn, 1 Keyes, 217 ; Read v. French, 28 N. Y. 285 ; Daniels $v$. Clatlin, 15 Iowa, 152; Clements $v$. Gerow, 1 Keyes, 297; Neusbaum $v$. 太(im, $2 \pm$ N. Y. 325.
2 Thompson $v$. Van Vechten, $27 \mathrm{~N}$. Y. 568, reversing 5 Abb. Pr. 458.

3 Lawless $v$. Hackett, 16 Johns. 149.

${ }^{4}$ Nichols $v$. Tribs, 10 Wis. 76.

5 Iiryan v. Miller, 28 MIo. 32. 
the defendant is indebted for a specified sum of money lent, giving the date of the loaning. ${ }^{1}$ According to several New York cases, a statement showing that money "was lent and adranced at divers times" after a specified date, is not suficiently particular. ${ }^{2}$ But the position taken in these cases is probably overthrown by a decision of the lighest court in the same State, in which it was said that the statement that the money "was lent by plaintiff to defendant at various times" after a certain date, could be supported within the current of the decisions. ${ }^{3}$

8. 556. For Balance Due.-A statement that "this confession of judgment is for and upon a balance of account against me for goods, wares and merchandise purchased by me" of plaintiffs, is defective. It does not state when the goods were bought, the terms, amount, quality, or kind; neither does it show what payments have been made, nor how the balance was ascertained. For like reasons, it is not sufficient to state that a demand sued upon "was given the plaintiff for the balance due on settlement."

3. 557. When Void.-Judgments by confession without action, like other judgments, are rarely voil in the extremo sense of the term. A judgment by confession, though unsupported by any statement, is valid between the parties. ${ }^{6}$ A statement purporting to authorize the entry of judgment against several, but which is signed by less than the whole number of the defendants, cannot support a judgment against those not signiug; but it is generally regarded as sufficient to empower the clerk to enter a valid judgment against tho signiers. ${ }^{7}$ In California, such a judgment is treated as an

1Johnston $v$. MrcAusland, $9 \mathrm{Abb}$. Pr. 214; Clements v. Gerow, 1 Keyes, 297 ; reversing 30 Barb. 325; Frost $v$. Koon, 30 N. Y. 428 .

2 Davis $v$. LIorris, 21 Barb. 152; 243. Stebbins v. East Society, 12 How. Pr. 410; Daly $v$. Matthews, 20 How. Pr. 267.

눈 Frost v. Koon, 30 N. Y. 428.
4 Miller v. Earle, 24 N. Y. 110.

5 Bernard \& Co. v. Douglas, 10 Iowa, 370 .

o Ea parte Fuller, 1 Saw. C. C. 7 North $v$. Mudge \& Co., 13 Iown, 426; The York Lank's Appeal, 86 Pa. S. 458. 
entirety; and being invalid as to one joint defendant, is invalid as to all. ${ }^{1}$ Defects in the statement do not impair the effect of the judgment between the parties. ${ }^{2}$ It can not, on that account, be collaterally attacked; but must be respected until set aside by appeal, or by action, or upon motion. ${ }^{3}$ If execution be issued, and a sale made, the title of the purchaser is not dependent on the statement's correctness in fact, or perfection in form. ${ }^{4}$ The insufficiency of the statement throws upon the plaintiff, in any proceeding for the purpose of setting aside the judgment, the burden of showing that it is not tainted by fraud, and that facts sufficient to authorize its entry in fact existed, though not set forth in the statement. ${ }^{5}$ The plaintiff may maintain an action to set aside a fraudulent conveyance, and to subject the property therein described to the lien of his judgment; though, as against other creditors, it is supported by an insufficient statement. ${ }^{6}$ A juclgment by confession, valid in the State where entered is ralid elsewhere. ${ }^{7}$ A judgment by confession is not void because entered before the debt is due, or for too large a sum. ${ }^{8}$ The judgment must be entered in fact, and an execution in advance of such entry is void. ${ }^{9}$ Judgments by confession are said to be supported by the same presumptions as if entered in actions. ${ }^{10}$ In Nevada, where the clerk of the court copied the statement and affidavit in the juagment book, and added the words, "Juảgment entered, April 14, A. D. 1874. Attest, J. H. Job, Clerk," and indorsed the same words on the back of the statement, this was adjudged to be a sufficient entry of the judgment. ${ }^{11}$

¿. 55̌s. Remedy of Defendant.-As in the case of judgments by default, a difference of opinion is manifest in re-

\footnotetext{
${ }^{1}$ Chapin v. Thompson, 20 Cal. 681.

${ }^{2}$ Bryan $v$. Miller, 28 Mo. 32; Kirby v. Fitzgelalel, 31 N. Y. 417; Plummer $v$. Douglas, 14 Iowa, 69; Lee $v$. Figs, 57 Cal. 328; Pond v. Davenport, 44 Cal. 481; How $v$. Dorscheimer, 31 Mo. 349 .

3 Sheldon $v$. Stryker, 34 Barb. 116 ; 21 How. P. 329.

${ }^{4}$ Miller $v$. Earle, 24 N. Y. 110.

${ }^{5}$ Cordier $v$. Schloss, 18 Cal. 576; Richards $v$. McMillan, 6 Cal. 419.

${ }^{6}$ Neusbaum $v$. Keim, 24 N. X. 325.

${ }^{7}$ Coleman $v$. Waters, 13 IV.Va. 278.

${ }^{8}$ Adam $v$. Arnold, 86 Ill. 155.

${ }^{9}$ Ling $v$. King \& Co., 91 Ill. 571;

Fing $v$. French, 2 Saw. C. C. 441.

${ }^{10}$ Allen $v$. Norton, 6 Or. $34 t$.

${ }^{11}$ Humbolat M. \& M. Co. v. Terry, 11 Nicv. 240.
}

584 
garl to the right of the defendant to question or correct the errors of the court, or of its clerk. On one land it is asserted that a confession of judgment admits the law to be against the defendant as well as the facts, and "silences all contests about the law of the case." On the other hand, "it has been held, that although the confession of judgment is a waiver of former errors, it does not prevent the defendant from objecting to errors of substance," as "that the statement required to bo filed in writing in insufficient." In New York, a judgment by confession may, after lapse of the term, be set aside for a defect in the statement, on motion of a junior judgment creditor; ${ }^{3}$ or by an action in the nature of a creditor's bill. ${ }^{4}$ But in California the latter is the exclusive remedy recognized. ${ }^{5}$ Courts of law exercise an equitable jurisdiction over judgments entered by confession upon notes and warrants of attorney, and it is necessary to justice that they should liberally exercise that jurisdiction. Where it clearly appears that the plaintiff was not entitled to the judgment on the notes and warrants of attorney, the court should vacate the judgment and leave him to pursue the ordinary remedy by action. But where the case is involved in doubt, or the testimony is so contradictory that the truth can not be ascertained with reasonable certainty, the defendant should bo let into a defense on the merits, the judgment in the mean time being allowed to stand as security until the merits of the case are heard and determined-all proceedings upon it, however, being. stayed until the suit is finally determined. ${ }^{6}$ The court ought not, where the case shown renders it proper to permit the defendant to contest the plaintiff's claim, to require as a condition of permitting such contest that the defendant first bring into court the sum supposed to be due. ${ }^{7}$

\footnotetext{
${ }^{1}$ Bonta $v$. Clay, 1 Litt. 27; Jeffries |Rae $v$. Lawser, 18 How. P. 23; Bon$v$. Morgan, 1 Pike, 169; Rush $v$. Hal- nell $v$. Henry, 13 How. P. 142; Bercyon, 67 N. C. 47.

${ }^{2}$ Miontgomery $v$. Barnett, 8 Tex. 143; Elgar $v$. Greer, 7 Iowa, 136; Kennedy $v$. Lowe, 9 Iowa, 580; HopLins $v$. Howard, 12 Tex. 7 . nard \& Co. $\%$ Donglas, 10 Iowa, 370. ${ }^{*}$ Dunham $v$. Waterman, 17 N. Y.9.

${ }^{5}$ Arrington v. Sherry, 5 Cal. 513.

${ }^{6}$ VVaher $v$. Ensign, 1 Ill. App. 113 ; Cowdon v. Besse, 86 Ill. 159.

${ }^{3}$ Chappel v. Chappel, 12 N. Y. 215; 1 Page v. Wallace, s7 Ill. 84.
} 


\section{CHAPTER XXVI.}

\section{JUDGMENTS OF OTHER STATES.}

5 559. Constitution and Legislative Provisions, in Regard to. $\S 560$. Jurisdictional Inquiries.

$\S 501$. Cases Denyiug the Tight to Inquire into Jurisdiction.

$\S 562$. Cases Showing Jurisdictional Inquiries always Permissible.

\$563. Recitals in the Record.

$\$ 564$. Jurisdiction of State Courts Confined by State Lines.

$\$ 565$. Jurisdiction Fresumed.

$\$ 506$ Defendant's Coming within the State.

$\S 507$. Constructive Summoning of Non-Residents.

$\S 508$. Constructive Summoning of Non-Tiesident Corporation.

$\$ 569$. Jurisdiction ouce acquired may be continued by Constructive Servico.

$\$ 570$. Constructive Service on Tiesidents.

\$ 5i1. By what Law considered.

$\S 572$. Jurisdiction of Subject Matter.

\& 573. Serrice by Attachment.

$\S 574$. Joint Debtor Acts.

$\S 575$. Given same Effect as at Home.

\$576. Defenses to.

$\S 577$. Courts not of Record.

$\$ 5$ is. Courts of the United Statcs.

\$ 579. Decrees of Divorce in States to which both parties have removed.

$\S 580$. Divorce obtained by gcing to ancther state.

$\S 581$. Divorces against Non-Resident.

$\S 582$. Domicile of Wife.

$\$$ 583. Constructive Service in Divorce Suits not Effective.

$\S 584$. Constructive Service in Divorce Suits Effective.

$\$ 585$. Summary of Law of Divorce in Sister States.

$\$ 586$. Decree on Constructive Service affects only Harriage Status.

$\$ 587$. Whether Court acting on Divorce Case is to be treated as of Specis Jurisdiction.

\section{559. Constitutional and Legislative Provisions.-A} judgment of any of the courts of any State of the American Union would, beyond the limits of the State in which it was pronounced, be regarded as a foreign judgment, were it not for the provisions of sec. 1, art. 4, of the Constitution of. the United States, ${ }^{1}$ and of an act of Cougress passe? May

1 The section of the Constitution re- $\mid$ revised statntes of the United States ferrcd to is as follows: "Full faith first provides for the mode of authenand ereclit shall be given in each tication, and then declares that "the State to the public acts, records, and said records and judicial proceedings, judicial procecelings of every other so anthenticated, shall have such faith State. Ancl the Congress may by and credit given to them in every general laws prescribe the manner in court within the United States as they which sueh acts, records, and procecd- have by law or usage in the courts of ings shall be proved, and the effect the State from which they are taken." thereof." Section $90 \mathrm{~J}$ of the present 
26,1790 . It was, for a while, insisted, by some of tho State eourts, that these provisions were not designed to do more than secure the admission of judgments in evidence, and to regulate the form and manner in which they should be anthenticated; and no greater efieet was, for some time, in some parts of the Union, giren to a judgment or decree pronounced in another State, than if it were pronounced by a tribnual in some foreign conntry. ${ }^{1}$ The Supreme Court of the United States, in a decision which, sinee its promulgation, has been adopted throughout the Union, declared that the act gave to the reeord of every judgment, when duly anthenticated, and offered in evidence in another. State, the same faith and eredit to which it was entitled in the State whence it was taken. That if, in such State, it had the faith and eredit of evidence of the highest nature-viz: record evidenee- then it must have the same faith and eredit in every other State. ${ }^{2}$ The ease in which this decision was prouounced, apparently involved a mero question of pleading. In an action of debt brought in the District of Columbia, upon a judgment of the Supreme Court of the State of New York, the defendant had interposed the pleit of nit debet; and his plea had, upon demurrer, been adjudged bad. Mr. Justice Story delivered the opinion of the court. He first took eare to remark that the defendant had had full notice of the action in which the judgment sued upon was rendered, and had, in that aetion, been arrested and had given bail; and that the judgment must, therefore, be eonclusive upon him. Ho then proceeded as follows: "Bat it is said that, admitting that the judgment is conclusive, still

${ }^{1}$ Hammon $v$. Smith, 1 Brev. 110; Evans $v$. Instine, 6 Ohio, 117; Burns Lambiin $v$. Nance, 2 Brer. 99; Bart- $v$. Belluap, 22 Verm. 419; Fullerton lett $v$. Knight, 1 Nass. 401; Hiteh- $v$. Horton, 11 Verm. 425; Hoxie $v$. cock $v$. Aicken, 1 Cai. 460; Taylor $v$. Wright, 2 Verm. 269; Daris $v$. ConBryclen, 8 Johns. 173; Pawling v. nelly's Ex., 4 B. Monr. 130; Hensley Bird's Ex., 13 Johns. 19?.

$v$. Force, 7 Eug. 756; Buchanan $v$.

${ }^{2}$ Mills 4 . Duryee, 7 Cranch, 481; Port, 5 Ind. 261; McJilton v. Love, 13 Hampton $v$. McConnel, 3 Wheat. 234; Ill. 486; Sharman v. Morton, 31 Geo. MicElmoyle v. Cohen, 13 Pet. 312; 4; Butcher $v$. The Bank, 2 Kan. 70; Lorden $v$. Fitelı, 1J Johms. 121; S Am. Thompson $v$. Emmert, 15 I1l. 415; Dec. 225; Andrews v. Montgomery, Lawrencev. Jarvis, 32 Ill. 304: Durall 19 Johns. 162; $10 \mathrm{Am}$. Dec. 213; v. Fearson, 18 Mla. 502; Pritchett $v$. Randolph v. Keiler, 21 Mio. 55\%; Clark, 3 Ilarrington, 211. 
nil debet was a good plea; and nul tiel record could not bo pleaded, because the record was of another State, and conld not be inspected or transmitted by certiorari. Whatever may be the validity of the plea of nil debet after verdict, it cannot, be sustained in this case. The pleadings in an action are governed by the dignity of the instrument on which it is founded. If it be a record conclusive between the parties, it cannot be denied but by the plea of mul tiel record; and when Congress gave the effect of a record to the judgment it gave all the collateral consequences. There is no dificulty in the proof. It may be proved in the manner preseribed by the act, and such proof is of as high a nature as an inspection, by the court, of its own record, or as an exemplification would be in any other court of the same State. Had this julgment been sued in any other court of New York, there is no doubt that nil debet would have been an inalmissible plea. Yet the same objection might be urged that the record could not be inspected. The law, however, is nuloubted that an exemplification would in such case be decisive. The original need not be produced.

"Another objection is that the act cannot have the effect contended for, because it does not enable the courts of anolher State to issue executions directly on the original judgment. This objection, if it were valid, would equally apply to every other court of the same State where the judrment was rendered. But it has no foundation. Tho right of a court to issue execution depends upon its own jowers and organization. Its judgments may be completo and perfect, and have full effect independent of the right to issuo execution.

"The last objection is, that the act does not apply to courts of this district. The words of the act afford a decisive answer, for they extend 'to every court within the United states.'

"Were the consiruction contended for by the plaintiff in crror to prevail, that julgments of the State courts ought to bo considered primu facie evidence only, this clause in the constitution would be nlterly unimportant and illusory. The common law would give such judgments precisely the same effect. It is mauifest, however, that the constitution 
contemplated a power in Congross to give a conclisivo effect to such judgments, and we can perceive no rational interpretation of the act of Congress, unless it declares a judgment conclusive when a court of the particular State where it is rendered would pronounce the same decision." It is now well settled, in harmony with Mlills v. Du'yee, that any plea to an action on a judgment of another State must correspond in dignity with the record sned upon. While upon the one side, a judgment having the dignity of a record cannot be met by a plea of nil debet, so also a judgment not regarded as a record cannot be contested under the plea of mul tiel record. Hence this latter plea is not proper when an action is brought upon the judgment of a justice of tho pence, or of any inferior tribunal which is not a court of record. ${ }^{2}$ In an action upon a decree for the payment of a specife sum of money, it was held that neither nil debet nor nul tiel record was a proper plea. That the former was bad, becanse under it everything is thrown open and the merits may be contested; and that the latter was equally inadmissible and inappropriate becanse the proceedings in conrts of chancery are not records. "It is to be observed," said the court, "that in the case before the court, the plaintiff"s declaration does not call the decree in chancery a record, and if the defendant intended to deny that any such decree existed, he might have framed his plea so as to meet the averment in the declaration; and the tender of the issue should have concluded to the conntry, according to the case in Yelverton."

8 560. Jurisdictional Inquiries.-The language of the Supreme Court in Mills v. Duryee, which, substantially, was but a quotation from the act of 1790 , that a judgment must, in every State, be given the same faith and credit to which it is entitled where it was rendered, was so comprehensive and distinct, as to seem to negative the existence of amy exception to the broad rule here laid down, and to impart to such a judgment in all cases, and in all localities, the full

${ }^{1}$ Mills v. Duryee, 7 Cranch, 484. 11 Am. Dec. 717; Doughty v. Fawn,

2 McElfatrick $v$. Taft, 10 Bush, 160 . Yelv. 226; Baxley $v$. Linah, 16 Pa. S.

${ }^{3}$ Evans v. Tatem, 9 S. \& R. 252; 243. 
effect of a domestic judgment. Henee, in a number of Stato courts, the act of 1790 has been strictly construed, and no defenso whaterer has been entertained in an action upon the judgment or decree of a sister State, which wonld havo been rejected, if offered in a like action, brought in the State where the judgment was rendered, even thongh such defense tendered an issne in relation to the jurisdiction of the court in the original action. Especially where the record contained clear and positive jurisdictional recitals, lias the defendant been denied the right to controvert those recitals, unless they would be proper subjects of controrersy in similar proceedings in the jurisdiction in which they were made. ${ }^{1}$

\section{561. Cases Denying the Right to Inquire into Juris-} diction.-In some States the broad ground is maintained that in all cases, if to escape the judgment where it was rendered, the party must show want of jurisdiction on the face of the record, he cannot escape it by any other means in any other State." Now, the act of Congress already mentioned, after providing the mode of anthentication, declares that " the said records and judicial proceedings, anthenticated as aforesaid, shall have such faith and credit given to them, in every cont within the United States, as they have by law or usage in the courts of the State from whence the saict records are, or shall be taken." In some of the States, a record, silent on the subject of jurisdiction, is, when collaterally assailed, supported by incontrovertible jurisdictional presumptions. In other States, while less effect is given to mero presumptions of jurisdiction, record declara-

\footnotetext{
${ }^{1}$ Hensley $v$. Force \& Co. 7 Eng. $v$. Kassick, 2 Mich. 165; Pritchett $v$. 756; Bimeler $v$. Lawson, 4 Scam. 536; Clark, 5 Harrington, 63, and 4 Harr. Westcott $v$. Drown, 13 Ind. S3; Law- 280; Wirren v. Lusk, 16 Mo. 102; rence $v$. Jarvis, 32 1ll. 309; Wester- Harbin $v$. Chiles, 20 Mo. 314; Newwelt $v$. Lewis, 2 McL. 511; Spencer comb v. Peck, 17 Verm. 302; Logansv. Brockway, 1 Ohio, 359; $13 \mathrm{Am}$. port Gas Co. v. Knowles, 2 Dillon, C. Dec. 615 ; Thompson $v$ Emmert, 4 C. 421 ; Wetherill $v$. Stillman, $65 \mathrm{~Pa}$. McL. 96; Lapham v. Briggs, 27 Vt. S. 105.

26; Lincoln $v$. Tower, 2 McL. 473; Tioberts $v$. Caldwell, 5 Dana, Ky. 512; Jacquette $v$. Hugunon, 2 McL. 129; 105.

May 2 . Jameson, 6 Eng. 365; Wilcox

${ }^{2}$ Lapham v. Briggs, 27 Verm. 26; Wetherill v. Stillman, 65 Penn. S.
} 
tions and recitals upon this subject are regarded as of that ligh "and uncontrollable verity, which admits of no plea or proof to the contrary." Whenerer a judgment of either of these States is made the basis of an action, or employed for any other legitimate object, in another State, it, according to the act of 1790 , should have such faith and credit given to it as by law or usage would bo accorded to it, under like circumstances, in the State whence it is taken. In the act there is no more authority for disputing its direct or implied jurisdictional adjudications than thero is for denying its effect upon an issuo by it determined on the merits, or its operation as a merger or extinguishment of the original canso of action. But it was soon perceived that a man living at one cxtremity of the Union, might be made the subject of judicial proceedings prosecuted at another extremity; and that, through presumption very different from the real facts, or from direct statements incorporated in the record, aud as false as they are explicit, he might be subjected to great wrong, a wrong from which he could escape, if at all, only by such proceedings as would be available to him if he were a resident within the Stato where the wrong was perpetrated. If the construction to the Fourteenth Amendment to the Constitution of the United States, given in several recent cases, ${ }^{1}$ meets with general acquiescence, it would seem that all questions regarding the jurisdiction of courts over the persons against whom they pronounce judgment, must ultimately bo determined in the wational courts, or at least according to the principles there recognized and applied; and, therefore, that the wide dissimilarity heretofore existing in tho difierent States must uitimately disappear. If so, the dificulty of conceding in cvery State to each judgment the faith and credit to which it is entitled in the State where pronounced, will be very materially diminished.

\section{? 563 . Cases holding that Jurisdiction is always open} to Investigation.-A proper regard for the inconvenience and injustice likely to ensue from giving effect to the letter of the law, should have resulted in the exercise of the legis-

${ }^{2}$ Belcher v. Chambers, $53 \mathrm{Cal}$, 63j; Pennoyer $v$. Neff, 95 U. S. 714. 
lative anthority vested in Congress, and by means of which the existing statute conld be so modified as to efface its ob. jectionable features. But the necessity of such an amendment was overcome, in a majority of the States, by the judicial construction, or judicial legislation, under which the whole question of the jurisdiction of the court pronouncing the judgment, was liablo to be re-opened, at the option of the person against whom such judgment was bronght forward, in another State. A judgment record of another State is, therefore, at present, in many of the States, of no greater eflect than a foreign judgment upon jurisdictional issues. The jurisdiction of the court in both cases being open to inquiry." "The cases are obvionsly irreconcilable, and something may bo said on either sile. If the statutory provision, that a judgment shall have the same failh and credit as in the State where it was rendered, extends to the proceedings of the court as set forth of record, a denial of notice, or of the authority of the attorney, will be as inadmissible in a suit on the judgment of another State, as it confessedly is when the action is based on a domestic judgment. If, on the other hand, the design of the Constitution, as interpreted by the statute, is that the judgment should not be conclusive unless tho court had juriscliction of the cause and the parties, there will always be room for the preliminary inquiry whether tho defendant was notified or appeared voluntarily, without process. Between these views there is, seemingly, no middle ground, and the balance of convenience inclines strongly in fivor of the latter doctrine." The effect of the provisions of the act of 1790 , upon this very material question, being thus involved in the doubt, produced in a large number of adjudged cases, opposite in the nature of the con-

\footnotetext{
${ }^{1}$ Kerr $v$. Kerr, 41 N. Y. 272; Kane Finnt, 72 N. Y. 217; McLaren $v$. v. Cook, 8 Cal. 449; Dissell $v$. Briggs, Kehler, 23 La. An. 80; 8 Am. Fiep. 9 Mass. 468; 6 Am. Dec. 88; Huil $v$. 591 ; McCanley $v$. Hargroves, 48 Geo. Williams, 6 Pick. 240; 17 Am. Dec. 50; 15 Am. Rep. 660; Hood $v$. State, 850; Shumway v. Stiliman, 4 Cow. 56 Ind. 263; 26 Am. Rep. 21; Bartlett 292; 15 Am. Dec. 374; Christmas v. v. Knight, 1, Mass. 401; 2 Am. Dec. Iussell, 5 Wallace, 305; Borden $v$. 36 , and note; Barrett $v$. Oppenheimer, Fitch, 13 Johns. 121; 8 Am. Dec. 325; 12 Heisk. 298.

Marr. v. Wetzel, 3 Col. 2; Hunt v. ${ }^{2} 2$ Am. Lead. Cas. 5th ed. p. 616.
} 592 
clusions announced, and very nearly equal in the numbers opposed to each other; and this doubt could be removed only by the decisions of the Supreme Court of the United States. We shall, in the next section, show that the question has at last been finally solved, and that the solution reached, leaves the judgments of courts of sister States always subject to attack on jurisdictional grounds.

8 563. Iffect of Recitals and Averments in the Records.-The general recital that the defendaut appeared, is, even in those States where direct jurisdictional statements are regarded as couclusive, susceptible of explanation and aroidance by showing that the appearance was by an unanthorized attorney. It is also thought to involve no dispute with the record to show that the attorney whom it states appeared had no authority so to do. "In theso instances, however, and others of a like kind, the courts have relied on the well-known rule that estoppels must be certain, as a reason for admitting evidence that might have been shut out by a clear and positive recital. There was said to be no direct or necessary conflict between an averment on the one part that the defendant appeared, and proof on the other that the appearance was by an attorney who did not represent the defendant. And there has been a manifest reluctance to go beyond this and assume the responsibility of holding that an unequivocal allegation that the defendant was served personally, or entered a personal appearance, can be disproved by parol evidence."2 Novertheless, numerons cases exist in which the authority to controvert the truth of unequivocal allegations found in the record in regard to jurisdiction is affirmed in express terms or by necessary implication. ${ }^{3}$ There is now no doubt that

${ }^{1}$ Lawrence $v$. Jarvis, 32 Ill. 301; Wend. 145; 21 Am. Dec. 172; Noyes Baltzell $v$. Nosler, 1 Iowa, 5Ss; Price $v$. Butler, 6 Barb. 613; Norwood $v$. $v$. Ward, 1 Dutch. 225; Arnott v. Cobb, 21 Tex. 55l; Kane $v$. Cook, 8 Webb, 1 Dillon C. C. 362; Gilman $v$. Cal. 449; Hoffman $v$. Hoffman, $46 \mathrm{~N}$. Gilman, 126 Mass. 26; 30 Am. Rep. Y. 30; Pollard v. Baldwin, 22 Iowa, 646.

2 Am. Lead. Cas. 5th ed. 643; see also sec. 560 of this work.

${ }^{3}$ Finneran $v$. Leonard, 7 Allen, 54; Norwood $v$. Cobb, 15 Tex. 500; Rape v. Heaton, 9 Wis. 328 ; Kerr $v$. Kierr, 41 N. Y. 272; Starbuck $v$. Murray, 5 
" a defendant sued hero upon a judgment recovered against him in a court of record of another State, in which it is recited that he was served with process, or appears by attorney, may controvert such recital and show that he was not serred with process, was not in any manner brought into court, had not submitted himself to its jurisdiction, or appeared therein by attorney or otherwise." The rule is the same when, instead of contradicting a mere jurisdictional recital, the defendant undertakes to show that the return of service endorsed on the summons is false. ${ }^{2}$ In the case of Christmas $v$. Russell, 5 Wall. 305, the supreme court of the United States stated that the judgments of a State court "are open to inquiry as to the jurisdiction of the court and notice to the defendant." This question was not, however, involved in the case then under consideration, and this statement was made by way of illustration rather than of decision. But at a later day the decision of the precise question became necessary and resulted in the affirmance of the rule that the jurisdiction of the court may be assailed even in direct opposition to the recitals in the record; ${ }^{3}$

1 Kingsbury $v$. Yniestra, 59 Ala. within the limits of said county, and 320; People $v$. Dawell, 25 Mich. 247; informed against her before two jus. 12 Am. Rep. 260; Bowler v. Huston, 30 Gratt. 266; 32 Am. Rep. 673.

${ }^{2}$ Webster $v$. Hunter, 50 Ia. 215; Lowe $v$. Lowe, 40 Ia. 220.

${ }^{3}$ Thompson $v$. Whitman, 18 Wall. 457; 1 C. L. J. 308. This was an action in the circuit court of the Southern District of New York brought by Whitman, a citizen of New York, against Thompson, sheriff of Monmouth county, New Jersey, for taking and carrying away the sloop Anua Whitman, and her cargo, furniture, and apparel. The sheriff, to justify the taking, pleaded that the plaintiff, a resident of New York, was raking and gathering clams with his sloop, in Monmouth county, at the time of its seizure, contrary to the laws of New Jersey, and that the defendant, as sheriff, and uncler and by virtue of said laws, seized the sloop tices of the peace, by whom she was condemned and ordered sold The plaintiff took issue on this plea by denying that the seizure was in Mon. month county. On the trial the de. fendant produced a record of the proceedings before the justices, which stated the offense to have been committed and the seizure to have been made within that county. The court instructed the jury that this record was prima facie evidence only of the jurisdictional facts stated therein. The jury found specially that the seizure was made in New Jersey, but not in Monmouth county, and further that the plaintiff was not on the day of the seizure engaged in taking clams in that county. Judgment having been entered for the plaintiff, the de. fendant prosecuted his writ of error to the supreme court of the United 
and very soon afterwards, the same court determined that parol evidence was admissible to contradict the

States. MIr. Justice Bradley, in delivering the opinion of that court, conceied that the rccord stated "with due jarticularity, sufficient facts to give the justices jurisdiction under the law of New Jersey," and that the judgment must be reversed unless " that statement could be questioned collaterally in another action brought in another State." He then proceeded to the consideration of the Constitution and statutes upon the subject, and the previous decisions made there. under, and, in so doing, said: "Without that provision of the Constitntion of the United States which declares that 'full faith and credit shall be given in each State to the public acts, records, and judicial proceedings of every other State,' and the act of Congress passed to carry it into effect, it is clear that the record in question would not be conclusive as to the facts necessary to give the justices of Monmouth county jurisdiction, whatever might be its effect in New Jersey. In any other State it would be regarded like any foreign judgment; and as to a. foreign judgment it is perfectly well settled that the inquiry is always open, whether the court by which it was rendered had jurisdiction of the person or thing. 'Upon principle,' says Chief Justice Marshall, 'it would seem that the operation of every judgment must depent on the power of the court to render that judgment; or, in other words, on its jurisdiction over the subject-matter which it has determined. In some cases, that jurisdiction unquestionably depends as well on the state of the thing as on the constitution of the court. If by any means whatever a prize court should be induced to condemn, as prize of war, a vessel which was never captured, it could not be contended that this condemnation operated a change of property. Upon principle, then, it would seem that, to a certain extent, the capacity of the court to act upon the thing condemned, arising from its being within or without their jurisdiction, as well as the constitution of the court, may be considered by that tribnnal which is to decide on the effect of the sentence.' [Rose $v$. Himely, 4 Cranch, 269. To the same cffect see Story on the Constitution, chap. XXIX; 1 Greenleaf on Eridence, sec. 540.]

"The act of Congress above referred to, which was passed 26 th of May, 1790 , after providing for the mode of authenticating the acts, records, and judicial proceedings of the States, declares, 'and the said records and judicial proceedings, authenticated as aforesaid, shall have such faith and credit given to them in every conrt within the United States, as they have by law or usage in the courts of the State from whence the said rec. ords are or shall be taken.' It has been supposed that this act, in connection with the constitutional provision which it was intendel to carry out, had the effect of rendering the judgrments of each State equivalent to domestic judgments in every other State, or at least of giving to them in cvery other State the same effect, in all respects, which they have in the State where they are rendered. And the language of this court in Mills v. Duryee [7 Cranch, 4S4], scemed to give countenance to this ilea. The court in that case held that the act gave to the judgments of each State the same conclusive effect, as records, in all the States, as they had at home; and that nil debet conld not be pleaded to an action brought thereon in another State. This decision has never becn 


\section{return of service endorsed by a sheriff on the summons}

departed from in relation to the general effect of such judgments where the questions raised were not questions of jurisdiction. But where the jurisdiction of the court which rendered the judgment has been assailed, quite a different view has prevailed. Justice Story, who pronounced the julgment in Mills v. Duryee, in his Commentary on the Constitation [\$ 1313], after stating the general doctrine established by that case with regard to the conclusive effect of judgments of one State in every other State, adds: 'But this does not pretent an inquiry into the jurisdiction of the court in which the original judgment was giten to pronounce it; or the right of the State itself to exercisc authority over the person or the subject-matter. The Constitation did not mean to confer [upon the States] a new power or jurisdiction, but simply to regulate the effect of the acknowledged jurisdiction over persons and things within their territory.' In the Commentary on the Conflict of Laws [sec. 609], substantially the same remarks are repeated, with this addition: 'It' (the Constitution) 'did not make the judgments of other States domestic judgments to all intents and purposes, but only gave a general validity, faith and credit to them, as evidence. No execution can issue upon such judgments without a new suit in the tribunals of other States. And they exjoy not the right of priority or lien which they have in the State where they are pronounced, but only that which the lex for $i$ gives to them by its own laws in their character of foreign judgments.' Many cases in the State courts are referred to by Justice Story in support of this view. Chancellor Kent expresses the same doctrine in nearly the same words, in a note to his Commentaries [vol. 1, p. 281; see, also, vol. 2, 95, note, and cases cited]. 'The doctrine in Mills $v$. Duryee,' says he, 'is to be taken with the qualification that in all instances the jurisdiction of the court rendering the judgment may be inquired into, and the plea of nit debet will allow the defendant to show that the court had no jurisdiction orer his person. It is only when the jurisdiction of the court in another State is not impeached, either as to the subject-matter or the person, that the record of the judgment is entitled to full faith and credit. The court must have had jurisdiction not only of the cause, but of the parties, and in that case the judgment is final and conclusivc.' The learned commentator adds, however, this qualifying re. mark: "A special plea in bar of a suit on a judgment in auother State, to be valid, must deuy, by positive averments, every fact which would go to show that the court in another State had jurisdiction of the person, or oi the subject-matter,

"In the case of Hampton $v$. MeComnel [3 Wheaton, 234], this court reiterated the doctrine of Mills $v$. Duryee, that 'the judgment of a State court shonld have the same eredit, validity, and effect in every other court of the United States which it had in the State conrts where it was pronounced; and that whaterer pleas were good to a suit therein in such State, and none others, could be pleacled in any court in the United States.' But in the subsequent ease of McElmoyle $v$. Cohen [13 Peters, 312], the court explained that neither in Mills $v$. Duryee, nor in Hampton $v$. McConnel, was it intended to exclude pleas of avoidance and satisfaction, such as payment, statute of limitatious, etc.; or pleas denying the jurisdiction of the court in which the 
in the case. (Knowles $v$. Gaslight and Coke Co., 19 Wall. 58.)

judgment was given; and quoted, and Webster $v$. Reid. D'Arcy $v$. with approbation, the remark of Jus- Ketchum [11 How. 105] was an ac. tice Story, that ' the Constitution did tion in the circuit court of the United not mean to confer a new power of States for Louisiana, brought on a jurisdiction, but simply to regulate judgment rendered in New York the effect of the acknowledged juris- under a local statute, against two dediction over person and things within fendants, only one of whom was the State."

"The case of Landes $v$. Brant [10 How. U. S. 348] has been quoted to show that a judgment can not be attacked in a collateral proceeding. There a judgment relied on by the defeudant was rendered in the territory of Louisiana, in 1808, and the objection to it was that no return appeared upon the sunmons, and the ciefendant was proved to have been absent in Mexico at the time; but the judgment commenced in the usual form: 'And now at this day come the parties aforesaid, by their attorneys,' etc. The court pertinently remarked [p. 371] that the defendant may have left behind, comnsel to defend suits brought against him in his absence, but that if the recital was false, and the judgment voidable, for want of notice, it should have been set aside by audita querela or motion in the usual way, and could not be impeached collaterally. Here it is evident the proof failed to show want of jurisdiction. The party assailing the judgment should have shown that the counsel who appeared were not employed by the defendant, according to the doctrine held in the cases of Shumway $v$. Stillman [6 Wendell, 453]; Aldrich $v$. Kinney [ 4 Conn. 350; 10 Am. Dec. 151]; and Price v. Ward [1 Dutcher, 225]. The remark of the court that the judgment could not be attacked in a collateral proceeding was unnecessary to the decision, and was, in effect, overruled by the subsequent cases of D'Arcy $v$. Ketchum,

scrved with process, the other being a resident of Louisiana. In that case it was held by this court that the judgment was void as to the defendant not served, and that the law of New York could not make it valid outside of that State; that the constitutional provision and act of Congress giving full faith, credit, and effect to the judgments of each State in every other State, do not refer to judgments rendered by a court having no jurisdiction of the parties; that the mischief intended to be remedied was not only the inconvenience of re-trying a cause which had once been fairly tried by a competent tribunal, but also the uncertainty and confusion that prevailed in England and this comtry, as to the credit and effect which should be given to foreign judgments, some courts holding that they should be conclusive of the matters adjudged, and others that they should be regarded as only prima facie binding. But this uncertainty and confusion related only to valid judgments; that is, to judgments rendered in a cause in which the court laad jurisdiction of the parties and canse, or (as might have been added), in pro. ceedings in rem, when the court han juriscliction of the res. No effect was ever given by any court to a judgment rendered by a tribunal which had not such jurisdiction. 'The international law, as it existed among the States in 1790 ,' say the court [page 176], was that a judgment rendered in one State, assuming to bind the person of 


\section{564. Jurisdiction of State Courts confined in State} Lines.-It is said that " no sovereignty can extend its pro-

a citizen of another, was void within the foreign State, when the defendant had not been served with process, or voluntarily made defense, because neither the legislative jurisdiction, nor that of courts of justice, had linding force. Subject to this established principle, Congress also legislated; and the question is whether it was intencled to overthrow this principle and to declare a new rule, which would bind the citizens of one State to the laws of another. There was no evil in this part of the existing law, and no remedy called for, and in our opinion Congress did not intend to overthrow the old rule by the enactment that such faith and credit should be given to records of julgments, as they laad in the States where made."

"In the subsequent case of Websier $v$. Tieid [11 How. 437], the plaintiff claimed, by virtue of a sale made under judgments in behalf of one Johnson and one Drigham against 'The Owners of Half-Breed Lands lying in Lee County,' Iorwa 'Territory, in pursuance of a law of the territory. The defendant offered to prove that no service had ever been male upon any person in the suits in which the judgments were rendered, and no notice by publication as required by the act. This court held that, as there was no service of process, the judgments were nullities. Perhaps it appeared on the face of the judgments in that case that no service was made; but the court held that the defendant was entitled to prove that no notice was given, and that none was published.

"In Harris $v$. Ifardeman et al. [14 How. U. S. 331], which was a writ of error to a judgment held roid by the court for want of service of process on the defendant, the subject now under consideration was gone over by Mr. Justice Daniel at some length, and several cases in the State courts were cited and approved, which held that a judgment may be attacked in a collateral proceeding by showing that the court had no jurisdiction of the person, or, in proceedings in rem, no jurisdiction of the thing. Amongst other eases quoted were those of Borden $v$. Fitch $[15$ Johns. 141; S Am. Dec. 225], and Starbnck $v$. Murray, [5 Wendell, 156; $21 \mathrm{Am}$. Dec. 172]; and from the latter the following remarks were quoted with apparent approval: 'But it is contended that if other matter may be pleaded by the defendant, he is estopped from asserting anything against the allegation contained in the record. It imports perfect verity, it is said, and the parties to it cannot be heard to impeach it. It appears to me that this proposition assumes the very fact to be established, which is the only question in issue. For what purpose does the defendant question the jurisdiction of the court? Solely to show that its proceedings and judgment are void, and, therefore, the supposed record is, in truth, no record. *** The plaintiffs, in effect, declare to the defendant-the paper declared on is a record because it says, you appeared, and you appeared because the paper is a record. This is reasoning in a circle.'

"The subject is adverted to in several subsequent cases in this court, and generally if not universally in terms implying acquiescence in the doctrine stated in D'Arcy $v$. Ketchum.

"Thus in Christmas v. Russell [5 Wallace, 290], where the court decided that frand in obtaining a julgment in another State is a good ground of lefense to an action on the 
cess beyond its own territorial limits, to subject either per-
son or property to its judicial decisions. Every exertion

judgment, it was distinctly stated/lied upon and brought before the (page 305), in the opinion, that such latter by a party claiming the benefit judgments are open to inquiry as to of such proceedings;' and 'the rule the jurisliction of the court, and prevails whether the decree or judgnotice to the defendant. And in a has been given in a court of admiralty, number of cases, in which was ques- ehancery, ecclesiastical court, or court tioned the jurisdiction of a court, of common law, or whethes the point whether of the same or another State, ruled lias arisen under the law of over the general subject-matter in nations, the lractice in chancery, or which the particular case adjudicated was embraced, this court has maintained the same general language. Thus, in Elliott et al. $v$. Peirsol et al. [1 Peters, 328, 340], it was held that the eircuit court of the United States for the District of Kentucky might question the jurisdiction of a county court of that State to order a certificate of acknowledgment to be correeted; and for want of such jurisdiction to regard the order as void. Justice Trimble, delivering theopinion of this court in that ease, said: 'Where a court has jurisdiction, it has a right to decide every question which occurs in the cause, and whether its decision be correct or otherwise, its judgment, until reversed, is regarded as binding in every other court. But, if it aet without authority, its judgments and orders are regarded as nullities. They are not voirlable, but simply void.'

"The same views were repeated in The United States $v$. Arredondo [6 Peters, 691]; Voorhees $v$. Bank of the United States [10 Id. 475]; Wilcox $v$. Jackson [13 Id. 511]; Shriver's Lessee $v$. Lynn [2 How. U. S. 59, 60]; Hickey's Lessee $v$. Stewart [3 Id. 762]; and Williamson $v$. Berry [S Id. 540]. In the last case the authorities are reriewed, and the court say: "The jurislietiou of any court exercising authority over a subject may be inquired into in every other court when the proceedings in the former are rethe municipal laws of States.'

"But it must be admitted that no decision has ever been made on the precise point involved in the case before us, in which evilence was admitted to contradict the record as to jurisdictional facts asserted therein, and especially as to facts stated to have beell passed upon by the court.

"But if it is once conceded that the validity of a judgment may be at. tacked collaterally by evidence showing that the court had no juriscliction, it is not perceived how any allegation contained in the record itself, however strongly made, can affect the right so to question it. The rery object of the evidence is to invalidate the paper as a record. If that can be suceessfully done, no statements contained therein have any force. If any such statements could be used to prevent inquiry, a slight form of words might always be adopted so as effectually to nullify the right of such inquiry. Recitals of this kind must be regarded like asseverations of good faith in a deed, which avail nothing if the in. strument is shown to be fraudulent. The records of the domestic tribunals of England, and some of the States, it is true, are held to import absolute verity as well in relation to jurisdictional as to other faets, in all collateral proceedings. Public policy and the dignity of the courts are supposed to require that no arerment shall be admitted to contradict the record. 
of authority of this sort beyond this limit is a mere nullity." While the Constitution expressly stipulates for the faith and credit to be given in each State "to the public acts, records and judicial proceedings of every other State," and that "Cougress may, by general laws, prescribe the manner in which such acts, records and proceedings shall be proved, and the effect thereof;" it is not probable that, in passing the act of 1790 , auy intention existed of extending the judicial authority of any of the States over citizens of other States not voluntarily coming within the State in which the original suit is conducted. "The jurisdiction of State courts is limited by State lines, and, upon principle, it is difficult to see how an order of a court, served upon a party out of tho State in which it is issued, can have any greater effect than knowledge brought home to the party in any other way."

But, as we have seen, that rule has no extraterritorial force.

"It may be observed that no courts have more decidedly affirmed the doctrine that want of jurisdiction may be shown by proof to invalidate the judgments of the courts of other States, than have the conrts of New Jersey. The subject was examined, and the doctrine affirmed, after a careful review of the cases, in the case of Moulin $v$. Insurance Company, in 4 Zabriskie [page 222], and again in the same case in 1 Dutcher [page 57], and Price $v$. Ward [1 Dutcher, 225], and as lately as Norember, 1870 , in the case of Mackay et al. $v$. Gordon et al. [34 N. J. 286]. The judgment of Chief Justice Beasley, in the last case, is an able exposition of the law. It was a case similar to that of D'Arcy $v$. Ketchuin, in 11 Howard, being a judgment rendered in New York under the statutes of that State, before referred to, against two persons, one of whom was not served with process. 'Every independent government,' says the chief justice, 'is at liberty to prescribe its own methods of judicial process, and to declare by

\section{0}

what forms parties shall be bronght before its tribunals. But, in the exercise of this power, no government, if it desires extraterritorial recognition of its acts, can violate those rights which are universally esteemed funda. mental and essential to society. Thus a judgment by the court of a State against a citizen of such State, in lis absence, and withont any notice, $\mathrm{er}$ press or implied, would, it is presumed, be regarded in every external jurisdiction as absolutely void and unenforceable. Such would certainly be the case if such judgment was so rendered against the citizen of a foreign State.' "On the whole, we think it clear that the jurisdiction of the court by which a judgment is rendered in any State may be questioned in a collat. eral proceeding in another State, notwithstanding the provision of the fourth article of the constitution, and the law of 1790, and notwithstanding the averments contained in the record of the judgment itself."

1 Story's Conflict Laws, sec. 539.

${ }^{2}$ Ewer $v$. Coffin, 1 Cush. 23; Reber v. Wright, $68 \mathrm{~Pa} . \mathrm{S} .471$. 
"It is a well-settled principle of law in the decisions in England and this country, and acquiesced in by the jurists of all civilized nations, that immovable property, known to the common law as real estate, is exclusively subject to the laws and jurisdiction of the courts of the nation or State in which it is located. No other laws or courts can affect it." Therefore, a judgment or decree rendered in one State cannot of itself affect the title to lands in another State. ${ }^{1}$ It seems to be generally and perhaps universally conceded, that, by no means, can a citizen of one State be compelled to go into another State to litigate a civil action, by means of process served in his own State; and that, even thougl process from the courts of any State be personally served beyond the limits of the State whence it issued, no personal liability against the defendant can result therefrom which will be recognized beyond the State in which the action originated. ${ }^{2}$ If then a court of no State can acquire jurisdiction over a non-resident by virtue of actual service of process, nor by any means, which its legislature is competent to describe, can it derive any authority from its own false record averments? Should not a judgment against a non-resident, not entering a voluntary appearance, always be deuied any extraterritorial obligation irrespective of the question whether the record is silent or explicit in regard to jurisdiction? And ought not the defendint to be always permitted to prove that he was a non-resident, and that he did not submit himself to the jurisdiction of the State whence the record is taken? On the other hand, if the defendant were a resident within the State when and where the record was made, the fact of his subsequent removal ought neither to impair nor to strengthen the obligation of the judgment. To whatsoever State he emigrated, the

${ }^{1}$ Davis v. Headley, 22 N. J. Eq. 120. | Ill. 304; Price v. Hickok, 99 Verm.

${ }^{2}$ Wilson v. Graham, 4 Wash. C. C. 292; Weil v. Lowenthal, 10 Iowa, 5.3; 55; Folger $v$. Columbian Ins. Co., 99 Steel $v$. Smith, 7 W. \&. S. 447; Hall Mass. 267; Moulin v. Trenton Ins. $v$. Williams, 6 Pick. 232; 17 Am. Dee. Co., 4 Zabr. 222; Bradshaw $v$. Heatl, 356; Harris $v$. Hardeman, 14 How. U. 13 Wend. 407; Holmes v. Holmes, 4 S. 340; Evans v. Instine, 7 Ohio, 273; Lansing, 3Ss; Dunn v. Dunn, 4 Pai. Reber $v$. Wright, 6S Pa. S. 471; Lutz Ch. 425; Ilsey v. Wilson, 1 Dev. \& $v$. Kelly, 47 Ia. 307; Peunoyer $v$. Batt. Eq. 565; Lawrence $v$. Jarvis, 32 Neff, 95 U. S. 714. 
record, when produced against him, should have the effect which would be given it in like circumstances if he still resided in the State whence it was taken, and this, too, independent of the question whether it is positive, donbtful or silent in reference to jurisdictional facts. It seems to us, then, that the only issue which onght to be tried in any State in regard to the jurisdiction of a court which has rendered a personal judgment in another State is, was the defendant, when the suit was instituted, within the State whose court assumed to exercise anthority over him, or if without the State, did he submit himself to its authority. If the issue should be answered in the negative, then the judgment ought to be disregarded, no matter how positively the record enumerates all needful jurisdictional facts. If, on the other hand, the issue be determined in the affirmative, then the record ought, upon jurisdictional as upon other questions, to have precisely " the same faith and credit given it, as it had by law or usage in the courts of the State whenco it was taken."

\& 565. Jurisdiction Presumed.-Courts of record aro presumed to act only in accordance with the authority vested in them by law. Their judgments will generally be treated as conclusive on the parties until the absence of jurisdiction is affirmatively shown. These principles are almost universally recognized in regard to domestic judgments. They are, by a preponderance of the anthorities, considered as applicable with equal force to judgrents of other States. ${ }^{1}$ "It is obvionsly essential to the effectual operation of the design of the Constitution, that the records of the judgments of other States, duly authenticated under the Act of Congress, should not merely prove themselves, but give rise to a presumption that the court possessed the anthority which it assumed to exercise." Where this presumption is

\footnotetext{
${ }^{1}$ Hassell $v$. Hamilton, 33 Ala. 280;| Tower, 2 MeL. 473; Tenney $v$. TownGunn v. Howell, 27 Ala. 663; Lat- send, 9 Blatch. 274; Shunrway $v$. terett $v$. Cook, 1 Iowa, 1; Wilson $v$. Stilman, 4 Cow. 292; 15 Am. Dec. Jackson, 10 Miss. 329; Numn v. Stur- 374; Dodge $v$. Coffin, 15 Kans. 277. ges, 22 Ark. 389; McLendon v. Dodge, ${ }^{2}$ Am. Lead. Cas., 5th ed. p. 647, 32 Ala. 491; Scott $v$. Coleman, 5 Litt. and numerous authorities there cited. 319; 15 Am. Dec. 71; Lincoln v.
} 
recognized, the complaint in an action on the judgment of a court of record of a sister State, need not allege that the court had jurisdiction either of the subject-matter of the action or of the person of the defendant. ${ }^{1}$ But it is conceded that the question whether jurisdiction should bo presumed when the record of judgment of another State fails to disclose the facts essential to its existence, is not altogether free from doubt; and that in some instances this question has beeu determined in the negative. ${ }^{2}$

8 566. Coming within a State.- We have already shown that by no means can a State compel anon-resident to come within its limits to answer a complaint in a civil action; and that if it should undertake to do so, the judgment and proceedings would not be recognized, beyoud its own boundaries, as creating any personal obligation. But a citizen of one State upon going voluntarily into another, submits limself to the juriscliction of the courts of the latter. A judgment pronounced against him upon service of process upon him while temporarily in a State, is as binding on him in every other State as it is in the State in which it was rendered. ${ }^{3}$ If it appear that the defendant was not a resident of the State when and where the judgment was entered, but that his property was attached in the action, and the record recites " that it appears that defendant had been notified of the pendency of this suit," this recital will not be construed as establishing that defendant went into such State and submitted his person to its jurisdiction. The words quoted were probably designed to affirm the existence of nothing in addition to the fact that such notice was given as the laws of the State prescribed to authorize a valid judgment against the property attached. ${ }^{4}$ A defendant, without going into a State, may submit himself to its jurisdiction by authorizing some one to appear for him there. In such case the judrment subsequently entered, is obligatory upon him. ${ }^{5}$ So if a per-

${ }^{1}$ Phelps $v$. Duffy, 11 Nev. $80 ; 4$ C. 538 . This last case applies to deL. J. 311; Wheeler $v$. Raymond, $\mathrm{s}$ crees of divorce only.

Cow. 311; contra, Gelhard v. Garnier, ${ }^{3}$ Mowry v. Chase, 100 Mass. 79; 12 Bush. 321; 23 Am. Rep. 721. Murphy v. Winter, Is Geo. 600;

${ }^{2}$ Warren v. McCarthy, 25 Ill. 95; Downer $v$. Shaw, 2 Foster, 277 .

Bimeler $v$. Dawson, 4 Scam. 541; ${ }^{4}$ Downer $v$. Shaw, 2 Foster, 277.

Rangely $v$. Webster, 11 N. H. 299; ${ }^{5}$ Walker $v$. Lathrop, 6 Iowa, 516; Commonwealth $v$. Blcol, 97 Mass. Hold $v$. Alloway, 2 Blackf. 10 . 
son anthorize an action to be instituted in another State, in his behalf, he becomes thereby subject to any judgment which may be taken against him in that suit. ' It has been held that if a person residing in one State is induced by false representations to come into another State, in order that service of process may be there made upon him, the jurisdiction thus acquired is fraudulently obtained, and the judgment based thereon will not be enforced against him in the State where he resides; ${ }^{2}$ and there seems to be no doubt that if any fraud be practiced upon the defendant whereby he is brought within the State and service of process there made upon him, he may, although he submits to the jurisdiction of the court, maintain an action against the persons who thus fraudulently induced him to leave his home; ${ }^{3}$ or he may, ou application to the court, obtain an order setting aside the service of the process. ${ }^{4}$

8 567. Construcive Service on Non-residents.-Persoual service being undoubtedly ineffectual to call into being such i personal judgment as will be given extraterritorial efiect against a non-resident, unless the service was made on him within the State, it follows, a fortiori, that no greater effect would be produced if the service were constractive instead of personal. ${ }^{5}$ Until a comparatively recent date, the opinion extensively prevailed, that judgments in personam entered after constructive service of process upon a non-resident, while they were not enforceable beyond the limits of the State where entered, were nevertheless so fur ralid in that State as to support a sale of the debtor's property situate therein. This opinion has been overthrown by the Supreme Court of the United States, in the case of Pennoyer $v$. Neff, 95 U. S. 714. This action was brought in the Circuit Court of the United States for the District of Oregon, by Neff, to recover a tract of land for which he held

1 Walton $v$. Sngs, Phil. N. C. 9S. |Winston $v$. Taylor, 2S Mo. 82; Igle-

${ }^{2}$ Dunlap v. Cody, 31 Iowa, 260; 7 lart $v$. Moore, 16 Ark. 46; Ryan $v$. Am. Rep. 129. Vallandingham, 25 IIl. 125; Robinson

${ }^{3}$ Cook v. Brown, 125 Mass. 503; 28 v. Ward, 8 Johns. 86; 5 Am. Dec. Am. Rep. 259.

${ }^{4}$ Townsend $v$. Smith, 47 Wis. 623 ; $32 \mathrm{Am}$. Riep. 793. 3ะ7; Bartlett $v$. Kinight, 2 A1n. Dec. 36 and note; Chamberlain $v$. Faris, 1 No. 517; 14 Am. Dec. 304 and note:

${ }^{5}$ Barkman $v$. Hopkins, 6 Eng. 157; Dartlett $v$. Spicer, 75 N. Y. $52 S$. Whittier $v$. Wendall, 7 N. H. 25; ; 
a patent from the government. Pennoyer, the defendant below, claimed under a judgment and execution sale against Neff. The latter was a non-resident of Oregon when the judgment was procured agairst him in personam upon a demand for money due to one J. H. Mitchell. The court held this judgment to be entirely inoperative; and proceeded upon the principle that property within the State, belonging to non-residents, can not be reached and applied to tho satisfaction of their creditors except by proceedings which are substantially in rem. The judgment in question does not seem to have been preceded by an attachment of the property. But it may well be doubted whether under the attachment laws in force in several of the States, as whero the sole object of the proceeding is merely to creato a lien for the satisfaction of the judgment sought, there is any such seizure of or proceeding against real estate, as to givo the judgment and the subsequent sale the force of a quasi proceeding in rem. ${ }^{1}$

\section{568. Non-resident Corporations.-A corporation cre-} ated under and by virtue of the laws of a particular State, is for many purposes to bo deemed and treated as a resident

1 That portion of the opinion of the enforcing a contract or lien respectiug court in Pennoyer $v$. Neff $(95 \mathrm{U}$. S. the same, or to partition it annong 727 ) bearing upon the question is as different owners, or, when the public follows: "Substituted service by publication, or in any other authorized form, may be sufficient to inform parties of the object of proceeding $\mathrm{S}$ taken where property is once brought under the control of the court by seizure or some equivalent act. The law assumes that property is always in the possession of its owner, in person or by agent; and it proceeds upon the theory that its seizure will inform him, not only that it is taken into the custody of the court, but that he must look to any proceedings authorized by law upon such seizure for its condemnation and sale. Such service may also be sufficient in case where the object of the action is to reach and dispose of property in the State, or of some intercst therein, by is a party, to condemn and appropriate it for a public purpose. In other worls, such service may answer in all actions which are substantially proceedings in rem. But where the entire object of the action is to deter. mine the personal rights and obligations of the defendants, that is, where the suit is merely in personam, constructive service in this form upon a non-resident is ineffectual for any purpose. Process from the tribunals of one State can not run into another State, and summon parties there domiciled to leave its territory and respond to proceedings against them. Publication of process or notice within the State where the tribnnal sits cannot create any greater obligation upon the non-resident to appear. Process 
thereof; and, at all events, under ordinary circumstances, it can not be treated as existing and being within the territorial jurisdiction of another State, so as to authorize the latter to require it to appear before its courts, and be subjected to judgments in personam against it. The statutes of some of the States authorize the service of summons on a foreign corporation to be made upon some offcer or agent thereof, residing or being in the State in which suit is brouglit. A service of summons on one of its agents made in pursuance of such statute, may sometimes be regarded as a mere constructive service, and the judgment thereon as laving no extraterritorial effect. ${ }^{2}$ A corporation is so far

sent to him out of the State, and process published within it, are equally unavailing in proceedings to establish his personal liability.

"The want of authority of the tribunals of a State to adjudicate upon the obligations of non-residents, where they have no property within its limits, is not denied by the court below: but the position is assumed, that, where they have property within the State, it is immaterial whether the property is in the first instance brought under the control of the court by attachment or some other equivalent act, and afterwards applied by its julgment to the satisfaction of demands against its owner; or such demands be first established in $a$ personal action, and the property of the non-resident be afterwards seized and sold on execution. But the answer to this position has already been given in the statement, that the jurisdiction of the court to inquire into and determine his obligations at all is only incidental to its jurisuietion orer the property. Its jurisclietion in that respect camot be marle to depend upon facts to be ascertained after it has tried the cause and rendered the judgment. If the judgment be previously voicl, it will not beeome valid, by the subsequent discovery of property of the defendant, or by his subsequent aequisition of it. The judg- ment, if void when rendered, will always remain void; it cannot occupy the doubtful position of being valid if property be found, and void if there be none. Even if the position assumed were confined to cases where the non-resident defendant possessed property in the State at the commencement of the action, it would still make the validity of the proeeedings and judgment depend upon the question whether, before the levy of the execution, the defendant had or had not disposed of the property. If before the levy the property should be sold, then according to this position, the judgment would not be binding. This doctrine would introduce a new element of uncertainty in judicial proceedings. The contrary is the law; the validity of every judgment depends upon the jurisdiction of the court before it is rendered, not upon what will oecur subsequently."

${ }^{1}$ Ohio \& M. R. R. Co. v. Wheeler, 1 Black. 286; Bank of Augusta v. Earle, 13 Pet. 512; Cowles v. Mercer Co., 7 Wall. 11S; Louisville C. \& C. R. R. Co. $v$. Letson, 2 How. U. S. 497.

${ }^{2}$ Latimer $v$. U. P. R. R. Co., 43 Mo. 105; Hurlbert v. Hope M. L. Ins. Co., 4 How. Pr. 275; Brewster $v$. Michigan Cent. R. R. Co., 5 How. Pr. 183; Bates $v$. New Orleans \& J. R. R. Co., 13 How. Pr. 516. 
a citizen of the State in which it is organized that it is entitled, on being sued in the courts of another State, to remove the suit to the federal courts, upon complying with the provisions of the judiciary act, and any agreement not to avail itself of this right, exacted under the provisions of a State statute as a condition of its doing business within such State, is inoperative, because "agreements in advance to oust the courts of the jurisdiction conferred by law, are illegal and void," though there seems to be no doubt that tho State may generally exclude a foreign corporation from doing any business within its limits, or may prescribe the conditions on which the business may be done, and may exact security for the performance of the corporate obligations entered into in such State. ${ }^{2}$ There are many instances in which a foreign corporation may so submit itself to the jurisdiction of the courts of another State as to be bound by their judgments. A corporation is an artificial person; and as a natural person may subject limself to the jurisdiction of the courts of a State in which he does not reside, so may an artificial person. Persons, whether natural or artificial, may authorize actions to which they are parties to be prosecuted or defended in foreign States, and, if they do so, are bound by the result. So it would seem to be competent for a State to provide, as a condition of a foreign corporation doing business within its limits, that it should consent to be sued there, and that the service of process on some of its agents should be valid; and further, that by doing business within such State, the corporation is deemed to assent to such law, and the conditions by it imposed, provided that such conditions are not repugnant to the constitution and laws of the United Stites. A judgment against a foreign corporation which has thus brought itself within the jurisdiction of the State in which the judgment is entered is entitled to that full faith and credit elsewhere, which is accorded to it where it is pronounced. ${ }^{3}$ 2. 569. Jurisdiction Acquired may be Continued by Constructive Service.-But if a court acquire jurisdiction over the parties, the courts of the same State may proceed

\footnotetext{
'Insurance Co. v. Morse, 20 Wall. ${ }^{3}$ Railroad Co. v. Harris, 12 Wall, 445; Railway Co. v. Whitton, 13 65; Lafayette Ins. Co. v. French, 18 Wall. 270.

${ }^{2}$ Paul $v$. Virginia, 8 Wall. 168. How. U. S. 404.
} 
until the final termination of the controversy, although one of the partios is a non-resident. Thus, if a resident of ono State submits himself to the jurisdiction of a subordinate court of another State, he may be brought as respondent before the appellate courts, although the process or notice required to compel him to appear in the higher court can not be personally served. If it were otherwise, a party unjustly prevailing in the subordinate court could retain his advantage by remaining without the State. The appeal or writ of error must be regarded not as a new suit, but rather as the continuation of an old one. Whether a nonresident respondent be brought into the appellate court by means of actual or constructive notice, a judgment will be as binding on him, in other States, as the judgment of the inferior court would have been if it had been against him. ${ }^{1}$

\& 570. Constructive Service on Residents.-In relation to the extra-territorial effect of a judgment procured against a person in the State of his domicile, in an action in which he entered no appearance, and in which the process was served constructively, in accordance with the laws of that State, radical and irreconcilable differences of opinion exist. In one case, the court said: "We will treat the judgment, not as void, nor as conclusive, but simply as prima facie." This is a kind of middle ground, or compromise treatment of the question; and, like most compromises, is probably less defensible, upon principle, than either of the extremes between which it is placed. The position, howerer, which seems to be best sustained, both by reason and by precedients, is that each State lias the authority to provide the means by which its own citizens may be brought before its courts; that the courts of other States have no authority to disregard the means thus provided; and, finally, that erery judgment or decree, obtained in a State against some of its citizens by virtue of a lawful, though constructive, service of process, should bo as obligatory upon such citizen in

${ }^{1}$ Nations $v$. Johnson, 24 How. U. S. 195; Cone v. Hooper, 18 Minn. 531.

2 Holt v. Alloway, 2 Blackf. 108. 
erery other State as it is in tho Stato rhence it is talson. ${ }^{1}$ For is it destructive of the extra-territorial cfect of a jud g ment based on constructive service, that the defendant, being a citizen of the State, was temporarily absent therefrom. It is suficient that he was, at the time, subject to the laws of the State and to the territorial authority of the court. ${ }^{2}$ Thus, in a recent Massachnsetts case, in which a judgment rendered in Califoruia, was called in question, Wells, J. delivering the opinion of the Supreme Judicial Court, said: "The defendant was not in California when the suit was commeneed against him there; nor at any time during its pendency. No service of process or notice was ever made npon him personally. He did not appear by counsel, or otherwise, nor assent to the judgment, which was rendered upon his default of appearance. Dut he had been, for a long time before that, a citizen of California; the contract was made there; and that continned to be his legal domicilo when the judgment was rendered. IIe was, therefore, upon principles of international right, subject to the laws, and to the juriscliction of the courts of that State." 3

On the other hand, it is insisted, that "a merely constructive notice by publication or attachment camnot rightfuily be stibstitrited for the direct and actual warning which every man ought to have before being condemned." "And that a sentence so pronouneed is not a judgment in any just sense of the term, and should not be enforced by any court which is free from constraint." 4

8571. By what Law Considered.-In the consideration of jurisdictional, as well as of other questrons in regard

1 McRae v. Mattoon, 13 Pick. 53; |Welsh v. Sykes, 3 Gilm. 197; Price Poorman v. Crane, 1 Wright Ohio, $v$. Hickok, 39 Verm. 202; Gilman $v$. 317; Hinton $v$. Tounes, 1 Hill S. C. Lewis, 4 Zabr. 246; Harker $v$. Brink, 439; Spencer $v$. Brockway, 1 Hamm. 4 Zalr. 333.

859; 13 Am. Dee. 615; Hunt $v$. Lyle, 8 Yerg. 142; Green v. Sarmiento, 1 Pet. C. C. 74 ; Buford $v$. Kirkpatrick, 13 Ark. 33; Cassidy $v$. Leitch, 2 Abb. N. C. 315 .

${ }^{2}$ Rangely $v$. Webster, 11 N. H. ${ }^{4}$ Am. Lead. Cas., 5th ed., pp. 654 299; Holt v. Alloway, 2 Blackf. 108; and C5̃; Bowler $v$. Huston, 30 Gratt. Bimcler v. Dawson, 4 Scam. 536; 266. 
to the effect to be given to a judgment of ancther State, the question arises, what law shall the court apply to the facts and records brought before it, when the parties fail to show the law regulating the subject in force in the State whence the record is taken? Upon one hand, it is insisted that, for this purpose, each State must take judicial cognizance of the laws of the other States; that as each case involving tho effect of a judgment, under the constitution and laws of the United States, is liable to bo heard on appeal in the United States Supreme Court, where judicial notice is taken of the laws of each State, it would follow that, unless the State courts also take like notice, the caso would be determined in the lower court by one law, and in the appellate court by another and perliaps entirely dissimilar law; ${ }^{1}$ on the other hand, it is held that "in the absence of proof, a court could not take notice of the law of another State, and should presume that it was in accordance with their [its] own;"2 while a third view is that, in the consideration of the judgment of another State, it will be presumed, until the contrary appears, that it is governed by the rules of the common law, and a record insufficient to constitute a valid judgment under that law will be disregarded, unless its sufficiency is shown by some law of the State whence it was taken. $^{3}$ When no written law or decision is produced which shows whether a service disclosed by a record or by other proof was sufficient in the State where it was made, the testimony of experts from that State may bo received to enable the court to determine whether the service was sufficient, according to usage and practice of the courts of that State. ${ }^{*}$ A judgment of another State, when offered in evidence, ought to be shown to be valid. If it would not be valid if rendered in the State where it is offered in evidence, the party who relies upon it must show that it is ralid according to the laws of the State within whose jurisdiction it was pronounced. ${ }^{5}$

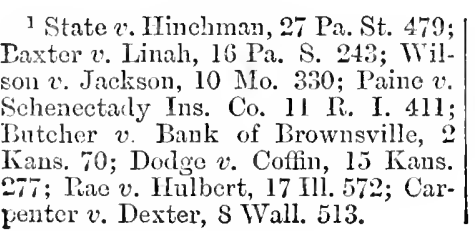

610 
2572. Jurisdiction of Subject Matter.- It is, of conrse, essontial to the validity of a judgment rendered in another State, that the court have juriscliction over the subject mattor of the controversy. A State can no more exercise jurisdiction over land bejond its boundaries than it can orer the citizens of other States. Thus, if a probate court in one State made an order under which lands of the decoased lying in another State are sold, the sale is null and roid, for want of authority in the court over the land authorized to be sold. ${ }^{1}$ For the same reason, a conveyance made by the oficers of a court of a sister State, in pursuance of s decree of such court, was disregarded as to lands lying in any other State. ${ }^{2}$ While courts of one State have no jurisdiction to determine a naked question of title to lands in another State, they probably are competent to enforce a trust, irrespective of the location of the land, and to decree a conveyance, though in so doing they may be compelled to determine the question of title. ${ }^{3}$

8573. Judgments in rem will be considered in a separate chapter, in which their extra-territorial effect will be stated. But a class of judgments will be spolien of here which, though frequently styled judgments in rem, are simply judgments obtained by one kind of constructive service. Iil several of the States, process may be served by attaching the defendant's real or personal estate. The State in which the property is situate may, no doubt, authorize its seizure, upon attachment; and the courts of the State may, in pursuance of State laws, exercise juriscliction orer the property, although its owner is not, by any means, brought within the jurisdiction of the court. The disposition mado of the property attached is as final and conclusive in any State to which it may be removed, as it was in the State where the judgment was entered." But if the seizure of property is employed as a constructive service of process

1 Wilkinson $v$. Leland, 2 Pet. 627 .

${ }^{2}$ Page $v$. Micíee, 3 Bush, Ky. 135.

${ }^{3}$ McGregor $v$. McGregor, 9 Iowa, 65; Massie $v$. Watts, 6 Cranch, 14S; Sturdevant $v$. Pike, 1 Cart. 277; Lewis v. Darling, 16 How. U. S. 1.
${ }^{4}$ Moore $v$. Spackman, $12 \mathrm{~S} . \& \mathrm{R}$. 287; Green $v$. Van Buskirk, 7 Wall. 139; Hall $\imath$ : Wiliams, 6 Pick. 232; 17 Am. Dec. 356; Molynenx $v$. Seymour, 30 Geo. 440; Melhop v. Doane, 31 Iowa, 397. 
on the defendant, npon which a judgment in perscrim is entered, such judgment can have no greater extraternitorial force than if based upon any other constructive service.'

\& 574. Joint Debtor Acts.-A judgment against two or more joint debtors on a citation served on but one, though anthorized by the laws of the State, is not binding elsewhere upon any of the defendants who were not within the State, and who did not appear in the action." "Personal judgments thus reudered have no operation out of the limits of the State where rendered. Their effects are merely local. Out of the State they are nullities, not binding upon the non-resident defendant, nor establishing an: claim against him." In Oregon, such a judgment seens to bo regarded as prima facie evidence against the defendasts who wore not served with process." The case of IIall ₹. Lanning, ${ }^{5}$ was one in which a recovery was sought upon a judgment rendered in the State of New York, against the plaintiffs in error. One of them, Lybrand, pleaded, questioning the jurisdiction over his person of the court which pronounced the judgment. This judgment was recovered against Lybrand and another, as partuers, and the record showed that both partners appeared by attorney snd answered the complaint. To avoid the effect of thia record Lybrand offered to prove that he was not a resident or citizen of New York; that he had not been within that State since a period long anterior to the commencement of the action, and that he had never been summoned in the action, nor had any notice thereof, and that he had not appeared in person nor anthorized any one to appear therein for him, nor to employ any attorney to so appear; that he was a

\footnotetext{
1 Arndt v. Arndt, 15 Ohio, 33; Robinson $v$. Ward, 8 Johns. $86 ; 5$ Am. Dec. 327; Kilburn $v$. Woodworth, 5 Jolıns. 41; 4 Am. Dec. 321; Bates $v$. Delavan, 5 Pai. Ch. 299; Thompson v. Emmert, 4 McL. 96; Lincoln v. Tower, 2 McL. 473; Melhop v. Doane, 31 Iowa, 397; Ward v. McKenzie, 33 Tcx. 297; Sevier $v$. Rorldie, 51 Mo. 580; Melhop v. Doane, 31 Ia. 397; Iles v. Elledge, 18 Kans. 296.
}

${ }^{2}$ Rogers v. Burns, 27 Penn. S. 525; Steel v. Smith, 7 W. \& S. 451; D'Arcy v. Ketchum, 11 How. U. S. 165; Phelps v. Brewer, 9 Cush. 390; Newlon $v$. Heaton, 42 Ia. 593; Bowler $v$. Huston, 30 Gratt. 266.

${ }^{3}$ Public Works v. Columbia College, 17 Wall. 527.

${ }^{4}$ Swift $v$. Stark, 2 Oregon, 97.

591 U. S. 160; 3 C. L. J. 58. 
partner of his co-defendant Hall at the time the transaction ccsurred upon which the suit in New York was brought; but that such partnership had been dissolved, and due notice thereof published six months prior to the commencement of such suit. The evidenco was overruled on objection of the plaintiffs below. The supreme court held that the partnership having been dissolved, one of the late partwers bad no power to enter an appearance for the other, nor to authorize it to be entered, and that it was very doubtful whether such an authority existed even during the continuance of the firm; and, therefore, that the court below erred in excluding the evidence offered. In reaching this couclusion, the court chiefly relied upon the rule (wlich it treated as unquestionable), "that a member of a partnership firm, residing in ono State, cannot bo rendered personally liable in a suit brought in another State against lim and his copartners, although the latter be duly served with process, and although the law of the State where the suit is brought authorizes julgment to be rendered against him."

8 575. Same Effect as at Home.-Except in regard to the allowance and effect of jurisdictional inquiries, the character of a judgment of a sister State is substantially that of a domestic judgment. ${ }^{1}$ Its effect, however, is often different from that of a similar record in the State in which it is sought to be enforced, because it is governed by the laws of the locality where it was created. The first question to be determined in regard to a judgment of another State, after jurisdictional inquiries have been satisfactorily answered, is, what is its effect in the State whence it was taken ?' 'l'he effect which it has there is precisely tho effect which must be accorded to it in every other state. ${ }^{3}$ If the judgment

${ }^{1}$ Tiggers $v$. Odell, 39 N. H. 452; Pa. S. 533; Black $v$. Smith, 13 T. Christmas v. Russell, 5 Wall. 290; Va. 780; Eaton v. Hasty, 6 Neb. 419; Moulin $v$. Insurance Co., 4 Zab. 22:; 29 Am. Rep. 365.

Armory v. Armory, 3 Bissell, 266; 2 Taylor \& Co. v. Runyan, 3 Clarke, Camplell $v$. Home Ins. Co., 1 S. C. 474; Suydam $v$. Barber, 18 N. Y. 468; 158; Barney v. White, 46 Mo. 137; Green v. Sarmiento, 3 Wash. C.C. 17. Zimmerman $v$. Ticlser, 32 Md. 274; ${ }^{3}$ McLaren $v$. Fiehler, 23 La. An. 80; Chew $v$. Brumagim, 21 N. J. Eq. 520; Simmons $v$. Clark, 56 Ill. 96; French Gulick v. Loder, 1 Green. L. 6S; 23 v. Pease, 10 Kans. 51.

Am. Dec. 711; Guthrie v. Lowry, 84 
appear on its face to be harsh and erroneous, it must bo received and enforced irrespective of its harshness. ${ }^{1}$ Tho pleas which might be made to it at home, and those only, can be made to it in any other part of the Union. ${ }^{2}$ If tho common law distinctions in forms of actions have been abolished in the State where the judgment is rendered, then it must not be treated in other States according to the rules growing out of those distinctions. ${ }^{3}$ If valid under the law of its creation, it must be treated as valid in States under whose laws it would, if a domestic judgment, be invalid. An interlocutory decree not being conclusive at home, is not conclusive in another State. ${ }^{5}$ If a person having a demand against another, go into a State and sue upon it, and the plea of the statute of limitations of that State bo interposed and sustained, he cannot return with his demand to the State whence he took it, and maintain an action on it there. The judgment being conclusive against him where entered, is equally so in every other State. ${ }^{6}$ An adjudication made in one State is equally conclusive as an estoppel in every other State. ${ }^{7}$ A decree in a court of chancery in one State enjoining a judgment for fraud, is conclusive in an action on the judgment in another State, though it has no extraterritorial force as an injunction. ${ }^{8}$ In some respects it is obvious that the judgment of a court of another State can not have the same effect as a domestic judgment. Writs of execution cannot issue thereon, hecause the domestic courts have no authority to issue such writs in aid of the juriscliction of foreign tribunals, nor can these latter tribunals issue writs which may be enforced in other States. From this inability to obtain satisfaction thereof by execution, it is clear that a judgment entered in another State is

1 Rankin v. Barnes, 5 Bush, 20.

${ }^{2}$ Cook v. Thornhill, 13 Tex. 293; Brunclell v. Vaux, 2 Dall. 302; Nills $v$. Duryee, 7 Cranch, 481; see, however, Judkins $v$. U. M. Fire Ins. Co., 57 N. H. 470.

${ }^{3}$ Grifin v. Eaton, 27 Ill. 379.

* Clemmer v. Cooper, 24 Iowa, 185.

${ }^{5}$ Baugh v. Baugh, 4 Bibb, 556; Brinkley $v$. Brinkley, 50 N. Y. 184; 10 Am. Rep. 460.
${ }^{6}$ Swect $v$. Brackley, 53 Maine, $34 \mathrm{G}$.

${ }^{7}$ Cannon $v$. Brame, 45 Ala. 262; Blodget $v$. Jordan, 6 Verm. 580; Spencer $v$. Brockway, I IIamm. உ59; 13 Am. Dec. 615; Cherry v. Speight, $2 S$ Tex. 503; Wernwag $v$. Pawling, 5 G. \& J. 500; R. R. Co. v. Wynne, 14 Ind. 385; Baker v. Tand, 13 Barb. 152; Taylor $v$. Dryden, 8 Johns. 173; 2 Am. Learl. Cas. 5th el. p. 619.

${ }^{8}$ Dobson $v$. Pearce, 12N. Y. 156. 
not a lien on property in this State, and for the purpose of sharing in the assets of the defendant, ranks no higher than a simple contract debt. ${ }^{3}$

8 576. Defenses.-All defenses which are admissible against a judgment where it was pronounced, are equally admissible in actions upon it in another State. Wint of jurisdiction, as we have seen, is generally recognized as a good defense. With this exception, no defense which would not be received in the forum whence the judgrnent was taken, will be allowed against it elsewhere, unless it be fraud in its procurement. Whether fraul can be assigned as a defense, seems to depend upon the form of practice in the State where the action on the judgment is brought. If, in such State, frand can be pleaded to an action on a domestic judgment, it is equally available and equally eficient in actions on judgments of other States. ${ }^{2}$ But if, to avoid a domestic judgment for fraud, proceedings must bo instituted in equity, then like proceedings, and those only, must be resorted to as against a judgment of another State. ${ }^{3}$ It is true that two of the decisions of the supreme court of the United States contain the general statement that tho plea of fraud is not available as an answer to an action on a judgment. We apprehend, however, that these decisions are inapplicable in those States in which the distinction between law and equity is attempted to be abolished, and equitable as well as legal defenses are, when properiy pleaded, admissible to actions at law. Circumstances may exist in which it would be competent to a court of equity, on the ground of fraud, to enjoin a party from enforcing a judgment recovered in another State. Certainly the defendant ought, when sued in a State acting under the reformed code of procedure, to be permitted to assert his equitable defense in that action, instead of being required to resort to a separate and independent suit. An action

${ }^{1}$ McElmoyle v. Cohen, 13 Pet. 312. $\quad{ }^{4}$ Christmas v. Russell, 5 Wall. 230;

$22 \mathrm{Am}$. Lead. Cas. 5th ed. 65S; Maxwell $v$. Stewart, 22 Wall. 77.

Rogers $v$. Gwinn, 21 Iowa, 58. See ${ }^{5}$ Black $v$. Smith, 13 V. Va. 791; also Davis $v$. Headley, 22 N. J. Eq. Pearce 2 . Olney, 20 Conn. 544; Eaton 115; David v. Smith, 5 Geo. 274.

32 Am. Lead. Cas. 5th ed. 58-9. 365 ; Ward v. Quinlivin, 57 Mo. 425. 
on a judgment confessed in another State, by a power of attorney, can be defeated by showing that the defendant neither executed the power of attorney, nor had any notice of the pendency of the suit. ${ }^{1}$ To an action in Tennessee, on a judgment rendered in Kentucky, the defendant pleaded, that plaintiff took advantage of political prejudices existing when the suit was commenced, to combine with citizens of the latter State to prevent his making any defense; and that, therefore, defendant permitted default to be taken because he could not appear without endangering his life. The plea was decided to be sufficient. ${ }^{2}$ Nothing which could have been pleaded in the original action can be pleaded against the judgment. ${ }^{3}$ Errors and irregularities in the proceedings in the original suit, do not, in any respect, impair the effect of the judgment, unless taken advantage of by an appeal, or some other appropriate correctory proceeding. ${ }^{4}$ An action may be maintained on the judgment of another State during the pending of an appeal or writ of error. ${ }^{5}$ The following plea, involving a denial of the jurisdiction of the court, was said to exclude every hypothesis in favor of the judgment: "And the said defendant says, that at the time when said proceedings were commenced as set forth in said declaration, and from that time up to and at the time when said supposed judgment was rendered as aforesaid, he, the said defendant, was a citizen of the State of Arkansas, and resident therein, and was not served with process, and had no notice whatever of the pendency of said action, and that he never appeared thereto in per'son nor by attorney, and this he is ready to verify."

8 577. Of Courts not of Record.-The means provided by Congress for the authentication of judicial records and proceedings, are not applicable to judgments of the justice of the peace. The attestation prescribed by the act of 1790

${ }^{1}$ Wilson $v$. Bank of Mount Pleas- Exrs. of Simonton, 7 Porter, 110; ant, 6 Leigh, 570.

${ }^{2}$ Coffee $v$. Neely, 2 Heisk. 304.

3 Norwood $v$. Cobb, 20 Tex. 5ss; Goodrich $v$. Jenkins, 6 IIamm. 43.

"Struble $v$. Míalone, 3 Clarke, 5s6; Conway v. Ellison, 14 Ark. 360; Olds 652 .

v. Glaze, 7 Iowa, 80; Crawford $v{ }^{6}$ Barkman v. Hopkins, 6 Eng. 161. 616 
must be made by the clerk, with the seal of the court, if there be one, annexed, and by the certificate of the chief justice or presiding magistrate, as the case may be. It seems to be generally conceded that in all cases where judgment cannot, from the nature of the court in which it originated, be authenticated under the act of Congress, its effect, in another State, is no greater than that of a foreign judgment to which nil debit is a proper plea. ${ }^{1}$ In New Hampshire it is said that a judgment of a justice of the peace of another State must be considered " as leaving the whole merits of the case open for discussion and examination, and that the defendant is not estopped from setting up a pajment made before the judgment was rendered. ${ }^{2}$ But in other States these judgments are undoubtedly given greater effect than is accorded to them in New Hampshire; and are, when proved in the same manner as a foreign judgment could be proved, and shown to be authorized by the laws of the State whence they are taken, and to have been pronounced by tribunals having jurisdiction over the parties to the suit and the subject-matter in controversy, conclusive upon the merits; though the plea properly filed in the action may be called nil debit or non assumpsit. ${ }^{3}$ The judgment of a justice of the peace of another State must "be proved by the oath of witnesses who have compared the copy produced in evidence" with the original." The question of what constitutes a sufficient authentication of judicial proceedings, under the law of Congress, has been cousidered in the chapter on "Judgments as Evidence."

\& 578. Courts of the United States.-The same rule applies to judgments rendered in the United States courts, when relied upon in another State, as that which would, in like circumstances, be applied to the judgment of any court of record of another State. ${ }^{5}$

\section{? 579. Decrees of Divorce in States to which both} Parties have Removed.-When the spouses remove from

${ }^{1}$ Graham v. Grigg, 3 Harr. 408; 203; Danforth $v$. Thompson, 34 Iowa, Taylor $v$. Barron, 10 Foster, 7S; War- 243.

ren $v$. Flagg, 2 Pick. 448.

${ }^{2}$ Robinson v. Prescott, 4 N. H. 450.

${ }^{3}$ Silver Lake Bank $v$. Harding, 5 Hamm. 546; Carpenter $v$. Pike, 30 Verm. S1; Kean v. Rice, $12 \mathrm{~S}$. and R.

${ }^{4}$ Am. Lead. Cas. 5 th ed. 660 .

${ }^{5}$ Niblett $v$. Scott, 4 La. An. 2:6; Barney v. Patterson, 6 II. \& J. 152; Thomson $v$. Lee County, 22 Iowa, 206 . 617 
the State in which they were married, the marriage relation becomes subject to the laws of the State of which they become bona fide residents; and a divorce granted there, though for some cause not recognized as sufficient where the marriage was celebrated, would bo binding on both parties in every other State. ${ }^{1}$

\section{580. Divorce in another State by Parties gcing} there to Procure it.-No doubt is entertained in regarl to the conclusive effect of a divorce obtained in a State to which the parties have removed with the intention of making their domicile there. But many instances occur in which the removal is apparently for the purpose of procuring a divorce for some act not regarded as a sufficient cause at the place of its commission, or in order to avoid such a defense as would probably be made if the action were prosecuted near the domicile of the defendant. No doubt most of the State courts have deemed a divorce so procured the consummation of a frand upon the laws and courts of the State where the cause of divorce was alleged to have occurred, as well as upon the defendant, and have refused to pay it any respect whatever. ${ }^{2}$ Thus the judge who delivered the opinion of the court in a recent case in New York, took the ground that only the courts of the State having jurisdiction over the domicile of the parties at the commission of the act, can grant a divorce, because they alone have jurisdiction over the subject-matter, and said: "I cannot agree to the proposition that a party domiciled in this State, desiring a ciivorce, for a cause occurring here, for which such a divorce will not be granted by the laws of this State, can remove to another state, where the act complained of is legal cause for such divorce; and then, upon the ground of such act, occurring here, before his becoming domiciled there, obtain the decree, and then return to this State and

\footnotetext{
${ }^{1}$ Larber v. Tioot, 10 Mass. 265; 407; 21 Am. Dec. 742 and note; State Pawling $v$. Bird's Exr's, 13 Johns. v. Armington, 25 Minn. 29.

192; Vischer v. Vischer, 12 Barb. 640; 2 Ilood v. State, 56 Ind. 203 ; 26 IIarding v. Allen, 9 Greenl. 14S; 23 Am. Rep. 21; 5 Cent. L. J. 35; NewAm. Dec. 519; Fellows $v$. Fellows, 8 comb $v$. Newcomb, 26 Am. Rep. 2a2; N. H. 160; Tolen $v$. Tolen, 2 Dlkf. People $v$ Baker, 76 N. Y. 75; $32 \mathrm{Am}$. 
use it here for any purpose." If a decree of divorce rendered in another State contain the recital that the parties resided in such State, this decreo may be contradicted, and its effect entirely destroyed, by showing that they had their domicile in a different State; and a party procuring such decree may be convicted of bigamy in the State of his actual domicile, if he contract another marriage there. ${ }^{2}$ The place in which the marriage was celebrated is not necessarily important in determining the juriscliction in an action for divorce; in truth the courts of the State in which such celebration occurred may become divested of their jurisdiction to annul the marriage. Thus if an alleged cause of divorce arose in a State where the spouses resided, the wife camnot return to the State in which she was married, and there, by constructive service of process, obtain a divorce from her husband, who remains domiciled in the State in which the cause of divorce arose. ${ }^{3}$ But it does not, according to some of the authorities, appear to be essential that the action be brought in the State where the cause of action arose, if, thereafter, the spouses removed to another State, in good faith, and not merely to escape the laws and courts of their domicile." "When a person domiciled in this State, goes, in evasion and fraud of the law of his domicile, into another State, in order to obtain a divorce there, for a canse which occurred here while the parties resided here, or for a cause which would not authorize a divorce by our law, it is within the power of the State by its courts, or its legislature, to declare or enact that a divorce so obtained before acquiring a domicile in the other State, is or shall be of no force or effect in this State. *** It is competent to show that a decree of divorce, granted by a court of another State, although appearing on its face to be valid, is in fact void, because the libelant, fraudulently and in evasion of the law of his own domicile, procured that court to exerciso jurisdiction over the case."

${ }^{1}$ Holmes $v$. Holmes, 4 Lansing, 333; see, to same effect, Inhabitants of Ifanover $v$. Turner, 14 Mass. 227; $7 \mathrm{Am}$. Dec. 203 and note; Greenlaw v. Greenlaw, 12 N. I. 200; Lyon $v$. Lyon, 2 Gray, 369.

${ }^{2}$ People $v$. Dawell. 25 Mich. 247.
${ }^{3}$ Harteau v. Hartean, 14 Pick. 181. $25 \mathrm{Am}$. Dec. 372; Proper $v$. Warner, 47 Vt. 667 ; 19 Am. Rep. 132.

${ }^{4}$ Ilarding $v$. Alden, 28 Am. Dec. 549 .

${ }^{5}$ Sewall $v$. Sewall, 122 Mass. 156; 23 Am. Rep. 299. 
8 581. Cases where Divorces may be granted against Non-residents. - We have already seen that neither the section of the Constitution of the United States in regard to judicial proceedings of other States, nor the act of Congress on the same subject, extends the authority of the courts of one State so as to authorize them to take jurisdiction over the citizens of other States. Some modification of this construction seems unavoidable in proceedings for divorce. "Suppose a husband commits adultery, and then purchases a house, and actually takes up his domicile in another State; but before his wife has joined him, she is apprised of the fact, and immediately files a libel for divorce, and obtains an order to protect her from the power of her husband, as by law sho may. Ho is an inhabitant of another State, and can in no sense be said to live in any connty in this State. And yet it would be difficult to say that she is not entitled to have a divorce here. Supposing, instead of the last case, he has actually purchased a house and changed his domicile to another State, and there commits adulters, and the wife not having joined him, and not having left her residenco in this State, becomes acquainted with the fact, and libels and obtains a similar order, could she not maintain it? Yet, in the latter case, at the time of the act clowe, and in the other at the time of the suit institnted, the respondent, one of the parties, did not live in this commonwealth. This suggests another course of inquiry; that is, how far the maxim is applicable to this case, that the domicile of the wife follows that of her husband. Can this maxim be true in its application to this subject, where the wife claims to act and by law, to a certain extent, and in certain eases, is allowed to act adversely to her husband? It would onst the court of its jurisdiction in all cases where the husband should change his domicile to another State before the suit is instituted. It is in the power of the husband to change and fix his domicile at will. If the maxim conld apply, a man might go from this country to Providence, take a house, live in open alultery, abandoning his wife altogether, and yet she conld not libel in this State, where, till such a change of domicile, they had always lived. It is probably a just view to consider that the maxim is founded 
upon the theoretic identity of person and of interest between husband and wife, as established by law, and the presumption that, from the nature of that relation, the homo of one is that of the other, and intended to promote, strengthen, and secure their interests in this relation, as it ordinarily exists where union and harmony prevail. But the law will recognize a wife as having a separate existence, and separate interests, and separate rights, in those cases where the express object of all proceedings is to show that the relation itself ought to be dissolved, or so modified as to establish separate interests, and especially a separate domicile and home, bed and board being put, a part for the whole, as expressive of the idea of home."1 The courts in Massachusetts recently took jurisdiction of a case which was a little different from either of the lyppothetical cases stated in the foregoing opinion of Chief Justice Shaw. A luusband and wife left Massachusetts, intending to remove to Colorado, and to have their permanent domicile there. They stopped temporarily at Philadelphia when on their way to Colorado. The husband there committed acts of cruelty, on account of which the wifo returned to her former home and applied for a divorce. The husband did not return to Massachusetts; but the courts of that State nevertheless exercised jurisdiction over him for the purpose of giving the wifo the relief sought for his violation of the marriage contract. ${ }^{2}$

8 582. Domicile of Wife.-That the domicile of the husband is in law the domicile of the wife, is not true where, on account of a final separation, they have taken up their residences in different States, ${ }^{3}$ nor where the husband is guilty of such a violation of his marital engagements as entitles the wife to a partial or entire dissolution of the marriage relation."

${ }^{1}$ Chief Justice Shaw in Harteau $v$. ing $v$. Alden, 9 Greenl. 140; 23 Am. Harteau, 14 Pick. 181; 25 Am. Dec. Dec. 549; Maguire $v$. Maguire, 7 Dana, 372 .

${ }^{2}$ Shaw $v$. Shaw, 9S Mass. 158.

3 Jenness $v$. Jenness, 24 Ind. 355.

- Ditson $v$. Ditson, 4 R. I. 87; Hard1S1; Hollister $v$. Hollister, 6 Penn. S. 449; Hunt $v$. Hunt, 72 N. Y. 217; 28 Am. Rep. 129. 
\& 5S3. Constructive Service Refected.-Now when, from any cause, the domicile of the parties is no longer in contemplation of the law identical, but, on the contrary, has become susceptible of separation, and the parties in fact reside in different States, it is evident that neither party conld obtain the redress authorized by law unless the State courts can render a decree which will be binding on the mon-resident defendant. The courts of the State of New York deny that if a husband and wife have their domicilo in that State, either of them can go into another State and obtain a divorce, without the appearance of the defendant, which can be of any validity in New York. In Pennsylvania, it is held that the injured spouse must seek redress in the State where the injury was committed, unless the defendant remove from the common domicile. ${ }^{2}$

8 584. Constructive Service Effective.-But if, from the destruction of their common domicile, the injured party has been authorized to acquire and has acquired a domicilo in another State, in which the dissolution of the marriage is sought, then there is an absolute necessity for some means by which the courts may compel the non-resident defendant to submit his claims to a continuance of the marriage relation to their juriscliction. The means usually provided by statute consists of some constructive service of process, as by the publication of the summons for a specified time in some public journal. Judgments procured in any State by constructive service of process upon non-residents, are, as we have already seen, of no extraterritorial force in imposing obligations in personam. But a sentence of divorce has, or may have, a dual nature. . It is a decree in rem, so far as it fixes the status of the parties by dissolving their marital obligations. But, so far as it disposes of any other matter than the marriage relation, it is in personam. The decisions already cited from the New York Reports, refuse to recognize a decree of divorce rendered in another State, upon constructive service of summons against a non-resident.

${ }^{1}$ Vischer $v$. Vischer, 12 Barb. 640; Hoffman $v$. Hoffman, 46 N. Y. 30; Holnes $v$. Holmes, 4 Lansing, 3s8; Kerr $v$. Kerr, 41 N. Y. 272.

${ }^{2}$ Reel $v$. Elder, 62 Pa. St. 308. 
But, in this respect, the New York cases are not sustained by the adjudications made in other States. ${ }^{1}$

\section{585. Summary of Lav of Divorce in Sister States.}

The conclusions which are sustained by a decided majority of the cases, are very clearly and correctly stated by $M i r$. Cooley, in his work on Constitutional Limitations, in the following language: "Wo conceive the true rule to be, that the actual bona fide residence of either husband or wife within a State will give to that State authority to determine the status of such party, and to pass upon any question affecting his or her continuance in the marriage relation, irrespective of the locality of the marriage or of any alleged offense; and that any such conrt in that State as the Legislature may have authorized to take cognizance of the subject, may lawfully pass upon such questions and annul the marriage for any causo allowed by tho local law. But if a party goes to a jurisdiction other than that of his domicile for the purpose of procuring a divorce, and has residence there for that purpose only, such residence is not bona fide, and does not confer upon the courts of that State or country jurisdiction over the marriago relation; and any decree they mav assume to make would be void as to the other party." The summary of the law just quoted has been confirmed by the Supremo Court of the United States, so far as it assumes that the petition for divorce may bo received and adjudicated upon by the courts of any State in which tho petitioner has a lona ficle domicile, irrespective of tho place of the marriage, of the offense, or of the domicile of the defendant. ${ }^{3}$ And while the language employed in this same opinion of tho Supreme Court of the United States affirms, in general terms, that a decree of divorce, valid and effectual by tho laws of the State where it was procured, is valid and effectnal in all other States, we do not understand that this or auy

${ }^{1}$ Hull $v$. IInll, 2 Strob. Eq. 17t; Dana, 1S1; Heirs of Holman $v$. Bank Iranley $v$. Manley, 4 Chand. 97 ; Hub. of Norfolk, 12 Ala. 369.

bell v. Hubbell, 3 Wis. 662; Mansfield ' Cooley's Const. Lim. pp. 400, 401; $v$. MeIntyre, 10 Ohio, 2S; Ditsou $\mathrm{r}$. see, also, Wharton's Confliet. Laws, Ditson, 4 R. I. S7; Harrison v. Harri- $\$ \$ 224$ to 239.

son, 19 Ala. 499; Thompson v. The ${ }^{3}$ Cheever $v$. WVilson, 9 Wall. 108; State, 2S Ala. 12; Harding v. Alden, 9 Hunt $v$. Hunt, 72 N. Y. 217; 28 Am. Greenl. 146; Maguire v. Maguire, 7 Rep. 129. 
other part of the opinion was designed to uphold a decreo obtained by a party who "goes to a jurisdiction other than that of his domicile for the purpose of procuring a divorce, and has residence there for that purpose only."

8 586. Fifrect as Decree in rem.-So far as the decree or judgment of divorce assumes to dispose of questions other than that of the marriage status of the parties, it is not a clecreo in rem, and can liave no extraterritorial obligation, unless the defendant was within the jurisdiction of the court. If it award alimony, or costs, to the complainant, or make any disposition in regard to the custody of the children, such award is of no force beyond the State wherein it was made. ${ }^{1}$

2 587. In a recent Case in Massachusetts the entirely novel view was announced, that the proceedings of a court of record, when aeting upon an application for a divorce, were not supported by the same presumptions which would support the records of the same court when exercising its jurisdiction upon other matters. The court said: "The paper offered as a record was not admissible. There was no proof that the court in California had jurisdiction of the cause and the parties. Although a court of record, its jurisdiction of the subject of divorce is a special authority not recognized by the common law, and its proceedings stand on the same footing with those of courts of limited jurisdiction.".

${ }^{1}$ Jackson $v$. Jackson, 1 Johns. 424; | Harr. 440; Cooley's Const. Lim. p. Crane v. Meginnis, 1 G. \& J. $463 ; 19406$.

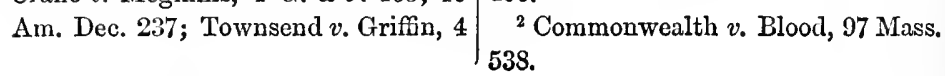


Chap. XYIII.] OF JURISDICTION.

\section{CHAPTER XXVII.}

\section{FOREIGN JUDGMENTS.}

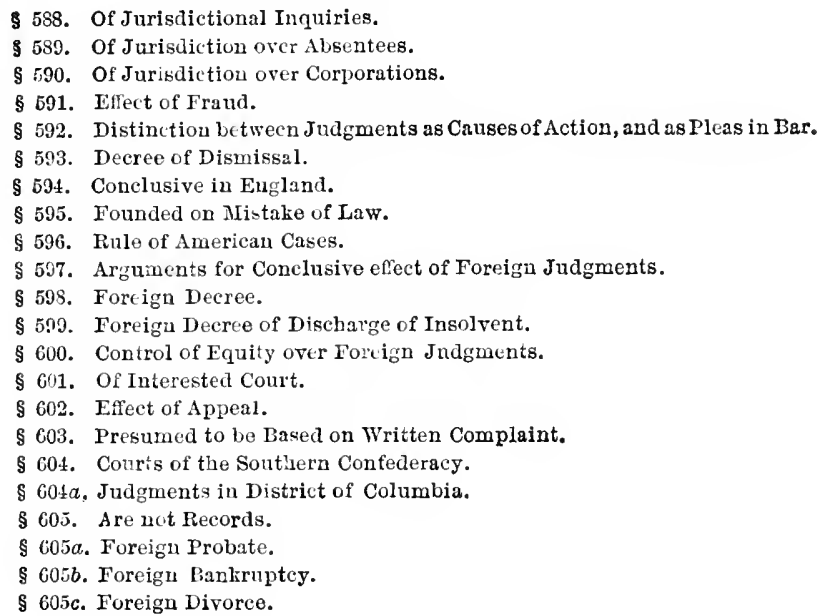

3 588. Of Jurisdiction.-The question which first suggests itself in regard to foreign judgments, is one which we have had occasion to investigate in reference to every other lind of judgment, viz.: is the jurisdiction of the court an open question; and if so, were tho subject matter of the controversy and the party against whom the judgment lias been pronounced, within the jurisdiction of the court? In treating of the judgments of other States of the American Union, we have shown that, notwithstanding the provisions of the Constitution and of the statutes made in pursuance thereof, no judgment can be of any validity beyond the State wherein it was entered, unless the defendant was a citizen of such State; or unless, by some act of his, he submitted himself to its laws, and thereby became subject to the anthority of its courts. ${ }^{1}$ The same general principle is applied to foreign judgments, as will be made apparent by quotations from the opinion of the court of Queen's Bench in a

1 See Sec. 564. 
recent English case. ${ }^{1}$ This case was an action on a judgment of a French tribunal given against the defendants for default of appearance. Among the pleas to the action, was "a special plea asserting that the defendants were not resident or domiciled in France, or in any way subject to the jurisdiction of the French court, nor did they appear; and that they were not summoned, nor had any notice or knowledge of the pending of the proceedings, or any opportunity of defending themselves therefrom." On the trial it appeared that tho plaintiff was a Dane, resident in France; and that the defendants also were Danes, but they were resident in London. The action in the French court was to obtain damages for an alleged violation of a contract. The placs at which the contract was made did not clearly appear; but "the fair intendment from the evidence was that it was made in London." "The following admissions were made, namely: that the judgment was regular, according to French law ; that it was given in favor of the plaintiff, a foreigner, domiciled in France, against the defendants, domiciled in England, and in no sense French subjects, and having no property in France." It also appeared that process was issued out of the French court, "and the French consulate in London served on the defendants a copy of the citation." The jury found that the defendants had lnowledge and notice of the summons and of the pendency of the action in time to make their defense in the French court. Bisckburn, J., in delivering the opinion of the Court of Queen's Bench, said: "We were much pressed on the argument with the fact that the British legislature has, by the Common Law Procedure Act, 1852, conferred a power of summoning foreigners, under certain circumstances, to appear, and in case they do not, giving judgment against them by default. It was this consideration, principally, which induced me at the trial to entertain the opinion which $I$ then expressed and have since clianged. And we think that if the principle on which foreign juckgments were enforced was that which is loosely called 'comity,' we could hardly decline to enforce a foreign judgment given in France

${ }^{1}$ Schibsby $v$. Westenholz, L. R. 6! mill, 8 Upper Canada Q. B. 407 ; Q. B. 155; see, also, Warren $v$. Lings- Burn v. Bletcher, $23 \mathrm{Ib} .28$. 
against a resident of Great Britain under circumstances hardly, if at all, distinguishable from those under which we, mutatis mutandis, might give judgment agrainst a resident in France.

"Should a foreigner be sued under the provisions of the statute referred to, and then come to the courts of this country and desire to be discharged, the only question which our courts could entertain wonld be, whether the acts of the British legislature, rightly construed, gave us jurisdiction over the foreigner; for we must obey them. But if judgment bcing given against him in our courts, an action were brought upon it in the courts of the United States (where the law as to enforcing foreign judgments is the same as our own), a further question would be open, viz. : Not only whether the British legislature had given the English courts jurisdiction over the defendant, but whether he was under any obligation which the American courts could recognize to submit to the jurisdiction thus created. This is precisely the question which we have now to determine with regard to a jurisdiction assumed by the French jurisprudence over foreigners.

"Again, it was argued before us that foreign judgments obtained by default, where the citation was (as in the present case) by an artificial mode prescribed by the laws of the country in which the judgment was given, were not enforceable in this country, because such a mode of citation was contrary to natural justice; and if this were so, doubtless tho finding of the jury in the present case would remove that objection. But though it appears by the report of Buchanan v. Rucker (1 Camp. 63), that Lord Ellenborough in the hurry of nisi prius at first used expressions to this effect, yet when the case came before him in banco (9 Last. 192), he entirely abandoned what (with all deference to so great an authority) we cannot regard as more than declamation, and rested his judgment on the ground that laws passed by our country were not obligatory on foreigners not subject to their jurisdiction. 'Can,' he said, 'the island of Tobago pass a law to bind the rights of the whole world?'

"The question we have now to answer is: Can the empire of France pass a law to bind the whole world? We admit, 
with perfect candor, that in the supposed case of a judgment obtained in this country against a foreigner under the Common Law Procedure Act, being sued on in a court of the United States, the question for the court of the United States would be, Can the island of Great Britain pass a law to bind the whole world? We think in each case the answer should be, No, but every country can pass laws to bind a great many persons; and therefore the further question has to be determined, whether the defendant in the particular suit was such a person as to be bound by the judgment which it is sought to enforce?

"Now on this we think some things are quite clear on principle, if the defendants had been at the time of the judgment subjects of the country whose judgment is sought to be enforced against then. Again, if the defendants had been, at the time when the suit was commenced, resident in the country, so as to have the benefit of its laws protecting them, or, as it is sometimes expressed, owing temporary allegiance to that country, we think that its laws would have bound them.

"If, at the time when the obligation was contracted, the defendants were within the foreign country, but left it before the suit was instituted, we should be inclined to think the laws of that country bound them; though before finally deciding this, we should like to hear the question argued. But every one of those suppositions is negatived in the present case.

"Again, we think it clear, npon principle, that if a person selected, as plaintiff, the tribunal of a foreign country as the one in which he would sue, he could not afterward say that the judgment of that tribunal was not binding upon him.

"In the case of General Steam Navigation Co. v. Guillou (11 M. \& W. 877, 894), on a demurrer to a plea, Parke, B., in delivering the considered judgment of the Court of Exchequer, then consisting of Lord Abinger, C. B., Parke, Aldeson, and Gurmey, B. B., thus expresses himself: 'The substance of the plea is, that the cause has been already ad. judicated upon, in a competent court, against the plaintiffs, and that the decision is binding upon them, and that they 
ought not to be permitted again to litigate the same question. Such a plea ought to have had a proper commencement and conclusion. It becomes, therefore, umnecessary to give any opinion whether the pleas are bad in substance; but it is not to be understood that we feel much doubt on that question. They do not state that tho plaintiffs were French subjects, or resident, or even present in Franco when the suit began, so as to be bound by reason of allegiance or temporary presence by the decision of a French court; and they did not select the tribunal and sue as plaintifis, in any of which cases the determination might have possibly bound them. They were mere strangers, who put forward the negligence of the defendant as an answer in an adverse suit in a foreign country, whoso laws they were under no obligation to obey.'

"It will be seen from this that those very learned judges, besides expressing an opinion conformable to ours, also expressed one to the effect that the plaintiffs in that suit did not put themselves under an obligation to obey the foreign judgment, merely by appearing to defend themselves against it. On the other hand, in Simpson v. Fogo (1 John. \& H. 18 ; 29 L. J. Ch. 657 ; 1 Hem. \& M. 195 ; 32 L. J. Ch. 249), where the mortgagees of an English ship had come into the courts of Louisiana to endeavor to prevent the sale of their ship, seized under an execution against the mortgagors, and the courts of Louisiana decided against them, the Vice Chancellor and the very learned counsel who argued in tho case seem all to have taken it for granted that the decision of the court of Louisiana would have bound the mortgagees, had it not been in contemptuous disregard of English law. The case of General Steam Navigation Co. v. Guillou (11 M. \& W. 877), was not referred to, and therefore cannot be considered as dissented from; but it seems clear they did agree in the latter part of the opinion they expressed.

"We think it better to leave this question open, and to express no opinion as to the effect of the appearance of a defendant, where it is so far not voluntary that he only comes in to try to sare some property in the hands of the foreign tribunal. Dut we must observe that the decision in DeCosse Drissac v. Iiathoone (6 H. \& N. 301 ; 30 L. J. Ex. 
238 ) is an authority that, where the defendant voluntarily appears and takes the chance of a judgment in his favor, he is bound.

"In Douglas v. Forrest (4 Bing. 703), the court, in deciding in favor of a party suing on a Scotcl judgment, say: "We coufine our judgment to a case where the party owed allogiance to the conntry in which the judgment was so given against him, from being born in it, and by the law of which country his property was, at the time those judgments were given, protected. The debts were contracted in the country in which the judgments were given while the debtor resided in it.' Those circumstances are all negatived here. Tio should, however, point out that, while we think that there may be other grounds for holding a person bound by the judgment of the tribunal of a foreign conntry than those enumerated in Douglas v. Forrest, we doubt very much whether the possession of property locally situated in that country, and protected by its laws, does afford such a ground. It should rather seem that, while every tribunal may very properly execute process against tho property within its jurisdiction, the existence of such property, which may be very small, affords no sufficient ground for imposing on the foreign owner of that property a duty or obligation to fulfill the judgment. But it is umnecessary to decide this, as the defendants had in this case no property in France.

"We think, and this is all we need decide, that there oxisted nothing in the present caso imposing on the defendants any duty to obey the judinment of a French tribunal."1

The decisions in the United States upon the subject of foreign judgments are but few. The law on that subject must, therefore, be regarded as not well settled. So far as jurisdictional inquiries are involved, no doubt the courts in this country would permit a party against whom a foreigu judgment was sought to be used, to avoid its effect to the same extent which is authorized by the English cases; and that no person would be held bound in this country by an adjudication made in some other country, unless he was a resident of, or submitted himself to the courts of, that

${ }^{1}$ Schibsby $v$. Westenholtz, I. R. 6 T. N. S. 93; 19 W. R. 587; Roussillon Q. B. $155 ; 40$ I. J. Q. B. 73; 24 L. $\mid$ v. Toussillon, 11 C. L. J. 270. 
country.' A novel case was recently determined by Judge Woolluff, of the Southern District of New York. The plaintiff had, in the empire of France, married the daughter. of the defendant, who was then residing in that country. Under a law of France the plaintiff sued the defendant in a French court, and obtained a judsment that the former should furnish and pay the latter 18,000 franes per year for the support of himself and his child. This judgment was based upon the French law, which obliges fathers-in-law to make an allowance for their sons-in-law when the latter are in need. The father-in-law was temporarily residing in France when the judgment was rendered against him. Ho prosecuted an appeal, and the judgment was affirmed. Judge Woodruff sustained a demurrer to the complaint, based on this judgment. He seemed to sustain the demurrer partly on the ground that the temporary residence in France did not subject the parties to the jurisdiction of the courts of that country; partly on the ground that the judgment was rendered in pursuance of local laws and obligations which could not thus be made binding in a foreign country; and partly on the ground that foreign judgments were enforced through comity, and that such comity forbids rather than requires a violation of the policy of our own laws and a violence to the rights of our own citizens. ${ }^{2}$

85S9. Jurisdiction of Absentees.-The English courts, no doubt, are not disposed to disregard a judgment rendered in a foreign country, merely because the service of process was constructive, and the defendant was, at the time, beyond the jurisdiction of the court. It must bo shown that the defendant was not domiciled in and did not owe allegiance to the nation whose courts proceeded against him in his absence; because, if he did owe such allegianco iv or was domiciled in the country, it was not repugnant to natural justice to provide some means of compelling him

\footnotetext{
${ }^{1}$ Bischoff $v$. Wethered, 9 Wall. 182; and 55 Me. 389; Foster $v$. Glazner, 27 Bissell v. Briggs, 9 Mass. 462; 6 Am. Ala. 391; Corly v. Wright, 4 Mo. Dec. 85; Middlesex Bank v. Butman, App. 443.

29 Ne. 19; Burnham v. Webster, $1{ }^{2}$ De Brimont v. Penniman, 10 W. \& M. 172; Story's Confl. Laws, Blatehf. 436. $\S 603$; Rankin v. Gouldard, 51 Me. 23,
} 
to pay his debts even after he had departed from the country. ${ }^{1}$

8.590. Jurisdiction of Corporations. - The members of a company formed in England to carry on business in a foreign country are bound in respect to the transactions of that company by the laws of the country where the business is carried on. If a statute of the foreign country authorize the company to be sued in the name of its chairman, a judgment so recovered is as conclusive on the members of the company in England as any other foreign judgment; and cannot be avoided by showing that they received no summons and had no notice of the suit." To a suit in England, on a French judgment, the defendant pleaded that he never was a resident of France during or since the accrual of the canse of action, nor was subject to the laws of France, nor served with process, nor did he have any notice or knowledge of the suit. The plaintiff, in reply, stated that the defendant was member of a company in France, by holding shares therein; that, by law of that country, it was necessary for defendant to elect a domicile; that such domicile was selected at Paris; that service of notice was left at such domicile as provided by the laws of France. This replication was held to be good, on the ground that natural justice was not violated by holding a man bound by a particular mode of notification, to which he had agreed to submit. ${ }^{3}$

8 591. Fraud.-Both in England and the United States, fraud in its procurement is a good ground on which to avoid the effect of a foreign judgment. ${ }^{4}$ A foreign judgment may be disregarded, both at law and in equity, when it is shown to have been obtained through fraud. But because the plea of fraud is a good defense to an action at law, on such judg-

\footnotetext{
${ }^{1}$ Douglas v. Forrest, 4 Bing. 6S6; 4 Reimers $v$. Druce, 23 Beav. 145; Cowan $v$. Brailwood, 9 Dowl. 27. The Price $v$. Dewhurst, 8 Sim. 279; Lazie* rule is the same in Canarla. Gauthier $v$. Westeott, $26 \mathrm{~N}$. Y. 146; Henderson v. Blight, 5 U. C. C. P. $122 . \quad$ v. Henderson, 6 Q. B. 288; Raukiu v.

2 Bank of Australasia $v$. Harding, 9 Coddard, 54 Me. 28 and 55 Me. 389; C. B. 661 ; Same v. Nias, 16 Q. B. 717. Story's Confl. Laws, see. 608.

${ }^{3}$ Vallie $v$. Dumergue, 4 Exc. 290; Copin v. Adamson, 3 C. L. J. 208.
}

632 
ment a court of equity will not interfere with the action at law, but will leave defendant to make his defense there. ${ }^{1}$

\section{592. Difference between Judgments as a cause of} Action and as a plea in Bar.-We have seen that a foreign judgment can have no extra-territorial obligation, if the defendant was not subject to the jurisdiction of the courts of the country wherein it was rendered, and that it is in all cases liable to be impeached for fraud in its procurement. Perhaps two other questions in reference to this class of judgments, could not be mentioned in regard to which the authorities are at all in unison. A distinction has been inade between the effect of a foreign judgment sought to be enforced as a cause of action, and that of the same judgment produced by the defendant as a bar. This distinction is supported by the judgment of Lord Chief Justice Eyre, in Phillips v. Hunter, ( 2 H. Black. 410), in which hesaid: "It is in one way only, that the sentence or judgment of the court of a foreign State is examinable in our courts; and that is, when the party who claims the benefit of it applies to our courts to enforce it. When it is thus voluntarily submitted to our jurisdiction, we treat it, not as obligatory, perhaps, as in this country in which it was pronounced, nor as obligatory to the extent to which by our law sentences and judgments aro obligatory; not as conclusive but as matter in pais; as a consideration prima facie sufficient to raise a promise. We examine it as we do all other considerations or promises; and for that purpose we receive evidence of what the law of the foreign State is, and whether the judgment is warranted by that law. In all other cases, we give entire faith and credit to the sentences of foreign courts, and consider them as conclusive upon us." This opinion so far as it treats foreign judgments as merely prima facie when brought forward as a cause of action; bat as conclusive when called in question incidentally or by a plea in bar (except as a merger of a cause of action), is sustained by a large number of English and American cases. ${ }^{3}$

${ }^{1}$ Ochsenbein $v$. Papelier, L. R. 8 trick $v$. Allen, 8 Mass. 237; 5 Am. Ch. Ap. 695; 21 W. R. 516; 28 L. T. Dec. 105; Galbraith v. Neville, 5 East, N. S. 58,459 .

75; Wood v. Gamble, 11 Cash. 8;

2 Seealso Woodburne $v$. Plummer, 1 Trilliams $v$. Preston, 3 J. J. M. 600; Barn. \& C. 625 .

$20 \mathrm{Am}$. Dec. 179; Bigelow on Estop.

3 Walker $v$. Witter, 1 Doug. 1 ; But- pel, p. 192. 
2 593. Decree of Dismissal.-Another distinction has been made by which a decree of dismissal has been treated as more conclusive than a decree sustaining a claim. Thus Lord Kames (2 Kames' Equity, p. 365 of 3d Ed.) says: "A foreign decree, sustaining the claim, is not one of those universal titles, which ought to be made effectual everywhere. It is a title that depends on the authority of the court whence it issued, and therefore has no coercive authority extra territorium. And yet, as it would be hard to oblige the person who claims on a decree to bring a new action against his party in every country to which he may retire; therefore, common utility, as well as regard to a sister court, has established a rule among all civilized nations, that a foreign decree shall be put in execution, unless some good exception is opposed to it in law or equity, which is making no wider step in favor of the decree than to pronounce it just, till the contrary be proved.

"A foreign decree, which, by dismissing the claim, affords an exceptio rei judicala against it, enjoys a more extensive privilege. We not only presume it to be just, but will not admit of any evidence of its being unjust. A decree dismissing a claim may, it is true, be unjust, as well as a decree sustaining it. But they differ widely in one capital point : in declining to give redress against a decree dismissing a claim, the court is not guilty of authorizing injustice, even supposing the decree to be unjust; the utmost that can be said is, that the court forbears to interpose in behalf of justice. But such forbearance, instead of being faulty, is highly meritorious in every case where private justice clashes with public utility. The case is very different with respeet to a decree of the other kind; for to award cxecution upon a foreign decree, without admitting any objection against it, would be, for aught the court can know, to support and promote injustice." Though the distinction here songht to be established between foreign decrees is substantially like that pointed out in Plillips v. Hunter, in regard to foreign judgments, it does not soem to be recognized in any of the reported cases; and, if ever so recognized, it must undoubtedly be obliterated by the recent decisions in the highest courts of England, in which the merits and jus634 
tice of the sentences of the courts of foreign countries, pronounced in cases of which those courts had jurisdiction, aro no longer proper subjects of inquiry.

8 594. Conclusive in England.-But the distinction made in Phillips v. Hunter against judgments sought to bo enforced as a canse of action, while it has no doubt been generally recognized in the United States, is now entirely overthrown in England. An action brought in that country on a foreign judgment, cannot be defeated by an examination into the merits of the judgment. Conceding that the judgment is valid, and still in force in the country where it was rendered; that the court liad jurisdiction over the cause and the parties, and that the judgment is free from the taint of fraud in its procurement, there remains no ground for avoiding its effect as a cause of action, unless it bo that the court of the foreign country, intentionally disregarded the law of England, in a case where the rights of the parties depended on a proper application of that law. ${ }^{1}$

\section{595. Mistake of Foreign Law.-The recent case of} Godard v. Gray (L. R. 6 Q. B. 139), disposes of the question, whether a mere error in regard to English law, entering into a judgment rendered in a foreign country, and occasioning such a determination as could not have been obtained in the English courts, is a good defense to an action on such foreign judgment brought in the English courts. The case is so recent and so anthoritative a construction, not only of the law necessarily involved, but also of the whole question concerning the conclusive nature of foreign adjudications, that we shall proceed to copy into this work the greater portion of the opinion of the court: "It is not an admitted principle of the law of nations, that a state is bound to enforce within its territories the judgment of a foreign tribunal. Several of the continental nations (iucluding France), do not enforce the judgments of other countries, unless where there are reciprocal treaties

\footnotetext{
${ }^{1}$ Ferguson $v$. Mahon, 11 Ad. \& El. 661; Decosse Brissac v. Rathbone, 6 179; IIenderson $v$. Henderson, 6 Ad. II. \& N. 301; 30 L. J. Ex. 233; Vau\& El. N. S. 288; Castrique $v$. Imrie, quelin v. Bouard, 15 C. B. N. S. 341; L. R. 4 H. L. 414; Bank of Austral- 10 Jur. N. S. 566; 33 L. J. C. B. 78; asia v. Nias, 16 O. B. 717; 20 I. J. 12 W. R. 126; 9 I. T. N. S. 582. C. P. 2st; Same v. Harding, 9 C. B.
} 
to that effect. But in England, and in those States which are governed by the common law, such judgments are enforced, not by virtue of any treaty, nor by virtue of any statute, but upon a principle very well stated by Parke B., in Tilliams v. Jones (13 M. \& W. 633): "Where a court of competent jurisdiction has adjudicated a certain sum to be due from one person to another, a legal obligation arises to pay that sum, on which an action of debt to enforce the judgment may be maintained. It is in this way that the judgments of foreign and colonial courts are enforced.' And taking this as the principle, it seems to follow, that anything which negatives the existence of this legal obligation, or excuses the defendant from the performance of it, must form a good defense to the action. It must be open, therefore, to the defendant to show that the court which pronounced the judgment had not jurisdiction to pronounce it, either because they exceeded the jurisdiction given to them by the foreign law, or because he, the defendant, was not subject to that jurisdiction; and so far the judgment must be examinable. Probably the defendant may show that the judgment was obtained by the fraud of the plaintiff, for that would show that the defendant was excused from the performance of an obligation thus obtained; and it may be, that where the foreign court has knowingly and perversely disregarded the rights given to an English subject by English law, that forms a valid excuse for disregarding the obligation thus imposed on him.

"There are many dicta and opinions of very eminent lawyers, tending to establish that the defendant in an action on a foreign judgment is at liberty to show that the judgment was founded on a mistake, and that the judgment is so far examinable. In Houlditch v. Donegall $(2 \mathrm{Cl}$. \& F. 477), Lord Brougham goes so far as to say: 'The language of the opinions on one side has been so strong, that we are not warranted in calling it merely the inclination of our lawyers; it is their decision that in this country a foreign j:ulgment is only prima facie, not as conclusive, evidence of a debt.' But there certainly is no case decided on such a principle; and the opinions on the other side of the ques636 
tion are at least as strong as those to which Lord Brougham refers.

"Indeed, it is difficult to understand how the common course of pleading is consistent with any notion that tho judgment was only evidence. If that were so, every count on a foreign judgment must be demurrable on that ground. The mode of pleading shows that the judgment was considered, not as merely prima facie evidence of that cause of action for which the juclgment was given, but as in itself giving rise, at least prima facie, to a legal obligation to obey that judgment and pay the sum adjudged. This may seem a technical mode of dealing with the question; but in truth it goes to the rout of the matter. For if the judgment were merely considered as evidence of the original cause of action, it must be open to meet it by any counter evidence negativing the existence of the original cause of action.

"If, on the other hand, there is a prima facie obligation to obey the judgment of a tribunal having jurisdiction over the party and the cause, and to pay the sum decreed, tho question would be, whether it was open to the unsuccessfiul party to try the cause over again in a court, not sitting as a court of appeal from that which gave the judgment. It is quite clear this could not be done where the action is brought on the judgment of an English tribunal; and, on principle, it seems the same rule should apply where it is brought on that of a foreign tribunal. But there still remains a question which has never, so far as we know, been expressly decided in any court.

"It is broadly laid down, by the very learned anthor of Smith's Leading Cases, in the original note to Doe v. Oliver, that 'it is clear that if the judgment appear on the face of the proceedings to be founded on a mistaken notion of the English law,' it would not be conclusive. For this he cites Novelli v. Rossi (2 B. \& Ad. 757), which does not decide that point, and no other authority; but the great learning and general accuracy of the writer makes his unsupported opinion an authority of weight; and accordingly it has been treated with respect.

"But the doctrine as laid down by Mr. Smith does apply here; and wo must express our opinion on it, and wo 
to that effect. But in England, and in those Staics which are governed by the common law, such judgments are enforced, not by virtue of any treaty, nor by virtue of any statute, but upon a principle very well stated by Parke B., in Tilliams v. Jones (13 M. \& W. 633): 'Where a court of competent jurisdiction has adjudicated a certain sum to be due from one person to another, a legal obligation arises to pay that sum, on which an action of debt to enforce the judgment may be maintained. It is in this way that the judgments of foreign and colonial courts are enforced.' And taking this as the principle, it seems to follow, that anything which negatives the existence of this legal obligation, or excuses the defendant from the performance of it, must form a good defense to the action. It must be open, therefore, to the defendant to show that the court which pronounced the judgment had not jurisdiction to pronounce it, either because they exceeded the juriscliction given to them by the foreign law, or because he, the defendant, was not subject to that jurisdiction; and so far the judgment must be examinable. Probably the defendant may show that the judgment was obtained by the fraud of the plaintiff, for that would show that the defendant was excused from the performance of an obligation thus obtained; and it may be, that where the foreign court has knowingly and perversely disregarded the rights given to an English subject by English law, that forms a valid excuse for disregarding the obligation thus imposed on him.

"There are many dicta and opinious of very eminent lawyers, tending to establish that the defendant in an action on a foreign judgment is at liberty to show that the judgment was founded on a mistake, and that the judgment is so far examinable. In Houlditch v. Donegall (2 Cl. \& F. 477), Lord Brougham goes so far as to say: 'The language of the opinions on one side has been so strong, that we are not warranted in calling it merely the inclination of our lawryers; it is their decision that in this country a foreign judgment is only prima facie, not as conclusive, evidence of a debt.' But there certainly is no case decided on such a principle; and the opinions on the other side of the ques636 
tion are at least as strong as those to which Lord Brougham refers.

"Indeed, it is difficult to understand how the common course of pleading is consistent with any notion that tho judgment was only evidence. If that were so, every count on a foreign judgment must bo demurrable on that ground. The mode of pleading shows that the judgment was considered, not as merely prima facie evidence of that cause of action for which the judgment was given, but as in itself giving rise, at least prima facie, to a legal obligation to obey that judgment and pay the sum adjudged. This may seem a technical mode of dealing with the question; but in truth it goes to the rout of the matter. For if the judgment were merely considered as evidence of the original canse of action, it must be open to meet it by any counter evidence negativing the existence of the original cause of action.

"If, on the other hand, there is a prima facie obligation to obey the judgment of a tribunal having jurisdiction over the party and the eause, and to pay the sum decreed, tho question would be, whether it was open to the unsuccessfial party to try the cause over again in a court, not sitting as a court of appeal from that which gave the judgment. It is quite elear this could not be done where the action is brought on the judgment of an English tribunal; and, on principle, it seems the same rule should apply where it is brought on that of a foreign tribunal. But there still remains a question which has never, so far as we know, been expressly decided in any court.

"It is broadly laid down, by the very learned author of Smith's Leading Cases, in the original note to Doe v. Oriver, that 'it is clear that if the judgment appear on the face of the proceedings to be founded on a mistalien notion of the English law,' it would not be conclusive. For this he cites Novelli v. Rossi (2 B. \& Ad. 757), which does not decide that point, and no other authority; but the great learning and general accuracy of the writer makes his unsupported opinion an authority of weight; and accordingly it has been treated with respect.

"But the doctrine as laid down by Mr. Smith does apply here; and we must express our opinion on it, and we 
persons who had voluntarily submitted themselves to such courts. ${ }^{1}$

8 597. Arguments for conclusive effect of foreign judgment.-The considerations which have influenced the adjudications in the English courts will, no doubt, malio themselves felt in America. No prediction in regard to future decisions is more likely to be realized than that our courts will in time place foreign judgments on the samo footing which they now occupy in the mother country. Indeed, the two great American jurists, Judges KENT and STori, at an early day, advanced most satisfactory reasons in favor of the conclusiveness of foreign judgments. The latter, in his Conflict of Laws ( $\%$ 607), has ably pointed out the difficulties involved in the law of foreign judgments, as it was then understood. The former, in pronouncing judgment, in the year 1811, in the case of Taylor v. Boyden, ( 8 Johns. 173), said: "To try over again, as of course, every matter of fact which had been duly decided by a competent tribunal, would be disregarding the comity which we justly owe to the courts of other States, and would be carrying the doctrine of re-examination to an oppressive extent. It would be the same as granting a new trial in every case, and upon every question of fact. Suppose a recovery in another State, or in any foreign court, in an action for a tort, as for an assault and battery, false imprisonment, slauder, etc., and the defendant was duly summoned and appeared and made his defense, and the trial was conducted orderly and properly, according to the rules of a civilized jurisprudence, is every such case to be tried again here on the merits? I much doubt whether the rule can ever go to this length. The general lauguage of the books is that tho defendant must impeach the judgment, by showing affirmatively that it was unjust, by being irregularly or unfairly procured." The decisions subsequently made in the same State kept pace with the change of opinion going on in England, ${ }^{2}$ until in the caso of Lazier v. Westcott (26 N. Y. 146),

\footnotetext{
${ }^{1}$ Burnham v. Webster, 1 W. \& MI. $\quad 2$ Monroe v. Douglas, 4 Sand. Ch. 172. 126; Cummings v. Banks, 2 Barb.
} 
the most advanced position was attained and the rule was broadly laid down, that " the same principles and decisions which we have made as to judgments from the courts of other States of the Union, should be applied to foreign julgments." Other American cases sustain substantially the sime view, except that they include "mistake" as one of the grounds for aroiding a foreign judgment, without showing what or whose mistake it is that may be employed for that purpose. ${ }^{1}$ In a recent ease in New York, it was held that a foreign judgment had the same effect, in that State, as evidence against an indemnitor, and in favor of the person against whom the foreign judgment was recovered as though it were a domestie judgment. ${ }^{2}$

2.598. Foreign Decree.-The English courts in addition to sustaining the judgments of foreign courts as considerations for actions of assumpsit, and as pleas in bar, also recognize the decrees in equity made in foreign tribunals; and a bill to earry such a decree into effect may be sustained in the English eourts." Such a decree will also sustain an action brought to recover a sum ascertained by it to be due from one party to the other. ${ }^{4}$

8599. Decrees discharging Debtors.-It is a general rule that a debt discharged by the laws of the country where it is created, is discharged in every other eountry; ${ }^{5}$ and that a debt discharged by the law of any country, other than that in which it was created, continues in full force bejond the country where the decree of dischargo was entered. $^{6}$

8 600. Control of Equity over Rights Secured in Foreign Courts.-As a general rule every creditor may pursue his debtor and his debtor's property into any foreign juris-

1 Rankin $v$. Goddard, 55 Maine, 359; Low v. Mussy, 44 Verm. 333; Silver Lake Bank $v$. Harding, 5 Ham. 545 .

2 Konitzky $v$. Meyer, 49 N. Y. 571.

Martin v. Nicholls, 3 Sim. 458; Iloulditch $v$. Donegale, 8 Bligh, N. S.

4 Henley $v$. Soper, 8 B. \& C. 16.
5 Ellis $v$. McEenry, L. R. 6 C. P. 228; citing Phillips $v$. Eyre, L. R. 6 Q. B. 1, 28; Gardnier $v$. Houghton, 2 B. \& S. $7\{3$.

6 Ellis $v$. McHenry, L. R. 6 C. P. 228 ; citing Lewis $v$. Owen, 4 B. \& Ald. 65t; Phillips $v$. Allen, 8 B. \& C. 477; Lartley $v$. Hodges, 1 B. \& S. 375. 
diction in which he or it may be found, and may arail himself of all the legal remedies which the courts of the foreign State are willing to afford him. If, for instance, a ship belonging in England be taken to the United States, and a creditor of the owner, residing in England, commence proceedings in the United States against the vessel, whereby the creditor secured advantages which he could not have obtained at home, the courts of equity in England will not compel him to yield up the advantages thus gained."

\& C01. Interested Tribunal.-In England it has been held that the judgment of a foreign tribunal emposed of persons interested in the proper'ty in dispute, who have decided for themselves and in their own favor, should be clisregarded. ${ }^{2}$

\& 602. Appeal. - The pendeney of an appeal, taken from a foreign judgment, is no bar to an action on such judgment, though, perhaps, it may afford sufficient ground to justify the court wherein the action is brought in interposing to prevent a possible abuse of its process. ${ }^{3}$

8 603. Irust be Supported by a Complaint. - In the absenee of proof to the contrary, it will be presumed that the courts of foreign nations are not authorized to act without some written statement of a canse of action being made. Therefore, in California, a record of a foreign court will bo disregarded unless it shows the allegations of fact on which the court acted in rendering judgment. ${ }^{4}$

3 604. Judgments of Courts of the Confederate States. In some of the States of the late Southern Confederacy a strong disposition has been manifested to entirely disregard the judicial proceediugs of courts acting under the confeclerate authority, and within territory not under the control of t?io federal government. The Supreme Court of Alabama, speating upon this subject, said: "The judgment was rendered on September 12th, 1863. It is known to the

${ }^{1}$ Liverpool Marine Credit Co. v. 41; S Jur. N. S. 557; 31 L. J. Q. B. Hunter, L. R., 3 Ch. Ap. 469.

2 Price $v$. Dewhurst, 8 Sim. 279 . $81 ; 6$ L. T. N. S. 81.

${ }^{3}$ Scott $v$. Pilkington, 2 Best \& S.

${ }^{4}$ Young $v$. Rosenbaum, 39 Cal. 646. 
cont as a part of the judicial history of the State, hat the court in which this judgment was rendered, constituted a portion of 'one of the departments of a government established in hostility to the constitution of the United States.' It hits been settled that the acts of the legislature of such a goverument are invalid. If this is admitted, and it seems to me it cannot bo denied, it cannot well be conceived low the judgments of such a government can be better or more valic than its laws. The reasons which invalidate the one, assail the other also. Both are parts of a whole; and if the whole is bad, as a general principle, the parts caunot be good." The question received further jndicial consideration in the same State, resulting for a time in the conclusion that judgments rendered during the rebellion by courts acting by virtue of powers granted by or exercised in subordination to the government of the Confederate States, shonld not be entirely disregarded. Neither were such judgments to be received with the respect accorded to domestic judgments. They were to be allowed about the same effect as a foreign judgment, namely, they were to be received as prima facie evidence, and carried into effect unless some reason was shown why they ought to be ignored. ${ }^{2}$ The latest decisions in this State place these judgments upon a higher foundation and gire them a more definite and unaroidable effect. "Our conclusion theu," said the Supreme Court of the State, "is that the courts of Alabama, during the war, were a portion of the rightful government of the State; and that tho judgments, decrees, and proceedings, not in riolation of the Constitution and laws of the United States, or of any right or obligation arising under them, and not in riolation of the Constitution of Alabama, are valid, and must have operation and effect accordingly." "Therelore a sale of property under execution upon a judgment entered during the late war by the courts of a State then in rebellion is valid at law and will not be vacated in equity, npon grounds

\footnotetext{
${ }^{1}$ Ray $v$. Thompson, 43 Ala. 4j4. |Pettywit $v$. Kollogg, 1 Cim. 17;

${ }^{2}$ Martin $v$. Hewitt, 44 Ala. 418; Steere $v$. Tenney, 50 N. H. 461. Bibb $v$. Avery, 45 Ala. 691; Mosely $v . \quad{ }^{3}$ Parks $v$. Coffey, 52 Ala. 42; Hill Tuthill, 45 Ala. 621, C50. See also $v$. Huckabee, 52 Ala. 155.
} 
which would be insufficient to warrant the vacating of the sale had it been made under somo other judgment. ${ }^{1}$ In Arkansas the constitution of the State adopted after the close of the rebellion, provided "that all the action of the State under authority of the convention which assembled in Little Rock, on the fourth day of March, 1861, of its ordinances, or its constitution, whether legislative, executive, indicial or military, was, and is, hereby declared null and void." The Supreme Court of the State has on several occasions determined that courts acting during the rebellion had no authority to compel defendants to appear before them; and therefore that judgments based on service of summons on such defendants were therefore void. ${ }^{2}$ But the later cases in this State show that the earlier ones upon this subject are no longer tenable. In Henry $v$. Cline, 29 Ark. 414, it was held that the judgments of the courts of Texas, rendered during the rebellion, must be received as those of a sister State, and given the full faith and credit exacted by the Constitution and laws of the United States in behalf of judgments rendered in a sister State. In Ohio, on the other luand, a very elaborate consideration of the question resulted in a decision that a judgment rendered after secession of the State, in an action brought in Arkansas before such secession, against a citizen of Ohio, was invalid. In this case the defendant had appeared by attorney and filed his plea, prior to the commencement of the war, and this same attorney continued to act. The court seemed to think that the attempted secession of the State, and the acts done in pursuance of it, divested the court of its jurisdiction over the non-resident defendant, and also divested the attorney of the power to continue to appear and represent the defendant, and that the proceedings and judgment were coram non judice and void. ${ }^{3}$ Doubtless the more recent and authoritative lecisions upon the subject show that judgments and decrees rendered in the rebellious States, during the rebellion, between persons within and subject to their jurisdic-

Hill $v$. Armistead, 56 Ala. 118.

${ }^{2}$ Penn v. Tollison, 26 Ark. 545; Thompson $v$. Mankin, 26 Ark. 556; Timms $v$. Grace, 20 Ark. 59S.
${ }^{3}$ Pennywit $v$. Foote, 27 Oh. S. 600; 22 Am. Rep. 340.

644 
tion, are, unless connected with proceedings or purposes, inrolving an attack on the federal government, to be regarded as valid. If the tribunal in which judgment was rendered was created and acting befor' the State became involved in secession and rebellion, its authority continued, because the ordinances of secession, and the governments set up under them, were all invalid; and it was not possible through the enactment of void laws to destroy a pre-existing legal jurisdiction. ${ }^{1}$ But courts created by acts of the Confederato Congress are regarded as never having any judicial authority. Thus, when several defendants songht to shield themselves in an action for malicious imprisonment, by showing that they acted as officers of a court known as the "District Court of the Confederate States of America for the Northern District of Alabama," the Supreme Court of the United States held, as follows: "The act of the Confederate Congress, creating the tribunal in question, was void. It was as if it were not. The court was a nullity, and could exercise no rightful jurisdiction. The forms of law with which it clothed its proceedings gave no protection to those who, assuming to be its officers, were the instruments by which it acted." But judgments rendered in the various Stato courts during the rebellion, have generally been regarded as valid, unless tainted with proceedings or in furtherance of objects designed to give aid and comfort to the Confederate States goverument. But the effect of such judgment can in no case extend to persons who were residing in those pirts of the United States not involved in the rebellion. ${ }^{3}$ The extent to which proceedings had in the several States during the rebellion, will bo recognized and enforced, by the tribunals of the federal government, are thus stated in a recent decision: "We admit that the acts of the sereral States in their individual capacities, aud of their difierent departments of government, executive, judicial, and legislative, during the war, so far as they did not impair or tend to impair the supremacy of the national authority, or the just rights of citizens under the Constitution, are, in

\footnotetext{
${ }^{1}$ White $v$. Cannon, 6 Wall. 443; 100; Livingston $v$. Jordan, 10 Am. I. Pepin $\imath$. Lachenmeyer, 45 N. Y. 27. Rey. 53 ; French $v$. Tomlin, 10 Am. L. ${ }^{2}$ Hickman $v$. Jones, 9 Wall. $197 . \quad$ Iieg. 642.

${ }^{3}$ Cuyler $v$. Terrill, 8 Am. L. Reg.
} 
general, to bo treated as valid and binding. The existenco of a stato of insurrection and war did not loosen the bonds of society, or do a way with civil goverument, or the regular administration of the laws. Order was to be preserved, police regulations maintined, crimes prosecuted, property protected, contracts enforced, mirriages celebrated, estates setiled, and the transfer and descent of property regulated precisely as in times of peace. No one that we are aware of serionsly questions the validity of judicial or legislative acts in the insurrectionary States touching these and kindred subjects, where they were not hostile, in their purpose or mole of enforcement, to the authority of the national goverument, and did not impair the rights of cilizens nuler the constitution." The judicial proceedings which were before the court and occasioned the use of the langnage embraced in the foregoing quotation, were the proceedings of a probate conrt of the State of Alabama. The proceedings were sustained, except so far as they approved an investment in confederate bonds, and directed in payment to the legatees on those bonds. The action of the eourt "in this respect, was an absolute nullity, and can afford no protection to the execntor in the conrts of the United States. The officers and tribunals exercising anthority within the Confederate States luring the rebellion were by the people recognized as being rightful officers and tribunals; their authority was generally respected, and if not respected roluntarily, they generally had the power to compel obedience, if not respect. They oaght therefore to be treated, for most purposes, as officers and tribunals de facto. Hence whero certain acts of incorporation were passed by the legislature of a State then in rebellion, and it was claimed that theso enactments proceeded from a body possessing no lawfin authority, and that the corporations formed under them were not entitled to recognition, tho Supreme Court very properly sail: "No loubt the Legislature of Georgia in 1861 and 1863, when the enactments were made for the incorporation of these plaintiffs, was not the legitimato logislature of the State. The State had thrown off its connection with the United States, and the members of the 
lexislature had repudiated or had not taken the oath by which the third section of the sixth article of the constitution requires the members of the several legislatures to be bound. But it does not follow from this that it was not a legislature, the acts of which were of force when they were mude, and are in force now. If not a legislature of the State de jure, it was at least a legislature de facto. It was the only law-making body in existence. Its members acted under color of office, by an election, though not qualified according to the requirements of the Constitution of the United States. Now, while it must be held that all their acts in hostility to that Constitution, or to the Union, of which the State was an inseparablo member, have no validity, no good reason can be assigned why all their other enactments, not forbidden by the Constitution, should not have the force which the law generally accords to the action of de facto oficers." *** "All the enactments of the de facto legislatures in the insurrectionary States, during the war, which were not hostile to the Union, or to the anthority of the general government, and which were not in conflict with the Constitution of the United States, have the same validity as if they had been the enactments of legitimate legislature. Any other doctrine than this wonkl work great and unnecessary hardship upon the people of those States, without any corresponding benefit to the citizens of other States, and withont any advantage to the national government." The courts in States in rebellion, it is clear, conld not exercise any authority over the officers and soldiers of the United States, by which the latter could bo called to account before such courts, civilly or criminally, and required to explain or justify octs done by them as such officers or soldiers. They might lawfully disregard a summons to appear in those courts, and a judgment by defanit entered for want of such appearance, is voil. This, however, did not result from any infirmity in the organization or jurisdiction of snch courts; but from the well-established principle that an oficer or soldier is not in time

${ }^{1}$ United States $v$. Insurance Co., $22 \mid$ cussed in Williams $v$. Bruffy, 96 U. Wall. 99; Ford v. Surget, 97 U.S. S. 176.

594. This question is elaborately dis- 
of war amenable to the civil authorities for his military acts.

\section{604a. Judgments rendered in the District of Colum-} bia have been considered as not within the provisions of the Constitution and laws of the United States, providing for the effect which the courts of one State must give to the judgments of other States. Judgments rendered in this district have, therefore, been treated as foreign judgments. ${ }^{2}$

\& 605. Are Not Records. - In two respects foreign judgments are, by a concurrence of the authorities, treated differently from judgments of other States of this Union. Though proceeding from superior courts of general jurisdiction, they are not records, and cannot be declared on as such. The actions brought upon them must, therefore, be in assumpsit. ${ }^{3}$ Judge Story, in his Conflict of Laws (sec. $599 a$ ), in commenting upon the opinion of Lord Chief Justice Eyre in Phillips v. Hunter, says: "It would seem a natural result of that view, that if a suit was brought for. the same cause of action, in an English court, which had already been decided in favor of either party in a foreign court of competent jurisdiction, and was final and conclusive there, that judgment might be well pleaded in bar of the new suit upon the original cause of action, and would, if bona ficle, be conclusive." If there was ever any reason why, in order to be consistent with themselves, the courts should hold that a foreign judgment was operative as a merger of the original cause of action, that reason has certainly become more imperative since the dignity and importance of those judgments have been so recognized and enforced by the latest adjudications of courts of last resort in England aud in this country. While a defendant, who succeeded in defeating a claim at law or in equity in the courts of any foreign country, could always avail himself, in the common law courts, of this adjudication in his faror, as a complete

Dow $v$. Jolnnson, 100 U. S. $158 ; \mid{ }^{3}$ Harris $v$. Saunders, 4 B. \& C. 411 ; Coleman $v$. Tennessee, 97 U. S. 509; Buttrick $v$. Allen, 8 Mass. 273; $5 \mathrm{Am}$. Lamar v. Browne, 92 U. S. 187.

Dec. 105; MeFarlane v. Derbishire, 8

${ }^{2}$ Draper's Ex. v. Gorman, 8 Leigh, (Upper Canada), Q. B. 12; Gooding $v$. $62 \mathrm{~s}$. 
plea in bar to another action involving the same demand; and while under the most recent decision the principle of res judicata is enforced in favor of the plaintiff as well as of the defendant in a foreign judgment, yet the law of merger has never been applied against the plaintiff in such a judgment, and he is, both in Eugland and in America, unquestionably entitled to disregard the judgment in his favor, and sue upon the original cause of action. ${ }^{1}$

\& 605a. Foreign Probate.-It is now well settled in the United States, England, and France, that the succession and distribution of the personal estate of a decedent, must be in accordance with the law of the domicile of snch decedent at the time of his decease, ${ }^{2}$ while, as to the real estate, the law of the place where it is situate controls. ${ }^{2}$ The mere collection and administration of personal assets proceeds under the laws of the country in which they are situate, and creditors of the decedent are entitled to seek satisfaction therefrom in accordance with the laws of such country; but after the administration is so far complete that the local claims and laws are satisfied, the remaining assets will be transmitted to the administration of the decedent's domicile for final distribution. ${ }^{3} \quad$ A decree of a foreign court of probate declaring a claimant to be the natural son and heir of a person who died within the jurisdiction of the court, is conclusive as an adjudication of the same question when it is brought in issne in another country in connection with the personal property of the deceased in the last named country. ${ }^{4}$

\& 605b. Foreign Froceedings in Bankruptoy or Insolvency have, in general, no effect upon persons or property

See $\$ 220$ of this book; Story's 26; 13 Am. Dec. 317; Dorsey's Ex. $v$. Confl. Laws, see. 599 «; Fergus v. Dorsey's Ad., 5J. J. Marshall, 2S0; 20 Wardlaw, 3 Kerr (New Brunswick), Am. Dee. 33; Sneed v. Ewing, 5 .T. 665 .

${ }^{2}$ Wharton's Confl. Laws, secs. 560, 561 ; Story's. Confl. Laws, sees. 4S0454; Erock's Admr., 51 Ala. 85; De Soliry v. De Laistre, 3 Am. Dee. 535; Desesbats $v$. Berquier, 2 Il. 448; Decouche $v$. Savetier, S Iu. 478; Holmes v. Remsen, Id. 58I; Embry v. Millar, 10 Id. 732; Bryan v. Moore, 11 Mart. J. Marsh, 460; 22 Am. Dec. 41; Oliver v. Townes, 2 Mart. N. S. 93.

${ }^{3}$ Miller's Estate, 3 liawle, 312; 24 Am. Dec. 345; Dawes v. Boylston, 0 Niss. 337; $6 \mathrm{Am}$. Dee. 72.

${ }^{*}$ Doglioni $v$. Crispin, L. R. 1 E. \& J. App. 301; S. C., 35 L. J. R. (N. S.) 129. 
not situate within the jurisdiction in which such proceedings are taken. Thus an assignment in England under proceellings in bankruptcy does not so operate upon pronerty of the bankrupt then situate in this country as to prerent its subsequent seizure under execution or attachment by American ereditors, ${ }^{1}$ nor does such assignment seem to have any effect whatever in this country, ${ }^{2}$ mless, perhaps in a controversy between tho bankrupt and his assignees. ${ }^{3}$ The discharge granted under proceedings in bankruptcy operates as against persons who were citizens of the country where the discharge is granted, unless its operation is restrained by some provision of constitutional law; but as against non-residents, or upon contracts made in a foreign jurisdiction, it has no effect whatever. ${ }^{5}$

\& 605c. Foreign Divorce.-Some States and nations have been very loth to recognize aud enforce judgments or decrees annulling the contract of marriage and freeing one or both the spouses therefrom. This has been especially true when the contract has been annulled by the conrts of some sovereignty other than that in which it was entered into, and upon some ground not regarded as suficient in the country where the contract was consummated. In the celebrated case of Rex $v$. Lolley, ${ }^{6}$ deciled in England, in the year 1812, the twelve judges were unanimonsly of the opinion that no sentence or act of any foreign country or State could dissolve an English marriage a vinculo matrimonii, for any gromal upon which it could not be thus dissolved in England. These were the material fiacts of this case: Lolley

Milne $v$. Moreton, 6 Binn. 353; 6 Am. Dee. 466 ; Blake $v$. Williams, 6 Tick. 286; 17 Am. Dec. 372.

${ }^{2}$ Dawes $r$. Doylston, 9 Mass. 337; 6 An. Dec. 72; Kelly v. Crapo, 45 N. I. 90; Osgood $v$. Maguire, 61 N. X. 529; Abraham v. Plestoro, $3 \mathrm{IV}$ cnd. 53̊s; $20 \mathrm{Am}$. Dec. 73s; Ackerman $v$. Cross, 40 N. I. 430 ; Willitts $v$. Waite, 25 N. Y. 583.

${ }^{3}$ Rolinson $v$. Crowder, 4 MeCord, 519; 17 Am. Dec. 762; Holmes v. Remsen, 4 Johns. Ch. 489; 8 Àm. Dec. ธงเ.
${ }^{4}$ Baker $v$. Wheaton, 5 Mass. 509; 4 Am. Dec. 71 and note; Norton $v$. Cook, 9 Conn. 314; 23 Am. Dec. 342 and note; Blanchard v. Rinssell, 13 Mass. 1; 7 Am. Dec. 106 and note.

5 Smith $v$. Smith, 2 Johns. 235; 3 Am. Dec. 410 and note; White $v$. Canfield, 7 Johns. 117; 5 Am. Dec. 249; Mitchell $v$. MeNillan, 3 Nia:t. 076; 6 Am. Dec. 690; Vaunxem $v$. Hazelhursts, 1 South. 192; 7 Am. Dec. 582; Norton $v$. Cook, 23 Am Dec. 542 and note.

${ }^{6} 2$ Tiuss. \& R. C. C. 237. 
was conricted of bigamy for marrying a wife in England while the wife of his former marriage was yet living. His defense was that his first wife had, before the second marriage, obtained a dirorce from lim in the Consistorial Court of Scotland. The judges unanimously denied the efficicy of this divorce. Lolley was sentenced to transportation, but was aiterwards pardoned. The doctrine of Lolley's case was fiequently assailed, but, upon the whole, seems rather to have been reaffirmed than overthrown in the courts which considered themselves as bound by the laws of Englind. ${ }^{1}$ Thero seems, however, to be some doubt whether the judges in Lolley's case intended to deny, under all circumstances, the authority of the courts of a foreign State, to dissolve an English marriage, or whether such denial was confined to eases in which the parties had not acquired bonce fide a domicile in that country to whose tribunals they resorted for a clissolution of their marital obligittions. ${ }^{2}$ At all erents Lolley's case does not affirm that the divorce in a foreign State would be invalid, if upon grounds entitling the applicant to a divorce in England. ${ }^{3}$ The Scotch courts, on the other hand, assume jurisdiction to dissolro marriages contracted in England, and such dissolntion may be valid in the former conntry and invalid in the latter', so that two English subjects may be divorced in Scotland, but remain married in England.. ${ }^{*}$ Where the husband, after his marriage in England removed to the United States, and became domiciled there, it was held that his wife, who remained in England, conld there prosecnto an action for divorce on the ground of adultery, the citation laving been personaliy served on the lunsband in America. ${ }^{5}$ But where a wife had separated from her husband in Eugland, and then removed to Iowa, and remained two years, where she then procured a dirorce withont personal servico

\footnotetext{
${ }^{1}$ Shaw 2. Attorney-general, L. T. 2 | P. \&D. 161; Warrender $v$. Warrender, 55,86 $2 \mathrm{Cl}$. \& Fin. 541.

${ }^{2}$ Conway $v$. Beazley, 3 Har. Ec. Fin. 511; Conway v. Deazley, 3 Hito. C52; Tovey $r$. Lindsay, 1 Dow. 117, Ee. 652.

1:7; Duntze v. Levet, Ferg. 403; 3 s Deck v. Deck, 25w. \& Ir. 20; 20 Eng. Le. 506.

L. J. (P. M. \& A.) 129.
} 
of process on her husband, it was disregarded in England. ${ }^{1}$ The court here manifestly proceeded upon the ground that the constructive service of process ought not to be tolerated in such circumstances. In this case the judge ordinary said: "The principles upon which the question here raised must be decided, have been so recently discussed in several cases in the court of ultimate appeal, that it is not necessary to enter upon the discussion at large on the present occasion. It may be sufficient to observe, first, that Lolly's case has never been overruled; secondly, that in no caso has a foreign divorce been held to invalidate an English marriage between English subjects where the parties were not domiciled in the country by whose tribunals the divorco was granted. Whether, if so domiciled, the English courts would recognize and act upon such a divorce appears to bo a question not wholly free from doubt; but the better opinion seems to be that they would do so if the divorce be for a ground of divorco recognized as such in this country, and the foreign country be not resorted to for the collusive purpose of calling in the aid of its tribunals. To my mind it is manifestly just and expedient that those who may havo permanently taken up their abode in a foreign country, resigning their English domicile, should, in contemplation of English law, be permitted to resort with effect to the tribunals exercising jurisdiction over the community of which, by their change of domicile, they have become a part, rather than they should be forced back for relief upon the tribunals of the country they have abandoned. But the inquiry is needless in this case, becauso it seems to me to be neither just nor expedient that a woman whose domicilo is English, and whose lnsband's domicile is Euglish, should, whilst living separate from him in a foreign state, in which he has never, up to the time of the divorce, set his foot, be permitted to resort to the local tribunal, and without any notice to her lusband, except an advertisement which he never saw and was never likely to see, obtain a divoreo against him behind his back. No case has ever yet decided that a man can, aecording to the laws of this country, bo divorced from his wife by the tribunals of a comtry in

${ }^{1}$ Shaw v. Attomey-gencral, L. I., 2 P. \& D. 156. 652 
which he has never had either domicile or residence. IIo has never submitted himself, either directly or inferentially, to tho jurisdiction of such a court, and has never, by any act of his own, laid himself open to be affected by its process, if it never reaches him. A judgment so obtained has, therefore, in addition to the want of jurisdiction, the incurable vice of being contrary to natural justice, becanse the proceedings are ex parte, and take place in the absence of the party affected by them." So where a husband, married in England, left that country to avoid his creditors, but without its being shown that he intended to abandon lis English domicile, and in the country to which ho went obtained a decree of divorce from his wife, who remained in England, it was held that such decree was ineffectual. ${ }^{1}$ While the law may not be finally settled or absolutely certain, we apprehend that, at the present day, the decided weiglat of authority is in favor of recognizing a foreigu divorce, when the parties were permanently domiciled bonce fide in the country in which they were divorced, irrespective of the place of their marriage; ${ }^{2}$ that in the United States it is sufficient that one only of the parties has become domiciled in the State where the divoree is granted, ${ }^{3}$ but this rule does not prevail in England. ${ }^{4}$

${ }^{1}$ Briggs $v$. Briggs, 11 Cent. L. J. 46. divorces to parties not permanently

${ }^{2}$ Conway $v$. Beazley, 3 Hag. Ec. domiciled in that country. Shields $v$. 639; Blumenthal $v$. Tannenholz, 9Rep. Shields, 15 Scotch Sess. Cas. N. S. 52 ; Seawall $v$. Seawall, 122 Mass. $156 ; 142$.

Prosser $v$. Warner, 47 Vt. 667; Han- ${ }^{3} 2$ Bishop Mar. \& D., secs. 156-17l. over v. Turner, $7 \mathrm{Am}$. Dec. 206, and ${ }^{4}$ Le Sucur $v$. Le Sueur, Law R. P. note. The courts of Scotland grant D. 139. 


\section{CHAPTER XXVIII.}

\section{JUDGMENTS IN REMr.}

\$606. Definition of.

$\$ 607$. Different Proceedings in Rem.

$\$$ c0s. Probates of Wills and Grants of Administration.

$\S 609$. Decree of Sale.

$\S 610$. Marriage and Divorce.

$\S 611$. Jurisdiction.

\$612. How Avoided, if from Forelgn Coart.

\section{PART II.-OF JUDGIENTS AND DECREES IN ADMIR:ITY.}

$\$ 613$. General Nature of.

$\S 614$. Jurisdiction.

$\$ 615$. Efiect as Res Judicata.

$\S 61 \mathrm{C}$. Sentence of Acquittal.

$\$ 617$. Effected as Res Judicata limited to Persons interested in the Res.

$\S 618$. Grounds of Sentence must Appear.

8606. Definition. - We come now to the consideration of a class of judgments, very well understood, but quite difficult to describe. A judgment in rem was, with some difidence, defined "to be the judgment of a court of exclusive, or at least peculiar, jurisdiction, declaratory eicher of the nature and condition of some particular thing, or of the condition and status of some particular person."1 According to the views expressed in the Supreme Court of Vermont, "A judgment in rem I understand to be an adjudication, pronounced upon the status of some particular subject matter, by a tribunal having competent authority for that purpose. It differs from a judgment in personam in this: that the latter judgment is, in form, as well as substance, between the parties claiming the right; and that it is so, inter partes appens by the record itself. A judgment in rem is founded on a proceeding instituted, not against the person, as such, but against or upon the thing or subject matter itself whoso state or condition is to be determinal. It is a proceeding to determine the state or condi- 
tion of the thing itself; and the judgment is a solemn declaration of the siatus of the thing, and it ipso facto renders it what it cleclares it to be." In a case before Chief Jusfice Marshall, he undertook to point out the distinguishing characteristics of judgment in rem, and, in so doing, said: "What is the nature of a proceeding in rem? And in what does its specific difference from an ordinary action consist? Is every action in which a specific article is demanded, a proceeding in rem? If it were, a writ of right which demands lands, of detinue which demands a personal chattel, would be a proceeding in rem, to which all the world wour ${ }^{\top}$. be parties, and by which the rights of all the world would be bound. But this, all know is not the law. What then is the rule by which cases of this description are to be ascertained?

"I have always mderstood that where the process is to be served on the thing itself, and where the mere possession of the thing itself, by the service of the process, and making proclamation, authorizes the court to decide upon it without notice to any individual whatever, it is a proceeding in rem, to which all the world are parties. Tho rule is one of convenience and of necessity. In cases to which it applies, it would often be impossible to ascertain the persons whose property is proceeded against, and it is presumable, that the person whose property is seized, is either himself attentire to it, or has placed it in the care of some person who has the power, and whose duty it is to represent him and assert. his claim. Such clain may bo asserted; but the jurisdiction of the conr's does not depend on its assertion. The claimant is a party whether ho speals or is silent, whether he asserts his claim or abandons it."

But perhaps the most correct, as well as the most concise definition anywhere given of a judgment in rem, is that to be found in Smith's Luading Cases, viz. : that "it is an adjudication upon the status of some particular subject matter by a tribunal having competent authority for that parposo," ciepeading for its effect on this principle, that it

1 Woodruff $v$. Tazior, 26 Verm. 65.

${ }^{2}$ Minulin $v$.Chautler a Cu, 3 brock. 125. 
is " a solemn declaration proeeding from an accredited quarter, concerning the status of the thing atjudicated upon, which very declaration operates accordingly upon the status of the thing adjudicated upon, and, ipso facto, renders it such as it is thereby declared to be."1

But from noue of these descriptions can a complete and correct idea of the class now known as "judgment in rem" be obtained. The definition first quoted was particularly inaccurate, in asserting that judgments of this class must proceed from "a court of exclusive, or at least peculiar, jurisdiction." For, in truth, all kinds and classes of courts may proceed in rem whenever the law authorizes them to do so; and a judgmont resulting from such proceeding is equally effective, whether the court wherein it was pronounced was of general or of special, of stperior or of inferior, of concurrent or of exclusive, jurisdiction. The description given by Chief Justice Marshall places too much stress upon the idea, that the thing on which the judgment operates should be taken into possession on or by tho service of process, and ignores the large class of cases in which, instead of proceeding against any thing, courts adjudicate upon the status of persons and obtain their autliority to do so by a service of their process, which, whether actual or constructive, is still, in its nature, personal. The definition found in Smith's Leading Cases is substanticlly the same as that which we have quoted from the case of 1 Voodruff v. Taylor. But when we undertake to say that a judgment in rem is necessarily "an adjuclication upon the status of some particular subject matter," it seems to us that we either overlook the only class of judgments to which the term in rem ought ever to have been applied, or elso wo give to the word status an unusual and nnauthorized signification. Laws exist under which property is responsible for damages done by it, for taxes imposed upon it, or for expenses incurred in its repairs and management. These same laws often authorize the obligation by them imposed upon the property, to be enforced by proceedings in which the property is the defendant, and in which no service of

1 Smith's Lead. Cas. vol. 2, pp. of Nevada v. C. P. R. R. Co., 10 Nev. 5S5-6; p. 660 of 6th Am. ed.; Sta+e $\mid$ So. 
process is required, except upon such property. The judgment resulting from such a proceeding is in rem, and satis. faction thereof is prodnced by an execution authorizing tho sale of the property. The sale acts upon the property, and in so acting, necessarily afeets all claimants thereto. Dut the judgment does not affect the status of the property, except in the same semse that a judgreent against A. B. for a sum of money affects lis slalus. In the one case, it is settled, that an obligation rests upon certain property; in the other, it is settled, that a similar obligation rests on a certain person. Each judgment adjuclicates upon a status, so far as it establishes, that the defendant is in the state or condition of being accomntable to the plaintiff for $2 \mathrm{sum}$ of money. Neither judgment establishes any status different from that established by the other. Therefore, a judgment against a brute, a tract of land, or a vessel, for a sum of money, to be satisfied by execution against such brute, land or vessel, though clearly in rem, no more determines a slatis than though the defenclant were a person.

Judgments in rem, it is well known, are not, as the namo implies, confined to adjudications against things. They are rendered in many instances where the prior proceedings are entirely in personam, as in cases establishing or dissolving marriages. Neither are they, as is frequently stated, binciing on the whole world, for decrees of divorce rendered in one of these United States have frequently been clisregarded in the other States, and they would almost certainiy be treated as nullities in England if the marriage were contracted in that country betreen natives thereof; and the probate of a will, though considered as a judgment in rem in the State in whose courts it is probated, would have no effect over real property beyond the juriscliction of that State. The distinguishing characteristic of judgments in $r e m$, is that wherever their obligation is recornized and enforced as against any person, it is equally recognized and enforced as against all per'sons. It secms to us that the true definition of a judgment in rem is that it "is an adjudication" against some person or thing, or "upon the status of some subject matter" which, wherever and whenever binding upon any person, is equally binding upon all persons. 
8 607. Difierent Proceedings In Rem.-Neither of the definitions or descriptions given in the preceding section will, of itself, enable the reader to determine whether a particular judgment is in rem, because the particular cases in which adjudications are binding on all persons, are to be ascertained only by reference to statutes, or to the common law as expressed in the reported decisions of its judges. Among the proceedings resulting in judgments or decrees in rem are; those in the prize courts of all civilized countries, those in the English "Court of Exchequer, in cases of forfeitures for treasons, felonies, or a violation of the revenue laws. Proceedings are had in the nature of proceedings in rem, and without notice, in courts admitting wills to probate, and granting administration, and the expectancies of leirs and distributees swept away when the weakness of infancy, or residence in a foreign land, should, seemingly, protect them, because of the permanent political consideration, that the rights of property thus situated should be speedily settled by a legal ascertainment of them. All of which adjudicatious are dictated by public policy and necessity, regardless, to some extent, of private rights." An action of replevin is not in rem, because although it is for specific property, the jurisdiction of the court is dependent upon the personal service of the process, and its judgment is conclusive only upon the parties to the action, and their privies in person or estate. ${ }^{2}$ In Iowa, proceedings by garnishment are deemed to be in rem, and the debtor who pays over money in such proceedings, in pursuance of the order of a court having jurisdiction, is protected from an action against him by his ereditor, though the latter was not before the court when the order was made against the garnishee. $^{3}$ In Maine, certain proceedings to secure liens on logs, are both in rem and in personam, and the court camot proceed until it takes the steps necessary to give it jurisdiction over the property as well as over the person of the allegुed owners. ${ }^{4}$

\footnotetext{
1 Pinson $v$. Ivey, 1 Yerg. 349.

2 Certain Mahogany Logs, 2 Sumn. 592.

${ }^{3}$ Moore $v$. C. R. I. \& P. R. Co., 43 Ia. 385.

${ }^{4}$ Sheridan $v$. Ireland and Logs, 66 IIe. 138.
} 
\& 607a. Proceedings by Attachment are not, strictly speaking, in in rem, and yet they are sometimes so spoken of; and in some respects their effect is more, and in others less comprehensive than the effect of proceedings in personam. Thus, by the seizure of the property, as where moneysare garnished, jurisdiction is acquired over the fund, so that orders may be made for its distribution or payment, which will bind the orrner, though he has not appeared nor been personally summoned in the case, ${ }^{1}$ provided such owner is in law or in fact a defendant in the action. But the judgment in such action must, in its effect, be restricted to the property before the court, and, even as to that property, it is not conclusive upon the title, except as between the parties to the action and those in privity with them. Proceedings by attachment being the subject of divers statutory regulations, their effect must doubtless vary to correspond with the proceedings themselves. In some of the States, as in California, attachments issue for the purpose of creating a lien upon property, in order the more surely to obtain a satisfaction of the judgment, should one be recovered. The service of the writ is in no way connected with the service of the summons, or with the presence or absence of the defendant from the State, nor does such service give the court any jurisdiction to pronounce any judgment against person or property, nor relieve it of the necessity of proceeding with the service of the summons, in the same manuer as if no attachment had issued. ${ }^{2}$ It may well be cloubted whether this proceeding is jurisdictional in its character; and, if not, whether there is any mode by which the property in this State belonging to a non-resident may be reached and compelled to contribute to the payment of his debts.

Under the custom of London, the attachment of his property is all the notice the defendant has of the proceeding against him; none other is required. In the United States, on the other hand, a summons usually precedes or accompanies the attachment. If both the summons and the attachment are personally served in the State, the proceeding becomes to a great extent in personam, except that tho

12 Smith's Lead. Cas., 7 Am. ed. 809. ${ }^{2}$ C. C. P. of Cal., secs. 537-559. 
property attached must be applied to the satisfaction of the judgment. If the summons is not served, and the defendant does not appear, then the validity of the proceedings and judgment depends on the attachment; and as jurisdiction, if obtained at all, is required by the seizure of the property, and such further notice as the statute requires to be given, in connection with the attachment, the proceeding and judgment are often characterized as in rem, though they can never possibly bind any one not a party to the suit, or in privity with such party. ${ }^{1}$

8 608. Grants of Probate and of Administration.- "A grant of probate or of administration is in the nature of a decree in rem, and actually invests the executor or administrator with the character which it declares to belong to him." The probate of a will can not be collaterally avoided on the ground that the will is a forgery; or that the testator made a subsequent will and appointed another executor. ${ }^{3}$ Neither can it be collaterally impeached on any other ground,4 nor set aside by a proceeding in chancery. ${ }^{5}$ The probate of a will establishes its status; and the status thus established adheres to the will " as a fixture, and the judgment or decree in the premises, unless avoided in some mode prescribed by law, binds and concludes the whole world." 6 "If probate is granted of a will, then that conclusirely establishes, in all courts, that the will was executed according to the law of the country where the testator was domiciled." "Of course, such probate does not touch the

${ }^{1}$ Magee $v$. Beirne, 39 Pa. S. 50; Drake on Attach., sec. 5; 2 Smith's L. C., 7 th ed. 809; Cooper $v$. Reynolds, 10 Wall. 30s; Maxwell $v$. Stewart, 22 Wall. 77.

22 Smith's Leading Cases, Gth Am. ed. p. 669; Noel $v$. Wells, 1 Lev. 235; Allen $v$. Dundas, 3 T. R. 125; Fry $v$. Taylor, 1 Heal, 59t; Archer $v$. Mosse, 2 Vornon, 8; Gingell $v$. Horne, $9 \mathrm{Sim}$. 539 . 42.

${ }^{3}$ Moore $v$. Janner's Adm'r, 5 Monr.

${ }^{4}$ Vanderpoel $v$. Van Valkunbergh, 6 N. Y. 190.
${ }^{5}$ Colton v. Ross, 2 Pai. 396; State v. McGlynn, 20 Cal. 234; Kerrick $v$. Bransby, 7 Brown's Cas. 437; Jones v. Jones, 7 Price's Ex. 663; Jones $v$. Frost, Jacobs, 466; Pemberton $v$. Pem. berton, 13 Ves. 290; Adams $v$. De Cook, 1 McAllister, 253.

${ }^{6}$ Derland $v$. Harrington's Heirs, 29 Ala. 95; Woodruff $v$. Taylor, 20 Verm. 65; Ballou $v$. Hudson, 13 Gratt. 682; State $v$. McGlynn, 20 Cal. 234.

${ }^{7}$ Whicker $v$. Hume, $7 \mathrm{H}$. of $\mathrm{L}$. Cases, 124. 
question of the application of the will to real estate, unless the will be executed and recorded according to the lex rei sitce."

2609 . Decrees of Sale.-In decreeing the sale of the real estate of a lunatic or of a deceased person, the court acts in rem. If a judgment be entered against a lunatic after such decree under which his property is sold, the purchaser can acquire nothing at the sale as against a person claiming under the decree. It is impossible for the subsequent lien holder to defeat the orders of the court in regard to real estate subject to its power. ${ }^{2}$

8610. Marriage and Divorce.- "A sentence in a matrimonial suit is conclusive, for it is an adjudication upon the slates of the parties. ${ }^{3}$ But it is otherwise when the suit is for a jacitation of marriage, for there the spiritual court does not intend to affect the status of the parties by its decree, but merely to prevent one party from falsely asserting that a marriage happened under certain specified circumstances." A sentence in a matrimonial suit, is no doubt binding, as a judgment in rem, and, as such, conclusive upon all persons in all countries where the power of the court to establish or annul the marriage relation is conceded. But this relation, in some countries, as for instance in England until the establishment of the divorco court in 1858, could not be destroyed by tho courts of the country wherein it was created, nor would the courts of that country recognize the power of any other courts to annul marital obligations contracted in England between natives thereof. A foreign divorce, therefore, had no effect either in rem or in personam, if the parties wero residents of England married therein." It is still clear that " in no case has a foreign

IWharton's Confliet of Laws, $\$ 645$; Teal, Str. 691; Bunting's Case, 4 Co. Story's Confliet of Laws, $\$ 474$; Rob- 29; Kenn's Case, 7 Co. 42; Medlowertson $v$. Barbour, 6 Monr. 523; Jones eroft $v$. Huguenin, 4 Moore, 3S6; $v$. Robinson, 17 Ohio St. 171; Kerr $v$. Perry $v$. Meddowcroft, 10 Bear. 122. Moore, 9 Wheat. 565.

${ }^{2}$ Latham $v$. Wiswall, 2 Ired. Eq. ${ }^{5}$ McCarthy $v$. Deeaix, 2 Rus. \& M. 294; Wyman v. Campbell, 6 Port. 219. 614; Rex $v$. Lolley, 1 R. \& R. C. C.

32 Smith's Leal. Cas., p. 6i0, of $23 \%$.

6th Am. ed., citing Da Costa $v$. Villa 
divorce been held to invalidate an English marriage between English subjects, where the parties were not domiciled in the comitry by the tribunals of which the divorce was granted. ${ }^{1}$ The extraterritorial effect of divorees granted in the State courts of the Uuited States, has already been considered in the chapter on judgments in the sister States. ${ }^{2}$

8611. Jurisdiction.-In treating of judgments in personam, we found that the first and most material inquiry in regard to an apparent record was in reference to the jurisdiction of the court from which the record was prodnced; that the first jurisdictional inquiry was whether the court had authority over the subject-matter, and the second was whether it had authority over the parties. A judgmont in rem, at least when against any thing, binds the "res in the absence of any personal notice to the parties interested." Those parties, even in the absence of personal notice, are to bo regarded as parties to the suit. ${ }^{4}$ Therefore, in a lirrge number of cases involving the effect of judgments and decrees in rem, no inquiry in regard to jurisdiction over the persons interested is material; but even in these cases two jurisdictional inquiries must be answered in tho affirmative in order to uphold the judgment or decree, viz.: 1st. Did tho court liave the authority to determine the sulject-matter of the controversy? 2d. Did the court have jurisdiction over the thing proceeded against as a defendant? The answer to the first inquiry must, as in the case of judgments $i n$ personam, be found in the laws creating the court and designating its general authority.

8 612. How Avoided if from Foreign Court. - In considering a judgment in rem pronounced in some foreign country, the inquiry is not whether the defendant was summoned or whether he appeared in the suit. "Tho question is, did the form rei sito proceed according to its

${ }^{1}$ Shaw $v$. Att'y-Gen'l, L. J. Rep. N. S. vol. 39, p. 81 ; Shaw $v$. Gould, 3 H. of L. Cas. 56; Robins $v$. Dolphin, 1 Swaby \& Tr. 37; affirmed 7 II. of L. Cas. 390 .

${ }^{2}$ See Secs. 579-554.

662
3 The Globe, 2 Bltchf. 427.

"Baudue's Syndics $v$. Nicholson, 4 Miller Lou. 81; Thomas $v$. Southard, ¿ Dana, 475; Burn v. Dletcher, 23 U. C. Q. B. 36. 
own municipal laws, in prononucing such judgment or decree?" The effect of the judgment or lecree may be avoided by showing that it was procured by frand; that it is roid on its face, or void by the local law, fori rei judicatce. It may be shown that the notice required by law was not giren. But errors of law appearing on the face of the proceedings will not be considered, for their consideration iuvolves the exercise of appellate jurisdiction."

PART II.-OF JUDGMENTS AND DECREES IN ADMIRAITY.

8. 613. General Nature of.-Courts of Admiralty are spoken of as courts held under the law of nations. To tho proceedings of these courts, all persons haring any interest in the subject-matter of the suit are regarded as parties and are allowed to appear and contest the rights of the libelant." Especially in proceedings in the exercise of their jurisdiction orer questions of prize, clo these courts act under and in accordance with the law of nations. And as each judgment is binding and conclusive thronghout the jurisdiction in which it is pronounced, the judgments determining questions of prize must be recognized and enforced in all countries where the law of nations uncler which the prize court acted, is acknowledged and respected." This general respect of the decisions of Admiraity Courts was, no doubt, engendered by considerations of the mcertainty, harship, and inconvenience which were sure to result, unless those decisions were conclusive in all countries. The subject-matter of the decisions being vessels, iutended for the purposes of commerce in all parts of the world, it is obrious that unless the decisions were binding everywhere, no one would dare to navigate any vessel beyond the jurisdiction of the nation in whose courts the title to such vessel had been divested from one person and rested in another. In an early English case, the judge, in holling the sentence of a foreign court in admiralty conclusire, irouically remarked, "that, otherwise, merchants would be in a pleusant condition." And an early American case

${ }^{1}$ Sec. 502, Story's Conflict Laws.

${ }^{2}$ Moore $v$. Dougias, 4 Sanf. Ch. 184. 170.

${ }^{3}$ Armroyd 2 . Williams, 2 Wash. C. C. 508 .
${ }^{4}$ Brown v. Union Ins. Co., 4 Day, ${ }^{5}$ Hughes 2 . Cornelius, 2 Shower, 232. 
espressed the same idea in a different and better form, when, in speaking of a Court of Admiralty, it is said: "If its decree were not biuding on all the world upon the points which it professes to decide, the consequences would be most mischievous to the public." The liaw in reference to condemuations in admiralty "appears to me to rest upon three very obvious considerations: the propriety of learing the cognizance of prize cases exclusively to courts of prize jurisdiction; the very great inconvenience, amounting nearly to an impossibility, of fully investigating such cases in the courts of common law; and the impropriety of revising the decisions of maritime courts of other nations whose jurisdiction is co-ordinate throughout the world."

\& 614. Jurisdiction. - A sentence of a court of admiralty, professing to proceed in rem, is liable to be avoided upon showing that the tribunal had no jurisdiction orer the res against which it proceeded, or that, by the law of its creation, it had no authority to determine the questions on whose determination the sentence is founded. Chief Justice Marshall considered and decided this question, in an opinion pronounced by him in 1808, in which he said: "Can this court examine the jurisdiction of a foreign tribunal?

" The court pronouncing sentence, of necessity, deciled in favor of its jurisdiction; and, if the decision was erroneous, that error, it is said, ought to be corrected by the superior tribunals of its own country, not by those of a foreign country.

“This proposition certainly can not be admitted to its full extent. A sentence, professing on its face to be the senteuce of a judicial tribunal, if rendered by a self-constituted body, or by a body not empowered by its government to take cognizance of the subject which it had decidel, could have no legal effect whatever.

"The power of the court, then, is, of necessity, examinable to a certain extent by that tribunal which is compelled to decide whether its sentence has changed the rights of property. The power ubder which it acts must be looked.

\footnotetext{
${ }^{1}$ Gelston $v$ Hoyt, 3 Wheat. 246.
} 
into, and its authority to decide questions which it professes to decide must be cousidered.

"But although the general power by which a court takes its jurisdiction, of necessity, must be inspected, in order to determine whether it may rightfully do what it professes to do, it is still a question of serious difficulty whether the situation of the particular thing on which the sentence is passed may be inquired into, for the purpose of deciding whether that thing was in a state which subjected it to the jurisdiction of the court passing sentence. For example, in every case of a foreign sentence condemning a ressel as a prize of war, the authority of the tribunal to aet as a prize court must be examinable. Is the question, whether the vessel condemned was in a situation to subject her to the jurisdiction of that court, also examinable? This question, in the opinion of the court, must be answered in the affirmative. Upon principle, it would seem that the operation of every judgment must depend on the power of the court to render that judgment; or, in other words, on its juristiction over the subject-matter which it has determined. In some cases, that jurisdiction unquestionably depends as well on the state of the thing, as on the constitution of the court. If, by any means whatever, a prize court should be induced to condemn, as prize of war, a vessel which was never captured, it could not be contended that the coudemnation operated as a change of property. Upon principle, then, it woald seem that, to a certain extent, the capacity of the court to act upon the thing condemned, arising from its being within or without their jurisdiction, as well as the coustitution of the court, may be considered by that tribunal, which is to decide on the effect of the sentence." $A$ prize court has no authority to "sit in the dominions of a neutral power. 'Its doing so,' as Sir William Scott observed in the celebrated case of the The Flad Oyen (8 T. R. 270 , note), 'is a licentious attempt to exercise the rights of war in the bosom of a neutral country.' Accordingly, to the sentence of such a tribunal, our courts attribute no credit or authority whatever."

${ }^{1}$ Tiose $v$. Himeiy, 4 Cranch, 241, Rockwood, 8 T. R. 276; Donaltson $v$. 269; Cheriot $v$. Foussat, 3 Binn. 220. Thompson, 1 Camp. 429; Odly $v$. Bo.

2 Smith's Lear. Cas., vol. 2, p. 6S3 vill, 7 T. R. 523. of 6th Am. ed.; eiting Havelock $v$. 
Z 615. Wffect as Pes Judicata.-Decisions of admiraliy courts proceeding in rem derive additional importance from the fact that, besides determining the rights of property in the thing seized and adjudicated upon, they also conclusively establish, even as agaiust others, than the owners and libelants, the facts distinctly found by the court and necessary to sustain the sentence. "The decree will be conclnsire upon the question as well as the thing, and can not bo contradicted in any subsequent controversy with referenco to the same property, although between persons who were not parties to the decision, and founded on a contract anterior to the period at which it was made." Thus, a decree condemuing a ressel for a breach of a blockade, or for a violation of revenue laws, is conclusive evidence of such breach or violation in any subsequent controversy between the owner of the vessel and its insurers. ${ }^{2}$ The same effect belongs to a decree resulting from a proceeding in rem in an admiralty court for damages done by oue vessel to another at sea. ${ }^{3}$ But the jurisdiction of courts of admiralty to make adjndications binding against persons not parties to the proceedings, may be limited by stipulation. A policy of insurance written in Philadelphia contained a warranty by the assured that the goods insured were "American property, to be proved, if required, in this city, and not elsewhere." These goods were condemned as euemy's property in a foreign court of admiralty; but the assured was held not to be bound by the decree of condemnation. $^{4}$

\section{616. Sentence of Acquittal as Res Judicata.-No} distinction exists between a sentence of condemuation and a sentence of acquittal in regard to the principle of res juclicala. The latter is as conclusive on all persons that the al-

12 Smith's Lead. Cas., 6th Am. ed. Ins. Co., 3 Sumner, 600; Baxter $v$. N. p. 836. A deeree that a vessel libeled E. Marine Ins. Co., 6 Mass. 277; Ludis a foreign vessel is eonelusive of its low $v$. Dale, 1 Johns. Ca. 16; Whitforeign charaeter. The Rio Grande, ney $v$. Walsh, 1 Cush. 29.

23 Wall. 466.

${ }^{2}$ Groning $v$. Union Ins. Co., $1 \mathrm{~N}$. Rieh. 13; Magoun $v$. N. Eng. Ins. \& McC. 537; Croudson v. Leonard, 4 Co., 1 Story, 157.

Craneh, 434; Bradstreet $v$. Neptune ${ }^{4}$ Calhoun v. Ins. Co., 1 Binn. 293. 666 
leged ground of condemnation does not exist, as the former is that it did exist. ${ }^{1}$

8617. Ffiect as Res Judicata Confined to Parties in Interest.-Notwithstanding the frequency with which it has been stated, in general terms, that a judgment in rem is conclusive on the whole world, this conclusiveness must, it seems, be confined to those persons who, from their interest in the subject of the proceeding in rem, were entitled to appear in such proceeding, and assert their interest in the thing condemned. In the year 1813, during the war between Great Britain and the United States, the brig Mary was captured by an American privateer and brought into an American port, where " the vessel and cargo were libeled as enemy property." No claim being made in behalf of the owners of the vessel she was condemned. The cargo was claimed by ono Visscher, for himself and others; and tho sentence of condemnation against the MLary was relied upon by her captors as establishing as against the claimants of the cargo that the brig was enemy's property. Chief Justice Marshall delivered the opinion of the court, denying the claim of the captors. He argued that, as the claim to the vessel and the claim to her cargo were distinct claims held by different persons, the failure to assert one ought not to prejudice the assertion of the other; that the owners of the cargo not having any interest in the vessel, could not appear for her nor conduct any proceedings in her behalf, tending to show that she was American property. In the course of his opinion he said: "This case is to be distinguished from those which have been decided on policies of insurance, not only by the circumstance that the cause respecting the vessel and her cargo came on at the same time before the same court, but by the differences in reason and in law, which appear to be essential.

"The decisions of a court of exclusive jurisdiction aro necessarily conclusive on all other courts, because tho subject-matter is not examinable in them. With respect to itself, no reason is perceived for yielding to them a further conclusiveness than is allowed to the judgments and decrees

${ }^{1}$ Gelston $v$. Hoyt, 13 Johns. 561; 318; Williams $v$. Armroyd, 7 Crancl, also same case in 3 Whcaton, $246,423$. 
of common law and equity. They bind the subject-matter as between parties and privies.

"The whole world, it is said, aro parties in an admiralty cause; and, therefore, the whole world is bound by the decision. The reason on which the dictum stands, will determine its extent. Every person may make himself a party, and appeal from the sentence; but notice of the controversy is necessary in order to become a party, and it is a principle of natural justice, of universal obligation, that before the rights of an individual can be bound by a judicial sentence, he shall have notice, either actual or constructive, of the proceedings against him. Where these proceedings are against the person, notice is served personally, or by publication; where they are in rem, notice is served on the thing itself. This is necessarily notice to all those who have any interest in the thing, and is reasonable because it is necessary, and becauso it is the part of common prudence for all those who have any interest in it, to guard that interest by persons who are in a situation to protect it. Every person, therefore, who could assert any title to the Mary, has constructive notice of her seizure, and - may fairly be considered a party to the libel. But those who have no interest in the vessel which could be asserted in the court of admiralty, have no notice of her seizure, and cin, on no principle of justice or reason, be considered as parties in the cause, so far as respects the vessel. When such person is brought before a court in which the fact is examinable, no sufficient reason is perceived for precluding him from re-examining it. The judgment of a court of common law, or the decree of a court of equity, would, under such circumstances, be re-cxaminable in a court of common law, or a court of equity; and no reason is discerned why the sentence of a court of admiralty, under the same circumstances, should not be re-examinable in a court of admirialty."

\section{The Grounds of the Eentence must Appear.-} No doubt a decree in rem, pronounced in an admiralty court, is not conclusive of any fact not uecessary to support

${ }^{1}$ The Mary, 9 Cranch, 126. 
it, ${ }^{1}$ and it is very questionable whether it is conclusive in regard to those ficts unless it professes to have determined them, and sets them up as the ground of its decision. Lord Mansfield was of the opinion that if a vessel were condemued as good and lavful prize, and no ground for such condemnation were specified, it must be presumed to have been on the ground that the ressel was enemy's property. ${ }^{2}$ But this opinion of his Lordship's is greatly shaken, if not entirely overthrown, both in England and in the United States. As there are other sufficient causes for condemning a vessel, besides that of its being an enemy's property, there is no reason why every condemnation should bo presumed to be based on that ground, because no other ground apperrs. ${ }^{3}$ A case came before the Supreme Court of the United States, involving the effect of a sentence condemning an American ship as lawful prize. The court held that the condemuation did not show any violation of the nentrality laws, and that it was open to the plaintifis to show that the ressel had behaved as an American, and not as an enemy's ship. ${ }^{*}$ If a sentence of condemuation is shown to be basel either on the ground that the ressel was an enemy's property, or that it had violated some law of regulation of the country where it was condemned, the sentence of condemnation is not evidence of a breach of the warranty of neutrality. ${ }^{5}$ If a decree of condemnation states a particular gromud, and then condemns the vessel on account of such gromil, or otherwise, the addition of the words or ollerwise, render's the grounds of the decree uncertain, and prevents it from being conclusive on the ground mentioned. ${ }^{6}$ But if a decreo professes to proceed for a specified cause, and for other sufficient causes, it is conclusive of the existence of the cause specified. ${ }^{7}$

1 Maley $v$. Shattuck, 3 Cranch, 45s.

${ }^{2}$ Saloucci $v$. Woodmass, Park. 352; 3 Doug. 345; see also Barring $v$. Clagett, 3 B. \& P. 215.

${ }^{3}$ Dalgleish $v$. Hodgson, 7 Bing. 504; Fisher $v$. Ogle, 1 Camp. 41s; Bailey $v$. South Carolina Ins. Co., 1 Nott \& McC. 541; Goix v. Low, 2 Johns. Cas. 480 .
'Fitzsimmons $v$. Newport Ins. Co., 4 Cranch, 185 .

${ }^{5}$ Bernardi v. Motteaux, 2 Dougl. 575; Lothian $v$. Henderson, 3 B. \& P. 526.

${ }^{6}$ Robinson $v$. Jones, 8 Mass. 530.

7 Baxter $v$. New England Marine Ins. Co., 6 Mass. 277. 
"The sentence of a foreign court of admiralty of competent jurisdiction is binding upon all parties, and in all countries, as to the fact upon which the condemnation proceded, when such fact appears on the face of the sentence, free from doubt and ambiguity.

"But it is, at the same time, well established that, in order to conclude the parties from contesting the ground of condemnation in an English court of law, such ground must clearly appear on the face of the sentence; it must not be collected by inference only, or left in uncertainty, whether the ship was condemned upon one ground which would be a just ground of condemnation by the law of nations, or on another ground which would amount only to a breach of the municipal regulations of the condemning country." Whenever a decree is ambiguous, and does not show clearly that it is based on some specified ground, it is not conclusive upon any ground, and the parties in interest are at liberty to show by any competent evidence the status of the vessel at the time of her condemnation. ${ }^{2}$

${ }^{1}$ Dalgleish $v$. Hodgson, 7 Bing. 495; | lock $v$. Stewart, 2 Bay, 363; WilliamHobs $v$. Henning, 17 C. B. N. S. 791. son v. Fitzsimmons, 2 Bay, 388; Gray ${ }^{2}$ Vasse $v$. Ball, 2 Dall. 270; Black- $v$. Swan, 1 Har. \& J. 142.

670 


\section{CHAPTER XXIX.}

ATTACKS ON JUDGMENTS BY HABEAS CORPUS.

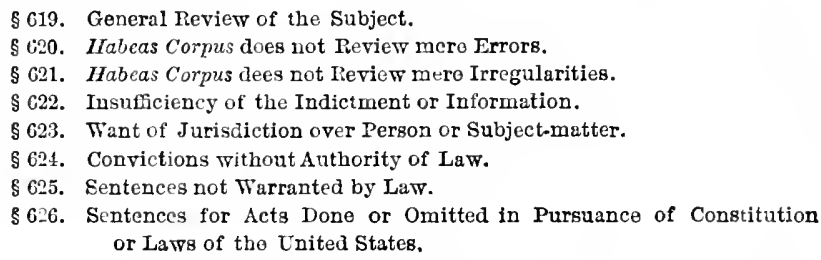
or Laws of the United States.

8619. General Review of the Subject.-The writ of habeas corpus usually issues in eases where no judgment has yet been entered, and where the object is to relieve from imprisonment persons against whom no charge warranting their arrest or detention has been made. But it sometimes appears from the return that the prisoner is held upoi a commitment issued pursuant to the judgment of some court or judge. The prisoner or bis counsel may then seek to attack or discredit this judgment, and the subject which we wish to consider in this chapter is the extent to which this attack may be carried. In the first place, we may remark that, so far as the judgment of conviction is questioned on habeas corpus, the attack is ordinarily a collateral one and subject to the rules restricting collateral attacks. In the Supreme Court of the United States, the writ may be issied in the exercise of appellate jurisdiction and accompanied by a writ of certiorari to bring up the records and proceedings of an inferior court, but even liere the court discliiins the right to review mere errors or to correct mere irregularities. ${ }^{1}$ Where the attack is collateral the judgment cannot be impeached for error ${ }^{2}$ or irregularity, ${ }^{3}$ except it be such as goes to the power of the court either to act in the case or to pass the sentence which it has given. The judg-

${ }^{1}$ Ex parte Virginia, 100 U. S. 341 ; Exparte Terger, 8 Wall. 85; Ex parte Siebold, 100 U. S. 374; Ex parte Parks, 93 U. S. 1 .
${ }^{2}$ Post, secs. 620, 622.

${ }^{3}$ Post, sec. 621. 
ment may be disregarded for illegality and want of jurisdiction. Perhaps it would be more accurate to say, for want of jurislictiou only, for the cases classed as illegalities, merely present instances in which the court had either no jurisdiction to punish for the offense named, or else no power to punish in the manner shown by the sentence. Judgments are disregarded for want of jurisdiction when the court had no jurisdiction over the subject-matter or none over the person sentenced. They are usually said to bo disregarded for illegality, when it appears that the offeuse is not punishable by any law, or, if so punishable, the sentence or judgment produced is not such as the court was empowered to render. There is also a class of cases, specified in section 753 of the Revised Statutes of the United States, in which the national courts are anthorized to extend the writ of hubeas corpus to persons confined for some act done or omitted pursuant to the Constitution and laws of the United States or the treaties made thereunder. Many of the causes for which a judgment may be assailed on habeas corpus will appear from the return to the writ or from the record in the case brought before the court by writ of certiorari or put in evidence in support of some issue made or tondered to the return. The cases in which the attack may involve the examination of evidence dehors the record, are doubtless limited and controlled by the rules applicable to collateral assaults on judgments in other cases.

8 620. The Writ of Habeas Corpus is not a Writ of Error, nor does it, except when perverted, discharge the functions of a writ of error. It is, therefore, no ground for the release of a prisoner that some error or irregularity has occurred in the course of the proceedings at or anterior to the trial, which, if presented to an appellate court by way of appeal or writ of error, must necessarily result in tho reversal of the judgment. ${ }^{1}$ Thus, if the point made against

${ }^{1}$ Ex: parte Siebold, 100 U. S. 371; Granice, 51 Cal. 375; People v. McIn re Schenck, 74 N. C. 607; Ex parte Leod, 1 Hill, 377; O'Nalice $r$. WentMax, 44 Cal. 32; State $v$. Fenderson, worth, 65 Me. 129; Ex parte Watkins, 28 La. An. S2; Ex parte Hartman, 44 3 Pet. 193; Ex parte Reed, 100 U. S. Cal. 579; Ex parte Sam, 51 Ala. 34; 13; Ex parte Toney, 11 Mo. 661; Ex parte Winston, 9 Nev. 71 ; Ex IVilliamson's case, $26 \mathrm{~Pa}$. S. 9; In re parte Parks, 93 U. S. 18; Phinney, Blair, 4 Wis. 522.

petitioner, 32 Me. 440; Ex partel 
the judgment is one which was or might have been urged upon demurrer to the indictment or by motion in arrest of judgment, the decision of the lower court, while it may be erroneous, is not void, and the judgment cannot bo treated as a uullity. ${ }^{1}$ The evidence before the lower court will not be considered for the purpose of determining whether a matter of defense was so proved that the defendant onght to have been acquitted. "When the prisoner las been committed for contempt, "it is quite clear that the juc?go has no authority to inquire into the truth of the fact adjudged by the committing magistrate, to wit, that the prisoner was in contempt for not answering a question put to him when giving his evidence; nor can he inquire whether the question was a proper one, or whether the prisoner was privileged from answering it." ${ }^{\prime}$ One who has been served with summons in an action cannot, when arrested under execution, obtain his release by showing that another person having the same name is the one against whom the judgment ougl,t to have been given. ${ }^{4}$

8 621. Irregularities in the Proceedings Anterior to the judgment do not justify the court in disregarding it or lin-iting its effect." "An irregularity is a disregard of some prescribed rule or mode of proceeding, and consists either in omitting to do some thing necessary to the due and orderly prosecution of the cause, or in doing it at an unseasonable time, or in an improper manner." 6 The juigment of conviction cannot be impeached on habeas corpus by showing that the indictment was not found by a grand jury, ${ }^{7}$ or that the verdict was received or recorded in the absence of the defendant. ${ }^{8}$ Nor can one imprisoned under 271.

${ }^{1}$ Ex parte Shaffenburg, 4 Dill. C. C.

${ }^{2}$ Griffn $v$. State, 5 Tex. App. 457; Ex parte $\mathrm{McCullough,} 35 \mathrm{Cal} .97 ; E x$ parte Bird, $19 \mathrm{Cal}$. 130; In re Bogart, 2 Saw. C. C. 396.

${ }^{3}$ Pcople v. Cassels, 5 Hill, 165; State $v$. Towle, 42 N. H. 540; Williamson's ease, $26 \mathrm{~Pa}$. S. 9; Ex parte Goodin, 18 Aib. L. J. 431.

4 Ii re Gorman, 6 C. L. J. 365.

${ }^{5}$ Ex parte MicGinl, 6 Tex. App. 493; Stewart's Case, 1 Abl. P. 210; Peolle v. N. Y. Juv. Asylmm, 12 Abb. P. 92; Bethell's Case, Salk. 345; Ex prarle Van Hagan, 25 Oh. S. 426; Puople $v$. Cavanagh, 2 Park. C. R. 650.

${ }^{6}$ Ex parte Schwartz, 2 Tex. App. 74.

' Ex parte Twohig, 13 Nev. 302;

State v. Fenderson, 28 La. An. S2.

${ }^{8}$ Lx parte Farnham, 3 Col. 545.

673 
execution in a civil case, avoid the judgment and obtain his release by showing that the court erred in not sustaining a plea in abatement by which he sought to avail himself of an irregularity in the service of the summons. ${ }^{1}$ A prisoner will not be discharged because lis sentence was imposed without waiting the time required by law after receiving the verdict or plea of guilty, ${ }^{2}$ nor because of any irregularity at the returning of the verdict, as where one of the offcers required to be present was in fact absent. ${ }^{3}$

\section{622. Insufficiency of the Indictment or Information.} To judge of the sufficiency of the complaint, inclictment, or information, and to determine whether the matters therein stated constitute a public offense, is certainly one of the duties intrusted to the court in which the conviction is had, and, if it be true that habeas corpus cannot be used for the same purpose as a writ of error, or an appeal, the decision of the trial court ought to be conclusive, and not subject to practical annulment because not in accord with the views of the court before which the writ of habeas corpus is returnable. Generally the courts have, on habeas corpus after conviction, refused to look in to the indictment for the purpose of passing upon its sufficiency. Thus, the supreme court of Michigan, when petition was presented to it for a writ of habeas corpus, to test the sufficiency of the information on which the conviction was had, denied the prayer of the petition, because to grant it "would be to make the writ of habeas corpus take the place of a writ of error." This ruling is in accord with that of the supreme courts of Mississippi ${ }^{5}$ and Texas. ${ }^{6}$ In Wisconsin, a prisoner brought before the supreme court on habeas corpus, clnimed his discharge on the ground that the information then pending against him did not charge him with a public offense, but the court refused to consider the question. ${ }^{7}$ Sub-

1 Ex parte Kellogg, 6 Vt. 509.

2 Petition of Smith, 2 Nev. 338.

${ }^{3}$ Rex $v$. Carlisle, 4 C. \& P. 415.

${ }^{4}$ Matter of Mary Eaton, 27 Mich. 1.

${ }^{5}$ Emanuel v. The State, 36 Miss. 6.27.

${ }^{6}$ Parker $v$. State, 5 Tex. Ap. 579. 7 Petition of Semler, 41 Wis. 517. leads to an inquiry as to the office of 674

In this case, at page 523, the court said: "Another question arising in this case is, can the petitioner be relieved by means of this writ, or mnst he resort to some other appropriate process to review and correct the proceedings of the eircnit court? This 
stantially the same question has arisen in and been determined by the Supreme Court of the United States. The first case was that known as Ex parte Tobias Watkins, 3 Pet. U.S. 193. It was then claimed that the prisoner ought, after conviction in the circuit court, to be discharged "on the allegation that the indictment charges no offense for which the prisoner was punishable in that court, or of which that court could take cognizance; and, consequently, that the proceedings are coram non judice, and totally void." Chief

the writ, and what matters can be circuit court act without jurisdietion, eonsidered upon it. And at the out- or in excess of its jurisdiction, in the set it may be observed, that the prin- matter complained of; or did it make eiple is well settled, that a writ of merely a wrong deeision? There can habeas corpus does not have the scope, be no doubt that the eircuit court had nor is it intended to perform the jurisdietion of the person of the petioffice, of a writ of error or appeal. tioner, and of the offense eharger in This doetrine is almost elementary in the information. But it is elaimed the law. The writ, then, cannot be that the first and seeond connts in the resorted to for the purpose of review- information eharged no offense; in ing and correeting orders and judg. other words, that the information is ments whieh are erroneous merely. insufficient, and that the motion to It deals with more radieal defeets, quash for that reason should be sus. which go to the jurisclietion of the court or officer, and which render the proceeding or judgment void. A distinction between a proceeding or judgment which is void, and one that is voidable only for error, is recognized in the eases, and must be ob. served. Says Dixon, C. J., in Petition of Crandall, 34 Wis. 177: 'It is conceded that for mere error, no mat. ter how flagrant, the remedy is not by writ of habeas corpus. For error, the party imprisoned must proseeute his writ of error or certinvari. Nothing will be investigated on leabeas cor$p^{m}$, exeept jurisclictional defects, or illegality, as some eourts and authors term it; by which is meant the want of any legal authority for the detention or imprisonment,' p.179. To the same effect is the doctrine laid down in In re Blair, 4 Wis. 522; In re O'Connor, 6 Id. 2SS; In re Perry, 30 Id. $26 \mathrm{~S}$. Now the inquiry is, in the light of these adjudications, Did the

tained. This may be at onee eonceded, but what follows? Manifestly this, that the cireuit eourt gave a wrong decision where it elearly had jurisdietion, in holding a defective informa. tion good. The court committed an error, but there is no ground for saying it aeted without jurisdiction in rendering its deeision. If a demurrer had been filed to the information and overruled by the eourt, preeisely the same question would have been presented. It is a ease of error; for whieh the petitioner can only have relief on writ of error ol some other appropriate process of review. He ean not have relief on a writ of habeas cor. pus, without making such writ perform all the office of a writ of error. This seems very obvious. Nor does the faet that this eourt, nnder the eonstitution, has appellate jurisdiction over the eircuit eourts, in any way affeet the question before us. For this court can only exert revisory or ap- 
Justice Marshall delivered the opinion of the court. Ho adverted to the fact, that by no appellate proceeding conld the judgment of the circuit court, convicting and sentencing the prisoner, be brought before the supreme court forrevier, and then proceeded as follows: "Can the court, upon this writ, look beyond the judgment, and re-examine the charges on which it was rendered. A judgment, in its nature, concludes the subject on which it is rendered and pronounces the law of the case. The julgment of a court of record, whose jurisdiction is final, is as conclusive on all the world

pellate jurisdiction on proper process, proceeding according to the rules of law. It cannot overlook and disregard the well-established distinction between the scope and operation of a writ of error and a writ of haveas cor$p u s$, and make the latter a substitute for the former. And the distinction has bcen clearly recognized in the above decisions. In the case of $\mathrm{Hau}$. ser $v$. The State of Wisconsin, 33 Wis. 678 , a strictly analogous question was considcred. That was a certiorari to review the decision of the municipal court of Milwaulee refusing to quash a criminal information for a libel against a corporation. It was claimed that a corporation could not be the object of a criminal libel, and that the municipal court erred in holding the contrary. But this court held that, even if that position was well taken, the rcal question presented to the municipal court for decision was, whether the information did or did not eharge the accused with the commission of a eriminal offense, and that this was in no sense a jurisdictional question. It refused to review the decision on the motion to quash upon certiorari and quash the writ. The operation of the writ of certiorari is certainly as extensive as the writ of habeas corpus; still this court declined to examine on that writ the correctness of the ruling of the municipal court in refusing to quash. The reason and principle of that decision are directly applicable to the case at bar. So in Ex parte Booth, 3 Wis. 145, the petitioner applicd to this court for a writ of habcas corpus to discharge him from imprisonment. It appeared that he was in confinement by force of a warrant of the district court of the United States, and that the object of the imprison. ment was to compel him to answer an indictment for a violation of the fugitive slave law. That law had been held to be unconstitutional by this court in a previous case. Whiton, C. J., says: "These facts slow that the district court of the United States has obtained jurisuliction of the case, and it is apparent that the indictmont pending against the petitioner is for an offense of which the courts of the United States have exclusive jurisdiction. We do not see, therefore, how we can, consistently with the principles of our former decision, interfere:' p. 148. The writwas denied. The petition before us shows that the applicant is committed on an order of the circuit court for want of bail. He is lield by the process of a court of com. petent jurisdiction, which had authority to make the order. For these reasons, neither the sufficiency of that order nor the correctness of the decis. ion on the motion to quash will now be inquired into." 
as the judgment of this court would be. It is as conclusive on this court as it is on other courts. It puts an end to the inquiry concerning the fact by deciding it.

"The counsel for the prisoner admit the application of these principles to a case in which the indictmont alleges a crime cognizable in the court by which the judgment was pronounced; but they deny their application to a case in which the indictment charges an offenso not punishable criminally according to the law of the land. But with what propriety can this court look into the indictment? We have no power to examine the proceedings on a writ of error, and it would be strange if, under color of a writ to liberate an individual from unlawful imprisonment, wo could substantially reverse a judgment which the law has placed beyond our control. An imprisonment under a judgment can not be unlawful, unless that judgment be an absolute nullity; and it is not a nullity if the court has general jurisdiction of the subject, although it should be erroneous. The eircuit court for the district of Columbia is a court of record, having general jurisdiction over criminal cases. An offense cognizable in any court, is cognizable in that court. If the offense be punishable by law, that court is competent to inflict the punishment. The judgment of such a tribunal has all the obligation which the judgment of any tribunal ean have. To determine whether the offense charged in the indictment be legally punishable or not, is among the most unquestionable of its powers and duties. The decision of this question is the exercise of jurisdiction, whether the judgment be for or against the prisoner. The judgment is equally binding in the one case and in the other; and must remain in full force, unless reversed regularly by a superior court capable of reversing it. If this judgment be obligatory, no court can look bolind it. If it be a nullity, the officer who obeys it is guilty of false imprisonment. Would the counsel for the prisoner attempt to maintain this position?"

After an exter:sive review of the authorities, the chief justice thus concluded: "Without looking into the indictments under which the prosecution against the prisoner was conducted, we are unanimously of opinion that the judgment of a court of general criminal jurisdiction justifies his imprison- 
ment, and that the writ of habeas corpus ought not to be awarded." So, in a very recent case, the same court adhered to the spirit of its earlier decisions, saying: "Whether an act charged in an indictment is or is not a crime by the law which the court administers, is a question to be met at every stage of criminal proceedings; on motions to quash the indictment, on demurrers, on motions to arrest judgments, etc. The court may err, but it has jurisdiction of the question. If it errs, there is no remedy after final judgment, unless a writ of error lies to some superior court." If it be assumed that the court has jurisdiction and power to punish every conceivable act, then it is doubtless true, that any leficiency in the indictment cannot be a cause for release upon habeas corpus. But no such power has ever been vested in any of our courts. They have been given juriscliction to try and punish for certain offenses; but they have no power to try and sentence a citizen for an act which is not made criminal by any law. Would it be claimed that under an indictment charging patriotism or chastity, the defendant conld be held in custody, and put to his writ of error, because, forsooth, the court in which the indictment was filed, was vested with the power to decide whether chastity and patriotism are felonies at common law or by statute? The plain answer would be, that the court had been vested with no criminal jurisdiction over these subjects. If it bo true, as mritten by Lord Hale, that a prisoner ought to be discharged if detained "for a cause for which a man ought not to be imprisoned," then there must be cases in which a discharge must be granted, because the charge of which conviction has been had, is totally devoid of criminality. In California, this view has prevailed, and a prisoner was discharged, though before trial, because the indictment against lim showed no crime; nothing which the court had jurisdiction to punish. ${ }^{2}$ If the complaint or information upon which the conviction was secured, was prosecuted in an inferior court of special and limited jurisdiction, there is strong reason for insisting that it state some act constituting a crime; because unless such act is charged, there is a failure to show any subject upon which the court had power to act or pun-

${ }^{1}$ Ex parte Parks, 93 U. S. $20 . \quad{ }^{2}$ In the Matter of Corryell, 22 Cal. 178. 678 
ish; and the jurisdiction of such a court must always afirmatively appear. Thus, in Fearney's case, ${ }^{1}$ he was tried, conricted, and sentenced in the police conrt of the city and county of San Francisco, under an ordinance thereof, providing that no person shall address to another, or utter in the presence of another, any words having a tendency to create a breach of the peace. The court construed this linguage as meaning that the person against and of whom the opprobrious words were uttered, must be present so that he might hear them, and be thereby inclined towards a breach of the peace; and that as the complaint failed to show that such person was present or heard the words spoken, it totally failed to allege a causo of actiou. "This," said the court, " is not the case of a complaint inartificially drawn, which intimates the existence of the facts necessary to the constitntion of the offense, or even of an attempted statement, insuficient, but indicating a purpose to declare on the essential facts." There must occasionally occur instances in which the act charged is so clearly one not criminal. nudur any existing law, that the prisoner must be released, whether convicted in a court of limited and special, or of general jurisdiction. ${ }^{2}$

\section{\& 623. Jurisdiction over the Person and the Subject-} matter may be inquired into upon habeas corpus, and if either be wanting, the judgment will be deemed void, and the imprisonment as withont lawful authority. If the judge or court which pronounced the sentence is a court or judge de facto, the writ of habecis corpus cannot be employed as a substitute for quo warranto, for the purpose of trying the right to office of the judge who pronounced the sentence. $^{3}$ But if the sentence proceeds from a court which has no jurisdiction over the subject-matter, no power to try the cause or to enter judgment therein, it will be treated as void. ${ }^{4}$ Where a prisoner is confined in the penitentiary on a judgment for an offense which the court rendering such judgment had no jurisdiction to try, he will be

15 Pac. C. L. J.430; 55 Cal. 212.

2 Post, secs. 624, 626.

${ }^{3}$ Ceasar Griffin's case, Chase Dec. L. J. 524.

364; Brown $v$. U. S., 2 Am. L. T. R. "Miller v. Snyder, 6 Ind. 1. 
discharged on habeas corpus; as where a free colored person was convicted in the court of oyer and terminer for petty larceny, which the statute made triable only by a justice. ${ }^{1}$ So, where a prisoner was convicted by a military commission sitting in a State in which the operations of the civil courts were unobstructed. ${ }^{2}$ So, where a prisoner was committed by a justico holding an inquest super visum corporis, without being authorized to hold such inquest. ${ }^{3}$ The jurisdiction of the legislature to imprison a contumacious witness may be inquired into on habeas corpus. ${ }^{4}$ Where a prisoner was convicted in a State court of perjury committed before a United States commissioner, he was discharged on Tiabeas corpus by the United States circuit court on the ground that a State court had no jurisdiction of that offense. ${ }^{5}$ Where it appears on the face of the record that a justice has exceeded his jurisdiction by issuing execution for a greater sum than allowed by law, tho prisoner will be discharged ou habeas corpus. ${ }^{6}$ So, where a magistrate issued a warrant for the arrest of a witness for nou-attendance beforo him, the cause in which his testimony was required having been terminated before the warrant issued, it was decided on habeas corpus that the issuance of such warrant was in excess of the magistrate's jurisdiction, and the prisoner was discharged. ${ }^{7}$

The question of jurisdiction over the subject-matter may, either in fact or in legal contemplation, become one of the issues to be tried, and the very fact of conviction may show that jurisdiction over it existed. Thus, if an indictment charges that an offense was committed within certain territorial limits over which the court has jurisdiction, whether the offense was so committed is one of the questions to be submitted to the jury and by them determined, and after they have decided this question by pronouncing their verdict of guilty as charged, the defendint cannot relitigate this question on habeas corpus. ${ }^{8}$ It is, in

\footnotetext{
${ }^{1}$ Cropper $v$. Commonwealth, 2 Rob. ${ }^{6}$ Geyger $v$. Stoy, 1 Dal. 135. Va. $8+2$.

${ }^{2}$ Ex parte Milligan, 4 Wall. 2.

${ }^{3}$ Ex: parte Schultz, 6 Wheat. 269.

4 Falvey $v$. Massing, 7 Wis. 630.

${ }^{5}$ Lx parte Bridges, 2 .Woods, 4:2s.

'Clarls's case, 12 Cush. $3 \cong 0$.

${ }^{8}$ Matter of Newton, 16 C. B. $97 ; 24$ L. J. C. P. 14S; 3 C. L. R. 1122; 1 Jur. N. S. 591, Q. B.
}

680 
all cases, essential that tho prisouer should have been brought under the jurisdiction of the court which tried him, or. which gave the judgment ander which the right to detain him is claimed. He must have his day in court. In most cases, he must have been arrested or otherwise brought before the court, and we apprehend that personal notico is always essential. Where the want of juriscliction over the person appears from the return or from the record in the action in which the judgment was pronounced, the case is free from embarrassment, and the prisoner must be discharged. With respect to cases in which the record does not disclose the jurisdictional infirmity, we apprehend that there must be a want of harmony in the decisions arising ont of the great divergence in the opinions of courts upon the extent to which collateral assaults upon judgments may be carried. With respect to conrts of record, of general jurisdiction, particularly if proceeding by trial by jury, they will be presumed to have proceeded rightfully. When such courts are acting in pursuance of a special and limited jurisdiction conferred by statute, and distinct from their general jurisdiction, the same presumption in their favor exists in some of the States. ${ }^{2}$

8 624. Conviction without Authority of Lav.-In a preceding section ${ }^{3}$ we considered the question whether the prisoner conld be discharged because of defects in the indictment or information. The cases there referred to, whilo they may, in one sense, be said to involve the inquiry whether the conviction was withont the authority of law, or in the absence of the allegation of facts which the existing laws made punishable as a crime, yet generally involved mere questions of the sufficiency of pleadings. The question of which we now wish to speak is not so much one of pleading. It is whether it may be shown that the act of which tho judgment shows a conviction, is, owing to some defect in the law, or owing to the absence of any law upon

I Mead $v$. Deputy Marshal of Va., Upon the general subject of jurisdic2 Wheeler's Cr. Cas. 509; Rex v. tion and presumptions thereof, see Chancellor, 1 Str. 55\%; Reynolds $v$. Hurd on Habeas Corpus, 370 .

Orvis, 7 Cow. 269.

${ }^{3}$ Sec. 622.

2 Deckard v. State, 33 Mid. 186. 
the subject, no crime at all. It may be said, on the one hand, that the court in which the prosecution and conviction were had, possessed the jurisdiction to inquire and determine what the law was; and, on the other, that the conviction of a lawful and innocent act can not warrant the deprivation of the liberty of the citizen or the infliction of any other punishment on him. In some of the cases convictions have been had under statutes standing unrepealed upon the books, and the discharge of the prisoner on turbeas corpus has been claimed on the ground that such statetes were unconstitutional and void; and therefore that the act of which the prisoner was convicted was not criminal. An unconstitutional enactment is never a law; and if there can be a case in which a conviction is illegal and without jurisdiction, it seems that such a case is presented when it appears either that there is no law making criminal the alleged crime, or authorizing its prosecution in the court wherein the sentence has been imposed. Nevertheless, perliaps tho majority of the adjudications upon this subject hold that the constitutionality of the law is a question which the court couvicting may determine; and that a conviction necessarily affirms the constitutionality of the statute; and that this afirmance can not be avoided on habeas corpus. ${ }^{1}$ So it has been held that, on habeas corpus, the force of the conviction can not be destroyed by showing that the statute anthorizing it had been repealed before the judgment wats rendered, ${ }^{2}$ or that it was entered as the result of a prosecution under a void ordinance of a municipal corporation. ${ }^{3}$ The decisions so far cited in the present section do not commend themselves to our understauding, and unavoidably support the conclusion that the citizen may not obtain release upon habeas corpus, although it appears that the act which he committed was not criminal under the laws of his country, or even that the Constitution of the State or nation las put it bejond the legislative power to punish such act as an offense. With respect to unconstitutional statutes,

Matter of Underwood, 30 Nich. 502; Ex parte Booth, 3 Wis. 145; Natter of Harris, 47 Mo. 104; Ex

${ }^{2}$ Ex parte Winston, 9 Nev. 71 ; In parte Fisher, 6 Neb. 303.

re Callicot, 8 Blatchf. 89.

${ }^{3}$ Platt $v$. Harrison. 6 Iowa, 79.

682 
we rather yield our assent to the reasoning thus expressed by Mr. Justice Bradley in the Supreme Court of the United States:" "The validity of the judgments is assailed on the ground that the acts of Congress under which the indictments were found are unconstitutional. If this position is well taken, it affects the foundation of the whole proceedings. An unconstitutional law is roid, and is as no law. An offense created by it is not a crime. A conviction under it is not merely erroneous, but is illegal and void, and cannot be a legal cause of imprisonment. It is true, if no writ of error lies, the judgment may be final, in the sense that there may be no means of reversing it. But personal liberty is of so great moment in the eye of the law, that the judgment of an inferior court affecting it is not deemed so conclusive but that, as we have seen, the question of the court's anthority to try and imprison the party may be reviewed in ?abeas corpus by a superior court or judge having authority to award tho writ. We are satisfied the present is one of the cases in which the court is authorized to take such jurisdiction. We think so, because, if the laws are uncoustitutional and void, the circuit court acquired no jurisdiction of the causes."

When it is alleged that the law under which the prisoner has been convicted is void, the allegation if sustained must rest upon one of two grounds, viz.: 1. That the legislative body which passed the enactment had no power to do so under any circumstances; or, 2. That, though such body had, under some circumstances, the power to make such enactment, this power did not exist in the present case for want of compliance with some essential formality. When the conviction has taken place, under an ordinance of a municipal corporation, it may, we thiuk, be shown that the ordinance, or that portion of it requisite to sustain the conviction, is void because the city council or other legislative body had no power to enact such an ordinance, ${ }^{2}$ but we have been unable to discover any authority showing whether the court on habeas corpus may take testimony for the purpose of determining whether the ordinance was passed or published with due formality.

${ }^{1}$ Ex parte Siebold, 100 U. S. 370; $\mid{ }^{2}$ Ex parte Burnett, 30 Ala. 461; Herrick v. Smith, 1 Gray, 49. People $v$. Roff, 3 Parker C. R. 216. 
All courts will take judicial notice of the general laws of the land, and if, viewed by those laws, the conviction and sentence is for an act possessing " a clear and manifest w:mt of criminality," the prisoner will be discharged. The leading authority on this subject is Bushel's case:" "There, twelve jurymen had been convicted in the oyer and terminer for rendering a verdict (against the charge of the court) acquitting Willian Penn and others, who were charged with meeting in conventicle. Being imprisoned for refusing to pay their fines, they applied to the court of common pleas for a habeas corpus; and though the court, having no jurisdiction in criminal matters, hesitated to grant the writ, yet, having granted it, they discharged the prisoners, on the gronud that their conviction was void, inasmuch as jurymen cannot be indicted for rendering any verdict they choose. The opinion of Chief Justice Vaughan in the case las rirely been excelled for judicial eloquence."'

\& 635. Sentence not Warranted by Law.-Jurisdiction is ordinarily defined as the power to hear and determine, aud where the existence of this power is conceded, no mere error or irregularity in its exercise can ordinarily render the judgment null. A person may be indicted for a crime; he may be present in court, and the court may have full power to hear and determine the cause and to pronounce sentence, in the event that a verdict of guilty should be returned by the jury. The law usually prescribes what this sentence shall be; or at least prescribes certain limits within which the sentence must be confined, as that the prisoner shall be confined in the State prison for not less than one nor more than ten years. If, lowever, the court should, in the case assumed, sentence the prisoner to less than one or more than ten years, its sentence is clearly not warranted by the law; but whether its action is a mere erroneous exercise of jurisdiction, and therefore voidable only, or is beyond and without its jurisdiction and therefore void, is a more difficult question. In the case of Ex parte Shaw, ${ }^{3}$ the

${ }^{1} \mathrm{~T}$. Jones, 13; Vaughan, 135; 6 said that error in sentencing a prisHow. St. Trials, 999.

${ }^{2}$ E.: parte Siebold, 100 U. S. 376.

37 Oh. St. 8l. See, also, People $v$. charge on habeas corpus. Cavanagh, 2 Abb. P. 89, where it was?

684 
prisoner having been convicted of horse-stealing, and having been sentenced to one year's imprisonment, when tho statute required such sentence to be for not less than three years, was bronght before the court on habeas corpus, and insisted, by his counsel, that the judmment was void. Tho supreme court thought the sentence complained of, whilo the result of error or mistake, was mevertheless valicl. It onght, we think, to be conceded in law as in mathematics, that the greater number always contains and includes the less; and that the power to impose a punishment of a specinied duration includes the power to impose a punishment of the same character but of less extent. Directly opposed to this view is the opinion of Department One of the Supreme Court of California, announced in its opinion filed April 25, 1881. ${ }^{1}$ The prisoner lad been convicted in a police court having jurisdiction over his person and over the offense of which he was accused, and the law required him to be punished by a fine of not less than one lundred dollars or by impris;onment not exceeding thirty clays, in case the fine was not paid. The court fined him twenty dollars only, and directed that in default in the payment thereof he be confined in the county jail for the period of ten days. The supreme court construed the statute as prohibiting the police conrt, in the case under cousideration, from imposing any fine less than one hundred dollars, and deemed its judmment not erroneous merely, but void. It was admitted that, perhaps, if the prisoner had appealed, the judgment would not have been rerersed, because upon appeal he would not be heard to complain of an error which did notinjure him, and which was unmistakably in his favor. The prisoner was discharged. This case is very extreme in its character. It is, perhaps, the logical result of other cases which have declared sentences other than those which the law aflixed, or directed the court to affix, as being without the authority of law, and therefore as utterly void.

In a case where the sentence is in excess of that sanctioned by law, the equities of the prisoner are much more persuasive; and it is not strange that, in the protection of personal liberty, many courts liave declined to treat such a

1 Ex parte Bernert, 7 Pac. C. L. J. 460. 
sentence as a mere error, but have, at least as to such excess, adjudged it to be void. In some instances, however, such sentences have been sustained on habeas corpus. In Ex parte Bond, the prisoner had been convicted of an assault with intent to kill, and sentenced to confinement in the penitentiary, and it appeared that such offense was not punishable by confinement in such prison. The Supreme Court held, that as the court a quo had general jurisdiction of the subject-matter, its judgment, though erroneous, was roidable only by appeal. So in Ex parte Crandall, ${ }^{2}$ the prisoner was prosecuted upún an information against him for an assault with intent to kill. The verdict found him guilty of "an assault as charged against him in the indictment." He was sentenced to imprisonment in the county jail for six months, and to pay a fine of five hundred dollars and costs of prosecution, taxed at forty dollars and eightynine cents. It was claimed that the court had no power to impose the fine in addition to the imprisonment. The error, if any, was thought not to involve the jurisdiction of the court, and the prisoner was remanded to the custody of the sheriff. In Olio, if the sentence inflicted is in excess of that authorized by law, it is erroneous merely, and not absolutely void. Relief can be had only by writ of error. ${ }^{3}$

In the year 1752, Collyer and Capon were brought before the court of King's Bench on habeas corpus, whereupon it appeared that they, being couvicted by a court of quarter sessions, of an assault on Thomas Smith, were "committed to New Prison, Clerkenwell, for the space of one month, and to ask pardon upon their knees of the said Thomas Smith, at the place where the offense was committed; and to cause an account of the said sentence to be printed in the Daily Advertiser, and not to be discharged ont of prison until they have undergone such imprisonment, asked such pardon, and caused such account to be published." By the court: "Every part of the judgment is illegal except the imprisonment. It has been said that the proper way for the defendants to be relieved against any part of this judgment is by writ of error. But it would be very hard that

I 9 S. C. 80 ; 30 Am. Rep. 20.

234 Wis. 177 .

686
${ }^{3}$ Ex parte Van Hagan, 25 Oh. S. 432. 
the defendants should continue in prison under the illegal parts of this judgment, until they can obtain a reversal of those parts upon writ of error." The prisoners were discharged. As the court of quarter sessions probably had no power, in any case, to sentence persons to ask pardon on their knees or to publish an account of their sentence, their judgment in this case was very manifestly without any authority in law. In a more recent case the judgment of certain justices which, among other matters, required the defendants to find recognizances not to offend again, was, as to such requirement, treated as void, because in excess of the law. ${ }^{2}$ This decision has since been explained by showing that it arose out of a summary conviction to which no writ of error applied; and the conrt refused to follow it with respect to an order made by a judge of a court of general and competent jurisdiction, holding that such order must be either obeyed, or reversed by appeal or writ of error. ${ }^{3}$

In Ex parte Page, ${ }^{4}$ the prisoner, after conviction for grand larceny, was sentenced to imprisonment for ten years, being three jears in excess of the greatest term specified by law as a punishment for such crime. $\mathrm{He}$ was released on habeas corpus, on the ground that it appeared from the record itself, and without any resort to extrinsic evidence, that the court exceeded its jurisdiction. If upon return to a habeas corpus it appears that the prisoner has been committed for contempt, no limit being fixed for his imprisonment, when the statute prescribes that such imprisonment shall not exceed thirty days, he may be discharged. ${ }^{5}$

The Supreme Court of the United States has very fully and explicitly committed itself to the doctrine that a sentence or decree, though made by a court having general jurisdiction over the person and subject-matter, is, whether in proceedings civil or criminal, as to any relief given or sentence imposed beyond that authorized by law, simply void. Thus, the district courts of the United States were, under the Confiscation Act of July 17, 1862, given jurisdiction

${ }^{1}$ Rex $v$. Collyer, Sayer, 44. 816 .

2 In re Henry Reynolds, 1 D. \& L.

${ }^{3}$ Ex parte Dunn, 5 D. \& L. $345 ; 5$ C. B. $215 ; 12$ Jur. $99 ; 17$ L. J. C. P.

105; see, also, Brenan's case, 59 Eng. Com. L. 492.

449 Mo. 291.

5 Shank's Case, 15 Abb. P. N. S. 38. 
over certain proceedings in rem for the condemnation and sale of property seized by the United States, and alleged to belong to persons who had been engaged in the rebellion, or had given aid and comfort thereto. A joint resolution of Congress passed concurrently with this act, provided that no proceedings against the offender should work a forfeiture of his estate beyond his natural life. A decree against the property of French Forrest was so worded that it was claimed to affect all his estate, right, title, and interest in the property. He, in fact, held an estate in fee simple. The purchaser, nnder this decree, therefore, insisted, in a suit brought by Forrest's heir, that the latter conld not liave any title in the premises, because the decree, and the sale in pursuance thereof, necessarily transferred the fee, and left nothing for the heir to inherit. The court sail, that assuming the decree to he as contended, yet the power of the district court under the act did not extend to the ordering of " a sale which should confer upon the purchaser rights outlasting the life of French Forrest." As, in this case, the court found that the decree did not on its face, when taken in connection with the statute, bear the construction claimed by the purchaser, the remarks of the Supreme Court upon the power of the district court might justly be regarded as mere dicta but for the fact that they are relied upon as anthority in subsequent cases, and particularly in Ex parte Lange, $18 \mathrm{Wall}$. 163, 177. In the latter case Edward Lange had been convicted in the Circuit Court of the United States for the Southern District of New York of stealing, purloining, and embezzling certain mail bags belonging to the post-ofice department, and thereupon had been sentenced to one year's imprisonment and to pay a fine of two hundred dollars. The statute authorized the court to imprison or fine, but not to do both. Lange was at once committed to jail. On tho next day he paid his fine. Five days after the original sentence was imposed, and four days after the fine was paid, and while he was yet in prison, Lange was brought into the same court upon habeas corpus, when the court entered an order vacating its former judgment, and again sentenced 
the prisoner to one year's imprisonment from the date of this last sentenco. A petition for a writ of habeas corpus was subsequently presented to the Supreme Court, which ordered the writ to issue, and with it a writ of certiorari to bring up the records and proceedings in the Circnit Court. In his return to the writ, the marshal claimed to hold tho prisoner under the last sentence. Thile disclaiming any right to review upon this writ the proceedings of the Circuit Court for mere error, the Supreme Court considered itself bound to inquire whether the former court had not exceeded its powers. The court, in its opinion, proceeded at great length, to show that no person could be twice put in jeopardy for the same act, or upon the same accusation, and that the true reason for this was that no person should be twice punished for the same offense. "For of what avail," inquired the court, "is the constitutional protection against more than one trial if there can be any number of sentences on the same verdict?" The final conclusion of the court was, that the prisoner could not be held under the second sentence, because the power of the court was exhaustel by the first. "Its authority was ended. All further exercise of it in that direction was forbiden by the common law, by the Constitution, and by the dearest principles of personal rights, which both of them are supposed to maintain." It was upon

${ }^{1}$ Ex parte Lange, 18 Wall. 17s. and had suffered five days' imprisonAt page 176 the court also say: ment on account of the other. It "We are of opinion that when the thus showed the court that its power prisoner, as in this case, by reason to punish for that offense was at an of a valid judgment, had fully suf- end. Unless the whole doctrine of fercel one of the alternative punish- our system of jurisprudence, both of ments to which alone the law sub- the Constitution and the common law, jected him, the power of the court to for the protection of personal rights punish further was gone. That the in that regard, are a nullity, the auprinciple we have discussed then in- thority of the court to punish the terposed its shield, and forbid that he should be punished again for that offense. The record of the court's proceedings, at the moment the second sentence was rendered, showed that in that very case, and for that very offonse, the prisoner had fully performed, completed and endured one of the alternative punishments which the law preseribed for that offense, follows that these two facts make 
the ground that but one sentence can be imposed as the result of one judgment of couviction, that TVm. M. Tweed obtained his release upon habeas corpus, though it appeared that the indictment upon which he was tried and found guilty charged many distiuct offenses.

8 626. The National Courts and judges have the power to issue writs of habeas corpus; ${ }^{2}$ and the writ may extend to a prisoner who is in custody for an act done or omitted in pursuance of a law of the United States, or of an order, process, or decree of a court or judge thereof, or is in custody in violation of the Constitution, or of a law or treaty of the United States; or, being a subject or citizen of a foreign state, and domiciled therein, is in custody for any act done or omitted under auy alleged right, title, authority, privilege, protection, or exemption claimed under the commission, order, or sanction of any foreign state, or under color thereof, the validity and effect whereof depend upon the law of nations." Under this section it is perfectly obvious that persons may be discharged on habeas corpus, though convicted after a regular prosecution and trial. The record of conviction would disclose the act for which the sentence was imposed; and if it appeared to be one of the acts or omissions mentioned in the Revised Statutes, or if

valid, however erroneous it may be, be confiscated to the State, it would any judgment the court may reuder in such case. If a justice of the peace, having jurisdiction to fine for a misdemeanor, and with the party charged properly before him, should render a judgment that he be hung, it would simply be void. Why void? Becanse he had no power to render such a judgment. So, if a court of general jurisdiction should, on an indictment for libel, render a judgment of death, or confiscation of property, it would, for the same reason, be void. Or if on an indictment for treason the court should render a judgment of attaint, whereby the heirs of the criminal could not inherit his property, which should, by the judgmentof the conrt, be void as to the attainder, becanse in excess of the authority of the court, and by the Constitutiou."

In a subseqnent case the Supreme Court explained the foregoing decision as follows: "In Ex parte Lange we proceeded on the ground, that when the court rendered its second judgment, the case was entirely out of its lands. It was functus officio in regard to it. The julgment first rendered had been executed and satisficd. The subsequent proceedings are, therefore, according to our view, void."

1 Pcople ex rel. Tweed $v$. Liscomb, 60 N. Y. 559; 19 Am. Rep. 211.

${ }^{2}$ Rev. St. U. S., secs. 75l, 752 . ${ }^{3}$ Sec. 753 , Rev. St. U. S. 
Chap. XXIX.] NATIONAL CovRTs. 2626 the imprisonment appeared to be in violation of the Constitution, or of any law or treaty of the United States, then the discharge of the prisoner follows as a matter of course. ${ }^{1}$

${ }^{1}$ U. S. v. McClay, 4 C. L. J. 255 ; C. L. J. 564; Ex parte McReady, 1 Ex parte Bridges, 2 Woods, 4:8; $l_{2}$ 日 $\mathrm{tgh}$, $59 \%$. re Wong Yung Quy, 9 Rep, 2it; 4 I. 



\section{INDEX.}

[N. B. -THE NUMBERS REFER TO THE SECTIONS.]

\section{A.}

ABSENTEE,

juriscliction of courts over, 589, 590 .

by compulsion, judgment against, void, 127 .

ACCIDENT,

as grounds for relief from judgment, $486,500 \mathrm{an}$

ACCOUNTS,

what constitute an indivisible demand, 239.

ACQUITTAL,

what a bar to, in criminal cases, 318 .

not evidence in civil cases, 319.

ACTIONS CONFLICTING WITH PRIOR JUDGMENTS,

for concealing defenses, 287.

for credits not allowed, 286.

for not dismissing as agreed, 292.

on promise to credit on judgment, 292.

Massachusetts cases in regard to, 285.

ACTIONS, JUDGMENT ESTOPPEL IN,

common recovery, 294.

distinctions between real and personal, 293.

ejectment, 295-302.

foreclosure, 303 .

partition, 301-307.

ACTIONS ON JUDGMENTS,

final judgment essential to, 432.

when sustainable, 432.

not sustainable on judgment of division court in Canada, 432.

not sustainable on judgment against a county, $432 a$.

on lost record, $432 b$.

on roidable judgment, 435 .

pending appeal, 433.

on decrees, 434 .

defenses in, $435,439$.

on judgments procured by attaching property, 436.

who may maintain, 437 . 


\section{ACTIONS ON JUDGMENTS-CONTINUED.}

did not survive defendant, 438.

execution not lost by pendency of, 440 .

interest in, when allowed, 441.

ACT OF OFFICERS,

when justified by judgment, 529-531.

what are treated as judicial, 531.

\section{ADJOURNMENT,}

of term of court, jurisdiction lost by, 121 .

of justice's court, without day, 526 .

\section{ADMINISTRATION,}

grant of, is a decree in rem, 607, 608.

on estate of a living person, $319 a$.

\section{ADMINISTRATOR,}

judgment for, is a new debt due him, 217.

lien of judgment against, 358 .

privity with creditors, 163.

privity with devisees, 163.

privity with heirs, 163.

privity with other administrator, 163

when relieved from judgment, 505.

\section{ADMIRALTY COURTS.}

general nature of, 613 .

are courts of nations, 613 .

jurisdiction may be questioned, 614 .

sentences of, effect as res judicata, 615, 616 .

sentences of, effect as res judicata limited to parties in interest, fil.

sentences of, conclusive only of matters distinctly found, 615 .

sentences of, lien of, 406.

ADMISSIONS,

estoppel by, $330,331$.

judgment, when evidence as, $417 a$.

ADVANCES,

lien of judgment for, 397.

\section{AFFIDAVIT,}

of merits on motion to vacate judgment, 108.

of merits by whom to be made, 108 .

of merits can not be controverted, 109.

for publication in justice's courts, 527 .

\section{AFTER-ACQUIRED R.IGHTS,}

affected by lien of prior judgment, $\mathbf{3 6 7}$.

not affected by estoppel of prior judgment, 302, 329 .

not subject to lis pendens, 201.

AGENT,

judgment based on unauthorized appearance of, 128.

may confess a judgment, 545 .

\section{AGREEMENT,}

can not extend effect of judgment as res judicata, 271. 


\section{AGREEMENT-CONTINUED.}

to satisfy judgment on part payment, 463 .

dismissal of suit by, when a bar, 202.

taking judgment contrary to ground for relief, 492.

ALIMONY,

must be adjudieated on in a divorce suit, 314 .

\section{ALTERATION OF JUDGMENT,}

makes it void, $14 S a$.

\section{ALTERED JUDGMENT,}

defendant may be relieved from, 490 .

\section{ANENDED PLEADINGS,}

effect as lis pendens, 199.

amount designating, $50 b$.

\section{AIENDNENTS,}

data for, 63,72 .

during the term, 69 .

of judgment, 70 .

of judgment entry, 71 .

of judgment in criminal cases, 71 .

of judgment with respect to amount, 71 .

of judgment with respect to names of parties, 71 .

of judgment after appeal, 71 .

delay in applying for, 73 .

must not prejudice third persons, 74 .

as a matter of course, 70 .

as a matter of course by inserting name, 70.

as a matter of course by inserting interest, 70 .

rule in England, 70, note.

of rerification to sustain judgment by confession, 5็0.

\section{ANCESTOR AND HEIR,} privity of, $16 \mathrm{~s}$.

\section{APPEAI,}

in attachment suits, what judgments final so as to permit, $21 b$. in criminal cases, what judgments final so as to permit, $21 a$. in intervention proceedings, what judgment final so as to permit, 2lc. amending judgments after, 71 .

cfiect on merger of cause of action, 218.

affirmance on, no bar to relief in equity, 495.

allowed only fron final judgment, $33,34$.

to correct clerical errors, 45 .

effeet of pendency on judgment estoppel, 328 .

effect of pendency on aetion on judgment, 433, 602.

from judgments by default, 537, $5+0$.

from judments by eonfession, 553 .

lien of judgment rendered on, 345 .

\section{ARBITRATION,}

entry of judgment on award, 55.

efiect of proceedings in, as res judicata, 320 . 
ARBITRATION-CONTINUED.

general submission of all demands, 320,321 .

of matters not in dispute, 322 .

ASSIGNEE OF DEBTOR, privity with creditors, 173 .

ASSIGNMENT OF JUDGMENTS,

at common law, 421.

effect on right of set-off, $467 a$.

statute made is cumulative, 421.

by parol, 422 .

by transfer of cause of action, 422 .

partial, 424.

of future judgments, 425 .

notice of, 426 .

action against assignor for satisfying judgment, $426 a$.

liability of assignor, $426 a$.

rights of assignee against the parties, 427 .

rights of assignee against third persons, 428 .

rights of assignee against prior assignee, 429.

rights of assignee on reversal, $482,484$.

rights passing with assignment, 429 .

can not be made by attorney at law, 430 .

ASSIGNOR AND ASSTGNEE,

privity of, 165, 186.

ATTACHMENT,

jurisliction in, $\mathbf{1 2 6 .}$.

judgment procured by, 573.

ATTACK, COLLATCRAL. Sce Estopper, Intpachment, Judgments by Default, Junisdiction.

ATTORNEY AT LAW,

authority of, presumed, 128.

appearance in absence of authority as ground for vacation of judg. ment, 98 .

appearance in absence of authority as ground for relief, 499, 500, 50S. appearance in absence of authority as ground for relief against purchasers, 509, 510 ,

appearance, whether authority to, may be questioned on judgment from another State, 563.

lien for fees, notice of, 211.

neglect of, considered as neglect of client, 112.

payment of judgment to, $462,463$.

neglect of, no ground for relief, 500 .

power to compromise, 463.

purchase at execution sale, how affected by reversal, 484 .

AUDITA QUERELA, 95.

AUTHENTICATION,

of judgments of sister States, 411, 412, 413.

of foreign judgments, 414 . 
AUTREFOIS ATTAINT,

effect of plea of, $\mathbf{2} 25$.

B.

BAILOR AND BAILEE, privity of, 166, 183.

BANKRUPTCY PROCEEDINGS, foreign, $605 b$.

impeaching judgment in, $337 a$.

modification of law of merger in, 245 .

preventing defense of, by fraud, 489 .

BILL DISMISSED, when a bar to further action, 270 .

BILL OF REVIET, barred by former bill, 323 .

BLANKS IN JUDGIIENT,

filed in by elerk, 49.

c.

CANADA,

effect of foreign judgment, 596, note.

no action on judgment of division court, 432 .

CAPIATUR,

judgment of, 8.

CAUSE OF ACTION,

. fraud in, no ground for relief in equity, 489 .

unconstitutional, no ground for relief in equity, $48 \%$.

CERTIFICATE,

to authenticate judgment of a sister State, 412.

CLAIM,

allowed by court is merged, as by judgment, 222 .

CLASSIFICATION,

common to julgments and decrees, 12.

of grounds of relief in equity, 488.

of judgments, 5,6 .

CLERICAL ERRORS, correction of, 71 .

CLEPK OF COURT, acts ministerially, 533 .

act, if unauthorized, is void, 129, 533.

act, if erroneous merely, is valid, 129,534 .

may act though the judge is disqualified, 535 .

CO-DEFENDANTS,

rights between one another not settled by judgment, 227 .

right of one to subrogation on paying entire judgment, 472 .

COIN JUDGMENT,

power of courts to enter, 3. 
COLLATERAL ATtACK. See Estoppel, Impeaching, Jorisdiction. Judgarents ey Default.

COLLATERAL SECURITY. not merged by judgment on the principal debt, 229 .

\section{COLLUSION,} avoids estoppel, 250 .

as ground for impeaching, 334, 435 .

\section{See Fradd.}

COLUMBIA, DISTRICT OF, judgment in, treated as foreign, 604a.

COMMENCEMENT, of lis pendens, 191, 19 .

COMNION RECOVERY, effect of judgment in, 294.

COMPLAINT, presumed, that written one is required in all countries, 603.

CONCEALMENT, when ground for relief, 491, 493 .

CONDEMNATION, judgment of, as a merger of causes of action, 222.

CONFEDERATE NOTES, payment of judgment by, 463.

CONFEDERATE STATES, judgments rendered in, 604 . legislatures of, were legislatures de facto, 604 .

CONFESSION OF JUDGMENT WITHOUT ACTION. acceptance by plaintiff essential to, 548 . appeal from, 558. causes of action on which it may be based, 546 . execution on, before entry, is void, 557 .

form of, 557.

jurisdiction of the court, essential as in other cases, 547. must be signed, like other judgments, 547 . persons who may make the confession, 545 . remedies to correct errors in, 558 . service of process in, 544 . statement in, when required, 544 . statement in, requisites of, 549,552 . statement in, signing, 551 . statement in, verification, 550 . verrication of statement, amendment of, 550 . statement in, for balance due, 556 . statement in, for goods sold, 554 . statement in, for money lent, 555 . statement in, on promissory note, 553. statcment in, effect of, insufficient, 557. statutes in regard to, strictly construed, 543. 


\section{CONSTRUCTION,}

of judgment entries, 45 .

\section{CONSTRUCTIVE SERVICE OF PROCESS,}

jurisdictional inquiries in judgments procured by, 127.

frand in employing, a ground for relief, 489.

in divorce suits, 583,584 .

on residents, 570 .

on residents of other States, 567.

on corporations of other States, 568 .

on residents in foreign countries, 588, 589.

\section{CONTINUANCES,}

defined, 77.

\section{CONTEMPT,}

judgment for, 137.

CONTRACT,

is a judgment in the nature of? 4.

\section{CONVICTION,}

form of judgment of, $50 \mathrm{~d}$.

of felony, effect of, as a merger, 225.

of act not criminal, 624 .

on insufficient indictment, 622.

habeas corpus to test validity of, 620-626.

when a bar to further prosecution, 318.

CO.OWNERS,

privity between, $171 a$.

CO-PLAINTIFFS,

rights between one another not settled by judgment, 227,230 .

COPY OF RECORD,

as proof of judgment, 407, 408.

\section{CORPORATION,}

constructive service of process on, 568 .

contracts by, not to remove suits, 568 .

judgment against, whether binds stockholders, 177 .

judgment against, whether merges claim against stockholders, 22S. proceedings against in another State, 568.

residence of, 568 .

\section{CORRECTING JUDGMENT, 69, 70.}

\section{cosTs,}

on motion to open judgment, 109.

judginent for may be given on dismissing appeal for want of jurisdiction, 121.

whether judgment for is final, 16.

when takes precedence over judgment lien, 338.

when paid out of proceeds of lien, 338 .

\section{CO-TENANT,}

lien of judgment against, $357 \alpha$.

privity between, $171 a$. 


\section{COUNTY,}

adjudication against, biuds its citizens, 178 .

effect of judgment against, $432 a$.

\section{COURTS OF RECORD,}

what are, 122.

when treated like inferior courts, 123.

\section{COURTS NOT OF RECOLD,}

distinction between, and courts of record, 122, 517.

jurisdiction must be shown, 517,525 .

jurisdiction not presumed, 517 .

jurisdiction may be disproved, 517.

jurisdiction, whether it may be proved aliunde, 518 .

jurisdiction not proved by docket entries, 519 .

justices' courts generally not courts of record, 520 .

process, service of, must be shown, 521 .

judgment prematurely entered, 52l.

judgment entered in other States, 577.

when process is authorized upon certain facts, 522, 523 .

judgments in, conclusive if they have jurisdiction, 524 .

adjournment, without day, 526.

publication, service by, 527 .

proceedings against defendants under common name, 528 . protection of officers acting under, $529,530,531$.

what tribunal and persons act as courts not of record, 531 .

proof of judgments of, 410 .

COURTS OF THE UNITED STATES,

judgments of, treated like judgments of another State, 578.

\section{COVENANTS,}

each can give but one cause of action, 240 .

\section{CREDITORS,}

no privity between, 159 .

privity with administrator, 163.

\section{CRIMINAL PROSECUTION,}

acquittal, as a bar, 318.

amendment of judgment in, 71.

as merger of civil liability, 225 .

equity can not relieve judgment in, $484 a$.

final judgment in, what is, 2I $a$.

form of judgment of conviction, 50d.

judgment on demurrer, when final, $21 a$.

nolle prosequi in, 315.

judgment in, not evidence in civil cases, 319.

\section{CROSS.CLAIM.}

what is, 282.

need not be presented by defendant, 282 . 


\section{D.}

DAMAGES,

all, mist be recovered in one judgment, 241 .

DATE OF JUDGMENT,

presumption in regard to, 45 .

DATA,

for amending entry, 72.

for nunc pro tunc entry, 61, 62, 63 .

DECEASED PERSON,

entry of judgment against, nunc pro tunc, 57-60.

judgment may be entered against, when, 57, 58, 139.

judgment against not void, 140, 153.

judgment against lien of, 369 .

DECREE,

actions on, 434 .

amending, 70 .

defined, 9.

enrollment not essential, 39.

estoppel of, 248.

final, what is, 22-36.

nisi, what is, 10.

nul tiel record, not a proper plea to, $\mathbf{5 5 9}$.

mo confesso, 11.

of bill dismissed, is a bar, 270 .

vacating, 100.

DEED,

whether necessary in partition, 308.

DEFAULT, JUDGMENT ON,

appeal from, 537-540.

discretion of court in vacating, 541 .

disqualified judge may enter, 535 .

effect of, $330,331,532$.

entry of, by clerk, 129, 533 .

error of clerk in entering, 129, 534.

vacation of, 541.

See Vacation of Judgments.

vacation of merits essentiol to, 541 .

vacation of, to allow meritorious defenses, 542 .

DEFECTS,

in acquiring jurisdiction, 126.

DEFENDANTS,

if numerous, part may represent all, 157, 173.

\section{DEFENSES,}

distinction between, and cross-claim, 282.

effect of general judgment when there are permanent and temporary, 258,256 .

equitable, when not barred, 281.

rejected, 279 , note. 
DEFENSES-CUNTINOED.

to action on judgment, 435 .

to action on judgment, sister State, 576 .

to action on judgment, how pleaded, 458.

DEFINITION AND DESCRIPTION,

of audita querela, writ of, 95.

of continuances, 77 .

of coram nobis and coram vobis, writ of, 94.

of courts of record, and not of record, 12:.

of decrees of various kinds, $9,10,11$.

of diligence, 503 .

of docket, doquet or dogget, 343 .

of entering judgment, 77 .

of estoppel, 246.

of facts in issue, 257.

of final judgments and decrees, 16-36.

of judgments, 1-2.

of judgments of different kinds, 6-8

of judgments in personam, 13, 606.

of judgments in rem, 13, 606 .

of judgments under the code, 14.

of jurisdiction, 118, and note to same page.

of lien, 338 .

of orders, 15.

of parties, 181.

of placita, 77.

of postea, 77.

of privies, 162.

of prorogated jurisdiction, 145.

of retraxit, 7.

of scire facias, 442 .

of signing judgment, 77 .

of terre-tenant, 449.

of void judgment, 116.

DELAY OF COUNSEL,

no ground for nunc pro tunc entry, 60 .

\section{DELAY OF THE COURT,}

as ground for nunc pro tunc entries, $5 \%, 58$.

\section{DELAY OF THE PARTIES,}

bars right to nunc pro tune entry, 60 .

though occasioned by adverse party, 60 .

in making motion to vacate judgment, 102 .

DEMAND,

judgment for part of, extinguishes the whole, 238, 239.

DEMURRER,

judgment on, when bar to future suit, 267.

DEVISEE,

lien on interest of, 356. 
DIES NON,

judgment on, void, 138.

DILIGENCE,

essential to relief, 493, 503.

in keeping up lis pendens, 202.

in prosecuting lien, 374.

DISCOVERY,

relief on, how obtained, $4 \$ 4 a$.

when obtainable after judgment, 506, 507 .

DISCRETION,

in vacating judgments, subject to review, 106.

DISMISSAL,

is a final judgment, 17.

but not a bar, 261 .

unless entered by agreement, 262 .

decree of, is a bar, 270 .

DISQUALIFIED JUDGE,

acts of, 144-148, 535 .

\section{DISTINCTIONS,}

between courts of record and not of record, 122.

between entry of judgment and entry of decree, 39 .

between final and interlocutory decree, 29,36 .

between a judgment and a decree, $\mathbf{9}$.

between a judgment in rem, and in personam, 13,

between a judgment under the code and at common law. 14 .

between a judgment and an order, 15.

between a retraxit and a nonsuit, 7 .

between want of jurisdiction and defect of jurisdiction, 126 .

DIVORCE, DECREE OF,

as evidence against third persons, 159, 313, 586.

as evidence of marriage, 154 .

effect of annulling, 333 .

foreign, $605 \mathrm{c}$.

relief in equity, against, 489 .

is res judicata, 270,313 .

effect of decree in another State, 579-587.

DOCKET,

what is, 343 .

correction of, 344 .

of judgment of appellate court, 345 .

of judgment of justice's court, 346 .

spelling of names in, 347 .

DOMICILE,

defendant bound by the law of his, 570 .

DOWER,

claim of, low affected by foreclosure, 303 .

claim of, how affected by partition, 304 .

claim of. how affected by judgment lien, $361 a$. 
EJECTMENT,

at common law, 295 .

at common law on confession, 296.

at common law on suit for mesne profits, 297.

at common law, costs must be paid, 298 .

under recent statutes, 299-302.

party against whom it must be brought, 162.

parties who may be dispossessed under, 171 .

ELECTION,

to interpose equitable defense, 501.

END OF LIS PENDENS, 206.

ENROLLMENT OF DECREE, 39.

ENTRY OF JUDGMENT,

required in all courts, 37.

is a ministerial act, $3 \mathrm{~S}$.

not essential to judgment, 38 .

distinction between, and decrees, 39 .

in judgment book, 40, 41 .

ought not to be delayed, 42.

on verdict, 42.

against joint defendants, $43,44$.

construction of entry, 45,54 .

against third persons, treated as clerical error, $\mathbf{4 5}$.

form, 46,47 .

under the code, 47.

must be in dollars and cents, 48 .

filling blanks, 49 .

sufficiency of, 50, 51, 52 .

in justices' courts, 53 , and note to 55 .

on award, 55 .

\section{See Nunc Pro Tunc Entries.}

EQUITY,

estoppel, recognized in, 248.

will not extend or limit judgment lien, $\mathbf{3 9 5}$.

will not extend or limit forcign judgment, 600 .

EQUITABLE INTERESTS,

when subject to judgment lien, 348, 357 .

EQUITABLE DEFENSES,

whether must be made at law, 281 .

ERROR OF THE COURT,

does not limit judgment estoppel, 249.

never makes judgment void, 135.

not a ground for nunc pro tunc entry, $6 \mathrm{~S}$.

not a ground for relief in equity, 4S5, 487 .

not a ground for relief on motion by vacating after term, 101. not a ground for avoiding foreign judgment, 595.

ESTORPEL,

definition of, 246. 


\section{ESTOPPEL-CONTINUED.}

error of court does not impair, 249.

not odious, 247.

of decrees, 248 .

general extent, 249.

reasoning of court does not limit or enlarge, 249.

requisites of, $250-271$.

evidence to establish or to rebut, 272-276.

where there are two or more defenses, $276 a$.

matters which defendant need not litigate, 277-82.

pleading to invoke, 283, $2 \$ 4$.

actions in conflict with julgment not allowed, 255-292.

of judgments in real actions, 293-311.

of judgments in personal actions, 312-317.

of admiralty proceedings, 615 .

of criminal cases, $318,319$.

of motions and special proceedings, 320-320.

effect of appeal on, 32s.

effect of reversal on, 333 .

of defaults and admissions, 330, 331 .

after-acquired rights, 329 .

last judgment prevails, 332 .

\section{EVIDENCE,}

for amending judgment entry, 72 .

for nunc pro tune entry, 61-63.

identity of, is the test of res judicata, 259 .

not received against the record, 275.

to show what is res judicata, 273 .

to show what is not res judicata, 272,274, 302

EVIDENCE, JUDGMENT AS,

to prove its own rendition, 416.

to prove title, 416 .

as matter of inducement, 417.

to prove that plaintiff is a judgment creditor, 418 .

to prove questions of public nature, 419.

EXCUSABLE NEGLECT,

See Proof.

what is, 114, 115.

EXECUTION SALE,

purchaser at, bound by lis pendens, 208.

EXECUTOR AND ADMINISTRATOR,

privity of, 163.

\section{FEDERAL COURTS,}

F.

contracts not to remove suits to, 569 .

judgments of, entitled to full faith and credit, 578 .

judgment lien of, 406 .

habeas corpus in, 626 .

lis pendens, state law does not apply, 192. 
FIGURES,

entry of judgment in, $4 \mathrm{Sa}$.

FINAL DECREE,

what is, 29.

FINAL JUDGMENT,

in criminal cases, $21 a$.

dismissing attachment, $21 b$.

dismissing petition for intervention, $21 c$.

essential to res judicato, 251.

essential to lien, 340 .

what is, 12, 17-28.

general test of, 36 .

FINDINGS,

immaterial, no estoppel, 271.

of jurisdictional facts, 130 .

of jurisdictional facts in judgments of other states, 560-563.

FORCIBLE ENTRY,

effect of judgment in, $302 a$.

\section{FORECLOSURE,}

decree of, as res juclicata, 303.

decree of, as licn, 398.

lien of judgment for deficiency, 339.

\section{FOREIGN JUDGMENTS,}

against temporary residents, 588 .

are not records, 605 .

authentication of, 414 .

effect, when against policy of our laws, 558 .

pleading, 453.

not a merger of cause of action, 220, 605 .

jurisdictional inquiries permitted, 5\$8, 595.

against non-resident, $5 S 8,589$.

against non-resilent corporations, 590.

distinction between, as causes of action and as pleas in bar, 592, 594

distinction between decree denying and granting relief, 593 .

fraud avoids, 591, 595 .

in acquiring jurisdiction, 566 .

not examinable on the merits, 594 .

not examinable for error of law, 595 .

American cases in regard to, 596.

effect against indemnitor, 597 .

foreign decree conclusive, 598 .

decree discharging insolvent, 599.

equity will not restrain, 600 .

rendered by interested tribunal, 601 .

not affected by pending appeal, 602 .

must be supported by a complaint, 603.

Southern Confederacy and District of Columbia, judgments in, 604, $604 a$.

of probate courts, $605 a$. 
FORMER ACQUITTAL,

what sustains plea, 318, note.

FORM OF ENTRY,

of judgments, $46,47,50,51,52$, note to $\S 55$.

of judgments, designating the parties, $50 a$.

of judgments, designating the amount, $50 b$.

of judgments, designating the property, $50 c$.

of decree of foreclosure, 47.

FRACTIONS OF A DAY,

when regarded, 370 .

FRAUD,

prevents merger, 223 .

avoids estoppel, 250.

in getting defendant within jurisdiction of court, 566 .

avoids foreign judgment, 591, 595 .

whether a ground for impeaching judgment, 132, 336.

is a ground for relief in equity, 486, 489, 490, 491.

as a ground for vacating judgment, 99 .

as a defense to judgment of sister State, 576.

FUTURE ADVANCES,

lien of judgment for, 397 .

\section{GAMBLING DEBT,}

\section{G.}

relief from judgment based on, 502.

\section{GARNISHEE,}

judgment against, no merger of demand against the principal, 228.

protected by the orders of the court, 167.

no privity with the creditors, 167 .

no privity with his principal, 167 .

GENERAL EXPRESSIONS,

confined to the parties, 155, and the issues, 158, 271.

GENERAL ISSUE,

effect of judgment put in evidence under, 284.

in actions on judgments, $45 \mathrm{~S}$.

GENERAL VEPDICT,

where there are both permanent and temporary defenses, 268.

GOLD COIN,

whether judgment may be for, 3 .

GRANTOR AND GRANTEE,

privity of, 165, 186.

GUARANTOR,

when bound by judgment against guarantee, 187.

H.

HABEAS CORPUS,

attack by on judgments, 619-626.

certiorari, in aid of, 619 . 


\section{HABEAS CORPUS-CONTINUED.}

conviction under repealed law, 624 .

conviction under unconstitutional law, 624 .

conviction without authority of law, 624 .

conviction of non-criminal act, 624 .

errors not reviewed on, 619, 620 .

federal courts, 626 .

gencral review of grounds of release, 619 .

indictment, sufficiency of, 622 .

irregularities no ground for release, 621 .

jurisdiction over person and subject-matter, 023.

merits of original cause not re-examinable, 620 .

sentences not warranted by law, 625 .

sentences less than warranted by law, 625 .

sentences greater than warranted by law, 625 .

sentences, second, after power of court is exhausted, 625 .

title of judge de facto, 623 .

whether decision on is res judicata, 324 .

HASTE OF COURT,

no ground for relief, 487 .

HEIR,

interest of, subject to lien, 356 .

HEIR AND ADMINISTRATOR, privity of, 163.

HEIR AND ANCESTOR, privity of, 167.

HOMESTEAD,

disposed of by foreclosure, 303.

judgment lien against, 355 .

IGNDRANCE,

of defense as a ground for relief in equity, 506.

of evidence as a ground for relief in equity, 507.

IMMATERIAL FINDING, creates no estoppel, 271.

IMPEACHING JUDGMENTS, 2S5, 2S6, 334-\$37. for fraud on bankrupt acts, 337a.

INADMISSIBLE CLAIMS, not barred by judgment, 269 .

INADVERTENCE AND INATTENTION, not a ground for relicf, $4 S 5,4 S 7$.

INDEMNITORS, when bound by judgment against person indemnified, 181, 184 . when bound by foreign judgment, 597 .

INDICTMENT, lost, can not be replaced, 89 , note.

INDIVISIBLE DEMANDS, 23S-212. 
INDORSER,

effect of payment of judgment by, 471.

INEXCUSABLE NEGLECT,

what is, 115 .

INFANTS,

are bound by judgments, 151, 513 .

when may move to vacate, 102.

when may obtain relief, 513 .

INFERIOR COURTS. See CouRts Not OF RECORD. proof of judgments of, 410 .

INJUNCTION SUIT, lis pendens of, 195.

INNOCENT PURCHASER,

relief can not be had against, 510, 513 .

not affected by nunc pro tunc entries, 66 .

not affected by amendments, 74,344 .

not affected by reversal, 484 .

not affected by secret vices, 509 .

INSANE PERSON.

bound by judgment, 152 .

INTEREST ON JUDGMENT, none at common law, 441.

is secured by the lien of the judgment, 341 .

statute changing rate of, $\mathbf{4 4 1}$.

INTERLOCUTORY JUDGMENT,

what is, $12,14,15$.

decree, what is, 29,31 .

is part of judgment roll, 84 .

is not res judicata, $25 \mathrm{l}$.

is called, by the code, an order, 14 .

no lien arises from, 340.

INTERVENTION,

dismissal of, when final, $21 c$.

IRREGULARITY,

is a ground for vacation, 97 .

but not for relief, 487.

no ground for discharge on habeas corzw6, 621 .

waiver of, 102.

ISSUES,

identity of, 256 .

judgment without, 135 a.

res judicata confined to, 257.

what become res judicata, 259 .

whether can be shown not to be res judicata, 272.

J.

JOINT DEBTOR ACTS.

judgment under, as a merger, 219, 233.

judgment under, no effect out of the State, 574 . 
JOINT DEFENDANTS,

entry of judgment against, 43, 44 .

judgment void as to one, void as to all, 136.

JOINT OBLIGORS,

judgment against one, releases all, 231.

unless the obligation is several, as well as joint, 235 .

or they reside in different States, 234 .

JUDGE,

de facto, 148 .

disqualified, 144-146.

may enter judgment against himself, 1 t5.

signature of, to judgment, $50 e$.

which may authenticate judgment of another State, 413.

\section{JUDGMENT,}

attack of, on habeas corpus, 619-626

different kinds of, 1-15.

evidence of admissions, $417 a$.

in figures, $4 \mathrm{Sa}$.

is a merger of another action for the same cause, 249 .

is a merger of prior equities, 217.

is a merger of judgment on which it is recovered, 216.

is a new debt, 217.

signing, 77.

void, when, 117, 264.

JUDGMENTS IN REI,

definition of, $\mathrm{COG}$.

different kinds of, 607-610.

in probate courts, 608.

in decreeing sale, 609 .

in decrees concerning marital relations, 610 .

jurisdictional inquiries in regard to, 611 .

causes for avoiding, 612 .

in admiralty courts, 613-61s.

JUDGMENTS IN OTHER STATES,

is a merger of cause of action, 221 .

constitutional and legislative provisions, 559.

faith and credit of, 559, 575, 576.

jurisdictional inquiries, 560-564.

jurisdictional inquiries, cases holding tisat they are open, 562.

jurisdictional inquiries, eases holding that they are not open, 561 .

jurisdictional inquiries against record recitals, 563,550 .

against non-residents, 564, 566 .

against non-rcsidents under joint debtor acts, 574.

against realty in another State, 564 .

against non-resident coming within State, 565.

against non-resident corporations, 567.

presumption of jurisdiction, 565.

constructive service of process, 567-570.

law applicable to, 571 . 
JUDGMENTS IN OTHER STATES-CONTINEED.

must be shown to be valid where reudered, $5 \boldsymbol{i} \mathbf{l}$.

jurisdiction of subject-matter, 572 .

obtained by attachment, 573 .

obtained by joint debtor acts, 574 .

defenses to, 576 .

of courts not of record, 577 .

of Federal courts, 578.

of decrees of divorce, 579-587.

JUDGMENT BOOK,

when entry may be made in, 40 .

use of, improper, 41.

as proof of judgment, 409.

JUDGMENT ROLL.

origin of, 75 .

verity of, 76 .

of what composed at common law, 78, 79 .

of what composed under statutes, 80.81 .

of what composed in California and Nevada, 82, 83, 84 .

on new trial, 85 .

States laving none, 86 .

effect of failure to make up, 87 .

in equity, $s 8$.

restoring, when lost, 89.

restoring, chancery has no power over, $89 a$.

silence of, as to jurisdiction, 132.

whether jurisdictional inquiries are confined to, 124. 131, 133.

JUDICIAL ACTS,

what are, 531.

JUNIOR JUDGMENT,

sale under, 377.

JURISDICTION,

acquired by fraud, 566 .

attachment, procured by, 126.

attorney, appearance by, 128, 499, 500.

consent cannot confer, 120.

constructive service of process, 127.

continues after service till judgment, 142.

default, 129.

defects in obtaining, 126.

definition of, 118.

inquirics in regard to, what allowable, 116, 122, 123, 131-134.

error does not affect, 135.

essential to judgment by confession, 547 .

findings of, 130.

for one purpose only, 143 .

loss of, 121,526 .

over deceased defendant, 139, 140, 153, 157, 158.

over party not named, 141.

over subject-matter, 120 . 


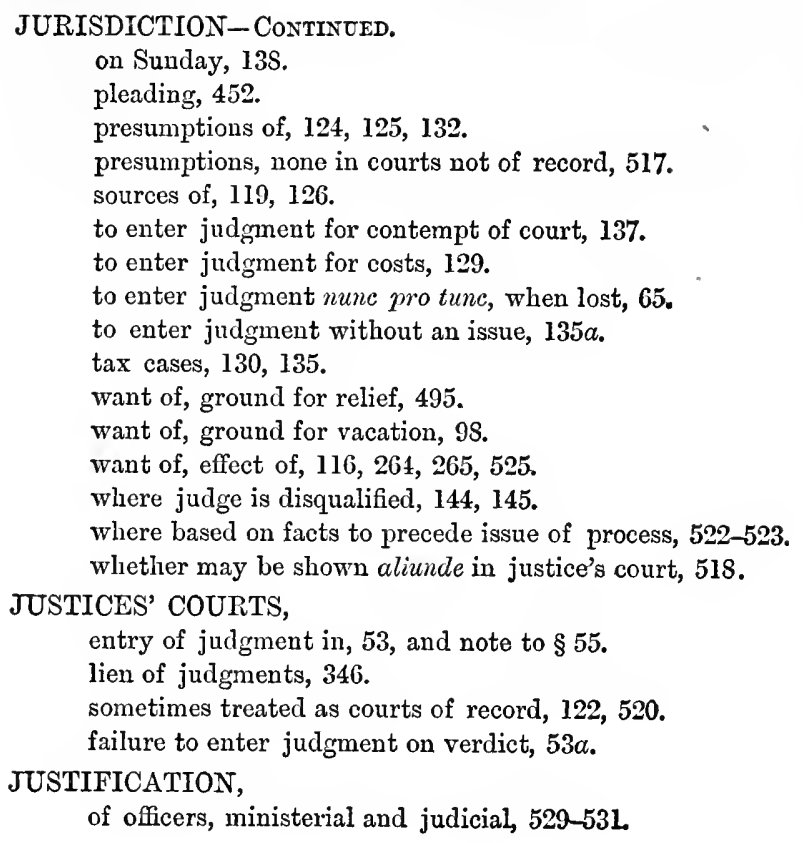

LACHES,

L.

in applying for vacation, 102 .

LANDLORD,

when bound by judgment against tenant, 185.

LANGUAGE OF JUDGMENT, 2, 46, 51.

confined to the issues, 158, 281.

confined to the parties, 155.

\section{LAST JUDGMENT,}

prevails as an estoppel, 332 .

LESSOR AND LESSEE,

privity of, 169, 185.

LEVY,

on lands as satisfaction of judgment, 474 .

on personalty as satisfaction of judgment, 475 .

\section{LIEN OF JUDGMENTS,}

nature of, 33S-342.

holder can not sue for waste, 338 .

attaches to all of defendant's interests, 338 .

is subordinate to the costs of suit and sale, 338.

index when essential, 347 .

final judgment for definite sum essential to, $\mathbf{5} 40$.

how created, 339.

arises from final judgment only, 340 . 


\section{LIEN OF JUDGMENTS-CONTINCED.}

includes interest, 341 .

is not subject to control by the court, 342 .

docketing, 343 .

docketing, correcting, 344 .

docketing, judgment of appellate court, 345 .

docketing, justice's judgment, 346 .

docketing, index when essential, 347.

docketing, misspelling names in, 347 .

docketing, omission of Cliristian name, 347.

docketing, spelling of names, 347 .

estates and interests affected by, 348-368.

equitable interests, 348 .

equity of redemption, 349 .

lands fraudulently conveyed, 350.

fixtures, 351.

rents, 352.

term of years, 353 .

lands not in possession, 354 .

lands exempt from execution, 355.

lands of co-tenancy, $357 a$.

affects only debtor's actual interest, 356-357.

against trustees and administrators, 358 .

against lands intended to be conveyed, 359 .

against lands subject to vendor's lien, 360 .

against lands of wife, 361 .

against dower interests of wife, $361 a$.

against lands, interests of vendor and vendee in, 363 .

of judgment for purchase money, 365 .

against lands conveyed by unrecorded deeds, 366 .

after-acquired title, $367-368$.

priority of. $369-378$.

See Priority of Judgment Liens.

suspension and discharge of, 379-391.

See Suspension and Discharge of Judgment Liekg.

extending and reviving, 392-396.

for future advances, 397 .

of foreclosure decrees, 398, 402.

of Federal courts, $403-406$.

See Aralysis on page 381 .

\section{LIS PENDENS,}

amended pleadings, 199.

between what parties, 200 .

commencement of, 195.

confincd to State, 210.

diligence required, 202.

dismissal, without prejudice, 204.

ejectment, 213.

effect of, 193, 198, 208.

end of, 206.

in federal courts, 192. 
LIS PENDENS-CoNTINUED.

paramount title not subject to, 201.

persons bound by, 201, 209.

purchaser at execution sale bound by, 208 .

property bound by, 194.

reasons for, 191.

requisites of, 196, 197.

revivor of, 203.

termination of, 206.

when may be filed, 212, 214.

LOST RECORD,

action on, $432 b$.

how proved, 407.

how replaced, $89,89 a$.

indictment cannot be replaced, 89 , nota.

LUNATIC,

bound by judgment, 152 .

M.

MARRIED WOMAN,

whether bound by judgment, 150 .

MASTER AND SERVANT, privity of, 179.

MAXIMS,

actis curie neminem gravabit, 56.

expedit republica ut sit finis litium, 284.

res inter alios acta, aliis nec prodest, nec nocet, 154.

res inter alios acta alteri nocere non debet, 154.

\section{MERGER,}

appeal, effect on, 218.

application of doctrine of, to bankruptcy proceedings, 245.

by conviction of another felony, 225 .

by conviction of part of felony, 225 .

by judgment against agent, $225 \alpha$.

general principles of, 215 .

includes all canses of action, 216.

judgment is a new debt, 217.

depends on valid judgment, 218 .

on judgments of no extraterritorial effect, 219.

of foreign judgments, 220 .

of sister State judgments, 221 .

pendente lite, 224.

of civil liability in criminal prosecution, 225.

of relation of principal and surety, 226 .

co-plaintiffs and co-defendants, 227.

of collateral security, 229 .

of joint obligations, 231-235.

under joint debtor acts, 233-234.

of joint and several obligations, 235 . 
MERGER-CONTINUED.

recovery in a different right or capacity, $235 a$.

of claims for torts, 236,237 .

of indivisible demands, 23s-243.

of indivisible demands, ex contractu, 238-239.

of aetions on aceount, 239 .

of indivisible demands, ex delicto, 241.

of actions for nuisances, 242.

of actions for separate torts, 243 .

of exceptions to general law of merger, 244, 245.

of civil remedy in crimiual, 225.

MERITS,

affidavit of, 108 .

indispensable to vacation of judgment, 102.

indispensable to relief from judgment, 498 .

judgment on, what is, $260,267$.

judgment on, essential to res judicata, $500,267,318$.

judgment on, classification of, 253.

MESNE PROFITS, action for, judgment in ejectment as evidence in, 297, 301.

MISCONCEIVED ACTIONS,

eannot bar proper action, 265.

MISERICORDIA,

judgment of, 8.

MISNOMER OF PARTIES,

does not relieve them from judgment, 154 .

MISPRISIONS OF CLERKS,

may be corrected, 71 .

MISTAKE,

as ground for relief in equity, 500a. '

as ground for vacation, 113.

as ground for nunc pro tunc entry, 60 .

MONEY,

power to enter judgment in particular kind, 3.

judgment must be paid in, 463 .

MORTGAGE,

whether lien of, merges in judgment, 398 .

MOTION,

how far decision of, is res judicata, $255,325,326,511$.

MUTUALITY,

essential to estoppels, 159.

N.

NAMES,

incorrect in judgment, 154 .

omitted in judgment, 154.

identity of, 154,347 .

docketing of, 347 .

inserting by amendment, 70 . 
NEGLECT,

bars relief, 4S6, 502 .

of attorney, 112.

of attorney, no ground for relief in equity, 500 .

what excusable, 114.

NEGOTIABLE PAPER,

lis pendens does not apply to, 194.

NEW TRIAL,

record of, 85 .

when and how deemed in equity, 484a.

NIHIL DICIT, judgment of, 7.

NOLLE PROSEQUI, judgment of, 7 .

when a bar, 261, 318.

NOMINAL DAMAGES,

judgment for, is an estoppel, 311.

NON OBSTANTE VEREDICTO,

judgment of, 7.

NON PROS,

judgment of, 7.

not a bar, 261 .

NON-RESIDENT,

judgments against, when void, 567.

NONSUIT,

judgment of, 7 .

not res judicata, 261.

NON SUM INFORMATUS,

judgment of, 7.

NOTE,

judgment recovered by one indorser, 227a.

NOTICE,

that judgment lien will attach, 364 .

by lis pendens, 191, 198 .

of application to amend judgment, 72 .

of application for nunc pro tunc entry, 64.

of application for vacation of judgment, 103 .

of assignment, 426 .

to defend suits, 176, 181, 1SS, 189.

want of ground for relief, 495 .

See Lis Pendens.

NUISANCE,

only one suit for each, 242.

NULLITY,

will be vacated, 98 .

NUL TIEL RECORD, plea of, 459. 
NUMEROUS DETENDANTS,

need not all be named, 157, 173.

NUNC PRO TUNC ENTRIES,

maxims on which founded, 56.

classification of grounds for, 57 .

on account of delay of court, 57 .

on account of delay occasioned by motions, 58.

can be made only when cause was ready for trial, 59 .

not for any delay, except that of the court, 60 .

evidence on which to base, 61-63.

notice of motion for, 64 .

termination of jurisdiction to make, $\mathbf{6 5}$.

effect on rights of third persons, 66 .

general effect, 67 .

must be based on previous act of the court, 68 .

\section{OFFICE HOURS,}

\section{O.}

instruments filed before, 371 .

\section{OFFICER,}

of corporation may confess judgment, $\mathbf{5 4 5}$.

public, may confess judgment, 545 .

payment of judgment to, 462 .

payment of judgment by, 469.

what acts of, are judicial, 531 .

when justified by process, 529 .

privity with successor, 170 .

receiving payment in confederate notes, 463.

OFFICERS DE FACTO,

in Confederate States, 604.

ONUS,

of proving res judicata, 276.

ORDER,

what is, 15.

res judicata of, 255, 325-327, 511.

OYER OF 1NSTRUMENT,

makes it part of record, 78 .

P.

PARTIES TO JUDGMENTS,

designating, $50 a$.

all persons may be, 149.

co-tenants as, $171 a$.

married woman, 150 .

infants, 151.

lunatics, 152.

deceased persons, 153.

judgment confined to, 154, 155.

bound only in the same capacity, 156. 
PARTIES TO JUDGMENTS-CoNTINUED.

when bound in two or more capacities, 156.

bound only when adversary parties, I5S.

bound, though not named in record, when numerous, 157 .

bound mutually or not at all, 159 .

second action with less parties than the first, 160 .

second action with more parties than the first, 161 .

privies. See Privity.

persons not in esse, 172 .

persons bound not parties, 174-190.

who may obtain relief from judgment, 512.

judgment for want of proper, no bar, 266.

PARTNER,

can not confess judgment against firm, 545 .

judgment against one releases others, 232.

PARTNERSHIP,

when established by judgment, 315 .

PAYMENT OF JUDGMENT,

when does not discharge lien, 391.

to whom may be made, 462 .

how made, 463.

- presumption of, 464, 465.

effect of, 466.

right of prayer to subrogation, $468-473$.

\section{PARTITION,}

decree of, as res judicata, 304.

decree of, against persons not in esse, 306.

decree of, against unznown owner, 307 .

where applicant was not in possession, 305.

PERJURY,

as defense to judgment, 435 .

as cause of action, 289.

as ground for relief, 503 .

as ground for vacating judgment, $111 a$.

PERSONAL PROPERTY,

what, bound by lis pendens, 194.

PERSONS BOUND BY JUDGMENT, THOUGH NOT PAPTIES, 174-90.

PERSONS NOT IN ESSE,

how bound by judgments, 172 .

PLACITA,

what is, and necessity of, 77 .

PLEA,

of nul tiel record, 559 .

\section{PLEADING,}

may explain the judgment, 45.

where judgment is part of claim of title, 283 .

judgment, as an estoppel, 283, 284.

judgment, general form, 450 . 
PLEADING-Continded.

judgment, must correspond with the dignity of the judgment, 451.

judgment, jurisdictional averments, 452, 453, 454.

judgment, jurisdictional denials, 455.

judgment, description, $456,457$.

defenses to judgment, 45S-460.

defenses to judgment of sister State, 461.

POSTEA,

what is, 77.

PREMATURE SUIT,

no bar, 26S, 274.

PRESUMPTIONS,

of jurisdiction, 124, 125, 132.

of jurisdiction, judgments of other States, 585 .

of jurisdiction, courts not of record, $51 \%$.

of payment, 464,465 .

of res judicata, 275,276 .

PRINCIPAL,

privity with agent, 164.

privity with garnishce, 167 .

privity with surety, 1 SO.

PRIORITY OF JUDGMENT LIENS,

judgments of same term, 369 .

fractions of a day, 370 .

office hours, 371 .

judgment on day of sale, 372 .

simultancous acquisition and conveyance, $\mathbf{3 7 3}$.

diligence in accuiring priority, 374 .

superior equity, 375 .

preferred debts due United States, 378.

sale under junior judgment, 377.

PRIVILEGE,

of exemption from process must be pleaded, 490 .

?RIVITY,

definition of, 162.

of administrator with administrator, 163.

of administrator with admiuistrator in another State, 103.

of administrator with creditor, 163.

of administrator with heir or clevisee, 163.

of ancestor with heir, l6s.

of assignor with assignee, 165 .

of bailor with bailee, 166 .

of co-tenants, $171 a$.

of creditor with creditor, 159.

of lessor with lessee, 169.

of officer with his successor, 170 .

of principal with agent, 164 .

of principal with garnishee, 167.

of remainder-men with tenant, 172.

of occupants with defendant in ejectment, 171 . 


\section{PROBATE DECREES AND ORDERS,}

effect of, $319 a, 608$.

effect of, on estates of living person, $319 a$.

\section{PROCESS,}

constructive scrvice of, 127, 527 .

defective service of, 126 .

of no force beyond the State, 564 .

service must be shown in inferior courts, 519-523.

want of service, ground for relief, 495.

PROOF,

identity of, is the test of res judicata, 259.

onus of, in regard to res judicata, 276.

to avoid estoppel, 272.

to establish estoppel, 273.

of vacation of judgment, 409 .

\section{PROOF OF JUDGMENTS,}

by the record, 407 .

by copy, 408.

by judgment book, 409 .

of inferior courts, 410 .

of courts of another State, 411-413.

of foreign courts, 414.

See Evidence.

PROPERTY BOUND BY LIS PENDENS, 194.

how designated in judgments, 50e.

PROPERTY HOLDER,

bound by judgment against eity, 178, 181.

PURCHASERS UNDER JUDGMENTS,

after satisfaction, acquire no title, 480 .

effect of reversal on, 483,484 .

not prejudiced by amendments, 74, 344 .

not prejudiced by nunc pro tunc entry, 46 .

not prejudiced by reversal, 484 .

not prejudiced by secret vices in the proceedings, 509, 510 .

not prejudiced by suit to set aside judgmeut, 509, 510 .

plaintifi, is not purchaser for value, $366 a$.

QUIETING TITLE,

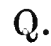

judgment in action to, effect of, 309, 329.

QUOD COMPUT'ET,

judgment of, 8 .

QUOD PARTITIO FIAT, judgment of, 8 .

QUOD RECUPERET, judgment of, 7 . 
IEAL ACTIONS,

I.

effect of judgment in, 293.

REAL ESTATE,

title not bound by judgment in another State, 564 .

REASONS OF THE COURT, are not a part of the judgment, 2.

do not limit or enlarge estoppel, 249.

RECEIPT,

finding of, as ground for relief, 504.

RECORD, OR JUDGMIENT ROLL.

evidence outside of, to show what was litigated, 273,275 .

as proof of judgment, 407 .

copy as proof of judgment, 408.

lost, how proved, 407 .

lost, how replaced, 89.

power of court over, 63 .

See JUDGMENT Roll.

RELIEF IN EQUITY FROM JUDGMENTS,

classification and statement of grounds of, 485-48s.

criminal prosecutions, $484 a$.

appeal, power to restore right of, $484 a$.

mode of obtaining from deeree or judgment, 484a.

new trial, when and how decreed, $484 a$.

to prevent one from gaining by his neglect, $496 a$.

irregularity as ground for, 487.

from judgment by default, 487, 532.

error in admitting or excluding evidence, 487.

error in rendering judgment on unconstitutional cause, 487.

for collusion, 489 .

for concealment, $490,493$.

for taking judgment contrary to agreement, 492.

from void julgment, 497.

for neglect of attorney, 500, 508.

mistake of fact, $500 a$.

accident, $500 a$.

mistake of the eourt, $500 a, 508$.

usury, 502.

gambling debt, 502 .

diligence required, 503.

cestui que trust, $505 a$.

for ignoranee, 500.

after motion at law, 511.

complainant must do equity, 516.

concealment a ground for, $491-493$.

defenses which must be presented at law, 501, 506.

discovery, 507.

error as ground for, 487.

executor and administrator when relieved, 505. 
IELIEF IN EQUTTY FROM JUDGMENTS-CONTINUED.

fraud as ground for, 489-493.

infants applying for, $5 \mathrm{l} 3$.

injury essential to, 514 .

innocent purchasers, 509, 510.

merits essential to, 498 .

neglect, a bar to, 502, 503, 503 .

receipt found, 504 .

threats in procuring judgment, 494.

unauthorized appearance by attorney, 499 .

unauthorized act of attorney, 500 .

want of jurisdiction is a ground for, 495 .

where remedy by motion exists, 497 .

REMAINDER-MEN AND REVERSIONERS,

when bound, though not parties, 172 .

REMOVAL OF CAUSES,

contracts restraining, 568 .

RENDITION OF JUDGMENT,

valid without and before entry, 40.

RES JUdiCATA. See Estoppel, Merger, Papires, Privity.

RESPONDEAT OUSTER,

judgment of, 7 .

RESTITUTION,

against whom enforced in ejectment, 171 .

on reversal of judgment, $482-484$.

RETRAXIT,

defined, 7.

judgment on, a bar, 261, 262.

REVERSAL OF JUDGMENT,

effect on estoppel, 333.

general effect of, 481 .

reversal of reversal, 481.

restitution between the parties, 482 .

restitution from assignee of judgment, 483 .

action to recover property, $482,4 S 3$.

restitution from defendant lien holder, 482.

effect on third persons, 484 .

S.

SALE,

after expiration of judgment lien, 394 .

after satisfaction of judgment, 480 .

SATISFACTION OF JUDGMENT,

by giving note, 493.

by payment, $462-467$.

by payment to prochcin ami, $4 \hat{\mathbf{2} 2}$.

by taking out execution against co tort feasor, 467 .

by levy on lands, 474 . 
SITRSACWION ON JUDGIENT-CoNTLNED.

by lery on personalty, 475.

by discharge of defendant, 476 .

by sale, $47 \mathrm{~S}$.

by set-off, $46 \%$ a.

by vacation of judgment, 478 .

by other means, 479 .

by release under seal, 463 .

effeet of, 466.

sale after, void, $4 \mathrm{SO}$.

action against assignee for, $426 a$.

See Paymient and Sterogation.

SCIRE FACIAS,

definition of, 442.

is not a new suit, 444 .

judgment in, 443 .

defenses in, 445 .

pleadings in, 446, 447.

parties bound by, 44S, 449.

SET-OFF,

defendant need not present, $277,280$.

whien deemed presented, 279.

not allowed, 279.

not decided, 279 .

voluntary allowance of, 280 .

code of California, 277.

of one judgment against another, $4 \& 7 a$.

motion for, $467 a$.

power to order, $467 a$.

assignment, effect on right of, $467 a$.

SETTLEAIENT OF PAUPER,

order of, as res judicata, 256.

SYGNATURE,

of judge, $50 e$.

SIGNING JUDGMENT, 77.

SLAVE,

judgment against, 149, note.

STATE,

lis pendens confined to, 210.

See JUdGMeNT OF Other States.

\section{STATUTES,}

in regard to judgment roll, \$0-\$2.

in regard to judgment roll construed, SI-\$3.

in regard to vaeating judgments, 105-115.

STOCKHOLDER,

whether bound by judgment against corporation, i: 7 .

STOCKS,

lis pendens as to, 194. 
SUPROGATION,

right of payer of judgment to, $463-473$.

co-defendant, 272 .

co-defendant and third person, 473 .

indorser, 471 .

officer, 469.

stranger, 468.

surety, 470.

SUMmons, See Jurisniction and Process.

SUNDAY,

docketing judgment on, 347.

judsment rendered on, 198.

SUPPLEMENTAL PLEADINGS,

lis pendens of, 199.

SUPPLEIENTAL PROCEEDINGS,

decision in, is conclusive, $325-327$.

\section{SURETY,}

when bound by judgment against his principal, 1 SO.

paying judgment entitled to subroration, 40.

whether rights of, merse in the judgment, 226 .

SUSPENSION OF JUDGMENT LIENS.

by $c \ell . s \iota_{.}, 379$.

by forthcoming bond, 380 .

by temporary vacation, 381 .

by stay of execution, 332 .

by dormant execution, 383 .

by act of defeulant, 381 .

by erecting new county, $3 \$ 5$.

by sale under crecution in Pennsylvania, 386.

by menger of judgment, 383.

T.

"TAX JUDGYMNTS, 130, 195.

TENANTS TN COMMON,

no privity between, 171 .

TERAI OF COUPT,

adjoumment of, 121.

continues till call of the next, 90 .

judgment is final after, 09 .

judgment out of, voin, 121.

jud grment may be amended rluring, 69 .

jurlgment may not be amended after, 70 .

power of courts out of, 121 .

TERRE-TENANTS,

who are, 4tJ.

THREATS,

by which defense was prevented. 494. 
TIT'LE,

paramonnt, not affected by lis pendens, 201 .

TORT,

vesting of, by judgment, 237 .

all damages for, furnish but one cause of action. 241 .

TORT FEASORS.

liability of, is joint and several, 236 .

cfifect of judgment against one of, 236 .

effect of julgment against, as transfer of title, 237 .

TRANSCRIPT OF JUDGIIENT,

as a lien, $\mathbf{3} 06$.

TRANSEER,

pendente lite. Sec Lis Pendens.

of title by judgment, 237.

TRESPASS,

judgment in action of, as res judicata, 310, 311, 317.

TRESPASSERS,

liability of, is joint and several, 236.

TROVER AND TRESPASS.

effect of judgment in, as a merger, 237.

TRUSTEES,

privity with, cestui que trust, 173.

lien of judgment against, 358 .

cannot confess judgment to bind trust estate, $\mathbf{5 4 5}$.

\section{U.}

UNKNOWN OWNER,

judgment against, in partition, who may be bound by, 307 .

UNRECORDED DEED,

takes precedence over judgment lien, 366 .

UNITED STATES COURTS,

lien of judgment in, 403 .

ISURY,

as ground for relief from judgment, 502.

\section{V.}

\section{VACATTNG JUDGMENTS,}

effect of, $104 b$.

may be done during term at discretion. yo.

who may apply for, 91,92 .

in California, 93.

by writ of error coram nobis, 94.

by writ of audita querela, 95 .

after term, 99.

for error, 101.

for irregularity, 97, 98.

for fraud, 99. 
VACATING JUDGMENTS-CONTINUED.

nullity, 93.

for unauthorized appearance of attorney, 98.

for mistake, 9S.

merits essential to, 102, 108.

laches in applying for, 102 .

notice of motion, 103.

by entry of second judgment, $104 a$.

proof of, 409.

in England, 100.

in Maryland, 100.

in Michigan, 100.

VACATING, satisfaction of judgments, $478,478 a$.

VACATION OF JUDGMENT FOR INADVERTENCE, MISTAKE, ANH EXCUSABLE NEGLECT,

statutes in regard to, 105.

statutes in regard to effect on right to apply in equity, 105.

discretion of court, 106.

who may apply for, 107.

affidavit of merits, 108.

afidavit of merits, by whom made, 108.

afficlavit of merits, cannot be controverted, 109.

costs must be paid, 109.

new motion as continuation of old one, 110 .

time to apply for, when not limited, 105.

lenience of courts in New York, 111.

fraud as a ground for, 111 .

perjury as a ground for, $111 a$.

neglect of attorney, 112.

mistake, 113.

excusable neglect, 114 .

VARIANCE,

in pleading judgments, 457.

- VENDEE,

of pendente lite purchaser, 209.

privity with veador, 165, 186.

lien of judgment against, 363.

VENDOR'S LIEN,

lias precedence over judgment lien. 390 .

VERDICT,

entry of judgment on, $4 z$.

no bar without judgment, 252.

VERITY,

of judgment roll, 76 .

VESTING TITLE,

by judgment against wrong॰llocr, 237.

VOID,

in part, void altogether, 136. 
VOID JUDGMENT,

defined, 116.

effect, 117 .

legislature can not make valid, 117.

whether judgment without any issue is, $135 a$.

when judgment for contempt is, 137.

on account of fraudulent alteration, $148 a$.

relief from, in equity, 497.

\section{W.}

WARRANTOR,

privity with warrantee, 187 .

notice to defend, 181.

WARRANTY,

judgment for breach of, 312 .

WITNESS,

not privy to judgment, 189.

WRIT,

of audita querela, 95 .

of error coram nobis, 94.

of error coram vobis, $9 \mathbf{h}$ 





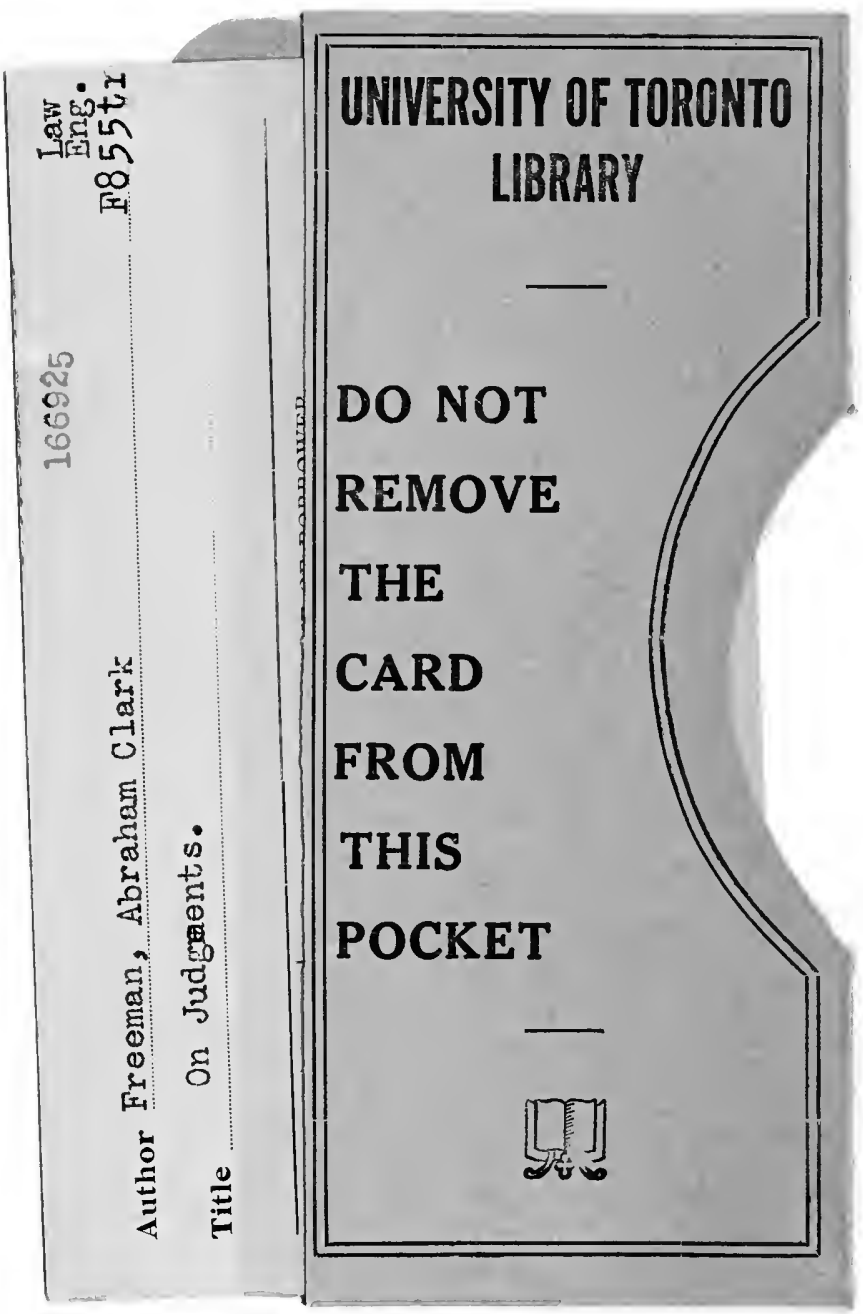


